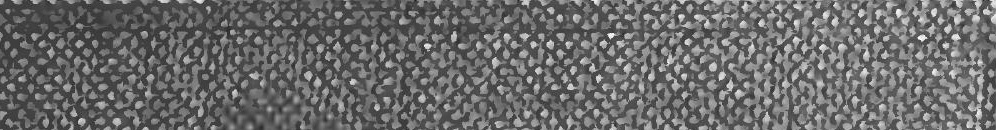

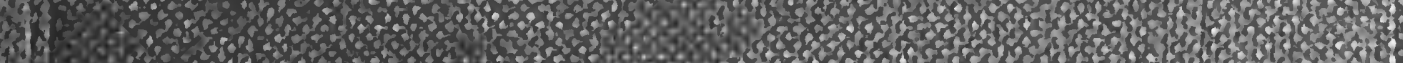

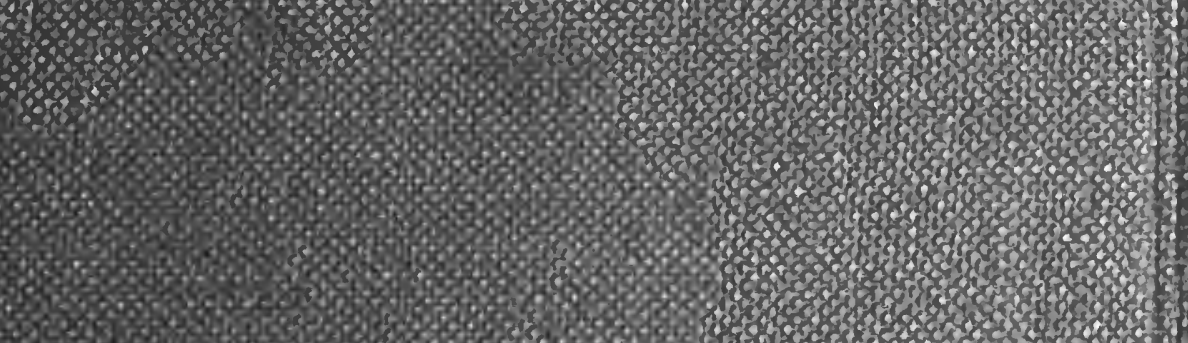

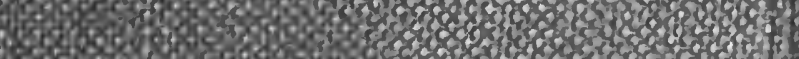

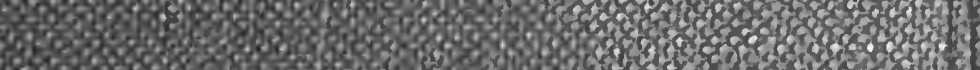

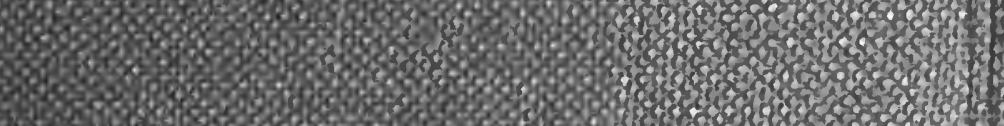

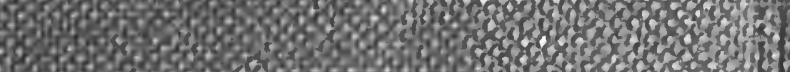

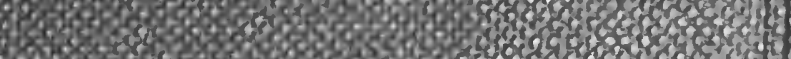

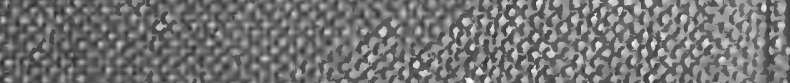

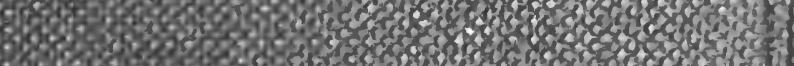

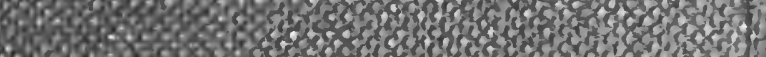

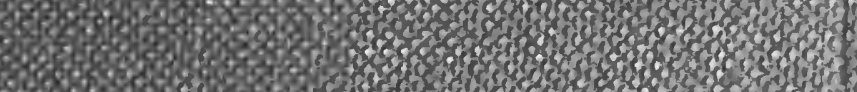

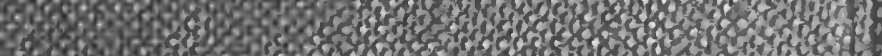

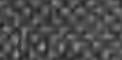

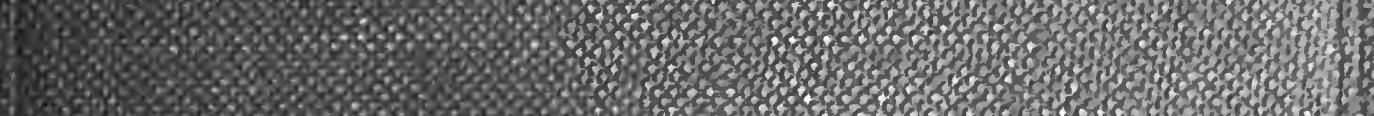

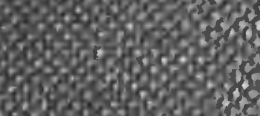

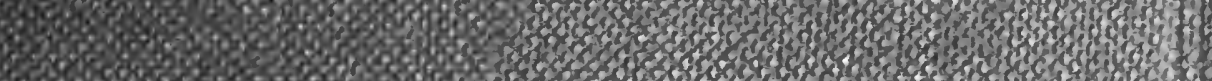

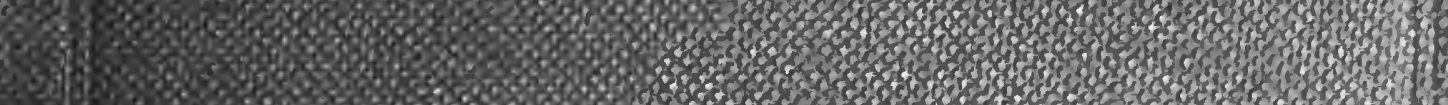

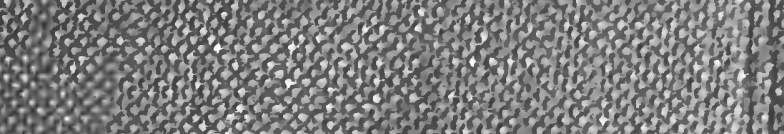


Law Books
Bancroft
Whitney
Company

San Francisco

$\checkmark$

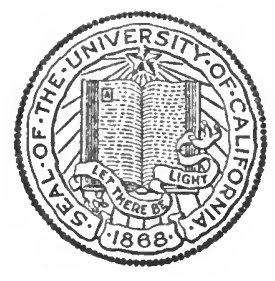

UNIVERSITY OF CALIFORNIA LOS ANGELES

SCHOOL OF LAW LIBRARY 


. 
Digitized by the Internet Archive in 2007 with funding from Microsoft Corporation 


\title{
UNIFORM STATE LAWS IN THE UNITED STATES
}

\author{
FULLY ANNOTATED
}

BY

\section{CHARLES THADDEUS TERRY}

President National Conference of Commissioners on Uniform State Laws 1913, 1914, 1915; Chairman New York State Commission on Uniform State Laws since 1904 ; Dwight, Professor of Law, Columbia University.

\author{
EDITED AND PUBLISHED
}

ONDER THE AUSPICES AND FOR TIIE PURPOSES OF THE NATIONAL CONFERENCE OF COMMISSIONERS ON UNIFORM STATE LAWS

\section{New York}

BAKER, VOORHIS \& CO., 1920 


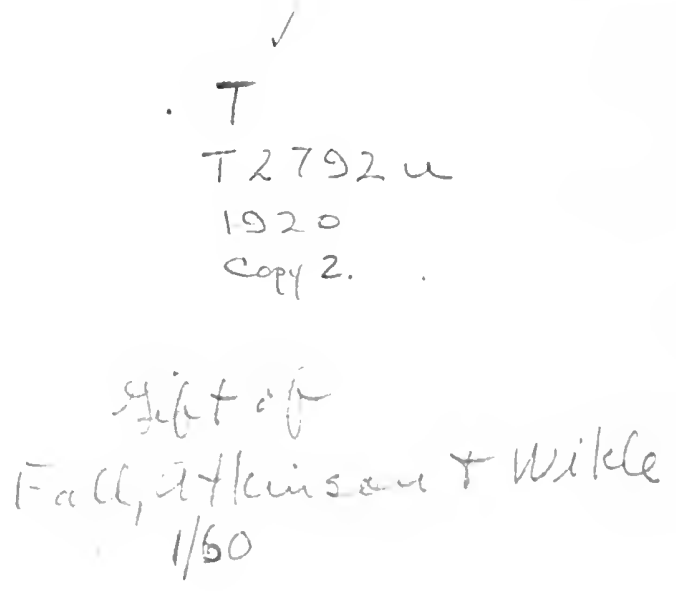

Copyright, 1920 ,

$\mathrm{BY}$

BAKER, VOORHIS \& CO.

$$
\begin{gathered}
1-13-60 \\
5 \% \\
5.2
\end{gathered}
$$




\section{FOREWORD}

A book containing the text of the Uniform State Laws promulgated by the National Conference of Commissioners on Uniform State Laws and enacted in the various states, should be of assistance to the Bench and Bar. Each of the Unifurm Acts approved in more recent years by the Conference has contained the provision that the Act shall be so construed as to effectuate its purpose of making uniform the law upon the subject with which it deals. Both the general theory of the movement for Uniform State Laws and the specific mandate involved in this provision give to the decisions in any particular state upon the question of the interpretation or construction of a particular section of any one of the Uniform Acts, substantially the force of a legal precedent of the utmost persuasiveness upon the particular court which may have the same question under consideration, although it may be the court of another state than that in which such decisions are found. Only thus can uniform State Laws be kept genuinely uniform. It should be, therefore, of considerable assistance to courts, in so deciding cases arising under the Uniform $\Lambda$ cts, as to keep the laws uniform, to have at hand in a single compilation all the decisions bearing upon the particular question at issue. Furthermore, it would seem that such a text-book would be of service to practicing attorneys, in that it will furnish a ready reference to decisions on points arising under the Uniform Acts which at this time are very important and of constant occurrence.

The purpose of this book, however, is simply to promote uniformity of laws and nothing else. To accomplish this purpose it is clear that after Uniform State Laws have been enacted they must be, on the one hand, kept free from statutory amendment (other than those approved by the National Conference of Commissioners in the same way in which the original act was approved), and also free from divergence of judicial con- 
struction. Both those purposes, it would seem, should be subserved by this book.

It is inevitable that inaccuracies should be found in the following pages. Where so many statutory enactments were presented for comparison and so many decisions were to be read, it would be strange indeed if there had not been errors and inadvertencies which have crept into the text. No claim is made that perfection has been accomplished; but on the contrary, indulgence, criticism and indication of errors, by those who may use the book, are invited. 


\section{KEY TO THE BOOK}

The precise text of the Uniform State Laws heretofore promulgated by the National Conference of Commissioners on Uniform State Laws will be set forth each in a separate chapter. The various sections of each law are numbered in accordance with the numbering given by the Conference at the time it approved the Acts respectively.

Under each section of each of the Acts will be printed the decisions bearing upon such section arranged in alphabetical order according to the names of the states in which such decisions were rendered. By this arrangement, it will be easy to find the decisions of any state on any provision of any Uniform Act.

Furthermore, in connection with the text of each of the Uniform Acts as approved by the Conference, there will be printed the citation or location of the corresponding statute in the laws of each of the states, or in other words, the place where each of such Uniform Acts may be found will be given with the text of the Act, and furthermore, the corresponding section numbers will be given as between the Act as approved by the National Conference of Commissioners, and as found in the statute books, or laws, of each of the states; and this information will be given likewise according to states, arranged in their alphabetical order. In this way, a search by court or practitioner in any state for decisions under a particular section of the Uniform Law, as it appears upon the statute books of his state, nay be prosecuted easily and without loss of time. In other words, each chapter of the book contains a complete Uniform Act, together with a full citation of decisions in all the states interpretating the Act. If one desires to learn the interpretation of a specific section of one of the Uniform Acts, he turns is that chapter of the book which is devoted to that Act; he then finds the particular section under which the question of 
law which he is investigating arises. Following that section, he will find every decision which interprets that section, so far as i. has been passed upon by the courts of any state which has adopted that Act. Owing to the fact that most persons desiring to interpret a section of the Act know only the number of the section, as the Act has been adopted in his own state, the writer has prepared a table of cross-references whereby the user of the book will be able readily to discover the section in the Uniform Act corresponding to the section of the Act of his own state which he is investigating. The table of cross-references to each Act immediately precedes that Act. As a specific example: suppose one desires to find a set of citations interpretating Section 4173 of the Arizona Code. By turning to the cross-reference index immediately preceding the Negotiable Instruments Law, he will find that Section 4173 of the Arizona Code corresponds to Section 28 of the Uniform Negotiable Instruments Law. Then turning to Section 28 of the Negotiable Instruments Law, he will find the complete list of all the citations arising under that section in any States which have passed that Uniform Law.

Some few states in passing one or another of the Uniform Laws have altered the wording and thereby perhaps the meaning of some of the sections as they were promulgated by the National Conference of Commissioners on Uniform State Laws, but wherever such a change has been made, foot notes will indicate the change. 


\section{SCHEDULE OF UNIFORM ACTS}

The schedule of Uniform Acts so far adopted by the National Conference of Commissioners on Uniform State Laws, witb the dates of their adoption, respectively; is as follows:

Uniform Acknowledgments of Written 1nstruments Act....... 1892

Uniform Act Relating to Wills Executed Without the State..... 1892

Uniform Negotiable Instruments Act................. 1896

Uniform Sales Aet . ........................ 1906

Uniform Warelouse Receipts Aet.................. 1906

Uniform Annulment of Marriage and Divorce Aet.......... 1907

Uniform Bills of Lading Act..................... 1909

Uniform Stock Transfer Act...................... 1909

Uniform Desertion and Non-Support Act.............. 1910

Uniform Child Labor Act....................... 1911

Uniform Marriage and Marriage Licenses Act............. 1911

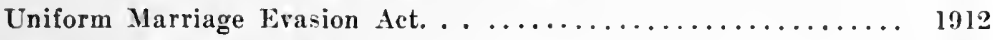

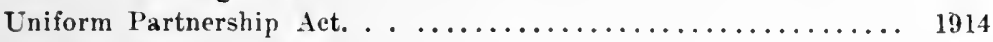

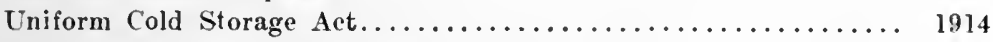

Uniform Workmen's Compensation Act............... 1914

Uniform Foreign Acknowledgments Act............... 19T4

Uniform Probate of Foreign Wills Act................. 1915

Uniform Land Registration Act.................. 1916

Uniform Limited Partnership Act.................. 1916

Uniform Extradition Act ......................... 1916

Uniform Flag Act........................... 1917

Uniform Conditional Sales Act.................... 1918

Uniform Fraudulent Conveyance Act.................. 1918 



\section{TABLE OF CONTENTS}

UNIFORM ACKNOWLEDGMENTS OF WRITTEN INSTRUMENTS $\mathrm{ACT}$

PAGF:

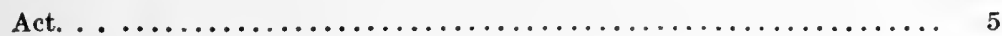

Index. . . ...................................... 589

UNIFORM ACT RELATING TO WILLS EXECUTED WITHOUT THE STATE

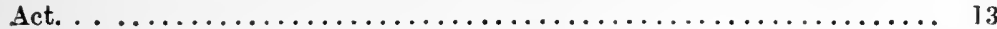

Index. . . ...................................... 590

UNIFORM NEGOTIABLE INSTRUMENTS ACT

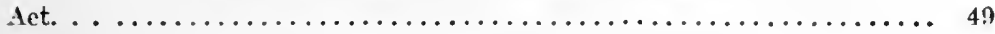

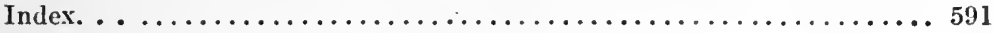

UNIFORM SALES ACT

Act. . . . . . . . . . . . . . . . . . . . . . 196

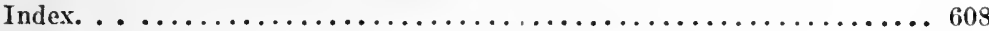

UNIFORM WAREHOUSE RECEIPTS ACT

Act. . . ......................................... 268

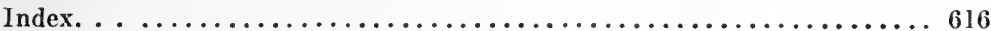

UNIFORM ANNULAIENT OF ITARRIAGE AND DIVORCE ACT

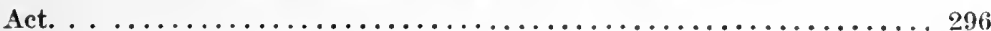

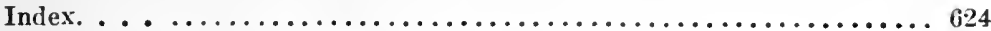

UNIFORIS BILLS OF LADING ACT

Act. . . ........................................... 316

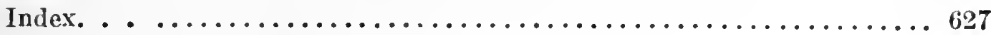

UNIFORM STOCK TRANSFER ACT

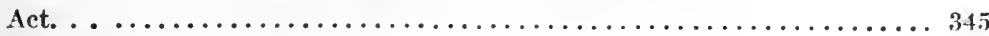

Index. . . . . . . . . . . . . . . . . . . . . . . . . . . . 633

ix 


\section{UNIFORM DESERTION AND NON-SUPPOR'T ACT}

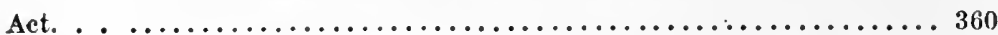

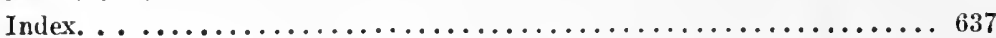

\section{UNIFORII CIIIDD LABBOR ACT}

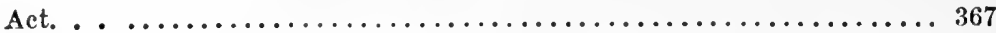

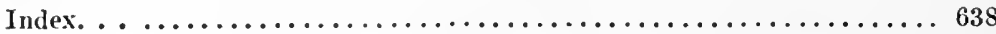

UNIFORM MARRIAGE AND MARRIAGF LICENSES ACT

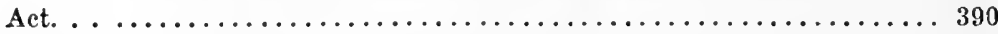

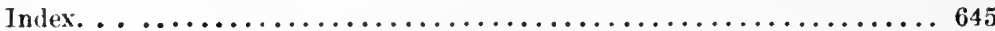

UXIFORII MARRIAGE EVAS]ON ACT

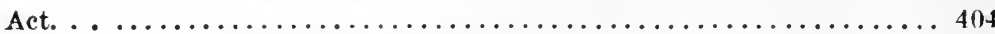

Index. . ................................... 649

UNIFORII PARTNERSIIP ACT

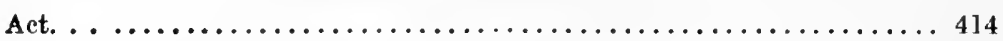

Index. . ...............................650

LXIFORM COLD STORAGE ACT

Act. . . .................................... 439

Index. . . . . . . . . . . . . . . . . . . . . . . . . . . . 655

UNIFORI WORKMIEN'S COMPENSATION ACT

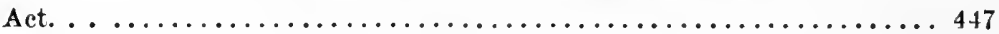

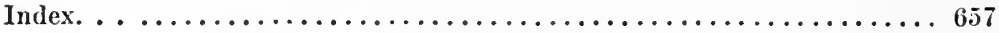

UNIFORM FOREIGN ACKNOWLEDGMENTS ACT

Act. . . ................................. 489

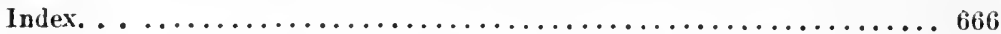

UNIFORM PROBATE OF FOREIGN WILLS ACT

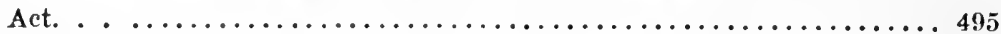

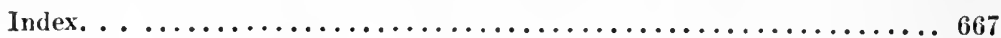

UNIFORM LAND REGISTRATION ACT

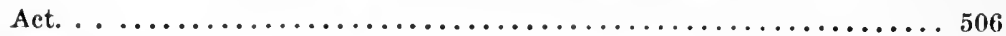

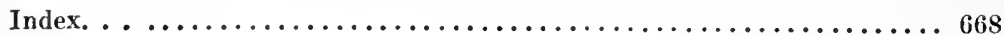

UNIFORM LIMTED PARTNERSHIP ACT

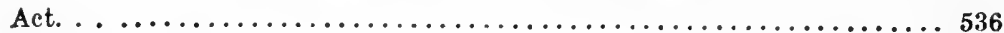

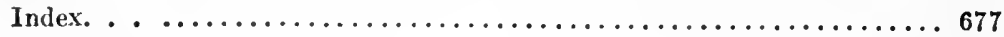


PAGE.

UNIFORM ACT FOR THE FXTRADITION OF PERSONS OF UNSOUND MIND

Act. 553

Index.

UNIFORM FLAG ACT

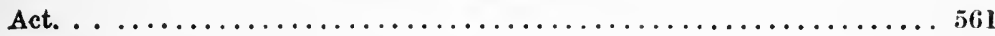

Index. . . .................................682

UNIFORII CONDITIONAL, SAI.FS ACT

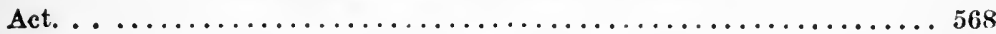

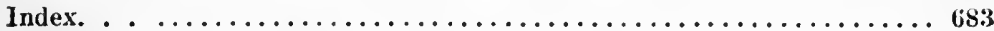

UNIFORM FRAUDULENT CONVEYANCE ACT

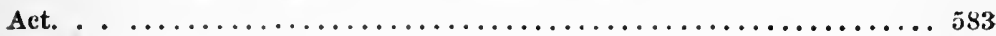

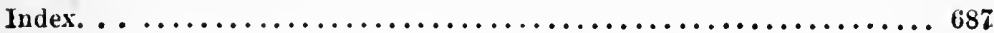



UNIFORM ACKNOWLEDGMENTS OF WRITTEN INSTRUMENTS ACT 



\section{UNIFORM ACKNOWLEDGMENTS OF WRITTEN}

INSTRUMENTS ACT

At the first meeting of the National Conference of Commissioners on Uniform State Jaws held at Saratoga, N. Y.. A In. 24-27, 1892, the following Uniform Act Relative to Acknowl. edgment of Written Instruments was adopted, approverl and recommended to the various legislatures for enactment into law. 



\section{UNIFORM ACKNOWLEDGMENTS OF WRITTEN INSTRUMENTS ACT}

Section 1. Either the forms of acknowledgment now in use in this state, or the following, may be used in the case of conveyances or other written instruments, whenever such acknowledgment is required or authorized by law for any purpose:

(Begin in all cases by a caption specifying the State and place where the acknowledgment is taken.)

1. In the case of natural persons acting in their own right:

On this day of sonally appeared A B (or A B and C D), to me known to be the person (or persons) described in and who executed the foregoing instrument, and acknowledged that he (or they) executed the same as his (or their) free act and deed.

2. In the case of natural persons acting by attorney:

On this day of, $19 \quad$ before me personally appeared $A B$, to me known to be the person who executed the foregoing instrument in behalf of $\mathrm{C} \mathrm{D}$, and acknowledged that he executed the same as the free act and deed of said C D.

3. In the case of corporations or joint-stock associations:

On this day of, 19 , before me appeared $A B$, to me personally known, who, being by me duly sworn (or affirmed) did say that he is the president (or other officer or agent of the corporation or association) of (describing the corporation or association), and that the seal affixed to said instrument is the corporate seal of said corporation (or association) and that said instrument was signed and sealed in behalf of said corporation (or association) by authority of its Board of Directors (or trustees) and said A B acknowledged said instrument to be the free act and deed of said corporation (or association). 
(In case the corporation or association has no corporate seal, omit the words "the seal affixed to said instrument is the corporate seal of said corporation (or association), and that," and add, at the end of the affidavit clause, the words, "and that said corporation (or association) has no corporate seal ".)

(In all cases add signature and title of the officer taking the acknowledgment.)

Sec. :. The acknowledgment of a married woman wher, required by law may be taken in the same form as if she were sole and without any examination separate and apart from her husband.

Sec. 3. The proof or acknowledgment of any deed or other written instrument required to be proved or acknowledged in order to enable the same to be recorded or read in evidence, when made by any person without this state and within any other state, territory or district of the United States, may be made before any officer of such state, territory or district, authorized by the laws thereof to take the proof and acknowledgment of deeds, and when so taken and certified as herein provided, shall be entitled to be recorded in this state, and may be read in evidence in the same manner and with like effect as proofs and acknowledgments taken before any of the officers now authorized by law to take such proofs and acknowledgments, and whose authority so to do is not intended to be hereby affected.

Sec. 4. To entitle any conveyance or written instrument, acknowledged or proved under the preceding section, to be read in evidence or recorded in this state, there shall be subjoined or attached to the certificate of proof or acknowledgment, signed by such officer, a certificate of the Secretary of State of the state or territory in which such officer resides, under the seal of such state, territory, or a certificate of the clerk of a court of record of such state, territory or district in the county in which said officer resides or in which he took such proof or acknowledgment under the seal of such court, stating that such officer was, at the time of taking such proof or acknowledgment, duly authorized to take acknowledgments and proof of decds of lands in said state, territory or district, and that said 
Secretary of State, or Clerk of Court is well acquainted with the handwriting of such officer, and that he verily believes that the signature affixed to such certificate of proof or acknowledgment is genuine.

Sec. 5. The following form of authentication of the proof of acknowledgment of a deed or other written instrument when taken without this state and within any other state, territory or district of the United States, of any form substantially in compliance with the foregoing provisions of this act, may be used.

Begin with a caption specifying the state, territory or district and county or place where the authentication is made.

I, Clerk of the in and for said county, which Court is a Court of record, having a seal (or, I, , the Secretary of State of such state, or territory do hereby certify that

by and before whom the foregoing ackowledgment (or proof) was taken, was, at the time of taking the same, a notary public (or other officer) residing or authorized to act) in said county, and was duly authorized by the laws of said state (territory or district) to take and certify acknowledgments or proofs of deeds of land in said state (territory or district), and further that I am well acquainted with the handwriting of said

and that $I$ verily believe that the signature to said certificate of acknowledgment (or proof) is genuine.

In testimony whereof, I have hereunto set my hand and affix the seal of the said court (or state) this day of , 19.

Sec. 6. The proof or acknowledgment of any deed or other instrument required to be proved or acknowledged in order to entitle the same to be recorded or read in evidence, when made by any person without the United States, may be made before any officer now authorized thereto by the laws of this state, or before any minister, consul, vice-consul, charge d'affairs, or consular agent of the United States resident in any foreign country or port, and when certified by him under his seal of office it shall be entitled to be recorded in any country of this state, and may be read in evidence in any court in this state, in the same manner and with like effect as if duly proved or acknowledged within this state. 

UNIFORM ACT RELATING TO WILLS EXECUTED WITHOUT THE STATE. 



\section{UNIFORM ACT RELATING TO WILLS EXECUTED WITHOUT THE STATE.}

In 1892, the Conference of Commissioners on Uniform State Laws recommended to the various states for adoption the Act to make Uniform the Law relating to the Execution of Wills. At the Conference in 1910, the Committee on Wills, Descent and Distribution reported that it could not do better than again recommend to the various states the Act approved by the Conference in 1892. The Conference resolved to adopt the Committee's suggestion and to recommend this Act to the various states for odoption.

The Act has been adopted by the following states: Kansas, 1911; Maryland, 1914; Michigan, 1911; Nevada, 1913; Utah, 1907; Alaska, 1913. 



\section{UNIFORM ACT RELATING TO WILLS EXECUTED WITHOUT THE STATE.}

Section 1. Be it enacted, etc., That a last will and testament, executed without this state in the mode prescribed by the law, either of the place where executed or of the testator's domicile, shall be deemed to be legally executed, and shall be oi the same force and effect as if executed in the mode prescribed by the laws of this state, provided, said last will and testament is in writing and subscribed by the testator. 



\section{UNIFORM NEGOTIABLE INSTRUMENTS ACT}





\section{UNIFORM NEGOTIABLE INSTRUMENTS ACT}

This act represents the first attempt at securing uniformity of . State laws in America. At the annual conference of the Commissioners on Uniform State Iaws, held in Detroit in 1895, a resolution was passed requesting the Committee on Commercial Law to prepare, as soon as practicable, a draft of a bill relating to commercial paper based upon the English Bills of Exchange Act and upon such sources of information as the Committee might deem proper to consult. The matter was referred to a sub-committee consisting of Judge Lyman D. Brewster of Connecticut, Henry C. Willeox of New York and Frank Bergen of New Jersey. This committe secured Mr. John J. Crawford of the New York Bar, a well known expert on the law of bills and notes, to draft the proposed bill.

Mr. Crawford's draft was laid before the sub-committee and with amendments was submitted to the Conference at Saratoga in 1896. The twenty-seven commissioners who were in attendance representing fourteen different states - considered and debated it section by section, and made some amendments to it. The draft as thus amended was approved by the Conference and in such form has been submitted to the various state legislatures.

The Uniform Negotiable Instruments Act has now been enacted in fifty jurisdictions, including States, Territories and insular possessions. These jurisdictions with the dates of their respective adoptions of the act are: Alabama, 1909; Arizona, 1913; Arkansas, 1913; California, 1917; Colorado, 1897; Connecticut, 1897; Delaware, 1911; Florida, 1897; Idaho, 1903; Illinois, 1907; Indiana, 1913; Iowa, 1902 ; Kansas, 1905 ; Kentucky, 1904 ; Louisiana, 1904; Maine, 1917; Maryland, 1898; Massachusetts, 1898: Michigan, 1905; Minnesota, 1913; Mississippi, 1916; Missouri, 1905 ; Montana, 1903 ; Nebraska, 1905; Nevada, 1907; New Hampshire, 1909; New Jersey, 1902; New Mexico, 1907; New York. 1897; North Carolina, 1899; North Dakota, 1899; Ohio, 1902; Oklahoma, 1909 ; Oregon, 1899 ; Pennsylvania, 1901; Rhode Island, 
1899; South Carolina, 1914; South Dakota, 1913; Tennessee, 1899; Utah, 1899 ; Vermont, 1912 ; Virginia, 1897; Washington, 1899; West Virginia, 1907; Wisconsin, 1899; Wyoming, 1905; Alaska, 1913; Hawaii, 1907; District of Columbia, 1899; Philippine Islands, 1911.

The only jurisdictions where the Uniform Negotiable Instraments Act has not been enacted are Georgia, Porto Rico and Texas. 


\begin{tabular}{|c|c|c|c|c|c|c|c|c|c|}
\hline & $\begin{array}{l}\text { Lamb } \\
1909 \text {. } \\
\text { v } 126 .\end{array}$ & $\begin{array}{l}\text { L.sws } \\
1913 \text {. } \\
\text { ch. } 64 .\end{array}$ & $\begin{array}{c}\text { Rev. Stat. } \\
1901, \\
\text { tit. } 49\end{array}$ & $\begin{array}{l}\text { Laws } \\
1913 . \\
\text { Act } \$ 1 .\end{array}$ & $\begin{array}{l}\text { Californıa } \\
\text { Code. }\end{array}$ & $\begin{array}{c}\text { Rev. Stat. } \\
1908 . \\
\text { ch. } 95\end{array}$ & $\begin{array}{c}\text { Gen. Stat. } \\
1902 . \\
\text { tit. } 33 \\
\text { ch. } 234 .\end{array}$ & $\begin{array}{l}\text { Lawe } \\
\text { law11. } \\
\text { ch. } 191 .\end{array}$ & $\begin{array}{l}\text { U. S. Stat } \\
\text { vol. } 30 . \\
\text { p. } 785 \\
\text { (D.C. } \\
\text { Code. } \\
\text { ch. } 46 \text { ) }\end{array}$ \\
\hline $\begin{array}{l}\text { Uniforto } \\
\text { Act } \\
\text { Sec. No. }\end{array}$ & $\begin{array}{l}1909 \\
\mathrm{Alz}\end{array}$ & $\begin{array}{c}1913 \\
\text { Alaska }\end{array}$ & $\begin{array}{c}1913 \\
\text { Arizonz }\end{array}$ & $\begin{array}{l}1913 \\
\text { Ark. }\end{array}$ & $\begin{array}{c}1917 \\
\text { Califordia }\end{array}$ & $\begin{array}{l}1897 \\
\text { Colorado }\end{array}$ & $\begin{array}{l}1897 \\
\text { Conn }\end{array}$ & $\begin{array}{l}1911 \\
\text { Del. }\end{array}$ & $\begin{array}{l}1898 \\
\text { D. C. }\end{array}$ \\
\hline 1 & I & 1 & 3301 & 1 & 3082 & 4161 & 4171 & 1 & 1 \\
\hline $\begin{array}{l}1 \\
2\end{array}$ & 2 & 2 & 3305 & 2 & 3083 & 446.5 & 4172 & 2 & 2 \\
\hline 3 & 3 & 3 & 3306 & 3 & 3081 & 4166 & 4173 & 3 & 3 \\
\hline 4 & 4 & 4 & 3307 & 4 & 3085 & 4467 & 4174 & 4 & 4 \\
\hline 5 & 5 & 5 & 3308 & 5 & 3086 & 4468 & 4175 & 5 & 5 \\
\hline 6 & 6 & 6 & 3309 & 6 & 3087 & 4469 & 4176 & 6 & 6 \\
\hline 7 & 7 & 7 & 3310 & 7 & 3088 & 4470 & 4177 & 7 & 7 \\
\hline 8 & 8 & 8 & 3311 & 8 & 3089 & 4471 & 4178 & 8 & 8 \\
\hline 9 & 9 & 9 & 3312 & 9 & 3090 & 4472 & 4179 & 9 & 9 \\
\hline 10 & 10 & 10 & 3313 & 10 & 3091 & 4473 & 4180 & 10 & 10 \\
\hline 11 & 11 & 11 & 3314 & 11 & 3092 & 4474 & 4181 & 11 & 11 \\
\hline 12 & 12 & 12 & 3315 & 12 & 3093 & 4.175 & 4182 & 12 & 12 \\
\hline 13 & 13 & 13 & 3316 & 13 & 3094 & 4476 & 4183 & 13 & 13 \\
\hline 14 & 14 & 14 & 3317 & 14 & 3095 & 4477 & 4184 & 14 & 14 \\
\hline 15 & 15 & 15 & 3318 & 15 & 3096 & 4478 & 4185 & 15 & 15 \\
\hline 10 & 16 & 16 & 3319 & 16 & 3097 & 4479 & 4186 & 16 & 16 \\
\hline 17 & 17 & 17 & 3320 & 17 & 3098 & 4480 & 4187 & 17 & 17 \\
\hline 18 & 18 & 18 & 3321 & 18 & 3099 & 4481 & 4188 & 18 & 18 \\
\hline 19 & 19 & 19 & 3.322 & 19 & 3100 & 4482 & 4189 & 19 & 19 \\
\hline 20 & 20 & 20 & 3323 & 20 & 3101 & 4483 & 4190 & 20 & 20 \\
\hline 21 & 2] & 21 & 3324 & 21 & 3102 & 4484 & 4191 & 21 & 21 \\
\hline 22 & 22 & 22 & 3325 & 22 & 3103 & 4485 & 4192 & 22 & 22 \\
\hline 23 & 23 & 23 & 3326 & 23 & 3101 & 4486 & 4193 & 23 & 23 \\
\hline 24 & 24 & 24 & 3327 & 24 & 3105 & 4487 & 4194 & 24 & 24 \\
\hline 25 & 25 & 25 & 3328 & 25 & 3106 & 4488 & 4195 & 25 & 25 \\
\hline 26 & 26 & 26 & 3329 & 26 & 3107 & 4489 & 4196 & 26 & 26 \\
\hline 27 & 27 & 27 & 3.3 .30 & 27 & 3108 & 4490 & 4197 & 27 & 27 \\
\hline 28 & 28 & 28 & 3331 & 28 & 3109 & 4491 & 4198 & 28 & 28 \\
\hline 29 & 29 & 29 & 3332 & 29 & 3110 & 4492 & $4199^{\prime}$ & 29 & 29 \\
\hline 30 & 30 & 30 & 3333 & 30 & 3111 & 4493 & 4200 & 30 & 30 \\
\hline 31 & 31 & 31 & 3331 & 31 & 3112 & 4494 & 4201 & 31 & 31 \\
\hline 32 & 32 & 32 & 3335 & 32 & 3113 & 4495 & 4202 & 32 & 32 \\
\hline 33 & 33 & 33 & 3336 & 33 & 3114 & 4496 & 4203 & 33 & 33 \\
\hline 31 & 34 & 34 & 3337 & 34 & 3115 & 4497 & 4204 & 34 & 34 \\
\hline 35 & 35 & 35 & 3338 & 35 & 3116 & 4498 & 4205 & 35 & 35 \\
\hline 36 & 36 & 36 & 3339 & 36 & 3117 & 4499 & 4206 & 36 & 36 \\
\hline 37 & 37 & 37 & 33.10 & 37 & 3118 & 4500 & 4207 & 37 & 37 \\
\hline 38 & 38 & 38 & 3311 & 38 & 3119 & 4501 & 4208 & 38 & 38 \\
\hline 39 & 39 & 39 & 3342 & 39 & 3120 & 4502 & 4209 & 39 & 39 \\
\hline 40 & 40 & 40 & 3343 & 40 & 3121 & 4503 & 4210 & 40 & 40 \\
\hline 41 & 41 & 41 & 3314 & 41 & 3122 & 4504 & 4211 & 41 & 41 \\
\hline 42 & 12 & 42 & 3315 & 42 & 3123 & 4505 & 4212 & 42 & 42 \\
\hline 43 & 43 & 43 & 3316 & 43 & 3124 & 4506 & 4213 & 43 & 43 \\
\hline 44 & 44 & 44 & 3347 & 44 & 3125 & 4507 & 4214 & 44 & 44 \\
\hline 45 & 45 & 45 & 3348 & 45 & 3126 & 4508 & 4215 & 45 & 45 \\
\hline 46 & 46 & 46 & 33.19 & 46 & 3127 & 4509 & 4216 & 46 & 46 \\
\hline 17 & 47 & 47 & 3350 & 47 & 3128 & 4510 & 4217 & 47 & 47 \\
\hline
\end{tabular}




\begin{tabular}{|c|c|c|c|c|c|c|c|c|c|}
\hline & $\begin{array}{l}\text { Laws } \\
1909 . \\
\text { p. } 126 .\end{array}$ & $\begin{array}{l}\text { Laws } \\
1913 \\
\text { ch. } 64 .\end{array}$ & $\begin{array}{c}\text { Rev. Stat. } \\
1901 . \\
\text { tit. } 49\end{array}$ & $\begin{array}{r}\text { Laws } \\
1913, \\
\text { Act } \$ 1 .\end{array}$ & $\begin{array}{c}\text { Cslifornia } \\
\text { Code, }\end{array}$ & $\begin{array}{c}\text { Rev. Stat. } \\
1908, \\
\text { ch. } 95 .\end{array}$ & $\begin{array}{c}\text { Gen. Stat. } \\
1902 \text {, } \\
\text { tit. } 33 \text {, } \\
\text { ch. } 234 .\end{array}$ & $\begin{array}{l}\text { Laws } \\
1911, \\
\text { ch. } 191 .\end{array}$ & $\begin{array}{l}\text { U. S. Stat. } \\
\text { voi. } 30 \text {, } \\
\text { p. } 785 \\
\text { (D.C. } \\
\text { Code, } \\
\text { ch. 46). }\end{array}$ \\
\hline $\begin{array}{l}\text { Oniform } \\
\text { Act } \\
\text { Sec. No. }\end{array}$ & $\begin{array}{l}1909 \\
\text { Ala. }\end{array}$ & $\begin{array}{c}1913 \\
\text { Alaska }\end{array}$ & $\begin{array}{c}1913 \\
\text { Arizona }\end{array}$ & $\begin{array}{l}1913 \\
\text { Ark. }\end{array}$ & $\begin{array}{c}1917 \\
\text { Californiz }\end{array}$ & $\begin{array}{c}1897 \\
\text { Colorado }\end{array}$ & $\begin{array}{l}1897 \\
\text { Conn. }\end{array}$ & $\begin{array}{l}1911 \\
\text { Del. }\end{array}$ & $\begin{array}{l}1899 \\
\text { D. C. }\end{array}$ \\
\hline 48 & 48 & 48 & 3351 & 48 & 3129 & 4511 & 4218 & 48 & 48 \\
\hline 49 & 49 & 49 & 3352 & 49 & 3130 & 4512 & 4219 & 49 & 49 \\
\hline 50 & 50 & 50 & 3353 & 50 & 3131 & 4513 & 4220 & 50 & 50 \\
\hline 51 & 51 & 51 & 3354 & 51 & 3132 & 4514 & 4221 & 51 & 51 \\
\hline 52 & 52 & 52 & 3355 & 52 & 3133 & 4515 & 4222 & 52 & 52 \\
\hline 53 & 53 & 53 & 33.56 & 53 & 3134 & 4516 & 4223 & 53 & 53 \\
\hline 54 & 54 & 54 & 3357 & 54 & 3135 & 4517 & 4224 & 54 & 54 \\
\hline 55 & 55 & 55 & 3358 & 55 & 3136 & 4518 & 4225 & 55 & 55 \\
\hline 56 & 56 & 56 & 3359 & 56 & 3137 & 4519 & 4226 & 56 & 56 \\
\hline 57 & 57 & 57 & 3360 & 57 & 3138 & 4520 & 4227 & 57 & 57 \\
\hline 58 & 58 & 58 & 3361 & 58 & 3139 & 4521 & 4228 & 58 & 58 \\
\hline 59 & 59 & 59 & 3362 & 59 & 3140 & 4522 & 4229 & 59 & 59 \\
\hline 60 & 60 & 60 & 3363 & 60 & 3141 & 4523 & 4230 & 60 & 60 \\
\hline 61 & 61 & 61 & 3364 & 61 & 3142 & 4521 & 4231 & 61 & 61 \\
\hline 62 & 62 & 62 & 3365 & 62 & 3143 & 4525 & 4232 & 62 & 62 \\
\hline 63 & 63 & 63 & 3366 & 63 & 3144 & 4526 & 4233 & 63 & 63 \\
\hline 64 & 64 & 64 & 3367 & 64 & 3145 & 4527 & 4234 & 64 & 64 \\
\hline 65 & 65 & 65 & 3368 & 65 & 3146 & 4528 & 4235 & 65 & 65 \\
\hline 66 & 66 & 66 & 3369 & 66 & 3147 & 4529 & 4236 & 66 & 66 \\
\hline 67 & 67 & 67 & 3370 & 67 & 3148 & 4530 & 4237 & 67 & 67 \\
\hline 68 & 68 & 68 & 3371 & 68 & 3149 & 4531 & 4238 & 68 & 68 \\
\hline 69 & 69 & 69 & 3372 & 69 & 3150 & 4532 & 4239 & 69 & 69 \\
\hline 70 & 70 & 70 & 3373 & 70 & 3151 & 4533 & 4240 & 70 & 70 \\
\hline 71 & 71 & 71 & 3374 & 71 & 3152 & 4534 & 4241 & 71 & 71 \\
\hline 72 & 72 & 72 & 3375 & 72 & 3153 & 4535 & 4242 & 72 & 72 \\
\hline 73 & 73 & 73 & 3376 & 73 & 3154 & 4536 & 4243 & 73 & 73 \\
\hline 74 & 74 & 74 & 3377 & 74 & 3155 & 4537 & 4244 & 74 & 74 \\
\hline 75 & 75 & 75 & 3378 & 75 & 3156 & 4538 & 4245 & 75 & 75 \\
\hline 76 & 76 & 76 & 3379 & 76 & 3157 & 4539 & 4246 & 76 & 76 \\
\hline 77 & 77 & 78 & 3380 & 77 & 3158 & 4540 & 4247 & 77 & 77 \\
\hline 78 & 78 & 78 & 3381 & 78 & 3159 & 4541 & 4248 & 78 & 78 \\
\hline 79 & 79 & 79 & 3382 & 79 & 3160 & 4542 & 4249 & 79 & 79 \\
\hline 80 & 80 & 80 & 3383 & 80 & 3161 & 4543 & 4250 & 80 & 80 \\
\hline 81 & 8] & 81 & 3384 & 81 & 3162 & 4544 & 4251 & 81 & 81 \\
\hline 82 & 82 & 82 & 338.5 & 82 & 3163 & 4545 & 4252 & 82 & 82 \\
\hline 83 & 83 & 83 & 3386 & 83 & 3164 & 4546 & 4253 & 83 & 83 \\
\hline 84 & 84 & 84 & 3387 & 84 & 3165 & 4547 & 4254 & 84 & 84 \\
\hline 85 & 8.5 & 85 & 3388 & 85 & 3166 & 4548 & 4255 & 85 & 85 \\
\hline 86 & 86 & 86 & 3389 & 86 & 3167 & 4549 & 4256 & 86 & 86 \\
\hline 87 & 87 & 87 & 3390 & 37 & 3168 & 4550 & 4257 & 87 & 87 \\
\hline 88 & 88 & 88 & 3391 & 88 & 3169 & 4551 & 4258 & 88 & 88 \\
\hline 89 & 89 & 89 & 3392 & 89 & 3170 & 4552 & 4259 & 89 & 89 \\
\hline 90 & 90 & 90 & 3393 & 90 & 3171 & 4553 & 4260 & 90 & 90 \\
\hline 91 & 91 & 91 & 3394 & 91 & 3172 & 4554 & 4261 & 91 & 91 \\
\hline 92 & 92 & 92 & 3395 & 92 & 3173 & 4555 & 4.262 & 92 & 92 \\
\hline 93 & 93 & 93 & 3396 & 93 & 3174 & 4556 & 4263 & 93 & 93 \\
\hline 94 & 94 & 94 & 3397 & 94. & 3175 & 4557 & 4264 & 94 & 94 \\
\hline
\end{tabular}




\begin{tabular}{|c|c|c|c|c|c|c|c|c|c|}
\hline & $\begin{array}{l}\text { Laws } \\
1909 . \\
\text { p. } 126 .\end{array}$ & $\begin{array}{c}\text { Laws } \\
1913 \\
\text { ch. } 64 .\end{array}$ & $\begin{array}{c}\text { Rev Stat. } \\
1901 \\
\text { tit. } 49\end{array}$ & $\begin{array}{l}\text { Law- } \\
1913 \\
\text { Act } 91 .\end{array}$ & $\begin{array}{c}\text { California } \\
\text { Code. }\end{array}$ & $\begin{array}{l}\text { Rev. Stat. } \\
1908 \\
\text { ch. } 95 .\end{array}$ & $\begin{array}{c}\text { Gen. Stat. } \\
1902 \\
\text { tit. } 33 \\
\text { et. } 234 .\end{array}$ & $\begin{array}{l}\text { Laws } \\
1911, \\
\text { ch. } 191 .\end{array}$ & $\begin{array}{l}\text { U. S. Stat } \\
\text { vol. } 30 . \\
\text { D. } 785 \\
\text { (D.C. } \\
\text { Code. } \\
\text { ch. } 46 \text { ). }\end{array}$ \\
\hline $\begin{array}{l}\text { Uniform } \\
\text { Act } \\
\text { Ser. No. }\end{array}$ & $\begin{array}{l}1909 \\
\text { Ala. }\end{array}$ & $\begin{array}{c}1913 \\
\text { Alaska }\end{array}$ & $\begin{array}{c}1913 \\
\text { Arizona }\end{array}$ & $\begin{array}{l}1913 \\
\text { Ark. }\end{array}$ & $\begin{array}{c}1917 \\
\text { Califordia }\end{array}$ & $\begin{array}{c}1897 \\
\text { Colorado }\end{array}$ & $\begin{array}{l}1897 \\
\text { Conn. }\end{array}$ & $\begin{array}{l}1911 \\
\text { De!. }\end{array}$ & $\begin{array}{l}1899 \\
\text { D. C. }\end{array}$ \\
\hline 95 & 95 & 95 & 3398 & 95 & 3176 & 15.58 & 4265 & 95 & 95 \\
\hline 96 & 96 & 96 & 3399 & 96 & 3177 & 1559 & 1266 & 96 & 96 \\
\hline 97 & 97 & 97 & 3400 & 97 & 3178 & 1560 & 4267 & 97 & 97 \\
\hline 98 & 98 & 98 & 3401 & 98 & 3179 & 4561 & 4268 & 98 & 98 \\
\hline 99 & 99 & 99 & 3402 & 99 & 3180 & 4562 & 4269 & 99 & 99 \\
\hline 100 & 100 & 100 & 3403 & 100 & 3181 & 4563 & 4270 & 100 & 100 \\
\hline 101 & 101 & 101 & 3401 & 101 & 3182 & 4564 & 4271 & 101 & 101 \\
\hline 102 & 102 & 102 & $340 j$ & 102 & 3183 & 4565 & 4272 & 102 & 102 \\
\hline 103 & 103 & 103 & 3406 & 103 & 3184 & 4566 & 4273 & 103 & 103 \\
\hline 10.4 & 101 & 101 & 3407 & $10 \mathrm{t}$ & 3185 & 4567 & 4274 & 10.1 & 104 \\
\hline 105 & 105 & 105 & 3408 & 105 & 3186 & 4568 & 4275 & 105 & 105 \\
\hline 106 & 106 & 106 & 3409 & 106 & 3187 & 4569 & 4276 & 106 & 106 \\
\hline 107 & 107 & 107 & 3410 & 107 & 3188 & 4570 & 4277 & 107 & 107 \\
\hline 108 & 108 & 108 & 3411 & 108 & 3189 & 4571 & 4278 & 108 & 108 \\
\hline 109 & 109 & 109 & 3412 & 109 & 3190 & 1572 & 4279 & 109 & 109 \\
\hline 110 & 110 & 110 & 3413 & 110 & 3191 & 4573 & 4280 & 110 & 110 \\
\hline 111 & 111 & i1] & 3414 & 111 & 310 & 45 & 4281 & 111 & 111 \\
\hline 112 & 112 & 112 & 3415 & 112 & 3193 & 4575 & 4282 & 112 & 112 \\
\hline 113 & 11.3 & 113 & $? .416$ & 113 & 3194 & 4576 & 4283 & 113 & 113 \\
\hline 11.1 & 114 & 114 & 3117 & 114 & 3195 & $457 ?$ & 4281 & 114 & 114 \\
\hline 115 & 115 & 115 & 3418 & 115 & 3196 & 4578 & 4285 & 115 & 115 \\
\hline 116 & 116 & 116 & 3419 & 116 & 319 & 4579 & 4286 & 116 & 116 \\
\hline 117 & 117 & 117 & 3120 & 117 & 3198 & 4580 & 4287 & 117 & 117 \\
\hline 118 & 118 & 118 & 3421 & 118 & 3199 & 4581 & 4288 & 118 & 118 \\
\hline 119 & 119 & 119 & 3422 & 119 & 3200 & 4582 & 4289 & 119 & 119 \\
\hline 120 & 120 & 120 & 3.23 & 120 & 3201 & 4583 & 4290 & 120 & 120 \\
\hline 121 & 121 & 121 & 3124 & 121 & 3202 & 4581 & 4291 & 121 & 121 \\
\hline 122 & 122 & 122 & 342 & 122 & 3203 & 4585 & 4292 & 122 & 122 \\
\hline 123 & 123 & 123 & 3426 & 123 & 3204 & 4586 & 4293 & 123 & 123 \\
\hline 124 & 121 & 12.4 & 3427 & 124 & 320.5 & 4587 & 4291. & 12.1 & 124 \\
\hline 125 & 125 & 125 & 3128 & 125 & 3206 & 4588 & 4295 & 125 & 125 \\
\hline 126 & 126 & 126 & 312 & 126 & 320 & 4589 & 4296 & 126 & 126 \\
\hline 127 & 127 & 127 & 3130 & 127 & 320 & 4590 & 4297 & 127 & 127 \\
\hline 128 & $12\}$ & 128 & 3131 & 128 & 3209 & 4591 & 4298 & 128 & 128 \\
\hline 129 & 129 & 129 & 3132 & 129 & & & 4299 & 129 & 129 \\
\hline 130 & 130 & 130 & 3433 & 130 & 3211 & 4503 & 4300 & 130 & 130 \\
\hline 131 & 131 & 131 & 3131 & 131 & 3212 & 4504 & 4301 & 131 & 131 \\
\hline 132 & 132 & 132 & 3135 & $1: 32$ & 3213 & 4595 & 4302 & 132 & 132 \\
\hline 133 & 133 & 133 & 3436 & 1333 & 3214 & 4596 & 4303 & 133 & 133 \\
\hline 134 & 131 & 13.1 & 3137 & 131 & 3215 & 4597 & 130.1 & 134 & 131 \\
\hline 135 & 135 & 135 & 3138 & 135 & 3216 & 4598 & 4305 & 135 & 135 \\
\hline 136 & 136 & 136 & 3439 & 136 & 3217 & 4599 & 4306 & 136 & 136 \\
\hline 137 & 137 & 137 & 3110 & 137 & 3218 & 4600 & 4307 & 137 & 137 \\
\hline i:34 & 138 & 138 & 344 & 138 & 3219 & 4601 & 4308 & 138 & 138 \\
\hline 139 & 139 & 139 & 3142 & 139 & 3220 & 4602 & 4309 & 139 & 139 \\
\hline 110 & 140 & 140 & 3443 & 140 & 3221 & 4603 & 4310 & 1.10 & 140 \\
\hline 141 & in1 & 141 & $3+11$ & 141 & 3222 & 4601 & 4311 & 141 & 141 \\
\hline
\end{tabular}




\begin{tabular}{|c|c|c|c|c|c|c|c|c|c|}
\hline & $\begin{array}{l}\text { Laws } \\
1909 \text {, } \\
\text { p. } 126 .\end{array}$ & $\begin{array}{l}\text { Laws } \\
1913, \\
\text { ch. 64. }\end{array}$ & $\begin{array}{c}\text { Rev. Stat. } \\
1901 \\
\text { tit. } 49\end{array}$ & $\begin{array}{l}\text { Law } \\
1913, \\
\text { Aet } 51 .\end{array}$ & $\begin{array}{l}\text { California } \\
\text { Code, }\end{array}$ & $\begin{array}{c}\text { Rev. Stat } \\
1908, \\
\text { ch. } 95 .\end{array}$ & $\begin{array}{l}\text { Gen. Stat. } \\
1902 \\
\text { tit. } 33 \\
\text { ch. } 234 .\end{array}$ & $\begin{array}{l}\text { Laws } \\
1911, \\
\text { ch. } 191 .\end{array}$ & $\begin{array}{c}\text { C. S. Stat } \\
\text { vol. } 30 . \\
\text { p. } 785 \\
\text { (D.C. } \\
\text { Code. } \\
\text { ch. } 46) .\end{array}$ \\
\hline $\begin{array}{l}\text { Uniform } \\
\text { Act } \\
\text { Se. No. }\end{array}$ & $\begin{array}{l}1909 \\
\mathrm{Ala}\end{array}$ & $\begin{array}{c}1913 \\
\text { Alaska }\end{array}$ & $\begin{array}{c}1913 \\
\text { Arizona }\end{array}$ & $\begin{array}{l}1913 \\
\text { Ark. }\end{array}$ & $\begin{array}{c}1917 \\
\text { California }\end{array}$ & $\begin{array}{c}3897 \\
\text { Colorado }\end{array}$ & $\begin{array}{l}1897 \\
\text { Conn. }\end{array}$ & $\begin{array}{l}1911 \\
\text { Del. }\end{array}$ & $\begin{array}{l}1899 \\
\text { D. C. }\end{array}$ \\
\hline 142 & 142 & 142 & 3445 & 142 & 3223 & 4605 & 4312 & 142 & 142 \\
\hline 143 & 143 & 143 & 3446 & 143 & 3224 & 4606 & 4313 & 143 & 143 \\
\hline 144 & 144 & 144 & 3447 & 144 & 3225 & 4607 & 4314 & 144 & 144 \\
\hline 145 & 145 & 145 & $\mathbf{3 4 4 8}$ & 145 & 3226 & 4608 & 4315 & 145 & 145 \\
\hline 146 & 146 & 146 & 3449 & 146 & 3227 & 4609 & 4316 & 146 & 146 \\
\hline 147 & 147 & 147 & 3450 & 147 & 3228 & 4610 & 4317 & 147 & 147 \\
\hline 148 & 148 & 148 & 3451 & 148 & 3229 & 4611 & 4318 & 148 & 148 \\
\hline 149 & 149 & 149 & 3452 & 149 & 323 & 4612 & 4319 & 149 & 149 \\
\hline 150 & 150 & 150 & 3453 & 150 & 3231 & 4613 & 4320 & 150 & 150 \\
\hline 151 & 151 & 151 & 3454 & 151 & 3232 & 4614 & 4321 & 151 & 151 \\
\hline 152 & 152 & 152 & 3455 & 152 & 3233 & 4615 & 4322 & 152 & 152 \\
\hline 153 & 153 & 153 & 3456 & 153 & 32 & 4616 & 4323 & 153 & 153 \\
\hline 154 & 154 & 154 & 3457 & 154 & 3235 & 4617 & 4324 & 154 & 154 \\
\hline 155 & 155 & 155 & 3458 & 155 & 3236 & 4618 & 4325 & 155 & 155 \\
\hline 156 & 156 & 156 & 3459 & 156 & 3237 & 4619 & 4326 & 156 & 156 \\
\hline 157 & 157 & 157 & 3460 & 157 & 3238 & 4620 & 4327 & 157 & 157 \\
\hline 158 & 158 & 158 & 3461 & 158 & 3239 & 4621 & 4328 & 158 & 158 \\
\hline 159 & 159 & 159 & 3462 & 159 & 3240 & 4622 & 4329 & 150 & 159 \\
\hline 160 & 160 & 160 & 3463 & 160 & 3241 & 4623 & 4330 & 160 & 160 \\
\hline 161 & 161 & 161 & 3464 & 161 & 3242 & 4624 & 4331 & 161 & 161 \\
\hline 162 & 162 & 162 & 3465 & 162 & 3243 & 4625 & 4332 & 162 & 162 \\
\hline 163 & 163 & 163 & 3466 & 163 & 3244 & 4626 & 4333 & 163 & 163 \\
\hline 164 & 164 & 164 & 3467 & 164 & 3245 & 4627 & 4334 & 164 & 164 \\
\hline 165 & 165 & 165 & 3468 & 165 & 3246 & 4628 & 4335 & 165 & 165 \\
\hline 166 & 166 & 166 & 3469 & 166 & 3217 & 4629 & 4336 & 166 & 166 \\
\hline 167 & 167 & 167 & 3170 & 167 & 3248 & 4630 & 4337 & 167 & 167 \\
\hline 168 & 168 & 168 & 3471 & 168 & 3249 & 4631 & 4338 & 168 & 168 \\
\hline 169 & 169 & 169 & 3472 & 169 & 3250 & 4632 & 4339 & 169 & 169 \\
\hline 170 & 170 & 170 & 3473 & 170 & 3251 & 4633 & 4340 & 170 & 170 \\
\hline 171 & 171 & 171 & 3474 & 171 & 3252 & 4634 & 4341 & 171 & 171 \\
\hline 172 & 172 & 172 & 3475 & 172 & 3253 & 4635 & 4342 & 172 & 172 \\
\hline 173 & 173 & 173 & 3476 & 173 & 3254 & 4636 & 4313 & 173 & 173 \\
\hline 174 & 174 & 174 & 3477 & 174 & 3255 & 4637 & 4344 & 174 & 174 \\
\hline 175 & 175 & 175 & 3478 & 175 & 3256 & 4638 & 4315 & 175 & 175 \\
\hline 176 & 176 & 176 & 3479 & 176 & 32 & 46 & 4346 & 176 & 176 \\
\hline 177 & 177 & 177 & 3480 & 177 & 3258 & 4640 & 4347 & 177 & 177 \\
\hline 178 & 178 & 178 & 318 & 178 & 3259 & 4611 & 4348 & 178 & 178 \\
\hline 179 & 179 & 179 & 3482 & 179 & 3260 & 46 & 4349 & 179 & 179 \\
\hline 180 & 180 & 180 & 3483 & 180 & 3261 & & 4350 & 180 & 180 \\
\hline 181 & 181 & 181 & 348 & 181 & 32 & & 4351 & 181 & 181 \\
\hline 182 & 182 & 182 & 348 & 182 & 32 & & 4352 & 182 & 182 \\
\hline 183 & 183 & 183 & 3486 & 183 & 3264 & 4646 & 4353 & 183 & 183 \\
\hline 184 & 184 & 181 & & 184 & 3265 & 4647 & 4354 & 184 & 184 \\
\hline 185 & 185 & 185 & & 185 & $3265 a$ & & 4355 & 185 & 185 \\
\hline 186 & 186 & 186 & & 186 & $3265 b$ & 4649 & 4356 & 186 & 186 \\
\hline 187 & 187 & 187 & $\ldots$ & 187 & $3265 \mathrm{c}$ & 4650 & 4357 & 187 & 187 \\
\hline
\end{tabular}




\begin{tabular}{|c|c|c|c|c|c|c|c|c|c|}
\hline & $\begin{array}{l}\text { Lsws } \\
1909 . \\
\text { p. } 126 .\end{array}$ & $\begin{array}{l}\text { Laws } \\
1913 \text {. } \\
\text { cb. } 64 .\end{array}$ & $\begin{array}{c}\text { Rev. Stat. } \\
1901, \\
\text { tit. } 49\end{array}$ & $\begin{array}{c}\text { Law: } \\
1913, \\
\text { Act } 81 .\end{array}$ & $\begin{array}{l}\text { California } \\
\text { Code. }\end{array}$ & $\begin{array}{l}\text { Rev. Stat. } \\
1908 \text {. } \\
\text { ch. } 95 .\end{array}$ & $\begin{array}{c}\text { Gen. Stat. } \\
1902 \\
\text { tit. } 33 \\
\text { ch. } 234 .\end{array}$ & $\begin{array}{l}\text { Laws } \\
1911, \\
\text { ch. } 191 .\end{array}$ & $\begin{array}{l}\text { U. S. Stat. } \\
\text { vol. 30. } \\
\text { p.785 } \\
\text { (D.C. } \\
\text { Code. } \\
\text { ch. 46). }\end{array}$ \\
\hline $\begin{array}{l}\text { Uniform } \\
\text { Act } \\
\text { Se?. No. }\end{array}$ & $\begin{array}{l}1909 \\
\text { Ala. }\end{array}$ & $\begin{array}{c}1913 \\
\text { Aleska }\end{array}$ & $\begin{array}{c}1913 \\
\text { Arizona }\end{array}$ & $\begin{array}{l}1913 \\
\text { Afk. }\end{array}$ & $\begin{array}{c}1917 \\
\text { Californas }\end{array}$ & $\begin{array}{l}1897 \\
\text { Colorado }\end{array}$ & $\begin{array}{l}\text { [897 } \\
\text { Conn. }\end{array}$ & $\begin{array}{l}1911 \\
\text { Del. }\end{array}$ & $\begin{array}{l}1899 \\
\text { D. C. }\end{array}$ \\
\hline 188 & 188 & 188 & $\ldots$ & 188 & $3265 d$ & $4.65 I$ & 4358 & 188 & 188 \\
\hline 189 & 189 & 189 & . & 189 & $3265 \mathrm{e}$ & 4652 & 4359 & 189 & 189 \\
\hline 190 & 190 & 190 & & 190 & & 4653 & & 190 & \\
\hline 191 & 191 & 191 & 3487 & 191 & 3266 & 4654 & 4170 & 191 & * \\
\hline 192 & 192 & 192 & $\mathbf{3 4 8 8}$ & 192 & $3266 a$ & 4655 & 4170 & 192 & • \\
\hline 193 & 193 & 193 & 3489 & 193 & $3266 \mathrm{~b}$ & 4656 & 4170 & 193 & * \\
\hline 194 & 194 & 194 & 3490 & 194 & $3266 c$ & 4657 & 4170 & 194 & $*$ \\
\hline 195 & 195 & 195 & & 195 & $3266 d$ & 4658 & 4170 & 195 & * \\
\hline 196 & 196 & 196 & 3491 & 196 & $3266 d$ & 4659 & 4170 & 196 & $*$ \\
\hline 197 & 197 & 197 & & 197 & $\ldots$ & $\ldots$ & $\cdots$ & 197 & 190 \\
\hline 198 & 198 & 198 & $\ldots$ & 198 & $\ldots$ & $\ldots$ & $\ldots$ & 198 & 191 \\
\hline
\end{tabular}

- General introduction. 


\begin{tabular}{|c|c|c|c|c|c|c|}
\hline & $\begin{array}{l}\text { Gen. Stat. } \\
1906 \text {. } \\
\text { ath Dir } \\
\text { tit. } 5 \text {. } \\
\text { ch. } 2 \text {. }\end{array}$ & $\begin{array}{c}\text { Laws } 190 \bar{i} . \\
\text { Act } 89 .\end{array}$ & $\begin{array}{c}\text { Pev. Codes } \\
1908 \\
\text { tit. } 13 \\
\text { p. } 1326 .\end{array}$ & $\begin{array}{c}\text { Rev. Stat. } \\
1911 . \\
\text { ch. } 98 .\end{array}$ & $\begin{array}{l}\text { Laws } 1913 . \\
\text { ch. } 63 .\end{array}$ & $\begin{array}{c}\text { Code Supp } \\
\text { 1907, } \\
\text { tit. } 15, \\
\text { p. } 729 .\end{array}$ \\
\hline $\begin{array}{l}\text { Uniform } \\
\text { Act } \\
\text { Sec. No. }\end{array}$ & $\begin{array}{l}1897 \\
\text { Filorida }\end{array}$ & $\begin{array}{c}190 \bar{i} \\
\text { Hawasi }\end{array}$ & $\begin{array}{l}1903 \\
\text { tdaho }\end{array}$ & $\begin{array}{l}1907 \\
\text { Illinois }\end{array}$ & $\begin{array}{c}1913 \\
\text { Indiana }\end{array}$ & $\begin{array}{l}1907 \\
\text { lowa }\end{array}$ \\
\hline 1 & 2935 & 1 & 3458 & 19 & 1 & 1 \\
\hline 2 & 2936 & 2 & 3459 & 20 & 2 & 2 \\
\hline 3 & 2937 & 3 & 3460 & 21 & 3 & 3 \\
\hline 4 & 2938-9 & 4 & 3461 & 22 & 4 & 4 \\
\hline 5 & 2939 & 5 & 3462 & 23 & 5 & 5 \\
\hline 6 & 2940 & 6 & 3463 & 24 & 6 & 6 \\
\hline 7 & 2941 & 7 & 3464 & 25 & 7 & 7 \\
\hline 8 & 2942 & 8 & 3465 & 26 & 8 & 8 \\
\hline 9 & 2943 & 9 & 3466 & 27 & 9 & 9 \\
\hline 10 & 2914 & 10 & 3467 & 28 & 10 & 10 \\
\hline 11 & 2945 & 11 & 3468 & 29 & 11 & 11 \\
\hline 12 & 2946 & 12 & 3469 & 30 & 12 & 12 \\
\hline 13 & 2917 & 13 & 3470 & 31 & 13 & 13 \\
\hline 14 & 2948 & 14 & 3471 & 32 & 14 & 14 \\
\hline 15 & 2949 & 15 & 3472 & 33 & 15 & 15 \\
\hline 16 & 2950 & 16 & 3473 & 34 & 16 & 16 \\
\hline 17 & 2951 & 17 & 3474 & 35 & 17 & 17 \\
\hline 18 & 2952 & 18 & 3475 & 36 & 18 & 18 \\
\hline 19 & 2963 & 19 & 3476 & 37 & 19 & 19 \\
\hline 20 & 2954 & 20 & 3477 & 38 & 20 & 20 \\
\hline 21 & 2955 & 21 & 3478 & 39 & 21 & 21 \\
\hline 22 & 2956 & 22 & 3479 & 40 & 22 & 22 \\
\hline 23 & 2957 & 23 & 3480 & 41 & 23 & 23 \\
\hline 24 & 2958 & 24 & 3481 & 42 & 24 & 24 \\
\hline 25 & 2959 & 25 & 3482 & 43 & 25 & 25 \\
\hline 26 & 2960 & 26 & 3483 & 44 & 26 & 26 \\
\hline 27 & 2961 & 27 & 3484 & 45 & 27 & 27 \\
\hline 28 & 2962 & 28 & 3485 & 46 & 28 & 28 \\
\hline 29 & 2963 & 29 & 3486 & 47 & 29 & 29 \\
\hline 30 & 2964 & 30 & 3487 & 48 & 30 & 30 \\
\hline 31 & 2965 & 31 & 3488 & 49 & 31 & 31 \\
\hline 32 & 2966 & 32 & 3489 & 50 & 32 & 32 \\
\hline 33 & 2967 & 33 & 3490 & 51 & 33 & 33 \\
\hline 34 & 2968 & 34 & 3491 & 52 & 34 & 34 \\
\hline 35 & 2969 & 35 & 3492 & 53 & 35 & 35 \\
\hline 36 & 2970 & 36 & 3493 & 54 & 36 & 36 \\
\hline 37 & 2971 & 37 & 3494 & 55 & 37 & 37 \\
\hline 38 & 2972 & 38 & 3495 & 56 & 38 & 38 \\
\hline 39 & 2973 & 39 & 3496 & 57 & 39 & 39 \\
\hline 40 & 2974 & 40 & 3497 & 58 & 40 & 40 \\
\hline $4 i$ & 2975 & 41 & 3498 & 59 & 41 & 41 \\
\hline 42 & 2976 & 42 & 3499 & 60 & 42 & 42 \\
\hline 43 & 2977 & 43 & 3500 & 61 & 43 & 43 \\
\hline 44 & 2973 & 44 & 3501 & 62 & 44 & 44 \\
\hline 45 & 2979 & 45 & 3502 & 63 & 45 & 45 \\
\hline 46 & 2979 & 46 & 3503 & 64 & 46 & 46 \\
\hline 47 & 2980 & 47 & 3504 & 65 & 47 & 47 \\
\hline 48 & 2981 & 48 & 3505 & 66 & 48 & 48 \\
\hline 49 & 2982 & 49 & 3506 & 67 & 49 & 49 \\
\hline
\end{tabular}




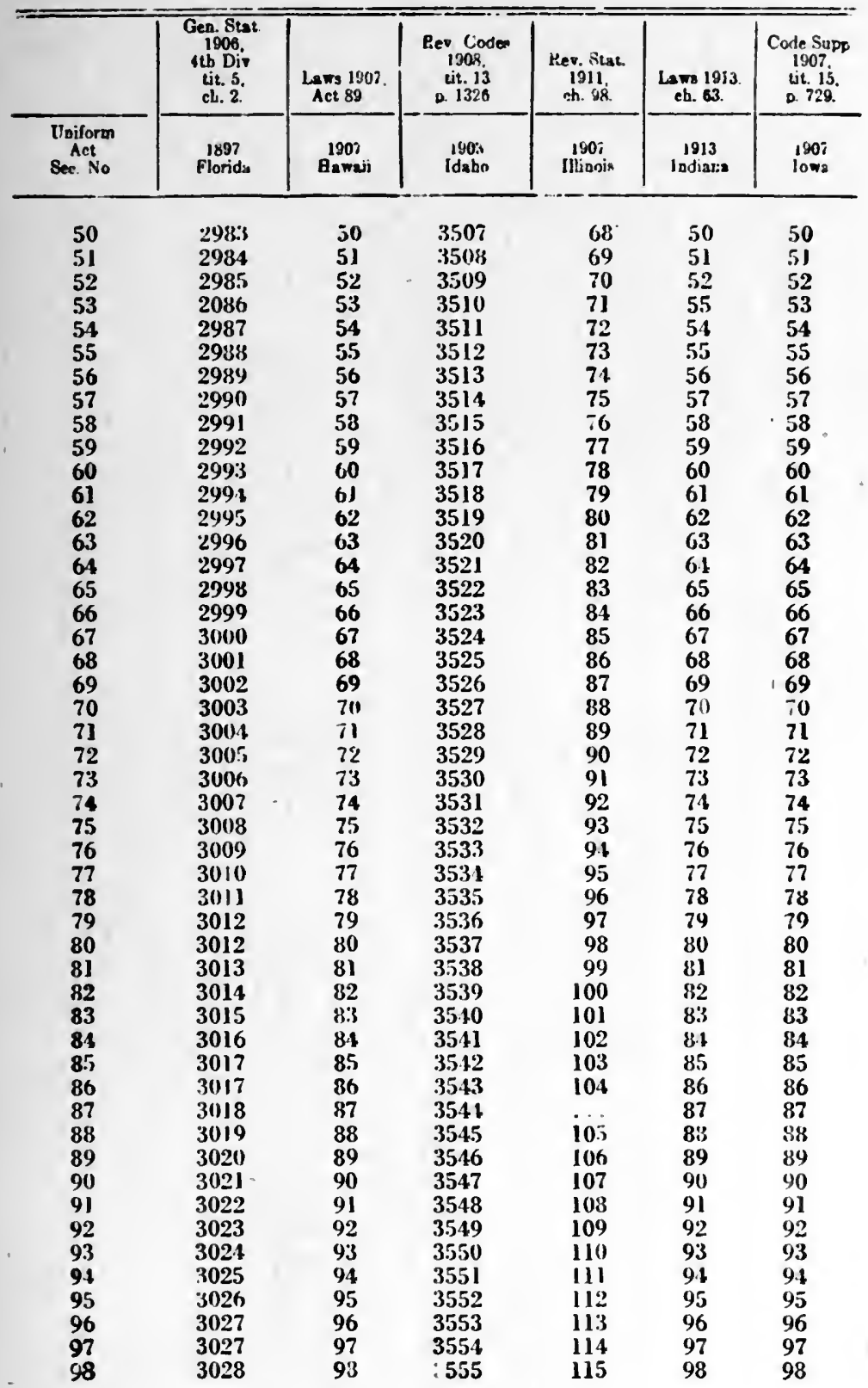




\begin{tabular}{|c|c|c|c|c|c|c|}
\hline & $\begin{array}{l}\text { Gen. Stat. } \\
1906 \text {, } \\
\text { 4th Div. } \\
\text { tit. 5, } \\
\text { ch. 2. }\end{array}$ & $\begin{array}{l}\text { Laws 1907, } \\
\text { Act } 89 .\end{array}$ & $\begin{array}{c}\text { Rev. Codes } \\
1908 \\
\text { tit. 13, } \\
\text { p. } 1326 .\end{array}$ & $\begin{array}{c}\text { Rev. Stat. } \\
\text { 1911, } \\
\text { ch. } 98 .\end{array}$ & $\begin{array}{l}\text { Lawg } 1913 . \\
\text { ch. } 63 .\end{array}$ & $\begin{array}{c}\text { Code Supp } \\
1907 \\
\text { tit. 15, } \\
\text { p. } 729 .\end{array}$ \\
\hline $\begin{array}{l}\text { Uniform } \\
\text { Act } \\
\text { Sec. No. }\end{array}$ & $\begin{array}{l}1897 \\
\text { Florida }\end{array}$ & $\begin{array}{c}1907 \\
\text { Hawaii }\end{array}$ & $\begin{array}{l}1903 \\
\text { Idaho }\end{array}$ & $\begin{array}{l}1907 \\
\text { Illinois }\end{array}$ & $\begin{array}{c}1913 \\
\text { Indiana }\end{array}$ & $\begin{array}{l}1907 \\
\text { Iowa }\end{array}$ \\
\hline 99 & 3029 & 99 & 3556 & 116 & 99 & 99 \\
\hline 100 & 3029 & 100 & 3557 & 117 & 100 & 100 \\
\hline 101 & 3030 & 101 & 3558 & 118 & 101 & 101 \\
\hline 102 & 3031 & 102 & 3559 & 119 & 102 & 102 \\
\hline 103 & 3031 & 103 & 3560 & 120 & 103 & 103 \\
\hline 104 & 3032 & 104 & 3561 & 121 & 104 & 104 \\
\hline 105 & 3033 & 105 & 3562 & 122 & 105 & 105 \\
\hline 106 & 3033 & 106 & 3563 & 123 & 106 & 106 \\
\hline 107 & 3034 & 107 & 3564 & 124 & 107 & 107 \\
\hline 108 & 3035 & 108 & 3565 & 125 & 108 & 108 \\
\hline 109 & 3036 & 109 & 3566 & 126 & 109 & 109 \\
\hline 110 & 3036 & 110 & 3567 & 127 & 110 & 110 \\
\hline 111 & 3036 & 111 & 3568 & 128 & 111 & 111 \\
\hline 112 & 3037 & 112 & 3569 & 129 & 112 & 112 \\
\hline 113 & $\mathbf{3 0 3 8}$ & 113 & 3570 & 130 & 113 & 113 \\
\hline 114 & 3039 & 114 & 3571 & 131 & 114 & 114 \\
\hline 115 & 3039 & 115 & 3572 & 132 & 115 & 115 \\
\hline 116 & 3039 & 116 & 3573 & 133 & 116 & 116 \\
\hline 117 & 3040 & 117 & 3574 & 134 & 117 & 117 \\
\hline 118 & 3041 & 118 & 3575 & 135 & 118 & 118 \\
\hline 119 & 3042 & 119 & 3576 & 136 & 119 & 119 \\
\hline 120 & 3042 & 120 & 3577 & 137 & 120 & 120 \\
\hline 121 & 3043 & 121 & 3578 & 138 & 121 & 121 \\
\hline 122 & 3014 & 122 & 3579 & 139 & 122 & 122 \\
\hline 123 & 3045 & 123 & 3580 & 140 & 123 & 123 \\
\hline 124 & 3046 & 124 & 3581 & 141 & 121 & 124 \\
\hline 125 & 3046 & 125 & 3582 & 142 & 125 & 125 \\
\hline 126 & 3047 & 126 & 3583 & 143 & 126 & 126 \\
\hline 127 & 3047 & 127 & 3584 & 144 & 127 & 127 \\
\hline 128 & 3047 & 128 & 3584 & 145 & 128 & 128 \\
\hline 129 & 3018 & 129 & 3586 & 146 & 129 & 129 \\
\hline 130 & 3049 & 130 & 3587 & 147 & 130 & 130 \\
\hline 131 & 3050 & 131 & 3588 & 148 & 131 & 131 \\
\hline 132 & 3051 & 132 & 3589 & 149 & 132 & 132 \\
\hline 133 & 30.51 & 133 & 3590 & 150 & 133 & 133 \\
\hline 134 & 30.51 & 134 & 3591 & 151 & 134 & 134 \\
\hline 135 & 3052 & 135 & 3592 & 152 & 135 & 135 \\
\hline 136 & 3053 & 136 & 3593 & 153 & 136 & 136 \\
\hline 137 & 3054 & 137 & 3594 & & 137 & 137 \\
\hline 138 & 3055 & 1.38 & 3595 & $154-155$ & 138 & 138 \\
\hline 139 & 3056 & 139 & 3596 & 156 & 139 & 139 \\
\hline 140 & 3056 & 140 & 3597 & 157 & 140 & 140 \\
\hline 141 & 3056 & 141 & 3598 & 158 & 141 & 141 \\
\hline 142 & 3057 & 142 & 3599 & 159 & 142 & 142 \\
\hline 143 & 3058 & 143 & 3600 & 160 & 143 & 143 \\
\hline 144 & 3059 & 144 & 3601 & 161 & 144 & 144 \\
\hline 145 & 3060 & 145 & 3602 & 162 & 145 & 145 \\
\hline 146 & 3061 & 146 & 3603 & 163 & 146 & 146 \\
\hline 147 & 3062 & 147 & 3604 & 164 & 147 & 147 \\
\hline 148 & 3062 & 148 & 3605 & 165 & 148 & 148 \\
\hline
\end{tabular}




\begin{tabular}{|c|c|c|c|c|c|c|}
\hline & $\begin{array}{c}\text { Gen. Stat. } \\
1906 \text {. } \\
\text { th Div. } \\
\text { tit. 5. } \\
\text { ch. } 2 .\end{array}$ & $\begin{array}{l}\text { Laws 1907, } \\
\text { Act } 89 .\end{array}$ & $\begin{array}{c}\text { Rev. Codes } \\
1908 . \\
\text { tit. } 13 . \\
\text { p. } 1326 .\end{array}$ & $\begin{array}{c}\text { Rev. Stat. } \\
1911 \text {, } \\
\text { ch. } 98 .\end{array}$ & $\begin{array}{l}\text { Laws 1913, } \\
\text { ch. } 63 .\end{array}$ & $\begin{array}{c}\text { Code Supp } \\
1907 \\
\text { tit. } 15 \\
\text { p. } 729 .\end{array}$ \\
\hline $\begin{array}{l}\text { Uniform } \\
\text { Act } \\
\text { Sec. No. }\end{array}$ & $\begin{array}{l}1897 \\
\text { Florida }\end{array}$ & $\begin{array}{c}1907 \\
\text { Hawaij }\end{array}$ & $\begin{array}{l}1903 \\
\text { Idabo }\end{array}$ & $\begin{array}{l}1907 \\
\text { Illinois }\end{array}$ & $\begin{array}{c}1913 \\
\text { Indiana }\end{array}$ & $\begin{array}{l}1907 \\
\text { lowa }\end{array}$ \\
\hline 149 & 3063 & 149 & 3606 & 166 & 149 & 149 \\
\hline 150 & 3063 & 150 & 3607 & 167 & 150 & 150 \\
\hline 151 & 3064 & 151 & 3608 & 168 & 151 & 151 \\
\hline 152 & 3065 & 152 & 3609 & 169 & 152 & 152 \\
\hline 153 & 3066 & 153 & 3610 & 170 & 153 & 153 \\
\hline 154 & 3066 & 154 & 3611 & 171 & 154 & 154 \\
\hline 155 & 3067 & 155 & 3612 & 172 & 155 & 155 \\
\hline 156 & 3067 & 156 & 3613 & 173 & 156 & 156 \\
\hline 157 & 3068 & 157 & 3614 & 174 & 157 & 157 \\
\hline 158 & 3069 & 158 & 3615 & $175^{\circ}$ & 158 & 158 \\
\hline 159 & 3070 & 159 & 3616 & 176 & 159 & 159 \\
\hline 160 & 3071 & 160 & 3617 & 177 & 160 & 160 \\
\hline 161 & 3073 & 161 & 3618 & 178 & 161 & 161 \\
\hline 162 & 3074 & 162 & 3619 & 179 & 162 & 162 \\
\hline 163 & 3075 & 163 & 3620 & 180 & 163 & 163 \\
\hline 164 & 3076 & 164 & 3621 & 181 & 164 & 164 \\
\hline 16.5 & 3076 & 16.5 & 3622 & 182 & 165 & 165 \\
\hline 166 & 3077 & 166 & 3623 & 183 & 166 & 166 \\
\hline 167 & 3078 & 167 & 3621 & 181 & 167 & 167 \\
\hline 168 & 3079 & 168 & 3625 & $18 \tilde{}$ & 168 & 168 \\
\hline 169 & 3080 & 169 & 3626 & 186 & 169 & 169 \\
\hline 170 & 3081 & 170 & 3627 & $18 \%$ & 170 & 170 \\
\hline 171 & 3082 & 171 & 3628 & 188 & 171 & 171 \\
\hline 172 & 3082 & 172 & 3629 & 189 & 172 & 172 \\
\hline 173 & 3083 & 173 & 3630 & 190 & 173 & 173 \\
\hline 174 & 3084 & 174 & 3631 & 181 & 174 & 174 \\
\hline 175 & 3085 & 175 & 3632 & 192 & 175 & 175 \\
\hline 176 & 3086 & 176 & 3633 & 193 & 176 & 176 \\
\hline 177 & 3086 & 177 & 3634 & 194 & 177 & 177 \\
\hline 178 & 3087 & 178 & 3635 & 193 & 178 & 178 \\
\hline 179 & 3088 & 179 & 3636 & 196 & 179 & 179 \\
\hline 180 & 3089 & 180 & 3637 & 197 & 180 & 180 \\
\hline 181 & 3090 & 181 & 3638 & 198 & 181 & 181 \\
\hline 182 & 3091 & 182 & 3639 & 199 & 182 & 182 \\
\hline 183 & 3092 & I83 & 3610 & 200 & 183 & 183 \\
\hline 184 & 3093 & 184 & 3611 & 201 & 184 & 184 \\
\hline 185 & 3094 & 185 & 3612 & 202 & 185 & 185 \\
\hline 186 & 3095 & 186 & 3613 & 203 & 186 & 186 \\
\hline 187 & 3096 & 187 & 3644 & 201 & 187 & 187 \\
\hline 188 & 3097 & 188 & 3615 & $20 \overline{3}$ & 188 & 188 \\
\hline 189 & 3098 & 189 & 3616 & 206 & 189 & 189 \\
\hline 190 & 2931 & 190 & 3617 & 207 & 190 & 190 \\
\hline 191 & 2934 & 191 & 3648 & 208 & 191 & 191 \\
\hline 192 & 2934 & 192 & 3619 & 209 & 192 & 192 \\
\hline 193 & 2934 & 193 & 3650 & 210 & 193 & 193 \\
\hline 19.1 & 2931 & 194 & 3651 & 211 & 191 & 194 \\
\hline 195 & & 19,5 & 3652 & 212 & 195 & 195 \\
\hline 196 & 2931 & 196 & 36.53 & 213 & 196 & 196 \\
\hline 197 & $\ldots$ & 197 & $\ldots$ & 211 & 197 & 197 \\
\hline 198 & $\ldots$ & 198 & $\ldots$ & $\ldots$ & 198 & 198 \\
\hline
\end{tabular}




\begin{tabular}{|c|c|c|c|c|c|c|c|c|c|}
\hline & $\begin{array}{c}\text { Gen. Stat. } \\
1909 \\
\text { ch. } 84 .\end{array}$ & $\begin{array}{c}\text { Stat. } 1909 \\
\text { (Carroll), } \\
\text { ch, 30B, } \\
\text { sec. } 3720 \text { b. }\end{array}$ & $\begin{array}{c}\text { Laws } \\
1904 . \\
\text { Act } 64 .\end{array}$ & $\begin{array}{l}\text { Laws } \\
1017 \text {, } \\
\text { ch. } 257 .\end{array}$ & $\begin{array}{l}\text { Ann. } \\
\text { Civ. } \\
\text { Code } \\
1910 \text {, } \\
\text { art. } 13 .\end{array}$ & $\begin{array}{l}\text { Rev. } \\
\text { Laws } \\
1902, \\
\text { ch. } 73 .\end{array}$ & $\begin{array}{c}\text { Pub. } \\
\text { Acts } \\
1905, \\
\text { Act } 265 .\end{array}$ & \begin{tabular}{|c|} 
1.aws \\
1913, \\
ch. 272, \\
Gen. St \\
St. 1913
\end{tabular} & $\begin{array}{r}\text { Laws } \\
1916 \text {, } \\
\text { ch. } 244 \\
\text { p. } 35 \overline{5} .\end{array}$ \\
\hline $\begin{array}{l}\text { Uniform } \\
\text { Act } \\
\text { Sec. No. }\end{array}$ & $\begin{array}{c}1905 \\
\text { Kansas }\end{array}$ & $\begin{array}{l}1904 \\
\text { Ky. }\end{array}$ & $\begin{array}{l}1904 \\
\mathrm{La} .\end{array}$ & $\begin{array}{c}1917 \\
\text { Maine }\end{array}$ & $\begin{array}{l}1898 \\
\text { Md. }\end{array}$ & $\begin{array}{l}1898 \\
\text { Mass. }\end{array}$ & $\begin{array}{l}1905 \\
\text { Mich. }\end{array}$ & $\begin{array}{c}1913 \\
\text { Minn. }\end{array}$ & $\begin{array}{l}1916 \\
\text { Miss. }\end{array}$ \\
\hline
\end{tabular}

\begin{tabular}{|c|c|c|c|c|c|c|c|c|}
\hline 1 & 52.54 & 1 & 1 & 1 & 20 & 18 & 3 & 1 \\
\hline 2 & 5255 & 2 & 2 & 2 & 21 & 19 & 4. & 2 \\
\hline 3 & 5256 & 3 & 3 & 3 & 22 & 20 & 5 & 3 \\
\hline 4 & 5257 & 4 & 4 & 4 & 23 & 21 & 6 & 4 \\
\hline 5 & 5258 & 5 & 5 & 5 & 24 & 22 & 7 & 5 \\
\hline 6 & 5259 & 6 & 6 & 6 & 25 & 23 & 8 & 6 \\
\hline 7 & 5260 & 7 & 7 & 7 & 26 & 24 & 9 & 7 \\
\hline 8 & 5261 & 8 & 8 & 8 & 27 & 25 & 10 & 8 \\
\hline 9 & 5262 & 9 & 9 & 9 & 28 & 26 & 11 & 9 \\
\hline 10 & 5263 & 10 & 10 & 10 & 29 & 27 & 12 & 10 \\
\hline 11 & 5264 & 11 & 11 & 11 & 30 & 28 & 13 & 11 \\
\hline 12 & 5265 & 12 & 12 & 12 & 31 & 29 & 14 & 12 \\
\hline 13 & 5266 & 13 & 13 & 13 & 32 & 30 & 15 & 13 \\
\hline 14 & 5267 & 14 & 14 & 14 & 33 & 31 & 16 & 14 \\
\hline 15 & 5268 & 15 & 15 & 15 & 34 & 32 & 17 & 15 \\
\hline 16 & 5269 & 16 & 16 & 16 & 35 & 33 & 18 & 16 \\
\hline 17 & 5270 & 17 & 17 & 17 & 36 & 34 & 19 & 17 \\
\hline 18 & 5271 & 18 & 18 & 18 & 37 & 35 & 20 & 18 \\
\hline 19 & 5272 & 19 & 19 & 19 & 38 & 36 & 21 & 19 \\
\hline 20 & 5273 & 20 & 20 & 20 & 39 & 37 & 22 & 20 \\
\hline 21 & 5274 & 21 & 21 & 21 & 40 & 38 & 23 & 21 \\
\hline 22 & 5275 & 22 & 22 & 22 & 41 & 39 & 24 & 22 \\
\hline 23 & 5276 & 23 & 23 & 23 & 42 & 40 & 25 & 23 \\
\hline 24 & 5277 & 24 & 24 & 24 & 43 & 41 & 26 & 2.1 \\
\hline 25 & 5278 & 25 & 25 & 25 & 41 & 42 & 27 & 25 \\
\hline 26 & 5279 & 26 & 26 & 26 & 45 & 43 & 28 & 26 \\
\hline 27 & 5280 & 27 & 27 & 27 & 46 & 44 & 29 & 27 \\
\hline 28 & 5281 & 28 & 28 & 28 & 47 & 45 & 30 & 28 \\
\hline 29 & 5282 & 29 & 29 & 29 & 48 & 46 & 31 & 29 \\
\hline 30 & 5283 & 30 & 30 & 30 & 49 & 47 & 32 & 30 \\
\hline 31 & 5284 & 31 & 31 & 31 & 50 & 48 & 33 & 31 \\
\hline 32 & 5285 & 32 & 32 & 32 & 51 & 49 & 34 & 32 \\
\hline 33 & 5286 & 33 & 33 & 33 & 52 & 50 & 35 & 33 \\
\hline 34 & 5287 & 34 & 31 & 34 & 53 & 51 & 36 & 34 \\
\hline 35 & 5288 & 35 & 35 & 35 & 54 & 52 & 37 & 35 \\
\hline 36 & 5289 & 36 & 36 & 36 & 55 & 53 & 38 & 36 \\
\hline 37 & 5290 & 37 & 37 & 37 & 56 & 54 & 39 & 37 \\
\hline 38 & 5291 & 38 & 38 & 38 & 57 & 55 & 40 & 38 \\
\hline 39 & 5292 & 39 & 39 & 39 & 58 & 56 & 41 & 39 \\
\hline 40 & 5293 & 40 & 40 & 40 & 59 & 57 & 42 & 40 \\
\hline 41 & 5291 & 41 & 41 & 41 & 60 & 58 & 43 & 41 \\
\hline 42 & 5295 & 42 & 42 & 42 & 61 & 59 & 44 & 42 \\
\hline 43 & 5296 & 43 & 43 & 43 & 62 & 60 & 45 & 43 \\
\hline 44 & 5297 & 44 & .14 & 44 & 63 & 61 & 46 & 44 \\
\hline 45 & 5298 & 45 & 45 & 45 & 64 & 62 & 47 & 45 \\
\hline 46 & 5299 & 46 & 46 & 46 & 65 & 63 & 48 & 46 \\
\hline 47 & 5300 & 47 & 47 & 47 & 66 & 64 & 49 & 47 \\
\hline 48 & 5301 & 48 & 48 & 48 & 67 & 65 & 50 & 48 \\
\hline 49 & 5302 & 49 & 49 & 49 & 68 & 66 & 51 & 49 \\
\hline
\end{tabular}




\begin{tabular}{|c|c|c|c|c|c|c|c|c|c|}
\hline & $\begin{array}{c}\text { Gen. Stat. } \\
1909 \\
\text { ch. } 84 .\end{array}$ & $\begin{array}{l}\text { Stat. } 1909 \\
\text { (Carroll). } \\
\text { ch, } 90 \mathrm{~B} \text {. } \\
\text { sec. } 3720 \mathrm{~b} .\end{array}$ & $\begin{array}{l}\text { Laws } \\
1904, \\
\text { Act } 64 .\end{array}$ & $\begin{array}{c}\text { Laws } \\
1917 . \\
\text { ch. } 257 .\end{array}$ & $\begin{array}{l}\text { Ann. } \\
\text { Civ. } \\
\text { Code } \\
1910 . \\
\text { art. } 13 .\end{array}$ & $\begin{array}{l}\text { Rev. } \\
\text { Laws } \\
1902 . \\
\text { ch. } 73\end{array}$ & $\begin{array}{l}\text { Pub. } \\
\text { Acts } \\
1905 \text {. } \\
\text { Act } 265 \text {. }\end{array}$ & $\begin{array}{c}\text { Laws } \\
1913 . \\
\text { ch. } 272, \\
\text { Gen. St } \\
\text { St. } 1913\end{array}$ & $\begin{array}{r}1 \text { aws } \\
1916 . \\
\text { cb. } 244 . \\
\text { p. } 355\end{array}$ \\
\hline $\begin{array}{l}\text { Uniform } \\
\text { Act } \\
\text { Sec. No. }\end{array}$ & $\begin{array}{c}1905 \\
\text { Kansas }\end{array}$ & $\begin{array}{l}1904 \\
\mathrm{Ky} .\end{array}$ & $\begin{array}{l}1901 \\
\mathrm{La} .\end{array}$ & $\begin{array}{l}1.17 \\
\text { Maine }\end{array}$ & $\begin{array}{l}1898 \\
\text { Mid. }\end{array}$ & $\begin{array}{r}1898 \\
\text { Mass. }\end{array}$ & $\begin{array}{l}1905 \\
\text { Mich. }\end{array}$ & $\begin{array}{c}1913 \\
\text { Minn. }\end{array}$ & $\begin{array}{l}1916 \\
\text { Mlis8. }\end{array}$ \\
\hline
\end{tabular}

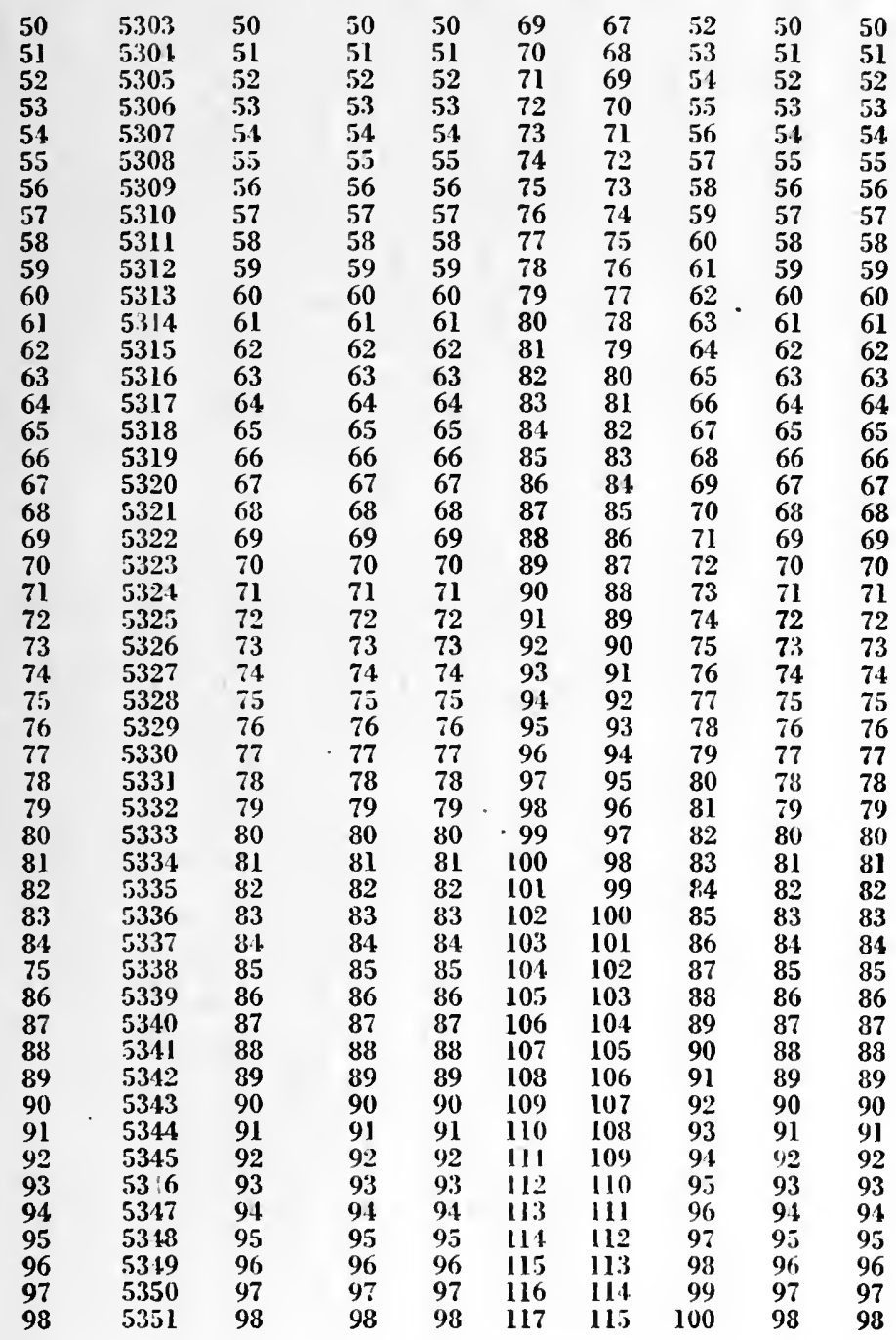




\begin{tabular}{|c|c|c|c|c|c|c|c|c|c|}
\hline & $\begin{array}{c}\text { Gen. Stat. } \\
1909 \\
\text { ch. } 84 .\end{array}$ & $\begin{array}{l}\text { Stat. } 1909 \\
\text { (Carroll), } \\
\text { ch, } 90 \mathrm{~B} \text {, } \\
\text { sec. } 3720 \mathrm{~b} .\end{array}$ & $\begin{array}{c}\mathrm{Laws} \\
104, \\
\text { Aet } 64 .\end{array}$ & $\begin{array}{c}\text { Law8 } \\
1917 . \\
\text { ch. } 257 .\end{array}$ & $\begin{array}{c}\text { Ann. } \\
\text { Civ. } \\
\text { Code } \\
1910, \\
\text { art. 13. }\end{array}$ & $\begin{array}{l}\text { Rev. } \\
\mathrm{L}_{\mathrm{sws}} \\
1902, \\
\text { ch. } 73 .\end{array}$ & $\begin{array}{c}\text { Pub. } \\
\text { Acts } \\
1905 \\
\text { Act } 265 .\end{array}$ & \begin{tabular}{|} 
Laws \\
1913, \\
ch. 272, \\
Gen. St \\
St. 1913
\end{tabular} & $\begin{array}{c}\text { Laws } \\
1916 . \\
\text { ch. } 244 . \\
\text { p. } 355 .\end{array}$ \\
\hline $\begin{array}{l}\text { Oniform } \\
\text { Act } \\
\text { Sec. Na. }\end{array}$ & $\begin{array}{c}1905 \\
\text { Kansas }\end{array}$ & $\begin{array}{l}1904 \\
\text { Ky. }\end{array}$ & $\begin{array}{l}1904 \\
\text { La. }\end{array}$ & $\begin{array}{l}1: 17 \\
\text { Maine }\end{array}$ & $\begin{array}{l}1898 \\
\text { Md. }\end{array}$ & $\begin{array}{l}1898 \\
\text { Mass }\end{array}$ & $\begin{array}{l}1905 \\
\text { Mich. }\end{array}$ & $\begin{array}{l}1913 \\
\text { Minn. }\end{array}$ & $\begin{array}{l}1916 \\
\text { Miss }\end{array}$ \\
\hline 99 & 5352 & 99 & 99 & 99 & 118 & 116 & 101 & 99 & 99 \\
\hline 100 & 5353 & 100 & 100 & 100 & 119 & 117 & 102 & 100 & 100 \\
\hline 101 & 5354 & 101 & 101 & 101 & 120 & 118 & 103 & 101 & 101 \\
\hline 102 & 5355 & 102 & 102 & 102 & 121 & 119 & 104 & 102 & 102 \\
\hline 103 & 5356 & 103 & 103 & 103 & 122 & 120 & 105 & 103 & 103 \\
\hline 104 & 5357 & 104 & 104 & 104 & 123 & 121 & 106 & 104 & 104 \\
\hline 105 & 5358 & 105 & 105 & 105 & 124 & 122 & 107 & 105 & 105 \\
\hline 106 & 5359 & 106 & 106 & 106 & 125 & 123 & 108 & 106 & 106 \\
\hline 107 & 5360 & 107 & 107 & 107 & 126 & 124 & 109 & 107 & 107 \\
\hline 108 & 5361 & 108 & 108 & 108 & 127 & 125 & 110 & 108 & 108 \\
\hline 109 & 5362. & 109 & 109 & 109 & 128 & 126 & 111 & 109 & 109 \\
\hline 110 & 5363 & 110 & 110 & 110 & 129 & 127 & 112 & 110 & 110 \\
\hline 111 & 5364 & 111 & 111 & 111 & 130 & 128 & 113 & 111 & 111 \\
\hline 112 & 5365 & 112 & 112 & 112 & 131 & 129 & 114 & 112 & 112 \\
\hline 113 & 5366 & 113 & 113 & 113 & 132 & 130 & 115 & 113 & 113 \\
\hline 114 & 5367 & 114 & 114 & 114 & 133 & 131 & 116 & 114 & 114 \\
\hline 115 & 5368 & 115 & 115 & 115 & 134 & 132 & 117 & 115 & 115 \\
\hline 116 & 5369 & 116 & 116 & 116 & 135 & 133 & 118 & 116 & 116 \\
\hline 117 & 5370 & 117 & 117 & 117 & 136 & 134 & 119 & 117 & 117 \\
\hline 118 & 5371 & 118 & 118 & 118 & 137 & 135 & 120 & 118 & 118 \\
\hline 119 & 5372 & 119 & 119 & 119 & 138 & 136 & 121 & 119 & 119 \\
\hline 120 & 5373 & 120 & 120 & 120 & 139 & 137 & 122 & 120 & 120 \\
\hline 121 & 5374 & 121 & 121 & 121 & 140 & 138 & 123 & 121 & 121 \\
\hline 122 & 5375 & 122 & 122 & 122 & 141 & 139 & 124 & 122 & 122 \\
\hline 123 & 5376 & 123 & 123 & 123 & 142 & 140 & 125 & 123 & 123 \\
\hline 124 & 5377 & 124 & 124 & 124 & 143 & 141 & 126 & 124 & 124 \\
\hline 125 & 5378 & 125 & 125 & 125 & 144 & 142 & 127 & 125 & 125 \\
\hline 126 & 5379 & 126 & 126 & 126 & 145 & 143 & 128 & 126 & 126 \\
\hline 127 & 5380 & 127 & 127 & 127 & 146 & 144 & 129 & 127 & 127 \\
\hline 128 & 5381 & 128 & 128 & 128 & 147 & 145 & 130 & 128 & 128 \\
\hline 129 & 5382 & 129 & 129 & 129 & 148 & 146 & 131 & 129 & 129 \\
\hline 130 & 5383 & 130 & 130 & 130 & 149 & 147 & 132 & 130 & 130 \\
\hline 131 & 5384 & 131 & 131 & 131 & 150 & 148 & 133 & 131 & 131 \\
\hline 132 & 5385 & 132 & 132 & 132 & 151 & 149 & 134 & 132 & 132 \\
\hline 133 & 5386 & 133 & 133 & 133 & 152 & 150 & 135 & 133 & 133 \\
\hline 134 & 5387 & 134 & 134 & 134 & 153 & 151 & 136 & 134 & 134 \\
\hline 135 & 5388 & 135 & 135 & 135 & 154 & 152 & 137 & 135 & 135 \\
\hline 136 & 5389 & 136 & 136 & 136 & 155 & 153 & 138 & 136 & 136 \\
\hline 137 & 5390 & 137 & 137 & 137 & 156 & 154 & 139 & 137 & 137 \\
\hline 138 & 5391 & 138 & 138 & 138 & 157 & 155 & 140 & 138 & 138 \\
\hline 139 & 5392 & 139 & 139 & 139 & 158 & 156 & 141 & 139 & 139 \\
\hline 140 & 5393 & 140 & 140 & 140 & 159 & 157 & 142 & 140 & 140 \\
\hline 141 & 5394 & 141 & 14.1 & 141 & 160 & 153 & 143 & 141 & 141 \\
\hline 142 & 5395 & 142 & 142 & 142 & 161 & 159 & 144 & 142 & 142 \\
\hline 143 & 5396 & 143 & 143 & 143 & 162 & 160 & 145 & 143 & 143 \\
\hline 144 & 5397 & 144 & 144 & 144 & 163 & 161 & 146 & 144 & 144 \\
\hline 145 & 5398 & 145 & 145 & 145 & 164 & 162 & 147 & 145 & 145 \\
\hline 146 & 5399 & 146 & 14.6 & 146 & 165 & 163 & 148 & 146 & 146 \\
\hline 147 & 5100 & 147 & 147 & 147 & 166 & 164 & 149 & 147 & 147 \\
\hline 148 & 5401 & 148 & 143 & 148 & 167 & 165 & 150 & 143 & 148 \\
\hline
\end{tabular}


UNTFORM NEGOTIABLE INSTRUMENTS ACT.

\begin{tabular}{|c|c|c|c|c|c|c|c|c|c|}
\hline 1 & $\begin{array}{c}\text { Gen. Stat. } \\
1909 \\
\text { ch. } 84 .\end{array}$ & $\begin{array}{c}\text { Stat. } 1909 \\
\text { (Carroll), } \\
\text { ch, 90B, } \\
\text { sec. } 3720 \mathrm{~b} .\end{array}$ & $\begin{array}{l}\text { Laws } \\
\text { 1904. } \\
\text { Act 64. }\end{array}$ & $\begin{array}{l}\text { Lawa } \\
1917 \\
\text { ch. } 257 .\end{array}$ & $\begin{array}{l}\text { Ann. } \\
\text { Civ. } \\
\text { Code } \\
1910 \text {, } \\
\text { art. } 13 .\end{array}$ & $\begin{array}{l}\text { Rev. } \\
\text { Law } \\
1902, \\
\text { ch. } 73 .\end{array}$ & $\begin{array}{l}\text { Pub. } \\
\text { Acts } \\
1905 \text {, } \\
\text { Act } 265 .\end{array}$ & $\begin{array}{r}\text { Law: } \\
1913 \\
\text { ch. } 272, \\
\text { Gen. St } \\
\text { St. } 1913\end{array}$ & $\begin{array}{r}\text { laws } \\
1916 . \\
\text { ch. } 244, \\
\text { p. } 355 .\end{array}$ \\
\hline $\begin{array}{l}\text { Oniform } \\
\text { Act } \\
\text { Sec. No. }\end{array}$ & $\begin{array}{c}1905 \\
\text { Kansas }\end{array}$ & $\begin{array}{c}1904 \\
\mathrm{Ky.}\end{array}$ & $\begin{array}{l}1904 \\
\mathrm{La} .\end{array}$ & $\begin{array}{l}1917 \\
\text { Maine }\end{array}$ & $\begin{array}{l}1898 \\
\text { Md. }\end{array}$ & $\begin{array}{r}1898 \\
\text { Mass. }\end{array}$ & $\begin{array}{l}1905 \\
\text { Mich. }\end{array}$ & $\begin{array}{r}1913 \\
\text { Minn. }\end{array}$ & $\begin{array}{l}1916 \\
\text { Misa. }\end{array}$ \\
\hline
\end{tabular}

$\begin{array}{llllllllll}151 & 5404 & 151 & 151 & 151 & 170 & 168 & 153 & 151 & 151\end{array}$

$\begin{array}{llllllllll}152 & 5405 & 152 & 152 & 152 & 171 & 169 & 154 & 152 & 152\end{array}$

$\begin{array}{llllllllll}153 & 5406 & 153 & 153 & 153 & 172 & 170 & 155 & 153 & 153\end{array}$

$\begin{array}{llllllllll}154 & 5407 & 154 & 154 & 154 & 173 & 171 & 156 & 154 & 154 \\ 155 & 5408 & 155 & 155 & 155 & 174 & 172 & 157 & 155 & 155\end{array}$

$\begin{array}{llllllllll}156 & 5409 & 156 & 156 & 156 & 175 & 173 & 158 & 156 & 156\end{array}$

$\begin{array}{llllllllll}157 & 5410 & 157 & 157 & 157 & 176 & 174 & 159 & 157 & 157\end{array}$

$\begin{array}{llllllllll}158 & 5411 & 158 & 158 & 158 & 177 & 175 & 160 & 158 & 158\end{array}$

$\begin{array}{llllllllll}159 & 5412 & 159 & 159 & 159 & 178 & 176 & 161 & 159 & 159\end{array}$

$\begin{array}{llllllllll}160 & 5413 & 160 & 160 & 160 & 179 & 177 & 162 & 160 & 160\end{array}$

$\begin{array}{llllllllll}161 & 5414 & 161 & 161 & 161 & 180 & 178 & 163 & 161 & 161\end{array}$

$\begin{array}{llllllllll}162 & 5415 & 162 & 162 & 162 & 181 & 179 & 164 & 162 & 162\end{array}$

$\begin{array}{llllllllll}163 & 5416 & 163 & 163 & 163 & 182 & 180 & 165 & 163 & 163\end{array}$

$\begin{array}{llllllllll}164 & 5417 & 164 & 164 & 164 & 183 & 181 & 166 & 164 & 164\end{array}$

$\begin{array}{llllllllll}165 & 5418 & 165 & 165 & 165 & 184 & 182 & 167 & 165 & 165\end{array}$

$\begin{array}{llllllllll}166 & 5419 & 166 & 166 & 166 & 185 & 183 & 168 & 166 & 166\end{array}$

$\begin{array}{llllllllll}167 & 5420 & 167 & 167 & 167 & 186 & 184 & 169 & 167 & 167\end{array}$

$\begin{array}{llllllllll}168 & 5421 & 168 & 168 & 168 & 187 & 185 & 170 & 168 & 168\end{array}$

$\begin{array}{llllllllll}169 & 5422 & 169 & 169 & 169 & 188 & 186 & 171 & 169 & 169\end{array}$

$\begin{array}{llllllllll}170 & 5423 & 170 & 170 & 170 & 189 & 187 & 172 & 170 & 170\end{array}$

$\begin{array}{llllllllll}171 & 5424 & 171 & 171 & 171 & 190 & 188 & 173 & 171 & 171\end{array}$

$\begin{array}{llllllllll}172 & 5425 & 172 & 172 & 172 & 191 & 189 & 174 . & 172 & 172\end{array}$

$\begin{array}{llllllllll}173 & 5426 & 173 & 173 & 173 & 192 & 190 & 175 & 173 & 173\end{array}$

$\begin{array}{llllllllll}174 & 5427 & 174 & 174 & 174 & 193 & 191 & 176 & 174 & 174\end{array}$

$\begin{array}{llllllllll}175 & 5428 & 175 & 175 & 175 & 195 & 192 & 177 & 175 & 175\end{array}$

$\begin{array}{llllllllll}176 & 5429 & 176 & 176 & 176 & 195 & 193 & 178 & 176 & 176\end{array}$

$\begin{array}{llllllllll}177 & 5430 & 177 & 177 & 177 & 196 & 194 & 179 & 177 & 177\end{array}$

$\begin{array}{llllllllll}178 & 5431 & 178 & 178 & 178 & 197 & 195 & 180 & 178 & 178\end{array}$

$\begin{array}{llllllllll}179 & 5432 & 179 & 179 & 179 & 198 & 196 & 181 & 179 & 179\end{array}$

$\begin{array}{llllllllll}180 & 5433 & 180 & 180 & 180 & 199 & 197 & 182 & 180 & 180\end{array}$

$\begin{array}{llllllllll}181 & 5434 & 181 & 181 & 181 & 200 & 198 & 183 & 181 & 181\end{array}$

$\begin{array}{llllllllll}182 & 5435 & 182 & 182 & 182 & 201 & 199 & 184 & 182 & 182\end{array}$

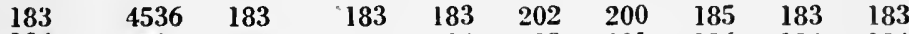

$\begin{array}{llllllllll}184 & 5437 & 184 & 184 & 184 & 203 & 201 & 186 & 184 & 184\end{array}$

$\begin{array}{llllllllll}185 & 5438 & 185 & 185 & 185 & 204 & 202 & 187 & 185 & 185\end{array}$

$\begin{array}{llllllllll}186 & 5439 & 186 & 186 & 186 & 205 & 203 & 188 & 186 & 186\end{array}$

$\begin{array}{llllllllll}187 & 5440 & 187 & 187 & 187 & 206 & 204 & 189 & 187 & 187\end{array}$

$\begin{array}{llllllllll}188 & 5441 & 188 & 188 & 188 & 207 & 205 & 190 & 188 & 188\end{array}$

$\begin{array}{llllllllll}189 & 5442 & 189 & 189 & 189 & 208 & 206 & 191 & 189 & 189\end{array}$

$\begin{array}{llllllllll}190 & 5247 & 190 & 190 & 190 & 13 & \ldots & 1 & 190 & 190\end{array}$

$\begin{array}{llllllllll}191 & 5248 & 191 & 191 & 191 & 14 & 207 & 2 & 191 & 19] \\ 192 & 5249 & 192 & 192 & 192 & 15 & 208 & 2 & 192 & 192\end{array}$

$\begin{array}{llllllllll}192 & 5249 & 192 & 192 & 192 & 15 & 208 & 2 & 192 & 192 \\ 193 & 5250 & 193 & 193 & 193 & 16 & 209 & 2 & 193 & 193\end{array}$

$\begin{array}{llllllllll}194 & 5251 & 194 & 194 & 194 & 17 & 210 & 2 & 194 & 194\end{array}$

$\begin{array}{llllllllll}195 & 5252 & 195 & 195 & 195 & 18 & 211 & 2 & 195 & 195 \\ 196 & 5253 & 196 & 196 & 196 & 19 & 212 & 2 & 196 & 196\end{array}$

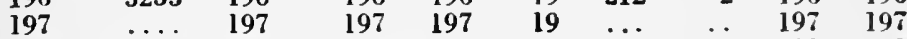

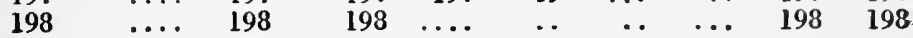




\begin{tabular}{|c|c|c|c|c|c|c|c|}
\hline & $\begin{array}{l}\text { Rev. Stat. } \\
1909 \\
\text { tit. } 15 \\
\text { ch. } 86 \\
\text { p. } 3122 .\end{array}$ & $\begin{array}{c}\text { Civ. Code } \\
1907 \\
\text { tit. } 15 \\
\text { p. } 1593 .\end{array}$ & $\begin{array}{c}\text { Rev. Stat. } \\
1913 \\
\text { ch. } 54 .\end{array}$ & $\begin{array}{c}\text { Rev. Laws } \\
1912, \\
\text { Vol. } 1, \\
\text { p. } 769 .\end{array}$ & $\begin{array}{c}\text { Laws } \\
1909 \\
\text { ch. } 123 .\end{array}$ & $\begin{array}{l}\text { Comp. } \\
\text { Stat. 1910, } \\
\text { Vol. } 3 \text {, } \\
\text { p. } 3732 .\end{array}$ & $\begin{array}{l}\text { Laws } \\
1907 \text {, } \\
\text { ch. } 83 .\end{array}$ \\
\hline $\begin{array}{l}\text { Uniform } \\
\text { Act } \\
\text { Sec. No. }\end{array}$ & $\begin{array}{c}1905 \\
\text { Missourı }\end{array}$ & $\begin{array}{c}1903 \\
\text { Montana }\end{array}$ & $\begin{array}{c}1905 \\
\text { Nebraska }\end{array}$ & $\begin{array}{c}1907 \\
\text { Nevada }\end{array}$ & $\begin{array}{l}1909 \\
\text { N. H. }\end{array}$ & $\begin{array}{l}\text { 1C02 } \\
\text { N.J. }\end{array}$ & N. Meaico \\
\hline 1 & 9972 & 5849 & 5319 & 2548 & 1 & 1 & 1 \\
\hline 2 & 9973 & 5850 & 5320 & 2549 & 2 & 2 & 2 \\
\hline 3 & 9974 & 5851 & 5321 & 2550 & 3 & 3 & 3 \\
\hline 4 & 9975 & 5852 & 5322 & 2551 & 4 & 4 & 4 \\
\hline 5 & 9976 & 5853 & 5323 & 2552 & 5 & 5 & 5 \\
\hline 6 & 8977 & 5854 & 5324 & 2553 & 6 & 6 & 6 \\
\hline 7 & 9978 & 5855 & 5325 & 2554 & 7 & 7 & 7 \\
\hline 8 & 9979 & 5856 & 5326 & 2555 & 8 & 8 & 8 \\
\hline 9 & 0980 & 5857 & 5327 & 2556 & 9 & 9 & 9 \\
\hline 10 & 9981 & 5858 & 5328 & 2557 & 10 & 10 & 10 \\
\hline 11 & 9982 & 5859 & 5329 & 2558 & 11 & 11 & 11 \\
\hline 12 & 9983 & 5860 & 5330 & 2559 & 12 & 12 & 12 \\
\hline 13 & 9984 & 5861 & 5331 & 2560 & 13 & 13 & 13 \\
\hline 14 & 9985 & 5862 & 5332 & 2561 & 14 & 14 & 14 \\
\hline 15 & 9986 & 5863 & 5333 & 2562 & 15 & 15 & 15 \\
\hline 16 & 9987 & 5864 & 5334 & 2563 & 16 & 16 & 16 \\
\hline 17 & 9988 & 5865 & 5335 & 2564 & 17 & 17 & 17 \\
\hline 18 & 9989 & 5866 & 5336 & 2565 & 18 & 18 & 18 \\
\hline 19 & 9990 & 5867 & 5337 & 2566 & 19 & 19 & 19 \\
\hline 20 & 9991 & 5868 & 5338 & 2567 & 20 & 20 & 20 \\
\hline 21 & 9992 & 5869 & 5339 & 2568 & 21 & 21 & 21 \\
\hline 22 & 9993 & 5870 & 5340 & 2569 & 22 & 22 & 22 \\
\hline 23 & 9994. & 5871 & 5341 & 2570 & 23 & 23 & 23 \\
\hline 24 & 9995 & 5872 & 5342 & 2571 & 24 & 24 & 24 \\
\hline 25 & 9996 & 5873 & 5343 & 2572 & 25 & 25 & 25 \\
\hline 26 & 9997 & 5874 & 5344 & 2573 & 26 & 26 & 26 \\
\hline 27 & 9998 & 5875 & 5345 & 2574 & 27 & 27 & 27 \\
\hline 28 & 9999 & 5876 & 5346 & 2575 & 28 & 28 & 28 \\
\hline 29 & 10000 & 5877 & 5347 & 2576 & 29 & 29 & 29 \\
\hline 30 & 10001 & 5878 & 5348 & 2577 & 30 & 30 & 30 \\
\hline 31 & 10002 & 5879 & 5349 & 2578 & 31 & 31 & 31 \\
\hline 32 & 10003 & 5880 & 5350 & 2579 & 32 & 32 & 32 \\
\hline $3: 3$ & 1000.1 & 5881 & 5351 & 2580 & 33 & 33 & 33 \\
\hline 34 & 10004 & 5882 & 5352 & 2581 & 34 & 34 & 34 \\
\hline $3 . \overline{5}$ & 10005 & 5883 & 5353 & 2582 & 35 & 35 & 35 \\
\hline 36 & 10006 & 5884 & 535.4 & 2583 & 36 & 36 & 36 \\
\hline 37 & 10007 & 5885 & 5355 & 2584 & 37 & 37 & 37 \\
\hline 38 & 10008 & 5886 & 5356 & 2585 & 38 & 38 & 38 \\
\hline 39 & 10009 & $588 ?$ & 5357 & 2586 & 39 & 39 & 39 \\
\hline 40 & 10010 & 5888 & 5358 & 2587 & 40 & 40 & 40 \\
\hline 41 & 10011 & 5889 & 5359 & 2588 & 41 & 41 & 41 \\
\hline 42 & 10012 & 5890 & 5360 & 2589 & 42 & 42 & 42 \\
\hline 43 & 10013 & 5891 & 5361 & 2590 & 43 & 43 & 43 \\
\hline 44 & 10014 & 5892 & 5362 & $259 \mathrm{I}$ & 44 & 44 & 44 \\
\hline 4.5 & 10015 & 5893 & 5363 & 2592 & 45 & 45 & 45 \\
\hline 46 & 10016 & 5894 & 5364 & 2593 & 46 & 46 & 46 \\
\hline 47 & 10017 & 5895 & 5365 & 2594 & 47 & 47 & 47 \\
\hline 48 & 10018 & 5896 & 5366 & 2595 & 43 & 48 & 48 \\
\hline 49 & 10019 & 5897 & 5367 & 2596 & 49 & 49 & 49 \\
\hline
\end{tabular}




\begin{tabular}{|c|c|c|c|c|c|c|c|}
\hline- & $\begin{array}{c}\text { Rev Stat. } \\
1909 \\
\text { tit. } 15 \text {. } \\
\text { ch. } 86, \\
\text { p. } 3122 .\end{array}$ & $\begin{array}{c}\text { Civ. Code } \\
1907 . \\
\text { tit. } 15 . \\
\text { p. } 1593 .\end{array}$ & $\begin{array}{c}\text { Rev. Stat. } \\
1913 \\
\text { ch. } 54 .\end{array}$ & $\begin{array}{l}\text { Rev. Laws } \\
\text { J912, } \\
\text { Vol. i, } \\
\text { p. } 769 .\end{array}$ & $\begin{array}{r}4.68 \\
1909 . \\
\text { ch. } 123 .\end{array}$ & $\begin{array}{l}\text { Comp. } \\
\text { Stat. 1910, } \\
\text { Vol. 3, } \\
\text { p. 3732. }\end{array}$ & $\begin{array}{l}\text { Laws } \\
1907 \text {, } \\
\text { ch. } 83 .\end{array}$ \\
\hline $\begin{array}{l}\text { Uniform } \\
\text { Aet } \\
\text { Sec. No. }\end{array}$ & $\begin{array}{c}1905 \\
\text { Missouri }\end{array}$ & $\begin{array}{c}1903 \\
\text { Montan. }\end{array}$ & $\begin{array}{c}1905 \\
\text { Nebraska }\end{array}$ & $\begin{array}{c}1907 \\
\text { Nevada }\end{array}$ & $\begin{array}{l}1909 \\
\text { N. } 11 .\end{array}$ & $\begin{array}{l}190 \% . \\
\text { N.J. }\end{array}$ & N. Mexico \\
\hline 50 & 10020 & 5898 & 5368 & 2597 & 50 & 50 & 50 \\
\hline 51 & 10021 & 5899 & 5369 & 2598 & 51 & 51 & 51 \\
\hline 52 & 10022 & 5900 & 5370 & 2599 & 52 & 52 & 52 \\
\hline 53 & 10023 & 5901 & 5371 & 2600 & 53 & 53 & 53 \\
\hline 54 & 10024 & 5902 & 5372 & 2601 & 54 & 54 & 54 \\
\hline 55 & 10025 & 5903 & 5373 & 2602 & 55 & 55 & 55 \\
\hline 56 & 10026 & 5904 & 5374 & 2603 & 56 & 56 & 56 \\
\hline 57 & 10027 & 5905 & 5375 & 2604 & 57 & 57 & 57 \\
\hline 58 & 10028 & 5906 & 5376 & 2605 & 58 & 58 & 58 \\
\hline 59 & 10029 & 5907 & 5377 & 2606 & 59 & 59 & 59 \\
\hline 60 & 10030 & 5908 & 5378 & $260 ?$ & 60 & 60 & 60 \\
\hline 61 & 10031 & 5909 & 5379 & 2608 & 61 & 61 & 61 \\
\hline 62 & 10032 & 5910 & 5380 & 2609 & 62 & 62 & 62 \\
\hline 63 & 10033 & 5911 & 5381 & 2610 & 63 & 63 & 63 \\
\hline 64 & 10034 & 5912 & 5382 & 2611 & 64 & 64 & 64 \\
\hline 65 & 10035 & 5913 & 5383 & 2612 & 65 & 65 & 65 \\
\hline 66 & 10036 & 5914 & 5384 & 2613 & 66 & 66 & 66 \\
\hline 67 & 10037 & 5915 & 5385 & 2614 & 67 & 67 & 67 \\
\hline 68 & 10038 & 5916 & 5386 & 2615 & 68 & 68 & 68 \\
\hline 69 & . 10039 & 5917 & 5387 & 2616 & 69 & 69 & 69 \\
\hline 70 & 10040 & 5918 & 5388 & 2617 & 70 & 70 & 70 \\
\hline 71 & 10041 & 5919 & 5389 & 2618 & 71 & 71 & 71 \\
\hline 72 & 10042 & 5920 & 5390 & 2619 & 72 & 72 & 72 \\
\hline 73 & 10043 & 5921 & 5391 & 2620 & 73 & 73 & 73 \\
\hline 74 & 10044 & 5922 & 5392 & 2621 & 74 & 74 & 74 \\
\hline 75 & 10045 & 5923 & 5393 & 2622 & 75 & 75 & 75 \\
\hline 76 & 10046 & 5924 & 5394 & 2623 & 76 & 76 & 76 \\
\hline 77 & 10047 & 5925 & 5395 & 2624 & 77 & 77 & 77 \\
\hline 78 & 10048 & 5926 & 5396 & 2625 & 78 & 78 & 78 \\
\hline 79 & 10049 & 5927 & 5397 & 2626 & 79 & 79 & 79 \\
\hline 80 & 10050 & 5928 & 5398 & 2627 & 80 & 80 & 80 \\
\hline 81 & 10051 & 5929 & 5399 & 2628 & 81 & 81 & 81 \\
\hline 82 & 10052 & 5930 & 5400 & 2629 & 82 & 82 & 82 \\
\hline 83 & 10053 & 5931 & 5401 & 2630 & 83 & 83 & 83 \\
\hline 84 & 10054 & 5932 & 5402 & 2631 & 84 & 84 & 84 \\
\hline 85 & 10055 & 5933 & 5403 & 2632 & 85 & 85 & 85 \\
\hline 86 & 10056 & 5934 & 5404 & 2633 & 86 & 86 & 86 \\
\hline 87 & 10057 & 5935 & & 2634 & 87 & 87 & 87 \\
\hline 88 & 10058 & 5936 & 5405 & 2635 & 88 & 88 & 88 \\
\hline 89 & 10059 & 5937 & $\mathbf{5 4 0 6}$ & 2636 & 89 & 89 & 89 \\
\hline 90 & 10060 & $\mathbf{5 9 3 8}$ & 54.07 & 2637 & 90 & 90 & 90 \\
\hline 91 & 10061 & 5939 & 5408 & 2638 & 91 & 91 & 91 \\
\hline 92 & 10062 & 5940 & 5409 & 2639 & 92 & 92 & 92 \\
\hline 93 & 10063 & 5941 & 5410 & 2640 & 93 & 93 & 93 \\
\hline 94 & 10064 & 5942 & 5411 & 2641 & 94 & 94 & 9.4 \\
\hline 95 & 10065 & 5943 & 5412 & 2642 & 95 & 95 & 95 \\
\hline 96 & 10066 & 59.44 & 54.13 & 2643 & 96 & 96 & 96 \\
\hline 97 & 10067 & 5945 & 5414 & 2644 & 97 & 97 & 97 \\
\hline 98 & 10068 & 59.46 & 5415 & 2645 & 98 & 98 & 98 \\
\hline 99 & 10069 & 5947 & 5416 & 2646 & 99 & 99 & 99 \\
\hline
\end{tabular}




\begin{tabular}{|c|c|c|c|c|c|c|c|}
\hline & $\begin{array}{c}\text { Rev. Stat. } \\
1909 \\
\text { tit. } 15 \\
\text { ch. } 86 \\
\text { p. } 3122 .\end{array}$ & $\begin{array}{c}\text { Civ. Code } \\
1907 \\
\text { tit. } 15 \\
\text { p. } 1593 .\end{array}$ & $\begin{array}{c}\text { Rev. Stat. } \\
1913 \text {. } \\
\text { ch. } 54 .\end{array}$ & $\begin{array}{c}\text { Rev I.aws } \\
1912 \\
\text { Vol. I. } \\
\text { p. } 769 .\end{array}$ & $\begin{array}{c}\text { Laws } \\
1909, \\
\text { ch. } 123 .\end{array}$ & $\begin{array}{l}\text { Comp. } \\
\text { Stat. } 1910 . \\
\text { Vol. } 3 \text {. } \\
\text { p. } 3732 .\end{array}$ & $\begin{array}{l}\text { Laws } \\
1907 \text {, } \\
\text { ch. } 83 .\end{array}$ \\
\hline $\begin{array}{l}\text { Uniform } \\
\text { Act } \\
\text { Sec. No. }\end{array}$ & $\begin{array}{c}1905 \\
\text { Missourı }\end{array}$ & $\begin{array}{c}1903 \\
\text { Montana }\end{array}$ & $\begin{array}{c}1905 \\
\text { Nebraska }\end{array}$ & $\begin{array}{c}1907 \\
\text { Nevada }\end{array}$ & $\begin{array}{l}\text { i.909 } \\
\text { N. H. }\end{array}$ & $\begin{array}{l}1902 \\
\text { N.J. }\end{array}$ & N. Mexico \\
\hline 100 & 10070 & 5948 & 5417 & 2647 & 100 & 100 & 100 \\
\hline 101 & 10071 & 5949 & 5418 & 2648 & I0I & 101 & 101 \\
\hline 102 & 10072 & 5950 & 5419 & 2649 & 102 & 102 & 102 \\
\hline 103 & 10073 & 5951 & 5420 & 2650 & 103 & 103 & 103 \\
\hline 104 & 10074 & 5952 & 5421 & 2651 & 104 & 104 & 104 \\
\hline 105 & 10075 & 5953 & 5422 & 2652 & 105 & 105 & 105 \\
\hline 106 & 10076 & 5954 & 5423 & 2653 & 106 & 106 & 106 \\
\hline 107 & 10077 & 5955 & 5424 & 2654 & 107 & 107 & 107 \\
\hline 108 & 10078 & 5956 & 5425 & 2655 & 108 & 108 & 108 \\
\hline 109 & 10079 & 5957 & 5426 & 2656 & 109 & 109 & 109 \\
\hline 110 & 10080 & 5958 & 5427 & 2657 & 110 & 110 & 110 \\
\hline 111 & 10081 & 5959 & 5428 & 2658 & 111 & 111 & 111 \\
\hline 112 & 10082 & 5960 & 5429 & 2659 & 112 & 112 & 112 \\
\hline 113 & 10083 & 5961 & 5430 & 2660 & 113 & 113 & 113. \\
\hline 114 & 10084 & 5962 & 5431 & 2661 & 114 & 114 & 114 \\
\hline 115 & 10085 & 5963 & 5432 & 2662 & 115 & 115 & 115. \\
\hline 116 & 10086 & 5964 & 5433 & 2663 & 116 & 116 & 116 \\
\hline 117 & 10087 & 5965 & 5434 & 2664 & 117 & 117 & 117 \\
\hline 118 & 10088 & 5966 & 5435 & 2665 & 118 & 118 & 118 \\
\hline 119 & 10089 & 5967 & 5436 & 2666 & 119 & 119 & 119 \\
\hline 120 & 10090 & 5968 & 5437 & 2667 & 120 & 120 & 120 \\
\hline 121 & 10091 & 5969 & 5438 & 2668 & 121 & 121 & 121 \\
\hline 122 & 10092 & 5970 & 5439 & 2669 & 122 & 122 & 122 \\
\hline 123 & 10093 & 5971 & 5440 & 2670 & 123 & 123 & 123. \\
\hline 124 & 10091 & 5972 & $544 \mathrm{I}$ & 2671 & 124 & 124 & 124. \\
\hline 125 & 10095 & 5973 & 544.2 & 2672 & 125 & 125 & 125 \\
\hline 126 & 10096 & 5974 & 5443 & 2763 & 126 & 126 & 126. \\
\hline 127 & 10097 & 5975 & 5444 & 2674 & 127 & 127 & 127 \\
\hline 128 & 10098 & 5976 & 5445 & 2675 & 128 & 128 & 128 \\
\hline 129 & 10099 & 5977 & 5446 & 2676 & 129 & 129 & 129 \\
\hline 130 & 10100 & 5978 & 5447 & 2677 & 130 & 130 & 130. \\
\hline 131 & 10101 & 5979 & 5448 & 2678 & 131 & 131 & 131 \\
\hline 132 & 10102 & 5980 & 5449 & 2679 & 132 & 132 & 132 \\
\hline 133 & 10103 & 5981 & 5450 & 2680 & 133 & 133 & 133. \\
\hline 134 & 10104 & 5982 & 5451 & 2681 & 134 & 134 & 134. \\
\hline 135 & 10105 & 5983 & 5452 & 2682 & 135 & 135 & 135 \\
\hline 136 & 10106 & 5984 & 5453 & 2683 & 136 & 136 & 136. \\
\hline 137 & 10107 & 5985 & 5454 & 2681 & 137 & 137 & 137 \\
\hline 138 & 10108 & 5986 & 5455 & 268.5 & 138 & 138 & 138 \\
\hline 139 & 10109 & 5987 & 5456 . & 2686 & 139 & 139 & 139 \\
\hline 140 & 10110 & 5988 & 5457 & 2687 & 140 & 140 & 140 \\
\hline 141 & 10111 & 5989 & 5458 & 2688 & 141 & 141 & 141 \\
\hline 142 & 10112 & 5990 & 5459 & 2689 & 142 & 142 & 142 \\
\hline 143 & 10113 & 5991 & 5460 & 2690 & 143 & 143 & 143 \\
\hline 144 & 10114 & 5992 & 5461 & 2691 & 144 & 144 & 144 \\
\hline 145 & 10115 & 5993 & 5462 & 2692 & 145 & 145 & 145 \\
\hline 146 & 10116 & 5994 & 5463 & 2693 & 146 & 146 & 146 \\
\hline 147 & 10117 & 5995 & 5164 & 2694 & 147 & 147 & 147 \\
\hline 148 & 10118 & 5996 & 5465 & 2695 & 148 & 148 & 148 \\
\hline 149 & 10119 & 5997 & 5466 & 2696 & 149 & 149 & 149 \\
\hline
\end{tabular}




\begin{tabular}{|c|c|c|c|c|c|c|c|}
\hline & $\begin{array}{c}\text { Rev. Stat. } \\
1909 \text {, } \\
\text { tit. } 15, \\
\text { ch. } 86 \text {, } \\
\text { p. } 3122 \text {. }\end{array}$ & $\begin{array}{c}\text { Civ. Code } \\
1907 \\
\text { tit. } 15, \\
\text { p. } 1593 .\end{array}$ & $\begin{array}{c}\text { Rev. Stat. } \\
1913 \\
\text { ch. } 54\end{array}$ & $\begin{array}{l}\text { Rev. Laws } \\
1912, \\
\text { Vol. i. } \\
\text { p. } 769 .\end{array}$ & $\begin{array}{r}1.2 \% s \\
1909 . \\
\text { cb. } 123 .\end{array}$ & $\begin{array}{l}\text { Comp. } \\
\text { Stat. } 1910 \\
\text { Vol. } 3 \\
\text { p. } 3732 .\end{array}$ & $\begin{array}{l}\text { Laws } \\
1907, \\
\text { ch. } 83 .\end{array}$ \\
\hline $\begin{array}{l}\text { Uniform } \\
\text { Act } \\
\text { Sec. No. }\end{array}$ & $\begin{array}{c}1905 \\
\text { Missouri }\end{array}$ & $\begin{array}{c}1903 \\
\text { Montana }\end{array}$ & $\begin{array}{c}1905 \\
\text { Nebrasks }\end{array}$ & $\begin{array}{c}1907 \\
\text { Nevada }\end{array}$ & $\begin{array}{l}1809 \\
\text { N. H. }\end{array}$ & $\begin{array}{l}1: 02 \\
\text { N. J. }\end{array}$ & న. Mesico \\
\hline 150 & 10120 & 5993 & 5467 & 2697 & 150 & 150 & 150 \\
\hline 151 & 10121 & 5999 & 5168 & 2698 & 151 & 151 & 151 \\
\hline 152 & 10122 & 6000 & 5469 & 2699 & 152 & 152 & 152 \\
\hline 153 & 10123 & 6001 & 5470 & 2700 & 153 & 153 & 153 \\
\hline 151 & 10124 & 6002 & 5471 & 2701 & 154 & 151 & 154 \\
\hline 155 & 10125 & 6003 & 5472 & 2702 & 155 & 155 & 155 \\
\hline 156 & 10126 & 6004 & 5473 & 2703 & 156 & 156 & 156 \\
\hline 157 & 10127 & 6005 & 5474 & 2701 & 157 & 157 & 157 \\
\hline 158 & 10128 & 6006 & 5475 & 2705 & 158 & 158 & 158 \\
\hline 159 & 10129 & 6007 & 5476 & 2706 & 159 & 159 & 159 \\
\hline 160 & 10130 & 6008 & 5477 & 2707 & 160 & 160 & 160 \\
\hline 161 & 10131 & 6009 & 5478 & 2708 & 161 & 161 & 161 \\
\hline 162 & 10132 & 6010 & 5479 & 2709 & 162 & 162 & 162 \\
\hline 163 & 10133 & 6011 & 5480 & 2710 & 163 & 163 & 163 \\
\hline 164 & 10134 & 6012 & 5481 & 2711 & 164 & 164 & 164 \\
\hline 165 & 10135 & 6013 & 5482 & 2712 & 165 & 165 & 165 \\
\hline 166 & 10136 & 6014 & 5483 & 2713 & 166 & 166 & 166 \\
\hline 167 & 10137 & 6015 & 5484 & 2714 & 167 & 167 & 167 \\
\hline 168 & 10138 & 6016 & 5485 , & 2715 & 168 & 168 & 168 \\
\hline 169 & 10139 & 6017 & 5486 & 2716 & 169 & 169 & 169 \\
\hline 170 & 10140 & 6018 & 5487 & 2717 & 170 & 170 & 170 \\
\hline 171 & 10141 & 6019 & 5188 & 2718 & 171 & 171 & 171 \\
\hline 172 & 10142 & 6020 & 5489 & 2719 & 172 & 172 & 172 \\
\hline 173 & 10143 & 6021 & 5490 & 2720 & 173 & 173 & 173 \\
\hline 174 & 10144 & 6022 & 5491 & 2721 & 174 & 174 & 174 \\
\hline 175 & 10145 & 6023 & 5492 & 2722 & 175 & 175 & 175 \\
\hline 176 & 10146 & 6024 & 5493 & 2723 & 176 & 176 & 176 \\
\hline 177 & 10147 & 6025 & 5491 & 2724 & 177 & 177 & 177 \\
\hline 178 & 10148 & 6026 & 5495 & 2725 & 178 & 178 & 178 \\
\hline 179 & 10149 & 6027 & 5496 & 2726 & 179 & 179 & 179 \\
\hline 180 & 10150 & 6027 & 5497 & 2727 & 180 & 180 & 180 \\
\hline 191 & 10151 & 6029 & 5498 & 2728 & 181 & 181 & 181 \\
\hline 182 & 10162 & 6030 & 5499 & 2729 & 182 & 182 & 182 \\
\hline 183 & 10153 & 6031 & 5500 & 2730 & 183 & 183 & 183 \\
\hline 181 & 10154 & 6032 & 5501 & 2731 & 184 & 184 & 184 \\
\hline 185 & 10155 & 6033 & 5502 & 2732 & 185 & 185 & 185 \\
\hline 186 & 10156 & 6034 & 5503 & 2733 & 186 & 186 & 186 \\
\hline 187 & 10157 & 6035 & 5504 & 2731 & 187 & 187 & 187 \\
\hline 188 & 10158 & 6036 & 5505 & 2735 & 188 & 188 & 188 \\
\hline 189 & 10159 & 6037 & 5506 & 2736 & 189 & 189 & 189 \\
\hline 190 & 9971 & 5842 & & 2737 & & 190 & 190 \\
\hline 191 & 10160 & 5843 & 5507 & 2738 & 190 & 191 & 191 \\
\hline 192 & 10161 & 5844 & 5508 & 2739 & 191 & 192 & 192 \\
\hline 193 & 10162 & 5845 & 5509 & 2710 & 192 & 193 & 193 \\
\hline 191 & 10163 & 5846 & 5510 & 2741 & 193 & 19.1 & 191 \\
\hline 195 & 10164 & 5847 & & 2742 & 194 & 195 & 195 \\
\hline 196 & 10165 & 5848 & 5511 & 2743 & 195 & 196 & 196 \\
\hline 197 & $\ldots \ldots$ & $\ldots$ & $\ldots$ & $\ldots$ & 196 & 197 & 197 \\
\hline 198 & $\ldots$ & $\ldots$ & $\ldots$ & $\ldots$ & 196 & 198 & 198 \\
\hline
\end{tabular}




\begin{tabular}{|c|c|c|c|c|c|c|c|c|c|}
\hline & $\begin{array}{c}\text { Consol. } \\
\text { Laws } \\
\text { ch. } 38 .\end{array}$ & $\begin{array}{l}\text { Rev. } \\
1905 \\
\text { cb. } 54 .\end{array}$ & $\begin{array}{l}\text { Rev. } \\
\text { Codes } \\
1905 \\
\text { (Civi. } \\
\text { Code), } \\
\text { ch. 90. }\end{array}$ & $\begin{array}{l}\text { Gen. } \\
\text { Code } \\
1910, \\
\text { Pt. 2, } \\
\text { tit. 7, } \\
\text { Div. 2, } \\
\text { p. } 1717 .\end{array}$ & $\begin{array}{l}\text { Rev. } \\
\text { laws } \\
1910, \\
\text { ch. } 49 .\end{array}$ & $\begin{array}{c}\text { Gen. } \\
\text { Laws } \\
1910 \\
\text { (L. O. L.), } \\
\text { tit. 40, } \\
\text { ch. } 2 \text {, } \\
\text { p. } 2128 .\end{array}$ & $\begin{array}{l}\text { Jaws } \\
1901 \text {, } \\
\text { p. } 194 .\end{array}$ & $\begin{array}{l}\text { Gen. } \\
\text { Laws } \\
1909 \text {, } \\
\text { tit. } 19 . \\
\text { ch. } 200 .\end{array}$ & $\begin{array}{c}\text { Acts, } \\
1914, \\
\text { Act } 396 \\
\text { o. } 668 .\end{array}$ \\
\hline $\begin{array}{l}\text { Uniform } \\
\text { Act } \\
\text { Sec. No. }\end{array}$ & $\begin{array}{l}1897 \\
\text { N. Y. }\end{array}$ & $\begin{array}{l}1899 \\
\text { N. C. }\end{array}$ & $\begin{array}{l}1899 \\
\text { N. D. }\end{array}$ & $\begin{array}{l}1902 \\
\text { Ohio }\end{array}$ & $\begin{array}{c}1909 \\
\text { Oklahoma }\end{array}$ & $\begin{array}{c}1899 \\
\text { Oregon }\end{array}$ & $\begin{array}{l}1901 \\
\text { Penn. }\end{array}$ & $\begin{array}{l}1899 \\
\text { R. } 1 .\end{array}$ & $\begin{array}{l}1914 \\
\text { S. C. }\end{array}$ \\
\hline & & & & & & 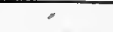 & & & \\
\hline 1 & 20 & 2151 & 6303 & 8106 & 4051 & 5834 & 1 & 7 & 1 \\
\hline 2 & 21 & 2152 & 6301 & 8107 & 4052 & 5835 & 2 & 8 & 2 \\
\hline 3 & 22 & 2153 & 630.5 & 8108 & 4053 & 5836 & 3 & 9 & 3 \\
\hline 4 & 23 & 2151 & 6306 & 8109 & 4054 & 5837 & 4 & 10 & 4 \\
\hline 5 & 24 & 2155 & 6307 & 8110 & 4055 & 5838 & 5 & 11 & 5 \\
\hline 6 & 25 & 2156 & 6308 & 8111 & 4056 & 5839 & 6 & 12 & 6 \\
\hline 7 & 26 & 2157 & 6309 & 8112 & 4057 & 5840 & 7 & 13 & 7 \\
\hline 8 & 27 & 2158 & 6310 & 8113 & 4058 & 5841 & 8 & 14 & 8 \\
\hline 9 & 28 & 2159 & 6311 & 8114 & 4059 & 5842 & 9 & 15 & 9 \\
\hline 10 & 29 & 2160 & 6312 & 8115 & 4060 & 5843 & 10 & 16 & 10 \\
\hline 11 & 30 & 2161 & 6313 & 8116 & 4061 & 5844 & 11 & 17 & 11 \\
\hline 12 & 31 & 2162 & 6314 & 8117 & 4062 & 3845 & 12 & 18 & 12 \\
\hline 13 & 32 & 2163 & 6315 & 8118 & 4063 & 5846 & 13 & 19 & 13 \\
\hline 14 & 33 & 2161 & 6316 & 8119 & 4064 & 5847 & 14 & 20 & 14 \\
\hline 15 & 34 & 2165 & 6317 & 8120 & 4065 & 5848 & 15 & 21 & 15 \\
\hline 16 & 35 & 2166 & 6318 & 8121 & 4066 & 5849 & 16 & 22 & 16 \\
\hline 17 & 36 & 2341 & 6319 & 8122 & 4067 & 5850 & 17 & 23 & 17 \\
\hline 18 & 37 & 2167 & 6320 & 8123 & 4068 & 5851 & 18 & 24 & 18 \\
\hline 19 & 38 & 2168 & 6321 & 8124 & 4069 & 5852 & 19 & 25 & 19 \\
\hline 20 & 39 & 2169 & 6322 & 8125 & 4070 & 5853 & 20 & 26 & 20 \\
\hline 21 & 40 & 2170 & 6323 & 8126 & 4071 & 5851 & 21 & 27 & 21 \\
\hline 22 & 41 & 2180 & 6324 & 8127 & 4072 & 5855 & 22 & 28 & 22 \\
\hline 23 & 42 & 2171 & 6325 & 8128 & 4073 & 5856 & 23 & 29 & 23 \\
\hline 24 & 50 & 2172 & 6326 & 8129 & 4074 & 5857 & 24 & 30 & 24 \\
\hline 25 & 51 & 2173 & 6327 & 8130 & 4075 & 5858 & 25 & 31 & 25 \\
\hline 26 & 52 & 2174 & 6328 & 8131 & 4076 & 5859 & 26 & 32 & 26 \\
\hline 27 & 53 & 2175 & 6329 & 8132 & 4077 & 5860 & 27 & $3 \overline{3}$ & 27 \\
\hline 28 & 54 & 2176 & 6330 & 8133 & 4078 & 5861 & 28 & 34 & 28 \\
\hline 29 & 55 & 2177 & 6331 & 8134 & 4079 & 5862 & 29 & 35 & 29 \\
\hline 30 & 60 & 2178 & 6332 & 8135 & 4080 & 5863 & 30 & 36 & 30 \\
\hline 31 & 61 & 2179 & 6333 & 8136 & 4081 & 5864 & 31 & 37 & 31 \\
\hline 32 & 62 & 2181 & 6334 & 8137 & 4082 & 5865 & 32 & 38 & 32 \\
\hline 33 & 63 & 2182 & 6335 & 8138 & 4083 & 5866 & 33 & 39 & $3 \overline{3}$ \\
\hline 34 & 64 & 2183 & 6336 & 8139 & 4084 & 5867 & 34 & 40 & 34 \\
\hline 35 & 65 & 2184 & 6337 & 81.40 & 4085 & 5868 & 35 & 41 & 35 \\
\hline 36 & 66 & 2185 & 6338 & 8141 & 4086 & 5869 & 36 & 42 & 36 \\
\hline 37 & 67 & 2186 & 6339 & 8142 & 4087 & 5870 & 37 & 43 & 37 \\
\hline 38 & 68 & 2187 & 6340 & 8143 & 4088 & 5871 & 38 & 44 & 38 \\
\hline 39 & 69 & 2188 & 6341 & 8144 & 4089 & 5872 & 39 & 45 & 39 \\
\hline 40 & 70 & 2189 & 6312 & 8145 & 4090 & 5873 & 40 & 46 & 40 \\
\hline 41 & 71 & 2190 & 6343 & 8146 & 4091 & 5874 & 41 & 47 & 41 \\
\hline 42 & 72 & 2191 & 6344 & 8147 & 4092 & 5875 & 42 & 48 & 42 \\
\hline 43 & 73 & 2192 & 6345 & 8148 & 4093 & 5876 & 43 & 49 & 43 \\
\hline 44 & 74 & 2193 & 6346 & 8149 & 4094 & 5877 & 44 & 50 & 44 \\
\hline 45 & 75 & 2194 & 6317 & 8150 & 4095 & 5878 & 45 & 51 & 45 \\
\hline 46 & 76 & 2195 & 6348 & 8151 & 4096 & 5879 & 46 & 52 & 46 \\
\hline 47 & 77 & 2196 & 6349 & 8152 & 4097 & 5880 & 47 & 53 & 47 \\
\hline
\end{tabular}




\begin{tabular}{|c|c|c|c|c|c|c|c|c|c|}
\hline & $\begin{array}{c}\text { Consol. } \\
\text { Iaws } \\
\text { ch. } 38 .\end{array}$ & $\begin{array}{l}\text { Rev. } \\
1905 . \\
\text { ch. } 54 .\end{array}$ & $\begin{array}{l}\text { Rev. } \\
\text { Codes } \\
1905 \\
\text { (Civ. } \\
\text { Corde), } \\
\text { ch. 90. }\end{array}$ & $\begin{array}{l}\text { Gen. } \\
\text { Code } \\
1910, \\
\text { Pt. } 2, \\
\text { tit. } 7, \\
\text { Div. } 2, \\
\text { p. } 1717 .\end{array}$ & $\begin{array}{l}\text { Rev. } \\
\text { Laws } \\
1910 \text {, } \\
\text { ch. } 49 .\end{array}$ & $\begin{array}{c}\text { Gen } \\
\text { Laws } \\
1910 \\
\text { (L. O. L.). } \\
\text { tit. 40, } \\
\text { ch. } 2 \text {. } \\
\text { p. } 2128 .\end{array}$ & $\begin{array}{l}\text { Laws } \\
1901 \text {. } \\
\text { D. } 194 .\end{array}$ & $\begin{array}{c}\text { Gern. } \\
\text { Law3 } \\
1009, \\
\text { tit. } 19 . \\
\text { ch. } 200 .\end{array}$ & $\begin{array}{c}\text { Acts } \\
1914 . \\
\text { Act } 396 \\
0.663 .\end{array}$ \\
\hline $\begin{array}{l}\text { Oniform } \\
\text { Act } \\
\text { Cec. No. }\end{array}$ & $\begin{array}{l}1897 \\
\text { N. Y. }\end{array}$ & $\begin{array}{l}1899 \\
\text { N. C. }\end{array}$ & $\begin{array}{l}1599 \\
\text { N. D. }\end{array}$ & $\begin{array}{l}1902 \\
\text { Otio }\end{array}$ & $\begin{array}{c}1909 \\
\text { Oklaboma }\end{array}$ & $\begin{array}{c}1899 \\
\text { Oregon }\end{array}$ & $\begin{array}{l}1901 \\
\text { Penn. }\end{array}$ & $\begin{array}{l}1899 \\
\text { li. I. }\end{array}$ & $\begin{array}{l}1914 \\
\text { S.C. }\end{array}$ \\
\hline 48 & 78 & 2197 & 6350 & 8153 & 4098 & 5881 & 48 & 54 & 48 \\
\hline 49 & 79 & 2198 & 6351 & 8154 & 4099 & 5882 & 49 & 5.5 & 49 \\
\hline 50 & 80 & 2199 & 6352 & 8155 & 4100 & 5883 & 50 & 56 & 50 \\
\hline 51 & 90 & 2200 & 6353 & 8156 & 4101 & 5884 & 51 & 57 & 51 \\
\hline 52 & 91 & 2201 & 6354 & 8157 & 4102 & 5885 & 52 & 58 & 52 \\
\hline 53 & 92 & 2202 & 6355 & 8158 & 4103 & 5886 & 53 & 59 & 53 \\
\hline 54 & 93 & 2203 & 6356 & 8159 & 4104 & 5887 & 54 & 60 & 54 \\
\hline 55 & 94 & 2204 & 6357 & 8160 & 4105 & 5888 & 55 & 61 & 55 \\
\hline 56 & 95 & 2205 & 6358 & 8161 & 4106 & 5889 & 56 & 62 & 56 \\
\hline 57 & 96 & 2206 & 6359 & 8162 & 4107 & 5890 & 57 & 63 & 57 \\
\hline 58 & 97 & 2207 & 6360 & 8163 & 4108 & 5891 & 58 & 64 & 58 \\
\hline 59 & 98 & 2208 & 6361 & 8164 & 4109 & 5892 & 59 & 65 & 59 \\
\hline 60 & 110 & 2209 & 6362 & 8165 & 4110 & 5893 & 60 & 66 & 60 \\
\hline 61 & 111 & 2210 & 6363 & 8166 & 4111 & 5894 & 61 & 67 & 61 \\
\hline 62 & 112 & 2211 & 6364 & 8167 & 4112 & 5895 & 62 & 68 & 62 \\
\hline 63 & 113 & 2212 & 6365 & 8168 & 4113 & 5896 & 63 & 69 & 63 \\
\hline 64 & 114 & 2213 & 6366 & 8169 & 4114 & 5897 & 64 & 70 & 64 \\
\hline 65 & 115 & 2214 & 6367 & 8170 & 4115 & 5898 & 65 & 71 & 65 \\
\hline 66 & 116 & 2215 & 6368 & 8171 & 4116 & 5899 & 66 & 72 & 66 \\
\hline 67 & 117 & 2216 & 6369 & 8172 & 4117 & 5900 & 67 & 73 & 67 \\
\hline 68 & 118 & 2217 & 6370 & 8173 & 4118 & 5901 & 63 & 74 & 68 \\
\hline 69 & 119 & 2218 & 6371 & 8174 & 4119 & 5902 & 69 & 75 & 69 \\
\hline 70 & 130 & 2219 & 6372 & 8175 & 4120 & 5903 & 70 & 76 & 70 \\
\hline 71 & 131 & 2220 & 6373 & 8176 & $412 \mathrm{~J}$ & 5904 & 71 & 77 & 71 \\
\hline 72 & 132 & 2221 & 6374 & 8177 & 4122 & 5905 & 72 & 78 & 72 \\
\hline 73 & 133 & 2222 & 6375 & 8178 & 4123 & 5906 & 73 & 79 & 73 \\
\hline 74 & 134 & 2223 & 6376 & 8179 & 4124 & 5907 & 74 & 80 & 74 \\
\hline 75 & 135 & 2224 & 6377 & 8180 & 4125 & 5908 & 75 & 81 & 75 \\
\hline 76 & 136 & 2225 & 6378 & 8181 & 4126 & 5909 & 76 & 82 & 76 \\
\hline 77 & 137 & 2226 & 6379 & 8182 & 4127 & 5910 & 77 & 83 & 77 \\
\hline 78 & 138 & 2227 & 6380 & 8183 & 4128 & 5911 & 78 & 84 & 78 \\
\hline 79 & 139 & 2228 & 6381 & 8184 & 4129 & 5912 & 79 & 85 & 79 \\
\hline 80 & 140 & 2229 & 6382 & 8185 & 413 & 5913 & 80 & 86 & 80 \\
\hline 81 & 141 & 2230 & 6383 & 8186 & 4131 & 5914 & 81 & 87 & 81 \\
\hline 82 & 142 & 2231 & 6384 & 8187 & 4132 & 5915 & 82 & 88 & 82 \\
\hline 83 & 143 & 2232 & 6385 & 8188 & 4133 & 5916 & 83 & 89 & 83 \\
\hline 84 & 144 & 2233 & 6386 & 8189 & 4134 & 5917 & 84 & 90 & 31 \\
\hline 85 & 145 & 2234 & 6387 & 8190 & 4135 & 5918 & 85 & 91 & 85 \\
\hline 86 & 146 & 2236 & 6388 & 8191 & 4136 & 5919 & 86 & 92 & 86 \\
\hline 87 & 147 & 2237 & 6389 & 8192 & 4137 & 5920 & 87 & 93 & 87 \\
\hline 88 & 148 & 2238 & 6390 & 8193 & 4138 & 5921 & 88 & 94 & 88 \\
\hline 89 & 160 & 2239 & 639] & 8194 & 4139 & 5922 & 89 & 95 & 89 \\
\hline 90 & 161 & 2240 & 6392 & 8195 & 4140 & 5923 & 90 & 96 & 90 \\
\hline 91 & 162 & 2241 & 6393 & 8196 & 4141 & 5924 & 91 & 97 & 91 \\
\hline 92 & 163 & 2242 & 6394 & 8197 & 4142 & 5925 & 92 & 98 & 92 \\
\hline 93 & 164 & 2243 & 6395 & 8198 & 4143 & 5926 & 93 & 99 & 93 \\
\hline 94 & 165 & 2244 & 6396 & 8199 & 4144 & 5927 & 94 & 100 & 94 \\
\hline 95 & 166 & 2245 & 6397 & 8200 & 4145 & 5928 & 95 & 101 & 95 \\
\hline
\end{tabular}




\begin{tabular}{|c|c|c|c|c|c|c|c|c|c|}
\hline - & $\begin{array}{c}\text { Consol. } \\
\text { Lams } \\
\text { ch. } 38 .\end{array}$ & $\begin{array}{l}\text { Rev. } \\
1905 \\
\text { ch. } 54 .\end{array}$ & $\begin{array}{l}\text { Rev. } \\
\text { Codes } \\
1905 \\
\text { (Civ. } \\
\text { Code). } \\
\text { ch. } 90 .\end{array}$ & $\begin{array}{l}\text { Gen. } \\
\text { Code } \\
1910 . \\
\text { Pt. } 2, \\
\text { tit. } 7 \\
\text { P)1 } 2.2 \\
\text { p. } 1717 .\end{array}$ & $\begin{array}{l}\text { Kev. } \\
\text { Laws } \\
1910, \\
\text { ch. } 49 .\end{array}$ & $\begin{array}{c}\text { Gen } \\
\text { Laws } \\
1910 \\
\text { (L. 0. L.) } \\
\text { tit. } 40 \text {. } \\
\text { ch. } 2 \text {. } \\
\text { p. } 2128 .\end{array}$ & $\begin{array}{c}\text { l.sws } \\
1901 \\
\text { p. } 194 .\end{array}$ & $\begin{array}{l}\text { Gen. } \\
\text { l.aws } \\
1909 . \\
\text { tit. 19, } \\
\text { ch. } 200 .\end{array}$ & $\begin{array}{c}\text { Acts } \\
1914, \\
\text { Act 398, } \\
\text { p. 668. }\end{array}$ \\
\hline $\begin{array}{l}\text { Uniform } \\
\text { Act } \\
\text { Sec. No. }\end{array}$ & N.Y & $\begin{array}{l}1899 \\
\text { N. C. }\end{array}$ & $\begin{array}{l}1899 \\
\text { N. D. }\end{array}$ & $\begin{array}{l}1902 \\
\text { Olinio }\end{array}$ & $\begin{array}{c}1909 \\
\text { Oklahoma }\end{array}$ & $\begin{array}{l}1899 \\
\text { Oregon }\end{array}$ & $\begin{array}{l}1901 \\
\text { Penn. }\end{array}$ & $\begin{array}{l}1899 \\
\text { R. } 1 .\end{array}$ & $\begin{array}{l}1914 \\
\text { S. C. }\end{array}$ \\
\hline 96 & 167 & 2246 & 6398 & 8201 & 4146 & 5929 & 96 & 102 & 96 \\
\hline 97 & 168 & 2247 & 6399 & 8202 & 4147 & 5930 & 97 & 103 & 97 \\
\hline 98 & 169 & 2248 & 6400 & 8203 & 4148 & 5931 & 98 & 104 & 98 \\
\hline 99 & 170 & 2249 & 6401 & 8204 & 4149 & 5932 & 99 & 105 & 99 \\
\hline 100 & 171 & 2250 & 6402 & 8205 & 4150 & 5933 & 100 & 106 & 100 \\
\hline 101 & 172 & 2251 & $640 ;$ & 8206 & 4151 & 5934 & 101 & 107 & 101 \\
\hline 102 & 173 & 2252 & $6401^{-}$ & 8207 & 4152 & 5935 & 102 & 108 & 102 \\
\hline 103 & 174 & 2253 & 6405 & 8208 & 4153 & 5936 & 103 & 109 & 103 \\
\hline 104 & 175 & 2254 & 6406 & 8209 & 4151 & 5937 & 104 & 110 & 104 \\
\hline 105 & 176 & 2255 & 6407 & 8210 & 4155 & $59: 38$ & 105 & 111 & 105 \\
\hline 106 & 177 & 2256 & 6408 & 8211 & 4156 & 5939 & 106 & 112 & 106 \\
\hline 107 & 178 & 2257 & 6409 & 8212 & 4157 & 940 & 107 & 113 & 107 \\
\hline 108 & 179 & 2258 & 6410 & 8213 & 4158 & 5941 & 108 & 114 & 108 \\
\hline 109 & 180 & 2259 & 6411 & 8214 & 4159 & 5942 & 109 & 115 & 109 \\
\hline 110 & 181 & 2260 & 6412 & 8215 & 4160 & 5943 & 110 & 116 & 110 \\
\hline 111 & 182 & 2261 & 6413 & 8216 & 4161 & 59.44 & 111 & 117 & 111 \\
\hline 112 & 183 & 2262 & 6414 & 8217 & 4162 & 5945 & 112 & 118 & 112 \\
\hline 113 & 184 & 2263 & 6415 & 8218 & 4163 & 5946 & 113 & 119 & 113 \\
\hline 114 & 185 & 2264 & 6416 & 8219 & 416 & 5947 & 114 & 120 & 114 \\
\hline 115 & 186 & 2265 & 6417 & 8220 & 4165 & 5948 & 115 & 121 & 115 \\
\hline 116 & 187 & 2266 & 6418 & 8221 & 4166 & 5949 & 116 & 122 & 116 \\
\hline 117 & 188 & 2267 & 6419 & 8222 & 4167 & 5950 & 117 & 123 & 117 \\
\hline 118 & 189 & 2268 & 6420 & 8223 & 4168 & 5951 & 118 & 124 & 118 \\
\hline 119 & 200 & 2269 & 6421 & 8224 & 4169 & 5952 & 119 & 125 & 119 \\
\hline 120 & 201 & 2270 & 6422 & 8225 & 4170 & 5953 & 120 & 126 & 120 \\
\hline 121 & 202 & 2271 & 6423 & 8226 & 4171 & 5954 & 121 & 127 & 121 \\
\hline 122 & 203 & 2272 & 6424 & 8227 & 4172 & 5955 & 122 & 128 & 122 \\
\hline 123 & 204 & 2273 & 6425 & 8228 & 4173 & 5956 & 123 & 129 & 123 \\
\hline 124 & 205 & 2274 & 6426 & 8229 & 4174 & 5957 & 124 & 130 & 124 \\
\hline 125 & 206 & 2275 & & $\mathbf{8 2 3 0}$ & 41 & & 125 & 131 & 125 \\
\hline 126 & 210 & 2276 & 6428 & 8231 & 417 & 5959 & 126 & 132 & 126 \\
\hline 127 & 211 & 2277 & 6429 & 8232 & 4177 & 5960 & 127 & 133 & 127 \\
\hline 128 & 212 & 2278 & & 8233 & 4178 & 5961 & 128 & 134 & 128 \\
\hline 129 & 213 & 2279 & & 8234 & 41 & & 129 & 135 & 129 \\
\hline 130 & 214 & 2280 & 6432 & 8235 & 418 & 5963 & 130 & 136 & 130 \\
\hline 131 & 215 & 2281 & 6433 & 8236 & 4181 & 5964 & 131 & 137 & 131 \\
\hline 132 & 220 & 2282 & 6434 & 8237 & 418 & 5965 & 132 & 138 & 132 \\
\hline 133 & 221 & 2283 & & & 418 & & 133 & 139 & 133 \\
\hline 131. & 222 & 2281 & 6436 & 8239 & 418 & 59 & 134 & 140 & 134 \\
\hline 135 & 223 & 2285 & 6437 & 8240 & 4185 & 5968 & 135 & 141 & 135 \\
\hline 136 & 224 & 2286 & 6438 & 8241 & 4186 & 5969 & 136 & 142 & 136 \\
\hline 137 & 225 & 2287 & 6439 & 8242 & 4.18 & 5970 & 137 & 143 & 137 \\
\hline 138 & 226 & 2283 & 6440 & 8243 & 418 & 5971 & 138 & 144 & 138 \\
\hline 139 & 227 & 2289 & 6441 & 8244 & 4189 & 5972 & 139 & 145 & 139 \\
\hline 140 & 228 & 2290 & 6442 & 8245 & 4190 & 5973 & 140 & 146 & 140 \\
\hline 141 & 229 & 2291 & 6443 & 82.16 & 4191 & 5974 & 141 & 147 & 141 \\
\hline 142 & 230 & 2292 & $6+41$ & 8247 & 4192 & 5975 & 142 & 148 & 142 \\
\hline 143 & 240 & 2293 & 6445 & 8248 & 4193 & 5976 & 143 & 149 & 143 \\
\hline
\end{tabular}




\begin{tabular}{|c|c|c|c|c|c|c|c|c|c|}
\hline & $\begin{array}{c}\text { Consol. } \\
\text { lsw3 } \\
\text { ch. } 38 .\end{array}$ & $\begin{array}{l}\text { Rev. } \\
1905 \text {, } \\
\text { ch. } 54 .\end{array}$ & $\begin{array}{l}\text { Rev. } \\
\text { Codes } \\
1905 \\
\text { (Civ. } \\
\text { Code). } \\
\text { ch. 90. }\end{array}$ & $\begin{array}{l}\text { Gen. } \\
\text { Code } \\
1910 . \\
\text { Pt. } 2, \\
\text { tit. 7. } \\
\text { Div. } 2 \\
\text { p. } 1717 .\end{array}$ & $\begin{array}{c}\text { Rev. } \\
\text { Laws } \\
1910 \\
\text { ch. } 49 .\end{array}$ & $\begin{array}{c}\text { Gen. } \\
\text { Laws } \\
1910 \\
\text { (L. } 0 . \mathrm{L} \text { ), } \\
\text { tit. } 40 . \\
\text { ch. } 2 \text {. } \\
\text { p. } 2128\end{array}$ & $\begin{array}{c}\text { Lews } \\
1901 . \\
\text { p. } 194 .\end{array}$ & $\begin{array}{c}\text { Gen. } \\
\text { Laws } \\
1909 . \\
\text { tit. } 19 \\
\text { ch. 200. }\end{array}$ & $\begin{array}{c}\text { Aets } \\
1914 . \\
\text { Aet } 396, \\
\text { p. } 668\end{array}$ \\
\hline $\begin{array}{l}\text { Uniform } \\
\text { Act } \\
\text { Sec. No. }\end{array}$ & $\begin{array}{r}1897 \\
\text { N. Y. }\end{array}$ & $\begin{array}{l}1899 \\
\text { N. C. }\end{array}$ & $\begin{array}{l}1899 \\
\text { N. D. }\end{array}$ & $\begin{array}{l}1902 \\
\text { Obio }\end{array}$ & $\begin{array}{c}1909 \\
\text { Orlahoma }\end{array}$ & $\begin{array}{l}1899 \\
\text { Oregon }\end{array}$ & $\begin{array}{l}1901 \\
\text { Penn. }\end{array}$ & $\begin{array}{l}1899 \\
\text { R. I. }\end{array}$ & $\begin{array}{l}1914 \\
\text { 8. C. }\end{array}$ \\
\hline 144 & 241 & 2294 & 6446 & 8249 & 4194 & 5977 & 144 & 150 & 144 \\
\hline 145 & 242 & 2295 & 6447 & 8250 & 4195 & 5978 & 145 & 151 & 145 \\
\hline 146 & 213 & 2296 & 6448 & 8251 & 4196 & 5979 & 146 & 152 & 146 \\
\hline 147 & 241 & 2297 & 6449 & 8252 & 4197 & 5980 & 147 & 153 & 147 \\
\hline 148 & 245 & 2298 & 6450 & 8253 & 4198 & 5981 & 148 & 154 & 148 \\
\hline 149 & 246 & 2299 & 6451 & 8254 & 4199 & 5982 & 149 & 155 & 149 \\
\hline 150 & 247 & 2300 & 6452 & 8255 & 4200 & 5983 & 150 & 156 & 150 \\
\hline 151 & 2.18 & 2301 & 6453 & 8256 & 4201 & 5981 & 151 & 157 & 151 \\
\hline 152 & 260 & 2302 & 6454 & 8257 & 4202 & 5985 & 152 & 158 & 152 \\
\hline 153 & 261 & 2303 & 6455 & 8258 & 4203 & 5986 & 153 & 159 & 153 \\
\hline 154 & 262 & $23 c 4$ & 6456 & 8259 & 4201 & 5987 & 154 & 160 & 154 \\
\hline 155 & 263 & 2305 & 6457 & 8260 & 4205 & 5988 & 155 & 161 & 155 \\
\hline 156 & 264 & 2306 & 6458 & 8261 & 4206 & 5989 & 156 & 162 & 156 \\
\hline 157 & 265 & 2307 & 6459 & 8262 & 4207 & 5990 & 157 & 163 & 157 \\
\hline 158 & 266 & 2308 & 6460 & 8263 & 4208 & $599 \mathrm{I}$ & 158 & 164 & 158 \\
\hline 159 & 267 & 2309 & 6461 & 8261 & 4209 & 5992 & 159 & 165 & 159 \\
\hline 160 & 268 & 2310 & 6462 & 8265 & 4210 & 5993 & 160 & 166 & 160 \\
\hline 161 & 280 & 2311 & 6463 & 8266 & 4211 & 5991 & 161 & 167 & 161 \\
\hline 162 & 281 & 2312 & 6461 & 8267 & 4212 & 5995 & 162 & 168 & 162 \\
\hline 163 & 282 & 2313 & 6465 & 8268 & 4213 & 5996 & 163 & 169 & 163 \\
\hline 164 & 283 & 2314 & 6466 & 8269 & 4214 & 5997 & 164 & 170 & 164 \\
\hline 165 & 284 & 2315 & 6467 & 8270 & 4215 & 5998 & 165 & 171 & 165 \\
\hline 166 & 285 & 2316 & 6468 & 8271 & 4216 & 5999 & 166 & 172 & 166 \\
\hline 167 & 286 & 2317 & 6467 & 8272 & 4217 & 6000 & 167 & 173 & 167 \\
\hline 168 & 287 & 2318 & 6470 & 8273 & 4218 & 6001 & 168 & 174 & 168 \\
\hline 169 & 288 & 2319 & 6471 & 8274 & 4219 & 6002 & 169 & 175 & 169 \\
\hline 170 & 289 & 2320 & 6472 & 8275 & 4220 & 6003 & 170 & 176 & 170 \\
\hline 171 & 300 & 2321 & 6473 & 8276 & 4221 & 6004 & 171 & 177 & 171 \\
\hline 172 & 301 & 2322 & 6474 & 8277 & 4222 & 6005 & 172 & 178 & 172 \\
\hline 173 & 302 & 2323 & 6475 & 8278 & 4223 & 6006 & 173 & 179 & 173 \\
\hline 174 & 303 & 2324 & 6476 & 8279 & 4224 & 6007 & 174 & 180 & 174 \\
\hline 175 & 304 & 2325 & 6477 & 8280 & 4225 & 6008 & 175 & 181 & 175 \\
\hline 176 & 305 & 2326 & 6478 & 8281 & 4226 & 6009 & 176 & 182 & 176 \\
\hline 177 & 306 & 2327 & 6479 & 8282 & 4227 & 6010 & 177 & 183 & 177 \\
\hline 178 & 310 & 2328 & 6480 & 8283 & 4228 & 6011 & 178 & 184 & 178 \\
\hline 179 & 311 & 2329 & 6481 & 8284 & 4229 & 6012 & 179 & 185 & 179 \\
\hline 180 & 312 & 2330 & 6482 & 8285 & 4230 & 6013 & 180 & 186 & 180 \\
\hline $18 \mathrm{l}$ & 313 & 2331 & 6483 & 8286 & 4231 & 6014 & 181 & 187 & 181 \\
\hline 182 & 314 & 2332 & 6484 & 8287 & 4232 & 6015 & 182 & 188 & 182 \\
\hline 183 & 315 & 2333 & 6185 & 8288 & 4233 & 6016 & 183 & 189 & 183 \\
\hline 184 & 320 & 2334 & 6186 & 8289 & 4234 & 6017 & 184 & 190 & 181 \\
\hline 185 & 321 & 2335 & 6487 & 8290 & 4235 & 6018 & 185 & 191 & 185 \\
\hline 186 & 322 & 2336 & 6488 & 8291 & 4236 & 6019 & 186 & 192 & 186 \\
\hline 187 & 323 & 2337 & 6489 & 8292 & 4237 & 6020 & 187 & 193 & 187 \\
\hline 188 & 324 & 2338 & 6490 & 8293 & 4238 & 6021 & 188 & 19.1 & 188 \\
\hline 189 & 325 & 2339 & 6491 & 8294 & 4239 & 6022 & 189 & 195 & 189 \\
\hline 190 & 1 & & 6192 & & 4014 & 6023 & 190 & & 190 \\
\hline 191 & 2 & 2310 & 6493 & 8295 & 4015 & 6023 & 191 & 1 & 191 \\
\hline
\end{tabular}




\begin{tabular}{|c|c|c|c|c|c|c|c|c|c|}
\hline & $\begin{array}{c}\text { Consol. } \\
\text { Laws } \\
\text { ch. } 38 .\end{array}$ & $\begin{array}{l}\text { Rev. } \\
1905 \text {. } \\
\text { ch. } 54 .\end{array}$ & $\begin{array}{l}\text { Rev. } \\
\text { Codes } \\
1905 \\
\text { (Civ. } \\
\text { Code). } \\
\text { ch. } 90 .\end{array}$ & $\begin{array}{l}\text { Gen. } \\
\text { Code } \\
1910 . \\
\text { Pt. } 2, \\
\text { it. } 7 \\
\text { Div. } 2 \\
\text { p. } 1717 .\end{array}$ & $\begin{array}{l}\text { Rer. } \\
\text { Laws } \\
1910, \\
\text { ch. } 49 .\end{array}$ & $\begin{array}{c}\text { Geo. } \\
\text { Laws } \\
1910 \\
\text { (L. O. L.). } \\
\text { tit. } 40 \\
\text { ch. 2. } \\
\text { p. } 2128 .\end{array}$ & $\begin{array}{l}\text { Laws } \\
1901 \text {, } \\
\text { p. } 194 .\end{array}$ & $\begin{array}{c}\text { Gen. } \\
\text { Laws } \\
1909 . \\
\text { tit. } 19 . \\
\text { ch. } 200 .\end{array}$ & $\begin{array}{c}\text { Acts, } \\
1914 . \\
\text { Act } 396 \\
\text { 5. } 668 .\end{array}$ \\
\hline $\begin{array}{l}\text { Oniform } \\
\text { Act } \\
\text { Bec. No. }\end{array}$ & $\begin{array}{c}1897 \\
\text { N. Y. }\end{array}$ & $\begin{array}{l}1898 \\
\text { N.C. }\end{array}$ & $\begin{array}{l}1899 \\
\text { N. D. }\end{array}$ & $\begin{array}{l}1902 \\
\text { Ohio }\end{array}$ & $\begin{array}{l}1909 \\
\text { Otrlahoma }\end{array}$ & $\begin{array}{c}1899 \\
\text { Oregon }\end{array}$ & $\begin{array}{l}1901 \\
\text { Penn. }\end{array}$ & $\begin{array}{l}1899 \\
\text { R. I. }\end{array}$ & $\begin{array}{l}1914 \\
\text { S. C. }\end{array}$ \\
\hline $\begin{array}{l}197 \\
193 \\
194 \\
195 \\
196 \\
197 \\
198\end{array}$ & $\begin{array}{r}3 \\
4 \\
5 \\
6 \\
? \\
340 \\
341\end{array}$ & $\begin{array}{c}2342 \\
2343 \\
\ldots 34 \\
2345 \\
2344 \\
\ldots \\
\ldots\end{array}$ & $\begin{array}{c}6494 \\
6495 \\
6495 \\
6497 \\
6498 \\
\ldots \ldots \\
\ldots \ldots\end{array}$ & $\begin{array}{c}8296 \\
8297 \\
8298 \\
8299 \\
8300 \\
\ldots \ldots \\
\ldots \ldots\end{array}$ & $\begin{array}{c}4046 \\
4047 \\
4048 \\
4049 \\
4050 \\
\ldots \\
\ldots \ldots\end{array}$ & $\begin{array}{c}6023 \\
6023 \\
6023 \\
6024 \\
6025 \\
\ldots \ldots \\
\ldots \ldots\end{array}$ & $\begin{array}{l}192 \\
193 \\
194 \\
195 \\
196 \\
197 \\
198\end{array}$ & $\begin{array}{r}2 \\
3 \\
4 \\
5 \\
6 \\
\cdots \\
\cdots\end{array}$ & $\begin{array}{l}192 \\
193 \\
19.1 \\
195 \\
196 \\
197 \\
198\end{array}$ \\
\hline
\end{tabular}




\begin{tabular}{|c|c|c|c|c|c|c|c|c|c|c|}
\hline & $\begin{array}{l}\text { Comp. } \\
\text { Laws } \\
1913 \text {, } \\
\text { Vol. 2, } \\
\text { p. } 298 .\end{array}$ & $\begin{array}{l}\text { Code } \\
\text { Supp. } \\
1897- \\
1903 \text {. } \\
\text { p. } 571 .\end{array}$ & $\begin{array}{c}\text { Comp. } \\
\text { Laws } \\
1907 . \\
\text { tit. } 53 . \\
\text { p. } 629 .\end{array}$ & $\begin{array}{l}\text { Law日 } \\
1912, \\
\text { Ar. } 99 .\end{array}$ & $\begin{array}{c}\text { Corle } \\
1904 \text {. } \\
\text { ch. 133a. } \\
\text { sec. } \\
2841-\mathrm{a} .\end{array}$ & $\begin{array}{c}\text { Rem. } \\
\& \text { Bal. } \\
\text { Code } \\
1910 . \\
\text { tit. } 19 \text {, } \\
\text { ch. } 3 \text {. }\end{array}$ & $\begin{array}{l}\text { Acts } \\
1907 \\
\text { ch. } 81 .\end{array}$ & $\begin{array}{l}\text { St. } 1913, \\
\text { ch. } 78 .\end{array}$ & $\begin{array}{l}\text { Comp. } \\
\text { St. } 1910 \text {, } \\
\text { ch } 210 .\end{array}$ & $\begin{array}{l}\text { Publio } \\
\text { Law! } \\
\text { Vol. } 8, \\
\text { p. } 116 .\end{array}$ \\
\hline $\begin{array}{l}\text { Uniform } \\
\text { Act } \\
\text { Bec. No. }\end{array}$ & $\begin{array}{l}1913 \\
\text { S. D. }\end{array}$ & $\begin{array}{c}1899 \\
\text { Tend. }\end{array}$ & $\begin{array}{r}1899 \\
\text { Utab }\end{array}$ & $\begin{array}{l}1912 \\
V_{t} .\end{array}$ & $\begin{array}{l}1897 \\
\text { Va. }\end{array}$ & $\begin{array}{c}1899 \\
\text { Wash. }\end{array}$ & $\begin{array}{c}1907 \\
\text { W. Va. }\end{array}$ & $\begin{array}{l}1899 \\
\text { Wis. }\end{array}$ & $\begin{array}{l}1905 \\
\text { Wyo. }\end{array}$ & $\begin{array}{c}1911 \\
\text { Phil. Ist }\end{array}$ \\
\hline
\end{tabular}

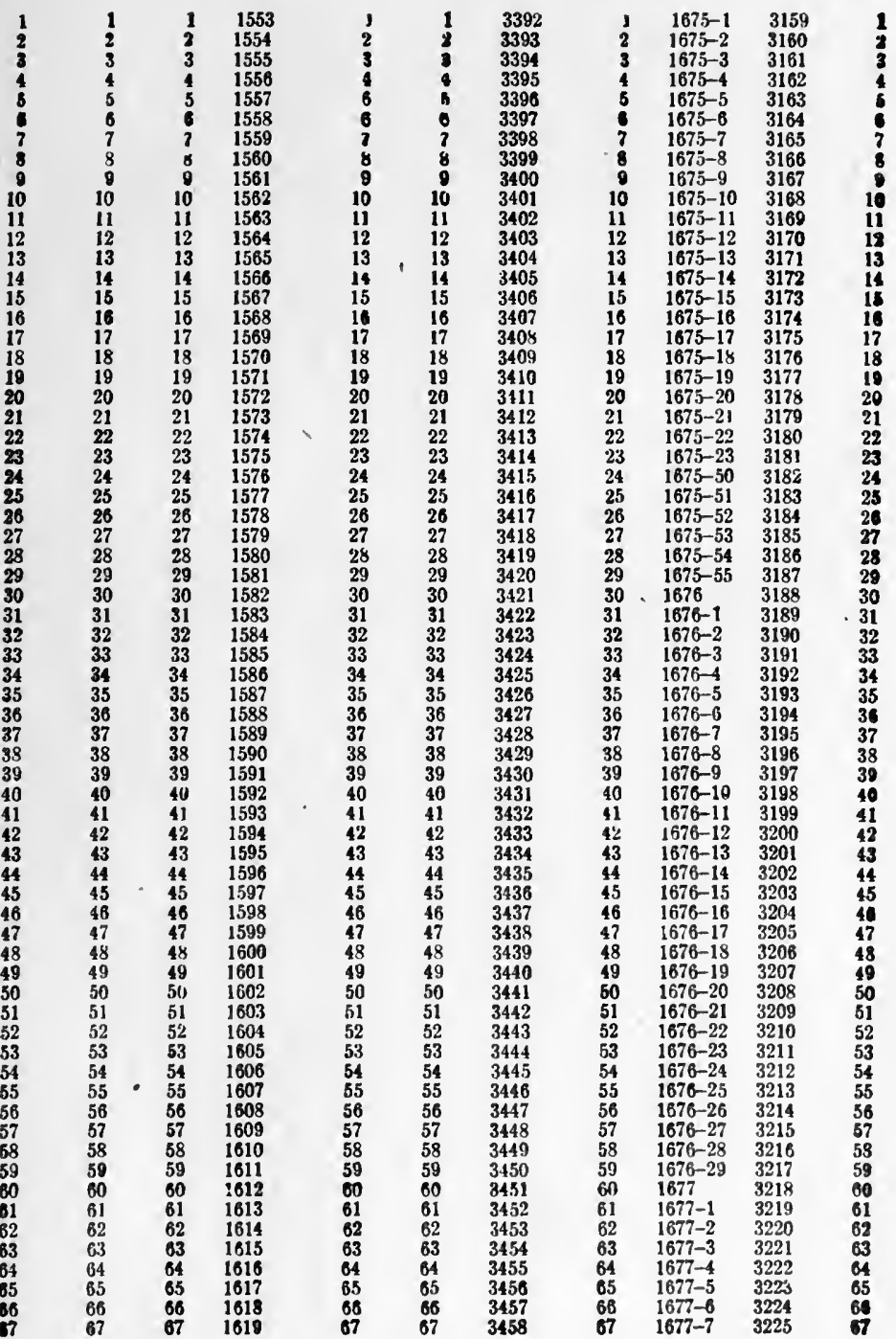




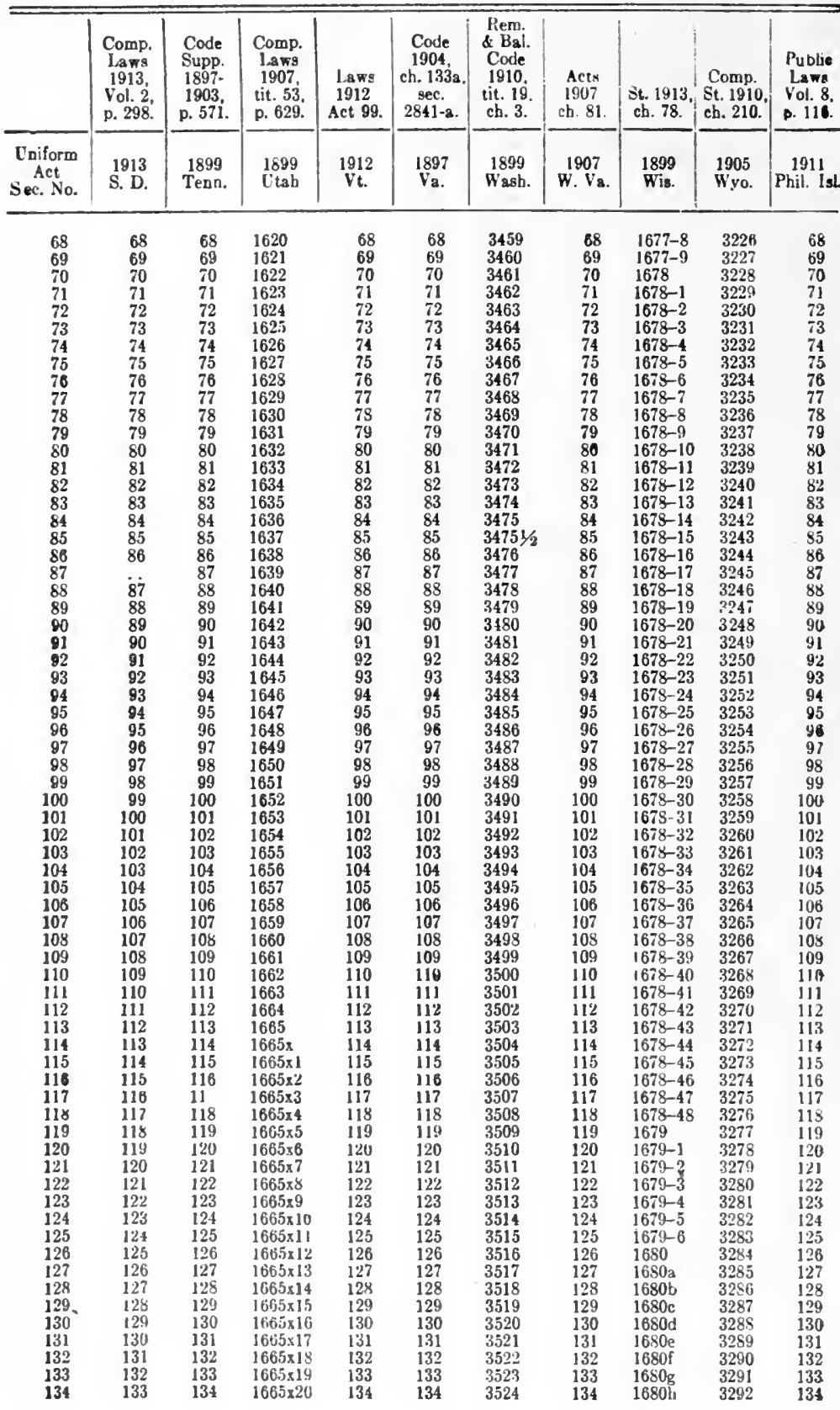




\begin{tabular}{|c|c|c|c|c|c|c|c|c|c|c|}
\hline & $\begin{array}{l}\text { Comp. } \\
\text { Laws } \\
1913 \text {, } \\
\text { Vol. 2, } \\
\text { p. } 298 .\end{array}$ & $\begin{array}{c}\text { Code } \\
\text { Supp. } \\
1597- \\
1903 \text {, } \\
\text { p. } 571 .\end{array}$ & $\begin{array}{l}\text { Comp. } \\
\text { Jaws } \\
1907 \text {, } \\
\text { tit. } 53 \text {, } \\
\text { p. } 629 .\end{array}$ & $\begin{array}{r}\text { Iaw' } \\
1912 \text {, } \\
\text { Act } 99 .\end{array}$ & $\begin{array}{c}\text { Code } \\
1904, \\
\text { ch. } 133 \mathrm{a} . \\
\text { sec. } \\
2841-\mathrm{a} .\end{array}$ & $\begin{array}{c}\text { Rem. } \\
\text { \& Bal. } \\
\text { Code } \\
1910 \\
\text { tit. } 19 \text {, } \\
\text { ch. } 3 \text {. }\end{array}$ & $\begin{array}{c}\text { Acts } \\
190 i \\
\text { cb. } 81 \text {. }\end{array}$ & $\begin{array}{c}\text { St. } 1913, \\
\text { ch. } 78 .\end{array}$ & $\begin{array}{l}\text { Comp. } \\
\text { St. } 1910 . \\
\text { ch. } 210 .\end{array}$ & $\begin{array}{l}\text { Public } \\
\text { I.sws } \\
\text { Vol. } 8 \text {, } \\
\text { p. } 116 .\end{array}$ \\
\hline $\begin{array}{l}\text { Uniform } \\
\text { Act } \\
\text { Sec. No. }\end{array}$ & $\begin{array}{c}1913 \\
\text { S. D. }\end{array}$ & $\begin{array}{r}1899 \\
\text { Tenn. }\end{array}$ & $\begin{array}{l}1899 \\
\text { Utsh }\end{array}$ & $\begin{array}{l}1912 \\
\text { Vt. }\end{array}$ & $\begin{array}{c}1897 \\
Y_{\mathrm{a} .}\end{array}$ & $\begin{array}{r}\text { IS99 } \\
\text { Wasb. }\end{array}$ & $\begin{array}{c}1907 \\
\text { W. Va. }\end{array}$ & $\begin{array}{l}1899 \\
\text { Wis. }\end{array}$ & $\begin{array}{l}1905 \\
\text { Wyo. }\end{array}$ & Pbil IsI. \\
\hline 135 & 134 & 135 & $165.5 \times 21$ & 135 & 135 & 3525 & 135 & $1680 \mathrm{i}$ & 3293 & 135 \\
\hline 136 & 135 & 136 & $1665 \times 22$ & 136 & 136 & 3526 & 136 & $1680 \mathrm{j}$ & 3294 & 136 \\
\hline 137 & & 137 & $1665 \times 23$ & 137 & 137 & 3527 & 137 & $1680 \mathrm{k}$ & 3295 & 137 \\
\hline 138 & 136 & 138 & $1665 \times 24$ & 138 & 138 & 3528 & 138 & 16801 & 3296 & 138 \\
\hline 139 & 137 & 139 & $1665 \times 25$ & 139 & 139 & 3529 & 139 & $1680 \mathrm{~m}$ & 3297 & 139 \\
\hline 140 & 138 & 140 & $1665 \times 26$ & 140 & 140 & 3530 & 140 & $1680 n$ & 3298 & 140 \\
\hline 141 & 139 & 141 & $1665 \times 27$ & 141 & 141 & 3531 & 141 & 16800 & 3299 & 141 \\
\hline 142 & 140 & 142 & $1665 \times 28$ & 142 & 142 & 3532 & 142 & $1650 p$ & 3300 & 142 \\
\hline 143 & 141 & 143 & $1665 \times 29$ & 143 & 143 & 3533 & 143 & 1681 & 3301 & 143 \\
\hline 144 & 142 & 144 & $1665 \times 30$ & 144 & 144 & 3534 & 144 & $1681-1$ & 3302 & 144 \\
\hline 145 & 143 & 145 & $1665 \times 31$ & 145 & 145 & 3535 & 145 & $1681-2$ & 3303 & 145 \\
\hline 146 & 144 & 146 & $1665 \times 32$ & 146 & 146 & 3536 & 146 & $1681-3$ & 3304 & 146 \\
\hline 147 & 145 & 147 & $1665 \times 33$ & 147 & 147 & 3537 & 147 & $1681-4$ & 3305 & 147 \\
\hline 148 & 146 & 148 & $1665 \times 34$ & 148 & 148 & 3538 & 148 & $1681-5$ & 3306 & 148 \\
\hline 149 & 147 & 149 & $1665 \times 35$ & 149 & 149 & 3539 & 149 & $1681-6$ & 3307 & 149 \\
\hline 150 & 148 & 150 & $1665 \times 36$ & 150 & 150 & 3540 & 150 & $1681-7$ & 3308 & 150 \\
\hline 151 & 149 & 151 & $1665 \times 37$ & 151 & 151 & 3541 & 151 & $1681-8$ & 3309 & 151 \\
\hline 152 & 150 & 152 & $1665 \times 38$ & 152 & 152 & 3542 & 152 & $1681-9$ & 3310 & 152 \\
\hline 153 & 151 & 153 & $1665 \times 39$ & 153 & 153 & 3543 & 153 & $1681-10$ & 3311 & 153 \\
\hline 154 & 152 & 154 & $1665 \times 40$ & 154 & 154 & 3544 & 154 & $1681-11$ & 3312 & 154 \\
\hline 155 & 153 & 155 & $1665 \times 41$ & 155 & 155 & 3545 & 155 & $1681-12$ & 3313 & 155 \\
\hline 156 & 154 & 156 & $1665 \times 42$ & 156 & 156 & 3546 & 156 & $16 \$ 1-13$ & 3314 & 156 \\
\hline 157 & 155 & 157 & $1665 \times 43$ & 157 & 157 & 3547 & 157 & $1681-14$ & 3315 & 157 \\
\hline 158 & 156 & 158 & $1665 \times 14$ & 158 & 158 & 3548 & 158 & $1681-15$ & 3316 & 158 \\
\hline 159 & 157 & 159 & $1665 \times 45$ & 159 & 159 & 3549 & 159 & $1681-16$ & 3317 & 159 \\
\hline 160 & 158 & 160 & $1665 \times 46$ & 160 & 160 & 3550 & 160 & $1681-17$ & 3318 & 160 \\
\hline 161 & 159 & 161 & $1665 \times 47$ & 161 & 161 & 3551 & 161 & $1681-18$ & 3319 & 161 \\
\hline 162 & 160 & 162 & $1665 \times 48$ & 162 & 162 & 3552 & 162 & $1681-19$ & 3320 & 162 \\
\hline 163 & 161 & 163 & $1665 \times 49$ & 163 & 153 & 3553 & 163 & $1681-20$ & 3321 & 163 \\
\hline 164 & 162 & 164 & $1665 \times 50$ & 164 & 164 & 3554 & 164 & $1681-21$ & 3322 & 164 \\
\hline 165 & 163 & 165 & $1665 \times 51$ & 165 & 165 & 3555 & 165 & $1681-22$ & 3323 & 165 \\
\hline 166 & 164 & 166 & $1665 \times 52$ & 166 & 166 & 3556 & 166 & $1681-23$ & 3324 & 166 \\
\hline 167 & 165 & 167 & $1665 \times 53$ & 167 & 167 & 3557 & 167 & $1681-24$ & 3325 & 167 \\
\hline 168 & 166 & 168 & $1665 \times 54$ & 168 & 168 & 3558 & 168 & $1681-25$ & 3326 & 168 \\
\hline 169 & 167 & 169 & $1665 \times 55$ & 169 & 169 & 3559 & 169 & $1681-26$ & 3327 & 169 \\
\hline 170 & 168 & 170 & $1665 \times 56$ & 170 & 170 & 3560 & 170 & $1681-27$ & 3328 & 170 \\
\hline 171 & 169 & 171 & $1665 \times 57$ & 171 & 171 & 3561 & 171 & $1681-28$ & 3329 & 171 \\
\hline 172 & 170 & 172 & $1665 \times 58$ & 172 & 172 & 3562 & 172 & $1681-29$ & 3330 & 172 \\
\hline 173 & 171 & 173 & $1665 \times 59$ & 173 & 173 & 3563 & 173 & $1681-30$ & 3331 & 173 \\
\hline 174 & 172 & 174 & $1665 \times 60$ & 174 & 174 & 3564 & 174 & $1681-31$ & 3332 & 174 \\
\hline 175 & 173 & 175 & $1665 \times 61$ & 175 & 175 & 3565 & 175 & $1681-32$ & 3333 & 175 \\
\hline 176 & 174 & 176 & $1665 \times 62$ & 176 & 176 & 3566 & 176 & $1681-33$ & 3334 & 176 \\
\hline 177 & 175 & 177 & $1665 \times 63$ & 177 & 177 & 3567 & $\cdot 177$ & $1681-34$ & 3335 & 177 \\
\hline 178 & 176 & 178 & $1665 \times 64$ & 178 & 178 & 3568 & 178 & $1681-35$ & 3336 & 178 \\
\hline 179 & 177 & 179 & $1665 \times 65$ & 179 & 179 & 3569 & 179 & $1681-36$ & $333 \%$ & 1.9 \\
\hline 180 & 178 & 180 & $1665 \times 66$ & 180 & 180 & 3570 & 180 & $1681-37$ & $333 s$ & 150 \\
\hline 181 & 179 & 181 & $1655-67$ & 181 & 181 & 3571 & 181 & $1681-38$ & 3939 & $1 \times 1$ \\
\hline 182 & 180 & 182 & $1665-68$ & 182 & 182 & 3572 & 182 & $1681-39$ & 3340 & 182 \\
\hline 183 & 181 & 183 & $1665-69$ & 183 & 183 & 3573 & 183 & $1681-40$ & 3341 & 153 \\
\hline 184 & 182 & 184 & $1665-70$ & 184 & 184 & 3574 & 184 & 1684 & 3342 & 184 \\
\hline 185 & 183 & 185 & $1065-71$ & 185 & 185 & 3575 & 185 & $16 \$ 4-1$ & 3343 & 185 \\
\hline 186 & 184 & 186 & $1665-72$ & 186 & 186 & 3576 & 186 & $1684-2$ & 3344 & 156 \\
\hline 187 & 185 & 187 & $1865-73$ & 187 & 187 & 3577 & 187 & $1684-3$ & 3345 & 187 \\
\hline 188 & 186 & 188 & $1665-74$ & 188 & 185 & 3578 & 188 & $1681-1$ & 3346 & 188 \\
\hline 189 & 187 & 189 & $1665-75$ & 189 & 189 & 3579 & 189 & $168 t-5$ & 3347 & 189 \\
\hline 190 & 188 & $*$ & $1665-76$ & 190 & 190 & 3580 & 190 & & 3348 & 190 \\
\hline 191 & 189 & * & $1665-77$ & 181 & 191 & 3581 & 191 & 1675 & 3349 & 191 \\
\hline 192 & 190 & $*$ & $1665-78$ & 192 & 192 & 3582 & 192 & 1675 & 3350 & 192 \\
\hline 193 & 191 & * & $1665-79$ & 193 & 193 & 3583 & 193 & 1675 & 3351 & 193 \\
\hline 194 & 192 & $\star$ & $166 ;-80$ & 194 & 194 & 3584 & 194 & 1675 & 3352 & 194 \\
\hline 195 & 193 & 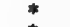 & $1665-81$ & 195 & 195 & 3585 & 195 & 1675 & 33.53 & 195 \\
\hline 196 & 194 & * & $1665-82$ & 196 & 196 & 3586 & 196 & 1675 & 3354 & 196 \\
\hline 197 & $\ldots$ & 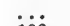 & $\ldots \ldots$ & 197 & 197 & $\ldots$ & 197 & $1681-7$ & $\ldots$ & 197 \\
\hline 198 & ... & 190 & $\ldots \ldots$ & 198 & 198 & ... & 198 & $\ldots \ldots$ & $\ldots$ & 198 \\
\hline
\end{tabular}

* Not numbered in general introduction. 


\section{UNIFORM NEGOTIABLE INSTRUMENTS ACT}

Sectiox 1. Form of Negotiable Instrument.

2. Certainty as to Sum; What Constitutes.

3. When Promise is Unconditional.

4. Determinable Future Time; What Constitutes.

5. Additional Provisions not Affecting Negotiablity.

6. Omissions; Seal; Particular Money.

7. When Payable on Demand.

8. When Payable to Order.

9. When Payable to Bearer.

10. Terms When Suffieient.

11. Date, Presumption as to.

12. Ante-dated and Post.dated.

13. When Date May be Inserted.

14. Blanks; When May be Filled.

15. Incomplete Instrument not Delivered.

16. Delivery; When Effectual; When Presumed.

17. Construction Where Instrument is Ambiguous.

18. Liability of Person Signing in Trade or Assumed Name.

19. Signature by Agent; Authority; How Shown.

20. Liability of Person Signing as Agent, etc.

21. Signature by Procuration; Effect of.

22. Effect of Indorsement by Infant or Corporation.

23. Forged Signature; Effect of.

24. Presumption of Consideration.

25. Consideration, What Constitutes.

26. What Constitutes Holder for Value.

27. When Lien on Instrument Constitutes Holder for Value.

28. Effect of Want of Consideration.

29. Liability of Accommodation Party.

30. Whet Constitutes Negotiation.

31. Indorsement; How Made.

82. Indorsement Must be of Entire Instrument. 
Secrion 33. Kinds of Indorsement.

34. Special Indorsement; Indorsement in Blank.

35. Blank Indorsement; How Changed to Special Indorsement.

36. When Indorsement Restrictive.

37. Effect of Restricting.

38. Qualified Indorsement.

39. Conditional Indorsement.

40. Indorsement of Instrument Payable to Bearer.

41. Indorsement Where Payable to Two or More Persons.

42. Effect of Instrument Drawn or Indorsed to a Person as Cashier.

43. Indorsement Where Name is Misspelled, etc.

44. Indorsement in Representative Capacity.

45. Time of Indorsement; Presumption.

46. Place of Indorsement; Presumption.

47. Continuation of Negotiable Character.

48. Striking Out Indorsement.

49. Transfer Indorsement; Effect of.

50. When Prior Party May Negotiate Instrument.

51. Right of Holder to Sue; Payment.

52. What Constitutes a Holder in Due Course.

53. When Person not Deemed Holder in Due Course.

54. Notice Before Full Amount Paid.

55. When Title Defective.

56. What Constitutes Notice of Defect.

57. Rights of Holder in Due Course.

58. When Subject to Original Defenses.

59. Who Deemed Holder in Due Course.

60. Liability of Maker.

61. Liability of Drawer.

62. Liability of Acceptor.

63. When Person Deemed Indorser.

64. Liability of Irregular Indorser.

65. Warranty Where Negotiation by Delivery, etc.

66. Liability of General Indorser.

67. Liability of Indorser Where Paper Negotiable by Delivery.

68. Order in Which Indorsers are Liable.

69. Liability of an Agent or Broker.

70. Effect of Want of Demand on Principal Debtor. 
SEctios 71. Presentment Where Instrument is not Payable on Demand and Where Payable on Demand.

72. What Constitutes a Sufficient Presentment.

73. Place of Presentment.

74. Instrument Must be Exhibited.

75. Presentinent Where Instrument Payable at Bank.

76. Presentment Where Principal Debtor is Dead.

7\%. Presentment to Persons Liable as Partners.

78. Presentment to Joint Debtors.

79. Wher Presentment Not Required to Cliarge the Drawer.

80. When Presentment Not Required to Charge the Indorser.

81. When Delay in Making Presentment is Excused.

82. When Presentment May be Dispensed Witl.

83. When Instrument Dishonored by Non-Payment.

84. Liability of Person Secondarily Liable, When Instrument Dishono:ed.

85. Time of Maturity.

86. Time; How Computed.

8\%. Rule Where Instrument Payable at Bank.

88. What Constituted Payment in Due Course.

89. To Whom Notice of Dishonor Must be Given.

90. By Whom Given.

91. Totice Given by Agent.

92. Effect of Notice Given on Belalf of Holder.

93. Efrect Where Notice is Given by Party Entitled Thereto.

94. When Agent May Give Notice.

95. When Notice Suflicient.

96. Form of Notice.

97. To Whom Notice May be Given.

98. Notice Where Party is Dead.

99. Notice to Partuers

100. Notice to Persons Jointly Liable.

101. Notice to Bankrupt.

102. Time Withın Which Notice Must Be Given.

103. Where Parties Reside in Same Place.

104. Where Parties Reside in Different Places.

105. When Sender Deemed to IIave Given Due Notice.

106. Deposit in Postoffice; What Constitufes.

10\%. Notice to subsequent Party; Time of.

108. Where Notice Must Be Sent.

109. Waiver of Notice.

110. Whom Affected by Waiver.

111 Waiver of Protest.

112. When Notice is Dispensed With.

113. Delay in Giving Notice: How Excused.

114. When Notice Need Not be Given to Drawer. 
Secrionl15. When Notice Need Not be Given to Indorser.

116. Notice of Non-Payment Where Acceptance Refused.

117. Effect of Omission to Give Notice of Non-Acceptance.

118. When Protest Need Not be Made; When Must be Made.

119. Instrument; How Discharged.

120. When Persons Secondarily Liable on, Discharged.

121. Right to Party Who Discharges Instrument.

122. Renunciation by Holder.

123. Cancellation; Unintentional; Burden of Proof.

124. Alteration of Instrument; Effect of.

125. What Constitutes a Material Alteration.

126. Bill of Exchange Defined.

127. Bill Not an Assignment of Funds in Hands of Drawee.

128. Bill Addressed to More than One Drawee.

129. Inland and Foreign Bills of Exchange.

130. When Bill May be Treated as Promissory Note.

131. Referee in Case of Need.

132. Acceptance; How Made, etc.

133. Holder Entitled to Acceptance on Face of Bill.

134. Acceptance by Separate Instrument.

135. Promise to Accept; When Equivalent to Acceptance.

13j. Time Allowed Drawee to Accept.

137. Liability of Drawee Retaining or Destroying Bill.

138. Acceptance of Incomplete Bill.

139. Kinds of Acceptances.

140. What Constitutes a General Acceptance.

141. Qualified Acceptance.

142. Rights of Parties as to Qualificd Acceptance.

143. When Presentment for Acceptance Must be Made.

144. When Failure to Present Releases Drawer and Indorser.

145. Presentment; How Made.

146. On What Days Presentment May be Made.

147. Presentment Where Time is Insufficient.

148. Where Presentment is Excused.

149. When Dishonored by Non-Acceptance.

150. Duty of Holder Where Bill Not Accepted.

151. Rights of Holder Where Bill Not Accepted.

152. In What Cases Protest Necessary.

153. Protest; How Made.

154. Protest; By Whom Made.

155. Protest. When to be Made.

156. Protest; Where Made.

157. Protest Both for Non-Acceptance and Non-Payment.

158. Protest Before Maturity Where Acceptor Insolvent.

159. When Protest Dispensed With.

160. Protest Where Bill is Lost, etc. 
Section161. When Bill May be Accepted for Honor.

162. Acceptance, for Honor; How Made.

163. When Deemed to be an Acceptance for Honor of the Drawer.

164. Liability of the Acceptor for Honor.

165. Agreement of Acceptor for Honor.

166. Maturity of Bill Payable After Sight; Accepted for Honor.

167. Protest of Bill Accepted for Honor, etc.

168. Presentment for Payment to Acceptor for Honor; How Made.

169. When Delay in Making Presentment is Excused.

170. Dishonor of Bill by Acceptor for Honor.

171. Who May Make Payment for Honor.

172. Payment for Honor; How Made.

173. Declaration Before Payment for Honor.

174. Preference of Parties Offering to Pay to Honor.

175. Effect on Subsequent Parties Where Bill is Paid for Fonor.

176. Where Holder Refuses to Receive Payment Superprotest.

177. Rights of Payer for Honor.

178. Bills in sets Constitute One Bill.

179. Right of Holders Where Different Parts are Negotiated.

180. Liability of Holder Who Indorses Two or More Parts of a Set to Different Persons.

181. Acceptance of Bills Drawn in Sets.

182. Payment by Acceptor of Bills Drawn by Sets

183. Effect of Discharging One of a Set.

184. Promissory Note Defined.

185. Check Defined.

186. Within What Time a Check Must be Presented.

187. Certification of Check; Effect of.

188. Effect Where the Holder of Check Procures it to be Certified.

189. When Check Operates as an Assignment.

190. Short Title.

191. Defintions and Meaning of Terms.

192. Person Primarily Liable on Instrument.

193. Reasonable Time, What Constitutes.

194. Time, How Computed; When Last Day Falls on Holiday.

195. Application of Act.

196. Cases Not Provided for in Act.

197. Repeals.

198. Tıme When Act Takes Effect. 


\section{TITLE I. \\ FEGOTIABLE INSTRUMENTS IN GENERAL.}

\section{ARTICLE I.}

\section{FORM AND INTERPRETATION.}

Section 1. An instrument to be negotiable must conform to the following requirements:

(1) It must be in writing and signed by the maker or drawer;

(2) Must contain an unconditional promise or order to pay $=$ sum certain in money;

(3) Must be payable on demand, or at a fixed or determinable future time;

(4) Must be payable to order or to bearer; and

(5) Where the instrument is addressed to a drawee, he inust be named or otherwise indicated therein with reasonable certainty.

Alabama.-Ex parte Bledsoe ' Connecticut.-Nat. Sav. Bk. v. (1913), 61 So. 813; Sherrill v. Cable (1901), 73 Conn. 568, 48 Atl. Merch. and Mech. Tr. and Salv. Bk. (1916), 70 So. 723; Oneonta Trust and Banking Co. v. Box (1917), 73 So. 759 ; Johnson v. Blackman (1918), 78 So. 891.

Arizona.- Slaughter v. Bk. of Bisbee (1916), 154 Pac. 1040.

Arkansas.- Morgan v. Center (1918), 202 S. W. 235.

California.- Navajo Co. Bk. v. Dolson (1912), 126 Pac. 153; Wetzel $v$ Cole (1917), 165 Pac. 692; Chinn v. Penn (1919), 175 Pac. 687.

Colorado.-Norman v. MeCarthy (1913), 138 Pac. 28; Ayers v. Walker (1913), 54 Col. 571; Johnson v. Engstone (1916), 155 Pac. 1095; Florence Oil and Refining Co. v. Hiawatha Gas, Oil and Refining Co. (1913), 55 Col. App. 378. 428; St. Paul's Episcopal Church v. Fields (1909), 81 Conn. 670, 72 Atl. 145.

Florida.- Gamble v. Malsby (1914), 64 So. 437.

Idaho.- Kimpton v. Studebaker Bros. Co. (1908), 14 Ida. 552. 94 Pac. 1039; Union Stock Yards Nat Bk. v. Bolan (1908), 14 Ida 87. 93 Pac. 508; Home Land Co. v Us. born (1910), 19 Ida. 75, 112 Pac 764 .

Illinoıs.-Stitzel v. Miller (1910). 157 III. App. 390 ; Peterson v Emery (1910). 154 Ill. App. 294: Bertolet v. Stomer (1911), 164 Ill App 605; Laumn v. Harrington (1915), 107 N. E. 826,267 III 57.

Indiana - Essig v. Porter (1916), 112 N. E. 1005; Bingham v Now Town Bank (1918), 118 N. E 318 ; 
Millikan v. Security Trust Co. (1918), 118 N E. 568.

lowa.-Allison $\nabla$ Hollembeak (19n8), 138 Jowa, 479, I14 N W 1059; Des Moines Sav Bk. v Ar thur (1913), 143 N W. 556; Blumes v. schmidt (1914), $146 \mathrm{~N}$ W. 751; Jewett Lumber ('o v. Martin Con roy (\% (1915), 15\% N IV 493; Manhard v First Natl Bk. (19/7), 165 N IV 185; Quinn v. Bane (1917), 164 N W. 788

Kansas.- The Hollıday st. Bk. v. Hoffman (1911), 85 Kans. 71, 115 Pac 239; The Rossville State Hk v. Heslet (1911), 84 Kans. 315, 113 Pac. 1052; Brown v Cruce (1913), 133 Pac. 865; Smith v Nelson l.and \& Cattle Co (1914), 212 Fed 56.

Kentucky.- Weltlaufer $\mathbf{v}$. Baxter (1910), 137 Ky 326, $125 \mathrm{~S}$. W. 741

Loussiana - Continental Bank and Trust Co. v limes Pub. Co (1917), 76 Su. 612; Donart v Rabeto (1917), T6 \$o. 166

Maryland - Vandeford v. Farmers and Mech's Nat Bk. of West. minster, 105 Md 164, 66 Atl. 47; Harper $\checkmark$ Davis (1911), 115 Md 349. 80 Atl 1012; First Denton Nat! BK v Kenney (1911), 116 Mid 24 81 Atl 227

Massachusetts - Shepard v. Ab. bontt 113011. 179 Mass $300,60 \mathrm{~N}$. C) is2; lorpey v. Tebo (1903), 184 Mass 307, 6.9 N \& 223; Mass. Nat $\mathrm{HK}$ * Snow (1905), 187 Mass 159 72 N H; 95:t; Berenson v London, etc.. Ins Co (1909), 201 Mass 172. 87 N. E. 687; Bryne v. Bryne (19111, 209 Mass, 179; Union I'r C. $v$ McGinty (1912), 212 Mass 205, 98 N. E. 679 ; Pierce v. Tal.
Dott $(1913), 213$ Mass 330, $100 \mathrm{~N}$. E) 553 .

Michigan.- schmudt v Pegg (1912), 172 Mich. 159. $137 \mathrm{~N}$ W. 524; White $\checkmark$ Wadhams (1919), 170 s. W. 60.

Mississippi.- Sivleg v Williamson (1916), 72 so 1008

Missour.-- Sublette $v$ Brewing. ton (1909), 139 Mo. App 410. 122 S. W 1150; Nelson v. Diffenderffer (1914), 163 is W 271; Hawkıns v. Wiest (1912), 167 Mo App 439; Val Blatz Brewing Co. v. Interstate lce \& Cold Storage Co (1912). 143 S. W. 542; Mudd $v$ Farmers and Merchants' Bk. of Hunnewell (1'y14). $162 \mathrm{~S}$ W. 314.

Montana.- Cornisb v Wolverton (1905). 32 Mont 456, 81 Pac. 4.

Nebraska.- Aurora State Bk v. Hayes Fames Elevator Co (1911), 88 Neb 187; Fisher v. O'Hanlon, Rowan, Appt. (1913), 93 Neb. 529. 141 ․ W. 157; First Nat'l Bk. จ. Greenlee (1918), 166 N. W. 559.

New Jersey.-Borough of Montvale v. Peoples Bank (1907), 67 At). 67

New York.- Deyo $v$ Thompson (1900), 53 A. D. 9; lzzo v. Luding. ton (1903), 79 A. D. 272, 79 N. X. Supp 744; Young v. Am. Bk No. 82 (1904), 44 Misc. 308,89 N. Y. Supp 915; Waddell v. Hanover Nat. Sav. Bk (1905), 48 Misc. 578, 97 N Y Supp. 305; Hibbs v, Brown (1907), 190 N. Y. 167, affirming 112 A D. $214,82 \mathrm{~N}$ E $1108,98 \mathrm{~N} . \mathrm{Y}$. Supp 353; Fulton v. Varney (1907). 117 A. D 572,102 N. Y. Supp. 608: Haddork. Blanchard \& Co. v. Haddock (1908), 192 N. Y. 499. 82 N. E 682,103 N. Y. Supp. 584; Zander v. N. Y. Security \& Tr. Co. 
(1902), 39 Misc. 98, 78 N. Y. Supp. 900; Tanner's Nat. Bk. v. Jacs (1909), 136 A. D. 92, 120 N. Y. Supp. 669; Wray v. Miller (1910), 120 N. Y. Supp. 787; Eq. Tr. Co. of N. Y. v. Were (1911), 132 N. Y. Supp. 351; Rosenburg v. Schoenwald (1911), 126 N. Y. Supp: 615; Eq. Tr. Co. of N. Y. จ. Howe (1911), 129 N. Y. Supp. 112; Czerney v. Hass (1911), 144 A. D. 430; Hilborn v. Penn. Cement Co. (1911), 145 A. D. 442; Ryan v. Sullivan (1911), 143 A. D. 471; Eq. 'Tr. Co. v. Taylor (1911), 131 N. Y. Supp. 475,72 Misc. 52 ; Eq. Tr. Co. of N. Y. v. Newman (1911), 129 N. Y. Supp. 259, 72 Mise. 502; St. Lawrence Co. Nat. Bk. v. Watkins (1912), 135 N. Y. Supp. 461; Owens v. Blackburn (1914), 161 A. D. 827, 146 N. Y. Supp. 966; Merchants Nat. Bk. of St. Paul v. Sante Maria Sugar Co. (1914), 147 N. Y. Supp. 498; Kinsella v. Lockwood (1913), 140 N. Y. Supp. 512; Eq. Tr. Co. of N. Y. v. Harger (1913), 102 N. E. 209; Kerr v. Smith (1913), 156 A. D. 807,142 N. Y. Supp. 57; Crosby v. Bank of Niagara (1915), 154 N. Y. Supp. 883; Hubbard v. Syemite Trap Rock Co. (1917), 165 N. Y. Supp. 486, 178 A. D. 531; Standard Steam Spec. Co. v. Corn Excl. Bk. (1917), 116 N. E. 386, 220 N. Y. 478; Lazarowitz v. Stafford (1917), 167 N. Y. Supp. 910; Shubert Theat. Co. v. Dalton (1917), 167 N. Y. Supp. 332.

North Carolina.- Myers v. Petty (1910), 153 N. Car. 462; Pope \& Ballance v. Righter-Parry Lumber Co. (1913), 78 S. E. 65; Newland v. Moore (1917), 92 S. E. 367.

North Dakota.-Fleming v. Sherwood (1912), 139 N. W. 101; Stuts- man County Bank v. Jones (1917), 162 N. W. 402.

Ohio.-Rockfield v. First Nat. Bk. of Springficld (1907), 77 Ohio St. 311, 83 N. E. 392; Miller v. Kyle (1911), 85 Ohio St. 186, 97 N. E. 372.

Oklahoma.- Longmont Nat. Bk. v. Loukonen (1912), 127 Pac. 947; Voris v. Anderson (1915), 153 Pac. 291; DeGroat v. Focht (1913), 131 Pac. 172; Iowa State Sav Bk. v. Wigmall (1916), 157 Pac. 725 ; Lambert v. Harrison (1919), 171 Pac. 45; Westlake v. Cooper (1918), 171 Pac. 859.

Oregon.-Hull v. Agnus (1911), 60 Oreg. 95, 118 Pac. 284; Triphonoff v. Sweeney (1913), 130 Pac. 979.

Pennsylvania.-Volk v. Shoemaker (1911), 229 Pac. 407.

South Carolina.-Folk v. Moore (1916), 88 S. E. 18.

South Dakota.-Coleman v. Valentin (1917), 164 N. W. 67.

Tennessee-Gilley v. Harrell (1906), 118 Tenn. 115, 101 S. W. 424: First Nat. Bk. of Elgin, IIl. v. Russell (1911), 139 S. W. 734 ; Ahrens \& Ott Co. v. Moore \& Sons (1915), 174 S. W. 270; White v. Hatcher (1916), 188 S. W. 61; Bank of Whitehouse v. White (1917), 191 S. IV. 332; Weems v. Neblett (1918), 202 S. W. 930.

Utah.-Smith v. Brown (1917), 165 Pac. 468.

Virginia.- IVilliams v. Liphart (1914), 81 s. E. 77; Colley v. Summers Parrott Hardware Co. (1916), 89 S. E. 906.

Washington.-Nelson v. Spokane Grain Co. (1907), 47 Wash. 85, 91 
Pac. 570; Thomson v. Koch (1911), 62 Wash. 438, 113 Pac. 1110; Parker v. Saxton (1911), 66 Wash. 260; Barker v. Sartori (1911), 63 Wash. 260, 119 Pac. 611; First Nat. Bk of Snohomish v. Sullivan (1911), 66 Wash. 375; Quast v. Ruggles (1913), 72 Wash. 609, 131 Pac. 202; Peninsula Nat. Bk. v. Pederson (1916), 158 Pac. 246; Coolidge \& McClaine v. Saltmarsh (1917), 165 Pac. 50s; Coolidge et al. v. Saltmarsh (1917), 165 Pac. 50 s.

West Virginia.- Pomeroy Nat. Bk. v. Huntington Nat. Bk. (1913), 79 S. E. 662; Eskridge v. Thomas
(1917), 91 S. E. 7; Thompson v. Curry (1917), 91 S. E. 801.

Wisconsin (Section on Municipal Orders and Warehouse Receipts added).-Westberg v. Chicago Lumber Co. (1903), 117 Wis. 589, 94 N. W. 572; Thorpe v. Mindeman (1904), 123 Wis. 149, 101 N. W. 417, 107 Am. St. 1003, 68 L. R. A. 146; Bank of Evansville v. Kurts (1918), 166 N. W. 658.

United States.-Forest v. Safety Banking \& Tr. Co. (1909), 174 Fed. 345 (E. D. Pa.); Klotz Throwing Co. v. Manufacturers Commercial Co. (1910), 103 C. C. A. 305 (N. Y.), 179 Fed. Rep. 397.

Section 2. The sum payable is a sum certain within the meaning of this act, although it is to be paid:

(1) With interest; or

(2) By stated instalments; or

(3) By stated instalments, with a provision that upon default in payment of any instalment or of interest, the whole shall become due; or

(4) With exchange, whether at a fixed rate or at the current rate; or

(5) With costs of collection or an attorney's fee, in case payment shall not be made at maturity.

Alabama.-Bledsoe v. City Nat. Bk. of Selma (1912), 7 Ala. App. 195. 60 So. 942 ; Ex parte Bledsoe (1913), 61 So. 813 ; Brooks v. Greil Bros. (1915), 68 So. 874 .

Arizona.- People's Nat. Bk. v. Taylor (1915), 149 Pae. 763.

California.-Navajo Co. Bk. v. Dolson (1912), 126 Pac. 153; Stoddart v. Goldin (1919), 178 Pac. 707.

Colorado.-The Firestone Coal Co. v. McKissick (1913). 24 Colo. App. 294; Florence Oil Refining Co. v. Hiawatha Oil, Gas \& Refining Co.
(1913), 135 Pac. 454; Florence Oil \& Refining Co. v. Hiawatha Gas, Oii \& Refining Co. (1913), 55 Colo. App. 378.

Florida.-Taylor v. Am. Nat. Bk. of Florida (1912), 63 Fla. 631. 57 So. 678; Holder Turpentiue Co. v. Kiser Co. (1915), 67 So. 85.

Idaho.-Union Stock Yards Nat. Bk. v. Bolan (1908), 14 Ida. 87, 93 Pac. 508; Tipton v. Ellsworth (1910), 18 Ida. 134, 109 Pac. 134. Illinois.-Graves v. Neeves (1913), 183 Ill. App. 235. 
Indiana.- Milliken v. Security Trust Co. (1918), 118 N. E. 568; Easley v. Deer (1919), 121 N. E. 542.

Iowa.- Farmers Loan \& Tr. Co. v. Planck (1915), 152 N. W. 390; State Bk. of Halstad v. Bilstad (1912), 136 N. W. 204.

Kansas.-Smith v. Nelson Land \& Cattle Co. (1914), 212 Fed. 56.

Louisiana.- First Nat. Bk. of Vicksburg v. Mayer (1912), 129 La. 981, 57 So. 308; Winn Parish Bk. v. White Sulphur Lumber Co. (1913), 62 So. 907.

Maryland.-Chestertown Bk. v. Walker (1908), 163 Fed. 510, 90 C. C. A. 140 .

Missouri.-Bank of Neelyville $\mathbf{v}$ Lee (1914), 168 S. W. 796; First Nat. Bk. v. Stam (1914), 171 S. W. 567; American Sav. Bk. v. Sutton (1918), 204 S. W. 572.

Montana.-Morrison v. Orubaun (1904), 30 Mont. 111, 75 Pac. 953; Cornish v. Wolverton (1905), 32 Mout. 456, 81 Pac. 4.

New Jersey.- Mackintosh v. Gibbs (1909), 79 N. J. L. 40, 74 Atl. 708 .

New Mexico.- Williams v. Dockwiler (1914), 145 Pac. 475.

North Carolina.- Exchange Bk. v. Appalachian L. \& L. Co. (1901), 128 N. Car. 193; Newbern Banking \& Trust Co. v. Duffy (1910), 153 N. Car. 62,68 S. E. 915; Franklin Nat. Bk. v. Roberts Bros. (1915), st s. E. 706.

Ohio.-Miller v. Kyle (1911), 85 Ohio st. 186, 97 N. E. 372.

Oklahoma.-First Nat. Bk. of Stigler $r$. Howard (1916), 158 Pac. 927; Seton v. Exchange Bk. (1915), 150 Pac. 1079; Potts v. Crudup (1915), 150 Pac. 170; Tr. \& Sav.
Bk. of Charles City v. Gleichman (1915), 150 Pac. 908; First Nat. Bk. v. Muskogee Pipe Line Co. (1914), 139 Pac. 1136; City Nat. Bk. v. Kelly (1915), 151 Pac. 1172; Voris v. Anderson (1915), 153 Pac. 291; Union Bank v. Mayfield (1917), 169 Pac. 626.

Pennsylvania. - Weiskircher $\nabla$. Сonnelly (1917), 100 Atl. 965.

Texas.-Sugg v. Smith (1918), 205 S. W. 363 ; Drinkard v. Jenkins (1919), 207 S. W. 353.

Tennessee.-Holstron Nat. Bk. v. Wood (1911), 125 Tenn. 6; First Nat. Bk. of Elgin, Ill. v. Russell (1911), 139 S. W. 734; Merrimon v. Parkey (1917), 191 S. W. 327.

Utah.- McCormick v. Swem (1909), 36 Utah, 6, 102 Pac. 626; Utah Banking Co. v. Newman (1914), 138 Pac. 1146.

Virginia.- Oglesby Co. v. Bk. of N. Y. (1913), 114 Va. 663,19 Va. L. Reg. 122,77 S. E. 468; Colley v. Summers Parrott Hardware Co. (1916), 89 S. E. 906; Triplett $\mathbf{}$. Second Nat. Bk. of Culpepper (1917), 92 Va. 897.

Washington.-Parker v. Saxton (1911), 66 Wash. 260; Barker v. Sartori (1911), 66 Wash. 260, 119 Pac. 611 ; First Nat. Bk. of Snohomish v. Sullivan (1911), 66 Wash. 375; Puget Sound State Bank v. Wash. Paving Co. (1917), 1ô2 Pac. 870; Davis v. Hibbs (1913), 73 Wash. 315, 131 Pac. 1135; Harris v. Jolınson (1913), 134 Pac. 1049; Scandinavian-American Bk. v. Long (1913), 134 Pac. 913; Pease v. Syler (1914), 135 Pac. 310; Balkema v. Giolimund (1916), 159 Pac. 127.

West Virginia.-First Nat. Bk. of Pineville v. Sanders (1916), 88 
S. E. 187; Raleigh Co. Bk. v. Poteet (1914), 82 S. E. 332 ; First Nat. Bk. v. Sanders (1916), 88 S. E. 187.

Wisconsin.-Thorpe v. Mindemall (1904), 123 Wis. 149, $101 \mathrm{~N}$. W. 417, 107 Am. St. 1003, 68 L. R. A.
146; First Nat. Bk. of Shawano v. Miller (1909), 139 Wis, 126, 120 N. W. 820 .

United States.-Kennedy v. Broderick (1914), 216 Fed. 137 (C. C. A., th Ct.).

Section 3. An unqualified order or promise to pay is unconditional within the meaning of this act, though coupled with:

(1) An indication of a particular fund out of which reimbursement is to be made, or a particular account to be debited with the amount; or

(2) A statement of the transaction which gives rise to the inetrument. But an order or promise to pay out of a particular fund is not unconditional.

Alabama.- People's Bank of Mobile v. Moore (1918), 78 So. 789.

Arkansas- Rector v. Strauss (1918), 203 S. W. 1024.

Arizona.- Slaughter v. Bank of Bisbee (1916), 154 Pac. 1040.

Colorado.- Johnson v. Engstone (1916), 155 Pac. 1095.

Connecticut.- Nat. Sar. Bk. v. Cable (1901), 73 Conn. 568, 48 Atl. 428.

Iowa.- The Union Bk. of Bridg. water v. Spies (1911), 151 Iowa, $1 \% 8$.

Kansas.- First Nat. Bk, of Hutchinson $\nabla$. Lightener (1906), 74 Kans. 736.

Maryland.-First Denton Nat. Bk. r. Kenney (1911), 116 Md. 24; Denton Nat. Bk. v. Kenney (1911), 116 Md. 124, 81 Atl. 227.

Massachusetts. - Shepard $\because$. Abbott (1901), 179 Mass. 300, $60 \mathrm{~N}$. E. 782 ; Nat. Bk. of Newberry $\mathbf{v}$. Wentworth (1915), 105 N. E. 620ิ.

Michigan.- White v. Wadhams (1919), 170 N. W. 60.
Missouri.- Howard v. Int. Bk. (1918), 200 S. W. 91.

Montana.- State v. Mitton (1908), 37 Mont. 366, 96 Pac. 926; First Nat. Bk. of Miles City v. Barrett (1916). 157 Pac. 951.

New York.-Hibbs v. Brown (1907), 190 N. Y. 167, affirming 112 A. D. 214,82 N. E. 1108,98 N. Y. Supp. 353; Fulton v. Varney (1907), 117 A. D. 5\%2. 102 N. Y. Supp. 608; Eq. Tr. Co. of N. Y. v. Newman (1910), 127 N. Y. Supp. 243 ; Eq. Tr. Co. v. Taylor (1911), 131 N. Y. Supp. 475, 72 Misc. 52;

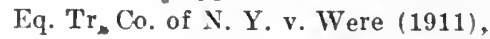
132 N. Y. Supp. 351; Merchants Nat. Bk. of St. Paul v. Sante Maria Sugar Co. (1914), 147 N. Y. Supp. 498, Waterbury Wallace Co. v. Ivey (1917), 163 N. Y. Supp. 719.

North Carolina.-Whitlock v. Auburn Lumber Co. (1907), 145 N. Car. 120,58 S. E. 909,12 L. R. A. (N. S.) 1214; Bk. of Sampson v. Hatcher (1909), $151 \mathrm{~N}$. Car. 359, $66 \mathrm{~S}$. E. 308; Commrs. of Cleveland Co. 
จ. Bk. of Gastonia (1911), $157 \mathrm{~N}$. Car. 191.

Oklahoma.- Welch v. Owenby (1919), 175 Pac. 746.

Texas.-Met. Nat. Bk. v. Vanderpool (1917), 192 S. W. 589.
Tennessee.-First Nat. Bk. of Elgin, Ill. v. Russell (1911), 139 S. W. 734.

Washington.-Peninsula Nat. Bk. v. Pederson (1916), 158 Pac. 246. Wyoming.-Brown v. Cow Creek Co. (1912), 126 Pac. 886.

Section 4. An instrument is payable at a determinable future time, within the meaning of this act, which is expressed to be payable:

(1) At a fixed period after date or sight; or

(2) On or before a fixed or determinable future time specified therein; or

(3) On or at a fixed period after the occurrence of a specified event, which is certain to happen, though the time of happening be uncertain.

An instrument payable upon a contingency is not negotiable, and the happening of the event does not cure the defect.

California.-Blake v. Craig (1918), 173 Pac. 1005.

Colorado.-Drake v. Pueblo Nat. Bk. (1908), 96 Pac. 996.

Iowa.- Iowa Nat. Bk. v. Carter (1909), 144 Iowa, 715, $123 \mathrm{~N}$. W. 237.

Kansas.-The Rossville State Bk. v. Heslet (1911), 84 Kans. 315. 113 Pac. 1052; The Holliday St. Bk. v. Hoffman (1911), 85 Kans. 71, 115 Pac. 239; Brown v. Cruce (1913), 133 Pac. 865.

Louisiana.- Hibernia Bk. \& Tr. Co. v. Dresser (1912-1913), 61 So. 561.

Maryland.-Agricultural Chem. Co. v. Stringer (1917), $100 \mathrm{Atl}$. 774.

Massachusetts.-Torpey v. Tebo (1903), 184 Mass. 307, 68 N. E. 223; McQueen v. Spalding (1919), 120 N. E. 850.
Michigan.-Schmidt v. Pegg (1912), 172 Mich. 159, 137 N. IV. 524; White v. Wadhams (1919), 170 N. W. 60.

New Mexico.-First Nat. Bk. of Albuquerque v. Stover (1916), 155 Pac. 905.

New York.-Schlesinger v. Scliultz (1905), 10 A. D. 356,96 X. Y. Supp. 383; Usefof v. Herzenstein (1909), 65 Misc. 45, 119 N. Y. Supp. 290; Wray v. Miłler (1910), 120 N. Y. Supp. 787; Eq. Tr. Co. of N. Y. v. Were (1911), 132 N. Y. Supp. 351; Devine v. Price (1915), 152 N. Y. Supp. 321; Osborne v. Nc., K. \& T. Ry. Co. (1915), $15 \%$ N. Y. Supp. 236; Kerr v. Smith (1913), 156 A. D. 807, 142 N. Y. Supp. 57; Powell v. Degan (1917), 167 N. Y. Supp. 770; Kulflik v. Vaccaro (1918), 170 N. Y. Supp. 13. 
Oklahoma.-DeGroat v. Focht (1913), 131 Pac. 172; Westlake v. Cocper (1918), 171 Pac. 859.

Oregon.-Western Farquhar Mch. Co. v. Burnett (1916), 161 Pac. 384.

Pennsylvania.- Empire Nat. Bk. of Clarksburg, W. Va. v. High Grade Oil Refining Co. (1918), 103 A. 602 .

Tennessee-First Nat. Bk. of Elgin, Ill. v. Russell (1911), 13! s.
W. 734; White v. Hatcher (1916), 188 S. W. 61.

West Virginia.-Hubbard v. Morton (1917), 92 S. E. 252.

Wisconsin.-Thorpe v. Mindeman (1904), 123 Wis. 149, 101 N. W. 417, 107 Am. St. 1003, 68 L. R. A. 146.

United States.-Kobey v. Hoffman (1916), 229 Fed. 486.

Section 5. An instrument which contains an order or promise to do any act in addition to the payment of money is not negotiable. But the negotiable character of an instrument otherwise negotiable is not affected by a provision which:

(1) Authorizes the sale of collateral securities in case the instrument be not paid at maturity; or

(2) Authorizes a confession of judgment if the instrument be not paid at maturity; or

(3) Waives the benefit of any law intended for the advantage or protection of the obligor; or

(4) Gives the holder an election to require something to be done in lieu of payment of money.

But nothing in this section shall validate any provision or stipulation otherwise illegal.

Alabama.- Ex parte Bledsoe (1913), 61 So. 813.

California.- Navajo Co. Bk. v. Dolson (1912), 126 Pac. 153.

Idaho.-Kimpton v. Studebaker Bros. Co. (1908), 14 Ida. 552, 94 Pac. 1039.

Iowa.- The Union Bk, of Bridgewater v. Spies (1911), 151 Iowa, 178; Steel v. Ingraham (1915), 155 N. IV. 294.

Kansas.-The Rossville State Bk. v. Heslet (1911), 84 Kans. 315, 113 Pac. 1052; The Holliday St. Bk. v. Hoffman (1911), 85 Kans. 71, 115 Pac. 239.
Kentucky.-Finley v. Smith (1915), 177 S. W. 262.

Maryland.- Whitcomb v. Nat. Exchange Bk. (1914), 91 Atl. 689, 123 Md. 612.

Minnesota.- Snelling State Bank v. Clasen (1916), 157 N. W. 643.

Nebraska.- First Nat. Bk. of Sydney v. Baldwin (1916), $158 \mathrm{~N}$. W. 371 .

New Jersey.- Strickland v. Nat. Salt Co. (1911), 77 N. J. Eq. 328, 81 Atl. 828, affirmed 79 N. J. Eq. 182 (1911).

North Carolina.-Sykes v. Everett (1914), 83 S. E. 585. 
Oklahoma. - lowa State Sav. Bk. v. Wignall (1916), 157 Pac. 725; Williams จ. Turnbull (1917), 162 Pac. 770

Pennsylvania.- Milton Nat. Bk. v. Beaver (1904), 25 Pac. Super. Ct. 494.

Tennessee.- Bank of Whitehouse

7. White (1917), 191 S. IV. 332. Washington.- Thomson v. Koch
(1911), 62 Wash. 438, 113 Pac. 1110; Moore \& Co. v. Burling (1916), 160 Pac. 420.

West Virgina.-Greenbrier Valley Bk. v. Bair (1913), 77 s E. 274.

Wisconsin.-Wisconsin Meeting of Baptists v. Babler (1902), 115 Wis. 289,91 N. W. 678 ,

Section 6. The validity and negotiable character of an instrument are not effected by the fact that:

(1) It is not dated; or

(2) Does not specify the value given, or that any value has been given therefor; or

(3) Does not specify the place where it is drawn or the place where it is payable; or

(4) Bears a seal; or

(5) Designates a particular kind of current money in which payment is to be made.

But nothing in this section shall alter or repeal any statute requiring in certain cases the nature of the consideration to be stated in the instrument.

Alabama.-Bledsoe v. City Nat. Bk. of Selma (1912), 7 Ala. App. 195, 60 So. 942.

Colorado.- Ullery v. Brohm (1905), 20 Colo. App. 389, 79 Pac. 180.

Connecticut.-St. Paul's Episcopal Church v. Fields (1909), 81 Conn. 670, 72 Atl. 145.

Florida.- Williams v. Peninsular Grocery Co. (1917), 75 So. 517.

Indiana.- Hubbard v. First Nat. Bk. (1916), 114 N. E. 642 ; Dieter v. Burke (1914), 107 N. E. 304.

Iowa.-Dille v. White (1906), 132 Iowa, 327, 109 N. W. 909, 10 L. R. A. (N. S.) 510; Allison v. Hollembeak (1908), 138 lowa, 479,
114 N. W. 1059 ; LeClere v. Philpott (1915), 151 N. W. 825.

Maryland.-Arn v. Heckert (1908), 108 Md. 300, 70 Atl. 417.

Massachusetts.-Clarke v. Pierce (1913), 215 Mass. 552.

Missouri.-Bk. of Houston v. Day (1909), 122 S. W. 756; Houston v. Day (1909), 145 Mo. App. 410; Mil. bank-Scampton Milling Co. v. Parkwood (1911), 133 S. W. 667; Nelson v. Diffenderffer (1914), 163 S. IV. 271.

New York.-McLeod v Hunter (1899), 29 Misc. 558, 61 N Y. Supp. 73; Didato v. Coniglio (1906), 100 N. Y. Supp. 466, 50 Mise. 290; Cluurch v. Stevens (1907), $107 \mathrm{~N}$. 
Y. Supp. 310; Amsinck v. Rogers (1907), 189 N. Y. 252, 82 N. E. 134, 12 L. R. A. (N. S.) 875,121 An. St. 858; Hebbelthwaite v. Flint (1919), 173 N. Y. Supp. 81.

North Carolina.- Burris v. Starr (1914), 81 S. E. 929; Aycock Sup- ply Co. v. Windlez (1918), 96 S. E. 664 .

Tennessee.-Easley v. East Tenn. Nat. Bk. (1917), 198 S. W. 66.

Texas.-Met. Nat. Bk. v. Vanderpool (1917), 192 S. W. 589.

Section $\%$ An instrument is payable on demand:

(1) Where it is expressed to be payable on demand, or at sight, or on presentation; or

(2) In which no time for payment is expressed.

Where an instrument is issued, accepted, or indorsed when overdue, it is, as regards the person so issuing, accepting, or indorsing it, payable on demand.

California.- Wetzel v. Cale 73; Schlesinger v. Schultz (1905), (1917), 165 Pac. 692. 10 A. D. 356,96 N. Y. Supp. 383 ;

Colorado.-Sullivan v. Ellis Didato v..Coniglio (1906), $100 \mathrm{~N}$. (1915), 219 Fed. 694 (C. C. A., 8th Y. Supp. 466, 50 Misc. 280; Usefof Ct.).

lowa.- City Dep. Bk. v. Green (1908), 138 Iowa, 156, $115 \mathrm{~N}$. IV. 893; Anderson v. First Nat. Bk. of Chariton (1909), 144 Iowa, 251, 122 N. W. 918 .

Kansas.-Doty v. Garfield Township (1913), 89 ハans. 719.

Maryland.- American Agricultural Chemical Co. v. Scrimger (1917), 100 Atl. 774.

Michigan.-First Nat. Bk. v. Coharset Woodenware Co. (1917), 161 N. W. 398.

Missouri.- Hawkins v. Wiest (1912), 167 Mo. App. 439.

v. Herzenstein (1909), 65 Misc. 45, 119 X. Y. Supp. 290; Riddle v. Bk. of Montreal (1911), 145 A. D. 207, 130 N. Y. Supp. 15; Gilbert v. Adams (1911), 131 N. Y. Supp. 787; Kuflik v. Vaccaro (1918), 170 N. Y. Supp. 13.

North Dakota.-First Nat. Bk. of Pomeroy v. Buttery (1908), $17 \mathrm{~N}$. D. 326,116 N. W. 341,168 L. R. A. (N. S.) 878; Shuman v. Citizens State Bk. of Rugby (1914), 147 N. W. 398.

Pennsylvania.- Rhone v. Keystone Coal Co. (1915), 95 Atl. 930.

West Virginia.- Lewis Hubbard

New York.- MeLeod v. Hunter \& Co. v. Morton (1917), 92 S. E. (1\$99), 29 Misc. 558, 61 N. Y. Supp.

Section 8. The instrument is payable to order where it is drawn payable to the order of a specified person or to him or his order. It may be drawn payable to the order of:

(1) A payee who is not maker, drawer, or drawee; or

(2) The drawer or maker; or 
(3) The drawee; or

(4) Two or more payees jointly; or

(5) One or some of several payees; or

(6) The holder of an office for the time being.

Where the instrument is payable to order the payee must be named or othewise indicated therein with reasonable certainty.

Colorado.-Scala v. M. \& M. North Dakota.-Aarnoth v. Bank (1918), 171 Pac. 752.

Illinois.-Peterson v. Emery (1910), 154 Ill. Apr. 294.

Iowa.- The Union Bk. of Bridgewater v. Spies (1911), 151 Iowa, 178.

Kansas.- Voris v. Schoonover (1914), 138 Pac. 607.

Massachusetts.-Mass. Nat. Bk. v. Snow (1905), 187 Mass. 159, 72 N. E. 959 .

New York.- Hilborn v. Penn. Cement Co. (1911), 145 A. D. 442. Hunter (1916), 157 N. W. 299; Passut v. Heubner (1913), 142 X. Y. Supp. 546, 81 Mise. 249.

Oregon.-Paye v. Ford (1913), 131 Pae. 1013.

Tennessee.-Moore v. Carey (1917), 197 S. W. 1093.

Virginia.-Guewant v. Guewant (1902), 7 Va. L. R. 639.

United States.- Milton v. Pensacola Bk. \& Tr. Co. (1911), 190 Fed. 126, 111 C. C. A. 166 .

Section 9. The instrument is payable to bearer:

(1) When it is expressed to be so payable; or

(2) When it is payable to a person named therein or bearer; or

(3) When it is payable to the order of a fictitious or non-existing person, and such fact was known to the person making it so payable; or

(4) When the name of the payee does not purport to be the name of any person; or

(5) When the only or last indorsement is an indorsement in blank.

Alabama.-Davis v. First Nat. Bk. of Blakely (1915), 68 So. 2ô1. Arizona.- People's Nat. Bk. v. Taylor (1915), 149 Pac. 763.

Arkansas.-Williamson Bk. \& Tr. Co. v. Miles (1914), 169 S. W. 368.

District of Columbia.- - Union Nat. Bank of Columbia v. Cook (1918), 96 S. E. 484.

Illinois.- Noel v. Security Bk. of Chicago (1911), 163 Ill. App. 82.
Kansas.-Grand Lodge v. Emporium Bank (1917), 166 Pac. 490.

Kentucky.-Ohio Valley Bk. \& Tr. Co. v. Gt. Southern Fire Ins. Co. (1917), 197 S. W. 399.

Louisiana.-Rose v. Shaw (1919), 80 So. 727.

Massachusetts.- Murphy v. Met. Nat. Bk. (1906), 191 Mass. 159; Boles v. IIarding (1909), 201 Mass. 103,87 N. E. 431. 
Missouri.-Equitable Life Assur. Co. of U. S. v. Nat. Bk. of Commerce (1916), 181 S. W. 1176.

New York. - Trust Co. of Am. V. Hamilton Bk. (1908), 127 A. D. 515, 112 N. Y. Supp. 84; Seaboard Nat. Bk. v. Bk. of America (1908), 193 N. Y. 26,85 N. E. 829 ; U. S. v. Chase Nat. Bk. (1918), 250 Fed. 105.

Oregon.-Hill v. McCrow (1918), 170 Pac. 306.

Pennsylvania.- Lincoln Nat. Bk. of Pittsburg v. Miller (1917), 100 Atl. 269, 255 Pac. 467.
Tennessee.-Unaka Nat. Bk. v. Butler (1904), 113 Tenn. 674, 83 S. W. 655 .

Vermont.-Hale v. Windsor Sav. Bk. (1917), 98 Atl. 993.

Virginia.-Colona v. Parksley Bk. (1917), 92 S. E. 979.

Washington.-Goodfellow v. First Nat. Bk. (1913), 129 Pac. 90.

Wisconsin.-Marling v. Fitzgerald (1909), 138 Wis. 93, 120 N. W. 388.

United States. - Nat. Bk. of Commerce v. U. S. (1915), 224 Fed. 679 (C. C. A., 9 th Ct.).

Section 10. The instrument need not follow the language of this act, but any terms are sufficient which clearly indicate an intention to conform to the requirements hereof.

Alabama.-Bledsoe v. City Nat. Bk. of Selma (1912), 7 Ala. App. 195, 60 So. 942.

Maryland.- Black v. First Nat. Bk. (1903), 96 Md. 399, 54 Atl. 88.
Missouri-- Osborne v. Fridrich (1908), 134 Mo. App. 449.

New York.-Gilbert v. Adams (1911), 131 N. Y. Supp. 787.

Washington.-Quast v. Ruggles (1913), 72 Wash. 609, 131 Pac. 202.

Section 11. Where the instrument or an acceptance or any indorsement thereon is dated, such date is deemed prima facie to be the true date of the making, drawing, acceptance, or indorsement as the case may be.

California.-Molley v. Pierson of Bardwell (1916), 185 S. W. 873. (1918), 174 Pac. 98.

New York.- Sugar v. Silverman

Kentucky.-Elsey v. People's Bk. (1919), 173 N. Y. Supp. 182.

Section 12. The instrument is not invalid for the reason only that it is ante-dated or post-dated, provided this is not done for an illegal or fraudulent purpose. The person to whom an instrument so dated is delivered acquires the title thereto as of the date of delivery. 
Idaho.-Smith v. Fields (1911), 19 Ida. 558, 114 Pac. 668.

Kentucky.-First Nat. Bk. . Bickel (1911), $143 \mathrm{Ky} .754,137 \mathrm{~S}$. W. 790 .

Missouri. - Houston v. Day (1909), 145 Mo. App. 410; Bk. of Houston v. Day (1909), 122 S. W. 756.

New York.-Albert v. Hoffman (1909), 64 Misc. 87.
Oregon.-Triphonoff v. Sweeney (1913), 130 Pac. 979.

Pennsylvania.-Rathfon v. Locher (1906), 215 Pac. 571.

Virginia.-Colona v. Parksley Bk. (1917), 92 S. E. 979.

West Virginia.- Lewis Hubbard \& Co. v. Morton (1917), 92 S. E. 252.

Wisconsin.- Citizens Nat. Bk. of Green Bay v. Harter (1908), 134 Wis. 408.

Section 13. Where an instrument expressed to be payable at a fixed period after date is issued undated, or where the acceptance of an instrument payable at a fixed period after sight is undated, any holder may insert therein the true date of issue or acceptance, and the instrument shall be payable accordingly. The insertion of a wrong date does not avoid the instrument in the hands of a subsequent holder in due course; but as to him, the date so inserted is to be regarded as the true date.

Iowa.-Booch v. Goochi (1916), 16 N. IV. 333.

Missouri.-Houston v. Day (1909), 145 Mo. App. 410; Bk. of Houston v. Day (1909), 122 S. W. 756.
Texas.-Landon v. Foster Drug Co. (1916), 186 S. W. 434.

United States.-Richards v. Street (1908), 31 App. D. C. 427.

Section 14. Where the instrument is wanting in any material particular, the person in possession thereof has a prima facie authority to complete it by filling up the blanks therein. And $\mathbf{a}$ signature on a blank paper deilvered by the person making the signature in order that the paper may be converted into a negotiable instrument operates as a prima facie authority to fill it up as such for any amount. In order, however, that any such instrument when completed may be enforced against any person who became a party thereto prior to its completion, it must be filled up strictly in accordance with the authority given and within a reasonable time. But if any such instrument, after completion, is negotiated to a holder in due course, it is valid and effectual for all purposes in his hands, and he may enforce it as if it had been filled up 
strictly in accordance with the authority given and within a reasonable time.

Connecticut.-Clevelana Co. v. Chittenden (1909), 81 Corn. 667, 71 Atl 935.

Illinois.- Manussier v. Wright (1910), 158 III. App. 214; Kramer v. Schnitzer, 109 N. L. 695.

Indiana.- lindler Co. v. First Nat. Bk. of Fond du Lac (1915), 109 N. E. 66

lowa.-Vander Ploey v. Van Zunk (1907), 135 lowa, 350, 112 N.W. 807; Johnston v. Hoover (1908), 139 lowa, 143,117 N. IV. 277; LeClere v. Plıilpott (1915), 151 N. IV. 825; Devoy v. Kuhn Coal \& Coke Co. (1916), 156 N. IV. 412 ; Farmers foan \& 'Tr. Co. v. Brown (1917), 165 N. IV. 70 .

Kansas.- Iowa City State Bk. v. Claypool (1914), 137 Pac. 949.

Kentucky.-Stanley v. Davis (1908), 32 Ky. I. 1135, 107 S. 'V. 773; Herman's Excr. v. Gregory (1909), 131 Ky. 819, 115 S. WV. 809.

Maryland.- Linthicum v. Bagby (1917), 102 Atl. 997.

Massachusetts.-Boston Steel \& Iron Co. v. Steuer (1903), 183 Mass. 140,66 N. E. 646; Perry v. Pye (1913), 102 N. E. 653; Stone v. Sergeant (1915), 107 N. E. 1014; Tower v. Stanley (1915), 107 N. E. 1010 .
Nebraska.- Hartington Bk. v. Breslin (1910), 88 Neb. 47, $128 \mathrm{~N}$. W. 659 .

New York.- Yonker's Nat. Bk. v. Mitchell (1913), 141 N. Y. Supp. 128; First Nat. Bk. of the City of Brooklyn v. Gridley (1906), 112 A. D. 398,98 N. Y. Supp. 445; Madden v. Gaston (1910), 137 A. D. 294, 121 N. Y Supp. 951; Rodgers v Baker (1910), 136 A. D. 849, 122 N. Y. Supp. 91; Eq. Tr. Co. of N. Y. v. Lyons (1911), 129 N. Y. Supp. 79; Dumbrow v. Gelb (1911), 130 N. Y. Supp. 182; Biz Men's League of Harlem v. Sragow (1915), 153 N. Y. Supp. 231; Cole v. Harrison. (1915), 153 N. Y. Supp. 200; Flood v. Steinmetz (1915), 153 N. Y. Supp. 192; Bank Franco-America v. Bergstrom (1916), 157 N. Y. Supp. 635; Union Tr. Co. of New Jersey v. MeCrum (1911), 145 A. D. 409; Bloom v. Horwitz (1918), 166 N. Y. supp. 786.

North Carolina.--Phillips v. Hensley (1917), 94 S. E. 673.

Virginia.-Guewant . v. Guewant. (1902), 7 Va. L. R. 639; Brown v. Thomas (1917), 92 S. E. 977.

West Virginia.-Rusmissel v. White Oak Co. (1917), 92 S. E. 672.

Section 15. Where an incomplete instrument has not been delivered it will not, if completed and negotiated, without authority, be a valid contract in the hands of any holder, as against any person whose signature was placed thereon before delivery.

Colorado.- Norman v. MeCarthy (1913), 138 Pac. 28.

Louisiana.-Polizotto v. People's
Sav. Bk. (1910), 125 La. 770,51 So. 843 .

Missouri.-Burchett v. Fink 
(1909), 139 Mo. App. 381; Chitwood v. Hatfield (1909), 136 Mo. App. 688; Allen Grocery Co. v. Bk. of Buclianan Co. (1916), 182 S. IV. 777.

New York.-Linick v. Nutting (1910), 125 N. Y. Supp. 93; Holzman, Cohen \& Co. v. Teague (1915), 156 N. Y. Supp. 290; Holtzman, Cohen \& Co. v. Teague (1910), 158
N. Y. Supp. 211; Rubel v. Honig (1917), 164 N. Y: Supp. 219.

Washington.-Seattle Nat. Bk. v. Becker (1913), 133 Pac. 613.

West Virginia.-Rusmissel v. White Oak Stave Co. (1917), $92 \mathrm{~S}$. IV. 672 .

United States.-In re Continental Engine Co. (1916), 234 Fed. 58.

Section 16. Every contract on a negotiable instrument is incomplete and revocable until delivery of the instrument for the purpose of giving effect thereto. As between immediate parties, and as regards a remote party other than a holder in due course, the delivery, in order to be effectual, must be made either by or under the authority of the party making, drawing, accepting or indorsing, as the case may be; and in such ease the delivery may be shown to have been conditional, or for a special purpose only, and not for the purpose of transferring the property in the instrument. But where the instrument is in the hands of a holder in due course, a valid delivery thereof by all parties prior to him so. as to make them liable to him is conclusively presumed. And where the instrument is no longer in the possession of a party whose signature appears thereon, a valid and intentional delivery by him. is presumed until the contrary is proved.

Alabama.-Bank of Tallasee v. Jordan (1917), 75 So. 930; Norwood v. Stinnett (1919), 80 So. 431.

Arizona.-Gray v. Baron (1910), 13 Ariz. 70, 108 Pac. 229.

Arkansas.-Ard v. Bowie (1916), 187 S. W. 1066; Horn v. Brand (1918), 203 S. W. 5.

Colorado.-Sayre v. Leonard (1914), 140 Pac. 196.

Connecticut.-Atwood v. Atwood (1913), 86 Atl. 29.

Florida.- Bland v. Fidelity Trust Co. (1916), 71 So. 630; Donegan v. Dekle Inv. Co. (1917), 74 So. 11; Williams v. Peninsular Grocery Co. (1917), 75 So. 517.
Illinois.- Strauss v. Citizen's St. Bk. of Elmhurst (1911), 164 Ill. App. 420.

Iowa.- Selma Sav. Bk. v. Harlan (1914), 149 N. W. 882; Roy v. Duff (1915), 152 N. W. 606; Rule v. Carey (1916), 159 N. W. 699.

Kansas.-Wood v. Bank of Whitewater (1914), 91 Kans, 522.

Kentucky.-Key v. Usher (1907), $30 \mathrm{Ky}$. L. R. $667,99 \mathrm{~S}$. W. 324.

Massachusetts.-Mass. Nat. Bk. v. Snow (1905), 187 Mass. 159. 72 N. F. 959; Stouffer v. Curtis (1908), 198 Mass. 560, 85 N. E. 150; Buzzell v. Tobin (1909), 201 Mass. 1, 86 N. E. 923. 
Michigan.-Gen. Conf. Assn. etc. v. Mich. Sanitarium (1911), 166 Micl. 504.

Minnesota.-Behrens v. Kruse (1916), 155 N. W. 1065.

Mississippi.-Homes Bros. v. McCall (1916), 74 So. 786 .

Missouri.-Semmes \& Co. v. Barnett (1916), 190 S. W. 394.

New Jersey.- Borough of Montvale v. People's Bank (1907), 67 Atl. 67.

New York.- Linbarger v. Board of Education of West N. Y. (1912), 83 N. J. L. 446; Greeser v. Sugar$\operatorname{man}$ (1902), 76 N. Y. Supp. 922, 37 Mise. 799 ; Poess v. Twelfth Ward Bk. (1904), 43 Misc. 45, 86 N. Y. Supp. 857; Moak v. Stevens (1904), 45 Misc. 147, 91 N. Y. Supp. 903; Colborn v. Arbean (1907), 54 Misc. 623, 104 N. Y. Supp. 968; Madden v. Gaston (1910), 137 A. D. 294, 121 N. Y. Supp. 951; Linick v. Nutting (1910), 125 N. Y. Supp. 93; Pfister v. Heins (1910), 136 A. D. 457; Stoughton v. Chu Fong (1911), 130 N. Y. Supp. 228; Niblock v. Sprague (1911). 200 N. Y. Supp. 390; Smith v. Dotterweich (1911), 200 N. Y. 299; In re Marine (1912), 140 N. Y. Supp. 230; Yonker's Nat. Bk. v. Michell (1913), 141 N. Y. Supp. 128; Senft v. Schaeffer-(1913), 142 N. Y. Supp. 350, 81 Misc. 152; Flood v. Steinmet\% (1915), 153 N. Y. Supp. 192; Holzman, Cohen \& Co. v. Teague (1915), 156 N. Y. Supp. 290; Schaeffer v. Marsh (1915), 153 N. Y. Supp. 96; Empire Trust Co. v. Manhattan Co. (1916), 162 N. Y. Supp. 629; Holtzman, Cohen \& Co. v. Teague (1916). 158 N. Y. Supp. 211; Empire Trust Co. v. President \& Directors Man Co. (1917), 162
N. Y. Supp. 629 ; Dalrymple v. Schwartz (1917), 164 N. Y. Supp. 496; Rubel v. Honig (1917), 164 N. Y. Supp. 219.

North Dakota.-First State Bk. of Eckman v. Kelly (1915), $152 \mathrm{~N}$. W. 125; Stockton v. Turner (1915), 152 N. W. 275; Marlatt v. Coulture (1919), 169 N. W. 582.

Ohio.- Carrara Paint Agency Co. v. Nat. Bk. of Barberton (1906), 29 O. C. 485; Starr Piano Co. v. Edgar (1909), 31 O. C. 295.

Oklahoma.-Gamble v. Riley (1913), 135 Pac. 390; Bank of Tallassee v. Jordan (1917), 75 So. 930; Bank of Catersville v. Gunter (1912), 58 So. 757; Stone v. Goldberg \& Lewis (1912), 6 Ala. App. 249, 60 So. 744; Bledsoe v. City Nat. Bk. of Selma (1912), 7 Ala. App. 195,60 So. 942 ; Haas v. Commerce Tr. Co. (1915), 69 So. 984; Citizens Nat. Bk. v. Bucheit (1916), 71 So. 82.

Oregon.-Gress v. Wessinger (1918), 172 Pac. 495; Louis County v. Bank of Peck (1918), 170 Pac. 98.

Pennsylvania.- First Nat. Bk. v. McBride (1911), 230 Pac. 261; Lincoln Nat. Bk. of Pittsburg v. Miller (1917), 100 Atl. 269, 255 Pac. 467.

South Carolina.- Commercial Security Co. v. Donnald Drug Co. (1918), 96 S. E. 529.

South Dakota.-Piper v. Hagen (1914), 146 N. W. 692; Larson v. Sequin (1914), 149 N. W. 174.

Utah.-. Smith v. Brown (1917), 165 Pac. 468.

Washington.-Angus v. Downs (1915), 147 Pac. 630.

Wisconsin.-Schultz v. Kosbab (1905), 125 Wis. 157; Hodge v. Smith (1907), 130 Wis. 326, 110 
N. W. 192; Paulson v. Boyd (1908), 137 Wis. 241,118 N. W. 841 ; U. S. Investment Co. v. Epley (1916), 160 N. W. 175 .
United States.- United States v. Chase Nat. Bk. (1917), 241 Fed. 535.

Section 17. Where the language of the instrument is ambiguous or there are omissions therein, the following rules of construction apply :

(1) Where the sum payable is expressed in words and also in figures and there is a discrepancy between the two, the sum denoted by the words is the sum payable; but if the words are ambiguous or uncertain, reference may be had to the figures to fix the amount;

(2) Where the instrument provides for the payment of interest, without specifying the date from which interest is to run, the interest runs from the date of the instrument, and if the instrument is undated, from the issue thereof;

(3) Where the instrument is not dated, it will be considered to be dated as of the time it was issued;

(4) Where there is a conflict between the written and printed provisions of the instrument, the written provisions prevail.

(5) Where the instrument is so ambiguous that there is doubt whether it is a bill or note, the holder may treat it as either at his election;

(6) Where a signature is so placed upon the instrument that it is not clear what capacity the person making the same intended to sign, he is to be deemed an indorser;

(7) Where an instrument containing the words "I promise to pay" is signed by two or more persons, they are deemed to be jointly and severally liable thereon.

Alabama.-Bill v. Birmingham (1913), 9 Ala. App. 212, Bell v. Birmingham (1913), 62 So. 971; Potter v. 'Tucker (1914), 66 So. 922; Turner v. Turner (1915), 69 So. 503; Long v. Givin (1919), 80 So. 440 .

Colorado.-Ullery v. Brohm (1904), 20 Colo. App. 389, 79 Pac. 180; Ullery v. Brohm (1905), 20 Colo. App. 389, 79 Pac. 180; Milnen
Bank \& Trust Co. v. Whipple (1916), 156 Pac. 1098.

Illinois.- Illinois v. Lewinger (1911), 252 Ill. 332; Burr v. Beckler (1914), 106 N. E. 206, 264 III. 230.

Iowa.- Porter v. Moles (1911), 151. Iowa, 279, 131 N. W. 23.

Kentucky.-Mechanies \& Farm. er's Sav. Bk. v. Katterjohn (1910), $137 \mathrm{Ky} .427,125$ S. W. 1071. 
Lourisiana.-J. I. Case Threshing Machine Co. v. Bridger (1913), 133

La. 754, 63 So. 319.

Massachusetts. - Lewenstein $\quad$. Forman (1916), 111 N. E. 962.

Minnesota.-Spiering v. Spiering (1917), 164 N. W. 583.

Missouri.-Bk. of Houston v. Day (1909), 122 S. W. 756; Houston v. Day (1909), 145 Mo. App. 410.

Nebraska.- Hornstein v. Clifuno (1910), 86 Neb. 103.

New Mexico.-Hill v. Hart (1917), 167 Pac. 710.

New York.-Didato v. Coniglio (1906), 100 N. Y. Supp. 466, 50 Misc. 280; Tanner's Nat. Bk. v. Lacs (1909), 136 A. D. 92, 120 N. Y. Supp. 669; Van Vlict v. Kanter (1910), 124 N. Y. Supp. 63.

Ohio.-Dollar Sav. Bk. v. Barberton Pottery Co. (1907), 17 Ohio Dec. 539.
Oklahoma.-Critser v. Steeley: (1917), 162 Pac. 795.

Oregon.-Lumberman's Nat. Bk. of Portland v. Campbell (1912), 61 Oreg. 123, 121 Pac. 427; Anderson v. Stayton State Bk. (1916), 159 Pac. 1033.

Rhode Island.-Deahey v. Choquet. (1907), 28 R. I. 338.

Tennessee-Moore v. Carey (1917), 197 S. W. 1093.

Washington.-Spencer v. Alki Point Transp. Co. (1909), 53 Wash. 77, 101 Pac. 509; Pease v. Syler (1914), 135 Pac. 310; Churehill v. Miller (1916), 156 Pac. 851; Smith. v. Doty (1916), 157 Pac. 881 .

Wisconsin.-Germania Nat. Bk. v. Mariner (1906), 129 Wis. 54t, 109 N. W. 574.

Wyoming.-Acme Coal Co. v. Northrup Nat. Bk. of Iola (1915), 146 Pac. 593.

Section 18. No person is liable on the instrument whose signature does not appear thereon, except as herein otherwise expressly provided. But one who signs in a trade or assumed name will be liable to the same extent as if he had signed in his own name.

Kansas.- New York L. Ins. Co. v. Martindale (1907), 75 Kans. 142, 88 Pac. 559, 121 Am. St. 362.

Missouri.- Mineral Belt Bank v. Elking Lead \& Zinc Co. (1913), 158 S. W. 1066.

Montana.-Kohrs v. Smith (1912), 45 Mont. 467, 124 Pac. 275; Young v. Bray (1918), 170 Pac. 104.
Oregon.-Gardner v. Wiley (1905), 46 Oreg. 96, 79 Pac. $3 \sharp 1$.

Washington.- Seattle Shoe Co. v. Packard (1906), 43 Wash. 527, 86 Pac. 845, 117 Am. St. 1064.

Wisconsin.-Frailing v, Sicher (1919), 169 N. W. 60\%.

United States.-In re Robson (1914), 218 Fed. 452 (C. C. A., 2d Ct.).

Section 19. The signature of any party may be made by a duly. authorized agent. No particular form of appointment is necessary for this purpose; and the authority of the agent may be established as in other cases of agency. 
lowa.- Watts v. Sarings Bank (1917), 165 N. W. 897.

Kansas.-New York L. Ins. Co. v. Martindale (1907), 75 Kans. 142, 88 Pac. 559, $121 \mathrm{Am}$. St. 362.

Massachusetts.-Stone v. Sergeant (1915), 107 N. E. 1014.

Missouri.-Houston v. Day (1909), 145 Mo. App. 410; Scotland Co. Nat. Bk. v. Hohn (1910), 146 Mo. App. 699, 125 S. W. 539; Gage v. Bank of Holcomb (1917), 196 S. W. 1077 .

Nebraska.- First Nat. Bk. of Slienandoah v. Kelgord (1912), 91 Neb. 178,135 N. W. 548.

New York.- Burstein v. People's
Tr. Co. (1911), 143 A. D. 165; Burstein v. Sullivan (1909), 134 A. D. 623; Hubbard v. Syemite Trap Rock Co. (1917), 165 N. Y. Supp. 486; Standard Steam Spec. Co. v. Corn Exch. Bk. (1917), 116 N. F. 356, 220 N. Y. 478.

Washington.-Nat. Bk. of Commerce of Seattle v. Puget Sound Biscuit Co. (1910), 6 Wash. 192, 112 Pac. 265; Citizens Nat. Bk. v. Ariss (1912), 68 Wash. 448; Hanson v. Northern Bk. \& Tr. Co. (1917), 167 Pac. 97.

United States.-Nat. Bk. of Commerce in St. Louis v. Sancho Pag. Co. $(1911), 110$ C. C. A. 112,186 Fed. 257 (La.).

Section 20. Where the instrument contains or a person adds to his signature words indicating that he signs for or on behalf of a principal, or in a representative capacity, he is not liable on the instrument if he was duly authorized; but the mere addition of words describing him as an agent, or as filling a representative character, without disclosing his principal, does not exempt him from personal liability.

Alabama.-Briel v. Ex. Nat. Bk. (1911), 172 Ala. 475, 55 So. 808; Peabody School Furniture Co. v. Whitman (1912), 6 Ala. App. 182, 60 So. 470.

Arkansas.-Corning v. Nimnich (1916), 183 S. W. 756.

Colorado.-New England Electric Co. v. Shook (1915), 145 Pac. 1002.

Connecticut.-Pascucci v. Rossi (1917), 101 Atl. 22.

Indiana.- Bayh v. Hanna (1919), 122 N. E. 7.

Iowa.-Schumacher v. Dolan (1912), 134 N. W. 624; Exch. Bk. of Marcus v. Schults (1914), 149 N. W. 99 .
Kansas.- Weston Grocer Co. v. Lackman (1907), 75 Kans. 34, 88 Pac. 527; Bateman v. Sarback (1914), 89 Kans. 458.

Louisiana,-Bayries v. Lindsly (1911), 128 La. 259, 54 So. 791.

Maryland.-Denton Nat. Bk. v. Kenney (1911), 116 Md. 124, 81 Atl. 227 ; First Denton Nat. Bk. v. Kenney (1911), 116 Md. 24; Belmont Dairy Co. v. Thrasher (1914), 92 Atl. 766,124 Md. 320 .

Massachusetts.- Tuttle v. First Nat. Bk. of Greenfield (1905), 187 Mass. 533, 73 N. E. 560; Dunham v. Blood (1911), 207 Mass, 512: Myers v. Chesley (1915), 17t S. W. 
326; Wurlizer Co. $\mathbf{v}$ Rossman (1916), 190 S. W. 636.

Nebraska.-First Nat. Bk. of Shenandoah v. Kelgord (1912), 91 Neb. 178, 135 N. W. 548.

New Jersey.- Phelps v. Weber (1913), 87 Atl. 468.

New York. - Megowan v. Peterson (1902), 173 N. Y. 1, 65 N. E. 738; Kerby v. Ruegamer (1905), 107 A. D. 491; Dunbar Co. v. Martin (1907), 53 Misc. 312,103 N. Y. Supp. 91; Burstein v. Sulli$\operatorname{ran}(1909), 134$ A. D. 623; The Van Norton Tr. Co. v. L. Rosenberg, Inc. (1909), 62 Misc. 285, 114 N. Y. Supp. 1025; Burstein v. People's Tr. Co. (1911), 143 A. D. 165 ; International Trust Co. v. Caroline (1912), 137 N. Y. Supp. 932.

Oregon.- Paye v. Ford (1913), 131 Pac. 1013.

Pennsylvania.-Chatham Nat. Bk. v. Gardner (1906), $31 \mathrm{~Pa}$. Super. Ct. 135; Birmingham Iron Foundry v. Rignery (1907), 33 Pa. Super. Ct. 54; Grange Trust Co. v. Brown (1911), 49 Pa. Super. Ct. 274.

Tennessee.-Wilson v. Clinton Chapel, Zion Church (1917), 198 S. W. 244 .

Washington.-Daniel v. Glidden (1905), 38 Wash. 556, 80 Pac. 111; Citizens Nat. Bk. v. Ariss (1912), 68 Wash. $4 \div 8$.

West Virginia.-Dollar Sav. \& Gr. Co. v. Crawford (1911), 70 S. E. 1089 .

Wisconsin.-Germania Nat. Bk. v. Mariner (1906), 129 Wis. 544, 109 N. W. 574.

United States.- Am. Trust Co. v. Canevin (1911), 107 C. C. A. 543; Nat. Bk. of Commerce in St. Louis v. Sancho Packing Co. (1911), 110 C. C. A. 112,186 Fed. 257.

Section 21. A signature by "procuration" operates as notice that the agent has but a limited authority to sign, and the principal is bound only in case the agent in so signing acted within the actual limits of his authority.

Arkansas.- Schaap v. State Nat. Bk. of Texarkana (1919), $208 \mathrm{~s}$. W. 309 .
New Jersey.- R. M. Owen \& Co. v. Storms \& Co. (1909), 78 N. J. L. 154, 72 Atl. 441.

Section 22. The indorsement or assignment of the instrument by a corporation or by an infant passes the property therein, notwithstanding that from want of capacity the corporation or infant may incur no liability thereon.

Alabama.-Citizens Nat. Bk. v. Bucheit (1916), 71 So. 82.

Minnesota.-Thorpe v. Cooley (1918), 165 N. W. 265.

New York.- Oppenheim v. Reigal Cigar Co. (1904), 90 N. Y. 355.
North Carolina.- Vance v. Bryau (1912), 158 N. Car. 502, 74 S. E. 459.

United States.-Willard v. Crook (1903), 21 App. D. C. 237. 
Section 23. When a signature is forged or made without the authority of the person whose signature it purports to be, it is wholly inoperative, and no right to retain the instrument, or to give a discharge therefor, or to enforce payment thereof against any party thereto, can be acquired through or under such signature, unless the party, against whom it is sought to enforce such right, is precluded from setting up the forgery or want of authority.

Illinois.-Hamlins Wizard Oil Co. v. U..S. Express (1914), 184111. App. 493.

Iowa.-Beend v. Farrell (1907), 135 Iowa, 670, 113 N. W. 509 ; State ex rel. Carroll v. Corning St. Sav. Bk. (1908), 139 Iowa, 338, $115 \mathrm{~N}$. W. 937; Reints \& DeBuhr v. Uhlenhop (1910), 149 Iowa, 284; Olsgard v. Lemke (1916), $156 \mathrm{~N}$. W. 102.

Kentucky.-Nat. City Bk. v. Third Nat. Bk. (1910), 177 Fed. 136; Jett v. Standefer (1911) \& 143 Ky. 787, 137 S. W. 513.

Massachusetts.-Murphy v. Met. Nat. Bk. (1906), 191 .Mass. 159; Blum Jro Sons v. Whipple (1907), 194 Mass. 253, 120 Am. St. 553, 80 N. E. 501, 13 L. R. A. (N. S.) 211; Boles v. Harding (1909), 201 Mass. 103, 87 N. E. 481; Jordan Marsh Co. v. Nat. Shawmut Bk. (1909), 201 Mass. 397, 87 N. E. 740; Franklin Sav. Bk. v. Framingham (1912), 212 Mass. 92; Newburyport v. First Nat. Bk. of Boston (1914), 216 Mass. 304; Munroe v. Stanley (1915), $107 \mathrm{~N}$. E. 1012.

Michigan.- Lonier v. State Sav. Bk. (1907), 149 Mich. 483, $112 \mathrm{~N}$. W. 1119.

Missouri--Mo. Lincoln Tr. Co. v. Third Nat. Bk. of St. Louis (1910), 154 Mo. App. 89; Mo. Lincoln Tr. Co. v. Third Nat. Bk. of St. Louis (1910), 154 Mo. App. 89; Miners
\& Merch. Bank v. St. Louis Smelt ing \& Refining Co. (1915), 178 Mo. App. 211; German-Am. Bank v. Barnes (1916), 185 S. W. 1194.

Montana.- First Nat. Bk. of Miles City v. Barrett (1916), 57 Pac. 951.

Nebraska.- Hoffman v. Am. Ex. Nat. Bk. (1901), 96 N. W. 112.

New Jersey.-Gluckman v. Darling (1914), 89 Atl. 1016.

New York.-First Nat. Bk. of Fort Worth v. Am. Ex. Nat. Bk. (1900), 49 A. D. 349; Critten v: Chemical Nat. Bk. (1902), 171 N. Y. 219 (May 13) ; Casey v. Pilkington (1903), 83 App. Div. 91; Sherman v. The Corn Ex. Bk. (1904), 91 A. D. 84; Kearny v. Met. Trust Co. (1905), 110 A. D. 236; Salem v. Bk. of the St. of N. Y. (1906), 110 A. D. 636, 97 N. Y. Supp. 361; Oriental Bk. v. Gallo (1906), 112 A. D. 360,98 N. Y. Supp. 561; Trust Co. of Am. v. Hamilton Bk. (1908), 127 A. D. 515, 112 N. Y. Supp. 84; Seaboard Nat. Bk. of America (1908), 193 N. Y. 26, 85 N. E. 829 ; 'The Mercantile Nat. Bk. of the City of N. Y. v. Silverman (1911), 148 A. D. 1; Stein v. Empire Tr. Co. (1912), 133 N. Y. Supp. 517; Kobre v. Corn Exchange Bk. (1913), 139 N. Y. ¿upp. 890 ; Anglo-South Am. Bk. v. Nat. City Bk. of N. Y. (1914), 146 N. Y. 
Supp. 457; Standard Steam Specialty Co. v. Corn Ex. Bk. (1914), 146 N. Y. Supp. 181; Wolfin v. Security Bk. (1915), 156 N. Y. Supp. 474 ; Bergstrom v. Ritz-Carlton Hotel Co. (1916), 157 N. Y. Supp. 959 ; Standard Steam Spec. Co. v. Corn Exch. Bk. (1917), 116 N. E. 386,220 N. Y. 478; Monk v. 23d Ward Bk. (1917), 165 N. Y. Supp. 1055; Standard Specialty Co. v. Corn Exch. Bk. (1917), 116 N. E. 386, 220 N. Y. Supp. 478; Cohen v. I. Rittner, Inc. (1918), $171 \mathrm{~N}$. Y. Supp. 312.

North Dakota.-First Nat. Bk. of Lisbon v. Bk. of Wyndemere (1906), 15 N. Dak. 299, 108 N. W. 546; Stutsman County Bk. v. Jones (1917), 162 N. W. 402.

Ohio.- Winters Nat. Bk. v. Roberts (1909), 20 Ohio Dec. 690; The S. Weishberger Co. v. The Barbeton Sav. Bk. Co. (1911), 84 Ohio St. 21; McHenry v. The Old Citizens Nat. Bk. (1911), 85 Ohio St. 203.

Oklahoma.- Turner v. Kimble (1913), 130 Pac. 563.

Oregon.-First Nat. Bk. of Cottage Grove v. Bk. of Cottage Grove (1911), 59 Oreg. 388, 117 Pac. 293.

Pennsylvania.- Tibby Bros Glass
Co. v. Farmers \& Mech. Bk. of Sharpsburg (1908), 200 Pa. 1; Cunningham v. First Nat. Bk. of Indiana (1908), 219 Pa. 310; Faleomi v. Magee (1911), $47 \mathrm{~Pa}$. Super. 560.

Rhode Island.-Tolman v. Am. Nat. Bk. (1901), 22 R. I. 462.

Tennessee.- Knoxville Water Co. v. E. 'T'enn. Nat. Bk. (1910), 123 Tenn. 364; Litchfield Shuttle Co. v. Cumberland Valley Nat. Bk. (1916), 183 S. W. 1006.

Utah.- Heavey v. Commercial Nat. Bk. (1904), 27 Utah, 222, 75 Pac. 727; Warren v. Smith (1909), 35 Utah, 455, 100 Pac. 1069; Simpson v. Denver \& Rio Grande Co. (1913), 134 Pac. 883.

Virginia.- Pettyjohn v. Nat. Ex. Bk. (1903), 101 Va. 111, 43 S. E. 203.

Washington.-Jamieson \& McFarland v. Heim (1906), 43 Wash. 153, 86 Pac. 165; Heim v. Neubert (1908), 48 Wash. 587, 94 Pac. 104; Goodfellow v. First Nat. Bk. (1913), 129 Pae. 90.

United States.- Cent. Nat. Bk. v. Nat. Met. Bk. (1908), 31 A. C. (D. C.) 391,35 Wash. L. R. 621 (C. C., Dist. Col.); Cent. Nat. Bk. v. Nat. Met. Bk., 31 A. C. (D. C.) 391.

\section{ARTICLE II.}

\section{CONSIDERATION.}

Section 24. Every negotiable instrument is deemed prima facie to have been issued for a valuable consideration; and every person whose signature appears thereon to have become a party thereto for ralue.

Alabama.-Jones,v. Bell (1917), 77 So. 918; Vogler v. Manson (1917), 76 so. 117 .

Arkansas. - Sins
(1914), 168 S. W. 559; Buckely v. Collins (1915), 177 S. W. 920.

California.-Molley v. Pierson (1918), 174 Pac. 98. 
Connecticut.- American Automobile Co. v. Perkins (1910), 83 Conn. 520, 77 Atl. 954.

Delaware.-Security Trust \& Safe Dep. Co. v. Duross (1913), 86 Atl. 209.

Florida.- Williams v. Peninsular Grocery Co. (1917), 75 So. 517.

Idaho.-McFarland v. Johnson (1912), 22 Ida. 694, 127 Pac. 908.

Illinois.-George J. Cooke Co. v. Pisano (1912), 174 Ill. App. 609; Harney v. Lee (1912), 175 Ill. App. 250 .

Indiana.-Deiter v. Burke (1914), 107 న. E. 304.

Iowa.- Zimbelman v. Finnegan 11909), 141 Iowa, 358, Brokaw v. MeElvoy (1913), 143 N. W. 1087; Perry Sav. Bk. v. Fitzgerald (1914), 149 N. W. 497; First Presbyterian Church of Mt. Vernon v. Dennis (1917), $161 \mathrm{~N}$. IV. 183; Higby v. Bahrenfuss (1917), $163 \mathrm{~N}$. IV. 247 .

Kansas.- Kawkins v. Windhost (1910), 82 Kans. 522, 108 Pac. 805.

Louisiana.- Scheuerman v. Monarch Fruit Co. (1909), 123 La. 59, 48 So. 647.

Maryland.-Black v. First Nat. Bk. (1903), 96 Md. 399, 54 Atl. 88; Louis Wekels \& Sons Ice Mfg. Co. v. Cornell Economizer Co. (1912), 86 Atl. 38; Bear Creek Lumber Co. v. Second Nat. Bk. of Cumberland (1913), 120 Md. 566, 87 Atl. 1084; Shaffer v. Bond (1917), 99 Atl. 972.

Massachusetts. - Lombard v. Bryne (1907), 194 Mass. 236, $80 \mathrm{~N}$. E. 489; Jennings v. Law (1908), $1 ! 9$ Mass. 124,85 N. E. 157 ; Clem(ous Flec. Mfg. Co. v. Walton (1910), 206 Mass. 215; North Anson Lumber Co. v. Smith (1911), 209 Mass. 333; Young v. Hayes (1912), 212
Mass. 525; Harvey v. Squire (1914), 105 N. E. 355; Seager v. Drayton (1914), 105 N. Ji. 461.

Minnesota.-Baxter v. Brandenburg (1917), 163 N. IV. 517.

Missouri.-Rhodes v. Guhman (1911), 156 Mo. App. 344; Nelson v. Diffenderffer (1914), $163 \mathrm{~S}$. W. 271; Miller v. Chinn (1917), 195 S. W. 552.

Montana.- Ford v. Drake. (1912), 46 Mont. 314.

Nebraska.-First Nat. Bk. of Scribner v. Golder (1911), 89 Neb. 377; Stannard v. Orleans Flour \& Oat Meal Milling Co. (1913), 93 Neb. 389.

New Jersey.- People's Nat. Bk. v. Schepflin (1905), 73 N. J. L. 29, 62 Atl. 333; Marine I'r. Co. v. St. James African M. E. Church (1913), 88 Atl. 1075; Bank of Roselle v. Dorvall (1916), 98 Atl. 476.

New York.-Riverside Bk. v. Woodhaven Junction Jand Co. (1898), 34 A. D. 359; McLeod v. Hunter (1899), 29 Misc. 558, $61 \mathrm{~N}$. Y. Supp. 73; Deyo v. Thompson (1900), 53 A. D. 9; Bringman v. Glahn (1902), 71 A. D. 537, 75 N. Y. Supp. 845 ; Karsch v. Pottier \& Stymers Mfg. \& Imp. Co. (1903), 81 N. Y. 782, 82 A. D. 230; Packard v. Windholz (1903), 40 Misc. 347, affirmed 88 A. D. 365 (1902); Moak v. Stevens (1904), 45 Misc. 147, 91 N. Y. Supp. 903; The Royal Bk. of N. Y. v. Goldschmidt (1906), 51 Misc. 622, 101 N. Y. Supp. 101; IVard v. City Tr. Co. of N. Y. (1907), 102 N. Y. Supp. 50; Cleary v. DeBeck Plate Glass Co. (1907), 54 Misc. 537, 104 N. Y. Supp. 531; Colborn r. Arbean (1907), 54 Misc. 623. 104 N. Y. Supp. 968; Joves. hoff v. Rockney (1908), 109 N. Y. 
Supp. 818, 58 Misc. 559; Nat. Park Bk. v. Saitta (1908), 127 A. D. 624, 111 N. Y. Supp. 927; Pfister v. Heins. (1910), 136 A. D. 45\%; Ferguson v. Netter (1910), 141 A. D. 274; Ryan v. Sullivan (1911), 143 A. D. 471; Glennan v. Rochester Tr. \& Safe Dep. Co. (1912), 136 N. Y. Supp. 747 ; First Nat. Bk. of Pittsburg v. Stallo (1914), $145 \mathrm{~N}$. Y. Supp. 747; Gerli v. Doorly (1915), 151 N. Y. Supp. 574; Schultz v. Cohen (1915), 156 N. Y. Supp. 610; Abrahamson v. Steel (1917), 163 N. Y. Supp. 827.

North Carolina.- Toms v. Jones (1900), 127 N. Car. 464; Myers v. Petty (1910), 153 N. Car. 462; Columbian Conservatory of Music v. Dickenson (1912), 758 N. Car. 207, 73 S. E. 990.

North Dakota.-Walters v. Rock (1908), 18 N. Dak. 45, 115 N. W. 511; Holbert v. Weber (1917), 161 N. W. 560.

Ohio.-Ginn v. Dolen (1909), 81 Ohio St. 121,90 N. E. 141 ; Pierce v. Harper (1918), 249 Fed. 867.

Oklahoma.-Hudson v. Moore (1913), 130 Pac. 774.

Oregon.-Fassett v. Boswell (1911), 59 Oreg. 288, 117 Pac. 302; Long v. Hoedle (1911), 60 Oreg. 377, 119 Pac. 484; First Nat. Bk. of Bangor v. Paff (1913), 87 Atl. 841; Adjustment Bureau of Portland Assn. of Credit Men v. Staats (1919), 175 Pac. 847.

South Carolina.-Cannon v. Clarendon Hardware Co. (1916), 88 S. E. 284.

Utah.- Cole Banking Co. v. Sinclair (1908), 34 Utah, 454, 98 Pac. 411; Utah Nat. Bk. of Salt Lake City v. Nelson (1910), 38 Utah, 169, 111 Pac. 907; Niles v. U. S. Ozocinte Co. (1911), 38 Utah, 367, 113 Pac. 1038.

Virginia.- Lynchburg Milling Co. v. Nat. Ex. Bk. of Lynchburg (1909), 109 Va. 639; Reid's Admr. v. Windsor (1911), 111 Va. 825, 69 S. E. 1101; Murphy's Hotel Co. v. Herndon's Admrs. (1917), 91 S. E. 634 .

Washington.-Nicholson v. Neavy (1914), 137 Pac. 492; State Bk. of Clarkson v. Morrison (1915), 147 Pac. 875.

West Virginia.-Dollar Sav. \& Gr. Co. v. Crawford (1911), 70 S. E. 1089 .

Wyoming.- Hamilton v. Diefenderfer (1913), 131 ac. 37.

United States.-Towles v. Tanner (1903), 21 App. D. C. 530; Nalitsky v. Williams (1917), 237 Fed. 802 .

Section 25. Value is any consideration sufficient to support a simple contract. An antecedent or pre-existing debt constitutes value; and is deemed such whether the instrument is payable on demand or at a future time.

Alabama.-Boatwright $\mathbf{r}$. Scheuer, Wise \& Co. (1914), 66 So. 819; Anders v. Sandlin (1915), 67 So. 684; Orr v. Stewart (1915), 69 So. 649; Dilworth v. Holmes Furniture
\& Vehicle Co. (1916), 73 So. 288; Peoples' Bank \& Trust Co. v. Floyd (1917), 75 So. 940.

Arkansas.-Hood v. Robson (1916), 187 S. W. 1059; Arnwell 
v. Arnold \& Co. (1917), 193 S. W. 506; Johnson V. Ankrun (1917), 199 S. W. 897 .

California.-Shoenhair v. Jones (1917), 165 Pac. 971; Ballou v. Avery (1917), 166 Pac. 1003; Wetzel v. Cole (1917), 165 Pac. 692; Perzoni v. Greenwell (1918), 174 Pac. 60; Mahana v. Van Alstyne (1919), 178 Pac. 853.

Colorado.- Lomax v. Colorado Nat. Bk. (1909), 104 Pac. 85; Western Investment and Land Co. v. First Nat. Bk. (1918), 172 Pac. 6; Western Slope Fruit Growers Assn. v. Divine (1918), 173 Pac. 426; U. S. Fidelity \& Guarantee Co. v. Walker (1918), 248 Fed. 42.

Connecticut.- New Haven Mfg. Co. v. New Haven Pulp Co. (1903), 76 Conn. 126, 55 Atl. 604; Russell El. Co. v. Bassett (1907), 79 Conn. 709, 66 Atl. 531; Ohittenden v. Carter (1909), 82 Conn. 585; Fairfield Co. Nat. Bk. v. Hammer (1915), 95 Atl. 31 ; Continental Credit Co. v. Ely (1917), 100 Atl. 435.

Florida.-Crystal River Lumber Co. v. Consolidated Naval Stores Co. (1912), 63 Fla. 119, 58 So. 129.

Idaho.-Federal State Bank v. Miller (1917), 162 Pac. 244; Fidelity Bank v. Miller (1917), 162 Pac. 244.

Illinois.-Many, Blanc \& Co. v. Krueger (1910), 153 Ill. App. 327; McHenry v. Croft (1911), 163 IIl. App. 426.

Indiana.-Merch. Nat. Bk. v. Nees (1916), 112 N. E. 904.

Iowa.-Gooeh v. Gooch (1916), 160 N. W. 333; Commercial Nat. Bk. v. Citizens State Bk. (1906), 132 Iowa, 706, 109 N. W. 198; Crawford Co. State Bk. v. Stegman (1908), 137 Iowa, 13, 114 N. W.
549; Voss v. Chamberlain (1908), 139 Iowa, 569, 117 N. W. 269; Zimbelman v. Finnegan (1909). 141 Iowa, 358; Robinson v. Robinson (1910), 147 Iowa, 615; Robertson v. United States Live Stock Co. (1914), 145 N. W. 535; Meginnes v. McChesney (1916), $160 \mathrm{~N}$. W. 50 ; State Bk. of Halstad v. Bilstad (1912), 136 N. W. 204; Mohn v. Mohn (1917), 164 N. W. 341.

Kansas.- Birket v. Ellward (1904), 68 Kans. 295, 74 Pac. 1100; Bridges v. Vann (1912), 88 Kans. 98.

Kentucky.- Wilkins v. Usher (1906), 123 Ку. 696, 97 S. W. 37; Citizens Bk. v. Bk. of Waddy (1907), 126 Ky. 169, 103 S. W. 249 ; Herman's Excr. v. Gregory (1909), 131 Ky. 819, 115 S. W. 809 ; Lovelace v. Lovelace (1910), $136 \mathrm{Ky} .452,124$ S. IV. 400; Campbell v. Fourth Nat. Bk. of Cincinnati (1910), $137 \mathrm{Ky} .555,126 \mathrm{~S}$. W. 114 ; Am. Nat. Bk. v. Minor \& Son (1911), 135 S. W. 278; Jett v. Standafer (1911), $143 \mathrm{Ky} \cdot 787,137$ S. IV. 513; Pratt v. Rounds (1914), 169 S. IV. 848; Overby v. IVilliams (1916), 185 S. IV. 822; Receiver First Nat. Bk. of Loudon v. Boreling (1916), 190 S. W. 1106; Ballard v. Ballard (1917), 197 S. IV. 661.

Louisiana.- Scheuerman v. Monarch Fruit Co. (1909), 123 La. 59, 48 So. 647; Interstate Trust \& Banking Co. v. Irwin (1915), 70 So. 313; Hyman ve. Parkerson (1916), 72 So. 953.

Massachusetts.-Boston Steel * Iron Co. v. Steuer (1903), 183 Mass. 140,66 N. E. 646; Widger v. Baxter (1906), 190 Mass. 130; Jennings v. Law (1908), 199 Mass. 124, 85 
N. E. 157; Lowell v. Bickford (1909), 201 Mass. 543, 88 N. E. 1; Shawmut Commercial Paper Co. v. Brigham (1912), 211 Mass. 72 ; Crosier v. Crosier (1913), 215 Mass. 535; Usher v. A. S. Tucker Co. (1914), 105 N. E. 360 ; Smith v. Johnson (1916), 112 N. E. 644; Ajemain v. Robinson (1917), 115 N. E. 749 .

Michigan.-Graham v. Smith (1908), 155 Mich. 65, 118 N. W. 726 ; J. D. Gruber Co. v. Smith (1917), 162 N. W. 124.

Minnesota.-German-Am. Bk. of Ritzville v. Lyons (1914), 149 N. W. 658; Security Nat. Bk. v. Pulver (1915), 155 N. W. 641; Am. Multigraph Sales Co. v. Grant (1916), 160 N. W. 676; Bank of Montreal v. Bucher (1916), $157 \mathrm{~N}$. W. 1070; Baxter v. Brandenburg (1917), 163 N. IV. 517; Baxter v. Brandenburg (1917), 163 N. W. 516.

Mississippi.-Sykes v. Moore (1917), 76 So. 538.

Missouri.-Wright v. Miss, Valley Tr. Co. (1910), 129 S. W. 407; Reeves v. Litts (1910), 143 Mo. App. 196, 128 S. W. 246; Dorris v. Cronan (1910), 129 s. IV. 1014; Nat. Bk. of Commerce in St. Louis v. Morris (1911), 156 Mo. App. 43, 135 S. W. 1008; Golden City Banking (o. v. Greisel (1912), 161 Mo. App. 477 ; State Bk. of Freeport v. Cape Girardeau \& C. R. Co. (1913), 155 S. IV. 1111; Greer v. Orchard (1913), 161 S. W. 875; Citizens Bk. of Pomono v. Oaks (1914), $179 \mathrm{~S}$. IV. 679 ; Citizens Nat. Bk. v. Bombauer (1916), 189 S. IV. 651; Central Bk. of Columbia v. Lydia (1917), 191 S. W. 245; Shawhan v. Distillery Co. (1917), 197 S. W. 369 ; Bank of Greentop v. Sloop
(1918), 200 S. W. 304; Boatmen's Bank v. St. Louis Union 'Trust Co. (1918), 205 S. W. 629; First Nat. Bk. v. Henry (1918), 202 S. IV. 281.

Montana.- Parchen v. Chessman (1914), 142 Pac. 631.

Nebraska.-Benton v. Sikyta (1909), 84 Neb. 808, 122 S. W. 60; Farmers Nat. Bk. of Lyons v. Dixon (1912), 91 Neb. 652, 136 N. IV. 845; Livestock Nat. Bk. v. Bragonier (1915), 153 N. W. 504; Macke v. Jungels (1918), 166 N. W. 191.

New Jersey.-Travis - v. Unkart (1916), 99 Atl. 320.

New York.- Riverside Bank v. Woodhaven Junction Land Co. (1898), 34 A. D. 359; Citizens Nat. Bk. v. Lilienthal (1899), 40 A. 1). 609; Brewster v. Schrader (1899), 26 Misc. 480; Rosenwald v. Goldstein (1899), 27 Misc. 827; Petrie v. Miller (1901), 57 A. D. 17, $67 \mathrm{~N}$. Y. Supp. 1042, 173 N. X. 596 (1903) (affirmed without an opinion); Sutherland v. Mead (1903), $80 \mathrm{~A}$. D. 103,80 N. Y. Supp. 504; Levy v. Huwer (1903), 80 A. D. 499; Roseman v. Mahoney (1903). 86 A. D. 377,83 N. Y. Supp. 749 ; Bk. of Am. v. Waydell (1905), 103 A. 1). 25, 92 N. Y. Supp. 666; Sutherland v. Mead, 80 A. D. 103; Roseman v. Mahoney, 86 A. D. 377; Nilins v. Kauffman (1905), 104 A. D. 442, 93 N. Y. Supp. 669 ; Hover v. Magley $(1905), 48$ Misc. 430,96 N. Y. Supp. 925 ; Nat. Bk. of Barre v. Foley (1907), 54 Misc. 126, $103 \mathrm{~N}$. Y. Supp. 553; English v. Schlesinger (1907), 55 Misc. 584, 105 N. Y. Supp. 989; MohIman Co. v. Melíane (1901), 60 A. D. 546; The Gansevort Bk. of N. Y. v. Gilday (1907), 
110 N. Y. Supp. 271, 53 Misc. 107; Bigelow v. Automatic Gas Producer Co. (1907), 107 N. Y. Supp. 894; The Wallabout Bk. v. Peyton (1908), 123 A. D. 727, 108 N. Y. Supp. 42; Joveshoff v. Rockney (1908), 109 N. Y. Supp. 818, 58 Misc. 559; Rosenthal v. Parsont (1908), 110 N. Y. Supp. 223; Valley Dew Distilling Co. v. Ritzmann (1908), 110 N. Y. Supp. 917; Harris v. Fowler (1908), 110 N. Y. Supp. 987, 59 Misc. 523; Wallabout Bk. v. Peyton (1908), 123 A. D. 727, 108 N. Y. Supp. 42; Macauley v. Holsten (1909), 114 N. Y. Supp. 611; Mindlln v. Appelbaum (1909), 62 Misc. 300,114 N. Y. Supp. 908; The Van Orden Tr. Co. v. L. Rosenberg, Inc. (1909), 62 Mise. 285, 114 N. Y. Supp. 1025; Uvalde Asphalt Paving Co. v. Nat. 'Trading Co. (1909), 135 A. D. 391, 120 N. Y. Supp. 11; Lehrenkrauss v. Bonnell (1910), 199 N. Y. 240, 92 N. E. 637; Rogonski v. Brill (1911), 131 N. Y. Supp. 589; King v. Bowling Green Tr. Co. (1911), 145 A. D. 398; Maurice v. Bowler (1912), 138 N. I. Supp. 424; Broderick \& Bascom Rope Co. v. MeGrath (1913), 142 N. Y. Supp. 496,81 Misc. 222; Martin L. Hall v. Todd (1912), 139 N. Y. Supp. 111; Shape v. Shape (1914), 150 N. Y. Supp. 367; Union Bk, of Brooklyn v. Sullivan (1915), 108 N. E. 558, 214 N. Y. 332; Brown v. Rowan (1915), 154 N. Y. Supp. 1098; McBee Co. v. Shoemaker (1916), 169 N. Y. Supp. \$34; Miller v. Campbell (1916), 160 N. Y. Supp. 834; Stokes v. Sanders (1918), 168 N. Y. Supp. 409; Lajani v. Abraham Schdala \& Sons Corporation (1918), 171 N. Y. Supp. 611; American Brass \& Copper Co. v. Pine (1919), 173 N. Y. Supp. 147.

North Carolina.- Brooks v. Sullivan (1901), 129 N. Car. 190, 39 S. E. 822 ; Singer Mfg. Co. v. Summers (1906), 143 N. C. $102 ; 55$ S. E. 522 ; Murchison Nat. Bk. v. Dunn Oil Mills Co. (1909), 150 N. Car. 718, 64 S. E. 885 ; J. L. Smathers \& Co. v. Toxaway Hotel Co. (1913), 78 S. E. 224 ; Am. Ex. Nat. Bk. v. Segroves (1914), 82 S. E. 947; Franklin Nat. Bk. v. Roberts Bros. (1915), 84 S. E. 706; Am. Nat. Bk. of Richmond v. Hill (1915), $85 \mathrm{~S}$. E. 209; Cherokee County v. Meroney (1917), 92 S. E. 616; Acme Mfg. Co. v. McCormick (1918), 95 S. E. 555 ; A. B. Hunter \& Co. v. Sherron (1918), 97 S. E. 5.

North Dakota.-Second Nat. Bk. v. Warner (1910), 126 N. W. 100; Farmer's Bk. of Mercer Co. v. Riedlinger (1914), 146 N. W. 556; Sawyer State Bk. v. Sutherland (1917), 162 N. W. 696.

Ohio._State v. Hills (1916), 113 N. E. 1045 .

Oklahoma.-Cain v. Munger (1915), 149 Pac. 1086; Ogle v. Armstrong (1915), 153 Pac. 1139; State v. Soliss (1915), 152 Pac. 1114; Purcell Mill \& Elevator Co. v. Canadian Val. Const. Co. (1916), 160 Pac. 485; First Nat. Bk. v. Harkey (1917), 163 Pac. 273; Starr v. Lonewolf (1917), 163 Pac. 532; Chandler $r$. Lach (1918), 1\%0 Pac. 516; Levy v. Reed (1918), 170 Pac. 497.

Oregon.- Matlock v. Scheuerman (1908), 51 Oreg. 49, 93 Pac. \$23. 17 L. R. A. (N. S.) 947 ; Anderson v. Stayton State Bank (1916), 159 Pac. 1033; Wicks v. Metcalf (1917), 163 Pac. 988. 
Pennsylvania.-Rathfon v. Locher (1906), 215 Pac. 571; Allentown Nat. Bk. v. Clay Prodnet Supply Co. (1907), 217 Pa. St. 128, 66 Atl. 252; Morrison v. Whitctield (1912), $46 \mathrm{~Pa}$. Super. 103; Levy v. Gilligan (1914), 90 Atl. 647.

Rhode Island.- Wilbour v. Hawkins (1915), 94 Atl. 856.

Tennessee.- Elgin City Bldg. Co. v. Hall (1907), 119 Tenn. 548, 108 S. W. 1068; Citizens Tr. Co. v. McDougal (1915), 178 S. W. 432.

Texas.- Magill v. McCamley (1916), 182 S. W. 22; Yantis v. Jones (1916), 184 S. W. 572.

Utah.-Utah Nat. Bk. of Salt Lake City v. Nelson (1910), 38 Utah, 169, 111 Pac. 907; Felt v. Bush (1912), 126 Pac. 685; Miller v. Marks (1915), 148 Pac. 412; Smith v. Brown (1917), 165 Pac. 468; Manson v. Harris (1918), 170 Pac. 970.

Virginia.-Payne v. Zell (1900), 98 Va. 294, 36 S. E. 379 ; Am. Bk. of Orange v. McComb (1906), 105 Va. 473, 54 S. E. 14; Saunders v. Bk. of Mecklenburg (1911), 71 S. E. 714; Ford v. Engelman (1915), 86 S. E. 852 ; Colley v. Summers Parrott Hardware Co. (1916), 89 S.
E. 906; Brenard Mfg. Co. v. Brown (1917), 92 S. E. 850.

Vermont.-Bean v. Parker (1916), 96 Atl. 17.

Washington. - Pitt v. Little (1910), 58 Wash. 355, 108 Pac. 941; German-Am. Bank of Seattle v. Wright (1915), 148 Pac. 769.

West Virginia.-Burner v. Nutter (1915), 87 S. E. 359.

Wisconsin.-Hodge v. Wallace (1906), 129 Wis. 84, 108 N. W. 212, 116 Am. St. R. 938; Pelton v. Spider Lake S. \& L. Co. (1907), 132 Wis. 219,112 N. W. 29, 122 Am. St. 963; Marling v. Fitzgerald (1909), 138 Wis. 93,120 N. W.' 388 ; Samson v. Ward (1911), 147 Wis. 48, 132 N. W. 629; Becker v. Noegel (1917), 160 N. W. 1055, 165 Wis. 73; Badger Co. v. Columbia Co. (1917), 163 N. W. 188.

United States.-Barnsdall v. Waltemeyer (1905), 142 Fed. 415, 73 C. C. A. 515 (Colo.); Scherer \& Co. v. Everest (1909), 168 Fed. 822, 94 C. C. A. 346 ; In re Hopper-Morgan Co. (1907), 154 Fed. 249 (N. Y.); Trust Co. of St. Louis Co. v. Markee (1910), 190 Fed. 126; Milton v. Pensacola Bk. \& Tr. Co. (1911), 190 Fed. 126, 111 C. C. A. 166.

Section 26. Where value has at any time been given for the instrument, the holder is deemed a holder for value in respect to all parties who became such prior to that time.

Alabama.-Armstrong v. Walker (1917), 76 So. 280; Hudson v. Repton State Bank (1917), 75 So. 695; Wilson v. Weaver (1917), 77 So. 238.

Idaho.-Kimpton v. Studebaker Bros. Co. (1908), 14 Ida. 552, 94 Pac. 1039.
Iowa.- Higby v. Bahrenfuss (1917), 163 N. W. 247.

Kentucky.- Herman's Excr. v. Gregory (1909), $131 \mathrm{Ky} .819,115 \mathrm{~s}$. IV. 809.

Maryland.-Black v. First Nat. Bk. (1903), 96 Md. 399, 54 Atl. 88. Massachusetts - Jennings $\mathrm{v}$. Law 
(1908), 199 Mass. 124, 85 N. E. 157; Nat. Investment \& Security Co. v. Carey (1916), 111 N. E. 357.

Michigan.-First Nat. Bk. v. Grand Rapids \& I. Ry. Co. (1917), 161 N. W. 859; National Bank of Montreal v. Bucher (1916), 157 N. W. 1070 .

Missouri.-Coleman v. Stocks (1911), 159 Mo. App. 43, 139 S. W. 216; Wright v. Wayland (1916), 188 S. W. 928; Wurlitzer Co. v. Rossman (1916), 190 S. W. 636; Howard v. Int. Bank (1918), $200 \mathrm{~S}$. W. 91.

Montana.- State Bk. of Moore v. Fursythe (1910), 41 Mont. 249.

Nebraska.-Nat. Bk. of Commerce v. Bossemeyer (1917), 162 N. W. 503.

New York.-Riverside Bk. v. Woodharen Junction Land Co. (1898), 34 A. D. 350; Petrie v. Miller (1901), 57 A. D. 17, 67 N. Y. Supp. 1042, 173 N. Y. 596, affirmed without an opinion, 173 N. Y. 596 (1903); Fleitman v. Ashley (1901), 60 A. D. 201; Sutherland v. Mead (1903), 80 A. D. 103, 80 N. Y. Supp. 504; Rogers v. Morton (1905), 46 Misc. 494, 95 N. Y. Supp. 49 ; Hover v. Magley (1905), 48 Misc. 430, 96 N. Y. Supp. 925; Rosenthal v. Freedman (1907), 53 Misc. 595, 103 N. Y. Supp. 714; Cleary v. DeBeck Plate Glass Co. (1907), 54 Misc. 537, 104 N. Y. Supp. 831; Van Nordin T'r. Co. v. L. Rosenberg, Inc. (1909), 62 Misc. 285, 114 N. Y. Supp. 1025; Heimbach v. Doublcday, Page Co. (1909), 130 A. D.
34; King v. Bowling Green Tr. Co. (1911), 145 A. D. 398 ; Broderick \& Bascom Rope Co. v. MeGrath (1913), 143 N. Y. Supp. 496, 81 Misc. 222; Lich-und-Spakassa Audorf v. Pfizer (1913), 158 A. D. 505, 143 N. Y. Supp. 744; Munnich v. Joffe (1914), 149 N. Y. Supp. 338, 164 A. D. 30; Sabine v. Painc (1915), 151 N. Y. Supp. 735; Poshkoff v. Bernstein (1916), 159 N. Y. Supp. 206; Republican Art Printer v. David (1916), $159^{\circ}$ N. Y. Supp. 1010.

Oklahoma.- Bledsoe v. City Nat. Bk. of Selma (1912), 7 Ala. App. 195, 60 So. 942 ; Miller v. Johnson (1914), 66 So. 486.

North Carolina.- Toms v. Jones (1900), 127 N. Car. 464; Citizens \& Marine Bk. of Newport News v. Southern R. W. (1910), 153 N. Car. 346.

Pennsylvania.- State Bank of Pittsburg v. Kirk (1907), 216 Pa. St. 452.

Utah.- McCormick v. Swem (1909), 36 Utah. 6, 102 Pac. 626; Felt v. Bush (1912), 126 Pac. 688.

Washington. - Bradley Engineering \& Mfg. Co. v. Heyburn (1910), 56 Wash. 62s, 106 Pac. 170; Metzger $v$. Sigall (1914), 145 Pac. 72; Wash. Trust Co. v. Keyes (1915), 152 Pac. 1029; Skagit State Bk. v. Moody (1916), 150 Pac. 425.

United States.-Richards v. Street (1908), 31 App. D. C. 42 $;$; Milton v. Pensacola Bk. \& Tr. Co. (1911), 190 Fed. 126, 111 C. C. A. 166; In re Chas. R. Partridge Lumber Co. (1914), 215 red. 973.

Section 27. Where the holder has a lien on the instrument, arising either from contract or by implication of law, he is deemed a holder for value to the extent of his lien. 
Connecticut.- Mersick v. Alderman (1905), 77 Conn. 634, 60 Atl. 109.

Illinois.-Peacock v. Phillips (1910), 155 Ill. App. 514.

Kentucky.-Citizens Bk. v. Bk. of Waddy (1907), $126 \mathrm{Ky} .169,103$ S. W. 249 ; Campbell v. Fourth Nat. Bk, of Cincinnnati (1910), $137 \mathrm{Ky}$. 555,126 S. W. 114; Am. Nat. Bk. v. Ninor \& Son (1911), 135 S. IV. 278; Jett v. Standafer (1911), 143 Ky. $78 \tau, 137$ \$. W. 513; Elk Valley Coal Co. v. Third Nat. Bk. of Lexington (1914), $163 \mathrm{~S}$. W. 766; Sparr v. Fulton Bank (1918), $201 \mathrm{~S}$. W. 310 .

Massachusetts.-Burnes v. New Mineral Fertil. Co. (1914), $105 \mathrm{~N}$. E. 1074 .

Michigan-Graliam v. Smith (1908), 155 Mich. 65, 118 N. W. 726.

Missouri.— Nat. Bk. of Commerce in St. Jouis v. Morris (1911), 156 Mo. App. 43, 135 S. W. 1008; State Bk. of Freeport v. Cape Girardean \& C. R. Co. (1913), 155 S. W. 1111; Central Bank of Columbia v. Lyda (1917). 191 S. W. 245.

North Carolina.-Brooks v. Sulli- van (1901), 129 N. Car. 190, 39 S. E. 822; Citizens \& Marine Bk. of Newport News v. Southern R. W. (1910), 153 N. Car. 346; J. L. Smathers \& Co. v. Toxaway Hotel Co. (1913), 78 S. E. 224.

North Dakota.-Shuman v. Citizen's State Bk. of Rugby (1914), 147 N. W. 388.

Oregon.-Bailey v. Inland Empire Co. (1915), 146 Pae. 991.

Tennessee.-First Nat. Bk. of Elgin, Ill. v. Russell (1911), 139 S. W. 734.

Utah.- Felt v. Bush (1912), 126 Pae. 688.

Virginia.-Payne v. Zell (1900), 98 Va. 294,36 S. F. 379.

Washington.- Bk. of Montreal $\mathbf{v}$. Howard (1906), 44 Wash. 10, 86 Pac. 1115; Hillman v. Stanley (1909), 56 Wash. 320, 105 Pac. 816; German-Am. Bank of Seattle v. Wright (1915), 148 Pae. 769; Crewdson v. Shultz (1919), 254 Fed. 24.

Wyoming.-George v. Emery (1909), 18 Wyo. 352, 107 Pac. 1.

United States.-Trust Co. of St. Louis Co. v. Markee (1910), 179 Fed. 764 .

Section 28. Absence or failure of consideration is matter of defense as against any person not a holder in due course; and partial failure of consideration is a defense pro tanto, whether the failure is an ascertained and liquidated amount or otherwise.

Alabama.-United Brothers of Friendship \& Sisters of Mysterious Ten v. C. S. Huffman Auditing Co. (1918), 78 So. 864 ; Conwell v. Kice (1919), 80 So. 406 .

Arizona. - Hurley v. Wilky (1916), 156 Pac. 83.

Arkansas.-Williamson v. Miles
(1914), 169 S. W. 368; Ozark Diamond Mines Co. v. Townes (1915), 174 S. W. 515; - Haglin v. Friedman (1915), 177 S. W. 429; Hamburg v. Ahrens (1915), 177 S. W. 14; Dodd v. Axle Nut Sigh Co. (1916), 189 S. W. 663.

Connecticut.-St. Paul's Episco- 
pal Church v. Fields (1909), 81 Conn. 670, 72 Atl. 145; Tice v. Moore (1909), 82 Conn. 244, 73 Atl. 133.

Delaware.- Security Tr. \& Safe Dep. Co. v. Duross (1913), 86 Atl. 209.

Florida.- Roess Lumber Co. v. State Exchange Bk. (1915), 67 So. 188; Odlin v. Stuckey (1919), 80 So. 291.

Idaho.- Daniels v. Englehart (1910), 18 Ida. 548, 111 Pac. 3.

Illinois.-Peacock v. Phillips (1910), 155 Ill. App. 514; Bechtel v. Marshall (1918), 119 N. E. 619.

Kansas.- Lynds v. Van Valkenburgh (1908), 77 Kans. 24, 93 Pac. 615; MeMillan v. Gardner (1912), 88 Kans. 279.

Kentucky.-Johnson v. MeMillan (1918), 199 S. W. 1070; Sparr v. Fulton Nat. Bk. (1918), 301 S. W. 310.

Louisiana.-Dicks v. Johnson (1913), 63 So. 700; Franz v. Schiro (1915), 67 So. 925.

Maryland.-Burke v. Smith (1909), 111 Md. 624, 75 Atl. 114; Shaffer v. Bond (1917), 99 Atl. 972; Herrman v. Combs (1912), 85 Atl. 1044; Morgan v. Cleaver (1917), 101 Atl. 610, 130 Md. 617.

Massachusetts. - Iombard v. Bryne (1907), 194 Mass. 236, $80 \mathrm{~N}$. E. 489; Centennial Electric Co. v. Morse (1917), 116 N. E. 901.

Michigan.-Green v. Ostrander (1910), 125 N. W. 735; East Side Tr. \& Sav. Bk. v. McGinnis (1917), 163 N. W. 949.

Mississippi.-Moore Dry Goods Co. v. Ainsworth (1916), 70 So. 885.

Missouri. - Jobes v. Wilson (1910), 124 S. W. 548; Nat. Bk. of
Commerce in St. Louis v. Morris (1911), 156 Mo. App. 43, 135 S. W. 1008; Rhodes v. Guhman (1911), 156 Mo. App. 344; Link v. Jackson (1911), 158 Mo. App. 63, 139 S. W. 583; Newburg St. Bk. v. Heflin (1915), 175 S. W. 297; Citizens Nat. Bk. v. Bombauer (1916), 189 S. W. 651; Hadley v. Greenville (1916), 187 S. W. 597; Glasse v. King (1917), 195 S. W. 521.

Nebraska.-Douglas v. Burton (1915), 154 N. W. 718.

New Jersey.-McCormack v. Williams (1915), 95 Atl. 978; Bank of Roselle v. Dorvall (1916), 98 Atl. 476.

New York.-Batterman v. Buteher (1904), 95 A. D. 213,88 N. X. Supp. 685; Rogers v. Morton (1905), 46 Mise. 494, 95 N. Y. Supp. 49; Rice v. Eisler (1907), 119 A. D. 132; Joveshoff v. Rockney (1908), 109 N. Y. Supp. 818, 58 Mise. 559; Valley Dew Distilling Co. v. Ritzmann (1908). 110 N. Y. Supp. 917; Wallabout Bk. v. Peyton (1908), 123 A. D. 727, 108 N. X. Supp. 42; Ferguson v. Netter (1910), 141 A. D. 274 ; Ginsberg v. Shurman (1911), 128 N. Y. Supp. 653; Newgass v. Shulhof (1911), 128 N. Y. Supp. 664; Ryan v. Sullivan (1911), 143 A. D. 471; Mechan. \& Metals Nat. Bk. v. Termini (1915), 156 N. Y. Supp. 433; Steinberger v. Hittel$\operatorname{man}$ (1915), 156 N. Y. Supp. 320; Miller v. Campbell (1916), $160 \mathrm{~N}$. Y. Supp. 834; Holbert v. Weber (1917), 161 N. W. 560; Malone v. Hirsh (1917), 167 N. Y. Supp. 723; In re Wiles (191S), 168 N. Y. Supp. 340; National City Bk. v. Mason (1917), 165 N. W. 103.

North Carolina.-Hardy v. Mitchell (1911), 156 N. Car. 76, 72 S. 
E. 95, 161 N. Car. 351 (1913); Piner v. Brittain (1914), 81 S. E. 462.

North Dakota.-Walters v. Rock (1908), 18 N. Dak. 45, 115 N. W. 511; First State Bank of Eckman v. Kelly (1915), 152 N. W. 125.

Ohio.- Ginn v. Dolan (1909), 81 Ohio St. 121, 90 N. E. 141.

Oklahoma.- Campbell v. Newton \& Driskoll (1915), 152 Pac. 841; Zebold v. Hurst (1917), 166 Pac. 99; Hannon v. Fink (1917), 167 Pac. 1152; Bank of Commerce of Sulphur v. Webster (1918), 172 Pac. 943.

Pennsylvania.- Marr's Nat. Bk. v. Hughes (1917), 100 Atl. 542.

Utah.- Smith v. Brown (1917), 165 Pac. 468.

Vermont.- Parry \& Jones v. Empire Granite \& Quarry Co. (1916), 97 Atl. 985.

Washington.-Press v. Vollintine
(1909), 53 Wash. 137, 101 Pac. 706; Reardon v. Cockrell (1909), 54 Wash. 400, 103 Pac. 457; Citizens Bk. \& Tr. Co. v. Limpright (1916), 160 Pac. 1046; Hamilton v. Mihills (1916), 159 Pac. 887; Hamilton v. Ramager (1916), 155 Pac. 151; City Nat. Bk. v. Shelton Elec. Co. (1917), 164 Pac. 993; Hoffman v. M. Gottstein Inv. Co. (1918), 172 Pac. 573.

West Virginia.-Interstate Finance Co. v. Schroder (1914), 81 S. E. 552 .

Wisconsin.--Marling v. Fitzgerald (1909), 138 Wis. 93.

United States.- Mowles v. Lorrimer (1914), 212 Fed. 155 (C. C. A., 3d Ct.); Taylor v. First Nat. Bk. of Aurora (1914), 212 Fed. 898 (C. C. A., 6th Ct.) ; Yates Center Nat. Bk. v. Schaede (1917), 240 Fed. 240; Cutler v. Fry (1917), 240 Fed. 238.

Section 29. An accommodation party is one who has signed the instrument as maker, drawer, acceptor, or indorser, without receiving value therefor, and for the purpose of lending his name to some other person. Such a person is liable on the instrument to a holder for value, notwithstanding such holder at the time of taking the instrument knew him to be only an accommodation party.

Alabama.- Tatum v. Commercial Bank \& 'Trust Co. (1914), 64 So. 561.

Arizona.- Cowan v. Ramsay (1914), 140 Pac. 501.

Arkansas.-Fisher v. Rice Grower's Bank (1916), 184 S. W. 36.

California.-Backer v. Grunnett (1919), 178 Pac. 312.

Connecticut.- Mersick v. Alderman (1905), 77 Conn. 634, 60 Atl. 109; Knapp Co. v. Tidewater Coal
Co. (1912), 85 Conn. 147, 81 Atl. 1063.

Delaware.- Security Tr. \& Safe Dep. Co. v. Daross (1913), 86 Atl. 209.

Florida.-Bass v. Geiger (1916), 73 So. 796.

Illinois.-Graves v. Neeves (1913), 183 Ill. App. 235; Biossat v. Louis (1913), 184 Ill. App. 436; Burr v. Beckler (1914), 106 N. E. 206, 264 III. 230 .

Iowa.-Banker's Iowa Śtate Bk. 
v. Mason Hand Leather Co. (1902), 90 N. W. 612; Farmers Loan \& Tr. Co. v. Brown (1917), 165 N. W. 70.

Kansas.- Lill v. Gleason (1914), 142 Pac. 287; German-American State Bank v. Watson (1917), 163 Pac. 637, 99 Kans. 686; First Nat. Bk. v. Stroup (1919), 177 Pac. 836.

Kentucky.- Owensboro Sav. Bk. \& Tr. Co.'s Receiver v. Haynes (1911), 136 S. W. 1004.

Louisiana.- N. \& C. Newman, Limited v. Pellerin (1910), 125 La. 67, 51 So. 70; Commercial Nat. Bk. v. Sanders (1916), 71 So. 891; First State Bank v. Davis (1916), 72 So. 185 ; Schaffter v. Irwin (1916), 71 So. 241.

Maine.-Kerr v. Dyer (1917), 102 Atl. 178.

Maryland.-Weant v. Southern Tr. \& Dep. Co. (1910), 112 Md. 463, 77 Atl. 289; Jamesson v. Citizen's Nat. Bk. (1917), 99 Atl. 994, 130 Md. 75; Bergen v. Tremble (1917), 101 Atl. 137.

Massachusetts.-Rowe v. Bowman (1903), 183 Mass. 488, $67 \mathrm{~N}$. E. 636; East Bridgewater Sav. Bk. v. Bates (1906), 191 Mass. 110; Lowell v. Bickford (1909), 201 Mass. 543, 88 N. E. 1; Nesson v. Miller (1910), 205 Mass. 515; Neal v. Scherber (1911), 207 Mass. 323, 39 N. E. 628 ; Union Tr. Co. v. McGinty (1912), 212 Mass. 205, $9 \mathrm{~S}$ N. E. 679 ; Neal v. Wilson (1913), 213 Mass. 336, 100 N. E. 544; Conners v. Sullivan (1915), 108 N. E. 503; Miller v. Levitt (1917), 115 N. E. 431.

Michigan. - Ensign v. Dunn (1914), 148 N. W. 343; East Side Tr. \& Sav. Bk. v. MeGinnis (1917), 163 N. W. 949.
Minnesota.-Bank of Montreal $\nabla$. Bucher (1916), 157 N. W. 1070.

Missouri.-First Nat. Bk. of Jefferson City v. Asel (1910), 154 Mo. App. 228; Lehnhard v. Sedway (1911), 160 Mo. App. 83, 141 S. W. 430; Citizen's Bk. of Senath v. Douglass (1913), 161 S. WV. 601; Golden City Banking Co. v. Morrow (1914), 179 S. W. 448; Cox v. Hagy (1916), 184 S. W. 495; Eaves v. Keeton (1917), 193 S. W. 629; Bk; of Dexter v. Simmons (1918), 204 S. WV. 837; Kage v. Oates (1919), 208 S. W. 126; Bank of Melyville v. Lee (1919), $208 \mathrm{~S}$. W. 143.

Montana.-First Nat. Bank of Hilger v. Lang (1918), 174 Pac. 597.

Nebraska.-Citizens Bk. v. Frederickson (1909), 83 Neb. 755; State Bank of Omaha v. Huffman (1916), 160 N. W. 115.

New Jersey.-Gerli v. Nat. Mill Supply Co. (1909), 78 N. J. I. 1, 73 Atl. 252; Morris Co. Brick Co. v. Austin (1910), 75 Atl. 550; Clark v. Barthold (1915), 93 Atl. 699.

New York.-Pryor v. Storke (1899), 37 A. D. 364 ; Citizens Nat. Bk. v. Lilienthal (1899), 40 A. D. 609 ; Howard v. Van Gieson (1900), 56 A. D. 217; Fleitman v. Ashley (1901), 60 A. D. 201; Strickland v. Henry (1901), 66 A. D. 23, 73 N. Y. Supp. 121; Nat. Citizens Bk. v. Toplitz (1903), 81 A. D. 593, 81 N. Y. Supp. 422; Roseman v. Maholley (1903), 86 A. D. 377,83 N. Y. Supp. 749; Packard v. Windholz (1903), 40 Mise. 347, affirmed 88 A. D. 365 (1902); Simpson v. Hefter (1904), 42 Misc. 482, 87 N. Y. Supp. 243; Batterman v. Butcher (1904), 95 A. D. 213, 88 N. Y. Supp. 685; Oppenheim v. Reigal Cigar Co. (1904), 90 N. Y. 355; 
Met. Pr. Co. v. Springer (1904), 90 N. Y. Supp. 376; Hover v. Magley (1905), 48 Mise. 430, 96 N. Y. Supp. 925; Westheimer v. Helmbold (1905), 109 A. D. 854; Schlesinger v. Kelly $(1906), 114$ A. D. 546, 99 N. Y. Supp. 1083 ; Nat. Bk. of Newport v. Snyder Mfg. Co. (1907), 117 A. D. 370, 102 N. Y. Supp. 478; Smith v. State Bank (1907), 54 Misc. 550, 104 N. Y. Supp. 750; English v. Schlesinger (1907), 55 Misc. 584, 105 N. Y. Supp. 989; The Gansevort Bk. of N. Y. v. Gilday (1907), 110 N. Y. Supp. 271, 53 Misc. 107; Haddock, Blanchard \& Co. v. Haddock (1908), 192 N. Y. Supp. 499,82 N. E. 682,103 N. Y. Supp. 584; Witteman v. Glass (1909), 117 N. Y. Supp. 940; Uvalde Asphalt Paving (o. v. Nat. Trading Co. (1909), 135 A. D. 391, 120 N. Y. Supp. 11; Easton Furniture Mfg. Co. v. Caminez (1911), 131 N. Y. Supp. 157; Blanchard v. Blanchard (1911), 201 N. Y. 134, 94 N. E. 630 , 133 A. D. 937 , affirming s. c., 133 A. D. 937 (1909), without opinion; Easton Mfg. Co. v. Caminez (1911), 146 A. D. 436; Martin L. Hall v. Todd (1912), 139 N. Y. Supp. 111; Building \& Engineering Co. v. Northern Bk. of N. Y. (1912), 206 N. Y. 400; Spencer \& Co. v. Brown (1913), 143 N. Y. Supp. 994; Neponset Nat. Bk. v. Dunbar (1913), 143 N. Y. Supp. 174, 158 A. D. 5; Cleary v. Dykeman (1914), $146 \mathrm{~N}$. Y. Supp. 611; Abbott v. LeProvost (1915), 151 N. Y. Supp. 616; Grannis v. Stevens (1916), 111 N. E. 263, 216 N. Y. Supp. 583; Brayer v. Edel (1917), 163 N. Y. Supp. 989; Kennedy v. Heyman (1918), 170 N. Y. Supp. 828.

New Mexico.-First Sav. Bk. \&
Tr. Co. v. Flowinoy (1918), 171 Pac. 793.

North Carolina.-Brown Carriage Co. v. Dowd (1911), 71 S. E. 721.

North Dakota.-First St. Bk. of Eckman v. Kelly (1915), 152 N. W. 125 ; First Nat. Bk. of MeClukly v. Meyer (1915), 152 N. W. 567.

Ohio.-Richards v. Market Ex. Bk. (1910), 81 Ohio St. 348, 55 Ohio Law Bull. 20.

Oklahoma.-Bank of Carrollton, Miss. v. Latting (1913), 130 Pac. 144 ; Fue v. Peoples Bank \& Trust Co. (1916), 156 Pac. 683; Oklahoma Bank v. Seaton (1918), 170 Pac. 477.

Oregon.-White v. Savage (1906), 48 Oreg. 604, 87 Pac. 1040; Cellers v. Meachem (1907). 49 Oreg. 186, 104 L. R. A. (N. S.) 133; Lumbermen's Nat. Bk. of Portland v. Campbell (1912), 61 Oreg. 123, 121 Pac. 427; Hunter v. Harris (1912), 63 Oreg. 505, 127 Pac. 786; Noble v. Beeman-Spaulding - Woodwar Co. (1913), 131 Pac. 1006; Farmers' State Bk. of North Powder v. Forsstroni (1918), 173 Pac. 935.

Pennsylvania.-Chambers v. MeLean (1903), 24 Pa. Super. Ct. 567; Diffenbacher's Estate (1906), $31 \mathrm{~Pa}$. Super. Ct. 35; Federal Nat. Bk. v. Cross Creek Co. (1908), 220 Pa. St. 39, 68 Atl. 1018; Ott v. Seward (1908), $221 \mathrm{~Pa}$. 630; Wolfgang v. Shirley (1913), 86 Atl. 1011; Manlini v. Serrano (1914), 28 Phil. Rep. 640; Ross v. Eyre (1918), 103 Atl. 894 ; Edward E. Buhler Co. v. Childester (1919), 105 AtI. 52.

Rhode Island.- Wilbour v. Hawkins (1915), 94 Atl. 856; Lee v. Benjamin (1918), 102 AtI. 713.

Tennessee.-Farmers \& Merchants Bk. v. Bk. of Rutherford (1905), 
115 Tenn. 64, 88 S. W. 939; Nolan v. H. E. Wilcox Motor Co. (1917), 195 S. W. 581; Noelan v. Wilcox Motor Co. (1917), 195 S. W. 581.

Texas.- Houston Trans. Co. v. Paine (1917), 193 S. W. 188.

Utah.- Wostenholme v. Smith (1908), 34 Utah, 300, 97 Pac. 329.

Washington.-Bradley Engineering \& Mfg. Co. v. Heyburn (1910), 56 Wash. 628, 106 Pac. 170; Gleeson v. Lichty (1911), 62 Wash. 656, 114 Pac. 518; Handsaker v. Pederson (1912), 71 Wash. 218; Metzger v. Sigall (1914), 145 Pac. 72; Northern Bank \& Trust Co. v. Graves (1914), 140 Pac. 328; Pease v. Syler (1914), 138 Pac. 310; Skagit State Bk. v. Moody (1916), 150 Pac. 425.

West Virginia.-First Nat. Bk. of Hinton v. Plumley (1915), 87 S. E. 94.

Wisconsin.- Bk. of Monticello v. Dooly (1902), 113 Wis. 590; Pelton v. Spider Lake S. \& L. Co. (1903),
117 Wis. 569; Weleh v. Kukuk (1906), 128 Wis. 419, $107 \mathrm{~N}$. W. 301 ; Marling v. Jones (1909), 138 Wis. 82, 119 N. W. 931; German Nat. Bk. v. Barber (1914), 149 N. W. 767; Comstock v. Buckley (1910), 141 Wis. 227, $124 \mathrm{~N}$. W. 414 ; Schoenwetter v. Schoenwetter (1916), 159 N. W. 737.

United States.- Willard v. Crook (1903), 21 App. D. C. 237; Reyburn v. Queen City Sav. Bk. \& Tr. Co. (1909), 171 Fed. 609, 96 C. C. A. 373; In re McCord (1909), 174 Fed. 72 ; Trust Co. of St. Louis Co. v. Markee (1910), 179 Fed. 764 (Pa.); Bluthenthal \& Bickart v. Carson (1911), 37 A. C. (D. C.) 118; I.a Normandie Hotel Co. v. Security Tr. Co. (1912), 38 A. C. (D. C.) 187; Howell v. Commercial Nat. Bk. (1913), 40 A. C. (D. C.) 370; Wilson v. Knowles (1914), 213 Fed. 782 (C. C. A., 2d Ct.) ; Leonard v. State Fxch. Bk. of Elk City (1916), 236 Fed. 316.

\section{AR'TICLE III.}

\section{NEGOTIATION.}

Section 30. An instrument is negotiated when it is transferred from one person to another in such a manner as to constitute the transferee the holder thereof. If payable to bearer it is negotiated by delivery; if payable to order it is negotiated by the indorsement of the holder completed by delivery.

Alabama.- Stone v. Goldberg \& Lewis (1912), 6 Ala. App. 249, 60 So. 744 ; Ger-Am. Nat. Bk. v. Lewis (1913), 9 Ala. App. 352; Goldberg \& Lewis v. Stone (1914), 65 So. 454; Davis v. First Nat. Bk. of
Blakely (1915), 68 So. 261; Sherrill v. Merch. \& Mech. Tr. \& Sav. Bk. (1916), 70 So. 723; Jones v. Bell (1917), 77 So. 918.

Arkansas.- Tancred v. First Nat. Bk. (1916), 187 S. W. 160. 
Florida.- Camp Lumber Co. v. State, Sav. Bk. (1910), 59 Fla. 455, 51 S. E. 543; Williams v. Peninsul? Grocery Co. (1917), 75 So. 517.

Illinois.- First Nat. Bk. of Chadwick v. Mackey (1910), 157 Ill. App. 408; Burr v. Beckler (1914), 106 N. E. 206, 264 Ill. 230; Trego v. Cunningham Est. (1915), $108 \mathrm{~N}$. E. 350,267 Ill. 367.

Iowa.- Irwin v. Deming (1909), 142 Iowa, 299, 120 N. W. 645; Roy v. Duff (1915), 152 N. W. 606; Young v. Hayes (1917), 165 N. W. 391.

Kentucky. - Foster's Admr. v. Metcalf (1911), 138 S. W. 314.

Massachusetts. - Johnson-Kettell Co. v. Longley Luncheon Co. (1910), 207 Mass. 52.

Missouri.- Sublette v. Brewington (1909), 139 Mo. App. 410, 122 S. W. 1150 ; Scotland Co. Nat. Bk. v. Hohn (1910), 146 Mo. App. 699, 125 S. W. 539; Cantrell v. Davidson (1914), 168 S. WV. 271; Chandler v. Hedrick (1915), $173 \mathrm{~s} . \mathrm{IV}$. 93; Miners \& Merch. Bank v. St. Louis Smelting \& Refining Co. (1915), 17s S. W. 211; Am. Union Tr. Co. v. Never Break Range Co. (1917), 190 S. W. 1045; Davis v. MeColl (1916), 184 S. W. 920.

Montana.-Case Medicine Co. $\mathbf{}$. Simpson (1918), 170 Pac. 12.

Nebraska.- Nat. Bk, of Commerce v. Farmers \& Merchants Bk. (1910), 87 Neb. 841; Aurora State Bk. v. Hayes-Eames Elevator Co. (1911), 88 Neb. 187.

New Mexico.-Hill v. Hart (1917), 167 Pac. 710.

New York.- Schlesinger v. Kurzvok (1905), 94 N. Y. Supp. 442, 47 Misc. 634 ; Rogers v. Morton (1905),
46 Misc. 494, 95 N. Y. Supp. 49; Seaboard Nat. Bk. v. Bk. of America (1908), 193 N. Y. 26, 85 N. E. 829; Manufacturer's Commercial Co. v. Blitz (1909), 131 A. D. 17, 115 N. Y. Supp. 402; Snith v. Dixon (1912), 150 A. D. 571; Barkley v. Muller (1914), 149 N. Y. Supp. 620, 164 A. D. 351; Sabine v. Paine (1915), 151 N. Y. Supp. 735 ; Wolfin v. Security Bk. of N. Y. (1915), 156 N. Y. Supp. 474; Dalrymple v. Schwartz (1917), 164 N. Y. Supp. 496.

North Carolina.-Steinhilper v. Basinght (1910), 153 N. Car. 293, 69 S. E. 222; Meyers v. Petty (1910), 153 N. Car. 462; Woods v. Finley (1910), 153 N. Car. 49\%, 69 S. E. 502; Elgin City Banking Co. v. McEacheon (1913), 79 S. E. 680.

North Dakota.-Nat. Bk. of Commerce r. Pick (1904), 13 N. Dak. 74,99 N. W. 63; Viets v. Silver (1905), 15 N. Dak. 51, 106 N. W. 35.

Ohio.-Thompson v. Citizens Nat. Bk. of Adams, N. Y. (1909), $32 \mathrm{U}$. C. 131 .

Pennsylvania.-Flanders v. Snare (1908), 37 Pa. Super. Ct. 28; Dominion Trust Co. v. Hildner (1914), 90 Atl. 69; Lincoln Nat. Bk. of Pittsburg v. Miller (1917), 100 Atl. 269, 255 Pac. 467; Johnston v. Knipe (1918), 103 Atl. 957.

South Dakota.- Piper v. Hagen (1914), 146 N. W. 692.

Wyoming.-Capitol Hill St. Bk. v. Rawlins Nat. Bk. (1916), 160 Pac. 1171.

United States.- McKee v. District Nat. Bk. (1912), 38 A. C. (D. C.) 465 . 
Section 31. The indorsement must be written on the instrument itself or upon a paper attached thereto. The signature of the indorser, without additional words, is a sufficient indorsement.

Alabama.-Clark v. Thompson curity Co. v. Main St. Pharmacy (1915), 69 So. 925 .

Colorado.- Marks v. Munson (1915), 149 Pac. 440.

Ransas.-Offenstein v. Weygandt (1913), 89 Kans. 739, 132 Pac. 991; Farmsworth v. Burdick (1915), 147 Pac. 863.

Massachusetts. - Mayberry . Sprague (1908), 199 Mass. 301.

Missouri.- Am. Union Tr. Co. v. Never Break Range Co. (1916), 190 S. W. 1045.

New York.-Manufacturer's Commercial Co. v. Blitz (1909), 131 A. D. 17, 115 N. Y. Supp. 402; People v. Fowler (1914), 152 N. Y. Supp. 672 .

North Carolina.-Comercial Se(1917), 94 s. E. 208.

Ohio.-Thompson v. Citizens Nat. Bk. of Adams, N. Y. (1909), 320. C. 131.

Oklahoma.- Howard v. Kincaid (1916), 156 Pac. 628; Mangold \& Glandt Bank v. Utterback (1916), 160 Pac. 713; Met. Discount Co. v. Davis (1918), 170 Pac. 707.

Oregon.-First Nat. Bk. of Pomeroy v. McCullough (1908), 50 Oreg. 508, 93 Pac. 366.

Pennsylvania.-Flanders v. Snare (1908), 37 Pa. Super. Ct. 28.

Virginia. - Colona v. Parksley Nat. Bk. (1917), 92 S. E. 979.

United States.-Wolf v. Am. Tr. \& Sav. Bk. (1914), 214 Fed. 761 (C. C. A., 7th Ct.).

Section 32. The indorsement must be an indorsement of the entire instrument. An indorsement which purports to transfer to the indorsee a part only of the amount payable, or which purports to transfer the instrument to two or more indorsees severally, does not operate as a negotiation of the instrument. But where the instrument has been paid in part, it may be indorsed as to the residue.

Kansas.-Offenstein v. Waygandt (1913), 89 Kans. 739, 132 Pac. 991.

Tennessee.-Ahrens \& Ott Co. v.

New York.-Barkley v. Muller Moore \& Sons (1915), 174 S. W. 270.

(1914), 149 N. Y. Supp. 620, 164

A. D. 351 .

Section 33. An indorsement may be either special or in blank; and it may also be either restrictive or qualified, or conditional.

Kentucky.-Goolrick v. Wallace (1913), 157 S. IV. 920.

Missouri.- Miller v. People's Sav. Bk. (1916), 186 S. W. 547.
New York.-Standard Steam Spec. Co. v. Corn Exch. Bk. (1917), 116 N. E. 386,220 N. Y. 478 . 
Section 34. A special indorsement specifies the person to whom, or to whose order, the instrument is to be payable ; and the indorsement of such indorsee is necessary to the further negotiation of the instrument. An indorsement in blank specifies no indorsee, and an instrument so indorsed is payable to bearer, and may be negotiated by delivery.

Colorado.- Wedge Mines Co. v. Denver Nat. Bk. (1903), 19 Colo. App. 182, 73 Pac. 873.

Missouri.- Simpson v. Van Laningham (1916), 183 S. W. 324; Priest v. Garnet (1917), 191 S. W. 1048.

New Jersey.- Mackintosh $\nabla$. Gibbs (1909), 79 N. J. L. 40, 74 Atl. 708.

New York.- Seabòard Nat. Bk. v. Bk. of America (1908), 193 N. Y. 26, 85 N. E. 829 ; Standard Steam Spec. Co. v. Corn Exch. Bk. (1917), 116 N. E. 386,220 N. Y. 478.

Oregon.- State v. Hinton (1910), 56 Oreg. 428, 109 Pac. 24.
Pennsylvania.- Jincoln Nat. Bk. of Pittsburg v. Miller (1917), 100 Atl. 269, 255 Pac. 467.

Tennessee.- Flgin City Bldg. Co. v. Hall (1907), 119 Tenn. 548, 108 S. W. 1068; First Nat. Bk. of Garner v. Smith (1916), $183 \mathrm{~S}$. W. 862 ; Kanaman v. Gahagan (1916), 185 S. W. 619.

Vermont.- Hale v. Windsor Sav. Bk. (1917), 93 Atl. 993.

United States.-Jerman v. Edwards (1907), 29 A. C. (D. C.) 535; Howell v. Commercial Nat. Bk. (1913), 40 A. C. (D. C.) 370 .

Section 35. The holder may convert a blank indorsement into a special indorsement by writing over the signature of the indorser in blank any contract consistent with the character of the indorsement.

Alabama.-Bank of Tallassee $\mathbf{v}$. Jordan (1917), 75 So. 930.

California.-Santa Márina Co. v. Cadanian Bk. of Commerce (1919), 254 Fed. 391; In re Jarmulowsky (1918), 249 Fed. 319.
Oklahoma.-Keisel v. Baldock (1915), 154 Pac. 1194.

United States.-Jerman $\nabla$. Edwards (1907), 29 A. C. (D. C.) 535.

Section 36. An indorsement is restrictive, which either:

(1) Prohibits the further negotiation of the instrument; or

(2) Constitutes the indorsee the agent of the indorser; or

(3) Vests the title in the indorsee in trust for or to the use of some other person.

But the mere absence of words implying power to negotiate does not make an indorsement restrictive. 
Alabama.- Haas v. Commerce Trust Co. (1915), 69 So. 894.

Arkansas. - Werner Piano Co. v. Henderson \& Reese (1915), $180 \mathrm{~S}$. W. 495 .

Connecticut.- Lippitt v. Thames Loan \& Trust Co. (1914), 90 A. 369.

Missouri-Citizens Trust Co. v. Ward (1916), 190 S. W. 364.

Nebraska.- Antelope Co. Bk. v. Wright (1912), 90 Neb. 621, 134
N. W. 1123; Nat. Bk. of Commerce v. Bossemeyer (1917), $162 \mathrm{~N} . \mathrm{W}$. 503.

New York.- Standard Steam Spec. Co. v. Corn Exch. Bk. (1917), 116 S. E. 386,220 N. Y. 478.

North Carolina,- Murchison Nat. Bk. v. Dunn Oil Mills Co. (1909), 150 N. Car. 718, 64 S. E. 885.

North Dakota.-Smith v. Show (1907), 16 N. Dak. 306, 112 N. W. 1062.

Section 37. A restrictive indorsement confers upon the indorsee the right:

(1) To receive payment of the instrument;

(2) To bring any action thereon that the indorser could bring;

(3) To transfer his rights as such indorsee, where the form of the indorsement authorizes him to do so.

But all subsequent indorsees acquire only the title of the first indorsee under the restrictive indorsement.

Nebraska.- Antelope Co. Bk. v. Wright (1912), 90 Neb. 621, 134 N. W. 1123.

New York.-Baruch v. Buckley (1915), 151 N. Y. Supp. 853.

North Carolina.- Murchison Nat. Bk. v. Dunn Oil Mills Co. (1909), 150 N. Car. 718, 64 S. E. 885.

Oregon.-Smith v. Bayer (1905),
58 Oreg. 578, 79 Pac. 497, 114 Am. St. 858 .

Washington.- Metzger v. Sigall (1914), 145 Pac. 72.

United States.- Jerman v. Edwards (1907), 29 A. C. (D. C.) 535; McKee v. District Nat. Bk. (1912), 38 A. C. (D. C.) 465 .

Section 38. A qualified indorsement constitutes the indorser a mere assignor of the title to the instrument. It may be made by adding to the indorser's signature the words "without recourse" or any words of similar import. Such an indorsement does not impair the negotiable character of the instrument.

Alabama.- People's Bank of Mobile v. Moore (1918), 78 So. 789.

Arkansas.- Morehead v. Harris (1916), 182 S. W. 521.

California. - Hammond Lumber
Co. $\nabla$. Kearsley (1918), 172 Pac. 404.

Indiana.- Colvert v. Harrington (1916), 112 N. F. 249. 
Iowa.- Higby v. Bahrenfuss (1917), 163 N. W. 247.

Kentucky.-Goolrick v. Wallace (1913), 157 S. W. 920.

Louisiana.- Puckett v. Fox Grocer Co. (1910), 127 La. 151, 53 'So. 475.

Massachusetts.-Aronson v. $\mathrm{Nu}$ renburg (1914), 105 N. E. 1056.

Michigan.-Gale v. Mayhew (1910), 161 Mich. 96, 125 N. W. 781; Schmidt v. Pegg (1912), 172 Mich, 159, 137 N. W. 524.

Minnesota.-Slimmer v. St. Bk. of Halstad (1916), 159 N. W. 795.

North Carolina.- Evans v. Freeman (1906), $142 \mathrm{~N}$. Car. 61, $54 \mathrm{~S}$. E. 847; Bk. of Sampson v. Hatcher (1909), 151 N. Car. 359, 63 S. E. 308; Merchants Nat. Bk. of Indian- apolis v. Branson (1914), 81 S. E. 410.

Oklahoma.-Copeland v. Burke (1916), 158 Pac. 1162; Howard v. Kincaid (1916), 156 Pac. 628.

Oregon.-Paye v. Ford (1913), 131 Pac. 1013.

Tennessee.- Elgin City Bldg. Co. v. Hall (1907), 119 Tenn. 548, 108 S. IV. 1068.

Utah.- Leavitt v. Thurston (1911), 3s Utah, 351, 113 Pac. 77.

West Virginia.-Dollar Sav. \& Tr. Co. v. Crawford (1911), $70 \mathrm{~S}$. E. 1089 ; Marion Nat. Bk. v. Harden (1918), 97 S. E. 600.

Wisconsin.-Thorpe v. Mindeman (1904), $1^{\circ} 3$ Wis. $149,101 \mathrm{~N}$. W. 417, 107 Am. St. 1003, 68 L. R. A. 146.

Section 39. Where an indorsement is conditional, a party required to pay the instrument may disregard the condition, and make payment to the indorsee or his transferee, whether the, condition has been fulfilled or not. But any person to whom an instrument so indorsed is negotiated, will hold the same, or the proceeds thereof, subject to the rights of the person indorsing conditionally.

Alabama.-Bank of Tallassee $\mathbf{v}$. Jordan (1917), 75 So. 930.

Florida.- Williams v. Peninsula Grocery Co. (1917), 75 So. 517.

Missouri.-Gumby vi' Hayden (1914), 168 S. W. 899.

New Mexico.- First Nat. Bk. of Albuquerque v. Stover (1916), 155 Pac, 905.

New York.- Pinto v. Pulidora (1917), 162 N. Y. Supp. 736.
North Dakota.- Smith v. Bradley (1907), $16 \mathrm{~N}$. Dak. 306, $112 \mathrm{~N}$. W. 1062 .

South Dakota.- Holbart v. Lauritson (1914), 148 N. IV. 19.

Tennessee.-Cohn v. Lunn (1916), 182 S. W. 584.

Utah. - Farmers \& Stock Growers' Bank v. Palivant Valley Land Co. (1917), 165 Pac. 462.

Section 40. Where an instrument, payable to bearer, is indorsed specially, it may nevertheless be further negotiated by delivery; 
but the person indorsing specially is liable as indorser to only such bolders as make title through his indorsement. .

United States.- Mechanics - Am.

Nat. Bk. v. Coleman (1913), 204

Fed. 24.

Section 41. Where an instrument is payable to the order of two or more payees or indorsees who are not partners, all must indorse unless the one indorsing has authority to indorse for the others.

Iowa.- The Union Bk. of Bridgewater v. Spies (1911), 151 Iowa, 178.

Kansas.- Voris v. Schoonover (1914), 138 Pac. 607.

Michigan.-Kaufman v. State Sav. Bk. (1908), 151 Mich. 65, 114 N. W. 863,18 L. R. A. (N. S.) 630 , 120 Am. St. 259; Worden Grocer Co. v. Blanding (1910), 126 N. W. 212.

Missouri.-Market \& Fulton Nat.
Bk. v. Ettenson's Estate (1913), 158 S. W. 448.

New York.-First Nat. Bk. of the City of Brooklyn v. Gridley (1906), 112 A. D. 398,98 N. Y. Supp. 445; Martz v. State Nat. Bk. of N. Tonawanda (1911), 131 N. Y. Supp. 1045,147 A. D. 250.

Pennsylvania.- Neyens v. Port (1911), 46 Pa. Super. Ct. 428.

Rhode Island.-Oaksdale Mfg. Co. v. Clarke (1908), 29 R. I. 192, 69 Atl. 681.

Section 42. Where an instrument is drawn or indorsed to a person as "Cashier" or other fiscal officer of a bank or corporation, it is deemed prima facie to be payable to the bank or corporation of which he is such officer; and may be negotiated by either the indorsement of the bank or corporation, or the indorsement of the officer.

Inlinois.- McClenathan v. Davis (1909), 243 Ill. 87, 90 N. E. 265.

Iowa.-Griffin v. Erskine (1906), 131 Iowa, 444, 109 N. W. 13; Watts v. Savings Bank (1917), 165 N. W. 897.

Kentucky.- Eades v. Muhlenberg Co. Sav. Bk. (1914), 163 S. W. 494.

Missouri.-Gage v. Bank of Holcomb (1917), 196 S. W. 1077.
Oregon.- First Nat. Bk. of Pomeroy v. MeCullough (1908), 50 Oreg. 508, 93 Pac. 366.

Pennsylvania.- Neyens v. Port (1911), 46 Pa. Super. Ct. 428.

Washington.- Hanson v. Northern Bk. \& Tr. Co. (1917), 167 Pac. 97. 
Section 43. Where the name of a payee or indorsee is wrongly designated or misspelled, he may indorse the instrument as therein describcd, adding, if he think fit, his proper signature.

Arkansas.-Soekland v. Storch (1916), 185 S. W. 262.

Section 44. Where any person is under obligation to indorse in a representative capacity, he may indorse in such terms as to negative personal liability.

New York.- Chelsea Bk. v. First Un. Presby. Church (1915), $152 \mathrm{~N}$. Y. Supp. 201.

Section 45. Except where an indorsement bears date after the maturity of the instrument, every negotiation is deemed prima facie to have been effected before the instrument was overdue.

Alabama.- Bledsoe v. City Nat. Ohio.-Wehrman v. Beech (1906), Bk. of Selma (1912), 7 Ala. App. 195, 60 So. 942 .

New York.-German-Am. Bk. v. Cunningham (1904), 97 App. Div. 244, 89 N. Y. Supp. 836 ; Colborn v. Arbrean (1907), 54 Misc. 623, 104 N. Y. Supp. 968; Lanning v. Trust Co. of Am. (1910), 122 N. Y. Supp. 485. 28 O. C. 128.

Oklahoma.-Met. Dis. Co. v. Davis (1918), 170 Pac. 707.

Wyoming.- Holdsworth v. Blyth \& Fargo (1915), 146 Pac. 603.

United States.-Catholic University v. Waggaman (1909), 32 App. D. C. 307 .

Section 46. Except where the contrary appears, every indorsement is presumed prima facic to have been made at the place where the instrument is dated.

New York.-Chemical Nat. Bk. v. Kellogg (1905), 183 N. Y. 92, 75 N. E. 1103 .

Section 4\%. An instrument negotiable in its origin continues to be negotiable until it has been restrictively indorsed or discharged by payment or otherwise.

Connecticut.- Cent. Nat. Bk. v. Stoddard (1910), 83 Conn. 330, 76 Atl. 472; Lippitt v. Thames Loan \& Trust Co. (1914), 90 Atl. 369;
Church v. Sweetland (1917), 243 Fed. 289; Emerson v. Fisher (1917), 246 Fed. 642. 
Missouri.-Lane v. Hyder (1912), 163 Mo. App. 688, 147 S. W. 514.

New Jersey.-Gibbs v. Allen (1915), 94 Atl. 61.

New York.-McBee Co. v. Shoemaker (1916), 160 N. Y. Supp. 251; Crusins v. Siegman (1913), 142 N.
Y. Supp. 348; McMill v. Shellito (1919), 173 N. Y. Supp. 810.

Oklahoma.-Union Nat. Bank of Massillon, Ohio v. Mayfield (1918), 174 Pac. 1034.

Rhode Island.-Oaksdale Mfg. Co. v. Clarke (1908), 29 R. I. 192, 69 Atl. 681 .

Section 48. The holder may at any time strike out any indorsement which is not necessary to his title. The indorser whose indorsement is struck out, and all indorsers subsequent to him, are thereby relieved from liability on the instrument.

Connecticut.- New Haven Mfg. Co. v. New Haven Pulp Co. (1903), 76 Conn. 126, 55 Atl. 604.

Kansas.-King v. Bellamy (1910), 82 Kans. 310.

Michigan.-Ensign v. Fogg (1913), 143 N. W. 82.

Missouri. - EMiott v. Qualls (1910), 130 S. W. 474; Nance v. Hayward (1914), 170 S. W. 429;
Carter v. Butler (1915), 174 S. W. 399.

New Jersey.- Pohlemus v. Prudential Realty Co. (1907), 74 N. J. L. 570, 67 Atl. 303; Mackintosh v. Gibbs (1909), 79 N. J. L. 40, 74 Atl. 708.

United States.-Jerman v. Edwards (1907), 29 A. C. (D. C.) 535; Howell v. Commercial Nat. Bk. (1913), 40 A. C. (D. C.) 370.

Section 49. Where the holder of an instrument payable to his order transfers it for value without indorsing it, the transfer vests in the transferee such title as the transferor had therein, and the transferee acquires, in addition, the right to have the indorsement of the transferor. But for the purpose of determining whether the transferee is a holder in due course the negotiation takes effect as of the time when the indorsement is actually made.

Arkansas.-Williamson Bk. \& Tr. Co. v. Miles (1914), 169 S. W. 3 ôs.

California.-Shoenhair v. Jones (1917), 165 Pac. 971.

Colorado.-Lane v. Lane (1914), 140 Pac. 804.

Connecticut.-Goodsell v. The McElroy Bros. Co. (1912), $86^{\prime}$ Conn. 402.
Florida.- Barnes v. Carr (1913), 61 So. 184.

Iowa.- Roy จ. Duff (1915), 152 N. IV. 606.

Kansas.- Smith v. Nelson Land \& Cattle Co. (1914), 212 Fed. 56.

Kentucky.- Callegham v. Louisville Dry Goods Co. (1910), $14 \mathrm{Ky}$. 712, 131 S. W. 995; Foster's Admr. v. Metcalf (1911), 138 S. W. 314. 
Minnesota.-Kiefer v. Tolbert (1915), 151 N. W. 529.

Missouri.-Market \& Fulton Nat. Bk. v. Ettenson's Estate (1913), 158 S. W. 448; Townsend v. Alwel (1918), 202 S. W. 447

New York.-Manufacturer's Commercial Co. v. Blitz (1909), 131 A. D. 17,115 N. Y. Supp. 402; Meuer v. Phoenlx Nat. Bk. (1904), 94 A. D. 331,88 N. Y. Supp. 83 ; Brown v. James (1911), 130 N. Y. Supp. 333; Martz v. State Nat. Bk. of N. Tonawanda (1911), 131 N. Y. Supp. 1045, 147 A. D. 250.

North Carolina.-- Mayers v. McRimmon (1906), 140 N. Car. 640, 53 S. E. 447, 111 Am. St. 879; Keal v. Construction Co. (1906), 143 N. Car. 429, 55 S. E. 826 ; Johnson Co. Sav. Bk. v. Scoggin Drug Co. (1910), 67 S. E. 253; Steinhilper v. Basinght $(1910), 153$ N. Car. 293, 69 S. E. 222; Elgin City Banking Co. v. McEachon (1913), 79 S. E. 680.

Oregon.-First Nat. Bk. of Pomeroy v. McCullough (1908), 50 Oreg. 508, 93 Pac. 366; Baker v. Moran
(1913), 136 Pac. 30; Witt ₹. Campbell-Lakin Soap Co. (1913), 134 (1913), 134 Pac. 316.

Pennsylvania.-Nat. Bk. of Pittsburg v. Miller (1917), 100 Atl. 269.

South Dakota.- Piper v. Hagen (1914), 146 N. W. 692.

Tennessee.-Landis v. White Bros. (1913), 152 S. W. 1031; Allen v. Hayes (1918), 201 S. W. 135.

Utah.-Escamilla v. Pingree (1914), 141 Pac. 103.

Washington-O'Connor v. Slatter (1908), 48 Wash. 493, 93 Pac. 1078; First Nat. Life Assurance Soc. of Am. v. Farquhar (1913), 135 Pac. 619; Puget Sound State Bank v. Washington Paving Co. (1917), 162 Pac. 870.

Wisconsin.- Lawless v. State (1902), 114 Wis. 189,89 N. W. 891 ; Marling v. Fitzgerald (1909), 138 Wis. 93, 120 N. W. 388; Swanby v. Northern St. Bk. (1912), 150 Wis. 572,137 N. W. 763 .

Wyoming.-Capitol Hill St. Bk. v. Rawings Nat. Bk. (1916), 160 Pac. 1171.

Section 50. Where an instrument is negotiated back to a prior party, such party may, subject to the provisions of this act, reissue and further negotiate the same. But he is not entitled to enforce payment thereof against any intervening party to whom he was personally liable.

Alabama.-German-Am. Nat. Bk. v. Lewis (1913), 9 Ala. App. 352; Britnell v. Smith (1914), 66 So. 569 ; Owings Lumber Co. v. Marlowe (1917), 76 So. 926.

Lllinois.- Trego v. Cunningham's Fst. (1915), 108 N. E. 350, 267 Ill. 367.

Kansas.-Security State Bk. V. Clark (1916), 160 Pac. 1149.
Massachusetts.-Quimby v. Varmum' (1906), 190 Mass. 211, $76 \mathrm{~N}$. E. 671 .

Mississippi.-Adair v. Bank of Hickory Flat (1917), 75 So. 758; Miller v. Chinn (1917), 195 S. W. 552.

New York.-Steinberger v. Hittelman (1915), 156 N. Y. Supp. 320. 


\section{AR'TICLE IV.}

\section{RIGHTS OF THE HOLDER.}

Section 51. The holder of a negotiable instrument may sue thereon in his own name and payment to him in due course discharges the instrument.

Alabama.-Darden v. Holloway (1911), 1 Ala. App. 661, 56 So. 32; Coats v. Mut. Alliance Co. (1911), 174 Ala. 565, 56 So. 915; Jefferson Co. Sav. Bk. v. Interstate Sav. Bk. (1912), 4 Ala. App. 363, 59 So. 348.

Arizona.- Leon v. Citizen's Bldg. \& Loan Assn. (1912), 14 Ariz. 294. Arkansas.-Pinson v. Cobb (1914), 166 S. W. 943; Keathley v. Holland Banking Co. (1914), $166 \mathrm{~S}$. W. 953; Little v. Arkansas Nat. Bk. (1914), 167 S. IV. 75.

Colorado. - Ullery v. Brohm (1905), 20 Colo. App. 389, 79 Pac. 180; Sykes v. Kruse (1911), 49 Colo. 560, 113 Pac. 1013; Bank of Bromfield v. MeKinley (1912), 125 Pac. 493.

Connecticut.- New Haven Mfg. Co. v. New Haven Pulp Co. (1903), 76 Conn. 126, 55 Atl. 604.

Idaho.-Craig v. Palo Alto Stock Farm (1901), 16 Ida. 701, 102 Pac. 393; Home Land Co. v. Osborn (1910), 19 Ida. 75, 112 Pac. 764; Utah Implement Vehicle Co. v. Kenyon (1917), 164 Pac. 1177.

Illinois.-Stitzel v. Miller (1910), 157 Ill. App. 390 (No. 2); Woodward v. Donovan (1912), $167 \mathrm{Ill}$. App. 503; Harney v. Lee (1912), 175 Ill. App. 250; W. A. Fowler Paper Co. v. Best Jones Sales Book Co. (1913), 183 Ill. App. 310.

Iowa.-Vander Ploey v. Van Zunk (1907), 135 Iowa, 350, 112 N. W. 807 .

Kansas.-Boline v. Wilson (1907),
75 Kans. 829, 89 Pac. 678; King v. Bellamy (1910), \$2 Kans. 310; Larner v. Shorthill (1919), 176 Pac. 107.

Kentucky.-Chảteau Tr. \& Banking Co. v. Smith (1909), 133 Ky. 418, 118 S. W. 279; Callaghan v. Louisville Dry Goods Co. (1910), 14 Ky. 712, 131 S. W. 995; Harrison v. Pearcy (1917), 192 S. W. 513; Harrison v. Nicholson-Foley Co. (1918), 200 S. W. 929; Sparr v. Fulton Bank (1918), 201 S. W. 310. Massachusetts.-Fay v. Hunt (1906), 190 Mass. 378; Jump v. Leon (1906), 192 Mass. 511; Eddy v. Fogg (1906), 192 Mass. 543; Lowell v. Biekford (1909), 201 Mass. 543, 88 N. E. 1; Whiddon v. Sprague (1909), 203 Mass. 526; Perry v. Pye (1913), 102 N. E. 653; Harvey v. Squire (1914), 105 N. E. 355 .

Michigan.-Gale v. Mayhew (1910), 161 Mich. 96, 125 N. W. 781; Gen. Conf. Assn. \& Co. v. Mich. Sanitarium (1911), 166 Mich. 504; Reed v. McReady (1912), 136 N. W. 488; Schmidt v. Pegg (1912), 172 Mich. 159, 137 N. W. 524.

Missouri-- Rhodes v. Guhman (1911), 156 Mo. App. 344; MilbankSeampton Milling Co. v. Parkwood (1911), 133 S. W. 667; Lipscomb v. Talbott (1912), 147 S. W. 799.

Montana.-Case Medicine Co. v. Simpson (1918), 170 Pac. 12.

Nebraska.-Antelope Co. Bk. v. Wright (1912), 90 Neb. 621, 134 
N. W. 1123; Ostenberg จ. Havka (1914), 145 N. W. 713.

New Jersey.-Hil! v. Buchanan (1905), 71 N. J. L. 301 ; R. M. Owen \& Co. v. Storms \& Co. (1909), 78 N. J. L. 154,72 Atl. 441.

New York.-Poess v. Twelfth Ward Bk. (1904), 43 Misc. 45, 86 N. Y. Supp. 857; Bunter v. Allen (1905), 106 A. D. 557; Schlesinger v. Kurzvok (1905), 94 N. Y. Supp. 442, 47 Misc. 634; Cleary $v$. Dykeman (1914), 146 N. Y. Supp. 611; Rogers v. Morton (1905), 46 Misc. 494, 95 N. Y. Supp. 49; Curtis v. Douglas (1911), 130 N. Y. Supp. 1054; Czerney v. Hass (1911), 144 A. D. 430 (May 12); Martz v. State Nat. Bk. of N. Tonowanda (1911), 131 N. Y. Supp. 1045, 147 A. D. 250 ; People's Nat. Bk. of Hackensack v. Rice (1912), 133 N. Y. Supp. 622; Schwartz v. Goin (1912), 149 A. D. 496; Mazur v. Urback (1913), 142 N. Y. Supp. 323, 81 Mise. 133; Dalrymple v. Schwartz (1917), 164 N. Y. Supp. 496.

North Carolina.- Roller v. McKinney (1912), 74 S. E. 966; Park v Exam. (1911), 156 N. Car. 228; Martin \& Garrett v. Mask (1912), 158 N. Car. 436; Vaughan v. Exam. (1ธ13), 161 N. Car. 492, 77 S. E. 679; First Nat. Bk. v. Warsaw Drug Co. (1914), 81 S. E. 993.

North Dakota.- Am. Soda Fountain Co. v. Hogue (1908), $17 \mathrm{~N}$. Dak. 375, 116 N. W. 339; Grover v. Muratt (1912), 23 N. Dak. 577. 137 N. W. 830; Farmer's Bank of Mercer Co. v. Riedlinger (1914), 146 N. W. 556 .

Ohio.-Wehrman v. Beech (1906), 28 O. C. 128; Moore v. Central Nat. Bk. of Cleveland (1910), 31 O. C. 614.
Oregon.- Fishburn v. Londershausen (1907), 50 Oreg. 363, 92 Pac. 1060,14 L. R. A. (N. S.) 1234; Smith v. Bayer (1911), 115 Pac. 148; Gleason v. Denson (1913), 132 Pac. 530; Hewitt v. Andrews (1914), 140 Pac. 438.

Pennsylvania.- Johnson Co. Sav. Bk. v. Kock (1908), $38 \mathrm{~Pa}$. Super. Ct. 553; Levy v. Gilligan (1914), 90 At1. 647.

Rhode Island.-Hutchings v. Renhalter (1902), 23 R. I. 515

South Dakota.-Piper v. Hagen. (1914), 146 N. W. 692.

Utah.-Escamilla v. Pingree(1914). 141 Pac. 103.

Virginia.-Fleshman v. Bibb (1916), 88 S. E. 64.

Washington.-Capitol Nat. Bk. $\mathbf{}$. Robinson (1906), 41 Wasl. 454, 83 Pac. 1021; Jackson v. Mercantile Fire Ins. Co. (1907), 45 Wash. 244, 88 Pac. 127; Hillman v. Stanley (1909), 56 Wash. 320, 105 Pac. S16; Gcodfellow v. First Nat. Bk. (1913), 129 Pac. 90; First Nat. Life Assurance Soc. of Am. v. Farquhar (1913), 135 Pac. 619; Harris v. Johnson (1913), 134 Pac. 1048; Carr v. Bonthires (1914), 140 Pac. 339.

West Virginia.-Farmer's Nat. Bk. v. Howard (1912), 71 IV. Va. 57, 76 S. F. 122.

Wisconsin.- Swanby v. Northern St. Bk. (1912), 150 Wis. 572, 13 7 N. W. 763 .

United States. - Milton v. Pensacola Bk. \& Tr. Co. (1911), 190 Fed. 126,111 C. C. A. 166 ; Loeb v. Weil (1913), 209 Fed. 608; Pensacola State Bk. v. Melton (1913), 210 Fed. 57; First Nat. Bk. v. For. (1913), 40 A. C. (D. C.) 430 . 
Section 52. A holder in due course is a holder who has taken the instrument under the following conditions:

(1) That it is complete and regular upon its face;

(2) That he became the holder of it before it was overdue, and without notice that it had been previously dishonored, if such was. the fact;

(3) That he took it in good faith and for value;

(4) That at the time it was negotiated to him he had no notice. of any infirmity in the instrument or defect in the title of the person negotiating it.

Alabama.- Merchants Nat. Bk. of Lafayette v. Morris (1909), 163 Ala. 51, 51 So. 15; Sneed v. Bar. clift (1911), 1 Ala. App. 297, 56 So. 592; Sneed v. Barclift (1911), 2 Ala. App. 297; Continental Credit Co. v. Ely (1917), 100 Atl. 435; Darden v. Holloway (1911), 1 Ala. App. 661, 56 So. 32; Moseley v. Selma Nat. Bk. (1911), 57 So. 91; Stone v. Goldberg \& Lewis (1912), 6 Ala. App. 249, 60 So. 744; Bruce v. Citizen's Nat. Bk. of Lineville (1913), 64 So. 82 ; Hartsell v. Roberts (1913), 64 So. 90; Clark v. Thompson (1915), 60 So. 925; Citizens Nat. Bk. v. Bucheit (1916), 71 So. 82 ; Sherrill v. Merch. \& Mech. Trust \& Savings Bk. (1916), 70 So. 723 ; Hudson v. Repton State Bk. (1917), 75 So. 695; Norris v. Merchants Nat. Bk. (1911), 2 Ala. App. 434, 57 So. 71; Bank of Tallassee (1917), 75 So. 930; Davis v. Floyd (1917), 77 So. 413; Birıningham Trust \& Sav. Co. v. Howell (1918), 79 So. 377.

Arkansas. - Harrison v. Morgan Curry Co. (1914), 170 S. W. 578; Calhoun v. Ainsworth (1915), 176 S. W. 316; Conqueror Trust Co. v. Reves Drug Co. (1915), 176 S. W. 119.
Colorado.-McMann v. Walker (1903), 31 Colo. 261, 72 Pac. 1055; Wedge Mines Co. v. Denver Nat. Bk. (1903), 19 Colo. App. 182, 73 Pac. 873 ; First Nat. Bk. of Iowa City v. Smith (1913), 136 Pac. 460; George v. Williams (1915), 149 Pac. 837; Min. \& Mill. Co. v. Stephenson (1917), 165 Pac. 601; Burnham Investment Co. v. Sethınan (1918), 171 Pac. 854; Church v. Sweetland (1917), 243 Fed. 289.

Connecticut.-Mersick v. Alderman (1905), 77 Conn. 634, 60 Atl. 109 ; Johnson Co. Sav. Bk. v. Walker (1909), 82 Conn. 24; s. c., 79 Conn. 348, 65 Atl. 132 (1906), 80 Conn. 509, 69 Atl. 15; First Nat. Bk. v. Fairfield Auto Co. (1917), 99 Atl. 577; Continental Credit Co. v. Ely (1917), 100 Atl. 435; Tice v. Moore (1909), 82 Conn. 244, 73 Atl. 133.

Delaware.- Security Tr. \& Safe Dep. Co. v. Duross (1913), 86 Atl. 209.

Florida.- Scott v. Taylor (1912), 63 Fla: 612; Berryhill-Cromatic Co. v. Manitowoc Shipbuilding \& Dry Dock Co. (1913), 63 So. 720; Jones v. Manitowoc Shipbuilding \& Dry Dock Co. (1913), 62 So. 590; Sumter Co. State Bk. v. Hays (1915), 67 So. 109; Jones v. The Manituwoc. 
Shipbuilding \& Dry Dock Co. (1913), 65 Fla. 457; Bass v. Lee (1917), 74 So. 7 .

Idaho.-Winter v. Nobs (1910), 19 Ida. 18, 112 Pac. 525; Union Stock Yards Nat. Bk. v. Bolan (1908), 14 Ida. 87, 93 Pac. 508; Shefficld v. Cleland (1911), 19 Ida. 612, 115 Pac. 20; Schellenberger v. Nourse (1911), 20 Ida. 323, 118 Pac. 508; Brown v. Miller (1912), 22 Ida. 307, 125 Pac. 981; Park v. Johnson (1911), 20 Ida. 548, 119 Pac. 52; Park v. Brandt (1911), 20 Ida. 660, 119 Pac. 877; Winter v. Hutchins (1911), 20 Ida. 749, 119 Pac. 883; McCarty v. Lowry (1912), 123 Pac. 943; Altschul v. Rogers (1912), 63 Ida. 512, 126 Pac. 1048; McFarland v. Johnson (1912), 22 Ida. 694, 127 Pac. 908; Nelson v. Hudgel (1913), 23 Ida. 327, 130 Pac. 85; The Southwest Nat. Bk. of Kansas City v. Baker (1913), 23 Ida. 428, 130 Pac. 799; S. W. Nat. Bk. of Kansas City v. Lindley (1916), 158 Pac. 1082.

Illinois.-Schintz v. Am. Tr. \& Sav. Bk. (1909), 152 Ill. App. 76; Peterson v. Emery (1910), 154 Ill. App. 294; Manussier v. Wright (1910), 158 Ill. App! 214; Perks v. Eshleman (1911), 165 Ill. App. 420; Black v. Downes (1912), 176 Ill. App. 35s; Richter v. Burdock (1913), 157 Ill. 410, 100 N. F. 1063; Christina v. Cusseniano (1912), 129 Ill. 873,57 So. 157 ; Weir \& Craig Mfg. Co. v. Bonus (1913): 177 Ill. App. 626; Justice v. Stonecipher (1915), 10 S N. E. 722, 267 Ill. 448.

Indiana.-Parker v. Hickman (1916), 111 N. E. 649.

Iowa.-Wankee Sav. Bk. v. Jones (1916), 150 N. W. 691; Commercial Nat. Bk. v. Citizens State Bk.
(1906), 132 Iowa, 706, 109 N. W. 198; McKnight v. Parsons (1907), 136 Iowa, 390, 113 N. W. 858, 125 Am. St. 265; Vander Ploey v. Van Zunk (1907), 135 Iowa, 350, 112 N. IV 807; Keegan v. Rock (1905), 128 Iowa, 39, 102 N. W. 805; City Nat. Bk. v. Jordan (1908), 139 Iowa, 499, $117 \mathrm{~N}$. W. 578; Montrose Sav. Bk. v. Claussen (1908), 137 Iowa, 73, 114 N. W. 547; Voss v. Chamberlain (1908), 139 Iowa, 569, 117 N. W. 269; Arnd v. Aylesworth (1909), 145 Iowa, 185, 123 N. W. 1000; O'Connor v. Kleiman (1909), 143 Iowa, 435, 121 N. W. 1088; Iowa Nat. Bk. v. Carter (1909), 144 Iowa, 715, 123 N. W. 237; Case v. Beyer (1910), 125 N. W. 947; Woodbury v. Glick (1911), 161 Iowa, 648, 132 X. W. 67; Citizens State Bk. v. Lankin (1912), 134 N. W. 882; Stotts v. Fawfield (1914), 145 N. W. 61; Farmers \& Merch. St. Bk. v. Shaffer (1915), 154 N. W. 485; LeClere v. Philpott (1915), 151 N. W. 825; Roy v. Duff (1915), 152 N. W. 606; Higby v. Bahrenfus (1917), 163 N. W. 247; Todd v. Bank of Edgewood (1917), $165 \mathrm{~N}$. W. 593.

Kansas.- Nyhart v. Hubach (1907), 76 Kans. 154, 90 Pac. 796; Youle v. Fosha (1907), 76 Kans. 20, 90 Pac. 1090; Gate City Nat. Bk. v. Thrall (1911), 85 Kans. 394; Bk. of Wilber v. Freeburg (1911), 84 Kans. 235; McMillan v. Gardner (1912), 88 Kans. 279; Doty v. Garfield Township (1913), 89 Kans. 719; Underwood v. Qúantie (1911), 116 Pac. 361; Murchison v. Nies (1912), 87 Kans. 77; Ireland v. Shore (1914), 137 Pac. 926; The Stock Ex. Bk. v. Wykes (1913), 88 Kans. 750; Smith v. Nelson Land 
\& Cattle Co. (1914), 212 Fed. 56; F. \& M. Bank v. Beal (1918), 170 Pac. 1007.

Kentucky.-Wilkins v. Usher (1906), 123 Ky. 696, 97 S. W. 37; Citizens Bank v. Bank of Weddy (1907), $126 \mathrm{Ky} .169,103$ S. W. 249; Chateau Tr. \& Banking Co. v. Smith (1909), $133 \mathrm{Ky} .418,118$ S. W. 279; Bothwell v. Corum (1909), $135 \mathrm{Ky} \cdot 767,123$ S. W. 291; Campbell v. Fourth Nat. Bk. of Cincinnati (1910), $137 \mathrm{Ky} .555,126 \mathrm{~S}$. W. 114; Jett v. Standefer (1911), 143 Ky. 787, 137 S. W. 513; Am. Nat. Bk. v. Madison (1911), $144 \mathrm{Ky}$. 152, 137 S. W. 1076; Austin v. First Nat. Bk. of Scottsville (1912), 150 Ky. 113; Robertson v. Commercial Security Co. (1913), 151 Ky. 336, 153 S. W. 450; Gahren, Dodge \& Malthy v. Parkersburg Nat. Bk. (1914), 162 S. W. 1135; Harrison v. Ford (1914), 165 S. W. 663; Pratt v. Rounds (1914), 169 S. W. 848; Edelen v. Muir (1915), 174 S. W. 474; Gaertner v. Kraft (1915), 176 S. W. 207; Bernard v. Napier (1916), 181 S. W. 624; Harrison v. Union Store Co. (1918), 201 S. W. 31.

Louisiana.-Wolf v. Zachary \& N. E. R. Co. (1911), 128 La. 1092, 55 So. 685; Dicks v. Johnson (1913), 63 So. 700; Gajan v. Patout \& Bouguieres (1913), 63 So. 585; MeCowen v. Barnett (1915), 68 So. 102.

Maryland.-Arnd v. Heckert (1908), 108 Md. 300, 70 Atl. 417; Burke v. Smith (1909), 111 Md. 624, 75 Atl. 114; Weant v. Southern Tr. \& Dep. Co. (1910), 112 Md. 463, 77 Atl. 289.

Massachusetts.-Boston Steel \& Iron Co. v. Steuer (1903), 183 Mass.
140, 66 N. E. 646; Rowe v. Bowman (1903), 183 Mass. 488, $67 \mathrm{~N}$. E. 636; Mehlinger v. Harriman (1904), 185 Mass. 245, 70 N. E. 51; Mass. Nat. Bk. v. Snow (1905), 187 Mass. 159, 72 N. E. 959; White v. Dodge (1905), 187 Mass. 449, $73 \mathrm{~N}$. E. 549; Thorpe v. White (1905), 188 Mass. 333,74 N. E. 592; Fille: brown v. Hayward (1906), 190 Mass. 472 ; Buzzell v. Tobin (1909), 201 Mass. 1, 86 N. E. 923; DeReiset v. Longhery (1910), 205 Mass. 8, 91 N. E. 297; Nesson v. Miller (1910), 205 Mass. 515; JohnsonKettell Co. v. Longley Luncheon Co. (1910), 207 Mass. 52; Lewiston Trust \& Safe Dep. Co. v. Shackford (1913), 213 Mass. 432; Franklin Sav. Bk. v. International Tr. Co. (1913), 215 Mass. 231, $102 \mathrm{~N}$. E. 363; Quincy Mutual Fire Ins. Co. v. International Tr. Co. (1914), 104 N. E. 845; Nat. Bk. of Newberry v. Wentworth (1915), $105 \mathrm{~N}$. E. 626; Nat. Inv. \& Security Co. v. Corey (1916), 111 N. E. 357; Bank Investment Security Co. v. Carey (1916), 111 N. E. 357; Colonial Fur Ranching Co. v. First. Nat. Bk. (1917), 116 N. E. 731.

Michigan.- Neyens v. Worthington (1908), 150 Mich. 580, $114 \mathrm{~N}$. W. 404,18 L. R. A. (N. S.) 142; People's Bldg. \& Loan Assn. v. Rutz (1909), 158 Mich. 440; Gale v. Mayhew (1910), 161 Mich. 96, $125 \mathrm{~N}$. W. 781; Hakes v. Thayer (1911), 131 N. W. 174 ; Crosby v. Reynolds (1912), 196 Fed. 640; White v. Wadhams (1919), 170 N. W. 60.

Minnesota.-Finseth $\vee$. Scherer (1917), 165 N. W. 124; Gould v. Svendsgaard (1919), 170 N. W. 595.

Mississippi.-Moyse Real Est. Co. v. First Nat. Bk. of Commerce 
(1916), 70 So. 821; First Nat. Bk. v. McGrath \& Son Co. (1916), 72 So. 701; Adair v. Bank of Hickory Flat (1917), 75 So. 759.

Missouri.-Chitwood v. Hatfield (1909), 136 Mo. App. 688; Sublette r. Brewington (1909), 139 Mo. App. $410,122 \mathrm{~S}$. W. 1150 ; Bk. of Houston v. Day (19.09), 122 S. W. 756; Jobes v. Wilson (1910), $124 \mathrm{~S}$. W. 548; Bk. of Ozsrk v. Hanaka (1910), 142 Mo. App. 110, 125 S. W. 221; Johnson Co. Sav. Bk. v. Mills (1910), 143 Mo. App. 265, 127 S. W. 425 ; Bk. of Ozark v. Tuttle (1910), 144 Mo. App. 294; Coleman v. Stocke (1911), 159 Mo. App. 43, 139 S. W. 216; Nat. Bk. of Commerce in St. Louis v. Morris (1911), 156 Mo. App. 43, 135 S. W. 1008; Link v. Jackson (1911), 158 Mo. App. 63, 139 S. W. 588; Birch Tree State Bk. v. Dowler (1912), 163 Mo. 65, 145 S. W. 843; Federal Discount Co. v. Reid (1912), 162 Mo. App. 238; Schneider v. Johnson (1912), 143 S. W. 78; Hill v. Dillon (1913), 161 S. W. 881; State Bk. of Freeport v. Cape Girardeau \& C. R. Co. (1913), 155 S. W. 1111; Greer v. Orchard (1913), 161 S. W. 875; Tapee v. Varley Wolter Co. (1914), 171 S. W. 19; Long v. Shafer (1914), 171 S. W. 690; Bank of Polk v. Wood (1915), $173 \mathrm{~S}$. W. 1093; Farmers \& Traders Bank v. Laird (1915), 175 S. W. 116; Fox v. Brosius (1915), 173 S. W. 693; Hadley v. Greenville (1916), $187 \mathrm{~S}$. W. 597; McLean County Bank v. Brown (1916), 186 S. W. 785; Miller v. People's Sav. Bk. (1916), 186 S. W. 547; Priest v. Garnet (1917), 191 S. W. 1048; Casimer v. Schwartz (1918), 201 S. W. 592; Long v. Mason (1918), 200 S. W. 1062; Bacon v. Reichardt (1919), 208 S. W. 24; Bacon v. Theiss (1919), 208 S. W. 254 ; Nevins v. Coleman (1918), 200 S. W. 445.

Montana.- N. W. Improvement Co. v. Rhoades (1916), 158 Pac. 832; State Bk. of Moore v. Forsythe (1910), 41 Mont. 249; Brophy Grocery Co. v. Wilson (1912), 45 Mont. 489, 124 Pac. 510; Baker State Bk. v. Grant (1917), 166 Pac. 27; Buhler v. Loftus (1917), 165 Pac. 601.

Nebraska.- Benton v. Sikyta. (1909), 84 Neb. 808, 122 S. W. 60; Bolew v. Wright (1911), 89 Neb. 116, 131 S. W. 185; Central Nat. Bk. v. Ericson (1912), 92 Neb. 396, 138 N. W. 563; Farmers Nat. Bk. of Lyons v. Dixon (1912), 91 Neb. 652, 136 N. W. 845; First Nat. Bk. of Shenandoah v. Kelgord (1912), 91 Neb. 178, 135 N. W. 548; Fisher v. O'Hanlon Rowan Appt. (1913), 93 Neb. 529, 141 N. W. 157; Storz Brewing Co. v. Skirving (1913), 142 N. W. 669; Ostenberg v. Kavka (1914), 145 N. W. 713; Douglas v. Burton (1915), $150 \mathrm{~N}$. W. 653 ; State Bk. of Omaha v. Huffman (1916), 160 N. W. 115; Marshall v. Kirschbaum (1917), 161 N. W. 577 .

New Jersey.- Borough of Montvale v. Peoples Bank (1907), 67 Atl. 67; Rice v. Barrington (1906), 75 N. J. L. 806, 70 Atl. 169; Louis De Yonge \& Co. v. Woodport Hotel \& Land Co. (1909), 72 Atl. 439; Clark'v. Barthold (1915), 93 Atl. 699; Linbarger v. Board of Education of West N. Y. (1912), 83 N. J. L. 446.

New York.-Brewster $\nabla$. Schrader (1899), 26 Misc. 480; Rosenwald v. Goldstein (1899), 27 Misc. 827; Citizens Nat. Bk. v. Lilienthal (1899), 
40 A. D. 609; McCannon v. Shantz (1900), 149 A. D. 460; Benedict v. Kress (1904). 89 N. Y. Supp. 607; Consolidated Nat. Bk. v. Kirkland (1904), 99 A. D. 121, 91 N. Y. Supp. 353; Ketchan v. Govin (1901), 35 Misc. 375, 71 N. Y. Supp. 991; M. Groh's Sons Co. v. Schneider (1901), 34 Misc. 195, 68 N. Y. Supp. 682; Greeser v. Sugarman (1902), $\tau 6 \mathrm{~N}$. Y. Supp. 922, 37 Misc. 799; Citizens Bk. of Buffalo v. The Rung Furniture Co. (1902), 76 A. D. 471; Perth-Amboy Mut. Loan Assn. v. Chapman (1903), 80 A. D. 556; Packard v. Figlinolo (1909), 114 N. Y. Supp. 753; Cominsky v. Coleman (1909), 114 N. Y. Supp. 875; Weiss v. Rieser (1909), 62 Misc. 292, 114 N. Y. Supp. 983; Sutherland v. Mead (1903), 80 A. D. 103, 80 N. Y. Supp. 504; Karsch v. Pottier \& Styners Mfg. \& Importing Co. (1903), 81 N. Y. 782, 82 A. D. 230; Mitchell v. Baldwin (1903), 88 A. D. 265, 84 N. Y. Supp. 1043; Packard v. Windholz (1903), 40 Misc. 347 , affirmed 88 A. D. 365 (1902); Simpson v. Hefter (1904), 42 Misc. 482, 87 N. Y. Supp. 243; Albany Co. Bk. v. People's Co-op. Ins. Co. (1904), 92 A. D. 47, 86 N. Y. Supp. 73; Schreyer v. Bailer \& Co. (1904), 97 A. D. 185; Goetting v. Day (1904), 87 N. Y. Supp. 510; Citizens State Bk. v. Cowles (1905), 180 N. Y. 346, 73 N. E. 33, reversing s. C., 89 A. D. 280; Chemica] Nat. Bk. v. Kellogg (1905), 183 N. Y. 92,75 N. E. 1103 ; The Bk. of Am. v. Waydell (1905), $103 \mathrm{~A}$. D. 25,92 N. Y. Supp. 666 , citing 25, Sutherland v. Mead, 80 A. D. 103 and Rosman v. Mahoney, 86 A. D. 377; Milins v. Kauffman (1905), 104 A. D. 442, 93 N. Y. Supp. 669;
Hamilton Nat. Bk. v. Upton (1905), 100 A. D. 105; Orr v. So. Amboy Terra Cotta Co. (1905), 94 N. Y. Supp. 524, 47 Misc. 604; Rogers v. Morton (1905), 46 Misc. 494, $95 \mathrm{~N}$. Y. Supp. 49; Hover v. Magley (1905), 48 Misc. 430, 96 N. Y. Supp. 925; Hathaway v. County of Delaware (1906), 185 N. Y. $368,78 \mathrm{~N}$. E. 153,13 L. R. A. (N. S.) 273,113 A. D. 909 ; Elias v. Whitney (1906), 98 N. Y. Supp. 667,50 Misc. 326 ; Schlesinger v. Lehmaire (1906), 99 N. Y. Supp. 389; Rosenthal v. Freedman (1907), 53 Misc. 595, 103 N. Y. Supp. 714; McGehee v. Cooke (1907), 55 Misc. 40, 105 N. Y. Supp. 60 ; Siegmeister v. Lispenard Realty Co. (1907), 107 N. Y. Supp. 158; The Gansevort Bk. of New York v. Gilday (1907), 110 N. Y. Supp. 271, 53 Misc. 107; Rice $\vee$. Eisler (1907), 119 A. D. 132; Arons v. Ziegfeld (1907), 52 Misc. 571; Nat. Bk. of Barre v. Foley (1907), 54 Misc. 126, 103 N. Y. Supp. 553; Strauss v. St. Louis Co. Bk. (1908), 126 A. D. 647; Rosenthal v. Parsont (1908), 110 N. Y. Supp. 223; Valley Dew Distilling Co. v. Ritzmann (1908), 110 N. Y. Supp. 917; Hunter v. Allen (1908), 127 A. D. 572 ; Nat. Park Bk. v. Saitta (1908), 127 A. D. 624, 111 N. Y. Supp. 927; Schlesinger $\mathrm{v}$. Lehmaier (1908), 191 N. Y. 69,83 N. E. 657,16 L. R. A. (N. S.) 626, 123 Am. St. 591; Joveshoff v. Rockney (1908), 109 N. Y. Supp. 818, 58 Misc. 559; Ward r. City Tr. Co. (1908), 192 N. Y. 61, 84 N. E. 585; Am. Seeding Machine Co. v. Slocum (1908), 58 Misc. 458; The Royal Bk. of N. Y. v. GermanAm. Ins. Co. (1908), 58 Misc. 563; Laschinsky v. Margolio (1908). 129 A. D. 529 ; Wallabout Bk. v. Peyton 
(1908), 123 A. D. 727, 108 N. Y. Supp. 42; Squire v. Ordemann (1909), 194 N. Y. 394; Heimbach v. Doubleday, Page Co. (1909), 130 A. D. 34 ; Republic Life Ins. Co. v. Hudson Trust Co. (1909), 130 A. D. 618; Bacon v. Montauk Brewing Co. (1909), 130 A. D. 73; Manufacturer's Commercial Co. v. Blitz (1909), 131 A. D. 17, 115 N. Y. Supp. 402; Horan v. Mason (1910), 125 N. Y. Supp. 668; Frank v. Wolff (1910), 125 N. Y. Supp. 530; Cluett v. Conture (1910), 140 A. D. 830,125 N. Y. Supp. 813 ; Ferguson v. Netter $(1910), 141$ A. D. 274; Empire State Surety Co. v. Nelson (1910), 126 N. Y. Supp. 453; Citizens Sav. Bk. v. Couse (1910), 68 Mise. 153; Hurst v. Lee (1911), 143 A. D. 614, 127 N. Y. Supp. 1040; Buckley v. Lincoln Trust Co. (1911), 131 N. Y. Supp. 105; Eq. Tr. Co. v. Taylor (1911), 131 N. Y. Supp. 475, 72 Misc. 52; Jacobus v. Jamestown Mantel Co. (1912), 149 A. D. 356,134 N. Y. Supp. 418; Borough Bk. of Brooklyn v. Lamphear (1912), 138 N. Y. Supp. 864; Bass v. Goldstein (1913), 83 Misc. 412, 145 N. Y. Supp. 38; First Bk. of Notasulga v. Jones (1913), 141 N. Y. Supp. 304 ; Kass v. Blumberg (1913), 142 N. Y. Supp. 544; Lang v. Hudgens (1913), 142 N. Y. Supp. 763, 82 Misc. 388; Lich-und-Spakassa Audorf v. Pfizer (1913), 158 A. D. 505, 143 N. Y. Supp. 744; Nat. Discount Co. v. William R. Jenkins Co. (1913), 143 N. Y. Supp. 996: Spencer \& Co. v. Brown (1913), 143 N. Y. Supp. 994; Cleary v. Dykeman (1914), 146 N. Y. Supp. 611; Clement v. Saratoga Holding Co. $(1914), 161$ A. D. $898,145:$ N. Y. Supp. 628; Coffin v. Tevis. (1914),
149 N. Y. Supp. 986, 164 Misc. 314; Rambaut v. 'levis (1914), 149 N. Y. Supp. 993, 164 A. D. 324; Zivendling v. Kitrosser (1914), $148 \mathrm{~N}$. Y. Supp. 99; Brown. v. Rowan (1915), 154 N. Y. Supp. 1098; Stoller v. Reichgott (1915), 156 N. Y. Supp. 551; Bergstrom v. Ritz-Carlton Hotel Co. (1916), 157 N. Y. Supp. 959 ; McBee Co. v. Shoemaker (1916), 160 N. Y. Supp. 251; Thornton v. Netherlands-Amer. Steam Nav. Co. (1917), 165 N. Y. Supp. 682; Garone v. Russo Ludice Realty Co. (1917), 164 N. Y. Supp. 135; Kennedy v. Hyman (1917), $167 \mathrm{~N}$. Y. Supp. 311; Gillevan v. Owens (1918), 169 N. Y. Supp. 958.

North Carolina.- Toms v. Jones (1900), 127 N. Car. 464; Manufacturing Co. v. Summers (1906), 143 N. Car. 102,55 S. E. 522 ; Singer Mfg. Co. v. Summers (1906), 1433 N. Car. 102, 55 S. E. 522; Am. Nat. Bk. v. Fountain (1908), 62 S. E. 738, 148 N. Car. 590; Am. Nat. Bk. v. Fountain (1908), 148 N. Car. 590, 62 S. E. 738; Murchison Nat. Bk. v. Dunn Oil Mills Co. (1909), 150 N. Car. 718, 64 S. E. 885; Johnston Co. Sav. Bk. v. Chase (1909), 151 N. Car. 108; Bk. of Sampson v. Hatcher (1909), $151 \mathrm{~N}$. Car. 359, 66 S. E. 308; First Nat. Bk. of Kansas City v. Griffin (1910), 153 N. Car. 72; Citizens \& Marine Bk. of Newport News v. Southern R. W. (1910), 153 N. Car. 346; Myers v. Petty (1910), 153 N. Car. 462; Hardy v. Mitchell (1911), 156 N. Car. 76, 72 S. E. 95, 161 N. Car. 351 (1913), Park v. Exam (1911), 72 S. E. 309 ; Am. Nat. Bk. of Richmond v. Hill (1915), 85 S. E. 209 ; Gulf States Steel Co. v. Ford (1917), 91 S. E. 844. 
North Dakota.-Drenkall v. Movius State Bk. (1901), 118 N. Dak. 10, 88 N. W. 724; Bank v. Garcean (1912), 22 N. Dak. 576, 134 N. W. 882; McCarty v. Kepveta (1913), 139 N. W. 992; Nat. Bk. of Commerce v. Pick (1904), 13 N. Dak. 74, 99 N. W. 63; Walters v. Rock (1908), 18 N. Dak. 45, 115 N. W. 511; Farmer's Bk. of Mercer Co. V. Riedlinger (1914), 146 N. W. 556.

Ohio.-Thompson v. Citizens Nat. Bk. of Adams (1909), 32 O. C. 131 ; Spring Valley Nat. Bk. v. Somers (1910), 21 Ohio Dec. 772; Hamilton Mach. Tool Co. v. Memphis Nat. Bk. (1911), 84 Ohio St. 184,95 N. E. $77 \%$.

Oklahoma.- Jenkins v. Planter's \& Mechanics Bk. (1912), 126 Pac. 757; Wood v. Stickle (1912), 128 Pac. 1082; First State Bk. of Oklahoma v. Tobin (1913), 134 Pac. 395; Cedar Rapids Nat. Bk. v. Bashara (1913), 35 Pac. 1051; Hudson v. Moore (1913), 130 Pac. 774; Jones v. Citizen's State Bk. (1913), 135 Pac. 373; Western Exchange Bk. of Kansas City v. Coleman (1913), 132 Pac. 488; Nat. Bk. of Commerce v. Arnbruster (1914), 142 Pac. 393; City Nat. Bk. v. Kelly (1915), 151 Pac. 1172; Hodgins v. Northwestern Finance Co. (1915), 148 Pac. 717; Keisel v. Baldock (1915), 154 Pac. 1194; Nicholas Co. v. Thomas (1915), 151 Pac. 847; Norman v. Lambert (1915), 153 Pac. 1097; Ogle v. Armstrong (1915), 153 Pac. 1139; Ward v. Oklahoma State Bank (1915), 151 Pac. 852; Lambert v. Smith (1916), 157 Pac. 909 ; Conqueror Trust Co. v. Simmon (1917), 162 Pac. 1098; Critser v. Steeley (1917), 162 Pac. 795.
Oregon. - Brown v. Felwert (1905), 46 Oreg. 363, 80 Pac. 414; White v. Savage (1906), 45 Oreg. 604, 87 Pac. 1040; First Nat. Bk. of Pomeroy v. MeCullough (1908), 50 Oreg. 508, 93 Pac. 366; Matlock v. Scheuerman (1908), 51 Oreg. 49, 93 Pac. 823,17 L. R. A. (N. S.) 747; First Nat. Bk. of Cottage Grove v. Bank of Cottage Grove (1911), 59 Oreg. 388, 117 Pac. 293; Hull v. Agnus (1911), 60 Oreg. 95, 118 Pac. 284; Bailcy v. Inland Empire Co. (1915), 146 Pac. 991; Sink v. Allen (1916), 154 Pac. 415; Everding \& Farrell v. Taft (1917), 160 Pac. 1160.

Pennsylvania. - Homewood People's Bk. v. Heckert (1903), $207 \mathrm{~Pa}$. 231; Neil v. Neil (1904), $25 \mathrm{~Pa}$. Super. Ct. 605; Garman v. Gumbiner (1906), 32 Pa. Super. Ct. 181; Allentown Nat. Bk. v Clay Product Supply Co. (1907), 217 Pa. St. 128, 66 Atl. 252; Lindsay v. Dutton (1907), 217 Pa. 148, 66 Atl. 250; Stouffer v. Kelchner (1908), $38 \mathrm{~Pa}$. Super. Ct. 475; Johnson Co. Sav. Bk. v. Kock (1908), 38 Pa. Super. Ct. 553; Lowry Nat. Bk. v. Hazard (1909), 223 Pa. 520; Bowles v. Frazer (1910), 109 Pa. 812; Grange Trust Co. v. Brown (1911), $49 \mathrm{~Pa}$. Sup. 274; People's Nat. Bk. of Pensacola v. Hazard (1911), 80 Atl. 554; Wolfgang v. Shirley (1913), 86 Atl. 1011.

Rhode Island.- Abram. v. Greer (1913), 88 Atl. 884.

South Carolina.-Commerce Trust Co. v. Grimes (1914), 82 S. E. 420; Edens v. Gibson (1915), 84 S. F. 1005; Farmer's Bk. v. Crawford (1916), 88 S. E. 13; Farmers Mech. Bk. of Florence $v$. Whitehead 
(1916), 89 S. E. 657; Stevens v. Khetter (1918), 96 S. E. 406.

South Dakota.-Kahney v. Thayer (1915), 154 N. W. 1103; Runely v. Anderson (1915), 150 N. W. 939.

Tennessee.-Kimbrough v. Hornsby (1904), 113 Tenn. 605; Elgin City Bldg. Co. v. Hall (1907), 119 Tenn. 548, 108 S. W. 1068; Jefferson Bk. of St. Louis v. ChapmanWhittee Lyons Co. (1909), 122 Tenn. 415, 123 S. W. 641; Edwards v. Hambly (1915), 180 S. W. 163; Merrimon v. Parkey (1917), $191 \mathrm{~S}$. W. 327 ; Madison Tr. Co. v. Stahlman (1916), 183 S. W. 1012; Bromley v. Chattanooga Co. (1917), 198 S. W. 775 .

Texas.-Davis v. Converse (1916), 188 S. W. 697; McCamant v. McCamant (1916), 187 S. W. 1096; Sayles v. First State Bank of Abilene (1917), 195 S. W. 230; Zielinski v. Hernig (1917), 195 S. W. 952.

Utah.- Cole Banking Co. v. Sinclair (1908), 34 Utah, 454, 98 Pac. 411; Leavitt v. Thurston (1911), 38 Utah, 351, 113 Pac. 77; Miller v. Marks (1915), 148 Pac. 412; Helper St. Bk. v. Jackson (1916), 160 Pac. 287 ; Interstate Trust Co. v. Headlund (1918), 171 Pac. 515.

Virginia.-Aragon Coffee Co. v. Rogers (1906), 105 Va. 51; Pennington $v$. Third Nat. Bk. of Columbus, Ga. (1913), 77 S. E. 455; Am. Bk. of Orange v. McComb (1906), 105 Va. 473, 54 S. E. 14; Fayette Nat. Bk. v. Sunners (1906), 105 Va. 689, 54 S. E. 862; City Nat. Bk. of Roanoke v. Hundley (1911), 70 S. E. 494; Miller v. Norton \& Smith (1913), 77 S. E. 452; Wi1liams v. Liphart (1914), 81 S. E. 77; Anderson v. Union Bk. of Rich- mond (1915), 83 S. E. 1080; Fleshman v. Bibb (1916), 88 S. E. 64; Holdsworth v. Anderson (1916), 87 S. E. 565; Ratcliffe v. Costello (1915), 85 S. E. 469; Colona v. Parksley Nat. Bk. (1917), 92 S. E. 979.

Washington.- McNamara v. Jose (1902), 28 Wash. 461; Keene v. Behan (1905), 40 Wash. 505, 82 Pac. 884; Gosline v. Dryfoos (1907), 45 Wash. 396, 88 Pac. 634; Reardan v. Cockrell (1909), 54 Wash. 400, 103 Pa. 457; Gray v. Boyle (1909), 55 Wash. 578, 104 Pac. 828; Bradley Engineering \& Mfg. Co. v. Heyburn (1910), 56 Wash. 628, 106 Pac. 170; Cedar Rapids Nat. Bk. v. Myhre (1910), 57 Wash. 596, 107 Pac. 518; Bowles v. Frazer (1910), 109 Pac. 812; Hughes \& Co. v. Flint (1911), 61 Wash. 460, 112 Pac. 633; Moyses v. Bell (1911), 62 Wash. 134, 114 Pac. 193; Scandinavian Am. Bk. v. Johnston (1911), 63 Wash. 187, 115 Pac. 102; Wells v. Duffy (1912), 69 Wash. 310; Am. Sav. Bk. \& Tr. Co. v. Helgesen (1911), 64 Wash. 54, 116 Pac. 837; Barker v. Sartori (1911), 66 Wash. 260, 119 Pac. 611; Parker v. Saxton (1911), 66 Wash. 260 ; Canadian Bk. of Commerce v. Sesuon Co. (1912), 123 Pac. 602; Davis v. Hibbs (1913), 73 Wash. 315, 131 Pac. 1135; Fournier v. Cornish (1913), 133 Pac. 9; Union Inv. Co. v. Rosenzweig (1914), 139 Pac: 874; Wash. Trust Co. v. Keyes (1915), 152 Keyes, 1029; Schultz v. Crewdson (1917), 163 Pac. 734; Hauson v. Roesch (1919), 176 Pac. 349.

Wisconsin.-Aebi $v$ Bk. of Evensville (1905), 124 Wis. 93, $102 \mathrm{~N}$. W. 329,68 L. R. A. (N. S.) 964, 
109 Am. St. 925; Hodge v. Smith (1907), 130 Wis. $326,110 \mathrm{~N}$. W. 192; Aukland v. Arnold (1907), 131 Wis. 64, 111 N. W. 212; Quiggle v. Herman (1907), 131 Wis. 379, 111 N. W. 479; Northfield Nat. Bk. v. Arndt (1907), 132 Wis. 383, $112 \mathrm{~N}$. W. 451; Paulson v. Boyd (1908), 137 Wis. 241, 118 N. W. 841; Kipp v. Smith (1908), 137 Wis. 234, 118 N. W. 848 ; Bk. of Baraboo v. Laird (1912), 136 N. W. 603; Washburn v. Riener (1912), 149 Wis. 387; Green v. Gunsten (1913), 142 N. W. 261; Badger Machinery Co. v. Columbia County Electric Co. (1917), 163 N. W. 188.

Wyoming.- Iowa State Sav. Bk. v. Henry (1913), 136 Pac. 863; Holdsworth v. Blyth \& Fargo (1915), 146 Pac. 603; In re HopperMorgan Co. (1907), 154 Fed. 249; In re Hill (1911), 187 Fed. 214;
First Nat. Bk. of Shenandoah v. Linver (1911), 187 Fed. 16, 109 U. S. C. C. A. 70 ; Nat. Bk. of Commerce in St. Louis v. Sancho Pag. Co. (1911), 110 C. C. A. 112,180 Fed. 257; Amalgamated Sugar Co. v. U. S. Nat. Bk. of Portland, Oreg. (1911), 109 C. C. A. 494; First Nat. Bk. of Wilkesbarre v. Barnum (1908), 160 Fed. 245; Milton v. Pensacola Bk. \& Tr. Co. (1911), 190 Fed. 126, 111 C. C. A. 166 ; Pensacola State Bk. v. Melton (1913), 210 Fed. 57; Howell v. Commercial Nat. Bk. (1913), 40 A. C. (D. C.) 370; O'Toole v. Lanson (1914), 41 App. D. C. 276; Pensacola State Bk. v. Thornberry (1915), 226 Fed. 611 (C. C. A., 6th Ct.) ; Postal Tel. Cable Co. v. Citizens Nat. Bk. (1916), 228 Fed. 601 (C. C. A., 3d Ct.); Nat. City Bk. of Seattle $\nabla$. Titlow (1916), 233 Fed. 838.

Section 53. Where an instrument payable on demand is negotiated an unreasonable length of time after its issue, the holder is not deemed a holder in due course.

Idaho.- Miller v. Del Rio Mining \& Milling Co. (1913), 136 Pac. 448. Illinois. - Greer v. Downing (1912), 176 Ill. App. 355.

Iowa.-Anderson v. First Nat. Bk. of Chariton (1909), 144 Iowa, 251, 122 N. W. 918; LeClere $\nabla$. Philpott (1915), 151 N. W. 825.

Kansas.- Doty v. Garfield Township (1913), 89 Kans. 719.

Massachusetts.-Gardner v. Beacon Trust Co. (1906), 190 Mass. 27; Gordon v. Levine (1908), 197 Mass. 267,83 N. E. 861,15 L. R. A. (N. S.) 243 .

Nebraska. - Ostenberg v. Kavka (1914), 145 N. W. 713.
New York.-Albany Co. Bk. v. People's Co-op. Ice Co. (1904). 92 A. D. 47, 86 N. Y. Supp. 73; Royal Bk. of N. Y. v. Reinschreiber (1911), 126 N. Y. Supp. 749; Stanley v. Franco-American Ferment Co. (1916), 161 N. Y. Supp. 365.

North Carolina.- Singer Mfg. Co. v. Summers (1906), 143 N. Car. 102,55 S. E. 522 ; Johnson v. Lasseter (1911), 155 N. Car. 47.

Oregon.- Matlock v. Scheuerman (1908), 51 Oreg. 49, 93 Pac. 823, 17 L. R. A. (N. S.) 747.

South Carolina.-Williams $\nabla$. Weekley (1915), 84 S. E. 299. 
Tennessee.-Easley v. East Tenn. Nat. Bk. (1917), 198 S. W. 66.

Virginia.-Aragon Coffee Co. v. Rogers (1906), 105 Va. 51; Am. Bk. of Orange v. McComb (1906), 105 Va. 473,54 S. E. 14; Pennington v. Third Nat. Bk. of Cohmbus, Ga. (1913), 77 S. E. 455; Colona v. Parksley Nat. Bk. (1917), 92 S. E. 979.

United States.-Pensacola State Bk. v. Melton (1913), 210 Fed. 57.

Section 54. Where the transferee receives notice of any infirmity in the instrument or defect in the title of the person negotiating the same before he has paid the full amount agreed to be paid therefor, he will be deemed a holder in due course only to the extent of the amount theretofore paid by him.

Arkansas.- Morehead v. Harris (1916), 182 S. W. 521.

Illinois.-Weir \& Craig Mfg. Co. v. Bonus (1913), 177 Ill. App. 626. Iowa.-Citizen's State Bk. v. Lankin (1912), 134 N. W. 882.

Michigan.-Peoples State Bk. v. Miller (1915), 152 N. W. 257.

Missouri.-Chitwood v. Hatfield (1909), 136 Mo. App. 688; Link v. Jackson (1911), 158 Mo. App. 63, 139 S. W. 588 ; 53 Nat. Bk. v. McCrory (1915), 177 S. W. 1058; Mount v. Neighbors Imp. \& Vehicle Co. (1916), 189 S. W. 614.

Nebraska.- Ostenberg v. Kavka (1914), 145 N. W. 713.

New York.- Perth-Amboy Mut. Loan Assn. v. Chapman (1903), 80 A. D. 556; Goetting v. Day (1904), 87 N. Y. Supp. 510; Ferguson v. Netter (1910), 141 A. D. 274; Posenbaum v. Roth (1914), 150 N. Y. Supp. 396, 164 A. D. 617 ; Interboro Brewing Co. v. Doyle (1915), 151 N. Y. Supp. 325 ; First Nat. Bk. of Winona v. Buff Brewing Co. (1915), 154 N. Y. Supp. 765 ; Title GuarCo. v. Pain (1915), 155 N. Y. Supp. 333.

North Carolina.- Johnson v. Lasseter (1911), 155 N. Car. 47.
North Dakota.- Walters v. Rock (1908), 18 N. Dak. 45, 115 N. W. 511; Bank v. Garcean (1912), 22 N. Dak. 576, 134 N. W. 882.

Ohio.-Hamilton Mech. Tool Co. v. Memphis Nat. Bk. (1911), 84 Ohio St. 184, 95 N. E. 777.

Oklahoma. - Hudson v. Moore (1913), 130 Pac. 774; Voris v. Birdsall (1917), 162 Pac. 951; State v. Emery (1918), 174 Pac. 770.

Pennsylvania.- Snyder v. Commercial Ex. Nat. Bk. (1908), 221 Pa. 599, 70 Atl. 876.

Utah.-Felt v. Bush (1912), 126 Pac. 688; Miller v. Marks (1915), 148 Pac. 412.

Virginia.-Aragon Coffee Co. $\nabla$. Rogers (1906), 105 Va. 51; Pennington v. Third Nat. Bk. of Columbus, Ga. (1913), 77 S. E. 455.

Washington.- Citizens Bk. \& Tr. Co. v. Limpright (1916), 160 Pac. 1046.

Wisconsin.- Hodge v. Smith (1907), 130 Wis. 326,110 N. W. 192 ; Green v. Gunsten (1913), 142 N. W. 261.

United States.-In re Continental Engine Co. (1916), 234 Fed. Rep. 58. 
Section 55. The title of a person who negotiates an instrument is defective within the meaning of this act when he obtained the instrument, or any signature thereto, by fraud, duress, or force and fear, or other unlawful means, or for an illegal consideration, or when he negotiates it in breach of faith, or under such circumstances as amount to a fraud.

Alabama. - Hass v. Commerce Trust Co. (1915), 69 So. 89 ; Peoples' Bank \& Trust Co. v. Floyd (1917), 75 So. 940; Jones v. Martin (1917), 74 So. 761; Bernheimer v. Gray (1918), 78 So. 840.

Arizona. - Hurley v. Wilky (1916), 156 Pac. 83.

Arkansas. - Moore v. Wade (1916), 186 S. W. 828.

California.- Merchants Collection Agency v. Roantrue (1918), 173 Pac. 600.

Colorado-Johnson Co. Sav. Bk. v. Gregg (1911), 51 Colo. 358, 117 Pac. 1003; First Nat. Bk. of Iowa City v. Smith (1913), 136 Pac. 460.

Connecticut.-Johnson Co. Sav. Bk. v. Walker (1909), 82 Conn. 24; 8. c., 79 Conn. 348,65 Atl. 132 (1906), 80 Conn. 509, 60 Atl. 15; Continental Credit Co. v. Ely (1917), 100 Atl. 435.

Idaho.- Shellenberger v. Nourse (1911), 20 Ida. 323, 118 Pac. 508; Park v. Johnson (1911), 20 Ida. 548, 119 Pac. 52; Park v. Brandt (1911), 20 Ida. 660, 119 Pac. 877; Winter v. Hutchins (1911), 20 Ida. 749, 119 Pac. 883; Brown v. Miller (1912), 22 Ida. 307, 125 Pac. 981; Southwestern Nat. Bk. of Kansas City v. Lindley (1916), 158 Pac. 1082.

Illinois-Black v. Downes (1912), 176 Ill. App. 358 ; Christina v. Cuseniano (1912), 129 Ill. 873,57 So. 157.
Iowa.- Keegan v. Rock (1905), 128 Iowa, 39, 102 N. W. 805; McKnight v. Parsons (1907), 136 Iowa, $390,113 \mathrm{~N}$. W. 858, $125 \mathrm{Am}$. St. 265; Cox v. Cline (1903), 139 Iowa, 128, 117 N. W. 48; O'Connor v. Kleiman (1909), 143 Iowa, 435, 121 N. W. 1088; Citizen's State Bk. v. Lankin (1912), 134 N. W. 882; Bk. of Bushnell v. Buck Bros. (1913), 142 N. W. 1004 ; Stotts v. Fawfield (1914), 145 N. W. 61; First Nat. Bk. of Shenandoah v. Hall (1915), 151 N. W. 120; LeClere v. Philpot (1915), 151 N. W. 825; Loos v. Callendar Sav. Bk. (1916), $156 \mathrm{~N}$. W. 712; State v. Wegener (1917), 162 N. W. 1040; German-Am. Bk. v. Kelley (1918), 166 N. W. 1053.

Kansas.-Underwood v. Quantie (1911), 116 Pac. 361; Bk. of Wilber v. Freeburg (1911), 84 Kans. 235; Murehison v. Nies (1912), 87 Kans. 77; The Stock Ex. Bk. v. Wykes (1913), 88 Kans. 750; Ireland v. Shore (1914), 137 Pac. 926; Farmers Nat. Bk. of Lincoln v. Francis (1917), 164 Pae. 146; Rodgers v. Slaveno (1917), 165 Pac. 655; First Nat. Bk. v. Stroup (1919), 177 Pac. 836.

Kentucky.-Asbury v. Taubo (1912), 151 S. W. 372; Muir v. Edelen (1913), 160 S. W. 1048; Gahren, Dodge \& Maltby v. Parkersburg Nat. Bk. (1914), $162 \mathrm{~S}$. W. 1135; Harrison v. Ford (1914), 165 S. W. 663 . 
Maryland.-Stouffer v. Alford (1910), 114 Md. 110, 78 Atl. 387; American Agricultural Chemical Co. v. Scringer (1917), 100 Atl. 774; Spoerer v. Wehland (1917), 100 Atl. 287, 130 Med. 226.

Massachusetts.-Caldwell v. Nash (1906), 190 Mass. 507; Demelman v. Brazier (1907), 193 Mass. 588, 79 N. E. 812; Clemons Elec. Mfg. Co. v. Walton (1910), 206 Mass. 215; Lewiston Trust \& Safe Dep. Co. v. Shackford (1913), 213 Mass. 432; Anthony \& Cowell Co. v. Brown (1913), 214 Mass. 439; Palmbaum v. Magulsky (1914), $104 \mathrm{~N}$. E. 746 .

Michigan.-First Nat. Bk. of Durand v. Shaw (1909), 157 Mich. 192, 121 N. W. 811; Crosby v. Reynolds (1912), 196 Fed. 640; J. D. Gruber Co. v. Smith (1917), 162 N. W. 124; Loveland v. Bump (1917), 165 N. W. 855.

Minnesota. - Thorpe v. Cooley (1917), 165 N. W. 265.

Missouri.- Whitener v. Scoggins (1910), 152 Mo. App. 343; Jobes v. Wilson (1910), 124 S. W. 548; Link v. Jackson (1911), 158 Mo. App. 63, 139 S. W. 588; Birch Tree State Bk. v. Dowler (1912), 163 Mo. 65, 145 S. W. 843 ; Hill v. Dillon (1913), 161 S. W. 881; Bank of Polk v. Wood (1915), 173 S. W. 1093; Newburg State Bk. $\nabla$. Heflin (1915), 175 S. W. 297; Miller v. People's Sav. Bk. (1916), 186 S. W. 547; Ozark Motor Co. v. Horton (1917), 196 S. W. 395; Pioneer Stock Powder Co. v. Goodman (1918), 201 S. W. 576.

Montana.- State Bk. of Moore $\mathbf{7}$ Forsythe (1910), 41 Mont. 249.

Nebraska.-Bolew v. Wright (1911), 89 Neb. 116, 131 N. W.
185; Ostenberg v. Kavka (1914), 145 N. W. 713.

New Jersey.-Bensel v. Anderson (1916), 96 Atl. 910.

New Mexico.- Bk. of Commerce v. Broyles (1911), 120 Pac. 6r0; First Nat. Bk. of Albuquerque v. Stover (1916), 155 Pac. 905.

New York.-M. Groh's Sons Co. v. Schneider (1901), 34 Misc. 195, 68 N. Y. Supp. 682; Strickland v. Henry (1901), 66 A. D. 23, 73 N. Y. Supp. 121; Citizens Bk. of Buffalo $\nabla$. The Rung Furniture Co. (1902), 76 A. D. 471; Sutherland v. Mead (1903), 80 A. D. 103, $80 \mathrm{~N}$. Y. Supp. 504; Perth-Amboy Mut. Loan Assn. v. Chapman (1903), 80 A. D. 556; Mitchell v. Baldwin (1903), 88 A. D. 265, 84 N. Y. Supp. 1043; Goetting v. Day (1904), 87 N. Y. Supp. 510; Schreyer v. Bailey \& Co. (1904), 97 A. D. 185; Hamilton Nat. Bk. v. Upton (1905), 100 A. D. 105; Schlesinger v. Kelly (1906), 114 A. D. 546, 99 N. Y. Supp. 1083; Douglass v. Richards (1906), 116 A. D. 27; Elliott v. Brady (1907), 118 A. D. 208; Schlesinger v. Gilhooly (1907). 189 N. Y. 1, 91 N. E. 619; Horwitz v. Wollowitz (1908), 59 Misc. 520, 110 N. Y. Supp. 972; Schlesinger v. Lehmaier (1908), 191 N. Y. 69. 83 N. E. 657,16 L. R. A. (N. S.) 626 , 123 Am. St. 591; Ward v. City Tr. Co. (1908), 192 N. Y. 61, 84 N. E. 585; Packard v. Figlinolo (1909), 114 N. Y. Supp. 753; Klar v. Kostink (1909), 119 N. Y. Supp. 683; Cluett v. Conture $(1910), 140$ A. D. 830,125 N. Y. Supp. 813; Kennedy v. Spilks (1911). 129 N. Y. Supp. 390 ; Broderick \& Bascom Rope Co. v. McGrath (1913), 142 N. Y. Supp. 496, 81 Misc. 222; Lang v. Hudgens 
(1913), 143 N. Y. Supp. 763, 82 Misc. 388; Waxberg v. Stappler (1913), 83 Misc. 78, 144 N. Y. Supp. 608; Zivendling v. Kitrosser (1914), 148 N. Y. Supp. 99; Interboro Brewing Co. v. Doyle (1915), 151 N. Y. Supp. 325; Kass v. Maisel (1915), 155 N. Y. Supp. 217; Title Guar. \& Tr. Co. v. Pam (1915), 155 N. Y. Supp. 333 ; Siegel v. Kovinsky (1916), 157 N. Y. Supp. 340; Empire Trust Co. v. President and Directors Manhattan Do. (1917), 162 N. Y. Supp. 629; Aetna Explosives Co. v. Bassick (1917), 163 N. Y. Supp. 917; Garone v. Russo Iodice Realty Co. (1917), 164 N. Y. Supp. 135.

North Carolina.- Johnston Co. Sav. Bk. v. Chase (1909), 151 N. Car. 108; Hardy v. Mitchell (1911), 156 N. Car. 76, 72 S. E. 95, 161 N. Car. 351; Merchants Nat. Bk. of Indianapolis v. Branson (1914), 81 S. E. 410 ; A. B. Hunter \& Co. v. Sherron (1918), 97 S. E. 5.

North Dakota.-Drenkall v. Movius State Bk. (1901), 118 A. D. 10. 88 N. W. 724; Walters v. Rock (1908), 18 N. Dak. 45, 115 N. W. 511; Am. Nat. Bk. v. Lundy (1910), 21 N. Dak. 167, 129 N. W. 99 ; Bank v. Garcean (1912), 22 N. Dak. 576, 134 N. W. 882; McCarty v. Kepveta (1913), 139 N. W. 992; Dow จ. Lillie (1914), 144 N. W. 1082; Grebe v. Swords (1914), 149 N. W. 126; Com. Security Co. v. Jack (1915), 150 N. W. 460.

Ohio.-Thompson v. Citizens Nat. Bk. of Adams (1909), 32 O. C. 131; State v. Hill (1916), 113 N. F. 1045.

Oklahoma.-Hudson v. Moore (1913), 130 Pac. 774; Jones v. Citizen's State Bank (1913), 135 Pac. 373; Western Ex. Bk. of Kansas
City v. Coleman (1913), 132 Pac. 488; Keisel v. Baldock (1915), 154 Pac. 1194; Barry จ. Kniseley (1916), 155 Pac. 1168; Phillips v. Hargardine-McKittrick Co. (1916), 159 Pac. 320; Huston v. Domeuy (1918), 173 Pac. 805; Daniels v. Bunch (1918), 172 Pac. 1086; Callahan v. Thurmond (1918), 172 Pac. 798.

Oregon.- Matlock v. Scheuerman (1908), 51 Oreg. 49, 93 Pac. 823, 17 L. R. A. (N. S.) 747; Mills v. Keep (1912), 197 Fed. 360; Baldwin Co. v. Savage (1916), 159 Pac. 80; Rostad v. Thorsen (1917), 163 Pac. 423; Wicks v. Metcalf (1917), 163 Pac. 988; Kohler \& Chase Co. v. Savage (1917), 167 Pac. 789.

Pennsylvania.- Second Nat. Bk. of Pittsburg v. Hoffman (1911), 229 Pa. St. 429, 78 Atl. 1002.

Rhode Island.-Hill v. Veloso (1915), 31 R. I. 160.

South Dakota.- Peterson v. Hoftiezer (1915), 150 N. W. 934.

Tennessee.-Unaka Nat. Bk. v. Butler (1904), 113 Tenn. 674, 83 S. W. 655 .

Texas.-Henderson v. MeDaniel (1916), 186 S. W. 865.

Utah.- Cole Banking Co. v. Sinclair (1908), 34 Utah, 454, 98 Pac. 411; Leavitt v. Thurston (1911), 38 Utah, 351, 113 Pac. 77.

Virginia.-Aragon Coffec Co. v. Rogers (1906), 105 Va. 51; Pennington $v$. Third Nat. Bk. of Columbus, Ga. (1913), 77 S. E. 455.

Washington.-Yakima Valley Bk. §. AcAllister (1905), 37 Wash. 566, r9 Pac. 1119; Nethercutt v. Hopkins (1905), 35 Wash. 5\% . So Pac. 798 ; Keene v. Behan (1905), 40 Wash. 505, S2 Pac. 884; Hynes v. Plastino (1906), 45 Wash. 190, 87 
Pac. 1127; Moyses v. Bell (1911), 62 Wash. 534, 114 Pac. 193; Wells v. Duffy (1912), 69 Wash. 310; Fournier v. Cornish (1913), 133 Pac. 9 ; Shultz v. Crewdson (1917), 163 Pac. 734 .

Wisconsin. - The New Bank of Eau Claire v. Kleiner (1901), 112 Wis. 287; Hodge v. Smith (1907), 130 Wis. 326,110 N. W. 192; Aukland v. Arnold (1907), 131 Wis. 64, City v. Coleman (1913), 132 Pac. 111 N. W. 212; Quiggle v. Herman (1907), 131 Wis. 379,111 N. W. 479; Samson v. Ward (1911), 147 Wis. 48,132 N. W. 629 .
Wyoming.-Acme Coal Co. v. Northrup Nat. Bk. of Iola (1915), 146 Pac. 593; Holdsworth v. Blyth \&. Fargo (1915), 146 Pac. 603.

United States.-Wood v. Babbitt (1907), 149 Fed. 818; Wirt v. Stubblefield (1900), 17 App. D. C. 283 ; Yates Nat. Bk. v. Lauber (1915), 240 Fed. 237; Patten v. Duntley (1915), 227 Fed. 381 (C. C. A., 7th Ct.) ; Bk. of Morehead v. Hernig (1908), 220 Pac. 224; Culter v. Fray (1917), 240 Fed. 238; Yates Center Nat. Bk. v. Schaede (1917), 240 Fed. 240.

Section 56. To constitute notice of an infirmity in the instrument or defect in the title of the person negotiating the same, the person to whom it is negotiated must have had actual knowledge of the infirmity or defect, or knowledge of such facts that his action in taking the instrument amounted to bad faith.

Alabama.-Elmore Co. Bk. v. Avant (1914), 66 So. 509; Sherrill v. Merch. \& Mech. Tr. \& Sav. Bk. (1916), 70 So. 723.

Arizona.- Ellis v. First Nat. Bk. (1918), 172 Pac. 281; Phoenix Safety Inv. Co. v. Michaels (1919), 176 Pac. 587.

Arkansas.- Keathley v. Holland Banking Co. (1914), 166 S. W. 935; Pinson v. Cobb (1914), 166 S. W. 943; Little v. Arkansas Nat. Bk. (1914), 167 S. W. 75; Hamburg Bank v. Ahrens (1915), 177 S. W. 14; Morehead v. Harris (1916), 182 S. W. 521; Manley Carriage Co. v. Fowler \& Hill (1917), 194 S. W. 708.

Colorado.-First Nat. Bk. of Iowa City v. Smith (1913), 136 Pac. 460; Wedge Mines Co. v. Denver Nat. Bk. (1903), 19 Colo. App. 182, 73
Pac. 873 ; Burnham Investment Co. v. Sethman (1918), 171 Pac. 884.

Connecticut.- Tice v. Moore (1909), 82 Conn. 244, 73 Atl. 133; Johnson Co. Sav. Bk. v. Walker (1909), 82 Conn. 24 ; s. c., 79 Conn. 348, 65 Atl. 132 (1906), 80 Conn. 509, 69 Atl. 15; First Nat. Bk. v. Fairfield Auto Co. (1917), 99 Atl. 577.

Florida._Jones v. The Manitowoc Shipbuilding \& Dry Dock Co. (1913), 65 Fla. 467; Bland v. Fidelity Tr. Co. (1916), 71 So. 630 ; Bass v. Lee (1917), 74 So. 7.

Idaho.- Winter v. Nobs (1910), 9 Ida. 18, 112 Pac. 525; Shellenberger v. Nourse (1911), 20 Ida. 323, 118 Pac. 508; Park v. Johnson (1911), 20 Ida. 548, 119 Pac. 52; Park v. Brandt (1911), 20 Ida. 6000, 119 Pac. 877; Vaughan v. Johnson 
(1911), 20 Ida. 669, 119 Pac. 879; Winter v. Hutchins (1911), 20 Ida. 749, 119 Pac. 883; Vaughan v. Brandt (1912), 21 Ida. 628, 123 Pac. 591; McCarty v. Lowry (1912), 123 Pac. 943; Redficld v. Wells (1918), 173 Pac. 640.

Illinois.-Schintz v. Am. Tr. \& Sav. Bk. (1909), 152 Ill. App. 76; Peterson v. Emery (1910), 154 Ill. App. 294; First Nat. Bk. of Mattoon v. Seass (1910), 158 Ill. App. 122; Black v. Downes (1912), 176 IIl. App. 358; Christina v. Cuseniano (1912), 129 Ill. 873, 57 So. 157; Richter v. Burdock (1913), $257 \mathrm{nl}$. 410, 100 N. F. 1063.

Indiana.- Bright Nat. Bk. v. v. Kartman (1915), 109 N. E. 846; Boxell v. Bright Nat. Bk. of Flora (1916), 110 N. E. 962; Parker v. Hickman (1916), 111 N. E. 649.

Iowa.-McKnight v. Parsons (1907), 136 Iowa, 390, 113 N. W. 858, 125 Am. St. Rep. 265; Iowa Nat. Bk. v. Carter (1909), 144 Iowa, 715, 123 N. W. 237; Arnd v. Aylesworth (1909), 145 Iowa, 185, 123 N. W. 1000 ; Citizen's State Bk. v. Lankin (1912), 134 N. IV. 882; Farmer's \& Mech. State Bk. v. Shaffer (1914), 147 N. W. 851; Stotts v. Fawfield (1914), $145 \mathrm{~N}$. W. 61; Higby v. Bahrenfus (1917), 163 N. W. 247; Limdeau v. Hamilton (1918), 169 N. W. 208.

Kansas.- Youle v. Fosha (1907), 76 Kans. 20, 90 Pac. 1090; People's Bk. of Minneapolis v. Reid (1912), 120 Pac. 339; Murchison v. Nies (1912), 87 Kans. 77; Ireland v. Shore (1914), 137 Pac. 926; First Nat. Bk. of Elk City v. Dikeman (1915), 153 Pac. 559; Elmo State Bk. v. Hildebrand (1919), 177 Pac.
6; Oscar Schmidt, Inc. v. Benedict (1919), 178 Pac. 444.

Kentucky.- Lawson v. First Nat. Bk. of Fulton (1907), $31 \mathrm{Ky}$. L. 318, 102 S. W. 324 ; Chateau Tr. \& Banking Co. v. Smith (1909), 133 Ky. 418, 118 S. W. 279; Bothwell v. Corum (1909), $135 \mathrm{Ky} .767,123$ S. W. 291; Childs v. Billiter (1911), 137 S. W. 795; Am. Nat. Bk. v. Madison (1911), 144 Ky. 152, 137 S. W. 1076; Ham v. Merritt (1912), 150 Ky. 11, 149 S. W. 1131; As. bury v. Taube (1912), $151 \mathrm{~S}$. W. 372 ; Citizens Bk. v. Crittenden Record-Press (1912). 150 Ky. 634 ; Gahren, Dodge \& Maltby v. Parkersburg Nat. Bk. (1914), 162 S. W. 1135 ; Elk Valley Coal Co. v. Third Nat. Bk. of Lexington (1914), 163 S. W. 766; Riehm v. Ill. Tr. \& Sav. Bk. (1915), 176 S. W. 32; Cit. Tr. \& Guar. Co. v. Hays (1915), 180 S. W. 811; Eichberg v. Board of Education (1915), 178 S. W. 1075; Bank of Willard v. Pennsylvania \& Ky. Firebrick Co. (1917), 194 S. W. 110; Citizens' State Bk. of Greenup v. Johnson County (1919), 207 S. W. 8.

Louisiana.- Wolf v. Zachary \& N. E. R. Co. (1911), 128 La. 1092, 55 So. 685; Dreyfuss v. Papalia (1918), 78 So. 843.

Maryland.-Black v. First Nat. Bk. (1903), 96 Md. 399, 54 Atl. 88; Valley Sav. Bk. v. Mereer (1903), 97 Md. 458, 55 Atl. 435; Weant v. Southern Tr. \& Dep. Co. (1910). 112 Md. 463, 7f Atl. 289; Wilson v. Kelso (1911), 115 Md. 162. so Atl. 895; Zielian v. Baltimore Plate Ice Co. (1911), 115 Md. 658. 81 Atl. 22 ; Denton Nat. Bk. v. Kenney (1911), 116 Md. 124, s1 Atl. 227.

Massachusetts. - Mass. Nat. Bk. 
v. Snow (1905), 187 Mass. 159, 72 N. E. 959; Fillebrown v. Hayward (1906), 190 Mass. 472, 77 N. E. 45; Bass v. Inhabitants of Wellesley (1906), 192 Mass. 526; City of Newburyport v. Fid. Mut. L. Ins. Co. (1908), 197 Mass. 596, 84 N. E. 111; Feigenspan v. McDonald (1909). 201 Mass. 341,87 N. E. 624 ; City of Newburyport v. Spear (1910), 204 Mass. 146; Ford v. Shapiro (1910), 207 Mass. 108; Brown v. Newburyport (1911), 209 Mass. 259; Broadway Nat. Bk. of Chelsea v. Hefferman (1915), 107 N. E. 921; Paika v. Perry (1917), 114 N. E. 830.

Michigan.-Hakes v. Thayer (1911), 131 N. W. 174; Van Slyke v. Rooks (1914), 147 N. W. 579; Stevens v. Venema (1918), $168 \mathrm{~N}$. W. 531 .

Minnesota.- Pope v. Ramsey Co, State Bk. (1917), 162 N. W. 1051; State Bank of Morton v. Adams (1919), 170 N. W. 925.

Missouri.-Chitwood v. Hatfield (1909), 136 Mo. App. 688; Burchett v. Fink (1909), 139 Mo. App. 381; Johnson Co. Sav. Bk. v. Redfearn (1910), 141 Mo.'App. 386; Reeves v. Litts (1910), 143 Mo. App. 19ô, 128 S. W. 246; Settles v. Moore \& Scobee (1910), 149 Mo. App. 724; Hill v. Dillon (1910), 151 Mo. App. 86; Coleman v. Stocke (1911), 159 Mo. App. 43, 139 S. W. 216; Link v. Jackson (1911), 158 Mo. App. 63, 139 S. W. 588; St. Charles Sav. Bk. v. Edwards (1912), 243 Mo. 553, 147 S. W. 978; Hill v. Dillon (1913), 161 S. W. 881; Southwest Bk. of Kansas City v. House (1913), 157 S. W. 809 ; State Bk. of Freeport v. Cape Girardeau \& C. R. Co. (1913), 155 S. W. 1111; Farmers
Sav. Bk. v. Reed (1915), 180 S. W. 1002 ; Mercantile Tr. Co. v. Donk (1915), 178 S. IV. 113; Willis v. Reed (1916), 190 S. W. 377; Central Bank of Columbia v. Lyda (1917), 191 S. W. 245; Mech. Am. Bk. v. Helenbacher (1918), 201 S. W. 383; German-American Bank v. Smith (1919), 208 S. W. 878; Atkins v. Brown (1919), 208 \$. W. 502.

Montana.- State Bk. of Moore $\mathbf{v}$. Forsythe (1910), 41 Mont. 249; Buhler v. Loftus (1917), 165 Pac. 601; Baker State Bank v. Grant (1917), 166 Pac. 27.

Nebraska.-First State Bank of Pleasant Dale v. Borchers (1909), 83 Neb. 530, 120 N. W. 142; Benton v. Sikyta (1909), 84 Neb. 808 , 122 S. W. 60 ; Bolew v. Wright (1911), 89 Neb. 116, 131 N. W. 185 ; Storz Brewing Co. v. Skirving (1913), 142 N. WV. 669; Ostenberg v. Kavka (1914), 145 N. W. 713; Hatfield v. Jakway (1919), $170 \mathrm{~N}$. IV. 181 .

New Jersey.-Borough of Montwale v. Peoples Bk. (1907), 87 Atl. 67; Rice v. Barrington (1908), 75 N. J. L. 806, 70 Atl. 169; DeYonge \& Co. v. Woodport Hotel \& Land Co. (1909), 77 N. J. L. 233; Davis v. Clark (1914), 90 Atl. 303.

New Mexico.-Sandall v. Norment (1915), 145 Pac. 259.

New York.-First Nat. Bk. of Fort Worth v. Am. Ex. Nat. Bk. (1900), 49 A. D. 349 ; McCannon v. Shantz (1900), 149 A. D. 460; McGroh's Sons So. v. Schneider (1901), 34 Misc. 195, 68 N. Y. Supp. 682; Ketcham v. Govin (1901), 35 Misc. 375, 71 N. Y. Supp. 991; Metropolitan Bk. v. Engel (1901), 66 A. D. 273; Campbell v. Upton (1901), 
66 A. D. 434 ; Citizens Bk. of Buffalo $v$. The Rung Furniture Co. (1902), 76 A. D. 471; Sutherland v. Mead (1903), 80 A. D. 103, 80 N. Y. Supp. 504 ; Perth-Amboy Mut. Loan Assn. v. Chapman (1903), 80 A. D. 556; Packard v. Windholz (1903), 40 Misc. 347, affirmed 88 A. D. 365 ; Jennings v. Carlucci (1904), 87 N. Y. Supp. 475; Schreyer v. Bailey \& Co. (1904), 97 A. D. 185; Meuer v. Phenix Nat. Bk. (1904), 94 A. D. 331,88 N. Y. Supp. 83; Poess v. Twelfth Ward Bk. (1904), 43 Misc. 45, 86 N. Y. Supp. 857; Orr v. So. Amboy Terra Cotta Co. (1905), 94 N. Y. Supp. 524, 47 Misc. 604; Hamilton Nat. Bk. v. Upton (1905), 100 A. D. 105; Douglass v. Richards (1906), 116 A. D. 27; Nat. Bk. of Newport v. Snyder Mfg. Co. (1907), 117 A. D. 370,102 N. Y. Supp. 478; Siegmeister v. Lispenard Realty Co. (1907), 107 N. Y. Supp. 158; Rice v. Eisler (1907), 119 A. D. 132; Schlesinger v. Lehmaier (1908), 191 N. Y. 69,83 N. E. 657,16 L. R. A. (N. S.) 626, 123 Am. St. 591; Ward v. City Tr. Co. (1908), 192 N. Y. 61,84 N. E. 585 ; The Royal Bk. of N. Y. v. German-Am. Ins. Co. (1908), 58 Misc. 563; U. S. Ex. Bk. v. Zimmerman (1908), 113 N. Y. Supp. 33; Strauss v. St. Louis Co. Bk. (1908), 126 A. D. 647; Barbieri v. Casazza (1909), 115 N. Y. Supp. 1074 ; Republic Life Ins. Co. v. Hud. son Trust Co. (1909), 130 A. D. 618; Squire v. Ordemann (1909), 194 N. Y. 394; Frank v. Wolff (1910), 125 N. Y. Supp. 530; Niagara Woolen Co. v. Pacific Bank (1910), 141 A. D. 265; Cluett v. Couture (1910), 140 A. D. 830, 125 N. Y. Supp. 813; Havana Cent. R.
Co. v. Knickerbocker Trust Co. (1910), 198 N. Y. 422; Eisenberg v. Lefkowitz (1911), 142 A. D. 569; Hurst v. Lee (1911), 143 A. D. 614, 127 N. Y. Supp. 1040; Kennedy v. Spilka (1911), 129 N. Y. Supp. 390; Rafsky v. Fred A. Smith Co. (1913), 139 N. Y. Supp. 1088; Clcary v. Dykeman (1914), $146 \mathrm{~N}$. Y. Supp. 611 ; Coffin v. Tevis (1914). 149 N. Y. Supp. 986, 164 Misc. 314 ; Feusterer v. Pressure Lighting $\mathrm{Co}$. (1914), 149 N. Y. Supp. 49, 85 Mise. 621; Rosenbaum v. Roth (1914), 150 N. Y. Supp. 396, 164 A. D. 617; Cole v. Harrison (1915), 153 N. Y. Supp. 200; Flood v. Steinmetz (1915), 153 N. Y. Supp. 192; Oliner v. Gronich (1915), 154 N. Y. Supp. 612; Anchor Realty Co. v. Bankers Trust Co. (1916), $161 \mathrm{~N}$. Y. Supp. 300; Hartford Nat. Bk. v. Gardner (1916), 157 N. Y. Supp. 849; Thornton $\nabla$. Netherlands-Amer. Steam Nav. Co. (1917), 165 N. Y. Supp. 682; Monk v. 23d Ward Bank (1917), 165 N. Y. Supp. 1055; Hudson Boiler Mfg. Co. v. Cardillo (1919), 174 N. Y. Supp. 638.

North Carolina.- Toms v. Jones (1900), 127 N. Car. 464; Setzer v. Deal (1904), 135 N. Car. 428; Murchison Nat. Bk. v. Dunn Oil Mills Co. (1909), 150 N. Car. 718, 64 S. E. 885 ; Johnston Co. Sav. Bk. v. Chase (1909), 151 N. Car. 10S; Bk. of Sampson v. Hatcher (1909), 151 N. Car. 359,66 S. F. 308 ; First Nat. Bk, of Lumberton v. Brown (1912), 160 N. Car. 23; Vance v. Bryan (1912), 158 N. Car. 502, $\tau 4$ S. E. 459 ; J. L. Smathers \& Co. v. Toxaway Hotel Co. (1913), 78 S. E. 224; First Nat. Bk. v. Warsaw Drug Co. (1914), 81 S. E. 993; Smathers \& Co. $\nabla$. Toxoway Hotel 
Co. (1914), 83 S. E. 844; Sykes v. Fverett (1914), 83 S. E. 585.

North Dakota.-Walters v. Rock (1908), 18 N. Dak. 45, 115 N. W. 511; Am. Nat. Bk. v. Lundy (1910), 21 N. Dak. 167, 129 N. W. 99; Bank v. Garcean (1912), 22 N. Dak. 576, $134 \mathrm{~N}$. W. 882; MeCarty v. Kepweta (1913), 139 N. W. 992; Stockyard Nat. Bk. of St. Paul, Minn. v. First Nat. Bank of Towner, N. D. (1918), 249 Fed. 421.

Ohio.-Thompson v. Citizens Nat. Bk. of Adams (1909), 32 O. C. 131; Hamilton Mach. Tool Co. v. Memphis Nat. Bk. (1911), 84 Ohio St. 184, 95 N. E. 777.

Oklahoma.-First State Bk. of Oklahoma v. Tobin (1913), 134 Pac. 395; Hudson v. Moore (1913), 130 Pae. 774; Jones v. Citizen's State Bk. (1913), 135 Pac. 373; Western Ex. Bk. of Kansas City v. Coleman (1913), 132 Pac. 488; Hardin v. Dale (1915), 146 Pac. 717; Tr. \& Sav. Bk. of Charles City v. Gleich: man (1915), 150 Pac. 908; Ringer v. Wilson (1916), 154 Pac. 1145; Cline v. First Nat. Bk. (1918), 170 Pac. 472; Mangold \& Glandt Bk. v. Utterback (1918), 174 Pac. 542; Producer's Nat. Bank v. Elrod (1918), 173 Pac. 659.

Oregon.-Everding \& Farrell v. Taft (1916), 160 Pac. 1160.

Pennsylvania.- Johnson Co. Sav. Bk. v. Kock (1908), 38 Pa. Super. Ct. 553; Lowry National Bank v. Hazard (1909), 223 Pa. 520; People's Nat. Bk. of Pensacola v. Hazard (1911), 80 Atl. 554; Washington \& Canonsburg Ry. Co. v. Murray (1914), 211 Fed. 440; Dominion Trust Co. v. Hildner (1914), 20 Atl. 69; Cox \& Sons Co. v.
Northampton Brewing Co. (1914), 91. Atl. 859; Levy v. Gilligan (1914), 90 Atl. 647.

South Carolina.-Merchants Nat. Bk. v. Smith (1918), 96 S. E. 690.

Tennessee.-Unaka Nat. Bk $\nabla$. Butler (1904), 113 Tenn. 674, 83 S. W. 655; Ford v. Brown (1905), 114 Tenn. 467; Pease \& Dwyer Co. v. State Nat. Bk. (1905), 114 Tenn. 693, 88 S. W. 172; Jefferson Bk. of St. Louis v. Chapman-Whitee Lyons Co. (1909), 122 Tenn. 415, $123 \mathrm{~S}$. W. 641; First Nat. Bk. of Elgin, Ill. v. Russell (1911), 139 S. W. 734 ; Madison Tr. Co. v. Stahlman (1916), 183 S. W. 1012.

Texas.- Henderson v. MeDaniel (1916), 186 S. W. 865.

Utah.-Cole Banking Co. v. Sinclair (1908), 34 Utah, 454, 98 Pac. 411; McCormiek v. Swem (1909), 36 Utah, 6, 102 Pac. 626.

Virginia.-Aragon Coffee Co. v. Rogers (1906), 105 Va. 51; City Nat. Bk. of Roanoke v. Hundley (1911), 70 S. E. 494; Pennington v. Third Nat. Bk. of Columbus, Ga. (1913), 77 S. E. 455; City Nat. Bk. v. McDonald (1914), 83 S. E. 389; Hawkes v. Bowles (1916), 2 Va. Law Reg. N. S. 268; Ratcliffe v. Costello (1915), 85 S. E. 469; Fleshman v. Bibb (1916), 88 S. E. 64; Castron v. Bostic (1918), 96 S. E. 845.

Washington.-MeNamara v. Jose (1902), 28 Wash. 461; Yakima Va)ley Bk. v. McAllister (1905), 37 Wash. 566, 79 Pac. 1119; Keene v. Behan (1905), 40 Wash. 505, 82 Pac. 884; Johnson Co. Sav. Bk. v. Rapp (1907), 47 Wash. 30, 91 Pac. 382 ; Spencer v. Alki Point Transp. Co. (1909), 53 Wesh. 77, 101 Pac. 
509; Gray v. Boyle (1909), 55 Wash. 578, 104 Pac. 828; Seandanavian Am. Bk. v. Johnston (1911), 63 Wash. 187, 115 Pac. 102; Scandanavian Am. Bk. v. Appleton (1911), 63 Wash. 203, 115 Pac. 109; Wells v. Duffy (1912), 69 Wash. 310; Fournier v. Cornish (1913), 133 Pac. 9; Washington Trust Co. v. Keyes (1914), 139 Pac. 638; Citizens Bk. \& Trust Co. v. Limpright (1916), 160 Pac. 1046; City Nat. Bk. v. Shelton Elec. Co. (1917), 164 Pac. 993; Schultz v. Crewdson (1917), 163 Pac. 734.

West Virginia.- Interstate Finance Co. v. Schroder (1914), 81 S. E. 552 .

Wisconsin.-Quiggle $\nabla$. Herman (1907), 131 Wis. 379,111 N. W. 479; Pelton v. Spider Lake S. \& L. Co. (1907), 132 Wis. 219, 112 N. W. 29, 122 Am. St. 963; Kipp v. Smith (1908), 137 Wis. 234, 118 N. W. 848.
Wyoming.-Holdsworth v. Blyth \& Fargo (1915), 146 Pac. 603.

United States.-Hutchins v. Langley (1906), 27 A. C. (D. C.) 34; Martin v. Poole (1911), 36 A. C. (D. C.) 281; Howell v. Commercial Nat. Bk. (1913), 40 A. C. (D. C.) 370; Hazen v. Van Senden (1915), 43 D. C. App. 161; Mills v. Keep (1912), 197 Fed. 360; First Nat. Bk. of Shenandoah v. Linver (1911), 187 Fed. 16, 109 U. S. C. C. A. 70; Nat. Bk. of Commerce in St. Louis $\nabla$. Sancho Pag. Co. (1911), 110 C. C. A. 112,186 Fed. 257; Amalgamated Sugar Co. v. U. S. Nat. Bk. of Portland (1911), 109 C. C. A. 494; Young v. Lowry (1912), 192 Fed. 825, 113 C. C. A. 149 ; Bison St. Bk. v. Billington (1915), 228 Fed. 116; Piedmont \& Caro Ry. Co. v. Shee (1915), 223 Fed. 973; Postal Tel. Cable Co. v. Citizens Nat. Bk. (1916), 228 Fed. 601; Brent v. Simpson (1915), 238 Fed. 285.

Section 57. A holder in due course holds the instrument free from any defect of title of prior parties, and free from defenses available to prior parties among themselves, and may enforce payment of the instrument for the full amount thereof against all parties liable thereon.

Alabama.- Snead v. Barclift (1911), 2 Ala. App. 297; Norris v. Merchants Nat. Bk. (1911), 2 Ala. App. 434, 57 So. 71; Bledsoe v. City Nat. Bk. of Selma (1912), 7 Ala. App. 195, 60 So. 942; Hudson v. Repton State Bk. (1917), 75 So. 695; Jones จ. Martin (1917), 74 So. 761; Jones จ. Bell (1917), 77 So. 918; Sample v. Tennessee Valley Bk. (1917), 76 So. 936; Vogler จ. Manson (1917), 76 So. 117.

Arkansas-Little $\nabla$. Arkansss
Nat. Bk. (1914), 167 S. W. 75; Manley Carriage Co. v. Fowler and Hill (1917), 194 S. W. 708; Huff v. Iowa City State Bk. (1918), 204 S. W. 306.

Connecticut.- Mersick v. Alderman (1905), 77 Conn. 634, 60 Atl. 109 ; Johnson Co. Sav. Bk. v. Walker (1909), 82 Conn. 24 ; s. c., 79 Conn. 348,65 Atl. 132 (1906), and 80 Conn. 509, 69 Atl. 15; Continental Credit Co. v. Ely (1917), 100 Atl. 435. 
Delaware.-Security Tr. \& Safe Dep. Co. v. Duross (1913), 86 Atl. 209.

Florida.-Jones $\mathbf{v}$. The Manitowoc Shipbuilding and Dry Dock Co. (1913), 65 Fla. 467; Bland v. Fidelity Co. (1916), 71 So. 630.

Idaho.-McCarty v. Lowry (1912), 123 Pac. 943; Nelson v. Hudgel (1913), 23 Ida. 327, 130 Pac. 85; Southwest Nat. Bk. of Kansas City v. Baker (1913), 23 Ida. 428, 130 Pac. 799; Harshbarger v. Eby (1916), 156 Pac. 619.

Illinois-Black v. Downes (1912), 176 Ill. App. 358; Richter v. Burdock (1913), 257 I1l. 410, 100 N. E. 1063; Niblack v. Farley (1919), 122 N. E. 160 .

Iowa.-Commercial Nat. Bk. v. Citizens State Bk. (1906), 132 Iонa, 706, 109 N. W. 198; Vander Ploey v. Van Zunk (1907), 135 Iowa, 350, 112 N. W. 807; Mcknight v. Parsons (1907), 136 Iowa, 390, $113 \mathrm{~N}$. IV. 858, 125 Am. St. 265; Kushner v. Abbott (1912), 137 N. W. 913.

Kansas.- Nyhart v. Kubach (1907), 76 Kans. 154, 90 Pac. 796; Gate City Nat. Bk. v. Thrall (1911), 85 Kans. 394.

Kentucky.- Alexander v. Hazelrigg (1906), $123 \mathrm{Ky.} \mathrm{677,} 97$ S. W. 353; Citizens Bk. จ. Bk. of Waddy (1907), 126 Ky. 169, 103 S. W. 249; Chateau Tr. and Banking Co. v. Smith (1909), 133 Kу. 418, 118 S. W. 279; Bothwell v. Corum (1909), 135 Ky. 767, 123 S. W. 291; Lovelace $\nabla$. Lovelace (1910), 136 Ky. 452, 124 S. W. 400; Jett г. Standafer (1911), $143 \mathrm{Ky.} \mathrm{787,}$ 137 S. W. 513; Holzbog v. Bakrow (1913), 160 S. W. 792; GahrenDodge and Maltby v. Parkersburg Nat. Bk. (1914), 162 S. W. 1135;
Pratt v. Rounds (1914), 169 S. W. 848.

Louisiana.-Wolf v. Zachary \& N. E. R. Co. (1911), 128 La. 1092, 55 So. 685.

Maryland.- Weant v. Southern Tr. and Dep. Co. (1910), 112 Md. 463. 77 Atl. 289.

Massachusetts.- Mass. Nat. 'Bk. v. Snow (1905), 187 Mass. 159, 72 N. E. 959 ; Fillebrown v. Hayward (1906), 190 Mass. 472; Colonial Fur Ranching Co. v. First Nat. Bank (1917), 116 N. E. 731; Willard v. Greenwood (1917), 117 N. E. 823.

Michigan. - Hakes v. Thayer (1911), 131 N. W. 174; People's State Bk. v. Miller (1915), 152 ‥ IV. 257.

Missouri-State Nat. Bk. of Shawnee $\nabla$. Levy (1910), 141 Mo. App. 288; Southwest Nat. Bk. of Kansas v. House (1913), 157 S. W. 809; Hadley v. Greenville (1916), 187 S. W. 1096; Miller v. Chinn (1917), 195 S. W. 552.

Montana.-Baker State Bank v. Grant (1917), 166 Pac. 27.

Nebraska. - Benton v. Sikyta (1909), 84 Neb. 808, 122 S. IV. 60; Storz Brewing Co. v. Skirving (1913), 142 N. W. 669; Ostanberg v. Karka (1914), 145 N. W. 713.

New Jersey.-Rice $v$. Barrington (1906), 75 N. J. L. 806, 70 Atl. 169; Davis v. Clark (1914), 90 Atl. 303; Clark v. Barthold (1915), 93 Atl. 699 ; Bensel v. Anderson (1916), 96 Atl. 910 (N. J. Ch.).

New York.-Ketcham v. Govin (1901), 35 Mise. 375, 71 N. Y. Supp. 991; Benedict v. Kress (1904), 89 N. Y. Supp. 607; Greeser v. Sugarman (1902), 76 N. Y. Supp. 922, 37 Misc. 799; Sutherland v. Mead (1903), 80 A. D. 103, 80 N. Y. 
Bupp. 504 ; Albany Co. Bk. v. People's Co-op. Ice Co. (1904), 92 A. D. 47, 86 N. Y. Supp. 73; Broadway Trust Co. v. Manheim (1905), 47 Misc. 415, 95 N. Y. Supp. 93; Schlesinger v. Kelly (1906), 114 A. D. 546,99 N. Y. Supp. 1083; Siegmeister v. Lispenard Realty Co. (1907), 107 N. Y. Supp. 158; The Gansevort Bank of N. Y. v. Gilday (1907), 110 N. Y. Supp. 271, 53 Misc. 107; Schlesinger $v$. Gilhooley (1907), 189 N. Y. 1, 81 N. E. 619; Schlesinger v. Lehmaier (1908), 191 N. Y. 69,83 N. E. 657, 16 L. R. A. (N. S.) 626, 123 Am. St. 591; Bruck v. Lambeck (1909), 118 N. Y. Supp. 494 ; Klar v. Kostink (1909), 119 N. Y. Supp. 683; Hurst v. Lee (1911), 143 A. D. 614, 127 N. Y. Supp. 1040; Eq. Tr. Co. v. Taylor (1911), 131 N. Y. Supp. 475, 72 Misc. 52; Eisenberg v. Lefkowitz (1911), 142 A. D. 569; Broderick \& Bascom Rope Co. v. MeGrath (1913), 142 N. Y. Supp. 496, 81 Misc. 222; Crusins v. Siegman (1913), 142 N. Y. Supp. 348; Cleary v. Dykeman (1914), $146 \mathrm{~N}$. Y. Supp. 611; Emanuel v. Misicki (1914), 149 N. Y. Supp. 905; Oeser v. Behrend (1915), 151 N. Y. Supp. 873; Baldinger \& Kupferman Mfg. Co v. Manf.-Citizens Tr. Co. (1915), 156 N. Y. Supp. 445 ; Curtis v. Davidson (1915), 215 N. Y. 395, 109 N. E. 481 ; Title Guar. Co. v. Pain (1915), 155 N. Y. Supp. 333; Miller v. Campbell (1916), 160 N. Y. Supp. 834; Garone v. Russo Iodice Realty Co, (1917), 164 N. Y. Supp. 135; Thornton v. Netherlands Amer. Steam Nav. Co. (1917), 165 N. Y. Supp. 682; United Cigar Store Co. v. American Raw Silk Co. (1918), 171 N. Y. Supp. 480; Sabine v.
Paine (1918), 223 N. Y. 401, 119 N. F. 849 .

North Carolina.- Muchison Nat. Bk. v. Dunn Oil Mills Co. (1909), 150 N. Car. 718, 64 S. E. 885; Vance v. Bryan (1912), 158 N. Car. 502, 74 S. E. 459 ; Amer. Nat. Bk. of Richmond v. Hill (1915), 85 S. E. 209; Standard Trust Co. v. Commercial Nat. Bk. (1917), 240 Fed. 303, (C. C. A., 4th Ct.).

Nortn Dakota.-Nat. Bk. of Commerce v. Pick (1904), 13 N. Dak. 74, 99 N. W. 63.

Ohio.-Spring Valley Nat. Bk. . Somers (1910), 21 Ohio Dec. 772; Hamilton Mach. Tool Co. v. Memphis Nat. Bk. (1911), 84 Ohio St. 184, 95 N. E. 777.

Oklahoma.-Wood v. Stickle (1912), 128 Pac. 1082; First State Bk. of Oklahoma City v. Tobin (1913), 134 Pac. 395; Hodgins $v$. Northwestern Finance Co. (1915), 148 Pac. 717; Mangold \& Glandt Bk. v. Utterback (1918), 174 Pac. 542.

Oregon.- Lassas v. MeCarty (1906), 47 Oreg. 474, 84 Pac. 76; Amalgamated Sugar Co. v. U. S. Nat. Bk. of Portland, Oreg. (1911), 109 C. C. A. 494; Bailey v. Inland Empire Co. (1915), 146 Pac. 991; Clarinda Trust \& Sav. Bk. v. Doty (1917), 163 Pac. 418.

Pennsylvania. - Homewood People's Bk. v. Heckert (1903), 20i Pa. 231; People's Nat. Bk. of Pensacola v. Hazard (1911), so Atl. 554; In re Young's Estate (1912), 83 Atl. 201; Wolfgang v. Shirley (1913), 86 Atl. 1011.

South Carolina.-Iowa City State Bk. v. Hoefer (1915), 85 S. E. 406.

Tennessee.-Unaka Nat. Bk. v. Butler (1904), 113 Teno. 674, 83 
S. W. 655; Jefferson Bk. of St v. Crewdson (1917), 163 Pac. 734; Louis v. Chapman-Whitee Lyons Co. (1909), 122 Tenn. 415, 123 S. W. 641.

Texas.-Lockney State Bk. v. Martin (1917), 191 S. W. 796 (Tex. Cir. App.); Sayles v. First State Bk. of Abilene (1917), 195 S. IV. 230 (Tex. Civ. App.); Zielinski v. Hernig (1917), 195 S. W. 952 ('Tex. Civ. App. 3.

Utah.-McCormick v. Swem (1909), 36 Utah, 6, 102 Pac. 626; Smith v. Brown (1917), 165 Pac. 468; Rosenblum v. Gonnell (1918), 173 Pac. 243.

Virginia.-Aragon Coffee Co. v. Rogers (1906), 105 Va. 51; Pennington $v$. Third Nat. Bk. of Columbus, Ga. (1913), 77 S. E. 455; Anderson v. Union Bk. of Richmond (1915), 83 S. E. 1080; Fleshman v. Bibb (1916), 88 S. E. 64; Colona v. Parksley Nat. Bk. (1917), $92 \mathrm{~S}$. E. 979 .

Washington.- MeNamara v. Jose (1902), 28 Wash. 461; Jamieson and McFarland v. Heim (1906), 43 Wash. 153, 86 Pac. 165; Amer. Sav. Bk. \& Tr. Co. v. Helgesen (1911), 64 Wash. 54, 116 Pac. 837; Schultz City Nat. Bk. v. Shelton Elec. Co. (1917), 164 Pac. 993; Interstate Finance Co. v. Schroder (1914), 81 S. E. 552 .

West Virginia. - Rusmissell v. White Oak Stave Co. (1917), $92 \mathrm{~S}$. W. 672; Nisson v. Shaffer (1918), 96 S. E. 1023.

Wisconsin.- Quiggle v. Herman (1907), 131 Wis. 379,111 N. W. 479; Arnd v. Sjoblom (1907), 131 Wis. 642,111 N. W. 666 ; Northfield Nat. Bk. v. Arndt (1907), 132 Wis. 383, 112 N. W. 451; Samson v. Ward (1911), 147 Wis. 48, 132 N. W. 629; Green v. Gunsten (1913), 142 N. W. 261.

Wyoming.-Holdsworth v. Blyth and Fargo (1915), 146 Pac. 603.

United States.-First Nat. Bk. of Shenandoah v. Linver (1911), 187 Fed. 16 (Neb.), 109 U. S. C. C. A. 70 ; Nat. Bk. of Commerce in St. Louis v. Sancho Pag. Co. (1911), 110 C. C. A. 112,186 Fed. 257 (La.); Milton v. Pensacola Bk. \& Tr. Co. (1911), 190 Fed. 126, 111 C. C. A. 166; Cutler v. Fry (1917), 240 Fed. 238 (U. S. D. C.).

Section 58. In the hands of any holder other than a holder in due course, a negotiable instrument is subject to the same defenses as if it were non-negotiable. But a holder who derives his title through a holder in due eourse, and who is not himself a party to any frand or illegality affecting the instrument, has all the rights of such former holder in respect of all parties prior to the latter.

Alabama.-- Stone v. Goldberg \& Lewis (1912), 6 Ala. App. 249, 60 So. 744; Jones v. Bell (1917), 77 So. 918 .

Arkansas. - Hooten v. State (1915), 178 S. W. 310; Dodd v.
Axle Nut Sign Co. (1916), $189 \mathrm{~S}$. W. 663 .

California.- Palo Alto \& L. Asso. v. First Nat. Bk. (1917), 164 Pac. 1124.

Connecticut.-Mersick v. Alder. 
$\operatorname{man}(1905), 77$ Conn. 634, 60 Atl. 109 ; Johnson Co. Sav. Bk. $\nabla$. Walker (1909), 82 Conn. 24 ; s. c., 79 Conn. 348, 65 Atl. 1906; 80 Conn. 509, 69 Atl. 15.

Florida.-Tucker v. Fouts (1917), 76 So. 130.

Illinois.-Strauss v. Citizen's St. Bk. of Elmhurst (1911), 164 Ill. App. 420.

Iowa.- McKnight v. Parsons (1907), 136 Iowa, 390, 3 N. W. 858, 125 Am. St. 265; Fullerton Lumber Co. v. Snouffer (1908), 139 Iowa, 176, 117 N. W. 50; City Nat. Bk. v. Jordan (1908), 139 Iowa, 499, 117 N. W. 578; Citizen's State Bk. v. Lankin (1912), 134 N. W. 882; German-Am. Bk. v. Kelley (1917), 166 N. W. 1053.

Kansas.-Underwood v. Fosha (1913), 89 Kans. 768; Smith v. Nelson Land \& Cattle Co. (1914), 212 Fed. 56; Rodgers v. Slaveno (1917), 165 Pac. 655; Stevens v. Keegan (1918), 172 Pac. 1025.

Kentucky.-Austin v. First Nat. Bk. of Scottsville (1912), $150 \mathrm{Ky}$. 113; Bernard v. Napier (1916), 181 S. W. 624 ; Bk. of Willard v. Pennsylvania \& Ky. Firebrick Co. (1917), 194 S. W. 110; Ohio Valley Bk. \& Tr. Co. $\nabla$. Gt. Southern Fire Ins. Co. (1917), 197 S. W. 399; Sparr v. Fulton Nat. Bk. (1918), 201 S. W. 310 .

Louisiana.-Wolf $\nabla$. Zachary \& N. E. R. Co. (1911), 128 La. 1092, 55 So. 685; Dicks v. Johnson (1913), 63 So. 700.

Maryland.-Spoerer v. Wehland (1917), 100 Atl. 287.

Massachusetts.-Symonds v. Riley (1905), 188 Mass. 470, 74 N. E. 926 ; DeReiset v. Longhery (1910), 205 Mass. 8, 91 N. E. 297; Berenson v. Conant (1913), 214 Mass. 127, 101 N. E. 60.

Michigan. - Poss v. Meader (1915), 155 N. W. 425.

Minnesota.-Bk. of Willow River v. Pangerl (1917), 165 N. W. 479. Mississippi.-Adair v. Bank of Hickory Flat (1917), 75 So. 759; Homes Bros, จ. McCall (1916), 74 So. 786 .

Missouri.-Long v. Shafer (1914), 171 S. W. 690; Farmers \& Traders Bk. v. Laird (1915), 175 S. W. 116; Morbrose Inv. Co. v. Flick (1915), 174 S. W. 189; Hadley v. Greenville (1916), 187 S. W. 597; Miller v. People's Sav. Bk. (1916), 186 S. W. 547; Schlanep v. Manewall (191ô), 190 S. W. 658; Miller v. Chinn (1918), 203 S. W. 212.

Montana.-Baker State Bk. v. Grant (1917), 166 Pac. 27; Buhler v. Loftus (1917), 165 Pac. 601.

Nebraska.- Ostenberg v. Kavka (1914), 145 N. W. 713.

New York.-M. Groh's Sons Co. v. Schneider (1901), 34 Mise. 195, 68 N. Y. Supp. 682; Jennings v. Carlucei (1904), 87 N. Y. Supp. 475; Am. Seeding Machine Co. v. Slocum (1907), 108 N. Y. Supp. 1042, 58 Misc. 458; Weiss v. Rieser (1909), 62 Misc. 292, 114 N. Y. Supp. 983; Bruck v. Lambeck (1909), 118 N. Y. Supp. 494; Horan v. Mason (1910), 141 A. D. 59; Royal Bk. of N. Y. v. Reinschreiber (1911), 126 N. Y. Supp. 749; Thornton v. Netherlands-Amer. Steam Nav. Co. (1917), 165 N. Y. Supp. 682; Kelso \& Co. v. Ellis (1919), 224 N. Y. 528, 121 N. E. 364; Furmers State Bk. of Cologne $\checkmark$. McGrath (1919). 170 N. W. 209.

North Dakota. - Bank v. (iareean (1912), 22 N. Dak. 576, 134 N. W. 
882; MoCarty v. Kepveta (1913), 139 N. W. 992.

Ohio.-Thompson v. Citizens Nat. Bk. of Adams, N. Y. (1909), 32 O. C. 131; Spring Valley Nat. Bk. v. Somers (1910), 21 Ohio Dec. 772.

Oklahoma.-City Nat. Bk. v. Kelly (1915), 151 Pac. 1172; Doug. lass v. Brown (1916), 155 Pac. 887; Curless v. Ruland (1916), 155 Pac. 1182; Deming Investment Co. v. Shannon (1917), 162 Pac. 471.

Oregon.-Hull v. Agnus (1911), 60 Oreg. 95, 118 Pac. 284.

Pennsylvania.-Lindsay v. Dutton (1907), 217 Pac. 148, 66 Atl. 250.

South Dakota.- Muschelwicz v. Tidrick (1918), 167 N. W. 499.

Texas.-Landon v. Huston Drug Co. (1916), 190 S. W. 534.

Virginia.-Aragon Coffee Co. v. Rogers (1906), 105 Va. 51; Pennington v. Third Nat. Bk. of Columbus, Ga. (1913), 77 S. E. 455; Cit. Nat. Bk. v. MeDonald (1914), 83 S. E. 389.
Washington.- Bradley Engineering \& Mfg. Co. v. Heyburn (1910), 56 Wash. 628, 106 Pac. 170; Moyses v. Bell (1911), 62 Wash. 534, 114 Pac. 193; Wells v. Duffy (1912), 69 Wash. 310; Fournier v. Cornish (1913), 133 Pac. 9; Metzger v. Sigall (1914), 145 Pac. 72.

Wisconsin.-Andrews v. Robertson (1901), 111 Wis. 324, 87 N. W. 190; Marling v. Fitzgerald (1909), 138 Wis. 93, 120 N. W. 338; Comstock v. Buckley (1910), 141 WVis. 228,124 N. W. 414.

United States. - Wirt v. Stubblefield (1900), 17 A. C. (D. C.) 283; Bryan v. Barr (1903), 21 D. C. App. 190; Amalgamated Sugar Co. v. U. S. Nat. Bk. of Portland, Oreg. (1911), 109 C. C. A. 494; Nat. Bk. of Commerce in St. Louis v. Sancho Pag. Co. (1911), 110 C. C. A. 112, 186 Fed. 257; Herman v. Combs (1912), S5 Atl. 1044; Cutler v. Fray (1917), 240 Fed. 238; Yates Center Nat. Bk. v. Schaede (1917), 240 Fed. 240.

Section 59. Every holder is deemed prima facie to be a holder in due course; but when it is shown that the title of any person who has negotiated the instrument was defective, the burden is on the holder to prove that he or some person under whom he claims acquired the title as holder in due course. But the last-mentioned rule does not apply in favor of a party who became bound on the instrument prior to the acquisition of such defective title.

Alabama.-Bledsoe v. City Nat. Bk. of Selma (1912), 7 Ala. App. 195, 60 So. 942 ; Bruce v. Citizen's Nat. Bk. of Lineville (1913), 63 so. 82; Ger.-Am. Nat. Bk. v. Lewis (1913), 63 So. 741; Tatum v. Commercial Bk. \& Tr. Co. (1914), 64 So. 561; Ger.-Am. Nat. Bk. v. Lewis (1913), 9 Ala. App. 352;
Hudson v. Repton State Bk. (1917), 75 So. 695; Davies v. Simpson (1918), 79 So. 48.

Arkansas. - Pinson v. Cobb (1914), 166 S. W. 943; Keathley v. Holland Banking Co. (1914), $166 \mathrm{~S}$. W. 953; Williamson v. Miles (1914), 169 S. W. 368; Finney v. Rollins (1917), 192 S. W. 210. 
California.-Burns v. Bauer

(1918), 174 Pac. 346.

Colorado.- Johnson Co. Sav. Bk. \. Gregg (1911), 51 Colo. 358, 117 Pac. 1003; First Nat. Bk. of Iowa City v. Smith (1913), 136 Pac. 460; Irvine v. Minshull (1915), 152 Pac. 1150.

Connecticut.-Parsons v. Utica Cement Mfg. Co. (1907), 80 Conn. 58, 66 Atl. 1024; Johnson Co. Sav. Bk. v. Walker (1909), 82 Conn. 24; s. c., 79 Conn. 348, 65 Atl. 132 (1906), 80 Conn. 509, 69 Atl. 15; Harris v. Johnson (1915), 93 Atl. 126; New Haven Nat. Banking Assn. v. Jordan (1918), 104 Atl. ¿92.

Forida.- Berryhill-Cromatic Co. v. Manitowoc Shipbuilding \& Dry Dock Co. (1913), 63 So. 720; Bass v. Lee (1917), 74 So. 7.

Idaho.- Winter v. Nobs (1910), 19 Ida. 18, 112 Pac. 525; Park v. Johnson (1911), 20 Ida. 548, 119 Pac. 52; Shellenberger v. Nourse (1911), 20 Ida. 323, 118 Pac. 508; Brown v. Miller (1912), 22 Ida. 307, 125 Pac. 981; Altschul v. Rogers (1912), 63 Ida. 512, 126 Pac. 1048.

Illinois. - Peterson v. Emery (1910), 154 Ill. App. 294; Stitzel v. Miller (1910), 157 Ill. App. 401; Black v. Downes (1912), $176 \mathrm{Ill}$. App. 358; Richter v. Burdock (1913), 257 Ill. 410, 100 N. E. 1063; Christina v. Cuseniano (1912), 129 Ill. 873,57 So. 157 ; MeClory v. Towne (1912), 173 Ill. App. 113; Weir \& Craig Mfg. Co. v. Bonus (1913), 177 Ill. App. 626; Justice v. Stonecipher (1915), 108 N. E. 722, 267 IIl. 448.

Indiana.- Bright Nat. Bk. of Flora v. Hartman (1915), $109 \mathrm{~N}$.
E. 846; Boxell v. Bright Nat. Bk. (1916),112 N. E. 3.

Iow2.- Keegan v. Rock (1905), 128 Iowa, 39, 102 N. W. 805; Vander Ploey v. Van Zunk (1907), 135 Iowa, 350, 112 N. W. 807; Me. Knight v. Parsons (1907), 136 Iowa. $390,113 \mathrm{~N}$. W. $858,125 \mathrm{Am}$. St. 365; Hawkins v. Young (1908), 114 N. W. 1041; City Dept Bk. v. Green (1908), 138 Iowa, 156, 115 N. W. 893; Cox v. Cline (1908), 139 Iowa, 128, 117 N. W. 48; City Nat. Bk. v. Jordan (1908), 139 Iowa, 499, 117 N. W. 578; O'Connor v. Kleiman (1909), 143 Iowa, 435, 121 N. W. 1088; Iowa Nat. Bk. v. Carter (1909), 144 Iowa, 715, $123 \mathrm{~N}$. W. 237; Arnd v. Aylesworth (1909), 145 Iowa, 185, $123 \mathrm{~N}$. IV. 1000 ; Kushner v. Abbott (1912), 137 N. W. 913; Bank of Bushnell v. Buck Bros. (1913), 142 N. W. 1004; LeClere v. Philpott (1915), 151 N. W. 825 ; Robertson v. United States Live Stock Co. (1914), 145 N. W. 535; Stotts v. Fawfield (1914), 145 N. W. 61; Biggs v. Carter (1917), 161 N. W. 322; State v. Wegener (1917), $162 \mathrm{~N} . \mathrm{W}, 1040$; German-Am. Bk. v. Kelley (1918), 166 N. W. 1053; Limdeau v. Hamilton (1918), 169 N. W. 208.

Kansas.- Abemeyer v. First Nat. Bk. of Horton (190\%), 76 Kans. $87 \%$, 92 Pac. 1109; Underwood v. Quantie (1911), 116 Pac. 361; Murchison v. Nies (1912), 87 Kans. 77; The Stock Ex. Bk. v. Wykes (1913), 83 Kans. 750; Ireland v. Shore (1914), 137 Pac. 926; Nat. Bk. v. Lyon. Exchange Bk. (1917), 164 Pac. 13\%; Security State Bk. of Wichita $r$. Seannier (1919), 178 Pac. 239.

Kentucky.-Wilkins v. Usher (1906), 123 Ky. 696, 97 S. W. 37: 
Citizens Bk. v. Bk. of Waddy (1907), $126 \mathrm{Ky} .169,103$ S. W. 249; Callaghan v. Louisville Dry Goods Co. (1910), 14 Ky. 712, 131 S. W. 995; Campbell v. Fourth Nat. Bk. of Cineinnati (1900), 137 Ky. 555, 126 S. W. 114; Asbury v. Taube (1912), 151 S. W. 372; Muir v. Edelen (1913), 160 S. W. 1048; Harrison v. Ford (1914), 165 S. W. 663; Pratt $\vee$. Rounds (1914), 169 S. W. 848 ; Bernard v. Mapier (1916), 181 S. W. 624; Mackenzie จ. Eschman's Exrs. (1917), 192 S. W. 521; Commereial Sec. Co. v. Archer (1918), 201 S. W. 479.

Maryland.-Arnd v. Heckert (1908), 108 Md. 300, 70 At1. 417; Weant v. Southern Tr. \& Dep. Co. (1910), 112 Md. 463, 77 Atl. 289; Stouffer v. Alford (1910), 114 Md. 110, 78 Atl. 387; Wilson $\nabla$. Kelso (1911), 115 Md. 162, 80 Atl. 895.

Massachusetts. - Savage v. Goldsmith (1902), 181 Mass. 420; Regester's Sons \& Co. v. Reed (1904), 185 Mass. 226, 70 N. E. 53; Bass v. Inhabitants of Wellesley (1906), 192 Mass. 526; Feigenspan v. McDonald (1909), 201 Mass. 341, 8т N. E. 624 ; Berenson v. Conant (1913), 214 Mass. 127, 101 N. E. 60; Lewiston Trust \& Safe Dep. Co. v. Shackford (1913), 213 Mass. 432; Munroe v. Stanley (1915), 107 N. E. 1012; Nat. Inv. \& Security Co. v. Cirey (1916), 111 N. E. 357; Colonial Fur Ranehing Co. v. First Nat. Bk. (1917), 116 N. E. 731.

Michigan.-Gen. Conf. Assn. etc. v. Mich. Sanitarium (1911), 166 Mich. 504; Merchants Nat. Bk. v. Wadsworth (1911), 166 Mich. 528, 131 N. W. 1108; Hakes $\nabla$. Thayer (1911), 131 N. W. 174; Crosby v. Reynolds (1912), 196 Fed. 640; Poss v. Meader (1915), 155 N. W. 125 ; Van Slyke $\nabla$. Rooks (1914), 147 N. W. 579 .

Minnesota.-Ger.-Am. Bk. of Ritzville v. Lyons (1914), 149 N. IV. 658; Stevens v. Pearson (1917), 163 N. W. 770.

Missouri. - Burchett v. Fink (1909), 139 Mo. App. 381; State Nat. Bk. of Shawnee v. Levy (1910), 141 Mo. App. 288; Johnson Co. Sav. Bk. v. Redfearn (1910), 141 Mo. App. 386; Bk. of Ozark v. Hanks (1910), 142 Mo. App. 110. 125 S. W. 221; Reeves v. Litts (1910), 143 Mo. App. 196, 128 S. W. 246 ; Johnson Co. Sav. Bk. v. Mills (1910), 14 3Mo. App. 265, 127 S. W. 425 ; Bk. of Ozark v. Tuttle (1910). 144 Mo. App. 294; Settles v. Moore \& Seobee (1910), 149 Mo. App. 724; Hill v. Dillon (1910), 151 Mo. App. 86; Jones v. Miner's \& Merchants Bk. (1910), 128 S. W. 829; Jobes v. Wilson (1910), 124 S. W. 548; Link v. Jaekson (1911), 158 Mo. App. 63, 139 S. W. 588; Bireh Tree State Bk. v. Dowler (1912), 163 Mo. 65, 145 S. W. 843; Hill v. Dillon (1913), 161 S. WV. 881; State Bk. of Freeport v. Cape Girardeau \& C. R. Co. (1913), 155 S. W. 1111; Nance v. Hayward (1914), $170 \mathrm{~S}$ IV. 429; Wade v. Boone (1914), 168 S. W. 360; Wing v. Un. Cent. Life Ins. Co. (1914), 168 S. W. 917; Bank of Polk v. Wood (1915), 173 S. W. 1093; Chandler v. Hedrick (1915), 173 S. IV. 93; Farmers \& Merchants Bk. v. Munson (1915), 177 S. W. 778; Engles v. Williams (1918), 203 S. W. 671.

Montana.- State Bk. of Moore $\nabla$. Forsythe (1910), 41 Mont. 249; N. IV. Improvement Co. v. Rhoades (1916), 158 Pac. 832; Citizen's State 
Bk. of Roundup v. Smelling (1919), 178 Pac. 744.

Nebraska.-Bolew v. Wright (1911), 89 Neb. 116, 131 N. W. 185;

Central Nat. Bk. . Ericson (1912), 92 Neb. 396, 138 N. WV. 563; Ostenberg v. Kavka (1914), 145 N. W. 713; Marshall v. Kirschbaum (1917), 161 N. W. 577 .

New Jersey.-DeYonge \& Co. v. Woodport Hotel \& Land Co. (1909), 77 N. J. L. 233; Louis DeYonge \& Co. . Woodport Hotel \& Land Co. (1909), 72 Atl. 439.

New Mexico.-Gibby v. Carrillo (1919), 177 Pac. 894.

New York.-Lucker v. Iba (1900), 54 A. D. 566, 66 N. Y. Supp. 1019; Cahen v. Everitt (1901), 67 A. D. 86; Sutherland v. Mead (1903), 80 A. D. 103,80 N. Y. Supp. 504; Karsch v. Pottier \& Stymers Mfg. \& Importing Co. (1903), 81 N. Y. 782,82 A. D. 230 Mitchell v. Baldwin (1903), 88 A. D. 265, 84 N. Y. Supp. 1043; Packard v. Windholz (1903), 40 Misc. 347, affirmed 88 A. D. 365; Benedict v. Kress (1904), 89 N. Y. Supp. 607; Consolidated Nat. Bk. v. Kirkland (1904), 99 A. D. 121, 91 N. Y. Supp. 353; Engle v Hyman (1907), 104 N. Y. Supp. 390, 54 Misc. 251; Colborn v. Arbrean (1907), 54 Misc. 623, $104 \mathrm{~N}$. Y. Supp. 968; Nat. Bk. of Barre v. Foley (1907), 54 Misc. 126, $103 \mathrm{~N}$. Y. Supp. 553; Siegel v. Oehl (1908), 110 N. Y. Supp. 916; Strauss v. St. Louis Co. Bk. (1908), 126 A. D. 647; Packard v. Figlinolo (1909), 114 N. Y. Supp. 753; Bech v. Maller (1909), 115 N. Y. Supp. 596; Becker v. Hart (1909), 120 N. Y. Supp. 270; Republic Life Ins. Co. v. Hudson Trust Co. (1909), 130 A. D. 618; Manufacturer's Cómmercial Co. v. Blitz (1909), 131 A. D. 17, 115 N. Y. Supp. 402; Midwood Park Co. v. Baker (1910), 128 N. Y. Supp. 954; Burst v. Lee (1911), 143 A. D. 614, 127 N. Y. Supp. 1040; Kennedy v. Spilka (1911), 129 N. Y. Supp. 390; Eisenberg v. Lefkowitz (1911), 142 A. D. 569; Bass v. Goldstein (1913), 83 Misc. 412, 145 N. Y. Supp. 38; Laing v. Hudgens (1913), 143 N. Y. Supp. 763,82 Misc. 388 ; Nat. Discount Co. v. William R. Jenkins Co. (1913), 143 N. Y. Supp. 996; Spencer \& Co. v. Brown (1913), 143 N. Y. Supp. 994; Waxberg v. Stappler (1913), 83 Misc. 78, 144 N. Y. Supp. 608; Cleary v. Dykeman (1914), $146 \mathrm{~N}$. Y. Supp. 611; Peterson v. Alton (1914), 147 N. Y. Supp. 280; Zivendling v. Kitrosser (1914), 148 N. Y. Supp. 99; Interboro Brewing Co. v. Doyle (1915), 151 N. Y. Supp. 325; Ecks v. Montanara (1915), 152 N. Y. Supp. 1010; Mech. \& Metals Nat. Bk. v. Termini (1915), 156 N. Y. Supp. 433; Anchor Realty Co. v. Bankers Trust Co. (1916), $161 \mathrm{~N}$. Y. Supp. 300; Jarone v. RussoIodice Realty Co. (1917), 164 N. Y. Supp. 135; Monk v. 23d Ward Bank (1917), 165 N. Y. Supp. 1055; Thornton v. Netherlands Stcam Nav. Co. (1917), 165 N. Y. Supp. 682; Kuflik v. Vaccaro (1918), 170 N. Y. Supp. 13; Martindale v. DeKay (1918), 166 N. Y. Supp. 405; Korn v. Davis (1919), 172 N. Y. Supp. 440; Robert G. Thomas Co. v. Zeiter (1918), 171 N. Y. Supp. 244.

North Carolina.- Mayers v. McRimmon (1906), 140 N. Car. 640, 53 S. E. 447, 111 Am. St. s 69 ; Singer Mfg. Co. v. Summers (1906), 143 N. Car. 102, 55 S. E. 522; Am. 
Nat. Bk. v. Fountain (1908), 62 S. E. 738, 148 N. Car. 590; Murchison Nat. Bk. v. Dunn Oil Mills Co. (1909), 150 N. Car. 718, 64 S. E. 885 ; Johnston Co. Sav. Bk. v. Chase (1909), 151 N. Car. 108; First Nat. Bk. of Kansas City v. Griffin (1910), 153 N. Car. 72; Myers v. Petty (1910), 153 N. Car. 462; Chadwick จ. Kirkman (1912), 159 N. Car. 259, 74 S. E. 968 ; First Nat. Bk. of Lumberton v. Brown (1912), 160 N. Car. 23; Fidelity Trust Co. v. Ellen (1913), 79 S. E. 263; Standing Stone Nat. Bk. v. Walser (1913), 77 S. E. 1006; Vaughan v. Exam. (1913), 161 N. Car. 492, 77 S. E. 679; Third Nat. Bk. of St. Louis v. Exam. (1913), 79 S. E. 498; First Nat. Bk. v. Warsaw Drug Co. (1914), 81 S. E. 993; Fidelity Trust Co. v. Whitehead (1914), 80 S. E. 1065; Merohants Nat. Bk. of Indianapolis v. Branson (1914), 81 S. E. 410; Raleigh Banking \& Tr. Co. v. Clark (1906), 90 S. E. 200; Gulf States Steel Co. v. Ford (1917), 91 S. E. 844; Metropolitan Discount Co. v. Becker (1919), 97 S. E. 495.

North Dakota.-Drenkall v. Movins State Bk. (1911), 118 N. Dak. 10, 88 N. W. 724; Tamlyn v. Peterson (1906), 15 N. Dak. 488, 107 N. W. 1081; Kerr v. Anderson (1907), 16 N. Dak. 36, 111 N. W. 614; McCarty v. Kepweta (1913), 139 N. W. 992; Farmer's Bank of Mercer Co. v. Riedlinger (1914), $146 \mathrm{~N}$. W. 556 ; Northern Savings Bk. v. Kelly (1915), 154 N. W. 650.

Ohio.-Wehrman v. Beech (1906), 28 O. C. 128; Carrara Paint Agency Co. v. Nat. Bk. of Barberton (1906), 29 O. C. 485; Thompson v. Citizens Nat. Bk. of Adams (1909), 32 O. C.
131; Spring Valley Nat. Bk. v. Somers (1910), 21 Ohio Dec. 772; Hamilton Mach. Tool Co. v. Memphis Nat. Bk. (1911), 84 Ohio St. 184,95 N. E. 777.

Oklahoma.-Wood v. Stickle (1912), 128 Pac. 1082; Hudson v. Moore (1913), 130 Pac. 774; Jones v. Citizen's State Bk. (1913), 135 Pac. 373 ; Western Ex. Bk. of Kansas City v. Coleman (1913), 132 Pac. 488; Gourley v. Pioneer Loan Co. (1915), 151 Pac. 1072; Waldock v. Winkler (1915), 152 Pac. 99; Barry v. Kniseley (1916), 155 Pac. 1168; Pittsburg Mfg. Inst. Co. v. Robins (1916), 158 Pac. 929; Mangold \& Glandt Bk. v. Utterback (1918), 174 Pac. 542.

Oregon.-Brown v. Feldwert (1905), 46 Oreg. 363, 80 Pac. 414; Mills v. Keep (1912), 197 Fed. 360; Everding \& Farrell v. Taft (1916), 160 Pac. 1160.

Pennsylvania. - Kensington Nat. Bk. v. Ware (1906), $32 \mathrm{~Pa}$. Super. Ct. 247; Hatboro Nat. Bk. v. Stevenson (1907), $33 \mathrm{~Pa}$. Super. Ct. 144; Stouffer v. Kelchner (1908), $38 \mathrm{~Pa}$. Super. Ct. 475; Lowry Nat. Bk. v. Hazard (1909), 223 Pa. 520; Schultheis v. Sellers (1909), $223 \mathrm{~Pa}$. 513, 72 Alt. 887; Grange Trust Co. v. Brown (1911), $49 \mathrm{~Pa}$. Sup. 274; Second Nat. Bk. of Pittsburg v. Hoffman (1911), 229 Pa. Ct. 429, 78 Atl. 1002 ; First Nat. Bk. of Bangor v. Paff (1913), 87 Atl. 841; Levy v. Gilligan (1914), 90 Atl. 647.

Rhode Island.-Cook v. Am. Tubing \& Webbing Co. (1906), 28 R. I. 41, 65 Atl. 641.

Sotuth Dakota.- Barnard v. Tidrick (1915), 152 N. W. 690; Peterson v. Hoftiezer (1915), 150 N. W. 
934; Shade v. Barnes Bros. (1915), 151 N. W. 42.

Texas.-Tuke v. Feagin (1915), 181 S. W. 805.

Utah.-Warren v. Smith (1909), 35 Utah, 455, 100 Pac. 1069; McCormick v. Swem (1909), 36 Utah, 6, 102 Pac. 626; Miller v. Marks (1915), 148 Pac. 412.

Vermont.-City Sav. \& Trust Co.

v. Peck (1918), 103 Atl. 1020.

Virginia.- Aragon Coffee Co. v. Rogers (1906), 105 Va. 51; Hawse v. First Nat. Bk. of Piedmont, W. Va. (1912), 113 Va. 588; Miller v. Norton \& Smith (1913), 77 S. E. 452.

Washington.- Keene v. Behan (1905), 40 Wash. 505, 82 Pac. 884; Hawse v. First Nat. Bk. of Pied. mont (1912), 75 S. E. 127; Pennington $\mathbf{v}$. Third Nat. Bk. of Columbus, Ga. (1913), 77 S. E. 455; Holdsworth v. Anderson (1916), 87 S. E. 565; Gosline v. Dryfoos (1907), 45 Wash. 396, 88 Pac. 634; Ireland $\nabla$. Scharpenburg (1909), 54 Wash. 558, 103 Pac. 801; Bradley Engineering \& Mfg. Co. v. Heyburn (1910), 56 Wash. 628, 106 Pac. 170; Cedar Rapids Nat. Bk. v. Myhre (1910), 57 Wash. 596, 107 Pac. 518; Gottstein v. Simmons (1910), 59 Wash. 178; City Nat. Bk. of Lafayette v. Mason (1911), 58 Wash. 492, 108 Pac. 1071; Moyses v. Bell (1911), 62 Wash. 534, 114 Pac. 193; Scandinavian Am. Bk. v. Johnston (1911), 63 Wash. 187, 115 Pac. 102 ;
Wells v. Duffy (1912), 69 Wash. 310; Fournier v. Cornish (1913), 133 Pac. 9 ; Union Inv. Co. v. Rosenzweig (1914), 139 Pac. 874; McLaughlin v. Dopps (1915), 147 Pac. 6 ; City Nat. Bk. v. Shelton Elec. Co. (1917), 164 Pac. 993.

West Virginia.-Interstate Finance Co. v. Schroder (1914), $81 \mathrm{~S}$. E. 552 .

Wisconsin.- Hodge v. Smith (1907), 130 Wis. 326, 110 N. W. 192 ; Pelton v. Spider Lake S. \& I. L. Co. (1907), 132 Wis. 219, 112 N. W. 29, 122 Am. St. 963; Northfield Nat. Bk. v. Arndt (1907), 132 Wis. 383, 112 N. W. 451; Shaffer v. Peavey (1915), 152 N. W. 829.

Wyoming.-Acme Coal Co. v. Northrup Nat. Bk. of Iola (1915), 146 Pac. 593; Holdsworth v. Blyth \& Fargo (1915), 146 Pac. 603; Capitol Hill St. Bk. v. Rawlins Nat. Bk. (1916), 160 Pac. 1171.

United States.-Bryan v. Barr (1903), 21 D. C. App. 190; Johnson Co. Sav. Bk. v. Mendell (1911), 30 A. C. (D. C.) 413; Thompson v. Franklin Nat. Bk. (1917), 45 D. C. App. 218; First Nat. Bk. of Shenandoah $\vee$. Linver (1911), 187 Fed. 16, 109 U. S. C. C. A. 70; Nat. Bk. of Com. in St. Louis v. Sancho Pag. Co. (1911), 110 C. C. A. 112, 106 Fed. 257; In re Hill (1911), 187 Fed. 214; Amalgamated Sugar Co. v. U. S. Nat. Bk. of Portland, Oreg. (1911), 109 C. C. A. 494.

\section{ARTICLE $V$. \\ IIAbilities OF PARTies.}

Section 60. The maker of a negotiable instrument by making it engages that he will pay it according to its tenor, and admits the existence of the payee and his then capacity to endorse. 
Alabama.- Jefferson Co. Sav. Bk.

v. Compton (1915), 68 So. 261.

Arizona.-Cowan v Ramsay (1914), 140 Pac. 501.

Colorado.- McMann v. Walker (1903), 31 Colo. 261. 72 Pac. 1055; Ullery v. Brohm (1904), 20 Colo. App. 389, 79 Pac. 180; Citizen's Tr. Co. v. Abston (1917), 242 Fed. 392. Florida.-Hough v. State Bk. of New Smyna (1911), 61 Fla. 290, 155 So. 461.

Iowa.-Hoyt v. Griggs (1914), 146 N. W. 745.

Kansas.-German-American State Bk. v. Watsen (1917), 163 Pac. 737, 99 Kans. 686; State Bk. v. Jeltz (1917), 167 Pac. 1067; Conqueror Trust Co. v. Danford (1919), 177 Pac. 357.

Massachusetts.- Union Tr. Co. v. MeGinty (1912), 212 Mass. 205, 98 N. E. 679; Harvey v. Squire (1914), 105 N. E. 355.

Michigan.-Neyens v. Worthington (1908), 150 Mich. 580, $114 \mathrm{~N}$. W. 404, 18 L. R. A. (N. S.) 142.

Mississippi.-Moyse Real Est. Co. v. First Nat. Bk. of Commerce (1916), 70 So. 821.

Missouri.-Young v. Gans (1908), 134 Mo. App. 166, 113 S. W. 735.

Nebraska.-First Nat. Bk. of Shenandoah v. Kelgord (1912), 91 Neb. 178, 135 N. W. 548.
New York.-Halsey v. Henry Jewett Co. (1907), 190 N. Y. 231, 83 N. E. 25; Ryan v. Sullivan (1911), 143 A. D. 471; Savine v. Paine (1915), 151 N. Y. Supp. 735; Lazarowitz v. Stafford (1917), 167 N. Y. Supp. 910.

North Dakota.-Nat. Bk. of Commerce v. Pick (1904), 13 N. D. 74, 99 N. W. 63; Grover v. Muratt (1912), 23 N. Dak. 577, 137 N. W. 830 ; Spring Valley Nat. Bk. v. Soners (1910), 21 Ohio Dec. 772.

Oklahoma.- Norman v. Lambert (1915), 153 Pac. 1097; Oklahoma Bank v. Seaton (1918), 170 Pac. 477.

Oregon.-Hill v. McCrow (1918), 170 Pac. 306.

Pennsylvania. - Weiskucher v. Connelly (1917), 100 Atl. 965; Wostenholme v. Smith (1908), 34 Utah, 300, 97 Pac. 329.

Washington.-Hillman v. Stanley (1909), 56 Wash. 320, 105 Pac. 816; Fisk Rubber Co. v. Pinkey (1918), 170 Pac. 581.

West Virginia. - Rusmissel v. White Oak Co. (1917), 92 S. E. 672.

United States.-Edwards v. Goode (1916), 228 Fed. 664; First Nat. Bk. of Memphis v. Towner (1917), 239 Fed. 433.

Section 61 . The drawer by drawing the instrument admits the existence of the payee and his then capacity to endorse; and engages that on due presentment the instrument will be accepted or paid, or both, according to its tenor, and that if it be dishonored and the necessary proceedings on dishonor be duly taken, he will pay the amount thereof to the holder, or to any subsequent indorser who may be compelled to pay it. But the drawer may insert in 
the instrument an express stipulation negativing or limiting his own liability to the holder.

Idaho.- Armstrong v. Sleck (1908), 14 Ida. 208, 93 Pac. 775.

Illinois.-Simonoff v. Granite City Nat. Bk. (1917), 116 N. E. 636.

Michigan.-People's State Bk. v. Miller (1915), 152 N. W. 257.

Minnesota.- Baxter v. Brandenburg (1917), 163 N. W. 517.
Nebraska.- Nat. Bk. of Commerce v. Bossemeyer (1917), 162 N. W. 503.

New York.- Weiss v. Rieser (1909), 62 Mise. 292, 114 N. Y. Supp. 983 ; U. S. Rail Co. v. Wiener (1915), 155 N. Y. Supp. 425.

Oregon.- State v. Hammelsey (1908), 52 Oreg. 156, 96 Pac. 865.

Section 62. The acceptor by accepting the instrument engages that he will pay it according to the tenor of his acceptance; and admits :

(1) The existence of the drawer, the genuineness of his signature, and his capacity and authority to draw the instrument; and,

(2) The existence of the payee and his then capacity to endorse.

Alabama.-Robinson Banking Co.

v. Brasfield (1918), 79 So. 651 .

Connecticut.-Hopkins v. Merrill (1907), 79 Conn. 626, 66 Atl. 174.

Idaho. - Armstrong, v. Sleck (1908), 14 Ida. 208, 93 Pac. 775.

Illinois.-Noel v. Security Bk. of Chicago (1911), 163 Ill. App. 82.

Missouri- - Nat. Bk. of Rolla v. First Nat. Bk. of Salem (1910), 141 Mo. 719, 125 S. W. 513; Nat. Bk. of Commerce v. Am. Nat. Bk. (1910), 127 S. W. 429; Stephens v. Bawles (1919), 206 S. W. 589.

Nebraska.- State Bk. of Chicago v. First Nat. Bk. of Omaha (1910), 87 Neb. 351

New York.-Meuer v. Phoenix Nat. Bk. (1904), 94 A. D. 331, 88 N. Y. Supp. 83 ; Schlesinger v. Kurzrok (1905), 94 N. Y. Supp. 442, 47 Misc. 634; Title Guarantee \& 'Trust Co. v. Haven No. 2 (1908), 126 A. D. 802,111 N. Y. Supp. 305 ; Trust Co. of Amer. v. Hamilton Bank
(1908), 127 A. D. 515, 112 N. Y. Supp. 84 ; Consolidated Nat. Bk. of N. Y. v. First Nat. Bk. of Middleton, N. Y. (1908), 129 A. D. 538; Title Guarantee \& Tr. Co. v. Haven, No. 1, No. 2 (1909), 196 N. Y. 487, 89 N. E. 1082 ; Springs v. Hanover Nat. Bk. (1911), 130 N. Y. Supp. 87; McMahony v. Roseville Tr. Co. (1913), 125 A. D. 240,144 N. Y. Supp. 841; Morrison v. Chapman (1913), 140 N. Y. Supp. 700; AngloSouth Amer. Bk. v. Nat. City Bk. or N. Y. (1914), 146 N. Y. Supp. 457.

North Dakota.-First Nat. Bk. of Lisbon v. Bk. of Windemere (1906), 15 N. Dak. 299, 108 N. W. 546.

Oklahoma.-Cherokee Nat. Bk. v. Union Tr. Co. (1912), 33 Okla. 342, 125 Pac. 464; Shaffer v. Govreau (1912), 128 Pac. 507; First Nat. Bk. v. Cummings (1918), 171 I'ac. S62.

Pennsylvania. - Cunningham v. First Nat. Bk. of Indiana (1908), 
$219 \mathrm{~Pa} .310$; McNeely Co. v. Bk. of No. Amer. (1908), $221 \mathrm{~Pa} .588$; Colonial Trust Co. v. Nat. Bk. of Western Pa. (1912), $50 \mathrm{~Pa}$. Super. 510.
West Virginia.- Bk. of Williamson v. MeDowell County Bk., W. Va. (1910), 66 S. E. 761; Interstate Finance Co. v. Sehroder (1914), 81 S. E. 552 .

Section 63. A person placing his signature upon an instrument. otherwise than as maker, drawer or acceptor, is deemed to be an indorser, unless he clearly indicates by appropriate words his intention to be bound in some other capacity.

Alabama.- Long v. Givin (1919), 80 So. 440 ; Zadek v. Forcheimer (1918), 77 So. 941.

Arkansas.- Hodges v. Collison (1915), 172 S. W. 1147; Tancred v. First Nat. Bk. (1916), 187 S. W. 160.

Colorado.-Crosby v. Woodbury (1906), 37 Colo. 1, 89 Pac. 34; Archuleta v. Johnston (1912), 127 Pac. 134.

Connecticut.-Hopkins v. Merrill (1907), 70 Conn. 626, 66 Atl. 174; Knapp Co. v. Tidewater Coal Co. (1912), 85 Conn. 147, 81 Atl.' 1063.

Florida.-Hough v. State Bk. of Smyna (1911), 61 Fla. 290, 55 So. 461; Baumeister v. Kuntz (1907), 53 Fla. 340, 42 So. 886; Hopkins v. Commercial Bk. (1912), 64 Fla. 310 ; Williams v. Peninsular Grocery Co. (1917), 75. So. 517.

Idaho.- Bank of Montpelier v. Montpelier Lumber Co. (1909), 16 Ida. 730, 102 Pac. 685.

Iowa.-Allison v. Hollembeak (1908), 138 Iowa, 479, 114 N. W. 1059; Porter v. Moles (1911), 151 Iowa, 279, 131 N. W. 23; Devoy \& Kuhn v. Huttig (1916), 156 N. W. 412.

Kentucky.- Diamond Distilleries Co. v. Gott (1910), $137 \mathrm{Ky}$. 585, 126 S. W. 131; Mechanics \& Farm- er's Sav. Bk. v. Katterjohn (1910), 137 Ky. 427, 125 S. W. 1071; Hoyland v. Nat. Bk. of Middleborough (1910), 137 Ky. 682, 126 S. W. 356 ; First Nat. Bk. v. Bickel (1911), 143 Ky. 754,137 S. W. 790; Williams v. Paintsville Nat. Bk. (1911), $143 \mathrm{Ky} .781,137 \mathrm{~S}$. W. 535 ; Lyons Lumber Co. v. Stewart (1912), 147 Ky. 653, 145 S W. 376; Elsey v. People's Bank of Hardwell (1916), 182 S. W. $8 \% 3$.

Louisiana. - Parker v. Guillot (1907), 118 La. 223; Pugh v. Sample (1909), 123 La. 791, 49 So. 526; Hackley State Bk. v. Magee (1911), 128 La. 1008 ; J. M. Druser v. Hibernia Bk. \& Tr. Co. (1915), 67 So. 15.

Maryland.- Lightner v. Roach(1915), $126 \mathrm{Md}$. 474.

Massachusetts.-Quimby v. Vermum (1906), 190 Mass. 211, $76 \mathrm{~N}$. E. 671 ; Toole v. Crafts (1906), 193 Mass. 110,78 N. E. 775,118 Am. St. 455; Bamford v. Boynton (1909), 200 Mass. 560, 86 N. E. 900 ; Arlington Nat. Bk. v. Bennett. (1913), 214 Mass. 352, 101 N. F. 982; Fourth Nat. Bk. v. Mead (1914), 104 N. E. 377; Aronson v. Nurenburg (1914), 105 N. E. 1056 ; Lankofsky v. Raymond (1914), 104. N. E. 489 . 
Michigan. - Ensign $\quad$ v. Fogg (1913), 143 N. W. 82.

Missouri.-Walker v. Dunham (1909), 135 Mo. App. 396, 115 S. W. 1086; Hawkins v. Wiest (1912), 167 Mo. App. 439; Bank Grant City v. Korn (1915), 179 S. W. 721.

New Hampshire- Trafton v. Garnsey (1916), 99 Atl. 290.

New Jersey.-Wilson v. Hendce (1907), 74 N. J. L. 640, 66 Atl. 413; Gibbs v. Guaraglis (1907), 75 N. J. L. 168, 67 Atl. 81; Mackintosh v. Gibbs (1909), 79 N. J. L. 40, 74 Atl. 708; Morris Co. Brick Co. v. Austin (1910), 75 Atl. 550.

New York.- Howard v, Van Gieson (1899), 46 A. D. 77; Williamsburg Tr. Co. v. Tum Suden (1907), 120 A. D. 518, 105 N. Y. Supp. 335; Haddock, Blanchard \& Co. v. Haddock (1908), 192 N. Y. 499, 82 N. E. 682,103 N. Y. Supp. 584; Roessle v. Lancaster (1909), 130 A. D. 1, 114 N. Y. Supp. 387; Blanchard v. Blanchard (1911), $201 \mathrm{~N}$. Y. 134,94 N. E. 630 , affirming s. c., 133 A. D. 937 (1909), without an opinion; Bender v. Bahr Trucking Co. (1911), 144 A. D. 742; Yonkers Nat. Bk. v. Mitchell (1913), 141 N. Y. Supp. 128; Carnegie Trust Co. v. Kistler (1915), 152 N. Y. Supp. 240; Mechanic v. Elgie Iron Works (1917), 163 N. Y. Supp. 97.

North Carolina.-Rouse v. Wooten (1906), 140 N. Car. 557, 53 S. E. 430, 111 Am. St. 875; Perry Co. v. Taylor (1908), 148 N. Car. 362; Sykes v. Everett (1914), 833 S. E. 585; Myers Co. v. Battle (1915), 86 S. E. 1034.

Ohio-Dollar Sav. Bk. v. Barberton Pottery Co. (1907), 17 Ohio Doc. 539; Rockfield v. First Nat.
Bk. of Springfield (1907), 77 Ohio St. 311,83 N. E. 392.

Oklahoma.-Shaffer v. Govreau (1912), 128 Pac. 507; Howard v. Kineaid (1916), 156 Pac. 628.

Oregon.-Hunter v. Harris (1912), 63 Oreg. 505, 127 Pac. 786; Noble v. Beeman-Spaulding-Woodward Co. (1913), 131 Pac. 1006.

Rhode Island.-McLean v. Bryer (1903), 24 R. I. 599, 54 Atl. 3r3; Deahey v. Choquet (1907), 28 R. I. 338; Nat. Ex. Bk. v. Lubrano (1908), 29 R. I. 64, 68 Atl. 944.

South Carolina.-Folk v, Moore (1916), 88 S. E. 18; Norwood Nat. Bk. v. Piedmont Pub. Co. (1917), 91 S. E. 866.

Tennessee. - Mercantile Bk. of Memphis v. Busby (1908), 120 'Tenn. $652,113 \mathrm{~S}$. W. 390 ; l'harr v. Stevens (1911), 124 Tenn. 670, $139 \mathrm{~S}$. W. 730 ; Am. Nat. Bk. v. Nat. Fertilizer Co. (1911), 125 Tenn. 329, 143 S. W. 587; Nolan v. H. E. Wilcox Mator Co. (1917), $195 \mathrm{~S}$. W. 581.

Texas.-Borschow v. Wilson (1916), 190 S. W. 202.

Virginia. - Colley v. Summers Parrott Hardware Co. (1916), S9 S. E. 906; Colona v. Parksley Nat. Bk. (1917), 92 S. E. 979.

West Virginia.-First Nat. Bk. of Hinton v. Plumley (1915), si s. E. 94; Toler v. Sanders (1915), 87 S. E. 462; Thompson v. Curry (1917), 91 S. E. 801 Bank of Greenville v. Lowry (191\%), 94 S. E. 98 :

Wisconsin.-Germania Nat. Bk. v. Mariner (1906), 129 Wis. 544, 109 N. W. 574; Union Bank of Milwaukee v. Commer. Securities Co. (1916), 147 N. W. 510.

Utah.-Wostenholme $v$. Smith (1908), 34 Utah, 300, 97 Pac. 329. 
United States.-McDonald v. Fed. 481; First Nat. Bk. v. Towner Luckenback (1909), 170 Fed. 434, (1917), 239 Fed. 433; First Nat. 95 C. C. A. 604; Murray v. Third Bk. of Memphis v. Towner (1917), Nat. Bk. of St. Louis (1916), 234239 Fed. 433.

Section 64. Where a person, not otherwise a party to an instrument, places thereon his signature in blank before delivery he is liable as indorser, in accordance with the following rules:

(1) If the instrument is payable to the order of a third person, he is liable to the payee and to all subsequent parties.

(2) If the instrument is payable to the order of the maker or drawer, or is payable to bearer, he is liable to all parties subsequent to the maker or drawer.

(3) If he signs for the accommodation of the payee, he is liable to all parties subsequent to the payee.

Alabama.- - Long v. Gevin (1914), 66 So. 88; Schillinger v. Wickersham (1917), 75 So. 11.

Connecticut. - Peck v. Easton (1902), 74 Conn. 456, 51 Atl. 134; Knapp Co. v. Tidewater Coal Co. (1912), 85 Conn. 147, 81 Atl. 1063.

Florida.-Baumeister v. Kuntz (1907), 63 Fla. 340, 42 So. 886; Hough v. State Bk. of New Smyna (1911), 61 Fla. 290, 55 So. 461.

Illinois.-First Nat. Bk. of Lincoln v. Snadmeyer (1911), 164 Ill. App. 98; Justice $\nabla_{0}$ Stonecipher (1915), 108 N. E. 722, 267 Ill. 448.

Iowa.-Devoy \& Kuhn Coal \& Coke Co. v. Huttig (1916), 156 N. W. 412 .

Kentucky.-First Nat. Bk. v. Bickel (1911), $143 \mathrm{Ky}$. 754, $137 \mathrm{~S}$. W. 790.

Louisiana.-Taylor v. Vossburg Mineral Spring Co. (1911), 128 La. 364,54 So. 907.

Massachusetts.- Leonard v. Draper (1905), 187 Mass. 536, 73 N. E. 644; Thorpe v. White (1905), 188 Mass. 333, 74 N. E. 592; Quimby v.
Varnum (1906), 190 Mass. 211, 76 N. E. 671; Toole v. Crafts (1906), 193 Mass. 110, 78 N. E. 775, 118 Am. St. 455; Bamfoid v. Boynton (1909), 200 Mass. 560, 86 N. E. 900 ; Winthrop Nat. Bk. v. Mead (1913), 102 N. E. 69; Fourth Nat. Bk. v. Mead (1914), 104 N. E. 377 ; Lankofsky v. Raymond (1914), 104 N. E. 489; Conners v. Sullivan (1915), 108 N. E. 503.

Michigan. - Ensign v. Dunn (1914), 148 N. W. 343.

Missouri.- Walker v. Dunham (1909), 135 Mo. App. 396, 115 S. W. 1086; Overland Auto Co. v. Winters (1915), 180 S. W. 561.

New Jersey.-Wilson v. Hendee (1907), 74 N. J. L. 640, 66 Atl. 413; Gibbs v. Guaragalia (1907), 75 N. J. L. 168, 67 Atl. 81; Morris Co. Brick Co. v. Austin (1910), 75 Atl. 550.

New York. - Howard v. Van Gieson (1899), 46 A. D. 77; Cohn v. The Consolidated Butter \& Egg Co. (1900), 30 Misc. 725; Corn v. Levy (1904), 9 ז A. D. 48, 89 N. Y. Supp. 
658; Far Rockaway Bk. v. Norton (1906), 186 N. Y. 484,75 N. Y. 709; Williamsburg Tr. Co $\checkmark$ Tum Suden (1907), 120 A. D. 518, 105 N. Y. Supp. 335; Haddock, Blanckard \& Co. v. Haddock (1908), 192 N. Y. 499,82 N. L. 682,103 N. Y. Supp. 584; Roessale v. Lancaster (1909), 130 A. D. 1, 114 N. Y. Supp. 387; Bender v. Bahr Truckıng Co. (1911), 144 A. D. 742; Abbott v. LeProvost (1915), 151 N. Y. Supp. 616; Flinch v. Wood (1913), 145 N. Y. Supp. 51; Yonkers Nat. Bk. v. Mitchell (1913), 141 N. Y. Supp. 128; Franklin v. Kidd (1917), 114 N. E. 839 .

North Carolina.- Rouse v. Wooten (1906), $140 \mathrm{~N}$. Car. 557, $53 \mathrm{~s}$. E. 430, 111 Am. St. 875; Perry Co. v. Taylor (1908), 148 N. Car. 362.

North Dakota.- Farquhar Co. v. Highem (1907), 16 N. Dak. 106, 112 N. W. 657; Harris v. Jones (1912), 23 N. Dak. 488, 136 N. W. 1080.

Ohio.-Dollar Sav. Bk. v. Barberton Pottery Co. (1907), 17 Ohio Dèc. 539; Rockfield v. First Nat. Bk. of Springfield (1907), 77 Ohio St. 311,83 N. E. 392.

Oregon.-Hunter v. Harris
(1912), 127 Pac. 786; Moll v. Roth Co. (1915), 152 Pac. 235.

Pennsylvania. - Aldred's Estate (No. 1), 229 Pa. 627; Am. Trust Co. v. Canevin (1911), 107 C. C. A. 543.

Rhode Island.-Downey v. O'Keefe (1905), 26 R. I. 571, 59 Atl. 929; Dealey v. Choquet (1907), 27 R. I. 338.

South Carolina.- Bank of Inman v. Elliott (1915), 84 S. F. 996; Norwood Nat. Bk. v. Piedmont Pub. Co. (1917), 91 S. E.' 866.

Tennessee.-Mercantile Bk. of Memphis v. Busby (1908), 120 Tenn. 652, 113 S. W. 390; Pharr v. Stevens (1911), 124 Tenn. 670, 139 S. IV. 730; Cohn v. Hitt (1916), 182 s. W. 235.

West Virginia. - Thompson v. Curry (1917), 91 S. E. 801.

Wisconsin.-Germania Nat. Bk. v. Mariner (1906), 129 Wis. 544, 109 N. W. 574.

United States. - In re Swift (1901), 106 Fed. 65; Richards v. Street (1908), 31 App. D. C. 427; In re McCord (1909), 174 Fed. 72; Wilson v. Knowles (1914), 213 Fed. 782.

Section 65. Every person negotiating an instrument by delivery or by a qualified indorsement, warrants:

(1) That the instrument is genuine and in all respects what it purports to be;

(2) That he has a good title to it;

(3) That all prior parties liad capacity to contract;

(4) That he has no knowledge of any fact which would impair the validity of the instrument or render it valueless.

But when the negotiation is by delivery only, the warranty extends in favor of no holder other than the immediate transferce. 
The provisions of subdivision three of this section do not apply to persons negotiating public or corporation securities, other than bills and notes.

Connecticut.- Hopkins v. Merrill (1907), 79 Conn. 626, 66 Atl. 174.

Illinois.-Graves v. Neeves (1913), 183 Ill. App. 235.

Iowa.- Dille v. White (1906), 132 Iowa, 327, 109 N. W. 909, 10 L. R. A. (N. S.) 510; State ex rel. Carroll v. Corning St. Sav. Bk. (1908), 139 Iowa, 338, 115 N. W. 937; Porter v. Moles (1911), 151 Iowa, 279, 131 N. W. 23; Devoy \& Kuhn C. \& C. Co. v. Huttig (1916), 156 N. W. 412.

Louisiana.- Taylor v. Vossburg Mineral Spring Co. (1911), 128 La. 364,54 So. 907.

Massachusetts. - Middleborough Nat. Bk. v. Cole (1906), 191 Mass. 168, 77 N. E. 781; Lankofsky v. Raymond (1914), 104 N. E. 489.

Michigan.-Sheffer v. Fleischer (1909), 158 Mich. 270, 122 N. W. 543.

Missouri.-Hawkins v. Wiest (1912), 167 Mo. App. 439; In re Ziegenheim (1916), 187 S. W. 893; Dominick v. Farmer (1918), $201 \mathrm{~S}$. W. 955 .

Nebraska.-Nat, Bk. of Commerce v. Farmers \& Merchants Bk. (1910), 87 Neb. 841.
Nevada. - Jensen - $\nabla$. Wilslef (1913), 132 Pac. 16.

New Jersey.-Morris Co. Brick Co. v. Austin (1910), 75 Atl. 550.

New York.-Williamsburg Tr. Co. v. Tum Suden (1907), 120 A. D. 518, 105 N. Y. Supp. 335; Steinberger v. Hittelman (1915), $156 \mathrm{~N}$. Y. Supp. 320.

North Dakota.-Smith v. Bradley (1907), 16 N. Dak. 306, 112 N. W. 1062.

South Dakota.-First Nat. Bk. v. Brule Nat. Bk. (1917), 161 N. W. 616; First Nat. Bk. v. Brule Nat. Bk. of Chamberlain (1918), $168 \mathrm{~N}$. W. 1054 .

Tennessee.--Litchfield Shuttle Co. v. Cumberland Valley Nat. Bk. (1916), 183 S. W. 1006; Figuers v. Fly (1917), 193 S. W. 117.

Virginia.-Main St. Bk. v. Planters Nat. Bk. of Richmond (1914), 81 S. E. 24.

Washington.-Hillman v. Stanley (1909), 56 Wash. 320, 105 Pac. 816; Fidelity Nat. Bk. v. Hosea (1916), 160 Pac. 960.

Wyoming.- Hamilton v. Drefenderfer (1913), 131 Pac. 37.

United States.-Willard v. Crook (1903), 21 App. D. C. 237.

Section 66. Every indorser who indorses without qualification, warrants to all subsequent holders in due course:

(1) The matters and things mentioned in subdivision one, two and three of the next preceding section; and

(2) That the instrument is at the time of his indorsement valid and subsisting.

And, in addition, he engages that on due presentment, it shall 
be accepted or paid, or both, as the case may be, according to its tenor, and that if it be dishonored, and the necessary proceedings on dishonor be duly taken, he will pay the amount thereof to the holder, or to any subsequent indorser who may be compelled to pay it.

Alabama.- Hudson v. Repton St.

Bk. (1917), 75 So. 695.

Colorado.- Marks v. Munson (1915), 149 Pac. 440; First Nat. Bk. of Denver v. Cripple Creek Bk. (1917), 163 Pac. 1134.

Connecticut.- Iopkins v. Merrill (1907), 79 Conn. 626, 66 Atl. 174.

Florida.- Worley v. Johnson (1910), 53 So. 542; Hough v. State Bk. of New Smyna (1911), 61 Fla. 290, 55 So. 461; Donegan v: Dekle Inv. Co. (1917), 74 So. 11; Williams v. Peninsular Grocery Co. (1917), 75 So. 517.

Idaho. - Armstrong v. Sleck (1908), 14 Ida. 208, 93 Pac. 775.

Illinois. - Graves v. Neeves (1913), 183 Ill. App. 235.

Iowa. - Allison v. Hollembeak (1908), 138 Iowa, 479, 114 N. W. 1059; Porter v. Moles (1911), 151 lowa, 279, 131 N. W. 23; Park v. Best (1916), 157 N. W. 233.

Kentucky. - Williams v. Paintsville Nat. Bk. (1911), $143 \mathrm{Ky}$. 781, 137 S. IV. 535 ; Riordan v. Thornburg (1917), 198 S. W. 920.

Louisiana.-Atkins v. Dixie Fair Co. (1914), 65 So. 762; Farmers \& Merchants Bk. v. Davis (1919), 80 So. 713 .

Massachusetts.-Wolfboro Loan \& Banking Co. v. Rollins (1907), 195 Mass. 323; Demelman v. Brazier (1908), 198 Mass. 458, 84 N. E. 856; State Bank \& Trust Co. v. Evans (1900), 198 Mass. 11; Dexter v. Fuller (1914), 217 Mass. 219;
Lankefsky v. Raymond (1914), 104 N. E. 489.

Missouri.-Nat. Bk. of Rolla v. First Nat. Bk. of Salem (1910), 141 Mo. 719, 125 S. W. 513.

Nevada. - Jensen v. Wilslef (1913), 132 Pac. 16.

New Jersey.- Macintosh v. Gibbs (1909), 79 N. J. L. 40, 74 Atl. 708; Morris Co. Brick Co. v. Austin (1910), 75 Atl. 550.

New York.-Gardner v. Pitcher (1905), 109 A. D. 106; First Nat. Bk. of the City of Brooklyn v. Gridley (1906), 112 A. D. 398, 98 N. Y. Supp. 445; Williamsburg Tr. Co. v. Tum Suden (1907), 120 A. D. 518,105 N. Y. Supp. 335; Horrwitz v. Wollowitz (1908), 59 Mise. 520, 110 N. Y. Supp. 972; Gilpin v. Savage (1908), 60 Mise. 605, 112 N. Y. Supp. 802 ; Abramovitz v. Abramovitz (1908), 113 N. Y. Supp. 798; Bruck v. Lambech (1909), 118 N. Y. Supp. 494; Klar v. Kostink (1909), 119 N. Y. Supp. 683; New York Produce Ex. Bk. $\vee$. Twelfth Ward Bk. (1909), 135 A. D. 52, 119 N. Y. Supp. 988; Gilpin v. Savage (1911), 201 N. Y. 167, 94 N. F. 656; Blanchard v. Blanchard (1911), 201 N. Y. 134,94 N. F. 630 ; Yonker's Nat. Bk. v. Mitchell (1913), 141 N. Y. Supp. 128; First Nat. Bk. of Binghamton v. Baker (1914), 148 N. Y. Supp. 352, 163 A. D. 72 ; Baruck v. Buckley (1915), 151 N. Y. Supp. 853.

North Carolina.-State Bank of 
Chicago v. Carr (1902), 130 N. Car. 479; Sedbury v. Duffy (1912), 158 N. Car. 432; Sykes v. Everett (1914), 83 S. E. 585; Edwards v. Jefferson Standard Life Ins. Co. (1917), 92 S. E. 695.

North Dakota.- Farquhar Co. v. Higham (1907), 16 N. Dak. 106, 112 N. W. 657.

Ohio.-Dollar Sav. Bk. v. Barberton Pottery Co. (1907), 117 Ohio Dec. 539; Rockfield v First Nat. Bk. of Springfield (1907), 77 Ohio St. 311,83 N. E. 392 .

Oklahoma.-Mangold \& Glandt Bank r. Utterback (1916), 160 Pac. 713.

Oregon.-First Nat. Bk. of Cottage Grove v. Bk. of Cottage Grove (1911), 59 Oreg. 388, 117 Pac. 293; Peterson v. Thompson (1915), 151 Pac. 721.

Pennsylvania.- Savings Inst. of the City of Williamsport v. Folk (1909), 38 Pa. Super. Ct. 54; In re Young's Estate (1912), 83 AtI. 201; Weiskucker v. Connelly (1917), 100 Atl. 965.

South Dakota.-Astoria State Bk. v. Markwood (1917), 161 N. W. 815.

Tennessee.-Farmers \& Merchants Bk. v. Bk. of Rutherford (1905), 115 Tenn. 64, 88 S. W. 939; Figuers. v. Fly (1917), 193 S. W. 117.

Texas.- Prudential Life Ins. Co. v. Smyer (1916), 183 S. IV. 825.

Washington.-Hillman y. Stanley (1909), 56 Wash. 320, 105 Pac. 816; Gleeson v. Lichty (1911), 62 Wash. 656, 114 Pac. 518.

West Virginia.-Rusmissell v. White Oak Stave Co. (1917), 92 S. W. 672 .

United States.- Willard v. Crook (1903), 21 App. D. C. 237.

Section 6\%. Where a person places his indorsement on an instrument negotiable by delivery he incurs all the liabilities of an indorser.

Alabama.- Long v. Givin (1919), 80 So. 440 .

Kentucky.-Riordan v. Thornburg (1917), 198 S. W. 920.

Louisiana. - Parker v. Guillot (1907), 118 La. 223.

Michigan.- Ensign v. Fogg (1913), 143 N. W. 82.

New York.-Williamsburg Tr. Co. v. Tum Suden (1907), 120 A. D. 518, 105 N. Y. Supp. 335.

Ohio.-Dollar Sav. Bk. v, Barberton Pottery Co. (1907), 117 Ohio Dec. 539.

Texas.- First Nat. Bk. of Garner v. Smith (1916), 183 S. W. 862.

Washington.-Gleeson v. Lichty (1911), 62 Wash. 656, 114 Pac. 518.

Section 68. As respects one another indorsers are liable prima facie in the order in which they indorse; but evidence is admissible to show that as between or among themselves they have agreed otherwise. Joint payees or joint indorsees who indorse are deemed to indorse jointly and severally. 
Kentucky.-First Nat. Bk. v. Bickel (1911), $143 \mathrm{Ky} .754,137 \mathrm{~S}$. W. 790; Williams v. Paintsville Nat. Bk. (1911), 143 Ky. 781, 137 s. W. 535.

Louisiana.-Parker v. Guillot (1907), 118 La. 223.

Massachusetts.-Bank of America v. Wilson (1904), 186 Mass. 214; Bamford v. Boynton (1909), 200 Mass. 560, 86 N. E. 900; Enterprise Brewing Co. v. Canning (1911), 210 Mass. 285; Shea v. Vahey (1913), 215 Mass. 80, 102 N. E. 119.

Michigan.-Ensign v. Fogg (1913), 143 N. W. 82 ; Butterfield v. Reynolds (1917), 163 N. W. 86.

Missouri.-Eaves v. Keeton (1917), 193 S. W. 629.

New Jersey.- Morgan v. Thompson $(1905), 72$ N. J. L. 244, 62 Atl. 410; Wilson v. Hendee (1907), 74 N. J. L. 640, 66 Atl. 413; Morris Co. Brick Co. v. Austin (1910), 75 Atl. 550; Schneider v. Mueller (1911), 82 N. J. L. 503; Nat. Newark Banking Co. v. Sweeney (1916), 96 Atl. 86.
New York.- State Bank v. Kahn (1906), 49 Mise. 500, 98 N. Y. Supp. 858; Haddock, Blanchard \& Co. v. Haddock (1908), 192 N. Y. 499, 82 N. E. 682,103 N. Y. Supp. 584; - George v. Bacon (1910), 123 N. Y. Supp. 103; Hodgens v. Jennings (1912), 143 A. D. 879,133 N. Y. Supp. 584; Myer v. Strasburger \& Co. (1915), 152 N. Y. Supp. 757.

North Carolina.- Lynch v. Loftin (1910), 153 N. Car. 270, 69 S. E. 143.

North Dakota.- Harris v. Jones (1912), 23 N. Dak. 488, 136 N. W. 1080.

Oregon.-Hunter v. Harris (1912), 63 Oreg. 505, 127 Pac. 786; Noble v. Beeman-Spaulding-Woodward Co. (1913), 131 Pac. 1006.

Tennessee.-Cohn v. Hitt (1916), 182 S. W. 235 ; Merrimon v. Parkey (1917), 191 S. W. 327.

West Virginia.-First Nat. Bk. of Hinton v. Plumley (1915), $87 \mathrm{~S}$. E. 94.

United States. - In re McCord (1909), 174 Fed. 72; Goldman v. Goldberger (1913), 208 Feù. 877.

Section 69 . Where a broker or other agent negotiates an instrument without indorsement he incurs all the liabilities prescribed by section sixty-five of this act, unless he discloses the name of his principal, and the fact that he is acting only as agent.

Massachusetts.- Cheney v. Taber (1915);, 108 N. E. 1072.

\section{ARTICLE VI. \\ PRESENTMENT FOR PAYMENT.}

Section 70. Presentment for payment is not necessary in order to charge the person primarily liable on the instrument; but if the insrument is, by its terms, payable at a special place, and he is able and willing to pay it there at maturity, such ability and willingness are equivalent to a tender of payment upon his part. But 
except as herein otherwise provided, presentment for payment is necessary in order to charge the drawer and indorsers.

Alabama.- Hall v. First Nat. Bk. of Crossville (1916), 72 So. 171.

California.- Nichols v. Asbeck. (1919), 178 Pac. 705.

Colorado.- Florence O. \& R. Co. v. First Nat. Bk. (1906), 38 Colo. 119, 85 Pac. 182; Sykes v. Kruse (1911), 49 Colo. 560, 113 Pac. 1013.

Florida.- Worley v. Johnson (1910), 53 So. 542.

Illinois. - State Bk. of Clinton v. Parkhurst (1910), 155 111. App. 101; First Nat. Bk. of Lincoln v. Sandmeyer (1911), 164 Jll. App. 98; Selree v. Thomas (1911), $166 \mathrm{Ill}$. App. 427 ; The N. E. Nat. Bk. of Kansas City, Mo. v. Dick (1911), 84 Kans. 252, 114 Pac. 378.

Kentucky.- Fritts v. Kirchdorfer (1910), 124 S. W. 882; Williams v. Paintsville Nat. Bk. (1911), 143 Ky. 781, 137 S. W. 535; Prov. Mining Co. v. Glass Bros. (1918), 201 S. WV. 308 .

Massachusetts. - Demelman v. Brazier (1908), 198 Mass. 458, 84 N. E. 856 ; Farmers Nat. Bk. v. Venner (1906), 192 Mass. 531, 78 N. E. 540 .

Montana.-U. S. Nat. Bank of Red Lodge v. Shupak (1918), 172 Pac. 324.

New York.-Badt v. Miller (1912), 135 N. Y. Supp. 13, 150 A. D. 920 ; Beall v. Russell (1912), 134 N. Y. Supp. 633; Bennett v. Kisler (1917), 163 N. Y. Supp. 555; Cohen v. Chelsea Ex. Bk. of N. Y. (1917), 164 N. Y. Supp. 75; Ger.-Am. Bk. v. Milliman $(1900), 65$ N. Y. Supp. 242, 31 Misc. 87; Gilpin v. Savage (1908), 60 Misc. 605,112 N. Y. Supp. 802; Gilpin v. Savage (1911),
201 N. Y. 167, 94 N. E. 656; Hyman v. Doyle (1907), 53 Misc. 597, 103 N. Y. Supp. 778; O'Brannon J. W. Co. v. Curran (1908), 129 A. D. 90,113 N. Y. Supp. 359; State of N. Y. Nat. Bk. v. Kennedy (1911), 130 N. Y. Supp. 412, 145 A. D. 669 ; Union Bk. of Brooklyn v. Sullivan (1915), 108 N. W. 558, 214 N. Y. 332; Van Vlict v. Kanter (1910), 124 N. Y. Supp. 63; O'Kane v. North American Distilling Co. (1918), 171 N. Y. Supp. 275.

North Carolina.- Myers Co. v. Battle (1915), 86 S. E. 1034; Perry Co. v. Taylor (1908), 148 N. Car. 362 ; Rouse v. Wooten (1906), 140 N. Car. 557, 53 S. E. 430, 111 Am. St. 875; WaIter v. Earnhart (1916), 88 S. E. 753.

North Dakota.- Nelson v. Grondahl (1904), 13 N. Dak. 363, 100 N. W. 1093; Sawyer State Bk. v. Sutherland (1917), 162 N. W. 696 .

Oregon.-Hodges v. Blaylock (1916), 161 Pac. 396.

Pennsylvania. - Aldred's Estate (1911), 229 Pa. 627; Delvees v. Mid States Coal Co. (1915), 93 Atl. 958; First Nat. Bk. v. McBride (1911), 230 Pa. 261.

South Carolina.-Farmers Bk. v. Crawford (1916), 88 S. E. 13.

South Dakota. - Scribner State Bk. v. Ransom (1915), 151 N. W. 1023.

Tennessee.- Pliarmacy v. First Nat. Bk. (1915), 176 S. W. 1038; Waterhouse v. Sterchi Bros. (1918), 201 S. W. 150.

Washington.-Bardshar v. Chaffee (1916), 156 Pac. 388; Bardsley v. Washington Mill Co. (1909), 103 
Pac. 822; Galbraith v. Shepard (1906), 43 Wash. 698, 86 Pac. 1113; Hillman v. Stanley (1909), 56 Wash. 320, 105 Pac. 816.

Wisconsin. - Schoenwetter v. Schoenwetter (1916), 159 N. W.
737; Welsch' v. Kukuk (1906), 128 Wis. $419,107 \mathrm{~N}$. W. 301.

United States.-Grandison $\nabla$. Robertson (1916), 231 Fed. 785; In re Swift (1901), 106 Fed. 65 (Dt. Mass.); Murray iv. Third Nat. Bk. of St. Louis (1916), 234 Fed. 481.

Section 71. Where the instrument is not payable on demand, presentment must be made on the day it falls due. Where it is payable on demand, presentment must be made within a reasonable time after its issue, except that in the case of a bill of exchange, presentment for payment will be sufficient if made within a reasonable time after the last negotiation thereof.

Colorado.- Babcock v. City of Rocky Ford (1914), 137 Pac. 899; Babcock v. The City of Rocky Ford (1914), 25 Colo. App. 312.

Idaho. - Sheffield v. Cleland (1911), 19 Ida. 612, 115 Pac. 20.

Illinois.-First Nat. Bk. of Chadwick v. Mackey (1910), 157 Ill. App. 408; Greer v. Downing (1912), 176 Ill. App. 355.

Iowa-Anderson v. First Nat. Bk. of Chariton (1909), 144 Iowa, 251, 122 N. W. 918; Citizens Bk. of Pleasantville v. First Nat. Bk. of Pleasantville (1907), 135 Jowa, 605, 13 L. R. A. (N. S.) 303, 113 N.W. 481.

Louisiana.- Lewy v. Wilkinson (1914), 64 So. 1003.

Massachusetts.- Merritt v. Jackson (1902), 181 Mass. 69, 62 N. E. 987; Plymouth County Trust Co. v. Scanlon (1917), 116 N. E. 468.

New Jersey.- Hill Savings \& Drawing Club v. Baronowitz (1916), 97 Atl. 28.

New York.-Becker v. Horowitz (1909), 114 N. Y. Supp. 161, 61
Misc. 608; Columbia-Knickerbocker Tr. Co. v. Miller (1913), 142 N. Y. Supp. 440; Commercial Nat. Bk. v. Zimmerman (1906), 185 N. Y. 210, 77 N. E. 1020; Congress Brewing Co. v. Habenicht (1903), 83 A. D. 141, 82 N. Y. Supp. 481; GermanAm. Bk. v. Milliman (1900), $65 \mathrm{~N}$. Y. Supp. 242, 31 Misc. 87; GermanAm. Nat. Bk. v. Mills (1904), 99 A. D. 312; Hussey v. Sutton (1916), 160 N. Y. Supp. 934; McBride v. Illinois Nat. Bk. (1910), 138 A. D. 339; Schlesinger v. Schultz (1905), 10 A. D. 356,96 N. Y. Supp. 383 ; Young v. Am. Bk., No. 82 (1904), 44 Misc. 308, 89 N. Y. Supp. 915.

Oregon. - Robinson v. Holmes (1910), 57 Oreg. 5, 109 Pac. 754.

Tennessee.-Am. Nat. Bk. v. Nat. Fertilizer Co. (1911), 125 Tenn. 329, 143 S. W. 597.

Wisconsin. - Columbian Banking Co. v. Bowen (1908), 134 Misc. 218, 114 N. W. 451.

United States.- Murray $v$. Third Nat. Bk. of St. Louis (1916), 234 Fed. 481 (C. C. A.). 
Section 72. Presentment for payment, to be sufficient, must be made:

(1) By the holder, or by some person authorized to receive payment on his behalf;

(2) At a reasonable hour on a business day;

(3) At a proper place as herein defined;

(4) To the person primarily liable on the instrument or if he is absent or inaccessible, to any person found at the place where the presentment is made.

California.-Freudenberg v. Lucas (1918), 175 Pac. 482.

Colorado.-Archuleta v. Johnston (1912), 127 Pac. 134.

Kentucky.-Doherty v. First Nat. Bk. (1916), 186 S. W. 937.

Massachusetts.- In re Poole (1917), 116 N. E. 227.

New York. - Columbia - Knickerbocker Trust Co. v. Miller (1915), 215 N. Y. 191, 109 N. E. 179; German-Am. Bk. v. Milliman (1900), 65 N. Y. Supp. 242, 31 Mise. 87; Gilpin v. Savage (1908), 60 Misc. 605,112 N. Y. Supp. 802; Gilpin v. Savage (1911), 201 N. Y. 167, 94 N. E. 656; McBride v. Illinois Nat. Bk. (1910), 138 A. D. 339.
North Dakota.- Nelson v. Grondahl (1904), 13 N. Dak. 363, $100 \mathrm{~N}$. W. 1093.

Ohio,-Rockfield v. First Nat. Bk. of Springfield (1907), 77 Ohio St. 311,83 N. E. 392.

Oregon:- Hodges v. Blaylock (1916), 161 Pac. 396.

Pennsylvania.- McNeely Co. v. Bk. of No. Am. (1908), 221 Pa. 588.

South Dakota.- Maupin v. Mobridge (1917), 161 N. W. 332.

Washington. - North Western Nat. Bk. of Portland v. Pearson (1918), 173 Pac. 730.

Wisconsin.-Cólumbian Banking Co. v. Bowen (1908), 134 Wis. 218, 114 N. W. 451.

Section 73. Presentment for payment is made at the proper place:

(1) Where a place of payment is specified in the instrument and it is there presented;

(2) Where no place of payment is specified, but the address of the person to make payment is given in the instrument and it is there presented.

(3) Where no place of payment is specified and no address is given and the instrument is presented at the usual place of business or residence of the person to make payment;

(4) In any other case if presented to the person to make payment wherever he can be found, or if presented at his last known place of business or residence. 
Colorado.-Archuleta v. Johnston (1912), 127 Pac. 134.

Florida.-Ryan v. State (1910), 60 Fla. 25, 53 So. 448.

Illinois.- Kewanee Nat. Bk. v. Ladd.(1912), 175 Ill. App. 151; Stewart v. Soenksen (1912), 173 Ill. App. 1.

Kentucky.-Doherty v. First Nat. Bk. (1916), 186 S. W. 937.

Louisiana.-Smitlı v. Shippers Oil Co. (1908), 120 La. 639, 45 So. 533.

Massachusetts. - In re Poole (1917), 116 N. E. 227.

Michigan.-Finch v. Calkins (1914), 149 N. W. 1037.

New York.-Baer v. Hoffman (1912), 135 N. Y. Supp. 28, 150 A. D. 475; Columbia-Knickerbocker 'Tr. Co. v. Miller (1915), 215 N. Y. 191, 109 N. E. 179; Congress Brewing
Co. v. Habenicht (1903), 83 A. D). 141, 82 N. Y. Supp. 481; GermanAm. Bk. v. Milliman (1900), $65 \mathrm{~N}$. Y. Supp. 242, 31 Mise. 87; Gilpin v. Savage (1908), 60 Mise. 605, 112 N. Y. Supp. 802 ; Gilpin v. Savage (1911), 201 N. Y. 167, 94 N. E. 656 ; Iron Clad Mfg. Co, v. Sackin (1908), 110 N. Y. Supp. 161; McBride v. Illinois Nat. Bk. (1910), 138 A. D. 339 ; Schlesinger v. Schultz (1905), 10 A. D. 356,96 N. Y. Supp. 383.

North Dakota.- Nelson v. Grondahl (1904), 13 N. Dak. 363, 100 N. IV. 1093.

South Carolina.- Norwood Nat. Bk. v. Piedmont Pub. Co. (1917), 91 S. E. 866 .

Washington.- Bardsley v. Wash. ington Mill Co. (1909), 103 Pac. 822 .

Section 74. The instrument must be exhibited to the person from whom payment is demanded, and when it is paid must be delivered up to the party paying it.

California.-Freudenberg v. Lucas (1918), 175 Pac. 482.

New York.-Congress Brewing Co. v. Habenicht (1903), 83 A. D. 141,82 N. Y. Supp. 481; GermanAm. Bk. v. Milliman (1900), $65 \mathrm{~N}$. Y. Supp. 242, 31 Misc. 87; Greco v. LoMonte (1917), 162 N. Y. Supp. 982; Klotz v. Silver (1911), 127
N. Y. Supp. 1090; MeBride v. Illinois Nat. Bk. (1910), 138 A. D. 339 ; State of N. Y. Nat. Bk. v. Kennedy (1911), 130 N. Y. Supp. 412, 145 A. D. 669.

North Dakota.-Shuman v. Citizen's State Bk. of Rugby (1914), 147 N. W. 388.

Section 75. Where the instrument is payable at a bank, presentment for payment must be made during banking hours, unless the person to make payment has no funds there to meet it at any time during the day, in which case presentment at any hour before the bank is closed on that day is sufficient.

New York,- Columbia - Knickerbocker Tr. Co. v. Miller (1913), 142 N. Y. Supp. 440; McBride v. Illi- nois Nat. Bk. (1913), 183 A. D. 339 ; Schlesinger $v$. Schultz (1905), 10 A. D. 256,96 N. Y. Supp. 383. 
Section 76. Where a person primarily liable on the instrument is dead, and no place of payment is specified, presentment for payment must be made to his personal representative if such there be, and if, with the exercise of reasonable diligence, he can be found.

New York.-Reed v. Spear (1905), 107 A. D. 144,94 N. Y. Supp. 1007.

Section 7\%. Where the persons primarily liable on the instrument are liable as partners, and no place of payment is specified, presentment for payment may be made to any one of them, even though there has been a dissolution of the firm.

Section 78. Where there are several persons, not partners, primarily liable on the instrument, and no place of payment is specified, presentment must be made to them all.

Colorado. - Prior v. Simonson (1916), 160 Pac. 1035.

New York.- State of N. Y. Nat. Bk. v. Kennedy (1911), 130 N. Y. Supp. 412, 145 A. D. 669.
North Dakota.- Shuman v. Cit. State Bk. of Rugby (1914), $147 \mathrm{~N}$. W. 388 .

Section 79. Presentment for payment is not required in order to charge the drawer where he has no right to expect or require that the drawee or acceptor will pay the instrument.

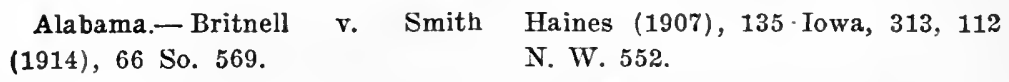

Iowa.-West Branch State Bk. v. United States.-In re Swift (1901), 106 Fed. 65 (Dt. Mass.).

Section 80. Presentment for payment is not required in order to charge an indorser where the instrument was made or accepted for his accommodation and he has no reason to expect that the instrument will be paid if presented.

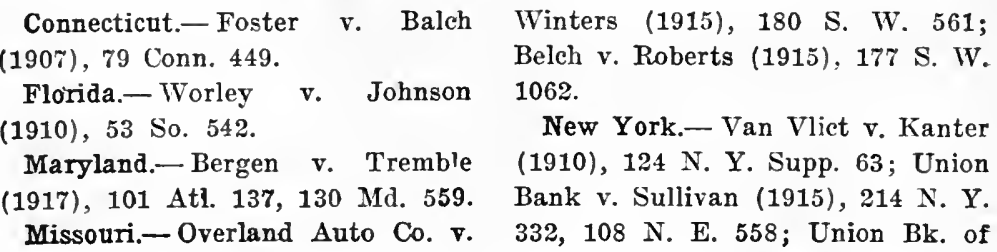


Brooklyn v. Sullivan (1915), 108 N. E. 558,214 N. Y. 332.

South Dakota.- Seribner State Bk. v. Ransom (1915), 151 N. W. 1023.
United States.-McDonald $\nabla$. Luckenback (1909), 170 Fed. 434, 95 C. C. A. 604 ; Murray v. Third Nat. Bk. of St. Louis (1916), 234 Fed. 481.

Section 81. Delay in making presentment for payment is excused when the delay is caused by circumstances beyond the control of the holder, and not imputable to his default, misconduct or negligence. When the cause of delay ceases to operate, presentment must be made with reasonable diligence.

Florida.-Worley $\quad$ v. Johnson bocker Tr. Co. v. Miller (1913), 142 (1910), 53 So. 542.

Kentucky.- Frazer v. Phoenix Nat. Bk. (1914), 170 S. W. 532.

New York.-Columbia - KnickerN. Y. Supp. 440.

Wisconsin.-Aebi v. Bk. of Evansville (1905), 124 Wis. 93, $102 \mathrm{~N}$. W. 329,68 L. R. A. (N. S.) 964, 109 Am. St. 925 .

Section 82. Presentment for payment is dispensed with:

(1) Where after the exercise of reasonable diligence presentment as required by this act cannot be made;

(2) Where the drawee is a fictitious person;

(3) By waiver of presentment, express or implied.

Alabama.-Blomberg $\quad$ v. Self $(1910), 161$ Mich. 61, 125 S. IV. (1919), 80 So. 631.

Colorado.-Torbet v. Montague (1906), 38 Colo. 325, 87 Pac. 1145.

Florida.-Worley v. Johnson (1910), 53 So. 542.

Kansas.- Nat. Bk. of Webb City จ. Dickinson (1918), 171 Pac. 636.

Kentucky.-Owensboro Sav. Bk. \& Tr. Co.'s Receiver v. Haynes (1911), 136 S. W. 1004.

Massachusetts.- Merritt v. Jaekson (1902), 181 Mass. 69, 62 N. E. 987; Toole v. Crafts (1906), 193 Mass. 110,78 N. E. 775,118 Am. St. 455; Hall v. Crane (1913), 213 Mass. 325.

Michigan.-Bessenger $\nabla$. Wenzel 750.

New York.-Congress Brewing Co. v. Habenicht (1903), 83 A. D. 141, 82 N. Y. Supp. 181 ; Reed v. Spear (1905), 107 A. D. 144, 94 N. Y. Supp. 1007; Gilpin v. Savage (1908), 60 Misc. 605, 112 N. Y. Supp. 802; O'Bannon J. W. Co. v. Curran (1908), 129 A. D. 90, 113 N. Y. Supp. 359 ; McBride v. Illinois Nat. Bk. (1910), 138 A. D. 339 ; First Nat. Bk. of Binghamton v. Baker (1914), 148 N. Y. Supp. 372, 163 A. D. 72 ; Cohen v. Chelsea Exchange Bk. of New York (1917), 164 N. Y. Supp. 75.

Oregon. - Robinson v. Holmes (1910), 57 Oreg. 5, 109 Pac. 754; 
Moll v. Roth Co. (1915), 152 Pac. 235.

Washington.- Galbraith v. Shep- ard (1906), 43 Wash. 698, 86 Pac. 1113.

United States. - In re Swift (1901), 106 Fed. 65 (Dt. Mass.).

Section 83. The instrument is dishonored by non-payment when :

(1) It is duly presented for payment and payment is refused or cannot be obtained; or

(2) Presentment is excused and the instrument is overdue and unpaid.

Colorado.-Archuleta v. Johnston (1912), 127 Pac. 134.

Massachusetts.-Leonard v. Draper (1905), 187 Mass. 536, 73 N. E. 644.

New York.- German-Am. Bk. v. Milliman (1900), 65 N. Y. Supp. 242, 31 Misc. 87; Reed v. Spear
(1905), 107 A. D. 144, 94 N. Y. Supp. 1007.

Tennessee.-Am. Nat. Bk. v. Nat. Fertilizer Co. (1911), 125 Tenn. 329, 143 S. W. 597.

Washington.-Hillman v. Stanley (1909), 56 Wash. 320, 105 Pac. 816.

Section 84. Subject to the provisions of this act, when the instrument is dishonored by non-payment, an immediate right, of recourse to all parties secondarily liable thereon accrues to the holder.

Massachusetts. - Leonard v. Draper (1905), 187 Mass. 536, 73 N. E. 644.

New York.-Gilpin v. Savage (1908), 60 Misc. 605, 112 N. Y. Supp. 802 ; Pittsburg, etc., Coal Co. v. Kerr (1917), 115 N. E. 465, 220 N. Y. 137 .
South Dakota.- Scribner State Bk. v. Ransom (1915), 151 N. W. 1023.

Tennessee.-Am. Nat. Bk. v. Nat. Fertilizer Co. (1911), 125 Tenn. 329, 143 S. IV. 597.

Washington.-Hillman $\nabla$. Stanley (1909), 56 Wash. 320, 105 Pac. 816.

Section 85. Every negotiable instrument is payable at the time fixed therein without grace. When the day of maturity falls upon Sunday, or a holiday, the instrument is payable on the next succeeding business day. Instruments falling due (or becoming payable) on Saturday are to be presented for payment on the next succeeding business day, except that instruments payable on demand may, at the option of the holder, be presented for payment before twelve o'clock noon on Saturday when that entire day is not a holiday. 
Massachusetts. - Demelman v. New Jersey.- Stanford v. StanBrazier (i:07), 193 Mass. 588, 79 ford (1917), 101 AtL 388.

N. E. 812 .

Section 86. Where the instrument is payable at a fixed period after date, after sight, or after the happening of a specified event, - the time of payment is determined by excluding the day from which the time is to begin to run, and by including the date of payment.

Section 87. Where the instrument is made payable at a bank it is equivalent to an order to the bank to pay the same for the account of the principal debtor thereon.

Colorado.-De La Vergne v. Globe Printing Co. (1915), 149 Pac. 923.

Kansas.-- The N. E. Nat. Bk. of Kansas City, Mo. v. Dick (1911), 84 Kans. 252, 114 Pac. 378.

Kentucky.- Price v. Gatliff's Exrs. (1908), 110 S. W. 332.

Massachusetts.- Elliott v. Worcester 'Tr. Co. (1905), 189 Mass. 542, 75 N. E. 944.
New York.-Glennan v. Rochester Tr. \& Safe Dep. Co. (1912). 152 A. D. 316 .

Tennessee.- Pharmacy v. First Nat. Bk. (1915), 176 S. W. 1038.

United States.-Carpenter v. Nat. Shawmut Bk. (1911), 109 C. C. A. 55.

Section 88. Payment is made in due course when it is made at or after the maturity of the instrument to the holder thereof in good faith and without notice that his title is defective.

Alabama.- Oneonta Trust " \& (1917), 164 N. Y. Supp. 113; GlenBanking Co. v. Box (1917), 73 So. nan v. Rochester Tr. \& Safe Dep. 759; Wade v. Kellen (1917), 75 So. Co. (1912), 152 A. D. 316 ; Potter 970.

Arkansas.-Johnson v. Aylor 438.

(1917), 195 S. W. 4. Washington.-Capitol Nat. Bk. v.

Iowa.-Wendt v. Haglestange Robinson (1906), 41 Wash. 454, 83 (1917), 161 N. W. 455.

Pac. 1021.

New York.-Hoch v. Bernstein

\section{ARTICLE VIT. NOTICE OF DISHONOR.}

Section 89. Except as herein otherwise provided, when a negotiable instrument has been dishonored by non-acceptance or non- 
payment, notice of dishonor must be given to the drawer and to each indorser. and any drawer or indorser to whom such notice is not given is discharged.

Arkansas.-Bibbs v. Hopper (1913), 160 S. W. 879.

California. - Wetzel v. Cole (1917), 165 Pac. 692.

Colorado.-Sykes v. Kruse (1911), 49 Colo. 560, 113 Pac. 1013

Connecticut.- Peck v. Easton (1902), 74 Conn. 456, 51 Atl. 134; Foster v Balch (1907), 79 Conn. 449; Hopkins v. Merrill (1907), 79 Conn. 626, 66 Atl. 174; Cent. Nat. Bk. v. Stoddard (1910), 83 Conn. 330, 76 Atl. 472; Blue Ribbo Garage $v$ Baldwin (1917), 101 Atl. 83.

Florida.- Worley v. Johnson (1910), 53 So. 542.

Illinois.- State Bk. of Clinton v. Parkhurst (1910), 155 Ill. App. 101; Sublette Ex. Bk. v. Fitzgerald (1912), 168 Ill. App. 240.

Kansas.-Guaranty Inv. Co. v. Ganıle (1918), 171 Pac. 1152.

Kentucky.-- Fritts v. Kirchdorfer (1910), 124 S. W. 882; Mechanics \& Farmer's Sav. Bk. v. Katterjohn (1910), 137 Ky. 427, 125 S. IV. 1071; Hoyland v. Nat. Bk. of Middleborough (1910), $137 \mathrm{Ky} .682,126$ S. W. 356 ; First Nat. Bk. v. Bickel (1911), $143 \mathrm{Ky} \cdot 754,137$ S. W. 790; Williams v. Paintsville Nat. Bk. (1911), 143 Ky. 781, 137 S. IV. 535; Sim v. Citizens Bk. (1917), 191 S. IV. 489.

Louisiana.- Wisdom \& Levy v. Bille (1908), 120 La. 699, 45 So. 554.

Maryland.- Lightner v. Roach (1915), 95 Atl. 62, 126 Md. 474.

Massachusetts.- Commercial Nat. Bk. v. Clarke (1902), 180 Mass.
249 ; Bennet v. Tremont Securities Co. (1915), 108 N. E. 891.

Missoun.- Overland Auto Co. v. Winter (1915), 180 S. IV. 561; Eaves v. Keeton (1917). 193 S. W. 629; Peoples Bank of Ava v Baker (1917), 193 S. W. 632.

New Hampshire-- Trafton v. Garnsey (1916), 99 Atl. 290.

New Jersey.- Battery Park Bk. v. Ramsey (1917), 100 Atl 51; Motley v. Darling (1918), 102 Atl. 853.

New York.- Ebling Brewing Co. v. Rheinheimer (1900), 32 Misc. 594, 66 N. Y. Supp. 458; University Press v. Williams (1900), 48 A. D. 188; Mohlman Co. v. McKane (1901), 60 A. D. 546; Kelly v. Theiss (1901), 65 A. D 146; Fonseca v. Hartman (1903), 84 N. Y. Supp. 131; Am. Ex. Nat. Bk. v. Am. Hotel Victoria Co. (1905), 103 A. D. 372,92 N. Y. Supp. 1006; Reed v. Spear (1905), 107 A. D. 144, 94 N. Y. Supp. 1007; Howard v. Bk. of the Metropolis (1916), 115 A.'D. 326 ; Scanlon v. Wallach (1907, 102 N. Y. Supp. 1090, 53 Misc. 104; Ewald v. Faulbaker Stable Co. (1907), 105 N. Y. 114; Sherman v. Ecker (1908), 58 Misc. 546, 110 N. Y. Supp. 265; Bacigalupo v. Parilli (1908), 112 N. Y. Supp. 1040; O'Bannon J. W. Co. v. Curran (1908), 129 A. D. 90,113 N. Y. Supp. 359; Kuflick v. Glasser (1909), 114 N. Y. Supp. 870; Dupont de Nemour Powder Co. v. Rooney (1909), 63 Misc. 344, 117 N. Y. Supp. 220; Studebaker Bros. Co. v. Guether (1910), 123 N. Y. 
Supp. 118; Noonan \& Price Co. v.

E. Kwanok Realty Co. (1910), 123 N. Y. Supp. 915; Klotz v. Silver (1911), 127 N. Y. Supp. 1090; Mayer v. Boyle (1912), 132 N. Y. Supp. 729; Smitl v. Leiman (1912). 133 N. Y. Supp. 1001; Pirl v. Cary (1912), 134 N. Y. Supp. 1036; Badt v. Miller (1912), 135 N. Y. Supp. 13, 150 A. D. 920 .

North Carolina.--Rouse v. Wooten (1906), 140 N. Car. 557, 53 S. E. 430, 111 Am. St. 875; Perry Co. v. Taylor (1908), 148 N. Car. 362; Houser v. Fayssoux (1914), $83 \mathrm{~s}$. E. 692; First Nat. Bk. of Henderson v. Johnson (1915), 86 S. E. 360 ; Edwards v. Standard Life Ins. Co. (1917), 92 S. E. 695; Newland v. Moore (1917), 92 S. E. 367; Barker v. W. M. Absher Co. (1918), 96 S. E. 43; Horton v. Wilson (1918), 95 S. E. 904.

North Dakota.- Union State Bk. v. Benson (1917), 165 N. W. 509.

Ohio.- Rockfield v. First Nat. Bk. of Springfield (1907), 77 Ohio St. 311,83 N. E. 392 .
Oregon- Robinson v. Holmes (1910), 57 Oreg. 5, 109 Pac. 754.

Pennsylvania.- Link v. Bergdoll (1907), $35 \mathrm{~Pa}$. Super. Ct. 155; First Nat. Bk. v. MeBride (1911), 230 Pa. 261.

Rhode Island.-Cook v. Am. Tub. ing \& Webbing Co. (1906), 28 R. L. 41, 65 Atl. 641; Dealey v. Choquet (1907), 28 R. I. 338.

Tennessee.-Am. Nat. Bk. v. Nat. Fertilizer Co. (1911), 125 Tenn. 329, 143 S. W. 597; Nolan v. H. E. Wilcox Motor Co. (1917), 195 S. W. 581.

Virginia.-Security Loan \& Trust Co. v. Fields (1910), 110 Va. 827, 67 S. E. 342 .

Washington.- Galbraith v. Shepard (1906), 43 Wash. 698, 86 Pac. 1113; Bardshar v. Chaffee (1916), 156 Pac. 388; Codd v. Von Der Ake (1916), 159 Pac. 686.

West Virginia. - Rusmissel v. White Oak Co. (1917), 92 S. E. 672.

Section 90. The notice may be given by or on behalf of the holder, or by or on behalf of any party to the instrument who might be compelled to pay it to the holder, and who upon taking it up would have a right to reimbursement from the party to whom the notice is given.

Connecticut.- Blue Ribbon .Garage v. Baldwin (1917), 101 Atl. 83.

Illinois.-W. A. Fowler Paper Co v. Best Jones Sales Book Co. (1913), 183 Ill. App. 310.

Kentucky.- Williams $\nabla$. Paintsville Nat. Bk. (1911), $143 \mathrm{Ky}$. 781, $137 \mathrm{~s}$. IV. 535.

Missouri. - Eaves v. Keeton (1917), 193 S. W. 629.
New York.- University Press v. Williams (1900), 48 A. D. 185; Trader's Nat. Bk. v. Jones (1905), 104 A. D. 433,93 N. Y. Supp. 66 s.

Rhode Island.- Cook v. Am. Tubing \& Webbing Co. (1906), 28 R. I. 41, 65 Atl. 641.

United States.-l'iedmont \& Caro. Ry. Co. v. Shee (1915), 283 Fed. 973 (C. C. A., 4th Ct.). 
Section 91. Notice of dishonor may be given by an agent either in his own name or in the name of any party entitled to give notice, whether that party be his principal or not.

Illinois.-W. A. Fowler Paper Co. Bk. v. Jones (1905), 104 A. D. v. Best-Jones Sales Book Co. (1913), 433, 93 N. Y. Supp. 768; First Nat. 183 Ill. App. 310.

New York.- Kelly v. Theiss Gridley (1906). 98 N. Y. Supp. 445, (1902), 77 A. D. 81; Trader's Nat. 112 A. D. 398.

Section 92. Where notice is given by or on behalf of the holder, it enures for the benefit of all subsequent holders and all prior parties who have a right of recourse against the party to whom it is given.

Pennsylvania.-Nat. Bk. of Phoenixville v. Bonsor (1909), $38 \mathrm{~Pa}$.

Super. Ct. 275.

Section 93. Where notice is given by or on behalf of a party entitled to give notice, it enures for the benefit of the holder and all parties subsequent to the party to whom notice is given.

New York.-Weiss v. Rieser United States.- Piedmont \& Ca. (1909), 62 Misc. 292, 114 N. Y. Ry. Co. v. Shee (1915), 223 Fea. Supp. 983.

973 (C. C. A., 4th Ct.).

Section 94. Where the instrument has been dishonored in the hands of an agent, he may either himself give notice to the parties liable thereon, or he may give notice to his principal. If he give notice to his principal, he must do so within the same time as if he were the holder, and the principal upon the receipt of such notice himself the same time for giving notice as if the agent had been an independent holder.

Colorado.-De La Vergne จ. New York.-Brill v. Jefferson Bk. Globe Printing Co. (1915), 148 Pac. (1913), 159 A. D. 461, 144 N. Y. 923.

Connecticut.- Gleason v. Thayer (1913), 87 Atl. 790 .

Illinois.-W. A. Fowler Paper Co. v. Best-Jones Sales Book Co. (1913), 183 IIl. App. 310.

Massachusetts. - Middleborough Nat. Bk. v. Cole (1906), 191 Mass. 168, 77 N. E. 781. Supp. 539.

Nortb Carolina.- State Bk. of Chicago v. Carr (1902), 130 N. Car. 479.

United States.-Lyons v. Westwater (1910), 103 C. C. A. 663, 181 Fed. 681 (Pa.). 
Section 95. A written notice need not be signed, and an insufficient written notice may be supplemented and validated by verbal communication. A misdescription of the instrument does not vitiate the notice unless the party to whom the notice is given is in fact mislead thereby.

California. - Smith v. Hirst (1917), 163 Pac. 334.

Connecticut.-Blue Ribbon Garage v. Baldwin (1917), 101 Atl. 83.

Iowa.- Higby v. Bahrenfuss (1917), 163 N. W. 247.

Kentucky.-Grayson Co. Bk. v. Elbert (1912), 137 S. W. 792.

New York. Wilson v. Peck
(1910), 121 N. Y. Supp. 344, 66 Misc. 179; Mayer v. Boyle (1912), 132 N. Y. Supp. 729.

Pennsylvania.- Marshall v. Sonneman (1906), 216 Pa. 65, 64 Atl. 874.

Wisconsin.-Second Nat. Bk. of Richmond v. Smith (1903), 118 Wis. 18, 94 N. W. 664; First Nat. Bk. v. McBride (1911), $230 \mathrm{~Pa} .261$.

Section 96. The notice may be in writing or merely oral and may be given in any terms which sufficiently identify the instrument, and indicate that it has been dishonored by non-acceptance or non-payment. It may in all cases be given by delivering it personally or through the mails.

Alabama.-Scarborough v. City Nat. Bk. (1908), 157 Ala. 577, 48 So. 62 .

California. - Smith v. Hirst (1917), 163 Pac. 334, 32 Cal. Ap.p. 507.

Colorado.- De La Vigne v. Globe Printing Co. (1915), 148 Pac. 923.

Florida.-Ryan v. State (1910), 60 Fla. 25, 53 S. E. 448; Jones v. Manitowoc Shipbuilding \& Dry Dock Co. (1913), 62 Só. 590.

Kentucky.-Grayson Co. Bk. v. Elbert (1912), 137 S. W. 792; Do. herty v. First Nat. Bk. (1916), 186 b. W. 937 .

New Jersey.- Battery Park Bk. v. Ramsay (1917), 100 Atl. 51. New York.-University Press v. Williams (1900), 48 A. D. 188; Kelly v. Theiss (1902), 77 A. D. 81; Am. Ex. Nat. Bk. v. Am. Hotel
Victoria Co. (1905), 103 A. D. 373, 92 N. Y. Supp. 1006; Reed v. Spear (1905), 107 A. D. 144, 94 N. Y. Supp. 1007; Klotz v. Silver (1911), 127 N. Y. Supp. 1090; Mayer v. Boyle (1912), 132 N. Y. Supp. 729; Merrell Chem. Co. v. Root (1915), 152 N. Y. Supp. 368.

Oregon.-Price v. Warner (1911), 60 Oreg. 7, 118 Pac. 173.

Pennsylvania.- Marshall v. Sonneman (1906), $216 \mathrm{~Pa} .65,64$ Atl. 874; Zoller v. Moffitt (1909), 222 Pa. 644; First Nat. Bk. v. MeBride (1911), 230 Pa. 261.

Washington.-Gleeson v. Lichty (1911), 62 Wash. 656, 114 Pac. 518; Schultz v. Crewdson (1917), 163 Pac. 734.

Wisconsin.-Second Nat. Bk. of Richmond v. Smith (1903), 118 Wis. 18,94 N. W. 664 . 
Section $9 \%$. Notice of dishonor may be given either to the party himself or to his agent in that behalf.

Florida.- Jones v. Manitowoc Shipbuilding \& Dry Dock Co. (1913), 62 So. 590 .

Illinois.-W. A Fowler Paper Co. v. Best-Jones Sales Book Co. (1913), 183 Ill. App. 310.

Indiana.- Swift \& Co. v. Miller (1917), 113 N. E. 447.
New York.-.- Mohlman Co. v. McKane (1901), 60 A. D. 546; Am. Ex. Nat. Bk. v. Am. Hotel Victoria Co. (1905), 103 A. D. 372,92 N. Y. Supp. 1006; Reed v. Spear (1905), 107 A. D. 144,94 N. Y. Supp. 1007.

Tennessee.-Am. Nat. Bk. v. Nat. Fertilizer Co. (1911), 125 Tenn. 329, 143 S. W. 597.

Section 98. When any party is dead, and his death is known to the party giving notice, the notice must be given to a personal representative, if there be one, and if with reasonable diligence he can be found. If there be no personal representative, notice may be sent to the last residence or last place of business of the deceased.

New York.- Merchants Bank v.

Brown (1903), 86 A. D. 599, 83 N.

Y. Supp. 1037.

Section 99. Where the parties to be notified are partners, notice to any one partner is notice to the firm even though there has been a dissolution.

Kentucky.-Aud v. McElvoy Jones (1905), 104 A. D. 433, 93 (1917), 197 S. W. 824. N. Y. Supp. 768.

Massachusetts. - Feigenspan v. Pennsylvania. - Kensington Nat. McDonald (1909), 201 Mass. 341, 87 Bk. v. Ware (1906), 32 Pa. Super. N. E. 624 . Ct. 247.

New York.- Trader's Nat. Bk. v.

Section 100. Notice to joint parties who are not partners must be given to each of them, unless one of them has authority to receive such notice for the others.

Kentucky.-Doherty v. First Nat. New York.-Bennett v. Kisler Bk. (1916), 186 S. W. 937. (1917), 163 N. Y. Supp. 555.

Section 101. Where a party has been adjudged a bankrupt or: an insolvent, or has made an assignment for the benefit of cred- 
itors, notice may be given either to the party himself or to his trustee or assignee.

Section 102. Notice may be given as soon as the instrument is dishonored; and unless delay is excused as hereinafter provided, must be given within the times fixed by this act.

California.- Smith v. Hirst (1917), 163 Pac. 334, 32 Cal. App. 507.

Kentucky.-Elsey v. Peoples Bk. of Bardwell (1916), 182 S. W. 873.

Maine.-Kerr v. Dyer (1917), 102 Atl. 178.
New York.-German-Am. Bk. v. Milliman (1900), 65 N. Y. Supp. 242, 31 Misc. 87.

Tennessee.-Am. Nat. Bk. v. Nat. Fertilizer Co. (1911), 125 Tenn. 329,143 S. W. 597.

Section 103. Where the person giving and the person to receive notice reside in the same place, notice must be given within the following times:

(1) If given at the place of business of the person to receive notice, it must be given before the close of business hours on the day following.

(2) If given at his residence, it must be given before the usual hours of rest on the day following.

(3) If sent by mail, it must be deposited in the post-office in time to reach him in usual course on the day following.

Colorado.- Emerson \& Buckingham Bk. \& Trust Co. v. GremanAmerican Trust Co. (1919), 176 Pac. 472.

Indiana.- Swift \& Co. v. Miller (1917), 113 N. E. 447.

New York.-Cassel v. Regierer (1908), 114 N. Y. Supp. 601; Kelly v. Theiss (1901), 65 A. D. 146; Jurgens v. Vichman (1908), 124 A. D. 531, 108 N. Y. Supp. 881; In re Mandelbaum (1913), 141 N. Y. Supp. 319; Klotz v. Silver (1911), 127 N. Y. Supp. 1090; Siegel $\nabla$.
Dubnisky (1907), 56 Misc. 68, 107 N. Y. Supp. 678; Smith Co. v. America-Europe Co. (1911), 128 N. Y. Supp. 81; Solomon v. Cohen (1905), 94 N. Y. Supp. 502; Wilson v. Peek (1910), 121 N. Y. Supp. 344, 66 Misc. 179.

Oregon.- Price v. Warner (1911), 60 Oreg. 7, 118 Pac. 173.

Rhode Island.-Dealey v. Choquet (1907), 28 R. I. 338.

South Carolina.- Norwood Nat. Bk. v. Piedmont Pub. Co. (1917), 91 S. E. 866.

Section 104. Where the person giving and the person to receive 
notice reside in different places, the notice must be given within the following times:

(1) If sent by mail, it must be deposited in the post,-office in time to go by mail the day following the day of dishonor, or if there be no mail at a convenient hour on that day, by the next mail thereafter.

(2) If given otherwise than through the post-office, then within the time that notice would have been received in due course of mail, if it had been deposited in the post-office within the time specified in the last subdivision.

Colorado.-De La Vergne v. Globe Printing Co. (1915), 148 Pac. 923.

Idaho. - Hudson v. Carlson (1918), 170 Pac. 100.

Indiana.- Swift \& Co. v. Miller (1916), 113 N. E. 447.

Iowa.-Citizens Bk. of Pleasantville v. First Nat. Bk. of Pleasantville (1907), 135 Iowa, 605, $13 \mathrm{~L}$. R. A. (N. S.) 303,113 N. W. 481.

Massachusetts.- Harris v. Baker (1917), 115 N. E. 292.

New Jersey.- Second Nat. Bk. of Hoboken v. Smith (1918), 103 Atl. 862.

New York.- Jurgens v. Wichman (1908), 124 A. D. 531, 108 N. Y.
Supp. 881; Kelly v. Theiss (1901), 65 A. D. 146; Metropolitan Bk. v. Engel (1901), 66 A. D. 273; Mohlman Co. v. MeKane (1901), 60 A. D. 546; Smith Co. v. AmericaEurope Co. (1911), 128 N. Y. Supp. 81; University Press Co. v. Williams (1900), 48 A. D. 188.

West Virginia.-Farmers Nat. Bk. v. Howard (1912), 71 W. Va. 57.

Wisconsin.- First Nat. Bk. of Shawano v. Miller (1909), 139 Wis. 126, 120 N. W. 820.

California.- Seeley v. Stoltz, Inc. (1917), 163 Pac. 681, 32 Cal. App. 458.

Section 105. Where notice of dishonor is duly addressed and deposited in the post-office, the sender is deemed to have given due notice, notwithstanding any miscarriage in the mails.

Mlinois.- Kewanee Nat. Bk. v. Ladd (1912), 175 Ill. App. 151.

Massachusetts. - Feigenspan v. McDonald (1909), 201 Mass. 341, $87^{\circ}$ N. E. 624 ; Harris v. Baker (1917), 115 N. E. 292.

Michigan.-- First Nat. Bk. of Manistee v. Star Watch Case Co. (1915), 153 N. W. 722.

Missouri. - Eaves v. Keeton (1917), 153 S. W. 629; First Nat.
Bk. of Grant City v. Korn (1915), 179 S. W. 721.

New Jersey.-Battery Park Bk. v. Ramsay (1917), 100 .Atl. 51.

New York.- Century Bk. of City of N. Y. v. Breithart (1915), 151 N. Y. Supp. 588; McGrath v. Francoline (1915), 156 N. Y. Supp. 981; State Bank v. Soloman (1903), 84 N. Y. Supp. 976; Union Rk. of 
Brooklyn v. Deshel (1910), 123 N. Pa. Super. Ct. 398; Zoller v. MofY. Supp. 585.

Pennsylvania. - First Nat. Bk. of Hanover v. Delone (1916), 98 Atl. 1042; Siegel v. Hirsch (1904), 26 fitt (1909), $222 \mathrm{~Pa} .644$.

West Virginia.- Board of Educa. tion v. Angel (1915), 84 S. E. 747 ; Farmer's Nat. Bk. v. Howard (1912), 71 W. Va. 57.

Section 106. Notice is deemed to have been deposited in the post-office when deposited in any branch post-office or in any letter box under the control of the post-office department.

California.- Seely v. Stoltz, Inc. (1917), 163 Pac. 681, 32 Cal. App. 458.

Connecticut.-Cent. Nat. Bk. v. Stoddard (1910), 83 Conn. 330, 76 Atl. 472.

New York.-Wilson v. Peck
(1910), 121 N. Y. Supp. 344, 66 Misc. 179.

New Jersey.-Battery Park Bk. v. Ramsay (1917), 100 Atl. 51.

Pennsylvania.- Phoenix Brewing Co. v. Weiss (1903), 23 Pa. Super. Ct. 519.

Section 10\%. Where a party receives notice of dishonor, he has, after the receipt of such notice, the same time for giving notice to antecedent parties that the holder has after the dishonor.

Connecticut.-Gleason v. Thayer (1913), 87 Atl. 790.

Kentucky.-Williams v. Paintsville Nat. Bk. (1911), 143 Ky. 781, 137 S. W. 535.

New York.-Brill v. Jefferson Bk.
(1913), 159 A. D. 461, 144 N. Y. Supp. 539; Fuller Buggy Co. v. Waldron (1907), 188 N. Y.' 630; Jurgens v. Wichman (1908), 124 A. D. 531, 108 N. Y. Supp. 881.

Section 108. Where a party has added an address to his signature, notice of dishonor must be sent to that address; but if he has not given such address, then the notice must be sent as follows:

(1) Either to the post-office nearest to his place of residence, or to the post-office where he is accustomed to receive his letters; or

(2) If he live in one place, and have his place of business in another, notice may be sent to either place; or

(3) If he is sojourning in another place, notice may be sent to the place where he is so sojourning.

But where the notice is actually received by the party within the time specified in this act, it will be sufficient, though not sent in accordance with the requirements of this section. 
Colorado.- Torbet v. Montague (1912), 127 Pac. 134.

Massachusetts.-Hall v. Crane Raymond (1914), 217 Mass. 98, 104 N. E. 489.

Missouri.- First Nat. Bank of Grant City v. Korn (1915), 179 S. W. 721; Vogel v. Starr (1908), 132 Mo. App. 430, 112 S. W. 27.

New York.-Albany Trust Co. v. Frothingham (1906), 50 Misc. 598, 99 N. Y. Supp. 343; Century Bk. of City of N. Y. v. Breithart (1915), 151 N. Y. Supp. 588; Dupont de Nemour Powder Co. v. Rooney (1909), 63 Misc. 344, 117 N. Y. Supp. 220; Ebling Brewing Co. v.
Rheinheimer (1900), 32 Misc. 594, 66 N. Y. Supp. 458; Fonseca v. Hartman (1903), 84 N. Y. Supp. 131; In re Mandelbaum (1913), 141 N. Y. Supp. 319; McGrath v. Francoline (1915), 156 N. Y. Supp. 981; Mohlman Co. v. McKane (1901), 60 A. D. 546; Smitl Co. v. AmericaEurope Co. (1911), 128 N. Y. Supp. 81.

Pennsylvania.- Scott v. Brown (1913), 87 Atl. 431; Siegel v. Hirsch (1904), 26 Pa. Super Ct. 398.

Rhode Island.-Knight v. Infantry Hall Auditorium Co. (1913), 35 R. I. 383, 87 Atl. 165.

Section 109. Notice of dishonor may be waived, either before the time of giving notice has arrived, or after the omission to give due notice, and the waiver may be express or implied.

Colorado.-Archuleta v. Johnston (1906), 38 Colo. 325, 87 Pac. 1145.

Florida.- Worley v. Johnson (1910), 53 So. 542.

Illinois.-Steward v. Soenksen (1912), 173 Ill. App. 1.

Iowa.- Porter v. Moles (1911), 151 Iowa, 279, 131 N. W. 23; Quinn v. Bane (1917), 164 N. W. 788.

Kentucky.-Doherty $\nabla$. First Nat. Bk. (1916), 186 S. W. 937; Mechanics \& Farmer's Sav. Bk. v. Katterjohn (1910), $137 \mathrm{Ky} .427,125$ S. W. 1071; Owensboro Sav. Bk. \& Tr. Co.'s Receiver v. Haynes (1911). 136 S. W. 1004.

Louisiana.-Frank Taylor Kendrick Co. จ. Voissement (1918), 77 So. 895 .

Maryland.- Linthicum v. Bagby (1917), 102 Atl. 997.

Massachusetts. - Lankof sky v. (1913), 213 Mass. 325; Toole v.
Crafts (1907), 196 Mass. 397, 82 N. E. 22.

Missouri. - Belch v. Roberts (1915), 177 S. W. 1062.

New York.- Hayward v. Empire St. Sugar Co. (1900), 105 A. D. 21; O'Bannon J. W. Co. v. Curran (1908), 129 A. D. 90, 113 N. Y. Supp. 359; Weil $\nabla$. Corn Ex. Bk. (1909), 63 Misc. 300, 116 N. Y. Supp. 665.

North Carolina.-First Nat. Bk. of Henderson v. Johnson (1915), 86 S. E. 360 .

Oregon.-Moll v. Roth Co. (1915), 152 Pa. 235; Robinson v. Holmes (1910), 57 Oreg. 5, 109 Pac. 754; Clark v. Sallaska (1918), 174 Pac. 505.

Pennsylvania. - Aldred's Estate, No. 1 (1911), 229 Pa. 627; Burgettstown Nat. Bk. จ. Nill (1906), 213 Pa. 456. 
Virginia.-Security Loan \& Trust Co. v. Fields (1910), 110 Va. 827, 67 S. E. 342.

Washington.-Galbraith v. Shep- ard (1906), 43 Wash. 698, 86 Pac. 1113.

West Virginia. - Thompson v. Curry (1917), 91 S. E. 801.

Section 110. Where the waiver is embodied in the instrument itself, it is binding upon all parties; but where it is written above the signature of an indorser, it binds him only.

Kentucky.-Owensboro Sav. Bk. \& Tr. Co.'s Receiver v. Haynes (1911), 136 S. W. 1004; Atkinson v. Skidmore (1913), 153 S. W. 456. Oregon. - Clark v. Sallaska (1918), 174 Pac. 505.
Pennsylvania.-Burgettstown Nat. Bk. v. Nill (1906), 213 Pa. 456.

West Virginia.-- Central Nat. Bk. v. Sciotsville Milling Co. (1917), 91 S. E. 808.

Section 111. A waiver of protest, whether in the case of a foreign bill of exchange or other negotiable instrument, is deemed to be a waiver not only of a formal protest, but also of presentment and notice of dishonor.

Idaho.-Bk. of Montpelier v. 554; Frank Taylor Kendrick Co. v. Montpelier Lumber Co. (1909), 16 Idaho, 730, 102 Pac. 685.

Kentucky.-Owensboro Sav. Bk. \& Tr. Co.'s Receiver v. Haynes (1911), 136 S. W. 1004; Atkinson v. Skidmore (1913), $152 \mathrm{Ky} .413$.

Louisiana.- Wisdom \& Levy v. Bille (1908), 120 La. 699, 45 So.

Voissement (1918), 77 So. 895.

North Carolina.- First Nat. Bk. of Henderson v. Johnson (1915), 86 S. E. 360 .

Tennessee.- Waterhouse v. Sterchi Bros. (1918), 201 S. W. 150.

Texas.-Barger v. Brubaker (1916), 187 S. W. 1025.

Section 112. Notice of dishonor is dispensed with when, after the exercise of reasonable diligence, it cannot be given to or does not reach the parties sought to be charged.

New York.-University Press v. (1903), 84 N. Y. Supp. 131; Silver Williams (1900), 48 A. D. 188; v. Locheim (1914), 147 N. Y. Supp Howard v. Van Gieson (1900), 56 29; Mechanic v. Elgic Iron Works A. D. 217; Fonseca v. Hartman (1917), 153 N. Y. Supp. 97.

Section 113. Delay in giving notice of dishonor is excused when the delay is caused by circumstances beyond the control of the holder, and not imputable to this default, misconduct or negli- 
gence. When the cause of delay ceases to operate, notice must be given with reasonable diligence.

New York.-University Press v. Williams (1900), 48 A. D. 188; Howard v. Van Gieson (1900), 56

A. D. 217 .

Section 114. Notice of dishonor is not required to be given to the drawer in either of the following cases:

(1) Where the drawer and drawee are the same person;

(2) When the drawee is a fictitious person or a person not having capacity to contract;

(3) When the drawer is the person to whom the instrument is presented for payment.

(4) Where the drawer has no right to expect or require that the drawee or acceptor will honor the instrument;

(5) Where the drawer has countermanded payment.

Arkansas. - Gibbs v. Hopper (1908), 77 N. J. L. 584, 71 Atl. (1913), 160 S. W. 879.

Florida.- Worley v. Johnson (1910), 53 So. 542 .

Massachusetts.- Leonard v. Dra-. per (1905), 187 Mass. 536, 73 N. E. 644.

Missouri.-First Nat. Bank of Grant City v. Korn (1915), 179 S. W. 721; Boaud v. Stewart (1916), 188 S. W. 317.

New Jersey.- Jordon v. Reed 280.

New York.- Trader's Nat. Bk. v. Jones (1905), 104 A. D. 435, 93 N. Y. Supp. 768; Scanlon v. Wallach (1907), 102 N. Y. Supp. 1090, 53 Misc. 104; Cassel v. Regierer (1908), 114 N. Y. Supp. 601; Adler v. Levinson (1909), 120 N. Y. Supp. 67.

Rhode Island.- Knight v. Infantry Hall Auditorium Co. (1913), 87 Atl. 195.

Section 115. Notice of dishonor is not required to be given to an indorser in either of the following cases:

(1) Where the drawee is a fictitious person or a person not having capacity to contract, and the indorser was aware of the fact at the time he indorsed the instrument;

(2) Where the indorser is the person to whom the instrument is presented for payment;

(3) Where the instrument was made or accepted for his accommodation. 
Connecticut.-Foster v. Balch (1907), 79 Conn. 449.

Illinois.-First Nat. Bk. of Lincoln $\nabla$. Sandmeyer (1911), 164 Ill. App. 98.

Massachusetts. - Lankofsky $\nabla$. Raymond (1914), 104 N. E. 489; Sweetser ₹. Jordan (1914), 216 Mass. 350.

Missouri.-Hawkins $\quad$. Wiest (1912), 167 Mo. App. 439; Overland Auto Co. v. Winters (1915), 180 S. W. 561.

New Jersey.-Jordan v. Reed (1908), 77 N. J. L. 584, 71 Atl. 280.
New York.-Williams v. Brown (1900), 53 A. D. 486; Trader's Nat. Bk. v. Jones (1905), 104 A. D. 433 , 93 N. Y. Supp. 768.

Pennsylvania. - Aldred's Estate, No. 1 (1911), 229 Pa. 627.

Tennessee.-Mercantile Bank of Memphis v. Busby (1908), 120 Tenn. 652, 113 S. W. 390; Nolan v. H. E. Wilcox Motor Co. (1917), 195 S. W. 581.

United States.-In re Swift (1901), 106 Fed. 65; McDonald v. Luckenback (1909), 170 Fed. 434, 95 C. C. A. 604.

Section 116. Where due notice of dishonor by non-acceptance has been given notice of a subsequent dishonor by non-payment is not necessary, unless in the meantime the instrument has been accepted.

Maryland - Scheffenacker v. Pennsylvania.-Colonial Tr. Co. Hoopes (1910), 113 Md. 111. v. Nat. Bk. of Western Pa. (1912), New York.-Mt. Morris Bk. v. $50 \mathrm{~Pa}$. Super. 510. Twenty-Third Ward Bk. (1902), 172 N. E. 244.

Section 11\%. An omission to give notice of dishonor by nonacceptance does not prejudice the rights of a holder in due course subsequent to the omission.

Maryland. - Scheffenacker v. New York.-Mt. Morris Bk. v. Hoopes (1910), $113 \mathrm{Md}, 111$ Twenty-Third Ward Bk. (1902), 172 Missouri.-Wing v. Union Cent. N. Y. 244. Life Ins. Co. (1914), $168 \mathrm{~S}$. W. 917.

Section 118. Where any negotiable instrument has been dishonored it may be protested for non-acceptance or non-parment, as the case may be; but protest is not required except in the case of foreign bills of exchange.

minois.-Sublette Ex. Bk. v. FitzMaryland. - Scheffenacker v. gerald (1912), 168 Ill. App. 240. Hoopes (1910), 113 Md. 111. 
Massachusetts. - Commercial Nat. Bk. v. Clarke (1902), 180 Mass. 249; Demelman v. Brazier (1907), 193 Mass. 588, 79 N. E. 812; Demelman v. Brazier (1908), 198 Mass. 458, 84 N. E. 856.

New York-Mt. Morris Bk. v. Twenty-Third Ward Bk. (1902), 172 N. Y. 244 ; Congress Brewing Co. v. Habenicht (1903), 83 A. D. 141, 82 N. Y. Supp. 481; Howard v. Bk. of the Metropolis (1906), 115 A. D. 326; McBride v. Illinois Nat. Bk. (1910), 138 A. D. 339; Nooman \& Price Co. v. E. Kwanok Realty Co. (1910), 123 N. Y. Supp. 915; Gens v. Hamilton (1910), 123 N. Y. Misc.
981; Badt v. Miller (1912), 135 N. Y. Supp. 13, 150 A. D. 920 .

Oregon.- Robinson v. Holmes (1910), 57 Oreg. 5, 109 Pac. 754.

Pennsylvania.- Wisner v. First Nat. Bk. of Gallitzin (1906), 220 Pa. 21, 68 Atl. 955, 17 L. R. A. (N. S.) 1266; Whitman v. First Nat. Bk. of Canton (1907), $35 \mathrm{~Pa}$. Super. Ct. 125; Friedman v. Maltingsky (1918), 103 Atl. 731.

Rhode Island.- Knight v. Infantry Hall Auditorium Co. (1913), 87 Atl. 195.

Tennessee.-Am. Nat. Bk. v. Nat. Fertilizer Co. (1911), 125 Tenn. 329, 143 S. W. 597.

\section{ARTICLE VIII. \\ DISCHARGE OF NEGOTIABLE INSTRUMENTS.}

Section 119. "A negotiable instrument is discharged:

(1) By payment in due course by or on behalf of the principal debtor;

(2) By payment in due course by the party accommodated, where the instrument is made or accepted fo raccommodation;

(3) By the intentional cancellation thereof by the holder;

(4) By any other act which will discharge a simple contract for the payment of money;

(5) When the principal debtor becomes the holder of the instrument at or after maturity in his own right.

Alabama.-Hagin v. Shoaf (1913), 63 So. 764, 9 Ala. App. 300; Montgomery Bk. \& Tr. Co. v. Jackson (1915), 67 So. 235; Sherill v. Merch. \& Mech. Tr. \& Sav. Bk. (1916), 70 So. 723 .

Arizona.-- Cowan v. Ramsay (1914), 140 Pac. 501; Big Eye Min. \& Mili. Co. v. Livingston (1918), 171 Pac. 989.

Arkansas.-Mammoth Vein Coal Co. r. Bishop (1914), 168 S. W. 1086; Calhoun v. Sharkey (1915),
180 S. W. 216; Tancred v. First Nat. Bk. (1916), 187 S. W. 160; Hamilton Nat. Bk. v. Emigh (1917), 192 S. W. 913 ; Manly Carriage Co. v. Fowler \& Hill (1917), 194 S. W. 708; Peoples Sav. Bk. v. Manes (1919), 206 S. W. 315.

California.- Levey v. Henderson (1917), 169 Pac. 673; Hall v. Thrustọn (1918), 171 Pac. 285.

Florida.-Peacock v. Home Life Ins. Co. (1917), 75 So. 799.

Idaho.-Fidelity State Bk. v. 
Miller (1917), 162 Pac. 244; Federal State Bk. v. Miller (1917), 162 Pac. 244.

Indiana.- Kelley v. York (1915), 109 N. E. 772.

Iowa.- Fullerton Lumber Co. v. Snouffer (1908), 139 Iowa, 176, 117 N. W. 50; Park v. Best (1916), 157 N. W. 233; McCullough v. Reynolds (1917), 165 N. W. 333.

Kansas. - The N. E. Nat. Bk. of Kansas City, Mo. v. Dick (1911), 84 Kans. 252, 114 Pac. 378; Niotaze State Bk. v. Cooper (1917), 162 Pac. 1169; Sigler v. Sigler (1916), 158 Pac. 864.

Kentucky.-Fritts v. Kirchdorfer (1910), 124 S. W. 882; First State Bk. of Nortonville $\mathbf{v}$. Williams (1915); 175 S. W. 10; Smith v. Smith (1915), 178 S. W. 1058; Bk. of Willard v. Pa. \& Ky. Fire Brick Co. (1917), 194 S. W. 110.

Louisiana.-J. I. Case Threshing Machine Co. v. Bridger (1913), 63 So. 319.

Massachusetts.-Austin v. Papanti (1908), 197 Mass. 584; Illustrated Card \& Novelty Co. v. Dolan (1911), 208 Mass. 53; Union Tr. Co. v. MeGinty (1912), 212 Mass. 205, 98 N. E. 679; Arlington Nat. Bk. v. Bennett (1913), 214 Mass. 352,101 N. E. 982; Baldwin v. Porter (1914), 217 Mass. 15; Clark v. Young (1918), 120 N. E. 397.

Mississippi.-Sivley v. Williamson (1916), 72 So. 1008; Davidson v. Plant (1917), 74 So. 328,113 Miss. 482; Bass v. Borries (1918), 77 So. 189.

Missouri-Lane v. Hyder (1912), 163 Mo. App. 688, 147 S. W. 514; Citizen's Bk. of Senath v. Douglass (1913), 161 S. W. 601; Meredith v.
Pemberton (1913), 170 Mo. App. 100, 156 S. W. 704; Shark v. Sherf (1919), 207 S. W. 863.

Nebraska.-Farmers \& Mech. Bk. of Ulysses v. Tate (1914), $147 \mathrm{~N}$. W. 213; Gillard v. Honeywell (1919), 170 N. W. 357; Belk v. Capital Fin. Ins. Co. (1919), 169 N. W. 262.

New York.-Schwartzman v. Post (1903), 84 N. Y. Supp. 922, 94 A. D. 474; First Nat. Bk. of the City of Brooklyn v. Gridley (1906), 112 A. D. 398,93 N. Y. Supp. 445; Pavenstedt $v^{\prime}$ N. Y. Life Ins. Co. (1906), 113 A. D. 866,99 N. Y. Supp. 614; The Royal Bk. of N. Y. v. Goldschmidt (1906), 51 Mise. 622, 101 N. Y. Supp. 101; Perry v. Van Norden Tr. Co. (1907), $10 \mathrm{~N}$. X. Supp. 543; Korkemas v. Macksond $(1909), 131 \mathrm{~A} . \mathrm{D} .728,116 \mathrm{~N}$. Y. Supp. 85; Bainbridge v. Hoes (1914), 149 N. Y. Supp. 20, 163 A. D. 870; Hoch v. Bernstein (1917), 164 N. Y. Supp. 113; Pittsburg v. Kerr (1917), 115 N, E. 465, 220 N. Y. 137; Broad \& Market Nat. Bk. v. Eastern Realty Co. (1918), 168 N. Y. Supp. 149; Elisberg v. Simpson (1919), 173 N. Y. Supp. 128.

North Carolina.-Am. Nat. Bk. of Richmond v. Hill (1915), $85 \mathrm{~s}$. E. 209; First Nat. Bk. of Lumberton v. Lennon (1915), 86 S. E. 715; First Nat. Bk. v. Hall (1917), 93 S. E. 981.

Ohio.-Richards v. Market Ex. Bk. (1910), 81 Ohio St. 348,55 Ohio Law Bull. 20; First Nat. Bk. of Wellston v. Patton Co. (1910), 32 Ollio Cir. 627.

Oklahoma.-Ardmore State Bk. $\mathrm{V}$. Lee (1916), 159 Pac. 903; Ricks v. 
Johnson (1917), 162 Pac. 476; Wade v. Hall (1917), 166 Pac. 720.

Oregon.-Cellers v. Meachem (1907), 49 Oreg. 186, 10 L. R. A. (N. S.) 133; Lumbermen's Nat. Bk. of Portland v. Campbell (1912), 61 Oreg. 123, 121 Pac. 427; Murphy v. Panter (1912), 62 Oreg. 522, 125 Pac. 292.

Pennsylvania.-Brown v. Marmadake (1915), 93 Atl. 1025.

South Dakota.-Astoria State Bk. v. Markwood (1916), 156 N. W. 583.

Texas.-Jackson v. Home Nat. Bk. (1916), 185 S. W. 893.

Utah.- Wostenholme v. Smith
(1908), 34 Utah, 300, 97 Pac. 329; Interstate Trust Co. v. Headlund (1918), 171 Pac. 515.

Washington.-Capitol Nat. Bk. v. Robinson (1906), 41 Wash. 454, 83 Pac. 1021; Pease v. Syler (1914), 138 Pac. 310; State Finance Co. $\nabla$. Moore (1918), 174 Pac. 22; Kelley v. Bansman (1917), 168 Pac. 181.

West Virginia,- Manchester v. Parsons (1915), 84 S. E. 885.

Wisconsin.- Citizens Nat. Bk. of Green Bay v. Harter (1908), 134 Wis. 408; Marling v. Jones (1909), 138 Wis. 82,119 N. W. 931; Comstock v. Buckley (1910), 141 Wis. 227,124 N. W. 414.

Section 120. A person secondarily liable on the instrument is discharged:

(1) By any act which discharges the instrumen;

(2) By the intentional cancellation of his signature by the holder;

(3) By the discharge of a prior party;

(4) By a valid tender of payment made by a prior party;

(5) By a release of the principal debtor, unless the holder's right of recourse against the party secondarily liable is expressly reserved;

(6) By any agreement binding upon the holder to extend the time of payment, or to postpone the holder's right to enforce the instrument, unless made with the assent of the party secondarily liable, or unless the right of recourse against such party is expressly reserved.

Arizona.-Cowan v. Ramsay (1914), 140 Pac. 501.

Florida.- Clark v. Union Grocery Co. (1915), 68 So. 766; Williams v. Penn (1917), 75 So. 517; William v. Peninsula Grocery Co. (1917), 75 So. 517 .

Idaho.- Frost v. Harbert (1911), 118 Pac. 1095.
Iowa.-Goodman Mfg, Co. v. Mammoth Vein Coal Co. (1918), 168 N. W. 912.

Kansas.-Peoples State Bk. of Wollsville v. Dryden (1914), 137 Pac. 928; Farmers \& Drovers Bk. v. Bashor (1916), 160 Pac. 208; Security State Bk. v. Clark (1916), 
160 Pac. 1149; Ger.-Am. St. Bk. v. Watson (1917), 163 Pac. 637.

Kentucky.-First State Bk. of Nortonville v. Williams (1915), 175 S. W. 10 ; Mut. Ben. Life Ins. Co. v. First Nat. Bk. (1914), 169 S. W. 1028.

Louisiana.-J. I. Case Threshing Machine Co. v. Bridger (1913), 133 La. 754,63 So. 319 ; Lewy v. Wilkinson (1914), 64 So. 1003; Commercial Nat. Bk. v. Sanders (1916), 72 So. 891.

Maryland.-Venderford v. Farmers \& Mechanics Nat. Bk. of Westminster (1907), 105 Md. 164, 66 Atl. 47.

Massachusetts.- Union Tr. Co. v. MeGinty (1912), 212 Mass. 205, 98 N. E. 679 ; Arlington Nat. Bk. v. Bennett (1913), 214 Mass. 352, 101 N. E. 982; Paul Revere Trust Co. v. Castle (1918), 120 N. E. 352.

Michigan-Buttertield v. Reynolds (1917), 163 N. W. 86.

Missouri-Miners \& Merchants Bk. v. Rogers (1907), 123 Mo. App. 569, 100 S. W. 534; Lane v. Hyder (1912), 163 Mo. App. 688, 147 S. W. 514 ; Citizen's Bk. of Senath v. Douglass (1913), 161 S. W. 601; Night \& Day Bk. v. Rosenbanm (1915), 177 S. W. 693; Bank of Chillicothe v. Gundy (1916), 189 S. W. 412.

New Jersey.- Friele v. Rudiger (1918), 104 Atl. 142.

New Mexico.- First Nat. Bk. of Albuquerque v. Stover (1916), 155 Pac. 905.

New York.- State Bk. v. Kahn (1906), 49 Misc. 500, 98 N. Y. Supp. 858; McCormick v. Shea (1906), 99 N. Y. Supp. 467, 50 Misc. 592 ; Ziegfried v. Stein (1909), 117 N. Y. Supp. 900; Nat. Park Bk. จ. Koeh- ler (1909), 137 A. D. 785, 121 N. Y. Supp. 640; Bloom v. Polacsek (1910), 121 N. Y. Supp. 951; Zim. merman v. Kastner (1910), $123 \mathrm{~N}$. Y. Supp. 952; Union Tr. Co. of New Jersey v. McCrum (1911), 145 A. D. 409; Greenberg v. Ginsberg (1913), 143 N. Y. Supp. 1017, 82 Misc. 415; Orth v. Anderson (1914), 146 N. Y. Supp. 689; Union Bk. v. Sullivan (1915), 108 N. E. 558, 214 N. Y. 332 ; Brosemer v. Brosemer (1917), 162 N. Y. Supp. 1067; Silverman v. Rubenstein (1917), 162 N. Y. Supp. 733.

North Carolina.-First Nat. Bk. of Henderson v. Johnson (1915), 88 S. E. 360 .

North Dakota.- First Nat. Bank of Pomeroy v. Buttery (1908), 17 N. D. 326,116 N. W. 341,16 L. R. A. (N. S.) 878 ; Northern State Bk. v. Bellany (1910), 125 N. W. 888.

Oklahoma.-Bank of Commerce v. Jackson (1918), 170 Pac. 474.

Oregon.-Cellers v. Meachem (1907), 49 Oreg. 186, 10 L. R. A. (N. S.) 133; Murphy v. Panter (1912), 62 Oreg. 522, 125 Pac. 292; Peterson v. Thompson (1915), 151 Pac. 721; Everding \& Farrell v. Taft (1916), 160 Pac. 1160.

Pennsylvania.-First Nat. Bk. of York v. Diehl (1907), 218 Pa. 588; In re Moritz's Estate (1913), 86 Atl. 875; Second Nat. Bk. of Mechanicsburg v. Graham (1914), 92 Atl. 198; First Nat. Bk. of Hanover v. Delone (1916), 98 Atl. 1042.

Rhode Island.-Dealey v. Choquet (1907), 28 R. I. 338.

South Carolina.-Bank of Inman v. Elliott (1915), 84 S. E. 996.

South Dakota.-Runely v. Anderson (1915), 150 N. W. 939; Wilcox 
v. McCain Land \& Live Stock Co. (1916), 159 N. W. 49; First Nat. Bk. v. Brule Nat. Bk. (1917), 161 N. W. 616 .

Tennessee.-Dies v. Wilson Co. Bk. (1914), 165 S. W. 248; Hamilton Nat. Bk. v. Breeden (1914), 171 S. W. 86 ; Graham v. Shepard (1916), 189 S. W. 867.

Texas.-Wills v. Tyler (1916), 186 S. W. 862.

Utah.-Wostenholme v. Smith (1908), 34 Utah, 300, 97 Pac. 329.

Virginia.-Cape Charles Bk. v.
Farmers Mutual Exchange (1917), 92 S. E. 918.

Washington.-Davis v. Byrne (1915), 152 Pac. 14; Davis v. Gutheil (1915), 152 Pac. 14, 87 Wash. 596.

Wisconsin.- Citizens Nat. Bk. of Green Bay v. Harter (1908), 134 Wis. 408; State Bk. of LaCrosse v. Michel (1913), 152 Wis. 88; Ger. Nat. Bk. v. Barber (1914), 149 N. W. 767 .

United States.- Nalitzky v. Williams (1917), 237 Fed. 802.

Section 121. Where the instrument is paid by a party secondarily liable thereon, it is not discharged; but the party so paying it is remitted to his former rights as regards all prior parties, and he may strike out his own and all subsequent indorsements, and again negotiate the instrument, except:

(1) Where it is payable to the order of a third person, and has been paid by the drawer; and

(2) Where it was made or accepted for accommodation, and has been paid by the party accommodated.

Indiana.- Parker v. First Nat. Bk. of Fort Wayne (1915), 109 N. E. 75 .

Kansas.- Lill v. Gleason (1914), 142 Pac. 287.

Massachusetts.- Quimby v. Varnum (1906), 190 Mass. 211, $76 \mathrm{~N}$. E. 671.

Missouri.- Cantrell v. Davidson (1914), 168 S. W. 271.

New Jersey.-Pohlemus v. Prudential Realty Co. (1907), 74 N. J. L. 570,67 Atl. 303 .
New York.- The Royal Bk. of New York v. Goldschmidt (1906), 51 Misc. 622, 101 N. Y. Supp. 101; Josepsohn v. Gens (1914), 147 N. Y. Supp. 451; Assets Realization Co. v. Mercantile Nat. Bk. (1915), 153 N. Y. Supp. 156.

Oregon.-Noble v. Beeman-Spaulding-Woodward Co. (1913), 131 Pac. 100j.

Washington.-Pease v. Syler (1914), 138 Pac. 310.

Section 122. The holder may expressly renounce his rights against any party to the instrument, before, at or after its maturity. An absolute and unconditional renunciation of his rights against the principal debtor made at or after the maturity of the instrument discharges the instrument. But a renunciation does not affect the rights of a bolder in due course without notice. A renun- 
ciation must be in writing, unless the instrument is delivered up to the person primarily liable thereon.

Louisiana.-J. I. Case Threshing Machine Co. v. Bridger (1913), 133 La. 754, 63 So. 319 .

Massachusetts. - Faneuil Hall Nat. Bk. v. Meloon (1903), 183 Mass. 66,66 N. E. 410 .

Maryland. - Whitcomb v. Nat. Exch. Bk. (1914), 91 Atl. 689, 123 Md. 612.

Missouri.-Dickinson v. Vail (1918), 203 S. W. 635.
New York.-Leask v. Dew (1905), 102 A. D. 529, 92 N. Y. Supp. 891.

Oklahoma.-Campbell v. Newton \& Driskoll (1915), 152 Pac. 841.

Oregon.-Cellers v. Meachem (1907), 49 Oreg. 186, 10 L. R. A. (N. S.) 133.

Washington.-Baldwin v. Daly (1906), 83 Pac. 724 ; Pitt v. Little (1910), 58 Wash. 355, 108 Pac. 941; Jinnet v. Greene (1915), 151 Pac. 99, 87 Wash. 40.

Section 123. A cancellation made unintentionally, or under a mistake or without the authority of the holder, is inoperative, but where an instrument or any signature thereon appears to have been cancelled the burden of proof lies on the party who alleges that the cancellation was made unintentionally, or under a mistake or without authority.

Illinois.-Fry v. Jenkins (1912), 173 Ill. App. 486.

Kansas.- Holyfield $\nabla$. Harrington (1911), 84 Kans. 760, 115 Pac. 546.

New York.-First Nat. Bk. of the City of Brooklyn v. Gridley (1906), 112 A. D. 398,98 N. Y. Supp. 445; McCormick v. Shea (1906), 99 N.
Y. Supp. 467, 50 Misc. 592; Union Bk. v. Sullivan (1915), 214 N. Y. 332, 108 N. E. 558.

Tennessee.-Gilley v. Harrell (1906), 118 Tenn. 115, 101 S. W. 424.

Virginia.-Jones Admrs. v. Cole$\operatorname{man}(1917), 92$ S. E. 910.

Section 124. Where a negotiable instrument is materially altered without the assent of all parties liable thereon, it is avoided, except as against a party who has himself made, authorized or assented to the alteration, and subsequent indorsers.

But when an instrument has been materially altered and is in the hands of a holder in due course, not a party to the alteration, he may enforce payment thereof according to its original tenor.

$\begin{array}{cccccc}\text { Arkansas. - Arnold } & \text { v. } & \text { Wood } & \begin{array}{c}\text { Colorado.-Ayers } \\ (1913), 54 \text { Colo. 571. }\end{array} & \text { Walker } \\ \begin{array}{c}\text { (1917), } 191 \text { S. W. } 960 . \\ \text { California - Smith }\end{array} & \text { v. } & \text { Hirst } & \begin{array}{c}\text { Connecticut_- Fairfield } \\ \text { Co. }\end{array}\end{array}$ (1917), 163 Pac. 334, 32 Cal. App. Bk. v. Hammer (1915), 95 Atl. 31. 507. 
Illinois.-Peterson v. Eniery (1910), 154 Ill. App. 294; Fry v. Jenkins (1912), 173 I1l. App. 486.

Iowa.-Johnston v. Hoover (1908), 138 Iowa, 143, 117 N. W. 277.

Kansas.- McCormick Harvesting Maehine Co. v. Lauber (1898), 7 Kans. Ct. of App. 739; New York L. Ins. Co. v. Martindale (1907), 75 Kans. 142, 88 Pac. 559, 121 Am. St. 362; Holyfield v. Harrington (1911), 84 Kans. 760, 115 Pac. 546; Fisher v. Spillman (1911), 85 Kans. 552; Edington v. McLeod (1912), 87 lians. 426.

Kentucky.-Stanley v. Davis 32 Ky. L. 1135, 107 S. W. 773; Dia. mond Distilleries Co. v. Gott (1910), 137 Ky. 585, 126 S. IV. 131; White v. Shepherd (1910), 131 S. W. 17; Tyler v, First Nat. Bk. of Winslow (1912), $150 \mathrm{Ky}$. 515; Robertson v. Commereial Security Co. (1913), 151 Ky. 336, 153 S. W. 450; Aud v. McElvoy (1917), 197 S. W. 824; Commercial Bank v. Arden (1917), 197 S. W. 951.

Massachusetts.-Jeffrey v. Rosenfeld (1901), 179 Mass. 506; Thorpe v. White (1905), 188 Mass. 333, 74 N. E. 592 ; Wood v. Skelley (1907), 196 Mass. 114, 81 N. E. 872; Tower v. Stanle (1915), 107 N. E. 1010. Michigan.-Ensign v. Fogg (1913), 143 N. W. 82.

Minnesota.- Public Bk. of N. Y. v. Burchard Mer. Co. (1916), 160 N. W. 667 .

Nebraska.- Bother $\nabla$. Schwietzer (1909), 84 Neb. 271, 120 N. W. 1129; Bothell v. Miller (1910), 87 Neb. 835 .

New Hampshire.- Bisbee v. Pui- pit Farm Dairy (1917), 100 Atl. 672.

New Jersey.-Stanford v. Stanford (1917), 101 Atl. 388.

New York.-Critten v. Chemical Nat. Bk. (1901), 60 A. D. 241; Mut. Loan Assn. v. Lesser (1902), 76 A. D. 614,78 N. Y. Supp. 629 ; Merchants Bk. v. Brown (1903), 86 A. D. 599,83 N. Y. Supp. 1037; Packard v. Windholz (1903), 40 Misc. 347 , affirmed 88 A. D. 365 ; Birmingham Tr. Co. v. Whitney (1904), 95 A. D. 280,88 N. Y. Supp. 578; Moskowitz v. Deutseh (1905), 46 Misc. 603, 92 N. Y. Supp. 721; Colonial Nat. Bk. v. Duerr (1905), 108 A. D. 215, 95 N. Y. Supp. 810; Colonial Nat. Bk. of the City of Brooklyn v. Gridley (1906), 112 A. D. 398, 98 N. Y. Supp. 445; Elias v. Whitney (1906), 98 N. Y. Supp. 667,50 Misc. 326; Smith v. State Bank (1907), 54 Misc. 550, 104 N. Y. Supp. 750; Timbel v. Garfield Nat. Bk. (1907), 121 A. D. 870, $108 \mathrm{~N}$. Y. Supp. 497; Nat. Ex. Bk. of Albany v. Lester (1909), 194 N. Y. 461,87 N. E. 79; Witteman v. Glass (1909), 117 N. Y. Supp. 940; Usef of v. Herzenstein (1909), 65 Misc. 45, 119 N. Y. Supp. 290; Trust Co. of Am. v. Conklin (1909), 65 Mise. 1, 119 N. Y. Supp. 367.

North Dakota.-Sawyer State Bk. v. Sutherland (1917), 162 N. W. 696.

Ohio.- Hoffman v. Wiedeman Brewing Co. (1910), 31 Ohio Cir. Ct. 609 .

Oklahoma.- Commonwealth Nat. Bk. of Dallas v. Baughman (1910), 27 Okla. 175, 111 Pac. 332; Barrett v. Effenber (1911), 29 Okla. Sup. Ct. 679; Cox v. Kirkwood (1916), 158 Pac. 930; Zehr v. Champlin 
(1916), 159 Pac. 118; Conqueror Trust Co. v. Simmon (1917), 162 Pac. 1098.

Pennsylvania.-Snyder v. Commercial Ex. Nat. Bk. (1908), 221 Pa. 599, 70 Atl. 876.

Rhode Island.-Abram v. Greer (1913), 88 Atl. 884.

Tennessee.-Moss v. Maddux (1902), 108 Tenn. 405.

Texas.- Landon v. Halcomb (1916), 184 S. W. 1098.

Utah.- Wostenholme v. Smith (1908), 34 Utah, 300, 97 Pac. 329; Farmers \& Stock Growers' Bank v. Palivant Valley Land Co. (1917), 165 Pac. 462.

Virginia.- Hoffman v. Planter's Nat. Bk. (1901), 99 Va. 480, $39 \mathrm{~S}$. E. $134 ; A m$. Bk. of Orange v. Mc-
Comb (1906), 105 Va. 473, 54 S. E. 14; Nottingham v. Ackiss (1907), 107 Va. 63, 57 S. E. 592.

Washington. - Washington Finance Corporation v. Glass (1913), 134 Pac. 480; Davis v. Byrne (1915), 152 Pac. 14; Lombardo v. Lombardini (1910), 57 Wash. 352, 106 Pac. 907; Pitt v. Little (1910), 5S Wash. 355, 108 Pac. 941.

Wisconsin.-Hecht v. Shenners (1905), 126 Wis. 27, 105 N. W. 309.

United States.- First Nat. Bk. of Wilkesbarre v. Barnum (1908), 160 Fed. 245; First Nat. Bk. of Shenandoah v. Linver (1911), 187 Fed. 16, 109 C. C. A. 70; Towles v. Tanner (1903), 21 App. D. C. 530; Pensacola State Bk. v. Melton (1913), 210 Fed. 57.

Section 125. Any alteration which changes:

(1) The date;

(2) The sum payable, either for principal or interest;

(3) The time or place of payment;

(4) The number or the relations of the parties;

(5) The medium or currency in which payment is to be made; Or which adds a place of payment where no place of payment is specified, or any other change or addition which alters the effect of the instrument in any respect, is a material alteration.

California. - Smith v. Hirst (1917), 163 Pac. 334, 32 Cal. App. 507.

Colorado.-Ayers v. Walker (1913), 54 Colo. 571.

Illinois.- Fry v. Jenkins (1912), 173 IIl. App. 486.

Florida. - Gamble v. Malsby (1914), 64 So. 437.

Kansas.- Holyfield v. Harrington (1911), 84 Kans. 760, 115 Pac. 546; Fisher v. Spillman (1911), 85 Kans.
552; Edington v. McLeod (1912), 87 Kans. 426.

Kentucky. - Tyler v. First Nat. Nat. Bk. of Winslow (1912), 150 Ky. 515.

Massachusetts.-Jeffrey v. Rosenfeld (1901), 179 Mass. 506; Rowe v. Bowman (1903), 183 Mass. 488, 67 N. E. 636 ; Broadway Nat. Bk. of Chelsea v. Hefferman (1915), 107 N. W. 921; Lewis v. Blume (191\%), 116 N. F. 271. 
Michigan.-Ensign ₹. Fogg (1913), 143 N. W. 82.

Minnesota. - Kiefer v. Tolbert (1915), 151 N. W. 529 ; Spiering v. Spiering (1917), 164 N. W. 583.

Montana. - State v. Milton (1908), 37 Mont. 366, 96 Pac. 926.

New Jersey.- Stanford v. Stanford (1917), 101 Atl. 388.

New York.-Witteman v. Glass (1909), 117 N. Y. Supp. 940; Birmingham Tr. Co., etc. v. Whitney (1904), 95 A. D. 280,88 N. Y. Supp. 578; Columbia Distilling Co. จ. Rech (1912), 151 A. D. 128, 135 N. Y. Supp. 206.

North Dakota.- Merchants Nat. Bk. of Wimbledon v. Bastrup (1918), 168 N. W. 42.

Ohio.-Hoffman v. Wiedeman Brewing Co. (1910), 31 Ohio C. C. 609.

Oklahoma.- Conqueror Trust Co. v. Simmon (1917), 162 Pac. 1098.

Oregon.-Palomaki v. Laurel (1917), 168 Pac. 935.
Rhode Island.-Abram v. Greer (1913), 88 Atl. 884.

Tennessee.-Moss v. Maddux (1902), 108 Tenn. 405.

Texas. - Spencer v. Triplett (1916), 184 S. W. 712.

Utah.-Farmers \& Stock Growers' Bk. v. Palivant Valley Land Co. (1917), 165 Pac. 462.

Virginia.-Hoffman v. Planter's Nat. Bk. (1901), 99 Va. 480, $39 \mathrm{~S}$. E. 134.

Washington.- Lombardo v. Lomburdini (1910), 57 Wash. 352, 106 Pac. 907; Pitt v. Little (1910), 58 Wash. 355, 108 Pac. 941; Handsaker v. Pedersen (1912), 71 Wash. 218; Washington Finance Corporation v. Glass (1913), 134 Pac. 480; Gould v. Gould (1917), 169 Pac. 324.

Wisconsin.-Lawless v. State (1902), 114 Wis. 189,89 N. W. 891.

United States.- Pensacola State Bk. v. Melton (1913), 210 Fed. 57.

\section{TITLE II.}

\section{BILTS OF EXCHANGE.}

\section{ARTICLE I.}

\section{FORM AND INTERPRETATION.}

Section 126. A bill of exchange is an unconditional order in writing addressed by one person to another, signed by the person giving it, requiring the person to whom it is addressed to pay on demand or at a fixed or determinable future time a sum certaic in money to order or to bearer.

Colorado.- Van Buskirk v. State Bk. of Rocky Ford (1905), 35 Colo. 142, 83 Pac. 778, 117 Am. St. 182.

Connecticut. - Windsor Cement Co. v. Thompson (1913), 86 Atl. 1.

Delaware.-Lawson v, Layton \& Layton (1913), 86 Atl. 105.
Iowa.-Dugane v. Hvezda Pokraku No. 14 (1909), 119 N. W. 141.

Massachusetts.-Bnttrick Lumber Co. v. Collins (1909), 202 Mass. 413, 89 N. E. 138.

Mississippi.-Country Shiloh \& 
Savannah Turnpike Co. v. Goch (1917), 113 Miss. 50, 73 So. 869.

Missouri.-Val Blatz Brewing Co. v. Interstate Ice \& Cold Storage Co. (1912), 143 S. W. 542.

New York.-Amsinck v. Rogers (1907), 189 N. Y. 252, 82 N. E. 134, 12 L. R. A. (N. S.) 875, 121 Am. St. 858 .

North Carolina.- Johnson v. Lasseter (1911), 155 N. Car. 47.

New Mexico.-Clayton Town Site Co. v. Clayton Drug Co. (1915), 147 Pac. 460.

New York.-Tisdale Lumber Co. v. Piquet (1912), 137 N. Y. Supp. 1021.

Oregon-U. S. Nat. Bk v. First Trust \& Sav. Bk. (1911), 60 Ore. 266, 119 Pac. 343.

Tenneseee.- First Nat. Bk. of Marfreesboro v. First Nat. Bk. of Nashville (1913), 154 S. W. 965.
Washington.-Frederick \& Nelson v. Spokane Grain Co. (1907), 47 Wash. 85, 91 Pac. 570; The State v. Garland (1908), 65 Wash. 666; Sheets v. Coast Coal Co. (1913), 133 Pac. 433; Plaza Farmer's Union Warehouse \& Elevator Co. v. Ryan (1914), 138 Pac. 651; National Market Co. v. Maryland Casualty Co. (1918), 174 Pac. 479.

West Virginia.- Lewis Hubbard \& Co. v. Morton (1917), 92 S. E. 252.

Wisconsin.-Westberg $\mathbf{v}$. Chicago Lumber Co. (1903), 117 Wis. 589, 94 N. W. 572; Columbian Banking Co. v. Bowen (1908), 134 Wis. 218, 114 N. W. 451.

Wyoming.-Brown v. Cow Creek Co. (1912), 126 Pac. 886.

United States.- United States v. Chase Nat. Bk. (1917), 241 Fed. 535.

Section 127. A bill of itself does not operate as an assignment of the funds in the hands of the drawee available for the payment thereof, and the drawee is not liable on the bill unless and until he accepts the same.

Delaware.- Lawson v. Layton \& Layton (1913), 86 Atl. 105.

Florida.-Fulton v. Gesteding (1904), 47 Fla. 150, 36 So. 56.

Kansas.-Rambo v. The First State Bk. of Argentine (1912), 88 Kans. 257.

Oregon.-U. S. Nat. Bk. v. First Trust \& Sav. Bk. (1911), 60 Oreg. 266, 119 Pac. 543.

Tennessee.-First Nat. Bk. of Murfreesboro v. First Nat. Bk. of Nashville (1913), 154 S. W. 965.
First Nat. Bk. (1904), 47 S. E. 837.

Washington.- Wadhams v. Portland V. \& Y. R. Co. (1905), 37 Wash. 86, 79 Pac. 597; Frederick \& Nelson v. Spokane Grain Co. (1907), 47 Wasb. 85, 91 Pac. 570; Nelson v. Nelson Bennett Co. (1903), 31 Wash. 116, 71 Pac. 7\$9; Sheets v. Coats Coal Co. (1913), 133 Pac. 433; Plaza Farmer's Union Warehouse \& Elevator Co. v. Ryan (1914), 138 Pac. 651.

Virginia.- B. \& O. R. R. Co. v. 
Section 128. A bill may be addressed to two or more drawees jointly, whether they are partners or not, but not to two or more drawees in the alternative or in succession.

Section 129. An inland bill of exchange is a bill which is, or on its face purports to be, both drawn and payable within this State. Any other bill is a foreign bill. Unless the contrary appears on the face of the bill, the holder may treat it as an inland bill.

minois.-Sublette Ex. Bk. v. Missouri-Bk. of Laddonia v. Fitzgerald (1912), 168 Ill. App. 240. Bright-Coy Comm. Co. (1909), 120

Indiana.-Bingham v. New Town Bk. (1918), 118 N. E. 318.

Massachusetts.-Buttrick Lumber Co. v. Collins (1909), 202 Mass. 413, 89 N. E. 138. S. W. 648.

New York.-Amsinck v. Rogers (1907), 189 N. Y. 252, 82 N. E. 134, 12 L. R. A. (N. S.) 875,121 Am. St. 858; Graham v. York (1910), 140 A. D. 639.

Section 130. Where in a bill drawer and drawee are the same person, or where the drawee is a fictitious person, or a person not having capacity to contract, the holder may treat the instrument, at his option, either as a bill of exchange or a promissory note.

New Mexico.- First Nat. Bk. of Artesia v. Home Ins. Co. of N. Y. (1911), 16 N. Mex. 66; First Nat. Bk. of Artesia v. Home Ins. Co. of N. Y. (1911), 113 Pac. 815.

New York.-Graham v. York (19:10), 140 A. D. 639; Pavenstedt v. N. Y. Life Ins. Co. (1911), $2 n 3$ N. Y. 91.

Pennsylvania.- Hannon v. Allegheny Bellevue Land Co. (1910), 44 Pa. Super. Ct. 266.

Washington.-Clemens v. E. H. Stanton Co. (1911), 61 Wash. 419, 112 Pac. 494.

Section 131. The drawer of a bill and any indorser may insert thereon the name of a person to whom the holder may resort in case of need, that is to say in case the bill is dishonored by nonacceptance or non-payment. Such person is called the referee in case of need. It is in the option of the holder to resort to the referee in case of need or not as he may see fit.

\section{ARTICLE II. ACCEPTANCE.}

Section 132. The acceptance of a bill is the signification by the drawee of his assent to the order of the drawer. The acceptance 
must be in writing an dsigned by the drawee. It must not express that the drawee will perform his promise by any other means than the payment of money.

Colorado.- Van Buskirk v. State Bk. of Rocky Ford (1905), 35 Colo. 142, 83 Pac. 778, 117 Am. St. 182.

Illinois.-Dumbeck v. Walsh (1913), 179 Ill. App. 239.

Iowa.-Dugane v. Hvezda Pokroku No. 14 (1909), 119 N. W. 141; Wells v. Western Un. Tel. Co. (1910), 123 N. W. 371.

Kansas.-Rambo v. The First State Bk. of Argentine (1912), 88 Kans. 257.

Kentucky.-Ewing v. Cit. Nat. Bk. (1915), 172 S. W. 955; Selma Sav. Bk. v. Webster County Bk. (1919), 206 S. W. 870.

Mississippi.-County Shiloh \& Savannah Turnpike Co. v. Goch (1917), 113 Miss. 50, 73 So. 869.

Missouri.-Lehnhard v. Sedway (1911), 160 Mo. App. 83, 141 S. W. 430; Carmichael v. Tishomingo Banking Co. (1917), 191 S. W. 1043; Southern Creosoting Co. v. Chicago \& A. R. Co. (1918), 205 S. W. 716.

- Nebraska.- State Bk. of Beaver Co. v. Bradstreet (1911), 89 Neb. 186, 130 N. W. 1038; Gruenther v. Bank of Monroe (1911), 90 Neb. 280.

New Mexico.-Clayton Town Site Co. v. Clayton Drug Co. (1915), 147 Pac. 460.

New York.-Izzo v. Ludington (1903), 79 A. D. 272, 79 N. Y. Supp. 744; Nat. Citizens Bk. v. Toplitz (1903), 81 A. D. 593, 81 N. Y. Supp. 422; Colcord v. Banco de Tamanlipas (1918), 168 N. Y. Supp. 710. Ohio.-First Nat. Bk. of Dunn,
N. C. v. First Nat. Bk. of Massillon, Ohio (1913), 210 Fed. 542.

Oklahoma.- Ballen \& Friedman v. Bk. of Krenlin (1913), 130 Pac. 539; First Nat. Bk. of Tulsa v. Muskorgee Pipe Line Co. (1914), 139 Pac. 1136.

Oregon.- First Nat. Bk. of Cottage Grove v. Bk. of Cottage Grove (1911), 59 Oreg. 388, 117 Pac. 293.

Pennsylvania.- Clarke \& Co. v. Warren Sav. Bk. (1906), 31 Pa. Super. Ct. 647; Wisner v. First Nat. Bk. of Gallitzin (1908), $220 \mathrm{~Pa}$. 21, 68 Atl. 955, 17 L. R. A. (N. S.) 1266; Croyle v. Guelich (1908), 35 Pa. Super. Ct. 356; Colonial Tr. Co. v. Nat. Bk. of Western Pa. (1912), $50 \mathrm{~Pa}$. Super. Ct. 510; John A. Schmitt's Sons v. Shadrach (1918), 251 Fed. 874.

South Dakota.-First Nat. Bk. of Pukwana v. Brule Nat. Bk. of Chamberlain (1917), 161 N. W. 616 .

Tennessee.- Watanga Co. Bk. v. McQueen (1914), 170 S. W. 1025; Ahrens \& Ott Co. v. Moore \& Sons (1915), 174 S. W. 270.

Washington,- Nelson v. Nelson Bennett Co. (1903), 31 Wash. 116, 71 Pac. 749; Wadhams v. Portland V. \& Y. R. Co. (1905), 37 Wash. 86, 79 Pac. 597; Seattle Shoe Co. v. Packard (1906), 43 Wash. 527, 86 Pac. 845, 117 Am. St. 1064; Sheets v. Coast Coal Co. (1913), 133 Pac. 433; Plaza Farmer's Union Warehouse \& Elevator Co. v. Ryan (1914), 138 Pac. 651.

Virginia.-B. \& O. R. R. Co. v. First Nat. Bk. (1904), 47 S. E. 837. 
Section 133. The holder of a bill presenting the same for acceptance may require that the acceptance be written on the bill and, if such request is refused, may treat the bill as dishonored.

Nebraska.-Swenson Co. v. Com- Saitta (1908), 127 A. D. 624, 111 mercial State Bk. (1915), 154 N. W. N. Y. Supp. 927. 233.

Oklahoma.-First Nat. Bk. of New York.-Nat. Park Bk. v. Tulsa v. Musgorgee Pipe Line Co. (1914), 139 Pac. 1136.

Section 134. Where an acceptance is written on a paper other than the bill itself, it does not bind the acceptor except in favor of a person to whom it is shown and who, on the faith thereof, receives the bill for value.

Arkansas.-First Nat. Bk. of Tulsa v. Musgorgee Pipe Line Co. (1914), 139 Pac. 1136.

Iowa.-Wells v. Western Un. Tel. Co. (1910), 123 N. W. 371.

Kentucky.-Selma Sav. Bk. v. Webster County Bk. (1919), $206 \mathrm{~S}$. W: 870 .

Missouri.-Lehnhard v. Sedway (1911), 160 Mo. App. 83, 141 S. W. 430.

Nebraska.-State Bk. of Beaver
Co. v. Bradstreet (1911), 89 Neb. 186, 130 N. W. 1038.

Oklahoma.-First Nat. Bk. v. Muskogee Pipe Line Co. (1914), 139 Pac. 1136.

Virginia.-James v. Crumpler (1916), 89 S. E. 232.

United States.-Barnsdall v. Watemayer (1905), 142 Fed. 415, 73 C. C. A. 515; First Nat. Bk. of Dunn, N. C. v. First Nat. Bk. of Massilon, Ohio (1913), 210 Fed. 542.

Section 135. An unconditional promise in writing to accept a bill before it is drawn is deemed an actual acceptance in favor of every person who upon the faith thereof, receives the bill for value.

Iowa.-Wells v. Western Union Tel. Co. (1910), 123 N. W. 371; Iowa State Bk. of Fairfield v. City Nat. Bk. of Tripton (1918), $168 \mathrm{~N}$. W. 148 .

Missouri.-Ensign v. Clark Bros. Co. (1917), 193 S. W. 961.

New York.- Nagle v. Richards (1909), 134 A. D. 25; Muller v. Kling (1912), 133 N. Y. Supp. 614, 149 A.
D. 176 ; Lemon Importing Co. $\nabla$. Garfield Sav. Bk. (1919), 173 N. Y. Supp. 55.

North Carolina.-Bk. of Morgantown v. Hay (1906), 143 N. Car. 326,55 S. E. 811.

United States.-Barnsdall v. Wattemayer (1905), 142 Fed. 415, 73 C. C. A. 515 .

Section 136. The drawee is allowed twenty-four hours after 
presentment, in which to decide whether or not he will accept the bill; but the acceptance if given, dates as of the day of presentation.

Tennessee.-First Nat. Bk. of Murfreesboro v. First Nat. Bk. of Nashville (1913), 154 S. W. 965.

Section 137. Where a drawee to whom a bill is delivered for acceptance destroys the same, or refuses within twenty-four hours after such delivery, or within such other period as the holder may allow, to return the bill accepted or non-accepted to the holder, he will be deemed to have accepted the same.

Arkansas.-Baily \& Co. v. S. W. Venser Co. (1916), 190 S. W. 430; Bailey \& Co. v. Southwestern Veneer Co. (1919), 207 S. W. 34.

New York.- State Bk. v. Weiss (1904), 46 Misc. 93, 91 N. Y. Supp. 276; Foley v. N. Y. Sav. Bk. (1913), 139 N. Y. Supp. 915.

Pennsylvania.-Wisner v. First Nat. Bk. of Gallitzin (1908), 220 Pa. 21, 64 Atl. 955, 17 L. R. A.
(N. S.) 1266; Providence Securities \& Banking Co. v. First Nat. Bk. of Gallitizin (1908), $37 \mathrm{~Pa}$. Super. Ct. 17.

Wisconsin.-Westberg v. Chicago Lumber Co. (1903), 117 Wis. 589, 94 N. W. 572.

United States.- First Nat. Bk. of Omaha v. Whitmore (1910), 177 Fed. Rep. 397, 101 C. C. A. 401.

Section 138. A bill may be accepted before it has been signed by the drawer, or while otherwise incomplete, or when it is overdue, or after it has been dishonored by a previous refusal to accept, or by non-payment. But when a bill payable after sight is dishonored by non-acceptance and the drawee subsequently accepts it, the holder in the absence of any different agreement, is entitled to have the bill accepted as of the date of the first presentment.

Section 139. An acceptance is either general or qualified. A general acceptance assents without qualification to the order of the drawer. A qualified acceptance in express terms varies the effect of the bill as drawn.

Section 140. An acceptance to pay at a particular place is a general acceptance, unless it expressly states that the bill is to be paid there only and not elsewhere.

Section 141. An acceptance is qualified, which is:

(1) Conditional, that is to say, which makes payment by the acceptor dependent on the fulfillment of a condition therein stated; 
(2) Partial, that is to say, an acceptance to pay part only of the amount for which the bill is drawn;

(3) Local, that is to say, an acceptance to pay only at a particular place.

(4) Qualified as to time;

(5) The acceptance of some one or more of the drawees, but not of all.

Kansas.-Milwaukee Carrington Co. v. Taylor (1915), 148 Pac. 653.

Section 142. The holder may refuse to take a qualified acceptance, and if he does not obtain an unqualified acceptance, he may treat the bill as dishonored by non-acceptance. Where a qualified acceptance is taken the drawer and indorsers are discharged from liability on the bill, unless they have expressly or impliedly authorized the holder to take a qualified acceptance, or subsequently assent thereto. When the drawer or an indorser receives notice of a qualified acceptance, he must, within a reasonable time, express his dissent to the holder, or he will be deemed to have assented thereto.

West Virginia.-Lewis Hubbard 252. \& Co. v. Morton (1917), 92 S. E.

\section{ARTICLE III. \\ PRESENTMENT FOR ACCEPTANCE.}

Section 143. Presentment for acceptance must be made:

(1) Where the bill is payable after sight, or in any other ease, where presentment for aceeptance is necessary in order to fix the maturity of the instrument; or

(2) Where the bill expressly stipulates that it shall be presented for acceptance; or

(3) Where the bill is drawn payable elsewhere than at the residence or place of business of the drawee.

In no other case is presentment for aceeptance necessary in order to render any party to the bill liable.

Alabama.- Hall v. First Bk. of Crosville (1916), 72 So. 171.

Colorado.- Van Buskirk v. State Bk. of Rocky Ford (1905), 35 Colo.
142, 83 Pac. 778, 117 Am. St. 182. Illinois.- Simonoff v. Granite City Nat. Bk. (1917), 116 N. E. 636. 
New York.- Gordon v. Benquist (1916), 159 N. Y. Supp. 1; Champion Shoe Machine Co. $\nabla$. Landin (1917), 162 N. Y. Supp. 346.
United States.-First Nat. Bk. of Omaha v. Whitmore (1910), 177 Fed. Rep. 397, 101 C. C. A. 401.

Section 144. Except as herein otherwise provided, the holder of a bill which is required by the next preceding section to be presented for acceptance must either present it for acceptance or negotiate it within a reasonable time. If he fails to do so, the drawer and all indorsers are discharged.

Illinois.-Simonoff v. Granite Kentucky.- Ewing v. Cit. Nat. City Nat. Bk. (1917), 116 N. E. Bk. (1915), 172 S. W. 955. 636.

Section 145. Presentment for acceptance must be made by or on behalf of the holder at a reasonable hour, on a business day and before the bill is overdue, to the drawee or some person authorized to accept or refuse acceptance on his behalf; and:

(1) Where a bill is addressed to two or more drawees who are not partners, presentment must be made to them all, unless one has authority to accept or refuse acceptance for all, in which case presentment may be made to him only;

(2) Where the drawee is dead, presentment may be made to his personal representative;

(3) Where the drawee has been adjudged a bankrupt or an insolvent or has made an assignment for the benefit of creditors, presentment may be made to him or to his trustee or assignee.

Section 146. A bill may be presented for acceptance on any day on which negotiable instruments may be presented for payment under the provisions of sections seventy-two and eighty-five of this act. When Saturday is not otherwise a holiday, presentment for acceptance may be made before twelve o'clock, noon, on that day.

Section 14\%. Where the holder of a bill drawn payable elsewhere than at the place of business or the residence of the drawee has not time with the exercise of reasonable diligence to present the bill for acceptance before presenting it for payment on the day that it falls due, the delay caused by presenting the bill for ac- 
ceptance before presenting it for payment is excused and does not discharge the drawers and indorsers.

New York.-Baldwins Bk. of N. Y. 76, 109 N. E. 138.

Penn Yan v. Smith (1915), 215

Section 148. Presentment for acceptance is excused and a bill may be treated as dishonored by non-acceptance, in either of the following cases:

(1) Where the drawee is dead, or has absconded, or is a fictitious person or a person not having capacity to contract by bill.

(2) Where, after the exercise of reasonable diligence, presentment cannot be made.

(3) Where, although presentment has been irregular, acceptance has been refused on some other ground.

Arkansas.- Jaggers v. Sparks Illinois.-Simonoff v. Granite City (1917), 193 S. W. 67. Nat. Bk. (1917), 116 N. E. $63 \hat{o}$.

Section 149. A bill is dishonored by non-aceeptance:

(1) When it is duly presented for acceptance and such an acceptance as is prescribed by this act is refused or cannot be obtained; or

(2) When presentment for acceptance is excused and the bill is not accepted.

New York.-Nat. Park Bk. v. N. Y. Supp. 927. Saitta (1908), 127 A. D. 624, 111

Section 150. Where a bill is duly presented for acceptance and is not accepted within the prescribed time, the person presenting it must treat the bill as dishonored by non-acceptance or he loses the right of recourse against the drawer and indorsers.

New York.-Nat. Park Bk. v. N. Y. Supp. 927. Saitta (1908), 127 A. D. 624, 111

Section 151. When a bill is dishonored by non-acceptance, an immediate right of recourse against the drawers and indorsers accrues to the holder and no presentment for payment is necessary.

New York.- Nat. Park Bk. v.

Saitta (1908), 127 A. D. 624, 111

N. Y. Supp. 927 . 


\section{ARTICLE IV.}

\section{PROTEST.}

Section 152. Where a foreign bill appearing on its face to be such is dishonored by non-acceptance, it must be duly protested for non-acceptance, and where such a bill which has not previously been dishonored by non-acceptance is dishonored by non-payment, it must be duly protested for non-payment. If it is not so protested, the drawer and indorsers are discharged. Where a bill does not appear on its face to be a foreign bill, protest thereof in case of dishonor is unnecessary.

Ulinois.-Sublette Ex. Bk. v. South Carolina.-City Nat. Bk. v. Fitzgerald (1912), 168 Ill. App. 240. Givin (1916), 87 S. E. 998.

New York.-Amsinck v. Rogers (1907, 189 N. Y. 22, 82 N. E. 134, 12 L. R. A. (N. S.) 875, 121 Am. St. 858; McBride v. Illinois Nat. Bk. (1910), 138 A. D. 339; Casper v. Kuhne (1913), 140 N. Y. Supp. 86.

Tennessee.-Wasterhouse v. Ster. chi Bros. (1918), 201 S. W. 150.

West Virginia.-Deming Nat. Bk. v. Baker (1919), 98 S. E. 438.

Section 153. The protest must be annexed to the bill, or must contain a copy thereof, and must be under the hand and seal of the notary making it, and must specify:

(1) The time and place of presentment;

(2) The fact that presentment was made and the manner thereof ;

(3) The cause or reason for protesting the bill;

(4) The demand made and the answer given, if any, or the fact that the drawee or acceptor could not be found.

minois-Sublette Ex. Bk. v. New York.-London \& River Fitzgerald (1912), 168 Il. App. 240. Plate Bk. v. Carr (1904), 105 N. Y. Supp. 679, 54 Misc. 94.

Section 154. Protest may be made by:

(1) A notary public; or

(2) By any respectable resident of the place where the bill is dishonored, in the presence of two or more credible witnesses.

Alabama.- Hooper v. Herring Fitzgerald (1912), $168 \mathrm{Ill}$. App. 240. (1915), 70 So. 308 .

New York.-McGrath v. Franco-

Illinois.- Sablette Ex. Bk. v. line (1915), 156 N. Y. Supp. 981. 
Section 155. When a bill is protested, such protest must be made on the day of its dishonor, unless delay is excused as herein provided. When a bill has been duly noted, the protest may be subsequently extended as of the date of the noting.

Missouri.-First Nat. Bk. of W. 721. Grunt City v. Korn (1915), 179 S.

Section 156. A bill must be protested at the place where it is dishonored, except that when a bill drawn payable at the place of business, or residence of some person other than the drawee, has been dishonored by non-acceptance, it must be protested for nonpayment at the place where it is expressed to be payable, and no further presentment for payment to, or demand on, the drawee is necessary.

Section 15\%. A bill which has been protested for non-acceptance may be subsequently protested for non-payment.

Section 158. Where the acceptor has been adjudged a bankrupt or an insolvent, or has made an assignment for the benefit of creditors, before the bill matures, the holder may cause the bill to be protested for better security against the drawer and indorsers.

Section 159. Protest is dispensed with by any circumstances which would dispense with notice of dishonor. Delay in noting or protesting is excused when delay is caused by circumstances beyond the control of the holder and not imputable to his default, misconduct or negligence. When the cause of delay cease sto operate, the bill must be noted or protested with reasonable diligence.

Kansas.-Dillon v. Bron (1915), 150 Pac. 553.

Section 160. When a bill is lost or destroyed or is wrongly detained from the person entitled to hold it, protest may be made on a copy or written particulars thereof.

\section{ARTICIE $V$.}

ACCEPTANCE FOR HONOR.

Section 161. Where a bill of exchange has been protested for dishonor by non-acceptance or protested for better security, and is not overdue, any person not being a party already liable thereon 
may, with the consent of the holder, intervene and accept the bill supra protest for the honor of any party liable thereon, or for the honor of the person for whose account the bill is drawn. The acceptance for honor may be for the part only of the sum for which the bill is drawn, and where there has been an acceptance for honor for one party, there may be a further acceptance by a different person for the honor of another party.

New York.-Canning v. Lane (1913), 139 N. Y. Supp. 884.

Section 162. An acceptance for honor supra protest must be in writing, and indicate that it is an acceptance for honor, and must be signed by the acceptor for honor.

Louisiana. - Thiel v. Butker New York-German-Am. Bk. v. (1910), 125 La. 473, 51 So. 500.

Cunningham (1904), 97 A. D. 244, 89 N. Y. Supp. 836.

Section 163. Where an acceptance for honor does not expressly state for whose honor it is made, it is deemed to be an acceptance for the honor of the drawer.

New York.-German-Am. Bk. v. Rhode Island.-McLean v. Bryer Cunningham (1904), 97 A. D. 244, (1903), 24 R. I. 599, 54 Atl. 373. 89 N. Y. Supp. 836.

Section 164. The acceptor for honor is liable to the holder and to all parties to the bill subsequent to the party for whose honor he has accepted.

Section 165. The acceptor for honor, by such acceptance engages that he will on due presentment pay the bill according to the terms of his acceptance, provided it shall not have been paid by the drawee, and provided also, that it shall. have been duly presented for payment and protested for non-payment and notice of dishonor given him.

New York.-German-Am. Bk. v. Conningham (1904), 97 A. D. 244, 89 N. Y. Supp. 836.

Section 166. Where a bill payable after sight is accepted for 
honor, its maturity is calculated from the date of the noting for non-acceptance and not from the date of the acceptance for honor.

Section 16\%. Where a dishonored bill has been accepted for honor supra protest or contains a reference in case of need, it must be protested for non-payment before it is presented for payment to the acceptor for honor or referee in case of need.

Scction 168. Presentment for payment to the acceptor for honor must be made as follows:

(1) If it is to be presented in the place where the protest for non-payment was made, it must be presented not later than the day following its maturity.

(2) If it is to be presented in some other place than the place where it was protested, then it must be forwarded within the time specified in section one hundred and four.

Section 169. The provisions of section eighty-one apply where there is delay in making presentment to the acceptor for honor or referee in case of need.

New York,-German-Am. Bk, v. Wisconsin.-Curry v. Wis. Nat. Cunningham (1904), 97 A. D. 244, Bk. (1912), 149 Wis. 413. 89 N. Y. Supp. 836.

Section 1\%0. When the bill is dishonored by the acceptor for honor it must be protested for non-payment by him.

\section{ARTICLE VI. \\ PAYMENT FOR HONOR.}

ARTICLE I.

Section 171. Where a bill has been protested for non-payment, any person may intervene and pay it supra protest for the honor of any person liable thereon or for the honor of the person for whose account it was drawn.

Alabama.-Hooper v. Herring (1915), 70 So. 308.

Section 172. The payment for honor supra protest in order to operate as such and not as a mere voluntary payment must be attested by a notarial act of honor which may be appended to the protest or form an extension to it. 
Section 173. The notarial act of honor must be founded on a declaration made by the payer for honor or by his agent in that behalf declaring his intention to pay the bill for honor and for whose honor he pays.

Section 174. Where two or more persons offer to pay a bill for the honor of different parties, the person whose payment will discharge most parties to the bill is to be given the preference.

Louisiana.-Cammer Bk. v. Sanders (1914), 66 So. 854.

Section 175. Where a bill has been paid for honor, all parties subsequent to the party for whose honor it is paid are discharged, but the payer for honor is subrogated for, and succeeds to, both the rights and duties of the holder as regards the party for whose honor he pays and all parties liable to the latter.

Section 176. Where the holder of a bill refuses to receive payment supra protest, he loses his right of recourse against any party who would have been discharged by such payment.

Section 17\%. The payer for honor, on paying to the holder the amount of the bill and the notarial expenses incidental to its dishonor, is entitled to receive both the bill itself and the protest.

\section{ARTICLE VII. \\ BILLS IN A SET.}

Section 178. Where a bill is drawn in a set, each part of the set being numbered and containing a reference to the other parts, the whole of the parts constitutes one bill.

New York.-Caras v. Thalmann (1910), 138 A. D. 297, 123 N. Y.

Supp. 97.

Section 179. Where two or more parts of a set are negotiated to different holders in due course, the holder whose title first accrues is as between such holders the true owner of the bill. But nothing in this section affects the rights of a person who in due course accepts or pays the part first presented to him.

Section 180. Where the holder of a set indorses two or more parts to different persons he is liable on every such part, and every 
indorser subsequent to him is liable on the part he has himself indorsed, as if such parts were separate bills.

Louisiana.- Interstate Tr. \&

Banking Co. v. Young (1914), 65

So. 611 .

Section 181. The acceptance may be written on any part and it must be written on one part only. If the drawee accepts more than one part, and such accepted parts are negotiated to different holders in due course, he is liable on every such part as if it were a separate bill.

Section 182. When the acceptor of a bill drawn in a set pays it without requiring the part bearing his acceptance to be delivered up to him, and that part at maturity is outstanding in the hands of a holder in due course, he is liable to the holder thereon.

Massachusetts. - Symonds v. Riley (1905), 188 Mass. 470, $74 \mathrm{~N}$.

E. 926.

Section 183. Except as herein otherwise provided where any one part of a bill drawn in a set is discharged by payment or otherwise the whole bill is discharged.

New York-Caras v. Thalmann Supp. 97; Casper v. Kuhne (1913), (1910), 138 A. D. 297,123 N. Y. 159 A. D. 389,144 N. Y. Supp. 502.

\section{TITLE III. PROMISSORY NOTES AND CHECKS.}

\section{ARTICLE I.}

Section 184. A negotiable promissory note within the meaning of this act is an unconditional promise in writing made by one person to another signed by the maker engaging to pay on demand, or at a fixed or determinable future time, a sum certain in money to order or to bearer. Where a note is drawn to the maker's own order, it is not complete until indorsed by him.

Alabama.-Ger.-Am. Nat. Bk. v. Lewis (1913), 63 So. 741.

Idaho.- Union Stock Yards Nat. Bk. v. Bolan (1908), 14 Ida. 87, 93 Pac. 508.

Illinois.-Van Kleeck v. Channon (1912), 175 Ill. App. 626.
Kentucky.- Alexander v. Hazelrigg (1906), $123 \mathrm{Ky} .677,97 \mathrm{~S} . \mathrm{W}$. 353; Weltlaufer v. Baxter (1910), $137 \mathrm{Ky} .362,125 \mathrm{~S}$. W. 741.

Missouri- Market \& Fulton Nat. Bk. v. Ettenson's Estate (1913), 158 S. W. 448. 
New York.-Young v. Am. Bk. No. 1 (1904), 44 Misc. 305, 89 N. Y. Supp. 913; Young v. Am. Bk. No. 82 (1904), 44 Misc. 308,89 N. Y. Supp. 915; Simon v. Murtz (1906), 51 Misc. 670, 101 N. Y. Supp. 86; Colborn v. Arbrean (1907), 54 Misc. 623, 104 N. Y. Supp. 968; Edelman v. Rams (1908), 58 Misc. 561, 109 N. Y. Supp. 816 ; Ed. Tr. Co. of N. Y. v. Newman (1910), 127 N. Y. Supp. 243; Yonkers Nat. Bk. v. Mitchell (1913), 141 N. Y. Supp. 128; Ryan v. Sullivan (1911), 143 A. D. 471 .
North Carolina.- Perry Co. v. Taylor (1908), 148 N. Car. 362; Johnson v. Lasseter (1911), $155 \mathrm{~N}$. Car. 47.

North Dakota. - Farquhar Co. v. Higham (1907), 16 N. Dak. 10ô, 112 N. W. 657; First Nat. Bk. of Pomeroy v. Buttery (1908), $17 \mathrm{~N}$. Dak. 326, 116 N. W. 341, 16 L. R. A. (N. S.) 878 .

Oklahoma.- Iowa State Sav. Bk. v. Wignall (1916), 157 Pac. 725.

Pennsylvania.- Milton Nat. Bk. v. Beaver (1904), $25 \mathrm{~Pa}$. Super. Ct. 494.

Section 185. A check is a bill of exchange drawn on a bank payable on demand. Except as herein otherwise provided, the provisions of this act applicable to a bill of exchange payable on demand apply to a check.

Colorado.- Van Buskirk v. State Bk. of Rocky Ford (1905), 35 Colo. 142, 83 Pac. 778, 117 Am. St. 182; Norman v. McCarthy (1913), 138 Pac. 28.

Idaho.-Camas Prairie State Bk. v. Newman (1909), 99 Pac. 833, 12 Id. 719 .

Illinois.-Sublette Ex. Bk. v. Fitzgerald (1912), 168 Ill. App. 240; People v. Miller (1917), 116 N. E. 131, 278 Ill. 490.

Indiana.- Williams v. Lowe (1916), 113 N. E. 471.

Kentucky.- Ewing v. Cit. Nat. Bk. (1915), 172 S. W. 955.

Maryland.-American Agricultural Chemical Co. v. Scrimger (1917), 100 Atl. 774.

Massachusetts.--Symonds v. Riley (1905), 188 Mass. 470, 74 N. E. 926; Gordon v. Levine (1907), 194 Mass. 418, 80 N. E. 505; Gordon v.
Levine (1908), 197 Mass. 267, 83 N. E. 861,15 L. R. A. (N..S.) 243.

Missouri.-Nat. Bk. of Commerce v. Am. Nat. Bk. (1910), 127 S. W. 429; Nelson v. Diftenderffer (1914), 163 S. W. 271; Kansas City Gas Co. v. Westport Ave. Bk. (1915), 177 S. W. 1092.

Nebraska.- Swenson Co. v. Commercial State Bk. (1915), $154 \mathrm{~N}$. W. 233.

New York.-State Bk. v. Weiss (1904), 46 Misc. 93, 91 N. Y. Supp. 276 ; Amsinck v. Rogers (1907), 189 N. Y. 252,82 N. E. 134,12 L. R. A. (N. S.) 875, 121 Am. St. 858; Schlesinger v. Kurzvok (1905), 94 N. Y. Supp. 442, 47 Misc. 634; Riddle v. Bk. of Montreal (1911), 145 A. D. 207, 130 N. Y. Supp. 15; Casper v. Kuhne (1913), 140 N. Y. Supp. 86.

North Carolina. - Manufacturing 
Co. v. Summers (1906), 143 N. Car. 102,55 S. E. 522; Singer Mfg. Co. v. Summers (1906), 143 N. Car. 102,55 S. E. 522.

Oklahoma.- Ballen \& Friedman v. Bk. of Krenlin (1913), 130 Pac. 539; Turner v. Kimble (1913), 130 Pac. 563.

Oregon.-State v. Hammelsey (1908), 52 Oreg. 156, 96 Pac. 865;

U S. Nat. Bk. v. First Trust \& Sav. Bk. (1911), 60 Oreg. 266, 119 Pac. 343; Triphonoff v. Sweeney (1913), 130 Pac. 979.

Pennsylvania.- Wisner v. First Nat. Bk. of Gallitzin (1908), 220 Pa. 21, 68 Atl. 955, 17 L. R. A. (N. S.) 1266; Hannon v. Allegheny Bellevue Land Co. (1910), $44 \mathrm{~Pa}$. Super. Ct. 266.
Tennessee.-Unaka Nat. Bk. v. Butler (1904), 113 Tenn. 674, 83 S. W. 655 ; Am. Nat. Bk. v. Nat. Fertilizer Co. (1911), 125 Tenn. 329, 143 S. W. 597; First Nat. Bk. of Murfreesboro v. First Nat. Bk. of Nashville (1913), 154 S. W. 965.

Vermont.- First Nat. Bank of Montpelier v. Bertoli (1914), 89 Atl. 359.

Virginia.-B. \& O. R. R. Co. v. First Nat. Bk. (1904), 47 S. E. 837.

Washington.- The State v. Garland (1911), 65 Wash. 666; Peninsula Nat. Bk. v. Pederson (1916), 158 Pac. 246.

Wisconsin.-Columbian Banking Co. v. Bowen (1908), 134 Misc. 218, 114 N. W. 451.

Wyoming.-Brown v. Cow Creek Co. (1912), 126 Pac. 886.

Section 186. A check must be presented for payment within a reasonable time after its issue or the drawer will be discharged from liability thereon to the extent of the loss caused by the delay.

Alabama.- Wallace v. City Nat. Bk. of Decatur (1919), 80 So. 405.

Iowa.- Plover Sav. Bk. v. Moodie (1906), 135 Iowa, 685, 110 N. W. 29.

Massachusetts.-Gordon v. Levine (1907), 194 Mass. 418, 80 N. E. 505; Gordon v. Levine (1909), 197 Mass. 267,83 N. E. 861,15 L. R. A. (N. S.) 243; Furber v. Dane (1909), 203 Mass. 108, 89 N. E. 227.

Missouri.-First Nat. Bk. of Grant City v. Korn (1915), $179 \mathrm{~s}$, W 721; City of Brunswick v. Peoples Sav. Bk. (1916), 190 S. W. 60.

New York.-Kramer v. Grant (1908), 111 N. Y. Supp. 709; Dehoust v. Lewis (1908), 128 A. D.
131, 112 N. Y. Supp. 559; Zaloom v. Garim (1911), 129 N. Y. Supp. 85 ; Knickerbocker Tr. Co. v. Miller (1912), 133 N. Y. Supp. 989; Sulsberger \& Sons Co. v. Cramer (1915), 155 N. Y. Supp. 775; McEwen Bros. v. Cobb (1918), 172 N. Y. Supp. 44.

North Carolina.- Singer Mfg. Co. v. Summers (1906), 143 N. Car. 102 , 55 S. E. 522; Bk. of Mt. Airy v. Greensboro Loan \& Tr. Co. (1912), 159 N. Car. 85,74 S. E. 747.

Oregon.-Matlock v. Scheuerman (1908), 51 Oreg. 49, 93 Pac. 823, 17 L. R. A. (N. S.) 747 .

Pennsylvania.- Hannon v. Allegheny Bellevue Land Co. (1910), 44 Pa. Super. Ct. 266; Rosenbaum v. 
Hazard (1911), 233 Pa. 206, 82 Atl. 62.

Washington.- Hunt v. Panhandle Lumber Co. (1912), 69 Wash. 645, 120 Pac. 538; Peninsule Nat. Bk. v. Pederson (1916), 158 Pac. 246.
Wisconsin.-Aebi v. Bk. of Evansville (1905), 124 Wis. 93, $102 \mathrm{~N}$. W. 329, 68 L. R. A. 964, 109 Am. St. 925; Columbia Banking Co. v. Bowen (1908), 134 Misc. 218, 114 N. W. 451.

Section 187. Where a check is certified by the bank on which it is drawn, the certification is equivalent to an acceptance.

Idaho.- Smith v. Field (1911), 19

Ida. 558, 114 Pac. 668.

Massachusetts.-Elliott v. Worcester Tr. Co. (1905), 189 Mass. 542, 75 N. E. 944.

New York.-Poess v. Twelfth Ward Bk. (1904), 43 Misc. 45, 86 N. Y. Supp. 857 ; Meuer v. Phonix Nat. Bk. (1904), 94 A. D. 331, 88 N. Y. Supp. 83 ; Schlesinger v. Kurzvok (1905), 94 N. Y. Supp. 442, 47 Misc. 634; St. Regis Paper Co. v. Gonswanada B. \& P. Co. (1905), 107 A. D. 90, 94 N. Y. Supp. 945; Gallo v. Brooklyn Sav. Bk. (1910), 199 N. Y. 222; Davenport v. Palmer (1912), 152 A. D. 761; McMahon r. Roseville Tr. Co. (1913), 125 A. D. 640,144 N. Y. Supp. 841; Carnegie Trust Co. v. First Nat. Bk. of City of N. Y. (1915), 107 N. Y. 693, 213 N. Y.
301; Baldinger \& Kupferman Mig. Co. v. Manf. Citizens Tr. Co. (1915), 156 N. Y. Supp. 445; Nat. Reserve Bk. of N. Y. City v, Corn Exchange Bk. (1916), 157 N. Y. Supp. 316.

North Dakota.- Security State Bk. v. State Bk. of Brantford (1915), 154 N. W. 282.

Oregon.- First Nat. Bk. of Cottage Grove v. Bk. of Cottrge Grove (1911), 59 Oreg. 388, 117 Pac. 293.

South Dakota.- First Nat. Bk. v. Brule Nat. Bk. (1917), 161 N. W. 616.

Tennessee.-Unaka Nat. Bk. v. Butler (1904), 113 Tenn. 674, 83 S. W. 655 ; Pease \& Dwyer Co. v. State Nat. Bk. (1905), 114 Tenn. 693,88 S. W. 172 ; Farmers \& Merchants Bk. v. Bk. of Rutherford (1905), 115 Tenn. 64, 88 S. W. 939.

Section 188. Where the holder of a check procures it to be accepted or certified the drawer and all indorsers are discharged from liability thereon.

Missouri.- Nat. Bk. of Rolla v. First Nat. Bk. of Salem (1910), 141 Mo. 719, 125 S. W. 513; Nat. Bk. of Commerce v. Mech. Am. Nat. Pk. (1910), 127 S. W. 429; City of Branswick v. Peoples Sav. Bk. (1916), 190 S. W. 60.

New Jersey.-Times Square Auto
Co. v. Rutherford Nat. Bk. (1909), 73 Atl. 479.

New York.-Calliman v. Union Surety \& Guaranty Co. (1903), 79 A. D. 409,80 N. Y. Supp. 58; Meuer v. Phenix Nat. Bk. (1904), 94 A. D. 331, 88 N. Y. Supp. 83; St. Regis Paper Co. v. Gonawanda B. \& P. 
Co. (1905), 107 A. D. 90, 94 N. Y. Supp. 946; Dunn v. Whalen (1907), 120 A. D. 729,94 N. Y. Supp. 588; Gallo v. Brookłyn Sav. Bk. (1910), 199 N. Y. 222; Davenport v. Palmer (1912), 152 A. D. 761; Lyons v. Union Ex. Nat. Bk. of N. Y. (1912), 135 N. Y. Supp. 121, 150 A. D. 493; Cor. Tr. Co. v. First Nat. Bk. of City of N. Y. (1913), 156 A. D. 712,141 N. Y. Supp. 745; McMahon v. Roseville Tr. Co. (1913), 125 A.
D. 640, 144 N. Y. Supp. 841; Carnegie Trust Co. v. First Nat. BK. of City of N. Y. (1915), 107 N. E. 693, 213 N. Y. 301; Felin v. Petix (1918), 167 N. Y. Supp. 1073.

Oregon.-First Nat. Bk. of Cottage Grove v. Bk. of Cottage Grove (1911), 59 Oreg. 388, 117 Pac. 393.

Oklahoma.-Cherokee Nat. Bk. v. Union Tr. Co. (1912), 33 Okla. 342, 125 Pac. 464.

Section 189. A check of itself does not operate as an assignment of any part of the funds to the credit of the drawer with the bank, and the bank is not liable to the holder, unless and until it accepts or certifies the check.

Colorado.- Van Buskirk v. State Bk. of Rocky Ford (1905), 35 Colo. 142, 83 Pac. 778, 117 Am. St. 182.

Idaho.- Smith v. Field (1911), 19 Ida. 558, 114 Pac. 668; Kaesemeyer v. Smith (1912), 22 Ida. 1, 123 Pac. 943.

Illinois.- The First Nat. Bk. of Chicago v. O'Byrne (1913), $177 \mathrm{lll}$. App. 473.

Iowa.- Hove v. Stanhope State Pk. (1908), 138 Iowa, 39, 115 N. W. 476.

Kentucky.-Boswell v. Citizen's Sav. Bk. (1906), 96 S. W. 797; Ewing v. Cit. Nat. Bk. (1915), 172 S. W. 955 .

Michigan-Lonier v. State Sav. Bk. (1907), 149 Mich. 483, $112 \mathrm{~N}$. W. 1119 .

New Jersey.-Nat. Bk. of New Jersey v. Berrall (1904), 70 N. J. L. 757,85 Atl. 189.

New York.-Poess v. Twelfth Ward Bk. (1904), 43 Misc. 45, 86 N. Y. Supp. 857 ; Meuer v. Phenix Nat. Bk. (1904), 94 A. D. 331, 88
N. Y. Supp. 83 ; State Bk. v. Weiss (1904), 46 Misc. 93, 91 N. Y. Supp. 276; Schlesinger v. Kurzvok (1905), 94 N. Y. Supp. 442, 47 Misc. 634; Ellery v. People's Bk. (1909), 114 N. Y. Supp. 108; Havana Cent. R. Co. v. Knickerbocker Trust Co. (1910), 135 A. D. 313; Balsam v. Mutual Alliance Tr. Co. (1911), 132 N. Y. Supp. 325 ; Shattuck v. Guardian Tr. Co. (1912), 130 N. Y. Supp. 658, 145 A. D. 734; Anglo-South Am. Bk. v. Nat. City Bk. of N. Y. (1914), 146 N. Y. Supp. 457; Cor. Tr. Co. v. First Nat. Bk. of City of New York (1913), 156 A. D. 712, 141 N. Y. Supp. 745; Hentz v. Nat. City Bk. of N. Y. (1913), 159 A. D. 743, 144 N. Y. Supp. 979.

North Carolina.- Perry v. Bk. of Smithfield (1902), 131 N. Car. 117. Oklahoma.- Ballen \& Friedman v. Bk. of Krenlin (1913), 130 Pac. 539.

Oregon.-U. S. Nat. Bk. v. First Trust \& Sav. Bk. (1911), 60 Oreg. 266, 113 Pac. 343. 
Pennsylvania.-Tibby Bros. Glass Co. v. Farmers \& Mech. Bk. of Sharpsburg (1908), 220 Pa. 1.

Tennessee.-Unaka Nat. Bk. v. Butler (1904), 113 Tenn. 674, 83 S. W. 655; Pease \& Dwyer Co. v. State Nat. Bk. (1905), 114 Tenn. 893, 88 S. W. 172; First Nat. Bk. of Murfreesboro v. First Nat. Bk. of Nashville (1913), 154 S. W. 965. Virginia.-B. \& O. R. R. Co. v. First Nat. Bk. (1904), 47 S. E. 837. Wisconsin-Jacobson v. Bedtzler (1906), 127 Wis. 566; Bank of Sioux City v. Old Nat. Bk. of Battle Creek (1917), 241 Fed. 1.

\section{TITLE IV. \\ GENERAL PROVISIONS.}

\section{ARTICLE I.}

Section 190. This act may be cited as the Uniform Negotiable Instruments Act.

Connecticut.-Atwood v. Atwood (1913), 86 Atl. 29.

Kentucky.-Callaghan v. Louis- ville Dry Goods Co. (1910), $14 \mathrm{Ky}$. 712, 131 s. W. 995.

Missouri. - Dickey v. Adler (1910), 127 S. W. 593.

Section 191. In this act, unless the context otherwise requires: "Acceptance" means an acceptance completed by delivery or notification.

"Action" includes connterclaim and set-off.

"Bank" includes any person or association of persons carrying on the business of banking, whether incorporated or not.

"Bearer" means the person in possession of a bill or nate which is payable to bearer.

"Bill" means bill of exchange, and "note" means negotiable promissory note.

"Delivery" means transfer of possession, actual or constructive, from one person to another.

"Holder" means the payee or indorsee of a bill or note, who is in possession of it, or the bearer thereof.

"Indorscment" means an indorsement completed by delivery.

"Instrument" means negotiable instrument.

"Issue" means the first delivery of the instrument, complete in form, to a person who takes it as a holder.

"Person" includes a body of persons, whether incorporated or not.

"Value" means valuable consideration.

“Written" includes printed, and "writing" includes print.

Arizona.-Gray v. Baron (1910), 13 Ariz. 70, 108 Pac. 229. 
Colorado.-Louisville Coal \& Mining $\mathrm{Ca}$. . Int. Trust Co. (1903), 18 Colo. App. 345, 71 Pac. 898.

Connecticut. - Knapp Co. v. Tidewater Coal Co. (1912), 85 Conn. 147, 81 Atl. 1063; New Haven Mfg. Co. v. New Haven Pulp Co. (1903), 76 Conn. 126, 55 Atl. 604.

Florida.- Scott v. Taylor (1912), 63 Fla. 612.

Idaho.-Craig v. Palo Alto Stock Farm (1901), 16 Ida. 701, 102 Pac. 393; Rinker v. Lauer (1907), 13 Ida. 163, 88 Pac. 1057.

Illinois.- First Nat. Bk. of Manlius v. Garland (1911), 160 Ill. App. 407.

Iowa.-Allison v. Hollembeak (1908), 138 Iowa, 479, 114 N. W. 1059; Irwin v. Deming (1909), 142 Iowa, 299, 120 N. W. 645; Vander Ploey v. Van Zunk (1907), 135 Iowa, 350, 112 N. W. 807; Voss v. Chamberlain (1908), 139 Iowa, 569, 117 N. W. 269.

Kansas.-Smith v. Nelson Land \& Cattle Co. (1914), 212 Fed. 56.

Missouri.-Burchett v. Fink (1909), 139 Mo. App. 381; GermanAm. Bk. v. Martin (1908), 129 Mo. App. 484; Greer v. Orchard (1913), 161 S. W. 875; Night \& Day Bk. v. Rosenbaum (1915), 177 S. W. 693.

Nebraska.- Aurora State Bk. v. Hayes-Eames Elevator Co. (1911), 88 Neb. 187.

New York.-Barkley v. Muller (1914), 149 N. Y. Supp. 620, 164 A. D. 351 ; Davenport v. Palmer (1912), 152 A. D. 761; Gilbert v. Adams (1911), 131 N. Y. Supp. 787; Lyons v. Union Ex. Nat. Bk. of N.
Y. (1912), 135 N. Y. Supp. 121, 150 A. D. 493; Manufacturer's Commercial Co. v. Blitz (1909), 131 A. D. 17, 115 N. Y. Supp. 402; Schwartzman v. Post (1903), 84 N. Y. Supp. 922, 94 A. D. 474; Wolfin v. Security Bk. of N. Y. (1915), $156 \mathrm{~N}$. Y. Supp. 474.

North Carolina.- Mayers v. McRimmon (1906), 140 N. Car. 640, 53 S. E. 447,111 Am. St. 879; Steinhilper v. Basinight (1910), 153 N. Car. 293, 69 S. E. 222.

Ohio.-Moore v. Central Nat. Bk. of Cleveland (1910), 31 Ohio C. 614; Starr Piano Co. v. Edgar (1909), 31 Ohio C. 295.

Pennsylvania.- Nat. Bk. of Phoenixville v. Bonsor (1909), $38 \mathrm{~Pa}$. Super. Ct. 275.

Rhode Island.- Wilbour v. Hawkins (1915), 94 Atl. 856.

Tennessee.-Farmers \& Merchants Bk. v. Bk. of Rutherford (1905), 115 Tenn. 64, 88 S. W. 939.

Utah.-Utah Nat. Bk. of Salt Lake City v. Nelson (1910), 38 Utah, 169, 111 Pac. 907.

Washington.-Hillman v. Stanley (1909), 56 Wash. 320, 105 Pac. 816.

Wisconsin.- Schultz v. Kosbab (1905), 125 Wis. 157; Swanby v. Northern State Bk. (1912), 150 Wis. 572,137 N. W. 763; Westberg v. Chicago Lumber Co. (1903), 117 Wis. 589,94 N. W. 572.

Wyoming.- Acme Coal Co. v. Northrup Nat. Bk. of Iola (1915), 146 Pac. 593; Capitol Hill St. Bk. v. Rawlins Nat. Bk. (1916), 160 Pac. 1171.

Section 192. 'The person "primarily" liable on an instrament is the person who by the terms of the instrument is absolutely required to pay the same. All other parties are "secondarily" liable. 
Alabama.- Hudson Tr. Co. v. Elliott (1915), 69 So. 631.

Arizona.-Cowan v. Ramsay (1914), 140 Pac. 501.

Arkansas.-Burke v. Jefferson Bk. (1915), 180 S. W. 500.

Kansas.- Farmers \& Drovers Bk. v. Bashor (1916), 160 Pac. 208; Nat. Bk. of Webb City v. Dickinson (1918), 171 Pac. 636.

Louisiana.-Lewy $\nabla$. Wilkinson (1914), 64 So. 1003.

Maryland.- Vanderford v. Farmers \& Mech's Nat. Bk. of Westminster (1907), 105 Md. 164, 66 Atl. 47.

Massachusetts.- Union Tr. Co. v. McGinty (1912), 212 Mass. 205, 98 N. E. 679 .

Michigan-Lamberson v. Love (1911), 165 Mich. 460.

Minnesota.-Baxter v. Brandenburg (1917), 163 N. W. 516.

Missouri-Citizen's Bk. of Senath v. Douglass (1913), 161 S. W. 601 ; Lane v. Hyder (1912), $163 \mathrm{Mo.}$ App. 688, 147 S. W. 514; Night \& Day Bk. v. Rosenbaum (1915), 177 S. W. 693.

New York.-Building \& Engineer ing Co. v. Northern Bk. of N. Y. (1912), 206 N. Y. 400; Graham v. York (1910), 140 A. D. 639; Nat. Citizens Bk. v. Toplitz (1903), 81 N. Y. Supp. 422; Schwartzman v.
Post (1903), 84 N. Y. Supp. 922, 94 A. D. 474.

North Carolina.- Rouse v. Wooten (1906), 140 N. Car. 557, $53 \mathrm{~S}$. E. 430, $111 \mathrm{Am}$. St. 875 .

North Dakota.- Northern State Bk. v. Bellany (1910), 125 N.W. 888.

Ohio.-Dollar Sys. Bk. v. Barberton Pottery Co. (1907), 17 Ohio Dec. 539; Richards v. Market Ex. Bk. (1910), 81 Ohio St. 348, 55 Ohio Law Bull. 20.

Oregon-Cellers v. Meachem (1907), 49 Oreg. 186, 10 L. R. A. (N. S.) 133; Everding \& Farrell v. Taft (1916), 160 Pac. 1160; Hunter v. Harris (1912), 63 Oreg. 505, 127 Pac. 786; Lumberman's Nat. Bk. of Portland v. Campbell (1912), 61 Oreg. 123, 121 Pac. 427; Murphy v. Panter (1912), 62 Orge. 522, 125 Pac. 292 ; Noble v. Beeman-Spaulding-Woodwar Co. (1913), 131 Pac. 1006.

Rhode Island.-Deahey v. Ohoquet (1907), 28 R. I. 338.

Texas.- Hackney Mfg. Co. v. Ce$\operatorname{lum}$ (1916), 189 S. W. 988.

Utah.-Wostentolme v. Smith (1908), 34 Utah, 300, 97 Pac. 329.

Washington.-Bradley Engineering \& Mfg. Co. v. Heyburn (1910), 56 Wash. 629, 106 Pac. 170; Pease v. Syler (1914), 138 Pac. 310.

Section 193. In determining what is a "reasonable time" or an " un reasonable time," regard is to be had to the nature of the instrument, the usage of trade or business (if any) with respect to such instruments, and the facts of the particular case.

Arkansas.- Thornton v." Bowie (1916), 185 S. W. 793.

Idaho.- Sheffield v. Cleland (I911), 19 Idt. 612, 115 Pac. 20.
Illinois.-Greer v. Downing (1912), 176 Ill. App. 335; Simonoff v. Granite City Nat. Bk. (1917), 116 N. E. 636. 
Iowa.-Anderson v. First Nat. Bk. of Chariton (1909), 144 Iowa, 251, 122 N. W. 918; LeClere v. Philpott (1915), 151 N. W. 825; Plover Sav. Bk. v. Moodie (1906), 135 Iowa, 685,110 N. W. 29.

Massachusetts.-Gordon v. Levine (1907), 194 Mass. 418, 80 N. E. 505; Gordon v. Levine (1908), 197 Mass. 267,83 N. E. 861,15 L. R. A. (N. S.) 243; Merritt v. Jackson (1902), 181 Mass. 69, 62 N. E. 987; Plymouth County Trust Co. v. Scanlon (1917), 116 N. E. 468.

New Jersey.-Hills Sav. \& Drawing Club v. Baronowitz (1916), 97 Atl. 28.

New York.-Commercial Nat. Bk. v. Zimmerman (1906), 185 N. Y. 210, 77 N. E. 1020; Weber v. Hirsch
(1917), 163 N. Y. Supp. 1086; Zaloom v. Ganim (1911), 129 N. Y. Supp. 85.

North Carolina.- Manufacturing Co. v. Summers (1906), 143 N. Car. 102,55 S. E. 522 ; Singer Mfg. Co. v. Summers (1906), 143 N. Car. 102,55 S. E. 522.

Pennsylvania.- Hannon v. Allegheny Bellevue Land Co. (1910), 44 Pa. Super. Ct. 266; Murray v. Real Est. Title Ins. \& Tr. Co. (1909), 39 Pa. Super. Ct. $\longleftarrow 38$.

Rhode Island.-McLean v. Bryer (1903), 24 R. I. 599, 54 Atl. 373.

Virginia.-Brown v. Thomas (1917), 92 S. E. 977; Colona v. Parksley Bk. (1917), 92 S. E. 979.

West Virginia. - Thompson v. Curry (1917), 91 S. E. 801.

Section 194. Where the day, or the last, day, for doing any act herein required or permitted to be done falls on Sunday or on a holiday, the act may be done on the next succeeding secular or business day.

Colorado.-Babcock v. The City of Rocky Ford (1914), 25 Colo. App. 312.
Disrict of Columbia.-Ambrose $\mathbf{v}$. Brown (1914), 42 App. D. C. 25.

Oregon.-Murphy v. Panter (1912), 125 Pac. 292.

Section 195. The provisions of this act do not apply to negotiable instruments made and delivered prior to the (taking effect) hereof.

Arkansas - Parish v. Smith (1918), 204 S. W. 415.

Colorado.-Louisville Coal \& Minin Co. v. Int. Trust Co. (1903), 18 Colo. App. 45, 71 Pac. 898.

Missouri.-Gate City Nat. Bk. v. Schmidt (1912), 152 S. W. 101.
Nebraska.-Dorsey v. Wellman (1909), 122 N. W. 989; Fassler v. Street (1913), 92 Neb. 786.

North Carolina.-Meyers v. Me Rimmon (1906), 140 N. Car. 640, 53 S. E. 447,111 Am. St. 879 .

Section 196. In any case not provided for in this act the rules of (law and equity including) the law merchant shall govern. 
Kentucky.- Mechanics \& Farm. Ohio.-Richards v. Market Ex. er's Sav. Bk. v. Katterjohn (1910), Bk. (1910), 81 Ohio St. 348. 55 Ohio 137 Ky. 427, 125 S. W. 1071.

Law Bull. 20.

Louisiana.-J. I. Case Threshing Pennsylvania.-Harvey v. Dimon Machine Co. v. Bridger (1913), 133 Ia. 754,63 So. 319 .

Missouri. - Houston v. Day (1909), 145 Mo. App. 410.

New York.-Pavestedt v. N. Y. Life Ins. Co. (1911), 203 N. Y. 91; Van Orden v. Simpson (1915), 153 N. Y. Supp. 134. (1908), $36 \mathrm{~Pa}$. Super. Ct. 82.

Oregon.- First Nat. Bk. of Cottage Grove v. Bk. of Cottage Grove (1911), 59 Oreg. 388, 117 Pac. 293.

United States.- Nichols v. Waukesha Canning Co. (1912), 195 Fed. 807.

Section 197. All acts and parts of acts inconsistent with this act are hereby repealed.

Tennessee-Dobbin v. Carroll (1917), 192 S. W. 166.

Section 198. This (act) shall take effect on 



\section{UNIFORM SALES ACT}





\section{UNIFORM SALES ACT}

At the instance of the National Conference of Commissioners on Uniform State Laws, an original draft of an "Act to make Uniform the Law of Sales" was prepared by Mr. Samuel Williston in 1902 and 1903. It was printed in the summer of 1903 and distributed with a request for criticism to teachers of the law of sales, writers and other experts on the subject. In the light of the criticisms that were received a revised draft was presented to the Commissioners in the summer of 1904 and was considered section by section at the National Conference of that year. At the Conference held in the summer of 1906 the draft was finally adopted by the Conference and recommended for passage. During the following winter it was enacted in Arizona, New Jersey and Connecticut and a year later in Massachusetts, Rhode Island and Ohio. A number of other states have since adopted it, so that now there are altogether nineteen jurisdictions in which the Uniform Sales Act is in force. These are: Arizona, 1913; Connecticut, 1907; Illinois, 1915; Maryland, 1910; Massachusetts, 1908; Michigan, 1913 ; Minnesota, 1917; Nevada, 1915; New Jersey, 1907; New York, 1911; North Dakota, 1917; Ohio, 1908; Pennsylvania, 1915; Rhode Island, 1908; Utah, 1917; Wisconsin, 1911; Wyoming, 1917; Alaska, 1913 ; Tennessee, 1919. 


\begin{tabular}{|c|c|c|c|c|c|c|c|c|c|c|}
\hline & $\begin{array}{l}\text { Law } \\
1913 \text {, } \\
\text { ch. } 66 .\end{array}$ & $\begin{array}{l}\text { Rev. } \\
1913 \text {. } \\
\text { tit. Li. }\end{array}$ & $\begin{array}{l}\text { Rev. } \\
1908 .\end{array}$ & $\begin{array}{l}\text { Laws } \\
1915 .\end{array}$ & $\begin{array}{l}\text { Laws } \\
1910 . \\
\text { art. } \\
\text { Ixxuii. }\end{array}$ & $\begin{array}{c}\text { Law8 } \\
1908 \text {, } \\
\text { ch. } 237 .\end{array}$ & $\begin{array}{c}\text { Acts } \\
1913 \\
\text { No. } 100 .\end{array}$ & $\begin{array}{c}\text { Law8 } \\
1917 . \\
\text { ch. } 466 .\end{array}$ & $\begin{array}{l}\text { Laws } \\
1915 .\end{array}$ & $\begin{array}{c}\text { Comp. } \\
\text { Stat. } \\
1910 .\end{array}$ \\
\hline $\begin{array}{l}\text { Oniform } \\
\text { Act } \\
\text { Bec. Na }\end{array}$ & $\begin{array}{l}1913 \\
\text { Alacta }\end{array}$ & $\begin{array}{l}1913 \\
\text { Ariz }\end{array}$ & $\begin{array}{c}1907 \\
\text { Cono. }\end{array}$ & $\begin{array}{l}1915 \\
\text { Illinois }\end{array}$ & $\begin{array}{l}1910 \\
\text { Md. }\end{array}$ & $\begin{array}{c}1908 \\
\text { Mass. } \\
.\end{array}$ & $\begin{array}{l}1913 \\
\text { Mich. }\end{array}$ & $\begin{array}{r}1917 \\
\text { Minn. }\end{array}$ & $\begin{array}{l}1915 \\
\text { Nev. }\end{array}$ & $\begin{array}{l}190 ? \\
\text { N. J. }\end{array}$ \\
\hline $\begin{array}{l}1 \\
2 \\
3 \\
1 \\
5 \\
6 \\
7 \\
8 \\
1 \\
10 \\
11 \\
12 \\
13 \\
14 \\
15 \\
16 \\
17 \\
18 \\
19 \\
20 \\
21 \\
22 \\
23 \\
24 \\
25 \\
28 \\
27 \\
28 \\
29 \\
30 \\
81 \\
32 \\
33 \\
34 \\
35 \\
86 \\
37 \\
38 \\
39 \\
40 \\
41 \\
42 \\
43 \\
44 \\
45 \\
46 \\
47 \\
48 \\
49 \\
50 \\
51 \\
52 \\
53 \\
54 \\
65 \\
66 \\
57 \\
58 \\
59 \\
60 \\
61 \\
62 \\
63 \\
64 \\
65 \\
86\end{array}$ & $\begin{array}{l}1 \\
2 \\
3 \\
4 \\
5 \\
6 \\
7 \\
8 \\
9 \\
10 \\
11 \\
12 \\
13 \\
14 \\
15 \\
16 \\
17 \\
18 \\
19 \\
20 \\
21 \\
22 \\
23 \\
24 \\
25 \\
26 \\
27 \\
28 \\
29 \\
30 \\
31 \\
32 \\
33 \\
34 \\
35 \\
36 \\
37 \\
38 \\
39 \\
40 \\
11 \\
42 \\
43 \\
44 \\
45 \\
46 \\
47 \\
48 \\
49 \\
50 \\
51 \\
52 \\
53 \\
54 \\
55 \\
56 \\
57 \\
58 \\
59 \\
60 \\
61 \\
62 \\
63 \\
64 \\
65 \\
66\end{array}$ & 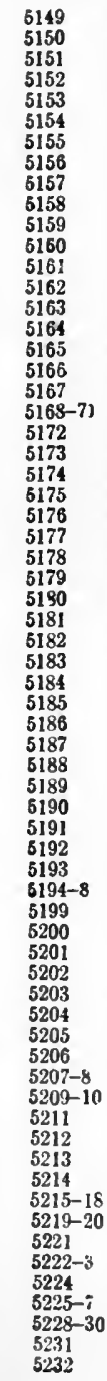 & $\begin{array}{l}4668 \\
4669 \\
4670 \\
4671 \\
4672 \\
4673 \\
4674 \\
4675 \\
4676 \\
4677 \\
4678 \\
4679 \\
4680 \\
4681 \\
4682 \\
4683 \\
4684 \\
4685 \\
4686 \\
4687 \\
4688 \\
4689 \\
4690 \\
4691 \\
4692 \\
4693 \\
4694 \\
4695 \\
4696 \\
4697 \\
4698 \\
4699 \\
4700 \\
4701 \\
4702 \\
4703 \\
4704 \\
4705 \\
4706 \\
4707 \\
4708 \\
4709 \\
4710 \\
47731 \\
4732\end{array}$ & 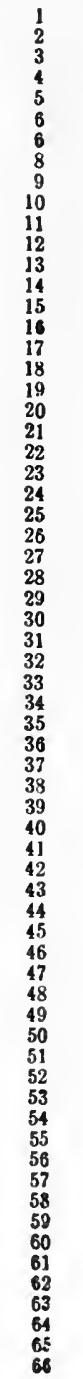 & $\begin{array}{l}19 \\
19 \\
20 \\
21 \\
22 \\
23 \\
24 \\
24 \\
25 \\
26 \\
27 \\
28 \\
29 \\
30 \\
31 \\
32 \\
33 \\
34 \\
35 \\
36 \\
37 \\
38 \\
39 \\
40 \\
41 \\
42 \\
43 \\
44 \\
45 \\
46 \\
47 \\
48 \\
49 \\
50 \\
51 \\
51 \\
52\end{array}$ & 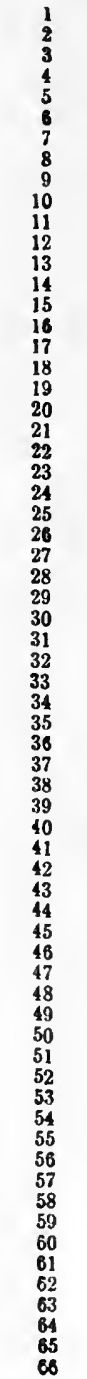 & 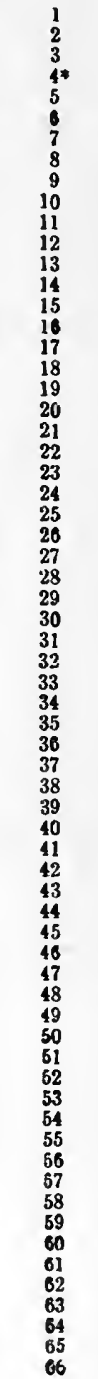 & 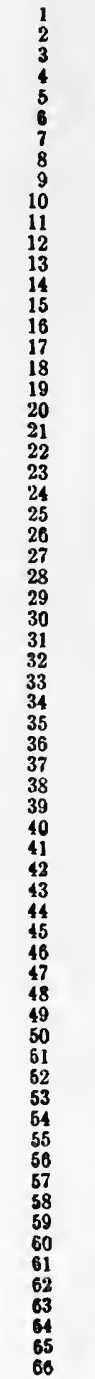 & 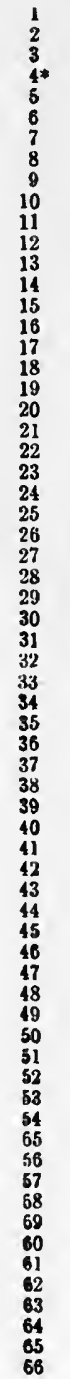 & 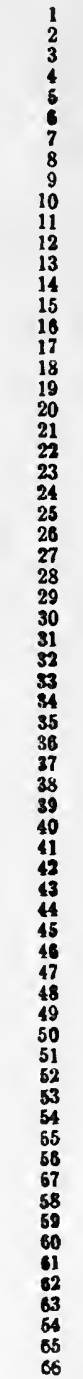 \\
\hline
\end{tabular}


UNIFORM SALES AOT.

\begin{tabular}{|c|c|c|c|c|c|c|c|c|c|c|}
\hline & $\begin{array}{l}\text { Lams } \\
1913, \\
\text { ch, } 66 .\end{array}$ & $\begin{array}{l}\text { Rov. } \\
\text { 1913. } \\
\text { tit LI }\end{array}$ & $\begin{array}{l}\text { Rev. } \\
1908 .\end{array}$ & $\frac{\text { Lams }}{1915 .}$ & $\begin{array}{l}\text { Larn: } \\
1910, \\
\text { art. } \\
\text { bexiii. }\end{array}$ & $\begin{array}{l}\text { Lows } \\
1908, \\
\text { ch.237. }\end{array}$ & $\begin{array}{c}\text { Aets } \\
1913, \\
\text { Na } 100 .\end{array}$ & $\begin{array}{c}\text { Laws } \\
1917 . \\
\mathrm{ch} 466 .\end{array}$ & $\begin{array}{l}\text { Lams } \\
1915 .\end{array}$ & $\begin{array}{c}\text { Comp. } \\
\text { Stat. } \\
1910 .\end{array}$ \\
\hline $\begin{array}{l}\text { Unifiorm } \\
\text { Act } \\
\text { Sec. Na. }\end{array}$ & $\begin{array}{c}1913 \\
\text { Alnata }\end{array}$ & $\begin{array}{l}1913 \\
\text { Arix. }\end{array}$ & $\begin{array}{l}1907 \\
\text { Conn. }\end{array}$ & $\begin{array}{l}1915 \\
\text { Ulinais }\end{array}$ & $\begin{array}{l}1910 \\
\text { Md. }\end{array}$ & $\begin{array}{l}1908 \\
\text { Mass. }\end{array}$ & $\begin{array}{l}1913 \\
\text { Mieh. }\end{array}$ & $\begin{array}{r}1917 \\
\text { Minn. }\end{array}$ & $\begin{array}{l}1915 \\
\text { Nev. }\end{array}$ & $\begin{array}{l}1907 \\
\text { N.J. }\end{array}$ \\
\hline $\begin{array}{l}67 \\
68 \\
69 \\
70 \\
71 \\
72 \\
73 \\
74 \\
75 \\
76 \\
76 a \\
76 b \\
77 \\
78 \\
70 \\
\end{array}$ & $\begin{array}{l}67 \\
68 \\
69 \\
70 \\
71 \\
72 \\
73 \\
71 \\
75 \\
76 \\
765 \\
76 b \\
77 \\
78 \\
79 \\
\end{array}$ & $\begin{array}{l}5233 \\
5234 \\
5235-40 \\
5241 \\
5242 \\
5243 \\
5244 \\
5245 \\
5246 \\
5247 \\
\ldots \ldots \\
\ldots \ldots \\
\ldots \ldots \\
\ldots \ldots \\
018\end{array}$ & $\begin{array}{l}4733 \\
4734 \\
4735 \\
4736 \\
4737 \\
4738 \\
4739 \\
4740 \\
4711 \\
4742 \\
\ldots \ldots \\
\ldots \ldots \\
\ldots \ldots \\
4743 \\
\end{array}$ & $\begin{array}{l}67 \\
68 \\
69 \\
70 \\
71 \\
72 \\
73 \\
71 \\
75 \\
76 \\
\cdots \\
\ddot{78} \\
\ddot{77}\end{array}$ & $\begin{array}{l}85 \\
86 \\
87 \\
88 \\
89 \\
90 \\
91 \\
92 \\
93 \\
94 \\
25 \\
96 \\
97 \\
97\end{array}$ & \begin{tabular}{l}
67 \\
68 \\
69 \\
70 \\
71 \\
72 \\
73 \\
74 \\
75 \\
76 \\
$\ldots$ \\
\hdashline 8 \\
79 \\
77 \\
\end{tabular} & $\begin{array}{l}67 \\
68 \\
69 \\
70 \\
71 \\
72 \\
73 \\
74 \\
75 \\
76 \\
76 a \\
76 b \\
77 \\
7 \dot{8} \\
\end{array}$ & $\begin{array}{l}67 \\
68 \\
69 \\
70 \\
71 \\
73 \\
73 \\
74 \\
75 \\
76 \\
76 a \\
76 b \\
77 \\
78 \\
79 \\
\end{array}$ & $\begin{array}{l}67 \\
68 \\
69 \\
70 \\
71 \\
72 \\
73 \\
74 \\
75 \\
76 \\
76 a \\
76 b \\
77 \\
78 \\
79\end{array}$ & $\begin{array}{l}67 \\
68 \\
69 \\
70 \\
71 \\
72 \\
73 \\
74 \\
85 \\
76 \\
\ldots \\
\ldots \\
\ldots \\
\ldots \\
\end{array}$ \\
\hline
\end{tabular}




\begin{tabular}{|c|c|c|c|c|c|c|c|c|c|}
\hline & $\begin{array}{c}\text { Personal } \\
\text { Prop. } \\
\text { Law. }\end{array}$ & $\begin{array}{c}\text { Ch. 202, } \\
1917 .\end{array}$ & $\begin{array}{l}\text { Laws } \\
1908 .\end{array}$ & $\begin{array}{l}\text { Rev. } \\
1915 .\end{array}$ & $\begin{array}{l}\text { Rev. } \\
1909 .\end{array}$ & $\begin{array}{l}\text { Laws } \\
1919 .\end{array}$ & $\begin{array}{c}\text { Comp. } \\
1917 .\end{array}$ & $\begin{array}{l}\text { Rev. } \\
1915 .\end{array}$ & $\begin{array}{l}\text { Laws } \\
1917 .\end{array}$ \\
\hline $\begin{array}{l}\text { Uniform } \\
\text { Act } \\
\text { Sec. No. }\end{array}$ & $\begin{array}{l}1911 \\
\text { N. Y. }\end{array}$ & $\begin{array}{c}1917 \\
\text { N. D. }\end{array}$ & $\begin{array}{l}1908 \\
\text { Ohio }\end{array}$ & $\begin{array}{c}1915 \\
\mathrm{~Pa}_{\mathrm{a}}\end{array}$ & $\begin{array}{l}1908 \\
\text { R. } 1 \text {. }\end{array}$ & $\begin{array}{l}1919 \\
\text { Tenn. }\end{array}$ & $\begin{array}{l}1917 \\
\text { Utab }\end{array}$ & $\begin{array}{l}1911 \\
\text { Wis. }\end{array}$ & $\begin{array}{l}1917 \\
\text { Wyo. }\end{array}$ \\
\hline $\begin{array}{r}1 \\
2 \\
3 \\
4 \\
5 \\
6 \\
7 \\
8 \\
9 \\
10 \\
11 \\
12 \\
13 \\
14 \\
15 \\
16 \\
17 \\
18 \\
19 \\
20 \\
21 \\
22 \\
23 \\
24 \\
25 \\
26 \\
27 \\
28 \\
29 \\
30 \\
31 \\
32 \\
33 \\
34 \\
35 \\
36 \\
37 \\
38 \\
39 \\
40 \\
41 \\
42 \\
43 \\
44 \\
45 \\
46 \\
47 \\
48 \\
49 \\
50 \\
51 \\
52 \\
53 \\
54 \\
55 \\
56 \\
57 \\
58 \\
59 \\
60 \\
61 \\
62 \\
63 \\
64 \\
65 \\
66 \\
37\end{array}$ & $\begin{array}{c}82 \\
83 \\
84 \\
85 * \\
86 \\
87 \\
88 \\
89 \\
90 \\
91 \\
92 \\
93 \\
94 \\
95 \\
96 \\
97 \\
98 \\
99 \\
100 \\
101 \\
102 \\
103 \\
104 \\
105 \\
106 \\
107 \\
108 \\
109 \\
110 \\
111 \\
112 \\
113 \\
114 \\
115 \\
116 \\
117 \\
118 \\
119 \\
120 \\
121 \\
122 \\
123 \\
124 \\
125 \\
126 \\
127 \\
128 \\
129 \\
130 \\
131 \\
132 \\
133 \\
134 \\
135 \\
136 \\
137 \\
138 \\
139 \\
140 \\
141 \\
142 \\
143 \\
144 \\
145 \\
146 \\
147 \\
148\end{array}$ & 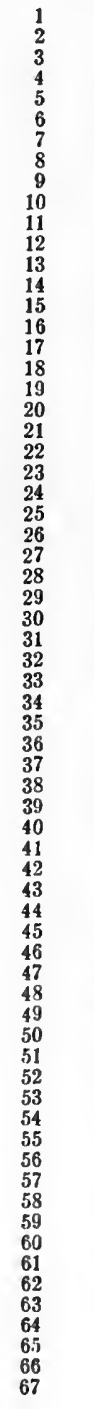 & $\begin{array}{r}1 \\
2 \\
3 \\
4 \\
5 \\
6 \\
7 \\
8 \\
9 \\
10 \\
11 \\
12 \\
13 \\
14 \\
15 \\
16 \\
17 \\
18 \\
19 \\
20 \\
21 \\
22 \\
23 \\
24 \\
25 \\
26 \\
27 \\
28 \\
29 \\
30 \\
31 \\
32 \\
33 \\
34 \\
35 \\
36 \\
37 \\
38 \\
39 \\
40 \\
41 \\
42 \\
43 \\
44 \\
45 \\
46 \\
47 \\
48 \\
49 \\
50 \\
51 \\
52 \\
53 \\
54 \\
55 \\
56 \\
57 \\
58 \\
59 \\
60 \\
61 \\
62 \\
63 \\
64 \\
65 \\
63 \\
67\end{array}$ & 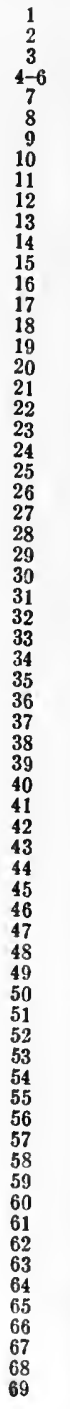 & $\begin{array}{l}261-1 \\
261-2 \\
261-3 \\
261-4 \\
261-5 \\
261-6 \\
261-7 \\
261-8 \\
261-9 \\
261-10 \\
261-11 \\
261-12 \\
261-13 \\
261-14 \\
261-15 \\
261-16 \\
262-1 \\
262-2 \\
262-3 \\
262-4 \\
262-5 \\
262-6 \\
262-7 \\
262-8 \\
262-9 \\
262-10 \\
262-11 \\
262-12 \\
262-13 \\
262-14 \\
262-15 \\
262-16 \\
262-17 \\
262-18 \\
262-19 \\
262-20 \\
262-21 \\
262-22 \\
262-23 \\
262-24 \\
263-1 \\
263-2 \\
263-3 \\
263-4 \\
263-5 \\
263-6 \\
263-7 \\
263-8 \\
263-9 \\
263-10 \\
263-11 \\
264-1 \\
264-2 \\
264-3 \\
264-4 \\
264-5 \\
264-6 \\
264-7 \\
264-8 \\
264-9 \\
264-10 \\
264-11 \\
265-1 \\
265-2 \\
265-3 \\
265-4 \\
265-5 \\
26\end{array}$ & & $\begin{array}{l}5110 \\
5111 \\
3112 \\
5113 \\
5114 \\
5115 \\
5116 \\
5117 \\
5118 \\
5119 \\
5120 \\
5121 \\
5122 \\
5123 \\
5124 \\
5125 \\
5126 \\
5127 \\
5128 \\
5129 \\
5130 \\
5131 \\
5122 \\
5133 \\
5134 \\
5135 \\
5136 \\
5137 \\
5138 \\
5139 \\
5140 \\
5141 \\
5142 \\
5143 \\
5144 \\
5145 \\
5146 \\
5147 \\
5148 \\
5149 \\
5150 \\
5151 \\
\mathbf{5 1 5 2} \\
\mathbf{5 1 5 3} \\
5154 \\
5155 \\
\mathbf{5 1 5 6} \\
\mathbf{5 1 5 7} \\
\mathbf{5 1 5 8} \\
5159 \\
5160 \\
5161 \\
\mathbf{5 1 6 2} \\
\mathbf{5 1 6 3} \\
\mathbf{5 1 6 4} \\
\mathbf{5 1 6 5} \\
\mathbf{5 1 6 6} \\
\mathbf{5 1 6 7} \\
\mathbf{5 1 6 8} \\
\mathbf{5 1 6 9} \\
\mathbf{5 1 7 0} \\
\mathbf{5 1 7 1} \\
\mathbf{5 1 7 2} \\
5173 \\
5174 \\
5175 \\
5176\end{array}$ & $\begin{array}{l}1684+1 \\
1684+2 \\
1684+3 \\
1684+4 * \\
1684+5 \\
1684+6 \\
1684+7 \\
1684+8 \\
1684+9 \\
1684+10 \\
1684+11 \\
1684+12- \\
1684+13 \\
1684+14 \\
1684+15 \\
1684+16 \\
1684+17 \\
1684+18 \\
1684+19 \\
1684+20 \\
1684+21 \\
1684+22 \\
1684+23 \\
1684+24 \\
1684+25 \\
1684+26 \\
1684+27 \\
1684+28 \\
1684+29 \\
1684+30 \\
1684+31 \\
1684+32 \\
1684+33 \\
1684+34 \\
1684+35 \\
1684+36 \\
1684+37 \\
1684+38 \\
1684+39 \\
1684+40 \\
1684+41 \\
1684+42 \\
1684+43 \\
1684+14 \\
1684+45 \\
1684+46 \\
1684+47 \\
1684+48 \\
1684+49 \\
1684+50 \\
1684+51 \\
1684+52 \\
1684+53 \\
1684+54 \\
1684+55 \\
1684+56 \\
1684+57 \\
1684+58 \\
1684+59 \\
1684+60 \\
1684+61 \\
1684+62 \\
1684+63 \\
1684+64 \\
1684+65 \\
1684+66 \\
1684+67\end{array}$ & $\begin{array}{r}1 \\
2 \\
3 \\
4 \\
5 \\
6 \\
7 \\
8 \\
9 \\
10 \\
11 \\
12 \\
13 \\
14 \\
15 \\
16 \\
17 \\
18 \\
19 \\
20 \\
21 \\
22 \\
23 \\
24 \\
25 \\
26 \\
27 \\
28 \\
29 \\
30 \\
31 \\
32 \\
33 \\
34 \\
35 \\
36 \\
37 \\
38 \\
39 \\
40 \\
41 \\
42 \\
43 \\
44 \\
45 \\
46 \\
47 \\
48 \\
49 \\
50 \\
51 \\
52 \\
53 \\
54 \\
55 \\
56 \\
57 \\
58 \\
59 \\
60 \\
61 \\
62 \\
63 \\
64 \\
65 \\
66 \\
67\end{array}$ \\
\hline
\end{tabular}




\begin{tabular}{|c|c|c|c|c|c|c|c|c|c|}
\hline & $\begin{array}{c}\text { Personal } \\
\text { Prop. } \\
\text { Law. }\end{array}$ & Cb. 202. & $\begin{array}{l}\text { Laws } \\
\text { 1908. }\end{array}$ & $\begin{array}{l}\text { Rev. } \\
1915 .\end{array}$ & $\begin{array}{l}\text { Rev. } \\
1909 .\end{array}$ & $\begin{array}{l}\text { Lawi } \\
1919 .\end{array}$ & $\begin{array}{l}\text { Comp. } \\
1917 .\end{array}$ & $\begin{array}{l}\text { Rev. } \\
1915 .\end{array}$ & $\begin{array}{l}\text { Laska } \\
1917 .\end{array}$ \\
\hline $\begin{array}{l}\text { Uniform } \\
\text { Act } \\
\text { Sec. No. }\end{array}$ & $\begin{array}{l}1911 \\
\text { N. Y. }\end{array}$ & $\begin{array}{l}1917 \\
\text { N. D. }\end{array}$ & $\begin{array}{l}1908 \\
\text { Obio }\end{array}$ & $\begin{array}{l}1915 \\
\mathrm{Pz}^{2} .\end{array}$ & $\begin{array}{l}1908 \\
\text { R. I. }\end{array}$ & $\begin{array}{l}1919 \\
\text { Tepn. }\end{array}$ & $\begin{array}{l}1917 \\
\text { Utab }\end{array}$ & $\begin{array}{l}1911 \\
\text { Wis. }\end{array}$ & $\begin{array}{l}1917 \\
\text { Wyo. }\end{array}$ \\
\hline $\begin{array}{l}68 \\
69 \\
70 \\
71 \\
72 \\
73 \\
74 \\
75 \\
76 \\
76 \mathrm{a} \\
76 \mathrm{~b} \\
77 \\
78 \\
79\end{array}$ & $\begin{array}{l}149 \\
150 \\
151 \\
152 \\
153 \\
154 \\
755 \\
155 \\
156 \\
157 \\
158 \\
159 \\
160\end{array}$ & $\begin{array}{l}68 \\
69 \\
70 \\
71 \\
72 \\
73 \\
74 \\
75 \\
76 \\
76 \mathrm{a} \\
76 \mathrm{~b} \\
\because \\
\because \\
\because\end{array}$ & $\begin{array}{l}68 \\
69 \\
70 \\
71 \\
72 \\
73 \\
74 \\
75 \\
76 \\
. \\
\because \\
77 \\
. .\end{array}$ & $\begin{array}{l}70 \\
71 \\
72 \\
73 \\
74 \\
75 \\
76 \\
77 \\
78 \\
81 \\
80 \\
79 \\
81 \\
82\end{array}$ & $\begin{array}{c}265-6 \\
265-7 \\
265-8 \\
266-1 \\
266-2 \\
266-3 \\
266-1 \\
266-5 \\
266-6 \\
\ldots \ldots \\
\ldots \ldots \\
\ldots \ldots . \\
\ldots \ldots . \\
\ldots \ldots\end{array}$ & & $\begin{array}{l}6177 \\
5178 \\
5179 \\
6180 \\
5181 \\
5182 \\
5183 \\
5184 \\
5185 \\
5186 \\
5187 \\
5188\end{array}$ & $\begin{array}{c}1684+68 \\
1684+69 \\
1684+70 \\
1684+71 \\
1684+72 \\
1684+73 \\
1684+74 \\
1634+75 \\
1684+76 \\
1684+77 \\
1684+78 \\
. . \\
1684779\end{array}$ & $\begin{array}{l}68 \\
69 \\
70 \\
71 \\
72 \\
73 \\
74 \\
75 \\
76 \\
763 \\
76 \mathrm{~b} \\
77 \\
78 \\
79\end{array}$ \\
\hline
\end{tabular}




\section{UNIFORM SALES ACT}

Sxcrion 1. Contracts to Sell and Sales.

2. Capacity - Liabilities for Necessaries.

3. Form of Contract or Sale.

4. Statute of Frauds.

5. Existing and Future Goods.

6. Undivided Shares.

7. Destruction of Goods Sold.

8. Destruction of Goods Contracted to be Sold.

9. Definition and Ascertainment of Price.

10. Sale at a Valuation.

11. Effect of Conditions.

12. Definition of Express Warranty.

13. Implied Warranties of Title.

14. Implied Warranty in Sale by Description.

15. Implied Warranties of Quality.

16. Implied Warranties in Sale by Sample.

17. No Property Passes Until Goods are Ascertained.

18. Property in Specific Goods Passes When Parties so Intend.

19. Rules for Ascertaining Intention.

20. Reservation of Right of Possession or Property When Goods: are Shipped.

21. Sale by Auction.

22. Risk of Loss.

23. Sale by a Person Not the Owner.

24. Sale by One Having a Voidable Title.

25. Sale by Seller in Possession of Goods Already Sold.

26. Creditors' Rights Against Sold Goods in Seller's Possession.

27. Definition of Negotiable Documents of Title.

28. Negotiation of Negotiable Documents by Delivery.

29. Negotiation of Negotiable Documents by Indorsement.

30. Negotiable Documents of Title Marked "Not Negotiable."

31. Transfer of Non-Negotiable Documents.

32. Who May Negotiate a Document.

33. Rights of Person to Whom Document Has Been Negotiated.

34. Rights of Person to Whom Document Has Been Transferred.

35. Transfer of Negotiable Document Without Indorsement.

36. Warranties on Sale of Document.

37. Indorser Not a Guarantor.

38. When Negotiation Not Impaired by Fraud, Mistake or Dares. 
Secrion 39. Attachment or Levy Upon Goods for Which a Negotiable Document Has Been Issued.

40. Creditors' Remedies to Reach Negotiable Documents.

41. Seller Must Deliver and Buyer Aecept Goods.

42. Delivery and Payment are Concurrent Conditions.

43. Place. Time and Manner of Delivery.

44. Delivery of Wrong Quantity.

45. Delivery in Instalments.

46. Delivery to a Carrier on Behalf of the Buyer.

47. Right to Examine the Goods.

48. What Constitutes Acceptance.

49. Acceptance Does Not Bar Aetion for Damages.

50. Buyer is Not Bound to Return Goods Wrongly Delivered.

51. Buyer's Liability for Failing to Accept Delivery.

52. Definition of Unpaid Seller.

53. Remedies of an Unpaid Seller.

54. When Right of Lien May be Exercised.

55. Lien After Part Delivery.

56. When Lien is Lost.

57. Seller May Stop Goods on Buyer's Insolvency.

58. When Goods are in Transit.

59. Ways of Exercising the Right to Stop.

60. When and How Resale May be Made.

61. When and How the Seller May Rescind the Sale.

62. Effect of Sale of Goods Subject to Lien or Stoppage in Transitu.

63. Action for the Price.

64. Action for Damages for Non-Acceptance of the Goods.

65. When Seller May Reseind Contract or Sale.

66. Action for Conyerting or Detaining Goods.

67. Action for Failing to Deliver Goods.

68. Specific Performance.

69. Remedies for Breach of Warranty.

70. Interest and Special Damages.

71. Variation of Implied Obligations.

72. Rights May be Enforced by Action.

73. Rule for Cases Not Provided for by This Act.

74. Interpretation Shall Give Effect to Purpose of Uniformity.

75. Provisions Not Applicable to Mortgages.

76. Definitions.

76a. Act Does Not Apply to Existing Sales or Contracts to Sell.

76b. No Repeal of Uniform Warehouse Receipt Act or Uniform Bills of Lading Act.

77. Inconsistent Legislation Repealed.

78. Tine When the Act Takes Effect.

79. Name of Act. 


\section{UNIFORM SALES ACT}

\section{PART I.}

FORMATION OF THE CONTRACT.

Section 1.-(Contracts to Sell and Sales.) - (1) A contract to sell goods is a contract whereby the seller agrees to transfer the property in goods to the buyer for a consideration called the price.

(2) A sale of goods is an agreement whereby the seller transfers the property in goods to the buyer for a consideration called the price.

(3) A contract to sell or a sale may be absolute or conditional.

(4) There may be a contract to sell or a sale between one part owner and another.

Connecticut.-State v. Mad River Co. (1917), 101 Atl. 496; Harlow v. Parsons Lumber \& Hardware Co. (1909), 81 Conn. 572, 71 Atl. 734; Merrill v. Hodson (1914), 91 Atl. 533.

nlinois.-Staackman, Horschitz \& Co. v. Cary (1916), 199 Ill. App. 601; The Slaymaker Lock Mfg. Corp. v. Olmsted (1916), 197 Ill. App. 496.

Maryland.- McGaw v. Hanway (1913), 120 Md. 197, 87 Atl. 666; Dinsmore v. Maag-Wahmann (1914), 122 Md. 177, 89 Atl. 399.

Massachusetts.-Arnold v. North American Chemical Co. (1919), 122 N. E. 283.

Michigan.- South Branch Cheese Co. v. American Butter \& Cheese Co. (1916), 158 N. W. 158; Decker v. Pierece (1916), 157 N. W. 384; Denton v. Booth (1918), 168 N. W. 491.

Minuesota. - International Harvester Co. of America v. Swenson (1917), 160 Pac. 255.

New York.-Penser v. Marsh (1916), 218 N. Y. 505, 113 N. E. 494; Hoyman v. Canton Art Metal Co. (1916), 160 N. Y. Supp. 42; Hall v. French Am. Wine Co. (1912), 149 App. Div. 609, 134 N. Y. Supp. 158; Shearer Co. v. Kakoulis (1913), 144 N. Y. Supp. 1077; In re Grand Union Co. (1914), 219 Fed. Rep. 353; Ballard v. Friedberg (1917), 164 N. Y. Supp. 912; Graves v. Warren (1917), 164 N. Y. Supp. 925; E. Eising \& Co. v. American Alcohol Co. (1918), 168 N. Y. Supp. 682 ; Raisler Heating Co. v. Clinton 
Wire Cloth Co. (1918), 168 N. Y. Supp. 668; Langenthal v. Oberman (1918), 171 N. Y. Supp. 144; American Aniline Products v. D. Nagase Co. (1919), 176 N. Y. Supp. 114.
Rhode Island.-Manes Co. v. Glass (1918), 102 Atl. 964.

United States.-American Drug. gists Syndicate v. Continental Sp. Co. (1918), 249 Fed. 290.

Section 2.-(Capacity-Liabilities for Necessaries.)-Capacity to buy and sell is regulated by the general law concerning capacity to contract, and to transfer and acquire property.

Where necessaries are sold and delivered to an infant, or to a person who by reason of mental incapacity or drunkenness is incompetent to contract, he must pay a reasonable price therefor.

Necessaries in this section mean goods suitable to the condition in life of such infant or other person, and to his actual requirements at the time of delivery.

Massachusetts.- Arnold v. North American Chemical Co. (1919), 122 N. E. 283.

Michigan. - Denton v. Booth (1918), 168 N. W. 491; Decker v. Pierce (1916), 157 N. W. 384 ; Rey- nolds v. Garber-Buick Co. (1914), 183 Mich. 157.

New York.-Graves v. Warren (1917), 164 N. Y. Supp. 925; Ballard v. Freidberg (1917), 164 N. Y. Supp. 912.

\section{FORMALITIES OF THE CONTRACT.}

Section 3.-(Form of Contract or Sale.)-Subject to the provisions of this act and of any statute in that behalf, a contract to sell or a sale may be made in writing (either with or withont seal), or by word of mouth, or partly in writing and partly by word of mouth, or may be inferred from the conduct of the parties.

Massachusetts. - Kehlor Flour Mill Co. v. Linden \& Lindstroem (1918), 230 Mass. 119, 119 N. E. 698.

Minnesota.- Moorhead v. Minneapolis Seed Co. (1917), 165 N. W. 484.
Mississippi.-Crenshaw Bros. Seed Co. v. Rauch (1916) (Miss.), 73 So. 53.

New Jersey.-Carnegie Steel Co. v. Connelly (1916) (N. J.), 97 Atl. 74.

Section 4.-(Statute of Frauds.)-(1) A contract to sell or a sale of any goods or choses in action of the value of five hun- 
dred dollars or upwards shall not be enforceable by action unless the buyer shall accept part of the goods or choses in action so contracted to be sold, and actually receive the same, or give something in earnest to bind the contract, or in part payment, or unless some note or memorandum in writing of the contract or sale be signed by the party to be charged or his agent in that behalf.

(2) The provisions of this section apply to every such contract or sale, notwithstanding that the goods may be intended to be delivered at some future time or may not at the time of such contract or sale be actually made, procured, or provided, or fit or ready for delivery, or some act may be requisite for the making or completing thereof, or rendering the same fit for delivery; but if the goods are to be manufactured by the seller especially for the buyer and are not suitable for sale to others in the ordinary course of the seller's business, the provisions of this section shall not apply.

(3) There is an acceptance of goods within the meaning of this section when the buyer, either before or after delivery of the goods, expresses by words or conduct his assent to becoming the owner of those specific goods.

Connecticut.-Wetopsky v. New Haven Gas Light Co. (1914), 88 Conn. 1, 90 Atl. 30; Barrett Mfg. Co. v. Ambrosio (1916), 96 Atl. 930; De Nunzio v. De Nunzio (1916), 97 Atl. 323.

Minnesota.- Moorland v. Minneapolis Seed Co. (1917), 165 N. W.

Maryland. - Brazer v. Levy (1914), 122 Md. 558, 90 Atl. 102; Willard v. Higdon (1914), 123 Md. 451, 91 Atl. 577; Castle v. Swift \& Co. (1918), 104 Atl. 187; Stenn v. Crawford (1919), 105 Atl. 780.

Massachusetts.-Peck v. Abbott \& Fernald Co. (1916), 111 N. E. 890 ; Brown v. Fredk. J. Quiney Co. (1910), 204 Mass, 206; Armstrong v. Orler (1915), 220 Mass. 112.

Michigan. - Meyer v. Shapton
(1914), 178 Mich. 417, 144 N. W. 887.

New Jersey.-Eigen v. Rosolin (1914), 85 N. J. L. 515, 89 Atl. 923; McAusland v. Rieser (1914), 90 Atl. 261.

New York.-Moskowitz v. White Bros. (1917), 166 N. Y. Supp. 15; Eagle Paper Box Co. v. Gatti McQuade Co. (1917), 164 N. Y. Supp. 201; Sehneider v. Lezinsky (1916), 163 N. Y. Supp. 769; Harrison v. Scott (1911), 203 N. Y. 369, 96 N. E. 755 ; Morse v. Canaswacta Knitting Co. (1912), 154 App. Div. 351, 139 N. Y. Supp. 634; Skinner v. Watson (1913), 159 A. D. 359; Poel v. Brunswick-Balke-Collender Co. (1913), 159 App. Div. 365, 144 N. Y. Supp. 725; Spiegel v. Lowen- 
stein (1914), 162 App. Div. 443, 147 N. Y. Supp. 655; Langstroth v. Turner Express Lumber Co. (1914), 162 App. Div. 818, 148 N. Y. Supp. 224; Richardson Press v. Vandergrift (1914), 165 App. Div. 180, 150 N. Y. Supp. 238; Goldowitz v. Hy Kupper \& Co. (1913), 141 N. Y. Supp. 531, 80 Misc. 478; Hager $\mathbf{~}$ Henneberger (1913), 145 N. Y. Supp. 152, 83 Misc. 417; Bauman v. Mendle-Lunepp Co. (1915), 153 N. Y. Supp. 896; A. Sidney Davison, Coal Co. v. Empire Brick \& Supply Co. (1918), 168 N. Y. Supp. 534; Blair \& Ralland v. Turner (1918), 168 N. Y. Supp. 660; Shongut v. Meyers (1918), 168 N.
Y. Supp. 2; Lipschitz v. W. R. Grace \& Co. (1918), 171 N. Y. Supp. 330; Zimmerman v. Gillman (1918), 172 N. Y. Supp. 263; Reisfeld v. Jacobs (1919), 176 N. Y. Supp. 223; New York M. Trading Co. v. Louis B. Prahar (1919), 176 N. Y. Supp. 179. Ohio.-Davis Laundry \& Cleaning Co. $\nabla$. Whitmore (1915), $110 \mathrm{~N}$. E. 518.

Rhode Island.- Namquit Worsted Co. v. Shitman (1915), 221 Fed. 49; Webster-Trapper Co. v. Esstern Hay Co. (1916), 98 Atl. 50.

Wisconsin.-Friedman v. Plous (1914), 158 Wisc. 438, 149 N. W. 218; Stack v. Roth Bras. Co. (1916), 153 N. W. 148.

\section{SUBJECT MATTER OF CONTRACT.}

Section 5.-(Existing and Future Goods.)-(1) The goods which form the subject of a contract to sell may be either existing goods, owned or possessed by the seller, or goods to be manufactured or acquired by the seller after the making of the contract to sell, in this act called "future goods."

(2) There may be a contract to sell goods, the acquisition of which by the seller depends upon a contingency which may or may not happen.

(3) Where the parties purport to effect a present sale of future goods, the agreement operates as a contract to sell the goods.

Michigan.-Dudley A. Tyng \& Co. v. Converse (1914), 180 Mich. 195, 146 N. W. 629.

New Jersey.- Leonard v. Pennypacker (1913), 85 N. J. L. 333.
New York-Proeter \& Gamble v. Peters, White \& Co. (1918), $176 \mathrm{~N}$. Y. Supp. 169.

Section 6.-(Undivided Shares.)-(1) There may be a contract to sell or a sale of an undivided share of goods. If the parties intend to effect a present sale, the bryer, by force of the agreement, becomes an owner in common with the owner or owners of the remaining shares. 
(2) In the case of fungible goods, there may be a sale of an undivided share of a specific mass, though the seller purports to sell and the buyer to buy a definite number, weight or measure of the goods in the mass, and though the number, weight or measure of the goods in the mass is undetermined. By such a sale the buyer becomes owner in common of such a share of the mass as the number, weight or measure bought bears to the number, weight or measure of the mass. If the mass contains less than the number, weight or measure bought, the buyer becomes the owner of the whole mass and the seller is bound to make good the deficiency from similar goods unless a contrary intent appears.

New York. - Gourd v. Healy (1912), 206 N. Y. Supp. 423, 99 N.

E. 1099.

Section 7.-(Destruction of Goods Sold.)-(1) Where the parties purport to sell specific goods, and the goods without the knowledge of the seller have wholly perished at the time when the agreement is made, the agreement is void.

(2) Where the parties purport to sell specific goods, and the goods without the knowledge of the seller have perished in part or have wholly or in a material part so deteriorated in quality as to be substantially changed in character, the buyer may at his option treat the sale:

(a) As avoided, or

(b) As transferring the property in all of the existing goods or in so much thereof as have not deteriorated, and as binding the bayer to pay the full agreed price if the sale was indivisible, or to pay the agreed price for the goods in which the property passes if the sale was divisible.

New York-J. A. Kirsch \& Co. v. Benyunes (1919), 105 Misc. Rep. 648174 N. Y. Supp. 794.

Section 8.-(Destruction of Goods Contracted to be Sold.) (1) Where there is a contract to sell specific goods, and subsequently, but before the risk passes to the buyer, without any 
fault on the part of the seller or the buyer, the goods wholly perish, the contract is thereby avoided.

( 2 Where there is a contract to sell specific goods, and subsequently, but before the risk passes to the buyer, without any fault of the seller or the buyer, part of the goods perish or the whole or a material part of the goods so deteriorate in quality as to be substantially changed in character, the buyer may at his option treat the contract:

(a) As avoided, or

(b) As binding the seller to transfer the property in all of the existing goods or in so much thereof as have not deteriorated, and as binding the buyer to pay the full agreed price if the contract was indivisible, or to pay the agreed price for so much of the goods as the seller, by the buyer's option, is bound to transfer if the contract was divisible.

New York.-J. A. Kirsch \& Co. v. Benyunes (1919), 105 Misc. Rep. 648, 174 N. Y. Supp. 794.

Massachusetts-Automatic Time
Table Adv. Co. v. Automatic Time Table Co. (1911), 208 Mass. 251, 94 N. E. 462; Carroll v. Haskins (1912); 212 Mass. 593, 99 N. E. 477.

\section{THE PRICE.}

Section 9.-(Definition and Ascertainment of Price.)(1) The price may be fixed by the contract, or may be left to be fixed in such manner as may be agreed, or it may be determined by the course of dealing between the parties.

(2) The price may be made payable in any personal property.

(3) Where transferring or promising to transfer any interest in real estate constitutes the whole or part of the consideration for transferring or for promising to transfer the property in goods, this act shall not apply.

(4) Where the price is not determined in accordance with the foregoing provisions the buyer must pay a reasonable price. What is a reasonable price is a question of fact dependent on the circumstances of each particular case.

Arizona.-Boyd v. Second Hand Supply Co. (1912), 14 Ariz. 39, 123 Pac. 619.
Massachusetts-Cobbs, Bates \& Yerxa Co. v. Hills (1911), 208 Mass. 270,94 N. E. 265. 
New York-Siegel v. Union Assur. Society (1915), 153 N. Y. Supp. 662 .
United States.-In re Pierce, Butler \& Pierce Mfg. Co. (191S) (U. S. C. C. A., N. Y.), 246 Fed. 814.

Section 10.-(Sale at a Valuation.) - (1) Where there is a contract to sell or a sale of goods at a price or on terms to be fixed by a third person, and such third person without fault of the seller or the buyer, cannot or does not fix the price or terms, the contract or the sale is thereby avoided; but if the goods or any part thereof have been delivered to and appropriated by the buyer he must pay a reasonable price therefor.

(2) Where such third person is prevented from fixing the price or terms by fault of the seller or the buyer, the party not in fault may have such remedies against the party in fault as are allowed by Parts IV and $V$ of this act.

\section{CONDITIONS AND WARRANTIES.}

Section 11.-(Effect of Conditions.) - (1) Where the obligation of either party to a contract to soll or a sale is subject to any condition which is not performed, such party may refuse to proceed with the contract or sale or he may waive performanee of the condition. If the other party has promised that the condition should happen or be performed, such first-mentioned party may also treat the non-performance of the condition as a breach of warranty.

(2) Where the property in the goods has not passed, the buyer may treat the fulfillment by the seller of his obligation to furnish goods as described and as warranted expressly or by implication in the contract to sell as a condition of the obligation of the buyer to perform his promise to accept and pay for the goods.

Illinois. - Bushnell v. Ohester (1917), 203 Ill. App. 229; Stauer Carriage Company v. Ricliardson (1917). 203 IIl. App. 620.

Massachusetts.-Federal Coal \& Coke Co. v. Coryell (1911), 111 N. E. 1041; Fechteler v. Whittemore (1910), 205 Mass. 6, 91 N. E. 155.
New Jersey.-Potter Printing Press Co. v. Newark Daily Advg. Co. (1912), 82 N. J. I. 671, 83 Atl. 969.

New York.- MacMonnies v. Phillippi (1918), 170 N. Y. Supp. 913; Sanford v. Brown Bros. Co. (1913), 208 N. Y. 90, 101 N. E. 797; Bram- 
ha!! Deane Co. v. McDonald (1916), 158 N. Y. Supp. 736; Cee Bee Cr? Waist \& Costume Co. v. Borenstein (1917), 164 N. Y. Supp. 703; Creamery Package Mfg. Co. v. Horton (1917), 165 N. Y. Supp. 257; Tawil Bros. v. Bennett \& Aspden Co. (1919), 176 N. Y. Supp. 10; Carlisle v. Lovell (1918), 171 N. Y. Supp.
996; American Metal Co. v. Newmann (1918), 171 N. Y. Supp. 560; Murphy v. Moon Motor Co. (1911), 147 App. Div. 91, 131 N. Y. Supp. 873.

Rhode Island.- Blair-Baker Horse Co. v. Hennesset (1915), 36 R. I. 132.

Section 12.-(Definition of Express Warranty.)-Any affirmation of fact or any promise by the seller relating to the goods is an express warranty if the natural tendency of such affirmation or promise is to induce the buyer to purchase the goods, and if the buyer purchases the goods relying thereon. No affirmation of the value of the goods, nor any statement purporting to be a statement of the seller's opinion only shall be construed as a warranty.

Connecticut.-Andrews v. Peck (1910), 83 Conn. 666, 78 Atl. 445.

Maryland.- Rittenhouse-Winterson Auto Co. v. Kissmer (1916), 98 Atl. 361; White Automobile Co. v. Dorsey (1913), 119 Md. 251, 86 Atl. 617; Greer v. Whalen (1913), 125 Md. 273, 93 Atl. 521.

Massachusetts. - Putman-Hooker Co. v. Hewins (1910), 204 Mass. 426, 90 N. E. 983; Am. Soda Fountain Co. v. Spring Water Carb. Co. (1911), 207 Mass. 488, 93 N. E. 801; Gascoigne v. Cary Brick Co. (1914), 217 Mass. 304, 104 N. E. 734 ; Leonard v. Carleton \& Honey Co. (1918), 230 Mass. 262, 119 N. E. 674.

Michigan.-Bates Tractor Co. v. Gregory (1917), 165 N. W. 612; Miller v. Du Val (1916), 158 N. W. 140; Waterman-Waterbury Co. v. Sehool Dist. No. 2 (1914), 148 N. W. 673 .

New Jersey.- Spencer Heater Co. v. Abbott (1918), 104 Atl. 91.

New York. - Mastin v. Boland
(1917), 165 N. Y. Supp. 468; Washburn-Crosby Co. v. Kindervatter (1911), 147 App. Div. 114, $131 \mathrm{~N}$. Y. Supp. 871; International Battery Co. v. Wistreich (1918), 182 App. Div. 843,170 N. Y. Supp. 149 ; Susquehanna Silk Mills v. Jaeobson (1918), 185 App. Div. 378, 173 N. Y. Supp. 271; Sidney B. Bowman Automobile Co. v. Seliultz (1919), 175 N. Y. Supp. 72; Nelson Co. v. Silver (1913), 160 App. Div. 445, 145 N. Y. Supp. 124; Coleman v. Simpson (1914), 162 App. Div. 335. 147 N. Y. Supp. 865; Wasserstrom v. Cohen, Frank \& Co. (1914). 165 App. Div. 171, 150 N. Y. Supp. 638; Debany v. Rosenthal (1915), $152 \mathrm{~N}$. Y. Supp. 1043.

Ohio.- Hamilton Iron \& Steel Co. v. Groveland Mining Co. (1916), 233 Fed. Rep. 388.

United States.-Hamilton Iron \& Steel Co. v. Groveland Mining Co. (1916) (U. S. C. C. A., Ohio), 233 Fed 388; H. Koehler \& Co. v. York 
Mfg. Oo. (1912), 193 Fed. 981, 113 C. C. A. 601 (N. Y.); Wendell \& Evans Co. v. Kennecott Co. (1914), 218 Fed. Rep. 622 (N. Y.); Nor- wood Paper Co. v. Columbia Paper Bag Co. (1911), 185 Fed. Rep. 454, 107 C. C. A. (Md.) 524.

Section 13.-(Implied Warranties of Title.) - In a contract to sell or a sale, unless a contrary intention appears, there is :

(1) An implied warranty on the part of the seller that in case of a sale he has a right to sell the goods, and that in case of a contract to sell he will have a right to sell the goods at the time when the property is to pass;

(2) An implied warranty that the buyer shall have and enjoy quiet possession of the goods as against any lawful claims existing at the time of the sale;

(3) An implied warranty that the goods shall be free at the time of the sale from any charge or encumbrance in favor of any third person, not declared or known to the buyer before or at the time when the contract or sale is made;

(4) This section shall not, however, be held to render liable a sheriff, auctioneer, mortgagee, or other person professing to sell by virtue of authority in fact or law goods in which a third person has a legal or equitable interest.

Massachusetts.- Hartley v. Rotman (1909), 200 Mass. 376, $86 \mathrm{~N}$. E. 903 .

Minnesota.- Jordan v. Van Duzee (1917), 165 N. W. 877, 139 Minn. 103.
New Jersey.-Dreisbach v. Eckelkamp (1912), 82 N. J. L. 726, 83 Atl. 175.

Wisconsin.-Kirkpatrick v. Kepler (1917), 164 Wis. 558, $160 \mathrm{~N}$. W. 1047.

Section 14.-(Implied Warranty in Sale by Description.) Where thero is a contract to sell or a sale of goods by description, there is an implied warranty that the goods shall correspond with the description and if the contract or sale be by sample, as well as by description, it is not sufficient that the bulk of the goods corresponds with the sample if the goods do not also correspond with the description.

Massachusetts.-Hanson \& Parker v. Wittenberg (1910), 205 Mass. 319, 91 N. E. 383; Cavanaugh v. D. W. Raulet Co. (1918), 229 Mass. 360, 118 N. E. 650; Proctor v. Atlantic Fish Co. (1911), 208 Mass.
351, 94 N. E. 281; Borden v. Fin(1912), 212 Mass. 427, 98 N. E. 1073; Interstate Grocer Co. v. Geo. Wm. Bentley Co. (1913), 214 Mass. 231, 101 N. E. 147. 
Michigan.- Nathan Kronman \& Co. v. Gardella (1916), 157 Pac. 377; Cheboygen Paper Co. v. Eichberg (1915), 150 N. W. 312.

New Jersey.-Lissberger v. Kel$\log$ (1909), 78 N. J. L. 89, 73 Atl. 67.
New York.-Mastin v. Boland (1917), 165 N. Y. Supp. 468.

Wisconsin. - Kelsey v. J. W. Ringrose Net Co. (1913), 152 Wisc. 499,140 N. W. 66; Ross v. Northrup, Krug \& Co. (1914), 156 Wisc. 327,144 N. W. 1124.

Section 15.-(Implied Warranties of Quality.)-Subject to the provisions of this act and of any statute in that behalf, there is no implied warranty or condition as to the quality or fitness for any particular purpose of goods supplied under a contract to sell or a sale, except as follows:

(1) Where the buyer, expressly or by implication, makes known to the seller the particular purpose for which the goods are required, and it appears that the buyer relies on the seller's skill or judgment (whether he be the grower or manufacturer or not), there is an implied warranty that the goods shall be reasonably fit for such purpose.

(2) Where the goods are bought by description from a seller who deals in goods of that description (whether he be the grower or manufacturer or not), there is an implied warranty that the goods shall be of merchantable quality.

(3) If the buyer has examined the goods, there is no implied warranty as regards defects which such examination ought to have revealed.

(4) In the case of a contract to sell or a sale of a specified article under its patent or other trade name, there is no implied warranty as to its fitness for any particular purpose.

(5) An implied warranty or condition as to quality of fitness for a particular purpose may be annexed by the usage of trade.

(6) An express warranty or condition does not negative a warranty or condition implied under this act unless inconsistent therewith.

Arizona.- Brought v. Redewill Music Co. (1915), 153 Pac. 285.

Connecticut.-Merrill v. Hodson (1914), 91 Atl. 533; Welshausen $v$.
Chas. Parker Co. (1910), 83 Conn. 231, 76 Atl. 271.

Illinois.-Nelson v. Miller (1915), 195 Ill. App. 233. 
Maryland.- Commercial Realty \& Const. Co. v. Dorsey (1910), 114 Md. 172, 78 Atl. 1099.

Massachusetts.- Proctor v. Atlantic Fish Co. (1911), 208 Mass. 351, 94 N. E. 281; Roberts v. Anheuser Busch Brewing Co. (1912), 211 Mass. 449, 98 N. E. 95; Interstate Grocer Co. v. Geo. Wm. Bentley (1913), 214 Mass. 227, $101 \mathrm{~N}$. E. 147; Gearing v. Berkson (1916), 111 N. E. 785; Ward v. Great Atlantic \& Pac. Tea Co. (1918), 120 N. E. 225; Friend v. Childs Dining Hall Co. (1918), 120 N. E. 407.

Michigan.-Wolverine Spice Co. v. Fallas (1914), 148 N. W. 701; Baker v. Kamantowsky (1915), 155 N. W. 430 ; Pentland v. Jacobson (1915), 155 N. W. 468; E. P. Stacy \& Sons v. Moher (1918), 200 Mich. 81,166 N. W. 849 .

Mississippi.- Lumberman's Supply Co. v. Poplarville Sawmill Co. (1918), 117 Miss. 274, 78 So. 157.

New Jersey.-- Mach. Mfg. Co. v. Donovan (1914), 86 N. J. L. 327, 91 Atl. 310; Quemahonuig Coal Co. v. Sanitary Earthenware Specialty Co. (1915), 95 Atl. 986.

New York.- Stroock Plush Co. v. Talcott (1912), 150 App. Div. 343, 134 N. Y. Supp. 1052; Standard Milling Co. v. DePas (1913), 154 App. Div. 525, 139 N. Y. Supp. 611; Coleman v. Simpson, Hendee Co. (1913), 158 App. Div. 461, 143 N. Y. Supp. 587; Race v. Krum (1914), 163 App. Div. 924, 147 N. Y. Supp. 818; Leahy v. Essex Co. (1914), 164 App. Div. 903, 148 N. Y. Supp. 1063; Wasserstrom v. Cohen Frank \& Co. (1914), 165 App. Div. 171, 150 N. Y. Supp. 638; Sure Seal Co. v. Loeber (1916), 157 N. Y. Supp. 327, 171 App. Div. 225; Leiter v.
Innis, Speiden \& Co. (1912), 138 N. Y. Supp. 536; Marx v. Locomobile Co. (1913), 144 N. Y. Supp. 937, 82 Misc. 468; Shearer Co., G. B. v. Kakoulis (1913), 144 N. Y. Supp. 1077; Bonwit Teller \& Co. v. Kinlen (1914), 150 N. Y. Supp. 966 ; Rinaldi v. Mohican Co. (1918), 225 N. Y. 70,121 N. E. 471 ; Coff-Garrod Co. v. Dodwell \& Co. (1918), 170 N. Y. Supp. 615; Thomson v. Meyer Cord Co. (1919), 174 N. Y. Supp. 732; Weinberg v. Peter Doelger Brewing Co. (1919), 174 N. Y. Supp. 69 ; Majestic Coal Co. v. W. J. Bush \& Co. (1918), 171 N. Y. Supp. 662; East End Amusement Co. v. Atmospheric S. Co. (1918), 171 N. Y. Supp. 283; Barrington v. Hotel Astor (1918), 171 N. Y. Supp. 840; Muller v. Childs Co. (1918), $171 \mathrm{~N}$. Y. Supp. 541; Stern Bros. v. Borwood (1918), 169 N. Y. Supp. 545; Zenkel v. Oneida County Creameries Co. (1918), 104 Misc. Rep. 251, 171 N. Y. Supp. 676 ; Polly v. Arony (1918), 172 N. Y. Supp. 305; Salino v. Latturalilo $(1918), 170$ N. Y. Supp. 30; Empire Cream Separator Co. v. Quinn (1918), 171 N. Y. Supp. 413; Race v. Krum (1918), $222 \mathrm{~N}$. Y. 410,118 N. E. 853 .

Ohio.-Marmet Coal Co. v. People's Coal Co. (1915), 226 Fed. 646; Thompson v. Miser (1910), 82 Ohio St. 289, 92 N. E. 420 .

Pennsylvania.-Shute v. Levin (1917), 66 Pa. Super. Ct. 67.

Rhode Island.-Matteson v. Iagace (1914), 89 Atl. 713.

United States.- Nashua Iron \& Steel Co. v. Brush (1898), 91 Fed. 213, 33 C. C. A. 456; Exeelsior Coal Co. v. Gildersleeve (1908), 160 Fed. 47 (Conn.); In re Nathen (1912), 200 Fed. 379 (N. Y.) 118 C. C. A. 
531; Kansas City Bolt \& Nut Co. v. Rodd (1915), 220 Fed. Rep. 760 (Ohio).

Utah.- Studebaker Bros. Co. v. Anderson (1917), 167 Pac. 663; Walters v. United Grocery Co. (1918), 172 Pac. 473.

Wisconsin.- Leonard Seed Co. v.
Crary Canning Co. (1911), 147 Wise. 166, 132 N. W. 902; Ross v. Northrup, King \& Co. (1914), 156 Wisc. 327, 144 N. W. 1124; Berry v. Wadhams Oil Co. (1914), 156 Wisc. 588, 14 i N. W. 783; Neck v. Marquetto Cement Mfg. Co. (1914), 158 Wisc. 298, 148 N. W. 869.

\section{SALE BY SAMPLE.}

Section 16.-(Implied Warranties in Sale by Sample.)In the ease of a contract to sell or a sale by sample:

(a) There is an implied warranty that the bulk shall correspond with the sample in quality.

(b) There is an implied warranty that the buyer shall have a reasonable opportunity of comparing the bulk with the sample, except so far as otherwise provided in section 47 (3).

(c) If the seller is a dealer in goods of that kind, there is an implied warranty that the goods shall be free from any defect rendering them unmerchantable which would not be apparent on reasonable examination of the sample.

Massachusetts.-West End Mfg. Co. v. Warren Co. (1908), 198 Mass. 320; Androvette v. Parks (1910), 207 Mass. 86, 92 N. E. 1006; Borden v. Fine (1912), 212 Mass. 425, 98 N. E. 1073; Interstate Grocer Co. v. Geo. Wm. Bentley Co. (1913), 214 Mass. 227, 101 N. E. 147; Gascoigne v. Cary Brick Co. (1914), 217 Mass. 302, 104 N. E. 734.

New Jersey.-Stewart v. M. N. Voll \& Son (1911), 81 N. J. L. 323, r9 Atl. 1041.

New York.- Regina Co. v. Gately Furniture Co. (1916), 157 N. Y. Supp. 746, 171 App. Div. 687;
American Lace Mfg. Co. v. Levy (1915), 155 N. Y. Supp. 232; Schwartz v. Kohn (1915), $155 \mathrm{~N}$. Y Supp. 547; Rosenberg v. Rosenzweig (1919), 173 N. Y. Supp. 421; Crook v. Lipton (1918), 182 App. Div. 858,170 N. Y. Supp. 345; P. J. Harney Shoe Co. v. A. H. Ginsberg-Grorden Co. (1918), 169 N. Y. Suppl. 848.

United States.-Levi Strauss \& Co. v. Silverstein (1918), 160 C. C. A. 403, 248 Fed. 393; In re Nathan (1912), 200 Fed. Rep. 379, 118 C. C. A. 531. 


\section{PART II. ,}

TRANSFER OF PLOPERTY AS BETWEEN SELTFR AND BUYER.

Section 17.-(No Property Passes until Goods are Ascertained.) - Where there is a contract to sell unascertained goods no property in the goods is transferred to the buyer unless and until the goods are ascertained, but property in an undivided share of ascertained goods may be transferred as provided in section 6 .

- Massachusetts.-Isaac v. Mac-

Donald (1913), 214 Mass. 487, 102

N. E. 81 .

Section 18.-(Property in Specific Goods Passeg when Parties so Intend.) - (1) Where there is a contract to sell specific or ascertained goods, the property in them is trans ferred to the buyer at such time as the parties to the contract intend it to be transferred.

(2) For the purpose of ascertaining the intention of the parties, regard shall be had to the terms of the contract, the conduct of the parties, usages of trade and the circumstances of the case.

Connecticut.- White v. Lansing Chemical Co. (1917), 92 Conn. 186, 102 Ätl. 579.

Maryland.-Dinsmore v. Maag . Wahmann Co. (1914), $122 \mathrm{Md}$. 177, 89 Atl. 399; Praeger v. Implement C. (1914), 122 Md. 303.
Massachusetts.-Carron v. Haskins (1912), 212 Mass. 593; Bondy v. Hardina (1913), 216 Mass. 44, 102 N. E. 935 .

New York.-Tompkins Kiel Mas. ble Co. v. Bockman (1915), 154 N. Y. Supp. 196.

Section 19.-(Rules for Ascertaining Intention.)-Onless a different intention appears, the following are rules for ascertaining the intention of the parties as to the time at which the property in the goods is to pass to the buyer.

Rule 1. Where there is an unconditional contract to sell specific goods, in a deliverable state, the property in the goods passes to the buyer when the contract is made and it is im- 
material whether the time of payment, or the time of delivery, or both, be postponed.

Rule 2. Where there is a contract to sell specific goods and the seller is bound to do something to the goods, for the purpose of putting them into a deliverable state, the property does not pass until such thing be done.

Rule 3. (1) When goods are delivered to the buyer "on sale or return," or on other terms indicating an intention to make a present sale, but to give tht buyer an option to return the goods instead of paying the price, the property passes to the buyer on delivery, but he may revest the property in the seller by returning or tendering the goods within the time fixed in the contract, or, if no time has been fixed, within a reasonable time.

(2) When goods are delivered to the buyer on approval or on trial or on satisfaction, or other similar terms, the property therein passes to the buyer:

(a) When he signifies his approval or acceptance to the seller or does any other act adopting the transaction;

(b) If he does not signify his approval or acceptance to the seller, but retains the goods without giving notice of rejection, then if a time has been fixed for the return of the goods, on the expiration of such time, and, if no time has been fixed, on the expiration of a reasonable time. What is a reasonable time is a question of fact.

Rule 4. (1) Where there is a contract to sell unascertained or future goods by description, and goods of that description and in a deliverable state are unconditionally appropriated to the contract, either by the seller with the assent of the buyer, or by the buyer with the assent of the seller, the property in the goods thereupon passes to the buyer. Such assent may be expressed or implied, and may be given oither before or after the appropriation is made.

(2) Where, in pursuance of a contract to sell, the seller delivers the goods to the buyer, or to a carrier or other baileo (whether named by the buyer or not), for the purpose of transmission to or holding for the buyer, he is presumed to have unconditionally appropriated the goods to the contract, except 
in the cases provided for in the next rule and in section 20 . This presumption is applicable, although by the terms of the contract, the buyer is to pay the price before receiving delivery of the goods, and the goods are marked with the words " collect on delivery" or their equivalent.

Rule 5. If the contract to sell requires the seller to deliver the goods to the buyer, or at a particular place, or to pay the freight or cost of transportation to the buyer, or to a particular place, the property does not pass until the goods have been delivered to the buyer or reached the place agreed upon.

Connecticut.- Home Pattern Co. v. Mertz Co. (1914), 88 Conn. 22; Silbermann v. Caplan (1919), 105 Atl. 350 .

Illinois.-Brain v. H. A. Barn Packers' Supply Co. (1917), 203 Ill. App. 262; Anderson Computing Scale Co. v. Hattenbach (1917), 199 IIl. App. 467; Rosenfeld v. Ehrhart (1917), 202 Ill. App. 617.

Maryland.-Dinsmore v. Rice (1916), 128 Md. 209, 97 N. E. 537;

Rice v. Dinsmore (1914), 124 Md. 276, 92 Atl. 847.

Massachusetts. - Kennedy v. Drake (1916), 114 N. E. 310; Barrie v. Quinly (1910), 206 Mass. 258, 92 N. E. 451; Twitchell-Champlin Co. v. Rodovsky (1910), 207 Mass. 72, 92 N. E. 1038; Automatic TimeTable Advertising Co. v. Automatic Time-Table Co. (1911), 208 Mass. 251, 94 N. E. 462; Wright v. Frank E. Andrews Co. (1912), 212 Mass. 186, 98 N. E. 798; Bristol Mfg. Co. v. Arkwright Mills (1912), 213 Mass. 172, 100 N. E. 55; Chandler Grain \& Milling Co. v. Shea (1913), 213 Mass. 398, 100 N. E. 663; Isaacs v. MacDonald (1913), 214 Mass. 487, 102 N. E. 81; Bondy $\nabla$.
Hardina (1913), 216 Mass. 44, 102 N. E. 935 .

Michigan.-Kemper-Thomas Co. v. Deitz (1918), 169 N. WV. 826.

New Jersey.- Ingersoll-Rand Co. v. U. S. Fidelity \& Guaranty Co. (1919), 105 Atl. 236; Champlin v. Church (1908), 76 N. J. L. 553, 70 Atl. 138; Massman v. Steiger (1910), 79 N. J. L. 442, 75 Atl. 746; Geo. A. Ohl \& Co. v. Barnet Leather Co. (1915), 93 Atl. 715, 87 N. J. L. 300 ; Engemann v. Delaware L. \& W. R. R. (1916), 97 Atl. 152.

New York.-Phelps v. McQuade (1917), 115 N. E. 441,220 N. Y. 232 ; Atlanta Mach. Works v. Felthausen (1916), 160 N. Y. Supp. 29; John Wanamaker v. Toole (1917), 166 N. Y. Supp. 112, 179 App. Div. 77; Jac Bolsenfahr Co. v. Gross (1917), 164 N. Y. Supp. 887; Neal, Clark \& Neal Co. v. Tarby (1917), 163 N. Y. Supp. 675; W. \& S. Job Co. v. N. B. Cook Oil Co. (1919), 175 N. Y. Supp. 878; Atlanta Bldg. Supply Co. v. Vulcanite Port. Cement Co. (1911), 203 N. Y. 133, 96 N. E. 370 ; Gass v. So. Pacific Co. (1912), 152 App. Div. 412, $137 \mathrm{~N}$. Y. Supp. 261; Westmoreland Coal Co. v. Syracuse Lighting Co. (1913), 
145 N. Y. Supp. 420, 159 App. Div. 323; White v. Schweitzer (1911), 147 App. Div. 544, 132 N. Y. Supp. 644; Dube v. Liberty Clothing Co. (1915), 153 N. Y. Supp. 577; Sanitary Carpet Cleaner v. Reed Mfg. Co. (1913), 159 A. D. 587; Fox v. Proctor (1914), 145 N. Y. Supp. 709. 160 App. Div. 712; Conroy v. Barrett (1916), 158 N. Y. Supp. 549, 95
Misc. 247; Schanz v. Bramwell (1913), 145 N. Y. Supp. 1057.

Pennsylvania.- Pittoburgh Provision \& Packing Co. v. Cudahy Packi. Co. (1918), $260 \mathrm{~Pa} .135,103 \mathrm{Atl}$. 548; Enterprise Wall Paper Co. v. Nilson Rantual Co. (1918), $260 \mathrm{~Pa}$. 540, 103 Atl. 923.

United States.-Graham v. United States (1911), 188 Fed. 651, 110 C. C. A. 465 (Md.).

Section 20.-(Reservation of Right of Possession or Property When Goods are Shipped.) - (1) Where there is a contract to sell specific goods, or where goods are subsequently appropriated to the contract, the seller may, by the terms of the contract or appropriation, reserve the right of possession or property in the goods until certain conditions have been fulfilled. The right of possession or property may be thus reserved notwithstanding the delivery of the goods to the buyer or to a carrier or other bailee for the purpose of transmission to the buyer.

(2) Where goods are shipped, and by the bill of lading the goods are deliverable to the seller or his agent, or to the order of the seller or of his agent, the seller thereby reserves the property in the goods. But if, except for the form of the bill of lading, the property would have passed to the buyer on shipment of the goods, the seller's property in the goods shall be deemed to be only for the purpose of securing performance by the buyer of his obligations under the contract.

(3) Where goods are shipped, and by the bill of lading the goods are deliverable to the order of the buyer or of his agent, but possession of the bill of lading is retained by the seller or his agent, the seller thereby reserves a right to the possession of the goods as against the buyer.

(4) Where the seller of goods draws on the buyer for the price and transmits the bill of exchange and bill of lading together to the buyer to secure acceptance or payment of the bill of exchange, the buyer is bound to return the bill of lading if he does not honor the bill of exchange, and if he wrongfully 
retains the bill of lading he acquires no added right thereby. If, however, the bill of lading provides that the goods are deliverable to the buyer or to the order of the buyer, or is indorsed in blank, or to the buyer by the consignee named therein, one who purchases in good faith, for value, the bill of lading, or goods from the buyer will obtain the property in the goods, although the bill of exchange has not been honered, provided that such purchaser has received delivery of the bill of lading indorsed by the consignee named thereir., or of the goods, without notice of the facts making the transfer wrongful.

Connecticut.-Alderman Bros. Co. v. Westinghouse Air Brake Co. (1918), 92 Conn. 419, 103 Atl. 267.

Maryland.- Praeger v. EmersonBrant Imp. Co. (1914), 122 Md. 303, 89 Atl. 501.

New York.-Wilson International
Railway Co. (1916), 160 N. Y. Supp. 367; Boss v. Hutchinson (1918), 169 N. Y. Supp. 513.

United States.-Lipschitz v. Napa Fruit Co. (1915), 223 Fed. 698 (C. C. A., $2 \mathrm{~d}$ Ct.).

Section 21.-(Sale by Auction.)-In the case of sale by auction :

(1) Where goods are put up for sale by auction in lots, each lot is the subject of a separate contract of sale.

(2) A sale by auction is complete when the auctioneer announces its completion by the fall of the hammer, or in other customary manner. Until such announcement is made, any bidder may retract his bid; and the auctioneer may withdraw the goods from sale unless the auction has been announced to be without reserve.

(3) A right to bid may be reserved expressly by or on behalf of the seller.

(4) Where notice has not been given that a sale by auction is subject to a right to bid on behalf of the seller, it shall not be lawful for the seller to bid himself or to employ or induce any person to bid at such sale on his behalf, or for the auctioneer to employ or induce any person to bid at such sale on behalf of the seller or knowingly to take any bid from the seller or any person employed by him. Any sale contravening this rule may be treated as fraudulent by the buyer.

Rhode Island.-Freeman v. Poole (1015), 93 Atl. 786, g1 Atl. 152 
Section 22.-(Risk of Loss.)-Unless otherwise agreed, the goods, remain at the seller's risk until the property therein is transferred to the buyer, but when the property therein is transfered to the buyer the goods are at the buyer's risk whether delivery has been made or not, except that:

(a) Where delivery of the goods has been made to the buyer, or to a bailee for the buyer, in pursuance of the contract and the property in the goods has been retained by the seller merely to secure performance by the buyer of his obligations under the contract, the goods are at the buyer's risk from the time of such delivery.

(b) Where delivery has been delayed through the fault of either buyer or seller the goods are at the risk of the party in fault as regards any loss which might not have oocurred but for such fault.

Connecticut.- Kinney v. Horwitz (1919), 105 Atl. 438; Alderman Bros. Co. v. Westinghouse Air Brake Co. (1918), 92 Conn. 419, 103 Atl. 267; O'Neill-Adams Co. v. Eklund (1915), 93 Atl. 524.

Maryland. - Rylance v. James Walker Co. (1916), 99 Atl. 596; Agri. Mfg. Co. v. Atlantic Ferti- lizer Co. (1916), 98 Atl. 365; Baltimore \& O. R. Co. v. Carter (1919) (Md.), 105 Atl. 760.

New Jersey.-Collerd v. Tully (1911), 78 N. J. L. 557, 80 Atl. 491.

Pennsylvania.-Pittsburgh Provision \& Packing Co. v. Cudahy Packing Co. (1918), 260 Pa. 135, 103 Atl. 548 .

\section{TRANSFER OP TITLE}

Section 23.-(Sale by a Person not the Owner.) - (1) Subject to the provisions of this act, where goods are sold by a person who is not the owner thereof, and who does not sell therm under the authority or with the consent of the owner, the buyer acquires no better title to the goods than the seller had, unless the owner of the goods is by his conduct precluded from denying the seller's authority to sell.

(2) Nothing in this act, however, shall affect:

(a) The provisions of any factors' acts, recording acts, or any enactment enabling the apparent owner of goods to disposo of them as if he were the true owner thereof.

(b) The validity of any contract to sell or sale under any 
special common law or statutory power of sale or under the order of a court of competent jurisdiction.

Arizona.- Webster Milling Co. v. Bingham (1912), 14 Ariz. 50, 125 Pac. 709.

Michigan. - Maley - Thompson \& Moffet Co. v. Thos. Forman Co. (1914), 179 Mich. 548, 146 N. W. 95.

New York-Canales v. Earl (1918), 168 N. Y. Supp. 726; A. F. T. Corporation v. Pathe Exchange, Inc. (1918), 172 N. Y. Supp. 364; Reichard v. Hutton (1913), 158 App.
Div. 122, 142 N. Y. Supp. 935; Phelps v. McQuade (1913), 158 App. Div. 528, 143 N. Y. Supp. 822.

Ohio.- B. \& O. S. W. Ry. Co. v. Good (1910), 82 Ohio St. 278, $92 \mathrm{~N}$. E. 435 .

Wisconsin.- L. C. Smith \& Bros. Typewriter Co. v. Luebkeman (1911), Wis. 317, 133 N. W. 33.

United States.-Cincinnati Ry. Supply Co. v. Hartlieb (1914), 214 Fed. Rep. 177, 130 C. C. A. 525 .

Section 24.-(Sale by One Having a Voidable Title.)Where the seller of goods has a voidable title thereto, but this title has not been avoided at the time of the sale, the buyer acquires a good title to the goods, provided he buys them in good faith, for value, and without notice of the seller's defect of title.

Section 25.-(Sale by Seller in Possession of Goods Already Sold.) - Where a person having sold goods continues in possession of the goods, or of negotiable documents of title to the goods, the delivery or transfer by that person, or by an agent acting for him, of the goods or documents of title under any sale, pledge, or other disposition thereof, to any person re ceiving and paying value for the same in good faith and without notice of the previous sale, shall have the same effect as if the person making the delivery or transfer were expressly authorized by the owner of the goods to make the same.

Ohio.- Hallet \& Davis Piano Co.

v. Starr Piano Co. (1911), 85 Ohio

St. 196,97 N. E. 377 .

Section 26.-(Creditors' Rights Against Sold Goods in Seller's Possession.) - Where a person having sold goods continues in passession of the goods, or of negotiable documents of 
title to the goods and such retention of possession is fraudulent under any rule of law, a creditor or creditors of the seller may treat the sale as void.

Arizona.-Nolte v. Winstanly Connecticut.-Patchin v. Rowell (1914), 16 Ariz. 323. (1912), 86 Conn. 372, 85 Atl. 511.

Section 27.-(Definition of Negotiable Documents of Title.) $-\mathrm{A}$ document of title in which it is stated that the goods re ferred to therein will be delivered to the bearer, or to the order of any person named in such document is a negotiable document of title.

Section 28.- (Negotiation of Negotiable Documents by Delivery.) - A negotiable document of title may be negotiated by delivery:

(a) Where by the terms of the document the carrier, warehouseman or other bailee issuing the same undertakes to deliver the goods to the bearer, or

(b) Where by the terms of the document the carrier, warehouseman or other bailee issuing the same undertakes to deliver the goods to the order of a specified person, and such person or a subsequent indorsee of the document has indorsed it in blank or to bearer.

Where by the terms of a negotiable document of title the goods are deliverable to bearer or where a negotiable document of title has been indorsed in blank or to bearer, any holder may indorse the same to himself or to any other specified person, and in such ease the document shall thereafter be negotiated only by the indorsement of such indorsee.

Section 29.-(Negotiation of Negotiable Documents by Indorsement.) - A negotiable document of title may be negotiated by the indorsement of the person to whose order the goods are by the terms of the document deliverable. Such indorsement may be in blank, to bearer or to a specified person. If indorsed to a specified person, it may be again negotiated br the indorsement of such person in blank, to bearer or to another specified person. Subsequent negotiation may be made in like manner. 
Section 30.-(Negotiable Documents of Title Marked "Not Negotiable.")-If a document of title which contains an undertaking by a carrier, warehouseman or other bailee to deliver the goods to the bearer, to a specified person or order, or to the order of a specified person, or which contains words of like import, has placed upon it the words " not negotiable." "nonnegotiated," or the like, such document may nevertheless be negotiated by the holder and is a negotiable document of title within the meaning of this act. But nothing in this act contained shall be construed as limiting or defining the effect upon the obligations of the carrier, warehouseman, or other bailee issuing a document of title of placing thereon the words "not negotiable," "non-negotiable," or the like.

Section 31.- (Transfer of Non-Negotiable Documents.) A document of title which is not in such form that it can be negotiated by delivery may be transferred by the holder by delivery to a purchaser or donee. A non-negotiable document cannot be negotiated and the indorsement of such a document gives the transferee no additional right.

Massachusetts.-Brown v. Floers-

heim Mercantile Co. (1910), 206

Mass. 373, 92 N. E. 494.

Section 32.-(Who May Negotiate a Document.) - A nego tiable document of title may be negotiated:

(a) By the owner thereof, or

(b) By any person to whom the possession or custody of the document has been entrusted by the owner, if, by the terms of the document the bailee issuing the document undertakes to deliver the goods to the order of the person to whom the possession or eustody of the document has been entrusted, or if at the time of such entrusting the document is in such form that it may be negotiated by delivery.

Section 33.-(Rights of Person to Whom Document Has Been Negotiated.) - A person to whom a negotiable document of title has been duly negotiated acquires thereby: 
(a) Such title to the goods as the person negotiating the document to him had or had ability to convey to a purchaser in good faith for value and also such title to the goods as the person to whose order the goods were to be delivered by the terms of the document had or had ability to convey to a purchaser in good faith for value, and

(b) The direct obligation of the bailee issuing the document to hold possession of the goods for him according to the terms of the document as fully as if such baileo had contracted directly with him.

Section 34.-(Rights of Person to Whom Document Has Been Transferred.) - A person to whom a document of title has been transferred, but not negotiated, acquires thereby, as against the transferor, the title to the goods, subject to the terms of any agreement with the transferor.

If the document is non-negotiable, such person also acquires the right to notify the bailee who issued the document of the transfer thereof, and thereby to acquire the direct obligation of such bailee to hold possession of the goods for him according to the terms of the document.

Prior to the notification of such bailee by the transferor or transferee of a non-negotiable document of title, the title of the transferee to the goods and the right to acquire the obligation of such bailee may be defeated by the levy of an attachment or execution upon the goods by a creditor of the transferor, or by a notification to such bailee by the transferor or a subse quent purchaser from the transferor of a subsequent sale of the goods by the transferor.

Massachusetts.-Brown v. Floersheim Mercantile Co. (1910), 206

Mass. 373, 92 N. E. 494.

Section 35.-(Transfer of Negotiable Document Without Indorsement.) - Where a negotiable document of title is transferred for value by delivery, and the indorsement of the transferor is essential for negotiation, the transferee acquires a right against the transferor to compel him to indorse the document 
unless a contrary intention appears. The negotiation shall take effect as of the time when the indorsement is actually made.

Section '36.-(Warranties on Sale of Document.) - A person who for value negotiates or transfers a document of title by indorsement or delivery, including one who assigns for value a claim secured by a document of title unless a contrary intention appears, warrants:

(a) That the document is genuine;

(b) That he has a legal right to negotiate or transfer it;

(c) That he has knowledge of no fact which wonld impair the validity or worth of the document, and

(d) That he has a right to transfer the title to the goods and that the goods are merchantable or fit for a particular purpose, whenever such warranties would have been implied if the contract of the parties had been to transfer without a document of title the goods represented thereby.

Section 37.-(Indorser Not a Guarantor.)-The indorsement of a document of title shall not make the indorser liable for any failure on the part of the bailee who issued the document or previous indorsers thereof to fulfill their respective obligations.

Section 38.-(When Negotiation Not Impaired by Frand, Mistake or Duress.)-The validity of the negotiation of a negotiable document of title is not impaired by the fact that the negotiation was a breach of duty on the part of the person making the negotiation, or by the fact that the owner of the document was induced by fraud, mistake or duress to entrust the possession or custody thereof to such person, if the person to whom the document was negotiated or a person to whom the doeument was subsequently negotiated paid value therefor, without notice of the breach of duty, or fraud, mistake or duress.

Section 39.-(Attachment or Lery Upon Goods for Which a Negotiable Document Has Been Issued.)-If goods are de 
livered to a bailee by the owner or by a person whose act in conveying the title to them to a purchaser in good faith for value would bind the owner and a negotiable document of title is issued for them they cannot thereafter, while in the passession of such bailee, be attached by garnishment or otherwise or be levied upon under an execution unless the document be first surrendered to the bailee or its negotiation enjoined. The bailee shall in no case be compelled to deliver up the actual possession of the goods until the document is surrendered to him or impounded by the court.

Section 40.- (Creditors' Remedies to Reach Negotiable Documents.) - A creditor whose debtor is the owner of a negotiable document of title shall be entitled to such aid from courts of appropriate jurisdiction by injunction and otherwise in attaching such document or in satisfying the claim by means thereof as is allowed at law or in equity in regard to property which cannot readily be attached or levied upon by ordinary legal process. 


\section{PART III \\ PERFORMANCE OF THE CONTRACT.}

Section 41.-(Seller Must Deliver and Buyer Accept Goods.) - It is the duty of the seller to deliver the goods, and of the buyer to accept and pay for them, in accordance with the terms of the contract to sell or sale.

Connecticut.- Kinney v. Horwitz (1919), 105 Atl. 438.

Massachusetts.-Fullam v. Wright \& Colton Wire Cloth Co. (1907), 196
Mass. 474; Haynes v. Temple (1908), 198 Mass. 372.

New York.-Levy v. Deltra \& Co. (1915), 154 N. Y. Supp. 176.

Section 42.-(Delivery and Payment Are Concurrent Conditions.) - Unless otherwise agreed, delivery of the goods and payment of the price are concurrent conditions; that is to say, the seller must be ready and willing to give possession of goods to the buyer in exchange for the price and the buyer must be ready and willing to pay the price in exchange for possession of the goods.

Connecticut.- Kinney v. Horwitz (1919), 105 Atl. 438; Bridgeport Hardware Mfg. Co. v. Bounial (1915), 93 Atl. 674.

Massachusetts.-Dame v. C. H. Hanson \& Co. (1912), 212 Mass. 124.

New Jersey.-Gruen v. Geo, A. Ohl Co. (1911), 81 N. J. I. 626,80 Atl. 547; Kelly Const. Co. v. Hockenbach (1918), 103 Atl. 417.
New York.-British Aluminum Co. v. Trefts (1914), 163 App. Div. 184, 148 N. Y. Supp. 144; Weinshauk v. Shack (1918), 168 N. Y. Supp. 7; Imperial Products Co. v. Capital Chemical Co. (1919), $17 \hat{o}$ N. Y. Supp. 49; Bemzweig v. Hyman Lewin Co., Inc. (1918), $172 \mathrm{~N}$. Y. Supp. 437; Diamond v. Ageney of Canadian Car \& Foundry Co., Ltd. (1918), 168 N. Y. Supp. 695.

Section 43.-(Place, Time and Manner of Delivery.)-(1) Whether it is for the buyer to take possession of the goods or for the seller to send them to the buyer is a question depending in each case on the contract, express or implied, between the parties. Apart from any such contract, express or implied, or usage of trade to the contrary, the place of delivery is the seller's place of business if he have one, and if not his residence; 
but in case of a contract to sell or a sale of specific goods, which to the knowledge of the parties when the contract or the sale was made were in some other place, then that place is the place of delivery.

(2) Where by a contract to sell or a sale the seller is bound to send the goods to the buyer, but no time for sending them is fixed, the seller is bound to send them within a reasonable time.

(3) Where the goods at the time of sale are in the possession of a third person, the seller has not fulfilled his obligation to deliver to the buyer unless and until such third person acknowledges to the buyer that he holds the goods on the buyer's behalf; but as against all others than the seller the buyer shall be re garded as having received delivery from the time when such third person first has notice of the sale. Nothing in this section, however shall affect the operation of the issue or transfer of any document of title to goods.

(4) Demand or tender of delivery may be treated as ineffectual unless made at a reasonable hour. What is a reasonable hour is a question of fact.

(5) Unless otherwise agreed, the expenses of and incidental to putting the goods into a deliverable state must be borne by the seller.

Connecticut.--Rochester Distilling Co. v. Geloso (1917), 101 Atl. 500; Harlow v. Parsons Lumber \& Hardware Co. (1909), 81 Conn. 57, 71 Atl. 734; Loomis v. Norman Printer's Supply Co. (1908), 81 Conn. 343, 71 Atl. 358; Bridgeport Hardware Mfg. Co. v. Bounial (1915), 93 Atl. 674.

Massachusetts. - New England Concrete Cons. Co. v. Shepard \& Morse Lumber Co. (1915), $107 \mathrm{~N}$. E. 917; Barrie v. Quinby (1910), 206, 258, 92 N. E. 451.

Michigan.-Schneider v. C. H. Little Co. (1915), 151 N. W. 587. Minnesota.-Krause v. Union Match Co. (1919), 170 N. W. 848. New Jersey.-Gruen v. Geo. A.
Ohl \& Co (1911), 81 N. J. L. 626, 80 Atl. 547; Dordoni v. Hughes (1912), 83 N. J. L. 355, 85 Atl. 353, Stephens-Adamson Mfg. Co. v. Bigelow (1914), 86 N. J. L. 707, 92 Atl. 398.

New York.-Am. Law Co. v. Ball (1917), 165 N. Y. Snpp. 925; Bemzweig v. Hyman Lewin Co., Inc. (1918), 172 N. Y. Supp. 437; DeHaff v. Aspegren (1916), 161 N. Y. Supp. 53; Weiss v. Meyer (1916), 95 Misc. 145, 159 N. Y. Supp. 211; Dressler Beard Mfg. Co. v. Winter Garden Co. (1916), 158 N. Y. Supp. 875; Federal Terra Cotta Co. v. Patterton Bros. (1916), 159 N. Y. Supp. 121; Michlowitz v. Krenik (1918), 170 N. Y. Supp. 923; Riegel 
Sack Co. v. Tidewater Cement Co. (1916), 158 N. Y. Supp. 954; Velleman $\nabla$. Sidney Blementhal Co. (1916), 158 N. Y. Supp. 393; Weinberg v. Gash (1916), 94 Misc. Rep. 303, 158 N. Y. Supp. 179; Schaffer v. Vandewater Co. (1914), 160 App. Div. 803, 145 N. Y. Supp. 769; Peck Bros. \& Co. v. Barman Plumbing, Heating \& Contracting Co. (1918), 170 N. Y. Supp. 664; Geo. Lenders \& Co. v. Fahlberg Saccharine Works (1914), 150 N. Y. Supp. 635; Schiff v. Winton Motor Car Co. (1915), 153 N. Y. Supp. 961.

Pennsylvania.- Warner Gear Co. v. Bergdoll (1916), $253 \mathrm{~Pa} .164,97$ Atl. 1085.

Rhode Island. - National Cash Register Co. v. Brainson (1915), 93 Atl. 645 .

Wisconsin.-Gehl v. Peycke Bras. Commission Co. (1914), 158 Wis. 494, 149 N. W. 275.

United States.-Hirsch v. Georgia Iron \& Coal Co. (1909) (Ohio), 169 Fed. 578, 95 C. C. A. 76; Pennsylvania Sugar Co. v. CzarnikowRionda Co. (1917), 158 C. C. A. 201, 245 Fed. 913; Weir v. Lang (1918) (U. S. C. C. A.. N. Y.), 252 Fed. 575.

Section 44.-(Delivery of Wrong Quantity.)-(1) Where the seller delivers to the buyer a quantity of goods less than he contracted to sell, the buyer may reject them, but if the buyer accepts or retains the goods so delivered, knowing that the seller is not going to perform the contract in full, he must pay for them at the contract rate. If, however, the buyer has used or disposed of the goods delivered before he knows that the seller is not going to perform his contract in full, the buyer shall not be liable for more than the fair value to him of the goods so received.

(2) Where the seller delivers to the buyer a quantity of goods larger than he contracted to sell, the buyer may accept the goods included in the contract and reject the rest, or he may reject the whole. If the buyer accepts the whole of the goods so delivered he must pay for them at the contract rate.

(3) Where the seller delivers to the buyer the goods he contracted to sell mixed with goods of a different description not included in the contract, the buyer may accept the goods which are in accordance with the contract and reject the rest, or he may reject the whole.

(4) The provisions of this section are subject to any usage of trade, special agreement, or course of dealing between the parties. 
Arizona.-Boyd v. Second Hand Supply Co. (1912), 14 Ariz. 36, 123 Pac. 619.

Massachusetts-Rock Glen Salt Co. v. Segal (1917), 118 N. E. 239.

New York.-Bloom v. Arthur Walker \& Co. (1918), 175 N. Y. Supp. 150; Doxey v. Coates, Bennett \& Reidenbach (1918), $168 \mathrm{~N}$. Y. Supp. 76; Pancoast v. Industrial Glass Co. (1911), 148 App. Div. 473, 132 N. Y. Supp. 821; Seaboard Brick Co. v. Bonacci (1912), 153 App. Div. 43, 137 N. Y. Supp. 1026; Hall v. New Hartford Canning Co.
(1912), 153 App. Div. 562, $138 \mathrm{~N}$. Y. Supp. 866; Kroshman v. Crawford-Plummer Co. (1914), $150 \mathrm{~N}$. Y. Supp. 886; Galland v. Kass (1915), 152 N. Y. Supp. 1074.

Ohio.- List \& Son Co. v. Chase (1909), 80 Ohio St. 42, 88 N. E. 120.

United States.- Snyder v. Rosenbaum (1909), 215 U. S. 261, 30 Sup. Ct. Rep. 73, 54 Law Ed. 186; Munroe v. Trenton Oil Cloth \& Linoleum Co. (1913) (N. Y.), 206 Fed. 456, 124 C. C. A. 362.

Section 45.-(Delivery in Instalments.) - (1) Unless otherwise agreed, the buyer of goods is not bound to accept delivery, thereof by instalments.

(2) Where there is a contract to sell goods to be delivered by stated instalments, which are to be separately paid for, and the seller makes defective deliveries in respect of one or more instalments, or the buyer neglects or refuses to take delivery of or any for one or more instalments, it depends in each case on the terms of the contract and the circumstances of the case, whether the breach of contract is so material as to justify the injured party in refusing to proceed further and suing for damages for breach of the entire contract, or whether the breach is severable, giving rise to a claim for compensation, but not to a right to treat the whole contract as broken.

Connecticut.- Home Pattern Co. v. Mertz Co. (1914), 88 Conn. 22.

Massachusetts.-Cumberland Glass Mfg. Co. v. Wheaton (1911), 208 Mass. 425, 94 N. E. 803; Haynes v. Temple (1908), 198 Mass. 372; Craig v. Lane (1912), 212 Mass. 195,98 N. E. 685; Bullard v. Eames (1914), 106 N. E. 584.

New York.-Thos. Gordon Matting Co. v. Bartels Brewing Co. (1912), 206 N. Y. 528, 100 N.
E. 461; Marrone v. Engel (1918 171 N. Y. Supp. 47; Hoffman Bros. Produce Co. v. I. V. Horn Co. (1916), 158 N. Y. Supp. 401; Hadficld v. Calter (1918), 103 Misc. Rep. 474, 170 N. Y. Supp. 643; McDowell v. Starobin Electrical Supply Co. (1919), 176 N. Y. Supp. 118; R. \& R. Handkerchief Co. v. Dix (1919), 176 N. Y. Supp. 36; Columbia Wax Products Co. v. Indian Refining Co. (1918), 184 App. Div. 
250, 170 N. Y. Supp. 820; Rudolf Saenger Co. v. Giant Silk Manufacturers (1918), 170 N. Y. Supp. 390; De Vivo v. Gallerani (1919), 174 N. Y. Supp. 13; Helgar Corp. v. Warner's Features (1918), $222 \mathrm{~N}$. Y. 449, 119 N. E. 113; Interboro Brew. ing $\mathrm{Co}$. v. Independent C. Ice $\mathrm{Co}$. (1915), 93 Misc. 24, 156 N. Y. Supp. 410.
Ohio.-Petersburg Fire Brick \& Tile Co. v. Am. Clay Mach. Co. (1914) (Ohio), 106 N. E. 33.

Pennsylvania.- Poland Coal Co. v. Rogers (1918), $260 \mathrm{~Pa} .118,103$ Atl. 559.

United States. - Alwart Bros. Coal Co. v. Royal Colliery Co. (1916), 148 C. C. A. 36, 234 Fed. 20.

Section 46.--(Delivery to a Carrier on Behalf of the Bayer.) -(1) Where, in pursuance of a contract to sell or a sale, the seller is authorized or required to send the goods to the buyer, delivery of the goods to a carrier, whether named by the buyer or not, for the purpose of transmission to the buyer is deemed to be a delivery of the goods to the buyer, except in the cases provided for in section 19 , Rule 5 , or unless a contrary intent appears.

(2) Unless otherwise authorized by the buyer, the seller must make such contract with the carrier on behalf of the buyer as may be reasonable, having regard to the nature of the goods and the other circumstances of the case. If the seller omit so to do, and the goods are lost or damaged in course of transit, the buyer may decline to treat the delivery to the carrier as a delivery to himself, or may hold the seller responsible in damages.

(3) Unless otherwise agreed, where goods are sent by the seller to the buyer under circumstances in which the seller knows or ought to know that it is usual to insure, the seller must give such notice to the buyer as may enable him to insure them during their transit, and, if the seller fails to do so, the goods shall be deemed to be at his risk during such transit.

Mississippi.- Merchants \& Mfg. Bk. of Ellisville v. Philip J. Toomer Lumber Co. (1917), 115 Miss. 647, 76 So. 565 .

New York,-Glanzer v. J. K. Armsby Co. (1917). 100 Misc. Rep. 476. 165 N. Y. Supp. 1006; Miller -. Harvey (1918), 116 N. E. 781,
221 N. Y. 54; (1913), 144 N. Y. Supp. 624, 83 Misc. 59; Woodland Lumber \& Mfg. Co. v. Barnett (1918), 173 N. Y. Supp. 4.

Massachusetts-Bay State Paper Co. v. Duggan (1913), 214 Mass. 166,100 N. E. 1083. 
United States.-United States v. R. P. Andrews \& Co. (1907), 207
U. S. 229, 28 Sup. Ct. Rep. 100, 52 Law Ed. 185.

Section 47.-(Right to Examine the Goods.) - (1) Where goods are delivered to the buyer, which he has not previously examined, he is not deemed to have accepted them unless and until he has had a reasonable opportunity of examining them for the purpose of ascertaining whether they are in conformity with the contract.

(2) Unless otherwise agreed, when the seller tenders delivery of goods to the buyer, he is bound, on request, to afford the buyer a reasonable opportunity of examining the goods for the purpose of ascertaining whether they are in conformity with the contract.

(3) Where goods are delivered to a carrier by the seller, in accordance with an order from or agreement with the buyer, upon the terms that the goods shall not be delivered by the carrier to the buyer until he has paid the price, whether such terms are indicated by marking the goods with the words "collect on delivery," or otherwise, the buyer is not entitled to examine the goods before payment of the price in the absence of agreement permitting such examinations.

Connecticut.-Urbansky v. Kutrinsky (1912), 86 Conn. 22, 84 Atl. 317; Bridgeport Hardware Co. v. Bouniol (1915), 93 Atl. 674; Emery Thompson Machine \& Supply Co. v. Graves (1916), 98 Atl. 331.

Massachusetts.-Garvan v. N. Y. C. \& H. R. R. R. Co. (1911), 210 Mass. 275, 96 N. E. 717; Mosler Safe Co. v. Thore (1914), 217 Mass. 153,104 N. E. 574.

Minnesota.-J. L. Ownes Co. v. O'Keefe (1918), 170 N. W. 204.

New Jersey.- Paul Gerli \& Co. v. Mistletoe Silk Mills (1910), 80 N. J. L. 128,76 Atl. 335 .

New York.-Imperial Products
Co. v. Capital Chemical Co. (1919), 176 N. Y. Supp. 49; Ford v. Ford Motor Co. (1917), 165 N. Y. Supp. 1001 ; Strauss v. Chas. H. Herr Dry Goods Co. (1917), 164 N. Y. Supp. 77 ; Imperial Products Co. v. Capital Chemical Co. (1918), 170 N. Y. Supp. 397; Greef Engineering \& Mfg. Co. v. Scourvene Mfg. Co. (1918), 169 N. Y. Supp. 550; Northern Grain Co. v. Wimer (1915), 158 A. D. 95, 153 N. Y. Supp. 723.

United States.-Phoenix Iron \& Steel Co. v. Wilkoff Co. (1918). (U. S. C. C. A., Ohio), 253 Fed. 165; Delaware, L. \& W. R. R. Co. v. United States (1913), 231 U. S. 363, 34 Sup. Ct. Rep. 65, 58 Law Ed. 269. 
Wisconsin.-Barta v. Blahnik Wayne Printing Co. v. Hurley(1919) (Wis.), 170 N. W. 281; Ft. Reilly Co. (1916), 157 N. W. 773.

Section 48.-(What Constitutes Acceptance.) - The buyer is deemed to have accepted the goods when he intimates to the seller that he has accepted them, or when the goods have been delivered to him, and he does any act in relation to them which is inconsistent with the ownership of the seller, or when, after the lapse of a reasonable time, he retains the goods without intimating to the seller that he has rejected them.

Maryland.- Loeblein v. Clements (1917), 130 Md. 627, 101 Atl. 693.

Massachusetts.-Puffer Mfg. Co. v. Krum (1911), 210 Mass. 211; Am. Steam Gauge \& Valve Co. v. Mechanics Iron Foundry Co. (1913), 214 Mass. 299, 101 N. E. 376.

Michigan.-Emert v. Nibblink (1914), 179 Mich. 335, 146 N.W. 120; Farmers Handy Wagon Co. v. Newcomb (1916), 159 N. W. 152; Bayer v. Winton Motor Car Co. (1916), 160 N. W. 642.

Minnesota.- Encycjopedia Press, Inc. v. Harris (1918), 167 N. W. 362.

Mississippi.-F. O. Evans Piano Co. v. Tully (1917), 76 So. 833.

New Jersey.- Paul Gerli \& Co. v. Mistletoe Silk Mills (1910), $80 \mathrm{~N}$. J. L. 128, 76 Atl. 335; Otis Elevator Co. v. Headley (1911), 81 N. J. L. 173, 80 Atl. 109; Paul Gerld \& Co. v. Mistletoe Silk Mills (1912), 83 N. J. L. 7, 84 Atl. 1065; Hayes v. Kluge (1914), 86 N. J. L. 657, 92 Atl. 358; Wurlitzer Mfg. Co. v. United R. \& A. Co. (1915), 87 N. J. I. 656 .

New York.- Strauss v. Chas. H. Heer Dry Goods Co. (1917), 164 N. Y. Supp. 77; Michlowitz v. Krenik (1918), 170 N. Y. Supp. 923;
White v. Schweitzer (1917), $221 \mathrm{~N}$. Y. 461, 117 N. E. 941; Beilman v. Goldstein (1918), 172 N. Y. Supp. 334; Friedman v. Ettenson (1918), 169 N. Y. Supp. 67; L. D. Powell จ. Bernstein (1917), 164 N. Y. Supp. 795; Reichenthal v. Glockner (1916), 158 N. Y. Supp. 699; Greenberg v. Atlantic Comb Works (1917), 165 N. Y. Supp. 1004; Mason v. Valentine Souvenir Co. (1918), 168 N. Y. Supp. 159; White v. Schweitzer (1911), 147 App. Div. 544, 132 N. Y. Supp. 644; Silberstein v. Blum (1915), 167 App. Div. 660, 153 N. Y. Supp. 34; Salomon v. Olpin (1915), 154 N. Y. Supp. 204; Stein v. LaPlante (1918), 169 N. Y. Supp. 429.

Pennsylvania.- Hoffman v. Adair (1917), $67 \mathrm{~Pa}$. Super. Ct. 164.

Wisconsin.-Ohio Electric Co. v. Wisconsin-Minnesota Lt. \& Power Co. (1915), 155 N. W. 112; J. L. Owens Co. v. Whitcomb (1916), 160 N. W. 161 ; Ft. Wayne Printing Co. v. Hurley-Reilly Co. (1916), $157 \mathrm{~N}$. W 773 ; J. B. Bradford Piano Co. v. Beal (1917), 164 N. W. 822 .

United States.- Marmet Coal Co. v. People's Coal Co. (1915), 226. Fed. 646. 
Section 49.- (Acceptance Does Not Bar Action for Damages.) - In the absence of express or implied agreement of the parties, acceptance of the goods by the buyer shall not discharge the seller from liability in damages or other legal remedy for breach of any promise or warranty in the contract to sell or the sale. But, if, after acceptance of the goods, the buyer fails to give notice to the seller of the breach of any promise or warranty within a reasonable time after the buyer knows, or ought to know of such breach, the seller shall not be liable therefor.

Maryland.- Louis Eckels \&. Sons Ice Mfg. Co. v. Cornell Economizer Co. (1912), 119 Md. 107, 86 Atl. 38.

Massachusetts.-Borden v. Fine (1912), 212 Mass. 425, 98 N. E. 1073; Gascoigne v. Cary Brick Co. (1914), 217 Mass. 302, 104 N. E. 734; Trimount Lumber Co. v. Murdough (1918), 229 Mass. 254, 118 N. E. 280 .

Michigan.-Wolverine Spice Co. v. Tallas (1914) (Mich.), $148 \mathrm{~N}$. W. - 701.

New Jersey.-Hayes v. Kluge (1914), 86 N. J. L. 657, 92 Atl. 358.

New York.- Mason v. Valentine Souvenir Co. (1918), 168 N. Y. Supp. 159; Silberstein v. Blum (1915), 167 App. Div. 660, 153 N. Y. Supp. 34; Salomon v. Olpin (1915), 154 N. Y. Supp. 204; Interboro Brewing Co. v. Independent C. Ice Co. (1915), 93 Misc. 24, 155 N. Y. Supp. 410; Maggiros v. Eoson Bros. (1917), 164 N. Y. Supp. 377; Ferguson v. Netter (1912), $204 \mathrm{~N}$. Y. 505,98 N. E. 16 ; Condict v. Onward Const. Co. (1913), 210 N. Y. 88,103 N. E. 886; Altkrug v. Willism Whitman Co., Inc. (1919), 173 N Y. Supp. 669; Salsberg v. Spero (1919), 106 Misc. Rep. 436, $175 \mathrm{~N}$. Y. Supp. 839 ; Stone r. Beirn (1919),
176 N. Y. Supp. 25; Kaufman v. Levy (1918), 102 Misc. Rep. 689, 169 N. Y. Supp. 454 ; Hesse v. Gude Bros. Kieffer Co. (1918), 170 N. Y. Supp. 211; Sempson v. J. I. Case Threshing Mach. Co. (1918), $170 \mathrm{~N}$. Y. Supp. 166; Standard Milling Co. v. DePass (1913), 154 App. Div. 525, 139 N. Y. Supp. 611; Powell v. New England Cotton Yarn Co. (1913), 154 App. Div. 875, 139 N. Y. Supp. 569; Rich v. Minolfi (1913), 157 App. Div. 783, $142 \mathrm{~N}$. Y. Supp. 771; Nelson Co. v. Silver (1913), 145 N. Y. Supp. 124, 160 App. Div. 445; Buffalo Wholesale Hardware Co. v. Hodgeboom (1915), 152 N. Y. Supp. 900; Marx v. Locomobile Co. (1913), 144 N. Y. Supp. 937, 82 Misc. Rep. 468; English Lumber Co. v. Smith (1916), 157 N. Y. Supp. 233; R. Young Bros. Feed Co. v. Seymour (1912), 151 App. Div. 549, 136 N. Y. Supp. 80; Kugelman v. Ritter (1915). $152 \mathrm{~N}$. Y. Supp. 1027; Regina Co. v. Gately Furniture Co. (1915), 154 N. Y. Supp. 888; Penser v. Marsh (1915), 167 N. Y. App. 604; Rothenberg v. Shapiro (1913), 140 N. Y. Supp. 148; Shearer Co., G. B. v. Kakoulis (1913), 144 N. Y. Supp. 1077.

United States.-H. Koehler \& Co. v. York Mfg. Co. (1912) (N. Y.), 193 Fed. 981, 133 C. C. A. 601. 
Wisconsin.- Oscar Smith \& Sons (1912), 150 Wis. 528, $137 \cdot$ N. W. Co. v. Janesville Batting Mills Co. 966.

Section 50.-(Buyer Is Not Bound to Return Goods Wrongly Delivered.) - Unless otherwise agreed, where goods are delivered to the buyer, and he refuses to accept them, having the right so to do, he is not bound to return them to the seller, but it is sufticient if he notifies the seller that he refuses to accept them.

Section 51.-(Buyer's Liability for Failing to Accept Delivery.) - When the seller is ready and willing to deliver the goods, and requests the buyer to take delivery, and the buyer does not within a reasonable time after such request take dolivery of the goods, he is liable to the seller for any loss occasioned by his neglect or refusal to take delivery, and also for a reasonable charge for the care and custody of the goods. If the neglect or refusal of the buyer to take delivery amounts to a repudiation or breach of the entire contract, the seller shall have the right against the goods and on the contract hereinafter provided in favor of the seller when the buyer is in default.

Connecticut.- House Cold Tire Setter Co. v. Ingraham (1910), 83 Conn. 31, 75 Atl. 80 .

Massachusetts.-Barrie v. Quinby (1910), 206 Mass. 258, 92 N. E.
New York.-Gourd v. Healy (1912), 206 N. Y. 42399 N. E. 1099; Wester v. Casein Co. (1912), 206 N. Y. 506, 100 N. E. 488. 451. 


\section{PART IV.}

RIGHTS OF UNPAID SELIER AGAINST THE GOODS.

Section 52.-(Definition of Unpaid Seller.) - (1) The seller of goods is deemed to be an unpaid seller within the meaning of this act:

(a) When the whole of the price has not been paid or tendered.

(b) When a bill of exchange or other negotiable instrument has been received as conditional payment, and the condition on which it was received has been broken by reason of the dishonor of the instrument, the insolvency of the buyer, or otherwise.

(2) In this part of this act the term "seller" includes an agent of the seller to whom the bill of lading has been indorsed, or a consignor or agent who has himself paid, or is directly responsible for, the price, or any other person who is in the position of a seller.

New York.-Newman v. United

Distillers Co., Inc. (1919), $175 \mathrm{~N}$.

Y. Supp. 176.

Section 53.-(Remedies of an Unpaid Seller.)-(1) Subject to the provisions of this act, notwithstanding that the property in the goods may have passed to the buyer, the unpaid seller of goods, as such, has:

(a) A lien on the goods or right to retain them for the price while he is in possession of them;

(b) In case of the insolvency of the buyer, a right of stopping the goods in transit after he has parted with the possession of them;

(c) A right of resale as limited by this act;

(d) A right to rescind the sale as limited by this act.

(2) Where the property in goods has not passed to the buyer, the unpaid seller has, in addition to his other remedies, a right of withholding delivery similar to and coextensive with his rights of lien and stoppage in transitu where the property has passed to the buyer. 
New York.- Northern Grain Co. Importing Co. (1915), 151 N. Y. v. Wiffer (1918), 223 N. Y. 169, Supp. 994.

119 N. E. 393 ; Newman v. United Distillers Co., Inc. (1919), $175 \mathrm{~N}$. Y. Supp. 176; Capuano v. Italian

Connecticut.-Urbansky v. Kutinsky (1912), 86 Conn. 22, 84 Atl. 317.

\section{UNPAID SELLER'S LIEN.}

Section 54.-(When Right of Lien May Be Exercised.)(1) Subject to the provisions of this act, the unpaid seller of goods who is in possession of them is entitled to retain possession of them until payment or tender of the price in the following cases namely:

(a) Where the goods have been sold without any stipulation as to credit;

(b) Where the goods have been sold on credit, but the term of credit has expired;

(c) Where the buyer becomes insolvent.

(2) The seller may exercise his right of lien notwithstanding that he is in possession of the goods as agent or bailee for the buyer.

Connecticut.-Urbansky v. Ku- \& Co. (1912), 212 Mass. 186, 98 N. tinsky (1912), 86 Conn. 22, 84 Atl. 317.

E. 798 .

Massachusetts. - Norfolk Hard-

New York.- Rummell v. Blanchwood Co. v. N. Y. C. \& H. R. R. R. Co. (1909), 202 Mass. 160, 88 N. E.

664; Wright v. Frank A. Andrews ard $(1915), 216$ N. Y. $348,110 \mathrm{~N}$. E. 765; Newman v. United Distillers, Inc. (1919), 175 N. Y. Supp. 176.

Section 55.-(Lien After Part Delivery.)-Where an unpaid seller has made part delivery of the goods, he may exercise his right of lien on the remainder, unless such part delivery has been made under such circumstances as to show an intent to waice the lien or right of retention.

New York.-Capuano v. Italian Importing Co. (1915), 151 N. Y. Supp. 994.

Section 56.-(When Lien Is Lost.) - (1) The unpaid seller of goods loses his lien thereon: 
(a) When he delivers the goods to a carrier or other bailee for the purpose of transmission to the buyer without reserving the property in the goods or the right to the possession thereof:

(b) When the buyer or his agent lawfully obtains possession of the goods;

(c) By waiver thereof.

(2) The unpaid seller of goods, having a lien thereon, does not lose his lien by reason only that he has obtained judgment or decree for the price of the goods.

Connecticut.-Urbansky v. Ku- Supp. 994; Rummell v. Blanchard tinsky (1912), 86 Conn. 22, 84 Atl. (1915), 153 N. Y. Supp. 159; North317.

New York-Capuano v. Italian N. Y. Supp. 723. Importing Co. (1915), 151 N. Y.

\section{STOPPAGE IN TRANSITU.}

Section 57.-(Seller May Stop Groods on Buyer's Insolvency.) - Subject to the provisions of this act, when the buyer of goods is or becomes insolvent, the unpaid seller who has parted with the possession of the goods has the right of stopping them in transit, that is to say, he may resume possession of the goods at any time while they are in transit, and he will then become entitled to the same rights in regard to the goods as he would have had if he had never parted with the possession.

Arizona.- Boyd v. Second Hand Supply Co. (1912), 14 Ariz. 36, 123 Pac. 619.

Massachusetts.-Coleman 'v. N. Y., N. H. \& H. R. R. Co. (1913), 215 Mass. 45,102 N. E. 92.
New York.-Gass v. Sonthern Pacific Co. (1912), 152 App. Div. 412, 137 N. Y. Supp. 261; Northern Grain Co. v. Wiffler (1915), $153 \mathrm{~N}$. Y. Supp. 723.

Section 58.-(When Goods Are in Transit.)-(1) Goods are in transit within the meaning of section 57 :

(a) From the time when they are delivered to a carrier by land or water, or other bailee for the purpose of transmission to the buyer, until the buyer, or his agent in that behalf, takes delivery of them from such carrier or other bailee;

(b) If the goods are rejected by the buyer, and the carrier 
or other bailee continues in possession of them, even if the seller has refused to receive them back.

(2) Goods are no longer in transit within the meaning of section 57 :

(a) If the buyer, or his agent in that behalf, obtains delivery of the goods before their arrival at the appointed destination;

(b) If, after the arrival of the goods at the appointed destination, the carrier or other bailee acknowledges to the buyer or his agent that he holds on his behalf and continues in possassion of them as bailee for the buyer or his agent; and it is immaterial that a further destination for the goods may have been indicated by the buyer;

(c) If the carrier or other bailee wrongfully refuses to deliver the goods to the buyer or his agent in that behalf.

(3) If goods are delivered to a ship ehartered by the buyer, it is a question depending on the eircumstances of the particular case, whether they are in the possession of the master as a carrier or as agent of the buyer.

(4) If part delivery of the goods has been made to the buyer, or his agent in that behalf, the remainder of the goods may be stopped in transitu, unless such part delivery has been made nnder such circumstances as to show an agreement with the buyer to give up possession of the whole of the goods.

New York.- Northern Grain Co. wood Co. v. N. Y. C. \& H. R. R. v. Wiffler (1915), 153 N. Y. Supp. R. Co. (1909), 202 Mass. 160, 88 723; Rummell v. Blanchard (1915), 216 N. Y. 348,110 N. E. 765.

Massachusetts. - Norfolk Hard-

N. E. 664 ; Coleman v. N. Y., N. H. \& H. R. R. R. Co. (1913), 215 Mass. 45,102 N E. 92.

Section 59.-(Ways of Exercising the Right to Stop.)-(1) The unpaid seller may exercise his right of stoppage in transitu either by obtaining actual possession of the goods or by giving notice of his claim to the carrier or other bailee in whose possession the goods are. Such notice may be given either to the person in actual possession of the goods or to his principal. In the latter case the notice, to be effectual, must be given at such time and under such circumstances that the prineipal, by the exercise of reasonable diligence, may prevent a delivery to the buyer. 
(2) When notice of stoppage in transitu is given by the seller to the carrier, or other bailee in possession of the goods, he must redeliver the goods to, or according to the directions of, the seller. The expenses of such delivery must be borne by the seller. If, however, a negotiable document of title representing the goods has been issued by the carrier or other bailee, he shall not be obliged to deliver or justified in delivering the goods to the seller unless such document is first surrendered for cancellation.

New York.- Northern Grain Co.

v. Wiffler (1915), 153 N. Y. Supp.

723.

RELEASE BY THE SELLER.

Section 60.-(When and How Resale May Be Made.)-(1) Where the goods are of a perishable nature, or where the seller expressly reserves the right of resale in case the buyer should make default, or where the buyer has been in default in the payment of the price an unreasonable time, an unpaid seller having a right of lien or having stopped the goods in transitu may resell the goods. He shall not thereafter be liable to the original buyer upon the contract to sell or the sale or for any profit made by such resale, but may recover from the buyer damages for any loss occasioned by the breach of the contract or the sale.

(2) Where a resale is made, as authorized in this section, the buyer acquires a good title as against the original buyer.

(3) It is not essential to the validity of a resale that notice of an intention to resell the goods be given by the seller to the original buyer. But where the right to resell is not based on the perishable nature of the goods or upon an express provision of the contract or the sale, the giving or failure to give such notice shall be relevant in any issue involving the question whether the buyer had been in default an unreasonable time before the resale was made.

(4) It is not essential to the validity of a resale that notice of the time arid place of such resale should be given br the seller to the original buyer.

(5) The seller is bound to exereise reasonable care and judg- 
ment in making a resale, and subject to this requirement may make a resalo either by public or private sale.

Connecticut.-Urbansky v. Ku- ster (1914), 218 Mass. 367, $103 \mathrm{~N}$. tinsky (1912), 86 Conn. 22, 84 Atl. E. 942.

317.

New York.-Storm v. Rosentha]

Maryland.-Dudley A. Tyng \& . (1913), 156 App. Div. 544, 141 N. Co. v. Woodward (1913), 121 Md. 422, 88 Atl. 243; Woodward v. Dudley A. Tyng Co. (1914), $123 \mathrm{Md}$. 98, 91 Atl. 166. Y. Supp. 339.

Wisconsin.- Hauster v. Marty (1914), 156 Wis. 208, 145 N. W. 775.

Massachusetts.-Putman v. Bol-

\section{RESCISSION BY THE SELLER.}

Section 61.-(When and How the Seller May Rescind the Sale.) -(1) An unpaid seller having a right of lien or having stopped the goods in transitu, may rescind the transfer of title and resume the property in the goods, where he expressly reserved the right to do so in case the buyer should make default, or where the buyer has been in default in the payment of the price an unreasonable time. The seller shall not thereafter be liable to the buyer upon the contract to sell or the sale, but may recover from the buyer damages for any loss occasioned by the breach of the contract or the sale.

(2) The transfer of title shall not be held to have been rescinded by an unpaid seller until he has manifested by notice to the buyer or by some other overt act an intention to rescind. It is not necessary that such overt act should be communicated to the buyer, but the giving or failure to give notice to the buyer of the intention to rescind shall be relevant in any issue involving the question whether the buyer had been in default an unreasonable time before the right of rescission was asserted.

Maryland.- Dudley A. Tyng \& Co. v. Woodward (1913), 121 Md. 422, 88 Atl. 243.

Massachusetts.-Wright v. Frank A. Andrews Co. (1912), 212 Mass. 186, 98 N. E. 798. New York.-Ullman v. C. C. N. W. 783.
Wormer Machinery Co. (1913), 210 N. Y. 41, 103 N. E. 766; Capuano v. Italian Importing Co. (1915), 151 N. Y. Supp. 994.

Wisconsin.-Berry v. Wadhams Oil Co. (1914), 156 Wis. 588, 146 
Section 62.- (Effect of Sale of Goods Subject to Lien or Stoppage in Transitu.) - Subject to the provisions of this act, the unpaid seller's right of lien or stoppage in transitu is not affected by any sale, or other disposition of the goods which the buyer may have made, unless the seller has assented thereto.

If, however, a negotiable document of title has been issued for goods, no seller's lien or right of stoppage in transitu shall defeat the right of any purchaser for value in good faith, to whom such document has been negotiated, whether such negotiation be prior or subsequent to the notification to the carrier, or other bailee who issued such document, of the seller's claim to a lien or right of stoppage in transitu.

Connecticut.-Urbansky v. Kutinsky (1912), 86 Conn. 22. .

New York.- Northern Grain Co. v. Wiffler (1915), 153 N. Y. Supp. 723; Rummell v. Branchard (1015), 153 N. Y. Supp. 159. 


\section{PART V. \\ ACTIONS FOR BREACH OF THE CONTRACT.}

Remedies of the Seller.

Section 63.-(Actions for the Price.)-(1) Where, under a contract to sell or a sale, the property in the goods has passed to the buyer, and the buyer wrongfully neglects or refuses to pay for the goods according to the terms of the contract or the sale, the seller may maintain an action against him for the price of the goods.

(2) Where, under a contract to sell or a sale, the price is payable on a day certain, irrespective of delivery or of transfer of title, and the buyer wrongfully neglects or refuses to pay such price, the seller may maintain an action for the price, although the property in the goods has not passed, and the goorls have not been appropriated to the contract. But it shall be a defense to such an action that the seller at any time before judgment in such action has manifested an inability to perform the contract or the sale on his part or an intention not to perform it.

(3) Although the property in the goods has not passed, if they cannot readily be resold for a reasonable price, and if the provisions of section 64 (4) are not applicable, the seller may offer to deliver the goods to the buyer, and, if the buyer refuses to receive them, may notify the buyer that the goods are thereafter held by the seller as bailee for the buyer. Thereafter the seller may treat the goods as the buyer's and may maintain an action for the price.

Connecticut. - Illustrated Postal Card \& Novelty Co. v. Holt (1912), 85 Conn. 140, 81 Atl. 1061; Urbansky v. Kutinsky (1912), 83 Conn. 22, 84 Atl. 317; Home Pattern Co. v. W. W. Mertz Co. (1913), 86 Conn. 494, 86 Atl. 19; United Machinery Co. v. Metzel \& Sons (1915), 94 Atl. 356.
Illinois.-Adkins, Young \& Allen Co. v. Rhinelander Paper Co. (1917), 199 Ill. App. 347.

Maryland. - Praeger v. Emer.Brantingham Imp. Co. (1914), 122 Md. 303; Rice v. Dinsmore (1915), 125 Md. 276.

Massachusetts.-Bellows v. McKenzie (1912), 212 Mass, 601; Bur- 
roughs Adding Machine Co. v. Mt. Auburn Cemetery (1914), 217 Mass. 378, 104 N. E. 744; Whitcomb v. Boston Dairy Co. (1914), 218 Mass. 24, 105 N. E. 554.

Minnesota.-J. L. Ownes Co. V. Simbalenks \& Raemka (1918), 167 N. W. 276.

New Jersey.-Bartley Co., R. C. v. Lee (1915) (N. J.), 93 Atl. 78.

New York.-Friedner v. Schenck (1917), 163 N. Y. Supp. 150; Mosher Safe Co. v. Brenner (1917), 100 Misc. 107, 165 N. Y. Supp. 336; Gourd v. Healy (1917), 163 N. Y. Supp. 637; Gourd v. Healy (1912),
206 N. Y. 423, 99 N. E. 1099; Crown Electric Illuminating Co. v. Chiariello (1919), 175 N. Y. Supp. 167; Wyllys Co. v. Nixon (1914), 165 App. Div. 373,150 N. Y. Supp. 944; E. H. Gallagher Trucking Co. v. Hudford Co. of N. Y. (1918), $1 \hat{\text { ô }}$ N. Y. Supp. 83; Mahon v. Profes. sional Bag \& Suit Case Co. (1918), 170 N. Y. Supp. 1058

North Dakota.-Skogness v. Seger (1916), 160 N. W. 508.

Wisconsin.- Haneter v. Marty (1914), 156 Wis. 208, $145 \mathrm{~N}$. W. 775 ; Sanger v. Fuich (1915), 160 Wis. 668 .

Section 64. (Action for Damages for Non-Acceptance of the Goods.) - (1) Where the buyer wrongfully neglects or refuses to accept any pay for the goods, the seller may maintain an action against him for damages for non-acceptance.

(2) The measure of damages is the estimated loss directly and naturally resulting, in the ordinary course of events, from the buyer's breach of contract.

(3) Where there is an available market for the goods in question, the measure of damages is, in the absence of special eircumstances, showing proximate damage of a greater amount. the difference between the contract price and the market or current price at the time or times when the goods ought to have been accepted, or, if no time was fixed for acceptance, then at the time of the refusal to accept.

(4) If, while labor or expense of material amount are necessary on the part of the seller to enable him to fulfill his obligations under the contract to sell or the sale, the buyer repudiates the contract or the sale, or notifies the seller to proceed no further therewith, the buyer shall be liable to the seller for no greater damages than the seller would have suffered if he lid nothing towards carrying out the contract or the sale after receiving notice of the buyer's repudiation or countermand. The profit the seller would have made if the contract or the sale had 
been fully performed shall be considered in estimating such damages.

Connecticut.-Churchill Grain \& Seed Co. v. Newton (1914), 89 Atl. 1121; Progressive Smeltering \& Metal Corporation v. Ansonia Foundry Co. (1919), 105 Atl. 322; Illustrated Postal Card \& Novelty Co. v. Holt (1912), 85 Conn. 140, 81 Atl. 1060; Urbansky v. Kutinsky (1912), s6 Conn. 22, 84 Atl. 317; Home Pattern Co. v. W. W. Mertz Co. (1913), 86 Conn. 494, 86 Atl. 19; United Machinery Co. v. Metzel \& Sons (1915), 94 Atl. 356; Jorkomian v. Russell (1916), 97 Atl. 760 .

Maryland.-Demeck v. Hendley (1912), 117 Md. 458, 84 Atl. 171; Philip Sheet \& Tin Plate Co. v. W. W. Boyer \& Co. (1918) (Md.), 105 At]. 166 .

Massachusetts.- Moffatt v. Davitt (1909), 200 Mass. 452, 86 N. E. 929; Hanson \& Parker v. Witten. berg (1910), 205 Mass. 319, $91 \mathrm{~N}$ E. 3S3; Barrie v. Quimby (1910), 206 Mass. 258, 92 N. E. 451; Cumberland Glass Mfg. Co. v. Wheaton (1911), 208 Mass. 425, 94 N. E. 803; F. W. Stock \& Sons v. Snell (1913), 213 Mass. 449, 100 N. E. 830; Raymond v. Phipps (1913), 215 Mass. 559, 102 N. E. 905; Bullard v. Eames (1914), 106 N. E. 584.

Michigan.-Balcom v. Tribbett (1917), 169 N. W. 261.

New Jersey.-Massman v. Steiger (1910), 79 N. J. L. 442, 75 Atl. 746; Bixler v. Finkle (1913), 85 N. J. L. 77,88 At1. 846 .

New York.-Thos. Gordon Malt- ing Co. v. Battels Brewing Co. (1912), 206 N. Y. 528, 100 N. E. 461; Stroock Plush Co. v. Talcott (1912), 150 App. Div. 343; Crown Electric Illuminating Co. v. Cliariello (1919), 175 N. Y. Supp. 167; Riegel Sack Co. v. Tidewater Cement Co. (1916), 158 N. Y. Supp. 954; Galland v. Kass (1915), 152 N. Y. Supp. 1074; Storm v. Rosenthal (1913), 156 App. Div. 544, 141 N. Y. Supp. 339; Poel v. Brunswick-Collender-Balke Co. (1913), 159 App. Div. 365, 144 N. Y. Supp. 726; Poppenberg v. R. M. Owen \& Co. (1914), 146 N. Y. Supp. 478, 84 Misc. 126; Varley v. Belford (1916), 156 N. Y. Supp. 597; Riegel Sack Co. v. Tidewater Portland Cement Co. (1916), 158 N. Y. Supp. 954, 95 Misc. 202; Young v. Curtis Telephone Co. (1918), 172 N. Y. Supp. 458; Benjamin Harris Co. v. Appelbaum (1918), 172 N. Y. Supp. 709; Mindlin v. Freyberg (1918), 171 N. Y. 250, under Personal Property Law, § 145; Blum v. White Co. (1919), 174 N. Y. Supp. 70.

United States.- Skeele Coal Co. v. Arnold (1912) (N. Y.), 200 Fed. 393, 118 C. C. A. 545; Whitcomb v. Shutz (1914) (N. Y.), 215 Fed. 75, 131 C. C. A. 383; Yates v. Whyel Coke Co. (1915) (Ohio), 221 Fed. 602 .

Wisconsin.-J. B. Bradford Piano Co. v. Hacker (1916), 156 N. W. 140.

Section 65.-(When Seller May Rescind Contract or Sale.) 
-Where the goods have not been delivered to the buyer, and the buyer has repudiated the contract to sell or sale, or has manifested his inability to perform his obligations thereunder, or has committed a material breach thereof, the seller may totally rescind the contract or the sale by giving notice of his election so to do to the buyer.

Connecticut.- Wetkopsky v. New Haven Gaslight Co. (1916), 90 Conn. 286, 96 Atl. 950.

Maryland.-Sullivan v. Boswell (1914), 122 Md. 539, 89 Atl. 940.

New York.-DeVivo v. Gallerani. (1919), 174 N. Y. Supp. 13; Alden Coal Mining Co. v. C. L. Amos Coal Co. (1918), 171 N. Y. Supp. 980; Rubber Trading Co. v. Manhattan
Rubber Mfg. Co. (1917), 221 N. Y. 120, 116 N. E. 789; McDowell v. Starobin Electrical Supply Co. (1919), 176 N. Y. Supp. 118; Wolins v. Conrad (1918), 172 N. Y. Supp. 216.

Wisconsin.-Krause v. Reichel (1918), 167 Wis. 360, 167 N. W. 817.

REMEDIES OF TIIE BUYER.

Section 66.- (Action for Converting or Detaining Goods.) -Where the property in the goods has passed to the buyer and and the seller wrongfully neglects or refuses to deliver the goods, the buyer may maintain any action allowed by law to the owner of goods of similar kind when wrongfully converted or withheld.

Massachusetts.-Brown v. Sallinger (1913), 214 Mass. 245.
New York.-Hetson v. Brolnitsky (1915), 153 N. Y. Supp. 1029.

Section 67.-(Action for Failing to Deliver Goods.)-(1) Where the property in the goods has not passed to the buyer, and the seller wrongfully neglects or refuse sto deliver the goods, the buyer may maintain an action against the seller for damages for non-delivery.

(2) The measure of damages is the loss directly and naturally resulting in the ordinary course of events, from the seller's breach of contract.

(3) Where there is an available market for the goods in question, the measure of damages, in the absence of special circumstanees showing proximate damages of a greater amount, is the difference between the contract price and the market or 
current price of the goods at the time or times when they ought to have been delivered, or, if no time was fixed, then at the time of the refusal to deliver.

Arizona.-Arizona Power Co. v. Racine Sattley Co. (1911), 13 Ariz. 283, 114 Pac. 55s; Consolidated Nat. Bk. of Tucson v. Giraux (1916), 158 Pac. 451; McFadden $\nabla$. Shanley (1914), 141 Pac. 732.

Connecticut.-Banks v. Warner (1912), 85 Conn. 613, 84 Atl. 325.

Maryland.-Dudley A. Tyng \& Co. v. Woodward (1913), 121 Md. 422, 88 Atl. 243; Sullivan v. Boswell (1914), 122 Md. 539, 89 Atl. 940; Westminster Metal \& Foundry Co: v. Coffman (1914), 123 Md. 619, 91 Atl. 716; Davison Chemical Co. of Baltimore County v. Baugh Chemical Co. of Baltimore, Md. (1918), 140 Atl. 404.

Massachusetts.-Brown v. Sallinger (1913), 214 Mass. 245; Ozzola v. Misoline (1917), 225 Mass. 512, 114 N. E. 733 ; Hanson \& Parker v. Wittenberg (1910), 205 Mass. 319, 91 N. E. 383; Chandler Grain \& Milling Co. v. Shea (1913), 213 Mass. 398, 100 N. E. 663.

Michigan.-Sauer v. McClinticMarshall Cons. Co. (1914), 179 Mich. 618,146 N. W. 422.

New Jersey.-Berg v. Rapid Motor Vehicle Co. (1910), 78 N. J. L. 724, 75 Atl. 933; Gruen v. Geo. A. Ohl \& Co. (1911), 81 N. J. L. 626, 80 Atl. 547; Pope v. Ferguson (1912), 82 N. J. L. 566, 83 Atl. 353; Rockwell v. Am. Law Book Co. (1910), 76 Atl. 334 ; U. S. Commercial Co. v. Joachimstahl (1909), 72 Atl. 46.

New York.- Seaboard Brick Co. v. Bonacci (1912), 153 App. Div.
43, 137 N. Y. Supp. 1026; Rice Co. v. Hodd̉man-Youmans Mills (1913), 158 App. Div. 309, 143 N. Y. Supp. 249; Salsberg v. Spero (1919), 106 Misc. Rep. 436, 175 N. Y. Supp. 839; Bonelli v. Pisani (1916), 158 N. Y. Supp. 1033; Seldin v. Golden (1916), 161 N. Y. Supp. 261; Lakner v. Korn (1917), 164 N. Y. Supp. -165; Osterweil v. Consolidated Machinery Co. (1917), 165 N. Y. Supp. 366; Mogilensky v. Abramson (1917), 164 N. Y: Supp. 700; Isaacson v. Crean (1917), 165 N. Y. Supp. 218; Goldstein v. Arkell \& Douglas (1917), 164 N. Y. Supp. 580; Goldfarb v. Campe Corp. (1917), 164 N. Y. Supp. 583; International Paper Co. v. Rockfeller (1914), 161 App. Div. 180, $146 \mathrm{~N}$. Y. Supp. 371; Langstroth v. Turner Cypress Lumber Co. (1914), 162 App. Div. 818, 148 N. Y. Supp. 224; Jersey City Mach. Co. v. Walter H. Foster Co. (1918), 172 N. Y. 121; Schultz v. Glickstein (1918); $168 \mathrm{~N}$. Y. Supp. 490; Samuel Quint Co. v. Goodman (1918), 168 N. Y. Supp. 638; Hencken \& Willenbrock Co. v. Rosenwasser Bros. (1918), $168 \mathrm{~N}$. Y. Supp. 1097; Cramer v. Grand Rapids Show Case Co. (1918), 223 N. Y. 63, 119 N. E. 227; Goldman v. Gartner Ribbon Co. (1919), 175 N. Y. Supp. 795; Fowler v. Gress Mfg. Co. (1916), 158 N. Y. Supp. 524. 94 Misc. 650.

Pennsylvania.- Thomas Ruby v. Ward-Meeham Co. (1918), 104 Atl. 750; Hauptman v. Pa. Working Home for Blind Men of the City ot Philadelphia (1917) (Pa.), 102 Ath. 
142; N. P. Sloan Corp. v. Linton (1918) (Pa.), 103 Atl. 1011.

Rhode Island.-Rhode Island Malleable Works v. O. K. Nut Lock Co. (1918), 103 Atl. 1036.

United States.-H. Kohler \& Co. v. York Mfg. Co. (1912) (N. Y.), 193 Fed. 981, 113 C. C. A. 601; Tri-Bullion smetling \& Development Co. v. Jacobsen (1916), 233 Fed. 646; N. Y. \& Ph. Coal \& Coke
Co. v. Meyersdale Coal Co. (1910), 149 C. C. A. 588, 236 Fed. 536; Sterling Coal Co. v. Silver Spring Bleaching \& S. Co. (1908) (C. C. A., R. I.), 162 Fed. 848; Kaye v. Eddvstone Ammunition Corp. (1918) (U. S. D. C., Pa), 250 Fed. 654.

Wisconsin.- Pope Metals Co. $\mathbf{}$. Sadek (1912), 149 Wis. 394, 135 N. W 85; Birdsong \& Co. v. Marty (1916), 158 N. W. 289.

Section 68.--(Specific Performance.)-Where the seller has broken a contract to deliver specific or ascertained goods, a court having the powers of a court of equity may, if it thinks fit, on the application of the buyer, by its judgment or decree direct that the contract shall be performed specifically, without giving the seller the option of retaining the goods on payment of damages. The judgment or decree may be unconditional, or upon such terms and conditions as to damages, payment of the price and otherwise, as to the court may seem just.

New York.- Halstead v. Schnitz- tounule pahn (1915), 152 N. Y. Supp. 561.

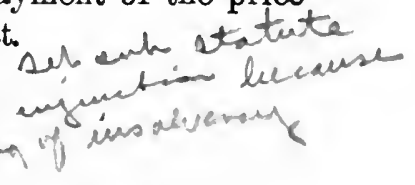

Section 69.-(Remedies for Breach of Warranty.)-(1) Where there is a breach of warranty by the seller, the buyer may, at his election:

(a) Accept or keep the goods and set up against the seller, the breach of warranty by way of recoupment in diminution or extinction of the price;

(b) Accept or kep the goods and maintain an action against the seller for damages for the breach of warranty;

(c) Refuse to accept the goods, if the property therein has not passed, and maintain an action against the seller for damages for the breach of warranty;

(d) Rescind the contract to sell or the sale and refuse to receive the goods, or if the goods have already been received, return them or offer to return them to the seller and recover the price or any part thereof which has been paid.

(2) When the buyer has claimed and been granted a remedy 
in any one of these ways, no other remedy can thereafter be granted.

(3) Where the goods have been delivered to the buyer, he cannot rescind the sale if he knew of the breach of warranty when he accepted the goods, or if he fails to notify the seller within a reasonable time of the election to rescind, or if he fails to return or to offer to return the goods to the seller in substantially as good condition as they were in at the time the property was transferred to the buyer. But if deterioriation or injury of the goods is due to the breach of warranty, such deterioration or injury shall not prevent the buyer from returning or offering: to return the goods to the seller and rescinding the sale.

(4) Where the buyer is entitled to rescind the sale and elects to do so, the buyer shall cease to be liable for the price upon returning or offering to return the goods. If the price or any part thereof has already been paid, the seller shall be liable to repay so much thereof as has been paid, concurrently with the return of the goods, or immediately after an offer to return the goods in exchange for repayment of the price.

(5) Where the buyer is entitled to rescind the sale and elects to do so, if the seller refuses to accept an offer of the buyer to return the goods, the buyer shall thereafter be deemed to hold the goods as bailee for the seller, but subject to a lien to secure the repayment of any portion of the price which has been paid, and with the remedies for the enforcement of such lien allowed to an unpaid seller by section 53.'

(6) The measure of damages for breach of warranty is the loss directly and naturally resulting, in the ordinary course of events, from the breach of warranty.

(7) In the case of breach of warranty of quality, such loss, in the absence of special circumstances showing proximate damage of a greater amount, is the difference between the value of the goods at the time of delivery to the buyer and the value they would have had if they had answered to the warranty.

Connecticut.-Kornblau v. MeDermitt (1916), 90 Conn. 624, 98 Atl. 587; Woodbridge Ice Co. v. Ice Cream Corp. (1909), 81 Conn. 479, 71 Atl. 577; Coast Central Milling
Co. v. Russell Lumber Co. (1914), 89 Atl. 898.

Illinois.- H. D. Smith \& Co. v. Aurora Automatic Machinery Co. 
(1917), 201 Ill. App. 606; Smith v. Whitham (1917), 204 Ill. App. 110.

Maryland.- Enterprise Mfg. Co. v. Oppenheim, Obendorf \& Co. (1911), 114 Md. 368, 79 Atl. 1007; White Auto Co. v. Dorsey (1913), 119 Md. 251, 86 Atl. 617; Greer v. Whalen (1915), 125 Md. 273, 93 Atl. 521; Impervious Products Co. v. Gray (1915), 127 Md. 64, 96 Atl. 1; Ady v. Jenkins (1918) (Md.), 104 Atl. 178.

Massachusetts.-Craig v. Lane (1912), 212 Mass. 195, 98 N. E. 685; Puffer Mfg. Co. v. Krum (1911), 210 Mass. 211; Collins v. Skillings (1916), 224 Mass. 275, 112 N. E. 938, under St. 1908 , c. 237 , § 69, subd. 3; Collins v. Skillings (1916), 112 N. E. 938.

Michigan.-Bayer v. Winton Motor Car Co. (1916), 160 N. W. 642; Patterson v. Gore (1913), 177 Mich. 591, 143 N. W. 643; American Varnish Co. v. Globe Furniture Co. (1918), 165 N. W. 1050.

Minnesota.-Dicudonni v. Arco Co. (1918), 139 Minn. 441, $166 \mathrm{~N}$. W. 1067; Przyblyski v. Pellewski (1918), 169 N. W. 707.

Mississippi. - D. Rosenbaum's Sons v. Davis \& Andrews Co. (1916), 71 So. 388.

New Jersey.- Erwin v. Detwiler (1907), 75 N. J. L. 420, 67 Atl. 932; Lissberger v. Kellogg (1909), 78 N. J. L. 85, 73 Atl. 67; Gerli \& Co. v. Mistletoe Silk Mills (1910), $80 \mathrm{~N}$. J. L. 128, 76 Atl. 335; Brown v. Nevins (1913), 84 N. J. L. 215, 86 Atl. 938; Freider v. Rosen (1914), 147 N. J. L. 442.

New York.-Wilford Hall Laboratories v. Schoenfield (1918), 169. N. Y. Supp. 912; Penser v. Marsh (1915), 167 App. Div. 604; Kauf- man v. Levy (1918), 102 Misc. Rep. 689, 169 N. Y. Supp. 454; Altkrug v. William Whitman Co., Inc. (1919), 173 N. Y. Supp. 669; Penser v. Marsh (1916), 218 N. Y. 505, 113 N. E. 494; Sorgen v. Jaffem (1918), 172 N. Y. Supp. 369 ; Salomon v. Olpin (1915), 154 N. Y. Supp. 204; Greenberg v. Atlantic Comb Works (1917), 165 N. Y. Supp. 1004; Reichenthal v. Glockner (1916), 158 N. Y. Supp. 699; Fowler v. Gress Mfg. Co. (1916), 158 N. Y. Supp. 524; Godfrey Keeler Co. v. Tarrytown Hygenia Ice Co. (1918), 182 N. Y. Supp. 179; Grabe Automatic Washer Co., Inc. v. Thorn (1919), 173 N. Y. Supp. 479; Opler Bros. v. Ceylon Cocoa \& Coffee Co. (1918), 175 N. Y. Supp. 829; Metropolis Woolen Co. v. Nemcof (1919), 174 N. Y. Supp. 649; Tenenbaum v. Cohen (1917), $165 \mathrm{~N}$. Y. Supp. 825; Seligman v. Underwriters' Salvage Co. (1916), $158 \mathrm{~N}$. Y. Supp. 874; Sire v. Wasserman (1917), 164 N. Y. Supp. 826; Levy v. Chonavitz (1917), 163 N. Y. Supp. 658; Posner v. Fink (1917), $163 \mathrm{~N}$. Y. Supp. 1082; Glauzer v. J. K. Armsby (1918), 170 N. Y. Supp. 1055; Meyer v. Rotenberg (1918), 168 N. Y. Supp. 630; Clarke v. Schmidt (1914), 210 N. Y. 211, 104 N. E. 613 ; Moran v. Standard Oil Co. (1914), 211 N. Y. 187, 105 N. E. 217; Stratton v. Spaeth (1911), 146 App. Div. 461, 131 N. Y. Supp. 333 ; Scholpf v. Bender (1911), 147 App. Div. 894, 131 N. Y. Supp. 875; Morse v. Canaswacta Knitting Co. (1912), 154 App. Div. 351, 139 N. Y. Supp. 634; Powell v. New England Cotton Yarn Co. (1913), 154 App. Div. 875, 139 N. Y. Supp. 569; Coble v. Potter (1913), 155 
App. Div. 716, 140 N. Y. Supp. 855; Sturges \& Burns Mfg. Co. v. Am. Separator Co. (1913), 158 App. Div. 63, 142 N. Y. Supp. 697; Interboro Brewing Co. v. Independent Consumers Ice Co. (1913), 144 N. Y. Supp. 820, 83 Misc. 119; Marx v. Locomobile Co. (1913), 144 N. Y. Supp. 937. 82 Misc. 468; Shearer Co., G. B. v. Kakoulis (1913), 144 I. Y. Supp. 1077; Cruver Mfg. Co. v. Spooner (1911), 147 App. Div. 471, 131 N. Y. Supp. 866; Miller v. Zander (1914), 147 N. Y. Supp: 479, 85 Mise. 499; Smith v. Hedges (1915), 152 N. Y. Supp. 95; Silberstein v. Blum (1915), 153 N. Y. Supp. 34; Penser v. Marsh (1915), 153 N. Y. Supp. 381, 167 App. Div. 604; Kennedy \& Sons v. Perkins \& Squire Co. (1915), 154 N. Y. Supp. 101; Levy v. Deltra \& Co. (1915), 154 N. Y. Supp. 176; Regina Co. v. Gately Furniture Co. (1915), 154 N. Y. Supp. 888; Shimel v. Williams Oven Mfg. Co. (1916), 93 Mise. 174, 154 N. Y. Supp. 1060; Schendler v. Sperling (1915), 155 N. Y. Supp.
348; Buffalo Wholesale Hardware Co. v. Hodgeboom (1915), $152 \mathrm{~N}$. Y. Supp. 900; Smith v. Hedges (1915), 155 N. Y. Supp. 934.

North Dakota.- Hagen v. Gresby (1916), 159 N. Y. 2.

Ohio.-Lewistown Foundry \& Machine Co. v. Hartford Stone Co. (1915), 110 N. E. 515; Marmet Coal Co. v. People's Coal Co. (1915), $2^{3}$ Fed. 646; Boviard \& Seyfang Mfg. Co. v. Maitland (1915), 110 N. E. 749 .

Rhode Island.-Descalzi Fruit Co. v. Wm. S. Sweet \& Son (1910), 30 R. I. 320,75 Atl. 308 .

United States.-Independent Harvester Co. v. Tinsman (1918) (U. S. C. C. A., Ill.), 253 Fed. 935 ; Norwood Paper Co. v. Columbia Paper Bag Co. (1911) (Md.), 185 Fed. 454, 107 C. C. A. 524.

Utah.-Summers v. Prood Foundry \& Machine Co. (1919), 178 Pac. 916.

Wisconsin.- Kelsey v. J. W. Rengrose Net Co. (1913), 152 Wis. 499 , 140 N. W. 66.

Section 70.-(Interest and Special Damages.) - Nothing in this act shall affect the right of the buyer or the seller to recover interest or special damages in any case where by law interest or special damages may be recoverable, or to recover money paid where the consideration for the payment of it has failed.

Michigan. - Glann v. White (1914), 181 Mich. 320, 148 N. W. 210.

New York.- Deaeon v. Horn \& Co. (1915), 152 N. Y. Supp. 1073.
Wisconsin.- Burstein v. Phillips (1913), 154 Wis. 591, 143 N. W. 679. 


\section{PART VI.}

\section{INTERPRETATION.}

Section 71.-(Variation of Implied Obligations.)-Where any right, duty or liability would arise under a contract to sell or a sale by implication of law, it may be negatived or varied by express agreement or by the course of dealing between the parties, or by custom, if the custom be such as to bind both parties to the contract or the sale.

Section 72.-(Rights May Be Enforced by Action.)-Where any right, duty or liability is declared by this act, it may, unless otherwise by this act provided, be enforced by action.

Section 73.--(Rule for Cases not Provided for by this Act.) -In any ease not provided for in this act, the rules of law and equity, including the law merchant, and in particular the rules relating to the law of principal and agent and to the effect of fraud, misrepresentation, duress or coercion, mistake, bankruptcy, or other invalidating cause, shall continue to apply to contracts to sell and to sales of goods.

Illinois.-Bixley v. Henson Mississippi-Watson $\nabla$ Herman (1916), 197 Ill. App. 101.

Massachusetts.-Donovan v. Clifford (1917), 114 N. E. 681; Phinney v. Friedman (1916), 113 N. E. 285. (1918), 79 So. 92.

Missouri.-Loose v. Larson (1916), 161 Pac. 514.

North Dakota.-Elliott Supply Co. v. Gwen (1917), 160 N. W. 1002.

Section 74.-(Interpretation Shall Give Effect to Purpose of Uniformity.) - This act shall be so interpreted and construed, as to effectuate its general purpose to make uniform the laws of those states which enact it.

Section 75.-(Provisions Not Applicable to Mortgages.) The provisions of this act relating to contracts to sell and to sales do not apply, unless, so stated, to any transaction in the form of a contract to sell or a sale which is intended to operate by way of mortgage, pledge, charge, or other security. 
Section 76.-(Definitions.)-(1) In this act, unless the context or subject matter otherwise requires:

"Action" includes counterclaim, set-off and suit in equity.

"Buyer" means a person who buys or agrees to buy goods of any legal successor in interest of such person.

"Defendant" includes a plaintiff against whom a right of set-off or counterclaim is asserted.

"Delivery" means voluntary transfer of possession from one person to another.

"Divisible contract to sell or sale" means a contract to sell or a sale in which by its terms the price for a portion or portions of the goods less than the whole is fixed or ascertainable by computation.

"Document of title to goods" includes any bill of lading, dock warrant, warehouse receipt or order for the delivery of goods, or any other document used in the ordinary course of business in the sale or transfer of goods, as proof of the possession or control of the goods, or authorizing or purporting to authorize the possessor of the document to transfer or receive, either by indorsement or by delivery, goods represented by such document.

"Fault" means wrongful act or default.

"Fungible goods" means goods of which any unit is from its nature or by mercantile usage treated as the equivalent of any other unit.

"Future goods" means goods to be manufactured or acquired by the seller after the making of the contract of sale.

"Goods" include all chattels personal other than things in action and money. The term includes emblements, industrial growing crops, and things attached to or forming part of the land which are agreed to be served before sale or under the' contract of sale.

"Order" in sections of this act relating to documents of title means an order by indorsement on the document.

"Person" includes a corporation or partnership or two or more persons having a joint or common interest.

"Plaintiff" includes defendant asserting a right of set-off or counterclaim. 
"Property" means the general property in goods, and not merely a special property.

"Purchaser" includes mortgagee and pledgee.

"Purchases" includes taking as a mortgagee or as a pledge.

"Quantity of goods" includes their state or condition.

"Sale" includes a bargain and sale as well as a sale and delivery.

"Seller" means a person who sells or agrees to sell goods, or any legal successor in the interest of such person.

"Specific goods" means goods identified and agreed upon at the time a contract to sell or a sale is made.

"Value" is any consideration sufficient to support a simple contract. An antecedent or pre-existing claim, whether for money or not, constitutes value where goods or documents or titles are taken either in satisfaction thereof or as security therefor.

(2) A thing is done "in good faith" within the meaning of this act when it is in fact done honestly, whether it be done negligently or not.

(3) A person is insolvent, within the meaning of this act who either has ceased to pay his debts in the ordinary course of business or cannot pay his debts as they become due, whether he has committed an act of bankruptcy or not, and whether he is insolvent within the meaning of the federal bankruptcy law or not.

(4) Goods are in a "deliverable state" within the meaning of this act when they are in such a state that the buyer would, under the contract, be bound to take delivery of them.

Arizona.-Boyd v. Second Hand Supply Co. (1912), 14 Ariz. 36, 123 Pac. 619.

Connecticut.-Wetkopsky $\nabla$. New Haven Gas Light Co. (1913), 88 Conn. 1, 90 Atl. 30; Merrill v. Hodson (1914), 91 Atl. 533.
Maryland.-Willard v. Higdon (1913), 123 Md. 447.

Massachusetts.-Coleman v. N. Y., N. H. \& H. R. R. Co. (1913), 215 Mass. 45, 102 N. E. 92.

New Jersey.-Wooley v. Cregcent Auto Co. (1912), 83 N. J. L。 244, "Value" and "Good Faith."

Section 76a.-(Act Does Not Apply to Existing Sales or Contracts to Sell.)-None of the provisions of this act shall 
apply to any sale, or to any contract to sell, made prior to the taking effect of this act.

New York.-Acme Glass Co. v. ware Co. v. Hodgeboom (1915), 152 Woods-Lloyd Co. (1918), 170 N. Y. N. Y. Supp. 900.

Supp. 448; Buffalo Wholesale Hard-

Section 76b.-(No Repeal of Uniform Warehouse Roceipt Act or Uniform Bills of Lading Act.) - Nothing in this act or in any repcaling clause thereof shall be construed to repeal or limit any of the provisions of the Act to Make Uniform the Law of Warehouse Receipts, or of the Act to Make Uniform the Laws of Bills of Lading.

Section 77.-(Inconsistent Legislation Repealed.)-All acts or parts of acts inconsistent with this act are hereby repealed except as provided in section $76 \mathrm{~b}$.

Section 78.-Time When the Act Takes Effect.)-This act shall take effect on the ..... day of .......... one thousand nine hundred and ...........

Section 79.-(Name of Act.) - This act may be cited as the Uniform Sales Act. 
UNIFORM WAREHOUSE RECEIPTS ACT 



\section{UNIFORM WAREHOUSE RECEIPTS ACT}

The draft of the Uniform Act concerning warehouse receipts was formulated by Mr. Samuel Williston and Mr. Barry Mohun of the Washington City Bar, who were professionally employed by the Commissioners for that purpose. It was then critically considered by the American Warehousemen's Association and by a committee of the American Bankers Association and was after diligent experiment and revision approved by the Commissioners in final form in 1906 and was adopted in 1907 by Connecticut, nlinois, Iowa, Massachusetts, New Jersey and New York. There are at present forty-two states in which the Warehouse Receipts Act is now part of the statute law. These are: Alabama, 1915; Arkansas, 1915 ; California, 1909 ; Colorado, 1911; Connecticut, 1907; Delaware, 1917; Florida, 1917; Idaho, 1915; Illinois, 1907; Iowa, 1907; Kansas, 1909; Louisiana, 1908; Maine, 1917; Maryland, 1910; Massachusetts, 1907; Michigan, 1909; Minnesota, 1913; Mississippi, 1913 ; Montana, 1917; Nebraska, 1909; Nevada, 1913; New Jersey, 1907; New Mexico, 1909; New York, 1907; North Carolina, 1917; North Dakota, 1917; Ohio, 1908; Oregon, 1913; Pennsylvania, 1909; Rhode Island, 1908; South Dakota, 1913; Tennessee, 1909; Utah, 1911; Vermont, 1912; Virginia, 1908; Washington, 1913; West Virginia, 1917; Wisconsin, 1909 ; Wyoming, 1917; Alaska, 1913; District of Columbia, 1910; Philippine Islands, 1912.

The only jurisdictions which have not yet adopted the Uniform Warehouse Receipts Act are Arizona, Georgia, Indiana, Kentucky, Missouri, New Hampshire, Oklahoma, Porto Rico, South Carolina, Texas and Hawaii. 


\begin{tabular}{|c|c|c|c|c|c|c|c|c|}
\hline & $\begin{array}{c}\text { General } \\
\text { Acts } \\
1915 .\end{array}$ & $\begin{array}{c}\text { Session } \\
\text { Laws } \\
1913 .\end{array}$ & $\begin{array}{l}\text { Digest } \\
\text { of Sts. } \\
1916\end{array}$ & $\begin{array}{l}\text { Gen. } \\
\text { Laws } \\
1915 .\end{array}$ & $\begin{array}{l}\text { Mills } \\
\text { Ann. St. } \\
1912 \text {. }\end{array}$ & $\begin{array}{l}\text { Gen. } \\
\text { Sts. } \\
1918 .\end{array}$ & \multicolumn{2}{|c|}{$\begin{array}{l}\text { Laws 1917, } \\
\text { ch. 221, p. } 697 .\end{array}$} \\
\hline $\begin{array}{l}\text { Uniform } \\
\text { Act } \\
\text { Sec. No. }\end{array}$ & $\begin{array}{l}1915 \\
\text { Ala. }\end{array}$ & $\begin{array}{c}1913 \\
\text { Alaska }\end{array}$ & $\begin{array}{l}1915 \\
\text { Ark. }\end{array}$ & $\begin{array}{l}1909 \\
\text { Cal. }\end{array}$ & $\begin{array}{l}1911 \\
\text { Colo. }\end{array}$ & $\begin{array}{l}1907 \\
\text { Conn. }\end{array}$ & \multicolumn{2}{|c|}{$\begin{array}{c}1917 \\
\text { Delaware. }\end{array}$} \\
\hline 1 & 1 & 1 & 9957 & 1 & 7763 & 4553 & 2633 & $\$ 13$ \\
\hline 2 & 2 & 2 & 9958 & 2 & 7764 & 4554 & 2634 & $\$ 14$ \\
\hline 3 & 3 & 3 & 9959 & 3 & 7765 & 4555 & 2635 & $\S 15$ \\
\hline 4 & 4 & 4 & 9960 & 4 & 7766 & 4556 & 2636 & $\$ 16$ \\
\hline 5 & 5 & 5 & 9961 & 5 & 7767 & 4557 & 2637 & $\$ 17$ \\
\hline 6 & 6 & 6 & 9962 & 6 & 7768 & 4558 & $2637 \mathrm{~A}$ & $\$ 17 \mathrm{~A}$ \\
\hline 7 & 7 & 7 & 9963 & 7 & 7769 & 4559 & $2637 B$ & $\$ 17 \mathrm{~B}$ \\
\hline 8 & 8 & 8 & 9964 & 8 & 7770 & 4560 & $2637 \mathrm{C}$ & $\$ 17 \mathrm{C}$ \\
\hline 9 & 9 & 9 & 9965 & 9 & 7771 & 4561 & 2637D & $\S 17 \mathrm{D}$ \\
\hline 10 & 10 & 10 & 9966 & 10 & 7772 & 4562 & $2637 \mathrm{E}$ & $\$ 17 \mathrm{E}$ \\
\hline 11 & 11 & 11 & 9967 & 11 & 7773 & 4563 & $2637 \mathrm{~F}$ & $\$ 17 \mathrm{~F}$ \\
\hline 12 & 12 & 12 & 9968 & 12 & 7774 & 4564 & $2637 \mathrm{G}$ & $\$ 17 \mathrm{G}$ \\
\hline 13 & 13 & 13 & 9969 & 13 & 7775 & 4565 & $2637 \mathrm{H}$ & $\$ 17 \mathrm{H}$ \\
\hline 14 & 14 & 14 & 9970 & 14 & 7776 & 4566 & $2637 \mathrm{I}$ & $\$ 17 \mathrm{I}$ \\
\hline 15 & 15 & 15 & 9971 & 15 & 7777 & 4567 & $2637 \mathrm{~J}$ & $\$ 17 \mathrm{~J}$ \\
\hline 16 & 16 & 16 & 9972 & 16 & 7778 & 4568 & $2637 \mathrm{~K}$ & $\$ 17 \mathrm{~K}$ \\
\hline 17 & 17 & 17 & 9973 & 17 & 7779 & 4569 & 2637L & $\S 17 \mathrm{~L}$ \\
\hline 18 & 18 & 18 & 9974 & 18 & 7780 & 4570 & $2637 \mathrm{M}$ & $\$ 17 \mathrm{M}$ \\
\hline 19 & 19 & 19 & 9975 & 19 & 7781 & 4571 & $2637 N$ & $\$ 17 N$ \\
\hline 20 & 20 & 20 & 9976 & 20 & 7782 & 4572 & 26370 & $\$ 170$ \\
\hline 21 & 21 & 21 & 9977 & 21 & 7783 & 4573 & $2637 \mathrm{P}$ & $\S 17 \mathrm{P}$ \\
\hline 22 & 22 & 22 & 9978 & 22 & 7784 & 4574 & 26370 & $\$ 170$ \\
\hline 23 & 23 & 23 & 9979 & 23 & 7785 & 4575 & $2637 \bar{R}$ & $\$ 17 \mathrm{H}$ \\
\hline 24 & 24 & 24 & 9980 & 24 & 7786 & 4576 & $2637 \mathrm{~S}$ & $\$ 17 \mathrm{~S}$ \\
\hline 25 & 25 & 25 & 9981 & 25 & 7787 & 4577 & 2637T & $\$ 17 \mathrm{~T}$ \\
\hline 26 & 26 & 26 & 9982 & 26 & 7788 & 4578 & $2637 \mathrm{U}$ & $\$ 17 U$ \\
\hline 27 & 27 & 27 & 9983 & 27 & 7789 & 4579 & $2637 \mathrm{~V}$ & $\$ 17 \mathrm{~V}$ \\
\hline 28 & 28 & 28 & 9984 & 28 & 7790 & 4580 & $2637 \mathrm{~W}$ & $\$ 17 \mathrm{~W}$ \\
\hline 29 & 29 & 29 & 9985 & 29 & 7791 & 4581 & $2637 X$ & $\S 17 \mathrm{X}$ \\
\hline 30 & 30 & 30 & 9986 & 30 & 7792 & 4582 & $2637 \mathrm{Y}$ & $\$ 17 \mathrm{Y}$ \\
\hline 31 & 31 & 31 & 9987 & 31 & 7793 & 4583 & $2637 \mathrm{Z}$ & $\$ 17 \mathrm{Z}$ \\
\hline 32 & 32 & 32 & 998 & 32 & 7794 & 4584 & $2637 \mathrm{AA}$ & $\$ 17 \mathrm{AA}$ \\
\hline 33 & 33 & 33 & 9989 & 33 & 779 & 4585 & $2637 \mathrm{BB}$ & $\S 17 \mathrm{BB}$ \\
\hline 34 & 34 & 34 & 9990 & 34 & 7796 & 4586 & $2637 \mathrm{CC}$ & $\$ 17 \mathrm{CC}$ \\
\hline 35 & 35 & 35 & 9991 & 35 & 7797 & 4587 & $2637 \mathrm{DD}$ & $\$ 17 \mathrm{DD}$ \\
\hline 36 & 36 & 36 & 9992 & 36 & 77 & 4588 & $2637 \mathrm{EE}$ & $\$ 17 \mathrm{EE}$ \\
\hline 37 & 37 & 37 & 9993 & 37 & 77 & 4589 & $2637 \mathrm{FF}$ & $\$ 17 \mathrm{FF}$ \\
\hline 38 & 38 & 38 & 9994 & 38 & 7800 & 4590 & $2637 \mathrm{GG}$ & $\$ 17 \mathrm{GG}$ \\
\hline 39 & 39 & 39 & 9995 & 39 & 7801 & 4591 & $2637 \mathrm{HH}$ & $\S 17 \mathrm{HH}$ \\
\hline 40 & 40 & 40 & 9996 & 40 & 7802 & 4592 & 2637II & $\$ 17$ II \\
\hline 41 & 41 & 41 & 9997 & 41 & 780 & 4593 & 2637JJ & $\S 17 \mathrm{JJ}$ \\
\hline 42 & 42 & 42 & 9998 & 42 & 7804 & 4594 & $2637 \mathrm{KK}$ & $\S 17 \mathrm{KK}$ \\
\hline 43 & 43 & 43 & 9999 & 43 & 7805 & 4595 & $2637 \mathrm{LL}$ & $\$ 17 \mathrm{LL}$ \\
\hline 44 & 44 & 44 & 10000 & 44 & 7806 & 4596 & $2637 \mathrm{MM}$ & I\$17MM \\
\hline 45 & 45 & 45 & 10001 & 45 & 7807 & 4597 & $2637 \mathrm{NN}$ & $\$ 17 N N$ \\
\hline 46 & 46 & 46 & 10002 & 46 & 7808 & 4589 & 263700 & $\$ 1700$ \\
\hline 47 & 47 & 47 & 10003 & 47 & 7809 & 4599 & 2637PP & $\S 17 \mathrm{PP}$ \\
\hline 48 & 48 & 48 & 10004 & 48 & 7810 & 4600 & $2637 \mathrm{QQ}$ & $\$ 1700$ \\
\hline 49 & 49 & 49 & 10005 & 49 & 7811 & 4601 & 2637RR & \$17R \\
\hline
\end{tabular}




\begin{tabular}{|c|c|c|c|c|c|c|c|c|}
\hline & $\begin{array}{c}\text { General } \\
\text { Acts } \\
1915 .\end{array}$ & $\begin{array}{c}\text { Session } \\
\text { Laws } \\
1913 .\end{array}$ & $\begin{array}{l}\text { Digest } \\
\text { of Sts. } \\
1916 .\end{array}$ & $\begin{array}{l}\text { Gen. } \\
\text { Laws } \\
1915 .\end{array}$ & $\begin{array}{l}\text { Mills } \\
\text { Ann. St. } \\
1912 .\end{array}$ & $\begin{array}{c}\text { Gen. } \\
\text { Sts. } \\
1918 .\end{array}$ & \multicolumn{2}{|c|}{$\begin{array}{l}\text { Laws } 1917 \\
\text { ch. } 221 \text {, p. } 697 .\end{array}$} \\
\hline $\begin{array}{l}\text { Uniform } \\
\text { Act } \\
\text { Sec. No. }\end{array}$ & $\begin{array}{l}1915 \\
\text { Ala. }\end{array}$ & $\begin{array}{c}1813 \\
\text { Alaska }\end{array}$ & $\begin{array}{l}1915 \\
\text { Ark. }\end{array}$ & $\begin{array}{l}1909 \\
\text { Cal. }\end{array}$ & $\begin{array}{l}1911 \\
\text { Colo. }\end{array}$ & $\begin{array}{l}1907 \\
\text { Conn. }\end{array}$ & Dela & 917 \\
\hline $\begin{array}{l}50 \\
51 \\
52 \\
53 \\
54 \\
55 \\
56 \\
57 \\
58 \\
59 \\
60 \\
61 \\
62\end{array}$ & $\begin{array}{l}\mathbf{5 0} \\
\mathbf{5 1} \\
\mathbf{5 2} \\
\mathbf{5 3} \\
\mathbf{5 4} \\
\mathbf{5 5} \\
56 \\
\mathbf{5 7} \\
\mathbf{5 8} \\
\mathbf{5 9} \\
\mathbf{6 0}\end{array}$ & $\begin{array}{l}50 \\
51 \\
52 \\
53 \\
51 \\
55 \\
56 \\
57 \\
58 \\
59 \\
60 \\
61 \\
62\end{array}$ & $\begin{array}{c}10006 \\
10007 \\
10008 \\
10009 \\
10010 \\
10011 \\
10012 \\
10013 \\
10014 \\
\ldots \ldots \\
\ldots \ldots \\
\ldots \ldots\end{array}$ & $\begin{array}{l}50 \\
51 \\
52 \\
53 \\
54 \\
55 \\
56 \\
57 \\
58 \\
59 \\
60 \\
\ddot{61}\end{array}$ & $\begin{array}{l}7812 \\
7813 \\
7814 \\
7815 \\
7816 \\
7817 \\
7818 \\
7819 \\
7820 \\
7821 \\
\ldots \ldots \\
\ldots \ldots\end{array}$ & $\begin{array}{l}4602 \\
4603 \\
4604 \\
4605 \\
4606 \\
4607 \\
4608 \\
4609 \\
4610 \\
4611 \\
\ldots \ldots \\
4612\end{array}$ & $\begin{array}{l}2637 \mathrm{SS} \\
2637 \mathrm{TT} \\
2637 \mathrm{UU} \\
2637 \mathrm{VV} \\
2637 \mathrm{WW} \\
2637 \mathrm{XX} \\
2637 \mathrm{YY} \\
2637 \mathrm{ZZ} \\
2637 \mathrm{AAA} \\
2637 \mathrm{BBB} \\
2637 \mathrm{CCC} \\
2637 \mathrm{DDD}\end{array}$ & 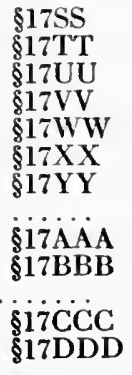 \\
\hline
\end{tabular}




\begin{tabular}{c|c|c|c|c|c|c}
\hline \hline & $\begin{array}{c}\text { Code D. C. } \\
\text { 1911. } \\
\text { Appendix }\end{array}$ & $\begin{array}{c}\text { Laws } \\
\text { of Fla. } \\
1917\end{array}$ & $\begin{array}{c}\text { Laws } \\
1915\end{array}$ & $\begin{array}{c}\text { Ill. Sts. } \\
1907\end{array}$ & $\begin{array}{c}\text { Code 1913 } \\
\text { Supp. }\end{array}$ & $\begin{array}{c}\text { Gen Sts. } \\
191 .\end{array}$ \\
\cline { 2 - 6 } & $\begin{array}{c}\text { Uniform } \\
\text { Act }\end{array}$ & $\begin{array}{c}1907 \\
\text { Dec. No. }\end{array}$ & $\begin{array}{c}1917 \\
\text { Dla. C. }\end{array}$ & $\begin{array}{c}1915 \\
\text { Idaho }\end{array}$ & $\begin{array}{c}1907 \\
\text { Illinois. }\end{array}$ & $\begin{array}{c}1909 \\
\text { Kansas. }\end{array}$ \\
\hline
\end{tabular}

\begin{tabular}{|c|c|c|c|c|c|c|c|}
\hline 1 & 1 & 1 & 1 & 9000 & $\S 1$ & 3138A1 & 4415 \\
\hline 2 & 2 & 2 & 2 & 9001 & $\S 2$ & 3138A2 & 4416 \\
\hline 3 & 3 & 3 & 3 & 9002 & $\S 3$ & 3138A3 & 4417 \\
\hline 4 & 4. & 4 & 4 & 9003 & $\$ 4$ & 3138A4 & 4418 \\
\hline 5 & 5 & 5 & 5 & 9004 & $\$ 5$ & 3138A5 & 4419 \\
\hline 6 & 6 & 6 & 6 & 9005 & $\$ 6$ & 3138A6 & 4420 \\
\hline 7 & 7 & 7 & 7 & 9006 & $\$ 7$ & 3138A7 & 4421 \\
\hline 8 & 8 & 8 & 8 & 9007 & $\S 8$ & 3138A8 & 4422 \\
\hline 9 & 9 & 9 & 9 & 9008 & $\$ 9$ & 3138A9 & 4423 \\
\hline 10 & 10 & 10 & 10 & 9009 & $\S 10$ & 3138A10 & 4424 \\
\hline 11 & 11 & 11 & 11 & 9010 & $\S 11$ & 3138A11 & 4425 \\
\hline 12 & 12 & 12 & 12 & 9011 & $\S 12$ & $3138 \mathrm{~A} 12$ & 4426 \\
\hline 13 & 13 & 13 & 13 & 9012 & $\S 13$ & 3138A13 & 4427 \\
\hline 14 & 14 & 14 & 14 & 9013 & $\$ 14$ & $3138 \mathrm{~A} 14$ & 4428 \\
\hline 15 & 15 & 15 & 15 & 9014 & $\$ 15$ & 3138A15 & 4429 \\
\hline 16 & 16 & 16 & 16 & 9015 & $\$ 16$ & $3138 \mathrm{~A} 16$ & 4430 \\
\hline 17 & 17 & 17 & 17 & 9016 & $\$ 17$ & 3138A17 & 4431 \\
\hline 18 & 18 & 18 & 18 & 9017 & $\$ 18$ & 3138A18 & 4432 \\
\hline 19 & 19 & 19 & 19 & 9018 & $\$ 19$ & 3138A19. & 4433 \\
\hline 20 & 20 & 20 & 20 & 9019 & $\S 20$ & 3138A20 & 4434 \\
\hline 21 & 21 & 21 & 21 & 9020 & $\S 21$ & 3138A21 & 4435 \\
\hline 22 & 22 & 22 & 22 & 9021 & $\$ 22$ & 3138A22 & 4436 \\
\hline 23 & 23 & 23 & 23 & 9022 & $\S 23$ & 3138A23 & 4437 \\
\hline 21 & 24 & 24 & 24 & 9023 & $\S 24$ & $3138 \mathrm{~A} 24$ & 4438 \\
\hline 25 & 25 & 25 & 25 & 9024 & $\$ 25$ & 3138A25 & 4439 \\
\hline 26 & 26 & 26 & 26 & 9025 & $\$ 26$ & 3138A26 & 4440 \\
\hline 27 & 27 & 27 & 27 & 9026 & $\$ 27$ & $3138 \mathrm{~A} 27$ & 4441 \\
\hline 28 & 28 & 28 & 28 & 9027 & $\$ 2 i$ & 3138A28 & 4442 \\
\hline 29 & 29 & 29 & 29 & 9028 & $\$ 29$ & 3138A29 & 4443 \\
\hline 30 & 30 & 30 & 30 & 9029 & $\$ 30$ & $3138 \mathrm{~A} 30$ & 4444 \\
\hline 31 & 31 & 31 & 31 & 9030 & $\$ 31$ & 3138A31 & 4445 \\
\hline 32 & 32 & 32 & 32 & 9031 & $\$ 32$ & 3138A32 & 4446 \\
\hline 33 & 33 & 33 & 33 & 9032 & $\S 33$ & 3138А33 & 4447 \\
\hline 34 & 34 & 34 & 34 & 9033 & $\$ 34$ & 3138A34 & 4448 \\
\hline 35 & 35 & 35 & 35 & 9034 & $\S 35$ & 3138A35 & 4449 \\
\hline 36 & 36 & 36 & 36 & 9035 & $\S 36$ & 3138A36 & 4450 \\
\hline 37 & 37 & 37 & 37 & 9035 & $\$ 37$ & 3138A37 & 4451 \\
\hline 38 & 38 & 38 & 38 & 9037 & $\$ 38$ & 3138A38 & 4452 \\
\hline 39 & 39 & 39 & 39 & 9038 & $\$ 39$ & 3138A39 & 4453 \\
\hline 40 & 40 & 40 & 40 & 9039 & $\$ 40$ & $3138 A 40$ & 4454 \\
\hline 41 & 41 & 41 & 41 & 9040 & $\$ 41$ & $3138 A 41$ & 4455 \\
\hline 42 & 42 & 42 & 42 & 9041 & $\$ 42$ & $3138 A 42$ & 4456 \\
\hline 43 & 43 & 43 & 43 & 9042 & $\$ 43$ & $3138 A 43$ & 4457 \\
\hline 44 & 44 & 44 & 44 & 9043 & $\$ 44$ & 3138A44 & 4458 \\
\hline 4.5 & 45 & 45 & 45 & 9044 & $\$ 45$ & 3138A45 & 4459 \\
\hline 46 & 46 & 46 & 46 & 9045 & $\S 46$ & 3138A46 & 4460 \\
\hline 47 & 47 & 47 & 47 & 9046 & $\$ 47$ & $3138 A 47$ & 4461 \\
\hline 18 & 48 & 48 & 48 & 9047 & $\S 48$ & 3138A48 & 44.62 \\
\hline 49 & 49 & 49 & 49 & 9048 & $\$ 49$ & 3138A49 & 4463 \\
\hline 50 & 50 & 50 & 50 & 9049 & $\$ 50$ & 3138 A50 & 4464 \\
\hline
\end{tabular}


UNIPORM WAREHOUSE RECEIPTS ACT.

\begin{tabular}{|c|c|c|c|c|c|c|}
\hline & $\begin{array}{c}\text { Code D. C. } \\
1911, \\
\text { Appendix }\end{array}$ & $\begin{array}{c}\text { Lans } \\
\text { of Fla. } \\
1917\end{array}$ & $\begin{array}{l}\text { Laws } \\
1905\end{array}$ & $\begin{array}{l}\text { III. Stg. } \\
1907\end{array}$ & $\begin{array}{l}\text { Code } 1913 \\
\text { Supp. }\end{array}$ & $\begin{array}{c}\text { Gen. Sts. } \\
1915\end{array}$ \\
\hline $\begin{array}{l}\text { Uniform } \\
\text { Act } \\
\text { Sec. No. }\end{array}$ & $\begin{array}{l}1910 \\
\text { D. C. }\end{array}$ & $\begin{array}{l}1917 \\
\text { Fla. }\end{array}$ & $\begin{array}{l}1915 \\
\text { Idaho }\end{array}$ & $\begin{array}{l}1907 \\
\text { Illinois. }\end{array}$ & $\begin{array}{l}1907 \\
\text { Iwoa. }\end{array}$ & $\begin{array}{c}1909 \\
\text { Kansas. }\end{array}$ \\
\hline $\begin{array}{l}51 \\
52 \\
53 \\
54 \\
55 \\
56 \\
57 \\
58 \\
59 \\
60 \\
61 \\
62\end{array}$ & $\begin{array}{l}\mathbf{5 1} \\
\mathbf{5 2} \\
\mathbf{5 3} \\
\mathbf{5 4} \\
\mathbf{5 5} \\
\mathbf{5 6} \\
\mathbf{5 7} \\
\mathbf{5 8} \\
\mathbf{5 9} \\
\mathbf{6 0} \\
\mathbf{6 1} \\
\mathbf{6 2}\end{array}$ & $\begin{array}{l}51 \\
52 \\
53 \\
54 \\
55 \\
56 \\
57 \\
58 \\
59 \\
60 \\
61 \\
62\end{array}$ & $\begin{array}{l}\mathbf{5 1} \\
52 \\
\mathbf{5 3} \\
\mathbf{5 4} \\
\mathbf{5 5} \\
\mathbf{5 6} \\
\mathbf{5 7} \\
\mathbf{5 8} \\
\mathbf{5 9} \\
60 \\
\ldots 1\end{array}$ & $\begin{array}{cc}9050 & \$ 51 \\
9051 & \$ 52 \\
9052 & \$ 53 \\
9053 & \$ 54 \\
9054 & \$ 55 \\
9055 & \$ 56 \\
9056 & \$ 57 \\
9057 & \$ 58 \\
9058 & \$ 59 \\
9059 & \$ 60 \\
. \ldots \ldots & \ldots \\
\ldots \ldots \ldots\end{array}$ & $\begin{array}{l}\text { 3138A51 } \\
\text { 3138A52 } \\
\text { 3138A53 } \\
\text { 3138A54 } \\
\text { 3138A55 } \\
\text { 3138A56 } \\
\text { 3138A57 } \\
\text { 3138A58 } \\
\text { 3138A59 } \\
\ldots \ldots \ldots \\
\ldots \ldots \ldots\end{array}$ & $\begin{array}{l}4465 \\
4466 \\
4467 \\
4468 \\
4469 \\
4470 \\
4471 \\
4472 \\
4473 \\
4474\end{array}$ \\
\hline
\end{tabular}




\begin{tabular}{c|c|c|c|c|c|c|c}
\hline \hline & $\begin{array}{c}\text { Marr's } \\
\text { Rev. St. } \\
\text { of Laws. }\end{array}$ & $\begin{array}{c}\text { Laws } \\
\text { of Me. } \\
1917 .\end{array}$ & $\begin{array}{c}\text { Md. } \\
\text { Code. }\end{array}$ & $\begin{array}{c}\text { Mass. } \\
\text { Rev. } \\
\text { Laws } \\
1902-8 .\end{array}$ & $\begin{array}{c}\text { Comp. } \\
\text { Laws of } \\
\text { Mich. } \\
1915 .\end{array}$ & $\begin{array}{c}\text { Gen. } \\
\text { Sts. of } \\
\text { Minn. } \\
\text { 1913. }\end{array}$ & $\begin{array}{c}\text { Laws } \\
\text { of Mo. } \\
1911 .\end{array}$ \\
\hline $\begin{array}{c}\text { Uniform } \\
\begin{array}{c}\text { Act } \\
\text { Sec. No. }\end{array}\end{array}$ & $\begin{array}{c}1908 \\
\text { La. }\end{array}$ & $\begin{array}{c}1917 \\
\text { Me. }\end{array}$ & $\begin{array}{c}1910 \\
\text { Md. }\end{array}$ & $\begin{array}{c}1909 \\
\text { Mass. }\end{array}$ & $\begin{array}{c}1909 \\
\text { Mich. }\end{array}$ & $\begin{array}{c}1913 \\
\text { Minn. }\end{array}$ & $\begin{array}{c}1911 \\
\text { Mo. }\end{array}$ \\
\hline
\end{tabular}

\begin{tabular}{|c|c|c|c|c|c|c|c|}
\hline I & 5002 & 1 & 1 & 2 & 6563 & 4514 & 1 \\
\hline 2 & 5003 & 2 & 2 & 3 & 6564 & 4515 & 2 \\
\hline 3 & 5004 & 3 & 3 & 4 & 6565 & 4516 & 3 \\
\hline 4 & 5005 & 4 & 4 & 5 & 6566 & 4517 & 4 \\
\hline 5 & 5006 & 5 & 5 & 6 & 6567 & 4518 & 5 \\
\hline 6 & 5007 & 6 & 6 & 7 & 6568 & 4519 & 6 \\
\hline 7 & 5008 & 7 & 7 & 8 & 6569 & 4520 & 7 \\
\hline 8 & 5009 & 8 & 8 & 9 & 6570 & 4527 & 8 \\
\hline 9 & 5010 & 9 & 9 & 10 & 6571 & 4522 & 9 \\
\hline 10 & 5011 & 10 & 10 & 11 & 6572 & 4523 & 10 \\
\hline 11 & 5012 & 11 & 11 & 12 & 6573 & 4524 & 11 \\
\hline 12 & 5013 & 12 & 12 & 13 & 6574 & 4525 & 12 \\
\hline 13 & 5014 & 13 & 13 & 14 & 6575 & 4526 & 13 \\
\hline 14 & 5015 & 14 & 14 & 15 & 6576 & 4527 & 14 \\
\hline 15 & 5016 & 15 & 15 & 16 & 6577 & 4528 & 15 \\
\hline 16 & 5017 & 16 & 16 & 17 & 6578 & 4529 & 16 \\
\hline 17 & 5018 & 17 & 17 & 18 & 6579 & 4530 & 17 \\
\hline 18 & 5019 & 18 & 18 & 19 & 6580 & 4531 & 18 \\
\hline 19 & 5020 & 19 & 19 & 20 & 6581 & 4532 & 19 \\
\hline 20 & 5021 & 20 & 20 & 21 & 6582 & 4533 & 20 \\
\hline 21 & 5022 & 21 & 21 & 22 & 6583 & 4534 & 21 \\
\hline 22 & 5023 & 22 & 22 & 23 & 6584 & 4535 & 22 \\
\hline 23 & 5024 & 23 & 23 & 24 & 6585 & 4536 & 23 \\
\hline 24 & 5025 & 24 & 24 & 25 & 6586 & 4537 & 24 \\
\hline 25 & 5026 & 25 & 25 & 26 & 6587 & 4538 & 25 \\
\hline 26 & 5027 & 26 & 26 & 27 & 6588 & 4539 & 26 \\
\hline 27 & 5028 & 27 & 27 & 28 & 6589 & 4540 & 27 \\
\hline 28 & 5029 & 28 & 28 & 29 & 6590 & 4541 & 28 \\
\hline 29 & 5030 & 29 & 29 & 30 & 6591 & 4542 & 29 \\
\hline 30 & 5031 & 30 & 30 & 31 & 6592 & 4543 & 30 \\
\hline 31 & 5032 & 31 & 31 & 32 & 6593 & 4544 & 31 \\
\hline 32 & 5033 & 32 & 32 & 33 & 6594 & 4545 & 32 \\
\hline 33 & 5034 & 33 & 33 & .34 & 6595 & 4546 & 33 \\
\hline 34 & 5035 & 34 & 34 & 35 & 6596 & 4547 & 34 \\
\hline 35 & 5036 & 35 & 35 & 36 & 6597 & 4548 & 35 \\
\hline 36 & 5037 & 36 & 36 & 37 & 6598 & 4549 & 36 \\
\hline 37 & 5038 & 37 & 37 & 38 & 6599 & 4550 & 37 \\
\hline 38 & 5039 & 38 & 38 & 39 & 6600 & 4551 & 38 \\
\hline 39 & 5040 & 39 & 39 & 40 & 6601 & 4552 & 39 \\
\hline 40 & 5041 & 40 & 40 & 41 & 6602 & 4553 & 40 \\
\hline 41 & 5042 & 41 & 41 & 42 & 6603 & 4554 & 41 \\
\hline 42 & 5043 & 42 & 42 & 43 & 6604 & 4555 & 42 \\
\hline 43 & 5044 & 43 & 43 & 44 & 6605 & 4556 & 43 \\
\hline 44 & 5045 & 44 & 44 & 45 & 6606 & 4557 & 44 \\
\hline 45 & 5046 & 45 & 45 & 46 & 6607 & 4558 & 45 \\
\hline 46 & 5047 & 46 & 46 & 47 & 6608 & 5459 & 46 \\
\hline 47 & 5048 & 47 & 47 & 48 & 6609 & 4560 & 47 \\
\hline 48 & 5049 & 48 & 48 & 49 & 6610 & 4561 & 48 \\
\hline 49 & 5050 & 49 & 49 & 50 & 6611 & 4562 & 49 \\
\hline
\end{tabular}




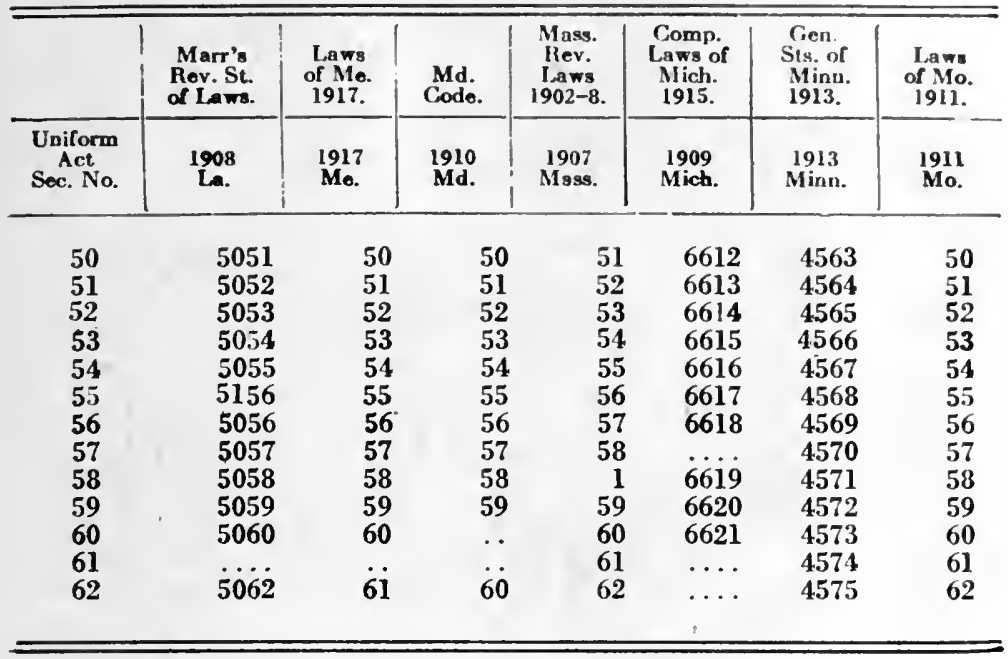




\begin{tabular}{c|c|c|c|c|c|c|c|}
\hline \hline & $\begin{array}{c}\text { Laws } \\
\text { of Mont. } \\
1917 .\end{array}$ & $\begin{array}{c}\text { Rev. St. } \\
\text { of Neb. } \\
1912 .\end{array}$ & $\begin{array}{c}\text { St. of } \\
\text { Nev. } \\
1913 .\end{array}$ & $\begin{array}{c}\text { Comp. } \\
\text { St. of } \\
\text { N. J. }\end{array}$ & $\begin{array}{c}\text { N. M. } \\
\text { St. } \\
1915 .\end{array}$ & $\begin{array}{c}\text { Business } \\
\text { Law. }\end{array}$ & $\begin{array}{c}\text { Public } \\
\text { Laws } \\
1917 .\end{array}$ \\
\cline { 1 - 3 } \\
$\begin{array}{c}\text { Act } \\
\text { Sec. No. }\end{array}$ & $\begin{array}{c}1917 \\
\text { Mont. }\end{array}$ & $\begin{array}{c}1909 \\
\text { Neb. }\end{array}$ & $\begin{array}{c}1913 \\
\text { Nev. }\end{array}$ & $\begin{array}{c}1907 \\
\text { N. J. }\end{array}$ & $\begin{array}{c}1909 \\
\text { N. M. }\end{array}$ & N. Y. & N. C. \\
\hline
\end{tabular}

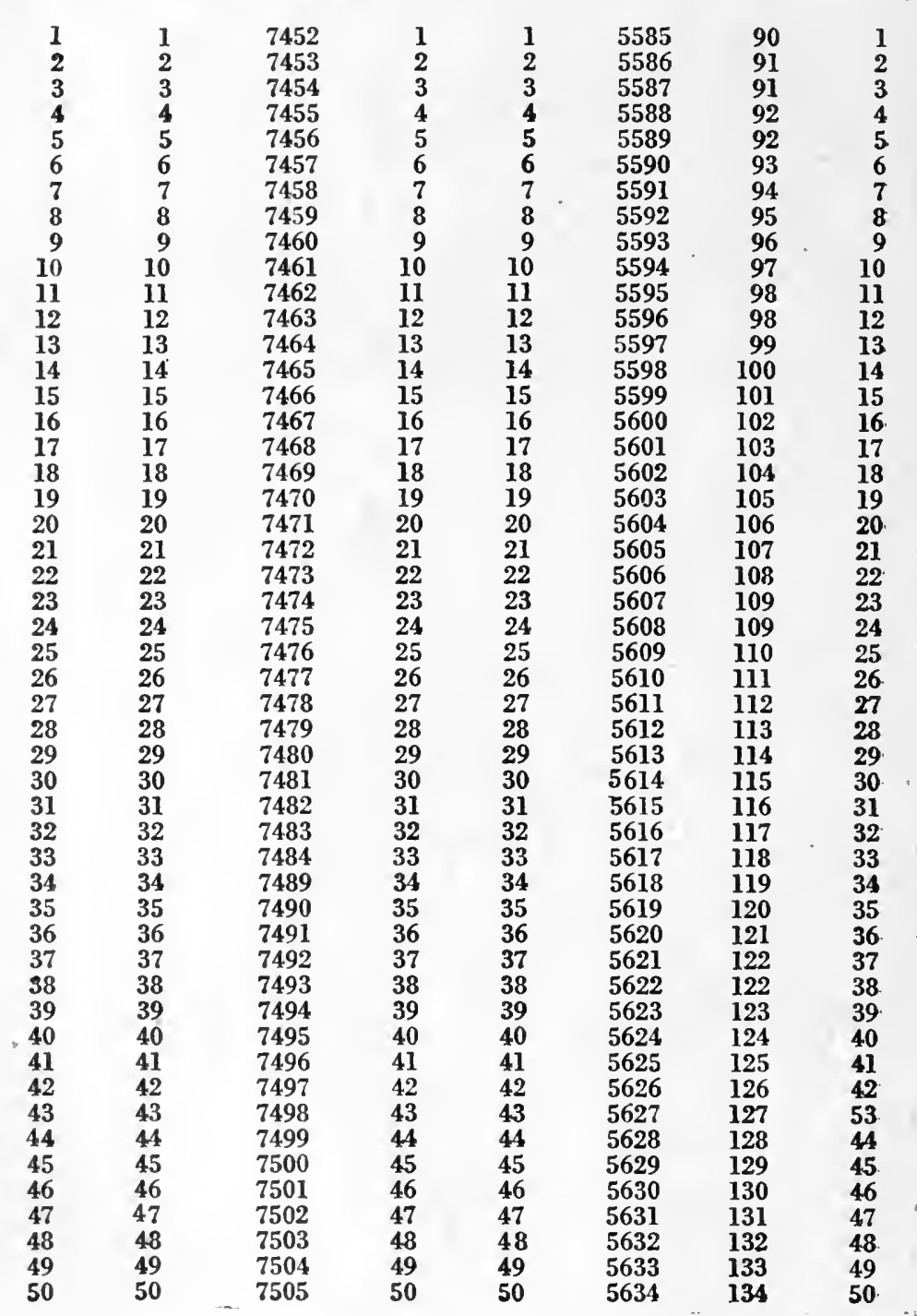




\begin{tabular}{|c|c|c|c|c|c|c|c|}
\hline & $\begin{array}{l}\text { Laws } \\
\text { of Mont. } \\
1917 .\end{array}$ & $\begin{array}{l}\text { Rev. St. } \\
\text { of Neb. } \\
1912 \text {. }\end{array}$ & $\begin{array}{l}\text { SL of } \\
\text { Nev. } \\
1913 .\end{array}$ & $\begin{array}{l}\text { Comp. } \\
\text { St. of } \\
\text { N. J. }\end{array}$ & $\begin{array}{c}\text { N. M. } \\
\text { St. } \\
1915 .\end{array}$ & $\begin{array}{l}\text { Business } \\
\text { Law. }\end{array}$ & $\begin{array}{l}\text { Public } \\
\text { Laws } \\
1917 .\end{array}$ \\
\hline $\begin{array}{l}\text { Uniform } \\
\text { Act } \\
\text { Sec. No. }\end{array}$ & $\begin{array}{l}1917 \\
\text { Mont. }\end{array}$ & $\begin{array}{l}1909 \\
\text { Neb. }\end{array}$ & $\begin{array}{l}1913 \\
\text { Nev. }\end{array}$ & $\begin{array}{l}1907 \\
\text { N.J. }\end{array}$ & $\begin{array}{l}1909 \\
\text { N. M. }\end{array}$ & $\begin{array}{l}1907 \\
\text { N.Y. }\end{array}$ & $\begin{array}{l}1917 \\
\text { N. C. }\end{array}$ \\
\hline $\begin{array}{l}51 \\
52 \\
53 \\
\mathbf{5 4} \\
\mathbf{5 5} \\
\mathbf{5 6} \\
\mathbf{5 7} \\
58 \\
59 \\
\mathbf{6 0} \\
\mathbf{6 1} \\
\mathbf{6 2}\end{array}$ & $\begin{array}{l}\mathbf{5 1} \\
\mathbf{5 2} \\
\mathbf{5 3} \\
\mathbf{5 4} \\
\mathbf{5 5}^{\circ} \\
\mathbf{5 6} \\
\mathbf{5 7} \\
\mathbf{5 8} \\
\mathbf{5 9} \\
\mathbf{6 0} \\
\mathbf{6 1} \\
\mathbf{6 2}\end{array}$ & $\begin{array}{c}7506 \\
7507 \\
7508 \\
7509 \\
7510 \\
7511 \\
7512 \\
7513 \\
\ldots \ldots \\
\ldots \ldots \\
\ldots \ldots\end{array}$ & $\begin{array}{c}51 \\
52 \\
53 \\
54 \\
55 \\
56 \\
57 \\
58 \\
59 \\
60 \\
\ddot{61}\end{array}$ & $\begin{array}{l}\mathbf{5 1} \\
\mathbf{5 2} \\
\mathbf{5 3} \\
\mathbf{5 4} \\
\mathbf{5 5} \\
\mathbf{5 6} \\
\mathbf{5 7} \\
\mathbf{5 8} \\
\mathbf{5 9} \\
\ldots \\
\ldots \\
. .\end{array}$ & $\begin{array}{l}\mathbf{5 6 3 5} \\
\mathbf{5 6 3 6} \\
\mathbf{5 6 3 7} \\
\mathbf{5 6 3 8} \\
\mathbf{5 6 3 9} \\
\mathbf{5 6 4 0} \\
\mathbf{5 6 4 1} \\
\mathbf{5 6 4 2} \\
\mathbf{5 6 4 3} \\
\mathbf{5 6 4 4}\end{array}$ & $\begin{array}{r}135 \\
136 \\
137 \\
138 \\
139 \\
140 \\
141 \\
142 \\
143 \\
\ldots \\
\ldots\end{array}$ & $\begin{array}{l}51 \\
52 \\
53 \\
54 \\
55 \\
56 \\
57 \\
58 \\
59 \\
60 \\
61 \\
62\end{array}$ \\
\hline
\end{tabular}




\begin{tabular}{|c|c|c|c|c|c|c|}
\hline & $\begin{array}{l}\text { Laws } \\
\text { of N.D. } \\
1917 .\end{array}$ & $\begin{array}{c}\text { Page \& } \\
\text { Adams } \\
\text { Ohio } \\
\text { Gen. Code }\end{array}$ & $\begin{array}{l}\text { Laws of } \\
1913 .\end{array}$ & $\begin{array}{l}\text { Purdon's } \\
\text { Digest } \\
\text { 13th Ed. }\end{array}$ & $\begin{array}{c}\text { Gen. Laws } \\
1909 .\end{array}$ & $\begin{array}{c}\text { Session } \\
\text { Laws } \\
\text { of S. D. } \\
1913 \text {. }\end{array}$ \\
\hline $\begin{array}{l}\text { Uniform } \\
\text { Act } \\
\text { Sec. No. }\end{array}$ & $\begin{array}{l}1917 \\
\text { N. D. }\end{array}$ & $\begin{array}{l}1908 \\
\text { Ohio. }\end{array}$ & $\begin{array}{l}1913 \\
\text { Ora. }\end{array}$ & $\begin{array}{l}1909 \\
\text { Penn. }\end{array}$ & $\begin{array}{l}1908 \\
\text { R. } 1 .\end{array}$ & $\begin{array}{l}1913 \\
\text { S. D. }\end{array}$ \\
\hline
\end{tabular}

\begin{tabular}{|c|c|c|c|c|c|c|}
\hline 1 & 1 & 8457 & 1 & 1 & Ch. 267-1 & \\
\hline 2 & 2 & 8458 & 2 & $2 \& 3$ & Ch. 267-2 & \\
\hline 3 & 3 & 8459 & 3 & 4 & Ch. 267-3 & \\
\hline 4 & 4 & 8460 & 5 & & Ch. 267-4 & \\
\hline 5 & 5 & 8461 & 5 & $6 \& 7$ & Ch. 267-5 & \\
\hline 6 & 6 & 8462 & 6 & & Ch. 267-6 & \\
\hline 7 & 7 & 8463 & 7 & $9 \& 10$ & Ch. 267-7 & \\
\hline 8 & 8 & 8464 & 8 & $11 \& 12$ & Ch. 268-1 & \\
\hline 9 & 9 & 8465 & 9 & 13 & Ch. 268-2 & \\
\hline 10 & 10 & 8466 & 10 & 14 & Ch. 268-3 & \\
\hline 11 & 11 & 8467 & 11 & 15 & Ch 268-4 & \\
\hline 12 & 12 & 8468 & 12 & 16 & Ch. 268-5 & \\
\hline 13 & 13 & 8469 & 13 & 17 & Ch. 268-6 & \\
\hline 14 & 14 & 8470 & 14 & 18 & Ch. 268-7 & \\
\hline 15 & 15 & 8471 & 15 & 19 & Ch. 268-8 & \\
\hline 16 & 16 & 8472 & 16 & 20 & Ch. 268-9 & \\
\hline 17 & 17 & 8473 & 17 & 21 & Ch 268-10 & \\
\hline 18 & 18 & 8474 & 18 & 22 & Ch. 268-11 & \\
\hline 19 & 19 & 8475 & 19 & 23 & Ch. 268-12 & \\
\hline 20 & 20 & 8476 & 20 & 24 & Ch. 268-13 & \\
\hline 21 & 21 & 8477 & 21 & 25 & Ch. 268-14 & \\
\hline 22 & 22 & 8478 & 22 & 26 & Ch. 268-15 & \\
\hline 23 & 23 & 8479 & 23 & 27 & Ch. 268-16 & \\
\hline 24 & 24 & 8480 & 24 & 28 & Ch. 268-17 & \\
\hline 25 & 25 & 8481 & 25 & 29 & Ch. 268-18 & \\
\hline 26 & 26 & 8482 & 26 & 30 & Ch. 268-19 & \\
\hline 27 & 27 & 8483 & 27 & 31 & Ch. 268-20 & \\
\hline 28 & 28 & 8484 & 28 & 32 & Ch. 268-21 & \\
\hline 29 & 29 & 8485 & 29 & 33 & Ch. 268-22 & \\
\hline 30 & 30 & 8486 & 30 & 34 & Ch. 268-23 & - \\
\hline 31 & 31 & 8487 & 31 & 35 & Ch. 268-24. & \\
\hline 32 & 32 & 8488 & 32 & 36 & Ch. 268-25 & \\
\hline 33 & 33 & 8489 & 33 & $\begin{array}{l}37,38 \\
39,40\end{array}$ & Ch. 268-26 & \\
\hline 34 & 34 & 8490 & 34 & 41,42 & Ch. 268-27 & \\
\hline 35 & 35 & 8491 & 35 & 43 & Ch. $268-28$ & \\
\hline 36 & 36 & 8492 & 36 & 44 & Ch. 268-29 & \\
\hline 37 & 37 & 8493 & 37 & 45 & Ch. 269-1 & \\
\hline 38 & 38 & 8494 & 38 & 46 & Ch. 269-2 & \\
\hline 39 & 39 & 8495 & 39 & 47 & Ch. 269-3 & \\
\hline 40 & 40 & 8496 & 40 & 48 & Ch. 269-4 & \\
\hline 41 & 41 & 8497 & 41 & 49 & Ch. 269-5 & \\
\hline 42 & 42 & 8498 & 42 & $50,51,52$ & Ch. 269-6 & \\
\hline 43 & 43 & 8499 & 43 & 53 & Ch. 269-7 & \\
\hline 44 & 44 & 8500 & 44 & 54 & Ch. 269-8 & \\
\hline 45 & 45 & 8501 & 45 & 55 & Ch. 269-9 & \\
\hline 46 & 46 & 8502 & 46 & 56 & Ch. 269-10 & \\
\hline 47 & 47 & 8503 & 47 & 57 & Ch. 269-11 & \\
\hline & 48 & 8504 & 48 & 58 & Ch. 269-12 & \\
\hline
\end{tabular}


UNIFORM WAREHOUSE RECEIPTS ACT.

\begin{tabular}{c|c|c|c|c|c|c}
\hline \hline & $\begin{array}{c}\text { Laws } \\
\text { of N. D. } \\
1917 .\end{array}$ & $\begin{array}{c}\text { Page } \\
\text { Adams } \\
\text { Ohio } \\
\text { Gen. Code. }\end{array}$ & $\begin{array}{c}\text { Laws of } \\
1913 .\end{array}$ & $\begin{array}{c}\text { Pardon's } \\
\text { Digest } \\
\text { 13th Ed. }\end{array}$ & $\begin{array}{c}\text { Session } \\
\text { Laws } \\
\text { of S. D. } \\
1913 .\end{array}$ \\
\hline $\begin{array}{c}\text { Uniform. Laws } \\
\text { Act } \\
\text { Sec. No. }\end{array}$ & $\begin{array}{c}1909 . \\
\text { N. D. }\end{array}$ & $\begin{array}{c}1908 \\
\text { Ohio. }\end{array}$ & $\begin{array}{c}1913 \\
\text { Ore. }\end{array}$ & $\begin{array}{c}1909 \\
\text { Ponn. }\end{array}$ & $\begin{array}{c}1908 \\
\text { R. I. }\end{array}$ & $\begin{array}{c}1913 \\
\text { S. D. }\end{array}$ \\
\hline
\end{tabular}

$\begin{array}{lrrrrll}\mathbf{4 9} & \mathbf{4 9} & \mathbf{8 5 0 5} & \mathbf{4 9} & \mathbf{5 9} & \text { Ch. 269-13 } & \mathbf{4 9} \\ \mathbf{5 0} & \mathbf{5 0} & \mathbf{1 3 1 1 8} & \mathbf{5 0} & \mathbf{6 0} & \text { Ch. 270-1 } & \mathbf{5 0} \\ \mathbf{5 1} & \mathbf{5 1} & \mathbf{1 3 1 1 9} & \mathbf{5 1} & \mathbf{6 1} & \text { Ch. 270-2 } & \mathbf{5 1} \\ \mathbf{5 2} & \mathbf{5 2} & \mathbf{1 3 1 2 0} & \mathbf{5 2} & \mathbf{6 2} & \text { Ch. 270-3 } & \mathbf{5 2} \\ \mathbf{5 3} & \mathbf{5 3} & \mathbf{1 3 1 2 1} & \mathbf{5 3} & \mathbf{6 3} & \text { Ch. 270-4 } & \mathbf{5 3} \\ \mathbf{5 4} & \mathbf{5 4} & \mathbf{1 3 1 2 2} & \mathbf{5 4} & \mathbf{6 4} & \text { Ch 270-5 } & \mathbf{5 4} \\ \mathbf{5 5} & \mathbf{5 5} & \mathbf{1 3 1 2 3} & \mathbf{5 5} & \mathbf{6 5} & \text { Ch. 270-6 } & \mathbf{5 5} \\ \mathbf{5 6} & \mathbf{5 6} & \mathbf{8 5 0 6} & \mathbf{5 6} & \mathbf{6 6} & \text { Ch. 271-1 } & \mathbf{5 6} \\ \mathbf{5 7} & \mathbf{5 7} & \mathbf{8 5 0 7} & \mathbf{5 7} & \mathbf{6 7} & \text { Ch. 271-2 } & \mathbf{5 7} \\ \mathbf{5 8} & \mathbf{5 8} & \mathbf{8 5 0 8} & \mathbf{5 8} & \mathbf{6 8} & \text { Ch. 271-3 } & \mathbf{5 8} \\ \mathbf{5 9} & \mathbf{5 9} & \mathbf{8 5 0 9} & \mathbf{5 9} & \mathbf{6 9} & \text { Ch. 271-4 } & \mathbf{5 9} \\ \mathbf{6 0} & \mathbf{6 0} & \ldots \ldots & \mathbf{6 0} & \mathbf{6 9} & \ldots \ldots \ldots \ldots & \mathbf{6 0} \\ \mathbf{6 1} & \mathbf{6 1} & \ldots \ldots & \mathbf{6 1} & \mathbf{7 0} & \ldots \ldots \ldots \ldots & \mathbf{6 1} \\ \mathbf{6 2} & \mathbf{6 2} & \ldots \ldots & \mathbf{6 2} & \mathbf{7 1} & \ldots \ldots \ldots \ldots & \mathbf{6 2}\end{array}$




\begin{tabular}{c|c|c|c|c|c}
\hline \hline & $\begin{array}{c}\text { Code of } \\
1917 .\end{array}$ & Laws 1911. & $\begin{array}{c}\text { Gen Laws of } \\
\text { Vt. 1917. }\end{array}$ & $\begin{array}{c}\text { Va. Codo } \\
1910 \text { Sup. }\end{array}$ & $\begin{array}{c}\text { Rem. Codo } \\
1915\end{array}$ \\
\hline $\begin{array}{c}\text { Uniforn } \\
\text { Act } \\
\text { Soc. No. }\end{array}$ & $\begin{array}{c}1909 \\
\text { Tennessea }\end{array}$ & $\begin{array}{c}1911 \\
\text { Utah. }\end{array}$ & $\begin{array}{c}1912 \\
\text { Vermont. }\end{array}$ & $\begin{array}{c}1908 \\
\text { Virginia. }\end{array}$ & $\begin{array}{c}1913 \\
\text { Washington. }\end{array}$ \\
\hline
\end{tabular}

\begin{tabular}{|c|c|c|c|c|c|}
\hline 1 & $3608 \mathrm{al}$ & 1 & & 1 & $3369-1$ \\
\hline 2 & $3608 a 2$ & 2 & 3116 & 2 & $3369-2$ \\
\hline 3 & $3608 a 3$ & 3 & 3117 & 3 & $3369-3$ \\
\hline 4 & $3608 \mathrm{a} 4$ & 4 & 3118 & 4 & $3369-4$ \\
\hline 5 & $3608 \mathrm{a} 5$ & 5 & 3119 & 5 & $3369-5$ \\
\hline 6 & $3608 a 6$ & 6 & 3120 & 6 & $3369-6$ \\
\hline 7 & $3608 a 7$ & 7 & 3121 & 7 & $3369-7$ \\
\hline 8 & $3608 a 8$ & 8 & 3122 & 8 & $3369-8$ \\
\hline 9 & $3608 a 9$ & 9 & 3123 & 9 & $3369-9$ \\
\hline 10 & $3608 \mathrm{al} 0$ & 10 & 3124 & 10 & $3369-10$ \\
\hline 11 & $3608 \mathrm{all}$ & 11 & 3125 & 11 & $3369-11$ \\
\hline 12 & $3608 \mathrm{al2}$ & 12 & 3126 & 12 & $3369-12$ \\
\hline 13 & $3608 \mathrm{a} 13$ & 13 & 3127 & 13 & $3369-13$ \\
\hline 14 & $3608 a 14$ & 14 & 3128 & 14 & 3369-14 \\
\hline 15 & $3608 \mathrm{a} 15$ & 15 & 3129 & 15 & $3369-15$ \\
\hline 16 & $3608 \mathrm{a} 16$ & 16 & 3130 & 16 & $3369-16$ \\
\hline 17 & $3608 \mathrm{a} 17$ & 17 & 3131 & 17 & 3369-17 \\
\hline 18 & $3608 a 18$ & 18 & 3132 & 18 & $3369-18$ \\
\hline 19 & $3608 \mathrm{al9}$ & 19 & 3133 & 19 & 3369-19 \\
\hline 20 & $3608 \mathrm{a} 20$ & 20 & 3134 & 20 & 3369-20 \\
\hline 21 & $3608 \mathrm{a} 21$ & 21 & 3135 & 21 & $3369-21$ \\
\hline 22 & $3608 \mathrm{a} 22$ & 22 & 3136 & 22 & $3369-22$ \\
\hline 23 & $3608 \mathrm{a} 23$ & 23 & 3137 & 23 & $3369-23$ \\
\hline 24 & $3608 \mathrm{a} 24$ & 24 & 3138 & 24 & $3369-24$ \\
\hline 25 & $3608 \mathrm{a} 25$ & 25 & 3139 & 25 & $3369-25$ \\
\hline 26 & $3608 \mathrm{a} 26$ & 26 & 3140 & 26 & $3369-26$ \\
\hline 27 & $3608 \mathrm{a} 27$ & 27 & 3141 & 27 & $3369-27$ \\
\hline 28 & $3608 \mathrm{a} 28$ & 28 & 3142 & 28 & $3369-28$ \\
\hline 29 & $3608 \mathrm{a} 29$ & 29 & 3143 & 29 & 3369-29 \\
\hline 30 & $3608 \mathrm{a} 30$ & 30 & 3144 & 30 & $3369-30$ \\
\hline 31 & $3608 \mathrm{a} 31$ & 31 & 3145 & 31 & $3369-31$ \\
\hline 32 & 3608 a32 & 32 & 3146 & 32 & 3369-32 \\
\hline 33 & $\begin{array}{l}3608 \mathrm{a} 33 \\
34,35,36 \\
37,38\end{array}$ & 33 & 3147 & 33 & $3369-33$ \\
\hline 34 & $3608 \bar{a} 39$ & 34 & 3138 & 34 & $3369-34$ \\
\hline 35 & $3608 \mathrm{a} 40$ & 35 & 3149 & 35 & $3369-35$ \\
\hline 36 & $3608 a 41$ & 36 & 3150 & 36 & $3369-36$ \\
\hline 37 & $3608 a 42 \& 43$ & 37 & 3151 & 37 & $3369-37$ \\
\hline 38 & $3608 a 44$ & 38 & 3152 & 38 & $3369-38$ \\
\hline 39 & $3608 \mathrm{a} 45$ & 39 & 3153 & 39 & $3369-39$ \\
\hline 40 & $3608 a 46$ & 40 & 3154 & 40 & $3369-40$ \\
\hline 41 & $3608 a 47$ & 41 & 3155 & 41 & $3369-41$ \\
\hline 42 & $3608 a 48$ & 42 & 3156 & 42 & $3369-42$ \\
\hline 43 & $3608 a 49$ & 43 & 3157 & 43 & $3369-43$ \\
\hline 44 & $3608 \mathrm{a} 50$ & 44 & 3158 & 44 & $3369-44$ \\
\hline 45 & $3608 a 51$ & 45 & 3159 & 45 & $3369-45$ \\
\hline 46 & $3608 \mathrm{a} 52$ & 46 & 3160 & 46 & $3369-46$ \\
\hline 47 & 3608203 & 47 & 3161 & 47 & $3369-47$ \\
\hline 48 & 3608055 & 48 & 3162 & 48 & $3369-48$ \\
\hline 78 & & 49 & 3163 & 49 & $3369-49$ \\
\hline
\end{tabular}


UNIFORM WAREHOUSE RECEIPTS ACT.

263

\begin{tabular}{|c|c|c|c|c|c|}
\hline & $\begin{array}{l}\text { Code of } \\
1917 \text {. }\end{array}$ & Laws 1911. & $\begin{array}{l}\text { Gen. Iaws of } \\
\text { Vt. 1917. }\end{array}$ & $\begin{array}{l}\text { Va. Code } \\
1910 \text { Sup. }\end{array}$ & $\begin{array}{l}\text { Rem. Code } \\
1915 .\end{array}$ \\
\hline $\begin{array}{l}\text { Uniforn } \\
\text { Act } \\
\text { Soc. No. }\end{array}$ & $\begin{array}{c}1909 \\
\text { Tennessoce. }\end{array}$ & $\begin{array}{l}1911 \\
\text { Utah. }\end{array}$ & Vermont. & $\begin{array}{c}1908 \\
\text { Virginia. }\end{array}$ & $\begin{array}{c}1913 \\
\text { Wanhingtan. }\end{array}$ \\
\hline $\begin{array}{l}\mathbf{5 0} \\
\mathbf{5 1} \\
\mathbf{5 2} \\
\mathbf{5 3} \\
\mathbf{5 4} \\
\mathbf{5 5} \\
\mathbf{5 6} \\
\mathbf{5 7} \\
\mathbf{5 8} \\
\mathbf{5 9} \\
60 \\
\mathbf{6 1} \\
\mathbf{6 2}\end{array}$ & $\begin{array}{l}3608 \mathrm{a} 56 \\
3608 \mathrm{a} 57 \\
3608 \mathrm{a} 58 \\
3608 \mathrm{a} 59 \\
3608 \mathrm{a} 60 \\
3608 \mathrm{a} 61 \\
3608 \mathrm{a} 62 \\
3608 \mathrm{a} 63 \\
3608 \mathrm{a} 64 \\
3608 \mathrm{a} 65 \\
3608 \mathrm{a} 66 \\
3608 \mathrm{a} 67 \\
3608 \mathrm{a} 68\end{array}$ & $\begin{array}{l}\mathbf{5 0} \\
\mathbf{5 1} \\
\mathbf{5 2} \\
\mathbf{5 3} \\
\mathbf{5 4} \\
\mathbf{5 5} \\
\mathbf{5 6} \\
\mathbf{5 7} \\
\mathbf{5 8} \\
\mathbf{5 9} \\
\mathbf{5 8} \\
\mathbf{6 1} \\
\mathbf{6 2}\end{array}$ & $\begin{array}{l}3164 \\
3165 \\
3166 \\
3167 \\
3168 \\
3169 \\
3171 \\
3172 \\
3114 \\
3170 \\
\ldots \ldots \\
\ldots \ldots\end{array}$ & $\begin{array}{c}\mathbf{5 0} \\
\mathbf{5 1} \\
\mathbf{5 2} \\
\mathbf{5 3} \\
\mathbf{5 4} \\
\mathbf{5 5} \\
\mathbf{5 6} \\
\mathbf{5 7} \\
\mathbf{5 8} \\
\mathbf{5 9} \\
\mathbf{6 0} \\
\mathbf{6 1}\end{array}$ & $\begin{array}{l}3369-50 \\
3369-51 \\
3369-52 \\
3369-53 \\
3369-54 \\
3369-55 \\
3369-56 \\
3369-57 \\
3369-58 \\
3369-59 \\
3369-60 \\
3369-61\end{array}$ \\
\hline
\end{tabular}




\begin{tabular}{|c|c|c|c|c|c|}
\hline & $\begin{array}{l}\text { W. Va. Code, } \\
1918 \text { Sup. }\end{array}$ & $\begin{array}{c}\text { Wisc. St. } \\
1917 .\end{array}$ & $\begin{array}{c}\text { Session } \\
\text { Laws of } \\
\text { Wyoming } \\
\text { 1917. }\end{array}$ & $\begin{array}{l}8 \text { Pablic } \\
\text { Laws } 271 .\end{array}$ & $\begin{array}{l}\text { Laws } 1918 . \\
\text { p. } 22 .\end{array}$ \\
\hline $\begin{array}{l}\text { Uniform } \\
\text { Act } \\
\text { Soc. No. }\end{array}$ & West Virginia. & $\begin{array}{c}1909 \\
\text { Wisconsin. }\end{array}$ & $\begin{array}{l}1917 \\
\text { Wyoming. }\end{array}$ & $\begin{array}{r}1912 \\
\text { Phil. Is. }\end{array}$ & Porto Rica. \\
\hline 1 & $4376-1$ & $1684 \mathrm{ml}$ & 1 & 1 & 1 \\
\hline 2 & $4376-2$ & $1685 \mathrm{~m}$ : & 2 & 2 & 2 \\
\hline 3 & $4376-3$ & $1684 \mathrm{m4}$ & 3 & 3 & 3 \\
\hline 4 & $4376-4$ & $1684 \mathrm{m5}$ & 4 & 4 & 4 \\
\hline 5 & $4376-5$ & $1684 \mathrm{~m} 6$ & 5 & 5 & 5 \\
\hline 6 & $4376-6$ & $1684 \mathrm{~m} 7$ & 6 & 6 & 6 \\
\hline 7 & $4376-7$ & $1684 \mathrm{~m} 8$ & 7 & 7 & 7 \\
\hline 8 & $4376-8$ & $1684 \mathrm{~m} 9$ & 8 & 8 & 8 \\
\hline 9 & $4376-9$ & $1684 \mathrm{mlo}$ & 9 & 9 & 9 \\
\hline 10 & $4376-10$ & $1684 \mathrm{mll}$ & 10 & 10 & 10 \\
\hline 11 & $4376-11$ & $1684 \mathrm{ml2}$ & 11 & 11 & 11 \\
\hline 12 & $4376-12$ & $1684 \mathrm{ml3}$ & 12 & 12 & 12 \\
\hline 13 & $4376-13$ & $1684 \mathrm{ml4}$ & 13 & 13 & 13 \\
\hline 14 & $4376-14$ & $1684 \mathrm{ml} 5$ & 14 & 14 & 14 \\
\hline 15 & $4376-15$ & $1684 \mathrm{ml} 6$ & 15 & 15 & 15 \\
\hline 16 & $4376-6$ & $1684 \mathrm{ml7}$ & 16 & 16 & 16 \\
\hline 17 & $4376-17$ & $1684 \mathrm{ml} 8$ & 17 & 17 & 17 \\
\hline 18 & $4376-18$ & $1684 \mathrm{ml} 9$ & 18 & 18 & 18 \\
\hline 19 & $4376-19$ & $1684 \mathrm{~m} 20$ & 19 & 19 & 19 \\
\hline 20 & $4376-20$ & $1684 \mathrm{~m} 21$ & 20 & 20 & 20 \\
\hline 21 & $4376-21$ & $1684 \mathrm{~m} 22$ & 21 & 21 & 21 \\
\hline 22 & $4376-22$ & $1684 \mathrm{~m} 23$ & 22 & 22 & 22 \\
\hline 23 & $4376-23$ & $1684 \mathrm{~m} 24$ & 23 & 23 & 23 \\
\hline 24 & $4376-24$ & $1684 \mathrm{~m} 25$ & 24 & 24 & 24 \\
\hline 25 & $4376-25$ & $1684 \mathrm{~m} 27$ & 25 & 25 & 25 \\
\hline 26 & $4376-26$ & $1684 \mathrm{~m} 28$ & 26 & 26 & 26 \\
\hline 27 & $4376-27$ & $1684 \mathrm{~m} 29$ & 27 & 27 & 27 \\
\hline 28 & $4376-28$ & $1684 \mathrm{~m} 30$ & 28 & 28 & 28 \\
\hline 29 & $4376-29$ & . $1684 \mathrm{~m} 31$ & 29 & 29 & 29 \\
\hline 30 & $4376-30$ & $1684 \mathrm{~m} 32$ & 30 & 30 & 30 \\
\hline 31 & $4376-31$ & $1684 \mathrm{~m} 33$ & 31 & 31 & 31 \\
\hline 32 & $4376-32$ & $1684 \mathrm{~m} 34$ & 32 & 32 & 32 \\
\hline 33 & $4376-33$ & $1684 \mathrm{~m} 35$ & 33 & 33 & 33 \\
\hline 34 & $43-6-34$ & $1684 \mathrm{~m} 36$ & 34 & $34^{\circ}$ & 34 \\
\hline 35 & $4376-35$ & $1684 \mathrm{~m} 37$ & 35 & 35 & 35 \\
\hline 36 & $4376-36$ & $1684 \mathrm{~m} 38$ & 36 & 36 & 36 \\
\hline 37 & $4376-37$ & $1684 \mathrm{~m} 39$ & 37 & 37 & 37 \\
\hline 38 & $4376-38$ & $1684 \mathrm{~m} 40$ & 38 & 38 & 38 \\
\hline 39 & $4376-39$ & $1684 \mathrm{~m} 41$ & 39 & 39 & 39 \\
\hline 40 & $4376-40$ & i $684 \mathrm{~m} 42$ & 40 & 40 & 40 \\
\hline 41 & $4376-41$ & $1684 \mathrm{~m} 43$ & 41 & 41 & 41 \\
\hline 42 & $4376-42$ & $1684 \mathrm{mA4}$ & 42 & 42 & 42 \\
\hline 43 & $4376-43$ & $1684 \mathrm{~m} 45$ & 43 & 43 & 43 \\
\hline 44 & $4376-14$ & $1684 \mathrm{~m} 46$ & 44 & 44 & 44 \\
\hline 45 & $4376-45$ & $1684 \mathrm{~m} 47$ & 45 & 4.5 & 45 \\
\hline 46 & $4376-46$ & $1684 \mathrm{~m} 48$ & 46 & 46 & 46 \\
\hline 47 & $4376-47$ & $1684 \mathrm{~m} 49$ & 47 & 47 & 47 \\
\hline 48 & $4376-48$ & $1684 \mathrm{~m} 50$ & 48 & 48 & 48 \\
\hline 49 & $4376-49$ & $1684 \mathrm{~m} 51$ & 49 & 49 & 49 \\
\hline EQ & $4376-50$ & $1684 \mathrm{~m} 52$ & 50 & 50 & 50 \\
\hline
\end{tabular}




\begin{tabular}{|c|c|c|c|c|c|}
\hline & $\begin{array}{l}\text { W. Va. Code, } \\
1918 \text { Sup. }\end{array}$ & $\begin{array}{c}\text { Wisc. St. } \\
1917 .\end{array}$ & $\begin{array}{c}\text { Session } \\
\text { I,aws of } \\
\text { W yoming } \\
1917 \text {. }\end{array}$ & $\begin{array}{l}8 \text { Public } \\
\text { Laws 271. }\end{array}$ & $\begin{array}{l}\text { Laws 1918, } \\
\text { p. } 22 .\end{array}$ \\
\hline $\begin{array}{l}\text { Uniform } \\
\text { Act } \\
\text { Soc. No. }\end{array}$ & $\begin{array}{l}1917 \\
\text { West Virginia. }\end{array}$ & $\begin{array}{c}1909 \\
\text { Wisconsin. }\end{array}$ & $\begin{array}{l}1917 \\
\text { Wyoming. }\end{array}$ & $\begin{array}{c}1912 \\
\text { Phil. Is. }\end{array}$ & Porko Kico. \\
\hline $\begin{array}{l}51 \\
52 \\
53 \\
54 \\
55 \\
56 \\
57 \\
58 \\
59 \\
60 \\
61 \\
62\end{array}$ & $\begin{array}{l}4376-51 \\
4376-52 \\
4376-53 \\
4376-54 \\
4376-55 \\
4376-56 \\
4376-57 \\
4376-58 \\
4376-59 \\
\ldots \ldots \ldots \\
\ldots \ldots \ldots\end{array}$ & $\begin{array}{l}1684 \mathrm{~m} 53 \\
1684 \mathrm{~m} 54 \\
1684 \mathrm{~m} 55 \\
1684 \mathrm{~m} 56 \\
1684 \mathrm{~m} 57 \\
1684 \mathrm{~m} 60 \\
1694 \mathrm{~m} 61 \\
1684 \mathrm{~m} 52 \\
1681 \mathrm{~m} 63 \\
\ldots \ldots \ldots \\
\ldots \ldots \ldots\end{array}$ & $\begin{array}{l}51 \\
52 \\
53 \\
54 \\
55 \\
56 \\
57 \\
58 \\
59 \\
60 \\
61 \\
62\end{array}$ & $\begin{array}{l}51 \\
52 \\
53 \\
54 \\
55 \\
56 \\
57 \\
58 \\
59 \\
60 \\
\ddot{61}\end{array}$ & $\begin{array}{l}51 \\
52 \\
53 \\
54 \\
55 \\
56 \\
57 \\
58 \\
59 \\
60 \\
61 \\
62\end{array}$ \\
\hline
\end{tabular}




\section{UNIFORM WAREHOUSE RECEIPTS ACT}

Section 1. Persons Who May Issue Receipts.

2. Form of Receipts. Essential Terms.

3. Form of Receipts. What Terms May be Inserted.

4. Definition of Non-Negotiable Receipt.

5. Definition of Negotiable Receipt.

6. Duplicate Reeeipts Must be so Marked.

7. Failure to Mark "Not Negotiable."

8. Obligation of Warehouseman to Deliver.

9. Justification of Warehouseman in Delivering.

10. Warelouseman's Liability for Misdelivery.

11. Negotiable Receipts Must be Canceled When Goods Delivered.

12. Negotiable Ręeeipts Must be Canceled or Marked When Part of Goods Delivered.

13. Altered Receipts.

14. Lost or Destroyed Receipts.

15. Effeet of Duplicate Receipts.

16. Warehouseman Cannot Set up Title in Himself.

17. Interpleader of Adverse Claimants.

18. Warehouseman has Reasonable Time to Determine Validity of Claims.

19. Adverse Title is no Defense Except as Above Provided.

20. Liability for Non-Existence or Misdescription of Goods

21. Liability for Care of Goods.

22. Goods Must be Kept Separate.

23. Fungible Goods May be Commingled, if Warehouseman Authorized.

24. Liability of Warehouseman to Depositors of Commingled Goods.

25. Attacliment or Levy Upon Goods for Which Negotiable Receipt Has Been Issued.

26. Creditor's' Remedies to Reach Negotiable Receipts.

27. What Claims are Included in the Warehouseman's Lien.

28. Against What Property the Lien May be Enforeed.

29. How the Lien May be Lost.

30. Negotiable Receipt Must State Charges for Which Lien is Clained.

31. Warehouseman Need Not Deliver Until Lien is Satisfied.

32. Warehouseman's Lien Does Not Preclude Other Remedies.

33. Satisfaction of Lien by Sale.

34. Perishable and Hazardous Goods. 
Srction 35. Other Methods of Enforcing Liens.

36. Effect of Sale.

37. Negotiation of Negotiable Receipts by Delivery.

38. Negotiation of Negotiable Receipts by Indorsement.

39. Transfer of Receipts.

40. Who May Negotiate a Receipt.

41. Rights of Person to Whom a Receipt Has Been Negotiated.

42. Rights of Person to Whom a Receipt Has Been Transferred.

43. Transfer of Negotiable Receipts Without Indorsement.

44. Warranties on Sale of Receipt.

45. Indorser Not a Guarantor.

46. No Warranty Implied From Accepting Payment of a Debt.

47. When Negotiation Not Impaired by Fraud, Mistake, or Duress.

48. Subsequent Negotiation.

49. Negotiation Defeats Vendor's Lien.

50. Issue of Receipt for Goods Not Received.

51. Issue of Receipt Containing False Statement.

52. Issue of Duplicate Receipts Not so Marked.

53. Issue for Warehouseman's Goods of Receipts Which Do Not State That Fact.

54. Delivery of Goods Without Obtaining Negotiable Receipt.

55. Negotiation of Receipt for Mortgaged Goods.

56. Cases Not Provided for in Act.

57. Interpertation Shall Give Effect to Purpose of Uniformity.

58. Definitions.

59. Act Does Not Apply to Existing Receipts.

60. Inconsistent Legislation Repealed.

61. Time When the Act Takes Effect.

62. Name of Aet. 


\section{PART I.}

Section 1. Warehouse receipts may be issued by any warehouseman.

Arkansas.- Page v. Andrews Erie Preserving Co. (1909), 171 Fed. (1918), 203 S. W. 273. 540.

United States.-Am. Can C. v.

Section 2. Warehouse receipts need not be in any particular form, but every such receipt must embody within its written or printed terms-

(a) The location of the warehouse where the goods are stored,

(b) The date of the issue of the receipt,

(c) The consecutive number of the receipt,

(d) A statement whether the goods received will be delivered to the bearer, to a specified person, or to a specified person or his order.

(e) The rate of storage charges,

(f) A description of the goods or of the packages containing them,

(g) The signature of the warehouseman, which may be made by his authorized agent,

(h) If the receipt is issued for goods of which the warehouseman is owner, either solely or jointly or in common with others, the fact of such ownership, and

(i) A statement of the amount of advances made and of liabilities incurred for which the warehouseman claims a lien. If the precise amount of such advances made or such liabilities incurred is, at the time of the issue of the receipt, unknown to the warehouseman or to his agent who issues it, a statement of the fact that advances have been made or liabilities incurred and the purpose thereof is sufficient. 
A warehouseman shall be liable to any person injured thereby, for all damage caused by the omission from a negotiable receipt of any of the terms herein required.

Illinois.-Mfg. Mercant. Co. v. Missouri.-Natl. Bk. of Commerce Monarch Refrig. Co. (1915), 107 S. v. Flanagan Mills \& Elevator Co. E. 885 .

Kansas.-Cowley Co. Natl. Bk. v. Rawlins-Dobs Elevator Co. (1915), 152 Pac. 647.

Louisiana.-Arbuthnot-Latham \& Co. v Richheimer \& Co. (1916), 139 La. 798,72 So. 251. (1916), 188 S. W. 117.

New Jersey.- N. J. T. G. \& T. Co. v. Rector (1910), 76 N. J. Eq. 587, 75 Atl. 931.

United States.-Interstate Bank. ing \& Trust Co. v. Brown (1916), 225 Fed. 32.

Section 3. A warehouseman may insert in a receipt issued by him, any other terms and conditions, provided that such terms and conditions shall not-

(a) Be contrary to the provisions of this act.

(b) In any wise impair his obligation to exercise that de gree of care in the safe-keeping of the goods entrusted to him which a reasonably careful man would exercise in regard to similar goods of his own.

Alabama.-Ashland Oil Mill \& (1912), 138 N. Y. Supp. 287, 153 Fertilizer Co. v. Lane (1918), 79 So. 9.

A. D. 516.

Oklahoma.- Inland Compress Co.

New York.-Belzer v. Daub Storv. Simmons (1917), 159 Pac. 262. Tennessee.-Swift \& Co. v. age Warehouse \& Van Co. (1911), Memphis C. S. Warehouse (1913), 130 N. Y. Supp. 153; Rapp v. Wash. Storage \& Warehouse Co. (1912), 134 N. Y. Supp. 855, 75 Misc. 16; Healy v. N. Y. C. \& H. R. R. R. Co. 158 So. 480.

Texas.-Jackson v. Greenville Compress Co. (1918), Tex. Civ. App. 202 Pac. 324.

- Section 4. A receipt in which it is stated that the goods received will be delivered to the depositor, or to any other specified person, is a non-negotiable receipt.

Illinois.-Mfg. Mercant. Co. v. E: 885 . Monarch Refrig. Co. (1915), $107 \mathrm{~N}$.

Section 5. A receipt in which it is stated that the goods received will be delivered to the bearer, or to the order of any person named in such receipt is a negotiable receipt. 
No provisions shall be inserted in a negotiable receipt that it is non-negotiable. Such provision, if inserted, shall be void.

Illinois.-Mfg. Mercant. Co. v. Natl. Bk. (1910), 129 S. W. 1160. Monarch Refrig. Co. (1915), 107 N. United States-Interstate BankE. 885 .

Texas.-Stamford Co. v. F. \& M. ing \& Trust Co. v. Brown (1916), 225 Fed. 32.

Section 6. When more than one negotiable receipt is issued for the same goods, the word "duplicate" shall be plainly placed upon the face of every such receipt, except the one first issucd. A warehouseman shall be liable for all damage caused by his failure so to do to any one who purchased the subsequent receipt for value supposing it to be an original, even though the purchase be after the delivery of the goods by the warehouseman to the holder of the original receipt.

Section 7. A non-negotiable receipt shall have plainly placed upon its face by the warehouseman issuing it "nonnegotiable," or " not negotiable." In case of the warehouseman's failure so to do, a holder of the receipt who purchased it for value supposing it to be negotiable, may, at his opinion, treat such receipt as imposing upon the warehouseman the same liabilities he would have incurred had the receipt been negotiable.

This section shall not apply, however, to letters, memoranda, or written acknowledgments of an informal character.

\section{PART II.}

Section 8. A warehouseman, in the absence of some lawful excuse provided by this act, is bound to deliver the goods upona demand made either by the holder of a receipt for the goods or by the depositor, if such demand is accompanied with-

(a) An offer to satisfy the warehouseman's lien,

(b) An offer to surrender the receipt if negotiable, with such indorsements as would be necessary for the negotiation of the receipt, and

(c) A readiness and willingness to sign, when the goods are 
delivered, an acknowledgment that they have been delivered if such signature is requested by the warehouseman.

In case the warehouseman refuses or fails to deliver the goods in compliance with a demand by the holder or depositor so accompanied, the burden shall be upon the warehouseman to establish the existence of a lawful excuse for such refusal.

Connecticut. - MacDonald v. Y. Supp. 825, 80 Misc. 122; Davison Aetna Indemnity Co. (1916), 97 Atl. v. Guardian Storage Co. (1913), 144 332.

Georgia.-Penick v. Almand (1916), 87 S. E. 845.

N. Y. Supp. 601.

North Dakota.-State v. Farmers Co-operative Elevator Co. (1918), 167 N. W. 223.

New York.-Kramer v. Harger Storage Warehouse Co. (1908), 108 N. Y. Supp. 1, 123 App. Div. 316; Porter v. Duval Co. (1908), 111 N.

Oregon.-Pelton v. Gold Hill Canal Co. (1914), 142 Pac. 769.

Texas.-Rex v. James (1910), 131 S. W. 248; American Express Co. v. Duncan (1917), 193 S. W. 411. Washington.-Nowell v. Seattle Transfer Co. (1911), 63 Wash. 685, 116 Pac. 287.

Section 9. A warehouseman is justified in delivering the goods, subject to the provisions of the three following sections, to one who is-

(a) The person lawfully entitled to the possession of the goods, or his agent,

(b) A person who is either himself entitled to delivery by the terms of a non-negotiable receipt issued for the goods, or who has written authority from the person so entitled either indorsed upon the receipt or written upon another paper, or

(c) A person in possession of a negotiable receipt by the terms of which the goods are deliverable to him or order or to bearer, or which has been indorsed to him or in blank by the person to whom delivery was promised by the terms of the receipt or by his mediate or immediate indorsee.

California. - Lewis-Simas Jones 1032; Oakes v. Sloane (1910). 129 Co. v. Kee \& Co. (1915), 148 Pac. 973.

N. Y. Supp. 626,135 A. D. 354.

United States.-Clyde Steamship

New York.-Queen Mfg. Co. v. F. Co. v. Whaley (1917). 231 Fe ?. 77. C. Linde Co. (1909), 117 N. Y. Supp.

Section 10. Where a warehouseman delivers the goods to one who is not in fact lawfully entitled to the possession of them, the 
warehouseman shall be liable as for conversion to all having a right of property or possession in the goods if he delivered the goods otherwise than as authorized by subdivisions (b) and (c) of the preceding section and though he delivered the goods as authorized by said subdivisions he shall be so liable, if prior to. such delivery he had either

(a) Been requested, by or on behalf of the person lawfully entitled to a right of property or possession in the goods, not. to make such delivery, or

(b) Had information that the delivery about to be made was. to one not lawfully entitled to the possession of the goods.

Alabama.-Kitchens v. Mann (1914), 106 N. E. 171; Greenall v. (1918), 80 So. 173; Pope \& Co. v. Hersum (1915), 107 N. E. 940.

Union Warehouse Co. (1915), 70 So. New York.-Gross v. Agello 159.

Colorado. - Duffy v. Wilson (1908), 44 Col. 340, 98 Pac. 826.

Illinois.-Mfg. Mercant. Co. v. Monarch Refrig. Co. (1915), 107 N. E. 885 . (1909), 116 N. Y. Supp. 380, 132 A. D. 25; Palestine Hebrew Wine Co. v. Terminal Warehouse Co. (1910), 123 N. Y. Supp. 346, 67 Misc. 456.

Oregon.-Pelton v. Gold Hill Canal Co. (1914), 142 Pac. 769.

Washington.-Northwestern Grain

Massachusetts. - Rosanberg v. Co. v. Kear-Clifford Grain Co. Nat. Dock \& Storage Warehouse Co. (1913), 136 Pac. 1154.

Section 11. Except as provided in Section 36, where a warehouseman delivers goods for which he had issued a negotiable receipt, the negotiation of which would transfer the right to the possession of the goods, and fails to take up and cancel the receipt, he shall be liable to any one who purchases for value in good faith such receipt, for failure to deliver the goods to him, whether such purchaser acquired title to the receipt before or after the delivery of the goods by the warehouseman.

Ulinois.-Mfg. Mercant. Co. v. United States.-Clyde Steamship Monarch Refrig. Co. (1915), 107 N. Co. จ. Whaley (1917), 231 Fed. 77. E. 885 .

Section 12. Except as provided in Section 36, where a warehouseman delivers part of the goods for which he had issued a negotiable receipt and fails either to take up and cancel such receipt, or to place plainly upon it a statement of what 
goods or packages have been delivered he shall be liable, to any one who purchases for value in good faith such receipt, for failuro to deliver all the goods specified in the receipt, whether such purehaser acquired title to the receipt before or after the delivery of any portion of the goods by the warehouscman.

Kansas.-Cowley Co. Natl. Bk. United States.- Clyde Steamship v. Rawlins-Dobs Elevator Co. Co. v. Whaley (1917), 231 Fed. 77. (1915), 152 Pac. 647.

Section 13. The alteration of a receipt shall not excuse the warehouseman who issued it from any liability if such alteration was
(a) Immaterial,
(b) Authorized, or
(c) Made without fraudulent intent.

If the alteration was authorized, the warehouseman shall be liable acco:ding to the terms of the receipt as altered. If the alteration was unauthorized, but made without fraudulent intent, the warehouseman shall be liable according to the terms of the receipt, as they were before alteration.

Material and fraudulent alteration of a receipt shall not excuse the warebouseman who issued it from liability to deliver, accordin to the terms of the receipt as originally issued, the goods for which it was issued, but shall excuse him from any other liability to the person who made the alteration and to any person who took with notice of the alteration. Any purchaser of the receipt for value without notice of the alteration shall acquire the same rights against the warehouseman which such purchaser would have acquired if the receipt had not been altered at the time of the purchase.

United States.-Clyde Steamship Co. v. Whaley (1917), 231 Fed. 77.

Section 14. Where a negotiable receipt has been lost or destroyed, a court of competent jurisdiction may order the de livery of the goods upon satisfactory proof of such loss or lestruction and upon the giving of a bond with sufficient sureties to be approved by the court to protect the warehousemau from any liability or expense, which he or any person injured by such delivery may incur by reason of the original receipt remaining 
outstanding. The court may also in its discretion order the payment of the warehouseman's reasonable costs and counsel fees.

The delivery of the goods under an order of the court as provided in this scetion, shall not relieve the warehouseman from liability to a person to whom the negotiable receipt has been or shall be negotiated for value without notice of the proceedings or of the delivery of the goods.

Georgia. - Penick
$\begin{aligned} & (1916), 87 \text { S. E. } 845 .\end{aligned}$

New York.-Brown Shoe Com.

Section 15. A receipt upon the face of which the word "duplicate" is plainly placed is a representation and warranty by the warehouseman that such receipt is an accurate copy of an original receipt properly issued and uncancelled at the date of the issue of the duplicate, but shall impose upon him no other liability.

Section 16. No title or right to the possession of the goods, on the part of the warehouseman, unless such title or right is derived directly or indirectly from a transfer made by the depositor at the time of or subsequent to the deposit for storage, or from the warehouseman's lien, shall excuse the warehouseman from liability for refusing to deliver the goods according to the terms of the receipt.

Section 17. If more than one person claims the title or possession of the goods, the warehouseman may either as a defense to an action brought against him for non-delivery of the goods, or as an original suit, whichever is appropriate, require all known claimants to interplead.

New Jersey.- N. J. L. G. \& T. Co. v. Rector (1909), 75 N. J. E. 423, 72 Atl. 968 .

New York.- Manhattan Storage
\& Warehouse Co. v. Benguiat Art Museum (1913), 139 N. Y. Supp. 1073, 155 App. Div. 196.

Section 18. If some one other than the depositor or person claiming under him has a claim to the title or possession of the 
goods, and the warehouseman has information of such claim, the warehouscman shall be excused from liability for rofusing to deliver the goods, either to the depositor or person claiming under him or to the adverse claimant, until the warehouseman has had a reasonable time to ascertain the validity of the adverso claim or to bring legal proceedings to compel all claimants to interplead.

Massachusetts.-Cushman v. Boston Storage Warehouse Co. (1911), 207 Mass. 407.

New Jersey.- N. J. L. G. \& T. Co. v. Rector (1909), 75 N. J. Eq. 423, 72 Atl. 968.

New York.-Zaber v. Mehrlo (1908), 112 N. Y. Supp. 1093.

Section 19.' Except as provided in the two preceding sections and in sections 9 and 36, no right or title of a third person shall be a defense to an action brought by the depositor or person claiming under him against the warehouseman for failure to deliver the goods according to the terms of the receipt.

Massachusetts.- Cushman v. Boston Storage Warehouse Co. (1911), 93 N. E. 639.

Section 20. A warehouseman shall be liable to the holder of a receipt for damages caused by the non-existence of the goods or by the failure of the goods to correspond with the description thereof in the receipt at the time of its issue. If, however, the goods are described in a receipt merely by a statement of marks or labels upon them, or upon packages containing them, or by a statement that the goods are said to be goods of a certain kind, or that the packages containing the goods are said to contain goods of a certain kind, or by words of like purport, such statements, if true, shall not make liable the warehouseman issuing the receipt, although the goods are not of the kind which the marks or labels upon them indicate, or of the kind they were said to be by the depositor.

Alabama. - Kitchens v. Mann (1918), Ala. App. 80 So. 173.
New Jersey.- Stewart v. Kilmer (1913), 88 Atl. 1051.

Section 21. A warehouseman shall be liable for any loss or injury to the goods caused by his failure to exercise such care 
in regard to them as a reasonably careful owner of similar goods would exercise, but he shall not be liable, in the absence of an agreement to the contrary, for any loss or injury to the goods which could not have been avoided by the exercise of such care.

Alabama.-Betha Starr Packing Co. v. Mayhew (1917), 68 So. 814.

Arkansas.-Gulf Compress Co. v. Harrington (1909), 119 S. W. 249; Farmers' Union Warehouse Co. v. Sturdwant (1916), 192 S. W. 377.

California.-Ruder v. Wells Fargo \& Co. (1911), 14 Cal. App. 790, 113 Pac. 342; Lynch et al. v. Bekins Van \& Storage Co. (1916), 159 Pac. 822.

Colorado.- Benedict Warehouse \& Transfer Co. v. Nickannon Piano Co. (1917), 161 Pac. 145; Lynch v. Union Pac. R. Co. (1918), 172 Pac. 1061. .

Delaware.-Keith v. Booth Fisheries (1913), 87 Atl. 75.

Georgia.-Farmers Ginnery \& Mfg. Co. v. Thrasher (1916), 87 S. E. 804 ; Norris v. Manget-Brannon Co. (1916), 90 S. E. 79.

Illinois.-Natl. Safe Dep. Co. v. Stead (1911), 250 Ill. 584, 95 N. E. 973; Cohen v. Atchison Topeka \& Sante Fe R. Co. (1917), 198 Ill. App. 174; Meyer v. Western Cold Storage Co. (1917). 204 Ill. App. 456; Schaefer v. Washington Safety Deposit Co. (1917), 281 I1l. 43, 117 N. E. 781 .

Kansas.-Locke v. Wiley (1909), 87 Kan. 143, 105 Pac. 11; Filson v. Pac. Exp. Co. (1911), 84 Kan. 614, 114 Pac. 863.

Louisiana.-Gibbons v. Yazoo \& M. V. R. Co. (1912), 130 La. 671, 58 So. 505 .
Maryland.-Security Storage \& Trust Co. v. Denys (1913), 86 Atl. Rep. 613, 119 Md. 331.

Maine.-Briggs Hardware Co. $\mathbf{\text { v. }}$ Aroostock Valley R. Co. (1918), 104 Atl. 8.

Massachusetts. - Rosenberg v. Nat. Dock \& Storage Warehouse Co. (1914), 106 N. E. 171; Wainwright v. Mass. Storage Warehouse Co. (1914), 106 N. E. 1001; Hecht v. Boston Wharf Co. (1915), $107 \mathrm{~N}$. E. 990 .

Minnesota.- Rustad v. Gt. Nor. Ry. Co. (1913), 142 N. W. 727.

Mississippi.-Chas. W. Shepard Cotton Co. v. New Orleans M. \& C. R. Co. (1918). 78 So. 193.

Missouri-Berger v. St. Louis Storage \& Comm. Co. (1909), 116 S. W. 444; Johnson v. Springfield Ice \& Refrig. Co. (1910), 127 S. W. 692 ; Levi v. M. K. \& T. Ry. Co. (1911), 138 S. W. 699; Disbrow v. People's Ice, Storage \& Fuel Co. (1913), 157 S. W. 116; Springfield C. I. E. Co. v. Springfield I. \& R. Co. (1914), 168 S. W. 772; Barnett v. Tonnies (1915), 180 S. W. 1000; State, Use of Hubbard \& iNoffit Comm. Co. v. Cochrane (1915), 175 S. W. 599.

New Jersey.-Champlin v. Erie R. Co. (1917), N. J. C. 103 Atl. 807; Levine v. DeWolff \& Co. (1909), 78 N. J. L. 306, 73 Atl. 73; Bobbink v. Erie R. R. Co. (1912), 82 Atl. 877.

New York.- Ressler v. Terminal Warehouse Co. (1918), 168 N. Y. 
Supp. 462; Carr v. West Side Warehouse Co. (1918), 168 N. Y. Supp. 564; MeCrory Stores Corp. v. West Side W. Co. (1918), 171 N. Y. Supp. 35; McCrory Stores Corp. v. West Side Warehouse Co. (1918), $168 \mathrm{~N}$. Y. Supp. 489; Clifford v. Univ. Stor. age Warehouse (1907), $102 \mathrm{~N}$. Y. Supp. 460, 52 Wisc. 595; Wheeler v. Blumenthal (1908), 107 N. Y. Supp. 57; Buffalo Grain Co. v. Sowerby (1909), 195 N. Y. 355, 88 N. E. 569; Lyons v. H. Y. C. \& N. R. R. Co. (1909), 119 N. Y. Supp. 703; Battell v. Mercantile Warehouse Co. (1910), 124 N. Y. Supp. 135, 139 A. D. 649 ; Ballston Refrig. Co. v. Eastern States Refrig. Co. (1911), 126 N. Y. Supp. 857, 142 A. D. 135; Finsilver v. Manhattan Storage \& Warehouse Co. (1911), 129 N. Y. Supp. 401; Herrman $\nabla$. N. E. Navigation Co. (1911), 128 N. Y. Supp. 380, 143 App. Div. 551; Mortimer v. Otto (1911), $126 \mathrm{~N}$. Y. Supp. 866. 142 A. D. 184; Mortimer v. Otto (1912), 206 N. Y. 89, 99 N. E. 189; Neville v. Woolverton (1913), 142 N. Y. Supp. 292 ; Murray v. J. F. Hayes (1915), $151 \mathrm{~N}$. Y. Supp. 1; People v. Wendel (1916), 111 N. E. 846; Hemphill \& Co. v. Southern Ry. Co. (1916), 87 S. E. 336.
Oklahoma.-Muskogee Crystal Ice Co. v. Riley (1910), 25 Okla. 778 , 108 Pac. 628; Inland Compress Co. v. Simmons (1917), 159 Pac. 262.

South Dakota.-Gilbert v. Hardiman (1918), 168 N. W. 25.

Tennessee.- Noel \& Co. v. Schuer (1918), 204 S. W. 632.

Texas.-American Express Co. v. Duncan (1917), 193 S. W. 411; Sherman Ice Co. v. Klein (1917), 195 S. W. 918.

United States.-United Metals Selling Co. v. Pryor (1917), 155 C. C. A. 521, 243 Fed. 91.

Vermont.-Chas. Bianchi \& Sons v. Montpelier \& W. R. R. Co. (1918). - Vt. 104 Atl. 144.

Washington. - Rosenbaum v. Northern Pacific Ry. Co. (1918), 172 Pac. 238; Patterson v. Wenatchee Canning Co. (1909), 53 Wash. 155, 101 Pac. 721; Smith v. Diamond Ice \& Storage Co. (1911), 65 Wash. 576, 116 Pac. 646; Perry Bros. v. Diamond Ice \& Storage Co. (1916), 158 Pac. 1008.

West Virginia.-Brown Shoe Ca. v. Harden (1916), 87 S. E. 1014.

Wisconsin.-Milwaukee M. \& A. Glass Works v. C. M. \& St. P. Ry. Co. (1912), 148 Wis. 173,134 N. W. 379.

Section 22. Except as provided in the following section, a warehouseman shall keep the goods so far separate from goods of other depositors, and from other goods of the same depositor for which a separate receipt has been issued, as to permit at all times the identification and re-delivery of the goods deposited.

Section 23. If authorized by agreement or by custom, a warehouseman may mingle fungible goods with other goods of 
the same kind and grade. In such case the various depositors of the mingled goods shall own the entire mass in common and each depositor shall be entitled to such portion thereof as tho amount deposited by him bears to the whole.

North Dakota.- Street v. Farmer's El. Co. of Elkton (1914), 146 N. W. 1077 .

South Dakota.-Natl. Bk. of Wheaton, Minn. v. Elkins, Sheriff et al (1916), 159 N. W. 60 .
United States.- Interstate Banking \& Trust Co. v. Brown (1916), 225 Fed. 32.

Section 24. The warehouseman shall be severally liable to each depositor for the care and re-delivery of his share of such mass to the same extent and under the same circumstances as if the goods had been kept separate.

Illinois. - Hobbs v. Monarch Refrig. Co. (1917), 277 Ill. 326, 115 N. E. 534.

Louisiana.-Jennings-Heywood Oil Syn. v. Koussiere Oil Co. (1910), 127 La. 971, 54 So. 318.
Washington.-Union El. \& Warehouse Co. v. Farmers Warehouse Co. (1912), 69 Wash. 664, 125 Pac. 960.

Section 25. If goods are delivered to a warehouseman by the owner or by a person whose act in conveying the title to them to a purchaser in good faith for value would bind the owner, and a negotiable receipt is issued for them, they can not thereafter, while in the possession of the warehouseman, be attached by garnishment or otherwise, or be leviel upon under an execution, unless the receipt be first surrendered to the warehouseman, or its negotiation enjoined. The warehouseman shall in no case be compelled to deliver up the actual possession of the goods until the receipt is surrendered to him or impounded by the court.

nlinois.-Mfg. Mercant. Co. $\nabla$. Monarch Refrig. Co. (1915), 107 S. E. 885 .

Michigan-Allswede v. Central Warehouse Co. (1918), 169 N. W. 13.
United States.-Arbathnot v. Cen. Tr. Co. of Illinois (1915), C. C. A., 7th Circuit, decided Jan. 23, 1915; In re Richheimer (1917), 221 Fed. 16. 
Section 26. A creditor whose debtor is the owner of a negotiable receipt shall be entitled to such aid from courts of appropriate jurisdiction, by injunction and otherwise, in attaching such receipt or in satisfying the claim by means thereof as is allowed at law in equity, in regard to property which can not readily be attached or levied upon by ordinary legal process.

Section 27: Subject to the provisions of Section 30, a warehouseman shall have a lien on goods deposited or on the proeeeds thereof in his hands, for all lawful charges for storage and preservation of the goods; also for all lawful claims for money advaneed, interest, insurance, transportation, labor, weighing, coopering and other charges and expenses in relation to such goods; also for all reasonable charges and expenses for notice, and advertisements of sale, and for sale of the goods where default has been made in satisfying the warehouseman's lien.

Arkansas.-Farmers' Union Warehouse Co. v. Sturdivant (1916), 192 S. W. 377.

California.-Shedoudy v. Spreckles Bros. Com. Co. (1909), 9 Cal. 198, 99 Pac. 535.

Georgia. - Penick v. Almand (1916), 87 S. E. 845.

Illinois.-Crane et al. v. Tooker
Storage \& Forwarding Co. (1918), 204 Ill. App. 354.

Massachusetts. - Rosenberg v. Nat. Dock Storage Co. (1914), 106 N. E. 171.

New York.-Fairell v. Harlem Term. Storage Warehouse Co. (1911), 127 N. Y. Supp. 306, 70 Misc. 565.

Section 28. Subject to the provisions of Section 30 a warehouseman's lien may be enforced-

(a). Against all goods, whenever deposited, belonging to the person who is liable as debtor for the claims in regard to which the lien is asserted, and

(b) Against all goods belonging to others which have been deposited at any time by the person who is liable as debtor for the claims in regard to which the lien is asserted if such person had been so entrusted with the possession of the goods that a pledge of the same by him at the time of the deposit to one who took the goods in good faith for value would have been valid.

Georgia.- Penick v. Almand cab Co. (1910), 121 N. Y. Supp. 271, (1916), 87 S. E. 845.

66 Misc. 191.

New York.-Alton v. N. Y. Taxi- 
Section 29. A warehouseman loses his lien upon goods-

(a) By surrendering possession thereof, or

(b) By refusing to deliver the goods when a demand is made with which he is bound to comply under the provisions of this act.

Section 30. If a negotiable receipt is issued for goods, the warehouseman shall have. no lien thereon, except for charges for storage of those goods subsequent to the date of the receipt, unless the receipt expressly enumerates other charges for which a lien is claimed. In such case there shall be a lien for the charges enumerated so far as they are within the terms of Section 27 , although the amount of the charges so enumerated is not stated in the receipt.

Missouri.-State ex rel. First Natl. Bk. of Morris, Okl. v. Federal
Union Storage Co. (1911), $137 \mathrm{~S}$. W. 613 .

Section 31. A warehouseman having a lien valid against the per'son demanding the goods may refuse to deliver the goods to him until the lien is satisfied.

Oklahoma.-Penick v. Almand (1916), 87 S. E. 845.
New York.-Zazer v. Mehrle (1908), 112 N. ${ }^{\circ}$ Y. Supp. 1093.

Seetion 32. - Whether a warehouseman has or has not a lien upon the goods, he is entitled to all remedies allowed by law to a creditor against his debtor, for the collection from the depositor of all charges and advanees which the depositor has expressly or impliedly contracted with the warehouseman to pay.

Massachusetts.-Cahill v. Phelps (1908), 198 Mass. 332,84 N. E. 496.
Utah.- Howard v. Paulson Co. (1912), 41 Utah 490, 127 Pac. 284.

Section 33. A warchouseman's lien for a elaim which has beeome due may be satisfied as follows:

The warehouseman shall give a written notice to the person on whose account the goods are held, and to any other person known by the warehouseman to claim an interest in the goods. Such notice shall be given by delivery in person or by registered letters addressed to the last known place of business or abode of the person to be notified. The notice shall contain- 
(a) An itemized statement of the warehouseman's claim, showing the sum due at the time of the notice and the date or dates when it became due,

(b) A brief description of the goods against which the lien exists,

(c) A demand that the amount of the claim as stated in the notice, and of such further claim as shall accrue, shall be paid on or before a day mentioned, not less than ten days from the delivery of the notice if it is personally delivered, or from the time when the notice should reach its destination, according to the due course of post, if the notice is sent by mail, and

(d) A statement that unless the claim is paid within the time specified the goods will be advertised for sale and sold by auction at a specified time and place.

In accordance with the terms of a notice so given, a sale of the goods by auction may be had to satisfy any valid claim of the warehouseman for which he has a lien on the goods. The sale shall be had in the place where the lien was acquired, or, if such a place is manifestly unsuitable for the purpose, at the nearest suitable place. After the time for the payment of the claim specified in the notice to the depositor has elapsed, an advertisement of the sale, describing the goods to be sold, and stating the name of the owner or person on whose account the goods are held, and the time and place of the sale, shall be published once a week for two consecutive weeks in a newspaper published in the place where such sale is to be held. The sale shall not be held less than fifteen days from the time of the first publication. If there is no newspaper published in such place. the advertisement shall be posted at least ten days before such sale in not less than six conspicuous places therein.

From the proceeds of such sale the warehouseman shall satisfy his lien, including the reasonable charges of notice, advertisement, and sale. The balance, if any, of such proceeds shall bo held by the warehouseman, and delivered on demand to the person to whom he would have been bound to deliver or justified in delivering the goods.

At any time before the goods are so sold any person claiming a right of property or possession therein may pay the warchouse- 
man the amount necessary to satisfy his lien and to pay the reasonable expenses and liabilities incurred in serving notices and advertising and preparing for the sale up to the time of such payment. The warehouseman shall deliver the goods to the person making such payment if he is a person entitled, under the provisions of this Act, to the possession of the goods on payment of charges thereon. Otherwise the warehouseman shall retain possession of the goods according to the terms of the original contract of deposit.

New York,-Dawley v. Lovia frigerating Co. (1918), 175 N. Y. (1919), 173 N. Y. Supp. 468; Heine- Supp. 504.

man Bros. Inc. v. Merchants Re-

Section 34. If goods are of a perishable nature, or by keeping will deteriorate greatly in value, or by their odor, leakage, inflammability, or explosive nature, will be liable to injure other property, the warehouseman may give such notice to the owner, or to the person in whose name the goods are stored, as is reasonable and possible under the circumstances, to satisfy the lien upon such goods, and to remove them from the warehouse, and in the event of the failure of such person to satisfy the lien and to remove the goods within the time so specified, the warehouseman may sell the goods at public or private sale without advertising. If the warehouseman after a reasonable effort is unable to sell such goods, he may dispose of them in any lawful manner, and shall incur no liability by reason thereof.

The proceeds of any sale made under the terms of this section shall be disposed of in the same way as the proceeds of sales made under the terms of the preceding section.

Tennessee.- Noel \& Co. v. Schuer (1918), 204 S. W. 632.

Texas.-Union Cold Storage \& W. Co. v. Pitts (1913), 161 S. W. 1182.
Washington. - Rosenbaum v. Northern Pacific Ry. Co. (1918), 172 Pac. 238.

Section 35. The remedy for enforcing a lien herein provided does not preclude any other remedies allowed by law for the enforcement of a lien against personal property nor bar the right to recover so much of the warehouseman's claim as shall not be paid by the procoeds of the sale of the property. 
Section 36. - After goods have been lawfully sold to satisfy a warehouseman's lien, or have been lawfully sold or disposed of because of their perishable or hazardons nature, the warohouseman shall not thereafter be liable for failure to deliver the goods to the depositor, or owner of the goods, or to a holder of the receipt given for the goods when they were deposited, even if such receipt be negotiable.

\section{PART III.}

Section 37. A negotiable receipt may be negotiated by do livery-

(a) Where, by the terms of the receipt, the warehouseman undertakes to deliver the goods to the bearer, or

(b) Where, by the terms of the receipt, the warehousernan undertakes to deliver the goods to the order of a specified person, and such person or a subsequent indorsee of the receipt has indorsed it in blank or to bearer.

Where, by the terms of a negotiable receipt, the goods are deliverable to bearer or where a negotiable receipt has been indorsed in blank or to bearer, any holder may indorse the samo to himself or to any other specified person, and in such case the receipt shall thereafter be negotiated only by the indorsement of such indorsee.

Section 38. A negotiable receipt may be negotiated by the indorsement of the person to whose order the goods are, by the terms of the receipt, deliverable. Such indorsement may be in blank, to bearer or to a specified person. If indorsed to a specified person, it may be again negotiated by the indorsement of such person in blank, to bearer or to another specified person. Subsequent negotiation may be made in like manner.

North Dakota. - Dammann v. Schibsby Implement Co. (1915), 151 N. W. 985 .

Section 39. A receipt which is not in such form that it can be negotiated by delivery may be transferred by the holder by delivery to a purchaser or donee. 
A non-negotiable receipt cannot be negotiated, and the indorsement of such a receipt gives the transferee no additional right.

Section 40. A negotiable receipt may be negotiated-

(a) By the owner thereof, or

(b) By any person to whom the possession or custody of the receipt has been entrusted by the owner, if, by the terms of the receipt, the warehouseman undertakes to deliver the goods to the order of the person to whom the possession or custody of the receipt has been entrusted, or if at the time of such entrusting the receipt is in such form that it may be negotiated by delivery.

United States.-Arbuthnot v. 568; Commercial Bank v. Canal Cen. Tr. Co. of Ill. (1915), C. C. A., Bank (1916), 239 U. S. 520; In re 7th Circuit, decided Jan. 23, 1915; Reishheimer (1917), 221 Fed. 1 ô. In re Dreuil \& Co. (1913), 205 Fed.

Section 41. A person to whom a negotiable receipt has been duly negotiated acquires thereby-

(a) Such title to the goods as the person negotiating the receipt to him had or had ability to convey to a purchaser in good faith for value, and also such title to the goods as the depositor or person to whose order the goods were to be delivered by the terms of the receipt had or had ability to convey to a purchaser in good faith for value, and

(b) The direct obligation of the warehouseman to hold possession of the goods for him according to the terms of the receipt as fully as if the warehouseman had contracted directly with him.

Minnesota.-Ammon v. Gamble Robinson Com. Co. (1910), $127 \mathrm{~N}$. W. 448, 111 Minn. 452.

North Dakota.-St. Antliony \& Dak. El. Co. $(1910), 20$ N. D. 18 , 126 N. W. 1013; Dammann v. Schibsby Imulement Co. (1915), 151 N. W. 985.

United States. - Arbuthnot v. Central Tr. Co. of Ill. (j1915), C. C.
A., 7th Circuit, decided Jan. 23. 1915; In re Dreuil \& Co. (1913), 205 Fed. 568; Commercial Bank v. Canal Bank (1916), 239 U. S. 520; In re Richbeimer (1917), 221 Fed. 16.

Washington.- Hancock v. Pacific Coast Elevator Co. (1919), 177 Pac. 639 . 
Section 42. A person to whom a receipt has been transferred but not negotiated, aequires thereby, as against the transferor, the title of the goods, subject to the terms of any agreement with the transferor.

If the receipt is non-negotiable such person also acquires the right to notify the warehouseman of the transfer to him of such receipt, and thereby to acquire the direct obligation of the warehouseman to hold possession of the goods for him according to the terms of the receipt.

Prior to the notification of the warehouseman by the transferor or transferee of a non-negotiable receipt, the title of the transferee to the goods and the right to acquire the obligation of the warehouseman may be defeated by the levy of an attachment or execution upon the goods by a creditor of the transferor, or by a notification to the warehouseman by the transferor or a subsequent purchaser from the transferor of a subsequent sale of the goods by the transferor.

California.- Callahan v. Marshall (1912), 163 Cal. 552, 126 Pac. 358.

Iowa.- In re New Glenwood Canning Co. (1911), 150 Iowa, 696, 130 N. W. 800 .

Missouri.-Wright v. Miss. Val.

Tr. Co. (1910), 129 S. W. 407.
Oregon.-U. S. v. Oregon \& Nav. Co. (1908), 159 Fed. 975.

United States.-In re Miller Pure Rye Dist. Co. (1910), 176 Fed. 606.

Section 43. Where a negotiable receipt is transferred for value by delivery and the indorsement of the transferor is essential for negotiation, the transferee acquires a right against the transferor to compel him to indorse the receipt, unless a contrary intention appears. The negotiation shall take effect as of the time when the indorsement is actually made.

Section 44. A person who for value negotiates or transfers a receipt by indorsement or delivery, including one who assigns for value a claim secured by a receipt, unless a contrary intention appears, warrants-

(a) That the receipt is genuine,

(b) That he has a legal right to negotiate or transfer it,

(c) That he has knowledge of no fact which would impair the validity or worth of the receipt, and 
(d) That he has a right to transfer the title to the goods and that the goods are merchantable or fit for a particular purpose whenever such warranties would have been implied, if the contract of the parties had been to transfer without a receipt the goods represented thereby.

New York.-Alvord v. Revillon Freres (1915), 151 N. Y. Supp. 920.

Section 45. The indorsement of a receipt shall not make the indorser liable for any failure on the part of the warehouseman or previous indorsers of the receipt to fulfill their respective obligations.

Section 46.-A mortgagee, pledgce or holder for security of a receipt who in good faith demands or receives payment of the debt for which such receipt is security, whether from a party to a draft drawn for such debt or from any other person, shall not by so doing be decmed to represent or warrant the genuineness of such receipt or the quantity or the quality of the goods therein described.

Section 47 The validity of the negotiation of a receipt is not impaired by the fact that such negotiation was a breach of duty on the part of the person making the negotiation, or by the fact that the owner of the receipt was induced by fraud, mistake, or duress to entrust the possession or custody of the receipt to such person if the person to whom the receipt was negotiated, or a person to whom the receipt was subsequently negotiated, paid value therefor, without notice of the breach of duty, or fraud, mistake, or duress.

United States. - Arbuthnot v. Cen. Tr. Co. of Ill. (1915), C. C. A., 7th Circuit, decided Jan. 23, 1915; In re Dreuil \& Co. (1913), 205 Fed.

Section 48. Where a person having sold, mortgaged, or pledged goods which are in a warehouse and for which a negotiable receipt has been issued, or having sold, mortgaged, or pledged the negotiable receipt representing such goods, continues in possession of the negotiable receipt, the subsequent negotiation thereof by that person under any sale, or other disposition thereof to any person receiving the same in good faith, 
for value and without notice of the previous sale, mortgage or pledge, shall have the same effect as if the first purchaser of the goods or receipt had expressly authorized the subsequent negotiation.

New York-Ludwig, Baumann \& Co. v. Roth (1910), 123 N. Y. Supp. 191, 57 Misc. 458.

Section 49. Where a negotiable receipt has been issued for goods, no seller's lien or right of stoppage in transitu shall defeat the rights of any purchaser for value in good faith to whom such receipt has been negotiated, whether such negotiation be prior or subsequent to the notification to the warehouseman who issued such receipt of the seller's claim to a lien or right of stoppage in transitu. Nor shall the warehouseman be obliged to deliver or justified in delivering the goods to an unpaid seller unless the receipt is first surrendered for concellation.

United States.-Arbuthnot v. Cen. Tr. Co. of Ill. (1915), C. C. A., 7th Richheimer (1917), 221 Fed. 16.

Circuit, decided Jan. 23, 1915; In re

\section{PART IV.}

Section 50. A warehouseman, or any officer, agent, or servant of a warehouseman, who issues or aids in issuing a receipt knowing that the goods for which such receipt is issued have not been actually received by such warehouseman, or are not under his actual control at the time of issuing such receipt, shall bo guilty of a crime, and upon conviction shall be punished for each offense by imprisonment not exceeding five years, or by a fine not exceeding five thousand dollars, or by both.

Section 51. A warehouseman, or any officer, agent or servant of a warehouseman, who fraudulently issues or aids in fraudulently issuing a receipt for goods knowing that it con- tains any false statement, shall be guilty of a crime and upon conviction shall be punished for each offense by imprisonment not exceeding one year, or by a fine not exceeding one thousand dollars, or by both. 
Section 52. A warehouseman, or any officer, agent or servant of a warehouseman, who issues or aids in issuing a duplicate or additional negotiable receipt for goods knowing that a former negotiable receipt for the same goods or any part of them is outstanding and uncancelled, without plainly placing upon the face thereof the word "Duplicate" except in the case of a lost or destroyed receipt after proceedings as provided for in Section 14, shall be guilty of a crime, and upon conviction shall be punished for each offense by imprisonment not exceeding five years, or by a fine not exceeding five thousand dollars, or by both.

$$
\text { Maryland. - State v. Gambrill (1911), } 81 \text { Atl. 10, } 120^{\circ} \text { Md. } 203 .
$$

Section 53. Where there are deposited with or held by a warehouseman goods of which he is owner, either solely or jointly or in common with others, such warehouseman, or any of his officers, agents, or servants who, knowing this ownership, issues or aids in issuing a negotiable receipt for such goods which does not state such ownership, shall be guilty of a crime, and upon conviction shall be punished for each offense by imprisonment not exceeding one year, or by a fine not exceeding one thousand dollars, or by both.

Section 54. A warehouseman, or any officer, agent, or servant of a warehouseman who delivers goods out of the possession of such warehouseman, knowing that a negotiable receipt the negotiation of which would transfer the right to the possession of such goods is outstanding and uncancelled, without obtaining the possession of such receipt at or before the time of such delivery, shall, except in the cases provided for in Sections 14 and 36 , be found guilty of a crime, and upon conviction shall be punished for each offense by imprisonment not exceeding one year, or by a fine not exceeding one thousand dollars, or by both.

United States.-Clyde Steamship Co. v. Whaley (1917), 231 Fed. 77.

Section 55. Any person who deposits goods to which he has not title, or upon which there is a lien or mortgage, and who 
takes for such goods a negotiable receipt which he afterwards negotiates for value with intent to deceive and without disclosing his want of title or the existence of the lien or mortgage shall be guilty of a crime, and upon conviction shall be punished for each offense by imprisonment not exceeding one year, or by a fine not exceeding one thousand dollars, or by both.

\section{PART V.}

Section 56. In any case not provided for in this Act, the rules of law and equity, including the law merchant, and in particular the rules relating to the law of principal and agent and to the effect of fraud, misrepresentation, duress or coercion, mistake, bankruptey, or other invalidating cause, shall govern.

Section 57. This Act shall be so interpreted and construed as to effectuate its general purpose to make uniform the law of those states which enact it.

United States.-Commercial Bank v. Canal Bank (1916), 239 U. S. 520.

Section 58. (1) In this Act, unless the context or subject matter otherwise requires-

"Action" includes counter claim, set-off, and suit in equity.

"Delivery" means voluntary transfer of possession from one person to another.

"Fungible goods" means goods of which any unit is, from its nature or by mercantile custom, treated as the equivalent of any other unit.

"Goods" means chattels or merchandise in storage, or which has been or is about to be stored.

"Holder" of a receipt means a person who has both actual possession of such receipt and a right of property therein.

"Order" means an order by indorscment on the receipt.

"Owner" does not include mortgagee or pledgee.

"Person" includes a corporation or partnership or two or more persons having a joint or common interest. 
To "purchase" includes to take as mortgagee or as pledgee.

"Purchaser" includes mortgagee and pledgee.

"Receipt" means a warehouse receipt.

"Value" is any consideration sufficient to support a simple contract. An antecedent or preexisting obligation, whether for money or not, constitutes value where a receipt is taken either in satisfaction thereof or as security therefor.

"Warehouseman" means a person lawfully engaged in the business of storing goods for profit.

(2) A thing is done "in good faith" within the meaning of this Act, when it is in fact done honestly, whether it be done negligently or not.

Minnesota.-State v. Minn. \& St. L. Ry. Co. (1911), 115 Minn. 116, 131 N. W. 1075.

New Jersey.-N. J. T. G. \& T. Co. v. Rector (1910), 76 N. J. Eq. 587, 75 Atl 931.

New York.-First Commercial National Bank of Pontiac v. Valentine (1914), 148 N. Y. Sụpp. 792, 163 A. D. 709.

Pennsylvania. - Nat. Un. Bk. Reading v. Shearer (1909), $225 \mathrm{~Pa}$. 470, 74 Atl. 351; Moore v. Thos. Moore Dist. Co. (1915), 93 Atl. 347.
Texas. - Exporters \& Traders Compress \& Warehouse Co. v. Wills (1918), Tex. Civ. App. 204 S. W. 1056; American Express Co. v. Duncan (1917), 193 S. W. 411.

West Virginia.-Belknap v. Baltimore \& Ohio R. R. Co. (1917), 91 S. E. 656 .

United States.-In re Rohrer (1911), 186 Fed. 997; Evans v. N. Y. \& P. S. S. C. (1908), 163 Fed. 405; Interstate Banking \& Trust Co. v. Brown (1916), 225 Fed. 32.

Section 59. The provisions of this Act do not apply to re eeipts made and delivered prior to the taking effect of this Act.

Section 60. All Acts or parts of Acts inconsistent with this act are hereby repealed.

Maryland.-State จ. Gambrill ing \& Trust Co. v. Brown (1916), (1911), 81 Atl. 10, 120 Md. 203.

225 Fed: 32 .

United States-Interstate Bank-

Section 61. This Act shall take effect on the of , one thousand nine hundred and

Section 62. This Act may be cited as the Uniform Ware house Receipts Act. 
UNIFORM ANNULMENT OF MARRIAGE AND DIVORCE ACT 



\section{UNLFORM ANNULMENT OF MARRIAGE AND DIVORCE ACT}

A National Congress on Uniform Divorce Laws held a meeting in the City of Washington on February 19-22, 1906, and subsequently by adjournment in Philadelphia, November 13-14, 1906. The result of this conference was the drafting and recommending of the proposed Uniform Annulment of Mar riage and Divorce Act.

By a resolution, the Conference of National Commissioners adopted at its fifteenth meeting, held at Narragansett Pier, Rhode Island, August 18-22, 1905, recognition of this Congress was given and the conference "promised" to aid the proposed Congress in any way within its power." In the Seventeenth Conference of the Commissioners, held at Portland, Me., August 22-24, 1907, the Committee on Marriage and Divorce reported that the Conference should recommend the act for adoption to the various states and territories and the District of Columbia. This was done by unanimous vote, August 24, 1907. 
294 UNIFORM ANNULMENT OF MEARRIAGE AND DIVORCE ACT.

\begin{tabular}{|c|c|c|c|}
\hline & $\begin{array}{c}\text { Ch. 86, p. } 1411 \\
\text { Rev. } 1915 .\end{array}$ & $\begin{array}{l}\text { II Comp, Stat, } \\
\text { p. } 2021\end{array}$ & Rev. 1917 \\
\hline $\begin{array}{l}\text { Uniform Act } \\
\text { Section No. }\end{array}$ & $\begin{array}{c}1907 \\
\text { Delawar: }\end{array}$ & $\begin{array}{c}1907 \\
\text { New Jersey }\end{array}$ & $\begin{array}{l}1909 \\
\text { W:sconsin. }\end{array}$ \\
\hline $\begin{array}{r}1 \\
2 \\
3 \\
4 \\
5 \\
6 \\
7 \\
8 \\
9 \\
10 \\
11 \\
12 \\
13 \\
14 \\
15 \\
16 \\
17 \\
18 \\
19 \\
20 \\
21 \\
22 \\
23 \\
24\end{array}$ & $\begin{array}{l}3004^{*} \\
3005 \\
3006^{*} \\
3007 \\
3008 \\
3009 \\
3010^{*} \\
3011^{*} \\
3012^{*} \\
3013^{*} \\
3020 \\
3021^{*} \\
3022 \\
3023 \\
3024 \\
3025 * \\
3026 \\
3027 \\
3028 \\
3029 \\
3030 \\
3032 \\
\ldots \ldots \\
\ldots \ldots\end{array}$ & . & 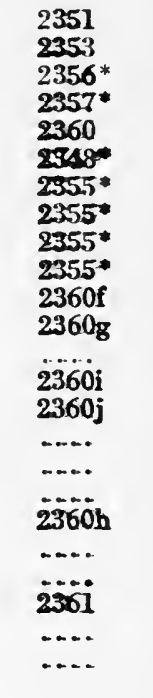 \\
\hline
\end{tabular}




\section{UNIFORM ANNULMENT OF MARRIAGE AND DIVORCE ACT}

SEction 1. Annulment, Causes for.

2. Divorce.

3. Divorce a Vinculo, Causes for.

4. Divorce a Mensa, Causes for.

5. Bars to Divorce.

6. Jurisdiction, in What Courts.

7. Jurisdiction, by Personal Service.

8. In Action for Divorce.

9. Jurisdiction, by Publication.

10. In Actions for Divorce.

11. Particeps Crimins.

12. Hearings and Trial.

13. Attorney, Appointment of.

14. Proof Required.

15. Impounding of Record, etc.

16. Decrees Nisi.

17. Absolute Decrees.

18. Decrees a Mensa.

19. Former Name of Wife.

20. Children, Legitimacy of. In Action by Wife.

21. In Action by Husband.

22. Foreign Decrees. Of Other States. Of Foreign Countries. Proviso. Evasion of Laws of this State.

23. Repealing Clause. Proviso.

24. When Act Shall Take Effect. 


\section{UNIFORM ANNULMENT OF MARRIAGE AND DIVORCE ACT}

Section 1.-(Annulment, Causes for.) - That a marriage may be annulled for any of the following causes existing at the time of the marriage:

(a) (Impotency, etc.) Incurable physical impotency, or incapacity for copulation, at the suit of either party: PROVIDED, That the party making the application was ignorant of such impotency or incapacity at the time of the marriage.

New Jersey.-Kaufman v. Kauf- $\operatorname{man}$ (1916), 97 Atl. 490.

(b) (Consanguinity, etc.) Consanguinity or affinity according to the table of degrees established by law, at the suit of either party; but when any such marriage shall not have been annulled during the lifetime of the parties the validity thereof shall not be inquired into after the death of either party.

(c) (Former Marriage.) When such marriage was contracted while either of the parties thereto had a husband or wife living, at the suit of either party.

New Jersey.- Harned v. Harned Krestovnikow (1917), 102 Atl. 246. (1907), 67 Atl. 180; Schaffer v.

(d) (Fraud, etc.) Fraud, force or coercion, at the suit of the innocent and injured party, unless the marriage has been confirmed by the acts of the injured party.

Wisconsin. $-\mathrm{C} \longrightarrow$ v. C (1914), 158 Wis. 301.

(e) (Insanity, Proviso.) Insanity of either party, at the suit of the other, or at the suit of the committee of the lunatic, or of the lunatic on regaining reason, unless such lunatic, after regaining reason, has confirmed the marriage: PROVIDED, That where the party compos mentis is the applicant, such party shall have been ignorant of the other's insanity at the time of the marriage, and shall not have confirmed it subsequent to the lunatic's regaining reason.

New Jersey.-Allen v. Allen (1916), 99 Atl. 309; Buffum v. Buf(1915), 95 Atl. 363; Allen v. Allen fum (1916), 97 Atl. 256. 
(f) (Non-Age of Wife.) At the suit of the wife when she was under the age of sixteen years at the time of the marriage, unless such marriage be confirmed by her after arriving at such age.

(g) (Non-Age of Husband.) At the suit of the husband when he was under the age of eighteen at the time of the marriage, unless such marriage be confirmed by him after arriving at such age.

New Jersey.-Taub v. Taub Titsworth (1910), N. J. Ch. 78 Atl. (1917), 101 Atl. 246; Titsworth v. 687.

Section 2.-(Divorce.)-Divorco shall be of two kinds:

Wisconsin.- Shequin v. Shequin (1915), 161 Wis. 183.

(a) (A Vinculo.) Divoree from the bonds of matrimony, or divorce a vincula matrimonii.

(b) (A Mensa.) Divorce from bed and board, or divorce a mensa et thoro.

Section 3.-(Divorce a Vinculo, Causes for.)-The causes for divorce from the bonds of matrimony shall be:

(a) (Adultery.) Adultery.

Delaware.-Bancroft v. Bancroft (1911), 27 Del. 9; Knowles v. Knowles (1917), 29 Del. 458.

New Jersey.- Bowers v. Bowers (1918), 104 Atl. 831; Clark v. Clark (1911), 81 Atl. 1126; Moyer v. Moyer (1911), 81 Atl. 575; Ludentz v. Ludentz (1917), N. J. Ch. 102 Atl. 661; Ross v. Ross (1918), N. J. Ch. 104 Atl. 199; Smith v. Smith (1916), N. J. Ch. 98 Atl. 84; Tiger v. Tiger (1917), N. J. Ch. 100 Atl. 848; Willie v. Willie (1918), 103 Atl. 74 .

(b) (Bigamy.) Bigamy, at the suit of the innocent and injured party to the first marriage.

New Jersey.-Gordon v. Gordon (1918), 105 Atl. 242.

(c) (Conviction, etc., for Crime Proviso.) Conviction and sentence for crime by a competent court having jurisdiction, followed by a continuous imprisonment for at least two years, or in the case of indeterminate sentence, for at least one year; 
PROVIDED, That such conviction has been the result of trial in some one of the states of the United States, or in a Federal Court, or in some one of the territories, possessions or courts subject to the jurisdiction of the United States, or in some foreign country granting a trial by jury, followed by an equally long term of imprisonment.

(d) (Extreme Cruelty.) Extreme cruelty, on the part of either husband or wife, such as to endanger the life or health of the other party or to render cohabitation unsafe.

Delaware. - Elliott v. Elliott (1915), 28 Del. 406; McClenahan $\nabla$. McClenahan (1911), 25 Del, 599.

New Jersey.- Calichio v. Calichio (1915), 96 Atl. 658.
Wisconsin. - Banks v. Banks (1916), 155 N. W. 916; Hiecke v. Hiecke -(1916), 157 N. W. 747; Kopplin v. Kopplin (1915), 159 Wis. 559.

(e) (Desertion.) Wilful desertion for two years.

New Jersey.-Bridge v. Bridge (1915), N. J. Ch. 93 Atl. 690; Fry v. Fry (1917), N. J. Ch. 100 Atl. 839; Fraser v. Fraser (1917), 101 Atl. 58; Fisher v. Fisher (1915), 95 Atl. 970; Hague v. Hague (1915), 95 Atl. 192; Gordon v. Gordon (1918), N. J. Ch. 103 Atl. 31; Getz v. Getz (1913), N. J. Ch. 88 Atl. 376; Myles v. Myles (1910), 76 Atl. 1037; Jones v. Jones (1915), 93 Atl.
580; Martin v. Martin (1911). N. J. Ch. 79 Atl. 261; Rector v. Rector (1911), N. J. Ch. 79 Atl. 295; Raymond v. Raymond (1911), N. J. Ch. 79 Atl. 430; Oertel v. Oertel (1914), N. J. Ch. 90 Atl. 1006; Sutton v. Sutton (1914), 90 Atl. 280; Orens v. Orens (1917), N. J. Eq. 102 Atl. 436; Pozzi v. Pozzi (1917), 102 Atl. 665; Yawger v. Yawger (1913), N. J. Ch. 86 Atl. 419.

(f) (Drunkenness.) Habitual drunkenness for two years.

Delaware. - Smith v. Smith (1919), 105 Atl. 833.

Section 4.-(Divorce a Mensa, Causes for.)-The causes for divorce from a bed and board shall be:

(a) (Adultery.) Adultery.

(b) (Bigamy.) Bigamy, at the suit of the innocent and injured party to the first marriage.

(c) (Conviction, etc., for Crime. Proviso.) Conviction and sentence for crime by a competent court having jurisdiction, followed by a continuous imprisonment for at least two years, 
or in case of indeterminate sentence, for at least one year: PROVIDED, That such conviction has been the result of trial in some one of the states of the United States, or in a Federal Court, or in some one of the territories, possessions or courts subject to the jurisdiction of the United States, or in some foreign country granting a trial by jury, followed by an equally long term of imprisonment.

(d) (Extreme Cruelty.) Extreme cruelty, on the part of either husband or wife, such as to endanger the life or health of the other party or to render cohabitation unsafe.

New Jersey.-Boyle v. Boyle J. Ch. 103 Atl. 675; Thomas v. (1907), N. J. Ch. 67 Atl. 690; Casey Thomas (1909), N. J. Ch. 74 Atl. v. Casey (1914), N. J. Ch. 93 Atl. 125. 720; Thomas v. Thomas (1916), N.

(e) (Desertion.) Wilfull desertion for two years.

(f) (Drunkenness.) Habitual drunkenness for two years. band.

(g) (Insanity of Husband.) Hopeless insanity of the hus-

Section 5.-(Bars to Divorce.)-No decree for divorce shall be granted if it appears to the satisfaction of the court that the suit has been brought by collusion, or that the plaintiff has procured or connived at the offense charged, or has condoned it, or has been guilty of adultery not condoned.

Delaware.-Knowles v. Knowles 1001; Johnson v. Johnson (1911), (1917), 29 Del. 458.

N. J. Ch. 80 Atl. 119; Newton v.

New Jersey.-Dilatusch v. Dila- Newton (1916), N. J. Ch. 97 Atl. tusch (1916), 98 Atl. 255; Engster 294; Sheehan v. Sheehan (1910), v. Engster (1917), 101 Atl. 575; N. J. Ch. 77 Atl. 1063; White v. Greims v. Greims (1913), 83 Atl. White (1915), 95 Atl. 197.

Section 6.-(Jurisdiction, in What Courts.) The......... court of this state shall have and entertain jurisdiction of all actions for annulment of marriage, or for divorce.

Section 7.-(Jurisdiction, by Personal Service In Actions for Annulment.) For purposes of annulment of marriage, jurisdiction may be acquired by personal service upon the de- 
fendant within this state when either party is a bona fide resident of this state at the time of the commencement of the action.
Delaware-Bethard $\nabla$. Bethard
New Jersey.- Hess v. Kimblo (1914), 28 Del. 56.
(1911), N. J. Ch. 1 Atl. 363.

Section 8.-(In Action for Divorce.) For purposes of divorce, either absolute or from bed and board, jurisdiction may be acquired by personal service upon the defendant within this state, under the following conditions:

Delaware.-Bethard v. Bethard (1914), 28 Del. 56.

(a) (Exception.) When, at the time the cause of actinn arose, either party was a bona fide resident of this state, and has continued so to be down to the time of the commencement oi the action; except that no action for absolute divorce shall be commenced for any cause other than adultery or bigamy, unless one of the parties has been for the two years next preceding the commencement of the action a bona fide resident of this state.

Delaware. - Carey v. Carey (1914), 92 Atl. 645; Slattery v. (1913), 28 Del. 53; Cohen v. Cohen Slattery (1917), 102 Atl. 872. (1912), 26 Del. 261.

New Jersey.-Berger v. Berger (1918), 105 Atl. 496; Flynn v. Flynn

Delaware. - Morris v. Morris (1912), 25 Del. 583; Sindowski v. Sindowski (1910), 25 Del. 547.

(b) (Proviso.) When, since the cause of action arose, either party has become, and for at least two years next preceding the commencement of the action has continued to be, a bona fide resident of this state: PROVIDED, The cause of action alleged was recognized in the jurisdiction in which such party resided at the time the cause of action arose, as a ground for the same relief asked for in the action in this state.

Section 9.- (Jurisdiction, by Publication. In Actions for Annulment.) When the defendant cannot be served personally within this state, and when at the time of the commencement of the action the plaintiff is a bona fide resident of this state, jurisdiction for the purpose of annulment of marriage may be ac 
quired by publication, to be followed, where practicable, by service upon or notice to the defendant without this state, or by additional substituted service upon the defendant within this state, as prescribed by law.

Section 10.-(In Actions for Divorce.) When the defendant cannot be served personally within this state, and when at the time of the commencement of the action the plaintiff is a bona fide resident of this state, jurisdiction for the purpose of divorce, whether absolute or from bed and board, may be acquired by publication, to be followed where practicable by service upon or notice to the defendant without this state, or by additional substituted service upon the defendant within this state, as prescribed by law, under the following conditions:

Delaware. - Morris v. Morris New Jersey.-Flynn v. Flynn (1912), 25 Del. 583. (1914), 92 Atl. 645.

(a) (Exception.) When, at the time the cause of action arose, the plaintiff was a bona fide resident of this state, and has continued so to be down to the time of the commencement of the action; except that no action for absolute divorce shall be commenced for any cause other than adultery or bigamy, unless the plaintiff has been for the two years next preceding the commencement of the action a bona fide resident of this state.

(b) (Proviso.) When, since the cause of action arose, the plaintiff has become, and for at least two years next preceding the commencement of the action has continued to be, a bona fide resident of this state: PROVIDED, The cause of action alleged was recognized in the jurisdiction in which the plaintiff resided at the time the cause of action arosc, as a ground for the same relief asked for in the action in this state.

Section 11.-(Particeps Crimins.) Any one charged as a particeps criminis shall be made a party, upon his or her application to the court, subject to such terms and conditions as the court may prescribe. 
Section 12.-(Hearings and Trials.) All hearings and trials shall be had before the court, and not before a master, referee, or any other delegated representative, and shall in all cases be public.

Delaware.-Bancroft $\nabla$. Bancroft (1911), 27 Del. 9.

Section 13.-(Attorney, Appointment of.) In all uncontested cases, and in any other case where the court may deem it necessary or proper, a disinterested attorney may be assigned by the court actively to defend the case.

Section 14.-(Proof Required.) No decree for annulment of marriage, or for divorce, shall be granted unless the cause is shown by affirmative proof aside from any admissions on the part of the defendant.

Delaware.-Bancroft $\nabla$. Bancroft (1911), 27 Del. 9.

Section 15.-(Impounding of Record, etc.) No record or evidence in any case shall be impounded, or access thereto ro fused.

Section 16.-(Decrees Nisi.) If after the hearing of any cause, or after a jury trial resulting in a verdict for the plaintiff, tie court shall be of opinion that the plaintiff is entitled to a decree annulling the marriage, or to a decree for divorce from the bonds of matrimony, a decree nisi shall be entered.

Delaware.-In re Jones (1917) 102 New Jersey.-Grant v. Grant Atl. 81; Jones V. Jones (1916), 29 (1914), X. J. Ch. 92 Atl. 791.

Del. 141.

Section 17.-(Absolute Decrees.) A decree nisi shall become absolute after the expiration of one year from the entry thereof, unless appealed from or proceedings for review are pending, or the court before the expiration of said period for sufficient cause, upon its own motion, or upon the application of any party, whetier interested or not, otherwise orders, and at the 
expiration of one year such final and absolute decree shall then be eutered upon application to the court by the plaintiff, unless prior to that time cause be shown to the contrary.

Delaware.-Donovan v. Donovan (1910), 24 Del. 321; Krussman v. Krussman (1910), 25 Del. 25; Tebo v. Weld (1915), 28 Del. 259.

Section 18.-(Decree a Mensa.) In all cases of divorce from bed and board for any of the causes specified in section 4 of this act, the court may decree a separation forever thereafter, or for a limited time, as shall seem just and reasonable, with a provision that in case of a reconciliation at any time thereafter, the parties may apply for a revocation or suspension of the decree; and upon such application the court shall make such order as may be just and reasonable.

Section 19.-(Former Name of Wife.)-The court upon $g_{\perp}$ anting a divorce from the bonds of matrimony to a woman may allow her to resume her maiden name, or the name of a . former deceased husband.

Section 20.-(Children, Legitimacy of. In action by Wife.) In an action brought by the wife, the legitimacy of any child born or begotten before the commencement of the action shall not be affected.

Section 21.-(In Action by Husband.)--In an action brought by the husband, the legitimacy of any child born or begotten before the commission of the offense charged shall not be affected; but the legitimacy of any other child of the wife may be determined as one of the issues of the action. All children begotten before the commencement of the action shall be presumed to be legitimate.

Section 22.-(Foreign Decrees. Of Other States. Of Foreign Countries. Proviso. Evasion of Laws of This State.)-Full faith and credit shall be given in all the courts of this state to a decree of annulment of marriage or divorce by a court of com- 
petent jurisdiction in another state, territory or possession of the United States when the jurisdiction of such court was obtained in the manner and in substantial conformity with the conditions prescribed in Sections 7, 8, 9 and 10 of this Act. Nothing herein contained shall be construed to limit the power of any court to give such effect to a decree of annulment or divorce by a court of a foreign country as may be justified by the rules of international comity: PROVIDED, That if any inhabitant of this state shall go into another state, territory or country in order to obtain a decree of divorce for a cause which occurred while the parties resided in this state, or for a cause which is not ground for divorce under the laws of this state, a decree so obtained shall be of no force or effect in this state.

Section 23.-(Repealing Clause. Proviso.)-The following

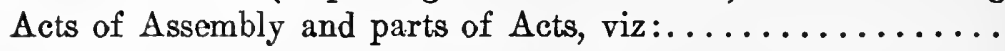
and all other Acts and parts of Acts of Assembly of this state, general, special or local, inconsistent with this Act, be and the same are hereby repealed: PROVIDED, That nothing in this Act contained shall affect or apply to any actions for annulment of marriage, or for divorce, now pending.

Section 24.-(When Act Shall Take Effect.)-This Act shall take effect on the day of A. D. 
UNIFORM BILLS OF LADING ACT 



\section{UNIFORM BILLS OF LADING ACT}

The first draft of this Act was submitted by Prof. Williston at the session of the Conference of Commissioners at St. Paul, Minn., in 1906. In the light of the suggestions received from different sources a second draft of the Act was prepared and submitted to the Conference in $190 \%$ at its meeting in Portland, Maine. After consideration, a third tentative draft was prepared and distributed in 1908 and considered by the Conference at its meeting in Seattle, Wash. In 1909 a fourth tentative draft was prepared and considered. In the light of all the suggestions and criticisms that had been made by various shippers, bankers and carriers as well as representatives of some of the law schools, and after full debato this draft was adopted by the Conference of Commissioners at Detroit in August, 1909. The Act was adopted by Maryland and Massachusetts in 1910. It is now the law of twenty-two jurisdictions. These are: California, 1915; Connecticut, 1911; Idaho, 1915; Illinois, 1911; Iowa, 1917; Louisiana, 1912; Maine, 1917; Maryland, 1910 ; Massachusetts, 1910 ; Michigan, 1911; Minnesota, 1917; Missouri, 1917; New Hampshire, 1917; New York, 1911; Ohio, 1911; Pennsylvania, 1911; Rhode Island, 1914; Vermont, 1915; Washington, 1915; Wisconsin, 1917; Alaska, 1913, Philippine Islands, -? 


\begin{tabular}{|c|c|c|c|c|c|c|}
\hline & $\begin{array}{l}\text { Laws } \\
1913, \\
\text { ch. } 59 . \\
\text { p. } 139 .\end{array}$ & $\begin{array}{c}\text { Rev. St. } \\
1918 \\
\text { p. } 1293 .\end{array}$ & $\begin{array}{l}\text { Sessions } \\
\text { Laws, } \\
\text { ch. 16, } \\
\text { p. } 53 \text {. }\end{array}$ & $\begin{array}{l}\text { III. Stat. } \\
\text { Ann. } \\
\text { Rev. } \\
1913 .\end{array}$ & $\begin{array}{l}\text { Supp. } \\
1913 \text { Code, } \\
\text { Rev. Stat. }\end{array}$ & $\begin{array}{c}\text { Marr's } \\
\text { Ann. } \\
\text { Rev. Stat. }\end{array}$ \\
\hline $\begin{array}{l}\text { Uniform } \\
\text { Act } \\
\text { Sec. No. }\end{array}$ & $\begin{array}{c}1913 \\
\text { Alaska. }\end{array}$ & $\begin{array}{l}1911 \\
\text { Conn. }\end{array}$ & $\begin{array}{l}1915 \\
\text { Idaho. }\end{array}$ & $\begin{array}{c}1911 \\
\text { Illinois. }\end{array}$ & $\begin{array}{l}1911 \\
\text { lowa. }\end{array}$ & $\begin{array}{c}1912 \\
\text { Louisiana. }\end{array}$ \\
\hline $\begin{array}{r}1 \\
2 \\
3 \\
4 \\
5 \\
6 \\
7 \\
8 \\
9 \\
10 \\
11 \\
12 \\
13 \\
14 \\
15 \\
16 \\
17 \\
18 \\
19 \\
20 \\
21 \\
22 \\
23 \\
24 \\
25 \\
26 \\
27 \\
28 \\
29 \\
30 \\
31 \\
32 \\
33 \\
34 \\
35 \\
36 \\
37 \\
38 \\
39 \\
40 \\
41 \\
42 \\
43 \\
44 \\
45 \\
46 \\
47 \\
48 \\
49 \\
50\end{array}$ & $\begin{array}{r}1 \\
2 \\
3 \\
4 \\
5 \\
6 \\
7 \\
8 \\
9 \\
10 \\
11 \\
12 \\
13 \\
14 \\
15 \\
16 \\
17 \\
18 \\
19 \\
20 \\
21 \\
22 \\
23 \\
24 \\
25 \\
26 \\
27 \\
28 \\
29 \\
30 \\
31 \\
32 \\
33 \\
34 \\
35 \\
36 \\
37 \\
38 \\
39 \\
40 \\
41 \\
42 \\
43 \\
44 \\
45 \\
46 \\
47 \\
48 \\
49 \\
50\end{array}$ & $\begin{array}{l}4613 \\
4614 \\
4615 \\
4616 \\
4617 \\
4618 \\
4619 \\
4620 \\
4621 \\
4622 \\
4623 \\
4624 \\
4625 \\
4626 \\
4627 \\
4628 \\
4629 \\
4630 \\
4631 \\
4632 \\
4633 \\
4634 \\
4635 \\
4636 \\
4637 \\
4638 \\
4639 \\
4640 \\
4641 \\
4642 \\
4643 \\
4644 \\
4645 \\
4646 \\
4647 \\
4648 \\
4649 \\
4650 \\
4651 \\
4652 \\
4653 \\
4654 \\
4655 \\
4656 \\
4657 \\
4658 \\
4659 \\
4660 \\
4661 \\
4662\end{array}$ & $\begin{array}{r}1 \\
2 \\
3 \\
4 \\
5 \\
6 \\
7 \\
8 \\
9 \\
10 \\
11 \\
12 \\
13 \\
14 \\
15 \\
16 \\
17 \\
18 \\
19 \\
20 \\
21 \\
22 \\
23 \\
24 \\
25 \\
26 \\
27 \\
28 \\
29 \\
30 \\
31 \\
32 \\
33 \\
34 \\
35 \\
36 \\
37 \\
38 \\
39 \\
40 \\
41 \\
42 \\
43 \\
44 \\
45 \\
46 \\
47 \\
48 \\
49 \\
50\end{array}$ & $\begin{array}{l}2166 \\
2167 \\
2168 \\
2169 \\
2170 \\
2171 \\
2172 \\
2173 \\
2174 \\
2175 \\
2176 \\
2177 \\
2178 \\
2179 \\
2180 \\
2181 \\
2182 \\
2183 \\
2184 \\
2185 \\
2186 \\
2187 \\
2188 \\
2189 \\
2190 \\
2191 \\
2192 \\
2193 \\
2194 \\
2195 \\
2196 \\
2197 \\
2198 \\
2199 \\
2200 \\
2201 \\
2202 \\
2203 \\
2204 \\
2205 \\
2206 \\
2207 \\
2208 \\
2209 \\
2210 \\
2211 \\
2212 \\
2213 \\
2214 \\
2215\end{array}$ & $\begin{array}{l}3138 b \\
3138 b 1 \\
3138 b 2 \\
3138 b 3 \\
3138 b 4 \\
3138 b 5 \\
3138 b 6 \\
3138 b 7 \\
3138 b 8 \\
3138 b 9 \\
3138 b 10 \\
3138 b 11 \\
3138 b 12 \\
3138 b 13 \\
3138 b 14 \\
3138 b 15 \\
3138 b 16 \\
3138 b 17 \\
3138 b 18 \\
3138 b 19 \\
3138 \mathrm{~b} 20 \\
3138 b 21 \\
3138 b 22 \\
3138 b 23 \\
3138 b 24 \\
3138 b 25 \\
3138 b 26 \\
3138 b 27 \\
3138 b 28 \\
3138 b 29 \\
3138 b 30 \\
3138 b 31 \\
3138 b 32 \\
3138 b 33 \\
3138 b 34 \\
3138 b 35 \\
3138 b 36 \\
3138 b 37 \\
3138 b 38 \\
3138 b 39 \\
3138 b 40 \\
3138 b 41 \\
3138 b 42 \\
3138 b 43 \\
3138 b 44 \\
3138 b 45 \\
3138 b 46 \\
3138 b 47 \\
3138 b 48 \\
3138 b 49\end{array}$ & $\begin{array}{l}5062 \\
5063 \\
5064 \\
5065 \\
5066 \\
5067 \\
5068 \\
5069 \\
5070 \\
5071 \\
5072 \\
5073 \\
5074 \\
5075 \\
5076 \\
5077 \\
5078 \\
5079 \\
5080 \\
5081 \\
5082 \\
5083 \\
5084 \\
5085 \\
5086 \\
5087 \\
5088 \\
5089 \\
5090 \\
5091 \\
5092 \\
5093 \\
5094 \\
5095 \\
5096 \\
5097 \\
5098 \\
5099 \\
5100 \\
5101 \\
5102 \\
5103 \\
5104 \\
5105 \\
5106 \\
5107 \\
5108 \\
5109 \\
5110 \\
5111\end{array}$ \\
\hline
\end{tabular}


UNIFORM BILLS OF ILADING ACT.

\begin{tabular}{|c|c|c|c|c|c|c|}
\hline & $\begin{array}{c}\text { Laws } \\
1913, \\
\text { ch. } 59 . \\
\text { p. } 139 .\end{array}$ & $\begin{array}{c}\text { Rev. St. } \\
1918, \\
\text { p. } 193\end{array}$ & $\begin{array}{l}\text { Sessions } \\
\text { Laws, } \\
\text { ch. } 16 \text {, } \\
\text { p. } 53 \text {. }\end{array}$ & $\begin{array}{c}\text { III. Stal. } \\
\text { Ann. } \\
\text { Rev. } \\
\text { J913. }\end{array}$ & $\begin{array}{l}\text { Supp. } \\
1913 \text { (Sode, } \\
\text { Rev. Stal. }\end{array}$ & $\begin{array}{c}\text { Marr's } \\
\text { Ann. } \\
\text { Rev. Stat. }\end{array}$ \\
\hline $\begin{array}{l}\text { Uniform } \\
\text { Act } \\
\text { Ser. No. }\end{array}$ & $\begin{array}{c}1913 \\
\text { Alaska. }\end{array}$ & $\begin{array}{l}1911 \\
\text { Conn. }\end{array}$ & $\begin{array}{l}1915 \\
\text { Idaho. }\end{array}$ & Illinois. & $\begin{array}{l}\text { l911 } \\
\text { Iowa. }\end{array}$ & $\begin{array}{c}1912 \\
\text { Louiniana. }\end{array}$ \\
\hline $\begin{array}{l}51 \\
52 \\
53 \\
54 \\
55 \\
56 \\
57\end{array}$ & $\begin{array}{l}51 \\
52 \\
53 \\
54 \\
55 \\
56 \\
57\end{array}$ & $\begin{array}{l}4663 \\
4664 \\
4665 \\
4666 \\
\ldots \\
4667\end{array}$ & $\begin{array}{l}51 \\
52 \\
53 \\
54 \\
55 \\
\ddot{56}\end{array}$ & $\begin{array}{l}2216 \\
2217 \\
2218 \\
2219 \\
2220 \\
\ldots \ldots \\
2221\end{array}$ & $\begin{array}{l}3138 b 50 \\
3138 b 51 \\
3138 b 52 \\
3138 b 53 \\
3138 b 54 \\
3138 b 55 \\
3138 b 56\end{array}$ & $\begin{array}{l}5112 \\
5113 \\
5114 \\
5115 \\
\ldots \ldots \\
5116\end{array}$ \\
\hline
\end{tabular}




\begin{tabular}{|c|c|c|c|c|c|c|c|}
\hline & $\begin{array}{c}\text { Laws } \\
1910 \\
\text { ch. } 132 .\end{array}$ & $\begin{array}{c}\text { Laws } \\
1910, \\
\text { ch. } 336 .\end{array}$ & $\begin{array}{c}\text { Laws } \\
1910 \text {, } \\
\text { p. } 149 .\end{array}$ & $\begin{array}{l}\text { Comp. } \\
\text { Laws, } \\
1915 .\end{array}$ & $\begin{array}{c}\text { Gen. Stat. } \\
\text { Minn. } \\
\text { Supp. } \\
1917 \\
\text { ch. } 393 .\end{array}$ & $\begin{array}{l}\text { Laws } \\
1917, \\
\text { p. } 564 .\end{array}$ & $\begin{array}{l}\text { Laws } \\
1917 \text {, } \\
\text { ch. 81, } \\
\text { p. } 543 .\end{array}$ \\
\hline $\begin{array}{l}\text { Uniform } \\
\text { Act } \\
\text { Sec. No. }\end{array}$ & $\begin{array}{c}1917 \\
\text { Maine. }\end{array}$ & $\begin{array}{l}1910 \\
\text { Md. }\end{array}$ & $\begin{array}{c}1910 \\
\text { Mass. }\end{array}$ & $\begin{array}{l}1911 \\
\text { Mich. }\end{array}$ & $\begin{array}{l}1917 \\
\text { Minn. }\end{array}$ & $\begin{array}{l}1917 \\
\text { Mo. }\end{array}$ & $\begin{array}{l}1917 \\
\text { N. H. }\end{array}$ \\
\hline 1 & 1 & 1 & 1 & 8174 & $4431-1$ & 1 & 1 \\
\hline 2 & 2 & 2 & 2 & 8175 & $4434-2$ & 2 & 2 \\
\hline 3 & 3 & 3 & 3 & 8176 & $4434-3$ & 3 & 3 \\
\hline 4 & 4 & 4 & 4 & 8177 & $4434-4$ & 4 & 4 \\
\hline 5 & 5 & 5 & 5 & 8178 & $4434-5$ & 5 & 5 \\
\hline 6 & 6 & 6 & 6 & 8179 & $4434-6$ & 6 & 6 \\
\hline 7 & 7 & 7 & 7 & 8180 & $4434-7$ & 7 & 7 \\
\hline 8 & 8 & 8 & 8 & 8181 & $4434-8$ & 8 & 8 \\
\hline 9 & 9 & 9 & 9 & 8182 & 4434-9 & 9 & 9 \\
\hline 10 & 10 & 10 & 10 & 8183 & $4434-10$ & 10 & 10 \\
\hline 11 & 11 & 11 & 11 & 8184 & $4434-11$ & 11 & 11 \\
\hline 12 & 12 & 12 & 12 & 8185 & $4434-12$ & 12 & 12 \\
\hline 13 & 13 & 13 & 13 & 8186 & $4434-13$ & 13 & 13 \\
\hline 14 & 14 & 14 & 14 & 8187 & $4434-14$ & 14 & 14 \\
\hline 15 & 15 & 15 & 15 & 8188 & $4434-15$ & 15 & 15 \\
\hline 16 & 16 & 16 & 16 & 8189 & $4434-16$ & 16 & 16 \\
\hline 17 & 17 & 17 & 17 & 8190 & $4434-17$ & 17 & 17 \\
\hline 18 & 18 & 18 & 18 & 8191 & $4434-18$ & 18 & 18 \\
\hline 19 & 19 & 19 & 19 & 8192 & $4434-19$ & 19 & 19 \\
\hline 20 & 20 & 20 & 20 & 8193 & $4434-20$ & 20 & 20 \\
\hline 21 & 21 & 21 & 21 & 8194 & $4434-21$ & 21 & 21 \\
\hline 22 & 22 & 22 & 22 & 8195 & $4434-22$ & 22 & 22 \\
\hline 23 & 23 & 23 & 23 & 8196 & $4434-23$ & 23 & 23 \\
\hline 24 & 24 & 24 & 24 & 8197 & $4434-24$ & 24 & 24 \\
\hline 25 & 25 & 25 & 25 & 8198 & $4434-25$ & 25 & 25 \\
\hline 26 & 26 & 26 & 26 & 8199 & $4434-26$ & 26 & 26 \\
\hline 27 & 27 & 27 & 27 & 8200 & $4434-27$ & 27 & 27 \\
\hline 28 & 28 & 28 & 28 & 8201 & $4434-28$ & 28 & 28 \\
\hline 29 & 29 & 29 & 29 & 8202 & $4434-29$ & 29 & 29 \\
\hline 30 & 30 & 30 & 30 & 8203 & $4434-30$ & 30 & 30 \\
\hline 31 & 31 & 31 & 31 & 8204 & $4434-31$ & 31 & 31 \\
\hline 32 & 32 & 32 & 32 & 8205 & $4434-32$ & 32 & 32 \\
\hline 33 & 33 & 33 & 33 & 8206 & 4434-33 & 33 & $3 \overline{3}$ \\
\hline 34 & 34 & 34 & 34 & 8207 & $4434-34$ & 34 & 34 \\
\hline 35 & 35 & 35 & 35 & 8208 & 4434-35 & 35 & 35 \\
\hline 36 & 36 & 36 & 36 & 8209 & $4434-36$ & 36 & 36 \\
\hline 37 & 37 & 37 & 37 & 8210 & $4434-37$ & 37 & 37 \\
\hline 38 & 38 & 38 & 38 & 8211 & $4434-38$ & 38 & 38 \\
\hline 39 & 39 & 39 & 39 & 8212 & $4434-39$ & 39 & 39 \\
\hline 40 & 40 & 40 & 40 & 8213 & $4434-40$ & 40 & 40 \\
\hline 41 & 41 & 41 & 41 & 8214 & $4434-41$ & 41 & 41 \\
\hline 42 & 42 & 42 & 42 & 8215 & $4434-42$ & 42 & 42 \\
\hline 43 & 43 & 43 & 43 & 8216 & $4434-43$ & 43 & 43 \\
\hline 44 & 44 & 44 & 44 & 8217 & $4434-44$ & 44 & 44 \\
\hline 45 & 45 & 45 & 45 & 8218 & $4434-45$ & 45 & 45 \\
\hline 46 & 46 & 46 & 46 & 8219 & $4434-46$ & 46 & 46 \\
\hline 47 & 47 & 47 & 47 & 8220 & $4434-47$ & 47 & 47 \\
\hline 48 & 48 & 48 & 48 & 8221 & $4434-48$ & 48 & 48 \\
\hline
\end{tabular}


UNIFORM BILLS OF LADING ACT.

\begin{tabular}{|c|c|c|c|c|c|c|c|}
\hline & $\begin{array}{c}\text { Laws } \\
1910 . \\
\text { ch. } 132 .\end{array}$ & $\begin{array}{c}\text { Laws } \\
1910, \\
\text { ch. 336. }\end{array}$ & $\begin{array}{l}\text { Laws } \\
1910 \text {, } \\
\text { p. } 149 .\end{array}$ & $\begin{array}{l}\text { Comp. } \\
\text { Laws, } \\
1915 .\end{array}$ & $\begin{array}{l}\text { Gen. Stal } \\
\text { Minn. } \\
\text { Supp. } \\
1917 . \\
\text { ch. } 393 .\end{array}$ & $\begin{array}{l}\text { Laws } \\
1917 \text {, } \\
\text { p. } 564 .\end{array}$ & $\begin{array}{l}\text { Laws } \\
1917, \\
\text { ch. } 81, \\
\text { p. } 543 .\end{array}$ \\
\hline $\begin{array}{l}\text { Uniform } \\
\text { Act } \\
\text { Sec. No. }\end{array}$ & $\begin{array}{c}1917 \\
\text { Maine. }\end{array}$ & $\begin{array}{l}1910 \\
\text { Md. }\end{array}$ & $\begin{array}{l}1910 \\
\text { Mass. }\end{array}$ & $\begin{array}{l}1911 \\
\text { Mich. }\end{array}$ & $\begin{array}{l}1917 \\
\text { Minn. }\end{array}$ & $\begin{array}{l}1917 \\
\text { Mo. }\end{array}$ & $\begin{array}{l}1917 \\
\text { N. } 11 .\end{array}$ \\
\hline $\begin{array}{r}49 \\
-50 \\
51 \\
52 \\
53 \\
54 \\
55 \\
56 \\
57\end{array}$ & $\begin{array}{l}49 \\
50 \\
51 \\
52 \\
53 \\
54 \\
55 \\
.56\end{array}$ & $\begin{array}{l}49 \\
50 \\
51 \\
52 \\
53 \\
54 \\
55 \\
\ddot{56}\end{array}$ & $\begin{array}{l}49 \\
50 \\
51 \\
52 \\
53 \\
54 \\
55 \\
56 \\
57\end{array}$ & $\begin{array}{l}8222 \\
8223 \\
8224 \\
8225 \\
8226 \\
8227 \\
8228 \\
.2229\end{array}$ & $\begin{array}{l}4434-4 \\
4434-5 \\
4434-5 \\
4434-5 \\
4434-5 \\
4434-5 \\
4434-5 \\
4434-5 \\
4134-5\end{array}$ & $\begin{array}{l}49 \\
50 \\
51 \\
52 \\
53 \\
54 \\
55 \\
\ddot{56}\end{array}$ & $\begin{array}{l}49 \\
50 \\
51 \\
52 \\
53 \\
54 \\
55 \\
56 \\
57\end{array}$ \\
\hline
\end{tabular}




\begin{tabular}{|c|c|c|c|c|c|c|}
\hline & $\begin{array}{l}\text { Pers. } \\
\text { Prop. } \\
\text { Law. }\end{array}$ & $\begin{array}{c}\text { Obio } \\
\text { Gen. } \\
\text { Code, } \\
\text { p. } 8993 .\end{array}$ & $\begin{array}{c}\text { Laws } \\
1914, \\
\text { ch. } 1029, \\
\text { p. } 17 .\end{array}$ & $\begin{array}{l}\text { Laws } \\
1915, \\
\text { p. } 239 .\end{array}$ & $\begin{array}{l}\text { Code, } \\
1915\end{array}$ & $\begin{array}{r}\text { Laws } \\
1917 \text {. } \\
\text { ch. } 179 .\end{array}$ \\
\hline $\begin{array}{l}\text { Uniforma } \\
\text { Act } \\
\text { Sec. No. }\end{array}$ & $\begin{array}{l}1911 \\
\text { N. Y. }\end{array}$ & $\begin{array}{l}1911 \\
\text { Ohio. }\end{array}$ & $\begin{array}{l}1914 \\
\text { R. I. }\end{array}$ & $\begin{array}{c}1915 \\
\text { Vt. }\end{array}$ & $\begin{array}{r}1915 \\
\text { Wash. }\end{array}$ & $\begin{array}{l}1917 \\
\text { Wisc. }\end{array}$ \\
\hline 1 & 187 & 8993-1 & 1 & 1 & 3385-1 & $1684 n-1$ \\
\hline 2 & 188 & 8993-1 & 2 & 2 & $3385-2$ & $1684 n-2$ \\
\hline 3 & 189 & 8993-2 & 3 & $\overline{3}$ & $3385-3$ & $1684 n-3$ \\
\hline 4 & 190 & 8993-3 & 4 & 4 & $3385-4$ & $1684 n-4$ \\
\hline 5 & 191 & $8993-4$ & 5 & 5 & 3385-5 & $1685 n-5$ \\
\hline 6 & 192 & 8993-5 & 6 & 6 & $3385-6$ & $1684 n-6$ \\
\hline 7 & 193 & 8993-6 & 7 & 7 & $3385-7$ & $1684 n-7$ \\
\hline 8 & 194 & 8993-7 & 8 & 8 & $3385-8$ & $1684 n-8$ \\
\hline 9 & 195 & $8993-8$ & 9 & 9 & 3385-9 & $1684 n-9$ \\
\hline 10 & 196 & 8993-9 & 10 & 10 & $3385-10$ & $1684 n-10$ \\
\hline 11 & 197 & 8993-10 & 11 & 11 & $3385-11$ & $1684 n-11$ \\
\hline 12 & 198 & $8993-11$ & 12 & 12 & $3385-12$ & $1684 n-12$ \\
\hline 13 & 199 & $8993-12$ & 13 & 13 & $3385-13$ & $1684 n-13$ \\
\hline 14 & 200 & 8993-13 & 14 & 14 & $3385-14$ & $1684 n-14$ \\
\hline 15 & 201 & 8993-14 & 15 & 15 & $3385-15$ & $1684 n-15$ \\
\hline 16 & 202 & 8993-15 & 16 & 16 & 3385-16 & $1684 n-16$ \\
\hline 17 & 203 & $8993-16$ & 17 & 17 & 3385-17 & $1684 n-17$ \\
\hline 18 & 294 & 8993-17 & 18 & 18 & 3385-18 & $1684 n-18$ \\
\hline 19 & 205 & 8993-18 & 19 & 19 & $3385-19$ & $1684 n-19$ \\
\hline 20 & 206 & 8993-19 & 20 & 20 & $3385-20$ & $1684 n-20$ \\
\hline 21 & 207 & 8993-20 & 21 & 21 & $3385-21$ & $1684 n-21$ \\
\hline 22 & 208 & $8993-21$ & 22 & 22 & $3385-22$ & $1684 n-22$ \\
\hline 23 & 209 & 8993-22 & 23 & 23 & $3385-23$ & $1684 n-23$ \\
\hline 24 & 210 & 8993-23 & 24 & 24 & $3385-24$ & $1684 n-24$ \\
\hline 25 & 211 & 8993-24 & 25 & 25 & $3385-25$ & $1684 n-25$ \\
\hline 26 & 212 & $8993-25$ & 26 & 26 & $3385-26$ & $1684 n-26$ \\
\hline 27 & 213 & $8993-26$ & 27 & 27 & $3375-27$ & $1684 n-27$ \\
\hline 28 & 214 & $8993-27$ & 28 & 28 & $3385-28$ & $1684 n-28$ \\
\hline 29 & 215 & 8993-28 & 29 & 29 & $3385-29$ & $1684 n-29$ \\
\hline 30 & 216 & 8993-29 & 30 & 30 & 3385-30 & $1684 n-30$ \\
\hline 31 & 217 & 8993-30 & 31 & 31 & $3385-31$ & $1684 n-31$ \\
\hline 32 & 218 & 8993-31 & 32 & 32 & $3385-32$ & $1684 n-32$ \\
\hline 33 & 219 & 8993-32 & 33 & 33 & $3385-33$ & $1684 n-33$ \\
\hline 34 & 220 & 8993-33 & 34 & 34 & $3385-34$ & $1684 n-34$ \\
\hline 35 & 221 & 8993-34 & 35 & 35 & 3385-35 & $1684 n-35$ \\
\hline 36 & 222 & 8993-35 & 36 & 36 & $3385-36$ & $1684 n-36$ \\
\hline 37 & 223 & 8993-36 & 37 & 37 & $3385-37$ & $1684 n-37$ \\
\hline 38 & 224 & 8993-37 & 38 & 38 & 3385-38 & $1684 n-38$ \\
\hline 39 & 225 & 8993-38 & 39 & 39 & $3385-39$ & $1684 n-39$ \\
\hline 40 & 226 & 8993-39 & 40 & 40 & $3385-40$ & $1684 n-40$ \\
\hline 41 & 227 & $8993-40$ & 41 & 41 & $3385-41$ & $1684 n-41$ \\
\hline 42 & 228 & $8993-41$ & 42 & 42 & $3385-42$ & $1684 n-42$ \\
\hline 43 & 229 & $8993-42$ & 43 & 43 & $3385-43$ & $1684 n-43$ \\
\hline 44 & 230 & $8993-43$ & 44 & 44 & $3385-44$ & $1684 n-44$ \\
\hline 45 & 231 & $8993-44$ & 45 & 45 & $3385-45$ & $1684 n-45$ \\
\hline 46 & 232 & $8993-45$ & 46 & 46 & $3385-46$ & $1684 n-46$ \\
\hline 47 & 233 & $8993-46$ & 47 & 47 & $3385-47$ & $1684 n-47$ \\
\hline 48 & 234 & $8993-47$ & 48 & 48 & $3385-48$ & $1684 n-48$ \\
\hline 49 & 235 & $8993-48$ & 49 & 49 & $3385-49$ & $1684 n-49$ \\
\hline
\end{tabular}


UNIFORM BILLS OF LADING ACT.

\begin{tabular}{|c|c|c|c|c|c|c|}
\hline & $\begin{array}{l}\text { Pers. } \\
\text { Prop. } \\
\text { Law. }\end{array}$ & $\begin{array}{c}\text { Ohio } \\
\text { Gen. } \\
\text { Code, } \\
\text { p. } 8993 .\end{array}$ & $\begin{array}{l}\text { Laws } \\
1914, \\
\text { ch. } 1029 \text {, } \\
\text { p. } 17 .\end{array}$ & $\begin{array}{l}\text { Laws } \\
1915, \\
\text { p. } 239 .\end{array}$ & $\begin{array}{l}\text { Code, } \\
1915 .\end{array}$ & $\begin{array}{c}\text { Laws } \\
1917 . \\
\text { ch. } 179 .\end{array}$ \\
\hline $\begin{array}{l}\text { Uniform } \\
\text { Act } \\
\text { Soc. Na. }\end{array}$ & $\begin{array}{l}1911 \\
\text { N. Y. }\end{array}$ & $\begin{array}{l}1911 \\
\text { Ohio. }\end{array}$ & $\begin{array}{l}1914 \\
\text { R. I. }\end{array}$ & $\begin{array}{c}1915 \\
\mathrm{VL}_{L}\end{array}$ & $\begin{array}{c}1915 \\
\text { Wash. }\end{array}$ & $\begin{array}{l}1917 \\
\text { Wisc. }\end{array}$ \\
\hline $\begin{array}{l}\mathbf{5 0} \\
\mathbf{5 1} \\
\mathbf{5 2} \\
\mathbf{5 3} \\
\mathbf{5 4} \\
\mathbf{5 5} \\
\mathbf{5 6} \\
\mathbf{5 7}\end{array}$ & $\begin{array}{l}236 \\
237 \\
238 \\
239 \\
240 \\
241 \\
\ldots .\end{array}$ & $\begin{array}{c}8993-49 \\
8993-50 \\
8993-51 \\
8993-52 \\
8993-53 \\
8993-54 \\
\ldots \ldots \ldots\end{array}$ & $\begin{array}{l}50 \\
51 \\
52 \\
53 \\
54 \\
55 \\
56 \\
57\end{array}$ & $\begin{array}{l}\mathbf{5 0} \\
\mathbf{5 1} \\
52 \\
\mathbf{5 3} \\
\mathbf{5 4} \\
\mathbf{5 5} \\
\mathbf{5 6} \\
\mathbf{5 7}\end{array}$ & $\begin{array}{l}3385-50 \\
3385-51 \\
3385-52 \\
3385-53 \\
3385-54 \\
3385-55 \\
33 . \\
3385-56\end{array}$ & $\begin{array}{l}1684 n-50 \\
1684 n-51 \\
1684 n-52 \\
1684 n-53 \\
1684 n-54 \\
\ldots \ldots \ldots \\
1681 n-55\end{array}$ \\
\hline & & & & & & \\
\hline
\end{tabular}




\section{UNIFORM BILLS OF LADING ACT}

Section 1. Bills Governed by This Act.

2. Form. of Bills. Essential Terms.

3. Form of Bills. What Terms May be Inserted.

4. Definition of Non-Negotiable or Straight Bill.

5. Definition of Negotiable or Order Bill.

6. Negotiable Bills Must Not be Issued in Sets.

7. Duplicate Negotiable Bills Must be so Marked.

8. Non-Negotiable Bills Shall be so Marked.

9. Insertion of Name of Person to be Notified.

10. Acceptance of Bill Indicates Assent to its Terms.

11. Obligation of Carrier to Deliver.

12. Justification of Carrier in Delivering.

13. Carrier's Liability for Misdelivery.

14. Negotiable Bills Must be Canceled When Goods Delivered.

15. Negotiable Bills Must be Canceled or Marked When Parts of Goods Delivered.

16. Altered Bills.

17. Lost or Destroyed Bills.

18. Effect of Duplicate Bills.

19. Carrier Cannot Set up Title in Himself.

20. Interpleader of Adverse Claimants.

21. Carrier Has Reasonable Time to Determine Validity of Claims.

22. Adverse Title is no Defence, Except as Above Provided.

23. Liability for Non-Receipt or Misdescription of Goods.

24. Attachment or Levy Upon Goods for Which a Negotiable Bill Has Been Issued.

25. Creditor's Remedies to Reach Negotiable Bills.

26. Negotiable Bill Must State Charges for Which Lien is Claimed.

27. Effect of Sale.

28. Negotiation of Negotiable Bills by Delivery.

29. Negotiation of Negotiable Bills by Indorsement.

30. Transfer of Bills.

31. Who May Negotiate a Bill.

32. Rights of Person to Whom a Bill Has Been Negotiated.

33. Rights of Person to Whom a Bill Has Been Transferred.

34. Transfer of Negotiable Bill Without Indorsement.

35. Warranties on Sale of Bill.

36. Indorser Not a Guarantor.

37. No Warranty Implied from Accepting Payment of a Debt. 
Section 38. When Negotiation Not Impaired by Fraud, Accident, Mistake, Duress or Conversion.

39. Subsequent Negotiation.

40. Form of the Bill as Indicating Rights of Buyer and Seller.

41. Demand, Presentation or Sight Draft Must be Paid, but Draft on More Than Three Days Time Merely Accepted Before Buyer is Entitled to the Accompanying Bill.

42. Negotiation Defeats Vendor's Lien.

43. When Rights and Remedies Under Mortgages and Liens are Not Limited.

44. Issue of Bill for Goods Not Received.

45. Issue of Bill Containing False Statement.

46. Issue of Duplicate Bills Not so Marked.

47. Negotiation of Bill for Mortgaged Goods.

48. Negotiation of Bill When Goods are Not in Carrier's Possession.

49. Indueing Carrier to Issue Bill When Goods Have Not Been Received.

50. Issue of Non-Negotiable Bill Not so Marked.

51. Rule for Cases Not Provided for in This Act.

52. Interpretation Shall Give Effeet to Purpose of Uniformity.

53. Definitions.

54. Act Does Not Apply to Fxisting Bills.

55. Inconsistent Legislation Repealed.

56. Time When the Act Takes Effect.

57. Name of Act. 


\section{PART I.}

The Issue of Bilis of Lading.

Section 1.-(Bills Governed by this Act.)-Bills of Lading issued by any common carrier shall be governed by this Act.

Arkansas.- Prescott \& N. W. R. Co. v. Davis (1916), 191 S. W. 210.

Massachusetts. - South Deerfield Onion Storage Co. v. N. Y., N. H. \& H. R. R. Co. (1916), 111 N. E. 367.

New Jersey.-Olivit Bros. v. Pa. R. R. Co. (1916), 96 Atl. 582.
New York.- Mayer v. Southern Pac. Co. (1916), 159 N. Y. Supp. 93; Greenwald v. N. Y. Cent. \& H. R. R. R. Co. (1916), 159 N. Y. Supp. 15. North Carolina.-Davis v. Norfolk \& S. R. R. (1916), 90 S. E. 123.

Section 2.-(Forms of Bills. Essential Terms.)-Every bill must embody within its written or printed terms;

(a) The date of its issue,

(b) The name of the person from whom the goods have been received,

(c) The place where the goods have been received,

(d) The place to which the goods are to be transported,

(e) A statement whether the goods received will be delivered to a specified person, or to the order of a specified person,

(f) A description of the goods or of the packages containing them which may, however, be in such general terms as are referred to in Section 23, and

(g) The signature of the carrier.

A negotiable bill shall have the words "order of " printed thereon immediately before the name of the person upon whose order the goods received are deliverable.

A carrier shall be liable to any person injured thereby for the damage caused by the omission from a negotiable bill of any of the provisions required in this section.

Alabama.- National Park Bank of New York v. Louisville R. Co. (1917), 74 So. 69. New York.-Dobbins v. Del. L. \& N. Y. Supp. 583.
W. R. R. (1917), 177 App. Div. 132, 162 N. Y. Supp. 849; Knight v. Delaware \& Hudson Co. (1917), 165 
North Dakota.-Knapp v. Minn. Oklahoma.-Chicago R. I. \& P. St. P. \& S. S. M. R. R. Co. (1916), Ry. Co. v. Cleveland (1916), 160 34 N. D. 466,159 N. W. 81.

Pac. 328.

Section 3.- (Forms of Bills. What Terms may be Inserted.)

A carrier may insert in a bill, issued by him, any other terms and conditions, provided that such terms and conditions shall not;

(a) Be contrary to law or public policy, or

(b) In any wise impair his obligation to exercise at least that degree of care in the transportation and safe-keeping of the goods entrusted to him which a reasonably careful man would exercise in regard to similar goods of his own.

Kansas.-McCullough v. Missouri Ry. Co. (1916), 160 Pac. 214.

Michigan.-King v. Van Slack (1916), 159 N. W. 157.

New Jersey.-Olivit Bros. v. Pa. R. R. Co. (1916), 96 Atl. 582; Sprottley v. Delaware L. \& W. R. Co. (1917), 101 Atl. 518.

New York.-Dodge and Dent Mfg. Co. v. Penn. R. Co. (1916), 175 App. Div. 823, 162 N. Y. Supp. 349; Dobbins v. Del. L. \& W. R. R. (1917), 177 App. Div. 132, 162 N. Y. Supp. 849; Omnstein v. New York Cent.
R. R. Co. (1917), 179 App. Div. 465, 165 N. Y. Supp. 996.

South Dakota. - Strommer v. Chicago M. \& St. R. Co. (1917), 161 N. W. 346 .

Vermont.-Charles Bianchi \& Sons v. Montpelier (1918), 104 Atl. 144.

United States.-Gilchrist Trans. Co. v. Boston Ins. Co. (1915), 223 Fed. 716, C. C. A., 6th Cir.; "The Jennie" (1915), 225 Fed. Rep. 178, U. D. D. Ct., W. D. Wash.

Section 4.-(Definition of Non-Negotiable or Straight Bill.) A bill in which it is stated that the goods are consigned or destined to a specified person, is a non-negotiable or straight bill.

Massachusetts.-Porter v. Oceanic

S. S. Co. of Savannah (1916), 111

N. E. 864 .

Section 5.-(Definition of Negotiable or Order Bill.) A bill in which it is stated that the goods are consigned or destined to the order of any person named in such bill, is a negotiable or order bill. 
Any provision in such a bill that it is non-negotiable shall not affect its negotiability within the meaning of this Act.

Section 6.-(Negotiable Bills Must Not Be Issued in Sets.) Negotiable bills issued in this state for the transportation of goods to any place in the United States on the continent of North America, except Alaska, shall not be issued in parts or sets.

If so issued the carrier issuing them shall be liable for failure to deliver the goods described therein to any one who purchases a part for value in good faith, even though the purchase be after the delivery of the goods by the carrier to a holder of one of the other parts.

Section 7.-(Duplicate Negotiable Bills Must be so Marked.) -When more than one negotiable bill is issued in this state for the same goods to be transported to any place in the United States on the continent of North America, except Alaska, the word "duplicate" or some other word or words indicating that the document is not an original bill shall be placed plainly upon the face of every such bill, except the one first issued. A carrier shall be liable for the damage caused by his failure so to do to any one who has purchased the bill for value in good faith as an original, even though the purchase be after the delivery of the goods by the carrier to the holder of the original bill.

Georgia.-Bowman and Tarpley $\mathbf{}$. Atlantic Ice \& Coal Co. (1916), 91

S. E. 215 .

Section 8.-(Non-Negotiable Bills Shall be so Marked.)A non-negotiable bill shall have placed plainly upon its face by the carrier issuing it "non-negotiable " or " not negotiable."

This section shall not apply, however, to memoranda or acknowledgments of an informal character.

Section 9.-(Insertion of Name of Person to be Notified.) The insertion in a negotiable bill of the name of a person to be notified of the arrival of the goods shall not limit the negotia- 
bility of the bill, or constitute notice to a purchaser thereof of any rights or equities of such person in the goods.

New York.- Canandaigua Nat. Bk. v. C. C. C. \& St. P. Ry. (1913), 139 N. Y. Supp. 561, 155 A. D. 53; Dodge \& Dent Mfg. Co. v. Penn. R. Co. (1916), 175 App. Div. 823, 163 N. Y. Supp. 549.
United States.- King v. Barbanie (1917), 161 C. C. A. 311,249 Fed. 303.

Section 10.-(Acceptance of Bill Indicates Assent to its Terms.) - Except as otherwise provided in this Act, where a consignor receives a bill and makes no objection to its terms or conditions at the time he receives it, neither the consignor nor any person who accepts delivery of the goods, nor any person who seeks to enforce any provision of the bill, shall be allowed to deny that he is bound by such terms and conditions, so far as they are not contrary to the law or public policy.

Arkansas.-Prescott \& N. W. R. Co. v. Davis (1916), 191 S. W. 210.

Georgia.- Southern R. R. Co. v. Massee \& Felton Lumber Co. (1919), 98 S. E. 106.

Iowa.- Chicago, R. I. \& P. Ry. Co. v. McElhany (1917), 165 N. W. 67.

Maine.-Lewis Poultry Co. v. New York Cent. R. R. Co. (1919), 105 Atl. 109.

Massachusetts.-Porter $\nabla$. Oceanic S. S. Co. of Savannah (1916), 111 N. E. 864 ; Aradalow v. N. Y. N. H. \& H. R. R. (1916), 225 Mass. 235, 114 N. E. 297; Keystone Grape Co. v. Hustes (1919), 122 N. E. 269.

Michigan.-King v. Vall Slack (1916), 159 N. W. 157.

Minnesota.-Quinn-Sheperdson Co. v. Great Northern Ry. Co. (1918), 169 N. W. 422.

New Jersey.-Olicit Bros. v. Pa. R. R. Co. (1916), 96 Atl. 582.
New York.-Bevo v. Erie Ry. Co. (1916), 176 App. Div. 241, 163 N. Y. Supp. 114; Boyle v. Bush Term. R. Co. (1912). 136 N. Y. Supp. 355, 151 A. D. 551 ; Central R. R. of N. J. v. Berry (1917), 99 Misc. 560, 165 N. Y. Supp. 1041; Dodge \& Dent Mfg. Co. v. Penn. R. Co. (1916), 175 App. Div. 823, 162 N. Y. Supp. 549; DeRochemont v. Boston \& Maine R. R. Co. (1916), 157 N. Y. Supp. 177; Siebert v. Erie R. R. (1916), 173 N. Y. Supp. 111.

United States.-Missouri K. \& T. Ry. Co. of Texas v. Ward (1917), 244 U. S. 383, 37 Sup. Ct. 617.

Vermont. - Charles Bianchi \& Sons v. Montpelier (1918), 104 Atl. 144.

Washington.-John Vittucei Co. r. Canadian Pac. Ry. Co. (1918), 174 Pac. 981; Oregon-Washington R. \& Nev. Co. v. Seattle Grain Ca (1919), 178 Pac. 648. 


\section{PART II.}

\section{Obligation and Rights of Carriers Upon Their Bitls or} Lading.

Section 11.-(Obligation of Carrier to Deliver.) - A carrier, in the absence of some lawful excuse, is bound to deliver goods upon a demand made either by the consignee named in the bill for the goods, or if the bill is negotiable, by the holder thereof, if such demand is accompanied by:

(a) An offer in good faith to satisfy the carrier's lawful lien upon the goods,

(b) An offer in good faith to surrender, properly indorsed, the bill which was issued for the goods, if the bill is negotiable, and

(c) A readiness and willingness to sign, when the goods are delivered, an acknowledgment that they have been delivered, if such signature is requested by the carrier.

In case the carrier refuses or fails to deliver the goods in compliance with a demand by the consignee or holder so accompanied, the burden shall be upon the carrier to establish the existence of a lawful excuse for such refusal or failure.

Iowa.-Davenport Savgs. Bk. v. Chi. R. I. \& Pa. Ry. Co. (1916), 158 N. WV. 737 .

Massachusetts.-Voghel v. N. Y., N. H. \& H. R. R. (1913), 216 Mass. 165, 103 N. E. 286.

New Jersey.-Pennsylvania R. Co. v. Townsend (1917), 100 Atl. 855.

New York.-Boyle v. Bush Term. Co. (1914), 210 N. Y. 389, 104 N. E. 933; Brewster v. N. Y. C. \& H. R. R. Co. (1911), 129 N. Y. Supp. 368, 145 App. Div. 51; Cheney Piano
Co. v. N. Y. C. \& H. R. Co. (1914), 148 N. Y. Supp. 108, 85 Misc 157; Plumb v. J. W. Hallaner \& Sons Co. (1911), 130 N. Y. Supp. 147, 145 A. D. 20; Tweedie Trading Co. v. Craig (1913), 144 N. Y. Supp. 64, 159 A. D. 192.

North Carolina.-Killingsworth $\nabla$. Norfolk \& Co. R. R. (1916), 87 S. E. 947 .

Texas.-Gulf C. \& S. F. Ry. Co. v. Nickel (1916), 191 S. W. 576, Tex. Civ. App.

Section 12.-(Justification of Carrier in Delivering.) - A carrier is justified, subject to the provisions of the three following sections, in delivering goods to one who is: 
(a) A person lawfully entitled to the possession of the goods, or

(b) The consignee named in a non-negotiable bill for the goods, or

(c) A person in possession of a negotiable bill for the goods by the terms of which the goods are deliverable to his order, or which has been indorsed to him or in blank by the consignee or by the mediate or immediate indorsee of the eonsignee.

Iowa.-Davenport Savgs. Bk. v. Chi. R. I. \& Pa. Ry. Co. (1916), 158 N. W. 737; Famous Mfg. Co. v. Chicago \& N. W. R. Co. (1914), 147 N. W. 754 .

Massachusetts.-Porter v. Oceanic S. S. Co. of Savannah (1916), 111 N. E. 864 .
New York.-Mayer v. Southern Pac. Co. (1916), 159 N. Y. Supp. 93.

Tennessee.-Louisville \& N. R. Co. v. McKay \& Morgan (1916), 182 S. W. 585 .

Section 13.-(Carrier's Liability for Misdelivery.)-Where a carrier delivers goods to one who is not lawfully entitled to the possession of them, the carrier shall be liable to any one having a right of property or possession in the goods if he delivered the goods otherwise than as authorized by subdivisions (b) and (c) of the preceding section; and, though he delivered the goods as authorized by either of said subdivisions, he shall be so liable if prior to such delivery he:

(a) Had been requested, by or on behalf of a person having a right of property or possession in the goods, not to make such delivery, or

(b) Had information at the time of the delivery that it was to a person not lawfully entitled to the possession of the goods.

A request or information to be effective within the meaning of this section must bo given to an officer or agent of the carrier, the actual or apparent scope of whose duties includes action upon such a request or information, and must be given in time to enable the officer or agent to whom it is given, acting with reasonable diligence, to stop delivery of the goods. 
Iowa.- Davenport Savgs. Bk. v. Chi. R. I. \& Pa. Ry. Co. (1916), 158 N. W. 737.

Micnigan.-Nelson Grain Co. v. Ann Arbor R. R. Co. (1913), 174 Mich. 80, 140 N. W. 486; Thomas v. Blair (1915), 151 N. W. 1041.

New York.-Mayer v. Southern Pac. Co. (1916), 159 N. Y. Supp. 93; Miles Mfg. Co. v. No. Ger. Lloyd
S. S. Co. (1915), 151 N. Y. Supp. 881.

Tennessee.-Louisville \& $\mathbf{N}$. $R$. Co. v. McKay \& Morgan (1916), 182 S. W. 585.

United States.- N. Y. Cent. \& H. R. R. v. Bank of Holly Springs (1916), 236 Fed. 562, decree modified 195 Fed. 456.

Section 14.-(Negotiable Bills Must be Cancelled When Goods Delivered.) - Except as provided in Section 27, and except when compelled by legal process, if a carrier delivers goods for which a negotiable bill had been issued, the negotiation of which would transfer the right to the possession of the goods, and fails to take up and cancel the bill, such carrier shall be liable for failure to deliver the goods to any one who for value and in good faith purchases such bill, whether such purchaser acquired title to the bill before or after the delivery of the goods by the carrier, and notwithstanding delivery was made to the person entitled thereto.

Georgia.- Southern R. R. Co. v. Massee \& Felton Lumber Co. (1919), - Ga. App. - 98 S. E. 106.

Illinois.- Babbitt v. Grand Trunk Ry. Co. (1918), 120 N. E. 803.

Iowa.-Chicago R. I. \& P. Ry. Co. v. McElhany (1917), 165 N. W. 67; Midland Linseed Co. v. American Liquid Fireproofing Co. (1917), 166 N. W. 573.
Massachusetts.- Keystone Grape Co. v. Hustes (1919), 122 N. E. 269. Minnesota.-Quinn-Shepardson Co. v. Great Northern Ry. Co. (1918), 169 N. W. 422.

United States.-King v. Barbanio (1917), 161 C. C. A. 311, 249 Fed. 303.

Section 15.-(Negotiable Bills Must be Cancelled or Marked When Parts of Goods Delivered.) - Except as provided in Section 27 , and except when compelled by legal process, if a carrier delivers part of the goods for which a negotiable bill had been issued and fails either:

(a) To take up, and cancel the bill, or

(b) To place plainly upon it a statement that a portion of 
the goods has been delivered, with a description, which may be in general terms, either of the goods or packages that have been so delivered or of the goods or packages which still remain in the carrier's possession, he shall be liable for failure to deliver all the goods specified in the bill, to any one who for value and in good faith purchases it; whether such purchaser acquired title to it before or after the delivery of any portion of the goods by the carrier, and notwithstanding such delivery was made to the person entitled thereto.

Section 16.-(Altered Bills.)-Any alteration, addition or erasure in a bill after its issue without authority from the carrier issuing the same either in writing or noted on the bill shall be void, whatever be the nature and purpose of the change, and the bill shall be enforceable according to its original tenor.

Kentucky.- Cincinnati N. O. \&

T. P. Ry. Co. v. Luke (1916), 186

S. W. $875,171 \mathrm{Ky} .50$.

Section 17.-(Lost or Destroyed Bills.) - Where a negotiable bill has been lost or destroyed, a court of competent jurisdiction may order the delivery of the goods upon satisfactory proof of such loss or destruction and upon the giving of a bond with sufficient surety to be approved by the court to protect the carrier or any person injured by such delivery from any liability or loss, incurred by reason of the original bill remaining outstanding. The cout may also in its discretion order the payment of the carrier's reasonable costs and counsel fees.

The delivery of the goods under an order of the court as provided in this section, shall not relieve the carrier from liability to a person to whom the negotiable bill has been or shall be negotiated for value without notice of the proceedings or of the delivery of the goods.

Section 18.-(Effect of Duplicate Bills.) - A bill upon the face of which the word "duplicate" or some other word or words indicating that the document is not an original bill is placed plainly shall impose upon the carrier issuing the same 
the liability of one who represents and warrants that such bill is an accurate copy of an original bill properly issued but no other liability.

Section 19.-(Carrier Cannot Set Up Title in Himself.) No title to goods or right to their possession, asserted by a carrier for his own benefit, shall excuse him from liability for refusing to deliver the goods according to the terms of a bill issued for them, unless such title or right is derived directly or indirectly from a transfer made by the consignor or consignee after the shipment, or from the carrier's lien.

Section 20.-(Interpleader of Adverse Claimants.)-If more than one person claims the title or possession of goods, the carrier may require all known claimants to interplead, either as a defense to an action brought against him for nondelivery of the goods, or as an original suit, whichever is appropriate.

Section 21.-(Carrier has Reasonable Time to Determine Validity of Claims.) - If some one other than the consignee or person in possession of the bill, has a claim to the title or possession of the goods, and the carrier has information of such claim, the carrier shall be excused from liability for refusing to deliver the goods either to the consignee or person in possession of the bill, or to the adverse claimant, until the carrier has had a reasonable time to ascertain the validity of the adverse claim or to bring legal proceedings to compel all elaimants to interplead.

Section 22.-(Adverse Title is no Defense, Except as Above Provided.)-Except as provided in the two preceding sections and in section 12, no right or title of a third person unless enforced by legal process shall be a defence to an action brought by the consignee of a non-negotiable bill or by the holder of a negotiable bill against the carrier for failure to deliver the goods on demand.

Section 23.-(Liability for Non-Receipt or Misdescription of Goods.) - If a bill of lading has been issued by a carrier or on 
his behalf by an agent or employee the scope of whose actual or apparent authority includes the issuing of bills of lading, the carrier shall be liable to:

(a) The consignee named in a non-negotiable bill, or

(b) The holder of a negotiable bill,

Who has given value in good faith relying upon the description therein of the goods, for damages caused by the non-receipt by the carrier or a connecting carrier of all or part of the goors or their failure to correspond with the description thereof in the bill at the time of its issue.

If, however, the goods are described in a bill merely by a statement of marks of labels upon them or upon packages containing them, or by a statement that the goods are said to be goods of a certain kind or quantity, or in a certain condition, or it is stated in the bill that packages are said to contain goods of a certain kind or quantity or in a certain condition, or that the contents or condition of the contents of packages are unknown, or words of like purport are contained in the bill, such statements, if true, shall not make liable the carrier issuing the bill, although the goods are not of the kind or quantity or in the condition which the marks or labels upon them indicate, or of the kind or quantity or in the condition they were said to be by the consignor. The carrier may, also, by inserting in the bill the words "shipper's load and count" or other words of like purport indicate that the goods were loaded by the shipper and the description of them made by him; and if such statement be true, the carrier shall not be liable for damages caused by the improper loading or by the non-receipt or by the misdescription of the goods described in the bill.

Alabama. - Nat. Park Bank of New York v. Louisville \& N. R. Co. (19:?), 74 So. 69.

Arkansas.-Prescott \& N. W. R. Co. v. Davis (1916), 191 S. W. 210.

Connecticut. - Munson v. DeTamble Motors Co. (1914), 91 Atl. 531.

Georgia.-Atlantic Coast Line v. Luke \& Flemming (1917), $20 \mathrm{Ga}$. App. 76, 93 S. E. 286.
Maine.-Lewis Poultry Co. v. New York Cent. R. R. Co. (1919), 105 Atl. 109.

New Jersey.-Sprottle v. Dela. ware I. \& IV. R. Co. (1917), 101 Atl. 518.

New York.-D'Utassy v. Mallory S. S. Co. (1914), 147 N. Y. Supp. 313. 162 A. D. 410 ; Penna R. R. v. Titus (1913). 142 N. Y. Supp. 43, 156 A. D. 830 ; Williams v. Delaware 
\& Hudson Co. (1913), 141 N. Y. Supp. 606, 156 A. D. 695.

North Carolina. - Commercial Nat. Bank v. Seaboard Air Line R. R. Co. (1918), 175 N. C. 415,95 S. E. 777 .

North Dakota.-Knapp v. Minn. St. P. \& S. S. M. R. R. Co. (1916), 34 N. D. 466,159 N. W. 81.
Oklahoma.- Chicago R. I. \& P. Ry. Co. v. Cleveland (1916), 160 Pac. 328.

Oregon.- Michellod v. OregonWashington R. \& Nav. Co. (1917), 86 Or. 329, 168 Pac. 621.

Washington.- Chas. W. Johnson Lumber Co. v. Great Northern Ry. Co. (1918), 176 Pac. 343.

Section 24.- (Attachment or Levy upon Goods for which a Negotiable Bill has been Issued.) - If goods are delivered to a carrier by the owner or by a person whose act in conveying the title to them to a purchaser for value in good faith would bind the owner and a negotiable bill is issued for them, they cannot thereafter, while in the possession of the carrier, be attached by garnishment or otherwise, or be levied upon under an execution, unless the bill be first surrendered to the carrier or its negotiation enjoined. The carrier shall in no such case be compelled to deliver the actual possession of the goods until the bill is surrendered to him or impounded by the court.

Arizona.- P. Pastene \& Co. v. First Nat. Bank (1918), 172 Pac. 656.

Iowa.-Exchange Natl. Bk. v. McCafferry, Sheriff (1916), 157 N. W. 209.
Missouri.-Kinsolving v. State Saving \& Trust Co. (1916) (Mo. App.), 190 S. W. 379.

Washington.-Commercial Bank of Port Huron v. Elliot (1916), 159 Pac. 377.

Section 25.- (Creditor's Remedies to Reach Negotiable Bills.) - A creditor whose debtor is the owner of a negotiable bill shall be entitled to such aid from courts of appropriate jurisdiction by injunction and otherwise in attaching such bill, or in satisfying the claim by means thereof as is allowed at law or in equity in regard to property which cannot readily be attached or levied upon by ordinary legal process.

Section 26.- (Negotiable Bill Must State Charges for which Lien is Claimed.) - If a negotiable bill is issued the carrier shall have no lien on the goods therein mentioned, except for charges on those goods for freight, storage, demurrage and 
terminal charges, and expenses necessary for the preservation of the goods or incident to their transportation subsequent to the date of the bill, unless the bill expressly enumerates other charges for which a lien is claimed. In such case there shall also be a lien for the charges enumerated so far as they are allowed by law and the contract between the consignor and the carrier.

Section 27.-(Effect of Sale.)-After goods have been lawfully sold to satisfy a carrier's lien, or because they have not been claimed, or because they are perishable or hazardous, the carrier shall not thereafter be liable for failure to deliver the goods to the consignec or owner of the goods, or to a holder of the bill given for the goods when they were shipped, even if such bill be negotiable.

North Carolina.-Culbreth v. Atl. C. L. R. R. Ca (1915), 86 S. E. 621.

\section{PART III.}

Negotiation and Transfer of Bilis.

Section 28.-(Negotiation of Negotiable Bills by Delivery.) -A negotiable bill may be negotiated by delivery where, by the terms of the bill, the carrier undertakes to deliver the goods to the order of a specified person, and such person or a subsequent indorsee of the bill has indorsed it in blank.

Section 29.-(Negotiation of Negotiable Bills by Indorsement.) - A negotiable bill may be negotiated by the indorsement of the person to whose order the goods are deliverable by the tenor of the bill. Such endorsement may be in blank or to a specified person. If indorsed to a specified person, it may be negotiated again by the indorsement of such person in blank or to another specified person. Subsequent negotiation may be made in like manner.

Massachusetts.-Roland M. Baker Co. v. Brown (1913), 214 Mass. 196, 100 N. E. 1025.
United States.-C. F. White \& Co. v. Century Srgs. Bk of Des Moines (1916), 229 Fed. 975, U. S. C. C. A. 
Section 30.-(Transfer of Bills.) - A bill may be transferred by the holder by delivery, accompanied with an agreement, express or implied, to transfer the title to the bill or to the goods represented thereby.

A non-negotiable bill cannot be negotiated, and the indorsement of such a bill gives the transferee no additional right.

Alabama.-People's Bank \& Trust ing v. State Savings \& Trust Co. Co. v. Walthal (1917), 75 So. 570.

Arkansas.- Prescott \& N. W. R. Co. v. Davis (1916), 191 S. W. 210.

Kansas.-Oklahoma State Bank v. Hicklin (1917), 164 Pac. 257.

Massachusetts.-Brown v. Floersheim Mercantile Co. (1910), 206 Mass. 373, 92 N. E. 494.

Missouri.- Kinsolving v. State Saving \& Trust Co. (1916) (Mo. App.), 190 S. W. 379; St. Joseph Hay \& Feed Co. v. Missouri Pac. Co. (1916), 185 S. W. 1162; Kinsalv(1916), 190 S. W. 379.

Texas.-West Texas Nat. Bank v. Wichita Mill \& Elevator Co. (1917) (Tex. Civ. App.), 194 S. W. 835.

United States.-Oliver v. Mt. Union Tanning \& Extract Co. (1919) (U. S. D. U. Pa.), 253 Fed. 593; Oliver v. Mt. Union Tanning \& Extract Co. (1919) (U. S. D. U. Pa.), 253 Fed. 593.

West Virginia.-Richards Brick Corp. v. Hurst Hardware Co. (1917), 92 So. 685.

Section 31.-(Who May Negotiate a Bill.) - A negotiable bill may be negotiated by any person in possession of the same, however, such possession may have been acquired if, by the terms of the bill, the carrier undertakes to deliver the goods to the order of such person, or if at the time of negotiation the bill is in such form that it may be negotiated by delivery.

Section 32.-(Rights of Person to whom a Bill has been Negotiated.) - A person to whom a negotiable bill has been duly negotiated acquires thereby:

(a) Such title to the goods as the person negotiating the bill to him had or had ability to convey to a purchaser in good faith for value, and also such title to the goods as the consignee and consignor had or had power to convey to a purchaser in good faith for value, and

(b) The direct obligation of the carrier to hold possession of the goods for him according to the terms of the bill as fully as if the carrier had contracted directly with him. 
Alabama - Owansboro Banking Co. v. Buck (1918), 77 So. 940.

Iowa.- Midland Linseed Co. v. American Liquid Fireproofing Co. (1917), 166 N. W. 573.

Massachusetts.-Brown v. Floersheim Mereantile Co. (1910), 206 Mass. 373, 92 N. E. 494.

Missouri.-Frank Adams \& Co. v. Orpheum Theatre Co. (1917) (Mo. App.), 193 S. W. 908.

New Jersey.-Carr et al. v. Pa. R. R. Co. (1916), 96 Atl. 588, N. J. L.

Oklahoma.-City Nat. Bank of Hobart v. State (1918), 176 Pac. 232; First Nat. Bank of Claremore v. Stallings (1919), 177 Pac. 373;
Marsh Milling \& Grain Co. v. Guaranty State Bank of Ardmore (1917), 171 Pac. 1122.

Texas.-Hubbell Slack \& Co. v. Farmers Unioll Cotton Co. (1917) (Tex. Civ. App.), 196 S. W. 681.

United States.- N. Y. Cent. \& H. R. R. Co. v. Bank of Holly Springs (1916), 236 Fed. 562, decree modified, 195 Fed. 456; Brown Bros. v. Smith Bros., Itd. (1916), 231 Fed. 475 (Iaa.).

Washington.- Commercial Bank of Port Huron v. Elliott (1916), 159 Pac. 377; Commercial Bank of Port Huron v. Elliott (1916), 92 Wash. 357, 159 Pac. 377; State Bk. of Buckley v. Neb. Bridge Supply \& Lumber Co. (1916), 151 Pac. 253.

Section 33.-(Rights of Person to whom a Bill has been Transferred.) - A person to whom a bill has been transferred but not negotiated acquires thereby as against the transferor, the title to the goods, subject to the terms of any agreement with the transferor. If the bill is non-negotiable, such person also acquires the right to notify the carrier of the transfer to him of such bill, and thereby to become the direct obligee of whatever obligations the carrier owned to the transferor of the bill immediately before the notification.

Prior to the notification of the carrier by the transferor or transferee of a non-negotiable bill, the title of the transferee to the goods and the right to acquire the obligation of the carricr may be defeated by garnishment or by attachment or execution upon the goods by a creditor of the transferor, or by a notification to the carrier by the transferor or a subsequent purchaser from the transferor of a subsequent sale of the goods by the transferor.

A carrier has not received notification within the meaning of this section unless an officer or agent of the carrier, the actual or apparent seope of whose duties includes action upon such a notification, has been notified; and no notification shall be effective until the officer or agent to whom it is given has had time with 
the exercise of reasonable diligence to communicate with the agent or agents having actual possession or control of the goods.

Alabama.-Peoples' Bank \& Trust Co. v. Walthall (1917), 75 So. 570.

Arizona.-P. Pastene \& Co. v. First Natl. Bank (1918), 172 Pac. 656.

Arkansas. - Prescott v. Davis (1916), 191 S. W. 210.

Colorado.-Plainesville Nat. Bank of Plainesville, Ohio, v. Hannan (1918), 171 Pac. 364.

Kansas.-Oklahoma State Bank v. Hicklin (1917), 164 Pac. 257.

Michigan.-Pukett v. Marieta \& N. E. R. Co. (1913), 175 Mich. 253, 141 N. W. 607.

Mississippi.-Merchants \& Manufacturers Bank v. P. J. Toomer Lbr. Co. (1917), 115 Miss. 647, 76 So. 565.

New York.-Am. Natl. Bk. จ. Warren et al. (1916), 160 N. Y. Supp. 413; First Nat. Bank of
Blanchester v. Stengel (1918), 169

N. Y. Supp. 217; Gass v. So. Pac. Co. (1912), 137 N. Y. Supp. 261, 152 A. D. 412.

Pennsylvania. - Sturgeon Bay Bank v. McLaughlin (1916), $63 \mathrm{~Pa}$. Supr. Ct. 588.

West Virginia.-Richards Brick Corp. v. Hurst Hardware Co. (1917), 92 So. 685.

United States.-Oliver v. Mt. Union Tanning \& Extract Co. (1919) (U. S. D. U. Pa.), 253 Fed. 593; C. E. White \& Co. v. Century Svgs. Bk. of Des Moines (1916), 229 Fed. 975 , U. S. C. C. A.; Oliver v. Mt. Union Tanning \& Extract Co. (1919) (U. S. D. U. Pa.), 253 Fed. 593; N. Y. Cent. \& H. R. R. Co. v. Bank of Holly Springs (1916), 236 Fed. 562, decree modified 195 Fed. 456.

Section 34.-(Transfer of Negotiable Bill Without Indorsement.) - Where a negotiable bill is transferred for value by delivery, and the indorsement of the transferor is essential for negotiation, the transferee acquires a right against the transferor to compel him to indorse the bill, unless a contrary intention appears. The negotiation shall take effect as of the time when the indorsement is actually made. This obligation may be specifically enforced.

Section 35.-(Warranties on Sale of Bill.)-A person who negotiates or transfers for value a bill by indorsement or dolivery including one who assigns for value a claim secured by a bill, unless a contrary intention appears, warrants:

(a) That the bill is genuine,

(b) That he has a legal right to transfer it,

(c) That he has knowledge of no fact which would impair the validity, or worth of the bill, and 
(d) That he has a right to transfer the title to the goods, and that the goods are merchantable or fit for a particular purpose whenever such warranties would have been implied, if the contract of the parties had been to transfer without a bill the goods represented thereby.

In the case of an assignment of a claim secured by a bill, the liability of the assignor shall not exceed the amount of the claim.

New York.-Am. Natl. Bk. v.

Warren et al. (1916), 160 N. Y.

Supp. 413.

Section 36.-(Indorser not a Guarantor.)-The indorsement of a bill shall not make the indorser liable for any failure on the part of the carrier or previous indorsers of the bill to fat fill their respective obligations.

Section 37.-(No Warranty Implied from Accepting Payment of a Debt.) - A mortgagee or pledgee, or other holder of a bill for security who in good faith demands or receives payment of the debt for which such bill is security, whether from a party to a draft drawn for such debt or from any other person, shall not be deemed by so doing to represent or to warrant the genuineness of such bill or the quantity or quality of the goods therein described.

Georgia.-Downing v. Pearson

Banking Co. (1917) (Ga. App.), 92

S. E. 968 .

Section 38.-(When Negotiation not Impaired by Fraud, Accident, Mistake, Duress or Conversion.) The validity of the negotiation of a bill is not impaired by the fact that such negotiation was a breach of duty on the part of the person making the negotiation, or by the fact that the owner of the bill was deprived of the possession of the same by fraud, accident, mistake, duress or conversion, if the person to whom the bill was negotiated, or a persion to whom the bill was subsequently negotiated, gave value therefor, in good faith, without notice 
of the breach of duty, or fraud, accident, mistake duress or conversion.

Massachusetts.-Roland M. Baker Co. v. Brown (1913), 214 Mass. 196, 100 N. E. 1025.

New York.- Knight v. Delaware
\& Hudson Co. (1917), 165 N. Y. Supp. 583; Knight v. Delaware \& Hudson Co. (1917), 178 App. Div. 518, 165 N. Y. Supp. 583.

Section 39.-(Subsequent Negotiation.)-Where a person having sold mortgaged, or pledged goods which are in a carrier's possession and for which a negotiable bill has been issued, or having sold, mortgaged, or pledged the negotiable bill representing such goods, continues in passession of the negotiable bill, the subsequent negotiation thereof by that person under any sale, pledge, or other disposition thereof to any person receiving the same in good faith, for value and without notice of the previous sale, shall have the same effect as if the first purchaser of the goods or bill had expressly authorized the subsequent negotiation.

Massachusetts.-Roland M. Baker Co. v. Brown (1913), 214 Mass. 196, 100 N. E. 1025.

Section 40.-(Form of the Bill as Indicating Rights of Buyer and Seller.) - Where goods are shipped by the consignor in accordance with a contract or order for their purchase, the form in which the bill is taken by the eonsignor shall indicate the transfer or retention of the property or right to the possession of the goods as follows:

(a) Where by the bill the goods are deliverable to the buyer or to the agent, or to the order of the buyer or of his agent, the consignor thereby transfers the property in the goods to the buyer.

(b) Where by the bill the goods are deliverable to the seller or to bis agent, or to the order of the seller or of his agent, the seller thereby reserves the property in the goods. But if, except for the form of the bill, the property would have passed to the buyer on shipment of the goods, the seller's property in the goods shall be deemed to be only for the purpose of securing performance by the buyer of his obligations under the contract. 
(c) Where by the bill the goods are deliverable to the order of the buyer or of his agent, but possession of the bill is retained by the seller or his agent, the seller thereby reserves a right to the possession of the goods, as against the buyer.

(d) Where the seller draws on the buyer for the price and transmits the draft and bill together to the buyer to secure acceptance or payment of the draft, the buyer is bound to return the bill if he does not honor the draft, and if he wrongfully retains the bill he acquires no added right thereby. If, however, the bill provides that the goods are deliverable to the buyer, or to the order of the buyer, or is endorsed in blank or to the buyer by the consignee named therein, one who purchases in good faith, for value, the bill or goods from the buyer, shall obtain the title to the goods, although the draft has not been honored, if such purchaser has received delivery of the bill indorsed by the consignee named therein, or of the goods, without notice of the facts making the transfer wrongful.

Michigan.-King v. Van Slack (1916), 229 Fed. 975, U. S. C. C A. (1916), 159 N. W. 157.

Washington.- State Bk. of Buck.

Iowa.-C. E. White \& Co. v. ley v. Neb. Bridge Supply \& IumCentury Svgs. Bk. of Des Moines ber Co. (1916), 151 Pac. 253.

Section 41.-(Demand, Presentation or Sight Draft Must be Paid, but Draft on More than Three Days Time Merely Accepted Before Buyer is Entitled to the Accompanying Bill.) Where the seller of goods draws on the buyer for the price of tho goods and transmit the draft and a bill of lading for the goods either directly to the buyer or through a bank or other agency, unless a different intention on the part of the seller appears, the buyer and all other partics interested shall be justified in assuming:

(a) If the draft is by its terms or legal effect payable on de mand or presentation or at sight, or not more than three days thereafter (whether such three days be termed days of grace or not), that the seller intended to require payment of the draft before the buyer should be entitled to receive or retain the bill.

(b) If the draft is by its terms payable on time, extending beyond three days after demand, presentation or sight (whether 
such three days be termed days of grace or not), that the seller intended to require acceptance, but not payment of the draft before the buyer should be entitled to receive or retain the bill. The provisions of this section are applicable whether by the terms of the bill the goods are consigned to the seller, or to his order, or to the buyer, or to his order, or to a third person, or to his order.

New York.-Helburn Thompson Corp. (1917), 180 App. Div. 167, 167 Co. v. All American Merchantile N. Y. Supp. 711.

Section 42.-(Negotiation Defeats Vendor's Lien.)-Where a negotiable bill has been issued for goods, no seller's lien or right of stoppage in transitu shall defeat the rights of any purchaser for value in good faith to whom such bill has been negotiated, whether such negotiation be prior or subsequent to the notification to the carrier who issued such bill of the seller's claim to a lien or right of stoppage in transitu. Nor shall the carrier be obliged to deliver or justified in delivering the goods to an unpaid seller unless such bill is first surrendered for cancellation.

Section 43.-(When Rights and Remedies Under Mortgages and Liens are not Limited.) - Except as provided in Section 42 , nothing in this act shall limit the rights and remedies of a mortgagee or lienholder whose mortgage or lien on goods would be valid, apart from this act, as against one who for value and in good faith purchased from the owner, immediately prior to the time of their delivery to the carrier, the goods which are subject to the mortgage or lien and obtained possession of them.

\section{PART IV.}

\section{Criminal Offences.}

Section 44.-(Issue of Bill for Goods not Received.)-Any officer, agent, or servant of a carrier, who with intent to defraud issues or aids in issuing a bill knowing that all or any part of the goods for which such bill is issued have not been received 
by such carrier, or by an agent of such carrier or by a connecting carrier, or are not under the carrier's control at the time of issuing such bill, shall be guilty of a crime, and upon conviction shall be punished for each effense by imprisonment not exceeding five years, or by a fine not exceeding five thousand dollars, or by both.

Maryland.-Baltimiore \& Ohio R. N. J. ₹. Berry (1917), 165 N. Y. R. Co. v. Rueter (1911), 80 Atl. 220.

New York.-Central Railroad of

Supp. 1041, 99 Misc. 560.

Section 45.-(Issue of Bill Containing False Statement.)Any officer, agent, or servant of a carrier, who with intent to defraud issues or aids in issuing a bill for goods knowing that it contains any falso statement, shall be guilty of a crime, and upon conviction shall be punished for each offense by imprisonment not exceeding one year, or by a fine not exceeding one thousand dollars, or by both.

Section 46.-(Issue of Duplicate Bills not so Marked.)Any officer, agent, or servant of a carrier, who with intent to defraud issues or aids in issuing a duplicate or additional negotiable bill for goods in violation of the provisions of Section 7 , knowing that a former negotiable bill for the same goods or any part of them is outstanding and uncancelled, shall be guilty of a crime, and upon conviction shall be punished for each offense by imprisonment not exceeding five years, or by a fine not exceeding five thousand dollars, or by both.

Section 47.-(Negotiation of Bill for Mortgaged Goods.) Any Person who ships goods to which he has not title, or upon which there is a lien or mortgage, and who takes for such goods a negotiable bill which he afterwards negotiates for value with intent to deceive and without disclosing his want of title or the existence of the lien or mortgage, shall be guilty of a crime, and upon conviction shall be punished for each offense by imprisonment not exceeding one year, or by a fine not exceeding one thousand dollars, ir by both.

Section 48.- (Negotiation of Bill when Goods are not in Carrier's Possession.) - Any person who with intent to deceive 
negotiates or transfers for value a bill knowing that any or all of the goods which by the terms of such bill appear to have been received for transportation by the carrier which issued the bill, are not in the possession or control of such carrier, or of a connecting carrier, without disclosing this fact, shall be guilty of a crime, and upon conviction shall be punished for each offense by imprisonment not exceeding five years, or by a fine not exceeding five thousand dollars, or by both.

Section 49.- (Inducing Carrier to Issue Bill when Goods have not been Received.) - Any person who with intent to defraud secures the issue by a carrier of a bill knowing that at the time of such issue, any or all of the goods described in such bill as received for transportation have not been received by such carrier, or an agent of such carrier or a connecting carrier, or are not under the carrier's control, by inducing an officer, agent, or servant of such carrier falsely to believe that such goods have been received by such carrier, or are under its control, shall be guilty of a crime, and upon conviction shall be punished for each offense by imprisonment not exceeding five years, or by a fine not exceeding five thousand dollars, or by both.

Section 50.-(Issue of Non-Negotiable Bill not so Marked.) -Any person who with intent to defraud issues or aids in issuing a non-negotiable bill without the words " not negotiable" placed plainly upon the face thereof, shall be guilty of a crime, and upon conviction shall be punished for each offense by imprisonment not exceeding five years or by a fine not exceeding five thousand dollars, or by both.

\section{PART V.}

\section{INTERPRETATION.}

Section 51.-(Rule for Cases Not Provided for in this Act.) - In any case not provided for in this Act, the rules of law and equity, including the law merchant, and in particular the rules relating to the law of principal and agent, executors, adminis trators and trustees, and to the effect of fraud, misrepresenta- 
tion, duress or cocrcion, accident, mistake, bankruptcy, or other invalidating cause shall govern.

Section 52.-(Interpretation Shall Give Effect to Purpose of Uniformity.) - This Act shall be so interpreted and construod as to effectuate its general purpose to make uniform the law of those states which enact it.

Section 53.- (Definitions.)-(1) In this Act, unless the context or subject matter otherwise requires:

"Action" includes counterclaim, set-off, and suit in equity.

"Bill" means bill of lading.

"Consignee" means the person named in the bill as the person to whom delivery of the goods is to be made.

"Consignor" means the person named in the bill as the person from whom the goods have been received for shipment.

"Goods" means merchandise or chattels in course of transportation, or which have been or are about to be transported.

"Holder" of a bill means a person who has both actual pos eession of such bill and a right of property therein.

"Order" means an order by indorsement on the bill.

"Owner" does not include mortgagee or pledgee.

"Person" includes a corporation or partnership or two or more persons having a joint or common interest.

To "purchase" includes to take as mortgagee and to take as pledgee.

"Purchaser" includes mortgagee and pledgee.

"Value" is any consideration sufficient to support a simplo contract. An antecedent or pre-existing obligation, whether for money or not, constitutes value where a bill is taken either in satisfaction thereof or as security therefor.

(2) A thing is done " in good faith," within the meaning of this Act, when it is in fact done honestly, whether it be done negligently or not.

New Jersey.-Pennsylvania R. Co. $\quad$ v Townsend (1917), 100 Atl. 855.

Section 54.-(Act does not Apply to Existing Bills.)-The provisions of this Act do not apply to bills made and delivered prior to the taking effect thereof. 
Section 55.-(Inconsistent Legislation Repealed.)-All Acts or parts of Acts inconsistent with this Act are hereby repealed.

Section 56.-(Time When the Act Takes Effect.)-This Act shall take effect on the day of , one thousand nine hundred and

Section 57.-(Name of Act.)-This Act may be cited as the Uniform Bills of Lading Act. 
UNIFORM STOCK TRANSFER ACT

[339] 



\section{UNIFORM STOCK TRANSFER ACT}

The original draft of this Act was prepared by Prof. Samuel Williston of the Harvard Law School, in 1906, and during four years it was considered, four separate drafts having been prepared before final approval was given by the National Conference of Commissioners on Uniform State Laws in 1910.

Recognizing the practices of the commercial world, this Act puts certificates of stock to the fullest extent possible representative of further than the Warehouse Receipts Act, in that by section 5 it provides that the delivery of a certificate is effectual to transfer title, though made by one having no right of possession and having no authority from the owner of the certificate or from the person purporting to transfer the title. The effect of this Act is to make certificates of stock to the fullest extent possible representative of the shares, and this is in accordance with mercantile usage.

The Act was adopted in 1910 by Louisiana, Maryland and Mississippi, and has up to this time been enacted as a part of statutes of fourteen states. These are: Connecticut, 1917; Illinois, 1917; Louisiana, 1910 ; Maryland, 1910 ; Mississippi, 1910 ; Michigan, 1913 ; New Jersey, 1916 ; New York, 1913; Ohio, 1911 ; Pennsylvania, 1911; Rhode Island, 1912; Tennessee, 1917; Wisconsin, 1913 ; Alask2, 1913. 


\begin{tabular}{|c|c|c|c|c|c|c|c|}
\hline & $\begin{array}{l}\text { Ch. 67, } \\
\text { Session } \\
\text { Laws } \\
1913 .\end{array}$ & $\begin{array}{c}\text { Adopted } \\
\text { 1917; } \\
\text { Rerised } \\
1918 .\end{array}$ & $\begin{array}{l}\text { Laws of } \\
1917 .\end{array}$ & $\begin{array}{c}\text { Act 180, } \\
\text { Lawr } \\
1910 .\end{array}$ & $\begin{array}{c}\text { Laws } \\
1910, \\
\text { ch. } 73 .\end{array}$ & $\begin{array}{c}\text { Ch. 171, } \\
\text { Aets of } \\
\text { 1910. }\end{array}$ & $\begin{array}{c}\text { Public } \\
\text { Acts } \\
1913, \\
\text { No. } 106 .\end{array}$ \\
\hline $\begin{array}{l}\text { Uniform } \\
\text { Act } \\
\text { Sec. Na. }\end{array}$ & $\begin{array}{c}1913 \\
\text { Alaska. }\end{array}$ & $\begin{array}{l}\text { I918 } \\
\text { Conn. }\end{array}$ & $\begin{array}{l}1917 \\
\text { Illinois. }\end{array}$ & $\begin{array}{l}1910 \\
\text { La. }\end{array}$ & $\begin{array}{l}1910 \\
\text { Md. }\end{array}$ & $\begin{array}{l}1910 \\
\text { Mass. }\end{array}$ & $\begin{array}{l}1913 \\
\text { Mich. }\end{array}$ \\
\hline $\begin{array}{r}1 \\
2 \\
3 \\
4 \\
5 \\
6 \\
7 \\
8 \\
9 \\
10 \\
11 \\
12 \\
13 \\
14 \\
15 \\
16 \\
17 \\
18 \\
19 \\
20 \\
21 \\
22 \\
23 \\
24 \\
25 \\
26\end{array}$ & $\begin{array}{r}1 \\
2 \\
3 \\
4 \\
5 \\
6 \\
7 \\
8 \\
9 \\
10 \\
11 \\
12 \\
13 \\
14 \\
15 \\
16 \\
17 \\
18 \\
19 \\
20 \\
21 \\
22 \\
23 \\
24 \\
25 \\
26\end{array}$ & $\begin{array}{l}\mathbf{3 4 6 9} \\
\mathbf{3 4 7 0} \\
\mathbf{3 4 7 1} \\
\mathbf{3 4 7 2} \\
\mathbf{3 4 7 3} \\
\mathbf{3 4 7 4} \\
\mathbf{3 4 7 5} \\
\mathbf{3 4 7 6} \\
\mathbf{3 4 7 7} \\
\mathbf{3 4 7 8} \\
\mathbf{3 4 7 9} \\
\mathbf{3 4 8 0} \\
\mathbf{3 4 8 1} \\
\mathbf{3 4 8 2} \\
\mathbf{3 4 8 3} \\
\mathbf{3 4 8 4} \\
\mathbf{3 4 8 5} \\
\mathbf{3 4 8 6} \\
\mathbf{3 4 8 6} \\
\mathbf{3 4 8 7} \\
\mathbf{3 4 8 8} \\
\mathbf{3 4 8 9} \\
\mathbf{3 4 9 0 *} \\
\mathbf{3 4 9 0 *} \\
\mathbf{3 4 9 0 *} \\
\mathbf{3 4 9 0}\end{array}$ & $\begin{array}{r}1 \\
2 \\
3 \\
4 \\
5 \\
6 \\
7 \\
8 \\
9 \\
10 \\
11 \\
12 \\
13 \\
14 \\
15 \\
16 \\
17 \\
18 \\
19 \\
20 \\
21 \\
22 \\
23 \\
24 \\
25\end{array}$ & $\begin{array}{r}1 \\
2 \\
3 \\
4 \\
5 \\
6 \\
7 \\
8 \\
9 \\
10 \\
11 \\
12 \\
13 \\
14 \\
15 \\
16 \\
17 \\
18 \\
19 \\
20 \\
21 \\
22 \\
23 \\
24 \\
25 \\
26\end{array}$ & $\begin{array}{l}\text { 37A } \\
\text { 37B } \\
\text { 37C } \\
\text { 37D } \\
\text { 37E } \\
\text { 37F } \\
\text { 37G } \\
\text { 37H } \\
\text { 37I } \\
\text { 37J } \\
\text { 37K } \\
\text { 37L } \\
\text { 37M } \\
\text { 37N } \\
\text { 37O } \\
\text { 37P } \\
370 \\
\text { 37Q } \\
\text { 37R } \\
\text { 37S } \\
\text { 37T } \\
\text { 37U } \\
\text { 37V } \\
\text { 37W } \\
\text { 37X } \\
\text { 37Y }\end{array}$ & $\begin{array}{r}1 \\
2 \\
3 \\
4 \\
5 \\
6 \\
7 \\
8 \\
9 \\
10 \\
11 \\
12 \\
13 \\
14 \\
15 \\
16 \\
17 \\
18 \\
19 \\
20 \\
21 \\
22 \\
23 \\
24 \\
26 \\
25\end{array}$ & $\begin{array}{r}1 \\
2 \\
3 \\
4 \\
5 \\
6 \\
7 \\
8 \\
9 \\
10 \\
11 \\
12 \\
13 \\
14 \\
15 \\
16 \\
17 \\
18 \\
19 \\
20 \\
21 \\
22 \\
23 \\
24 \\
25\end{array}$ \\
\hline
\end{tabular}




\begin{tabular}{|c|c|c|c|c|c|c|c|}
\hline & $\begin{array}{c}\text { Ch. 191, } \\
\text { Session } \\
\text { Laws } \\
\text { 1916. }\end{array}$ & $\begin{array}{l}\text { Pers. } \\
\text { Prop. } \\
\text { Law. }\end{array}$ & $\begin{array}{l}\text { Laws } \\
1911 .\end{array}$ & $\begin{array}{l}\text { Laws } \\
1911 .\end{array}$ & $\begin{array}{c}\text { Ch. 840, } \\
\text { Iaws } \\
1912 .\end{array}$ & $\begin{array}{l}\text { Ch. 113, } \\
\text { Laws } \\
1917 .\end{array}$ & $\begin{array}{c}\text { Ch. 458, } \\
\text { Laws } \\
1913 .\end{array}$ \\
\hline $\begin{array}{l}\text { Uniform } \\
\text { Act } \\
\text { Sec. No. }\end{array}$ & $\begin{array}{l}1916 \\
\text { N. J. }\end{array}$ & $\begin{array}{l}1913 \\
\text { N. Y. }\end{array}$ & $\begin{array}{l}1911 \\
\text { Obio. }\end{array}$ & $\begin{array}{c}1911 \\
\text { Penn. }\end{array}$ & $\begin{array}{l}1912 \\
\text { R. I. }\end{array}$ & $\begin{array}{l}1917 \\
\text { Tenn. }\end{array}$ & $\begin{array}{l}1913 \\
\text { Wisc. }\end{array}$ \\
\hline $\begin{array}{l}1 \\
2 \\
3 \\
4 \\
5 \\
6 \\
7 \\
8 \\
9 \\
10 \\
11 \\
12 \\
13 \\
14 \\
15 \\
16 \\
17 \\
18 \\
19 \\
20 \\
21 \\
22 \\
23 \\
24 \\
25 \\
26\end{array}$ & $\begin{array}{r}1 \\
2 \\
3 \\
4 \\
5 \\
6 \\
7 \\
8 \\
9 \\
10 \\
11 \\
12 \\
13 \\
14 \\
15 \\
16 \\
17 \\
18 \\
19 \\
20 \\
21 \\
22 \\
23 \\
25 \\
24\end{array}$ & $\begin{array}{l}162 \\
163 \\
164 \\
165 \\
166 \\
167 \\
168 \\
169 \\
170 \\
171 \\
172 \\
173 \\
174 \\
175 \\
176 \\
177 \\
178 \\
179 \\
180 \\
181 \\
182 \\
183 \\
184 \\
185 \\
\ldots\end{array}$ & $\begin{array}{r}1 \\
2 \\
3 \\
4 \\
5 \\
6 \\
7 \\
8 \\
9 \\
10 \\
11 \\
12 \\
13 \\
14 \\
15 \\
16 \\
17 \\
18 \\
19 \\
20 \\
21 \\
22 \\
23 \\
\ddot{24} \\
\ldots\end{array}$ & $\begin{array}{r}1 \\
2 \\
3 \\
4 \\
5 \\
6 \\
7 \\
8 \\
9 \\
10 \\
11 \\
12 \\
13 \\
14 \\
15 \\
16 \\
17 \\
18 \\
19 \\
20 \\
21 \\
22 \\
23 \\
24 \\
25 \\
26\end{array}$ & $\begin{array}{r}1 \\
2 \\
3 \\
4 \\
5 \\
6 \\
7 \\
8 \\
9 \\
10 \\
11 \\
12 \\
13 \\
14 \\
15 \\
16 \\
17 \\
18 \\
19 \\
20 \\
21 \\
22 \\
23 \\
24 \\
25 \\
26\end{array}$ & $\begin{array}{l}1 \\
2 \\
3 \\
4 \\
5 \\
6 \\
7 \\
8 \\
9 \\
10 \\
11 \\
12 \\
13 \\
14 \\
15 \\
16 \\
17 \\
18 \\
19 \\
20 \\
21 \\
22 \\
23 \\
24 \\
25 \\
26\end{array}$ & $\begin{array}{l}175 \ln 1 \\
175 \ln 2 \\
175 \ln 3 \\
175 \ln 4 \\
175 \ln 5 \\
175 \ln 6 \\
175 \ln 7 \\
175 \ln 8 \\
175 \ln 9 \\
175 \ln 10 \\
175 \ln 11 \\
175 \ln 12 \\
175 \ln 13 \\
175 \ln 14 \\
175 \ln 15 \\
175 \ln 16 \\
175 \ln 17 \\
175 \ln 18 \\
175 \ln 19 \\
175 \ln 20 \\
175 \ln 21 \\
175 \ln 22 \\
1730.0 \\
175 \ln 23 \\
175 \ln 23\end{array}$ \\
\hline
\end{tabular}




\section{UNIFORM STOCK TRANSFER ACT}

Secrion 1. How Title to Certificates and Shares May be Transferred.

2. Powers of Those Lacking Full Legal Capacity and of Fiduciaries Not Enlarged.

3. Corporation Not Forbidden to Treat Registered Holder as Owner.

4. Title Derived from Certificate Extinguishes Title Derived from a Separate Document.

5. Who May Deliver a Certificate.

6. Indorsement effectual in Spite of Fraud, Duress, Mistake, Revocation, Deatl, Incapacity or Lack of Consideration or Authority.

7. Rescission of Transfer.

8. Rescission of Transfer of Certificate Does Not Invalidate Subsequent Transfer by Transferee in Possession.

9. Delivery of Unindorsed Certificate Imposes Obligation to Indorse.

10. Ineffectual Attempt to Transfer amounts to a promise to Transfer.

11. Warranties on Sale of Certificate.

12. No Warranty Implied from Accepting Payment of a Debt.

13. No Attachment or Levy Upon Shares Unless Certificate Surrendered or Transfer enjoined.

14. Creditor's Remedies to Reach Certificate.

15. There Shall be no Lien or Restriction Unless Indicated on Certificate.

16. Alteration of Certificate Does Not Divest Title to Shares.

17. Lost or Destroyed Certificate.

18. Rule for Cases Not Provided for by This Act.

19. Interpretation Shall Give Effect to Purpose of Uniformity.

20. Definition of Indorsement.

21. Definition of Person Appearing to be the Owner of Certificate.

22. Other Definitions. 


\section{UNIFORM STOCK TRANSFER ACT}

Section 1. Title to a certificate and to the shares repro sented thereby can be transferred only,

(a) By delivery of the certificate indorsed either in blank or to a specified person by the person appearing by the certificate to be the owner of the shares represented thereby, or

(b) By delivery of the certificate and a separate document containing a written assignment of the certificate or a power of attorney to sell, assign, or transfer the same or the shares represented thereby, signed by the person appearing by the certificate to be the owner of the shares represented thereby. Such assignment or power of attorney may be either in blank or to a specified person.

The provisions of this section shall be applicable although the charter or articles of incorporation or code of regulations or bylaws of the corporation issuing the certificate and the certificate itself, provide that the shares represented thereby shall be transferable only on the books of the corporation or shall be registered by a registrar or transferred by a transfer agent.

California.-Seyman v. Salsberry (1918), 171 Pac. 938; Geary St. P. S. C. R. Co. v. Bradbury Estate Co. (1918). 175 Pac. 457.

Delaware.-Lippman v. Kehoe Stenograph Co. (1916), 98 Atl. 943. Georgia.-Bank of Norwood v. Ray (1918), 94 S. E. 819.

Illinois.-Carus v. Matthiessen (1915), 196 Ill. App. 445.

- Kentucky. - Jones v. Bowman (1918), 205 S. W. 923; Will's Adm'r v. George Wiedemann Brewing Co. (1916), 188 S. W. 778.

Louisiana.-First Nat. Bk. v. Bell (1917), 74 So. 628.
Minnesota. - Peavey v. Wells (1917), 161 N. W. 508; Oxford v. Western Syndicate Inv. Co. (1919), 170 N. W. 587.

New York.-Leishing v. Van Burn (1918), 170 N. Y. Supp. 688, 183 App. Div. 296; Fisher v. Mch. \& Metals Nat. Bk. (1915), 153 N. Y. Supp. 786, 89 Misc. 587; Clark v. Bankers Trust Co. (1917), 163 N. Y. Supp. 748.

Ohio.- Davis Laundry \& Cleaning Co. v. Whitmore (1916), 110 N. E. 518, 92 Ohio St. 44.

Utah.-Brown v. Wright (1916), 161 Pac. 448. 
Washington. - Nagel v. Ham, United States. - Wolf v. Am. Yearsley \& Ryie (1915), 152 Pac. Trust \& Sav. BK. (1914), 214 Fed. 520; West v. Empire Life Ins. Co. 761. (1917), 242 Fed. 605.

Section 2. Nothing in this Act shall be construed as enlarging the powers of an infant or other person lacking full legal capacity, or of a trustee, executor or administrator, or other fiduciary, to make a valid indorsement, assignment or power of attorney.

Illinois.-Carus v. Matthiessen Vermont.-Noyes v. Woodruff (1915), 196 Ill. App. 445. (1917), 100 Atl. 759, 91 Vt. 407.

Section 3. Nothing in this Act shall be construed as forbidding a corporation,

(a) To recognize the exclusive right of a person registered on its books as the owner of shares to receive dividends, and to vote as such owner, or

(b) To hold liable for calls and assessments a person registered on its books as the owner of shares.

New York.- Richards v. Robins 162 N. Y. Supp. 12, 175 App. Div. (1914), 148 N. Y. Supp. 822, 86 296.

Misc. 528; Richards v. Robin (1916),

Section 4. The title of a transferee of a certificate under a power of attorney or assignment not written upon the certificate, and the title of any person claiming under such transferee, shall cease and determine if, at any time prior to the surrender of the certificate to the corporation issuing it, another person, for value in good faith, and without notice of the prior transfer, shall purchase and obtain delivery of such certificate with the indorsement of the person appearing by the certificate to be the owner thereof, or shall purchase and obtain delivery of such certificate and the written assignment or power of attorney of such person, though contained in a separato document.

Louisiana. - First Natchez Bk. $\nabla$.

Malacher Damare Co. (1914), 63 So.

270, 135 La. 295. 
Section 5. The delivery of a certificate to transfer title in accordance with the provisions of Section 1, is effectual, except as provided in Section 7, though made by one having no right of possession and having no authority from the owner of the certificate or from the person purporting to transfer the title.

California.- Northwestern Portland Cement Co. v. Atlantic Cement Co. (1916), 163 Pac. 47.
Illinois. - Swigart v. Stoops (1917), 204 Ill. App. 194.

Texas.-Mooringsport Oil Co. v. Aldridge (1917), 193 S. W. 400.

Section 6. The indorsement of a certificate by the person appearing by the certificate to be the owner of the shares represented thereby is effectual, except as provided in Section 7 , though the indorser or transferor,

(a) Was induced by fraud, duress or mistake, to make the indorsement or delivery, or

(b) Has revoked the delivery of the certificate, or the anthority given by the indorsement or delivery of the certificate, or

(c) Has died or become legally incapacitated after the indorsement, whether before or after the delivery of the certifcate, or

(d) Has received no consideration.

Alabama. - Mobile Touring \& Minnessota. Peavey v. Wells Wrecking Co. v. First Nat. Bank (1917), 161 N. W. 508. (1918), 78 So. 797.

Arkansas.-Paine Webber \& Co. v. Arkansas \& Arizona Copper Co. (1918), 206 S. W. 447.

California.- Northwestern Portland Cement $\mathrm{Co}$. v. Atlantic Cement Co. (1916), 163 Pac. 47.

Kentucky.-Goad v. Lewis (1917), 192 S. W. 30, $174 \mathrm{Ky} .394$; Will's Adm'r v. George Wiedemann Brewing Co. (1916), 188 S. W. 778.

Missouri. - Johnson v. Bixby (1918), 252 Fed. 103 (U. S. C. C. A. Mo.); Williams v. Everett (1917), 200 S. W. 1045.

New York.-Halgern v. Cure (1917), 173 N. Y. Supp. 385.

Pennsylvania.-Colonial Trust Co. v. Central Trust Co. (1914), 90 Atl. 189 ; Deal v. Erie Coal \& Coke Co. (1914), 90 Atl. 915.

Section 7. If the indorsement or delivery of a certificate,

(a) Was procured by frand or duress, or

(b) Was made under such mistake as to make the indorsement or delivery inequitable; or 
If the delivery of a certificate was made

(c) Without authority from the owner, or

(d) After the owner's death or legal incapacity, the possession of the certificate may be reclaimed and the transfer thereof rescinded, unless :

(1) The certificate has been transferred to a purchaser for value in good faith without notice of any facts making the transfer wrongful, or,

(2) The injured person has elected to waive the injury, or has been guilty of laches in endeavoring to enforce his rights.

Any court of appropriate jurisdiction may enforce specifically such right to reclaim the possession of the certificate or to rescind the transfer thereof and, pending litigation, may enjoin the further transfer of the certificate or impound it.

Alabama.-Bank of Florala v. Am. Nat. Bank of Pensacola (1917), 75 So. 310; Mobile Touring \& Wrecking Co. v. First Natl. Bank (1918), 78 So. 797.

Arkansas.- Paine, Webber \& Co. v. Arkansas \& Arizona Copper Co. (1918), 206 S. W. 447.

California.- Northwestern Portland Cement Co. v. Atlantic Cement Co. (1916), 163 Pac. 47.

Kentucky. - Will's Adm'r v. George Wiedemann Brewing Co. (1916), 188 S. W. 778; Goad v. Lewis (1917), 92 S. W. 30, $174 \mathrm{Ky}$. 394.

Michigan.- Hubbard v. Oliver (1913), 139 N. W. 77.

Missouri. - Johnson v. Bixby (1918), 252 Fed. 103 (V. S. C. C. A. Mo.); Dawson v. Flinton (1916), 190 S. W. 972.
New York.-Clark v. Borough Asphalt Co. (1916), 157 N. Y. Supp. 581, 93 Mise. 662.

Oklahoma.- State Bank v. Seales (1916), 159 Pac. 925.

Pennsylvania. - Paul v. Bialy (1917), 100 Atl. 1000.

Texas.-Mooringsport Oil Co. v. Aldridge (1917), 193 S. W. 400.

Utah.-Brown v. Wright (1916), 161 Pac. 448.

Vermont.-Noyes $\quad$. Woodruff (1917), 100 Atl. 759.

Wisconsin.-Schwab v. Esbenshade (1913), 139 N. W. 420, 151 Wisc. 513; McMillen v. Strange (1915), 150 N. W. 434; Miley $\nabla$. Heaney (1918), 169 N. W. 64.

United States,-Davis v. Finch (1916), 236 Fed. 89, 149 C. C. A. 299.

Section 8. Although the transfer of a certificate or of shares represented thereby has been rescinded or set aside, nevertheless, if the transferee has possession of the certificate or of a new certificate representing part or the whole of the same shares of stock, a subsequent transfer of such certificate by the trans- 
feree, mediately or immediately, to a purchaser for value in good faith, without notice of any facts making the transfer wrongful, shall give such purchaser an indefeasible right to the certificate and the shares represented thereby.

California.- Harvey v. Stowe Harding (1912), 83 Atl. 586, $235 \mathrm{~Pa}$. (1914), 219 Fed. 17.

Pennsylvania.- Crawford v. Dollar Savings Fund \& Tr. Co. (1912), 84 Atl. 694, $236 \mathrm{~Pa}$. 206; French v.

79.

United States.-Nat. City Bk. v. Wagner (1914), 216 Fed. 473.

Section 9 . The delivery of a certificate by a person appearing by the certificate to be the owner thereof without the indorsement requisite for the transfer of the certificate and the shares represented thereby, but with intent to transfer such certificate or shares shall impose an obligation, in the absence of an agreement to the contrary, upon the person so delivering, to complete the transfer by making the necessary indorsement. The transfer shall take effect as of the time when the indorsement is actually made. This obligation may be specifically enforced.

Alabama.-Bank of Guntersville v. U. S. Fidelity Co. (1917), 75 So. 168.

Georgia.- Massengale v. Hodgson (1918), 95 S. E. 975.

Massachusetts.-Baker v. Davie (1912), 97 N. E. 1094, 211 Mass. 429, 37 L. R. A. (N. S.) 944.
Minnesota. - Peavy v. Wells (1917), 161 N. W. 508.

New York.-Union Trust Co. of Rochester v. Oliver (1913), 140 N. Y. Supp. 681, 155 A. D. 646.

Section 10. An attempted transfer of title to a certificate or to the shares represented thereby without delivery of the certficate shall have the effect of a promise to transfer and the obligation, if any, imposed by such promise shall be determined by the law governing the formation and performance of contracts.

Section 11. A person who for value transfers a certificate, including one who assigns for value a claim secured by a certificate, unless a contrary intention appears, warrants-

(a) That the certificate is genuine,

(b) That he has a legal right to transfer it, and 
(c) That he has no knowledge of any fact which would impair the validity of the certificate.

In the case of an assignment of a claim secured by a certificate, the liability of the assignor upon such warranty shall not exceed the amount of the claim.

Massachusetts.-Barstow v. City Trust Co. (1914), 103 N. E. 911, 216

Mass. 330.

Section 12. A mortgagee, pledgee, or other holder for security of a certificate who in good faith demands or receives payment of the debt for which such certificate is security, whether from a party to a draft drawn for such debt, or from any other person, shall not by so doing be deemed to represent or to warrant the genuineness of such certificate, or the value of the shares represented thereby.

Section 13. No attachment or levy upon shares of stock for which a certificate is outstanding shall be valid until such certificate be actually seized by the officer making the attachment or levy, or be surrendered to the corporation which issued it, or its transfer by the holder be enjoined. Except where a certificate is lost or destroyed, such corporation shall not be compelled to issue a new certificate for the stock until the old certificate is surrendered to it.

California. - Ramage v. Gould (1917), 169 Pac. 670.
Massachusetts. - Parkhurst v. Almy (1915), 109 N. E. 733.

Section 14. A creditor whose debtor is the owner of a certificate shall be entitled to such aid from the courts of appropriate jurisdiction, by injunction and otherwise, in attaching such certificate or in satisfying the claim by means thereof as is allowed at law or in equity, in regard to property which can not readily be attached or levied upon by ordinary legal process.

Section 15. There shall be no lien in favor of a corporation upon the shares represented by a certificate issued by such corporation and there shall be no restriction upon the transfer 
of shares so represented by virtue of any by-law of such corporation, or otherwise, unless the right of the corporation to such lien or the restriction is stated upon the certificate.

Georgia.-American Nat. Bank of Atlanta v. East Atlanta Bank (1918), 95 S. E. 286,147 Ga. 750.

Louisiana.- State ex rel. Scott v. Caddo Rock Drill Bit Co. (1917), 75 So. 78,141 La. 353.

Michigan. - Weiland v. Hogan (1913), 143 N. W. 599, 171 Mich. 686.

North Dakota. - Chaffee v. Farmers Co-op. Elevator Co. (1918), 168 N. W. 616.
Texas. - Millner v. Brewer, Monoghan Mercantile Co. (1916), 188 S. W. 49, Tex. Civ. App.

Virginia.-U. S. Cigarette Ma. chine Co. v. Brown (1916), 89 S. E. 850,119 Va. 813.

Wisconsin.-Casper v. Kaib-Zimmers Mfg. Co. (1914), 149 N. W. 754.

Section 16. The alteration of a certificate, whether fraudulent or not and by whomsoever made, shall not deprive the owner of his title to the certificate and the shares originally represented thereby, and the transfer of such a certificate shall convey to the transferee a good title to such certificate and to the shares originally represented thereby.

Section 17. Where a certificate has been lost or destroyed, a court of competent jurisdiction may order the issue of a new certificate therefor on service of process upon the corporation and on reasonable notice by publication, and in any other way which the court may direct, to all persons interested, and upon satisfactory proof of such loss or destruction and upon the giving of a bond with sufficient surety to be approved by the court to protect the corporation or any person injured by the issue of the now certificate from any liability or expense, which it or they may incur by reason of the original certificate remaining outstanding. The court may also in its discretion order the payment of the corporation's reasonable costs and counsel fees.

The issue of a new certificate under an order of the court as provided in this section, shall not relieve the corporation from liability in damages to a person to whom the original certificate has been or shall be transferred for value without notice of the procedings or of the issuance of the new certificate. 
Section 18. In any case not provided for by this Act, the rules of law and equity, including the law merchant, and in particular the rules relating to the law of principal and agent, executors, administrators and trustees, and to the effect of fraud, misrepresentation, duress or coercion, mistake, bankruptcy, or other invalidating cause, shall govern.

Delaware. - Lippman v. Kehoe Stenograph Co. (1916), 98 Atl. 943.

Massachusetts.-Boston Tow Boat Co. v. Medford Nat. Bank (1919), 121 N. E. 491.

Minnesota.-Oxford v. Western Syndicate Inv. Co. (1919), $170 \mathrm{~N}$. W. 587 .
New York. - Schafus v. Betts (1916), 157 N. Y. Supp. 608, 94 Misc. 463.

United States.- Irvin v. Koehler (1916), 230 Fed. 795, 145 O. C. A. 105.

Section 19. This Act shall be so interpreted and construed as to effectuate its general purpose to make uniform the law of those states which enact it.

Section 20. A certificate is indorsed when an assignment or a power of attorney to sell, assign, or transfer the certificate or the shares represented thereby is written on the certificate and signed by the person appearing by the certificate to be the owner of the shares represented thereby, or when the signature of such person is written without more upon the back of the certificate. In any such cases a certificate is indorsed though it has not been delivered.

Delaware. - Lippman v. Kehoe (1916), 162 N. Y. Supp. 12, 175 App. Stenograph Co. (1916), 99 Atl. 843. Div. 296.

New York.- Richards v. Robin

Section 21. The person to whom a certificate was originally issued is the person appearing by the certificate to be the owner thereof, and of the shares represented thereby, until and unless be endorses the certificate to another specified person, and thereupon such other specified person is the person appearing by the certificate to be the owner thereof until and unless he also indorses the certificate to another specified person. Subsequent special indorsements may be made with like effect. 
Alabama.- Mobile Touring and Wrecking Co. v. First Nat. Bank (1918), 78 So. 797.

Arkansas.- Paine Webber \& Co. v. Arkansas \& Arizona Copper Co. (1918), 206 S. W. 447.

Illinois. - Swigart v. Stoops (1917), 204 Ill. App. 194.

New York.-Hannahs v. Hammond Typewriter Co. (1913), $143 \mathrm{~N}$.
Y. Supp. 939, 158 A. D. 620; IR: l. ards v. Wells Fargo Express Co. (1913), 141 N. Y. Supp. 306, 156 A. D. 268; Mitchell v. Boyer (1914), 145 N. Y. Supp. 715. 160 A. D. 365 ; Richards v. Robins (1914), 148 N. Y. Supp. 822, 86 Misc. 528; Halpern v. Cure (1917), 173 N. Y. Supp. 385. Utah.-Brown v. Wright (1916), 161 Pac. 448.

Section 22. (1) In this Act, unless the context or subject matter otherwise requires-

"Certificate" means a certificate of stock in a corporation organized under the laws of this state or of another state whose laws are consistent with this Act.

"Delivery" means voluntary transfer of possession from on person to another.

"Person" includes a corporation or partnership or two or more persons having a joint or common interest.

To "purchase" includes to take as mortgagee or as pledgee.

"Purchaser" includes mortgagee and pledgee.

"Shares" means a share or shares of stock in a corporation organized under the laws of this state or of another state whose laws are consistent with this Act.

"State" includes state, territory, district and insular possession of the United States.

"Transfer" means transfer of legal title.

"Title" means legal title and does not include a merely equitable or beneficial ownership or interest.

"Value" is any consideration sufficient to support a simple contract. An antecedent or pre-existing obligation, whether for money or not, constitutes value where a certificate is taken either in satisfaction thereof or as security therefor.

(2) A thing is done "in good faith" within the meaning of this Act, when it is in fact done honestly, whether it be dono negligently or not.

Kentucky.-Husband v. Linehan (1916), 181 S. W. 1089.

Section 23. The provisions of this Act apply only to certificates issued after the taking effect of this Act. 
Section 24. All Acts or parts of Acts inconsistent with this Act are hereby repealed.

Section 25. This Act shall take effect on the day of , one thousand nine hundred and Section 26. This Act may be cited as the Uniform Stock Transfer Act. 
UNIFORM DESERTION AND NON-SUPPORT ACT 



\section{UNIFORM DESERTION AND NON-SUPPORT ACT}

At the nineteenth meeting of the National Commissioners (1909) a tentative draft of an Act relating to family desertion and non-support was reported. This draft after consideration was referred back to the committee of marriage and divorce with certain suggested amendments for fature consideration. The Committee held meetings in Washington in January, 1910, in Philadelphia in May, 1910, and in Cape May in June, 1910, where further consideration was given to the suggestions and a new draft was prepared. This draft was presented to the conference at its seventeenth meeting in Chattaunooga, Tenn., August 25-29, 1910, and was adopted August 26, 1910, and recommended to the various states for adoption. 


\section{LANIFORM DESERTION AND NON-SUPPORT ACT.}

\begin{tabular}{|c|c|c|c|c|c|}
\hline & $\begin{array}{l}\text { Laws } \\
1915, \\
\text { p. } 565 .\end{array}$ & $\begin{array}{l}\text { Laws of } \\
1911, \\
\text { p. } 247 .\end{array}$ & Ch. 456. & $\begin{array}{l}\text { Jaws } \\
1911 .\end{array}$ & $\begin{array}{l}\text { Laws } \\
1915 .\end{array}$ \\
\hline $\begin{array}{l}\text { Uniform } \\
\text { Act } \\
\text { Sec. No. }\end{array}$ & $\begin{array}{c}1915 \\
\text { Alabama. }\end{array}$ & $\begin{array}{c}1911 \\
\text { Kansas. }\end{array}$ & $\begin{array}{l}1911 \\
\text { Mass. }\end{array}$ & $\begin{array}{c}1911 \\
\text { North Dakota. }\end{array}$ & $\begin{array}{c}1915 \\
\text { Tennessee. }\end{array}$ \\
\hline $\begin{array}{r}1 \\
2 \\
3 \\
4 \\
5 \\
6 \\
7 \\
8 \\
9 \\
10\end{array}$ & $\begin{array}{c}1^{*} \\
2^{*} \\
3 \\
4 \\
5^{*} \\
9 \\
\cdots \\
\text { ii } \\
11\end{array}$ & \begin{tabular}{c}
1 \\
2 \\
3 \\
4 \\
$5^{*}$ \\
6 \\
7 \\
$\ldots$ \\
\hdashline 8
\end{tabular} & $\begin{array}{c}1^{*} \\
3^{*} \\
4 \\
5^{*} \\
6^{*} \\
7^{*} \\
8^{*} \\
9 \\
10 \\
\ldots\end{array}$ & $\begin{array}{c}1 \\
2 \\
3 \\
4 \\
5 \\
6 \\
7 \\
8 \\
\ldots \\
. .\end{array}$ & $\begin{array}{l}\text { (Greatly } \\
\text { Modified) }\end{array}$ \\
\hline
\end{tabular}


UNIFORM DESERTION AND NON-SUPPORT ACT. 359

\begin{tabular}{|c|c|c|c|c|c|c|}
\hline & $\begin{array}{c}\text { Laws } \\
1913 . \\
\text { ch. } 101 .\end{array}$ & $\begin{array}{l}\text { Laws } \\
1913 \text {, } \\
\text { p. } 118 .\end{array}$ & $\begin{array}{l}\text { Laws } \\
1915 . \\
\text { ch. } 10 . \\
\text { p. } 192 .\end{array}$ & $\begin{array}{l}\text { Laws } \\
1917 . \\
\text { ch. } 51 .\end{array}$ & Ch. 576. & $\begin{array}{l}\text { laws } \\
1915 . \\
\text { ch. } 72 . \\
\text { p. } 66 .\end{array}$ \\
\hline $\begin{array}{l}\text { Uniform } \\
\text { AcL } \\
\text { Sec. No. }\end{array}$ & $\begin{array}{c}1913 \\
\text { Texas. }\end{array}$ & $\begin{array}{l}1913 \\
\text { Utah. }\end{array}$ & $\begin{array}{c}1915 \\
\text { Vermont. }\end{array}$ & $\begin{array}{l}1917 \\
\text { W. Va. }\end{array}$ & $\begin{array}{c}1911 \\
\text { Wisconsin. }\end{array}$ & $\begin{array}{c}1915 \\
\text { Wyoming. }\end{array}$ \\
\hline $\begin{array}{l}1 \\
2 \\
3 \\
4 \\
5 \\
6\end{array}$ & $\begin{array}{l}1 \\
2 \\
2 \\
\dddot{3}\end{array}$ & $\begin{array}{ll} & 1^{*} \\
1^{*} & 1^{*} \\
1^{*} & 1^{*} \\
\text { Laws } & 1911 \\
2\end{array}$ & $\begin{array}{l}1^{*} \\
2 \\
3 \\
4 \\
5 \\
6\end{array}$ & $\begin{array}{l}1 * \\
2^{*} \\
3^{*} \\
4 \\
5^{*} \\
6\end{array}$ & $\begin{array}{l}\text { (Greally } \\
\text { Modified) }\end{array}$ & $\begin{array}{l}1 \\
2 \\
3 \\
4 \\
5 \\
6\end{array}$ \\
\hline $\begin{array}{r}7 \\
8 \\
9 \\
10\end{array}$ & $\begin{array}{l}\ldots \\
\cdots \\
\cdots\end{array}$ & $\begin{array}{l}\cdots \\
\ldots \\
\ldots\end{array}$ & $\begin{array}{l}7 \\
8 \\
\cdots \\
\cdots\end{array}$ & $\begin{array}{l}\ddot{8} \\
9 \\
\cdots\end{array}$ & & $\begin{array}{l}\cdots \\
\ddot{7} \\
8\end{array}$ \\
\hline
\end{tabular}




\section{UNIFORM DESERTION AND NON-SUPPORT ACT}

Section I. That any husband who shall, without just cause, desert or wilfully neglect or refuse to provide for the support and maintenance of his wife in destitute or necessitous circumstances: or any parent who shall without lawful excuse, desert or wilfully neglect or refuse to provide for the support and maintenance of his or her child or children under the age of sixteen years in destitute or necessitous circumstances, shall be guilty of a crime and, on conviction thereof, shall be punished by a fine not exceeding five hundred dollars, or imprisonment in the , not exceeding two years, or both, with or without hard labor, in the discretion of the court.

Delaware. - Donaghy v. State (1917), 29 Del. 467.

Kansas.-In re A. T. Fowles (1913), 89 Kan. 430; State v. Waller (1913), 90 Kan. 829; State v. Wellman (1918), 102 Kan. 503.

Massachusetts. - Commonwealth v. Shamon (1916), 223 Mass. 62.

Tennessee.-Moye v. State (1917), 139 Tenn. 680; State v. Dixon (1917), 138 Tenn. 195.
Texas.-Pippins v. State (1916), 79 Tex. Crim. Cases, 525; Windham v. The State (1917), 80 Tex. Crim. Cases, 551.

Utah.-State v. Bliss (1913), 44 Utah, 39, 137 Pac. 829; State v. Smith (1915), 45 Utah, 381, 140 Pac. 286.

Wisconsin. - Adams v. State (1916), 164 Wis. 223; Brandel v. State (1915), 161 Wis. 532.

Section II. Proceedings under this Act may be instituted upon complaint made under oath or affirmation by the wife or child or children, or by any other person, against any person guilty of either of the above named offenses.

Section III. At any time before the trial, upon petition of the complainant and upon notice to the defendant, the court, or a judge thereof in vacation, may enter such temporary order as may seem just, providing for support of the deserted wife or children, or both, pendente lite, and may punish for violation of such order as for contempt. . 
Section IV. Before the trial, with the consent of the defendant, or at the trial, on entry of a plea of guilty, or after convietion, instead of imposing the penalty hereinbefore provided, or in addition thereto, the court in its descretion, having regard to the eircumstances, and to the financial ability or earning capacity of the defendant, shall have the power to make an order, which shall be subject to change by the court from time to time, as cireumstances may require, directing the do fendant to pay a eertain sum periodically, for a term not exceeding two years, to the wife or to the guardian, curator or custodian of the said minor child or children, or to an organization or individual approved by the court as trusteo; and shall also have the power to release the defendant from custody on probation for the period so fixed, upon his or her ontering into a recognizance, with or without surety, in such sum as the court or a judge thereof in vacation, may order and approve. The condition of the recognizance shall be such that if the defendant shall make his or her personal appearance in eourt whenever ordered to do so and shall further comply with the terms of such order of support, or of any subsequent modification thereof, then such recognizance shall be void, otherwise of full force and effect.

Seetion V. If the court be satisfied by information and duo proof under oath, that at any time during said period of two years the defendant has violated the terms of such order, it may forthwith proceed with the trial of the defendant under the original charge, or sentence him or her under the original conviction, or enforce the suspended sentence, as the case may be. In case of forfeiture of recognizance, and enforcement thereof by execution, the sum recovered may, in the discretion of the court, he paid, in whole or in part, to the wife, or to the guardian, curator, custodian or trustee of the said minor child or children.

Section VI. No other or greater evidence shall be required to prove the marriage of such liusband and wife, or that the defendant is the father or mother of such ehild or ehildren, than is 
or shall be required to prove such facts in a civil action. In no prosecution under this Act shall any existing statute or rule of law prohibiting the disclosure of confidential communications between husband and wife apply, and both husband and wife shall be competent witnesses to testify against each other to any and all relevant matters, including the fact of such marriage and the parentage of such child or children; provided that neither shall be compelled to give evidence incriminating himself or herself. Proof of the desertion of such wife, child or children in destitute or necessitous circumstances or of neglect or refusal to provide for the support and maintenance of such wife, child or children shall be prima facie evidence that such desertion, noglect or refusal is wilful.

Utah.-State v. Smith (1915), 45

Utah, 381, 146 Pac. 286.
Texas. - Qualls v. The State (1913), 71 Tex. Crim. Cases, 67.

Section VII. It shall be the duty of the sheriff, warden, or other official in charge of the county jail, or of the custodian of the reformatory, workhouse, or house of correction, in which any person is confined on account of a sentence at hard labor, under this act, to pay over to the wife, or to the guardian, curator or custodian of his or her minor child or children, or to an organization or individual approved by the court as trustee, at the end of each week, for the support of such wife, child, or children, a sum equal to .......... for each day's hard labor performed by said person so confined.

Section VIII. This Act shall be so interpreted and construed as to effectuate its general purpose to make uniform the law of those states which enact it.

Kansas. - State v. Waller (1913), 90 Kan. 829.

Section IX. Repealing clause.

Vermont. - Ex parte Turner (1918), 102 Atl. 943.

Section X. This Act shall take effect the Anno Domini, 19 


\section{UNIFORM CHILD LABOR ACT.}





\section{UNIFORM CHIWD LABOR ACT.}

In 1909 a special committee appointed by the President of the National Conference of Commissioners on Uniform State Laws to consider and report as to the advisability of some legislation on the question of child labor, reported that it was advisable that a special committee of five be appointed by the President with authority to draft aud present to the next Conference an Act to make uniform the law relating to child labor. This report was adopted by the Conference and a committee appointed of which Mr. Hollis R. Bailey was made chairman.

In 1910, this committeo reported that it had met in Detroit in 1909 and in Washington in 1910 and had held several public hearings which were well attended; that it had decided to use the so-called Standard Child Labor Law prepared by the National Child Labor Committee as its starting point, and had sent out circulars containing interrogatories accompanied by a copy of the so-called Standard Child Labor Law for the purpose of obtaining suggestions and information, and that a tentative draft of a Uniform Child Labor Law had been prepared and submitted to the officers of the National Child Labor Committee, and that a new draft had been prepared taking into consideration the answers to the interrogatories, which draft the Committee submitted to the Conference with its report. This draft was recommitted for further revision.

The Cummittee with the assistance of the National Child Labor Committee carefully revised and rewrote the draft of a Uniform Child Labor Law during the year following the 1910 Conference. During that year there had been a considerable amount of child labor legislation, and this was considered by the Committee in preparing its final draft of an Act. The Act which the Committee prepared was almost entirely based upon legislation already in force in one or more states of the Union. 
The Committee in submitting this final draft to the 1911 Conference, reported that the Child Labor Law, if approved by the Conference would have its chief value as a model for legislation in those states which at that time were without any law on the subject, and in those states which were revising and codifying their laws. The Act reported by the Committee was approved by the Conference and recommended to the state legislatures for adoption.

The Uniform Child Labor Law has been adopted in the following states: Kentucky, 1914; Massachusetts, 1913; Missigsippi, 1914; Utah, 1915. 


\section{UNIFORM CHILD LABOR ACT.}

Be it enacted, etc., as follows:

CHILDREN UNDER FOUTTEEN.

Section 1. No child under 14 years of age shall be employed, permitted or suffered to work in, about or in connection with any (1) mill, (2) factory, (3) workshop, (4) mercantile or mechanical establishment, (5) tenement-house manufactory or workshop, (6) store, (7) office, ( 8 ) office building, (9) restaurant, (10) boarding-house, (11) bakery, (12) barber shop, (13) hotel, (14) apartment house, (15) bootblack stand or establishment, (16) public stable, (17) garage, (18) laundry, (19) place of amusement, (20) club, (21) or as a driver, (22) or in any brick or lumber yard, (23) or in the construction or repair of buildings, (24) or in the distribution, transmission or sale of merchandise, (25) or in the transmission of messages.

Sec. 2. It shall be unlawful for any person, firm or corporation to employ, permit or suffer to work any child under 14 years of age in any business or service whatever during any of the hours when the public schools of the district in which the child resides are in session.

\section{CHILDREN UNDER SIXTEEN.}

Sec. 3. No child under the age of 16 years shall be employed. permitted or suffered to work at any of the following occupations or in any of the following positions: (1) Adjusting any belt to any machinery; (2) sewing or lacing machine belts in any workshop or factory; (3) oiling, wiping or cleaning maehinery or assisting therein; (4) operating or assisting in operating any of the following machines: (a) Circular or band saws; (b) wood shapers; (c) wood jointers; (d) planers; (e) sandpaper or wood-polishing machinery; (f) woodturning or boring machinery; $(\mathrm{g})$ picker machines or machines used in picking wool, cotton, hair or any other material; (h) carding machines; (i) paper-lace machines; (j) leather-burnishing ma- 
chines; (k) job or cylinder printing presses operated by power other than foot power; (l) boring or drill presses; (m) stamping machines used in sheet-metal and tin-ware or in paper and leather manufacturing, or in washer and nut factories; (n) metal or paper cutting machines; (o) corner staying machines in paper box factories; $(p)$ corrugating rolls, such as are used in corrugated paper; roofing or washboard factories; (q) steam boilers; ( $r$ ) dough brakes or cracker machinery of any description; (s) wire or iron straightening or drawing machinery; (t) rolling mill machinery; ( $u$ ) power punches or shears; (v) washing, grinding or mixing machinery; (w) calendar rolls in paper and rubber manufacturing; (x) laundering machinery; (5) or in proximity to any hazardous or unguarded belts, machinery or gearing; (6) or upon any railroad, whether steam, electric or hyraulic; (7) or upon any vessel or boat engaged in navigation or commerce within the jurisdiction of this state.

Sec. 4. No child under the age of 16 years shall be employed, permitted or suffered to work in any capacity (1) in, about, or in connection with any processes in which dangerous or poisonous acids are used; (2) nor in the manufacture or packing of paints, colors, white or red lead; (3) nor in soldering; (4) nor in occupations causing dust in injurious quantities; (5) nor in the manufacture or use of dangarous or poisonous dyes; (6) nor in the manufacture or preparation of compositions with dangerous or poisonous gases; (7) nor in the manufacture or use of compositions of lye in which the quantity thereof is injurious to health; (8) nor on scaffolding; (9) nor in heavy work in the building trades; (10) nor in any tunnel or excavation; (11) nor in, about or in connection with any mine, coal breaker, coke oven, or quarry; (12) nor in assorting, manufacturing or packing tobacco; (13) nor in operating any automobile, motor car or truck; (14) nor in a bowling alley; (15) nor in a pool or billiard room; (16) nor in any other occupation dangerous to the life and limb, or injurious to the health or morals of such child; (17) nor shall any child under the age of 16 years be employed upon the stage of any theater or concert hall or in connection with any theatrical per formance or other exhibition or show. 
Sec. 5. The state board of health may, from time to time, after a hearing duly had, determine whether or not any particular trade, process of manufacture or occupation, in which the employment of children under the age of 16 years is not already forbidden by law, or any particular method of carrying on such trade, process of manufacture or occupation, is sufficiently dangerous to the lives or limbs or injurious to the health or morals of children under 16 years of age to justify their exclusion therefrom. No child under 16 years of ago shall be employed, permitted or suffered to work in any occupation thus determined to be dangerous or injurious to such children. There shall be a right of appeal to the [Superior] Court from any such determination.

\section{EMPLOFMENT CERTIFICATES.}

Sec. 6. No child under 16 years of age shall be employed, permitted or suffered to work, in, about or in connection with any establishment or occupation named in section 1 unless tho person, firm or corporation employing such child procures and keeps on file, and accessible to any truant officer [or attendance officer], inspector of factories, or other authorized inspector or officer charged with the enforcement of this Act, the employment certificate as hereinafter provided, issued to said child; and keeps two complete lists of the names together with the ages of all boys under 16 years of age and all girls under 18 years of age employed in or for such establishment or in such occupation. one on file and one conspicuously posted near the principal entrance of the place or establishment in which such children are employed.

Sec. 7. Truant officers [or attendance officers], inspectors of factories, or other authorized inspectors, or officers charged with the enforcement of this Act, shall require that the emplovment certificates and lists provided for in this Act be producerl for their inspection.

Sec. 8. On termination of the employment of a child whose employment certificate is on file, such certificate shall be ruturned by the employer within two days to the official who issued 
the same with a statement of the reasons for the termination of said employment.

Sec. 9. An employment certificate shall be issued only by: the superintendent of schools or by a person authorized by him in writing, or [where there is no superintendent of schools] by a person authorized in writing by the school board or committee in the city, town or village where such child resides, or in case the child resides outside of the state of the city, town or village in which the child is to be employed, upon the application in person of the parent or guardian or custodian of the child desiring such employment; provided, that no member of a school board or committee, or other person authorized as aforesaid, shall have authority to issue such certificate for any child then in or about to enter such person's own employment or the employment of a firm or corporation of which he is a member, officer or employee.

Sec. 10. The person authorized to issue an employment certificate shall not issue such certificate until he has received, examined, approved and filed the following papers, duly executed, viz. :

(1) The written pledge or promise of a person, firm or corporation to legally employ the child and also the written agreement to return the employment certificate within two days after the termination of such employment, as provided in section 9 of this Act.

(2) The school record of such child properly filled out and signed, as provided in this Act.

(3) A certificate signed by a physician appointed by the school board or committee stating that such child has been examined by him and, in his opinion, has reached the normal development of a child of his age, and is in sufficiently sound health and physically able to be employed in any of the occupations or processes in which a child between 14 and 16 years of age may be legally employed.

(4) Evidence of age that the child is 14 years old or upwards, which shall consist of one of the following proofs of age and shall be required in the order herein designated as follows: 
(a) A duly attested transcript of the birth certificate filed according to law with a registrar of vital statistics, or other officer charged with the duty of recording births, which certificato shall be prima facie evidence of the age of such child.

(b) A passport or a duly attested transcript of a certificato of baptism showing the date of birth and place of baptism of such child.

(c) In case none of the above proofs of age can be produced, other documentary evidence of age which shall appear to be satisfactory to the officer issuing the certificate (aside from the school record of such child or the affidavit of parent, guardian or custodian), may be accepted in lieu thereof. In such case a school census or enumeration record, duly attested, may be used as proof of age in the discretion of the officer issuing the certificate.

(d) In case no documentary proof of age of any kind can be produced, the officer issuing the certificate may receive and file an application signed by the parent, guardian or custodian of the child for physicians' certificates. Such application shall contain the name, alleged age, place of birth, and present residence of the child, together with such further facts as may be of assistance in determining the age of such child, and shall contain a statement certifying that the parent, guardian or custodian signing such application is unable to produce any of the documentary proofs of age specified in the preceding subdivisions of this section. Such application shall be filed for not less than sixty days for an examination to be made of the statements contained therein, and in case no facts appear within such period or by such examination tending to discredit or contradict any material statement of such application, the officer issuing the certificate may direct such child to appear thereafter for physical examination before two physicians officially designated by the school board or committee, and in case such physicians shall certify in writing that they have separately examined such child and that, in their opinion, such child is at least 14 years of age, such officer shall accept such certificates as sufficient proof of the age of such child for the purposes of this section. In case the opinions of such physicians do not concur, the child 
shall be examined by a third physician and the concurring opinions shall be sufficient for the purpose of this section as to the age of such child.

The officer issuing the certificate shall require the evidence of age specified in subdivision $(a)$ in preference to that specified in any subsequent subdivision and shall not accept the evidence of age permitted by any subsequent subdivision unless he shall receive and file in addition thereto an affidavit of the parent, guardian or custodian showing that no evidence of age specified in any preceding subdivision or subdivisions of this section can be procured. Such affidavit shall contain the age, date and place of birth, and present residence of such child, which affidavit must be taken before the officer issuing the employment certificate, who is hereby authorized and required to administer such oath and who shall not demand or receive a fee therefor.

Sec. 11. No employment certificate shall be issued until the child in question has personally appeared before and been examined by the officer issuing the certificate, nor until such officer, after making such examination, has signed and filed in bis office a statement that the child can read intelligently and write legibly simple sentences in the English language, and is qualified in the studies enumerated in section 13, and that, in his opinion, the child is 14 years of age or upwards.

Sec. 12. Every such employment certificate shall state the name, sex, the date and place of birth and the place of residence of the child, and describe the color of the hair and eyes, the height and weight and any distinguishing facial marks of such child, and shall contain a statement of the proof of age accepted and shall certify that the papers required by the preceding sections have been duly examined, approved and filed, and that the child named in such certificate has appeared before the officer issuing the certificate and has been examined.

Every such certificate shall be signed, in the presence of the officer issuing the same, by the child in whose name it is issued. It shall show the date of its issue. A record giving all the facts contained on every certificate issued shall be kept on file in the office issuing the same, and also a record of the names and addresses of the children to whom certificates have boen refused, 
together with the names of the schools which such children should attend and the reasons for refusal.

Sec. 13. The school record required by this Act shall be filled out and signed by the principal or chief executive officer of the school which such child has last attended, and shall bo furnished to a child who, after due examination and investigation, may be entitled thereto.

It shall contain a statement certifying that the child has regularly attended the public school or schools equivalent thereto or parochial schools for not less than 130 days, either during the twelve months previous to arriving at the age of 14 years, or during the twelve months previous to applying for such school record, and is able to read intelligently and write legibly simple sentences in the English language, and had completed a courso of study equivalent to five yearly grades in reading, spelling, writing, English language and geography, and is familiar with the fundamental operations of arithmetic up to and including fractions.

Such school record shall also give the name, date of birth and residence of the child as shown on the records of the school and the name of the parent or guardian or custodian.

In case a child has attended more than one school during the twelve months previous to arriving at the age of 14 years or during the twelve months previous to applying for such school record, the principal or chief executive officer of each school shall separately certify to the number of days attended by the child in such school during such period, and no employment certificate shall be issued to such child unless the total of the days so attended shall be at least 130 days.

Sec. 14. The blank certificate and other papers required in the issuing of employment certificates shall be formulated by the chief factory inspector [or commissioner of labor, or state superintendent of public schools] and furnished by him to the local school boards or committees.

Sec. 15. The superintendent of schools or other person authorized to issue employment certificates shall transmit between the first and tenth days of each month, to the office of the chief factory inspector [or commissioner of labor], upon tho 
blanks to be furnished by him, a list of the names of the children to whom certificates have been issued. Such lists shall give the name and address of the prospective employer and the nature of the occupation the child intends to engage in.

\section{CHILDREN APPARENTLY UNDER SIXTEEN.}

Sec. 16. An inspector of factories, truant officer [or attendance officer], or other officer charged with the enforcement of this Act may make demand on any employer in or about whose place or establishment a child apparently under the age of 16 years is employed or permitted or suffered to work, and whose employment certificate is not filed as required by this Act, that such employer shall either furnish him, within ten days, satisfactory evidence that such child is in fact over 16 years of age, or shall cease to employ or permit or suffer such child to work in such place or establishment. The inspector of factories, truant officer [or attendance officer], or other officer charged with the enforcement of this Act, shall require from such employer the same evidence of age of such child as is required upon the issuance of an employment certificate, and the employer furnishing such evidence shall not be required to furnish any further evidence of the age of the child.

Sec. 17. In case any employer shall fail to produce and deliver to a factory inspector, truant officer [attendance officer], or other officer charged with the enforcement of this Act, within ten days after demand made pursuant to section 16 of this Act, the evidence of age therein required, and shall thereafter continue to employ such child or permit or suffer such child to work in such place or establishment, proof of the making of such demand and of such failure to produce and file such evidence shall be prima facie evidence of the illegal employment of such child in any prosecution brought therefor.

\section{CHILDREN UNDER EIGHTEEN.}

Sec. 18. No child under the age of 18 years shall be employed, permitted or suffered to work (1) in, about or in connection with blast furnaces, docks, or wharves ; $(2)$ in the outside erection and repair of electric wires; (3) in the running 
or management of elevators, lifts or hoisting machines, or dynamos; (4) in oiling or cleaning machinery in motion; (5) in the operation of emery wheels or any abrasive, polishing or buffing wheel where articles of the baser metals or iridium are manufactured; (6) at switch tending; (7) gate tending; (8) track repairing; $(9)$ or as brakeman, freman, engineers, motormen or conductors upon railroads; $(10)$ or as railroad telograph operators; (11) as pilots, firemen or engineers upon boats and vessels; (12) or in or about establishments wherein nitroglycerine, dynamite, dualin, guncotton, gunpowder or other high or dangerous explosives are manufactured, compounded or stored; (13) or in the manufacture of white or yellow phosphorus or phosphorus matches; (14) or in any distillery, brewery, or any other establishment where malt or alcoholic liquors are manufactured, packed, wrapped or bottled; (15) or in any hotel, theater, concert hall, place of amusement, or any other establishment where intoxicating liquors are sold.

Sec. 19. The state board of health may, from time to time, after hearing duly had, determine whether or not any particular trade, process of manufacture or occupation, in which the employment of children under 18 years of age is not already forbidden by law, or any particular method of carrying on such trade, process of manufacture or occupation, is sufficiently dangerous to the lives or limbs or injurious to the health or morals of children under eighteen years of age to justify their exclusion therefrom.

No child under 18 years of age shall be employed, permitted or suffered to work in any occupation thus determined to be dangerous or injurious to such children. There shall be a right of appeal to the [Superior] Court from any such determination.

\section{PERSONS UNDER TWENTY-ONE.}

Sec. 20. No person under 21 years of age shall be employed, permitted or suffered to work in, about or in connection with any saloon or bar-room where intoxicating liquors are sold.

Sec. 21. No female under 21 years of age shall be employed, permitted or suffered to work in or about any (1) mine, (2) 
quarry, (3) or coal breaker, except in the office thereof, (4) or * in oiling or cleaning machinery while in motion.

Sec. 22. No female under 21 years of age shall be employed, permitted or suffered to work in any capacity where such employment compels her to remain standing constantly.

Every person who shall employ any female under 21 years of age in any place or establishment mentioned in section 1 shall provide suitable seats, chairs or benches for the use of females so employed, which shall be so placed as to be accessible to said employees; and shall permit the use of such seats, chairs or benches by them in so far as the nature of their work allows, and there shall be provided at least one seat to every three females.

HOURS OF LABOR.

Sec. 23. No boy under the age of 16 and no girl under the age of 18 years shall be employed, permitted or suffered to work in, about or in connection with any establishment or occupation named in section 1 (1) for more than six days in any. one week, (2) nor more than forty-eight hours in any week, (3) nor more than eight hours in any one day; (4) or before the hour of 7 o'clock in the morning or after the hour of 6 o'clock in the evening. The presence of such child in any establishment during working hours shall be prima facie evidence of its employment therein.

Sec. 24. No boy under the age of 18 years and no girl under the age of 21 years shall be employed, permitted or suffered to work in, about or in connection with any establishment or occupation named in section 1 (1) for more than six days in any one week, (2) nor more than fifty-four hours in any week, (3) nor more than ten hours in any one day, (4) or before the hour of 6 o'clock in the morming or after the hour of 10 o'clock in the evening.

Sec. 25. In cities [of the first and second class] no person under the age of 21 years shall be employed, permitted or suffered to work as a messenger for telegraph, telephone or messenger companies in the distribution, transmission or delivery of goods or messages before 5 o'clock in the morning or after 10 c'clock in the evening of any day. 
Sec. 26. Every employer shall post and keep posted in a conspicuous place in every room where any boy under the age of 18, or any girl under the age of 21 years is employed, permitted or suffered to work, a printed notice stating the maximum number of hours such person may be required or perınitted to work on each day of the week, the hours commencing and stopping work, and the hours allowed for dinner or for other meals. The printed form of such notices shall be furnished by the chief inspector of factories [or commissioner of labor] and the employment of any minor for a longer time in any day than so stated, or at any time other than as stated in said printed notice shall be deemed a violation of the provisions of this Act.

\section{STREET TRADES.}

Sec. 27. No boy under 12 years of age, and no girl under 16 years of age shall, in any city [of the first or second class], distribute, sell, expose, or offer for sale (1) newspapers, (2) magazines or (3) periodicals in any street or public place.

Sec. 28. No boy under 14 years of age and no girl under 16 years of age shall, in any city [of the first or second class] be employed or permitted or suffered to work at any timo as (1) a bootblack, or (2) in any other trade or occupation performed in any street or public place, or (3) in the distribution of hand bills or circulars, or (4) any other articles except newspapers, magazines and periodicals as hereinafter provided.

Sec. 29. No boy under 16 years of age shall, in any eity [of the first or second class], distribute, sell, expose or offer for sale in any street or public place any (1) newspapers, (2) magazines, (3) or periodicals, (4) or work in any of the trades or occupations mentioned in section 28 , unless he complies with all of the legal requirements concerning school attendance, and unless a permit and badge as hereinafter provided shall have been issued to him by the superintendent of schools or by a person authorized by him in writing, or, where there is no superintenient of schools, by a person authorized by the school board or committee of the city or school district where such bov resides, upon the application in person of the parent, guardian or cmstodian of the child desiring such permit and badge, or in caso 
said child has no parent, guardian or custodian, then upon the application of his next friend, being an adult.

Sec. 30. Such permit and badge shall not be issued until the officer issuing the same shall have received, examined, approved and filed the following papers, duly executed, viz.:

(1) Evidence that such boy is of the age required by section 27 or 28, as the case may be. Such evidence of age shall consist of the proof of age required for the issuing of an employment certificate as specified in section 10 , subdivision (4), of this Act.

(2) The written statement of the principal or chief executive officer of the school which the child is attending, stating that such child is an attendant at such school with the grade such child shall have attained, and that he has reached the normal development of a child of his age and is physically and mentally fit for such employment and that he is able to do such work beside the regular school work required by law.

After having received, examined and placed on file such papers, the officer shall issue to the child a permit and badge, provided, that in the case of a boy between the ages of 14 and 16 having an employment certificate, such certificate shall be acecpted by the officer issuing such permit and badge in lieu of any other requirements.

Principals or chief executive officers of schools shall keep complete lists of all children in their schools to whom permits and badges, as herein provided, have been granted.

Sec. 31. Such permit shall state the name and the date and place of birth of the child, the name and address of the parent or guardian or custodian or next friend making application for such permit, and shall describe the color of the hair and eyes, the height and weight and any distinguishing facial marks of such child and shall further state that the papers required by. the preceding sections have been duly examined and signed, and that the child named in such permit has personally appeared. before the officer issuing the permit. The badge furnished by, the officer issuing the permit shall bear on its face a number corresponding to the number of the permit and the name of the child. Every such permit and every such badge on its reverse 
side shall be signed in the presence of the offcer issuing the same by the child in whose name it is issued.

Sec. 32. The badge provided for herein shall be worn conspicuously at all times by such child while so working. All such permits and badges shall expire annually on the first day of January, and no such permit or badge shall be authority beyond the period fixed therein for its duration. The color of the badge shall be changed each year.

No ehild to whom such permit and badge are issued shall transfer the same to any other person. He shall exhibit the same upon demand at any time to any officer charged with the duty of enforcing the provisions of this Act relating to strect trades.

Sec. 33. No child under 16 to whom a permit and badge are issued as provided for in the preceding sections of this Act shall distribute, sell, expose, or offer for sale, any newspapers, magazines or periodicals, or work at any of the trades or occupations mentioned in section 28 in any street or public place (1) after 8 o'clock in the evening, (2) or before 6 o'clock in the morning, (3) nor during the hours when the public schools in the city in which such child resides are in session, unless provided with an employment certificate.

Sec. 34. Any child in any city [of the first or second class] who shall distribute, sell, expose or offer for sale newspapers, magazines or periodicals, or shall work at any of the trades or occupations mentioned in section 28 in violation of any of the provisions of this Act shall be deemed delinquent and may be arrested and brought before the juvenile court, if there be any juvenile court in the city where such child resides, or, if not, before any court or magistrate having jurisdiction over offenses committed by children, and shall be dealt with according to law. Upon the recommendation of the principal or chief executive officer of the school which such child is attending, or upon the complaint of any officer charged with the duty of enforcing this Act, or of any police officer, truant officer [attendance officer] or probation officer of a juvenile court, the permit of any child who violates any of the provisions of this Act, or who becomes delinquent or fails to comply with all the legal requirements concerning school attendance, may be revoked by the officer is- 
suing the same, for a period of six months and a badge taken from such child. The refusal of any child to surrender such permit and badge, or the working at any of the occupations abovo mentioned in any street or public place by any child after notice of the revocation of such permit shall be deemed a violation of this Act.

Sec. 35. The chief factory inspector [or commissioner of labor] or any inspector authorized by him shall enforce the provisions of the preceding sections relating to the employment of children in street trades.

\section{GENERAL PROVISIONS.}

Sec. 36. Inspectors of factories, truant officers [attendance officers] and other authorized inspectors may, within their respective districts or jurisdictions visit and inspect at any time any place of employment mentioned in this Act, and shall ascertain whether any minors are employed therein contrary to the provisions of this Act; and they shall report weekly to the school authorities any cases of children under 16 years of age discharged for illegal employment; and truant officers shall also report the same to the chief or district factory inspector [or commissioner of labor].

It shall be the duty of factory inspectors, truant officers [attendance officers] and other officers charged with the enforcement of this Act, to make complaints against any person violating any of the provisions of this Act and to prosecute the same.

This shall not be construed as a limitation upon the right of other persons to make and prosecute such complaints.

Sec. 37. A failure by an employer to produce to a truant officer [attendance officer], factory inspector, or other authorized inspector or officer charged with the enforcement of this Act, any employment certificate or list required by this Act shall be prima facie evidence of the illegal employment of any child whose employment certificate is not produced or whose name is not so listed.

Sec. 38. Nothing in this Act shall prevent children of any age from receiving industrial education furnished by the United 
States, this state or any city or town in the state and duly approved by the state board of education or by [the school board or committee or] other duly constituted public authority.

PENALTIES.

Sec. 39. Any person, firm or corporation, agent or manager of any firm or corporation, who, whether for himself or for such firm or corporation or by himself, or through agents, servants or foremen, employs any child and whoever having under his control as parent, guardian, custodian or otherwise, any child, permits or suffers such child to be employed or to work in violation of any of the provisions of this Act, shall, for a first offense be punished by a fine of not less than five dollars nor more than fifty dollars; for a second offense by a fine of not less than fifty dollars nor more than two hundred dollars, or by imprisonment for not more than thirty days or by both such fine and imprisonment; for a third offense by a fine of not less than two hundred dollars, or by imprisonment for not more than sixty days, or by both such fine and imprisonment.

Sec. 40. Whoever continues to employ any child in violation of any of the provisions of this Act, after being notified thereof in writing by a factory inspector, truant officer [attendance officer], or other officer charged with the enforcement of this act, shall, for every day thereafter that such employment continues, be fined not less than five nor more than twenty dollars.

Sec. 41. Any person, firm or corporation retaining an employment certificate in violation of section 8 of this Act shall be fined not less than five nor more than fifty dollars.

Sec. 42. Every employer who fails to procure and keep on file employment certificates for all children cmployed under the age of 16 years, or who fails to kcep and post lists, as provided in section 6 of this Act, shall be fined not less than five dollars nor more than one hundred dollars.

Sec. 43. Any employer who fails to post and keep posted the printed notices required by section 26 of this Act in the manner therein specified shall be fincd not less than five dollar's nor more than fifty dollars. 
Sec. 44. Every employer who fails to provide suitable seats, chairs or benches and to allow the use of the same as provided in section 22 of this Act, shall be fined not less than five dollars nor more than one hundred dollars.

Sec. 45. Any person, firm or corporation who hinders or delays any factory inspector, truant officer [attendance officer], or any other officer charged with the enforcement of any of the provisions of this Act in the performance of his or her duties, (2) or refuses to admit or locks ont any such officer from any place which said inspectors or officers are authorized to inspect shall be punished by a fine of not less than five nor more than two hundred dollars, or by imprisonment for not less than ten days nor more than thirty days, or by both such fine and imprisonment.

Sec. 46. Any inspector of factories, or other authorized inspector, truant officer [attendance officer], superintendent of schools or other person authorized to issue employment certificates or permits and badges as required by this Act, or other person charged with the enforcement of any of the provisions of this Act, who knowingly and wilfully violates or fails to comply with any of the provisions of this act shall be fined not less than five nor more than one hundred dollars.

Sec. 47. Any person authorized to sign any certificate, affidavit or paper called for by this Act, who knowingly certifies to any material false statement therein, shall be fined not less than five dollars nor more than one hundred dollars.

Sec. 48. Any child working in or in connection with any of the establishments or places or in any of the occupations mentioned in this Act, who refuses to give to the factory inspector or other authorized inspector or truant officer [attendance officer] his or her name, age and place of residence, shall be forthwith conducted by the inspector or truant officer [attendance officer] before the juvenile court if there be any juvenile court in the city where such child resides, or if not before any court or magistrate having jurisdiction of offenses committed by children, for examination and to be dealt with according to law.

Sec. 49. Any person who, either for himself or herself or as 
agent of any other person or of any corporation, furnishes or sells to any minor any article of any description with the knowledge that said minor intends to sell said article in violation of the provisions of this Act, or who shall continue to furnish or sell articles of any description to a minor after having received written notice from any officer charged with the enforcement of this Act, or from the officer issuing the permit and badge required by section 29 , that said minor is unlicensed to sell such articles, shall be punished by a fine of not less than five dollars nor more than two hundred dollars, or by imprisonment for not less than ten days nor more than thirty days, or by both such fine and imprisonment.

Sec. 50. This Act may bo cited as the Uniform Child Labor Law. It shall be so interpreted and construed as to effectuate its general purpose to make uniform the law of those states which enact it.

Sec. 51. All Acts or parts of Acts inconsistent with any of the provisions of this Act are hereby repealed.

Sec. 52. This Act shall take effect on the day of A. D. 19 . 



\section{UNIFORM MARRIAGE AND MARRIAGE LICENSES}

ACT 



\section{UNIFORM MARRIAGE AND MARRIAGE LICENSES $\mathrm{ACT}$}

By resolution of the National Conference of Commissioners on Uniform State Laws adopted at its annual meeting in 1905, recognition of the National Conference on Uniform Divorce Laws, which was ealled to meet at Washington, D. C., in 1906, at the suggestion of the Governor of Pennsylvania, was given; the Conference expressed its satisfaction at the prospect of receiving " any assistance in solving the many and difficult problems relating to the divorce laws of the several states and territories," and promised "to aid the proposed congress in any way within its power."

During the meeting of the Divorce Congress, a resolution was adopted reading as follows:

"Resolved, That the President of this Congress appcint a committee of five members of this Congress to consider the propriety of adopting a uniform Marriage License Law with power to report such a uniform Marriage License Law, to be recommended for adoption."

The committee was appointed and submitted a report embodying therein the essential requirements of a uniform Marriage License Law. Upon the filing of this report, the Divorce Congress adopted a resolution in which it expressed its hope that some body wonld make an effort to secure a uniform Marriage and Marriage License Law, as these subjects were not within the purview of the Congress. This action of the Congress and its report were submitted to the Committee on Marriage and Divorce of the Commissioners on Uniform State Laws.

The first tentative draft of this Act, after having bren eircuiated for eriticisms and suggestions, was submitted to the Conference at its 19th annual meeting at Detroit, Michigin. In 1909. A revised draft of the Act was prepared in harmony with the suggestions and eriticisms received and the same was 
388 UNIFORM MARRIAGE AND MARRIAGE LICENSES ACT.

resubmitted to the Conference in 1910, at its meeting held in Chattanooga, Tennessce. A third draft of the Act was prepared in 1911, and duly submitted to the Conference at its meeting that year in Boston, Mass., where it was finally approved and recommended for adoption in all the states.

The Act was adopted by Massachusetts, with slight modifications in 1911 and by Wisconsin in 1917. 
UNIFORM MARRIAGE AND MARRIAGE LICENSES ACT. 389

\begin{tabular}{|c|c|c|}
\hline & & WIs. Stats. (1917) \\
\hline $\begin{array}{l}\text { Uniform Act } \\
\text { Section No. }\end{array}$ & $\begin{array}{l}1911 \\
\text { Massachusetts }\end{array}$ & $\begin{array}{l}1917 \\
\text { Wisconsin }\end{array}$ \\
\hline 1 & (Adopted with slight & $2339 n-1$ \\
\hline 2 & modifications) & $2339 n-2$ \\
\hline 3 & & $2339 n-3$ \\
\hline 4 & Mass. R. L. C. 151, Secs. & $2339 n-4$ \\
\hline 5 & 16-44, Vol. 2, pp. 1347- & $2339 n-5$ \\
\hline 6 & 1352; Amended by St. 1907 , & $2339 n-6$ \\
\hline 7 & c. 159, p. 113 ; St. 1911 , c. & $2339 n-7$ \\
\hline 8 & 736 , p. 938 ; St. 1912 , c. 120 & $2339 n-8$ \\
\hline $\mathbf{9}$ & p. 85 ; St. 1912 , c. 463 , p. & $2339 n-9$ \\
\hline 10 & 393 ; St. 1912 , c. 535 , p. 491 ; & $2339 n-10$ \\
\hline 11 & St. 1913 , c. 752, p. 713 ; St. & $2339 n-11$ \\
\hline 12 & 1914 , c. 121 , p. 89 ; St. 1914 , & $2339 n-12$ \\
\hline 13 & c. 428 , p. 383 . & $2339 n-13$ \\
\hline 14 & & $2339 n-14$ \\
\hline 15 & & $2339 n-14$ \\
\hline 16 & & $2339 n-15$ \\
\hline 17 & & $2339 n-16$ \\
\hline 18 & . & $2339 n-17$ \\
\hline 19 & & $2339 n-18$ \\
\hline 20 & & $2339 n-19$ \\
\hline 21 & - & $2339 n-20$ \\
\hline 22 & & $\ddot{2} 339 n-\dot{2} 1$ \\
\hline 23 & & $\begin{array}{l}2339 n-21 \\
2339 n-22\end{array}$ \\
\hline $\begin{array}{l}24 \\
25\end{array}$ & & \\
\hline $\begin{array}{l}25 \\
26\end{array}$ & & $\begin{array}{l}2339 n-23 \\
2339 n-24\end{array}$ \\
\hline $\begin{array}{l}26 \\
27\end{array}$ & . & $2339 n-25$ \\
\hline 28 & & $\ddot{2} 3 \ddot{3} \ddot{n}-26$ \\
\hline 29 & & $\begin{array}{l}2339 n-26 \\
2339 n-27\end{array}$ \\
\hline $\begin{array}{l}30 \\
31\end{array}$ & & $\ldots \ldots$ \\
\hline 32 & & $\cdots \cdots \cdots$ \\
\hline
\end{tabular}




\section{UNIFORM MARRIAGE AND MARRIAGE LICENSES $\mathrm{ACT}$}

Section I. Be it enacted, etc., That marriage may be validly contracted in this state only after a license has been issued therefor, in the manner following:

1. Before any person authorized by the laws of this state to celebrate marriages (and hereinafter designated as the officiating person), by declaring in the presence of at least two competent witnesses other than such officiating person, that they take each other as husband and wife; or,

2. In accordance with the customs, rules and regulations of any religious society, denomination or sect to which either of the parties may belong, by declaring in the presence of at least two competent witnesses, that they take each other as husband and wife.

Section II. No persons shall be joined in marriage within this state until a license shall have been obtained for that purpose from the ................ of the ...... in which one of the parties resides; provided that if both parties be non-residents of the state, such license may be obtained from the ............ of the ........... where the marriage ceremony is to be performed.

Section III. Application for a marriage license must be mado at least five days before the license shall be issued; provided, that in cases of emergency, or extraordinary circumstances, the judge of the court having probate jurisdiction may authorize the license to be issued at any time before the expiration of said five days.

Section IV. No license shall be issued unless both of the contracting parties shall be identified to the satisfaction of the proper .........., who shall further require of the parties, either separately or together, a statement under oath relative to the legality of the contemplated marriage, the date of same, the names, relationship, if any, age, nationality, color, residence, and occupation of the parties, the names of the parents, guardians, or curators of such as are under the age of legal majority, any prior marriage or marriages of the parties, or either of 
them, and the manner of the dissolution thereof; and if there be no legal objection thereto, such ....... shall issue a marriage license in the form hereinafter prescribed. Or, the parties intending marriage may, either separately or together, appear before any ........., magistrate, or justice of the peace of the $\ldots \ldots \ldots \ldots$ (whether in this or any other state) wherein either of the contracting parties resides, or of the ......... where the marriage is to be performed, who shall require of them a statement under oath as above provided; and such statement, having been duly subscribed and sworn to, and the parties having been duly identified, shall be forwarded to the proper ........., who, if satisfied after an examination thereof, that the same is in proper legal form, and that no legal objection to the contemplated marrigge exists, shall issue a license therefor.

Section $\nabla$. No license shall be issued if either of the contracting parties be under the marriageable age of consent as established by law. If either of the contracting parties be between the marriageable age of consent as established by law, and the age of legal majority, to wit, between ............ years and..$\ldots \ldots$ years, if a male, and between ....... years and $\ldots \ldots \ldots \ldots$ years, if a female, no license shall be issued without the consent of his or her parents, guardian, or curator, or of the parent having the actual care, custody and control of such minor or minors, given before the .......... under oath, or certified under the hand of such parents, guardian or curator as aforesaid, and properly verified by affidavit before a notary public or other official authorized by law to take affidavits, which certificate shall be filed of record in the office of said ......... and entered by him on the marriage license docket before issuing said license; provided, that if there be no guardian or curator of either or both of such minors, or if there be no competent person having the actual care, custody, and control of such minor or minors, then the judge of the ........ of the residence of the minor having probate jurisdiction may, after hearing, upon proper cause shown, make an order allowing the marriage of such minor or minors.

Section VI. Immediately upon entering an application for a license, the ........ shall post in his office a notice giv- 
ing the names and residences of the parties applying therefor, and the date of the application. Any person believing that the statements of the application are falso or insufficient, or that the applicants or either of them are incompetent to marry, may file with the court having probate jurisdiction in the ...... in which the license is applied for, a petition under oath, setting forth the grounds of objection to the marriage, and asking for a rule upon the parties making such application to show cause why the license should not be refused. Whereupon, said court, if satisfied that the grounds of objection are prima facie valid, shall issue a rule to show cause as aforesaid, returnable as the court may direct, but not more than ten days from and after the date of said rule, which rule shall be served forthwith upon the applicants for such license, and upon the clerk before whom such application shall have been made, and shall operate as a stay upon the issuance of the license until further ordered. If, upon hearing, the objections be sustained, the court shall make an order refusing the license; the costs to rest in the discretion of the court; but if the objections be overruled, the party or parties filing the same shall be liable for all costs of the proceedings.

Section VII. Any person who shall, in any affidavit or statement required or provided for by sections IV, V, or VI of this Act, wilfully and falsely swear, or who shall procure another to swear falsely in regard to any material fact relating to the competency of either or both of the parties applying for a marriage license, or as to the ages of such parties, if minors, or who shall falsely pretend to be the parent, guardian or curator, having authority to give consent to the marriage of such minors, shall be guilty of a misdemeanor and upon conviction thereof be punished by a fine of not less than $\$ 100.00$ or more than $\$ 500.00$, or by imprisonment in the ........ for not more than one year, or by both such fine and imprisonment.

Section VIII. Any ............ who shall knowingly issue a marriage license contrary to, or in violation of, the provisions of this Act shall be guilty of a misdemeanor, and upon conviction thereof, be punished by a fine of not less than $\$ 100.00$ or more than $\$ 500.00$, or imprisonment in the ........ for not more than one year, or by both such fine and imprisonment. 
Section IX. Model forms for blank applications, statemeuts, consent of parents, affidavits, licenses, and marriage certificates and such other forms as shall be necessary to comply with the provisions of this Aet shall be preseribed by the .......... and provided at the expense of the state; and a sample copy of each of said forms shall be furnished to the ........... of each ........... of the state. The ........ authorities shall furnish, at the cost of said ............ to the ................ all of the aforesaid blanks, together with a suitable book to be called the marriage license docket, which said ........... shall keep in his office among his records, and enter therein a complete record of the applieations for and the issuing of all marriage licenses, and of all mattere which he is required by this act to ascertain relative to the rights of any person to obtain a license. Said marriage license docket shall be open for public inspection or examination at all times during office hours.

Section $X$. The license shall authorize the marriage eeremony to be performed in any $\ldots \ldots \ldots \ldots$ of this state, excepting that where both parties are non-residents of the state, tho ceremony shall be performed only in the $\ldots \ldots \ldots$. in which the license is issued. The license shall be directed "to any person authorized by the law of this state to solemnize marriage," and shall authorize him to solomnize marriage between the parties therein named, at any time not more than one year from and after the date thereof. If the marriage is to be solemnized by the parties without the presence of an officiating person, as provided by paragraph 2 of section I of this Act, the license shall be directed to the parties to the marriage. If either of the parties be not of the age of legal majority, then his or her age shall be stated, and the fact of the consent of his or her parents, guardian, or curator, shall likewise be stated; and if eithor of said parties shall havo been theretofore married, then the number of times he or she shall have been previously married, and the manner in which the prior marriage or marriages was or were dissolved, shall be stated. The officiating peron shall satisfy himself that the parties presenting themselves to be married by him are the parties named in the licenso; and if he knows of any legal impediment to such marriage, he shall re- 
fuse to perform the ceremony. The issue of a license shall not be deemed to remove or dispense with any legal disability, impediment or prohibition rendering marriage between the parties illegal, and the license shall contain a statement to that effect.

Section XI. Said license shall be in form substantially as follows:

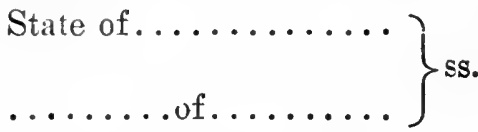

No.

To any person authorized by the laws of this state to solemnize marriage:

You are hereby authorized at any time not more than one year from and after the date hereof, within the ..... of ..... (not knowing any legal impediment thereto) to join together in marriage in accordance with the laws of this state, A....... B...... aged....., and never heretofore married, (or married on the .... day of ...., A. D. ....., to E. ...... F. ....., said E. ....... F. .... having died on the ...... day of ........ A. D. ...... or, said A. ..... B. ..... having been divorced from said E. ... F. ..... by the Court of ..... of the .... of .... State of ....... on the ...... day of ....... A. D. $\ldots \ldots \ldots$, , and $C . \ldots . D . \ldots$ aged $\ldots \ldots$ and never heretofore married, (or married on the ...... day of A. D. ....... to $\mathrm{G} \ldots$. . . H ..... said G. .............. having died on the ..... day of A. D. ..... ; or said C. ...... D. ....... having been divorced from said G. ..... H. .... by the Court of $\ldots \ldots$ of the $\ldots \ldots$ of $\ldots \ldots$. State of ...... on the $\ldots .$. day of $\ldots . .$. A. D. ..... The consent of $\ldots \ldots \ldots$ the $\ldots \ldots$ of the said $A \ldots \ldots$. . . . . . . . and of $\ldots \ldots$, the $\ldots \ldots$ of the said C..... D...... having been duly given. The issue of this license shall not be deemed to remove or dispense with any legal disability, impediment or prohibition rendering marriage hetween the parties illegal.

Given under my hand and seal of the ....... Court of 
$\ldots \ldots$ at $\ldots \ldots$. State of $\ldots \ldots$ this $\ldots \ldots$. day of Anno Domini one thousand nine hundred and ......

[Seal]

Marriage License Clerk.

Section XII. If the marriage is to be solemnized by the parties without an officiating person, as provided by paragraph 2 of section I of this Act, the license shall be in form substantially as follows:

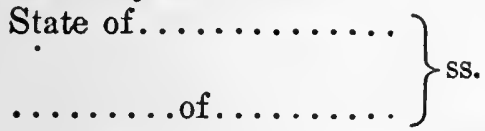

No.......

To A.................. aged and D.

This is to certify that, legal evidence baving been furnished to me as required by law, and the consent of ...... the ..... of the said A................. and of .... the of the said C........ D ....... having been duly given, I am satisfied there is no legal impediment to your joining yourselves in marriage in accordance with the customs, rules, and regulations of any religious society, denomination or sect to which you, or either of you, may belong, at any time not more than one year from and after the date hereof, within the .... of .....

The issue of this license shall not be deemed to remove or dispense with any legal disability, impediment or prohibition rendering marriage between you illegal.

Given under my hand and the seal of the ..... Court of ....... at ...... State of ...... this ..... day of Anno Domini one thousand nine hundred and ......

[Seal]

Marriage License Clerk.

Sec. XIII. The license shall have appended to it three certifieates, numbered to correspond with the license, (one marked "original," one marked "duplieate" and one narked "triplieate"), which shall be in form substantially as follows:

\section{Marriage Certificate.}

I,$\ldots \ldots \ldots$ hereby certify that on the $\ldots \ldots \ldots$ das of ..... Anno Domini one thousand nine hundred and ..... at $\ldots \ldots \ldots$ in the $\ldots \ldots$ of $\ldots \ldots$. State of $\ldots . .$. 
A............. of ..... State of ..... and C...... D..... of ...... State of ...... were by me united in marriage as authorized by a marriage license issued for that purpose by the ....... of ....... and State of ...... numbered ....... and dated the ...... day of ........ A. D. $19 \ldots$

Signed

(Official designation)

We, the undersigned, were present at the marriage of A... B...... and C....... D ......, as set forth in the foregoing certificate, at their request, and heard their declarations that they took each other for husband and wife.

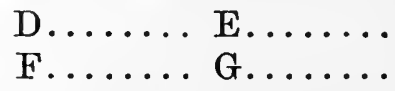

But if, as provided by section XII of this Act, the license has been issued to the parties themselves, then the certificate (in triplicate) shall be in form substantially as follows:

\section{Marriage Certificate.}

We hereby certify that on the ..... day of ..... Anno Domini one thousand nine hundred and ....... we united ourselves in marriage in accordance with the customs, rules and regulations of the ...... at ...... in the ...... of $\ldots \ldots$ and State of ...... having first obtained from the ...... of the ..... of ...... State of ....., a marriage license numbered.... and dated the ..... day of A. D. $19 \ldots$, certifying that he was satisfied that there was no legal impediment to our so doing.

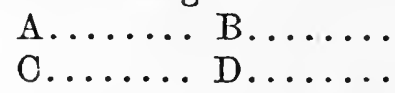

We, the undersigned, were present at the marriage of $\mathrm{A} . .$. B..... and C....... D...... as set forth in the foro going certificate, at their request, and heard their declarations that they took each other as husband and wife.

$$
\mathrm{D} \ldots \ldots \ldots \mathrm{E} . \ldots \ldots
$$

And the triplicate certificate in each case shall contain the following words: "N. B. This triplicate certificate must be returned to the license clerk who issued the license within thirty days from the date of the marriage." 
Section XIV. The marriage certificates marked "original" and "duplicate," duly signed, shall be given by the officiating person to the persons married by him; and the certificate marked "triplicate" shall be returned by such officiating person, or, in the ease of a marriage ceremony performed without an officiating person, then by the parties to the marriage contract, or either of them, to the ....... who issued the license, within thirty days after the date of said marriage.

Section XV. The said ..... upon receiving such triplicate certifieate, shall immediately enter the same on the docket where the marriage license of said parties is recorded, and place such certificate on file.

Section XVI. If any officiating person shall solemnize a marriage unless the contracting parties shall first have obtained a proper lieense as hercinbefore provided; or unless the parties to such marriage declare that they take each other as husband and wife; or without the presence of two competent witnesses; or, in the case of a minor or minors, unless the consent, as hereinbefore provided, of the parent, guardian or curator of such minor or minors be stated in such license; or shall solemnize a marriage knowing of any legal impediment thereto; or shall solemnize a marriage more than one year from and after the date of the license; or shall falsely certify to the date of a marriage solemnized by him; or shall solemnize a marriage in a .... other than the .... preseribed in section $\mathrm{X}$ of this $\Lambda$ ct, he shall be guilty of a misdemeanor, and on conviction thereof, shall be punished by a fine of not less than $\$ 100.00$ or more than $\$ 500.00$, or by imprisonment in the ..... for not more than one year, or by both such fine and imprisonment.

Section XVII. Where a marriage is solemnized without the presence of an officiating person, then, and in that case, if the parties to such marriage shall solemnize the same more than one year from and after the date of the license; or shall falsely certify to the date of such marriage; or shall solemnizo the same

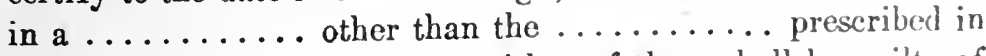
section $\mathrm{X}$ of this Act, they or either of them slall be guilty of a misdemeanor, and on conviction thereof shall be punished by a fine of not less than $\$ 100.00$ or more than $\$ 500.00$ or by im- 
prisonment in the ....... for not more than one year, or by both such fine and imprisonment.

Section XVIII. If any person, not being duly authorized by the laws of this state, shall wilfully or knowingly undertake to solemnize a marriage in this state, he shall be guilty of a misdemeanol, and on conviction thereof, shall be punished by a fine of not less than $\$ 100.00$ or more than $\$ 1,000.00$, or by imprisonment in the ....... for not more than one year, or by both such fine and imprisonment.

Section XIX. Every officiating person, or persons marrying without the presence of an officiating person as provided by paragraph 2 of section I of this Act, who shall neglect or refuse to transmit the triplicate certificate of any marriage solemnized by him or them, to the ..... issuing the license within thirty days after the date of such marriage, shall be fined the sum of one hundred dollars.

Section XX. Any ...... who shall refuse or neglect to enter upon the marriage license docket a complete record of each application and of each marriage license issued from his office, immediately after the same shall have been made or issued, as the case may be, or to enter the triplicate certificate of any marriage upon the marriage license docket, as required by section $\mathrm{XV}$ of this Act, or shall fail to keep such marriage license docket open for inspection or examination by the public during office hours, or shall prohibit or prevent any person from making a copy or abstract of the entries in the marriage license docket, shall for each such illegal act, omission or denial, be fined the sum of fifty dollars.

Section XXI. Any fine or forfeiture aceruing under the provisions of this Act may be recovered by an action of debt in the same manner as other debts are recovered by law, with the usual costs, in any court of record in any ..... in this state in which the defendant or defendants may be found.

Section XXII. A copy of the record of the marriage license, and marriage certificate, certified under the hand of said ...... and the seal of the court, shall be received in all courts of this state as prima facie evidence of such marriage between the parties therein named. 
Section XXIII. All marriages hereafter contracted in violation of any of the requirements of section I of this Act shall be null and void, (except as provided in sections XXIV and XXV of this Act); provided, that the parties to any such void marriage may, at any time, validate such marriage by complying with the requirements of this Act, and the issue thereof, if any, shall thereupon become legitimate, as provided by section XXVII of this Act.

Section XXIV. No marriage hereafter contracted shall be void by reason of want of authority or jurisdiction in the officiating person solemnizing such marriage, if the marriage is in other respects lawful, and is consummated with the full belief on the part of the persons so married, or either of them, that they have been lawfully joined in marriage.

Section $X X V$. No marriage hereafter contracted shall bo void either by reason of the license having been issued without the consent of the parents, guardian or curator of a minor, or by a ....... not having jurisdiction to issue the same, or by reason of any omission, informality or irregularity of form in the application for the license or in the license itself, or by reason of the incompetency of the witnesses to such marriage, or because the marriage may have been solemnized in a ....... other than the ....... prescribed in section $\mathrm{X}$ of this $\Lambda$ ct, or more than one year after the date of the license, if the marriage is in other respects lawful and is consummated with the full belief on the part of the persons so married, or either of them, that they have been lawfully joined in marriage. Where a marriage has been celebrated in one of the forms provided for in Section I of this Act, and the parties thereto have immediately thereafter assumed the habit and repute of husband and wife, and have continued the same uninterruptedly thereafter for the period of one year, or until the death of either of them, it shall be deemed that a license has been issued as required by this Act.

Section XXVI. If a person during the lifetime of a hushand or wife with whom the marriage is in force, enters into a subsequent marriage contract in accordance with the provisions of section I of this Act, and the parties thereto live together there 
after as husband and wife, and such subsequent marriage contract was entered into by one of the parties in good faith, in the full belief that the former husband or wife was dead, or that the former marriage had been annulled, or dissolved by a divorce, or without knowledge of such former marriage, they shall, after the impediment to their marriage has been removed by the death or divorce of the other party to such former marriage, if they continue to live together as husband and wife in good faith on the part of one of them, be held to have been legally married from and after the removal of such impediment, and the issue of such subsequent marriage shall be considered as the legitimate issue of both parents.

Section XXVII. In any and every case where the father and mother of an illegitimate child or children shall lawfully intermarry, such child or children shall thereby become legitimated, and enjoy all the rights and privileges of legitimacy as if they had been born during the wedlock of their parents; and this section shall be taken to apply to all cases prior to its date, as well as those subsequent thereto; provided, that no estate already vested shall be divested by this Act.

Section XXVIII. The ..... of each ..... shall, on or before the first day of February in each year, make return to the ...... of this state, upon suitable blank forms to be provided by the state, of a statement of all marriage licenses issued by him during the preceding calendar year, including all the facts required to be ascertained by him upon the issuing of each license; and shall also make return of a statement of all marriage certificates which shall have been returned to him during such period; and upon neglect or refusal so to do, such ... shall forfeit and pay the sum of one hundred dollars for the use of the proper ...........

Section XXIX. This Act shall be so interpreted and construed as to effectuate its general purpose to make uniform the law of those states which enact it.

Section XXX. Each ....... shall be entitled to receive the following. fees.

Section XXXI. (Repealing clause.)

Section XXXII. This Act shall take effect the ..... day of ........., Anno Domini 191.... 
UNIFORM MARRIAGE EVASION ACT 



\section{UNIFORM MARRIAGE EVASION ACT}

It was at the meeting of the Conference at Boston in Angust, 1911, that the question involved in the above Act was first presented and discussed. The Committee on Marriage and Divorce took the matter under consideration and before the next ecrnference held two meetings which were devoted entirely to a consideration of this Aet. The first was held at Philadelphia on "October 28th, 1911, and the second at the same place on April 8th, 1912. The result of these meetings was submitted to the Conference at Milwaukee, Wisconsin, in August, 1912, where it was finally approved and recommended for adoption in all the states. The Act was first adopted by the State of Vermont in 1912. It is now the law of five jurisdietions. They are: Illinois, 1915; Louisiana, 1914; Massachusetts, 1913; Vermont, 1912; and Wisconsin, 1915.

\begin{tabular}{|c|c|c|c|c|c|}
\hline - & $\begin{array}{c}\text { Callaghan's } \\
\text { Illinois Laws } \\
1913-16 .\end{array}$ & $\begin{array}{c}\text { Marr's } \\
\text { Am. Rev. } \\
\text { St. of La. }\end{array}$ & $\begin{array}{l}\text { Acts and } \\
\text { Resolves } \\
\text { of Mass. } \\
\text { (1913), } \\
\text { Ch. 360. }\end{array}$ & $\begin{array}{c}\text { General } \\
\text { Laws of } \\
\text { Vermont } \\
(1917)\end{array}$ & $\begin{array}{c}\text { Wis. St. } \\
(191 i)\end{array}$ \\
\hline $\begin{array}{l}\text { Uniform } \\
\text { Act } \\
\text { Sec. No. }\end{array}$ & $\begin{array}{r}1915 \\
\text { Illinois }\end{array}$ & $\begin{array}{c}1914 \\
\text { Louisana }\end{array}$ & $\begin{array}{l}1913 \\
\text { Mass. }\end{array}$ & $\begin{array}{c}1912 \\
\text { Vermont }\end{array}$ & $\begin{array}{l}1915 \\
\text { Wisconsin }\end{array}$ \\
\hline 1 & 7363 (1) & 4458 & 1 & 3514 & 2330.11 (1) \\
\hline 2 & 7363 (2) & 4459 & 2 & 3515 & $2330 M$ \\
\hline 3 & $7363(3)$ & 4460 & 3 & $\bullet 3517$ & $\ldots \ldots \ldots$ \\
\hline 4 & 7363 (4) & 4461 & 4 & 3518 & ........... \\
\hline
\end{tabular}

- Modified. 


\section{UNIFORM MARRIAGE EVASION ACT}

Section 1. Be it enacted, etc., That if any person residing and intending to continue to reside in this state who is disabled or prohibited from contracting marriage under the laws of this state shall go into another state or country and there contract a marriage prohibited and declared void by the laws of this state such marriage shall be null and void for all purposes in this state with the same effect as though such prohibited marriage had been entered into this state.

Massachusetts.-Ewald v. Ewald (1914), 219 Mass. 111.
Wisconsin.-Hall v. Industrial Commission (1917), 165 Wis. 364.

Section 2. No marriage shall be contracted in this state by a party residing and intending to continue to reside in another state or jurisdiction if such marriage would be void if contracted in such other state or jurisdiction and every marriage celebrated in this state in violation of this provision shall be null and void.

Illinois. - Powell v. Powell Wisconsin.-Hall v. Industrial (1917), 207 Ill. App. $292 . \quad$ Commission (1917), 165 Wis. 364.

Section 3. Before issuing a license to marry to a person who resides and intends to continue to reside in another state the officer having authority to issue the license shall satisfy himself by requiring affidavits or otherwise that such person is not prohibited from intermarrying by the laws of the jurisdiction where he or she resides.

Section 4. Any official issuing a license with knowledge that the parties are thus prohibited from intermarrying and any person authorized to celebrate marriage who shall knowingly celebrate such a marriage shall be guilty of a misdemeanor, and shall be punished by........ 


\section{UNIFORM PARTNERSHIP ACT}





\section{UNIFORM PARTNERSHIP ACT}

The subject of a uniform law on partnership was taken up by the Conference of Commissioners on Uniform State Laws in 1902, and the Committee on Commercial Law was instructed to employ an expert and prepare a draft to be submitted to the next annual Conference. At the meeting in 1903 the committee reported that it had secured the services of James Barr Ames, dean of the law school of Hąrvard University, as expert to draft the act.

In 1905 the Committee on Commercial Law reported progress on this subject, and a resolution was passed by the Conference, directing that a draft be prepared upon the mercantile theory. In 1906 the committee reported that it had in its hands a draft of an act on this subject, which draft was recommitted to the committee for revision and amendment, with directions to report to the next Conference for discussion and action.

In 1907 the matter was brought before the Conference and postponed until the 1908 meeting. In 1908 the matter was discussed by the Conference. In 1909 the second tentative draft of the Partnership Act was introduced and discussed.

In 1910 the committee reported that on account of the death of Dean Ames no progress had been made, but that Mr. Wm. Draper Lewis, then dean and now professor of law at the law school of the University of Pennsylvania, and Mr. James B. Lichtenberger of the Philadelphia Bar, had prepared a draft of a partnership act on the so-called entity idea, with the aid of the various drafts and notes of Dean Ames, and that they were ready to submit a draft of a proposed uniform act, embodying the theory that a partnership is an aggregate of individuals associated in business, which is the theory at present accepted in nearly all the states of the Union. Dean Lewis expressed his belief that with certain nodifications the aggregate or common law theory should be adopter. A resolution was passed by the Conference that any action that might have theretofore been adopted by it, tending to limit the Corn- 
mittee on Commercial Law in its consideration of the partnership law to what is known as the entity theory, be rescinded and that the committee be allowed and directed to consider the subject of partnership at large as though no such resolution had been adopted by the Conference.

In the fall of 1910 the committee invited to a conference, held in Philadelphia, all the teachers of, and writers on, partnerships, besides several other lawyers known to have made a special study of the subject. There was a large attendance. For two days the members of the committee and their guests discussed the theory on which the proposed act should be drawn. At the conclusion of the discussion the experts present recommended that the act be drawn on the aggregate or common law theory, with the modification that the partners be treated as owners of partnership property holding by a special tenancy which should be called tenancy in partnership. Accordingly, at the meeting of the Conference in the summer of 1911, the committee reported that, after hearing the discussion of experts, it had voted that Dean Lewis be requested to prepare a draft of a partnership act on the so-called common law theory.

The committee reported another draft of the act to. the Conference at its session in 1912, drawn on the aggregate or common law theory, with the modification referred to. At this session the Conference spent several days in the discussion of the act, again referring it to the Committee on Commercial Law for their further consideration.

The Committee on Commercial Law held a meeting in New York on March 29, 1913, and took up the draft of the act referred back to it by the Conference, and after careful consideration of the amendments suggested by the Conference, prepared their seventh draft, which was, at their annual session in the summer of 1912, submitted to the Conference. The Conference again spent several days in discussing the act and again referred it to the Committee on Commercial Law, this time mainly for perfection in form.

The Committee on Commercial Law assembled in the city of New York, September 21, 1914, and had before it a new draft of the act, which had been prepared by Mr. Lewis with valuable sug- 
gestions submitted by Charles E. Shepard, Esq., one of the commissioners from the State of Washington, and others interested in the subject. The committee reported the eighth draft to the Conference which, on October 14, 1914, passed a resolution recommending the act for adoption to the legislatures of all the states. The law has now been passed in Alaska, 1917; Illinois, 1917; Maryland. 1916; Michigan, 1917; New York, 1919; Pennsylvania, 1915; Tennesee, 1917; Virginia, 1918; Wisconsin, 1915, Wyoming, 1917. 


\begin{tabular}{|c|c|c|c|c|c|}
\hline & $\begin{array}{l}\text { Laws } \\
1917, \\
\text { p. } 159 .\end{array}$ & $\begin{array}{l}\text { Laws } \\
1917, \\
\text { p. } 625 .\end{array}$ & $\begin{array}{c}\text { Laws } \\
1916, \\
\text { ch. } 175 .\end{array}$ & $\begin{array}{l}\text { Laws } \\
1917, \\
\text { p } 119 .\end{array}$ & $\begin{array}{c}\text { Laws } \\
1919 . \\
\text { ch. } 408 .\end{array}$ \\
\hline $\begin{array}{l}\text { Jniform } \\
\text { Act } \\
\text { Sec. No. }\end{array}$ & $\begin{array}{l}1917 \\
\text { Alaska. }\end{array}$ & $\begin{array}{c}1917 \\
\text { Illinois. }\end{array}$ & $\begin{array}{c}1916 \\
\text { Maryland. }\end{array}$ & $\begin{array}{c}1917 \\
\text { Michigan. }\end{array}$ & $\begin{array}{c}1919 \\
\text { New York. }\end{array}$ \\
\hline 1 & 1 & 1 & 1 & I & 1 \\
\hline 2 & 2 & 2 & 2 & 2 & 2 \\
\hline 3 & 3 & 3 & 3 & 3 & 3 \\
\hline 4 & 4 & 4 & 4 & 4 & 4 \\
\hline 5 & 5 & 5 & 5 & 5 & 5 \\
\hline 6 & 6 & 6 & 6 & 6 & 10 \\
\hline 7 & 7 & 7 & 7 & 7 & I1 \\
\hline 8 & 8 & 8 & 8 & 8 & 12 \\
\hline 9 & 9 & 9 & 9 & 9 & 20 \\
\hline 10 & 10 & 10 & 10 & 10 & 21 \\
\hline 11 & 11 & 11 & 11 & 11 & 22 \\
\hline 12 & 12 & 12 & 12 & 12 & 23 \\
\hline 13 & 13 & 13 & 13 & 13 & 24 \\
\hline 14 & 14. & 14 & 14 & 14 & 25 \\
\hline 15 & 15 & 15 & 15 & 15 & 26 \\
\hline 16 & 16 & 16 & 16 & 16 & 27 \\
\hline 17 & 17 & 17 & 17 & 17 & 28 \\
\hline 18 & 18 & 18 & 18 & 18 & 40 \\
\hline 19 & 19 & 19 & 19 & 19 & 41 \\
\hline 20 & 20 & 20 & 20 & 20 & 42 \\
\hline 21 & 21 & 21 & 21 & 21 & 43 \\
\hline 22 & 22 & 22 & 22 & 22 & 44 \\
\hline 23 & 23 & 23 & 23 & 23 & 45 \\
\hline 24 & 24 & 24 & 24 & 24 & 50 \\
\hline 25 & 25 & 25 & 25 & 25 & 51 \\
\hline 26 & 26 & 26 & 26 & 26 & 52 \\
\hline 27 & 27 & 27 & 27 & 27 & 53 \\
\hline 28 & 28 & 28. & 28 & 28 & 54 \\
\hline 29 & 29 & $29^{\circ}$ & 29 & 29 & 60 \\
\hline 30 & 30 & 30 & 30 & 30 & 61 \\
\hline 31 & 31 & 31 & 31 & 31 & 62 \\
\hline 32 & 32 & 32 & 32 & 32 & 63 \\
\hline 33 & 33 & 33 & 33 & 33 & 64 \\
\hline 34 & 34 & 34 & 34 & 34 & 65 \\
\hline 35 & 35 & 35 & 35 & 35 & 66 \\
\hline 36 & 36 & 36 & 36 & 36 & 67 \\
\hline 37 & 37 & 37 & 37 & 37 & 68 \\
\hline 38 & 38 & 38 & 38 & 38 & 69 \\
\hline 39 & 39 & 39 & 39 & 39 & 70 \\
\hline 40 & 40 & 40 & 40 & 40 & 71 \\
\hline 41 & 41 & 41 & 41 & 41 & 72 \\
\hline 42 & 42 & 42 & 42 & 42 & 73 \\
\hline 43 & 43 & 43 & 43 & 43 & 74 \\
\hline 44 & $\cdots$ & & $43(3)$ & & 111 \\
\hline 45 & 44 & 44 & $43(2)$ & 44 & 110 \\
\hline
\end{tabular}




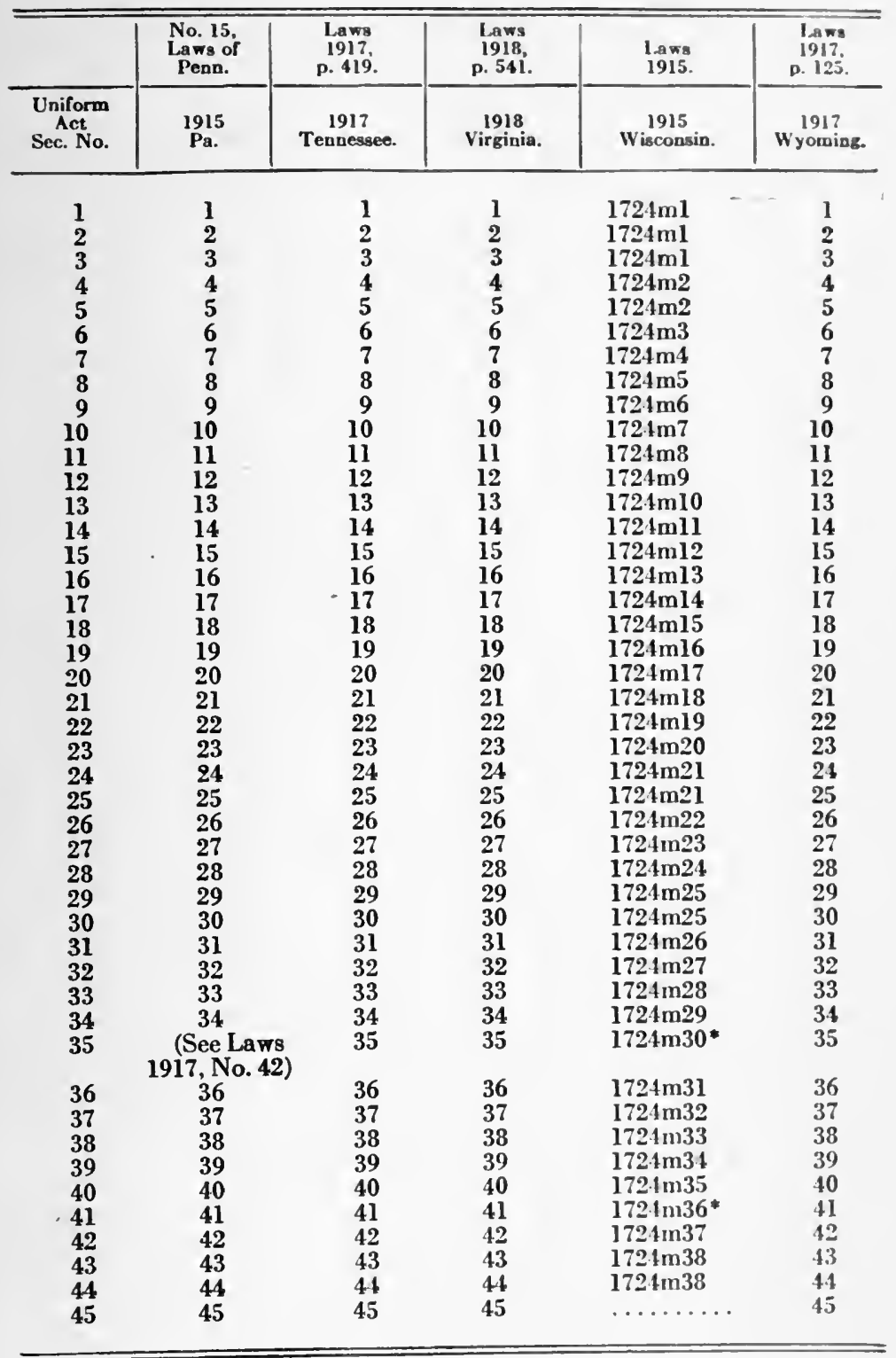




\section{UNIFORM PARTNERSHIP ACT}

Section 1. Name of Act.

2. Definition of Terms.

3. Interpretation of Knowledge and Notice.

4 Rules of Construction.

5. Rules for Cases Not Provided for in This Act.

6. Partnership Defined.

7. Rules for Determining the Existence of a Partnership.

8. Partnership Property.

9. Partner Agent of Partnership as to Partnership Business.

10. Conveyance of Real Property of the Partnership.

11. Partnership Bound by Admission of Partner.

12. Partnership Charged With Knowledge of or Notice to Partner-

13. Partnership Bound by Partner's Wrongful Act.

14. Partnership Bound by Partner's Breach of Trust.

15. Nature of Parent's Liability.

16. Partner by Estoppel.

17. Liability of Incoming Partner.

18. Rules Determining Rights and Duties of Partners.

19. Partnership Books.

20. Duty of Partners to Render Information.

21. Partner Accountable as a Fiduciary.

22. Right to an Account.

23. Continuation of Partnership Beyond Fixed Term.

24. Extent of Property Rights of a Partner.

25. Nature of a Partner's Right in Specific Partnership Property.

26. Nature of Partner's Interest in the Partnership.

27. Assignment of Partner's Interest.

28. Partner's Interest Subject to Charging Order.

29. Dissolution Defined.

30. Partnership Not Terminated by Dissolution.

31. Causes of Dissolution.

32. Dissolution by Decree of Court.

33. General Effect of Dissolution on Authority of Partner.

34. Right of Partner to Contribution From Co-partners After Dissolution.

35. Power of Partner to Bind Partnership to Third Persons After Dissolution.

36. Effect of Dissolution on Partner's Existing Liability.

37. Right to Wind Up. 
Section 38. Rights of Partners to Application of Partnership Property.

39. Rights Where Partnership is Dissolved for Fraud or Misrepresentation.

40. Rules for Distribution.

41. Liability of Persons Continuing the Business in Certain Cases.

42. Rights of Retiring or Estate of Deceased Partner When the Business is Continued.

43. Accrual of Actions.

44. When Act Takes Effect.

45. Legislation Repealed. 


\section{PART I.}

\section{Preliminary Provisions.}

Section 1.-(Name of Act.) - This Act may be cited as Uniform Partnership Act.

Section 2.-(Definition of Terms.) -In this Act, "court" includes every court and judge having jurisdiction in the case.

"Business" includes every trade, occupation, or profession.

"Person" includes individuals, partnerships, corporations, and other associations.

"Bankrupt" includes bankrupt under the Federal Bankruptey Act or insolvent under any state insolvent Act.

"Conveyance" includes every assignment, lease, mortgage, or eneumbrance.

"Real property" includes land and any interest or estate in land.

Section 3.-(Interpretation of Knowledge and Notice.) (1) A person has "knowledge" of a fact within the meaning of this Act not only when he has actual knowledge thereof, but also when he has knowledge of such other facts as in the circumstances shows bad faith.

(2) A person has "notice" of a fact within the meaning of this Act when the person who claims the benefit of the notice

(a) States the fact to such person, or

(b) Delivers through the mail, or by other means of communication. a written statement of the fact to such person or to a proper person at his place of business or residence.

Section 4.-(Rules of Construction.)-(1) The rule that statutes in derogation of the common law are to be strictly construed shall have no application to this Aet.

(2) The law of estoppel shall apply under this Act.

(3) The law of agency shall apply under this Act.

(4) This Act shall be so interpreted and construed as to effeet its general purpose to make uniform the law of those states which enact it. 
(5) This Act shall not be construed so as to impair the obligations of any contract existing when the Act goes into effect, nor to affect any action or proceedings begun or right aecrued before this Act takes effect.

Section 5.-(Rules for Cases not Provided for in this Act.) - In any case not provided for in this Aet the rules of law and equity, including the law merehant, shall govern.

\section{PART II.}

\section{Nature of a Partnership.}

Section 6.-(Partnership Defined.)-(1) A partnership is an association of two or more persons to carry on as co-owners a business for profit.

(2) But any association formed under any other statute of this state, or any statute adopted by authority, other than the authority of this state, is not a partnership under this Aet, unless such association would havo been a partnership in this state prior to the adoption of this Act; but this Act shall apply to limited partnerships except in so far as the statutes relating to such partnerships are inconsistent herewith.

Section 7.-(Rules for Determining the Existence of a Partnership.)-In determining whether a partnership exists, these rules shall apply:

(1) Except as provided by Seetion 16 persons who are not partners as to each other are not partners as to third persons.

(2) Joint tenancy, tenaney in common, tenancy by the entireties, joint property, common property, or part ownershup does not of itself establish a partnership, whether such co-owners do or do not share any profits made by the use of the property.

(3) The sharing of gross returns does not of itself cstallish a partnership, whether or not the persons sharing them hive is joint or common right or interest in any property from which the returns are derived.

(4) The receipt by a person of a share of the profits of a business is prima facie evidence that he is a partner in the business, 
but no such inference shall be drawn if such profits were received in payment:

(a) As a debt by installments or otherwise,

(b) As wages of an employee or rent to a landlord,

(c) As an annuity to a widow or representative of a deceased partner,

(d) As interest on a loan, though the amount of payment vary with the profits of the business.

(e) As the consideration for the sale of the good-will of a business or other property by installments or otherwise.

Illinois.-Fitch v. King (1917), 279 Ill. 62, 116 N. W. 624.

Maryland.- Shawmut Mining Co. v. Padgett (1919), 104 Atl. 40.

Michigan.-Fletcher v. Fletcher (1917), 163 N. W. 488.

Pennsylvania.-First Nat. Bank v. Gitt (1917), $259 \mathrm{~Pa} .84,102$ Atl. 428; In re Hauen Estate (1915),
248 Pa. 93, 93 Atl. 1013; Producers Lumber Co. v. Guinmere (1918), 260 Pa. 423, 103 Atl. 916; Strauss v. Mendelsohr (1916), $63 \mathrm{~Pa}$. Super. Ct. 504; Whitman v. Levan (1916), $62 \mathrm{~Pa}$. Super. Ct. 262.

Virginia. - Manor v. Hindman (1919), 97 S. E. 332.

Section 8.-(Partnership Property.)-(1) All property originally brought into the partnership stock or subsequently acquired, by purchase or otherwise, on account of the partnership is partnership property.

(2) Unless the contrary intention appears, property acquired with partnership funds is partnership property.

(3) Any estate in real property may be acquired in the partnership name. Title so acquired can be conveyed only in the partnership name.

(4) A conveyance to a partnership in the partnership name, though without words of inheritance, passes the entire estate of tho grantor unless a contrary intent appears.

\section{PART III.}

Relations of Partaners to Persons Dealing with the Partiership.

Section 9.-(Partner Agent of Partnership as to Partnership Business.) - (1) Every partner is an agent of the partnership 
for the purpose of its business, and the act of every partner, including the execution in the partnership name of any instrument, for apparently carrying on in the usual way the business of the partnership of which he is a member binds the partnership, unless the partner so acting has in fact no authority to act for the partnership in the particular matter, and the person with whom he is dealing has knowledge of the fact that he has no such authority.

(2) An act of a partner which is not apparently for tho carrying on of the business of the partnership in the usual way does not bind the partncrship unless authorized by the other partners.

(3) Unless authorized by the other partners or unless they have abandoned the business, one or more but less than all the partners bave no authority to:

(a) Assign the partnership property in trust for creditors or on the assignee's promise to pay the debts of the partnership,

(b) Dispose of the good-will of the business,

(c) Do any other act which would make it impossible to carry on the ordinary business of the partnership,

(d) Confess a judgment,

(e) Submit a partnership claim or liability to arbitration or reference.

(4) No act of a partner in contravention of a restriction on his autbority shall bind the partnership to persons having knowledge of the restriction.

Illinois.-Sterling Wholesale Gro. Cn. v. Pisetter (1918), 204 Ill. App. 61.

Michigan.- In re Farmers v. Merchants Bank of Lawerence, Mich. (1916), $160 \mathrm{~N}$. W. 601; Ward v. Cary (1918), 200 Mich. 217, $166 \mathrm{~N}$.
W. 952; Wexford Tp. v. Secley (1917), 163 N. W. 16.

Pennsylvania.-Funk v. Young (1916), 254 Pa. 548, 99 Atl. 75; Whitman v. Levan (1916), $62 \mathrm{~Pa}$. Super. Ct. 68.

Section 10.-(Conveyance of Real Property of the Partnership.)-(1) Where title to real property is in the partnership name, any partner may conrey title to such property by a conveyance executed in the partnership name; but the partnership may recover such property unless the partner's act binds the 
partnership under the provisions of paragraph (1) of Section 9 , or unless such property has been conveyed by the grantee or a person claiming through such grantee to a holder for value without knowledge that the partner, in making the conveyance, has exceeded his authority.

(2) Where title to real property is in the name of the partnership, a conveyance executed by a partner, in his "own name, passes the equitable interest of the partnership, provided the act is one within the authority of the partner under the provisions of paragraph (1) of Section 9.

(3) Where title to real property is in the name of one or more but not all the partners, and the record does not disclose the right of the partnership, the partners in whose name the title stands may convey title to such property, but the partnership may recover such property if the partners' act does not bind the partnership under the provisions of paragraph (1) of Section 9 , unless the purchaser or his assignee, is a holder for value, without knowledge.

(4) Where the title to real property is in the name of one or more or all the partners, or in a third person in trust for the partnership, a conveyance executed by a partner in the partnership name, or in his own name, passes the equitable interest of the partnership, provided the act is one within the authority of the partner under the provisions of paragraph (1) of Section 9.

(5) Where the title to real property is in the names of all the partners a conveyance executed by all the partners passes all their rights in such property.

Section 11.-(Partnership Bound by Admission of Partner.) -An admission or representation made by any partner concerning partnership affairs within the scope of his authority as conferred by this Act is evidence against the partnership.

Section 12.-(Partnership Charged with Knowledge of or Notice to Partner.) - Notice to any partner of any matter relating to partnership affairs, and the knowledge of the partner acting in the particular matter, acquired while a partner or then present to his mind, and the knowledge of any other partner who reasonably could and should have communicated it to the 
acting partner, operate as notice to or knowledge of the partnership, except in the case of a fraud on the partnership committed by or with the consent of that partner.

Section 13.- (Partnership Bound by Partner's Wrongful Act.) - Where, by any wrongful act or omission of any partner acting in the ordinary course of the business of the partnership. or with the authority of his co-partners, loss or injury is caused to any person, not being a partner in the partnership, or any penalty is incurred, the partnership is liable therefor to the same extent as the partner so acting or omitting to aet.

Section 14.- (Partnership Bound by Partner's Breach of Trust.)-The partnership is bound to make good the loss:

(a) Where one partner acting within the scope of his apparent authority receives money or property of a third person and mis-applies it; and

(b) Where the partnership in the course of its business receives money or property of a third person and the money or property so received is misapplied by any partner while it is in the custody of the partnership.

Section 15.-(Nature of Partner's Liability.) - All partners are liable

(a) Jointly and severally for everything chargeable to the partnership under sections 13 and 14 .

(b) Jointly for all other debts and obligations of the partnership; but any partner may enter into a separate obligation to perform a partnership contract.

Pennsylvania.- Harding v. Pen Argyle Nat. Bank (1918), 67 Pa. Sup. Ct. 68; Hendley v. Bittinger (1915), 249 Pa. 193, 94 Atl. 831.

Section 16.--(Partner by Estoppel.)-(1) When a person by words spoken or written or by conduct, represents himself. or consents to another representing him to any one, as a partner .1n an existing partnership or with one or more persons mot actual partners, he is liable to any such person to whum such representation has been made. who has, on the faith of such representation, given credit to the actual or apparent partucr- 
ship, and if he has made such representation or consented to its being made in a public manner he is liable to such person, whether the representation has or has not been made or communicated to such person so giving credit by or with the knowledge of the apparent partner making the representation or consenting to its being made.

(a) When a partnership liability results, he is liable as though he were an actual member of the partnership.

(b) When no partnership liability results, he is liable jointly with the other persons, if any, so consenting to the contract or representation as to incur liability, otherwise separately.

(2) When a person has thus been represented to be a partner in an existing partnership, or with one or more porsons not actual partners, he is an agent of the persons consenting to such representation to bind them to the same extent and in the manner as though he were a partner in fact, with respect to persons who rely upon the representation. Where all the members of the existing partnership consent to the representation, a partnership act or ebligation results; but in all other cases it is the joint aet or obligation of the person acting and the persons consenting to the representation.

Illinois.-H. Albrecht \& Co. v. Church (1917), 129 Md. 595, 99 Atl. Massing (1918), 199 Ill. App. $182 . \quad 793$; N. Sakelos \& Co. v. Hutchin-

Maryland.-Erdman v. Trustees son Bros. (1916), 129 Md. 300, 99 of Eutan Methodist Protestant Atl. 357.

Section 17.-(Liability of Incoming Partner.) -A person admitted as a partner into an existing partnership is liable for all the obligations of the partnership arising before his admission as though he had been a partner when such obligations were incurred except that his liability shall be satisfied only out of partnership property.

\section{PART IV.}

Relations of Partners to One Another.

Section 18.-(Rules determining Rights and Duties of Partners.) - The rights and duties of the partners in relation to the partnership shall be determined, subject to any agreement between them, by the following rules: 
(a) Each partner shall be repaid his contributions, whether by way of eapital or advances to the partnership property and share equally in the profits and surplus remaining after all liabilities, ineluding those to partners, are satisfied; and must contribute towards the losses, whether of capital or otherwise, sustained by the partnership according to his share in the profits.

(b) The partnership must indemnify every partner in respeet of payment made and personal liabilities reasonably incurred by him in the ordinary and proper conduct of its business, or for the preservation of its business or property.

(e) A partner, who in aid of the partnership makes any payment or advance beyond the amount of eapital which he agreed to contribute, shall be paid interest from the date of the payment or advance. .

(d) A partner shall receive interest on the eapital contributed by him only from the date when repayment should be made.

(e) All partners have equal rights in the management and conduct of the partnership business.

(f) No partner is entitled to remuneration for acting in the partnership business, except that a surviving partner is entitled to reasonable compensation for his serviees in winding up the partnership affairs.

(g) No person ean become a member of a partnership without the consent of all the partners.

(h) Any difference arising as to ordinary matters connected with the partnership business may be decided by a majority of the partners; but no act in contraveution of any agreement between the partners may be done rightfully without the consent of all the partners.

Wisconsin.-Keith v. Rust Land \& Lumber Co. (1918), 167 N. W. 432.

Seetion 19.-(Partnership Books.) - The partnership books shall be kept, subject to any agreement between the partners at the principal place of business of the partnership, and every partner shall at all times have access to and may inspect and copy any of them. 
Section 20.-(Duty of Partners to Render Information.)Partners shall render on demand true and full information of all things affecting the partnership to any partner or the legal representative of any deceased partner or partner under legal disability.

Section 21.-(Partner Accountable as a Fiduciary.)-(1) Every partner must account to the partnership for any benefit, and hold as trustee for it any profits derived by him without the consent of the other partners from any transactions connected with the formation, conduct, or liquidation of the partnership or from any use by him of its property.

(2) This section applies also to the representatives of a deceased partner engaged in the liquidation of the affairs of the partnership as the personal representatives of the last surviving partner.

Section 22.-(Right to an Account.)-Any partner shall have the right to a formal account as to partnership affairs.

(a) If he is wrongfully excluded from the partnership business or possession of its property by his co-partners,

(b) If the right exists under the terms of any agreement,

(c) As provided by Section 21,

(d) Whenever other circumstances render it just and reasonable.

Wisconsin-McCartney v. Boyd (1915), 152 N. W. 820.

Scction 23.-(Continuation of Partnership Beyond Fixed Term.) - (1) When a partnership from a fixed term or particular undertaking is continued after the termination of such term or particular undertaking without any express agreement, the rights and duties of the partners remain the same as they were at such termination, so far as is consistent with a partnership at will.

(2) A continuation of the business by the partners or such of them as habitually acted therein during the term, without any settlement or liquidation of the partnership affairs, is prinia facie evidence of a continuation of the partnership. 


\section{PART V.}

\section{Property Rights of a Partan.}

Section 24.-(Extent of Property Rights of a Partner.) The property rights of a partner are (1) his rights in specific partnership property, (2) his interest in the partnership, and (3) his right to participate in the management.

Section 25.-(Nature of a Partner's Right in Specifie Partnership Property.)-(1) A partner is a co-owner with his partners of specitic partnership property holding as a tenant in partnership.

(2) The incidents of this tenacy are such that:

(a) A partner, subject to the provisions of this Act and to any agreement between the partners, has an equal right with his partners to possess specific partnership property for partnership purposes; but he has no right to possess such property for any other purpose without the consent of his partners.

(b) A partner's right in specific partnership property is not assignable except in connection with the assignment of the rights of all the partners in the same property.

(c) A partner's right in specifie partnership property is not subject to attachment or execution, except on a elaim against the partnership. When partnership property is attached for a partnership debt the partners, or any of them, or the representatives of a deceased partner, cannot claim any right under the homestead or exemption laws.

(d) On the death of a partner his right in specific partnership property vests in the surviving partner or partners except where the deeeased was the last surviving partner, when his right in such property vests in his legal representative. Such surviving partner or partners. or the legal representative of the last surviving partner, has no right to possess the partnership property for any but a partnership purpose.

(e) A partner's right in specific partnership property is not subject to dower, curtesy, or allowances to widows, heirs, or next of kin.

Pennsylvania.-Kreis v. Cortledge (1919), 104 Atl. 855. 
Section 26.-(Nature of Partner's Interest in the Partnership.) - A partner's interest in the partnership is his share of the profits and surplus, and the same is personal property.

Section 27.-(Assignment of Partner's Interest.)-(1) A conveyance by a partner or his interest in the partnership does not of itself dissolve the partnership, nor, as against the other partners in the absence of agreement, entitle the assignee, during the continuance of the partnership, to interfere in the management or administration of the partnership business or affrirs, or to require any information or account of partnership transactions, or to inspect the partnership books; but it merely entitles the assignee to receive in accordance with his contract the profits to which the assigning partner would otherwise be entitled.

(2) In case of a dissolution of the partnership, the assignee is entitled to receive his assignor's interest and may require an account from the date only of the last account agreed to by all the partners.

Section 28.- (Partner's Interest Subject to Charging Order.) -(1) On due application to a competent court by any judgment creditor of a partner, the court which entered the judgment, order, or decree, or any other court, may charge the interest of the debtor partner with payment of the unsatisfied amount of such judgment debt with interest thereon; and may then or later appoint a receiver of his share of the profits, and of any other money due or to fall due to him in respect of the partnership, and make all other orders, directions, accounts and inquiries which the debtor partner might have made, or which the circumstances of the case may require.

(2) The interest charged may be redeemed at any time before foreclosure, or in case of a sale being directly by the court may be purchased without thereby causing a dissolution:

(a) With separate property, by any one or more of the partners, or

(b) With partnership property, by any one or more of partners with the consent of all the partners whose interests are not so charged or sold. 
(3) Nothing in this Act shall be held to deprive a partner of his right, if any, under the exemption laws, as regards his iuterest in the partnership.

\section{PART VI.}

\section{Dissolution and Winding Up.}

Section 29.-(Dissolution Defined.) - The dissolution of a partnership is the change in the relation of the partners caused by any partner ceasing to be associated in the carrying on as distinguished from the winding up of the business.

Seetion 30.- (Partnership Not Terminated by Dissolution.) - On dissolution the partnership is not terminated, but continues until the winding up of partnership affairs is completed.

Section 31.-(Causes of Dissolution.)-Dissolution is caused:

(1) Without violation of the agreement between the partners,

(a) By the termination of the definite term or particular undertaking specified in the agreement,

(b) By the express will of any partner when no definite term or particular undertaking is specified,

(c) By the express will of all the partners who have not assigned their interests or suffered them to be charged for their separate debts, either before or after the termination of any specified term or particular undertaking,

(d) By the expulsion of any partner from the business bona fide in accordance with such a power conferred by the agreement between the partners;

(2) In contravention of the agreement between the partners, where the circumstancees do not permit a dissolution under any other provision of this section, by the express will of any partner at any time;

(3) By any event which makes it unlawful for the busines? of the partnership to be carried on or for the members to carry it on in partnership; 
(4) By, the death of any partner;

(5) By the bankruptcy of any partner or the partnership;

(6) By decree of court under Section 32.

Wisconsin.-Crossman v. Gibney (1916), 164 Wis. 395,160 N. W. 172.

Section 32.-(Dissolution by Decree of Court.)-(1) Application by or for a partner the court shall decree a dissolution whenever:

(a) A partner has been declared a lunatic in any judicial proceeding or is shown to be of unsound mind,

(b) A partner becomes in any other way incapable of performing his part of the partnership contract,

(c) A partner has been guilty of such conduct as tends to affect prejudicially the carrying on of the business,

(d) A partner wilfully or persistently commits a breach of the partnership agreement, or otherwise so conducts himself in matters relating to the partnership business that it is not reasonably practicable to carry on the business in partnership with him,

(e) The business of the partnership can only be carried on at a loss,

(f) Other circumstances render a disolution equitable.

(2) On the application of the purchaser of a partner's interest under Sections 28 or 29 :

(a) After the termination of the specified term or particular undertaking,

(b) At any time if the partnership was a partnership at will when the interest was assigned or when the charging order was issued.

Section 33.-(General Effect of Dissolution on Authority of Partner.) -Except so far as may be necessary to wind up partnership affairs or to complete transactions begun but not then finished, dissolution terminates all authority of any partner to act for the partnership,

(1) With respect to the partners, 
(a) When the dissolution is not by the act, bankruptcy or death of a partner; or

(b) When the dissolution is by such act, bankruptcy or death of a partner, in cases where Section 34 so requires.

(2) With respect to persons not partners, as declared in Section 35.

Section 34.-(Right of Partner to Contribution from CoPartners After Dissolution.)-Where the dissolution is caused by the act, death or bankruptcy of a partner, each partner is liable to his co-partners for his share of any liabilitiy created by any partner acting for the partnership as if the partnership had not been dissolved unless

(a) The dissolution being by act of any partner, the partner i.cting for the partnership had knowledge of the dissolution, or

(b) The dissolution being by the death or bankruptcy of a partner, the partner acting for the partnership had knowledge or notice of the death or bankruptcy.

Section 35.- (Power of Partner to Bind Partnership to Third Persons After Dissolution.)-(1) After dissolution a partner can bind the partnership except as provided in Paragraph (3)

(a) By any act appropriate for winding up partnership affairs or completing transactions unfinished at dissolution;

(b) By any transaction which would bind the partnership if dissolution had not taken place, provided the other party to the transaction

(I) Had extended credit to the partnership prior to dissolntion and had no knowledge or notice of the dissolution; or

(II) Though he had not so extended credit, had nerertheless known of the partnership prior to dissolution, and, having no knowledge or notice of dissolution, the fact of dissolution had not been advertised in a newspaper of general circulation in the place (or in each place if more than one) at which the partnership business was regularly carried on.

(2) The liability of a partner under Paragraph (1b) shall be satisfied out of partnership assets alone when such partner had been prior to dissolution 
(a) Unknown as a partner to the person with whom the con-. tract is made; and

(b) So far unknown and inactive in partnership affairs that the business reputation of the partnership could not be said to have been in any degree due to his connection with it.

(3) The partnership is in no case bound by any act of. a partner after dissolution

(a) Where the partnership is dissolved because it is unlawful to carry on the business, unless the act is appropriate for winding up partnership affairs; or

(b) Where the partner has become bankrupt; or

(c) Where the partner has no authority to wind up partnership affairs; except by a transaction with one who

(I) Had extended credit to the partnership prior to dissolution and had no knowledge or notice of his want of authority; or

(II) Had not extended credit to the partnership prior to dissolution, and, having no knowledge or notice of his want of authority, the fact of this want of authority has not been advertiscd in the manner provided for advertising the fact of dissolution in Paragraph (1bII).

(4) Nothing in this section shall affect the liability under Section 16 of any person who after dissolution represents himself or consents to another representing him as a partner in a partnership engaged in carrying on business.

Section 36.-(Effect of Dissolution on Partner's Existing Liability.) - (1) The dissolution of the partnership does not of itself discharge the existing liability of any partner.

(2) A partner is discharged from any existing liability upon dissolution of the partnership by an agreement to that effect between himself, the partnership creditor and the person or partnership continuing the business; and such agreement may be inferred from the course of dealing between the creditor having knowledge of the dissolution and the person or partnership continuing the business.

(3) Where a person agrees to assume the existing obligations of a dissolved partnership, the partners whose obligations 
have been assumed shall be discharged from any liability to any creditor of the partnership who, knowing of the agreement, consents to a material alteration in the nature or time of payment of such obligations.

(4) The individual property of a deceased partnêr shall be liable for all obligations of the partnership incurred while he was a partner but subject to the prior payment of his separate debts.

Section 37.-(Right to Wind Up.) -Unless otherwise agreed the partners who have not wrongfully dissolved the partnership or the legal representative of the last surviving partner, not bankrupt, has the right to wind up the partnership affairs; provided, however, that any partner, his legal representative, or his assignee, upon cause shown, may obtain winding up by the court.

Section 38.-(Rights of Partners to Application of Partnership Property.) - (1) When dissolution is caused in any way, except in contravention of the partnership agreement, each partner, as against his co-partners and all persons claiming through them in respect of their interests in the partnership, unless otherwise agreed, may have the partnership property applied to discharge its liabilities, and the surplus applied to pay in cash the net amount owing to the respective partners. But if dissolution is caused by expulsion of a partner, bona fide under the partnership agreement, and if the expelled partner is discharged from all partnership liabilities, either by payment or agreement under Section 36 (2), he shall receive in cash only the net amount due him from the partnership.

(2) When dissolution is caused in contravention of the partnership agreement the rights of the partners shall be as follows:

(a) Each partner who has not caused dissolution wrongfully shall have,

I. All the rights specified in paragraph (1) of this section, and

II. The right, as against each partner who has caused the dissolution wrongfully, to damages for breach of the agreement. 
(b) The partners who have not caused the dissolution wrongfully, if they all desire to continue the business in the same name, either by themselves or jointly with others, may do so, during the agreed term for the partnership and for that purpose may possess the partnership property, provided they secure the payment by bond approved by the court, or pay to any partner who has eaused the dissolution wrongfully, the value of his interest in the partnership at the dissolution, less any damages recoverable under clause (2aII) of this action indemnify him against all present or future partnership liabilities.

(c) A partner who has caused the dissolution wrongfully shall have:

I. If the business is not continued under the provisions of paragraph (2b) all the rights of a partner under paragraph (1), subject to clause (2aII), of this section,

II. If the business is continued under paragraph (2b) of this section the right as against his co-partners and all claiming through them in respect of their interests in the partnership, to have the value of his interest in the partnership, less any damages caused to his co-partners by the dissolution, ascertained and paid to him in cash, or the payment secured by bond approved by the court, and to be released from all liabilities of partnership; but in ascertaining the value of the partner's interest the value of the good will of the business shall not be considered.

Wisconsin.-Crossman v. Gibney (1916), 164 Wis. 395,160 N. W. 172.

Section 39.-(Rights Where Partnership is Dissolved for Fraud or Misrepresentation.) - Where a partnership contract is rescinded on the ground of the fraud or misrepresentation of one of the parties thereto, the party entitled to rescind is, without prejudice to any other right, entitled,

(a) To a lien on, or right of retention of, the surplus of the partnership property after satisfying the partnership liabilities to third persons for any sum of money paid by him for the pur- 
chase of an interest in the partnership and for any capital or advances contributed by him; and

(b) To stand, after all liabilities to third persons have been satisfied in the place of the ereditors of the partnership for any payments made by him in respect of the partnership liabili. ties; and

(e) To be indemnified by the person guilty of the fraud or making the representation against all debts and liabilities of the partnership.

Section 40.-(Rules for Distribution.)-In settling accounts between the parties after dissolution, the following rules shall be observed, subject to any agreement to the contrary:

(2) The assets of the partnership are;

I. The partnership property,

II. The contributions of the partners necessary for the payment of all the liabilities specified in elause (b) of this paragraph.

(b) The liabilities of the partnership shall rank in order of payment, as follows:

I. Those owing to ereditors other than partners,

II. Those owing to partners other than for capital and profits,

III. Those owing to partners in respect of capital,

IV. Those owing to partners in respect of profits.

(c) The assets shall be applied in the order of their declaration in clause (a) of this paragraph to the satisfaction of the liabilities.

(d) The partners shall contribute, as provided by Section 18 (a) the amount necessary to satisfy the liabilities; but if any, but not all, of the partners are insolvent, or, not being subject to process, refuse to contribute, the other partners shall contribute their share of the liabilities, and, in the relative proportions in which they share the profits, the additional amount necessary to pay the liabilities.

(e) An assignee for the benefit of ereditors or any person appointed by the court shall have the right to enforce the contributions specified in clause (d) of this paragraph. 
(f) Any partner or his legal representative shall have the right to enforce the contributions spocified in clause (d) of this paragraph, to the extent of the amount which he has paid in excess of his share of the liability.

(g) The individual property of a deceased partner shall be liable for the contributions special in clause (d) of this paragraph.

(h) When partnership property and the individual properties of the partners are in the possession of a court for distribution, partnership creditors shall have priority on partnership property and separate creditors on individual property, saving the rights of lien or secured creditors as heretofore.

(i) Where a partner has become bankrupt or his estate is insolvent the claims against his separate property shall rank in the following order:

I. Those owing to separate creditors,

II. Those owing to partnership creditors,

III. Those owing to partners by way of contribution.

Section 41.-(Liability of Persons Continuing the Business in Certain Cases.)-(1) When any now partner is admitted into an existing partnership, or when any partner retires and assigns (or the representative of a decreased partner assigns) his rights in partnership property to two or more of the partners, or to one or more of the partners and one or more third persons, if the business is continued without liquidation of the partnership affairs, creditors of the first or dissolved partnership are also creditors of the partnership so continuing the business.

(2) When all but one partner retire and assign (or the representative of a deceased partner assigns) their rights in partnership property to the remaining partner, who continues the business without liquidation of partnership affairs, either alone or with others, creditors of the dissolved partnership are also creditors of the person or partnership so continuing the business.

(3) When any partner retires or dies and the business of the dissolved partnership is continued as set forth in paragraphs (1) and (2) of this section, with the consent of the retired partners or the representative of the deceased partner, but without any assignment of his right in partnership property, rights of 
creditors of the dissolved partnership and of the creditors of the person or partnership continuing the business shall be as if such assignment had been made.

(4) When all the partners or their representatives assign their rights in partnership property to one or more third person who promise to pay the debts and who continue the business of the dissolved partnership, creditors of the dissolved partnership are also creditors of the person or partnership continuing the business.

(5) When any partner wrongfully causes a dissolution and the remaining partners contiuue the business under the provisions of Section $38(2 \mathrm{~b})$, either alone or with others, and without liquidation of the partnership affairs, creditors of the dissolved partnership are also creditors of the person or partnership continuing the business.

(6) When a partner is expelled and the remaining partners continue the business either alone or with others, without liquidation of the partnership affairs, creditors of the dissolved partnership are also creditors of the person or partnership continuing the business.

(7) The liability of a third person becoming a partner in the partnership continuing the business, under this section to the creditors of the dissolved partnership shall be satisfied out of partnership property only.

(8) When the business of a partnership after dissolution is continued under any conditions set forth in this section the creditors of the dissolved partnership, as against, the separate creditors of the retiring or deceased partner or the representative of the deceased partner, have a prior right to any claim of the retired partner or the representative of the deceased partner against the person or partnership continuing the business, on account of the retired or deceased partner's interest in the dissolved partnership or on account of any consideration promised for such interest or for his right in partnership property.

(9) Nothing in this section shall be held to modify any right of creditors to set aside any assignment on the ground of fraud.

(10) The use by the person or partnership continuing the business of the partnership name, or the name of a deceased 
partner as part thereof, shall not of itself make the individual property of the deceased partner liable for any debts contracted by such person or partnership.

Illinois.-H. Albrecht \& Co. v. Massing (1918), 199 Ill. App. 182.

Section 42.-(Rights of Retiring or Estate of Deceased Partner When the Business is Continued.) - When any partner retires or dies, and the business is continued under any of the conditions set forth in Section $41(1,2,3,5,6)$ or Section $3 S(2 \mathrm{~b})$, without any settlement of accounts as between him or his estate and the person or partnership continuing the business, unless otherwise agreed, he or his legal representative as against such persons or partnership may have the value of his interest at the date of dissolution ascertained, and shall receive as an ordinary creditor an amount equal to the value of his interest in the dissolved partnership with interest, or, at his option or at the option of his legal representative, in lieu of interest, the profits attributable to the use of his right in the property of the dissolved partnership; provided that the creditors of the dissolved patnership as against the separate creditors, or the representative of the retired or deceased partner, shall have priority on any elaim arising under this section, as provided by Section 41 (8) of this Act.

Section 43.-(Acerual of Actions.)-The right to an account of his interest shall acerue to any partner, or his legal representative, as against the winding up partners or the surviving partners or the person or partnership continuing the business, at the date of the dissolution, in the absence of any agreement to the contrary.

\section{PART VII.}

Miscellaneous Provisions.

Section 44.-(When Act Takes Effect.)-This Act shall take effect on the day of , one thousand nine hundred and

Section 45.-(Legislation Repealed.)-All Acts or parts of Acts ineonsistent with this Act are hereby repealed. 


\section{UNIFORM COLD STORAGE ACT}





\section{UNIFORM COLD STORAGE ACT}

The Committee on Purity of Articles of Commerce, at the meeting of the Conference of Commissioners held in Montreal, August, 1913, submitted as directed by the conference of 1912, a draft of "An Act to Regulate Cold Storage of Articles of Food." The draft was recommitted to the Committee with instructions to re-draft and submit the second draft to the Conference in 1914. The second draft was prepared by the committee at a meeting held in New York City, on November 22, 1913 and at subsequent meetings. In this work, the Committee was greatly aided by Dr. M. E. Pennington, Chief of Reserved Laboratory, United States Department of Agriculture and by many suggestions and criticisms received from associations and individuals interested in the business of cold storage of articles of food. This second draft was submitted to the Conference held in Washington, D. C., October 14-19, 1914, and was approved and recommended to the various states for adoption on October 19, 1914. 


\begin{tabular}{|c|c|c|c|c|c|c|}
\hline & $\begin{array}{c}\text { Laws } \\
1917 . \\
\text { p. } 648 .\end{array}$ & $\begin{array}{l}\text { Laws } \\
1916 . \\
\text { cl. } 163 \\
\text { p. } 281 .\end{array}$ & $\begin{array}{c}\text { Laws } \\
1912 . \\
\text { ch. } 652 . \\
\text { p. } 711 .\end{array}$ & & $\begin{array}{l}\text { Comp. } \\
\text { Laws } \\
1917 .\end{array}$ & $\begin{array}{c}\text { Rev. 1917, } \\
\text { ch. } 428 .\end{array}$ \\
\hline $\begin{array}{l}\text { Uniform } \\
\text { Act } \\
\text { Sec. No. }\end{array}$ & $\begin{array}{c}1917 \\
\text { Illinois. }\end{array}$ & $\begin{array}{c}19 ! 6 \\
\text { Maryland. }\end{array}$ & $\begin{array}{c}1912 \\
\text { Mlass. }\end{array}$ & $\begin{array}{l}1919 \\
\text { Tenn. }\end{array}$ & $\begin{array}{l}1917 \\
\text { Utah. }\end{array}$ & $\begin{array}{l}1917 \\
\text { Wisc. }\end{array}$ \\
\hline I & 1 & $177 \mathrm{l}$ & $1^{*}$ & Not & 840 & $1684 w-1$ \\
\hline 2 & 2 & $177 \mathrm{~J}$ & $2^{*}$ & Yet & 841 & $1684 w-2$ \\
\hline 3 & 3 & $177 \mathrm{~K}$ & $2^{*}$ & Out & 842 & $1684 w-3$ \\
\hline 4 & 4 & $177 \mathrm{~L}$ & $2^{*}$ & & 843 & $1684 w-4$ \\
\hline 5 & 5 & $177 \mathrm{M}$ & $3 *$ & & 844 & $1684 w-5$ \\
\hline 6 & 6 & $177 \mathrm{~N}$ & $4^{*}$ & & 845 & $1684 w-6$ \\
\hline 7 & 7 & 1770 & $4^{*}$ & & 846 & $1684 w-7$ \\
\hline 8 & 8 & $177 \mathrm{P}$ & $5 *$ & & 847 & $1684 w-8$ \\
\hline 9 & 9 & 1720 & $6^{*}$ & & 848 & $1684 w-9$ \\
\hline 10 & 10 & $177 \mathrm{R}$ & $7 *$ & & 849 & $1684 w-10$ \\
\hline 11 & 11 & $177 \mathrm{~S}$ & 9 & ${ }^{\circ}$ & 850 & $1684 w-11$ \\
\hline 12 & 12 & $177 \mathrm{~T}$ & 10 & & 851 & $1684 w-12$ \\
\hline 13 & 13 & 2 & $\ldots$ & & 852 & $1684 w-13$ \\
\hline 14 & 14 & 3 & $\because$ & & 853 & $1684 w-14$ \\
\hline 15 & 15 & 4 & ii & & 854 & $\ldots \ldots \ldots$ \\
\hline
\end{tabular}




\section{UNIFORM COLD STORAGE ACT ${ }^{1}$}

Section 1. For the purpose of this Act, " cold storage" shall mean the storage or keeping of articles of food at or below a temperature above zero of 45 degrees Fahrenheit in a cold storage warehouse; "cold storage warehouse" shall mean any place artificially cooled to or below a temperature above zero of 45 degrees Fahrenheit, in which articles of food are placed and held for thirty days or more; "article of food" shall mean fresh meat and fresh meat products and all fish, game, poultry, eggs and butter.

Section 2. No person, firm or corporation shall maintain or operate a cold storage warehouse without a license so to do issued by the State Food Commissioner. ${ }^{2}$ Any person, firm or corporation desiring such a license shall make written application to the State Food Commissioner for that purpose, stating the location of the warehouse. The State Food Commissioner thereupon shall cause an examination to be made of said warehouse and, if it be found by him to be in a proper sanitary condition and otherwise properly equipped for its intended use, he shall issue a license authorizing the applicant to operate the same as a cold storage warehouse during one year. The license shall be issued upon payment by the applicant of a license fee of to the Treasurer of the State.

Section 3. In case any cold storage warehouse, or any part thereof, shall at any time be deemed by the State Food Commissioner to be in an unsanitary condition, or not properly equipped for its intended use, he shall notify the licensee of such condition and upon the failure of the licensce to put such cold storage warehouse in a sanitary condition or to properly equip

1 The title should be made to conform to the constitutional provisions of the state.

2 Wherever in this act the words "State Food Commissioner" are used the name of any other officer or board may be substituted. 
the same for its intended use, within a time to be designated by the State Food Commissioner, he shall revoke such license.

Section 4. Every such licensee shall keep accurate records of the articles of food received in and of the articles of food withdrawn from his cold storage warehouse, and the State Food Commissioner shall have free access to such records at any time. Every such licensee shall submit a monthly report to the State Food Commissioner, setting forth in itemized particulars the quantities and kinds of articles of food in his cold storage warehouse. Such monthly reports shall be filed on or before the fifth day of each month, and the reports so rendered shall show the conditions existing on the last day of the preceding month reported and a summary of such reports shall be prepared by the State Food Commissioner and shall be open to public inspection on or before the tenth day of each month.

Section 5. The State Food Commissioner shall inspect and supervise all cold storage warehouses and make such inspection of articles of food therein as he may deem necessary to secure the proper enforcement of this act, and he shall have access to all cold storage warehouses at all. reasonable times. The State Food Commissioner may appoint such persons as he deems qualified to make any inspection under this Act.

Section 6. No article of food intended for human consumption shall be placed, received or kept in any cold storage warehouse, if diseased, tainted, otherwise unfit for human consumption, or in such condition that it will not keep wholesome for human consumption. No article of food, for use other than for human consumption, shall be placed, received or kept in any cold storage warehouse unless previously marked, in accordance with forms to be prescribed by the State Food Commissioner, in such a way as to indicate plainly the fact that such article of food is not to be sold or used for human food.

Section 7. No person, firm or corporation shall place, ro ceive or keep in any cold storage warehouse in this state articles of food unless the same shall be plainly marked, stamped or tagged, either upon the container in which they are packed, or 
upon the article of food itself, with the date when placed therein; and no person, firm or corporation shall remove, or allow to be removed, such article of food from any cold storaige warehouse unless the same shall be plainly marked, stamped or tagged, either on the container in which it is enclosed or upon the article of food itself, with the date of such removal, and such marks, stamps and tags shall be prima facie evidence of such receipt and removal and of the dates thereof. All articles of food in any cold storage warehouse at the time this Aet goes into effect shall. before being removed therefrom, be plainly marked, stamped or tagged with the date when this Act goes in to effect and the date of removal therefrom.

Section 8. No person, firm or corporation shall hereafter keep or permit to remain in any cold storage warehouse any article of food which has been held in cold storage either within or without the state, for a longer aggregate period than twelve months, except with the consent of the State Food Commissioner as hereinafter provided. The State Food Commissioner shall, upon application during the twelfth month, extend the period of storage beyond twelve months for any particular article of food. provided the same is found upon examination to be in proper condition for further cold storage. The length of time for which such further storage is allowed shall be specified in the order granting the permission. A report on each case in which such extension of storage may be permitted, including information relating to the reason for the action of the State Food Commissioner, the kinds and amounts of the wrticles of food for which the storage period was extended, and the length of time for which this continuance was granted, shall be filed, open to public inspection, in the office of the State Food Commissioner, and shall be included in his annual report. Such extention shall be not more than sixty days; a second extension of not more than sixty days may be granted upon a re-examination, but the entire extended period shall be not more than one hundred and twenty days in all.

Section 9. It shall be unlawful to sell, or to offer for sale, any article of food which has been held for a period of thirty 
days or over in cold storage either within or without the state without notifying persons purchasing, or intending to purchase, the same, that it has been so held, by the display of a placard plainly and conspicuously marked, "Cold Storage Goods" on the bulk mass or articles of food; and it shall be unlawful to represent or advertise as fresh any article of food which has been held in cold storage for a period of thirty days or over.

Section 10. It shall be unlawful to return to any cold storage warehouse any article of food which has been once released from storage for the purpose of placing it on the market for sale. It shall be unlawful to transfer any article of food from one cold storage warehouse to another if such transfer is made for the purpose of avoiding any provision of this Act, and such transfer shall be unlawful unless all prior stampings, markings and taggings upon such articles shall remain thereon.

Section 11. The State Food Commissioner may make all necessary rules and regulations to carry this Act into effect. Such rules and regulations shall be filed in the Commissioner's office, and shall not take effect until filing.

Section 12. Any person, firm or corporation violating any provision of this Act shall be guilty of a misdemeanor and shall upon conviction be punished for the first offense by a fine not exceeding sccond or any subsequent offense by a fine not exceeding

$(\$)$ or by imprisonment of not more than six months, or by both such fine and imprisonment in the discretion of the court.

Section 13. This Act shall be so interpreted and construed as to effect its general purpose to make uniform the law of those states which enact it.

Section 14. This Act may be cited as the Uniform Cold Storage Act.

Section 15. All Acts or parts of Acts inconsistent with this Art are hercby repealed. 
UNIFORM WORKMEN'S COMPENSATION ACT

[443] 



\section{UNIFORM WORKMEN'S COMPENSATION ACT}

At the conference held at Chattanooga, 'Tenn., in August, 1910, at the suggestion of the president at the Conference, it was voted that the president appoint a special committee of seven to consider the advisability of framing a uniform law on the subject of Workmen's Compensation for Personal Injuries, and, if found expedient, to draft such a law.

The committee appointed found it desirable to undertake the work of preparing a Uniform Workmen's Compensation Law, and prepared a draft on the theory of compulsory compensation, which it later supplanted with a tentative draft framed upon an elective basis requiring the assent of both employer and employee before it should take effect as to either of them. This draft was submitted to the Conference in Boston in 1911 and it was voted that the committee continue its work and prepare two drafts to be submitted to the Conference at Milwaukee in August, 1912, one framed on the elective and one on the compulsory basis.

The Conference at Milwaukee in 1912, ' after considering both drafts, tentatively approved the draft of a compulsory Workmen's Compensation Law in a somewhat amended form and instructed the committee to continue its work and report to the next Conference.

At the conference in Montreal, Canada, in August, 1913, the committee submitted two drafts, one, an elective act and the other a compulsory act. The two acts as amended were tentatively approved and the committee was again instructed to continue its work and report to the next Conference.

The committee finally came to the conclusion that a compulsory act was constitutional and it accordingly at the Conference in Washington, D. C., in 1914, submitted a compulsory act which was approved by the Conference and recommended to the states for adoption. 


\begin{tabular}{|c|c|c|c|}
\hline & $\begin{array}{l}\text { Session Laws of } 1917 \\
\text { ch. } 81 \text { p. } 252 ; \mathrm{ch} .256 \\
\text { of Code. } 1919 .\end{array}$ & $\begin{array}{l}\text { Acts of General Assem- } \\
\text { bly. 1917. ch. 106, p. } \\
392 .\end{array}$ & $\begin{array}{l}\text { Ch. 407, pp. 675, 694, } \\
\text { effect Oct. 1, 1913. } \\
\text { Amended to ch. 209, pp. } \\
285,300 \text { of Laws of } \\
\text { 1915, effect July 1, } \\
\text { 1915. } \\
\text { (G. S. Minn. 1917, } \\
\text { Supp., secs. 8195- } \\
\text { 8230). }\end{array}$ \\
\hline $\begin{array}{c}\text { Uniform } \\
\text { Acl } \\
\text { Section No. }\end{array}$ & $\begin{array}{l}1917 \\
\text { Jdabo. }\end{array}$ & $\begin{array}{c}1917 \\
\text { Indiana. }\end{array}$ & $\begin{array}{c}1913 \\
\text { Minnesota. }\end{array}$ \\
\hline 1 & (Modified) & (Mlodified & (Modified) \\
\hline
\end{tabular}




\title{
UNIFORM WORKMEN'S COMPENSATION ACT
}

\author{
I. \\ RIGHT AND REMEDIES GRANTED AND AFFECTED. \\ Employments Covered.
}

Section 1. This Act shall apply to all public and all industrial employment, as hereinafter defined. If a workman receives personal injury by accident arising out of and in the course of such employment, his employer or the insurance carrier shall pay compensation in the amounts and to the person or persons hereinafter specified.

\section{State and Municipal Bodies.}

Section 2. This Act shall apply to employees (other than officials as hereafter defined) of the state, and all counties, cities, towns, and other public corporations, within the state. Policemen and firemen and others entitled to pensions sliall be deemed employees within the meaning of this Act. If. however, any policeman or fircman or other person entitled to a pension claims eompensation under this Act there shall be de ducted from such compensation any sum which such policeman or fireman or other person may be entitled to receive from any pension or other benefit fund to which the state or municipal body may contribute.

Indiana.-In re Boyer (1917) (Ind. App.), 117 N. E. 507.

\section{Injuries Not Covered.}

Section 3. No compensation shall be allowed for an injury caused (1) by the employee's wilful intention to injure himself or to injure another, or (2) by his intoxication. If the employer claims an exemption or forfeiture under this scetion the burden of proof shall be upon him.

Indiana.- Haskell \& Borker Car Co. v. Kay (1918) (Ind. App.), 119 N. E. 811 ; In re Ayers (1918) (Ind. App.), 118 N. E. 386; In re Bow. ers (1917) (Ind. App.); In re Bow- ers, In re IVilliams, In re Colan. 116 N. F. 842; Northern lnd. Gas \& Electrie Co. v. Pietrak (1915) (Ind. App.), 118 N. E. 132. 


\section{Right to Compensation Exclusive.}

Section 4. The rights and remedies herein granted to an employee on account of a personal injury for which he is entitled to compensation under this Act shall exclude all other rights and remedies of such employees, his personal representatives, dependents, or next of kin, at common law or otherwise, on account of such injury.

Employers, who hire workmen within this state to work outside of the state, may agree with such workmen that the remedies under this Act shall be exclusive as regards injuries re ceived outside this state by accident arising out of and in the course of such employment; and all contracts of hiring in this state shall be presumed to include such an agreement.

Indiana.- In re Bowers (1917) Williams, In re Colan. $116 \mathrm{~N}$. Ł. (Ind. App.); In re Bowers, In re 842.

\section{Liability of Third Persons.}

Section 5. When any injury for which compensation is payable under this Act shall have been sustained under circumstances creating in some other person than the employer a legal liability to pay damages in respect thereto, the injured employee may, at his option, either claim compensation under this act or obtain damages from or proceed at law against such other person to recover damages; and if compensation is claimed and awarded under this Act any employer having paid the compensation or having become liable therefor shall be subrogated to the rights of the injured employee to recover against that person, provided, if the employer shall recover from such other person damages in excese of the compensation already paid or awarded to be paid under this Act, then any such excess shall be paid to the injured employee less the employer's expenses and costs of action.

\section{Contracting Out Forbidden.}

Section 6. No contract rule, regulation, or device whatsoever shall operate to relieve the employer in whole or in part from any liability, created by this Act.

Indiana. - In re Beggs (1917) (Ind. App.), 117 N. E. 215. 


\section{II.}

COM PENSATION.

\section{Death Benefits.}

Section 7. If death results from the injury within ( ) years, the employer or the insurance carrier shall pay to the persons entitled to compensation or, if there are none, then to the personal representative of the deceased employee, burial expenses not to exceed ( ) dollars; and shall also pay to or for the following persons for the following periods a weekly compensation equal to the following percentages of the deceased employee's average weekly wages as defined in section 15 :

(a) To the dependent widow or widower, if there be no dependent children ( ) per cent.

(b) To the dependent widow or widower if there be one or two dependent children ( ) per cent.; or if there be three or more dependent children ( ) per cent. Such compensation to the widow or widower shall be for the use and benefit of such widow or widower and of the dependent children, and the Industrial Accident Board may from time to time apportion such compensation between them in such way as it deems best.

(c) If there be no dependent widow or widower, but a dependent child or children, then to such child or children ( ) per cent., with ( ) per cent. additional for each child in excess of two, with a maximum of ( ) per cent., to be divided equally among such children if more than one.

(d) If there be neither dependent widow, widower, nor child, but there be a dependent father or mother, then to such parent, of wholly dependent ( ) per cent., or if partially dependent ( ) per cent., or if both parents be dependent then one-half of the foregoing compensation to each of them; or, if there be no such parents, but a dependent grandparent, then to every such grandparent the same compensation as to a parent.

(e) If there be neither dependent widow, widower, chilı, 
parent, or grandparent, but there be a dependent grandchild, brother, or sister, or two or more of them, then to such dependents ( ) per cent. for one such dependent, and ( ) per cent. additional for each additional such dependent, with a maximum of ( ) per cent. to be divided equally between such dependents if more than one.

Indiana.- People Hardware Co. Minnesota.-State v. District Ofv. Croke (1918) (Ind. App.), 118 fice Co. (1918), 159 N. W. 755. N. E. 314 .

\section{Dependents.}

Section 8. The following persons, and they only, shall be deemed dependents and entitled to compensation under the provisions of this act:

A child if under ( ) years of age, or incapable of selfsupport and unmarried, whether ever actually dependent upon the deceased or not.

The widow only if living with the deceased, or actually dependent, wholly or partially, upon him.

The widower only if incapable of self-support and actually dependent, wholly or partially, upon the deceased at the time of her injury.

A parent or grandparent only if actually dependent, wholly or partially, upon the deceased.

A grandchild, brother, or sister only if under ( ) years of age, or incapable of self-support, and whoily dependent upon the deceased. The relation of dependency must exist at the time of the injury.

Indiana.- People Hardware Co. Muncie Foundry \& Machine Co. v. v. Croke (1918) (Ind. App.), 118 Coffre (1918) (Ind. App.), $117 \mathrm{~N}$. N. E. 314; Bloomington-Bedford F. 524; In re Lanman (1918) (Ind. Stone Co. v. Phillips (1917) (Ind. App.), 116 N. E. 850; In re Peters App.), 117 N. E. 671 .

Minnesota.- State v. District Of (1917) (Ind. App.), 116 N. E. 84S; fice Co. (1918), 159 N. W. 755.

\section{Periods of Compensation.}

Section 9. The compensation herein provided for shall be payable during the following periods:

To a widow, until death or remarriage, but in no case to exceed ( ) weeks. 
To a widower, during disability or until remarriage. bus in no case to exceed ( ) weeks.

To or for a child, until ( ) years of age, but in the case of a child incapable of self-support and unmarried as long as so incapable, but in no case to exceed ( ) weeks beyond saill age of ( ) years.

To a parent or grandparent, during the continuation of a condition of actual dependency, but in no case to excees! ( ) weeks.

To or for a grandchild, brother, or sister, during dependency as hereinbefore defined, but in no ease to exceed () week.

Upon the cessation of compensation under this section to or on account of any person, the compensation of the remaining person entitled to compensation for the unexpired part of the period during which their compensation is paralle shall be that which such persons would have received if they had been the only persons entitled to compensation at the time of the decedent's death.

\section{Certain Words Defined.}

Section 10. As nsed in this section the term "child" includes step-children, adopted children, posthumous children, and acknowledged illegitimate children, but dres not include married children unless dependent. The terms "brother" and "sister" include step-brother and step-sisters, half-brothers and half-sisters, and brothers and sisters by adoption, but do not include married brothers nor married sisters unless dependent. The term "grandchild" includes children of artipteil children and children of step-ehildren, but does not include step-children of children, step-ehildren of step-chilltren, stepchildren of adopted children, nor married grandehild ren unless dependent. The term "parent" includes step-parents amil parents by adoption. The term "grandparents" includes parents. of parents by adoption, but does not include parents of stopparents, step-parents of parents, nor step-parents of step-piarents. The words "adopted" and "adoption" as used in this Act shall include cases where persons are treated as anoptod as well as those of legal adoption. 


\section{Sundry Provisions as to Death Benefits.}

Section 11. In computing death benefits the average weekly wages of the deceased employee shall be considered not to be more than ( ) dollars, nor less than ( ) dollars; but the total weekly compensation shall not exceed in any case the average weekly wages computed as provided in section 15 .

Payment of death benefits by an employer in good faith to a dependent subsequent in right to another or other dependents shall protect and discharge the employer unless and until such dopendent or dependents prior in right shall have given him notice of his or their claim. In case the employer is in doubt as to the respective rights of rival claimants he may apply to the Industrial Accident Board to decide between them.

In case death occurs after a period of disability, either total or partial, the period of disability shall be deducted from the total periods of compensation respectively stated in section 9 .

The compensation of a person who is insane shall be paid to his or her guardian.

\section{Medical Attendance.}

Section 12. During the first ( ) days of disability the employer shall furmish reasonable surgical, medical and hospital service and supplies not exceeding the amount of ( ) dollars. The pecuniary liability of the employer for the medical, surgical, and hospital service herein required shall be limited to such charges as prevail in the same community for similar treatment of injured persons of a like standard of living when such treatment is paid for by the injured person.

Indiana.-Bom \& Co. v. Durr (1917) (Ind. App.). 116 N. E. 428; In re Henderson (191\%) (Ind. App.), 116 N. E. 315; In re Kelly (1917) (Ind. App.), 116 N. E. 306; In re
McCasket (1918) (Ind. App.), 117 N. E. 268; In re Myers (1917) (Ind. App.), 116 N. E. 314 ; Kirkoff Bros. v. McElwaine \& McCoal (1917) (Ind. App.), 116 N. E. 439.

\section{Total Disability.}

Section 13. Where the injury causes total disability for work the employer during such disability, but not including the first ( ) days thereof, shall pay the injured employee 
a weekly comperisation equal to ( ) per cent. of his average weekly wages, but not more than ( ) dollars, nor less than ( ) dollars, a week. In no ease shall the weekly payments continue after the disability ends, nor longer than ( ) weeks.

In case of an employee whose average weekly wages are less than ( ) dollars a week the weekly compensation shall be the full amount of such average weekly wages, but where the disability is permanent the weekly compensation in such case shall be (five) dollars. In case the total disability begins after a period of partial disability, the period of partial disability shall be deducted from such total period of ( ) weeks.

In the case of the following injuries the disability caused thereby shall be deemed total and permanent; to wit:

(1) The total and permanent loss of sight in both eyes.

(2) The loss of both feet at or above the ankle.

(3) The loss of both hands at or above the wrist.

(4) The loss of one hand and one foot.

(5) An injury to the spine resulting in permanent and complete paralysis of both legs or both arms or of one leg or of one arm.

(6) An injury to the skull resulting in incurable imbecility or insanity.

The above enumeration is not to be taken as exclusive.

\section{Partial Disability.}

Section 14. Where the injury causes partial disability for work, the employer, during such disability and for a period of ( ) years beginning on the ( ) day of disability, shall pay the injured workman a weekly compensation equal to ( ) per cent. of the difference between his arerage weckls wages before the accident and the weekly wages he is most probably able to earn thereafter, but not more than ( ) dollars a week. In no case shall the weekly payments continue after the disability ends, and in case the partial disability be gins after a period of total disability the period of total lisability shall be deducted from such total period of ( ) years.

In the ease of the following injuries the compensation shall 
be ( ) per cent. of the average weekly wages, but not more than ( ) dollars to be paid weekly for the periods stated against such injuries respectively; to wit:

(1) The loss by separation of one arm at or above the elbow joint, or the permanent and complete loss of the use of one arm ( ) weeks.

(2) The permanent and complete loss of hearing in both ears ( ) weeks.

(3) The loss by separation of one leg at or above the kneo joint or the permanent and complete loss of the use of one leg ( ) weeks.

(4) The loss iny separation of one hand at or above the wrist joint, or the permanent and complete loss of the use of one hand ( ) weeks.

(5) The loss by separation of one foot at or above the ankle joint, or the permanent and complete loss of the use of one foot ( ) weeks.

\section{Computation of Wages.}

Section 15. Average weekly wages shall be computed in such a manner as is best calculated to give the average weekly earnings of the workman during the twelve months preceding his injury; provided that where, by reason of the shortness of the time during which the workman has been in the employment, or the casual nature of the employment, or the terms of the employment, it is impracticable to eompute the rate of remuneration, regard may be had to the average weekly earnings which, during the twelve months previous to the injury, were being earned by a person in the same grade employed at the same work by the employer of the injured workman, or if there is no person so emploved, by a person in the same grade emplored in the same class of employment and in the same distriet.

If a workman at the time of the injury is regularly employed in a higher grade of work than formerly during the year and with larger regular wages, only such larger wages shall be taken into consideration in computing his average weekly wages. 


\section{Voluntary Payments.}

Section 16. Any payments made by the employer or his insurer to the injured workman during the period of his disability, or to bis dependents, which, by the terms of this Act, were not due and payable when made, may, subject to the approval of the board, be deducted from the amount to be paid as compensation; provided that in ease of disability such deduction shall be made by shortening the period during which compensation must be paid, and not by reducing the amount of the weekly payments under sections 13 and 14 .

\section{Periodical Payments.}

Section 17. The board, upon the application of either party. may in its discretion, having regard to the welfare of the employees and the convenience of the emplorer. anthorize compensation to be paid monthly or quarterly instead of weekly.

Indiana.-In re Beggs (1917) (Ind. App.), 117 N. F. 215.

\section{Commulation of Payments.}

Section 18. Whenever the board determines that it is for the best interest of all parties, the liability of the employer for compensation may, on application to the hard by any party interested, be discharged in whole or in part by the parmont of one or more lump sums to be fixed by the board.

$$
\text { Indiana.-In re Beggs (191i) (Ind. App.), } 117 \text { N. F. } 215 .
$$

\section{Trustee in Case of Lump Sum Payments.}

Section 19. Whenever for any reason the board deems it ex. pedient, ans lump sum which is to be paid as provided in sertion 18 shall be paid by the emplorer to some suitable person or corporation appointed by the ( ) eourt as trustee to administer or apply the same for the benefit of the person or persons entitled thereto in the manner provided by the board. The receipt of such trustee for the amount so paid shall discharge the employer or ans one else who is liable therefor.

Indiana.-In re Stone (1917) (Ind. App.), 117 N. E. 669. 
III.

PROCEDURE IN OBTAINING COMPENSATION.

Medical Examination.

Section 20. After an injury and during the period of disability, the workman, if so requested by his employer, or ordered by the board, shall submit himself to examination, at reasonable times and places, to a duly qualified physician or surgeon designated and paid by the employer. The workman shall have the right to a physician or surgeon designated and paid by himself present at such examination, which right, however, shall not be construed to deny to the employer's physician the right to visit the injured workman at all reasonable times. and under all reasonable conditions during total disability. If a workman refuses to submit himself to or in any way obstructs such examination, his right to take or prosecute any proceeding under this Act shall be suspended until such refusal or obstruction ceases, and no compensation shall be payable for the period during which such refusal or obstruction continues.

Indiana.-Indianapolis Abattior Co. v. Bryant (1918) (Ind. App.), 119 N. E. 24.

\section{Notice of Injury and Claim for Compensation.}

Section 21. No proceedings under this Act for compensation for an injury shall be maintained unless a notice of the injury shall have been given to the employer as soon as practicable after the happening thereof, and unless a claim for compensation with respect to such injury shall have been made within ( ) after the date of the injury; or, in the case of death, then within ( ) after such death, whether or not a claim had been made by the employee himself for compensation. Snch notice and such claim may be given or made by any person claiming to be entitled to compensation or by some one on his behalf. If payments of compensation have been made voluntarily the making of a claim within said period shall not be required.

Indiana.- Homebrook Ice Co. v.

Stewart (1918) (Ind. App.), $118 \mathrm{~N}$.

E. 315 . 


\section{Form of Notice and Claim.}

Section 22. Such notice and such claim shall be in writing. and such notice shall contain the name and address of the employee, and shall state in ordinary language the time. place, nature, and cause of the injury, and shall be signed by him or by a person on his behalf, or, in the event of his death, by any one or more of his dependents or by a person on their behalf. The notice may include the claim.

Indiana.- Hombrook Price Co. v.

Stewart (1918) (Ind. App.), 118 N.

E. 315 .

Giving of Notice and Making of Claim.

Section 23. Any notice under this Act shall be given to the employer, or, if the employer be a partnership, then to any one of the partners. If the employer be a corporation, then the notice may be given to any agent of the eorporation upon whom process may be served, or to any officer of the corporation, or any agent in charge of the business at the place where the injury occurred. Such notice shall be given by delivering it or by sending it by mail by registered letter addrossed to the employer at his or its last known residence or place of business. The foregoing provisions shall apply to the making of a claim.

\section{Sufficiency of Notice.}

Section 24. A notice given under the provisions of saction 21 of this Act not be held invalid or insufficient by reasen of any inaccuracy in stating the time, place, nature, or cause of the injury, or otherwise, unless it is shown that the employer was in fact misled to his injury thereby. Want of notice or delay in giving notice shall not be a bar to proceedings under this Act if it be shown that the employer, his agent or representative, had knowledge of the accident, or that the omployer has not been prejudiced by such delay or want of notice.

Limitation of Time as Regards Minors and Insane.

Section 25. No limitation of time provided in this. Iet shall run as agaiinst any porson who is mentalls inenmpetent or a minor dependent so long as ho has no committee, grardian, or next friend. 


\section{IV.}

INDUSTRIAL ACCIDENT BOARD.

\section{Creation of Board.}

Section 26. A Board is hereby created to be known as the Industrial Accident Board, consisting of five members to be appointed by the Governor, by and with the consent of the ( ) one of whom shall be designated by the Governor as chairman. Appointments to fill vacancies may be made during the recesses of the ( ), but shall be subject to confirmation by the ( ) at the next ensuing session of the ( ). Each member of the Board shall hold office for five vears, except that when the Board is first constituted one member shall be appointed for one year, one for two years, one for three years, one for four years, and one for five years. Thereafter one member shall be appointed every year for the full term of five years.

\section{Salaries and Expenses.}

Section 27. The salaries and expenses of the Board shall be paid by the state. The salary of the chairman shall be ( ) dollars per year, and the salary of the other members shall be ( ) dollars per year each. The Board may appoint a secretary at a salary of not more than ( ) dollars per year, and may remove him. The Board shall be provided with offices in the capitol, or in some other suitable building in the city of ( ), in which its records shall be kept, and it shall also be provided with necessary office furniture, stationery and other supplies. The Board shall have a seal for the authentication of the orders, awards, and proceedings, upon which shall he inscribed the words, "Industrial Accident Board-( )Seal." It shall employ such assistants and clerical help as it may deem necessary, and fix the compensation of all persons so employed: Provided that all such clerical assistants shall be subject to existing laws regulating the selection grading, and compensation of department clerks. The members of the Board and its assistants shall be entitled to receive from the state their actual and necessary expenses while traveling on the business of the Board, but such expenses shall be sworn to by the person 
who incurred the same, and shall be approved by the chairman of the Board before payment is made. All such salaries and expenses shall be audited and paid out of the state treasury in the manner prescribed for similar expenditures in other depart ments or branches of the state service.

Rules of Board, Witnesses, Blanks.

Section 28. The Board may make rules not inconsistent with this Act for carrying out the provisions of this Act. Process and procedure under this Act shall be as summary and simple as reasonably may be. The Board, or any member thereof, shall have the power to subpoena witnesses, administer oaths, and to examine such of the books and records of the parties to a proceeding as relate to the questions in dispute. The ( ) court shall have power to enforce by proper proceedings the attendance and testimony of witnesses, and the production and examination of books, papers, and records. The Board shall cause to be printed and furnished free of charge to any employer or employee such blank forms as it shall deem requisite to facilitate or promote the efficient administration of this Act.

\section{Agreements.}

Section 29. If the employer and the injured employee reach an agreement in regard to compensation under this Act, a memorandum of the agreement shall be filed with the Board and, if approved by it. therempon the memorandum shall for all purposes be enforceable under the provisions of section 38. 11 les: modified as provided in section 36 .

Such agreements shall be approved by the Board only when the terms conform to the provisions of this Act.

Indiana.-In re Beggs (1917) (Ind. App.), 117 N. E. 215.

\section{Committee of Arbitration.}

Section 30. If the compensation is not settled by agreement, either party may make an application to the Board for the formation of a committee of arbitration. Such committee shall consist of three members, one of whom shall be a member of the Industrial Accident Board, or appointed by it, who shall act 
as chairman. The other two members shall be named, respectively, by the parties. If a vacancy occurs it shall be filled in the same way as the original appointment.

\section{Formation of Committee.}

Section 31. Immediately after such application the Board shall designate one of its members, or a substitute, to act as chairman of the committee of arbitration, and shall request the parties to appoint their respective representatives. If within seven days after such request, or after a vacancy has occurred, either party does not appoint his representative the Board shall fill the vacancy and notify the parties to that effect.

\section{Hearings and Awards.}

Section 32. The committee on arbitration shall make such inquiries and investigations as it shall deem necessary. The hearings of the committee, unless otherwise agreed, shall be held in the city or town where the injury occurred if within this state, and the award of the committee, together with a statement of its findings of fact, rulings of law, and.any other matters pcrtinent to the questions arising before it, shall be filed with the Industrial Accident Board. A copy of the award shall be immediately sent to the parties. Unless a claim for a review is filed by either party within ( ) days the award shall be enforceable under the provisions of Section 38.

\section{Examination by Physician.}

Section 33. The Industrial Accident Board, or any member thereof, may appoint a duly qualified impartial physician to examine the injured employee and to report. The fee for this service shall be ( ) dollars and traveling expenses, but the Board may allow additional reasonable amounts in extraordinary cases.

\section{Expenses of Arbitrators and Physician.}

Section 34. The fees and expenses of arbitrators under section 32 and of physicians under Section 33, shall be paid by the state, as the other expenses of the Board are paid. 


\section{Review of Award.}

Section 35. If an application for review is made to tho Board, or if the committee fails to make an award within thirty days after its formation, the Board shall allow a full trial and shall make an award whieh shall be filled with the record of proceedings and shall state its conclusions of fact and rulings of law, and shall immediately send to the parties a copy of the award.

Indiana.- Kingan \& Co. v. Bu- Elwaine v. YeCool (1917) (Ind. ford (1917) (Ind. App.), 116 N. E. App.), 116 N. F. 439; Union Sani754 ; Kokomo Steel \& Wire Co. v. tary Mfg. Co. v. Davis (1917) (Ind. Griswold (1917) (Ind. App.), 117 App.), 114 N. E. 872.

N. E. 265; Kirkofl Bros. and M.r-

Modification of Awards and Agreements.

Section 36. On the application of any party on the gruund of a charge in conditions, the Board may at any time, but not oftener than once in six months, review any agreement or award, and on such review may make an award ending, diminishing, or increasing the compensation previously agreed upou or awarded subject to the maximum and minimum provided in this Act, and shall state its conclusions of fact and rulings of law, and immediately send to the parties a copy of the award, but this section shall not apply to a commutation of payments under Section 18.

Indiana.-Kirkhoff Bros. \& McElwaine v. McCool (1917) (Ind. App.), 116 N. E. 439; Union Sanitary Mfg. Co. v. Davis (1917). 114 N. F. 872 .
Minnesota.-State v. District Court. Henmepin County (1917). 136 Minn. 14\%, 161 N. W. 391; State v. Nye (191\%). 161 N. W. 224 .

\section{Appeals from Board.}

Section 37. An award of the Board, in the abscme of frand, shall be final and conclusive between the parties except its provided in Section 36 , unless witbin ( ) days after a copy has been sent to the parties either party appeals to the ( ) court. On such appeal the juristiction of said court sball be 
limited to a review of questions of law. The Board may certify questions of law to the highest court for its determination.

Indiana. - Union Sanitary Mfg.

Co. v. Davis (1916) (Ind. App.), 114

N. E. 872 .

\section{Enforcement of Award.}

Section 38. Any party in interest may file in the ( ) court for the county in which the injury occurred, or for the county of ( ), a certified copy of the decision of the Board awarding compensation from which no appeal has been taken within the time allowed therefor, or a certified copy of a decision of an arbitration committee awarding compensation from which no claim fur review has been filed within the time allowed therefor, or a certified copy of a memorandum of agreement approved by the Board, whereupon said court shall render a decree or judgment in accordance therewith and notify the parties thereof. Such decree or judgment shall have the same effect, and all proceedings in relation thereto shall thereafter be the same, as though said decree or judgment had been rendered in a suit duly heard and determined by said court, except that there shall be no appeal therefrom.

\section{Costs.}

Section 39. If the committee of arbitration, Industrial Accident Board, or any court before whom any proceedings are brought under this Act, determines that such proceedings have bcen brought, prosecuted, or defended without reasonable ground, it may assess the whole cost of the proceedings upon the party who has so brought, prosecuted, or defended them.

\section{General Powers of Board.}

Scction 40. All questions arising under this Act, if not settled by agreement of the parties interested therein with the approval of the Board, shall, except as otherwise herein provided, be determined by the Board. The decisions of the Board shall be enforceable by the ( ) court under the provisions of Section 38. There shall be a right of appeal from de- 
cisions of the Board to the ( ) court as provided in Section 37, but in no case shall such an appeal either under this section or under Section 37, operate as a supersedeas or stay unless the Board or the ( ) court shall so order.

\section{Revision of Decrees.}

Section 41. The ( ) court, upon the filing with it of a certified copy of a decision of the Industrial Accident Board ending, diminishing or increasing compensation previously awarded, shall revoke or modify its prior decree or judgment so that it will conform to said decision.

\section{Injuries Outside the State.}

Section 42. If a workman who has been hired in this state receives personal injury by accident arising out of and in the course of such employment, he shall be entitled to compensation according to the law of this state even though such injury was received outside of this state.

If a workman who has been hired outside of this state is injured while engaged in his employer's business, and is entitled to compensation for such injury under the law of the state whero he was hired, he shall be entitled to enforce against his em. ployer his rights in this state if his rights are such that they can reasonably be determined and dealt with by the Board and the court in this state.

\section{V.}

PREFERENCES AND ASSIGNMENTS.

Preferences.

Section 43. All rights of compensation granted by this Act shall have the same preference or priority for the whole thereof against the assets of the employer as is allowed by law for any unpaid wages for labor.

\section{Assignments; Attorney's Fees.}

Section 44. No claims for compensation under this Act shall be assignable, and all compensation and claims therefor shall bo exempt from all claims of creditors. Claims of attorness 
and of physicians for services under this Act shall be subject to the approval of the Board.

VI.

SECURITY FOR COMPENSATION.

Security for Payment of Compensation.

Section 45. Employer's, but not including state or the municipal bodies mentioned in Section 2, shall secure compensation to their employees in one of the following ways:

(1) By insuring and keeping insured the payment of such compensation in the state insurance fund, or

(2) By insuring and keeping insured the payment of such compensation with any stock corporation or mutual association authorized to transact the business of workmen's compensation insurance in this state, or

(3) By obtaining and keeping in force guarantee insurance with any company authorized to do such guarantee business within the state, or

(4) By depositing and maintaining with the state insurance manager security satisfactory to said manager securing the payment by said employer of compensation according to the terms of this Act.

Indiana.-In re Kelly (1917) (Ind. App.), 116 N. E. 306.

\section{Notice of Insurance.}

Section 46. If the insurance so effected is not with the state insurance fund the employer shall forthwith file with the state insurance manager in form prescribed by him a notice of his insurance, together with a copy of the contract or policy of insurance.

\section{Posting of Notice Regarding Insurance.}

Section 47. Every employer who has complied with Section 45 of this Act shall post and maintain in a conspicuous place or places in and about his place or places of business typewritten or printed notices in form prescribed by the state insurance manager, stating the fact that he has complied with the law as to securing the payment of compensation to his employees and their dependents in accorlance with the provisions of this Act. 
Effect of Failure to Secure Compensation.

Section 4S. If an employer fails to comply with the provisions of Section 45 he shall be liable to a penalty for every lay during which such failure continnes of one dollar tor every employee to be recoverel in an action brouglit by the state insurance manager in the name of the state or in his own name, and the amounts so collected shall be paid into the state in. surance fund.

The state insurance manager may, however, in his discretion, for good cause shown remit any such penalty in whole or in part provided the employer in default secures compensation, as provided in Section 45.

Furthermore, if any employer shall be in default under Sintion 45 , for a period of thirty days, he may be enjoined by the ( ) court from carrying on his bu-iness while such default continues.

\section{The Insurance Contract.}

Section 49. Every policy of insurance and every guarantee contract covering the liability of the employer for compensation, whether issued by the state insurance manager, or by a stock company, or by a mutual association authorized to transact workmen's compensation or guarantee insurance in this state shall cover the entire liability of the employer to his employees covered by the policy or contract, and also shall contain a provision setting forth the right of the employees to enforce in their own names either by at any time filing a separate claim or by at any time making the insurance carrier a party to the original claim, the liability of tho insurance carrier in whele or in part for the payment of such compensation ; provided. however, that payment in whole or in part of such compensation by either the employer or the insurance carrier shall. to the "xient. thereof, be a bar to the recovery against the other of the amount so paid.

Knowledge of Employer to Affert Insurance Carrirr.

Section 50. Every such policy and contract shall contain a provision that, as between the employee and the in urance car- 
rier, the notice to or knowledge of the occurrence of the injury on the part of the employer shall be deemed notice or knowledge, as the case may be, on the part of the insurance carrier; that jurisdiction of the employer shall, for the purpose of this Act, be jurisdiction of the insurance carricr, and that the insurance carrier shall in all things be bound by and subject to the orders, findings, decisions, or awards rendered against the employer for the payment of compensation under the provisions of this Act.

$$
\text { Indiana.-In re Kelly (1917) (Ind. App.), } 116 \text { N. E. } 306 .
$$

\section{Insolvency of Employer Not to Release Insurance Carrier.}

Section 51. Every such policy and contract shall contain a provision to the effect that the insolvency or bankruptcy of the employer and his discharge therein shall not relieve the insurance carrier from the payment of compensation for injuries or death sustained by an employee during the life of such policy or contract.

\section{Cancellation of Insurance Contracts.}

Section 52. No policy or contract of insurance or guaranty issued by a stock company or mutual association against liability arising under this Act shall be cancelled within the time limited in such contract for its expiration until at least ten days after notice of intention to cancel such contract, on a date specified in such notice, shall have been filed in the office of the state insurance manager and also served on the employer.

\section{Insurance by the State, Counties and Municipalities.}

Section 53. The state, and each county, city, town, or other public corporation, which is liable to its employees for compensation may insure either with the state insurance fund or with any other authorized insurance carrier.

\section{Employees Not to Pay For Insurance.}

Section 54. No agreement by an employee to pay any portion of the premiums paid by his employer to the state insurance fund or to contribute to a benefit fund or department maintained by such employer or to the cost of mutual or other in- 
surance maintained for or carried for the purpose of securing compensation as herein required shall be valid; and any employer who makes a deduction for such purpose from the wages or salary of any employee entitled to the benefits of this Act shall be guilty of a misdemeanor.

\section{VII. \\ STATE INSURANCE FUND. \\ Creation of State Fund.}

Section 55. There is hereby created a fund, to be known as "The State Insurance Fund," for the purpose of insuring cmployers against liability for compensation under this Act and - of assuring to the persons entitled thereto the compensation provided by this Act. Such fund shall consist of all premiums and penalties received and paid into the fund, of property and securities acquired by and through the use of moneys belonging to the fund, and of interest earned upon moneys belonging to the fund and deposited or invested as herein provided.

Such fund shall be administered by the state insurance manager withont liability on the part of the state beyond the amount of such fund. Such fund shall be applicable to the payment of losses sustained on account of insurance and to the payment of compensation and of expenses in the manner provided in this Act.

\section{State Insurance Manager.}

Section 56. The Governor, with the approval of the ( ), shall appoint a manager of the state insurance fund, who shall hold office for the term of five years unless sooner removed by the Governor for cause stated. Any vacancy in said office mity be filled at any time by appointment made by the Governor with the approval of the ( ). If such an appointment is made during a recess of the () it shall be subject to confirmation by the ( ) at its next ensuing session. 
Powers and Duties of State Insurance Manager.

Section 57. It shall be the duty of such state insurance manager to conduct the business of the state insurance fund, and he is hercby vested with full authority over the said fund, and may do any and all things which are necessary or convenient in the administration thereof, or in connection with the insurance business to be carried on by him under the provisions of this Act.

\section{Further Statement of Powers.}

Section 58. The state insurance manager shall have full power to determine the rates to be charged for insurance in said fund, and to conduct all business in relation thereto, all of which business shall be conducted in his official name of state insurance manager.

\section{Power to Sue and be Sued.}

Section 59. The state insurance manager may in his official name sue and be sued in all the courts of the state, including the Industrial Accident Board, in all actions or proceedings arising out of anything done or suffered in connection with the state insurance fund or business relating thereto.

\section{Contracts.}

Section 60 . The state insurance manager may in his official name make contracts of insurance as herein provided and such other contracts relating to the state insurance fund as are authorized or permitted under the provisions of this Act.

\section{Employment of Assistants.}

Section 61. The state insurance manager may employ such assistants, experts, statisticians, actuaries, accountants, in$s_{i}$ ectors, clerks, and other employees as he may deem necessary to carry out the provisions of this Act or to perform the duties imposed upon him by this Act; provided that all such clerical assistants shall be subject to existing laws regulating the selection, grading, and compensation of department clerks. 


\section{Personal Liability.}

Section 62. The state insurance manager shall not, nor shall any person employed by him, be personally liable in his private capacity for or on account of any act performed or contract entered into in an official capacity in good faith and without intent to defraud, in connection with the administraton of the state insurance fund or affairs relating thereto.

\section{Salaries, Expenses; and Payment of Same.}

Section 63. The salary of the state insurance manager shall be ( ) dollars per year. His salary, and the salaries or compensation of his several employees, and all expenses incurred by him shall be audited and paid in the first instance out of the state treasury in the manner prescribed for similar expenditures in other departments or branches of the state service.

\section{Delegation of Powers.}

Section 64. The state insurance manager may act through proper deputies and may delegate to such deputies such powers as he deems necessary or convenient.

Among the powers which may be so delegated shall be the power to enter into contracts of insurance, insuring employers against liability for compensation as herein provided and insuring to employees the compensation fixed by this Act; also the power to make agreements, subject to the approval of the Industrial Aceident Board, for the settlement of claims against said fund for compensation for injulies in accordance with the provisions of this Act; also the power to determine to whom and through whom payments of such compensation shall be made; and also the power to contract with physicians, surgeons, and hospitals for medical and surgical treatment and care and nursing of injured persons entitled to compensation from said fund.

\section{Bond.}

Section 65. Before entering on the duties of his office tho state insurance manager shall give an official bond in the sum of ( ) dollars and shall take and subscribe an official oath. 
Said bond shall be approved and filed as in the case of other official bonds required of state officials.

\section{State Treasurer Custodian of Fund.}

Section 66 . The state treasurer shall be the custodian of the state insurance fund; and all disbursements therefrom shall be paid by him upon warrants or vouchers authorized and signed by the state insurance manager, and also signed by the state auditor. The state treasurer shall give a separate and additional bond in an amount to be fixed by the Governor, and with sureties approved by him, conditioned for the faithful performance of his duty as custodian of the state insurance fund. The state treasurer may deposit any portion of the said fund not needed for immediate use, in the manner and subject to all the provisions of law respecting the deposit of other state funds by him. Interest earned by such portion of the state insurance fund deposited by the state treasurer shall be collected by him and placed to the credit of the fund.

\section{Surplus and Reserve.}

Section 67. Ten per centum of the premiums collected from employers insured in the fund shall be set aside by the state insurance manager for the creation of a surplus, until such surplus shall amount to the sum of one bundred thousand dollars, and thereafter five per centum of such premiums, until such time as in the judgment of the state insurance manager such surplus shall be sufficiently large to cover the catastrophe hazard and all other unanticipated losses. The state insurance manager shall also set up and maintain a reserve adequate to meet anticipated losses and carry all claims and policies to maturity. The amount of such surplus and reserve shall be subject to the approval of the state insurance commissioner.

\section{Investment of Surplus or Reserve.}

- Section 68. 'The state insurance manager may invest any of the surplus or reserve funds belonging to the state insurance fund in the same securities and investment authorized for investments by savings banks. All such securities or evidences of 
indebtedness shall be placed in the hands of the state treasurer, who shall be the custodian thereof. He shall collect the principal and interest thereof, when due, and pay the same into the state insurance fund. The state treasurer shall pay all warrants or vouchers drawn on the state insurance fund for the making of such investments when signed by the state insurance manager and by the state auditor. The state insurance manager, with the consent of the state auditor, may sell any of such securities, the proceeds thereof to be paid over to the state treasurer for said state insurance fund.

\section{Administration Expenses.}

Section 69. The entire expenses of administering the state insurance fund shall be paid in the first instance by the state, out of moneys appropriated therefor. In the month of (

), nineteen hundred and ( ), and annually thereafter in such month, the state insurance manager shall ascertain the just amount of expense incurred by him during the preceding calendar year, in the administration of the state insurance fund, including expense incurred for the examination, determination, and payment of losses and claims, and shall refund such amount to the state treasury.

\section{Classification of Risls and Adjustment of Premiums.}

Section 70. Employments insured in the state insurance fund shall be divided by the state insurance manager for the purposes of the said fund, into classes. Separate acconnts shall be kept of the amounts collected and expended in respect to each such class for convenience in determining equitable rates: but for the purpose of paying compensation the state insurance funl shall be deemed one and indivisible. The state insurance manager shall have power to rearrange any of the classes by withdrawing any employment embraced in it and transferriur it wholly or in part to any other class, and from such employments to set up new classes in his discretion. The state insurance manager shall determine the hazards of the different classes and fix the rates of premiums therefor based upon the total parroll and number of employoes in each of such classes 
of employment at the lowest possible rate consistent with the maintenance of a solvent state insurance fund and the creation of a reasonable surplus and reserve; and for such purpose may adopt a system of schedule rating in such a manner as to take account of the peculiar hazard of each individual risk.

\section{Accounts.}

Section 71. The state insurance manager shall keep an accurate account of the money paid in premiums by each of the several classes of employments, and the expense of administering the state insurance fund and the disbursements on account of injuries and deaths of employees in each of said classes, including the setting up of reserves adequate to meet anticipated and unexpected losses and to carry the claims to maturity; and also an account of the money received from each individual employer'; and of the amount disbursed from the state insurance fund for expenses, and on account of injuries and death of the employees of such employer, including the reserves so set up.

\section{Dividends.}

Section 72. At the end of every year, and at such other times as the state insurance manager in his discretion may determine, a readjustment of the rate shall be made for each of the several classes of employments or industries. If at any time there is an aggregate balance remaining to the credit of any class of employment or industry which the state insurance manager deems may safely and properly be divided, he may in his discretion credit to each individual member of such class who shall have been a subscriber to the state insurance fund for a period of six months or more prior to the time of such readjustment such proportion of such balance as he is properly entitled to, having regard to his prior paid premiums since the last readjustment of rates.

\section{Assessments.}

Section 73. If the premiums fixed for any class and collected from its members are subsequently found by the state insurance manager to have been too small for any period, he may 
determine what additional premiums are required from said class for said period, and may make assessments accordingly, and each of the members of such class shall be liable to the said manager to pay such assessment so made upon him within thirty days after notice thereof.

\section{Readjustment of Payrolls.}

Section 74. If the amount of premium collected from any employer at the beginning of any period is ascertained by using the estimated expenditure of wages for the period of time covered by such premium payment as a basis, an adjustment of the amount of such premium shall be made at the end of such period and the actual amount of such premium shall be delivered in accordance with the amount of the actual expenditure of wages for such period; and if such wage expenditure for such period is less than the amount on which such estimated premium was collected, such employer shall be entitled to receive a refund from the state insurance fund of the difference between the amount so paid by him and the amount so found to be actually due, or to have the amount of such difference credited on succeeding premium payments at his option; and if such actual premium, when so ascertained, exceeds in amount a premium so paid by such employer at the beginning of such period, such employer shall immediately, upon being advised of the true amount of such premium due, forthwith pay to the state insurance manager an amount equal to the difference between the amount actually found to be due and the amount paid by him at the beginning of such period.

\section{Policies and Payment of Premiums.}

Section 75. (1) Every employer insuring in the state insurance fund shall receive from the state insurance manager a contract or policy of insurance in a form to be approved by the state insurance commissioner.

(2) Except as otherwise provided in this Act all premiums shall be paid by every employer who elects to insure with the state insurance fund to the state insurance manager on or before (July) first, nineteen hundred and ( ) and semi-annually 
thereafter or at such other times as may be prescribed by the state insurance manager. Receipts shall be given for such payments and the money shall be paid over to the state treasurer to the credit of the state insurance fund.

Actions for Collection in Case of Default; Penalty.

Section 76. If an employer shall default in any payment required to be made by him to the state insurance fund, the amount due from him shall be collected by civil action against him in the name of the state or of the state insurance manager, and it shall be the duty of the state insurance manager forthwith to bring or cause to be brought against each such employer a civil action in the proper court for the collection of such amount so due; and the same, when collected by the state insurance manager, shall be paid into the state insurance fund, and such employer's compliance with the provisions of this Act requiring parments to be made to the state insurance fund shall date from the time of the payment of said money so collected to the state insurance manager.

Any employer who is in default for ten days in payment of any premium shall also be liable to a penalty as provided in Section 48.

\section{Withdrawal from Fund.}

Section 77. Any employer may, upon complying with subdivisions two, three, or four of Section 45 of this Act, withdraw from the fund by turning in his insurance contract or policy for cancellation, provided he is not in arrears for premiums due to the fund and has given to the state insurance manager written notice of his intention to withdraw thirty days before the expiration of the period for which he has elected to insure in said fund; and also provided that in case any employer so withdraws, his liability to assessments shall continue after the date of such withdrawal as against all liabilities for such compensation accruing prior to such withdrawal.

Any employer so withdrawing may, however, terminate his entire liability by paying to the state insurance manager such sum as said manager may deem sufficient to cover such liabilities. 


\section{Reinsurancc.}

Section 78. The state insurance manager may reinsure any risk, or any part thereof, and may enter into agreements of roinsurance in the same way and to the same extent as other in. surance carriers.

\section{Audit of Payrolls.}

Section 79. Every employer who is insured in the state insuranee fund shall keep a true and accurate record of the number of his employees and the wages paid by him, and shall furnish to the state insurance manager, upon demand, a sworm statement of the same. Such record shall be open to inspection at any time and as often as the state insuranee manager shall require to verify the number of the employees and the amount of the payroll.

\section{Falsification of Payroll.}

Seetion 80. An employer who shall wilfully inisrepresent the anount of the payroll upon which the premiums chargeable by the state insurance fund are to be based shall be liable to the state in ten times the amount of the difference between the premiums paid and the amonnt the employer should have paid had his payroll been correctly computed; and the liability to the state under this section shall be enforced in a civil action by the state insurance manager in the name of the state, or in his own name, and any amount so collected shall become a part of tho state insurance fund.

\section{Wilful Misrepresentation.}

Section 81. Any person who wilfully misrepresents any fact in order to obtain insurance in the state insurance fund at less than the proper rate for sueh insurance, or in order to obtain payment out of such fund, shall be guilty of a misdemeanor.

\section{Inspections.}

Section 82. The state insurance manager shall have tho right to inspect the plants and establishments of employers insured in the state insurance fund; and the inspectors designated by the state insurance manager shall have free access 
to such premises during regular working hours, and at other reasonable times.

\section{Disclosures Prohibited.}

Section 83. Information acquired by the state insurance manager or his officers or cmployees from employers or employees pursuant to this Act shall not be open to public inspection, and any officer or employee of the state insurance manager who, without authority of the state insurance manager or pursuant to his rules, or as otherwise required by law, shall disclose the same shall be guilty of a misdemeanor.

\section{Approval of Premium Rates.}

Section 84. All premium lates fixed by the state insurance manager for the state insurance fund shall be subject to the approval of the insurance commissioner in the same way and to the same extent as may be provided by law in the case of private insurance carriers.

\section{Payment of Compensation.}

Section 85. The state insurance manager shall submit each month to the state auditor an estimate of the amount necessary to meet the current disbursements for insurance losses and workmen's compensation from the state insurance fund, during each succeeding calendar month, and when such estimate shall be approved by the state auditor, the state treasurer is authorized to pay the same out of the state insurance fund. At the end of each calendar month the state insurance manager shall account to the state auditor for all moneys so received, furnishing proper vouchers therefor.

\section{Reports of State Insurance Manager.}

Sectiou 86. The state insurance manager shall file with the state insurance commissioner such reports as may be required of other insurance carriers; and shall also, whenever so requested by the state insurance commissioner, furnish him with such further information as he may need for the performance of the duties imposed upon him by this Act. 


\section{VIII.}

REPORTS, DEFINITIONS, AND GENERAL PROVISIONS.

\section{Report of Accident by Employers.}

Section 87. Every employer shall hereafter keep a record of all injuries, fatal or otherwise, received by his employees in the course of their employment. Within forty-eight hours, not counting Sundays and legal holidays, after the occurrence of an injury causing absence from work for one day or more, a report thereof shall be made in writing to the Industrial Accident Board on blanks to be procured from the Board for the purpose.

Upon the termination of the disability of the injured employee, the employer shall make a supplemental report upon blanks to be procured from the Board for that purpose. If the disability extends beyond a period of sixty days, the employer shall report to the Board at the end of such period that the injured employee is still disabled, and upon the termination of the disability shall file a final supplemental report as provided above.

The said reports shall contain the name and the nature of the business of the employer, the situation of the establishment, the name, age, sex, wages, and occupation of the injured employee, and shall state the date and the hour of the accident causing the injury, the nature and cause of the injury, and such other information as may be required by the Board.

Any employer who refuses or neglects to make the report re quired by this section shall be punished by a fine of not more than ( ) dollars for each offense.

Within sixty days after the termination of the disability of the injured employee, the employer or other party liable to pay the compensation provided for hy this Act shall file with the Board a statement showing the total parments made or to be made for compensation and for medical services for such injured employee.

Indiana.- In re Burk (1918) (Ind. App.). 119 X. F. 540. 


\section{Interstate Commerce.}

Section 88. This Act shall affect the liability of employers to employees engaged in interstate or foreign commerce or otherwise only so far as the same is permissible under the laws of the United States.

Indiana.- In re Burk (1918) (Ind. Chicago L. \& I. Ry. Co. (1917) (Ind. App.), 118 N. E. 540 ; Walker v. App.), 117 N. E. 969.

\section{Reports of Industrial Accident Board.}

Section 89. Annually on or before the first day of February, the Board shall make a report to the legislature which shall include a properly classified statement of the expenses of the Board, together with any other matters which the Board deems. proper to report to the legislature, including any recommendations it may desire to make. The Board shall, at the samo time, send a copy of said report to the state insurance commissioner, and also to the state insurance manager.

\section{Definitions.}

Section 90. In this Act, unless the context otherwise requires:

(a) "Employer," unless otherwise stated, includes any body of persons, corporate or unincorporated, public or private, and the legal representative of a deceased employer. It includes the owner or lessee of premises, or other person who is virtually the proprietor or operator of the business there carried on, but who, by reason of their being an independent contractor, or for any other reason. is not the direct employer of the workmen there employed. If the employer is insured it includes his insurer so far as applicable.

(b) "Workman" is used as synonymous with "employee," and means any person who has entered into the employment of, or works under contract of service or apprenticeship with, an employer. It does not include a person whose employment is purely casual or not for the purpose of the employer's trade or business, or whose remuneration exceeds ( ) dollars a year. Any reference to a workman who has been injured shall, where the workman is dead, include a reference to his dependents as 
herein defined, if the context so requires, or, where tho employee is a minor or incompetent, to his committee or guardian or next friend.

(c) "Injury" or "personal injury" includes death re sulting from injury within ( ) years.

(d) The words "personal injury by accident arising out of and in the course of such employment" shall include an injury caused by the wilfull act of a third person directed against an employee because of his employment.

They shall not include a disease except as it shall result from the injury.

(e) "Employment," in the case of private employers, includes employment only in a trade or occupation which is carried on by the employer for the sake of pecuniary gain.

Public employment means employment by the state or by a county, city, or town, or by any of the other public corporations mentioned in Section 2.

It does not include the employment of public officials who are elected by popular vote or who receive salaries exceeding ( ) dollars a year.

(f) The word "Board," whenever used in this Act, unless the context shows otherwise, shall be taken to mean the Industrial Aecident Board.

(g) "Partial Disability." Diminished ability to obtain employment owing to disfigurement resulting from an injury may be held to constitute partial disability.

(b) "Wages" shall include the market value of board, lodging, fuel, and other advantages which can be estimated in money which the employce receives from the employer as a part of his remuneration.

"Wages" shall not include any sums which the employer has paid to the employee to cover any special expenses entailer on him by the nature of his emplornent.

(i) "Insurance Carrier" shall include the state insuraner manager representing the state insurance fund and also stock corporations or mutual associations from any of which crm. ployers have obtained workmen's compensation, insurance or 
guaranty insurance in accordance with the provisions of this Act.

(j) Any term shall include the singular and plural and both sexes where the context so requires.

Indiana.-Indian Creek Coal \& Smock (1917) (Ind. App.), $117 \mathrm{~N}$. Mining Co. v. Calvert (1918) (Ind. E 665; Polar Ice \& Fuel Co. v. App.) 119 N. E. 519; In re Maroney Mulray (1918) (Ind. App.), 119 N. (1917) (Ind. App.), 118 N. W. 134; In re Harraden (1917) (Ind. App.), 118 N. E. 142; Inland Steel Co. v. Lambert (1917) (Ind. App.), $118 \mathrm{~N}$. E. 162 ; Interstate Iron \& Steel Co. v. Szot (1917) (Ind. App.), $115 \mathrm{~N}$. E. 599; In re Ayers (1918) (Ind. App.), 118 N. E. 386; Zeitlow v. E. 149; United Paperboard Co. v. Lewis (1917) (Ind. App.), 117 N. E. 276.

Minnesota. - State v. District Court of Brown County (1917), 162 N. W. 678; State v. District Court of St. Louis County (1917), $164 \mathrm{~N}$. W. 585 .

\section{Unconstitutional Provisions.}

Section 91. If any part or section of this Act be decided by the courts to be unconstitutional or invalid, the same shall not affect the validity of the Act as a whole, or any part thereof which can be given effect without the part so decided to be unconstitutional or invalid.

\section{Penalties for False Representations.}

Section 92. If for the purpose of obtaining any benefit or payment under the provisions of this Act, either for himself or for any other person, any one wilfully makes a false statement or representation, he shall be guilty of a misdemeanor and liable to a fine of not exceeding ( ) dollars, and he shall forfeit all right to compensation under this Act after conviction for such offense.

Prior Injuries.

Section 93. The provisions of this Act shall not apply to injuries sustained, or accidents which occur, prior to the taking effect thereof.

\section{Rules of Construction.}

Section 94. (a) The rule that statutes in derogation of the common law are to be strictly construed shall have no application to this Act. 
(b) This Act shall be so interpreted and construed as to effect its general purpose to make uniform the law of those states which enact it.

Prior Statutes; Repeal.

Section 95. All Acts and parts of Acts inconsistent with this Act are hereby repealed.

\section{Title of Act.}

Section 96. This Act may be cited as the Uniform Workmen's Compensation Act.

\section{Time of Taking Effect.}

Section 97. Part VII of this Act shall take effect on the first day of July, nineteen hundred and ( ); the remainder thereof shall take effect on the first day of January, nineteen hundred and ( ). 


\section{APPENDIX.}

ELECTIVE ACT.

\section{Election to Come Under This Act.}

\section{Election by Employer and Employee.}

Section 1. This Act, except Sections ( ) relating to defenses, and Section ( ), relating to reports, shall not apply to any employer or employee unless prior to the injury they shall have so elected by agreement, either express or implied, as hereinafter provided. Such agreement shall be a surrender by the parties thereto of their rights to any other method, form, or amount of compensation or determination thereof than as provided in this Act, and shall bind the employee himself, his widow and next of kin and dependents as hereinafter defined, as well as the employer and those conducting his business during bankruptcy or insolvency.

Every contract of hiring-verbal, written, or implied-now in operation or made or implied prior to the time limited for this Act to take effect shall after this Act takes effect be presumed to continue subject to the provisions of this Act unless either party shall at any time prior to accident, in writing, notify the other party to such contract and the Board that the prorisions of this Act, other than Sections ( ) are not intended to apply.

Every contract of hiring-verbal, written, or implied-made subsequent to the time provided for this Act to take effect shall be presumed to have been made subject to the provisions of this Act, unless there be, as a part of said contract, an express statement in writing prior to accident, either in the contract itself or by written notice by either party to the other and the Board, that the provisions of this Act other than Sections ( ) are not intended to apply, and it shall be presumed that the parties have elected to be subject to the provisions of this Act and to be bound thereby. In the employment of minors this Act shall be presumed to apply unless the notice be given by or to the parent or guardian of the minor. 
The agreement for the operation of the provisions of this Act other than Sections ( ) may be terminated by either party upon sixty days' notice to the other and to the Board in writing prior to any accident.

\section{Defenses in Case Employer Does Not Elect To Come Under This Act.}

Section 2. If an employee has elected as aforesaid to come under this Act and his employer has elected as aforesaid not to come under this Act, then if an action is brought by the employee or his next of kin or personal representative to recover for personal injuries sustained after such election by the employer arising out of and in the course of his employment, it shall not be a defense-

(a) That the employee was negligent;

(b) That the injury was caused by the negligence of a fellow employee;

(c) That the employee had assumed the risk of the injury.

Defenses in Case Employee Does not Elect to Come Under This Act.

Section 3. If an employer has elected as aforesaid to come under this Act and his employee has elected as aforesaid not to come under this Act, then if an action is brought by the employee to recover damages for personal injuries sustained after the employee has so elected, and arising out of and in the course of his employment, the employer shall have all the defeuses which he would have had if this Act had not been enacted. 



\section{UNIFORM FOREIGN ACKNOWLEDGMENTS ACT}





\section{UNIFORM FOREIGN ACKNOWLEDGMENTS ACT}

At the Conference of the Commissioners on Uniform State Laws held at Washington, D. C., in October, 1914, a draft of the law to make uniform acknowledgments to deeds, etc., taken outside of the United States was considered, approved and adopted by the Conference and recommended to the various legislatures for enactment.

The act has been adopted in the following states: Louisiana, 1916; Maryland, 1916; Nevada, 1917; New Hampshire, 1917; Tennessee, 1919 ; Wisconsin, 1915. 
UNIFORM FOREIGN ACKNOWLEDGMENTS ACT.

\begin{tabular}{|c|c|c|c|c|c|c|}
\hline & $\begin{array}{r}\text { Laws } \\
1916, \\
\text { p. } 376 .\end{array}$ & $\begin{array}{c}\text { Laws } \\
1916, \\
\text { ch. } 174 .\end{array}$ & $\begin{array}{r}\text { Laws } \\
1917 . \\
\text { ch. } 152 .\end{array}$ & $\begin{array}{l}\text { Laws } \\
1917, \\
\text { ch. } 53 \text {, } \\
\text { p. } 501 .\end{array}$ & & $\begin{array}{r}\text { Laws } \\
1915, \\
\text { ch. } 275 .\end{array}$ \\
\hline $\begin{array}{l}\text { Uniform } \\
\text { Act } \\
\text { Sec. No. }\end{array}$ & $\begin{array}{c}1916 \\
\text { La. }\end{array}$ & $\begin{array}{l}1916 \\
\text { Md. }\end{array}$ & $\begin{array}{l}1917 \\
\text { Nev. }\end{array}$ & $\begin{array}{l}1917 \\
\text { N. H. }\end{array}$ & $\begin{array}{l}1919 \\
\text { Tenn. }\end{array}$ & $\begin{array}{l}1915 \\
\text { Wisc. }\end{array}$ \\
\hline $\begin{array}{l}1 \\
2 \\
3\end{array}$ & $\begin{array}{l}1 \\
2 \\
3\end{array}$ & $\begin{array}{l}5 \\
5 \\
5\end{array}$ & $\begin{array}{l}1 \\
2 \\
3\end{array}$ & $\begin{array}{l}1 \\
2 \\
3\end{array}$ & $\begin{array}{l}\text { Not } \\
\text { Yet } \\
\text { Out }\end{array}$ & $\begin{array}{l}1 \\
2^{*}, 3\end{array}$ \\
\hline
\end{tabular}




\section{UNIFORM FOREIGN ACKNOWLEDGMENTS ACT}

Section 1. All deeds or other instruments requiring acknowledgment, if acknowledged without the United States, shall be acknowledged before an ambassador, minister, envoy or charge d'affairs of the United States, in the country to which he is accredited, or before one of the following officers commissioned or accredited to act at the place where the acknowledgment is taken, and having an official seal, viz.: any consular officer of the United States; a notary public; or a commissioner or other agent of this state having power to take acknowledgments to deeds.

Section 2. Every certificate of acknowledgment, made without the United States, shall contain the name or names of the person or persons making the acknowledgment, the date when and place where made, a statement of the fact that the person or persons making the acknowledgment knew the contents of the instrument, and acknowledged the same to be his, her or their act; the certificate shall also contain the name of the person before whom made, his official title, and be sealed with his official seal and may be substantially in the following form: . (name of country).

. (name of city, province or other political subdivision).

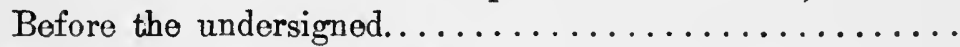
(naming the officer and designating his official title) duly commissioned (or appointed) and qualified, this day personally appeared at the place above named.................... (naming the person or persons acknowledging) who declarer that he (she or they) knew the contents of the foregoing instrument, and acknowledged the same to be his (her or' their) act. Witness my hand and official seal this............ day of

$19 \ldots$

[SEAL]

(name of officer). (official title). 
When the seal affixed shall contain the name or the official style of the officer, any error in stating, or failure to state otherwise the name or the official style of the officer, shall not render the certificate defective

Section 3. A certificate of acknowledgment of a deed or other instrument acknowledged without the United States befor any officer mentioned in Section 1 shall also be valid if in the same form as now is or hereafter may be required by law, for an acknowledgment within this state. 
UNIFORM PROBATE OF FOREIGN WILLS ACT 



\section{UNIFORM PROBATE OF FOREIGN WILLS ACT}

The subject of a uniform law covering the probate of foreign wills was taken up by the Commissioners of Uniform State Laws in 1909 and referred to the Committee on Wills, Descent and Distribution, on which Mr. W. O. Hart of Louisiana, was chairman.

In 1912, this committee submitted a draft of the proposed act, and in 1914, the committee submitted to the conference a resume of the statutes and decisions of the various states on the subject. The law in the various states was discovered from this resume to be very different, and the matter was referred back to the committo for further consideration.

In 1915, the committee submitted four drafts of a uniform law regarding the probate of foreign wills, and after discussion and amendment, the conference approved one of these drafts and recommended its adoption by the states. 
494 UNIFORM PROBATE OF FOREIGN WILLS ACT.

\begin{tabular}{|c|c|c|c|c|c|c|}
\hline & $\begin{array}{l}\text { Laws } \\
1913 \\
\text { p. } 155 .\end{array}$ & $\begin{array}{l}\text { Laws } \\
1917 . \\
\text { p. } 800 .\end{array}$ & $\begin{array}{c}\text { Laws } \\
1911, \\
\text { ch. 336, } \\
\text { p. } 597 .\end{array}$ & $\begin{array}{r}\text { l.aws } \\
1914, \\
\text { ch. } 238 .\end{array}$ & $\begin{array}{c}\text { Laws } \\
1911, \\
\text { ch. } 246 .\end{array}$ & $\begin{array}{c}\text { Navell's } \\
\text { Stat.. } \\
\text { p. 4385, } \\
\text { par. } 11025 .\end{array}$ \\
\hline $\begin{array}{l}\text { Uniform } \\
\text { Act } \\
\text { Sec. No. }\end{array}$ & $\begin{array}{l}1913 \\
\text { Alaska. }\end{array}$ & $\begin{array}{c}1917 \\
\text { Illinois. }\end{array}$ & $\begin{array}{c}1911 \\
\text { Kansas. }\end{array}$ & $\begin{array}{l}1914 \\
\text { Md. }\end{array}$ & $\begin{array}{l}1911 \\
\text { Mass. }\end{array}$ & $\begin{array}{l}1911 \\
\text { Mich. }\end{array}$ \\
\hline 1 & 1 & $\begin{array}{l}1,2,3 \\
4,5^{*}, 6\end{array}$ & 1 & 1 & L & 1 \\
\hline
\end{tabular}

\begin{tabular}{c|c|c|c|c|c}
\hline \hline & $\begin{array}{c}\text { Laws } \\
\text { 1915, } \\
\text { ch. 36, } \\
\text { p. 36. }\end{array}$ & $\begin{array}{c}\text { Comp. } \\
\text { Laws } \\
1917 .\end{array}$ & $\begin{array}{r}\text { Laws } \\
\text { 1911, } \\
\text { ch. 8. }\end{array}$ & $\begin{array}{c}\text { Comp. } \\
\text { Stat.; } \\
1917 .\end{array}$ & ch. 294. \\
\hline $\begin{array}{c}\text { Uniform } \\
\text { Act } \\
\text { Sec. No. }\end{array}$ & $\begin{array}{c}1915 \\
\text { Nevada. }\end{array}$ & $\begin{array}{c}1907 \\
\text { Utah. }\end{array}$ & $\begin{array}{c}\text { 1911 } \\
\text { Washington. }\end{array}$ & $\begin{array}{c}1895 \\
\text { Wisconsin. }\end{array}$ & $\begin{array}{c}1919 \\
\text { New York }\end{array}$ \\
\hline 1 & 1 & $6324^{*}$ & 1 & 2283 & $\ldots \ldots$ \\
\hline
\end{tabular}




\section{UNIFORM PROBATE OF FOREIGN WILLS ACT}

Be it enacted, etc.

Section 1. A will duly proved, allowed and admitted to probate outside of this state, may be allowed and recorded in the proper court of any county in this state, in which the testator shall have left any estate.

Section 2. When a copy of the will and the probate thereof, duly authenticated, shall be presented by the executor or by any other person interested in the will, with a petition for probate, the same must be filed and a time must be appointed for a hearing thereon and such notice must be given as required by law on a petition for the original probate of a domestic will.

Section 3. If upon hearing, it appears to the satisfaction of the court that the will has been duly proved, allowed and admitted to probate outside of this state, and that it was executed according to the law of the place in which the same was made, or in which the testator was at the time domiciled, or in conformity with the laws of this state, it must be admitted to probate, which probate shall have the same force and effect as the original probate of a domestic will.

Section 4. When a duly authenticated copy of a will from any state or country where probate is not required by the laws of such state or country, with a duly authenticated certificate of the legal custodian of such original will that the same is a true eopy, and that such will has become operative by the laws of such state or country, and when a copy of a notarial will in pos. session of a notary in a foreign state or country entitled to the custody thereof (the laws of which state or country require that such will remain in the custody of such notary), duly authenticated by such notary, is presented by the executor or other persons interested to the proper court in this state, such court shall appoint a time and place of hearing and notice thereof shall be given as in case of an original will presented for probate.

If it appears to the court that the instrument ought to be allowed in this state, as the last will and testament of the de- 
ceased, the copy shall be filed and recorded, and the will shall have the same effect as if originally proved and allowed in the said court.

Section 5. All laws and parts of laws in conflict or inconsistent herewith be and the same are hereby repealed.

Section 6. This Act may be cited as the Uniform Foreign Probate Act, and shall be so interpreted and construed as to effectuate its general purpose to make uniform the law of the states which enact it.

Section 7. This Act shall take effect from and after the ........ day of ......... 


\section{UNIFORM LAND REGISTRATION ACT}




\section{-}




\section{UNIFORM LAND REGISTRATION ACT}

The Uniform Land Registration Act is an adaptation of the Torrens system.

The Torrens system takes its name from Sir Robert Richard Torrens, anthor of the registration act adopted in South Australia on January 27, 1858, the principles of which soon spread throughout Australia, Tasmania, New Zealand, and other English possessions. The registration of possessory titles has been compulsory in London since 1897. The Torrens system was original with Sir Robert, but in the brief of Attorney General Knowlton in the suit of Tyler v. Judges (175 Mass. 71 ), it is stated:

"Registers of ownership have existed from time immemorial in Bohemia. In Vienna registers of 1368 are still preserved; in Prague, of 1377; in Munich, of 1440 . In the Rhine provinces the present system of registering land titles was introduced comparatively recently.

"Registration of title was made universal in Australia in 1811; it was adopted in Saxony in 1843; in Hungary in 184956 ; and in Prussia in 1872."

The subject was pending before the National Conference of Commissioners on Uniform State Laws from 1903 to 1915.

In 1903 the conference met at the Hot Springs of Virginia immediately following the fifteenth annual meeting of the Virginia State Bar Association, at which a land-registration bill prepared for Virginia was under discussion. One of the fruits of that discussion in the State Bar Association was a resolution adopted by the Conference of Commissioners for the appointment of a committee to report upon the feasibility of drafting a uniform act on the subject. And from 1903 down to the present time the Torrens land-registration system has been under discussion in the national Conference of Commissioners. At first the matter was referred to a special committee, but sinco 
1905 it has been in the hands of one of the standing committees of the Conference, formerly entitled "The committee on the Torrens system and registration of land titles," and now known as "The committee on registration of title to land" under the new constitution of the Conference. It chanced that in 1912 the draftsman of the Virginia act was made chairman of this committee of the Conference. In the meantime the original Virginia bill had been pending in every Legislature of Virginia since 1903 and had been subjected to the criticism not only of lawyers in Virginia, but of lawyers and publicists throughout the United States. It was used as the basis of the first tentative draft for the uniform land registration act presented to the national Conference of Commissioners on uniform state laws at their twenty-third annual conference held at Montreal in August, 1913. A second tentative draft was presented to the Conference at its twenty-fourth annual meeting held in the city of Washington in October, 1914. And in August, 1915, the third tentative draft was presented to the Conference in its twenty-fifth annual meeting held at Salt Lake City. Members of the committeo rendered valuable service and finally their labors were rewarded by the adoption of this third tentative draft, with certain amendments, after a prolonged and thorough discussion.

The resolution of the conference adopting the acts authorized the committee to make such verbal changes as they might deem appropriate not affecting any matter of substance and to recommend it to the legislatures of the various states for adoption as "The Uniform Land Registration Act." 


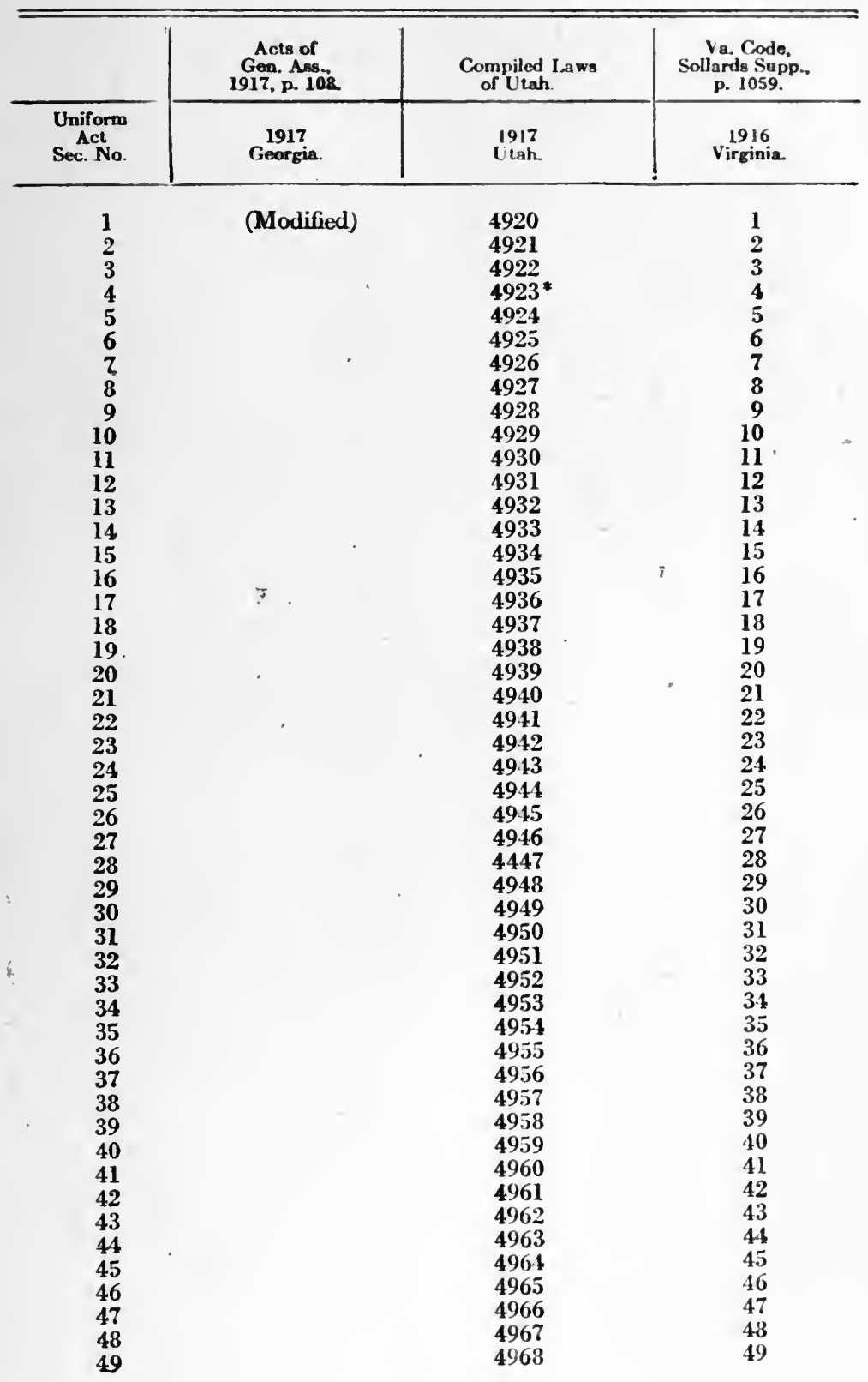


UNIFORM LAND REGISTRATION ACT.

\begin{tabular}{|c|c|c|c|}
\hline & $\begin{array}{c}\text { Acts of } \\
\text { Gen. Ass. } \\
\text { 1917, p. } 108 .\end{array}$ & $\begin{array}{l}\text { Compiled Laws } \\
\text { of Utah. }\end{array}$ & $\begin{array}{l}\text { Va. Code, } \\
\text { Sollard's Supp., } \\
\text { p. } 1059 .\end{array}$ \\
\hline $\begin{array}{l}\text { Uniform } \\
\text { Act } \\
\text { Sec. No. }\end{array}$ & $\begin{array}{c}1917 \\
\text { Georgia. }\end{array}$ & $\begin{array}{l}1917 \\
\text { Utah. }\end{array}$ & $\begin{array}{c}1916 \\
\text { Virginia. }\end{array}$ \\
\hline $\begin{array}{l}50 \\
51 \\
52 \\
53 \\
54 \\
55 \\
56 \\
57 \\
58 \\
59 \\
60 \\
61 \\
62 \\
63 \\
64 \\
65 \\
66 \\
67 \\
68 \\
69 \\
70 \\
71 \\
72 \\
73 \\
74 \\
75 \\
76 \\
77 \\
78 \\
79 \\
80 \\
81 \\
82 \\
83 \\
84 \\
85 \\
86 \\
87 \\
88 \\
89 \\
90\end{array}$ & & $\begin{array}{l}4969 \\
4970 \\
4971 \\
4972 \\
4973 \\
4974 \\
4975 \\
4976 \\
4977 \\
4978 \\
4979 \\
4980 \\
4981 \\
4982 \\
4983 \\
4984 \\
4985 \\
4986 \\
4987 \\
4988 \\
4989 \\
4990 \\
4991 \\
4992 \\
4993 \\
4994 \\
4995 \\
4996 \\
4997 \\
4998 \\
4999 \\
5000 \\
5001 \\
5002 \\
5003 \\
5004 \\
5005 \\
5006 \\
5007 \\
300 \\
5008\end{array}$ & $\begin{array}{l}\mathbf{5 0} \\
\mathbf{5 1} \\
52 \\
53 \\
54 \\
\mathbf{5 5} \\
\mathbf{5 6} \\
\mathbf{5 7} \\
\mathbf{5 8} \\
\mathbf{5 9} \\
\mathbf{6 0} \\
\mathbf{6 1} \\
\mathbf{6 2} \\
\mathbf{6 3} \\
\mathbf{6 4} \\
\mathbf{6 5} \\
\mathbf{6 6} \\
\mathbf{6 7} \\
\mathbf{6 8} \\
\mathbf{6 9} \\
\mathbf{7 0} \\
\mathbf{7 1} \\
\mathbf{7 2} \\
\mathbf{7 3} \\
\mathbf{7 4} \\
\mathbf{7 5} \\
\mathbf{7 6} \\
\mathbf{7 7} \\
\mathbf{7 8} \\
\mathbf{7 9} \\
80 \\
81 \\
\mathbf{8 2} \\
83 \\
\mathbf{8 4} \\
\mathbf{8 5} \\
\mathbf{8 6} \\
87 \\
\mathbf{8 8} \\
89 \\
90\end{array}$ \\
\hline
\end{tabular}




\section{UNIFORM LAND REGISTRATION ACT}

Secrion 1. Name of Act.

2. Definitions.

3. Purposes.

4. Courts of Land Registration.

5. Jurisdiction.

6. Powers.

7. Sessions.

8. Mode of Trial.

9. Proceedings to be in Rem.

10. Rules of Court.

11. Petitions for Rehearing, Appeals and Bills of Review.

12. Books and Cases for Record.

13. Court May be Held by Designated Judge.

14. Clerks to be Registrars of Title.

15. Duties and Powers of Registrars of Title.

16. Examiners of Titles.

17. Petition for Registration.

18. Petition by Representative.

19. Equity Practice.

20. Signature and Oath to Petition.

21. Contents of Petition.

22. Petition to be Filed and Docketed.

23. Notice of Lis Pendens.

24. Memorandum of Other Papers.

25. Reference to Examiner of Titles.

26. Report of Examiner.

27. Order of Publication in Rem.

28. Notice by Mail.

29. Notice by Posting on Land.

30. Notice to State.

31. Other Notice.

32. Effect of Notice.

33. Certificate of Service.

34. Time of Hearing.

35. Guardian Ad Litem.

36. Answer to letition.

37. Signature and Oath to Answer.

38. Action on Report of Examiner of Titles.

39. Order of Survey, ete. 
Srction 40. Petition May be Dismissed.

41. Amendments to Petition and Other Pleadings.

42. Land May be Dealt With, Pending Registration, Subject to Decree of the Court.

43. Certificate of Taxes Paid.

44. Decree of Registration is Final, Quiets Title, and Binds all the World, Subject to Appeal, etc.

45. Form of Decree and Manner of Registration.

46. Time of Taking Effect.

47. Registrar's Memorandum.

48. Entry in Registry of Titles.

49. Entry Book Kept by Registrars.

50. Register of Titles Kept by Registrar.

51. Certificate of Title.

52. Owner's Duplicate Certificate.

53. Certificates of Title to be Numbered and Memorials Thereon to be Signed and Sealed.

54. Transfers of the Whole of Any Registered Estate.

55. Partial Transfers, Encumbrances, Leases.

56. Memorials to be Noted.

57. Registration of Voluntary Transactions.

58. Registration of Involuntary Transactions.

59. Production of Duplicate Certificate Required.

60. Registration of Trusts, Conditions, Limitations and Other Equitable Interests and Estates.

61. Registration of Estates of Decedents.

62. Powers of Personal Representatives.

63. Registration of Delinquent Taxes and Levies.

64. Registration of Sales for Delinquent Taxes or Levies.

65. Same-Registration of Redemption.

66. Same-Registration of Final Sale, If no Redemption.

67. Same-Future Interests Not Affected.

68. Petitions Concerning Registered Land and Caveats and Decrees Thereon.

69. Same-Hearing and Decree.

70. Same - Service of Notice.

71. Proceedings Upon Loss or Destruction of Duplicate Certifieate.

72. Effect of Registration as Notice to Subsequent Purcbasers.

73. Effect of Registration Upon Adverse Claims.

74. Same-Fraud or Forgery.

75. Effect of Registration Procured Through Fraud or Forgery.

76. Land to Remain Forever Registered.

77. No Rights by Adverse Possession of Preseription.

78. Effect of Subsequent Dealings With Registered Land.

79. Conflicting Claims Between Registered Owners.

80. Fee for Original Registration. 
Secrion 81. Payments Into State Treasury Upon Trust.

82. Funds to be Invested.

83. Suits Against the Assurance Fund.

84. Defendants to Suits Against Assurance Fund.

85. Judgments Against the Assurance Fund.

86. When Assurance Fund Not Liable.

87. How Judgments Shall be Satisfier Out of Assurance Fund.

88. Fees of Registrar and Other Officers of the Court.

89. Referendum. 


\section{PART I.}

PRELIMINARY PROVISIONS.

Section 1.-(Name of Act. $)$-This Act may be cited as the Uniform Land Registration Act.

Section 2.-(Definitions.)-Words and phrases used in this Act are to be construed as follows:

(1) The words "voluntary transaction" mean all devises and all contractual or other acts or dealings, by any registered owner of any estate or interest in land with reference to such estate or interest, and to any statutory right or exemption claimed therein.

(2) The words "involuntary transaction" mean the transmission of registered land or any interest therein by descent, the rights of eurtesy and dower, all equitable rights and elaims, judicial proceedings or statutory liens or charges, the exercise of the right of eminent domain, the lien of delinquent taxes and levies affecting registered land, or any interest therein.

(3) The phrase "writing, instrument, or record" means all transactions, whether voluntary or involuntary, as herein defined.

(4) The word "registrar" means the elerk of the court having jurisdietion of the cause within the county or city in which the land lies. decree.

(5) The word "decree" means judgment, decision, order, or

(6) The word "appeal" means writ of error, supersedeas, or appeal.

(7) Except where the context requires a different construction, the word "court" means the court having jurisdiction for the settlement, registration, transfer, and assurance of titles to lands in the county or city where the land lies.

Section 3.-(Purposes. -For the certain, cheaper, and more speedy settlement, registration, transfer, and assurance of titles 
to land there is hereby established a system of land-title registration having the following purposes in detail:

(1) To establish or designate courts of land registration.

(2) To provide for the appointment and duties of registrars of title.

(3) To regulate proceedings to obtain registration of title.

(4) To authorize the adjudication of title.

(5) To prescribe the nature of certificates of title.

(6) To provide for the registration of subsequent dealings with registered titles.

(7) To regulate sundry proceedings after registration of title.

(8) To determine the logal effects of registration of title.

(9) To establish an assurance fund.

(10) And to regulate the fees for registration of titles.

\section{PART II.}

\section{COURTS OF LAND REGISTRATION.}

Section 4.-(Courts of Iand Registration.)-The courts throughout those portions of the state specified in section eighty-nine of this Act, and in those portions of the state which shall so elect as provided in said section, are hereby constituted or designated courts of land registration for the purpose of the settlement, registration, transfer, and assurance of titles to lands (or any interest therein as hereinafter provided) within thoir respective jurisdictions.

Section 5.-(Jurisdiction.) - Such courts shall have exclitsive, original, and general jurisdiction, subject to the right of appeal hereinafter allowed.

(1) Of all petitions and procedings for the registration of titles to lands.

(2) And of all transactions affecting registored titles to lands lying within their respective jurisdictions.

Section 6.-(Powers.)-Their powers shall include all tho powers possessed by the (circuit and corporation) courts of the 
state, in law and equity, for the purpose of enforcing any of the provisions of this act.

Section 7.-(Sessions.) - They shall be open as courts of land registration, except on Sundays and legal hoidays; and their process as such may be issued at any time, returnable as they may direct.

Section 8.-(Mode of Trial.) - The whole matter of law and fact in any case shall be heard and determined by the court: Provided, however, That on the motion of any person interested the court shall direct and frame an issue or issues to be tried by jury.

Section 9.-(Proceedings to be in Rem.) - The proceedings under any petition for the registration of land, and all procedings or transactions in relation to registered land, shall be proceedings in rem against the land, and the decrees of the court and registered transactions shall operate directly on the land, and shall vest and establish title thereto in accordance with the provigions of this Act.

Section 10.-(Rules of Court.)-The - court (court of last resort) shall from time to time make general rules and forms for procedure, subject to the provisions of this Act and the general laws, and such rules and forms shall be uniform throughout the state.

Section 11.-(Petitions for Rehearing, Appeals and Bills of Review.) - A petition for rehearing or an appeal may be taken (or a bill of review or bill of exceptions, or writ of certiorari) may be filed, within (ninety days) and not afterwards, from any decree of the court, under the same circumstances, in the same manner, and on the same conditions as if such decree had been rendered by a - court.

Said period may not be extended by any disability.

Section 12.-(Books and Cases for Record.) - It shall be the duty. of the - of each county (or the of each city) 
in which the office of a registrar of titles may be located to provide appropriate cases and other furniture for the safe and convenient keeping of all the books, documents, and papers in the custody of such registrar, and also an official seal, and all necessary books and such printed blanks and stationery for use in registration in such country or corporation as may be ordered by the court.

Section 13.- (Court May be Held by Designated Judge.)If the judge of the court for any reason shall become disqualified or temporarily incapacitated, the court may be held by any other judge of a court of record designated acoording to law.

\section{PART III.}

REGISTRARS AND EXAMINERS OF TITLES.

Section 14.-(Clerks to be Registrars of Title.)-The clerks of said courts shall be registrars of title under this Act.

(1) They shall do all things required of them by this Act, under the direction of their respective courts, and pursuant to rules and regulations established for such courts, and shall be governed by the same general laws as clerks of (circuit and munioipal) courts in so far as the same may be applicabie.

(2) Their official designation under this Act shall be registrar of title for their respective counties or cities.

(3) They shall qualify and give bond in accordance with law for the faithful performance of their duties as such.

Section 15.-(Duties and Powers of Rogistrars of Title.) -Registrars of title and their deputies shall be authorized and required, under the direotion of their respective courts-

(1) To issue process and to enter the decree of the court touching lands in their respective counties or cities;

(2) To enter and issue certificates of title as provided herein;

(3) To affix the seal of the court to such certificates and their duplicates;

(4) To make entries and memoranda and perform all acts of registration affecting the title to such lands; 
(5) To keep a separate account of all moneys with which they may be chargable under this Act, and to make a special return thereof in accordance with the general laws and the special provisions of this Act;

(6) And generally to perform such other acts as the court may prescribe.

Section 16.-(Examinel's of Titles.)-The courts of land registration shall appoint, subject to removal at any time, one or more attorneys at law in their respective counties or cities to be examiners of titles, or the court may, in any case on motion appoint special examiners.

(2) Their duty shall be to search the records and investigate all facts stated in the petition or otherwise brought to their notice in any case referred to them.

(3) They shall have the powers of (commissioners in chancery) and may hear the parties and receive evidence.

(4) They shall make report to the court, in the form required by it, with a certificate of their examination of the title and their findings of fact.

\section{PART IV. \\ PROCEEDINGS TO OBTAIN REgISTRATIOX.}

Section 17.-(Petition for Registration.) - Suit for registration of title shall be begun by a petition to the court by a person or persons claiming, singly or collectively-

(1) To own ; or

(2) To have the power of appointing or disposing of an estate in fee simple in any land whether subject to liens or not.

Section 18.-(Petition by Representative.)-Infants and other persons under disability may sue and defend by guardian, committec, or trustee, as the case may be, and corporations by an officer duly authorized.

(1) But the person in whose behalf the petition is made shall always be named as petitioner.

(2) A nonresident petitioner shall appoint a resident agent. upon whom process and notices may be served. 
Section 19.-(Equity Practica)-Except as otherwise provided, the suit shall be subject to the general rules of pleading and practice in equitable actions.

Section 20.-(Signature and Oath to Petition.)-The petition and any amendment thereto shall be signed and sworn to by each petitioner or, in the case of a corporation or person under disability, by the person authorized to file the petition.

Section 21.-(Contents of Petition.) - The petition shall set forth-

(1) A full description of the land and any improvements thereon, with the description and valuation in its last assessment for taxation.

(2) When, how, and from whom it was acquired.

(3) Whether or not it is occupied.

(4) An enumeration of all known liens, interests, and elaims, adverse or otherwise, vested or contingent.

(5) And the full names and addresses, if known, of all persons that may be interested by marriage or otherwise, including adjoining owners and occupants.

(6) The petition shall be accompanied by a plan made in accordance with the rules of court.

Section 22.-(Petition to be Filed and Docketed.)-The petition shall be filed with the registrar of titles, and shall be forthwith docketed, numbered, and indexed by him in a book to be known as the land registration docket of his county or city.

Section 23.-(Notice of Lis Pendens.) - The registrar shall also forthwith cause to be recorded and indexed in the proper record book of such county or eity a notice, such as is required by law for notice of lis pendens, which shall be filed with the petition, and which shall have the full force and effect of a notice of lis pendens.

Section 24.-(Memorandum of Other Papers.) - A memorandum of all other pleadings and papers filed with said registrar shall in each case be entered upon his registration docket under the proper number as aforesaid, and the papers in the 
cause and all writings, instruments, and records filed with him shall be safely kept by him in his office, duly numbered, dated, and indexed.

Section 25.-(Reference to Examiner of Titles.)-Upon the filing of a petition for the registration of any land, the court shall refer the same to one of the examiners of title provided for by the Act, to examine and report thereon.

Section 26.-(Report of Examiner.) - Such report shall include:

(1) An abstract of title to the land, made from the records, and all other evidence that can be reasonably obtained by the examiner.

(2) Full extracts from the records to enable the court to decide the questions involved.

(3) The names and addresses so far as ascertained of all persons interested in the land, as well as adjoining owners and occupants, showing their several interests and indicating upon whom and in what manner process should be served or notice given in accordance with the provisions of this Act.

Section 27.-(Order of Publication in Rem.)-Upon the filing of the report of the examiner of titles the court shall cause notice thereof to all persons shown therein to be entitled to the same and "to all whom it may concern," to be publishod and to be posted in the county or city where the land lies, in the same manner and with the same effect as an order of publication in other proceedings in rem, subject, however, to the limitation imposed by Section 11 of this Act.

Section 28.-(Notice by Mail.) - A copy of the order of publication shall in all cases be mailed by registered letter demanding a return, to every person interested, named in the petition or in the report of the examiner of titles whose address is given or known.

Section 29.-(Notice by Pasting on Land.) - The court shall also cause an attestad copy of said order to be posted in a con- 
spicuous place by the sheriff on each parcel of land included in the petition.

It shall require such sheriff to go upon the lands and ascertain and report to the court the names and addresses of any person or persons actually occupying the premises under any claim of title.

Section 30.-(Notice to State.)-If the petition involves the determination of any public rights or interests, the court shall cause a copy of the order of publication to be delivered by the registrar to the proper attorney for the state, county, or city.

Section 31.-(Other Notico.) - The court may cause other or further notice to be given in such manner and to such person as it may deem proper.

And such personal service of process as is required in equitable actions shall also be made upon residents of the state, not under disability, who are made known to the court before final decree and can be reached by its process, unless such service be waived by appearance or otherwise.

Section 32.-(Effect of Notice.) - Notice given under the preceding sections shall be in lieu of personal service of process, except as provided in Section thirty-one, and shall be conclusive and binding on all the world.

Section 33.-(Certificate of service.)-Certificates from the registrar and sheriff, or their deputies, showing the due execntion of said order of publication and the mailing and posting of copies thereof, as required by Sections twenty-seven to thirty, inclusive, shall be filed among the papers in the cause and be conclusive proof of such service.

Section 34.-(Time of Hearing.) - After the expiration of at least (fifteen) days from the publication and posting of said order of publication as aforesaid, the cause shall be set down for hearing.

Section 35.-(Guardian ad Litem.) - And thereupon the 
court shall appoint some discreet and competent (attorney at law) of the county or city in which the land lies, as guardian ad litem for all persons under disability, not in being, unascertained, unknown, or out of the state, who may have or appear to have an interest in or claim against the land.

Section 36.-(Answer to Petition.) - Any person having any interest in or claim against the land, whether named in the petition and order of publication or not, may appear and file an answer at any time before final decree, unless such person shall have heen served personally with notice.

Section 37.-( Signature and Oath to Answer.) - The answer shall be personally signed and sworn to by the claimant, or in case of a corporation or a person under disability, by the person authorized to file the answer, unless the court, for good cause shown, otherwise direct.

\section{PART V.}

\section{ADJUDICATION OF TITLE.}

Section 38.-(Action on Report of Examiner of Titles.) After the expiration of the time as provided by Section thirtyfour, the court may proceed to take such action as may be proper, upon the report of the examiner of titles and all other evidence before it with reference to the rights of all persons. appearing to have any interest in or claim against the land, and may refer the cause again or require further proof.

Section 39.-(Order of Survey, etc.) - While the cause is pending before the examiner of titles, or at any time before final decree, and whenever after initial registration a tract of land is subdivided, the court-

(1) May require the land to be surveyed, after due notice to owners of adjoining land, by a competent surveyor appointed by the court;

(2) Shall order durable bounds to be set and a plat thereof to be filed among the papers of the suit; 
(3) Shall enter all necessary docrees for the establishnent, declaration, and protection of the right and title of all persons appearing to have any interest in or claim against the land.

Section 40.-(Petition May be Dismissed.) - If in any ease the petitioner so desires, or if the court is of opinion that the petitioner's title is not and can not be made proper for registration, the petition may be dismissed without prejudice, on terms to be determined by the court.

Section 41.-(Amendments to petition and Other Pleadings.) -Amendments to petitions or other pleadings, or the sererance thereof, including joinder, substitution of ally person or persons, or discontinuance of parties, and the omission or severance of any portion or parcel of the land, may be ordered or allowed by the eourt at any time before final decree upon terms that may be just and reasonable; and the court may require facts to be stated in an amended petition in addition to those preescribed by this Act.

Section 42.- (Land May be Dealt With, Pending Registration, Subject to Decree of the Court.) - The land described in any petition may be dealt with pending registration as if no such petition had been filed.

(1) But any instrument admitted to record under the general laws in relation to such land pending action on said petition shall also be docketed and indexed as required by Section twentytwo of this Act.

(2) And any person who shall acquire any interest in or claim against such land shall at once appear as a petitioner or answer as a party defendant in the proceedings for registration, and such interest or claims shall be subject to the decree of the court.

Section 43.-(Certificate of Taxes Paid.) - No final decreo of registration shall be entered until proof is made by certificate from the proper officer that all taxes and levies assessed on said land and then due or delinquent have been paid in full. 
Section 44.-(Decree of Registration is Final, Quiets Title, and Binds all the World, Subject to Appeal, etc.)-If the court, after final hearing, is of opinion that the petitioner has title proper for registration, a decreo of confirmation and registration shall be entered; and every decree of registration entered in accordance with the provisions of this Aet-

(1) Shall bind the land and quiet the title thereto, except as herein otherwise provided;

(2) Shall be forever binding and conclusive upon all persons, resident or nonresident, ineluding the state, whether mentioned by name in the order of publication or included under the general description, "to all whom it may concern;"

(3) And shall not be attacked or opened or set.aside by reason of the absence, infancy, or other disability of any person affected thereby, nor by any proceeding at law or in equity for rehearing or reversing judgments or decrees, except as herein especially provided.

Section 45.-(Form of Decree and Manner of Registraticn.) -Every decree of initial registration and subsequent memorial shall be made in convenient form for transcription upon the certificate of title, showing the following items:

(1) Owners:

Name and residence of the owner, and whether married or unmarried, and the name of the consort, if any;

If the owner is under disability, the nature thereof, and if an infant, his age;

If a corporation, the place of incorporation and its chief office;

If a personal representative or trustee, the name of decedent or beneficiary.

(2) Land:

Doscription of the land as finally determined by the court: The estate of the owner therein;

Also all the rights and easements appurtenant to said land;

And also a description of all particular estates, easements, liens, or other encumbranees, or rights to which the land or the owner's estate is subject, showing their relative priorities. 
(3) Other matters:

Any other matter determined in pursuance of the provisions of this Act.

Section 46.-(Time of Taking Effect.) - Such decree or memorial shall take effect upon the land described therein as of tho day, hour, and minute it is filed for registration in the office of the proper registrar.

Section 47.-(Registrar's Memorandum.)-The registrar shall forthwith record the said decreo in the proper book of tho court, and shall forthwith enter and properly number, minutely date, and index a memorandum thereof on his land registration docket and in the entry book hereinafter directed to be kept by him, and shall cause to be recorded and indexed a like memorandum in the proper deed book of the county or eity.

\section{PART VI.}

CERTIFICATES OF TITLE.

Section 48.-(Entry in Registry of Titles.) - Said decreo or memorial, or so much thereof as may be ordered by the court. shall be copied, numbered, signed, and sealed with the seal of the court by said registrar and registered in the book hereinafter directed to be kept by him, to be known as the register of titles, for his county or city and when so registered shall constituto tho original certificate of title.

Subsequent certificates covering the same land shall be in a like form, but shall be designated "transfer certificate No.

(the number of the next previous certificate covering the same land), original certificate registered - (date, volume, and page of registration)."

New and appropriate numbers shall be adopted for any subsequent certificates not covering the whole of said land.

Section 49.-(Entry Book Kept by Registrars.) - (1) Each registrar shall keep an entry book in which he shall enter, in the order of their reception, a memorandum of any writing, in- 
strument, or record filed with him for registration, and shall noto in such book the year, month, day, hour, and minute of such filing.

(2) Ever such writing, instrument, or record shall be numbered indexed and indorsed with reference to the entry thereof and securely kept in the office of the registrar.

(3) Every such entry shall be minutely dated, numbered, and indexed, and shall refer to the certificate of title hereinafter mentioned, upon which, as well as upon its duplicate or duplicates. a memorandum of such entry shall be made.

Section 50.-(Register of Titles Kept by Registrar.)-Each registrar shall also keep a register of titles book. in which, under the director of the court, he shall-

(1) Register, number, and index the original certificates of title and all subsequent certificates of title, and all voluntary or involuntary transactions anthorized to be registered under this Act; and

(2) Note thereon, and also upon the duplicate certificate thereof, when originally issued or subsequently presented, the dar, hour, and minute of registration in each case in conformity with the date shown by the entry book.

Section 51.-(Certificate of Title.)-(1) Every certificate of title entered in the register of titles as aforesaid, together with the memorials thereon. if any, shall be known as "the certificate of title."

(2) Said certificate shall be conclusive evidence of all matters contained therein, except as otherwise provided in this Act.

(3) No erasure, alteration, or amendment of said certificate, or of any memorial thereon, shall be made except by order of conrt.

Section 52.-(Owner's Duplicate Certificate.)-An exact copy of the certificate of title shall be made, except that it shall be conspicuously stamped or marked "owner's duplicate" and shall be delivered to the owner or his attorney duly appointed upon his receipt therefor in writing upon said certificate of title, attested by the registrar or his deputy. 
Section 53.--(Certificates of 'Title to be Numbered and Me morials Thereon to be Signed and Sealed.) - (1) All the cortificates of title of land in each county or eity shall be numbered consecutively.

(2) A separate folium, with appropriate spaces for subsequent memorials, shall be devoted to each title in the register of titles for each county or eity.

(3) Every certificate and memorial thoreon shall appropriately conform to the requirements of Sections forty-five and forty-eight of this Aet as to particulars of form.

(4) Every memorial made upon any certificate of title or duplicate certificate under any provision of this Act shall be signed by the registrar and sealed with the seal of the court and minutely dated and numbered in conformity with the dato and number shown by the entry book.

\section{PAR'T VII.}

\section{REGISTRATION OF TRANSFERS AND OTHER TRANSACTIONS.}

Section 54.- (Transfers of the Whole of any Registered E,tate.) - Whenever the whole of any registered estate is transferred, the transaction shall be duly noted and registered in accordance with the provisions of this Act.

Thereupon the certificate of title and any duplicate certificate relating to such estate shall be canceled by the registrar of each county or eity in which the land, or any part thereof, lies, if desired by the registered owner, and a new certificate or certifieates of title shall be entered in the register of titles for such county or city, and a duplicate or duplieates thereof issued as the caso may require.

Section 55.-(Partial Transfers, Encumbrances, Ieases.)If only a portion of such estate is transferred, or in case of an encumbrance or lease for more than one year, the transaction shall be duly noted and registerod as aforeaid; and a new certificate of title shall be entered in the register of titles and new owner's duplicate certificate shall be issued for the portion transferred and the portion untransferred, or a beneficiary's duplicate or lessee's duplicate nay be issued as the case may require. 
Section 56.-(Memorials to be Noted.)-All registered encumbrances, rights, or adverse claims affecting the estate represented thereby, shall continue to be noted upon every outstanding certificate of title and duplicate certificate until the same shall have been released or discharged or terminated.

Soction 57.-(Registration of Voluntary Transactions.)be presented along with the writing or instrument filed for regIn voluntary transactions, the duplicate certificate of title must istration; and thereupon, and not otherwise, the registrar shall be authorized to register the transaction, under the direction of the court, upon proof of payment of all delinquent taxes and levies, if any.

Section 58.-(Registration of Involuntary Transactions. ) In involuntary transactions, a certificate from the proper state, county, city, or court officer, or a certified copy of the order, decree, or judgment of any court of competent jurisdiction, or other appropriate evidence of compliance with the statute in relation to such transaction, when filed in the office of the proper registrar, shall be authority for him to register the transaction under the direction of the eaurt: Provided, That any writing or instrument for the purpose of transferring, encumbering, or otherwise dealing with equitable interests in registered land may be registered with such effect as it may be entitled to have.

Section 59.-(Production of Duplicate Certificate Required.) - Whenever a duplicate certificate is not presented to the registrar along with any writing, instrument, or record filed for registration under this Act, he shall forthwith send notice by registered mail to the owner of such duplicate requesting him forthwith to produce the same in order that a memorial of the transaction may be made thereon; and such production may be required by suitable process of the court of necessary.

Section 60.-(Registration of Trusts, Conditions, Limitations, and Other Equitable Interests and Estates.) - Whenever a writing, instrument, or record is filed for the purpose of transferring registered land in trust, or upon any equitable condi- 
tion or limitation expressed therein, or for the purpose of creating or declaring a trust or other equitabie interest in such land withont transfer, the particulars of the trust, condition. limitation, or other equitable interest shall not be entered on the certificates, but it shall be sufficient to enter in the entry book and upon the certificates a memorial thereof by the terms "in trust," or " "pon condition," or other apt words, and to refer by number to the writing, instrument, or record authorizing or creat- ing the same.

And if express power is given to sell, encumber, or deal with the land in any manner, such power shall be noted upon the certificates by the terms "with power to sell," or "with power to encumber," or by other apt words.

And unless express power be given as aforesaid, no subsequent transfel or memorial shall be registered on such certificate except by special order of court.

Section 61.-(Registration of Estates of Decodents.)-(1) Lands and any estate or interest therein registered under this Act shall, upon the death of the owner, testate or intestate, go to his personal representative in like manner as personal estate, and shall be subject to the same rules of administration as personalty, except as otherwise provided in this Act.

(2) But nothing herein contained shall alter or affect-

(a) The course of ultimate descent under the statute of descents and distributions and the rights of dower and curtesy when duly registered;

(b) Nor the order in which real and personal assets, respectively, are now applicable in and toward the payment of funeral and testamentary expenses, debts, or legacies;

(c) Nor the liability of real estate to be charged with the payment of debts and legacios.

Section 62.-(Powers of Personal Representatives.)-(1) Subject to the powers, rights and duties of administration, the personal representatives of such deceased owner shall hold such real estate as trustees for the persons by law benefically entitled thereto; 
(2) But, unless otherwise entitled by law to commissions, shall be entitled to no commissions thereon except in cases of necessary sales in due course of administration;

(3) And the heirs at law or beneficiaries aforesaid shall have the same power of requiring a transfer of such estate as if it were personal estate.

Section 63.- (Registration of Delinquent Taxes and Levies.) -(1) It shall be the duty of the treasurer or other collector of . taxes or levies of each county, town, or city, not later than the - day of - in each year, to file an exact memorandum of the delinquency, if any, of any registered land for the nonpayment of the taxes or levies thereon, including the penalty therefor, in the office of the proper registrar for registration.

(2) If any such officer fail to perform said duty. he and his sureties shall be liable for the payment of said taxes and levies, with the penalty and interest thereon.

Section 64.-(Registration of Sales for Delinquent Taxes or Ievies.) - (1) Whenever any sale of registered land is made for delinquent taxes or levies, it shall be the duty of the treasurer or other officer making such sale, forthwith to file a memorandum thereof for registration in the office of the proper registrar.

(2) Thereupon the registered owner shall be required to produce his duplicate certificate for cancellation, and a new duplicate certificate shall be issued in favor of the purchaser, and the land shall be transferred on the land books to the name of such purchaser, unless such delinquent charges and all penalties and interest thereon be paid in full within 90 dars after the date of such sale.

(3) But a memorial shall be entered upon the certificate of title, and also upon any such new duplicate certificate, reserving the privilege of redemption in accordance with law.

Section 65.-(Same-Registration of Redemption.)-In case of any redemption under the preceding section, a memorial of the fact shall be duly registered; and if a duplicate certificate has been issued to any purchaser, the same shall be cancelled 
and a new duplicate shall be issued to the person who has re deemed.

Section 66.-(Same-Registration of Final Sale, if no Redemption.) - (1) If there be not redemption under said soction in accordance with law, it shall be the duty of the treasurer, or other collector of taxes of the county or corporation in which the land lies, to sell the same, at public auction, for eash, having first given reasonable notice of the time and place of sale.

(2) The proceeds of sale shall be applied-

First, to the payment of all taxes then due the state, and all levies then due the county, town, or city, with interest, penalty and costs;

Second, to the payment of all sums paid by any person who purchased at the former tax sale, with interest and the additional sum of $\$ 5$;

Third, to the payment of a eommission to the officer making the sale of fire per centum on the first $\$ 300$ and two per centum on the residue of the proceeds;

Fourth, to the satiofaction of any liens other than said taxes and levies registered against said land in the order of their priorities ;

Fifth, and the surplus, if any, to the person in whose name the land was previously sold for taxes, subject to redemption, as provided by section sixty-four of this Act, his heirs, personal representatives, or assigns.

(3) A memorial of the sale under this section shall be duly registered, and a new certificate shall be entered and a duplicate issued in favor of the purchaser, in whom title shall be thereby vested as registered owner, in accordance with the provisions of this Aet.

Section 67.-(Same-Future Interests Not Affected.)Nothing in the preceding section shall be so construed as to affect, or divest, the title of a tenant in revision or remainder to any real estate which has been returned delinquent and sold on account of the default of the tenant for life in paying the taxes or levies assessed thereon. 


\section{PART VIII.}

\section{SUNDRY PROCEEDINGS AFTER REGISTRATION.}

Section 68.-(Petitions Concerning Registered Land and Caveats and Decrees Thereon.) - Any registered owner of any estate or interest in land, or any person having any claim against registered land arising from any other cause than fraud or forgery since the land was registered, may, within ninety days after the claim or cause of complaint shall have arisen, petition the court for relief in any matter within its jurisdiction; and it shall be the duty of the proper registrar, upon the request of any such person, to register a memorial that such petition has been or will be filed, which memorial shall serve as a caveat and be notice to all persons.

(2) And whenever any registrar is in doubt as to the proper registration to be made in any case, or when any person is aggrieved by any act or refusal to act by the registrar, the question may be likewise submitted by petition.

Section 69.-(Same-Hearing and Decree.)-After notice to the parties interested, the court shall hear the cause, and, with due regard to the provisions of this Act, shall enter such decree as justice and equity may require, which shall be registered, and take effect in like manner as the original decree for registration.

Section 70.-(Same-Service of Notice.) - Notice in lieu of process under this Act or otherwise in relation to registered land, may be served upon any person by registered mail, and the post office registry return receipt shall be evidence of such service, and shall be binding, whether such person resides within or without the state; but the court may in any case order different or further service by publication once a week for four successive weeks in some convenient newspaper or otherwise, which shall be likewise binding.

Section. 71.-(Proceedings Upon Loss or Destruction of Duplicate Certificate.) - (1) Whenever a duplicate certificate 
of title is lost or destroyed, the owner, or his personal representative, may petition the court for the issuance of a new duplicate.

(2) Notice of such petition shall be published once a week for four successive weeks, under the direction of the court, in some convenient newspaper.

(3) Upon satisfactory proof that said duplicate eertificato has been lost or destroyed, the eourt may direct the issuance of a new duplicate eertificate, which shall be appropriately designated and take the place of the original duplieate.

\section{PAR'T IX.}

LEGAI, EFFECTS OF REGISTR.TTION OF TITLE.

Section 72.- (Effeet of Registration as Notice to Subsequent Purchasers.) - Every voluntary or involuntary transiction which, if recorded, filed, or entered in any elerk's office would affect unregistered land, shall, if duly registered in the office of the proper registrar, and not otherwise, be notice to all persons from the time of such registration and operate in accordance with law and with the provisions of this Aet upon any registered land in the county or eity of such registrar to which it relates.

Section 73.-(Effect of Registration Upon Adverse Claims.) - Every registered owner of any estate or interest in land brought under this Aet shall hold the land free from any and all adverse claims, rights, or encumbrances not noted on the certificate of title, except-

First. Liens, claims, or rights arising or existing under the laws or Constitution of the United States which the statutes of this state can not require to appear of record under registry laws.

Second. Taxes and levies assessed thereon but not delinquent.

Third. Any lease for a term not exceeding one year under which the land is actıally occupied.

Section 74.-(Same-Frand or Forgery.) - The protection of the foregoing section shall not apply to the benofit of a registered owner in cases of fraud or forgery to which he is a party 
or in which he is a privy without valuable consideration paid in good faith.

Section 75.-(Effect of Registration Procured Through Fraud or Forgery.) - Any registration procured through frand or forgery may be set aside by the court according to the rules of equity; but the rights and title of an innocent intervening registered cneumbrancer or purchaser for value and without notice shall not be affected thereby. And in all such easos the injured party may pursue all his legal and equitable remedies against the party or parties to such fraud or forgery.

Section 76.-C(Tand to Remain Forever Registered.)-The obtaining of a decree of registration and the entry of a certificate of title shall be construed as an agreement running with the land, and the same shall forever remain registered land, strbject to the provisions of this Act and all amendments thereof.

Section 77.-(No Rights by Adverse Poszession of Prescription.) - No title to, nor right, nor interest in, registered land in derogation of that of the registered owner shall be aequired by prescription or adverse possession.

Section 78.- (Effect of Subsequent Dealings with Registered Iand.) - Except as otherwise specially provided by this Act, registered land and ownership therein shall be subject to the same rights, burdens, and incidents as unregistered land, and may be dealt with by the owner, and shall be subject to the jurisdiction of the courts in the same manner as if it had not been registered.

(2) But registration shall be the only operative act to transfer or affect the title to registered land, and shall date from the time the writing, instrument, or record to be registered is duly filed and entered in the office of the proper registrar.

(3) Subject to the provisions of Section 73 hereof, no voluntary nor involuntary transaction shall affect the title to registered land until registered in accordance with the requirements of this Act. 
Section 79.-(Conflicting Claims Between Registered Owners.) - In case of conflicting claims between registered owners, the right, title, or estate derived from or held under the older certificate of title shall prevail.

\section{PART X.}

\section{ASSURANCE FUND.}

Section 80.-(Fee for Original Registration.)-Upon (the filing of the petition for) the original registration of any land under this Aet there shall be paid to the registrar one-tenth of one per centum of the assessed value of such land as an assurance fund, which shall be subject to the trusts and conditions hereinafter declared for the uses and purposes of this Act.

Section 81.-(Payments Into State Treasury Upon Trust.) -All moneys received by the registrars under the preceding section shall be kept in a separate account, and shall be paid into the state treasury upon the special trust and condition that the same shall be set aside by the — in trust as a separate fund for the uses and purposes of this Act, to be known as the "land registration assurance fund," which said fund is hereby appropriated to the uses and purposes set forth in this Act.

Section 82.-(Funds to be Invested.)- - Said moneys, in so far as the same may not be required to satisfy any judgment certified against the assurance fund under Section eighty-fivo of this Act, shall be invested by the treasurer of the state in state bonds in trust for the uses and purposes set forth in this Act until said fund amounts to the sum of (five hundred thonsand) dollars; but the income, or so much thereof as may be required therefor, may be applied towards the payment of the expenses of the administration of this Act and the satisfaction of any such judgment.

Whenever and so long as the face value of the bonds purchased as aforesaid equals said sum of $\$ 500,000$, other moneys thereafter coming into said fund, together. with any income not $\mathrm{r}$ quired for the purposes aforesaid, shall be transferred from the land registration assurance fund to the general treasury. 
Section 83.-(Suits Against the Assurance Fund.)--Any person who had no actual notice of any registration under this Act by which he may be deprived of any estate or interest in land, and who is without remedy herennder, may within two years next after the time at which the right to bring such action shall have first accrued to him or to some person through whom he claims, bring an action against the treasurer of the state in the _ court of _ for the recovery ont of the assurance fund of any damages to which he may be entitled by reason of of such deprivation.

(2) The assurance fund shall be defended in such action and in any appeal by the attorney general for the state.

(3) The measure of damages in such action shall be the value of the property at the time the right to bring such action first acclued, and any judgment rendered therefor shall be paid as hereinafter provided.

(4) If any person entitled to bring such action be under the disability of infancy, insanity, imprisonment, or absence from the state in the service of the state or of the United States at the time the right to bring such action first accrued, the same may be brought by him or his privies within two years after the removal of such disability.

Section 84.- (Defendants to Suits Against Assurance Fund.) - If such action be brought to recover for loss or damage arising only through the legal operation of this Act, then the treasurer of the state shall be the sole defendant.

(2) But if such action be brought to recover for loss or damage arising on account of any registration made or procured through the fraud or wrongful act of any person not exercising a judicial function, then both the treasurer of the state and such person shall be made parties defendant.

Soction S5.-- (Judgments Against the Assurance Fund.)If judgment be rendered for the plaintiff in any such action, execution shall issue against the defendants, if any, other than the treasurer of the state.

(2) And if snch execution be returned unsatisfied in wholo or in part, or if there be no such defendants, then the clerk of 
the court in which the judgment was rendered shall certify to the - - the amount due on account thereof, and the same shall then be paid by said treasurer out of the assuraneo fund on warrant from said —under the special appropriation hereby made of said fund for that purpose.

(3) Any person other than the treasurer of the state against. whom any such judgment may have been rendered shall remain liable therefor, or for so much thereof as may be paid out of the assurance fund, and said treasurer may bring suit at any time to enforce the lien of such judgment against such person or his estate for the recovery of any amount, with interest, paid out of the assurance fund as aforesaid.

Section 86.-(When Assurance Fund Not Tiable.)-The assurance fund shall not, under any circumstances, be liable for any loss, damage, or deprivation occasioned by a breach of trust, whether express, implied, or constructive, on the part of the registered owner of any estate or interest in land.

Section 87.- (How .Judgments Shall be Satisfied Out of Assurance Fund.) - If at any time the assurance fund be insufficient to satisfy any judgment certified against it as aforcsaid, the unpaid amount shall bear interest and be paid in its order out of any moneys thereafter coming into said fund.

\section{PART XI.}

FEES FOR REGISTRATION.

Section 88.- (Fees of Registrar and Other Officers of the Court.) - The fees payable under this Act shall be as follows:

(a) To registrars: For docketing, indexing, and filing any original petition and exhibits therewith and publishing and mailing the notices thereof, the postage required and $\$ 3$.

For docketing, indexing, and filing any other paper, 50 cents.

For the entry of the original certificate of title and issning one duplicate certificate and recording and indexing memorandum, $\$ 3$.

For each additional duplicate, 50 cents. 
For the registration of any writing, instrument, or record, or any memorial, including every act necessary therefor, $\$ 1$.

(b) To examiners of titles: For examining title and making report to the court, one-tenth of one per centum of the value of the land, and postage and $\$ 10$.

(c) To sheriffs: For ascertaining and reporting to court the names and addresses of the persons actually occupying the premises described in any petition, $\$ 1$.

(d) For any service of the registrars, or of any sheriff or surveyor not specially provided for herein, such fee as may be allowed by law for like services in other cases.

\section{PART XII}

\section{APPLICATION OF ACT.}

Section 89.-(Referendum.) - This Act shall not apply to land in any city or county, except the - until it shall be so determined by the votes of a majority of those voting for or against the adoption thereof at any general or special election to be held in such city or county, after notices thereof shall have been duly posted for at least thirty days at each voting precinct in such city or county by order of the judge of the court of such city or county upon the petition of one hundred frecholders residing in such city or fifty freeholders residing in such county, the question to be submitted by ballots upon which the words "For land registration" and "Against land registration" shall be printed, and one or the other of said expressicns being stricken out as the voter may favor or oppose the Act.

Section 90. This Act shall be so interpreted and construed as to effectuate its general purpose to make uniform the law of those states which enact it. 


\section{UNIFORM LIMITED PARTNERSHIP ACT}





\section{UNIFORM LIMITED PARTNERSHIP ACT}

In pursuance of a resolution adopted at the Milwaukec Conference in 1912, the Committee on Commercial Law directed its attention to the preparation of the first draft of a Limited Partnership Act. This draft was submitted to the Conference held at Salt Lake City, Utah, in August, 1915, and it was recommitted to the committee for re-drafting in the light of the discussion had, with directions to the committee to report a new draft the following year.

At the conference in Chicago in August, 1916, the new draft was approved and recommended to the various legislatures for enactment into law.

The following states have adopted the Limited Partnership Act: Alaska, 1917; Illinois, 1917; Maryland, 1918; Pennsylvania, 1917; 'Tennessee, 1919, Virginia, 1918. 


\begin{tabular}{|c|c|c|c|c|c|c|}
\hline & $\begin{array}{l}\text { Session } \\
\text { I,ABws of } \\
\text { Alaska. } \\
1917 \text {. }\end{array}$ & $\begin{array}{l}\text { laws of } \\
\text { 1llinois. } \\
1917 .\end{array}$ & $\begin{array}{l}\text { Laws of } \\
\text { Md. } \\
1918 .\end{array}$ & $\begin{array}{c}\text { Laws of } \\
\text { Pend. } \\
1917 .\end{array}$ & $\begin{array}{l}\text { laws of } \\
\text { Tenn. } \\
1919 .\end{array}$ & $\begin{array}{c}\text { Acts of } \\
\text { Assembly. } \\
1918 \text {. }\end{array}$ \\
\hline $\begin{array}{l}\text { Uniform } \\
\text { Act } \\
\text { Sec. No. }\end{array}$ & $\begin{array}{c}1917 \\
\text { Alaska. }\end{array}$ & $\begin{array}{c}1917 \\
\text { Illinois. }\end{array}$ & $\begin{array}{l}1918 \\
\text { Md. }\end{array}$ & $\begin{array}{l}1917 \\
\mathrm{~Pa} .\end{array}$ & $\begin{array}{l}1919 \\
\text { Tenn. }\end{array}$ & $\begin{array}{l}1918 \\
\text { Va. }\end{array}$ \\
\hline 1 & 1 & 1 & 1 & 1 & 1 & 1 \\
\hline 2 & 2 & 2 & 2 & 2 & 2 & 2 \\
\hline 3 & 3 & 3 & 3 & 3 & 3 & 3 \\
\hline 4 & 4 & 4 & 4 & 4 & 4 & 4 \\
\hline 5 & 5 & 5 & 5 & 5 & 5 & 5 \\
\hline 6 & 6 & 6 & 6 & 6 & 6 & 6 \\
\hline 7 & 7 & 7 & 7 & 7 & 7 & 7 \\
\hline 8 & 8 & 8 & is & 8 & 8 & 8 \\
\hline 9 & 9 & 9 & 9 & 9 & 9 & 9 \\
\hline 10 & 10 & 10 & 10 & 10 & 10 & 10 \\
\hline 11 & 11 & 11 & 11 & 11 & 11 & 11 \\
\hline 12 & 12 & 12 & 12 & 12 & 12 & 12 \\
\hline 13 & 13 & 13 & 13 & 13 & 13 & 13 \\
\hline 14 & 14 & 14 & 14 & 14 & 14 & 14 \\
\hline 15 & 15 & 15 & 15 & 15 & 15 & 15 \\
\hline 16 & 16 & 16 & 16 & 16 & 16 & 16 \\
\hline 17 & 17 & 17 & 17 & 17 & 17 & 17 \\
\hline 18 & 18 & 18 & 18 & 18 & 18 & 18 \\
\hline 19 & 19 & 19 & 19 & 19 & 19 & 19 \\
\hline 20 & 20 & 20 & 20 & 20 & 20 & 20 \\
\hline 21 & 21 & 21 & 21 & 21 & 21 & 21 \\
\hline 22 & 22 & 22 & 22 & 22 & 22 & 22 \\
\hline 23 & 23 & 23 & $22 \mathrm{~A}$ & 23 & 23 & 23 \\
\hline 24 & 24 & 24 & $22 B$ & 24 & 24 & 24 \\
\hline 25 & 25 & 25 & $22 \mathrm{C}$ & 25 & 25 & 25 \\
\hline 26 & 26 & 26 & $22 \mathrm{D}$ & 26 & 26 & 26 \\
\hline 27 & 27 & 27 & $22 \mathrm{E}$ & 27 & 27 & 27 \\
\hline 28 & 28 & 28 & $22 \mathrm{~F}$ & 28 & 28 & 28 \\
\hline 29 & 29 & 29 & $22 \mathrm{G}$ & 29 & 29 & 29 \\
\hline 30 & 30 & 30 & 2211 & 30 & 30 & 30 \\
\hline 31 & 31 & 31 & $\ldots$ & 31 & 31 & 31 \\
\hline
\end{tabular}




\section{UNIFORM LIMITED PARTNERSHIP ACT}

Secrion 1. Limited Partnership Defined.

2. Formation.

3. Business Which llay be Carried On.

4. Claracter of Limited Partner's Contribution.

5. Name Not to Contain Surname of Limited Partner. Fxceptions.

6. Liability for False Statements in Certificate.

7. Limited Partner Not Liable to Creditors.

8. Admission of Additional Limited Partners.

9. Rights, Powers and Liabilities of a General Partner.

10. Rights of a Limited Partner.

11. Status of Person Frroneously Believing Himself a Limited Partner.

12. One Person Botlı Genera] and Limited Partner.

13. Loans and Other Business Transactions With Limited Partner.

14. Relation of Limited Partners Inter Se.

15. Compensation of Limited Partner.

16. Withdrawal or reduction of Limited Partner's Contribution.

17. Liability of Limited Partner to Partnership.

18. Nature of Limited Partner's Interest in Partnership.

19. Assignment of Limited Partner's Interest.

20. Effect of Retirement, Death or Insanity of a General Partner.

21. Death of Limited Tartner.

22. Rights of Creditors of Limited Partner.

23. Distribution of Assets.

24. When Certificate Shall be Cancelled or Amended.

25. Requirements for Amendment and for Cancellation of Certificate.

26. Parties to Actions.

27. Name of Act.

28. Rules of Construction.

29. Rules for Cases Not ['rovided for in This Act.

30. Provisions for Existing Limited Partnerships.

31. Act (Acts) Repealed. 


\section{UNIFORM LIMITED PARTNERSHIP ACT}

Section 1.-(Limited Partnership Defined.) -A limited partnership is a partnership formed by two or more persons under the provisions of Section 2, having as members one or more general partners and one or more limited partners. The limited partners as such shall not be bound by the obligations of the partnership.

Section 2.-(Formation.)-(1) Two or more persons desiring to form a limited partnership shall

(a) Sign and swear to a certificate, which shall state

I. The name of the partnership,

II. The character of the business,

III. The location of the principal place of business,

IV. The name and place of residence of each member; general and limited partners being respectively designated,

$V$. The term for which the partnership is to exist,

VI. The amount of cash and a description of and the agreed value of the other property contributed by each limited partner,

VII. The additional contributions, if any, agreed to be made by each limited partner and the times at which or events on the happening of which they shall be made,

VIII. The time, if agreed upon, when the contribution of each limited partner is to be returned,

IX. The share of the profits or the other compensation by way of income which each limited partner shall receive by reason of his contribution,

$\mathrm{X}$. The right, if given, of a limited partner to substitute an assignee as contributor in his place, and the terms and conditions of the substitution,

XI. The right, if given, of the partners to admit additional limited partners,

XII. The right, if given, of one or more of the limited partners, to priority over other limited partners, as to contributions or as to compensation by way of income, and the nature of such priority. 
XIII. The right, if given, of the remaining general partner or partners to continue the business on the death, retirement or insanity of a general partner, and

XIV. The right, if given, of a limited partner to demand and receive property other than cash in return for his contribution.

(b) File for record the certificate in the office of (here designate the proper office.)

(2) A limited partnership is formed if there has been substantial compliance in good faith with the requirements of paragraph (1).

Section 3.-(Business Which May Be Carried on.)-A limited partnership may carry on any business which a partnership without limited partners may carry on, except (here designate the business to be prohibited).

Section 4.-(Character of Limited Partner's Contribution.) - The contribution of a limited partner may be cash or other property, but not services.

Section 5.-(A Name Not to Contain Surname of Limited Partner; Exceptions. ) - (1) The surname of a limited partner shall not appear in the partnership name, unless

(a) It is also the surname of a general partner, or

(b) Prior to the time when the limited partner became such the business had been carried on under a name in which his surname appeared.

(2) A limited partner whose name appears in a partnership name contrary to the provisions of paragraph (1) is liable as a general partner to partnership creditors who extend credit to the partnership without actual knowledge that he is not a general partner.

Section 6.-(Liability for False Statements in Certificate.) - If the certificate contains a false statement, one who suffers loss by reliance on such statement may hold liable any party to the certificate who knew the statement to be false. 
(a) At the time he signed the certificate; or

(b) Subsequently, but within a sufficient time before the statement was relied upon to enable him to eancel or amend the certificate, or to file a petition for its cancellation or amendment as provided in Section 25 (3).

Section 7.-(Limited Partner not Liable to Creditors.) - A limited partner shall not become liable as a general partner unless, in addition to the exercise of his rights and powers as a limited partner, he takes part in the control of the business.

Section 8.-(Admission of Additional Limited Partners.)After the formation of a limited partnership, additional limited partners may be admitted upon filing an amendment to the original certificate in accordance with the requirements of Section 25.

Section 9.-(Rights, Powers and Liabilities of a General Partner.--(1) A general partner shall have all the rights and powers and be subject to all the restrictions and liabilities of a partner in a partnership without limited partners, except that without the written consent or ratification of the specific act by all the limited partners, a general partner or all of the general partners have no authority to

(a) Do any act in contravention of the certificate,

(b) Do any act which would make it impossible to carry on the ordinary business of the partnership,

(c) Confess a judgment against the partnership,

(d) Possess partnership property, or assign their rights in specific partnership property, for other than a partnership purpose,

(e) Admit a person as a general partner,

(f) Admit a person as a limited partner, unless the right so to do is given in the certificate,

(g) Continue the business with partnership property on the death. retirement or insanity of a general partner, unless the right so to do is given in the certificate. 
Section 10.-(Rights of a Limited Partner.)-(1) A limited partner shall have the same rights as a general partner to

(a) Have the partnership books kept at the principal place of business of the partnership, and at all times to inspect and copy any of them,

(b) Have on demand true and full information of all things affecting the partnership, and a formal account of partnership affairs whenever eircumstances render it just and reasonable, and

(c) Have dissolution and winding up by decree of eourt.

(2) A limited partner shall have the right to receive a share of the profits or other eompensation by way of income, and to the return of his contribution as provided in Sections 15 and 16.

Section 11.- (Status of Person Erroneously Believing Himself a Limited Partner.) -A person who has contributed to the eapital of a business conducted by a person or partnership erroneously believing that he has become a limited partner in a limited partnership, is not, by reason of his exercise of the rights of a limited partner, a general partner with the person or in the partnership earrying on the business or bound by the obligations of such person or partnership; provided that on ascertaining the mistake he promptly renounces his interest in the profits of the business or other compensation by way of income.

Section 12.- (One Person Both General and Limited Partner.)-(1) A person may be a general partner and a limited partner in the same partnership at the same time.

(2) A person who is a general, and also at the same time a limited partner, shall have all the rights and powers and be subject to all the restrictions of a general partner; except that, in respect to his eontribution, he shall have the rights against the other members which he would have had if he were not also a general partner.

Section 13.-(Loans and Other Business Transactions With Limited Partner.)-(1) A limited partner also may loan 
money to and transact other business with the partnership, and, unless he is also a general partner, receive on account of resulting claims against the partnership, with general creditors, a pro rata share of the assets. No limited partner shall in respect to any such claim

(a) Receive or hold as collateral security any partnership property, or

(b) Receive from a general partner or the partnership any payment, conveyance, or release from liability, if at the time the assets of the partnership are not sufficient to discharge partnership liabilities to per'sons not claiming as general or limited partners.

(2) The receiving of collateral security, or a payment, conveyance, or release in violation of the provisions of paragraph (1) is a fraud on the creditors of the partnership.

Section 14.-(Relation of Limited Partners Inter Se.)Where there are several limited partners the members may agree that one or more of the limited partners shall have a priority over other limited partners as to the return of their contributions, as to their compensation by way of income, or as to any other matter. If such an agreement is made it shall be stated in the certificate, and in the absence of such a statement all the limited partners shall stand upon equal footing.

Section 15.-(Compensation of Limited Partner.)-A limited partner may receive from the partnership the share of the profits or the compensation by way of income stipulated for in the certificate; provided, that after such payment is made, whether from the property of the partnership or that of a general partner, the parnership assets are in excess of all liabilities of the partnership except liabilities to limited partners on account of their contributions and to general partners.

Section 16.- (Withdrawal or Reduction of Limited Partner's Contribution.)-(1) A limited partner shall not receive from a general partner or out of partnership property any part of his contribution until 
(a) All liabilities of the partnership, except liabilities to generál partners and to limited partners on account of their contributions, have been paid or there remains property of the partnership sufficient to pay them,

(b) The consent of all members is had, unless the return of the contribution may be rightfully demanded under the provisions of paragraph (2), and

(c) The certificate is cancelled or so amended as to set forth the withdrawal or reduction.

(2) Subject to the provisions of paragraph (1) a limited partner may rightfully demand the return of his eontribution

(a) On the dissolution of a partnership, or

(b) When the date specified in the certificate for its return has arrived, or

(c) After he has given six months' notice in writing to all other members, if no time is specified in the certificate either for the return of the contribution or for the dissolution of the partnership.

(3) In the absence of any statement in the certificate to the contrary or the consent of all members, a limited partner, irrespective of the nature of his contribution, has only the right to demand and receive cash in return for his contribution.

(4) A limited partner may have the partnership dissolved and its affairs wound up when

(a) He rightfully but unsuccessfully demands the return of his contribution, or

(b) The other liabilities of the partnership have not been paid, or the partnership property is insuffieient for their payment as required by paragraph (1a) and the limited partner would otherwise be entitled to the return of his eontribution.

Section 17.- (Liability of Limited Partner to Partnership.)-(1) A limited partner is liable to the partnership.

(a) For the difference between his contribution as actually made and that stated in the certificate as having been made, and

(b) For any unpaid contribution which he agreed in the certificate to make in the future at the time and on the conditions stated in the certificate. 
(2) A limited partner holds as trustee for the partnership

(a) Specific property stated in the certificate as contributed by him, but which was not contributed or which has been wrongfully returned, and

(b) Money or other property wrongfully paid or conveyed to him on account of his contribution.

(3) The liabilities of a limited partner as set forth in this section can be waived or compromised only by the consent of all nembers; but a waiver or compromise shall not affect the right of a creditor of a partnership, who extended credit or whose claim arose after the filing and before a cancellation or amendment of the certificate, to enforce such liabilities.

(4) When a contributor has rightfully received the return in whole or in part of the capital of his contribution, he is nevertheless liable to the partnership for any sum, not in excess of such return with interest, necessary to discharge its liabilities to all creditors who extended credit or whose claims arose before such return.

Section 18.- (Nature of Limited Partner's Interest in Partnership.) - A limited partner's interest in the partnership. is personal property.

Section 19.-(Assignment of Limited Partner's Interest.) (1) A limited partner's interest is assignable.

(2) A substituted limited partner is a person admitted to all the rights of a limited partner who has died or has assigned his interest in a partnership.

(3) An assignee, who does not become a substituted limited partner, has no right to require any information or account of the partnership transactions or to inspect the partnership books; he is only entitled to receive the share of the profits or other compensation by way of income, or the return of his contribution, to which his assignor would otherwise be entitled.

(4) An assignee shall have the right to become a substituted limited partner if all the members (except the assignor) con- 
sent thereto or if the assignor, being thereunto empowered by the certificate, gives the assignee that right.

(5) An assignee becomes a substituted limited partner when the certificato is appropriately amended in aceordance with Section 25.

(6) The substituted limited partner has all the rights and powers, and is subject to all the restrictions and liabilities of his assignor, except those liabilities of which he was ignorant at the time he beeame a limited partner and which could not be ascertained from the certificate.

(7) The substitution of the assignee as a limited partner does not release the assignor from liability to the partnership under Sections 6 and 17.

Section 20.-(Effect of Retirement, Death or Insanity of a General Partner.) - The retirement, death or insanity of a general partner dissolves the partnership, unless the business is continued by the remaining general partners

(a) Under a right so to do stated in the eertificate, or

(b) With the consent of all members.

Seetion 21.-(Death of Limited Partner.)-(1) On the death of a limited partner his executor or administrator shall have all the rights of a limited partner for the purpose of settling his estate, and such power as the deceased had to constitute his assignee a substituted limited partner.

(2) The estate of a deceased limited partuer shall be liable for all his liabilities as a limited partner.

Section 22.-(Rights of Creditors of Limited Partner.)(1) On due application to a court of competent jurisdietion by any judgment ereditor of a limited partner, the court may charge the interest of the indebted limited partner with payment of the unsatisfied amount of the judgment debt; and may appoint a receiver, and make all other orders, directions, and inquiries which the eircumstances of the case may require. 
(2) The interest may be redeemed with the separate property of any general partner, but may not be redeemed with partnership property.

(3) The remedies conferred by paragraph (1) shall not be deemed exclusive of others which may exist.

(4) Nothing in this Act shall be held to deprive a limited partner of his statutory exemption.

Section 23.-(Distribution of Assets.)-(1) In settling accounts after dissolution the liabilities of the partnership shall be entitled to payment in the following order:

(a) Those to creditors, in the order of priority as provided by law, except those to limited partners on account of their contributions, and to general partners,

(b) Those to limited partners in respect to their share of the profits and other compensation by way of income on their contributions,

(c) Those to limited partners in respect to the capital of their contributions,

(d) Those to general partners other than for capital and profits,

(e) Those to general partners in respect to profits,

(f) Those to general partners in respect to capital.

(2) Subject to any statement in the certificate or to subsequent agreement, limited partners share in the partnership assets in respect to their claims for capital and in respect to their claims for profits or for compensation by way of income on their contributions respectively, in proportion to the respective amounts of such claims.

Section 24.- (When Certificate Shall be Cancelled or Amended.)--(1) The certificate shall be cancelled when the partnership is dissolved or all limited partners cease to be such. 
(2) A certificate shall be amended when

(a) There is a change in the name of the partnership or in the amount or character of the contribution of any limited partner,

(b) A person is substituted as a limited partner,

(c) An additional limited partner is admitted,

(d) A person is admitted as a general partner,

(e) A general partner retires, dies, or becomes insane, and the business is continued under Section 20 .

(f) There is a change in the character of the business of the partnership,

(g) There is a false or erroneous statement in the certificate,

(b) There is a change in the time as stated in the certificate for the dissolution of the partnership or for the return of a contribution,

(i) A time is fixed for the dissolution of the partnership, or the return of a contribution, no time having been specified in the certificate, or

(j) The members desire to make a change in any other statement in the certificate in order that it shall accurately represent the agreement between them.

Section 25.-(Requirements for Amendment and for Cancellation of Certificate.)-(1) The writing to amend a certificate shall

(a) Conform to the requirements of Section 2 (1a) as far as necessary to set forth clearly the change in the certificate which it is desired to make, and

(b) Be signed and sworn to by all members, and an amendment substituting a limited partner or adding a limited or general partner shall be signed also by the member to be substituted or added, and when a limited partner is to be substituted, the amendment shall also be signed by the assigning limited partner.

(2) The writing to cancel a certificate shall be signed by all members. 
(3) A person desiring the cancellation or amendment of a certificate, if any person designated in paragraphs (1) and (2) as a person who must exccute the writing refuses to do so, may petition the (here designate the proper court) to direct a cancellation or amendment thereof.

(4) If the court finds that the petitioner has a right to have the writing executed by a person who refuses to do so, it shall order the (here designate the responsible official in the office designated in Section 2) in the office where the certificate is recorded to record the cancellation or amendment of the certificate; and where the certificate is to be amended, the court shall also cause to be filed for record in said office a certified copy of its decree setting forth the amendment.

(5) A certificate is amended or cancelled when there is filed for record in the office (here designate the office designated in Section 2) where the certificate is recorded

(a) A writing in accordance with the provisions of paragraph (1), or (2) or

(b) A certified copy of the order of court in accordance with the provisions of paragraph (4).

(6) After the certificate is duly amended in accordance with this section, the amended certificate shall thereafter be for all purposes the certificate provided for by this Act.

Section 26.--(Parties to Actions.)-A contributor, unless he is a general partner, is not a proper party to proceedings by or against a partnership, except where the object is to enforce a limited partner's right against or liability to the partnership.

Section 27.-(Name of Act.) - This Act may be cited as the Uniform Limited Partnership Act.

Section 28.-(Rules of Construction.)-(1) The rule that statutes in derogation of the common law are to be strictly construed shall have no application to this Act.

(2) This Act shall be so interpreted and construed as to. effect its general purpose to make uniform the law of those states which enact it.

(3) This Act shall not be so construed as to impair the 
obligations of any contract existing when the Act goes into effect, nor to affect any action or proceedings begun or right accrued before this Act takes effect.

Section 29.-(Rules for Cases not Provided for in this Act.) -In any case not provided for in this Act the rules of law and equity, including the law merchant, shall govern.

Section 30.-(Provisions for Existing Limited Partnerships.)-(1) A limited partnership formed under any statute of this state prior to the adoption of this Act, may become a limited partnership under this Aet by complying with the provisions of Section 2; provided the eertificate sets forth

(a) The amount of the original contribution of each limited partner, and the time when the contribution was made, and

(b) That the property of the partnership exceeds the amount. sufficient to discharge its liabilities to persons not claiming as general or limited partner's by an amount greater than the sum of the contributions of its limited partners.

(2) A limited partnership formed under any statute of this state prior to the adoption of this Act, until or unless it becomes a limited partnership under this Act, shall continue to bo governed by the provisions of (here insert proper reference to the existing limited partnership Act or Acts), except that such partnership shall not be renewed unless so provided in the original agreement.

Section 31.-[Act (Acts) Repealed.]-Except as affecting existing limited partnerships to the extent set forth in Section 30, the Act (Acts) of (here designate the existing limited partnership Act or Acts) is (are) hereby repealed. 

UNIFORM ACT FOR THE EXTRADITION OF PERSONS OF UNSOUND MIND. 



\section{UNIFORM EXTRADITION ACT}

Under a resolution adopted by the Conference October 14, 1914, a Special Committee on a Uniform Law for the Extradition of Lunaties was appointed, to eonsider the question of providing by Uniform State Statute for the return upon gubernational requisition of lunatics who may flee or have been removed from the state of their residence. The Committee submitted an Act at the Conference held in Salt Lake City, Utah, Angust 10-16, 1915. This Aet was re-eommitted for further consideration. At the Seventy-sixth Ammual Meeting of the Conference, held in Chicago, Ill., August 23-29, 1916, the present Act was submitted. This Aet was adopted, approved and recommended to the various legislations for enactment into law. 


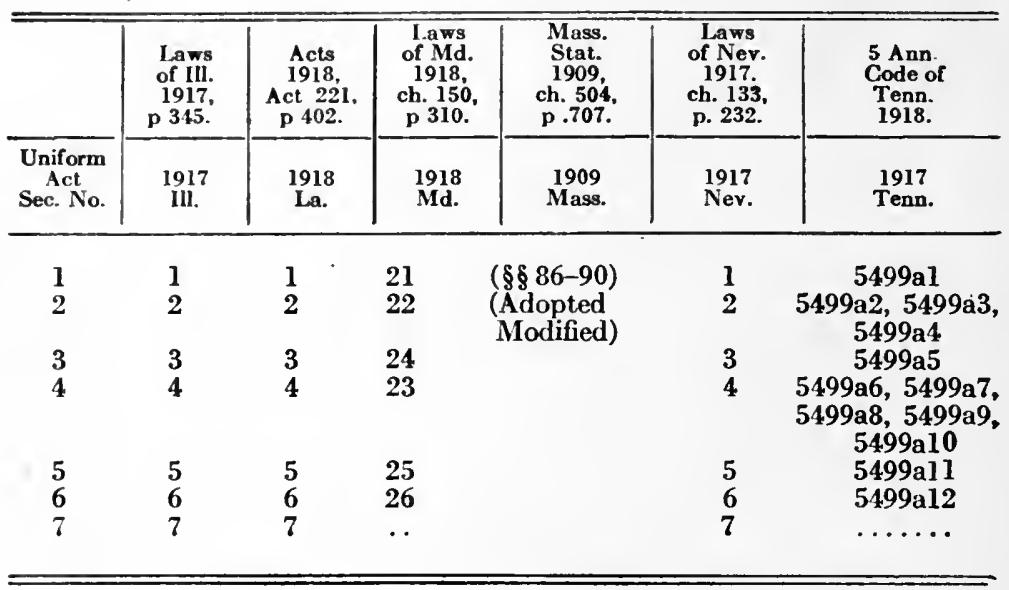




\section{UNIFORM EXTRADITION ACT}

Section 1. Name of the Act.

2. Definition of Terms.

3. Persons Subject to the Act.

4. Procedure.

5. Limitation.

6. Interpretation.

7. Repeal.

Section 1.-(Name of the Act. $)$ - This Act may be cited as the Uniform Act for Extradition of Persons of Unsound Mind.

Section 2.-(Definition of Terms.)-The terms "flight" and "fled" as used in this Act, shall be construed to mean any voluntary or involuntary departure from the jurisdiction of the court where the proceedings hereinafter mentioned may have been instituted and are still pending, with the effect of avoiding, impeding or delaying the action of the court in which such proceedings may have been instituted or be pending, or any such departure from the state where the person demanded then was, if he then was under detention by law as a person of unsound mind and subject to detention. The word "state" wherever used in this Act shall include states, territories, districts and insular and other possessions of the United States. As applied to a request to return any person within the purview of this Act to or from the District of Columbia, the words "executive authority," "Governor" and "Chief Magistrate" respectively shall include a justice of the Supreme Court of the District of Columbia and other authority.

Section 3.-(Persons Subject to the Act.) - A person alleged to be of unsound mind found in this state, who has fled from another state, in which at the time of his flight:

(a) He was under detention by law in a hospital, asylum or other institution for the insane as a person of unsound mind; or

(b) He had been theretofore determined by legal proceedings to be of unsound mind, the finding being unreversed and 
in full force and effect, and the control of his person having been acquired by a court of competent jurisdiction of the state from which he fled; or

(c) $\mathrm{He}$ was subject to detention in such state, being then his legal domicile (personal service of process having been made) bused on legal proceedings there pending to have him declared of unsound mind:

Shall, on demand of the executive authority of the state from which he fled, be delivered up to be removed thereto.

Section 4.-(Procedure.)-Whenever the executive authority of any state demands of the executive authority of this state, any fugitive within the purview of Section 3 and produces a copy of the commitment, decree or other judicial process and proceedings, certified as authentic by the Governor or Chief Magistrate of the state whence the person so charged has fled, with an affidavit made before a proper officer showing the person to be such a fugitive, it shall be the duty of the execntive authority of this state to cause him to be apprehended and secured, if found in this state, and to cause immediate notice of the apprehension to be given to the executive authority making such demand, or to the agent of such authority appointed to receive the fugitive, and to cause the fugitive to be delivered to such agent when he shall appear. If no such agent appears within thirty days from the time of the apprehension, the fugitive may be discharged. All costs and expenses incurred in the apprehending, securing, maintaining and transmitting such fugitive to the state making such demand, shall be paid by such state. Any agent so appointed who receives the fugitive into his custody shall be empowered to transmit him to the state from which he has fled. The executive authority of this state is hereby rested with the power, on the application of any person interested, to demand the return to this state of any fugitive within the purview of this Act.

Section 5.-(Limitation.)-Any proceedings under this Act shall be begun within one year after the flight referred to in this Act. 
Soction 6.-(Interpretation.)-This Act shall be so interpreted and construed as to effectuate its general purpose to make uniform the law of those states which enact it.

Section 7.-(Repeal.) -All acts or parts of acts inconsistent with this Act are hereby repealed. 



\section{UNIFORM FLAG ACT}





\section{UNIFORM FLAG ACT}

In 1915 the Committee on Uniform Flag Law reported to the Conference in Salt Lake City, a Uniform Act which was approved by that Conference. At the conference in Chicago in 1916, the Committee on the Uniform Flag Law submitted a draft of a Uniform Flag Law which had been rewritten since the previous conference, and it recommended the draft as a substitute for the one approved at the meeting in Salt Lake City in August, 1915.

At the National Conference in Saratoga Springs, New York, in August and September, 1917, the Committee on the Uniform Flag Law submitted a draft of a Uniform Flag Law which was a revision of the one of 1916 and which it recommended to the Conference as a substitute for the act approved at the meeting in Salt Lake City in 1915.

The Conference finally approved and adopted a Uniform Flag Law as printed in this volume and recommended the same to the legislatures of the various states and territories for enactment.

The act has been adopted in the states of Louisiana and Maryland in 1918. 


\begin{tabular}{|c|c|c|c|}
\hline & & $\begin{array}{c}\text { Acts } \\
1918 \\
\text { Act } 220 \text {, } \\
\text { p } 401 .\end{array}$ & $\begin{array}{c}\text { Laws } \\
\text { of Md. } \\
1918 \\
\text { ch. } 28 \mathrm{i} \text {. } \\
\text { p } 676 .\end{array}$ \\
\hline & $\begin{array}{l}\text { Uniform } \\
\text { Act } \\
\text { Sec No. }\end{array}$ & $\begin{array}{c}1918 \\
\text { Louisiana. }\end{array}$ & $\begin{array}{c}1918 \\
\text { Maryland. }\end{array}$ \\
\hline$=$ & $\begin{array}{l}1 \\
2 \\
3 \\
4 \\
5 \\
6 \\
7 \\
8 \\
9\end{array}$ & $\begin{array}{l}1 \\
2 \\
3 \\
4 \\
5 \\
6 \\
7 \\
8 \\
9\end{array}$ & $\begin{array}{l}74 \\
74 \mathrm{~A} \\
74 \mathrm{~B} \\
74 \mathrm{C} \\
74 \mathrm{D} \\
\dddot{74 E} \\
74 \mathrm{~F} \\
\ldots\end{array}$ \\
\hline
\end{tabular}




\section{UNIFORM FLAG ACT}

Section 1.-(Definition.) - The words flag, standard, color, ensign or shield, as used in this Act, shall inelude any flag, standard, color, ensign or shield, or eopy, picture or representation thereof, made of any substance or represented or produced thereon, and of any size, evidently purporting to be such flag, standard, color, ensign or shield of the United States or of this state, or a copy, picture or representation thereof.

Section 2.-(Desecration.) - No person shall, in any manner, for exhibition or display :

(a) Place or cause to be placed any word, figure, mark picture, design, drawing or advertisement of any nature upon any flag, standard, color, ensign or shield of the United States or of this state, or authorized by any law of the United States or of this state; or

(b) Expose to public view any such flag, standard, color, ensign or shield upon which shall have been printed, painted or otherwise produced, or to which shall have been attached, appended, affixed or annexed any such word, figure, mark, picture, design, drawing or advertisement; or

(c) Expose to public view for sale, manufacture, or otherwise, or to sell, give or have in possession for sale, for gift or for use for any purpose, any substance, being an article of merchandise, or receptacle, or thing for holding or earrying merchandise, upon or to which shall have been produced or attached any such flag, standard, color, ensign or shield, in order to advertiso, eall attention to, decorate, mark or distinguish such article or subr stance.

Section 3.-(Mutilation.) -No person shall publiely mutilate deface, defile, defy, trample upon, or by word or act cast contempt upon any such flag, standard, color, ensign or shield. 
Section 4.-(Exceptions.) - This statute shall not apply to any act permitted by the statutes of the United States (or of this state), or by the United States Army and Navy regulations, nor shall it apply to any printed or written document or production, stationery, ornament, $\mathrm{p}$ : ture or jewelry whereon shall be depicted said flag, standard, color, ensign or shield with no do sign or words thereon and disconnected with any advertisement.

Section 5.-(Penalty.) - Any violation of Section 2 of this Act shall be a misdemeanor and punishable by a fine of not more than ....... dollars. Any violation of Section 3 of this Act shall be punishable by a fine of not more than ..... dollars, or by imprisonment for not more than ..... days, or by both fine and imprisonment, in the discretion of the Court.

Section 6.-(Inconsistent Acts Repealed.)-All laws and parts of laws in conflict herewith are hereby repealed.

Section 7.-(Interpretation.)-This Act shall be so construed as to effectuate its general purpose and to make uniform the laws of the states which enact it.

Section 8.- (Name of Act.) - This Act may be cited as the Uniform Flag Law.

Sec. 9.-(Time of Taking Effect.)-This Act shall take effect...$\ldots$. days after .......... 
UNIFORM CONDITIONAL SALES ACT 



\section{UNIFORM CONDITIONAL SALES ACT}

At the National Conference of Commissioners on Uniform State Laws at Salt Lake City, Utah, in August, 1915, a resolution was adopted that the subject of Conditional Sales Contracts be referred to the Committee on Commercial Law for consideration with directions to draft a Uniform Act on that subject, if in its judgment it should deem that wise, and to employ such expert assistance as it might deem proper.

In accordance with this resolution the Committee retained the services of Prof. Bogert of Cornell University who prepared a tentative draft of the act which was submitted to the Conference held at Chicago in August, 1916, and after being debated section by section, was then recommitted to the Committee on Commercial Law.

The second tentative draft, revised by Prof. Bogert, was submitted to the Conference at Saratoga Springs, New York, in 1917, and was considered by the Conference sitting as a committee of the whole. The Conference recommended that the act be again recommitted to the Committee on Commercial Law for consideration in the light of the discussion and suggestions, and that it be reported to the 1918 Conference.

At the conference in Cleveland, Ohio, in August, 1918, a resolution was adopted approving the third tentative draft of the Uniform Conditional Sales Act and recommending the same to the various legislatures for enactment.

The act has been adopted in New Jersey in 1919. 


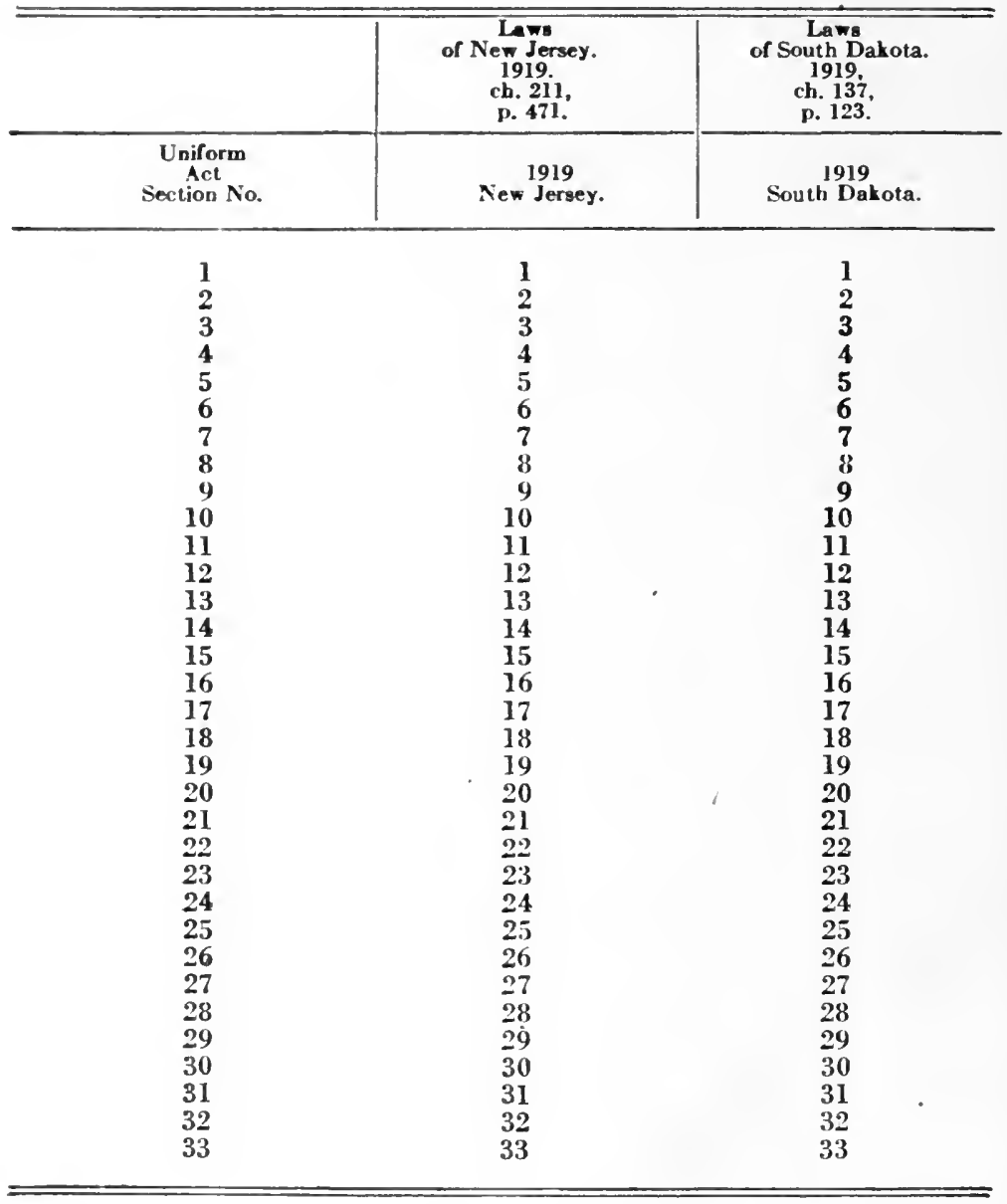




\section{UNIFORM CONDITIONAL SALES ACT}

Secriox 1. Definition of Terms.

2. Primary Rights of Buyer.

3. Primary Rights of Seller.

4. Conditional Sales Valid Except as Otherwise Provided.

5. Conditional Sales Void as to Certain Persons.

6. Place of Filing.

7. Fixtures.

8. Railroad Equipment or Rolling Stock.

9. Conditional Sale of Goods for Resale.

10. Filing.

11. Refiling.

12. Cancellation of Contract.

13. Prohibition of Removal or Sale Witlout Fotice.

14. Refiling on Removal.

15. Fraudulent Injury. Concealment, Removal or Sale.

16. Retaking Possession.

17. Notice of Intention to Retake.

18. Redemption.

19. Compulsory Resale bý Seller.

20 Resale at Option of Parties.

21. Proceeds of Resale.

22. Deficiency on Resale.

23. Rights of Parties When There is no Resale.

24. Election of Remedies.

25. Recovery of Part Payments.

26. Waiver of Statutory Protection.

27. Loss and Increase.

28. Act Prospective Only.

29. Rules for Cases Not Provided for.

30. Uniformity of Interpretation.

31. Short Title.

32. Inconsistent Laws Repealed.

33. Time of Taking Effect. 


\title{
UNIFORM CONDITIONAL SALES ACT
}

\author{
AN ACT.
}

Section 1.-(Definition of Terms.)-In this Act "Conditional sale" means (1) any contract for the sale of goods under which possession is delivered to the buyer and the property in the goods is to vest in the buyer at a subsequent time upon the payment of part or all of the price, or upon the performance of any other condition or the happening of any contingency; or (2) any contract for the bailment or leasing of goods by which the bailee or lessee contracts to pay as compensation a sum substantially equivalent to the value of the goods, and by which it is agreed that the bailee or lessee is bound to become, or has the option of becoming the owner of such goods upon full compliance with the terms of the contract.

"Buyer" means the person who buys or hires the goods covered by the conditional sale, or any legal suecessor in interest of such person.

"Filing district" means the subdivision of the state in which conditional sale contracts, or copies thereof, are required by this Act to be filed.

"Goods" means all chattels personal other than things in action and money, and includes emblements, industrial growing crops, and things attached to or forming a part of land which are agreed to be severed before sale or under the conditional sale.

"Performance of the condition" means the occurrence of the event upon which the property in the goods is to vest in the buyer, whether such event is the performance of an act by the buyer or the happening of a contingency.

"Person" includes an individual, partnership, corporation, and any other association.

"Purchase" includes mortgage and pledge.

"Purchaser" include mortgagee and pledgee.

"Seller" means the person who sells or leases the goods covered by the conditional sale, or any legal successor in interest of such person. 
Section 2.-(Primary Rights of Buyer.) - The buyer shall have the right when not in default to retain possession of the goods, and he shall also have the right to acquire the property in the goods on the performance of the conditions of the contract. The seller shall be liable to the buyer for the breach of all promises and warranties, express or implied, made in the conditional sale contract, whether or not the property in the goods has passed to the buyer.

Section 3.-(Primary Rights of Seller.) - The buyer shall be liable to the seller for the purchase price, or for installments thereof, as the same shall become due, and for breach of all promises made by him in the conditional sale contract, whether or not the property in the goods has passed to the buyer.

Section 4.-(Conditional Sales Valid Exeept as Otherwise Provided.) - Every provision in a conditional sale reserving property in the seller after possession of the goods is delivered to the buyer, shall be valid as to all persons, except as hereinafter otherwise provided.

Section 5.-(Conditional Sales Void as to Certain Persons.) - Every provision in a conditional sale reserving property in the seller, shall be void as to any purchaser from or ereditor of the buyer, who, without notice of such provision, purchases the goods or acquires by attachment or levy a lien upon them, before the contract or a copy thereof shall be filed as hereinafter provided, unless such contract or copy is so filed within ten days after the making of the conditional sale.

Section 6.-(Place of Filing.)-The conditional sale contract or copy shall be filed in the office — in (the city), (eounty), (registration district) in which the goods are first kept for use by the buyer after the sale. It shall not be necessary to the validity of such conditional sale contract, or in order to entitle it to be filed, that it be acknowledged or attested. This section shall not apply to the contracts described in Section $\varepsilon$.

Section 7.-(Fixtures.)-If the goods are so affixed to realty, at the time of a conditional sale or subsequently as to become a part thereof and not to be severable wholly or in any 
portion without material injury to the frechold, the reservation of property as to any portion not so severable shall be void after the goods are so affixed, as against any person who has not expressly assented to the reservation. If the goods are so affixed to realty at the time of a conditional sale or subsequently as to become part thereof but to be severable without material injury to the freehold, the reservation of property shall be void after the goods are so affixed as against subsequent purchasers of the realty for value and without notice of the conditional seller's title, unless the conditional sale contract, or a copy thereof, together with a statement signed by the seller briefly describing the realty and stating that the goods are or are to be affixed thereto, shall be filed before such purchase in the office where a deed of the realty would be recorded or registered to affect such realty. As against the owner of realty the reservation of the property in goods by a conditional seller shall be void when such goods are to be so affixed to the realty as to become part thereof but to be severable without material injury to the freehold, unless the conditional sale contract, or a copy thereof, together with a statement signed by the seller briefly describing the realty and stating that the goods are to be affixed thereto, shall be filed before they are affixed, in the office where a deed would be recorded or registered to affect such realty.

Section 8.-(Railroad Equipment or Rolling Stock.)-No conditional sale of railroad, or street or interurban railway equipment or rolling stock shall be valid as against the purchasers and creditors described in Section 5, unless the contract shall be acknowledged by the buyer or attested in like manner as a deed of real property, and the contract, or a copy thereof, shall be filed or recorded in the office of - - ; and unless when any engine or car so sold is delivered there shall then be plainly and conspicuously marked upon each side thereof the name of the seller, followed by the word "owner."

Section 9.-(Conditional Sale of Goods for Resale.)-When goods are delivered under a conditional sale contract and the seller expressly or impliedly consents that the buyer may resell them prior to performance of the condition, the reservation of 
property shall be void against purchasers from the buyer for value in the ordinary course of business, and as to them the buyer shall be deemed the owner of the goods, even though tho contract or a copy thereof shall be filed acoording to the provisions of this Aet.

Section 10.-(Filing.) - The filing officer shall mark upon the contract or copy filed with him the day and hour of filing and shall file the contract or copy in his office for public inspection. He shall keep a separate book in which he shall enter the names of the seller and buyer, the date of the contract, the day and hour of filing, a brief description of goods, the price named in the contract and the date of cancellation thereof; except that in entering the contracts mentioned in Section $S$ the shall record either the sum remaining to be paid upon the contract or the price of the goods. Such book shall be indexed under the names of both seller and buyer. For filing and entering such contract or copy the filing officer shall be entitled to a fee of (ten cents), except that for filing and entering a contract described in Section 8 the shall be entitled to a fee of (one dollar).

Section 11.-- (Refiling.)-The filing of conditional sale contracts provided for in Sections 5, 6 and 7 shall be valid for a periud of three years only. The filing of the contract provided for by Section $S$ shall be valid for a period of fifteen vears only. The validity of the filing may in each case be extended for successive additional periods of one rear from the date of refiling by filing in the proper filing district a copy of the original contract within thirty days next preceding the expiration of each period, with a statement attached signed by the seller, showing that the contract is in force and the amount remaining to be paid thereon. Such copy, with statement attached, shall be filed and entered in the same manner as a contract or copy filed and cntered for the first time, and the filing officer shall be entitled to a like fee as upon the original filing.

Section 12.-(Cancellation of Contract.) - After the performance of the condition, upon written demand delivered personally or by registered mail by the buyer or any other person 
having an interest in the goods, the seller shall execute, acknowledge and deliver to the demandant a statement that the condition in the contract has been performed. If for ten days after such demand the seller fails to mail or deliver such a statement of satisfaction, he shall forfeit to the demandant five dollars $(\$ 5.00)$ and be liable for all damages suffered. Upon presentation of such statement of satisfaction the filing officer shall file the same and note the cancellation of the contract and the date thereof on the margin of the page where the contract has been entered. For filing and entering the statement of satisfaction the filing officer shall be entitled to a fee of (ten cents), except that the - shall be entitled to a fee of (fifty cents) for filing and entering a statement of the satisfaction of a contract described in Section 8.

Section 13.- (Prohibition of Removal or Sale Without Notice.)-Unless the contract otherwise provides, the buyer may, without the consent of the seller, remove the goods from any filing district and sell, mortgage or otherwise dispose of his interest in them; but prior to the performance of the condition, no such buyer shall remove the goods from a filing district in which the contract or a copy thereof is filed, except for temporary uses for a period of not more than thirty days, unless the buyer not less than ten days before such removal shall give the seller personally or by registered mail written notice of the place to which the goods are to be removed and the approximate time of such intended removal; not prior to the performance of the condition shall the buyer sell, mortgage or otherwise dispose of his interest in the goods, uniess he, or the person to whom he is about to sell, mortgage or otherwise dispose of the same, shall notify the seller in writing personally or by registered mail of the name and address of the person to whom his interest in the goods is about to be sold, mortgaged or otherwise transferred, not less than ten days before such sile, mortgage or other dispasal. If any buyer does so remove the goods, or does so sell, mortgage or otherwise dispose of his interest in them without such notice or in violation of the contract, the seller may retake passession of the goods and deal with them as in case of default in payment of part or all of the purchase price. The provisions 
of this section regarding the removal of goods shall not apply, however, to the goods described in Section 8.

Section 14.-(Refiling on Removal.)-When, prior to the performance of the condition, the goods are removed by the buyer from a filing district in this state to another filing district in this state in which such contract or a copy thereof is not filed, or are removed from another state into a filing district in this state where such contract or copy is not filed, the reservation of the property in the seller shall be void, as to the purchasers and creditors described in Section 5, unless the conditional sale contract or a copy thereof shall be filed in the filing district to which the goods are removed, within ten days after the seller has received notice of the filing district to which the goods havo been removed. The provisions of this section shall not apply, however, to the goods described in Section 8. The provisions of Section 11 regarding the duration of the validity of the filing and the necessity for refiling shall apply to contracts or copies which are filed in a filing district other than that where the goods are originally kept for use by the buyer after the sale.

Section 15.-(Fraudulent Injury, Concealment, Removal, or Sale.) - When, prior to the performance of the condition, the buyer maliciously or with intent to defraud, shall injure, dostroy or conceal the goods, or remove them to a filing district where the contract or a copy thereof is not filed, without having given the notice required by Section 13, or shall sell, mortgage, or otherwise dispose of such goods under claim of full ownership, he shall be guilty of a crime and upon conviction thereof shall be imprisoned (in the county jail) for not more than (one year) or be fined not more than $(\$ 500)$ or both.

Section 16.-(Retaking Possession.) - When the buyer shall be in default in the payment of any sum due under the contract, or in the performance of any other condition which the contract requires him to perform in order to obtain the property in the goods, or in the performance of any promise, the breach of which is by the contract expressly made a ground for 
the retaking of the goods, the seller may retake possession thereof. Unless the goods can be retaken without breach of the peace, they shall be retaken by legal process; but nothing herein shall be construed to authorize a violation of the criminal law.

Seetion 17.-(Notice of Intention to Retake.)-Not more than forty nor less than twenty days prior to the retaking, the seller, if he so desires, may serve upon the buyer personally or by registered mail a notice of intention to retake the goods on account of the buyer's default. The notice shall state the defanlt and the period at the end of which the goods will be retaken, and shall briefly and elearly state what the buyer's rights under this Act will be in case they are retaken. If the notice is so served and the buyer does not perform the obligations in which he has made defanlt before the day set for retaking, the seller may retake the goods and hold them subject to the provisions of Sections 19,20,21,22 and 23 regarding resale, but without any right of redemption.

Section 18.-(Redemption.)-If the seller does not give the notice of intention to retake described in Section 17, he shall retain the goods for ten days after the retaking within the state in which they were located when retaken, during which period the buyer, upon payment or tender of the amount due under the contract at the time of retaking and interest, or upon performance or tender of performance of such other condition as may be named in the contract as precedent to the passage of the property in the goods, or upon performance or tender of performance of any other promise for the breach of which the goods were retaken, and upon payment of the expenses of retaking, keeping and storage, may redeem the goods and become entitled to take possession of them and to continue in the performance of the contract as if no default had occurred. Upon written demand delivered personally or by registered mail by the buyer, the seller shall furnish to the buyer a written statement of the sum due under the contract and the expense of retaking, keoping and storage. For failure to furmish such statement within a reasonable time after demand, the seller shall for- 
feit to the buyer $(\$ 10)$ and also be liable to him for all damages suffered because of such failure. If the goods are perishable s' that retention for ten days as herein prescribed would result in their destruction or substantial injury, the provisions of this section shall not apply, and the seller may resell the goods immediately upon their retaking. The provision of this section requiring the retention of the goods within the state during the period allowed for redemption shall not apply to the goods doseribed in Section 8.

Section 19.-(Compulsory Resale by Seller.)-If the buyer does not redeem the goods within ten days after the seller has retaken possession, and the buyer has paid at least fifty per cent. of the purchase price at the time of the retaking, the seller shall sell them at public auction in the state where they were at the time of the retaking, such sale to be held not more than thirty days after the retaking. The seller shall give to the buyer not less than ten days' written notice of the sale, either personally or by registererl mail, directed to the buyer at his last known place of business or residence. The seller shall also give notice of the sale by at least three notices posted in different public places within the filing district where the goods are to be sold, at least five days before the sale. If at the time of the retaking $\$ 500$ or more has been paid on the purchase price, the seller shall also give notice of the sale at least five days before the sale by publication in a newspaper published or having a general eirculation within the filing district where the goods are to be sold. The seller may bid for the goods at the resale. If the goods are of the kind described in Section S, the parties may fix in the conditional sale contract the place where the goods shall be resold.

Section 20.-(Resale at Option of Partics.)-If the buyer has not paid at least fifty per cent. of the purchase price at the time of the retaking, the seller shall not be under a duty to resell the goods as prescribed in Section 19. unless the buyer serves upon the seller, within ten days after the retaking. a written notice demanding a resale, delivered personally or by registered 
mail. If such notice is served, the resale shall take place within thirty days after the service, in the manner, at the place and upon the notice prescribed in Section 19. The seller may voluntarily resell the goods for account of the buyer on compliance with the same requirements.

Soction 21.-(Proceeds of Resale.)-The proceeds of the re sale shall be applied (1) to the payment of the expenses thereof, (2) to the payment of the expenses of retaking, keeping and storing the goods, (3) to the satisfaction of the balance due under the contract. Any sum remaining after the satisfaction of such claims shall be paid to the buyer.

Section 22.-(Deficiency on Resale.)-If the proceeds of the resale are not sufficient to defray the expenses thereof, and also the expenses of retaking, keeping and storing the goods and the balance due upon the purchase price, the seller may recover the deficiency from the buyer, or from anyone who has succeeded to the obligations of the buyer.

Section 23.-(Rights of Parties Where There is no Resale.) -Where there is no resale, the seller may retain the goods as his own property without obligation to account to the buyer except as provided in Section 25, and the buyer shall be discharged of all obligation.

Section 24.-(Election of Remedies.)-After the retaking of possession as provided in Section 16 the buyer shall be liable for the price only after a resale and only to the extent provided in Section 22. Neither the bringing of an action by the seller for the recovery of the whole or any part of the price, nor the recovery of judgment in such action, nor the collection of a portion of the price, shall be deemed inconsistent with a later retaking of the goods as provided in Section 16. But such right of retaking shall not be exercised by the seller after he has collected the entire price, or after he has claimed a lien upon the goods, or attached them, or levied upon them as the goods of the buyer.

Section 25.-(Recovery of Part Payments.) - If the seller fails to comply with the provisions of Sections $18,19,20,21$ 
and 23 after retaking the goods, the buyer may recover from the seller his actual damages, if any, and in no event less than onofourth of the sum of all payments which have been made under the contract, with interest.

Section 26.--(IVaiver of Statutory Protection.)-No act or agreement of the buyer before or at the time of the making of the contract, nor any agreement or statement by the buyer in such contract, shall constitute a valid waiver of the provisions of Section 18, 19, 20, 21 and 25.

Section 27.-(Loss and Increase.)-After the delivery of the goods to the buyer and prior to the retaking of them by the seller, the risk of injury and loss shall rest upon the buyer. The increase of the goods shall be subject to the same conditions as the original goods.

Section 28.-(Act Prospective Only.) - This Act shall not apply to conditional sales made prior to the time when it takes effect.

Section 29.-(Rules for Cases Not Provided for.) - In any case not provided for in this Act the rules of law and equity, including the law merchant, and in particular those relating to principal and agent and to the effect of fraud, misrepresentation, duress or coercion, mistake, bankruptcy, or other invalidating oause, shall continue to apply to conditional sales.

Section 30.-(Uniformity of Interpretation.)-This Act shall be so interpreted and construed as to effectuate its general purpose to make uniform the law of those states which enact it.

Section 31.-(Short Title.) - This Act may be cited as the Uniform Conditional Sales Act.

Section 32.-(Inconsistent Laws Repealed.)-Except so far as they are applicable to conditional sales made prior to the time when this Act takes effect, the following acts shall be and hereby are repealed. (Here repeal all existing acts in the field of conditional sales.)

Section 33.-(Time of Taking Effect.) - This Act shall tako effect- 

UNIFORM FRAUDULENT CONVEYANCE ACT 



\section{UNIFORM FRAUDULENT CONVEYANCE ACT}

In pursuance of a resolution of the Committee on Commercial Law, adopted at the session of the Conference held at Salt Lake City, Utah, on August 14, 1915, that committee sumbitted to the Conference held at Chicago in August, 1916, a tentative draft of an act to make uniform The Law of Conveyances in Fraud of Creditors. The Conference considered the draft submitted section by section and at the conclusion of its consideration of the draft returned the same to the committee with directions to consider the same further and report a second tentative draft to the Conference at its next annual meeting. In accordance with this resolution, the committee, with the assistance of Dr. William Draper Lewis, draftsman, prepared a second tentative draft for submission to the Conference at Saratoga Springs, New York, in August, 191\%. On August 31, 1917, the Conference again considered it section by section, and recommended that the act be recommitted to the Committee on Commercial Law for re-drafting and that it be presented for consideration at the 1918 meeting.

At the National Conference held at Cleveland, Ohio, in August, 1918 , a resolution was adopted approving the third tentative draft of the act and recommending it to the legislatures of the different states and territories for enactment.

The act was adopted in Tennessee in 1919. 
UNIFORM FRAUDULUENT CONVEYANCE ACT.

\begin{tabular}{|c|c|c|}
\hline & $\begin{array}{c}\text { I aws } \\
1919, \\
\text { ch. } 125 \\
\text { p. } 402 .\end{array}$ & $\begin{array}{c}\text { Laws } \\
1919, \\
\text { ch. } 209 . \\
\text { p. } 203 .\end{array}$ \\
\hline $\begin{array}{l}\text { Uniform Act } \\
\text { Section No. }\end{array}$ & $\begin{array}{c}1919 \\
\text { Tennessee. }\end{array}$ & $\begin{array}{c}1919 \\
\text { South Dakota. }\end{array}$ \\
\hline $\begin{array}{r}1 \\
2 \\
3 \\
4 \\
5 \\
6 \\
7 \\
8 \\
9 \\
10 \\
11 \\
12 \\
13 \\
14\end{array}$ & $\begin{array}{r}1 \\
2 \\
3 \\
4 \\
5 \\
6 \\
7 \\
8 \\
9 \\
10 \\
11 \\
12 \\
13 \\
14\end{array}$ & $\begin{array}{r}1 \\
2 \\
3 \\
4 \\
5 \\
6 \\
7 \\
8 \\
9 \\
10 \\
11 \\
12 \\
13 \\
14\end{array}$ \\
\hline
\end{tabular}




\section{UNIFORM FRAUDULENT CONVEYANCE ACT}

SEcrion 1. Definition of Terms.

2. Insolvency.

3. Fair Consideration.

4. Conveyances by Insolvent.

5. Conveyances by Persons in Business.

6. Conveyances by Persons About to Incur Debtg.

7. Conveyances Made With Intent to Defraud.

8. Conveyances of Partnership Property.

9. Rights of Creditors Whose Claims Have Matured.

10. Rights of Creditors Whose Claims Have Not Matured.

11. Cases Not Provided for in the Act.

12. Construction.

13. Name of Act.

14. Inconsistent Legislation Repealed.

Section 1.-(Definition of Terms.)-In this Act "Assets" of a debtor means property not exempt from liability for his debts. To the extent that any property is liable for any debts of the debtor, such property shall be included in his assets.

"Conveyance" includes every payment of money, assignment, release, transfer, lease, mortgage or pledge of tangible or intangible property, and also the creation of any lien or incumbrance.

"Creditor" is a person having any claim, whether matured or unmatured, liquidated or unliquidated, absolute, fixed or contingent.

"Debt" includes any legal liability, whether matured or unmatured, liquidated or unliquidated, absolute, fixed or contingent.

Section 2.-(Insolvency.)-(1) A person is insolvent $v$ hen the present fair salable value of his assets is less than the amount that will be required to pay his probable liability on his existing debts as they become absolute and matured. (2) In determining whether a partnership is insolvent there shall be added to the partnership property the present fair salable value of the separate assets of each general partner in excess of the amount probably sufficient to meet the claims of his separate creditors, 
and also the amount of any unpaid subscription to the partnership of each limited partner, provided the present fair salable value of the asssets of such limited partner is probably sufficient to pay his debts, including such unpaid subscription.

Section 3.-(Fair Consideration.)-Fair consideration is given for property, or obligation,

(a) When in exchange for such property, or obligation as a fair equivalent therefor, and in good faith, property is conveyed or an antecedent debt is satisfied, or

(b) When such property, or obligation is received in good faith to secure a present advance or antecedent debt in amount not disproportionately small as compared with the value of the property, or obligation obtained.

Section 4.-(Conveyances by Insolvent.) - Every conveyance made and every obligation incurred by a person who is or will be thereby rendered insolvent is fraudulent as to ereditors without regard to his actual intent if the conveyance is made or the obligation is incurred without a fair consideration.

Section 5.-(Conveyances by Persons in Business.)-Every conveyance made without fair consideration when the person making it is engaged or is about to engage in a businese or transaction for which the property remaining in his hands after the conveyance is an unreasonably small capital, is fraudulent as to creditors and as to other persons who become creditors during the continuance of such business or transaction without regard to his actual intent.

Section 6.-(Conveyances by a Person About to Incur Debts.) - Every conveyance made and every obligation incurred without fair consideration when the person making the conveyance or entering into the obligation intends or believes that he will incur debts beyond his ability to pay as they mature, is fraudulent as to both present and future ereditors.

Section 7.-(Conveyance Made With Intent to Defraud.)Every conveyance made and every obligation incurred with 
actual intent, as distinguished from intent presumed in law, to hinder, delay, or defraud either present or future creditirs, is fraudulent as to both present and future ereditors.

Section 8.-(Conveyance of Partnership Property.)-Every conveyance of partnership property and every partnership obligation incurred when the partnership is or will be thereby rendered insolvent, is fraudulent as to partnership creditors, if tho conveyance is made or obligation is incurred,

(a) To a partner, whether with or without a promise by him to pay partnership debts, or

(b) To a person not a partner without fair consideration to the partnership as distinguished from consideration to the individual partners.

Section 9.-(Rights of Creditors Whose Claims Have Matured.) - (1) Where a conveyance or obligation is fraudulent as to a creditor, such creditor, when his claim has matured, may, as against any person except a purchaser for fair consideration without knowledge of the fraud at the time of the purchase, or one who has derived title immediately or mediately from such a purchaser,

(a) Have the conveyance set aside or obligation annulled to the extent necessary to satisfy his claim, or

(b) Disregard the conveyance and attach or levy execution upon the property conveyed.

(2) A purchaser who without actual fraudulent intent has given less than a fair consideration for the conveyance or obligation, may retain the property or obligation as security for ro payment.

Section 10.-(Rights of Creditors Whose Claims Have Not Matured.) - Where a conveyance made or obligation incurred is fraudulent as to a creditor whose claim has not matured he may proceed in a court of competent jurisdiction against any person against whom he could have proceeded had his claim matured, and the court may,

(a) Restrain the defendant from disposing of his property, 
(b) Appoini a receiver to take charge of the property,

(c) Set aside the conveyance or annul the obligation, or

(d) Make any order which the circumstances of the case may require.

Section 11.-(Cases Not Provided for in Act.) - In any case not provided for in this Act the rules of law and equity including the law merchant, and in particular the rules relating to the law of principal and agent, and the effect of fraud, misrepresentation, duress or coercion, mistake, bankruptcy or other invalidating cause shall govern.

Section 12.-(Construction of Act.) - This Act shall be so interpreted and construed as to effectuate its general purpose to make uniform the law of those states which enact it.

Section 13.-(Name of Act.) - This Act may be cited as the Uniform Fraudulent Conveyance Act.

Section 14.-(Inconsistent Legislation Repealed.)-Sections are hereby repealed, and all acts or parts of acts inconsistent with this Act are hereby repealed. 


\section{INDICES}





\section{INDEX TO UNIFORM ACKNOWLEDGMENTS OF WRITTEN INSTRUMENTS ACT}

Acknowledgment-

PAGE

authentication of, to deed, $\$ 5 \ldots \ldots \ldots \ldots \ldots \ldots \ldots \ldots \ldots \ldots$

foreign, who may take, $\S 6 \ldots \ldots \ldots \ldots \ldots \ldots \ldots \ldots \ldots \ldots \ldots$

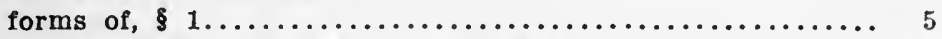

of married woman, as if she were sole, $\$ 2 \ldots \ldots \ldots \ldots \ldots \ldots 6$

taken as provided, instrument admissible in evidence, $\$$ \$, 4.. 6

Attorney, form for acknowledgment by, $\$ 1$ (2).......... 5

Certificate-

may be made by, as to notary, $\$ 4 \ldots \ldots \ldots \ldots \ldots \ldots \ldots \ldots \ldots$

who may make, as to foreign instrument, $\S 6 \ldots \ldots \ldots \ldots \ldots 7$

Clerk of court may certify as to acknowledgment, $\S 4 \ldots \ldots \ldots \ldots 6$

Consul may take acknowledgment, $\$ 6 \ldots \ldots \ldots \ldots \ldots \ldots \ldots \ldots .7$

Corporation, form of acknowledgment by, $\$ 1$ (3) .......... 5

Deed of another state inadmissible in evidence, when certified,

$\S \S 3,4 \ldots \ldots \ldots \ldots \ldots \ldots \ldots \ldots \ldots \ldots \ldots \ldots \ldots \ldots \ldots \ldots \ldots \ldots$

Evidence-

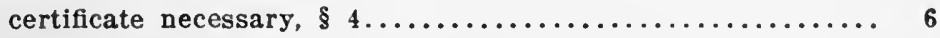

foreign instrument may be received in, when, $\S 6 \ldots \ldots \ldots \ldots 7$

when acknowledgment taken, how, $\S 3 \ldots \ldots \ldots \ldots \ldots \ldots \ldots$

Forms-

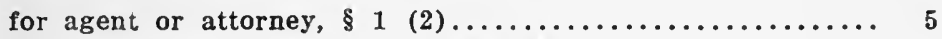

for authentication of proof of deed, $\$ 5 \ldots \ldots \ldots \ldots \ldots \ldots .7$

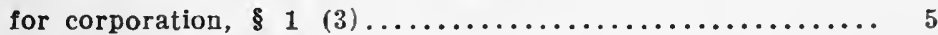

for nataral person, $\$ 1$ (1)....................... 5

Married woman, acknowledgment taken as if sole, $\S 2 \ldots \ldots \ldots \ldots 6$

Minister may take, $\S 6 \ldots \ldots \ldots \ldots \ldots \ldots \ldots \ldots \ldots \ldots \ldots \ldots . \ldots \ldots$

Secretary of State, must make certificate as to official position, \$ 46

Written instrument-

admissible in evidence, when, as respects acknowledgment, $\$ 3 \quad 6$

authentication of acknowledgment of, $\$ 5 \ldots \ldots \ldots \ldots \ldots \ldots .7$ 
INDEX TO UNIFORM EXECUTION OF WILLS ACT

PAGK

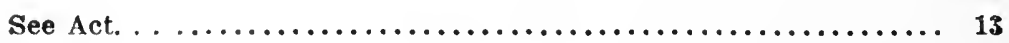




\section{INDEX TO UNIFORM NEGOTIABLE INSTRUMENTS ACT}

Acceptance- PAOE

bill of exchange in sets, provisions, $\S 181 \ldots \ldots \ldots \ldots \ldots \ldots 176$

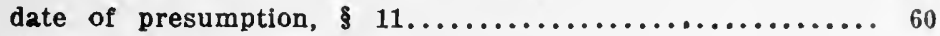

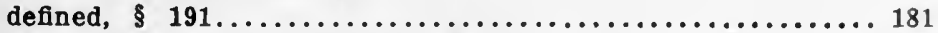

general acceptance construed, $\$ 139 \ldots \ldots \ldots \ldots \ldots \ldots \ldots \ldots 16 \ldots \ldots \ldots$

presentment for acceptance must be made. $\$ 143 \ldots \ldots \ldots \ldots 168$

qualified acceptance construed, $\S 139 \ldots \ldots \ldots \ldots \ldots \ldots \ldots \ldots 1$

Acceptance, bill of exchange-

acceptance for honor, see Acceptance for honor.

bill of exchange, construed, $\S 132 \ldots \ldots \ldots \ldots \ldots \ldots \ldots \ldots \ldots 16 \ldots \ldots \ldots$

general acceptance, what constitutes, $\$ 140 \ldots \ldots \ldots \ldots \ldots 167$

holder may require acceptance written on bill, $\$ 133 \ldots \ldots \ldots 166$ how made, requirements, incomplete bill, effect, $\S 132$,

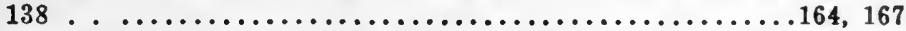

presentment for acceptance, see Presentment for acceptance,

bill of exchange.

qualified acceptance, rights and liabilities of parties, $\$ 142 \ldots 169$

separate instrument, effect, $\S 134 \ldots \ldots \ldots \ldots \ldots \ldots \ldots \ldots 16$

time allowed drawee to accept, $\$ 136 \ldots \ldots \ldots \ldots \ldots \ldots \ldots \ldots$

Acceptance for honor-

payment, presentment for, to acceptor, delay, excuses, $\S 169.174$ Acceptance for honor, bill of exchange-

acceptance how made, requirements, $\S 162 \ldots \ldots \ldots \ldots \ldots 173$

acceptor for honor, extent of agreement, obligations, $\S 165 . .173$

acceptor for honor, liability of, $\S 164 \ldots \ldots \ldots \ldots \ldots \ldots \ldots \ldots \ldots \ldots$

dishonor of bill by acceptor, $\S 170 \ldots \ldots \ldots \ldots \ldots \ldots \ldots \ldots \ldots$

drawer's honor, when deemed to be made for, $\$ 163 \ldots \ldots \ldots 173$

maturity of bill payable after sight, $\S 166 \ldots \ldots \ldots \ldots \ldots \ldots 173$

payment, presentment for, to acceptor, $\S 168 \ldots \ldots \ldots \ldots \ldots 174$

when acceptance may be made, $\$ 161 \ldots \ldots \ldots \ldots \ldots \ldots \ldots \ldots 2$

Acceptor-

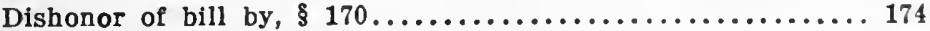

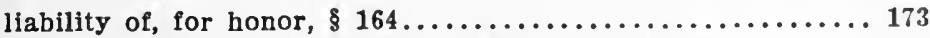

obligations, extent of agreement, for honor, $\$ 165 \ldots \ldots \ldots 173$

presentment for payment to, for honor, how made, $\$ 168 \ldots \ldots 174$

[591] 
Acceptor's liability-

PAGE

drawer's existence, signature and capacity admitted, $\$ 62 \ldots 125$ payee, signature and capacity admitted, $\S 62 \ldots \ldots \ldots \ldots \ldots 125$ payment according to tenor of the acceptance, $\S 62 \ldots \ldots \ldots 125$ Accomodation party-

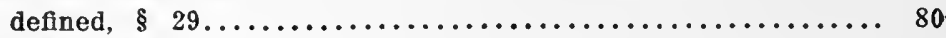

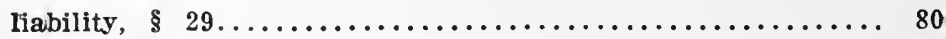

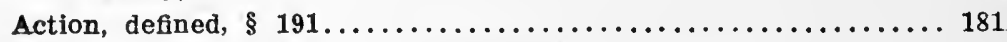

Additions made to instrument, effect, $\S 125 \ldots \ldots \ldots \ldots \ldots \ldots \ldots 161$

Agent-

liability on negotiation of paper without indorsement, $\S 69 \ldots 133$ notice of dishonor given by, $\S \S 91,94 \ldots \ldots \ldots \ldots \ldots \ldots \ldots \ldots$

signature by, authority, how shown, $\S 19 \ldots \ldots \ldots \ldots \ldots \ldots 66$

signature by, liability, $\S 20 \ldots \ldots \ldots \ldots \ldots \ldots \ldots \ldots \ldots \ldots 67$

Alteration-

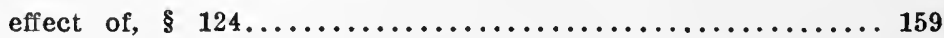

material, what constitutes, $\S 125 \ldots \ldots \ldots \ldots \ldots \ldots \ldots \ldots \ldots 1$

Ambiguous instrument, construction, $\S 17 \ldots \ldots \ldots \ldots \ldots \ldots \ldots .65$

Ante-dated instrument, validity, $\S 12 \ldots \ldots \ldots \ldots \ldots \ldots \ldots \ldots \ldots 60$

Assumed name, liability of person signing, $\S 18 \ldots \ldots \ldots \ldots \ldots \ldots 66$

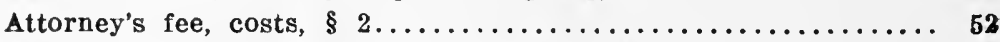

Authority, signature of agent, how shown, $\S 19 \ldots \ldots \ldots \ldots \ldots \ldots 66$ Bank-

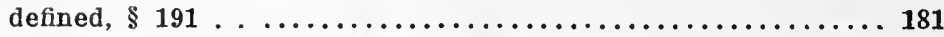

certification of check, effect, $\S 187 \ldots \ldots \ldots \ldots \ldots \ldots \ldots \ldots . \ldots 179$

instrument drawn on or indorsed to, effect, $\S 42 \ldots \ldots \ldots \ldots . . .89$

instrument payable at, an order on it to pay, $\$ 87 \ldots \ldots \ldots \ldots 141$

presentment for payment to, requirements, $\S 75 \ldots \ldots \ldots \ldots 137$

Bankrupt-

acceptor, protest before maturity, $\S 158 \ldots \ldots \ldots \ldots \ldots \ldots \ldots 172$

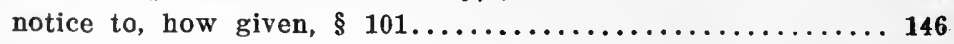

Bearer-

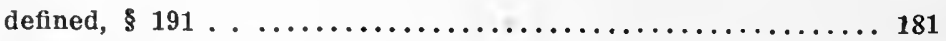

payable to, what constitutes, $\S 9 \ldots \ldots \ldots \ldots \ldots \ldots \ldots \ldots \ldots . \ldots \ldots$

Bill, defined, $\S 191 \ldots \ldots \ldots \ldots \ldots \ldots \ldots \ldots \ldots \ldots \ldots \ldots \ldots \ldots 1$

Bill of exchange-

acceptance, see Acceptance, bill of exchange.

acceptance for honor, see Acceptance for honor.

bill, not accepted, duty of holder, $\$ 150 \ldots \ldots \ldots \ldots \ldots \ldots . \ldots 170$.

bill not accepted, rights of holder, $\S 151 \ldots \ldots \ldots \ldots \ldots \ldots \ldots 170$

bill not an assignment of funds, $\S 127 \ldots \ldots \ldots \ldots \ldots \ldots \ldots \ldots$

bill in sets, see Bill of exchange in sets.

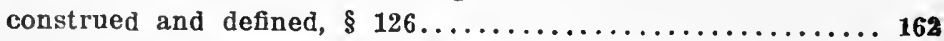

dishonor by non-acceptance, $\S 149 \ldots \ldots \ldots \ldots \ldots \ldots \ldots \ldots . \ldots 170$ 
Bill of exchange--Continued.

dishonored blll accepted for honor (protest for non-pay-

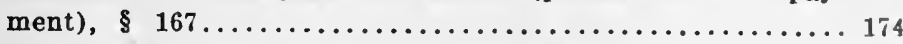

dishonor of bill by acceptor for honor, $\& 170 \ldots \ldots \ldots \ldots \ldots 174$ drawee retaining or destroying bill, $\S 137 \ldots \ldots \ldots \ldots \ldots \ldots 167$ duty of holder where bill not accepted, $\S 150 \ldots \ldots \ldots \ldots \ldots 170$ foreign, non-acceptance on non-payment, not required ex-

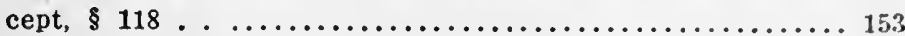

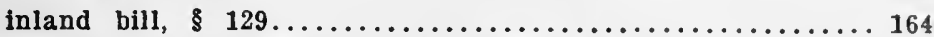
maturity of bill payable after sight, acceptor for honor,

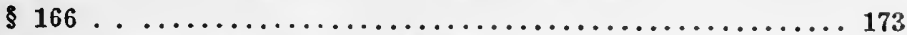
non-acceptance, dishonor by, $\S 149 \ldots \ldots \ldots \ldots \ldots \ldots \ldots \ldots 170$ payment for honor, see Payment for honor, bill of exchange. presentation for payment, when, $\$ 71 \ldots \ldots \ldots \ldots \ldots \ldots \ldots \ldots \ldots$ presentment for acceptance, see Presentment for acceptance,

bill of exchange.

presentment for payment to acceptor for honor, $\$ 168 \ldots \ldots 174$ presentment for payment to acceptor for honor, delay, ex-

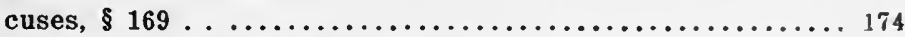

promissory note, when bill may be treated as, $\$ 130 \ldots \ldots \ldots 164$ protest, see Protest, bill of exchange.

provisions for, payable on demand apply to checks, $\$ 185 \ldots . .177$ referee in case of need, provisions, $\S 131 \ldots \ldots \ldots \ldots \ldots \ldots 16$ reference in case of need, protest for non-payment, $\S 167 \ldots 174$ Bill of exchange in sets-

aoceptance provisions, $\S 181 \ldots \ldots \ldots \ldots \ldots \ldots \ldots \ldots \ldots \ldots \ldots$ different parts negotiated, holder's rights, $\S 179 \ldots \ldots \ldots \ldots 175$ discharging one of set, effect, $\S 183 \ldots \ldots \ldots \ldots \ldots \ldots \ldots \ldots$ 17c indorsement by holder of parts of set to different parties.

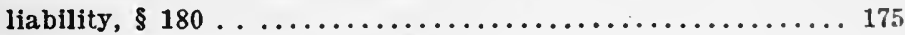
payment by acceptor of bill, $\S 182 \ldots \ldots \ldots \ldots \ldots \ldots \ldots \ldots \ldots$

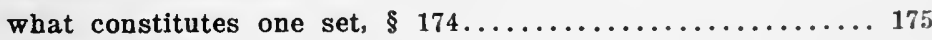
whole of the parts constitutes one set, $\S 178 \ldots \ldots \ldots \ldots \ldots 175$ Blank indorsement, see Indorsement Blanks.

Blanks in instrument-

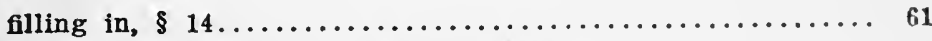

person in possession to complete, $\S 14 \ldots \ldots \ldots \ldots \ldots \ldots \ldots 61$

Broker, liability on negotiation of paper without indorsement, $\S 69.138$ Cancellation-

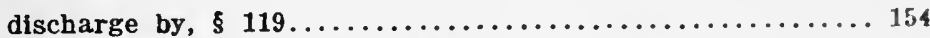

unintentional, burden of proof, $\S 123 \ldots \ldots \ldots \ldots \ldots \ldots \ldots \ldots$

Cashier, instrument drawn on or indorsed to, effect, $\$ 42 \ldots \ldots \ldots 89$ 
Certification of check-

PAGE

by bank, effect, $\delta 187 \ldots \ldots \ldots \ldots \ldots \ldots \ldots \ldots \ldots \ldots \ldots \ldots \ldots \ldots$

procured by holder, effect, $188 \ldots \ldots \ldots \ldots \ldots \ldots \ldots \ldots \ldots \ldots$

when treated as promissory note, $\$ 130 \ldots \ldots \ldots \ldots \ldots \ldots \ldots . \ldots \ldots$

Change made in instrument, effect, $\S 124 \ldots \ldots \ldots \ldots \ldots \ldots \ldots \ldots . \ldots \ldots$

Check-

assignment of funds, when check operates, as, § $189 \ldots \ldots . .180$

bill of exchange payable on demand, provisions relating to,

apply to checks, \& $185 \ldots \ldots \ldots \ldots \ldots \ldots \ldots \ldots \ldots \ldots . \ldots \ldots \ldots$

certification procured by the holder, effect, $\S \S 187,188 \ldots \ldots 179$

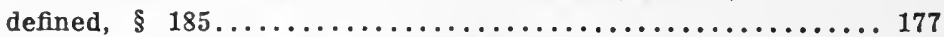

presentation for payment, time, $\S 186 \ldots \ldots \ldots \ldots \ldots \ldots . \ldots 178$

Conditional indorsement, see Indorsement.

Conformity with terms and requirements, $\S 10 \ldots \ldots \ldots \ldots \ldots 60$

Consideration--

absence not affecting negotiability, $\S 6 \ldots \ldots \ldots \ldots \ldots \ldots \ldots, 57$

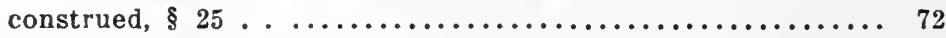

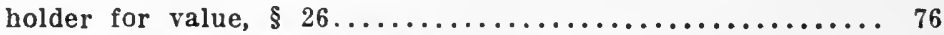

partial failure of as defense, $\S 28 \ldots \ldots \ldots \ldots \ldots \ldots \ldots \ldots, 78$

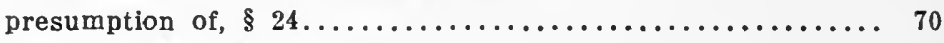

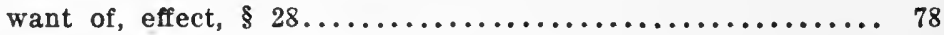

Construction-

ambiguous instrument, $\S 17 \ldots \ldots \ldots \ldots \ldots \ldots \ldots \ldots \ldots \ldots \ldots \ldots$

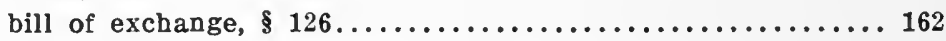

Corporation-

indorsement by, $\S 22 \ldots \ldots \ldots \ldots \ldots \ldots \ldots \ldots \ldots \ldots \ldots \ldots, 68$

instrument drawn or indorsed to, effect, $\S 42 \ldots \ldots \ldots \ldots \ldots .89$

Date-

absence not affecting negotiability, $\S 6 \ldots \ldots \ldots \ldots \ldots \ldots \ldots . \ldots \ldots$

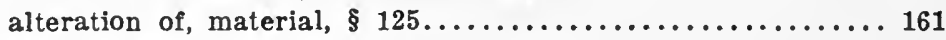

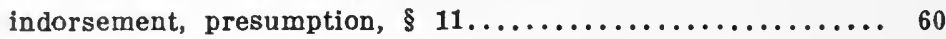

insertion by holder, $\$ 13 \ldots \ldots \ldots \ldots \ldots \ldots \ldots \ldots \ldots \ldots, 61$

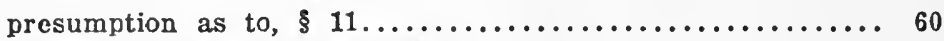

wrong date inserted, effect, $\$ 13 \ldots \ldots \ldots \ldots \ldots \ldots \ldots \ldots, 61$

Death-

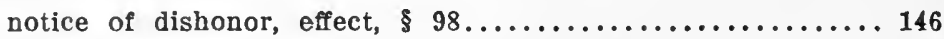

principal debtor, presentment, how made, $\S 76 \ldots \ldots \ldots \ldots \ldots 138$

Defect in instrument, notice, effect on holder, $\S 54 \ldots . . \ldots \ldots \ldots . . .104$

Defect in title-

notice of effect on holder, $\S 54,55 \ldots \ldots \ldots \ldots \ldots \ldots \ldots 104,105$

notice of, what constitutes, $\S 56 \ldots \ldots \ldots \ldots \ldots \ldots \ldots \ldots \ldots . \ldots \ldots$

Defense-

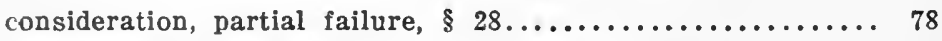

consideration, want of, $\S 28 \ldots \ldots \ldots \ldots \ldots \ldots \ldots \ldots \ldots \ldots \ldots \ldots \ldots \ldots$

original defenses, when instrument is subject to, $\S 58 \ldots \ldots \ldots 116$ 


\section{Definitions-}

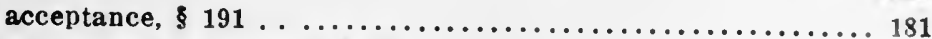

accommodation party, $\$ 29 \ldots \ldots \ldots \ldots \ldots \ldots \ldots \ldots \ldots \ldots \ldots . \ldots \ldots$

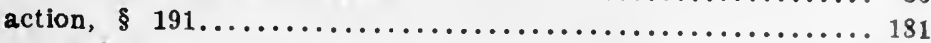

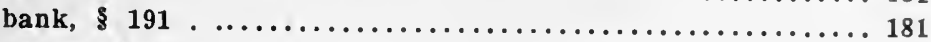

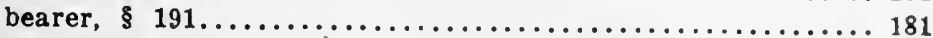

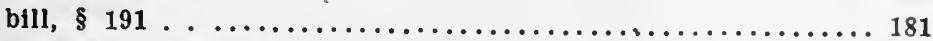

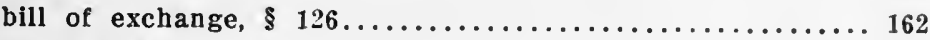

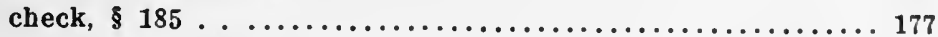

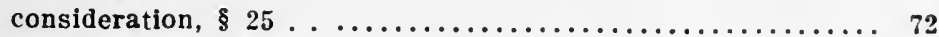

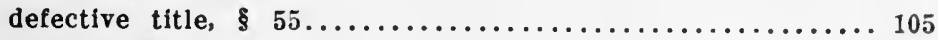

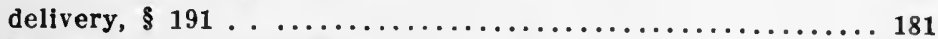

foreign bill of exchange, $\S 129 \ldots \ldots \ldots \ldots \ldots \ldots \ldots \ldots \ldots \ldots 164$

general acceptance (bill of exchange), $\$ 139 \ldots \ldots \ldots \ldots \ldots 167$

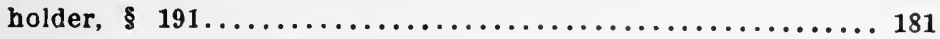

holder for value, $\$ 26 \ldots \ldots \ldots \ldots \ldots \ldots \ldots \ldots \ldots \ldots \ldots \ldots \ldots \ldots$

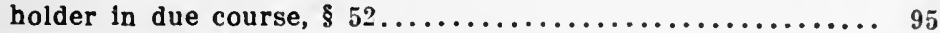

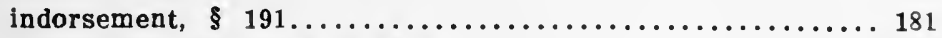

indorsement in blank, $\$ 34 \ldots \ldots \ldots \ldots \ldots \ldots \ldots \ldots \ldots \ldots$

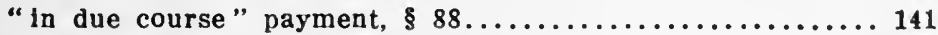

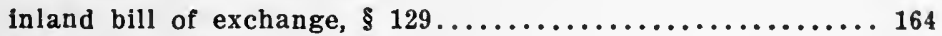

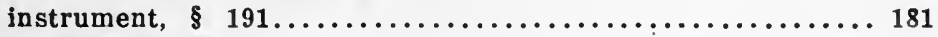

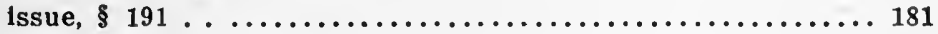

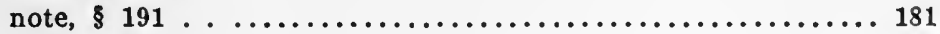

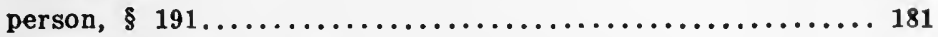

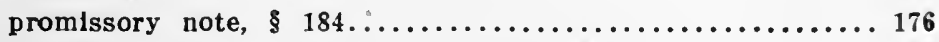

qualified acceptance (bill of exchange), $\S 139 \ldots \ldots \ldots \ldots \ldots 167$

referee in case of need, $\$ 131 \ldots \ldots \ldots \ldots \ldots \ldots \ldots \ldots \ldots \ldots \ldots$

restrictive indorsement, $\$ 36 \ldots \ldots \ldots \ldots \ldots \ldots \ldots \ldots \ldots \ldots 6$

special indorsement, $\S 34 \ldots \ldots \ldots \ldots \ldots \ldots \ldots \ldots \ldots \ldots \ldots$

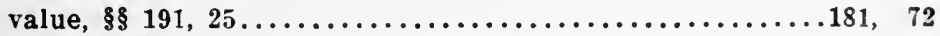

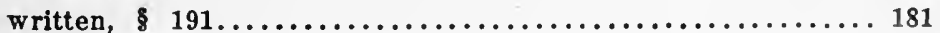

Delay-

giving notice of dishonor, how excused, $\S 113 \ldots \ldots \ldots \ldots \ldots 1$

presentment for payment, when excused, $\$ \S 81,82 \ldots \ldots \ldots \ldots 139$

presentment to acceptor for honor, excused, $\S 169 \ldots \ldots \ldots 174$

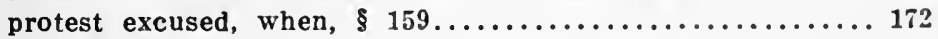

\section{Delivery-}

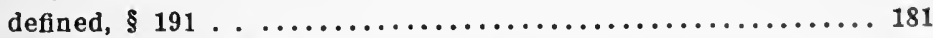

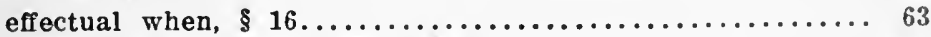

incomplete instrument, effect, $\S 15 \ldots \ldots \ldots \ldots \ldots \ldots \ldots \ldots \ldots 62$

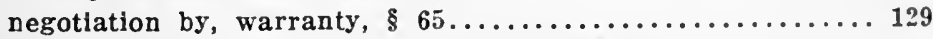

notice of dishonor personally or by mall, $\$ 96 \ldots \ldots \ldots \ldots \ldots 145$

paper negotiable by, Indorser's liabllity, $\S 67 \ldots \ldots \ldots \ldots \ldots 132$

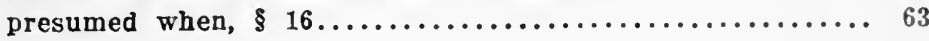


Demand (see also Presentment for payment)- PAGE

payable on, what constitutes, $\$ 7 \ldots \ldots \ldots \ldots \ldots \ldots \ldots \ldots . \ldots \ldots$

Discharge (see also Payment) -

cancellation by mistake, burden of proof, $\S 123 \ldots \ldots \ldots \ldots 159$

effect of payment of one of set, $\S 183 \ldots \ldots \ldots \ldots \ldots \ldots \ldots \ldots$

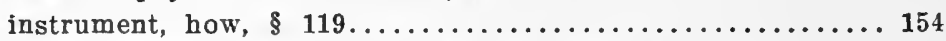

persons secondarily liable, how dischárged, $\S 120 \ldots \ldots \ldots 156$

Dishonor-

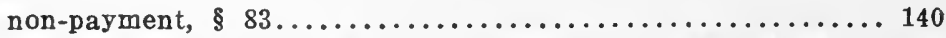

non-payment, liability of person secondarily liable, $\S 84 \ldots 140$ notice of, see Notice of dishonor.

Dishonor, bill of exchange, acceptor for honor, dishonor by, $\S 170 . .174$

Drawee, bill of exchange-

bill addressed to more than one, $\S 128 \ldots \ldots \ldots \ldots \ldots \ldots \ldots 164$

retaining or destroying bill, $\S 137 \ldots \ldots \ldots \ldots \ldots \ldots \ldots \ldots \ldots$

Drawer-

capacity and authority admitted, when, $\S 62 \ldots \ldots \ldots \ldots \ldots 125$

deemed an acceptance for honor of, $\S 163 \ldots \ldots \ldots \ldots \ldots \ldots 173$

notice of dishonor must be given to, $\S 89 \ldots \ldots \ldots \ldots \ldots \ldots 141$

notice of dishonor, when need not be given, $\S 114 \ldots \ldots \ldots \ldots 152$

presentment for payment, when necessary to charge, $\S 70 \ldots 133$

presentment for payment, when not necessary to charge, $\S 79.138$

Drawer's liability-

acceptance and payment promised, $\S 61 \ldots \ldots \ldots \ldots \ldots \ldots \ldots 124$

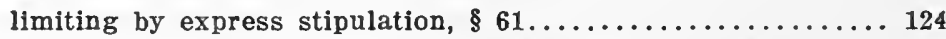

payee's existence and capacity to indorse admitted, $\S 61 \ldots \ldots 124$

Drawing instrument-

date of, presumption, $\S 11 \ldots \ldots \ldots \ldots \ldots \ldots \ldots \ldots \ldots \ldots 6 . \ldots \ldots$

fiscal officer, instrument drawn on or indorsed to, effect, $\$ 42$. . 89

Foreign bill of exchange, defined, $\S 129 \ldots \ldots \ldots \ldots \ldots \ldots \ldots 164$

Form and interpretation, bill of exchange-

bill addressed to more than one drawee, $\S 128 \ldots \ldots \ldots \ldots \ldots 164$

bill not an assignment of funds, $\S 127 \ldots \ldots \ldots \ldots \ldots \ldots \ldots 16 \ldots \ldots$

bill when may be treated as promissory note, $\S 130 \ldots \ldots \ldots 164$

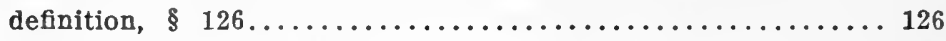

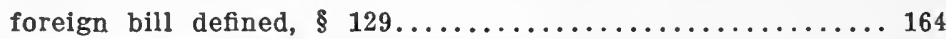

inland bill defined, $\S 129 \ldots \ldots \ldots \ldots \ldots \ldots \ldots \ldots \ldots \ldots \ldots \ldots$

referee in case of need, definition, provision, $\S 131 \ldots \ldots \ldots 164$

Form and substance-

acceptance, date of, presumption, $\S 11 \ldots \ldots \ldots \ldots \ldots \ldots \ldots 60$

ambiguous instrument, construction, $\S 17 \ldots \ldots \ldots \ldots \ldots \ldots 65$

ante-dated instrument, validity, $\$ 12 \ldots \ldots \ldots \ldots \ldots \ldots \ldots . \ldots 60$

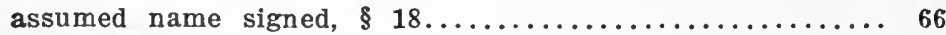

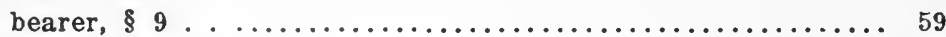

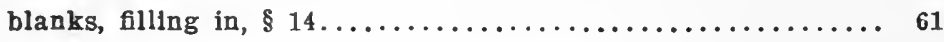


Form and substance-Continued.

conformity with terms and requirements, $\$ 10 \ldots \ldots \ldots \ldots \ldots 60$

corporation, indorsement by, $\S 22 \ldots \ldots \ldots \ldots \ldots \ldots \ldots \ldots . \ldots \ldots$

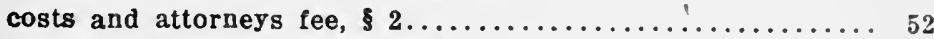

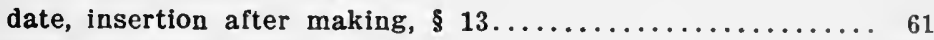

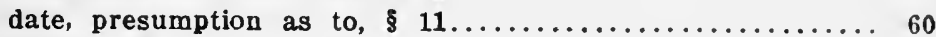

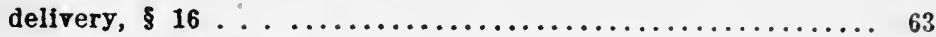

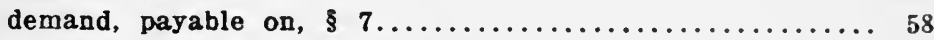

drawing, date of, presumption, $\$ 11 \ldots \ldots \ldots \ldots \ldots \ldots \ldots 60$

incomplete instrument not delivered, $\S 15 \ldots \ldots \ldots \ldots \ldots \ldots \ldots 62$

indorsement, date of, presumption, $\$ 11 \ldots \ldots \ldots \ldots \ldots \ldots 60$

infant, indorsement by, $\S 22 \ldots \ldots \ldots \ldots \ldots \ldots \ldots \ldots \ldots . \ldots \ldots$

making, date of, presumption, $\$ 11 \ldots \ldots \ldots \ldots \ldots \ldots \ldots \ldots 6$

negotiability, additional provisions not affecting, $\$ 5 \ldots \ldots \ldots 6$

negotiability, requirements of, $\S 1 \ldots \ldots \ldots \ldots \ldots \ldots \ldots \ldots \ldots$

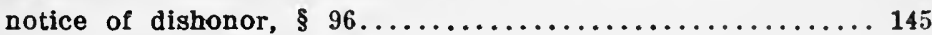

omissions not affecting, $\S 6 \ldots \ldots \ldots \ldots \ldots \ldots \ldots \ldots \ldots \ldots \ldots \ldots$

order, payable to, $\$ 8 \ldots \ldots \ldots \ldots \ldots \ldots \ldots \ldots \ldots \ldots \ldots \ldots \ldots$

post-dated instrument, validity, $\S 12 \ldots \ldots \ldots \ldots \ldots \ldots \ldots \ldots 60$

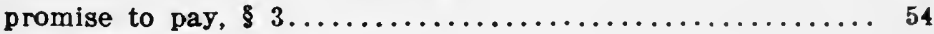

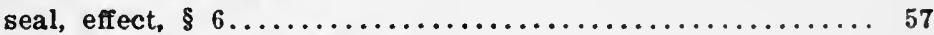

signature by agent, $\S \S 19,20 \ldots \ldots \ldots \ldots \ldots \ldots \ldots \ldots \ldots, 67$

signature by procuration, effect, $\S 21 \ldots \ldots \ldots \ldots \ldots \ldots \ldots \ldots 68$

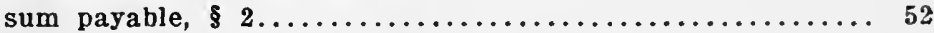

terms, sufficiency to meet requirements, $\S 10 \ldots \ldots \ldots \ldots \ldots 60$

time, future determinable, $\S 4 \ldots \ldots \ldots \ldots \ldots \ldots \ldots \ldots \ldots \ldots 55$

trade name signed, $\S 18 \ldots \ldots \ldots \ldots \ldots \ldots \ldots \ldots \ldots \ldots \ldots 6$

Fonds-

bill of exchange, not assignment of, $\$ 127 \ldots \ldots \ldots \ldots \ldots 163$

check, when it operates as assignment of, $\$ 189 \ldots \ldots \ldots \ldots \ldots 180$

General acceptance (bill of exchange), defined, $\S 139 \ldots \ldots \ldots \ldots \ldots 167$

Holder-

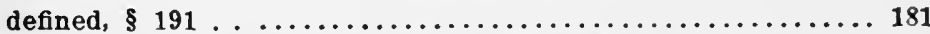

failure to give notice of non-acceptance, effect, $\S 117 \ldots \ldots \ldots 153$

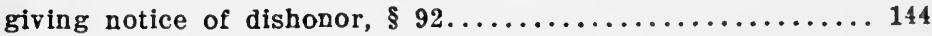

Holder, bill of exchange-

duty where bill not accepted, $\S 150 \ldots \ldots \ldots \ldots \ldots \ldots \ldots \ldots$

payment supra protest, refused by, effect, $\S 176 \ldots \ldots \ldots \ldots 175$

Holder for value-

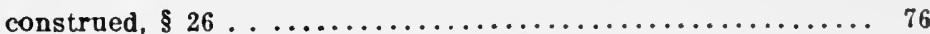

lien on instrument as constituting, $\S 27 \ldots \ldots \ldots \ldots \ldots \ldots 77$

Holder in due course (see also Holder, rights of) -

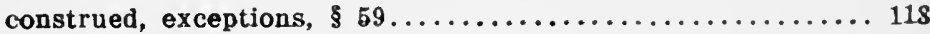

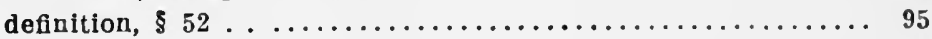

person not deemed to be, when, $\$ 53 \ldots \ldots \ldots \ldots \ldots \ldots \ldots \ldots$ 
Holder in due course-Continued. PAGE

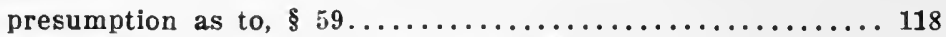

renunciation by, against party, effect, $\S 122 \ldots \ldots \ldots \ldots \ldots 158$

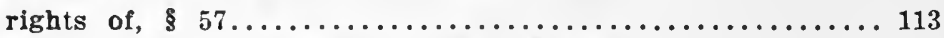

striking out indorsement by, effect, $\S 48 \ldots \ldots \ldots \ldots \ldots \ldots . . \ldots 1$

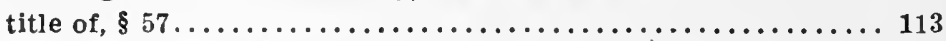

what constitutes, $\$ 52 \ldots \ldots \ldots \ldots \ldots \ldots \ldots \ldots \ldots \ldots \ldots \ldots . \ldots \ldots$

Holder, rights of-

bill of exchange in sets, different parts negotiated, $\S 179 \ldots 175$

defect in instrument or title, notice of, effect, $\S 54 \ldots \ldots \ldots \ldots 104$ defect in instrument or title, notice of, what constitutes, §56. 108 holder in due course, construed, exceptions, $\$ 59 \ldots \ldots \ldots \ldots 118$ holder in due course, what constitutes, $\S 52 \ldots \ldots \ldots \ldots \ldots \ldots 95$ holder in due course, when person not deemed to be, $\$ 53 \ldots 103$ original defense, when subject to, $\S 58 \ldots \ldots \ldots \ldots \ldots \ldots \ldots 116$

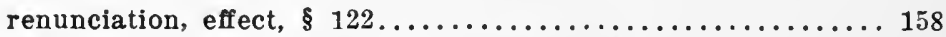
rights of, bill of exchange not accepted, $\S 151 \ldots \ldots \ldots \ldots 170$ right of recourse on dishonor by non-payment, $\S 84 \ldots \ldots \ldots 140$ rights of holder in due course, $\$ 57 \ldots \ldots \ldots \ldots \ldots \ldots \ldots \ldots$ suing on instrument, $\S 51 \ldots \ldots \ldots \ldots \ldots \ldots \ldots \ldots \ldots \ldots \ldots . \ldots \ldots$ title derived through a holder in due course, $\S 58 \ldots \ldots \ldots \ldots 116$ title of holder in due course, $\$ 57 \ldots \ldots \ldots \ldots \ldots \ldots \ldots \ldots \ldots . \ldots 113$ Holiday-

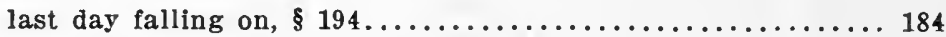
paper falling due on, when payable, $\S 85 \ldots \ldots \ldots \ldots \ldots \ldots . \ldots 140$ Saturday half-holiday, presentment of bill of exchange for ac-

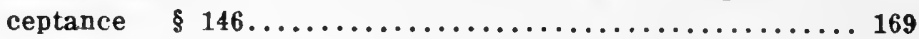
Honor-

delay in presentment to acceptor, excused, $\S 169 \ldots \ldots \ldots \ldots 174$

when bill may be accepted for honor, $\S 161 \ldots \ldots \ldots \ldots \ldots \ldots 172$

Incomplete instrument not delivered, validity, $\S 15 \ldots \ldots \ldots \ldots \ldots 62$ Indorsee-

name wrongly designated or misspelled, indorsement, $\S 43 . .90$ restrictive indorsement, rights, $\$ 37 \ldots \ldots \ldots \ldots \ldots \ldots \ldots \ldots 87$

Indorsement-

bearer, indorsed, specially, effect, $\S 40 \ldots \ldots \ldots \ldots \ldots \ldots \ldots 88$

blank, construed, effect, $\S 34 \ldots \ldots \ldots \ldots \ldots \ldots \ldots \ldots \ldots . \ldots 6$

blank, now changed to special, $\S 35 \ldots \ldots \ldots \ldots \ldots \ldots \ldots \ldots . \ldots 6$

blank specified, $\S 33 \ldots \ldots \ldots \ldots \ldots \ldots \ldots \ldots \ldots \ldots \ldots \ldots$

broker liable on negotiation of paper without, unless, $\S 69 \ldots 133$ condition, construed, effect, $\S 39 \ldots \ldots \ldots \ldots \ldots \ldots \ldots \ldots \ldots 8$

conditional, specified, $\S 33 \ldots \ldots \ldots \ldots \ldots \ldots \ldots \ldots \ldots \ldots . \ldots . \ldots \ldots$

corporation, indorsement by, effect, $\S 22 \ldots \ldots \ldots \ldots \ldots \ldots 68$

dat of, presumption, $\S 11 \ldots \ldots \ldots \ldots \ldots \ldots \ldots \ldots \ldots \ldots \ldots 6 . \ldots \ldots$ 
Indorsement-Continued.

defined, $\$ 191 \ldots \ldots \ldots \ldots \ldots \ldots \ldots \ldots \ldots \ldots \ldots \ldots \ldots \ldots \ldots 1$

entire instrument to be indorsed, $\$ 32 \ldots \ldots \ldots \ldots \ldots \ldots \ldots . \ldots \ldots$

fiscal officers, $\$ 42 \ldots \ldots \ldots \ldots \ldots \ldots \ldots \ldots \ldots \ldots \ldots \ldots \ldots$

holder of parts of sets to others, liability, $\$ 180 \ldots \ldots \ldots \ldots \ldots 175$

infant, indorsement by, effect, $\S 22 \ldots \ldots \ldots \ldots \ldots \ldots \ldots \ldots$

instrument paid in part, $\$ 32 \ldots \ldots \ldots \ldots \ldots \ldots \ldots \ldots \ldots . \ldots \ldots$

maker's note must be indorsed by him, $\$ 184 \ldots \ldots \ldots \ldots \ldots 176$

manner of making, $\S 31 \ldots \ldots \ldots \ldots \ldots \ldots \ldots \ldots \ldots \ldots \ldots \ldots$

name wrongly designated or misspelled, $\S 43 \ldots \ldots \ldots \ldots \ldots . . .60$

negotiated by, $\$ 30 \ldots \ldots \ldots \ldots \ldots \ldots \ldots \ldots \ldots \ldots \ldots \ldots . \ldots \ldots$

negotiation without, by agent, liability, $\$ 69 \ldots \ldots \ldots \ldots \ldots \ldots 133$

part of instrument paid, indorsement as to residue, $\$ 32 \ldots \ldots 85$

place of, presumption, $\$ 46 \ldots \ldots \ldots \ldots \ldots \ldots \ldots \ldots \ldots . \ldots \ldots$

qualified, effect, how made, $\S 38 \ldots \ldots \ldots \ldots \ldots \ldots \ldots \ldots \ldots$. 8 .

qualified, negotiation by, warranty, $\$ 65 \ldots \ldots \ldots \ldots \ldots \ldots \ldots 129$

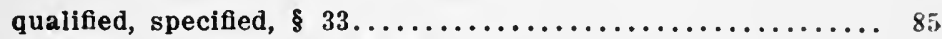

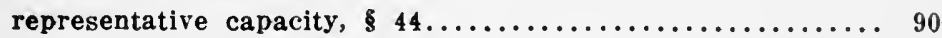

restrictive construed, $\S 36 \ldots \ldots \ldots \ldots \ldots \ldots \ldots \ldots \ldots \ldots . \ldots \ldots$

restrictive, effect, $\$ 37 \ldots \ldots \ldots \ldots \ldots \ldots \ldots \ldots \ldots \ldots \ldots \ldots . \ldots \ldots \ldots$

restrictive, specified, $\$ 33 \ldots \ldots \ldots \ldots \ldots \ldots \ldots \ldots \ldots \ldots \ldots \ldots$

special, construed, effect, $\$ 34 \ldots \ldots \ldots \ldots \ldots \ldots \ldots \ldots \ldots . \ldots 6$

special liability, $\$ 40 \ldots \ldots \ldots \ldots \ldots \ldots \ldots \ldots \ldots \ldots \ldots \ldots \ldots$

special, specified, $\S 33 \ldots \ldots \ldots \ldots \ldots \ldots \ldots \ldots \ldots \ldots \ldots \ldots \ldots$

striking out, by holder, effect, $\$ 48 \ldots \ldots \ldots \ldots \ldots \ldots \ldots \ldots . \ldots 1$

time when made, presumption, $\$ 45 \ldots \ldots \ldots \ldots \ldots \ldots \ldots . \ldots$

transfer of a part of amount payable, effect, $\$ 32 \ldots \ldots \ldots \ldots . \quad 85$

transfer without indorsement, effect, $\$ 49 \ldots \ldots \ldots \ldots \ldots \ldots . \ldots 1$

two or more payees, $\S 41 \ldots \ldots \ldots \ldots \ldots \ldots \ldots \ldots \ldots \ldots \ldots 9$

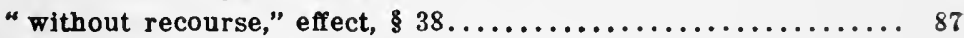

Indorser-

general indorsers' liability and warranty, $\$ 66 \ldots \ldots \ldots \ldots \ldots 130$

infant, effect of indorsement, $\S 22 \ldots \ldots \ldots \ldots \ldots \ldots \ldots \ldots 68 \ldots \ldots \ldots \ldots$

irregular indorser, liability, rules, $\$ 64 \ldots \ldots \ldots \ldots \ldots \ldots \ldots 128$

liability, special indorsement, instrument payable to bearer,

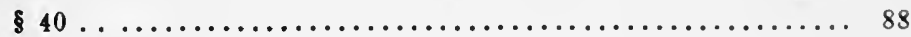

notice of dishonor must be given to, $\$ 89 \ldots \ldots \ldots \ldots \ldots \ldots 141$

notice of dishonor when need not be given to, $\$ 115 \ldots \ldots \ldots 152$

order in which indorsers are liable, $\$ 68 \ldots \ldots \ldots \ldots \ldots \ldots . \ldots 132$

paper negotiable by delivery, liability, $\S 67 \ldots \ldots \ldots \ldots \ldots \ldots$

person when deemed an indorser, $\$ 63 \ldots \ldots \ldots \ldots \ldots \ldots \ldots . \ldots \ldots$

presentment for payment, when not required to change, $\$ 80$.. 138 presentment for payment, when not necessary to change, $\S \div 0.133$ striking out indorsement by holder, effect, $\$ 48 \ldots \ldots \ldots \ldots . . .91$ 
Indorsement in blank-

PAGE

negotiated, how, $\$ 34 \ldots \ldots \ldots \ldots \ldots \ldots \ldots \ldots \ldots \ldots \ldots \ldots . \ldots \ldots$

what constitutes, $\$ 34 \ldots \ldots \ldots \ldots \ldots \ldots \ldots \ldots \ldots \ldots \ldots \ldots \ldots \ldots$

Infant, indorsement by, effect, $\$ 22 \ldots \ldots \ldots \ldots \ldots \ldots \ldots \ldots \ldots .68$

Infirmity in instrument-

notice of, what constitutes, $\S 56 \ldots \ldots \ldots \ldots \ldots \ldots \ldots \ldots \ldots$

notice to tranferee before full amount paid, effect, $\$ 54 \ldots \ldots \ldots 104$

Inland bill of exchange, defined, $\S 129 \ldots \ldots \ldots \ldots \ldots \ldots \ldots \ldots$

Instrument-

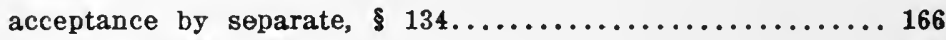

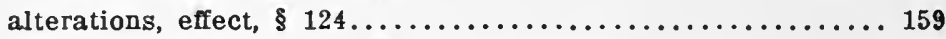

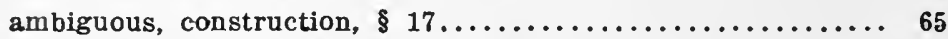

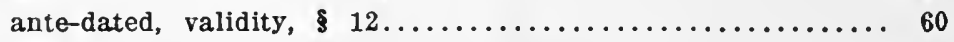

conformity with terms and requirements, $\$ 10 \ldots \ldots \ldots \ldots \ldots 60$

continuation of negotiability until, $\S 47 \ldots \ldots \ldots \ldots \ldots \ldots . . \ldots 90$

defect in, notice of, what constitutes, $\S 56 \ldots \ldots \ldots \ldots \ldots . \ldots 108$

defect in, or title, notice of effect, $\S 54 \ldots \ldots \ldots \ldots \ldots \ldots \ldots . \ldots 10 \ldots$

defect, see Infirmity in instrument.

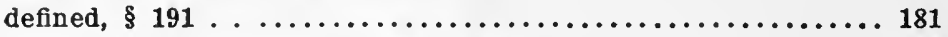

drawn on or endorsed to, effect, $\S 42 \ldots \ldots \ldots \ldots \ldots \ldots \ldots \ldots 89$

dishonored, liability of persons, secondarily liable, $\$ 84 \ldots \ldots 140$

entire, must be, indorsed, $\S 32 \ldots \ldots \ldots \ldots \ldots \ldots \ldots \ldots \ldots \ldots 85$

exhibited and delivered to party paying it, $\S 74 \ldots \ldots \ldots \ldots \ldots 137$

incomplete, not delivered, $\S 15 \ldots \ldots \ldots \ldots \ldots \ldots \ldots \ldots \ldots . \ldots 2$

indorsement must be entire, $\S 32 \ldots \ldots \ldots \ldots \ldots \ldots \ldots \ldots . \ldots 5$

lien on, lienor a holder for value, $\S 27 \ldots \ldots \ldots \ldots \ldots \ldots \ldots 77$

material alterations, what constitutes, $\S 125 \ldots \ldots \ldots \ldots \ldots 1$

negotiability of, not affected by omissions, $\S 6 \ldots \ldots \ldots \ldots \ldots 57$

negotiated unreasonable time after issue, effect, $\S 53 \ldots \ldots \ldots 103$

omissions do not affect negotiability, $\S 6 \ldots \ldots \ldots \ldots \ldots \ldots .57$

part of, paid, indorsement of as to residue, $\S 32 \ldots \ldots \ldots \ldots \ldots 8$

payable at bank, an order for bank to pay, $\S 87 \ldots \ldots \ldots \ldots 141$

payable to order, $\S 8 \ldots \ldots \ldots \ldots \ldots \ldots \ldots \ldots \ldots \ldots \ldots \ldots \ldots$

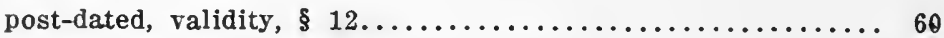

renunciation must be in writing, unless, $\S 122 \ldots \ldots \ldots \ldots \ldots 158$

specially indorsed, negotiability, $\S 40 \ldots \ldots \ldots \ldots \ldots \ldots \ldots . \ldots 8$

subject to original defense, when, $\S 58 \ldots \ldots \ldots \ldots \ldots \ldots \ldots 116$

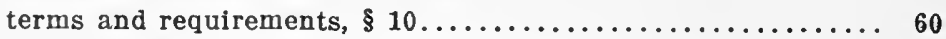

Issue, defined, $\S 191 \ldots \ldots \ldots \ldots \ldots \ldots \ldots \ldots \ldots \ldots \ldots \ldots \ldots \ldots \ldots$

Joint parties-

notice of dishonor, how given, $\S 100 \ldots \ldots \ldots \ldots \ldots \ldots \ldots \ldots$

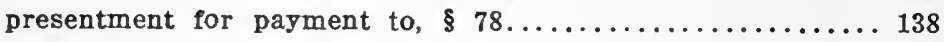

Law merchant, application, $\S 196 \ldots \ldots \ldots \ldots \ldots \ldots \ldots \ldots \ldots \ldots$ 
INDEX TO UNIFORM NEGOTIABLE INSTRUMENTS ACT. 601

Liability-

PAGE

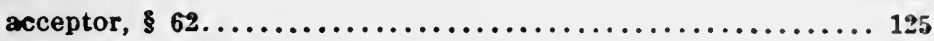

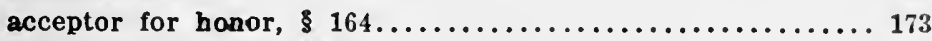

accomodation party, $\S 29 \ldots \ldots \ldots \ldots \ldots \ldots \ldots \ldots \ldots \ldots \ldots . \ldots \ldots$

agent, person signing as, $\$ 20 \ldots \ldots \ldots \ldots \ldots \ldots \ldots \ldots \ldots . \ldots 67$

drawer's acceptance and payment promised, $\$ 61 \ldots \ldots \ldots \ldots 124$

drawer's, limited by stipulation, $\$ 61 \ldots \ldots \ldots \ldots \ldots \ldots \ldots \ldots 124$

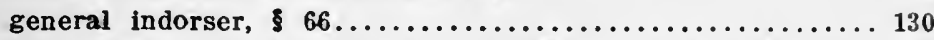

holder of set who indorses parts to different persons $\$ 180 \ldots 175$

indorsers where instrument negotiable by dellvery, $\S 67 \ldots \ldots 132$

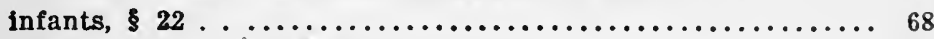

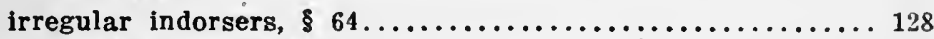

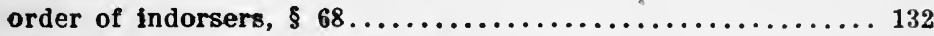

parties, see Parties, liability of person secondarily liable when

instrument is dishonored, $\$ 84 \ldots \ldots \ldots \ldots \ldots \ldots \ldots \ldots \ldots$

person signing trade or assumed name, $\S 18 \ldots \ldots \ldots \ldots \ldots \ldots 66$

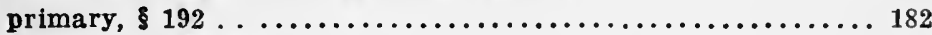

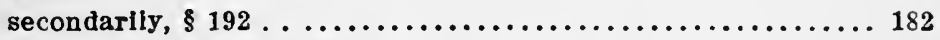

Llabllity of agent, see Agent.

Liability of broker, see Broker.

Llen on instrument, lienor a holder for value, $\$ 27 \ldots \ldots \ldots \ldots \ldots 77$

Malling, notice of dishonor, what constitutes, $\$ 106 \ldots \ldots \ldots \ldots . .149$

Mail, miscarriage of notice of dishonor, effect, $\S 105 \ldots \ldots \ldots \ldots .148$

Maker's Liability -

payee's existence and capacity to indorse admitted, $\$ 60 \ldots \ldots 123$

payment according to tenor of instrument, $\S 60 \ldots \ldots \ldots \ldots 123$

Making, date of, presumption, $\S 11 \ldots \ldots \ldots \ldots \ldots \ldots \ldots \ldots \ldots . \ldots 6$

Material alteration, see alteration.

Maturity, bill of exchange payable after sight, $\$ 166 \ldots \ldots \ldots \ldots 173$

Mistake-

cancellation by, $\S 123 \ldots \ldots \ldots \ldots \ldots \ldots \ldots \ldots \ldots \ldots \ldots \ldots \ldots 159$

indorser's name misspelled, $\$ 43 \ldots \ldots \ldots \ldots \ldots \ldots \ldots \ldots . \ldots$

Name-

assumed, llability of person signing, $\$ 18 \ldots \ldots \ldots \ldots \ldots \ldots 66$

trade, liability of person signing, $\S 18 \ldots \ldots \ldots \ldots \ldots \ldots \ldots 66$

wrongly designated or misspelled, $\S 43 \ldots \ldots \ldots \ldots \ldots \ldots \ldots 90$

Negotiabllity-

bearer, indorsed specially, delivery, $\$ 40 \ldots \ldots \ldots \ldots \ldots \ldots 88$

continuation of negotiable character, $\$ 47 \ldots \ldots \ldots \ldots \ldots \ldots 90$

indorsement in part, effect, $\$ 32 \ldots \ldots \ldots \ldots \ldots \ldots \ldots \ldots \ldots . \ldots \ldots$

lack of consideration does not effect, $\$ 6 \ldots \ldots \ldots \ldots \ldots \ldots \ldots 57$

omissions not affecting, $\$ 6 \ldots \ldots \ldots \ldots \ldots \ldots \ldots \ldots \ldots \ldots \ldots \ldots$

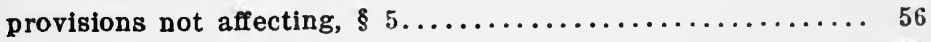

requirements of, $\& 1 \ldots \ldots \ldots \ldots \ldots \ldots \ldots \ldots \ldots \ldots \ldots, 49$ 
PAGE

Negotiable instrument, how discharged, $\S 119 \ldots \ldots \ldots \ldots \ldots \ldots \ldots \ldots 154$

Negotiable instruments Law-

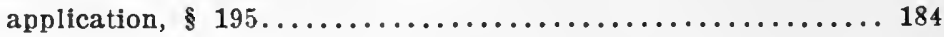

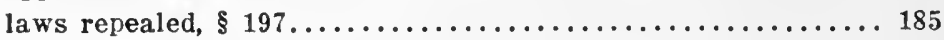

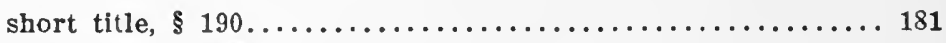

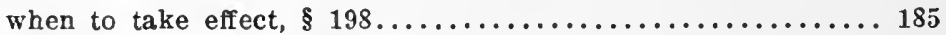

Negotiation-

bill of exchange in sets, different parts, $\S 179 \ldots \ldots \ldots \ldots \ldots 175$

bill indorsed in blank, how, $\$ 34 \ldots \ldots \ldots \ldots \ldots \ldots \ldots \ldots . \ldots 6$

by delivery or qualified indorsement, $\S 65 \ldots \ldots \ldots \ldots \ldots \ldots . \ldots 129$

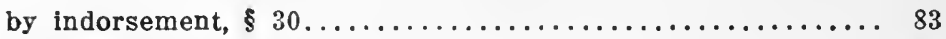

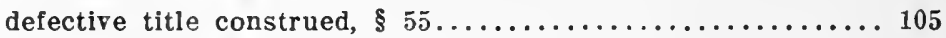

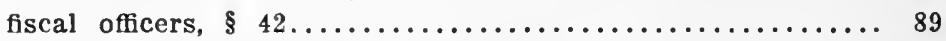

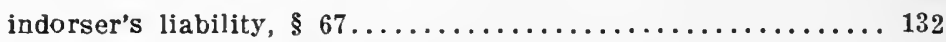

prior party, when may negotiate, restrictions, $\S 50 \ldots \ldots \ldots .92$

unreasonable length of time after issue, $\$ 53 \ldots \ldots \ldots \ldots \ldots 103$

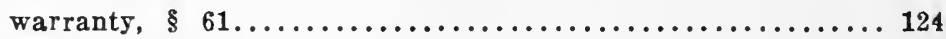

Non-payment-

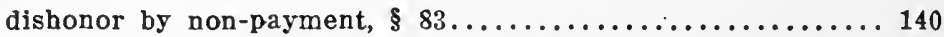

liability of person secondarily liable, $\S 84 \ldots \ldots \ldots \ldots \ldots \ldots 140$

notice of, not required where non-acceptance notice given,

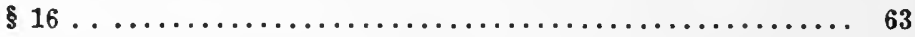

Notarial act of honor, bill of exchange, payment for honor-

supra protest, $\S \S 172,173 \ldots \ldots \ldots \ldots \ldots \ldots \ldots \ldots \ldots \ldots \ldots 174,175$

Note, defined, $\S 191 \ldots \ldots \ldots \ldots \ldots \ldots \ldots \ldots \ldots \ldots \ldots \ldots \ldots \ldots$

Notice of dishonor-

agent may give notice, $\S \S 91,94 \ldots \ldots \ldots \ldots \ldots \ldots \ldots \ldots \ldots \ldots 14$

antecedent party, time for giving notice, $\S 107 \ldots \ldots \ldots \ldots 149$

bankrupt, notice how given to, $\S 101 \ldots \ldots \ldots \ldots \ldots \ldots \ldots 146$

death of party, notice given to, whom, $\S 98 \ldots \ldots \ldots \ldots \ldots 146$

delay in giving notice, how excused, $\S 113 \ldots \ldots \ldots \ldots \ldots \ldots 151$

delivery personally or by mail, $\S 96 \ldots \ldots \ldots \ldots \ldots \ldots \ldots \ldots 145$

drawer, when notice need not be given to, $\S 114 \ldots \ldots \ldots \ldots 152$

due notice, when sender is deemed to have given, $\S 105 \ldots \ldots .148$

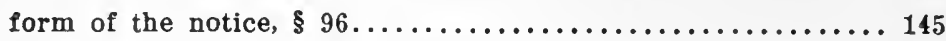

holder giving notice, effect, $\S 92 \ldots \ldots \ldots \ldots \ldots \ldots \ldots \ldots \ldots \ldots$

Indorser, when notice need not be given to, $\S 115 \ldots \ldots \ldots \ldots 152$

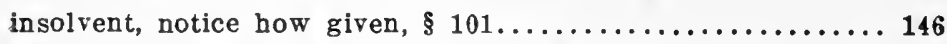

joint parties not partners, how given, $\S 100 \ldots \ldots \ldots \ldots \ldots \ldots 146$

mailing, what constitutes, effect, $\S 106 \ldots \ldots \ldots \ldots \ldots \ldots \ldots 149$

misdescription of instrument, effect, $\S 96 \ldots \ldots \ldots \ldots \ldots \ldots \ldots 145$

non-acceptance, failure to give notice, effect, $\S 117 \ldots \ldots \ldots 153$ 
Notice of dishonor-Continued.

non-acceptance, notice given, notice of non-payment not re-

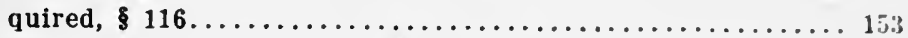

notice, by whom to be given, $\$ 90 \ldots \ldots \ldots \ldots \ldots \ldots \ldots \ldots \ldots$

notice dispensed with in certain cases, $\$ 112 \ldots \ldots \ldots \ldots \ldots 151$

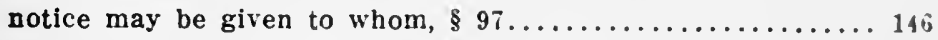

notice, to whom must be given, $\S 89 \ldots \ldots \ldots \ldots \ldots \ldots \ldots \ldots 141$

notice, when it need not be given indorser, $\$ 115 \ldots \ldots \ldots \ldots 152$

parties, residing in different places, time for giving, $\$ 104 \ldots 147$

parties residing in same place, time for giving, $103 \ldots \ldots \ldots 147$

partners, notice to one sufficient, $\S 99 \ldots \ldots \ldots \ldots \ldots \ldots \ldots 146$

party entitled to give notice, effect, $\S 93 \ldots \ldots \ldots \ldots \ldots \ldots \ldots 14$

post office, deposit in, what constitutes, $\S 106 \ldots \ldots \ldots \ldots \ldots 143$

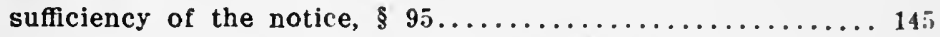

time within which notice must be given, $\S 102 \ldots \ldots \ldots \ldots \ldots 147$

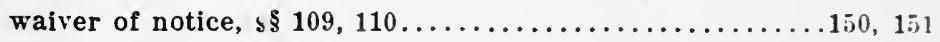

where notice must be sent, $\$ 108 \ldots \ldots \ldots \ldots \ldots \ldots \ldots \ldots \ldots \ldots$

Obligations, of acceptor for honor, $\S 165 \ldots \ldots \ldots \ldots \ldots \ldots \ldots \ldots . \ldots \ldots$

Officer-

indorsement by or to fiscal, effect, $\$ 42 \ldots \ldots \ldots \ldots \ldots \ldots \ldots 89$

instrument drawn on, indorsed to, effect, $\$ 4 \ldots \ldots \ldots \ldots \ldots \ldots$

Order, payable to, what constitutes, $\$ 8 \ldots \ldots \ldots \ldots \ldots \ldots \ldots \ldots$. 58

Parties-

alteration in number or relations, effect, $\$ 125 \ldots \ldots \ldots \ldots \ldots 161$

subsequent, in payment for honor, effect, $\$ 175 \ldots \ldots \ldots \ldots \ldots 175$

Parties, liability of (see also Liability)-

acceptor's liability, see Acceptor's liability.

drawer's liability, see Drawer's liability.

generai indorser's liability, see Indorser.

indorser, order of liability, see Indorser..

indorser, paper negotiable by delivery, see Indorser.

infant, see Infant.

irregular indorser, see Indorser.

maker's liability, see Maker liability.

notice to parties not partners, how given, $\$ 100 \ldots \ldots \ldots \ldots \ldots 146$

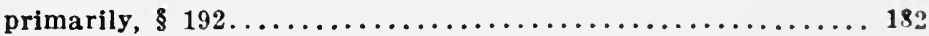

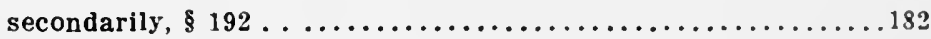

Partners-

notice of dishonor to one sufficient, $\$ 93 \ldots \ldots \ldots \ldots \ldots \ldots \ldots 14$

presentment for payment to, place of payment not specified,

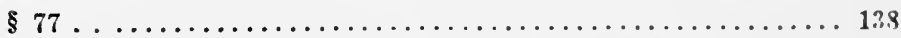

Payable after sight, bill, maturity calculated from, $\$ 166 \ldots \ldots \ldots 173$

Payabie on demand, what instruments are, $\$ 7 \ldots \ldots \ldots \ldots \ldots \ldots$

Payable to bearer, what instruments are, $\$ 3 \ldots \ldots \ldots \ldots \ldots \ldots \ldots 59$

Payable to order, what instruments are, $\$ 8 \ldots \ldots \ldots \ldots \ldots \ldots . \ldots 5$ 
Payee-

PAGE

name wrongly designated or misspelled, indorsement, $\S 43 \ldots 90$

two or more, indorsement, $\S 41 \ldots \ldots \ldots \ldots \ldots \ldots \ldots \ldots \ldots . . . \ldots 9$

Payment (see also Discharge) -

according to tenor of acceptance, $\S 62 \ldots \ldots \ldots \ldots \ldots \ldots \ldots \ldots 125$

alteration of the medium with which payment is made, $\S 125 \ldots 161$

bill of exciange in sets, payment by acceptor, $\$ 182 \ldots \ldots \ldots \ldots 176$

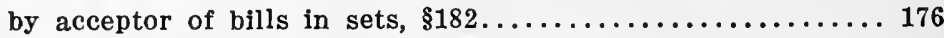

holder refuses, supra protest, effect, $\S 176 \ldots \ldots \ldots \ldots \ldots \ldots \ldots 175$

" in due course" a discharge, $\S 119 \ldots \ldots \ldots \ldots \ldots \ldots \ldots \ldots \ldots 154$

" in due course," construed, $\S 88 \ldots \ldots \ldots \ldots \ldots \ldots \ldots \ldots \ldots \ldots 141$

in due course to holder, effect, $\S 51 \ldots \ldots \ldots \ldots \ldots \ldots \ldots \ldots \ldots . . \ldots 3$

paper payable at a bank an order for bank to pay, $\S 87 \ldots \ldots \ldots 141$

party secondarily liable, effect, $\S 121 \ldots \ldots \ldots \ldots \ldots \ldots \ldots 158$

place, alteration of, effect, $\S 125 \ldots \ldots \ldots \ldots \ldots \ldots \ldots \ldots \ldots \ldots 161$

Payment for honor, bill of exchange-

declaration before payment, $\S 173 \ldots \ldots \ldots \ldots \ldots \ldots \ldots \ldots \ldots \ldots \ldots$

holder refusing to accept payment, supra protest, $\S 176 \ldots \ldots 175$

how payment must be made, $\S \S 172,173 \ldots \ldots \ldots \ldots \ldots \ldots 174,175$

payer for honor, rights of, $\S 177 \ldots \ldots \ldots \ldots \ldots \ldots \ldots \ldots \ldots \ldots$

preference of parties offering to pay, $\S 174 \ldots \ldots \ldots \ldots \ldots \ldots \ldots 175$

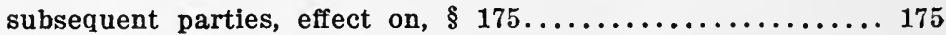

who may make payment for honor, $\S 171 \ldots \ldots \ldots \ldots \ldots \ldots \ldots 174$

Payment, presentment for, see Presentment for payment.

Person, defined, $\$ 191 \ldots \ldots \ldots \ldots \ldots \ldots \ldots \ldots \ldots \ldots \ldots \ldots \ldots \ldots \ldots$

Post-dated instrument, validity, $\S 12 \ldots \ldots \ldots \ldots \ldots \ldots \ldots \ldots \ldots \ldots 60$

Post-office, notice deposited in, see Notice of dishonor.

Presentment for acceptance-

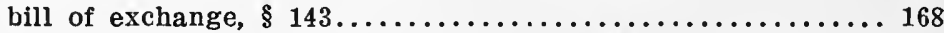

days on which presentment may be made, $\S 146 \ldots \ldots \ldots \ldots 169$

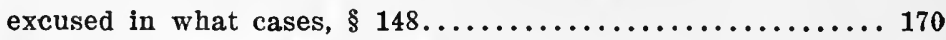

failure to present, effect, $\S 144 \ldots \ldots \ldots \ldots \ldots \ldots \ldots \ldots \ldots \ldots 169$

how to be made, $\$ 145 \ldots \ldots \ldots \ldots \ldots \ldots \ldots \ldots \ldots \ldots \ldots \ldots . \ldots \ldots$

time insufficient for presentment, effect, $\S 147 \ldots \ldots \ldots \ldots \ldots 169$

when presentment must be made, $\$ 143 \ldots \ldots \ldots \ldots \ldots \ldots \ldots \ldots 168$

Presentation for payment, check, $\S 186 \ldots \ldots \ldots \ldots \ldots \ldots \ldots \ldots . \ldots 178$

Presentment for payment-

acceptor for honor, to, how made, $\S 168 \ldots \ldots \ldots \ldots \ldots . \ldots 174$

acceptor, for honor, to, delay, excuses, $\S 169 \ldots \ldots \ldots \ldots \ldots 174$

death of principal debtor, where made, $\S 76 \ldots \ldots \ldots \ldots \ldots \ldots 138$

delay in making, when excused, $\S 81 \ldots \ldots \ldots \ldots \ldots \ldots \ldots \ldots 139$

dispensed with, in what cases, $\S 82 \ldots \ldots \ldots \ldots \ldots \ldots \ldots \ldots 139$

drawer, when presentment not required to charge, $\S 79 \ldots \ldots 138$

indorser, when presentment not required, to charge, $\S 80 \ldots 138$

instrument to be delivered to party paying it, $\S 74 \ldots \ldots \ldots \ldots 137$ 
Presentment for payment-Continued.

PAGE

instrument to be exhibited, $\S 74 \ldots \ldots \ldots \ldots \ldots \ldots \ldots \ldots \ldots \ldots$

joint debtors not partners, $\S 78 \ldots \ldots \ldots \ldots \ldots \ldots \ldots \ldots \ldots \ldots$

necessity for, to charge drawer and indorser, $\$ 70 \ldots \ldots \ldots \ldots 133$

partners liable, no place of payment specified, $\S 77 \ldots \ldots \ldots 138$

payable at a bank, requirements, $\S 75 \ldots \ldots \ldots \ldots \ldots \ldots \ldots . \ldots 137$

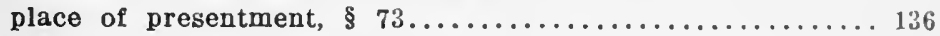

sufficient presentment, what constitutes, $\$ 72 \ldots \ldots \ldots \ldots \ldots 136$

time for, when to be made, $\$ 71 \ldots \ldots \ldots \ldots \ldots \ldots \ldots \ldots \ldots \ldots \ldots$

Presumption-

acceptance for honor of drawer, $\S 163 \ldots \ldots \ldots \ldots \ldots \ldots \ldots 173$

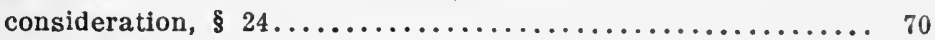

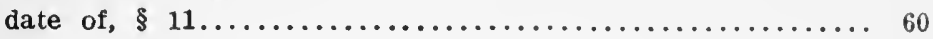

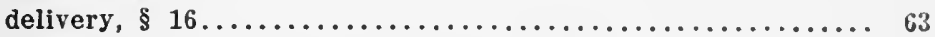

indorsement, date of, prima facie true, $\S 11 \ldots \ldots \ldots \ldots \ldots \ldots 60$

indorsement, place of $\S 46 \ldots \ldots \ldots \ldots \ldots \ldots \ldots \ldots \ldots . \ldots \ldots$

indorsement, time when made, $\$ 45 \ldots \ldots \ldots \ldots \ldots \ldots \ldots . \ldots 90$

Prior party, when may negotiate instrument negotiated back to

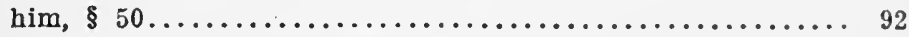

"Procuration," signature by, effect, $\S 21 \ldots \ldots \ldots \ldots \ldots \ldots \ldots \ldots 68$

Promise to pay-

conditional promise to pay, $\S 3 \ldots \ldots \ldots \ldots \ldots \ldots \ldots \ldots \ldots \ldots 4$

unconditional promise to pay, $\S 3 \ldots \ldots \ldots \ldots \ldots \ldots \ldots \ldots \ldots$

Promissory note-

defined, $\S 184 \ldots \ldots \ldots \ldots \ldots \ldots \ldots \ldots \ldots \ldots \ldots \ldots \ldots \ldots \ldots$

drawn to maker's order requires his indorsement to make

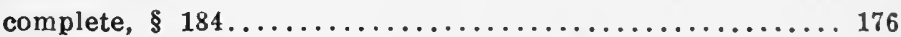

when bill of exchange may be treated as, $\S 130 \ldots \ldots \ldots \ldots .164$

Protest-

dishonor of bill by acceptor for honor must be protested, \& 170.174

non-acceptance on non-payment not required except for

foreign bills of exchange, $\S 118 \ldots \ldots \ldots \ldots \ldots \ldots \ldots \ldots \ldots 3$

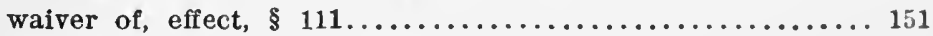

Protest, bill of exchange-

acceptor insolvent, protest before maturity, $\$ 158 \ldots \ldots \ldots \ldots 172$

bill wrongly detained, how made, $\S 160 \ldots \ldots \ldots \ldots \ldots \ldots \ldots 2$

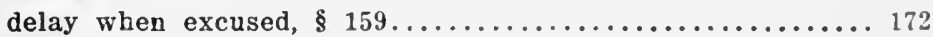

detained or destroyed bill, how made, $\S 160 \ldots \ldots \ldots \ldots \ldots \ldots 2$

dishonored bill accepted for honor supra protest, $\$ 167 \ldots \ldots \ldots 174$

dispensed with in certain cases, $\S 159 \ldots \ldots \ldots \ldots \ldots \ldots \ldots . \ldots \ldots$

foreign bill, necessity for protest, $\S 152 \ldots \ldots \ldots \ldots \ldots \ldots \ldots 17$

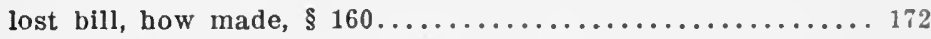

necessity for, in what cases, $\S 152 \ldots \ldots \ldots \ldots \ldots \ldots \ldots \ldots \ldots 17$

non-acceptance and non-payment, $\S 157 \ldots \ldots \ldots \ldots \ldots \ldots \ldots \ldots . \ldots \ldots$

requirements of, how protest made, $\$ 153 \ldots \ldots \ldots \ldots \ldots \ldots 17$ 
Protest, bill of exchange-Continued. PAGR

when protest must be made, $\$ 155 \ldots \ldots \ldots \ldots \ldots \ldots \ldots \ldots \ldots 172$

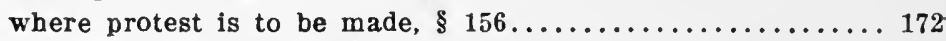

who may make protest, $\S 154 \ldots \ldots \ldots \ldots \ldots \ldots \ldots \ldots \ldots \ldots 171$

Qualified acceptance (bill of exchange)-

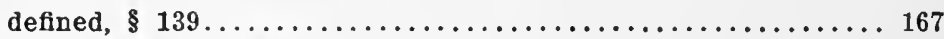

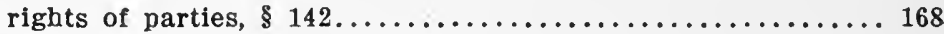

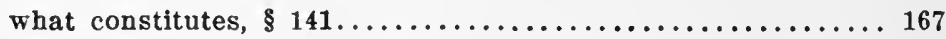

Qualified indorsement, see Indorsement.

Reasonable time, determination of, $\S 193 \ldots \ldots \ldots \ldots \ldots \ldots \ldots \ldots . \ldots 183$

Recourse, right of-

bill of exchange, bill not accepted, $\S 151 \ldots \ldots \ldots \ldots \ldots \ldots \ldots 170$

holder's right accrues on dishonor by non-payment, $\$ 84 \ldots \ldots 140$

Referee in case of need (bill of exchange), defined, $\S 131 \ldots \ldots \ldots 164$

Renunciation by holder, $\S 122 \ldots \ldots \ldots \ldots \ldots \ldots \ldots \ldots \ldots \ldots \ldots$

Representative capacity, indorsement by person in, $\S 44 \ldots \ldots \ldots .90$

Restrictive indorsement, see Indorsement.

Right of recourse, see Recourse, right of.

Rights of holder, see Holder, rights of.

Saturday half-holiday, see Holiday.

Seal, negotiability and validity not affected by, $\S 6 \ldots \ldots \ldots \ldots \ldots .57$

Separate instrument, acceptance (bill of exchange), $\$ 134 \ldots \ldots \ldots 166$

Sets, see Bill of exchange in sets.

Signature-

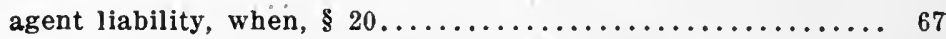

agent signing, authority how shown, $\$ 19 \ldots \ldots \ldots \ldots \ldots \ldots 66$

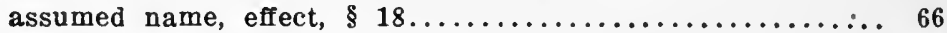

forged, effect, $\S 23 \ldots \ldots \ldots \ldots \ldots \ldots \ldots \ldots \ldots \ldots \ldots \ldots \ldots$

indorsement, how made, $\S 31 \ldots \ldots \ldots \ldots \ldots \ldots \ldots \ldots \ldots . \ldots 5$

on a blank paper, $\S 14 \ldots \ldots \ldots \ldots \ldots \ldots \ldots \ldots \ldots \ldots \ldots \ldots \ldots$

presumption of consideration, $\S 24 \ldots \ldots \ldots \ldots \ldots \ldots \ldots \ldots \ldots$

" procuration," effect, $\$ 21 \ldots \ldots \ldots \ldots \ldots \ldots \ldots \ldots \ldots \ldots \ldots 68$

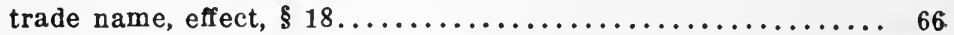

Special indorsement, see Indorsement.

Striking out indorsement by holder, see Indorsement.

Substance and form, see Form and substance.

Eum payable-

alteration of, effect, $\S 125 \ldots \ldots \ldots \ldots \ldots \ldots \ldots \ldots \ldots \ldots \ldots 1$

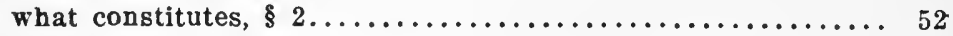

Sunday (see holiday)-

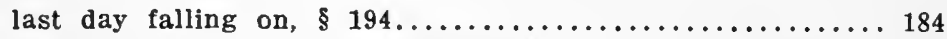

paper falling due on, when payable, $\$ 85 \ldots \ldots \ldots \ldots \ldots \ldots \ldots 140$

Terms, when sufficient to meet requirements, $\S 10 \ldots \ldots \ldots \ldots \ldots \ldots 60$ 
INDEX TO UNIFORM NEGOTIABLE INSTRUMENTS ACT. 607

Time-

PAGE

aiteration of time of payment, effect, $\$ 125 \ldots \ldots \ldots \ldots \ldots \ldots 161$

bill may be accepted for honor, $\$ 161 \ldots \ldots \ldots \ldots \ldots \ldots \ldots . \ldots 172$

computation, iast day falling due on holiday, $\$ 194 \ldots \ldots \ldots \ldots 184$

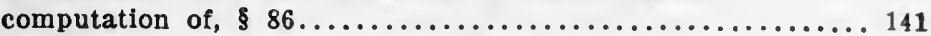

determinable, what constitutes, $\$ 4 \ldots \ldots \ldots \ldots \ldots \ldots \ldots \ldots$

drawee must accept bill of exchange, when, $\$ 136 \ldots \ldots \ldots \ldots 166$

future time, what constitutes, $\S 4 \ldots \ldots \ldots \ldots \ldots \ldots \ldots \ldots \ldots . \ldots \ldots$

maturity, Sunday, holiday, $\$ 85 \ldots \ldots \ldots \ldots \ldots \ldots \ldots \ldots \ldots \ldots$

notice of dishonor, parties residing in different places, $\$ 104 \ldots 147$

notice of dishonor, parties residing in same place, $\$ 103 \ldots \ldots 147$

notice of dishonor, to antecedent party, $\S 107 \ldots \ldots \ldots \ldots \ldots 149$

notice must be given, when, $\S 102 \ldots \ldots \ldots \ldots \ldots \ldots \ldots \ldots \ldots 14$

"reasonable time," what constitutes, $\S 193 \ldots \ldots \ldots \ldots \ldots \ldots 183$

when presentment for acceptance must be made, $\$ 146 \ldots \ldots .169$ Title-

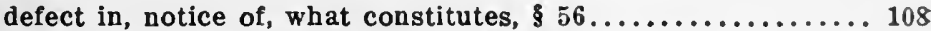

defect, notice of, effect on holder, $\$ \S 54,55 \ldots \ldots \ldots \ldots \ldots . \ldots 4,105$

Trade name, liabiiity of person signing, $\$ 18 \ldots \ldots \ldots \ldots \ldots \ldots \ldots 66$

Transfer, indorsement omitted, effect, $\$ 49 \ldots \ldots \ldots \ldots \ldots \ldots \ldots . \ldots 1$

Uniform negotiable instruments law, see Negotiable Instruments law.

Un reasonable time, determination of, $\S 193 . \ldots \ldots \ldots \ldots \ldots \ldots 183$

Validity-

ante-dated instrument, $\$ 12 \ldots \ldots \ldots \ldots \ldots \ldots \ldots \ldots \ldots \ldots . \ldots \ldots$

omissions not affecting, $\$ 6 \ldots \ldots \ldots \ldots \ldots \ldots \ldots \ldots \ldots \ldots \ldots 7$

Value-

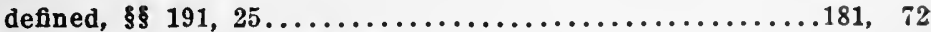

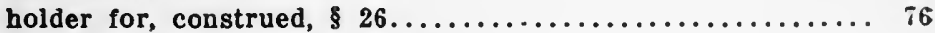

holder for, what constitutes, $\$ 27 \ldots \ldots \ldots \ldots \ldots \ldots \ldots \ldots . \ldots 77$

Waiver-

notice of dishonor, $\$ \S 109,110 \ldots \ldots \ldots \ldots \ldots \ldots \ldots \ldots \ldots, 151$

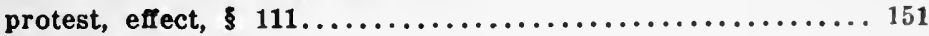

Warranty-

general indorser's warranty, $\$ 66 \ldots \ldots \ldots \ldots \ldots \ldots \ldots \ldots \ldots$

negotiation by delivery or by qualified indorsement, $65 \ldots 129$

Written, defined, $191 \ldots \ldots \ldots \ldots \ldots \ldots \ldots \ldots \ldots \ldots \ldots \ldots \ldots$ 


\section{INDEX TO UNIFORM SALES ACT}

Acceptance of Goods- PAGE

does not bar action for damages, $\S 49 \ldots \ldots \ldots \ldots \ldots \ldots \ldots . \ldots 227$

what constitutes, $\S \S 48,4 \ldots \ldots \ldots \ldots \ldots \ldots \ldots \ldots \ldots \ldots, 197$

\section{Actions-}

for price buyer neglects or refuses to pay, $\S 63 \ldots \ldots \ldots \ldots 236$

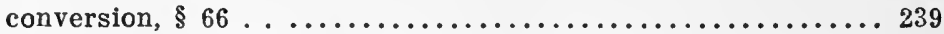

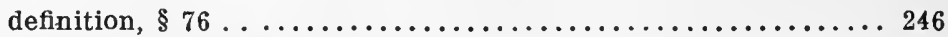

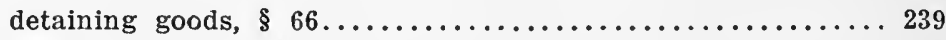

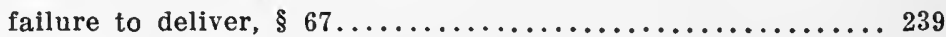

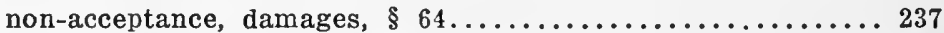

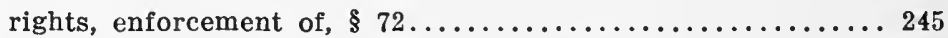

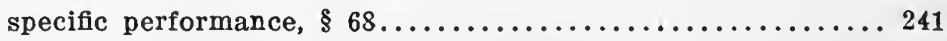

Attachment, goods for which negotiable document of title has

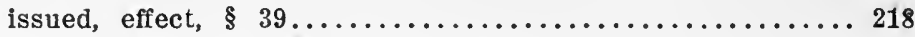

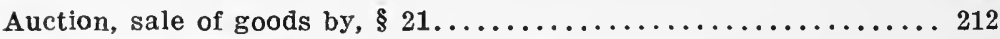

Bankruptcy, sales of goods, applications to, $\S 73 \ldots \ldots \ldots \ldots \ldots 245$

Buyer-

acceptance of goods does not bar action for damages, $\S 49 \ldots 227$

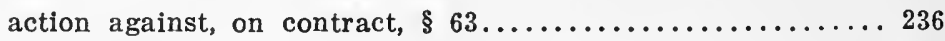

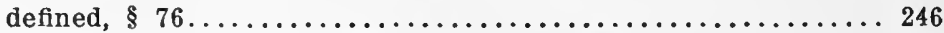

delivery to carrier on behalf of, effect, $\S 46 \ldots \ldots \ldots \ldots \ldots \ldots 224$

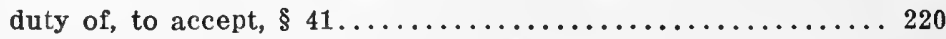

insolvency, seller may stop goods, $\S 57 \ldots \ldots \ldots \ldots \ldots \ldots \ldots 231$

liability for failure to accept delivery, $\S 51 \ldots \ldots \ldots \ldots \ldots \ldots 228$

may maintain conversion, when, $\S 66 \ldots \ldots \ldots \ldots \ldots \ldots \ldots 239$

measure of liability for non-acceptance of goods, $\S 64 \ldots \ldots \ldots 237$

need not accept delivery in installments, unless, $\S 45 \ldots \ldots .223$

remedy of, on breach of warranty by seller, $\S 69 \ldots \ldots \ldots \ldots 241$

right to examination of goods, unless, $\S 47 \ldots \ldots \ldots \ldots \ldots \ldots 225$

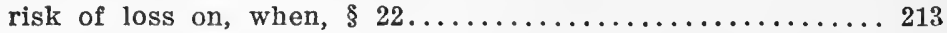

sale by, does not effect lien or right of stoppage in transitu,

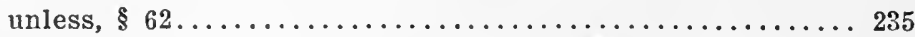

wrongly delivered goods, need not return, $\S 50 \ldots \ldots \ldots \ldots 228$

Capacity, to buy and sell, $\S 2 \ldots \ldots \ldots \ldots \ldots \ldots \ldots \ldots \ldots \ldots \ldots \ldots$

Carriers, delivery of goods to, on behalf of buyer, $\S 46 \ldots \ldots \ldots 224$

Coercion, law of sales of goods, application to, $\S 73 \ldots \ldots \ldots \ldots 245$

Conditional sale, effect of condition, $\S 11 \ldots \ldots \ldots \ldots \ldots \ldots \ldots \ldots 202$ 
Conditions, concurrent, delivery and payment, $\$ 42 \ldots . . \ldots \ldots . .220$

Contracts to sell goods-

act does not apply to existing sales or contracts to sell, \& $76 \mathrm{a} .247$ application of rules of law and equity, $\$ 73 \ldots \ldots \ldots \ldots \ldots \ldots 245$

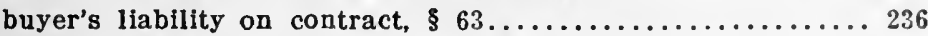

definition, absolute or conditional, $\S 1 \ldots \ldots \ldots \ldots \ldots \ldots \ldots 196$

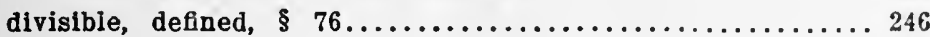

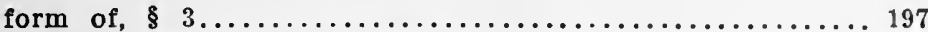

rescission of, by seller, when, $\S 65 \ldots \ldots \ldots \ldots \ldots \ldots \ldots \ldots 238$

requirements, $\$ 4 \ldots \ldots \ldots \ldots \ldots \ldots \ldots \ldots \ldots \ldots \ldots \ldots \ldots \ldots$

Conversion-

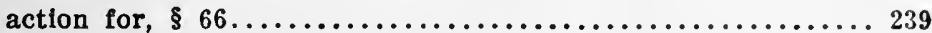

buyer may maintain when, $\S 66 \ldots \ldots \ldots \ldots \ldots \ldots \ldots \ldots \ldots . \ldots 239$

Creditors-

rights, sold goods in seller's possession, $\S 26 \ldots \ldots \ldots \ldots \ldots 214$

remedy to reach negotiable document of title, $\$ 40 \ldots \ldots \ldots \ldots 219$

Damages-

measure of, for neglect or refusal to deliver, $\S 67 \ldots \ldots \ldots \ldots 239$

measure of, for non-acceptance of goods, $\S 64 \ldots \ldots \ldots \ldots \ldots 237$

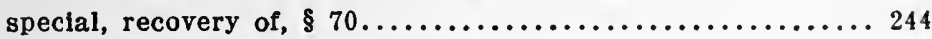

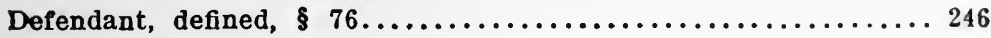

Definitions-

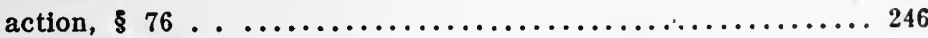

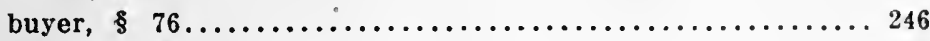

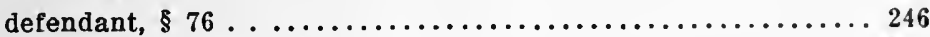

“deliverable state," $\S 76 \ldots \ldots \ldots \ldots \ldots \ldots \ldots \ldots \ldots \ldots \ldots \ldots 246$

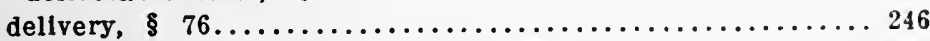

"divisible contract to sell or sale," $\S 76 \ldots \ldots \ldots \ldots \ldots \ldots 246$

"document of title to goods," $\S 76 \ldots \ldots \ldots \ldots \ldots \ldots \ldots \ldots \ldots 246$

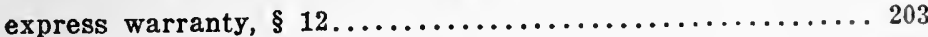

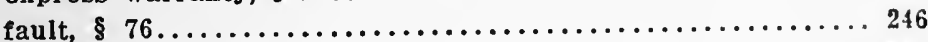

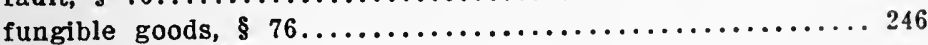

future goods, $\S \S 5,76 \ldots \ldots \ldots \ldots \ldots \ldots \ldots \ldots \ldots \ldots \ldots \ldots, 246$

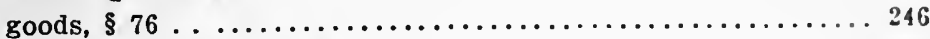

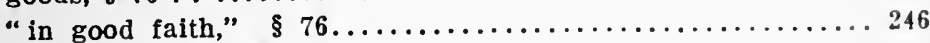

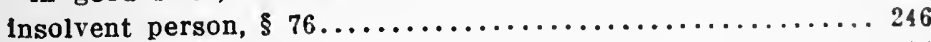

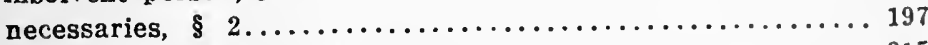

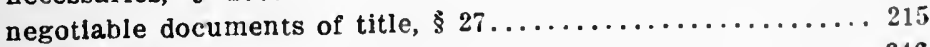

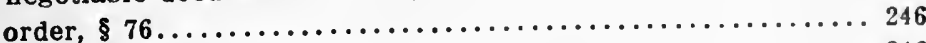

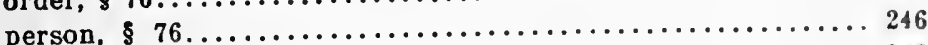

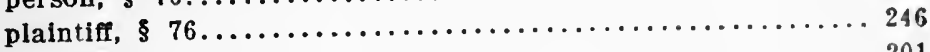

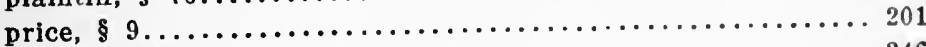

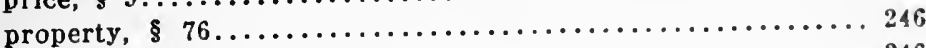

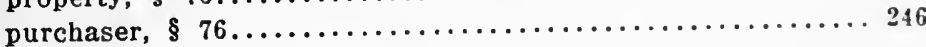


Definitions-Continued. PAGE

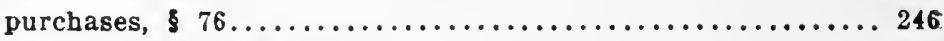

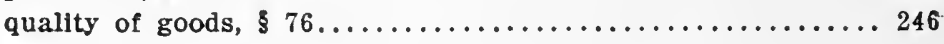

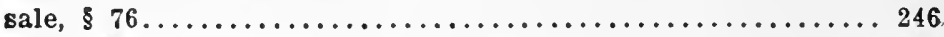

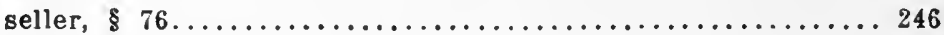

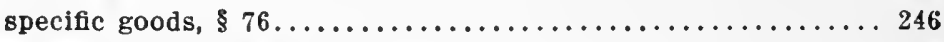

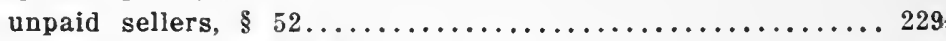

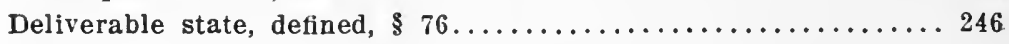

Delivery-

buyer's liability for failure to accept, $\$ 51 \ldots \ldots \ldots \ldots \ldots \ldots 228$

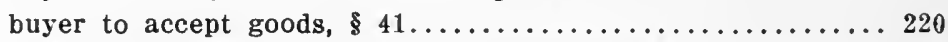

delivery and payment, concurrent conditions, $\$ 42 \ldots \ldots \ldots 220$

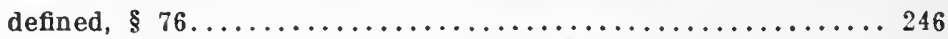

examination of goods, right to unless, $\$ 47 \ldots \ldots \ldots \ldots \ldots 225$

failure to, property has not passed, damages, $\$ 67 \ldots \ldots \ldots \ldots 239$

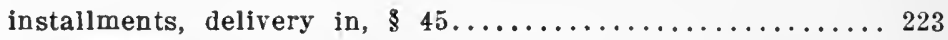

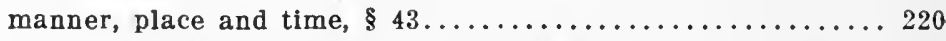

negotiation of documents of title by, $\$ 28 \ldots \ldots \ldots \ldots \ldots \ldots 215$

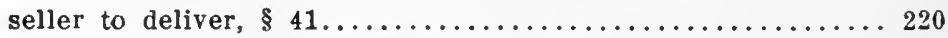

to carrier on behalf of buyer is delivery, except, $\S 46 \ldots \ldots \ldots 224$

wrongly delivered, buyer not bound to return goods, $\$ 50 \ldots .228$

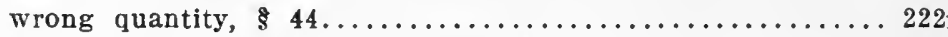

Description, sale by implied warranty, $\$ 14 \ldots \ldots \ldots \ldots \ldots \ldots 204$

Destruction-

goods contracted to be sold, effect, $\S 8 \ldots \ldots \ldots \ldots \ldots \ldots \ldots$

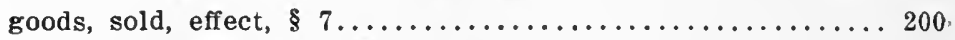

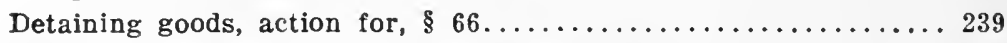

Devisable contract to sell or sale, defined, $\$ 76 \ldots \ldots \ldots \ldots \ldots \ldots 246$

Documents of Title, defined (see Negotiable Documents of Title),

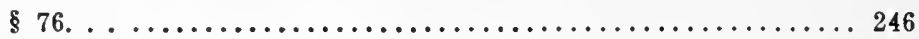

Duress, law of-

application to sales of goods, $\S 73 \ldots \ldots \ldots \ldots \ldots \ldots \ldots \ldots \ldots \ldots \ldots$.

negotiation of negotiable documents of title not impaired by,

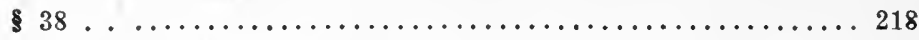

Drunkard, liability for necessities, $\$ 2 \ldots \ldots \ldots \ldots \ldots \ldots \ldots \ldots \ldots$.

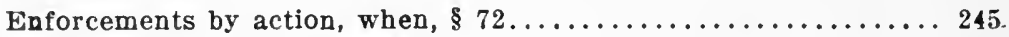

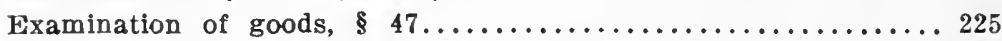

Existing and future goods, $\S 5 \ldots \ldots \ldots \ldots \ldots \ldots \ldots \ldots \ldots \ldots$ 19.

Existing contract to sell, act does not apply, $\$ 76 \mathrm{a} \ldots \ldots \ldots \ldots \ldots 247$

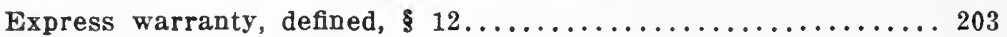

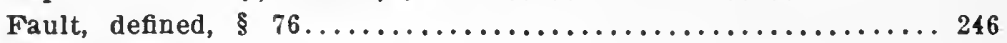

Fraud, law of-

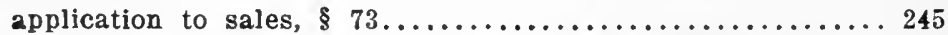

negotiations of negotiable documents of title not impaired by

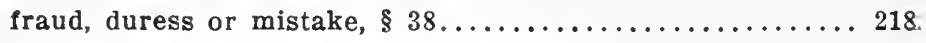


Frauds, see Statute of Frauds.

Fungible goods-

defined, $\$ 76$.

sale of undivided share, effect, $\$ 6 \ldots \ldots \ldots \ldots \ldots \ldots \ldots \ldots$

Future goods-

defined, \& 76 .

sale of, $\S 5$

Goods-

acceptance does not bar action for damages, $\$ 49 \ldots \ldots \ldots \ldots 227$

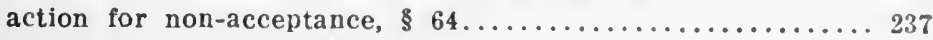

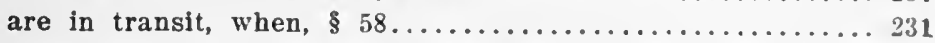

attachment or levy on, where negotiable document of title has

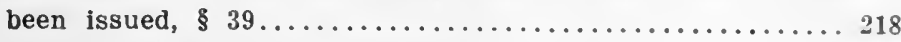

conversion of, detaining, liability, $\$ 66 \ldots \ldots \ldots \ldots \ldots \ldots \ldots 239$

destruction of, contracted to be sold, effect, $\$ 8 \ldots \ldots \ldots \ldots 200$

destruction of, where sold, effect, $\S 7 \ldots \ldots \ldots \ldots \ldots \ldots . \ldots 200$

examination of, on delivery, unless, $\$ 47 \ldots \ldots \ldots \ldots \ldots \ldots \ldots . \ldots \ldots$

existing and future, contracts regarding, $\S 5 \ldots \ldots \ldots \ldots \ldots 19$

fallure to deliver, $\S 67 \ldots \ldots \ldots \ldots \ldots \ldots \ldots \ldots \ldots \ldots \ldots \ldots . \ldots \ldots$

future, see Future Goods.

identification of, necessary before property passes, $\$ 17 \ldots \ldots 208$

implied warranties as to quality of, \& $15 \ldots \ldots \ldots \ldots \ldots \ldots . \ldots 205$

intention that property in, passes, when, $\S 19 \ldots \ldots \ldots \ldots 208$

lien on, after partial delivery, unless, $\S 55 \ldots \ldots \ldots \ldots \ldots \ldots 230$

manner, place and time of delivery of, $\$ 43 \ldots \ldots \ldots \ldots \ldots 220$

no property passes in unascertained, $\$ 17 \ldots \ldots \ldots \ldots \ldots . \ldots 208$

sale by auction, rules governing, $\$ 21 \ldots \ldots \ldots \ldots \ldots \ldots \ldots 212$

sale of, by buyer does not effect seller's lien, except, $\S 62 \ldots . .235$

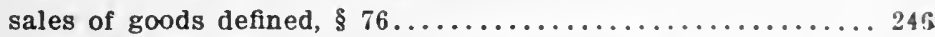

possession of, retained for price, title passed, $\S 53 \ldots \ldots \ldots .229$

wrongly delivered, buyer need not return, $\$ 50 \ldots \ldots \ldots \ldots 228$

Incompetents, liable for necessaries, $\$ 2 \ldots \ldots \ldots \ldots \ldots \ldots \ldots . \ldots \ldots 7$

Indorsements, negotiation of documents of title by, $\$ 29 \ldots \ldots \ldots 215$

Indorser of a negotiable document of title not a guarantor, $\$ 37 \ldots 218$

Infants, necessaries, liability for, $\$ 2 \ldots \ldots \ldots \ldots \ldots \ldots \ldots \ldots$

"In Good Faith," defined, $\S 76 \ldots \ldots \ldots \ldots \ldots \ldots \ldots \ldots \ldots \ldots$

Injunction, creditor's remedy to reach negotiable documents of

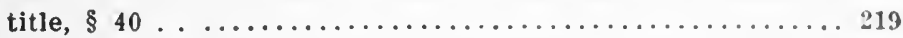

Insolvency, buyers, rights of seller to stoppage in transitu, \& 57.. 231

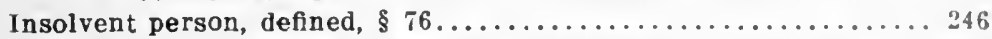

Installments, delivery in, buyer will not accept, unless, \& 45... 223

Intention of Parties, rules for ascertaining, $\$ 19 \ldots \ldots \ldots \ldots \ldots 208$

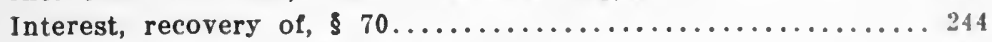

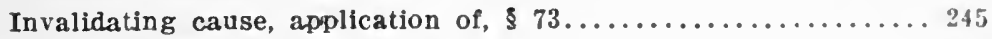

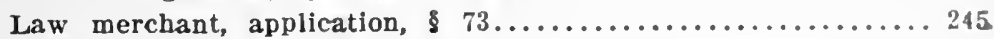


Levy, see Attachment.

PAGE

Liability-

buyer's, for failure to accept goods, $\S 64 \ldots \ldots \ldots \ldots \ldots \ldots \ldots 237$

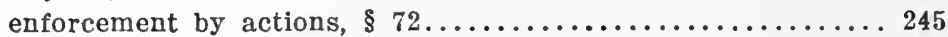

failure to deliver goods by seller, $\S 67 \ldots \ldots \ldots \ldots \ldots \ldots \ldots 239$

implied, may be varied by agreement, $\$ 71 \ldots \ldots \ldots \ldots \ldots 245$

infants and incompetents, for necessities, $\S 2 \ldots \ldots \ldots \ldots \ldots 197$

seller's, for detaining or converting goods, $\$ 66 \ldots \ldots \ldots \ldots 239$

Lien of seller-

sale of goods by buyer does not effect, except, $\S 62 \ldots \ldots \ldots 235$

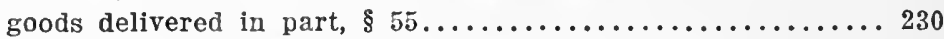

goods unpaid for, $\$ 53 . \ldots \ldots \ldots \ldots \ldots \ldots \ldots \ldots \ldots \ldots \ldots \ldots . \ldots \ldots$

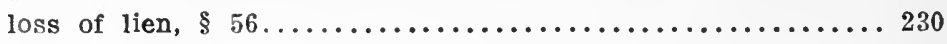

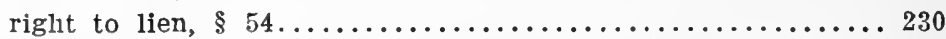

Lien of unpaid seller (see Sales of Goods, Lien of Seller).

Loss, risk of, who must carry, when, $\S 22 \ldots \ldots \ldots \ldots \ldots \ldots \ldots \ldots 213$

Mental incapacity, liability for necessities, $\S 2 \ldots \ldots \ldots \ldots \ldots \ldots \ldots 197$

Misrepresentation, law of, application, $\S 73 \ldots \ldots \ldots \ldots \ldots \ldots \ldots 245$

Mistake-

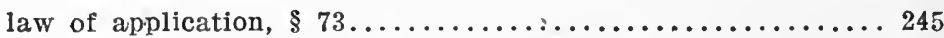

negotiation of negotiable documents of title not impaired by,

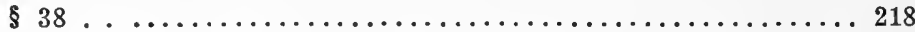

Mortgages, provisions relating to sales of goods not applicable,

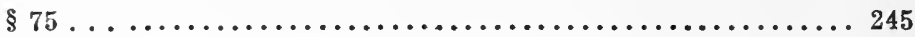

Necessaries-

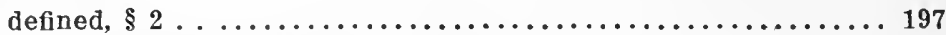

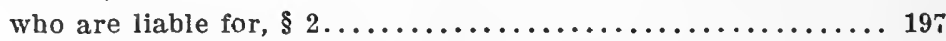

Negotiable documents of title-

attachment or levy upon goods, for which issued, effect, § $39 \ldots 218$

creditor's remedy to reach, $\$ 40 \ldots \ldots \ldots \ldots \ldots \ldots \ldots \ldots \ldots . \ldots \ldots$

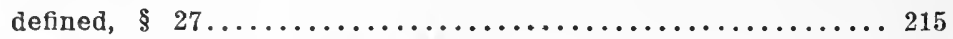

duress in negotiation, effect, $\S 38 \ldots \ldots \ldots \ldots \ldots \ldots \ldots \ldots \ldots . \ldots \ldots$

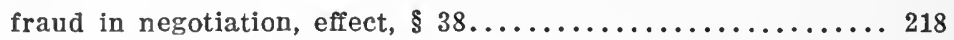

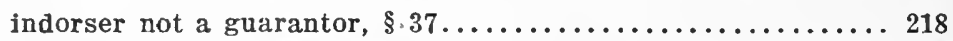

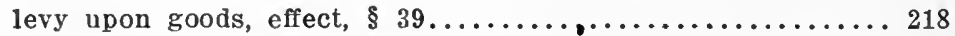

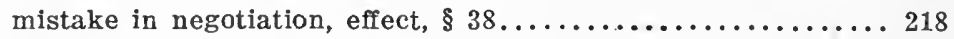

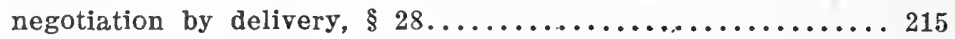

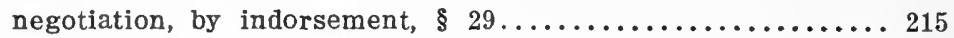

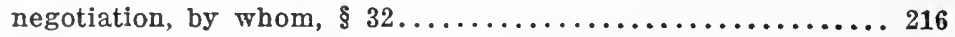

non-negotiable documents, transfer, $\S 31 \ldots \ldots \ldots \ldots \ldots \ldots . \ldots 216$

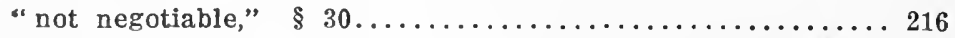

rights of person to whom document has been negotiated, $\S 33.216$

rights of person to whom document has been transferred, $\S 34.217$

transfer without endorsement, $\S 35 \ldots \ldots \ldots \ldots \ldots \ldots \ldots \ldots \ldots 217$

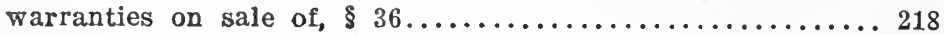


Negotiation-

of documents of title, may be made by whom, $\$ 32 \ldots \ldots \ldots 216$

negotiable documents of title by delivery, when, $\$ 28 \ldots \ldots 215$

negotiable documents of title by indorsement, $\delta 29 \ldots \ldots \ldots 215$

negotiable instrument marked, " not negotlable," effect, $\$ 30$. 216

rights of person to whom document negotiated, $\$ 33 \ldots \ldots \ldots 216$

Non-acceptance of goods, action for, $\S 64 \ldots \ldots \ldots \ldots \ldots \ldots \ldots \ldots 237$

Non-negotiable documents of title, transfer of, $\$ 31 \ldots \ldots \ldots \ldots \ldots 216$

Obligations, implied, variation of, $\$ 71 \ldots \ldots \ldots \ldots \ldots \ldots \ldots \ldots 245$

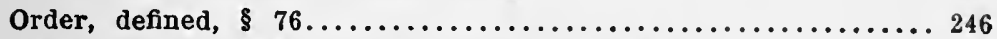

Parties, intention of, rules for ascertaining, $\$ 19 \ldots \ldots \ldots \ldots \ldots 208$

Payment and delivery, concurrent conditions, $\S 42 \ldots \ldots \ldots \ldots \ldots 220$

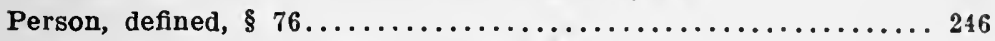

Person not the owner, sale by, effect, $\$ 23 \ldots \ldots \ldots \ldots \ldots \ldots \ldots 213$

Place, manner and time of delivery, $\$ 43 \ldots \ldots \ldots \ldots \ldots \ldots \ldots \ldots 220$

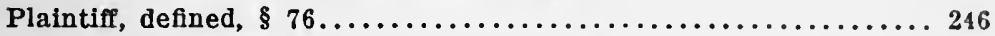

Pledge, provisions of act, not applicable, $\$ 75 \ldots \ldots \ldots \ldots \ldots \ldots 245$

Possession-

:oods already sold, sale by seller in, $\$ 25 \ldots \ldots \ldots \ldots \ldots \ldots 214$

Price-

reservation of right to, when goods shipped, $\S 20 \ldots \ldots \ldots \ldots 211$

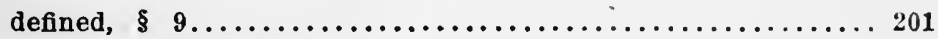

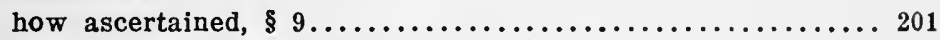

Principal and agent, law of application, $\S 73 \ldots \ldots \ldots \ldots \ldots \ldots . \ldots 245$

Property-

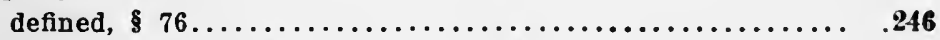

passes when parties intend, where, $\$ 18 \ldots \ldots \ldots \ldots \ldots \ldots \ldots 208$

reservation of right of, when goods shipped, $\S 20 \ldots \ldots \ldots \ldots 211$

Provisions, not applicable to mortgages, $\S 75 \ldots \ldots \ldots \ldots \ldots \ldots 245$

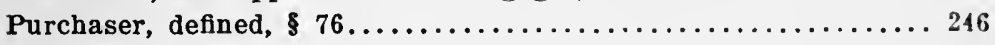

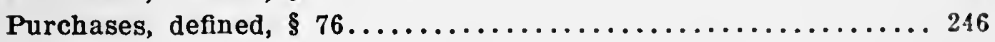

Quality of goods-

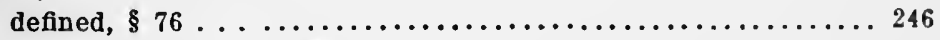

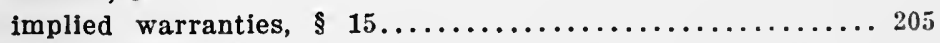

Quantity, delivery of wrong, may accept or reject, when, $\S 44 \ldots 222$

Rescission of contract of sale by seller, when, $\S 65 \ldots \ldots \ldots \ldots \ldots 238$

Remedies-

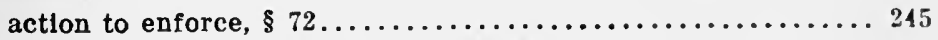

buyer's, on breach of warranty, $\S 69 \ldots \ldots \ldots \ldots \ldots \ldots \ldots . \ldots 24$

conversion agalnst seller, $\$ 66 \ldots \ldots \ldots \ldots \ldots \ldots \ldots \ldots \ldots \ldots . \ldots \ldots$

creditor's, to reach negotiable documents of title, $\$ 40 \ldots \ldots 219$

seller's, for breach of contract, $\$ 63 \ldots \ldots \ldots \ldots \ldots \ldots \ldots \ldots . \ldots \ldots$

unpaid seller's, where property passed to buyer, $\$ 53 . \ldots \ldots 229$

Resale-

right of (see Unpald Seller), $\S 53 \ldots \ldots \ldots \ldots \ldots \ldots \ldots \ldots \ldots \ldots 229$

when and how, may be made, $\S 60 \ldots \ldots \ldots \ldots \ldots \ldots \ldots \ldots$ 
Rights- PAGE

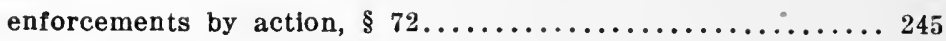

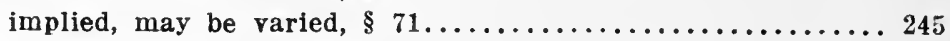
Sale-

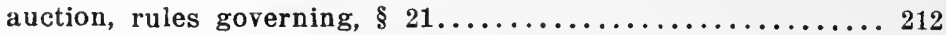

by description, implied warranty, $\S 14 \ldots \ldots \ldots \ldots \ldots \ldots . \ldots 204$

by one having a voidable title, effect, $\S 24 \ldots \ldots \ldots \ldots \ldots \ldots . \ldots 214$

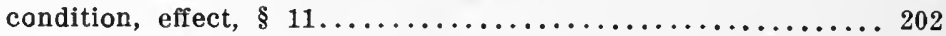

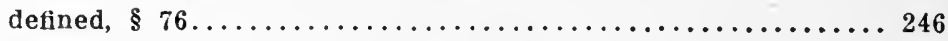

governed by, when not provided for, $\S 73 \ldots \ldots \ldots \ldots \ldots \ldots \ldots 245$

sale by sample, implied warranties, $\S 16 \ldots \ldots \ldots \ldots \ldots \ldots \ldots 20 \ldots$

seller in possession of property already sold, effect, $\S 25 \ldots .214$

time and place of, must be given in notice, $\$ 60 \ldots \ldots \ldots \ldots 233$

undivided share of fungible goods, $\S 6 \ldots \ldots \ldots \ldots \ldots \ldots \ldots$

valuation by third party, effect of his failure, $\S 10 \ldots \ldots \ldots 202$

Sale of goods, lien of seller not effected by buyer's, except, $\S 62 \ldots 235$

Sample, see Sale.

Seller-

breach of warranty by, liability, $\S 69 \ldots \ldots \ldots \ldots \ldots \ldots \ldots 241$

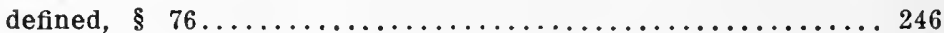

delivers, by delivering to carrier, except, $\S 46 \ldots \ldots \ldots \ldots \ldots 224$

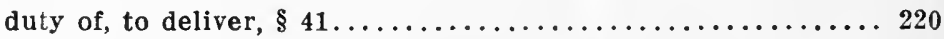

duty of, where property has not passed, $\S 63(3) \ldots \ldots \ldots \ldots 236$

having a voidable title only, effect, $\$ 24 \ldots \ldots \ldots \ldots \ldots \ldots . \ldots 214$

liable on contract, though goods accepted, $\$ 49 \ldots \ldots \ldots \ldots \ldots 227$

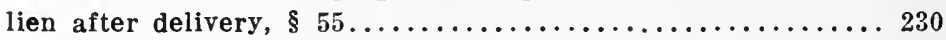

lien of, where title passed, $\S 53 \ldots \ldots \ldots \ldots \ldots \ldots \ldots \ldots \ldots . \ldots 29$

remedies of, for breach of contract, $\$ 63 \ldots \ldots \ldots \ldots \ldots \ldots 236$

retaining possession of sold goods, creditor's rights, $\$ 26 \ldots \ldots 214$

rights of, on insolvency of buyer, $\S 57 \ldots \ldots \ldots \ldots \ldots \ldots \ldots 231$

right of stoppage in transitu, buyer insolvent, $\S 53 \ldots \ldots \ldots \ldots 229$

right to make resale, when and how, $\$ 60 \ldots \ldots \ldots \ldots \ldots \ldots 233$

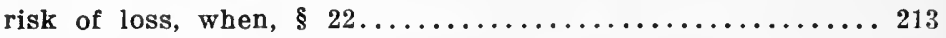

sale by, in possession of goods already sold, effect, $\S 25 \ldots \ldots 214$

unpaid lien, party delivery, $\S 52 \ldots \ldots \ldots \ldots \ldots \ldots \ldots \ldots \ldots 229$

when, may exercise right of lien, $\S 54 \ldots \ldots \ldots \ldots \ldots \ldots \ldots \ldots 230$

Shipment, reservation of right of possession and property, $\S 20 \ldots 211$

Specific goods-

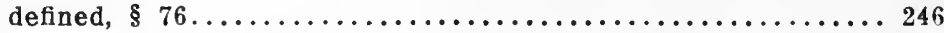

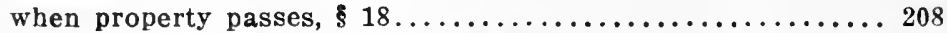

Specific performance, action for, when, $\S 68 \ldots \ldots \ldots \ldots \ldots \ldots \ldots 241$

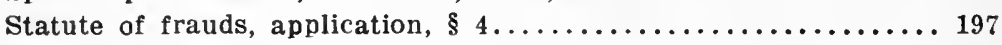

Stoppage in transitu-

right of, where property passed, $\S 53 \ldots \ldots \ldots \ldots \ldots \ldots \ldots \ldots 229$

sale of goods by buyer does not effect seller's right of, except,

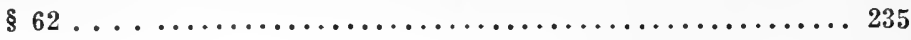


Stoppage in transit-Continued.

seller has right of, where buyer insolvent, $\$ 57 \ldots \ldots \ldots \ldots 231$

ways of exercising this right, $\$ 53 \ldots \ldots \ldots \ldots \ldots \ldots \ldots \ldots 232$

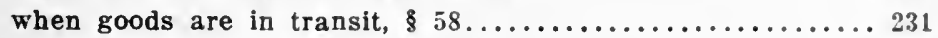

Time, manner and place of delivery, $\$ 43 \ldots \ldots \ldots \ldots \ldots \ldots \ldots \ldots 220$

mitle, see Voidable Title and Negotiable Documents of Title.

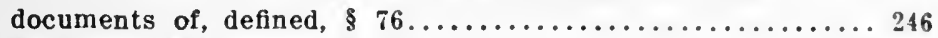

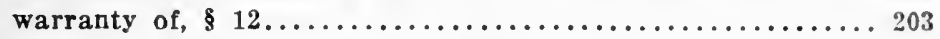

Transfer-

negotiable document without indorsement, $\S 35 \ldots \ldots \ldots \ldots 217$

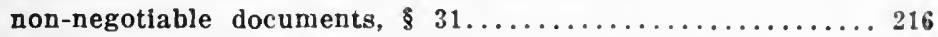

rights of person to whom document transferred, $\$ 34 \ldots \ldots \ldots 217$

Unascertained goods, see Goods.

Undivided share, rights of parties, \& $6 \ldots \ldots \ldots \ldots \ldots \ldots \ldots \ldots$

Uniform Sales Act, provisions not applicable, $\$ 75 \ldots \ldots \ldots \ldots \ldots 245$

Unpaid seller-

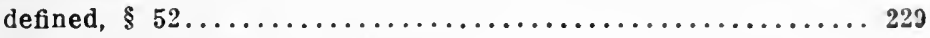

lien on goods (see Lien of Seller).

rescission, $\$ \$ 53,60,61 \ldots \ldots \ldots \ldots \ldots \ldots \ldots \ldots \ldots .229,233,234$

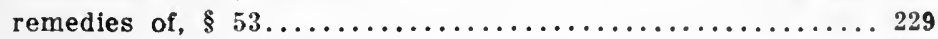

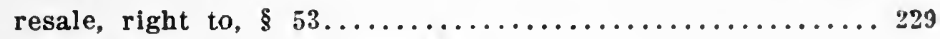

resale, when and how made, $\$ 60 \ldots \ldots \ldots \ldots \ldots \ldots \ldots . \ldots . \ldots 233$

right of stoppage in transitu;

(a) buyer insolvent though property passed, $\$ \$ 53,57 . .229,231$

(b) goods in transit within meaning of act, $\$ 58 \ldots \ldots \ldots 231$

(c) ways of exercising right, $\$ 59 \ldots \ldots \ldots \ldots \ldots \ldots 232$

(d) sale of goods by buyer does not effect seller's right of,

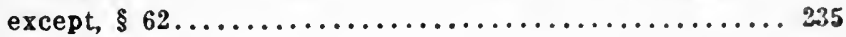

Valuation-

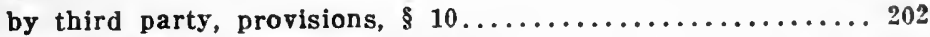

Voidable title, sale by one having, $\S 24 \ldots \ldots \ldots \ldots \ldots \ldots \ldots \ldots 214$

Warehouse receipts law, Bill of Lading Act not repealcd, $\S 76$ b. . 248

Warranty-

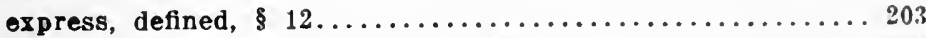

implied in sale by description, $\$ 14 \ldots \ldots \ldots \ldots \ldots \ldots \ldots \ldots 204$

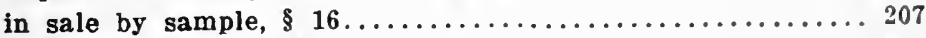

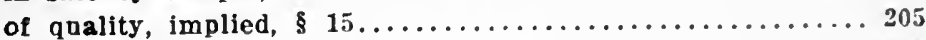

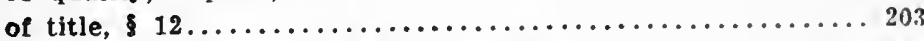

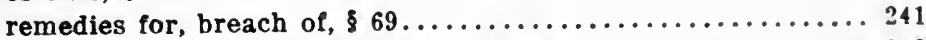

sale of documents of title, effect, $\$ 36 \ldots \ldots \ldots \ldots \ldots \ldots \ldots 218$ 


\section{INDEX TO UNIFORM WAREHOUSE RECEIPTS}

\section{ACT}

PAGE
Pa.

Action, defined, $\$ 58 \ldots \ldots \ldots \ldots \ldots \ldots \ldots \ldots \ldots \ldots \ldots \ldots \ldots \ldots \ldots . \ldots \ldots 9$

Advances-

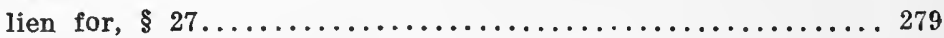

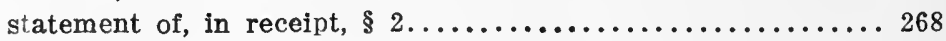

Adverse claims-

excuse for non-delivery, interpleader, $\S \S 17,19 \ldots \ldots \ldots \ldots 274,275$

reasonable time to determine validity of, $\S 18 \ldots \ldots \ldots \ldots \ldots 274$

Advertisement-

of sale, lien for, expenses of, $\S 27 \ldots \ldots \ldots \ldots \ldots \ldots \ldots \ldots \ldots \ldots$

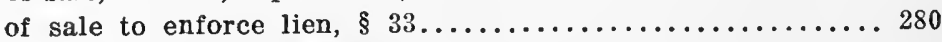

Agent, responsibility, see Offenses.

fallure to obtain receipt penalty, $\S 54 \ldots \ldots \ldots \ldots \ldots \ldots \ldots 288$

Alteration, receipt shall not relieve from liability, when, $\S 13 \ldots 273$

Applicability of law to existing warehouse receipts, $\S 59 \ldots \ldots \ldots 290$

Attachment, goods stored cannot be, until, $\S 25 \ldots \ldots \ldots \ldots \ldots \ldots 278$

Attorney's fees and costs, when allowed, $\S 14 \ldots \ldots \ldots \ldots \ldots \ldots \ldots 273$

Bona fide purchaser-

rights cannot be defeated by rights of vendor, $\S 49 \ldots \ldots \ldots 287$

warehouse receipts after mortgage or pledge of goods, $\$ 48 \ldots 286$

Burden, on warehouseman on refusal to deliver, when, $\S 8 \ldots \ldots \ldots 270$

Care, liable for reasonable, $\S 21 \ldots \ldots \ldots \ldots \ldots \ldots \ldots \ldots \ldots \ldots \ldots$

Charges-

storage and preservation, lien, $\S 27 \ldots \ldots \ldots \ldots \ldots \ldots \ldots \ldots . \ldots . \ldots 279$

storage, subsequent to issuance of, lien, receipt, $\S 30 \ldots \ldots 280$

Claims, reasonable time to determine validity of, $\S 18 \ldots \ldots \ldots \ldots 274$

Common law, rules applicable when, $\S 56 \ldots \ldots \ldots \ldots \ldots \ldots \ldots . \ldots 289$

Conditions, may be inserted in receipts, $\S 3 \ldots \ldots \ldots \ldots \ldots \ldots \ldots 269$

Confusion of goods, liability for, $\S 24 \ldots \ldots \ldots \ldots \ldots \ldots \ldots \ldots \ldots$

Creditor's remedies to reach negotiable receipts, $\S 26 \ldots \ldots \ldots \ldots 279$

Debt, no warranty implied from accepting payment of, $\S 46 \ldots \ldots \ldots 286$

Definitions-

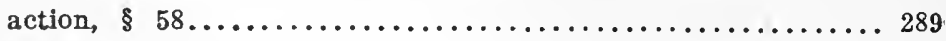

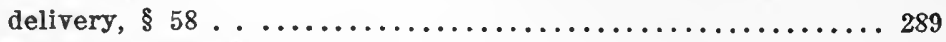

fungible goods, $\$ 58 \ldots \ldots \ldots \ldots \ldots \ldots \ldots \ldots \ldots \ldots \ldots \ldots \ldots \ldots$

good faith, $\$ 58 \ldots \ldots \ldots \ldots \ldots \ldots \ldots \ldots \ldots \ldots \ldots \ldots \ldots \ldots$ 
Definitions-Continued. PAGE

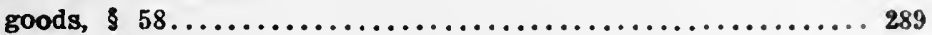

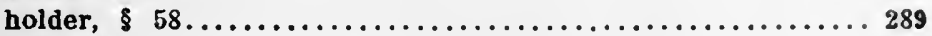

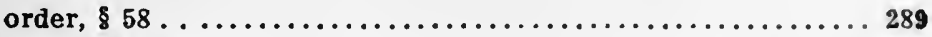

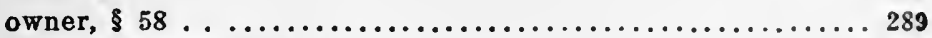

negotiable receipt, $\S 5 \ldots \ldots \ldots \ldots \ldots \ldots \ldots \ldots \ldots \ldots \ldots \ldots . \ldots \ldots$

non-negotiabie receipt, $\$ 4 \ldots \ldots \ldots \ldots \ldots \ldots \ldots \ldots \ldots \ldots \ldots . \ldots \ldots$

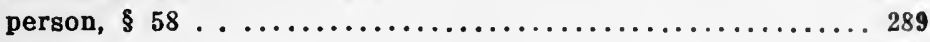

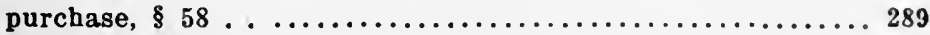

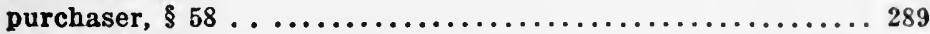

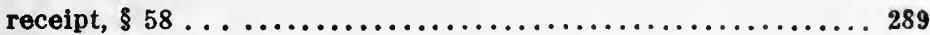

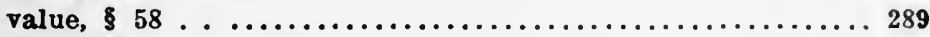

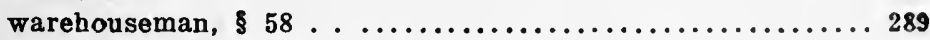

Degree, of care of goods stored, $\S 21 \ldots \ldots \ldots \ldots \ldots \ldots \ldots \ldots \ldots \ldots 275$

Delivery-

canceliation of receipt, $\S 11 \ldots \ldots \ldots \ldots \ldots \ldots \ldots \ldots \ldots 272$

claim of ownership as excuse for refusal to make, $\$ 16 \ldots \ldots 274$

defined, $\$ 58 \ldots \ldots \ldots \ldots \ldots \ldots \ldots \ldots \ldots \ldots \ldots \ldots \ldots \ldots . \ldots \ldots$

excuse for non-delivery, $\S \S 17,19 \ldots \ldots \ldots \ldots \ldots \ldots \ldots 274,275$

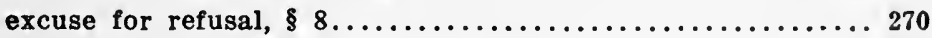

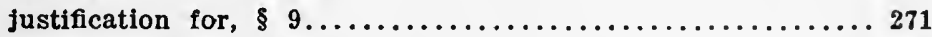

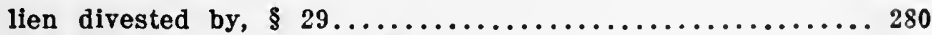

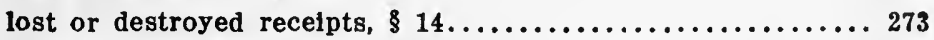

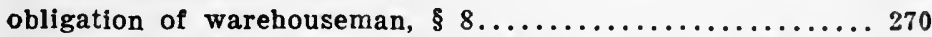

of goods, alteration of receipt as affecting obligation, $\$ 13 \ldots 273$

negotiation by delivery of recelpt, $\S \S 37,43 \ldots \ldots \ldots \ldots \ldots 283,285$

partial, of goods without taking up receipt, $\S 12 \ldots \ldots \ldots \ldots 272$

penalty, $\S 54 \ldots \ldots \ldots \ldots \ldots \ldots \ldots \ldots \ldots \ldots \ldots \ldots \ldots \ldots . \ldots \ldots \ldots$

receipt must specify to wbom, will be made, $\$ 2 \ldots \ldots \ldots \ldots 268$

refusal to make, divesting lien, $\S 29 \ldots \ldots \ldots \ldots \ldots \ldots \ldots \ldots 280$

sale to enforce lien as excusing non-delivery to depositor, $\$ 36.283$

to persons entitied to possession, $\S 9 \ldots \ldots \ldots \ldots \ldots \ldots \ldots \ldots 271$

to person not entitled, liability, $\S 10 \ldots \ldots \ldots \ldots \ldots \ldots \ldots \ldots 271$

transfer of non-negotiable by, $\$ 39 \ldots \ldots \ldots \ldots \ldots \ldots \ldots \ldots \ldots$

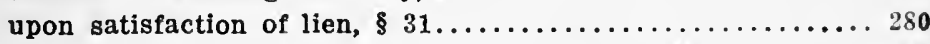

without obtaining negotiable receipt, penalty, $\$ 54 \ldots \ldots \ldots 288$

Delivery of part of goods without taking up or marking negotiable

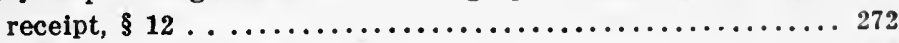

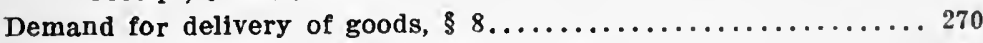

Demand, for payment before sale to enforce lien, $833 \ldots \ldots \ldots \ldots 280$

Duplicate receipts-

not so marked as such, liability, $8 \ldots \ldots \ldots \ldots \ldots \ldots \ldots \ldots . \ldots 270$

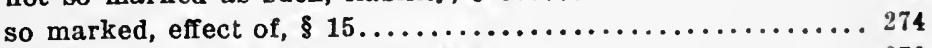

to be marked as such liability, $\S 6 \ldots \ldots \ldots \ldots \ldots \ldots \ldots . \ldots . \ldots . \ldots$ 


\section{Duress-}

common law rules applicable, $\S 56 \ldots \ldots \ldots \ldots \ldots \ldots \ldots \ldots \ldots 289$

negotiation of receipt, not impaired, $\$ 47 \ldots \ldots \ldots \ldots \ldots \ldots$

Execution cannot be had against goods stored, unless, $\S 25 \ldots \ldots .278$

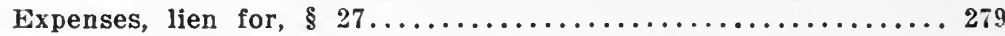

Explosive articles, rights of warehouseman, $\S 34 \ldots \ldots \ldots \ldots \ldots .282$

Form and contents of receipts, $\S 2,3 \ldots \ldots \ldots \ldots \ldots \ldots \ldots \ldots, 269$

Fraud-

common law rules applicable, $\$ 56 \ldots \ldots \ldots \ldots \ldots \ldots \ldots \ldots \ldots 289$

negotiation of receipts not impaired by, $\S 47 \ldots \ldots \ldots \ldots \ldots 286$

procuring and negotiation of receipt on mortgaged goods, $\$ 55.288$

Fungible goods-

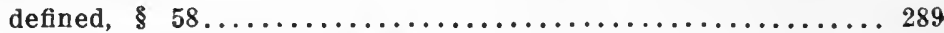

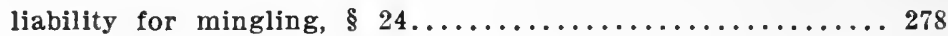

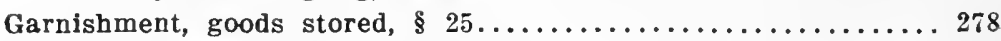

Good faith, defined, $\$ 58 \ldots \ldots \ldots \ldots \ldots \ldots \ldots \ldots \ldots \ldots \ldots \ldots$

Goods-

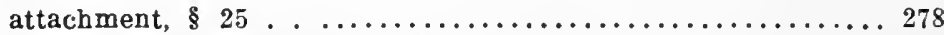

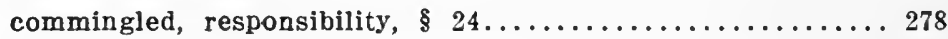

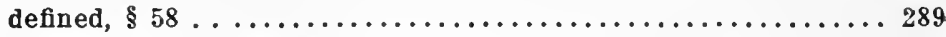

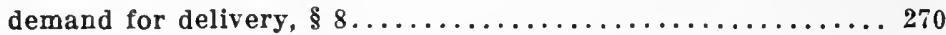

delivered, receipt not obtained, penalty, $\S 54 \ldots \ldots \ldots \ldots \ldots 288$

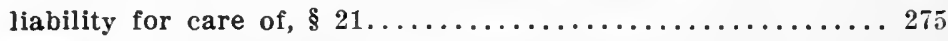

liability of warehouseman for non-existence of, $\$ 20 \ldots \ldots \ldots 275$

lien to be satisfied before delivery, $\S \S 8,31 \ldots \ldots \ldots \ldots \ldots 270,280$

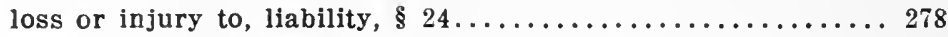

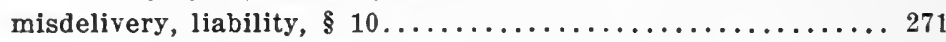

must be kept separate for identification, $\S 22 \ldots \ldots \ldots \ldots \ldots . \ldots 277$

ownership of, asserted by warehouseman, $\S 16 \ldots \ldots \ldots \ldots .274$

partial delivery of, without taking up receipt, $\S 12 \ldots \ldots \ldots \ldots 272$

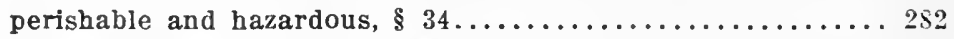

person entitled to delivery, $\S 9 \ldots \ldots \ldots \ldots \ldots \ldots \ldots \ldots \ldots . \ldots \ldots$

receipt issued when goods not received, penalty, $\S 50 \ldots \ldots \ldots 287$

receipt to be surrendered before delivery of, $\$ 49 \ldots \ldots \ldots \ldots 287$

title to, passing by transfer of receipt, $\$ \S 41,43 \ldots \ldots \ldots 281,285$

Guaranty, effect of indorsed receipts, $\S 45 \ldots \ldots \ldots \ldots \ldots \ldots$

Hazardous goods, sale by warehouseman, $\$ 34 \ldots \ldots \ldots \ldots \ldots \ldots 282$

Holder of receipt-

defined, $\$ 58 \ldots \ldots \ldots \ldots \ldots \ldots \ldots \ldots \ldots \ldots \ldots \ldots \ldots . \ldots \ldots . \ldots \ldots$

entitled to delivery of goods, when, $\$ \S 8,9 \ldots \ldots \ldots \ldots \ldots 270,271$

pledged as security, no warranty implied from accepting pay-

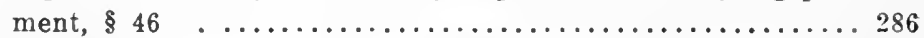

Implied warranty on sale of receipt, $\S \S 44,46 \ldots \ldots \ldots \ldots \ldots 285,286$ Indorsement-

negotiable receipt, right of transferee to compel, $\S 43 \ldots \ldots \ldots 285$

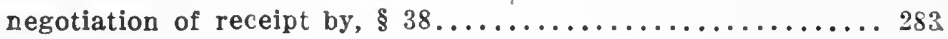


Indorser or recelpt, not a guarantor, $\mathbf{s}$. $\ldots \ldots \ldots \ldots \ldots \ldots \ldots$

Inflammable articles, rights of warehouseman, $\$ 34 \ldots \ldots \ldots \ldots . \ldots 282$

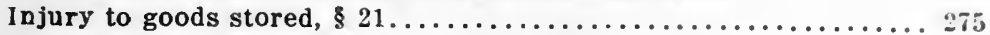

Insurance, lien for insurance money, $\$ 27 \ldots \ldots \ldots \ldots \ldots \ldots \ldots$

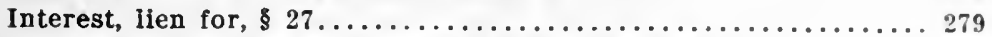

Interpieader, adverse claimants, who may bring. $\$ 17 \ldots \ldots \ldots \ldots 274$

Interpretation of law in interest of uniformity, $\$ 57 \ldots \ldots \ldots \ldots \ldots 2 \$ 9$

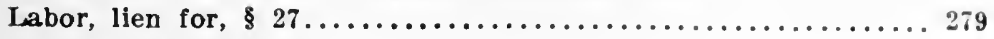

Levy, see Attachment.

Liability -

alteration of receipt as affecting, $\S 13 \ldots \ldots \ldots \ldots \ldots \ldots . \ldots 273$

defective or informal receipt, $\$ 2 \ldots \ldots \ldots \ldots \ldots \ldots \ldots \ldots 26$

delivery of part of goods, fallure to mark receipt, $\$ 12 \ldots \ldots \ldots 272$

delivery without obtaining receipt, penalty, $\$ 54 \ldots \ldots \ldots \ldots 288$

failure to mark duplicate receipts, $\$ 6 \ldots \ldots \ldots \ldots \ldots \ldots 270$

failure to take up receipt, $\$ 11 \ldots \ldots \ldots \ldots \ldots \ldots \ldots \ldots \ldots 272$

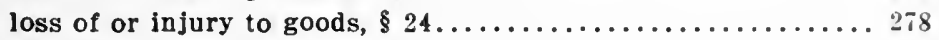

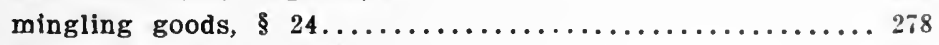

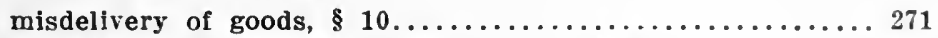

non-existence or misdescription of goods, $\S 20 \ldots \ldots \ldots \ldots \ldots 275$

warehouseman's, for care of goods, $\$ 21 \ldots \ldots \ldots \ldots \ldots \ldots 275$ Lien-

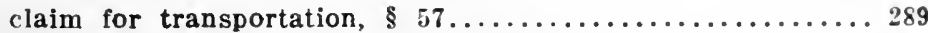

does not preciude other remedies, $\$ 32 \ldots \ldots \ldots \ldots \ldots \ldots \ldots 280$

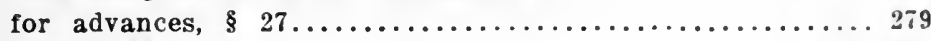

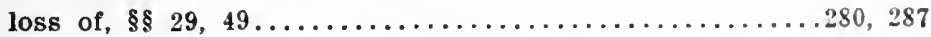

negotiating receipt defeats vendor's lien on goods, $\$ 49 \ldots \ldots 287$

on goods stored after rental receipts issued, except, $\$: 30 \ldots 280$

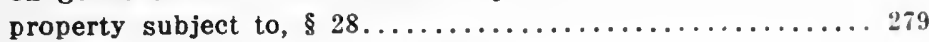

remedies for enforcement, $\S 35 \ldots \ldots \ldots \ldots \ldots \ldots \ldots \ldots \ldots 2$

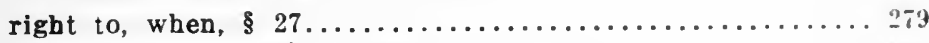

sale to satisfy, effect, $\$ 36 \ldots \ldots \ldots \ldots \ldots \ldots \ldots \ldots \ldots \ldots$

satisfaction before delivery of goods, $\$ \$ \$, 31 \ldots \ldots \ldots \ldots 270,280$

satisfaction by sale of goods, $\$ 33 \ldots \ldots \ldots \ldots \ldots \ldots \ldots \ldots \ldots$

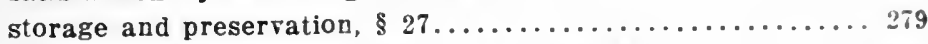

vendor's, defeated by negotiation of receipt, $\$ 49 \ldots \ldots \ldots \ldots .287$

Location of warehouse, shown in receipt, $\$ \$ 2,3 \ldots \ldots \ldots \ldots \ldots 26,269$

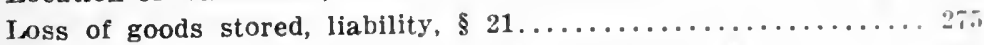

Lost receipts, dellvery of goods by warehouseman, $\$ 14 \ldots \ldots \ldots .273$

Mingling goods of like kind, $\S \S 23,24 \ldots \ldots \ldots \ldots \ldots \ldots \ldots . \ldots . \ldots \ldots, 278$

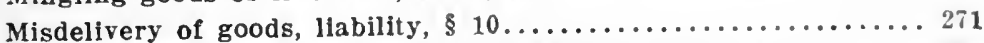

Misdescription of goods, llability of warehouseman, $\$ 20 \ldots \ldots .275$

Misrepresentations, common-law applicable, $\$ 6 \ldots \ldots \ldots \ldots . . .289$ 
Mistake-

common law rules applicable, $\$ 56 \ldots \ldots \ldots \ldots \ldots \ldots \ldots \ldots . \ldots 289$

negotiation of receipt not impaired by, $\S 47 \ldots \ldots \ldots \ldots \ldots \ldots 286$

Mortgaged goods, procuring negotiation of receipt on, penalty, §55 288

Mortgagee, payment accepted by holder of receipt, no warranty im-

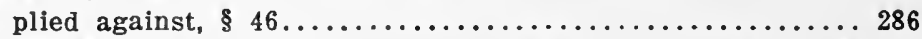

Mortgage of pledged goods, subsequent negotiation of receipt, ef-

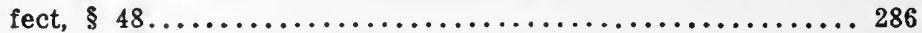

Negotiable and non-negotiable receipts, $\$ \S 4, \ldots \ldots \ldots \ldots \ldots \ldots \ldots 269$

Negotiable receipts-

attachment or levy upon goods for which receipt has been is-

sued, effect, $\S 25 \ldots \ldots \ldots \ldots \ldots \ldots \ldots \ldots \ldots \ldots \ldots \ldots \ldots \ldots$

cancellation on delivery of goods, $\S 11 \ldots \ldots \ldots \ldots \ldots \ldots \ldots . \ldots 272$

charges arising subsequent to issuance of, constitute lien, $\$ 30.280$

creditor's remedies to reach, $\S 26 \ldots \ldots \ldots \ldots \ldots \ldots \ldots \ldots \ldots 279$

failure to mark, upon delivery of part of goods, $\$ 12 \ldots \ldots \ldots .272$

goods, delivery when receipt not surrendered, penalty, $\S 54 \ldots 288$

liability to holder, $\$ 11 \ldots \ldots \ldots \ldots \ldots \ldots \ldots \ldots \ldots \ldots \ldots \ldots . \ldots \ldots 2$

negotiation by indorsement, $\S 38 \ldots \ldots \ldots \ldots \ldots \ldots \ldots \ldots \ldots . \ldots \ldots$

receipt has been issued, effect, $\S 25 \ldots \ldots \ldots \ldots \ldots \ldots \ldots \ldots 278$

transferred by delivery, right to require indorsement, $\S 43 \ldots 285$

who may negotiate, $\S 40 \ldots \ldots \ldots \ldots \ldots \ldots \ldots \ldots \ldots \ldots \ldots \ldots . \ldots 284$

Negotiation of receipt-

defeats vendor's lien, $\S 49 \ldots \ldots \ldots \ldots \ldots \ldots \ldots \ldots \ldots \ldots \ldots . \ldots \ldots$

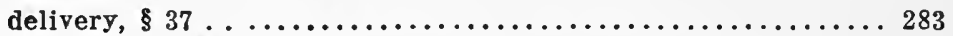

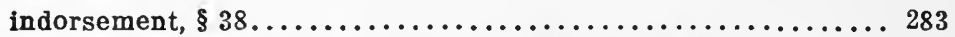

not impaired by fraud, duress or mistake, when, $\S 47 \ldots \ldots \ldots 286$

on mortgaged goods, penalty, $\S 55 \ldots \ldots \ldots \ldots \ldots \ldots \ldots \ldots \ldots 28$

subsequent to sale, mortgage or pledge of goods or receipt,

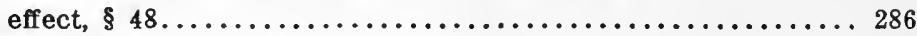

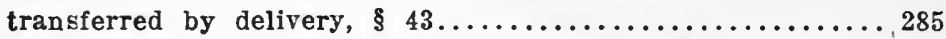

Non-existence of goods, liability of warehouseman, $\S 20 \ldots \ldots \ldots 275$

Non-negotiable receipts-

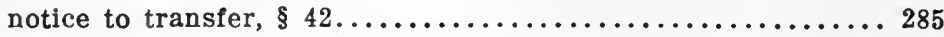

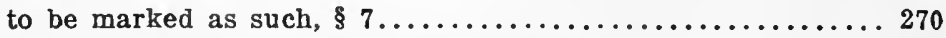

transfer by delivery without indorsement, $\$ 39 \ldots \ldots \ldots \ldots \ldots 283$

Notice of sale, to satisfy lien, publication, $\S 33 \ldots \ldots \ldots \ldots \ldots \ldots \ldots 280$

Notice of transfer of non-negotiable receipt, $\S 42 \ldots \ldots \ldots \ldots \ldots \ldots 285$

Numbering receipts, $\S \S 2,3 \ldots \ldots \ldots \ldots \ldots \ldots \ldots \ldots \ldots \ldots . \ldots \ldots, 269$

Obligation of warehouseman to deliver goods, $\S 8 \ldots \ldots \ldots \ldots \ldots .270$

Offenses-

delivery of goods without obtaining negotiable receipt, § 54.. 288

false statement in receipt, $\S 51 . \ldots \ldots \ldots \ldots \ldots \ldots \ldots \ldots \ldots \ldots 287$

giving receipt for goods not received, $\S 50 \ldots \ldots \ldots \ldots \ldots 287$

issuance of duplicate receipts not so marked, $\$ 52 \ldots \ldots \ldots \ldots 288$ 
Offenses-Continued.

negotiation of receipt issued for mortgaged goods, $855 \ldots \ldots 288$

receipt issued for goods owned by warehouseman, $853 \ldots \ldots 288$

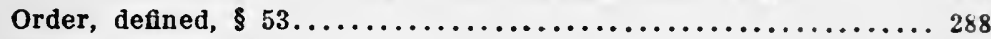

Owner, defined, $\S 58 \ldots \ldots \ldots \ldots \ldots \ldots \ldots \ldots \ldots \ldots \ldots \ldots \ldots . \ldots \ldots 259$

Ownershlp of goods stored, assertion by warehonseman, $\S 16 \ldots \ldots 274$

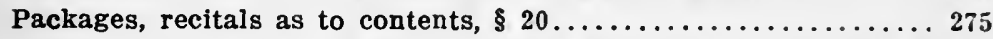

Partial delivery of goods without taking up or marking negotiable

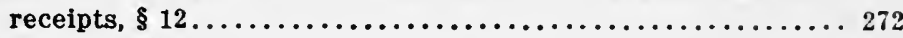

Penalties, see Offenses.

Penalty for negotiation of recelpt on mortgaged goods, \&55.... 288

Perishable goods, sale by warehouseman, $\$ 34 \ldots \ldots \ldots \ldots \ldots \ldots 282$

Person as used includes corporation, $\$ 58 \ldots \ldots \ldots \ldots \ldots \ldots \ldots \ldots . \ldots 289$

Persons entitled to delivery of goods, $\$ 9 \ldots \ldots \ldots \ldots \ldots \ldots \ldots \ldots$

Person who may issue receipts, $\$ 1 \ldots \ldots \ldots \ldots \ldots \ldots \ldots \ldots . \ldots 268$

Pledgee of receipt accepting payment of debt, no warranty implied

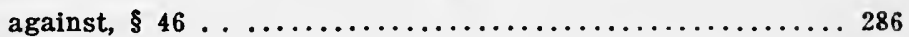

Pledgee of goods, subsequent negotiation of receipt, $\$ 48 \ldots \ldots \ldots 286$

Posting notice of saie to enforce lien, $\$ 33 \ldots \ldots \ldots \ldots \ldots \ldots \ldots 280$

Principal and agent, rules of common law appiicable, $\S 56 \ldots \ldots .289$

Property subject to lien, $\$ 28 \ldots \ldots \ldots \ldots \ldots \ldots \ldots \ldots \ldots \ldots \ldots \ldots$

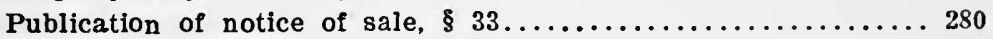

Purchase and purchaser, defined, $\S 58 \ldots \ldots \ldots \ldots \ldots \ldots \ldots \ldots \ldots 289$

Purchaser of altered receipt, rights of, $\S 13 \ldots \ldots \ldots \ldots \ldots \ldots \ldots 273$

Rate of storage charge, recital in receipt, $\$ 30 \ldots \ldots \ldots \ldots \ldots \ldots 280$

Receipts-

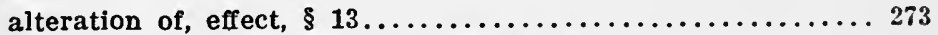

cancellation on delivery of goods, $\S 11 \ldots \ldots \ldots \ldots \ldots \ldots \ldots 2$

defined, $\S 27 \ldots \ldots \ldots \ldots \ldots \ldots \ldots \ldots \ldots \ldots \ldots \ldots \ldots \ldots . \ldots \ldots$

duplicate, see Duplicate Receipt.

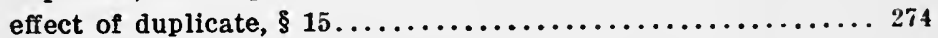

failure to obtain, when goods delivered, $\S 54 \ldots \ldots \ldots \ldots \ldots 288$

form and contents, $\$ \S 2,3 \ldots \ldots \ldots \ldots \ldots \ldots \ldots \ldots \ldots \ldots 26,269$

fraud, mistake, or duress not impairing negotiation of, $\$ 47 \ldots 286$ goods partly owned by warehouseman, $\$ \S 2,3 \ldots \ldots \ldots \ldots 268,269$

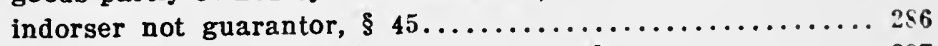

issuance of, containing false statement, $\S 51 \ldots \ldots \ldots \ldots \ldots 287$

issued for goods owned by warehouseman, penalty, $\$ 53 . \ldots .2$ s $\$$

issued for goods not received, $\$ 50 \ldots \ldots \ldots \ldots \ldots \ldots \ldots \ldots . \ldots \ldots 7$

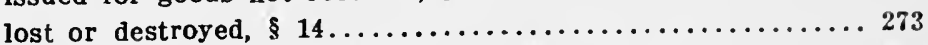

must state charges constituting lien, $\$ 30 \ldots \ldots \ldots \ldots \ldots \ldots . \ldots 280$

negotiable and non-negotiable, $\$ \S 4,5 \ldots \ldots \ldots \ldots \ldots \ldots \ldots 269$

negotiation of, by indorsement, $838 \ldots \ldots \ldots \ldots \ldots \ldots \ldots \ldots . \ldots 283$

notice of transfer of non-negotiable receipt, \& $42 \ldots \ldots \ldots \ldots 285$

numbering, $\$ \$ 2,3 \ldots \ldots \ldots \ldots \ldots \ldots \ldots \ldots \ldots \ldots \ldots \ldots, 269$ 
Receipts-Continued. PAGE

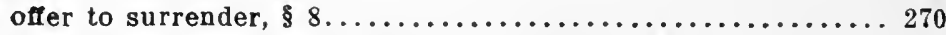

penalty for lssuing duplicate not so marked, $\$ 52 \ldots \ldots \ldots \ldots 288$

recitals as to contents of packages, $\$ 20 \ldots \ldots \ldots \ldots \ldots \ldots 275$

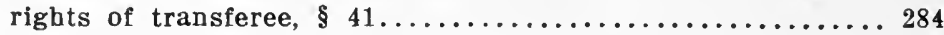

subsequent negotiation of, $\S 48 \ldots \ldots \ldots \ldots \ldots \ldots \ldots \ldots \ldots \ldots$

surrender before delivery of goods, $\S 49 \ldots \ldots \ldots \ldots \ldots \ldots \ldots 287$

surrendered before attachment or levy, $\S 25 \ldots \ldots \ldots \ldots \ldots \ldots 278$

terms and conditions, $\S \S 2,3 \ldots \ldots \ldots \ldots \ldots \ldots \ldots \ldots \ldots . \ldots \ldots, 269$

transfer of, effect, $\S \S 37,43 \ldots \ldots \ldots \ldots \ldots \ldots \ldots \ldots \ldots \ldots 28,285$

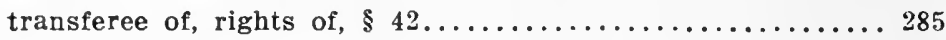

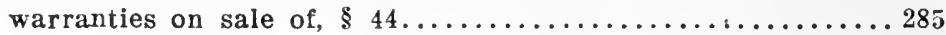

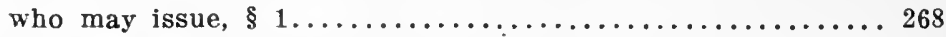

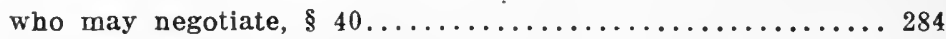

Redemption after notice of sale, $\S 33 \ldots \ldots \ldots \ldots \ldots \ldots \ldots \ldots \ldots$

Remedies-

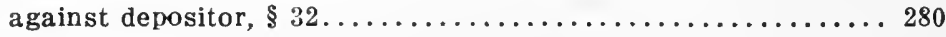

creditors to reach negotiable receipts, $\S 25 \ldots \ldots \ldots \ldots \ldots \ldots 278$

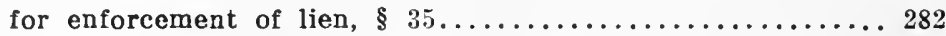

Rights of transferee of receipt, $\$ 42 \ldots \ldots \ldots \ldots \ldots \ldots \ldots \ldots \ldots . \ldots 285$

Sale of goods-

lien for expenses, $\S 27 \ldots \ldots \ldots \ldots \ldots \ldots \ldots \ldots \ldots \ldots \ldots \ldots . \ldots \ldots$

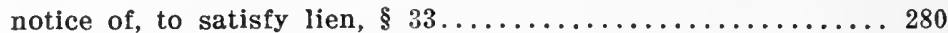

perishable and hazardous, $\S 34 \ldots \ldots \ldots \ldots \ldots \ldots \ldots \ldots \ldots 28$

to satisfy lien effect, $\S \S 33,36 \ldots \ldots \ldots \ldots \ldots \ldots \ldots \ldots \ldots, 283$

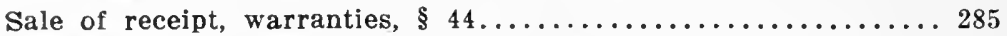

Satisfaction, need not deliver until lien, $\$ 31 \ldots \ldots \ldots \ldots \ldots \ldots \ldots . \ldots 280$

Seller's lien, defeated by negotiation of receipt, $\$ 49 \ldots \ldots \ldots \ldots \ldots 287$

Separation of goods for purposes of identification, $\S 22 \ldots \ldots \ldots \ldots 277$

Signature of, receipt, $\S \S 2,3 \ldots \ldots \ldots \ldots \ldots \ldots \ldots \ldots \ldots \ldots \ldots, 269$

Statement, false, issuance of receipt, $\S 51 \ldots \ldots \ldots \ldots \ldots \ldots \ldots 287$

Subsequent negotiation of receipts, $\$ 48 \ldots \ldots \ldots \ldots \ldots \ldots \ldots \ldots 286$

Surrender of-

receipt before delivery of goods, $\$ 49 \ldots \ldots \ldots \ldots \ldots \ldots \ldots 287$

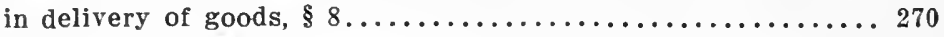

Terms of receipts, $\S \S 2,3 \ldots \ldots \ldots \ldots \ldots \ldots \ldots \ldots \ldots \ldots \ldots \ldots, 269$

Title of goods-

passing by transfer of receipt, $\S 81,43 \ldots \ldots \ldots \ldots \ldots \ldots 284,285$

stored, assertion of warehouseman, $\S 16 \ldots \ldots \ldots \ldots \ldots \ldots 274$

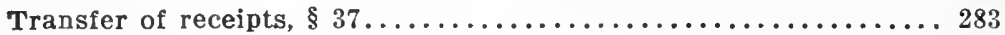

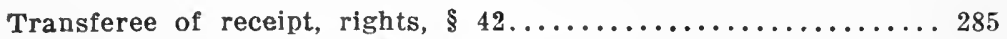

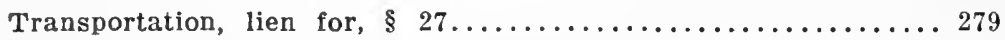

Uniform warehouse receipts, applicability, $\S 59 \ldots \ldots \ldots \ldots \ldots \ldots 290$

Uniformity in interpretation of law, $\S 57 \ldots \ldots \ldots \ldots \ldots \ldots \ldots . \ldots 289$

Value, defined, $\S 58 \ldots \ldots \ldots \ldots \ldots \ldots \ldots \ldots \ldots \ldots \ldots \ldots \ldots \ldots$ 
Vendor's lien on goods defeated by negotiation of receipt, \$43 . . 287

Warehouse, location of, to be in receipt, $\$ \S 2,3 \ldots \ldots \ldots \ldots \ldots 268,269$ Warehouseman-

cannot set up title in himself, $\$ 16 \ldots \ldots \ldots \ldots \ldots \ldots \ldots \ldots \ldots 274$

commingling goods, responsibility, $\$ 24 \ldots \ldots \ldots \ldots \ldots \ldots \ldots 278$

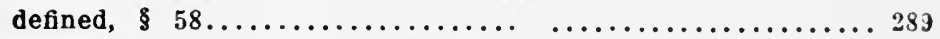

delivery by, justified, when, $\S 9 \ldots \ldots \ldots \ldots \ldots \ldots \ldots \ldots \ldots \ldots \ldots$

delivery of goods with recelpt lost, when, $\$ 14 \ldots \ldots \ldots \ldots \ldots 273$

failure to take up receipt, liability, when, $\$ 11 \ldots \ldots \ldots \ldots 273$

issuance of receipt for goods not recelved, penalty, $\$ 50 \ldots \ldots 287$

interplead adverse claimants, when, $\$ 17 \ldots \ldots \ldots \ldots \ldots \ldots 274$

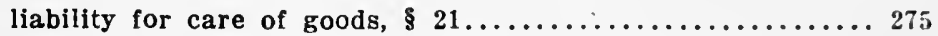

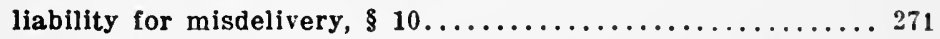

liability for non-existence or misdescription of goods, $\S 20 \ldots 275$

may insert terms and conditions, unless, $\S 3 \ldots \ldots \ldots \ldots \ldots 269$

must deliver the goods, when, $\S 8 \ldots \ldots \ldots \ldots \ldots \ldots \ldots \ldots . \ldots \ldots$

must keep goods separate for identification, $\$ 22 \ldots \ldots \ldots \ldots 277$

must mark non-negotlable recelpt as such, $\$ 7 \ldots \ldots \ldots \ldots \ldots 270$

must obtain receipt when goods delivered, penalty, $\$ 54 \ldots \ldots 288$

need not deliver goods until lien satisfied, $\$ \S 8,31 \ldots \ldots \ldots 270,280$

not liable where goods sold to satisfy llen, $36 \ldots \ldots \ldots \ldots 283$

other remedies not precluded by this lien, $\$ 32 \ldots \ldots \ldots \ldots . .280$

penalty for issuance of receipt containing false statement, $\$ 51.287$ receipt must be surrendered before delivery of goods

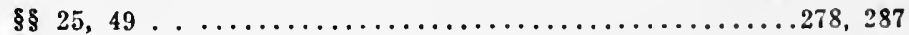

right of, as to perishable and hazardous goods, $\$ 34 \ldots \ldots \ldots 282$ satisfaction of lien, sale, notice, advertisement expense, $\$ 33.280$ to hold possession of goods for transferee of non-negotiable

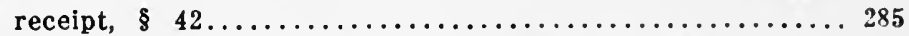

ralidity of claims, reasonable time to determine, $\$ 18 \ldots \ldots \ldots 274$

where receipt issued fails to state interest of, $\$ 53 \ldots \ldots \ldots \ldots 283$ Warranty-

on sale of receipts, $\$ 44 \ldots \ldots \ldots \ldots \ldots \ldots \ldots \ldots \ldots \ldots . \ldots \ldots 5$

not implied from accepting payment of debt, $\$ 16 \ldots \ldots \ldots \ldots 286$ 
INDEX TO UNIFORM ANNULMENT OF MARRIAGE AND DIVORCE ACT

Act-

PAGE

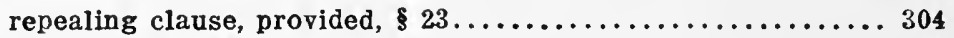

when to take effect, $\S 24 \ldots \ldots \ldots \ldots \ldots \ldots \ldots \ldots \ldots \ldots \ldots \ldots . \ldots . \ldots . \ldots$

Action-

by husband, legitimacy of children, presumption, $\S 21 \ldots \ldots \ldots 303$

by wife, legitimacy of children, $\S 20 \ldots \ldots \ldots \ldots \ldots \ldots \ldots \ldots . \ldots . \ldots 30 . \ldots$

defendant may be served by publication, provisions, $\S 10 \ldots \ldots 301$

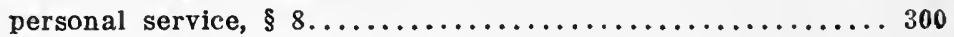

Adultery-

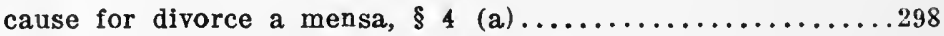

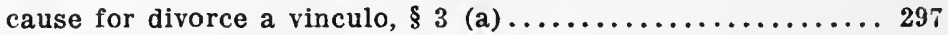

of the plaintiff as bar to divorce, $\S 5 \ldots \ldots \ldots \ldots \ldots \ldots \ldots \ldots 299$

Annulment of marriage, causes for, at time of marriage, $\S 1 \ldots \ldots 296$

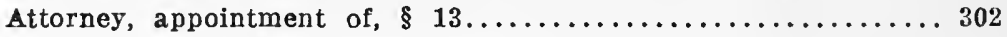

Bars to divorce, $\S 5 \ldots \ldots \ldots \ldots \ldots \ldots \ldots \ldots \ldots \ldots \ldots \ldots \ldots \ldots . \ldots \ldots 9$

Bigamy-

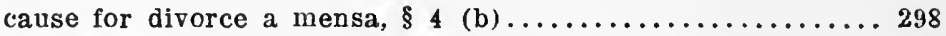

cause for divorce a vinculo, $\S 3$ (b) $\ldots \ldots \ldots \ldots \ldots \ldots \ldots \ldots . \ldots 297$

Children-

legitimacy of, in action by husband, $\$ 21 \ldots \ldots \ldots \ldots \ldots \ldots \ldots$

legitimacy of, in action by wife, $\S 20 \ldots \ldots \ldots \ldots \ldots \ldots \ldots . \ldots 303$

Coercion, cause for annulment, unless, $\S 1$ (d) .............. 296

Collusion as bar to divorce, $\S 5 \ldots \ldots \ldots \ldots \ldots \ldots \ldots \ldots \ldots \ldots . \ldots . \ldots 299$

Condonation as bar to divorce, $\S 5 \ldots \ldots \ldots \ldots \ldots \ldots \ldots \ldots \ldots . \ldots 299$

Connivance at the offense charged as bar to divorce, $\S 5 \ldots \ldots . .299$

Consanguinity, cause for annulment, when, $\S 1$, (b) .......... 296

Copulation, incapacity, cause for annulment provided, § 1 (a) .... 296

Courts, jurisdiction in what, $\S 6 \ldots \ldots \ldots \ldots \ldots \ldots \ldots \ldots \ldots \ldots . \ldots . \ldots . \ldots$

Crime, conviction of-

cause for divorce a mensa, $\S 4$ (c) ................. 298

cause for divorce a vinculo, $\S 3 \ldots \ldots \ldots \ldots \ldots \ldots \ldots \ldots \ldots . \ldots 297$

\section{Decrees-}

absolute, at expiration of one year, unless, $\S 17 \ldots \ldots \ldots \ldots 302$

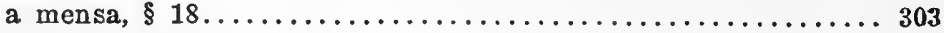

foreign, proviso, $\S 22 \ldots \ldots \ldots \ldots \ldots \ldots \ldots \ldots \ldots \ldots \ldots \ldots \ldots \ldots$

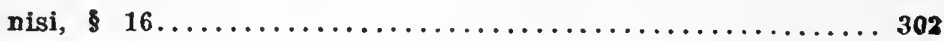


Desertion-

cause for divorce a mensa, $\$$ (e) .................. 2y9

Divorce-

cause for divorce a vinculo, $\& 3$ (e).................... 298

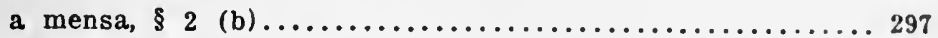

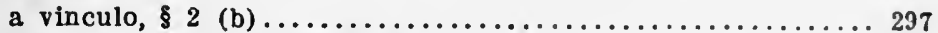

cause for divorce a mensa, $\S 4 \ldots \ldots \ldots \ldots \ldots \ldots \ldots \ldots . \ldots . \ldots 298$

cause for divorce a vinculo, $\S 3 \ldots \ldots \ldots \ldots \ldots \ldots \ldots \ldots . \ldots . \ldots 297$

Drunkenness-

cause for divorce a mensa, $\$ \&$ (f) $\ldots \ldots \ldots \ldots \ldots \ldots \ldots \ldots . \ldots 299$

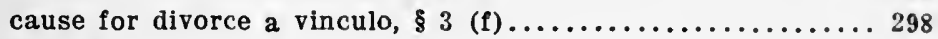

Extreme cruelty-

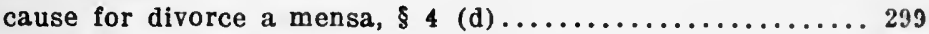

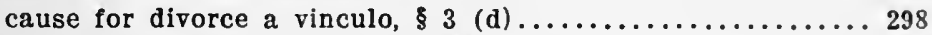

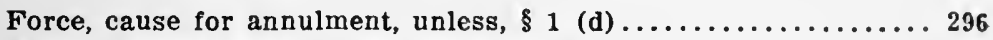

Former marriage, cause for annulment, $\$ 1$ (c) .............. 296

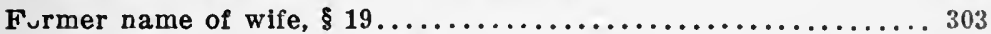

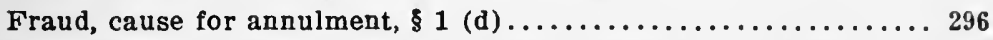

Full faith and credit to decrees of other states, except, $\$ 22 \ldots \ldots 303$

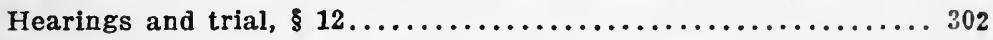

Husband-

action by, legitimacy of children, $\$ 21 \ldots \ldots \ldots \ldots \ldots \ldots \ldots . \ldots 3$

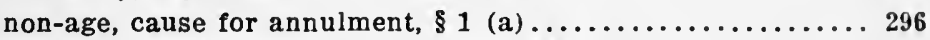

Impotency, cause for annulment, provided, $\S 1$ (a) ........... 296

Impounding of records, $\$ 15 \ldots \ldots \ldots \ldots \ldots \ldots \ldots \ldots \ldots \ldots \ldots . \ldots \ldots$

Insanity-

cause for annulment, provided, $\$ 1$ (e) ............... 296

of husband, cause for divorce a mensa, $\$ 4$ (g) ........... 299

Judgments, see Decrees.

Jurisdiction-

in what courts, $\$ 6 \ldots \ldots \ldots \ldots \ldots \ldots \ldots \ldots \ldots \ldots \ldots \ldots \ldots . \ldots \ldots$

personal service for annulment, $\S 7 \ldots \ldots \ldots \ldots \ldots \ldots \ldots \ldots . \ldots \ldots$

personal service for divorce, $\S 8 \ldots \ldots \ldots \ldots \ldots \ldots \ldots \ldots \ldots \ldots \ldots \ldots \ldots \ldots \ldots \ldots \ldots$

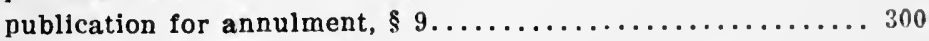

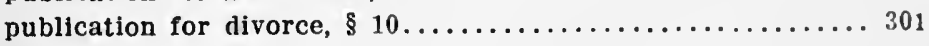

Legitimacy of children-

In action by husband, $\S 21 \ldots \ldots \ldots \ldots \ldots \ldots \ldots \ldots \ldots \ldots \ldots \ldots \ldots \ldots$

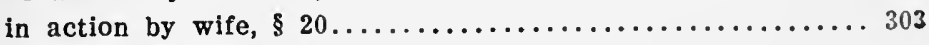

Marriage, see Former Marriage.

Non-age-

of husband, cause for annulment, $\S 1$ (g) $\ldots \ldots \ldots \ldots \ldots \ldots 297$

of wife, cause for annulment, $\S 1$ (f) ..................... 297

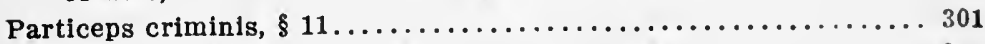

Presumption of legitimacy of children, when, $821 \ldots \ldots \ldots \ldots \ldots 303$

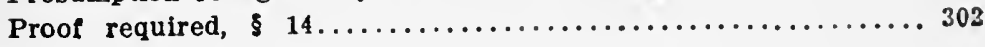


Records, Impounding of, \& 15 .

PAGE

Repealing clause, $\$ 23$

Service-

personal, for annulment, $\$ 7 \ldots \ldots \ldots \ldots \ldots \ldots \ldots \ldots \ldots \ldots . \ldots \ldots$

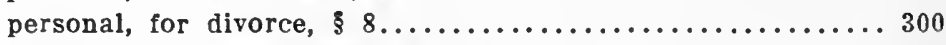

publication, for annulment, $\S 9 \ldots \ldots \ldots \ldots \ldots \ldots \ldots \ldots \ldots \ldots \ldots \ldots \ldots$

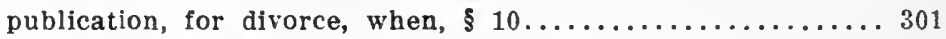

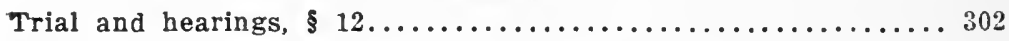

Wife-

former name of, $\$ 19 \ldots \ldots \ldots \ldots \ldots \ldots \ldots \ldots \ldots \ldots \ldots \ldots . \ldots \ldots$

non-age, cause for annulment, $\$ 1$ (f)................ 297 


\section{INDEX TO UNIFORM BILLS OF LADING ACT}

PAGE

Acceptance, indicates assent to terms of blll, $\$ 10 \ldots \ldots \ldots \ldots \ldots 313$

Accident-

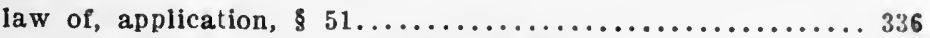

when negotiation not impaired by, $\S 38 \ldots \ldots \ldots \ldots \ldots \ldots \ldots . \ldots 31$ Act-

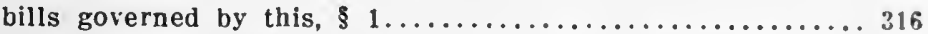

cases not provided for, rules of law and equity applicable, $\$ 51.336$

cited as Uniform Bills of Lading Act, $\$ 57 \ldots \ldots \ldots \ldots \ldots \ldots 38$

does not apply to existing bills, $\$ 54 \ldots \ldots \ldots \ldots \ldots \ldots \ldots \ldots 37$

inconsistent acts are repealed, $\$ 55 \ldots \ldots \ldots \ldots \ldots \ldots \ldots \ldots . \ldots . \ldots 38$

interpretation to affect uniformity, $\$ 52 \ldots \ldots \ldots \ldots \ldots \ldots \ldots 337$

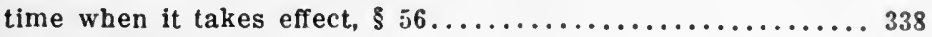

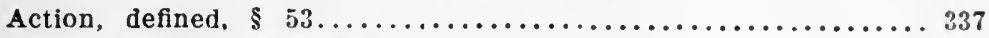

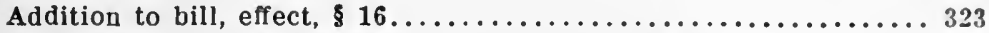

Administrators, law relating to, application, $\$ 51 \ldots \ldots \ldots \ldots \ldots 36$

Adverse claimants-

carrier has reasonable time to determine claims of, $\$ 21 \ldots \ldots 324$

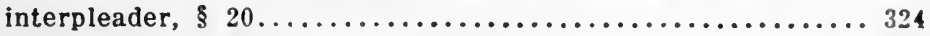

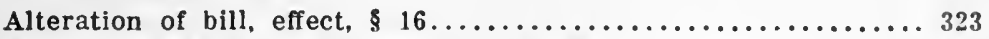

Application of law to existing bills, \& $54 \ldots \ldots \ldots \ldots \ldots \ldots \ldots . \ldots 37$

Attachment upon goods for which bill issued, when, $\$ 24 \ldots \ldots \ldots 326$

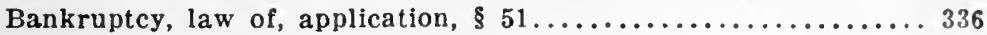

Bill-

acceptance of, indicates assent to its terms, $\$ 10 \ldots \ldots \ldots 319$

alteration, addition or erasure in a blll, effect, $\$ 16 \ldots \ldots \ldots 323$

attachment upon goods for which bill issued, when, $\$ 24 \ldots 326$

creditors remedies to reach negotiable, $\$ 25 \ldots \ldots \ldots \ldots \ldots . \ldots 326$

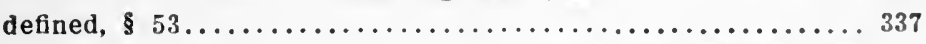

demand, presentation or sight draft must be paid before buyer entitled to delivery of, must be merely accepted if draft for more than three days, $\$ 41 . \ldots \ldots \ldots \ldots \ldots \ldots \ldots \ldots \ldots . \ldots . \ldots 33$ duplicate, see Duplicate Bills.

form in which taken, indicates transfer or retention of prop-

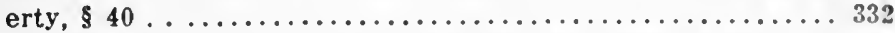

form of bill as indicating rights of, buyer and seller, \& $40 \ldots \ldots 332$

form of, essential terms, $\S 2 \ldots \ldots \ldots \ldots \ldots \ldots \ldots \ldots \ldots \ldots \ldots \ldots \ldots \ldots \ldots \ldots \ldots \ldots \ldots$

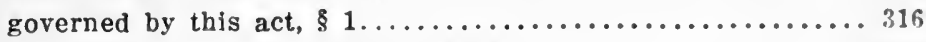

issued for goods not received, $\$ 44 \ldots \ldots \ldots \ldots \ldots \ldots \ldots \ldots . \ldots . \ldots 34$ 
Bill-Continued.

PAGE

issue of, containing false statements, $\$ 45 \ldots \ldots \ldots \ldots \ldots \ldots 335$

lost or destroyed, bond before delivery, $\$ 17 \ldots \ldots \ldots \ldots \ldots 323$

must be canceled when goods delivered, $\S 14 \ldots \ldots \ldots \ldots \ldots . \ldots 322$

must state charges for which lien claimed, $\S 26 \ldots \ldots \ldots \ldots . \ldots 326$

negotiation of, by delivery, $\S 28 \ldots \ldots \ldots \ldots \ldots \ldots \ldots \ldots \ldots \ldots \ldots \ldots$

negotiation of, not impaired by fraud, etc., when, $\S 38 \ldots \ldots \ldots 331$

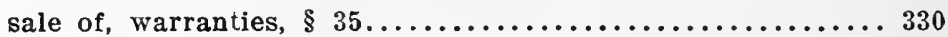

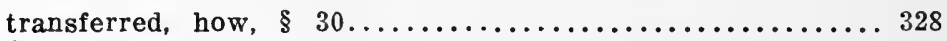

transferred $:$ ithout indorsement, rights, $\$ 34 \ldots \ldots \ldots \ldots \ldots 330$

where it has been issued no lien or right of stoppage in

transitu, shall defeat, $\S 42 \ldots \ldots \ldots \ldots \ldots \ldots \ldots \ldots \ldots \ldots \ldots$

Buyer-

must pay demand, presentation or sight draft, only accept

draft for more than three days before entitled to bill, $\S 41$. 333

rights of, indicated by form of bill, $\S 40 \ldots \ldots \ldots \ldots \ldots \ldots . \ldots 332$

Cancellation on delivery of goods, $\$ \S 14,15 \ldots \ldots \ldots \ldots \ldots \ldots \ldots . \ldots 322$

Carriers-

adverse claimants, time to determine validity of claims, $\S 21 \ldots . .324$

adverse title, no defense for failure to deliver, except, $\S 22 \ldots 324$

bill must be surrendered before attachment will lie, when, $\$ 24$. 326

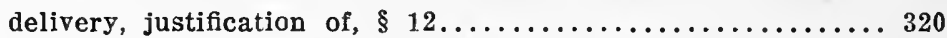

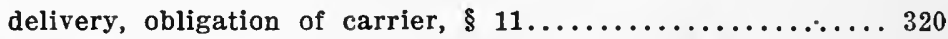

entitled to a bond where bill lost or destroyed, $\S 17 \ldots \ldots \ldots 323$

goods not in possession, negotiation of bills, liability, $\S 48 \ldots 335$

goods not received, issue of bill, $\S 49 \ldots \ldots \ldots \ldots \ldots \ldots \ldots 36$

liable for issuing negotiable bills in parts or sets, $\S 6 \ldots \ldots . .318$

liable where he fails to so mark duplicate bills, $\S 7 \ldots \ldots \ldots . .318$

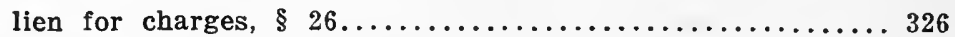

may require adverse claimants to interplead, $\S 20 \ldots \ldots \ldots \ldots . \ldots 324$

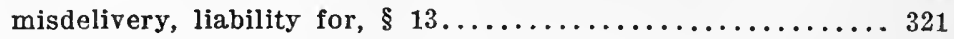

misdescription of goods, liability, $\S 23 \ldots \ldots \ldots \ldots \ldots \ldots \ldots . \ldots 324$

must take up and cancel bill on delivery of goods, $\S 14 \ldots \ldots \ldots 322$

non-negotiable bill to be so marked by, $\S 8 \ldots \ldots \ldots \ldots \ldots \ldots . \ldots 318$

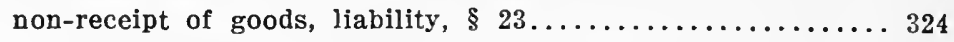

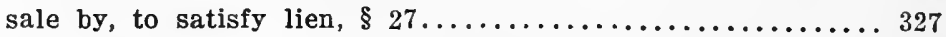

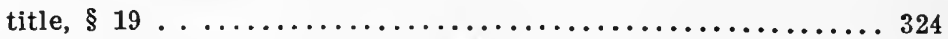

Claimants, interpleader of adverse, $\S 20 \ldots \ldots \ldots \ldots \ldots \ldots \ldots . \ldots \ldots 24$

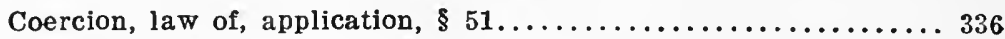

Consignee-

adverse title no defense, for failure to delivery, except, $\S 22 \ldots 324$

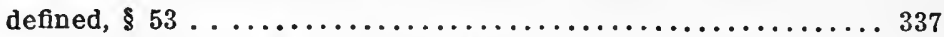

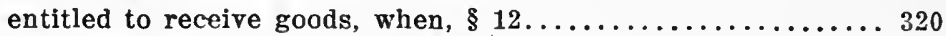

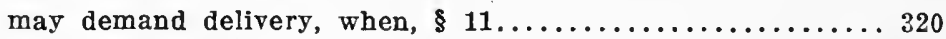

Consignor, defined, $\$ 53 \ldots \ldots \ldots \ldots \ldots \ldots \ldots \ldots \ldots \ldots \ldots \ldots \ldots$ 
PAC:

Conversion, when negotiation not impaired by, $38 \ldots \ldots \ldots \ldots . \ldots 31$

Creditor's remedies to reach negotiable bills, \& $25 \ldots \ldots \ldots \ldots \ldots \ldots . \ldots 326$

Criminal offenses-

inducing carrier to issue bill when goods not received, $\$ 49$. 336

issue of bill containing false statements, 8 15.......... 335

issue of bill for goods not recelved, $\$ 44 \ldots \ldots \ldots \ldots \ldots \ldots . \ldots 34$

issue of duplicate bills not so marked, $846 \ldots \ldots \ldots \ldots \ldots \ldots 335$

issue of non-negotiable blll not so marked, $850 \ldots \ldots \ldots \ldots . \ldots 36$

negotiation of bill for mortgaged goods, $47 \ldots \ldots \ldots \ldots \ldots 335$

negotiation of bill when goods not in carrier's possession, 848. 335

Definitions-

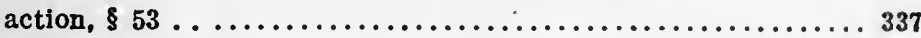

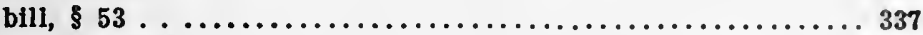

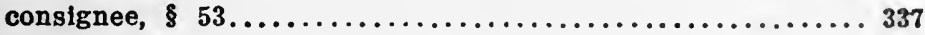

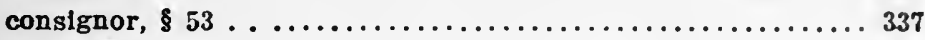

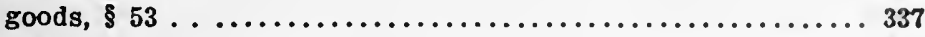

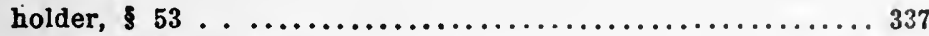

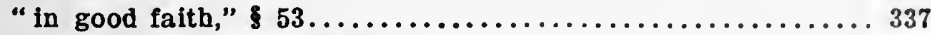

negotiable or order bill, $\$ 5 \ldots \ldots \ldots \ldots \ldots \ldots \ldots \ldots \ldots \ldots \ldots \ldots \ldots \ldots$

non-negotiable or straight bill, $\$ 4 \ldots \ldots \ldots \ldots \ldots \ldots \ldots \ldots \ldots 317$

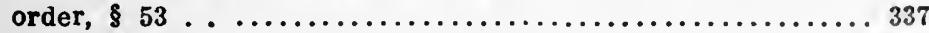

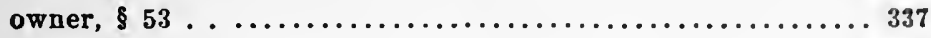

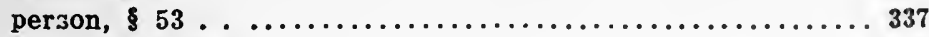

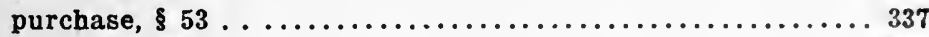

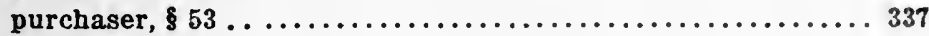

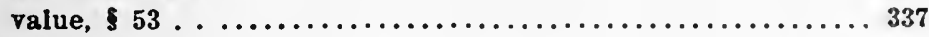

Delivery-

bill to be marked before partial, $\$ 15 \ldots \ldots \ldots \ldots \ldots \ldots \ldots . \ldots 322$

bill to be taken up or cancelled before, $\$ 14 \ldots \ldots \ldots \ldots \ldots \ldots 322$

carrier entitled to bond where bill lost or destroyed, $\$ 17 \ldots . .323$

carrier obligated to make, when, $\$ 11 \ldots \ldots \ldots \ldots \ldots \ldots \ldots \ldots 32$

negotiation of negotiable bills by, $\$ 28 \ldots \ldots \ldots \ldots \ldots \ldots \ldots . \ldots 327$

of bill as affected by terms of draft, $\S 41 \ldots \ldots \ldots \ldots \ldots \ldots . \ldots 33$

when carrier justified in making, $\$ 12 \ldots \ldots \ldots \ldots \ldots \ldots \ldots . \ldots 322$

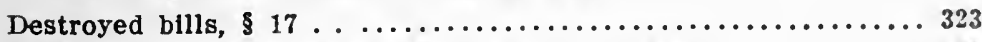

Draft on bills of lading as affecting delivery, $\$ 41 \ldots \ldots \ldots \ldots \ldots 333$

Duplicate bills-

liability on constraction, $\$ 18 \ldots \ldots \ldots \ldots \ldots \ldots \ldots \ldots \ldots \ldots$

must be so marked, $\$ 7 \ldots \ldots \ldots \ldots \ldots \ldots \ldots \ldots \ldots \ldots \ldots \ldots \ldots \ldots$

not so marked as such, liability, $\$ 46 \ldots \ldots \ldots \ldots \ldots \ldots \ldots . \ldots . \ldots 35$

Duress-

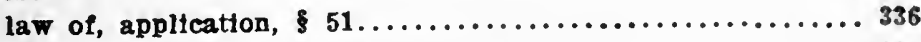

when negotiation not impaired by, $\$ 35 \ldots \ldots \ldots \ldots \ldots \ldots \ldots . \ldots 331$

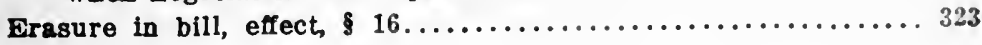




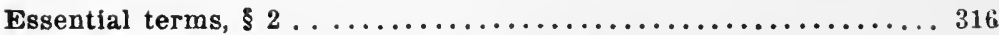

Executor's law relating to application, $\$ 51 \ldots \ldots \ldots \ldots \ldots \ldots \ldots 36$

False statement in bill, liabllity, $\S 45 \ldots \ldots \ldots \ldots \ldots \ldots \ldots \ldots . \ldots . \ldots . \ldots 35$

Form of bills-

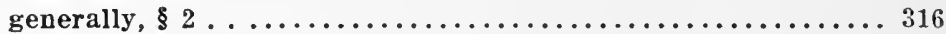

indicating rights of buyer or seller, $\S 40 \ldots \ldots \ldots \ldots \ldots \ldots \ldots 32$

what terms may be inserted, $\S 3 \ldots \ldots \ldots \ldots \ldots \ldots \ldots \ldots . \ldots . \ldots 17$

Fraud-

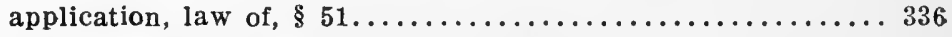

when negotiation not impaired by, $\S 38 \ldots \ldots \ldots \ldots \ldots \ldots \ldots 331$

Goods-

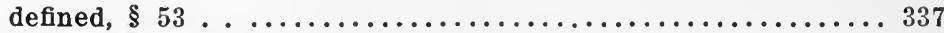

misdescription of, carrier's liability, $\$ 23 \ldots \ldots \ldots \ldots \ldots \ldots 324$

mortgaged goods, liability for negotiation of bill, $\$ 47 \ldots \ldots \ldots 335$

non-recelpt of, carrier's liability, except, $\$ 23 \ldots \ldots \ldots \ldots \ldots 324$

not in carrier's possession, negotiation of bill, $\$ 48 \ldots \ldots \ldots . .335$

not received, inducing carrier to issue bill, $\S 49 \ldots \ldots \ldots \ldots . \ldots 36$

where bill issued for, negotiation defeats vendor's lien and

right of stoppage in transitu, $\S 42 \ldots \ldots \ldots \ldots \ldots \ldots \ldots \ldots \ldots \ldots$

Holder-

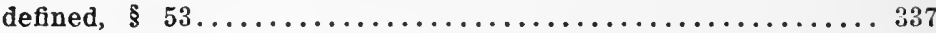

no warranty implied from accepting payment of debt, §37... 331

Indorsement-

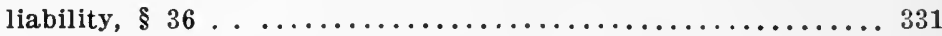

negotiation of negotiable bills by, $\S 29 \ldots \ldots \ldots \ldots \ldots \ldots \ldots . \ldots \ldots$

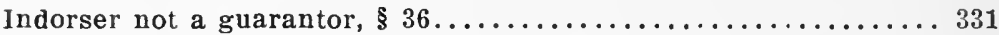

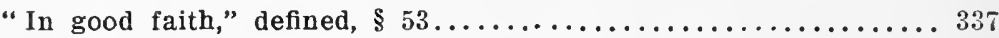

Interpleader-

carrier has time to, where necessary, $\S 21 \ldots \ldots \ldots \ldots \ldots \ldots 324$

carrier may have, where adverse claimants, $\S 20 \ldots \ldots \ldots \ldots . \ldots 324$

Interpretation to effect uniformity, $\S 52 \ldots \ldots \ldots \ldots \ldots \ldots \ldots \ldots 337$

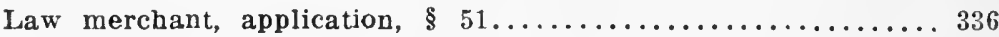

Levy upon goods, for which bill issued, $\$ 24 \ldots \ldots \ldots \ldots \ldots \ldots \ldots 326$

Liability -

carrier's, for failure to take up and cancel on delivery of goods,

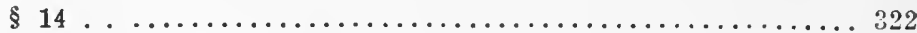

carrier's, for issuing negotiable bills in parts or sets, $\$ 6 \ldots \ldots 318$

carrier's, on partial delivery, must mark or take up bill, $\S 15.322$

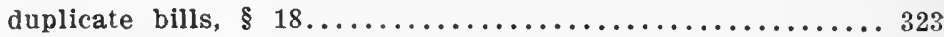

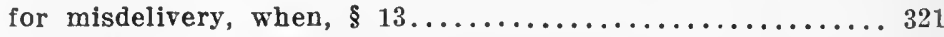

issue of bill containing false statement, $\S 45 \ldots \ldots \ldots \ldots \ldots . \ldots 335$

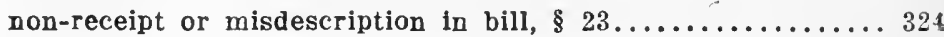




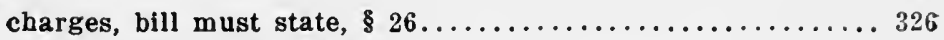

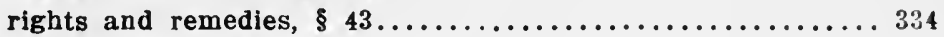

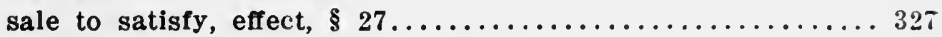

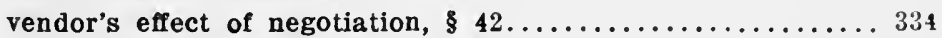

Lost bill, carrier may require bond, $\$ 17 \ldots \ldots \ldots \ldots \ldots \ldots \ldots \ldots$

Misdescription of goods in bill, liability, $\$ 23 \ldots \ldots \ldots \ldots \ldots \ldots . \ldots \ldots$

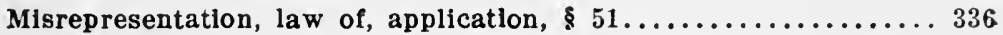

Mistake-

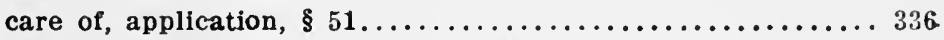

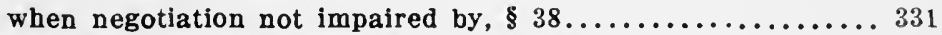

Mortgaged goods, negotiation of bill for, $\$ 47 \ldots \ldots \ldots \ldots \ldots \ldots . \ldots 335$

Mortgagee, no warranty implied from accepting payment of debt,

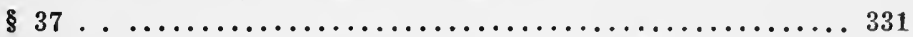

Mortgages, rights and remedies, not limited, when, $\S 43 \ldots \ldots \ldots . .334$

Negotiable bills-

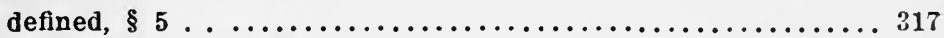

insertion of name of person to be notified shall not limit, $\S 9$. . 318

must be cancelled before delivery, $\S 14 \ldots \ldots \ldots \ldots \ldots \ldots \ldots 322$

must be cancelled or marked when part of goods delivered,

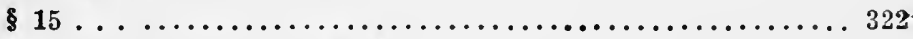

must not be issued in sets, $\S 6 \ldots \ldots \ldots \ldots \ldots \ldots \ldots \ldots \ldots \ldots$

Negotiation of bill-

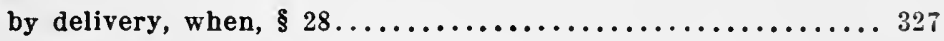

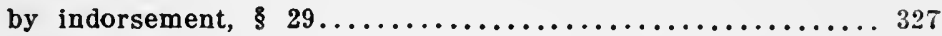

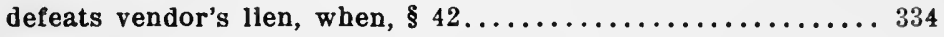

goods not in carrier's possession, liability, $\S 48 \ldots \ldots \ldots \ldots . \ldots 335$

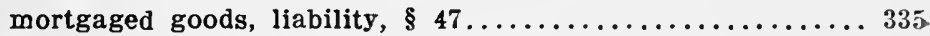

not impaired by fraud, etc., when, $\S 38 \ldots \ldots \ldots \ldots \ldots \ldots \ldots \ldots \ldots$

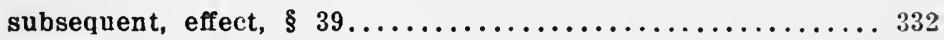

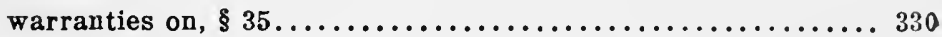

Non-negotiable bill-

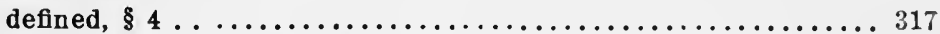

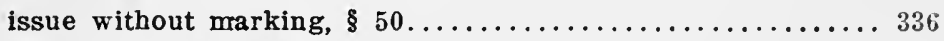

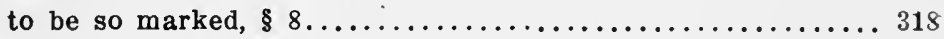

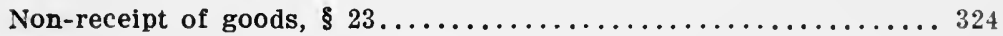

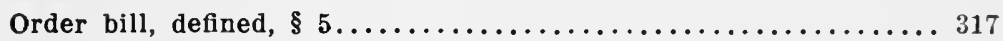

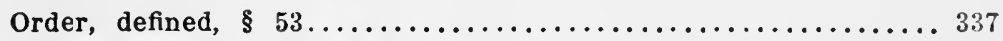

Penalty, see Criminal Offenses.

Person-

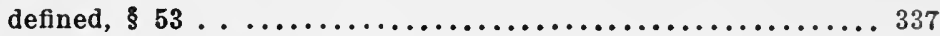

insertion of, to be notified shall not limit negotiability, § 9... 318

rights of, to whom bill negotiated, $\S 32 \ldots \ldots \ldots \ldots \ldots \ldots \ldots 28$

rights of, to whom bill transferred, $\$ 33 \ldots \ldots \ldots \ldots \ldots \ldots . \ldots 329$ 
Pledgee, no warranty implied from accepting payment of debt,

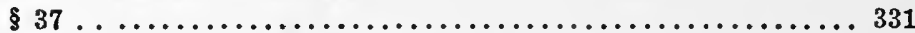

Principal and agent, law of, application, § $51 \ldots \ldots \ldots \ldots \ldots \ldots . \ldots . \ldots 336$

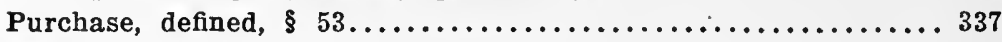

Purchaser-

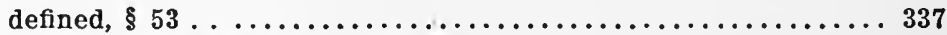

in good faith gets title, when, $\S 38 \ldots \ldots \ldots \ldots \ldots \ldots \ldots \ldots . \ldots \ldots$

Remedies-

creditor's, to reach negotiable bill, $\S 25 \ldots \ldots \ldots \ldots \ldots \ldots . . \ldots 326$

under mortgages and liens not limited, $\$ 43 \ldots \ldots \ldots \ldots \ldots 334$

Repeal of inconsistent legislation, $\S 55 \ldots \ldots \ldots \ldots \ldots \ldots \ldots \ldots . \ldots \ldots$

Right of stoppage in transitu shall not defeat bill issued for goods,

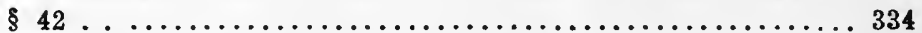

Rule for uses not provided for in this act, $\S 51 \ldots \ldots \ldots \ldots \ldots . \ldots 36$

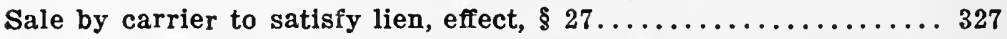

Seller's form of bill as indicating rights of, $\S 40 \ldots \ldots \ldots \ldots \ldots 332$

Straight bill, defined, $\S 4 \ldots \ldots \ldots \ldots \ldots \ldots \ldots \ldots \ldots \ldots \ldots \ldots \ldots \ldots \ldots \ldots \ldots$

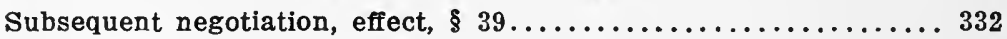

Terms-

acceptance of bill indicates assent to, $\S 10 \ldots \ldots \ldots \ldots \ldots . \ldots 319$

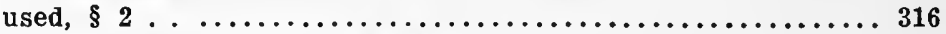

what terms may be inserted, $\S 3 \ldots \ldots \ldots \ldots \ldots \ldots \ldots \ldots \ldots . \ldots \ldots 17$

Time-

carrier has reasonable, to determine validity of claims, § $21 . .324$

when act shall take effect, $\S 56 \ldots \ldots \ldots \ldots \ldots \ldots \ldots \ldots \ldots . \ldots . \ldots . \ldots 38$ Title-

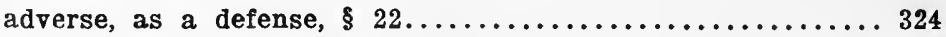

carrier cannot claim, except, $\$ 19 \ldots \ldots \ldots \ldots \ldots \ldots \ldots \ldots . \ldots . \ldots 24$

Transfer of bills-

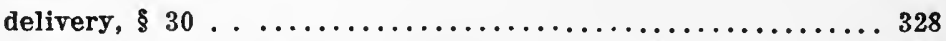

rights of person to whom bill is transferred, $\$ 33 \ldots \ldots \ldots \ldots 329$

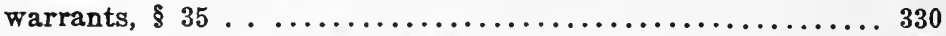

without indorsement, effect, $\S 34 \ldots \ldots \ldots \ldots \ldots \ldots \ldots \ldots . \ldots 330$

Trustees, law relating to, application, $\S 51 \ldots \ldots \ldots \ldots \ldots \ldots \ldots . \ldots \ldots$

Vendor's lien, effect of negotiation, $\$ 42 \ldots \ldots \ldots \ldots \ldots \ldots \ldots \ldots \ldots \ldots \ldots \ldots$

Warranties-

non-implied, from accepting payment of debt, § $37 \ldots \ldots \ldots . . .331$

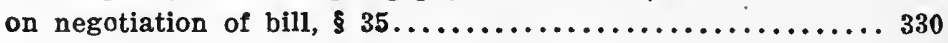




\section{INDEX TO UNIFORM STOCK TRANSFER ACT}

Act -

does not apply to existing certificates, $\$ 23 \ldots \ldots \ldots \ldots \ldots \ldots$

interpretation to effect purpose of uniformtty, $\$ 19 \ldots \ldots \ldots 352$

repeals inconsistent legislation, $\$ 24 \ldots \ldots \ldots \ldots \ldots \ldots \ldots \ldots 4$

rule where cases not provided for by, $\S 18 \ldots \ldots \ldots \ldots \ldots \ldots \ldots . \ldots 35$

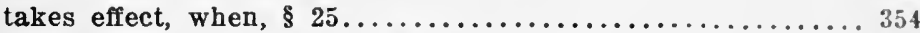

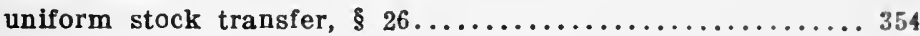

Administrators-

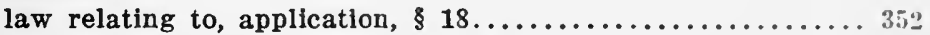

powers of transfer not enlarged, $\$ 2 \ldots \ldots \ldots \ldots \ldots \ldots \ldots . \ldots . \ldots . \ldots . \ldots$

Alteration of certificate does not divest title to shares, $\$ 16 \ldots \ldots 351$

Assignment, power of fiduciaries not enlarged, $\$ 2 \ldots \ldots \ldots \ldots \ldots . \ldots 345$

Attachment, of shares, provision, when, $\$ 13 \ldots \ldots \ldots \ldots \ldots \ldots . \ldots 350$

Authority, lack of, effect on indorsement, $\$ 6 \ldots \ldots \ldots \ldots \ldots \ldots 47$

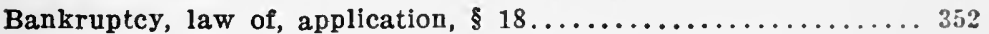

Certificate-

alteration of, effect on title to shares, $\$ 16 \ldots \ldots \ldots \ldots \ldots . \ldots 351$

creditor's remedies to reach, $\S 14 \ldots \ldots \ldots \ldots \ldots \ldots \ldots \ldots . \ldots . \ldots . \ldots$

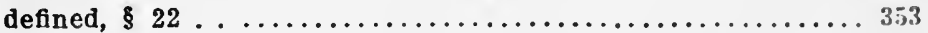

delivery of unindorsed, imposes obitgation to indorse, $\$ 9 \ldots \ldots 343$

how title to, may be transferred, $\$ 1 \ldots \ldots \ldots \ldots \ldots \ldots \ldots \ldots \ldots$

lien to be good must be indicated on, $\$ 15 \ldots \ldots \ldots \ldots \ldots . \ldots 30$

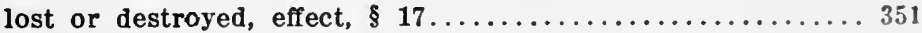

may rescind transfer of, when, $\$ 7 \ldots \ldots \ldots \ldots \ldots \ldots \ldots \ldots \ldots \ldots$

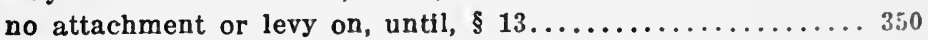

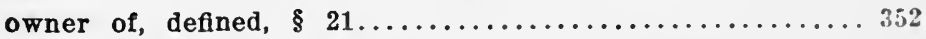

rescission of transfer of, does not invalidate, when, 8 8... 348

title derived from, distingulshes one from separate document,

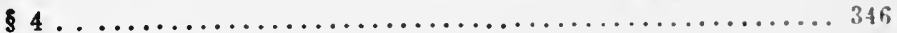

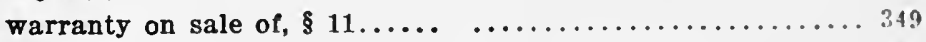

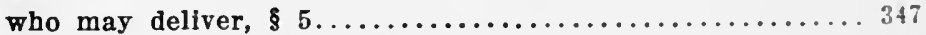

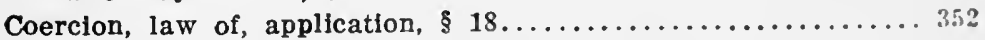

Consideration, lack of, effect on indorsement, $\$ 6 \ldots \ldots \ldots \ldots \ldots . \ldots$

Corporation-

may treat registered holder as owner, $\$ 3 \ldots \ldots \ldots \ldots \ldots \ldots 345$

shall have no lien unless restriction on certificate, $\$ 15 \ldots \ldots . .50$

Creditor's remedies to reach certificate, $\$ 14 \ldots \ldots \ldots \ldots \ldots \ldots \ldots$

Death, indorsement effectual in spite of, $\$ 6 \ldots \ldots \ldots \ldots \ldots . \ldots . \ldots 47$ 
Definitions-
PAGE

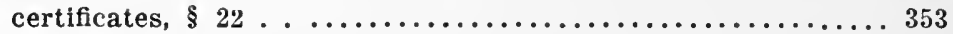

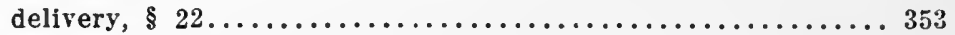

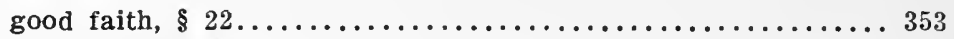

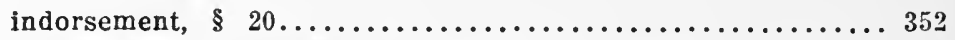

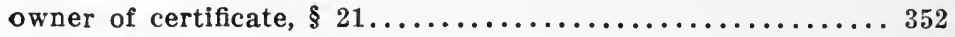

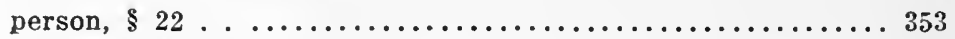

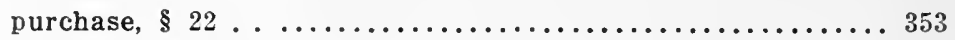

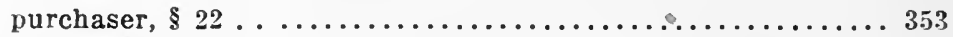

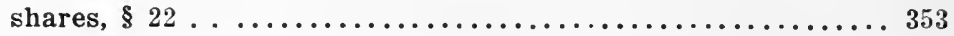

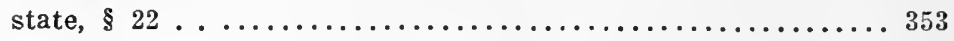

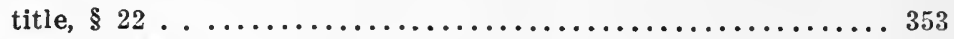

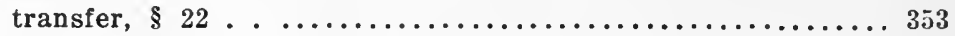

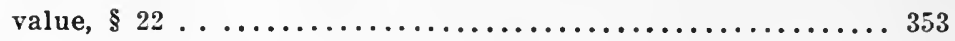

Delivery-

how title to certificate may be transferred, $\S 1 \ldots \ldots \ldots \ldots . .345$

induced by fraud, etc., effect, $\S 6 \ldots \ldots \ldots \ldots \ldots \ldots \ldots \ldots \ldots \ldots \ldots$

unindorsed certificate, negotiation to endorse, $\S 9 \ldots \ldots \ldots \ldots 349$

who may make, $\S 5 \ldots \ldots \ldots \ldots \ldots \ldots \ldots \ldots \ldots \ldots \ldots \ldots . \ldots \ldots 7$

Duress-

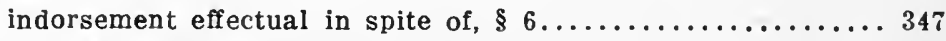

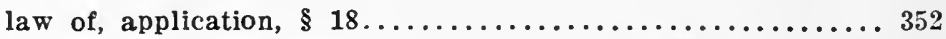

rescission of transfer of certificate for, when, $\S 7 \ldots \ldots \ldots 347$

Executors-

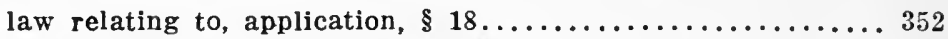

power to transfer not enlarged, $\$ 2 \ldots \ldots \ldots \ldots \ldots \ldots \ldots \ldots . \ldots 346$

Fiduciaries, powers not enlarged, $\S 2 \ldots \ldots \ldots \ldots \ldots \ldots \ldots \ldots \ldots$

Fraud-

indorsement effectual in spite of, $\S 6 \ldots \ldots \ldots \ldots \ldots \ldots \ldots \ldots \ldots \ldots$

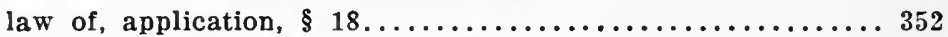

may rescind transfer for, when, $\S 7 \ldots \ldots \ldots \ldots \ldots \ldots \ldots \ldots \ldots \ldots \ldots$

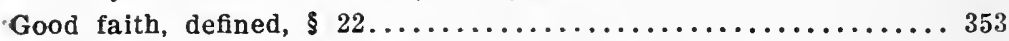

Incapacity, indorsement effectual in spite of, $\S 6 \ldots \ldots \ldots \ldots \ldots . \ldots 34$

Inconsistent legislation repealed, $\S 24 \ldots \ldots \ldots \ldots \ldots \ldots \ldots \ldots \ldots 4$

Indorsement-

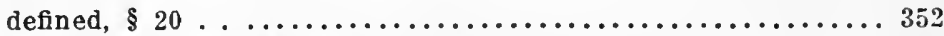

effectual in spite of fraud, etc., $\S 6 \ldots \ldots \ldots \ldots \ldots \ldots \ldots \ldots \ldots \ldots \ldots$

power of fiduciaries not enlarged, $\S 2 \ldots \ldots \ldots \ldots \ldots \ldots \ldots \ldots \ldots$

Ineffectual attempt to transfer, $\$ 10 \ldots \ldots \ldots \ldots \ldots \ldots \ldots \ldots \ldots . \ldots . \ldots . \ldots$

Infants, power to transfer not enlarged, $\S 2 \ldots \ldots \ldots \ldots \ldots \ldots \ldots \ldots 346$

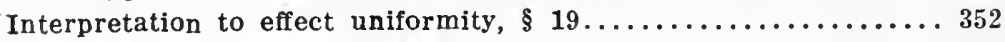

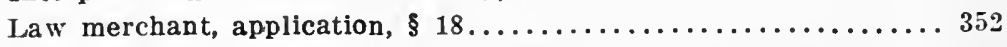

Legal capacity, nower of those lacking, and of fiduciaries, not

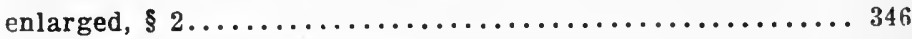

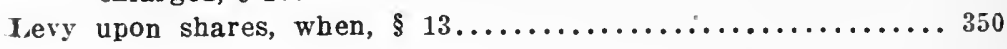


Lien, none in favor of corporation, unless, $815 \ldots \ldots \ldots \ldots \ldots \ldots . \ldots 350$

Lost or destroyed certificate, how replaced, $\$ 17 \ldots \ldots \ldots \ldots \ldots . \ldots 35$

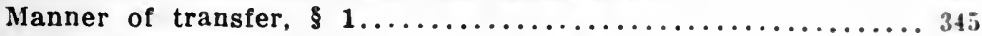

Misrepresentation, law of, application. $\$ 18 \ldots \ldots \ldots \ldots \ldots \ldots \ldots . \ldots 35$

Mistake-

indorsement effectual in spite of, $\$ 6 \ldots \ldots \ldots \ldots \ldots \ldots \ldots 347$

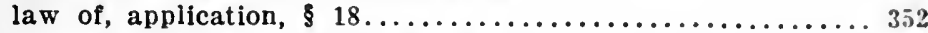

rescission of transfer for, when, $\$ 7 \ldots \ldots \ldots \ldots \ldots \ldots \ldots . \ldots 347$

Mortgagee, pledgee or holder for security, no warranty inplied

from accepting payment of debt, $\$ 12 \ldots \ldots \ldots \ldots \ldots \ldots \ldots$

Owner of certificate-

corporation may treat registered holder as, $\$ 3 \ldots \ldots \ldots \ldots \ldots 346$

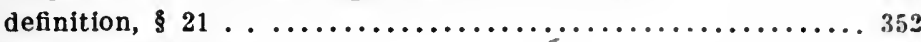

Person, defined, $\$ 22 \ldots \ldots \ldots \ldots \ldots \ldots \ldots \ldots \ldots \ldots \ldots \ldots \ldots . \ldots . \ldots 35$

Power of attorney, power of fiduciacies nct enlarged, $\$ 2 \ldots \ldots \ldots 345$

Principal and agent, law, application, $\$ 18 \ldots \ldots \ldots \ldots \ldots \ldots \ldots \ldots$

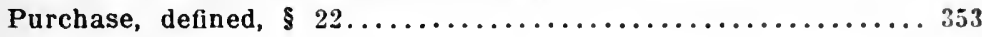

Purchaser-

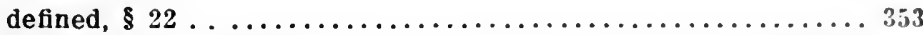

rescission of transfer does not invalida e subsequent transfer

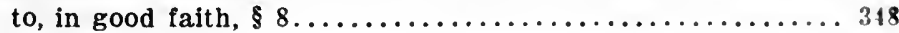

Rescission-

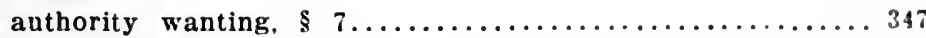

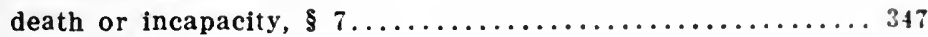

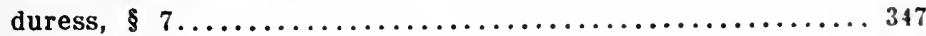

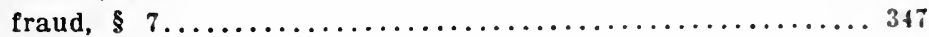

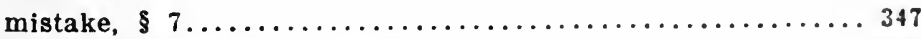

subject to transfer by transferee in possession. $\$ 8 \ldots \ldots \ldots . . \ldots 34$

Registered holders as owners, $\$ 3 \ldots \ldots \ldots \ldots \ldots \ldots \ldots \ldots \ldots \ldots \ldots$

Restriction in favor of corporation, $\$ 15 \ldots \ldots \ldots \ldots \ldots \ldots \ldots . \ldots \ldots$

Revocation, indorsement effectual in spite of, $\$ 6 \ldots \ldots \ldots \ldots \ldots 3+7$

Sale of certificate, warranty, $\$ 11 \ldots \ldots \ldots \ldots \ldots \ldots \ldots \ldots \ldots \ldots$

Share-

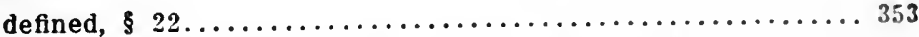

title to, not divested by alteration of certificate, $\$ 16 \ldots \ldots \ldots 351$

title transferred by delivery, $\$ 1 \ldots \ldots \ldots \ldots \ldots \ldots \ldots \ldots \ldots . \ldots \ldots 45$

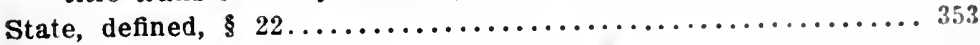

Title-

alteration of certificate, does not divest. $\$ 16 \ldots \ldots \ldots \ldots \ldots \ldots 351$

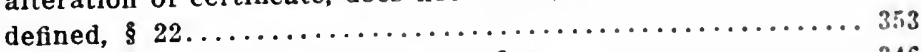

derived from certificate, superior, $\$$ f....................... 346

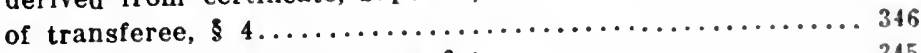

transfer of, to certificate, how, $\$ 1 \ldots \ldots \ldots \ldots \ldots \ldots \ldots \ldots . \ldots . \ldots 34$

transferred by delivery of certificate, when. $\$ 5 \ldots \ldots \ldots \ldots 347$ 
altered certificate does not convey title, $\S 16 \ldots \ldots \ldots \ldots \ldots 351$

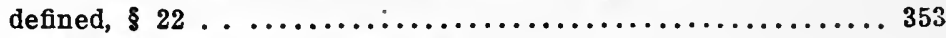

ineffectual without delivery, $\S 10 \ldots \ldots \ldots \ldots \ldots \ldots \ldots \ldots \ldots 349$

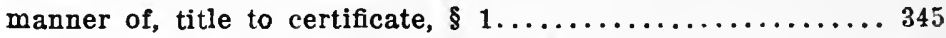

must be enjoined before attachment, $\S 13 \ldots \ldots \ldots \ldots \ldots \ldots . \ldots 350$

no warranty on, in payment of debt, $\S 12 \ldots \ldots \ldots \ldots \ldots \ldots 350$

of certificate may be rescinded, when, $\S 7 \ldots \ldots \ldots \ldots \ldots \ldots 347$

rescission of, of certificate does not invalidate, $\S 8 \ldots \ldots \ldots 348$

Trustees-

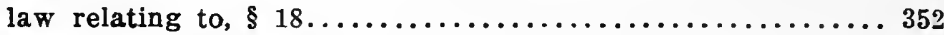

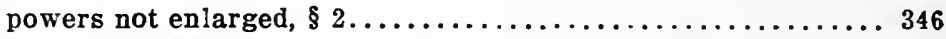

Value, defined, $\$ 22 \ldots \ldots \ldots \ldots \ldots \ldots \ldots \ldots \ldots \ldots \ldots \ldots \ldots \ldots \ldots$

Warranty-

sale of certificate, $\S 11 \ldots \ldots \ldots \ldots \ldots \ldots \ldots \ldots \ldots \ldots \ldots \ldots \ldots \ldots$

transfer in payment of debt, $\$ 12 \ldots \ldots \ldots \ldots \ldots \ldots \ldots \ldots . \ldots 350$ 


\section{INDEX TO UNIFORM DESERTION AND NON- SUPPORT ACT}

Act-

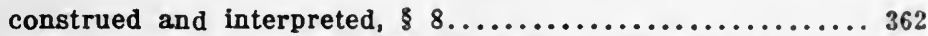

proceedings under, how and by whom instituted, $2 \ldots \ldots .360$

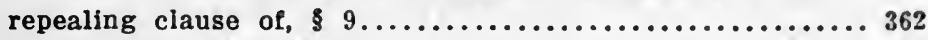

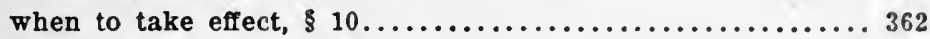

Complaint, who may make, $\S 2 \ldots \ldots \ldots \ldots \ldots \ldots \ldots \ldots \ldots \ldots . \ldots . \ldots . \ldots$

Confidential communications, rules governing, repealed, when, $\$$. 361

Confinement in workhouse, pay allowance each week for, \$ 7... 362

Construed and interpreted to effect uniformity, $8 \ldots \ldots \ldots \ldots . \ldots 2$ Evidence-

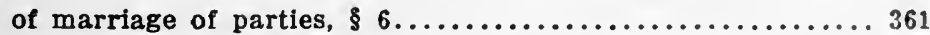

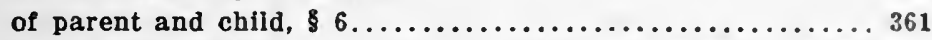

Husband, who wilfully negiects or refuses to support, when

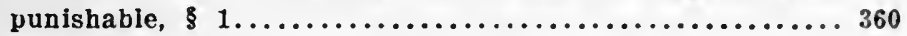

Husband and Wife-

confidential communications, rules governing repealed, 6 .. 361

competent witnesses, when, $\$ 6 \ldots \ldots \ldots \ldots \ldots \ldots \ldots \ldots \ldots \ldots$

Official to pay to wife amount allowed by law to person con-

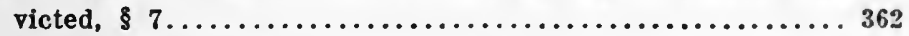

Order providing for support-

may be made instead of imposing penalty prescribed, when,

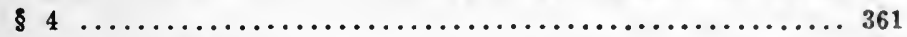

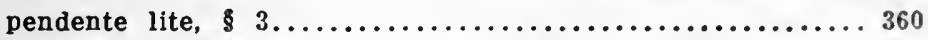

Parent, desertion of child, punishment, $\$ 1 \ldots \ldots \ldots \ldots \ldots \ldots \ldots 360$

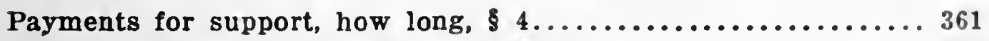

Persons who may make complaint, $\$ 2 \ldots \ldots \ldots \ldots \ldots \ldots \ldots \ldots . \ldots \ldots$

Proceedings, how and by whom instituted, $\$ 2 \ldots \ldots \ldots \ldots \ldots \ldots . \ldots 360$

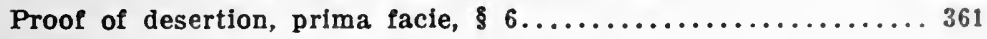

Punishment-

for desertion of child by parent, $\$ 1 \ldots \ldots \ldots \ldots \ldots \ldots \ldots+\ldots \ldots$

for desertion of wife by husband, $\$ 1 \ldots \ldots \ldots \ldots \ldots \ldots \ldots$

for violation of court's order within two years, effect, \&5...361

for violation of order to support pendente lite, $\$ 3 \ldots \ldots \ldots 360$

Recognizance-

court may accept without surety, condition, $\$ 4 \ldots \ldots \ldots \ldots 361$

forfeiture of, disposition of sum recovered, \& $5 \ldots \ldots \ldots \ldots \ldots 1$

Release from custody on probation, recognizance, $\$ 4 \ldots \ldots \ldots 361$

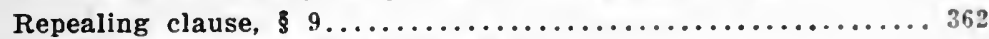

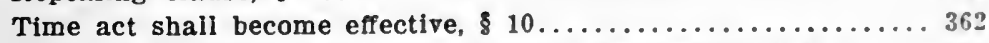

Violation of terms of the order of court, punishment, $\$ 5 \ldots \ldots 361$ 


\section{INDEX TO UNIFORM CHILD LABOR ACT}

Act-

PAGE

continuing to employ child in violation of, penalty, $\S 40 \ldots \ldots 381$

employment of children in violation of, penalty, $\$ 39 \ldots \ldots 381$

inconsistent laws repealed by, $\S 51 \ldots \ldots \ldots \ldots \ldots \ldots \ldots \ldots 383$

interpretation and construction of, $\S 50 \ldots \ldots \ldots \ldots \ldots \ldots . \ldots 383$

provisions of, bow to be enforced, $\S 35 \ldots \ldots \ldots \ldots \ldots \ldots \ldots 380$

retaining certificate in violation of, penalty, $\S 41 \ldots \ldots \ldots \ldots 381$

shall not prevent children receiving industrial education, $§ 38$. 380

takes effect, when, $\S 52 \ldots \ldots \ldots \ldots \ldots \ldots \ldots \ldots \ldots \ldots \ldots . \ldots \ldots$

Affidavit, penalty for making false, $\S 47 \ldots \ldots \ldots \ldots \ldots \ldots \ldots \ldots 2$

Age--

employer fails to produce evidence of, effect, $\S 17 \ldots \ldots \ldots 374$

evidence of, to be furnished by employer, when, $\S 16 \ldots \ldots \ldots 374$

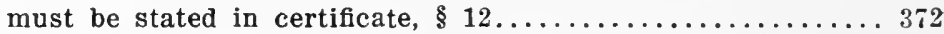

proof of, must be received before certificate issued, $\S 10 \ldots .370$

shall not prevent children receiving industrial education, $\S 38380$

Agent-

penalty for employment of child contrary to act, $\S 39 \ldots \ldots \ldots 381$

selling articles for resale in violation of act, penalty, $\$ 49 \ldots 382$

Appeals, may be taken from rulings of state board of health,

$\S \S 5,9 \ldots \ldots \ldots \ldots \ldots \ldots \ldots \ldots \ldots \ldots \ldots \ldots \ldots \ldots \ldots, 370$

Badge-

boys under sixteen must have, when, $\S 29 \ldots \ldots \ldots \ldots \ldots \ldots 377$

how numbered, $\S 31 \ldots \ldots \ldots \ldots \ldots \ldots \ldots \ldots \ldots \ldots \ldots$

issued when, list of holders to be kept, $\S 30 \ldots \ldots \ldots \ldots \ldots 378$

must be worn, expiration of life of, displayed, when, not

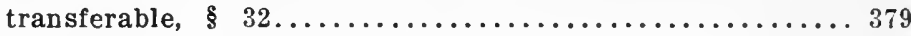

taken and permit revoked, when, $\S 34 \ldots \ldots \ldots \ldots \ldots \ldots \ldots . \ldots 379$

Blank certificates to be prepared by whom, $\S 14 \ldots \ldots \ldots \ldots \ldots \ldots 373$

Boys-

employers must post names and certificates of, if under

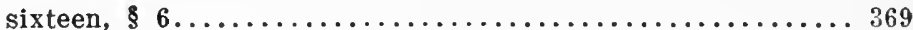

hours of labor for, under eighteen, $\S 24 \ldots \ldots \ldots \ldots \ldots \ldots . \ldots 376$

hours of labor for, under sixteen, $\S 23 \ldots \ldots \ldots \ldots \ldots \ldots \ldots . \ldots \ldots$

if under sixteen, must have badge, when, $\S 29 \ldots \ldots \ldots \ldots \ldots 377$

newspapers not to be sold by, under twelve, $\S 27 \ldots \ldots \ldots \ldots 377$

Chairs-

failure to provide, penalty, $\S 44 \ldots \ldots \ldots \ldots \ldots \ldots \ldots \ldots \ldots 2$

must be furnished females under twenty-one, $\$ 22 \ldots \ldots \ldots \ldots 376$ :

[638] 


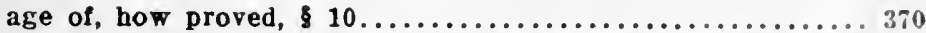

continuing to employ, in violation of act after notice, penalty,

$\& 40$

delinquent, when, effect, $\$ 34 \ldots \ldots \ldots \ldots \ldots \ldots \ldots \ldots \ldots . \ldots . \ldots 39$

employed under act, to be taken to court on refusal to give

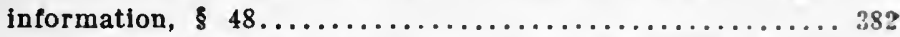

must be examined personaliy before certificate issued, $\& 11$.. 372

must sign certificate before whom, $\$ 12 \ldots \ldots \ldots \ldots \ldots \ldots \ldots$.

school record of to show in certificate, $\$ 13 \ldots \ldots \ldots \ldots . \ldots 37$

what hours, may work in street trades, $\$ 33 \ldots \ldots \ldots \ldots \ldots . . . . .379$

Children-

act shall not be construed to prevent, receiving industrial

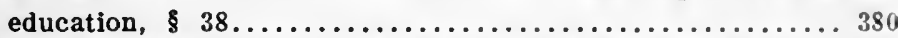

apparently under sixteen cannot be employed unless, $\$ 16 \ldots 374$

employment certificate necessary if under sixteen, $6 \ldots \ldots$. 6 .

names of, to be furnished chief factory inspector, when, $\$ 15 . .37$.

under eighteen how shall not be employed in, $\$ 18 \ldots \ldots \ldots 374$

under fourteen how shall not be employed in, $\$ 1 \ldots \ldots \ldots \ldots 367$

under sixteen shall not be employed in, $\$ 3 \ldots \ldots \ldots \ldots \ldots 367$

unlawful to empioy, under fourteen during school term, \& 2.. 367

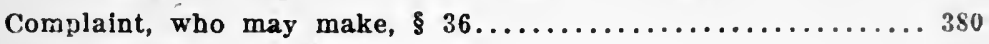

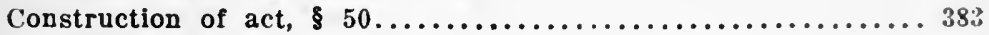

Corporation-

employing boys under sixteen and girls under eighteen must

post names, $\$ 6 \ldots \ldots \ldots \ldots \ldots \ldots \ldots \ldots \ldots \ldots \ldots \ldots \ldots . \ldots \ldots$

must agree to employ, before certificate issued, $\$ 10 \ldots \ldots \ldots 370$

penaity for employment of children contrary to act, $\$ 39 \ldots 381$

penalty for refusing admission to or delaying inspector, \& 45. . 33:

retaining certificate contrary to act, penalty, $\$ 41 \ldots \ldots \ldots \ldots 31$

shall not employ children under fourteen during school term,

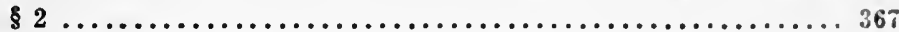

Courts-

appeals from rulings may be had to, $85 \ldots \ldots \ldots \ldots \ldots \ldots . \ldots 369$

employers may appeal from rulings of board to, $\$ 19 \ldots \ldots \ldots 375$ Day -

eight hours is, for boy under sixteen and girl under elghteen.

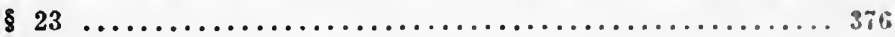

ten hours is, for boy under eighteen and girl under twenty-

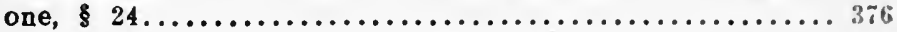

\section{Eighteen-}

boy under, hours of labor, $\$ 24 \ldots \ldots \ldots \ldots \ldots \ldots \ldots \ldots \ldots \ldots$

children under, how shall not be employed, $\$ 18 \ldots \ldots \ldots \ldots 374$

girl under, hours of labor, $\$ 23 \ldots \ldots \ldots \ldots \ldots \ldots \ldots \ldots \ldots \ldots \ldots \ldots \ldots . \ldots \ldots$ 


\section{Employer-}

certificate to be returned in two days to official, when, $\$ 8$.. 369 child apparently under sixteen, evidence of age to be given,

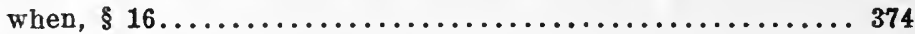

failure of, to keep certificate and lists as provided, penalty,

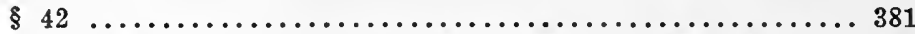

failure of, to produce evidence of age of child, effect, $\S 17 \ldots 374$ failure to produce certificate or lists prima facie evidence of illegal employment, $\S 37 \ldots \ldots \ldots \ldots \ldots \ldots \ldots \ldots \ldots \ldots \ldots 380$

failure to keep notices posted, penalty, $\S 43 \ldots \ldots \ldots \ldots \ldots \ldots 381$ must post names of boys under sixteen and girls under eighteen and file certificates, $\S 6 \ldots \ldots \ldots \ldots \ldots \ldots \ldots \ldots \ldots 369$ notice must be posted by, stating hours for boys and girls,

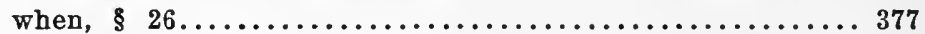
penalty for continuing to employ child after notice, $\S 40 \ldots 381$ penalty for failure to provide seats, $\S 44 \ldots \ldots \ldots \ldots \ldots \ldots \ldots . \ldots 382$ retaining certificate in violation of act, penalty, $\S 41 \ldots \ldots \ldots 381$

Employment-

continuing of child in violation of act, penalty, $\S 40 \ldots \ldots \ldots . \ldots 381$

failure to produce certificate, evidence of illegal, $\S 37 \ldots \ldots \ldots 380$

Employment certificates-

blank, to be prepared by whom, $\S 14 \ldots \ldots \ldots \ldots \ldots \ldots \ldots . \ldots 373$

child must be personally examined before issuance of, $\S 11$... 372 employer's failure to produce, evidence of illegal employment,

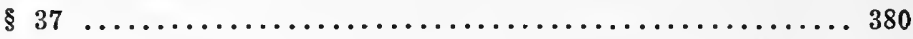

may not be issued until papers received and approved, $\S 10 \ldots 370$

must be inspected by whom, $\S 7 \ldots \ldots \ldots \ldots \ldots \ldots \ldots \ldots \ldots . \ldots 369$

must be kept in accessible place, $\S 6 \ldots \ldots \ldots \ldots \ldots \ldots \ldots . \ldots 369$

must be returned to official within two days, when, $\S 8 \ldots \ldots 369$

penalty for employer's failure to keep, $\$ 42 \ldots \ldots \ldots \ldots \ldots \ldots 381$

retaining, in violation of act, penalty, $\S 41 \ldots \ldots \ldots \ldots \ldots \ldots 381$

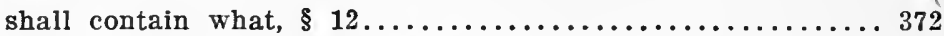

who may issue, and when, $\S 9 \ldots \ldots \ldots \ldots \ldots \ldots \ldots \ldots \ldots \ldots$

Female-

under twenty-one, how shall not be employed, § $21 . \ldots \ldots \ldots . \ldots 375$ under twenty-one, shall not be employed where she must

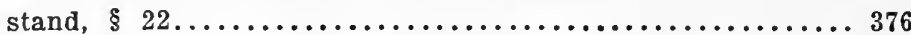

Fourteen-

no boy under, allowed to work, where, $\S 28 \ldots \ldots \ldots \ldots \ldots 377$

no child under, shall work in certain employment, $\S 1 \ldots \ldots 367$

unlawful to employ child under, when, $\S 2 \ldots \ldots \ldots \ldots \ldots \ldots 367$

Guardian-

affidavit of to procure employment certificate, when, $\S 10 \ldots 370$ application for certificate to be made by, when, $\S 9 \ldots \ldots \ldots .370$ 
Guardian-Continued.

application for permit to be made by, when, $29 \ldots \ldots \ldots 377$

penaity for permitting employment of child contrary to act,

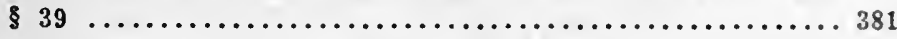

Girls-

hours of labor for, under eighteen, $\$ 23 \ldots \ldots \ldots \ldots \ldots \ldots \ldots$

hours of labor for, under twenty-one, $\$ 24 \ldots \ldots \ldots \ldots \ldots 376$

names of, must be posted and certificates filed, if under

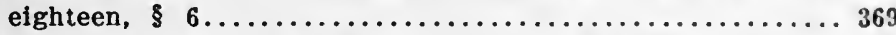

newspapers not to be sold by, under sixteen, $\$ 27 \ldots \ldots \ldots \ldots 377$

Hours-

for boy under sixteen and girl under eighteen, $\$ 23 \ldots \ldots \ldots 376$

in which child may work on street, $\$ 33 \ldots \ldots \ldots \ldots \ldots \ldots . \ldots 379$

for boy under eighteen and girl under twenty-one, $\$ 24 \ldots \ldots 376$

notice giving, of work, must be posted by employer of boys

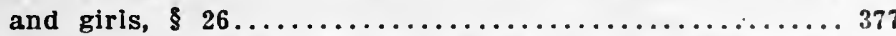

persons under twenty-one may be employed as messengers

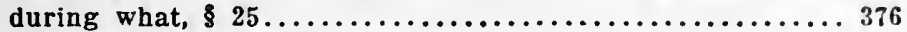

Inconsistent acts repealed, $\$ 51 \ldots \ldots \ldots \ldots \ldots \ldots \ldots \ldots \ldots \ldots \ldots$

Industries-

certain, may not employ females under twenty-one, \& 21... 375

children under eighteen not to be employed in what, $\$ 18 \ldots 374$

children under fourteen shall not be employed in what, $\$ 1$. 367

children under sixteen shall not be employed in what, $\$ 3 . .367$

in what, employment in any capacity under sixteen forbidden.

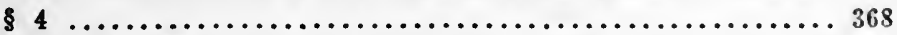

state board of health to determine which are dangerous or

injurious, $\$ 5 \ldots \ldots \ldots \ldots \ldots \ldots \ldots \ldots \ldots \ldots \ldots \ldots \ldots \ldots \ldots$

Inspector-

blank certificates shall be prepared by chief factory, $\$ 14 \ldots 373$

certificates and lists muist be accessible to, $\$ 6 \ldots \ldots \ldots \ldots . \ldots 369$

certificates and lists shall be produced for, \& $7 \ldots \ldots \ldots \ldots . \ldots 36$

child apparently under sixteen, employer must satisfy, as to

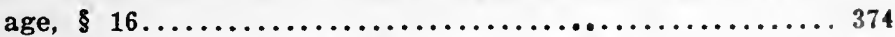

must enforce provisions as to street trades, $\$ 35 \ldots \ldots \ldots \ldots . \ldots 30$

must inspect, make reports and complaints, $\$ 36 \ldots \ldots \ldots \ldots 380$

must supply notice of hours boys and girls to work, $\$ 26 \ldots 377$ must take children before court on refusal to give informa-

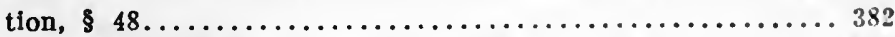

names of children to be sent to chief, when, $\$ 15 \ldots \ldots \ldots \ldots 373$

penalty for hindering work of, $\$ 45 \ldots \ldots \ldots \ldots \ldots \ldots \ldots \ldots \ldots$

violation of duty under act by, penalty, $\$ 46 \ldots \ldots \ldots \ldots \ldots 382$

Labor, hours of, for boy under sixteen and girl under eighteen,

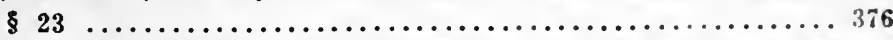

Messenger, no person under twenty-one, to be employed as,

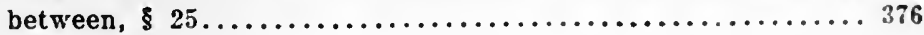


Notice-

employers of boys and girls must post, when, $\S 26 \ldots \ldots \ldots \ldots 377$

penalty for failure to keep, posted, $\S 43 \ldots \ldots \ldots \ldots \ldots \ldots . \ldots 381$

Occupations-

boys under fourteen and girls under sixteen not to be employed

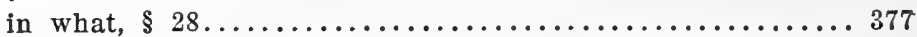

children under fourteen may not be employed in what, $\$ 1$.. 367

children under sixteen may not be employed in what, $\S 3,4$..

367,368

females under twenty-one not to be employed in what, § 21. 375

may not employ children under eighteen in what, $\S 18 \ldots \ldots 374$

Parent-

affidavit of, to procure employment certificate, when, $\S 10 \ldots 370$

application for certificate to be made by, when, $\$ 9 \ldots \ldots \ldots 370$

application for permit to be made by, when, $\$ 29 \ldots \ldots \ldots 377$

penalty for permitting employment of child contrary to act,

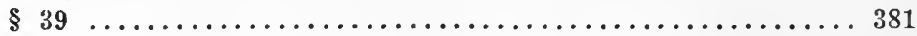

Penalty-

abuse of authority under act, by inspector, $\$ 46 \ldots \ldots \ldots \ldots 382$

for certificate to false statement, $\S 47 \ldots \ldots \ldots \ldots \ldots \ldots . \ldots 382$

for continuing to employ child in violation of act, $\S 40 \ldots \ldots 381$

for employer's failure to keep notices posted, $\S 43 \ldots \ldots \ldots \ldots 381$

for failure to keep certificates and lists, $\S 42 \ldots \ldots \ldots \ldots \ldots 381$

for failure to provide seats, $\S 44 \ldots \ldots \ldots \ldots \ldots \ldots \ldots \ldots \ldots 2$

for employing or allowing child to be employed contrary to

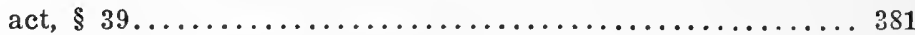

for hindering or delaying inspector in work, $\S 45 \ldots \ldots \ldots \ldots 382$

for retaining certificate in violation of act, $\$ 41 \ldots \ldots \ldots \ldots . \ldots 381$

where articles sold to minor for resale contrary to act, $\S 49$. 382

Permit-

boys under sixteen must have, when, $\S 29 \ldots \ldots \ldots \ldots \ldots \ldots 377$

issued when, list of holders must be kept, $\S 30 \ldots \ldots \ldots \ldots . \ldots 378$

revoked for six months and badge taken, when, $\S 34 \ldots \ldots \ldots 379$

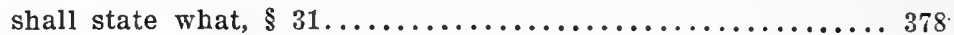

Person-

female under twenty-one shall not be employed by any,

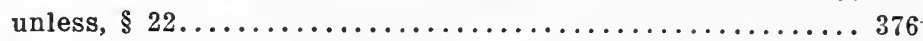

who knowingly certifies to false statement, penalty, $\S 47 \ldots . .382$.

who knowingly sells article to minor for resale in violation.

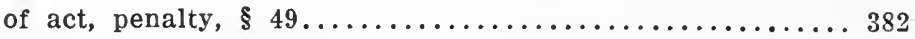

retaining certificate contrary to act, penalty, $\S 41 \ldots \ldots \ldots 381$

under twenty-one may not be employed as messenger, when,

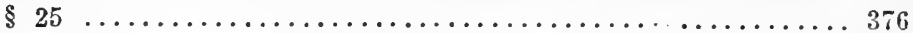

under twenty-one not to work in saloon, $\$ 20 \ldots \ldots \ldots \ldots \ldots 37$. 
Person-Continued.

who hinders work of inspectors, penalty, $\$ 45 \ldots \ldots \ldots \ldots . \ldots 382$

who may make complaints, $\$ 36 \ldots \ldots \ldots \ldots \ldots \ldots \ldots \ldots \ldots$

Physician, certificate of, must be recelved before employment

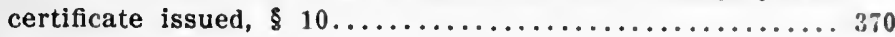

\section{Principal-}

certificate to be filled out and signed by, $\$ 13 \ldots \ldots \ldots \ldots . \ldots 373$

must keep list to whom permits and badges issued, $30 \ldots \ldots 378$

penalty for violation of provisions of act by, $\$ 46 \ldots \ldots \ldots \ldots 352$

Saloon, not to employ persons under twenty-one, $\$ 20 \ldots \ldots \ldots . .375$

School-

children under fourteen must not work during, hours, $\$ 2 . .367$

record to be signed before certificate issued, $\$ 10 \ldots \ldots \ldots . \ldots 370$

record to show attendance of child, $\$ 13 \ldots \ldots \ldots \ldots \ldots \ldots . \ldots 33$

superintendent of, shall issue employment certificate, when,

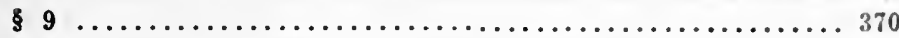

superintendent of, to furnish names to, when, $\S 15 \ldots \ldots \ldots 373$

Seats, see Chairs.

Sixteen-

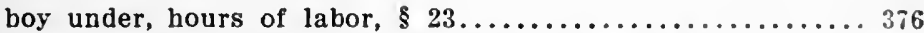

boy under, must have permit and badge, when, $\$ 29 \ldots \ldots \ldots 377$

children apparently under, duty of employer, $\$ 16 \ldots \ldots \ldots 374$

hours child under, may work in street trades, $\$ 33 \ldots \ldots \ldots .379$

no child under, shall be employed where, $\$ \S 3,4 \ldots \ldots \ldots .36$, 368

no girl under, allowed to sell newspapers, $\$ 27 \ldots \ldots \ldots \ldots 377$

no girl under, allowed to work, where, $\$ 28 \ldots \ldots \ldots \ldots \ldots 377$

State board of health, may determine, after hearing, what occupa-

tions are dangerous or injurious, $\$ \$ 5,19 \ldots \ldots \ldots \ldots . \ldots, 375$

Street trades-

boy under sixteen must have permit and badge to work at,

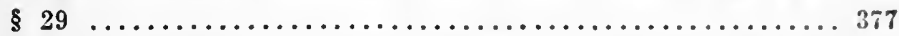

child who violates provisions relating to, delinquent, $\$ 34 \ldots 379$

hours child may work in, $\$ 33 \ldots \ldots \ldots \ldots \ldots \ldots \ldots \ldots . \ldots \ldots$

no boy under fourteen or girl under sixteen to be employed

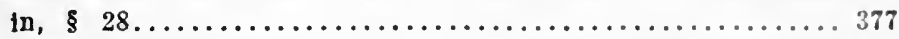

no boy under twelve or girl under sixteen shall sell news-

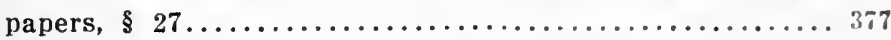

provisions relating to, must be enforced by, $\$ 35 \ldots \ldots \ldots \ldots 350$

Time-

act takes effect, when, $\$ 52 \ldots \ldots \ldots \ldots \ldots \ldots \ldots \ldots \ldots \ldots . \ldots \ldots 3$

boys under sixteen and girls under eighteen may work what

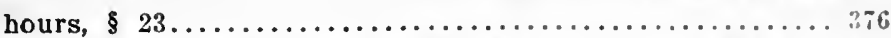

persons under twenty-one may work as messengers, \$ $\$ 5 ., 376$

Transfer, shall be no, of badge, $\$ 32 \ldots \ldots \ldots \ldots \ldots \ldots \ldots \ldots$ 
Truant officer-

PAGE

child apparently under sixteen, evidence of age must be pro-

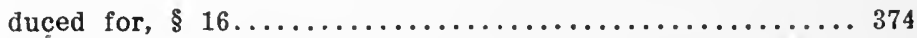

employment certificates and lists must be accessible to, $\S 6$. . 369

must inspect, report violations and make complaints, $\S 36 \ldots 380$

must require certificates and lists be produced, $\S 7 \ldots \ldots \ldots . .369$

penalty for hindering work of, $\S 45 \ldots \ldots \ldots \ldots \ldots \ldots \ldots \ldots . \ldots . \ldots . \ldots . \ldots$

to take child withholding information before court, $\$ 48 \ldots \ldots 382$

violation of duty under act by, penalty, $\$ 46 \ldots \ldots \ldots \ldots \ldots 382$

Twelve, no boy under, to sell newspapers, $\S 27 \ldots \ldots \ldots \ldots \ldots \ldots 37$

Twenty-one-

female under, shall not be employed, how, $\S 21 \ldots \ldots \ldots \ldots . . .375$

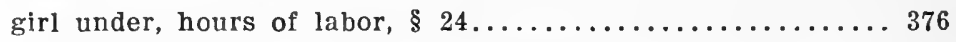

persons under, shall not be employed in saloon, $\S 20 \ldots \ldots 375$

Week-

for boy under eighteen and girl under twenty-one, $\S 24 \ldots \ldots 376$

for boy under sixteen and girl under eighteen, $\S 23 \ldots \ldots \ldots . .376$

Work-

certain industries shall not employ children under sixteen,

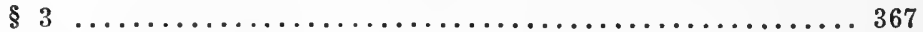

children under eighteen not to be employed in, $\S 18 \ldots \ldots \ldots 374$

children under fourteen shall not be employed in certain

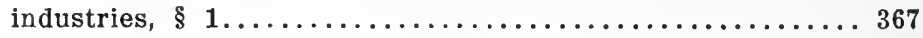

forbidden if under sixteen, where, $\S 4 \ldots \ldots \ldots \ldots \ldots \ldots \ldots . \ldots 368$

unlawful to, during school hours, $\S 2 \ldots \ldots \ldots \ldots \ldots \ldots \ldots \ldots 367$

what is dangerous or injurious to be determined, how, § 5... 369 


\section{INDEX TO UNIFORM MARRIAGE AND MARRIAGE LICENSES ACT}

Act-

applies to children born out of wedlock, when, $827 \ldots \ldots \ldots 400$

construction and interpretation of, $\$ 29 \ldots \ldots \ldots \ldots \ldots \ldots \ldots 400$

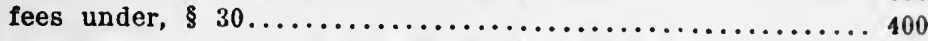

marriages contracted in violation of, effect, $\$ 23 \ldots \ldots \ldots \ldots 399$

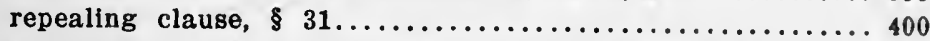

solemnization of marriage in violation of, penalty, $\$ 16 \ldots .397$

time of taking effect, $\$ 32 \ldots \ldots \ldots \ldots \ldots \ldots \ldots \ldots \ldots \ldots \ldots$

Affidavit-

false, as to competency of parties, penalty, $\$ 7 \ldots \ldots \ldots \ldots \ldots 392$

forms of, to be supplied by state, $\S 9 \ldots \ldots \ldots \ldots \ldots \ldots . \ldots . \ldots 39$

Application for license-

irregularities in, shall not invalidate marriage, $825 \ldots \ldots \ldots .399$

when to be made, $\S 3 . \ldots \ldots \ldots \ldots \ldots \ldots \ldots \ldots \ldots \ldots \ldots \ldots . \ldots . \ldots . \ldots . \ldots$

Certificate, see Marriage Certificate.

Children-

made legitimate by marriage of parents, effect, $\$ 27 \ldots \ldots \ldots 400$

of subsequent marriage, legitimate, when, $\$ 26 \ldots \ldots \ldots \ldots 39$

of void marriage, made legitimate, $\$ 23 \ldots \ldots \ldots \ldots \ldots \ldots \ldots . \ldots . \ldots 39$

Construction and interpretation of act, $\$ 29 \ldots \ldots \ldots \ldots \ldots \ldots 400$

Costs-

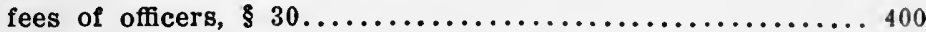

parties raising objection to marriage, liable for, $\$ 6 \ldots \ldots \ldots 391$

Courts, shall receive certified copy of license as evidence, $\$ 22 \ldots 398$

Customs, marriage may be celebrated in accordance with, $\$ 1 \ldots . .390$

Duty, clerk's failure to perform, penalty, $\$ .20 \ldots \ldots \ldots \ldots \ldots 398$

Evidence, certified copy of license to be prima facie, of marriage,

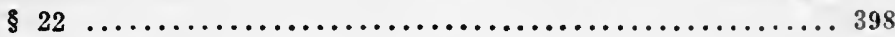

Fine, see Penalty.

Forfelture, see Penalty.

Forms-

license, $\$ 11 \ldots \ldots \ldots \ldots \ldots \ldots \ldots \ldots \ldots \ldots \ldots \ldots \ldots \ldots \ldots \ldots . \ldots \ldots$

license where parties to solemnize marriage without oflici-

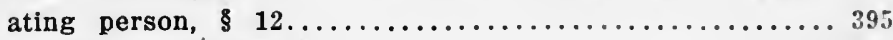

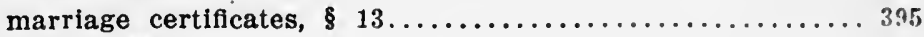

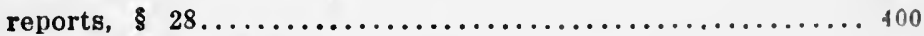

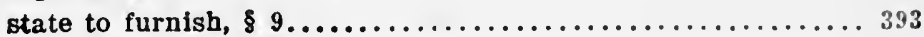




\section{Guardian-}

marriage shall not be void for lack of consent of, $\$ 25 \ldots . .399$

must have consent of, where, $\S 5 \ldots \ldots \ldots \ldots \ldots \ldots \ldots \ldots \ldots \ldots . \ldots 391$ Jndge-

authorized to order issuance of license, when, $\S 3 \ldots \ldots \ldots . \ldots 390$

may make order permitting marriage of minors, when, $\S 5$.. 391

Justice of the Peace-

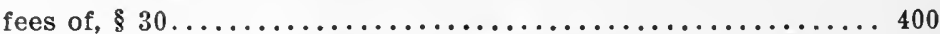

may take statement of parties contemplating marriage, $\S 4 \ldots 390$

Legitimate, see Children.

\section{License-}

application for, when to be made, unless, $\S 3 \ldots \ldots \ldots \ldots \ldots . \ldots 390$

authorizes ceremony to be performed, where, $\$ 10 \ldots \ldots \ldots 393$

certified copy of marriage certificate, prima facie evidence

of marriage, $\$ 22 \ldots \ldots \ldots \ldots \ldots \ldots \ldots \ldots \ldots \ldots \ldots \ldots . \ldots \ldots$

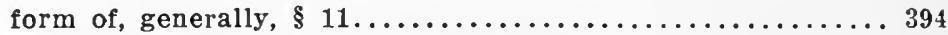

form, where parties to solemnize marriage without officiating

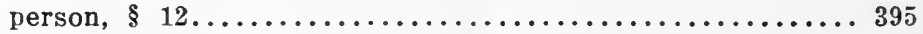

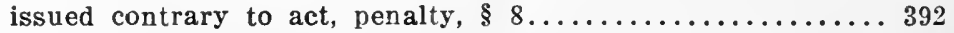

marriage shall not be void for error in, $\S 25 \ldots \ldots \ldots \ldots \ldots \ldots 399$

must be obtained, where, $\S 2 \ldots \ldots \ldots \ldots \ldots \ldots \ldots \ldots \ldots \ldots . \ldots . \ldots 390$

must have three marriage certificate ferms attached to it, $\S 13.395$

necessary before valid marriage celebrated, $\S 1 \ldots \ldots \ldots \ldots . . .390$

operative for one year only, $\S 10 \ldots \ldots \ldots \ldots \ldots \ldots \ldots \ldots \ldots 39 . \ldots \ldots$

parties must be identified before issuance of, $\S 4 \ldots \ldots \ldots \ldots 390$

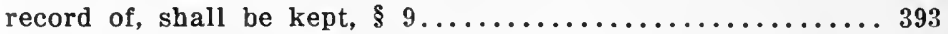

reports of, must be made, $\$ 28 \ldots \ldots \ldots \ldots \ldots \ldots \ldots \ldots \ldots 400$

shall not be issued if parties under age, unless, $\S 5 \ldots \ldots \ldots \ldots 391$

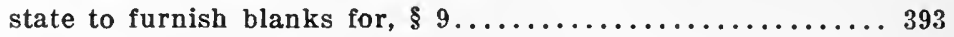

who may object to issuance of, how, $\$ 6 \ldots \ldots \ldots \ldots \ldots . \ldots . \ldots 39$

Marriage-

contracted in violation of Sec. 1 , null and void, $\S 23 \ldots \ldots \ldots 393$

license must be procured before, $\S 2 \ldots \ldots \ldots \ldots \ldots \ldots \ldots \ldots . \ldots 390$

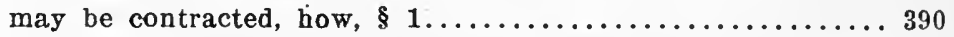

penalty for attempting to solemnize, without authority, void,

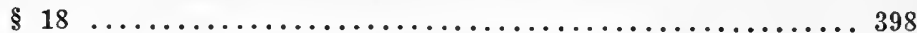

shall not be void by reason of certain things, $\S 25 \ldots \ldots \ldots . .399$

shall not be void for want of authority in officiating person,

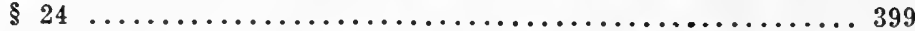

solemnization of, contrary to provisions of act, penalty,

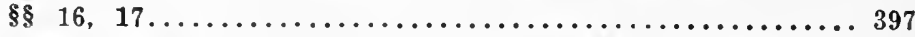

subsequent, one party married, valid when, $\S 26 \ldots \ldots \ldots \ldots . \ldots 39$

Marriage certificate-

certified copy of, prima facie evidence, $\$ 22 \ldots \ldots \ldots \ldots \ldots \ldots 398$

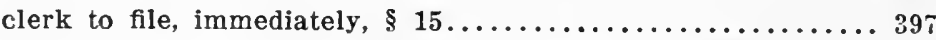

forms, to be in triplicate, $\$ 13 \ldots \ldots \ldots \ldots \ldots \ldots \ldots \ldots \ldots \ldots . \ldots . \ldots . \ldots$ 
Marriage certificate-Continued.

must be given to parties and filed, $\$ 14 \ldots \ldots \ldots \ldots \ldots \ldots 397$

penalty for fallure to return to clerk, $819 \ldots \ldots \ldots \ldots \ldots . \ldots 39$

report of, must be made, $\$ 28 \ldots \ldots \ldots \ldots \ldots \ldots \ldots \ldots \ldots \ldots 400$

Marriage license clerks-

failure to perform dutles, penalty, $\$ 20 \ldots \ldots \ldots \ldots \ldots \ldots \ldots 39$

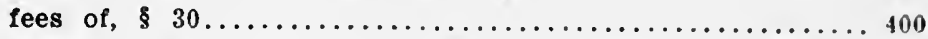

lack of authority in, to issue license shall not invalidate, 25.393

must file certificate immediately, $15 \ldots \ldots \ldots \ldots \ldots \ldots \ldots . \ldots 397$

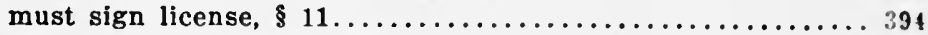

penalty for failure to make proper report, $\$ 28 \ldots \ldots \ldots \ldots .400$

penalty for wrongful issuance of license, $\$ 8 \ldots \ldots \ldots \ldots \ldots 39$

triplicate certificate to be returned to, when, $\$ 14 \ldots \ldots \ldots .397$

Marriage license docket-

certificate to be filed in, $\$ 15 \ldots \ldots \ldots \ldots \ldots \ldots \ldots \ldots \ldots \ldots \ldots$

penalty for failure to keep, $\$ 20 \ldots \ldots \ldots \ldots \ldots \ldots \ldots \ldots . \ldots 39$

record of applications to be kept in, open to inspection, \& 9.393

Non-residents-

license to be obtained, where, $\S 2 \ldots \ldots \ldots \ldots \ldots \ldots \ldots \ldots . \ldots 390$

must be married where license issued, $\$ 10 \ldots \ldots \ldots \ldots \ldots . \ldots 93$

Notice, must be posted, of application for license, $\$ 6 \ldots \ldots \ldots . \ldots 391$

Officiating person-

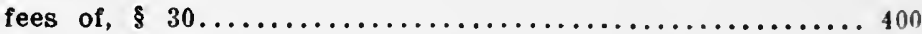

license where marriage solemnized without, $\$ 12 \ldots \ldots \ldots \ldots 395$

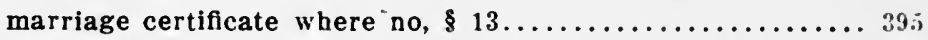

penalty for failure to return triplicate certificate, $\$ 19 \ldots \ldots 39$

solemnizing marriage in violation of act, penalty, $\$ 16 \ldots \ldots 397$

want of authority of, shall not render marriage void, $\$ 24 \ldots 399$

Parents-

consent of, to be obtalned, where, $\$ 5 \ldots \ldots \ldots \ldots \ldots \ldots \ldots . \ldots . \ldots 39$

marriage of, shall make children legitimate, effect, $\$ 27 \ldots \ldots 400$

Parties-

marriage shall not be invalid for lack of consent of, $82 \ldots 393$

acting in good faith, subsequent marriage, valid when, $\$ 26 \ldots 393$

form of license where, to solemnize marriage without offici-

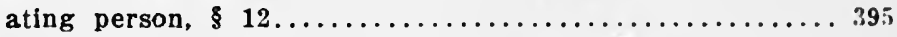

marriage certificate where license issued to, $\$ 13 \ldots \ldots \ldots \ldots 35$

marriage to be solemnized without officiating person, $\$ 1 \ldots 390$

must make statement under oath as to qualifications, $\$ 4$. $39 n$

no license to be issued, if, under age, unless, $5 \ldots \ldots \ldots \ldots 391$

penalty for solemnization of marriage by, contrary to act.

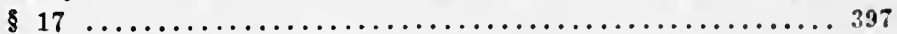

penalty on, for failure to return triplicate certificate, $\$ 19 \ldots 398$

Penalty-

for clerk failing to perform duties, $\$ 20 \ldots \ldots \ldots \ldots \ldots \ldots . \ldots 39$

for fallure to make proper report, $\$ 28 \ldots \ldots \ldots \ldots \ldots \ldots \ldots$ 
Penalty-Continued.

PACE

for failure to return triplicate certificates, when, $\S 19 \ldots \ldots 398$

for making false statement as to competency, $\S 7 \ldots \ldots \ldots \ldots 392$

may be recovered in an action of debt, $\$ 21 \ldots \ldots \ldots \ldots \ldots . \ldots 39$

in case of officiating person solemnizing marriage contrary

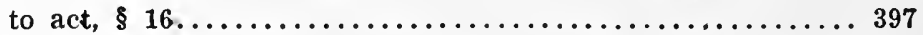

in case of person attempting to solemnize marriage without

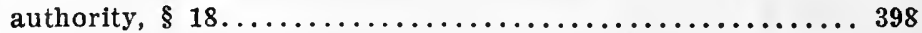

for violation of act as to issuance of license, $\S 8 \ldots \ldots \ldots \ldots 392$

Person attempting to solemnize marriage without authority,

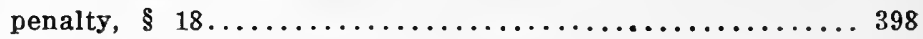

Petition, objection to marriage to be filed by, $\S 6 \ldots \ldots \ldots \ldots \ldots 391$

Repealing clanse of act, $\S 31 \ldots \ldots \ldots \ldots \ldots \ldots \ldots \ldots \ldots \ldots \ldots \ldots$

State-

blanks to be furnished by, $\S 9 \ldots \ldots \ldots \ldots \ldots \ldots \ldots \ldots \ldots \ldots$

person attempting to solemnize marriage without authority

of, penalty, $\$ 18 \ldots \ldots \ldots \ldots \ldots \ldots \ldots \ldots \ldots \ldots \ldots . \ldots \ldots$

Statement-

made falsely as to competency, $\S 7 \ldots \ldots \ldots \ldots \ldots \ldots \ldots \ldots . \ldots 392$

must be made under oath before license issued, $\S 4 \ldots \ldots \ldots .390$

to be made by parents or guardian, when, $\S 5 \ldots \ldots \ldots \ldots \ldots 391$

Subsequent marriage, one acting in good faith, valid when, $\S 26 . .399$

Time act shall take effect, $\$ 32 \ldots \ldots \ldots \ldots \ldots \ldots \ldots \ldots \ldots \ldots \ldots 40 . \ldots$

Void marriage may be validated and children made legitimate, § 23399 Witnesses-

incompetency of, shall not invalidate marriage, when, $\S 25 \ldots 399$

two competent, necessary to ceremony, $\S 1 \ldots \ldots \ldots \ldots \ldots . \ldots 390$ 


\section{INDEX TO ONIFORM MARRIAGE EVASION ACT}

\section{License-}

before issuance of, to non-resident, proof of absence of in-

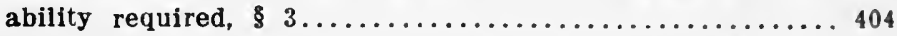

issued with knowledge of violations of laws, penalty, $\$ 4 \ldots . .404$ Marriage-

contracted in another state to avoid laws of own state, effect,

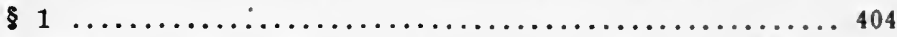

contracted or celebrated in this state in violation of laws of

other, effect, $\$ 2 \ldots \ldots \ldots \ldots \ldots \ldots \ldots \ldots \ldots \ldots \ldots \ldots \ldots 4$

Non-residents to furnish affidavit of right to marry in home state,

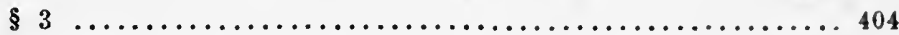

Official一

shall require affidavits of non-residents as to qualifications,

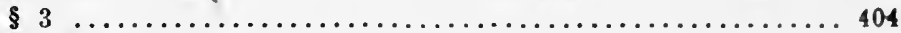

who knowingly issues license to parties not entitled to it,

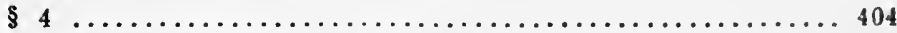

Penalty for knowingly violating act, $\$ 4 \ldots \ldots \ldots \ldots \ldots \ldots \ldots \ldots 404$

Person-

marrying in one state in violation of laws of state of domicile,

effect, $\$ 1 \ldots \ldots \ldots \ldots \ldots \ldots \ldots \ldots \ldots \ldots \ldots \ldots \ldots \ldots 4$

resident of another state, must furnish proof, $\$ 3 \ldots \ldots \ldots \ldots 404$ State-

marriage contracted here void if in violation of laws of state

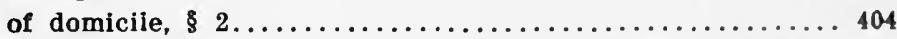

marriage contracted in one, in violation of laws of state of domicile, effect, $\$ 1 . \ldots \ldots \ldots \ldots \ldots \ldots \ldots \ldots \ldots \ldots \ldots \ldots 40 . \ldots \ldots$ 


\section{INDEX TO UNIFORM PARTNERSHIP ACT}

Account-

action for, on date of dissolution, against whom, $\S 43 \ldots \ldots .434$

assignee may require on dissolution, not otherwise, $\S 27 \ldots 424$

partners right to, when, $\S 22 \ldots \ldots \ldots \ldots \ldots \ldots \ldots \ldots \ldots \ldots 422$

Accountability-

partner as fiduciary, $\$ 21(1) \ldots \ldots \ldots \ldots \ldots \ldots \ldots \ldots \ldots \ldots \ldots 422$

personal representatives, when, $\$ 21$ (2)............. 422 Act-

becomes effective, $\S 44 \ldots \ldots \ldots \ldots \ldots \ldots \ldots \ldots \ldots \ldots \ldots \ldots 434$

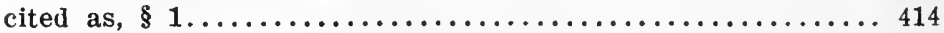

inconsistent legislation repealed, $\S 45 \ldots \ldots \ldots \ldots \ldots \ldots \ldots 434$

rules of cases not provided for in this, $\S 5 \ldots \ldots \ldots \ldots \ldots \ldots 415$

shall not affect existing contracts or suits, $\S 4$ (5) . . . . . . 414

Actions against winding up or surviving partners on dissolution,

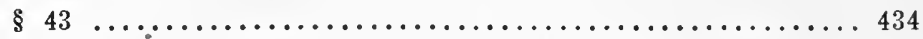

Admission of partners binds partnership, $\S 11 \ldots \ldots \ldots \ldots \ldots \ldots 418$

Agency-

law of, applies, $\S 4 \ldots \ldots \ldots \ldots \ldots \ldots \ldots \ldots \ldots \ldots \ldots \ldots \ldots \ldots \ldots \ldots$

partner is agent as to partnership business limitations, $\S 9 . .416$

Application of partnership property, rights of partners to, $\S 38 \ldots 429$ Assignee-

rights of, partner's interest, $\S 27 \ldots \ldots \ldots \ldots \ldots \ldots \ldots \ldots . \ldots \ldots 4$

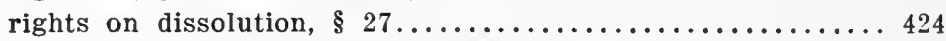

Assignment of partnership interest, $\S 27 \ldots \ldots \ldots \ldots \ldots \ldots \ldots \ldots 424$

Authority, effect of dissolution on partner's, $\$ 33 \ldots \ldots \ldots \ldots \ldots \ldots 426$

Bankrupt, defined, $\$ 2 \ldots \ldots \ldots \ldots \ldots \ldots \ldots \ldots \ldots \ldots \ldots \ldots \ldots \ldots$

Books of partnership, to be kept at place of business, $\$ 19 \ldots \ldots 421$

Breach of trust by partners bind partnership, $\$ 14 \ldots \ldots \ldots \ldots \ldots .419$

Business-

defined, $\S 2 \ldots \ldots \ldots \ldots \ldots \ldots \ldots \ldots \ldots \ldots \ldots \ldots \ldots \ldots \ldots . \ldots . \ldots . \ldots . \ldots \ldots$

liability of persons continuing, $\$ 41 \ldots \ldots \ldots \ldots \ldots \ldots \ldots \ldots \ldots 42$

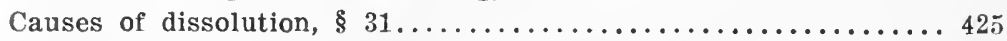

Charging orders, partner's interest subject to, $\S 28 \ldots \ldots \ldots \ldots \ldots 424$

Construction-

Impairing obligations forbidden, $\S 4 \ldots \ldots \ldots \ldots \ldots \ldots \ldots \ldots 414$

to affect general purpose, $\S 4 \ldots \ldots \ldots \ldots \ldots \ldots \ldots \ldots \ldots 414$

Continuation of partnership beyond fixed terms, $\$ 23 \ldots \ldots \ldots .422$

Continuing the business in certain cases, liabilities of persons,

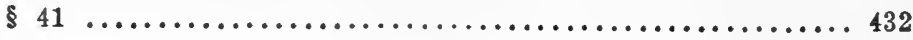


Contribution from copartner after dissolution, right to, \& 34.... 427

Conveyance-

defined, $\S 2 \ldots \ldots \ldots \ldots \ldots \ldots \ldots \ldots \ldots \ldots \ldots \ldots \ldots \ldots \ldots \ldots \ldots$

Court-

real property of the partnership, $\$ 10 \ldots \ldots \ldots \ldots \ldots \ldots \ldots \ldots 417$

charging partner's interest, $\$ 28 \ldots \ldots \ldots \ldots \ldots \ldots \ldots \ldots \ldots . \ldots 424$

decree of dissolution, when, $\$ 32 \ldots \ldots \ldots \ldots \ldots \ldots \ldots \ldots \ldots 26$

defined, $\S 2 \ldots \ldots \ldots \ldots \ldots \ldots \ldots \ldots \ldots \ldots \ldots \ldots \ldots \ldots \ldots \ldots \ldots$

Creditor-

dissolution does not discharge liability to, except, $\$ 36 \ldots \ldots 428$

general, priority to retiring or deceased partner, $\$ 42 \ldots \ldots .434$

may charge interest and get receiver, $\$ 28 \ldots \ldots \ldots \ldots \ldots .424$

one partner cannot assign for benefit of, $\$ 9$ (3) ......... 416

Deceased partner-

property liable, when, $\S 36$ (4) .................. 428

rights of estate, when business continued, $\$ 41 \ldots \ldots \ldots \ldots \ldots 432$

Decree, see Court.

Definitions-

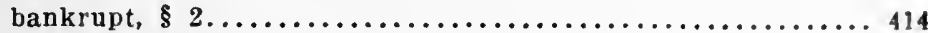

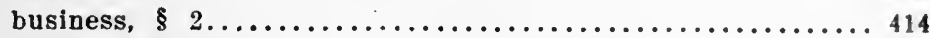

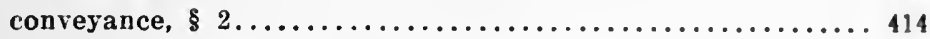

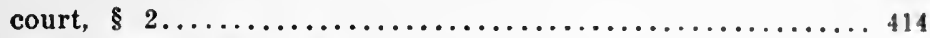

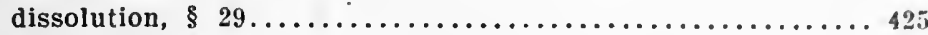

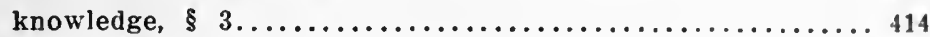

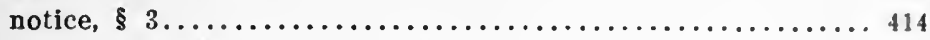

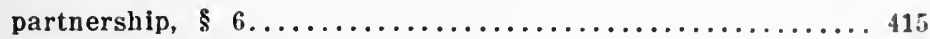

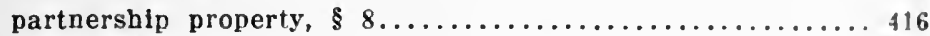

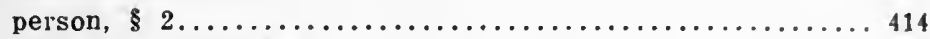

real property, $\$ 2 \ldots \ldots \ldots \ldots \ldots \ldots \ldots \ldots \ldots \ldots \ldots \ldots \ldots \ldots \ldots \ldots$

Derogation of common law rule, not applicable, $\$ 4 \ldots \ldots \ldots \ldots . .414$

Dissolution-

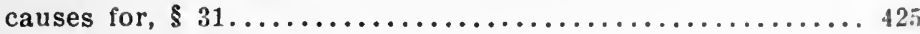

decree of court, $\$ 32 \ldots \ldots \ldots \ldots \ldots \ldots \ldots \ldots \ldots \ldots \ldots \ldots \ldots$

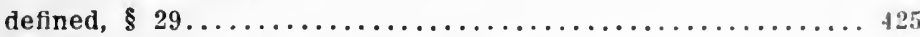

does not terminate partnership, $\$ 30 \ldots \ldots \ldots \ldots \ldots \ldots \ldots \ldots 4 . \ldots \ldots$

effect on partner's existing liability, $\$ 36 \ldots \ldots \ldots \ldots \ldots \ldots . \ldots 42$

for fraud or misrepresentations, rights, $\$ 39 \ldots \ldots \ldots \ldots \ldots \ldots 430$

general effect of, on authority of partner, $\$ 33 \ldots \ldots \ldots \ldots \ldots 466$

partner's power to bind partnership to third parties, $\$ 35 \ldots .427$

right of partners to application of property, $\$ 3 \$ \ldots \ldots \ldots .429$

right of partners to contribution after, $\$ 34 \ldots \ldots \ldots \ldots \ldots \ldots 427$

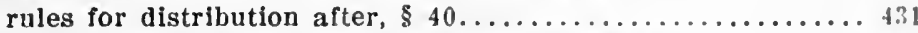

Duties and rights of partners, rules determining, $\$ 1 \$ \ldots \ldots \ldots \ldots 420$

Duty of partners to render information, $\$ 20 \ldots \ldots \ldots \ldots \ldots \ldots . \ldots 22$ 
Estoppel, law of-

PAGE

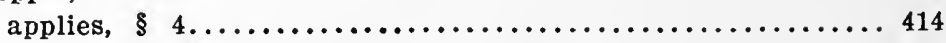

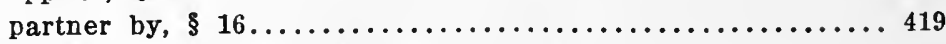

Extent of property rights of a partner, $\S 24 \ldots \ldots \ldots \ldots \ldots \ldots \ldots 423$

Fiduciary-

partners accountable as, $\S 21$ (1)................4 422

rule applies to personal representatives, when, $\S 21$ (2) ....4422

Fraud, dissolution for, rights, $\S 39 \ldots \ldots \ldots \ldots \ldots \ldots \ldots \ldots \ldots 430$

General effect of dissolution on authority of partner, $\S 33 \ldots \ldots .426$

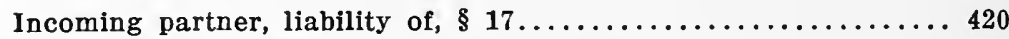

Information, duty of partner to render, $\S 20 \ldots \ldots \ldots \ldots \ldots \ldots . \ldots 22$

Interpretation-

knowledge and notice, $\S 3 \ldots \ldots \ldots \ldots \ldots \ldots \ldots \ldots \ldots \ldots \ldots 414$

to affect generai purpose of uniformity, $\S 4 \ldots \ldots \ldots \ldots \ldots \ldots 414$

Joint and several liability, when, $\S 15 \ldots \ldots \ldots \ldots \ldots \ldots \ldots \ldots . \ldots 19$

Knowledge-

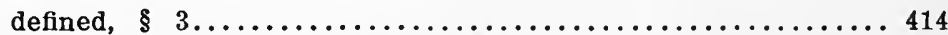

of partner charges partnership, $\S 12 \ldots \ldots \ldots \ldots \ldots \ldots \ldots \ldots 418$

Law merchant governs, when, $\S 5 \ldots \ldots \ldots \ldots \ldots \ldots \ldots \ldots \ldots \ldots . \ldots \ldots$

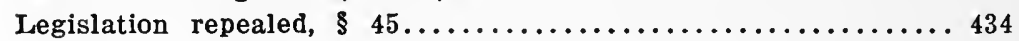

Liability-

effect of dissolution on partner's, $\S 36 \ldots \ldots \ldots \ldots \ldots \ldots \ldots . \ldots 428$

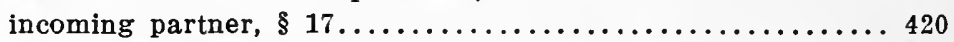

nature of partner's, joint and several, $\S 15 \ldots \ldots \ldots \ldots \ldots \ldots . \ldots 419$

partner by estoppel, $\$ 16 \ldots \ldots \ldots \ldots \ldots \ldots \ldots \ldots \ldots \ldots \ldots$

persons continuing the business in certain cases, $\S 40 \ldots \ldots 431$

Misrepresentation, dissolution for, rights, $\S 39 \ldots \ldots \ldots \ldots \ldots \ldots 40$

Nature-

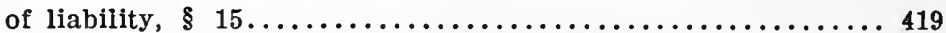

of partner's interest in the partnership, $\S 26 \ldots \ldots \ldots \ldots \ldots \ldots 424$

of rights in specific partnership property, $\S 25 \ldots \ldots \ldots \ldots \ldots 423$

Notice-

defined, $\S 3 \ldots \ldots \ldots \ldots \ldots \ldots \ldots \ldots \ldots \ldots \ldots \ldots \ldots \ldots \ldots \ldots . \ldots \ldots \ldots$

to partner charges partnership, $\S 12 \ldots \ldots \ldots \ldots \ldots \ldots \ldots \ldots 418$

Partner-

accountable as a fiduciary, $\S 21$ (1) ................4422

action against winding up or surviving partner, $\S 43 \ldots \ldots \ldots 434$

admissions of, binds partnership, $\S 11 \ldots \ldots \ldots \ldots \ldots \ldots \ldots 418$

agent of partnership as to partnership business, $\S 9 \ldots \ldots \ldots 416$

application for dissolution, when allowed, $\S 32 \ldots \ldots \ldots \ldots \ldots 426$

assignment of interest, effect, $\S 27 \ldots \ldots \ldots \ldots \ldots \ldots \ldots \ldots \ldots 424$

authority, effect of dissolution upon, $\S 33 \ldots \ldots \ldots \ldots \ldots \ldots \ldots 426$

breach of trust binds partnership, $\S 14 \ldots \ldots \ldots \ldots \ldots \ldots \ldots \ldots 419$

by estoppel, liability, $\S 16 \ldots \ldots \ldots \ldots \ldots \ldots \ldots \ldots \ldots \ldots \ldots \ldots$

deceased, rights of estate, business continued, $\S 41 \ldots \ldots \ldots 432$

dissolution, effect on liability of, $\S 36 \ldots \ldots \ldots \ldots \ldots \ldots \ldots 428$ 
Partiner-Continued.

duty to render information, $\$ 20 \ldots \ldots \ldots \ldots \ldots \ldots \ldots \ldots \ldots \ldots 22$

extent of property rights, \& $24 \ldots \ldots \ldots \ldots \ldots \ldots \ldots \ldots \ldots \ldots \ldots . \ldots 23$

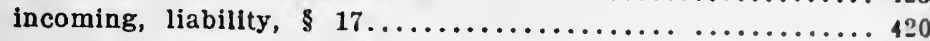

interest, assignment of, $\S 27 \ldots \ldots \ldots \ldots \ldots \ldots \ldots \ldots \ldots \ldots 424$

Interest in the partnership, nature of, $\$ 26 \ldots \ldots \ldots \ldots \ldots 42$ ?

interest subject to charging orders, $\$ 28 \ldots \ldots \ldots \ldots \ldots \ldots 424$

knowledge or notice of, charges partnership, $\$ 12 \ldots \ldots \ldots \ldots 418$

liability, nature of, jointly and severally, $\& 15 \ldots \ldots \ldots \ldots \ldots 419$

liabllity, power to bind partnership to third persons after dis-

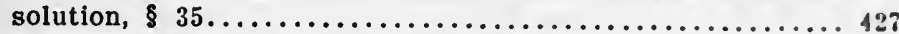

limitation of, agency as to business, $\$ 9 \ldots \ldots \ldots \ldots \ldots \ldots \ldots 416$

may have access to and inspect books, $\$ 19 \ldots \ldots \ldots \ldots \ldots 421$

personal representatives accountable as fiduciary, when, $\$ 21.422$

retiring or deceased, rlghts when business discontinued, 842.434

right in specific property, nature of, $\$ 25 \ldots \ldots \ldots \ldots \ldots \ldots 423$

right in winding up, $\S 37 \ldots \ldots \ldots \ldots \ldots \ldots \ldots \ldots \ldots \ldots \ldots 429$

right to an account, $\S 22 \ldots \ldots \ldots \ldots \ldots \ldots \ldots \ldots \ldots \ldots \ldots \ldots 422$

right to application of partnership property, $\& 38 \ldots \ldots \ldots \ldots 429$

right to contribution after dissolution, $\$ 34 \ldots \ldots \ldots \ldots \ldots 427$

rules determining rights and duties of, $\$ 18 \ldots \ldots \ldots \ldots \ldots 420$

rules for distribution after dissolution, $\$ 40 \ldots \ldots \ldots \ldots \ldots . \ldots 31$

wrongful act binds partnership, $813 \ldots \ldots \ldots \ldots \ldots \ldots \ldots \ldots 419$

Partnership-

books, to be kept at place of business, $\$ 19 \ldots \ldots \ldots \ldots \ldots 421$

bound by acts of partner as to business, limitation, $\$ 9 \ldots \ldots 416$

bound by admission of partner, $\$ 11 \ldots \ldots \ldots \ldots \ldots \ldots \ldots$. . . .

bound by partner's breach of trust, $\$ 14 \ldots \ldots \ldots \ldots \ldots \ldots \ldots 419$

bound by partner's wrongful act, $\$ 13 \ldots \ldots \ldots \ldots \ldots \ldots \ldots 419$

causes for dissolution of, $\$ 31 \ldots \ldots \ldots \ldots \ldots \ldots \ldots \ldots \ldots \ldots+\ldots \ldots \ldots$

charged with knowledge of or notice of partner, $\$ 12 \ldots \ldots 418$

continuation beyond fixed term, $\S 23 \ldots \ldots \ldots \ldots \ldots \ldots \ldots \ldots 42$

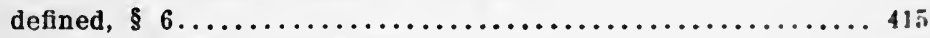

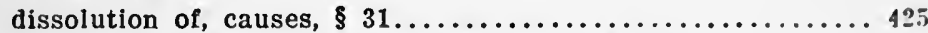

dissolved for fraud or misrepresentation, $\$ 39 \ldots \ldots \ldots \ldots \ldots 430$

liability on continuing business, when, $\$ 41 \ldots \ldots \ldots \ldots \ldots 432$

nature of partner's interest in, $\$ 26 \ldots \ldots \ldots \ldots \ldots \ldots \ldots \ldots 424$

nature of rights of partner in, property, $\$ 25 \ldots \ldots \ldots \ldots \ldots 423$

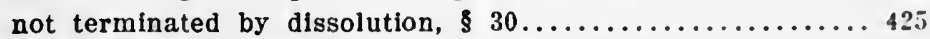

partners must render information as to, $\$ 20 \ldots \ldots \ldots \ldots \ldots+22$

power of partner to bind, after dissolution, $\$ 35 \ldots \ldots \ldots \ldots 427$

property of, 8 \&........................ 416

property, partners rights to application of, $\$ 3 s \ldots \ldots \ldots \ldots 429$

property, rules for distribution after dissolution, $\$ 40 \ldots \ldots 431$

real property of, how conveyed, $810 \ldots \ldots \ldots \ldots \ldots \ldots \ldots 117$ 
Partnership-Continued. PAGE

rules for determining the existence of, $\$ 7 \ldots \ldots \ldots \ldots \ldots \ldots \ldots 415$

ivinding up, who is entitled in, $\S 37 \ldots \ldots \ldots \ldots \ldots \ldots \ldots \ldots . \ldots 429$

Person-

defined, $\S 2 \ldots \ldots \ldots \ldots \ldots \ldots \ldots \ldots \ldots \ldots \ldots \ldots \ldots \ldots \ldots \ldots . \ldots 414$

continuing the business, liability, $\S 41 \ldots \ldots \ldots \ldots \ldots \ldots \ldots 432$

Personal representatives, accountable as fiduciaries, $\S 21$ (2).... 422

Power of partner to bind partnership to third persons after disso-

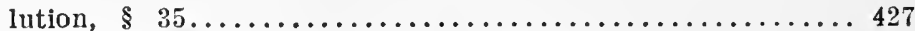

Property-

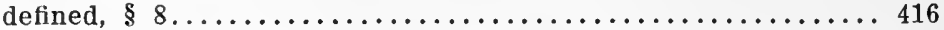

distribution, $\S 38 \ldots \ldots \ldots \ldots \ldots \ldots \ldots \ldots \ldots \ldots \ldots \ldots \ldots \ldots . \ldots \ldots$

partner's rights in specific, $\$ 25 \ldots \ldots \ldots \ldots \ldots \ldots \ldots \ldots \ldots \ldots 423$

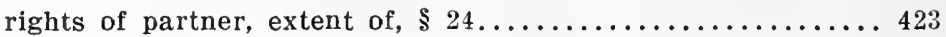

Real property-

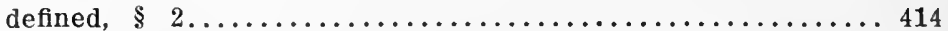

the partnership, conveyed, how, $\$ 10 \ldots \ldots \ldots \ldots \ldots \ldots \ldots 417$

Receiver, may be appointed at instance of judgment creditor, \& 28. 424 Right of partner-

contribution from co-partner atter dissolution, $\S 34 \ldots \ldots \ldots 427$

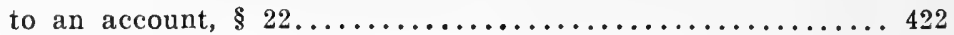

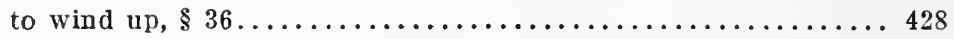

Rights and duties of partners-

as to application of partnership property, $\S 37 \ldots \ldots \ldots \ldots 429$

in specific partnership property, $\S 25 \ldots \ldots \ldots \ldots \ldots \ldots \ldots \ldots 423$

retiring or estate of deceased when business continued, $\S 41 . .432$

rules determining, $\$ 18 \ldots \ldots \ldots \ldots \ldots \ldots \ldots \ldots \ldots \ldots \ldots 420$

where fraud or misrepresentations, $\$ 39 \ldots \ldots \ldots \ldots \ldots \ldots . \ldots 430$

Rules-

cases not provided for in this act, $\S 5 \ldots \ldots \ldots \ldots \ldots \ldots \ldots \ldots 415$

determining rights and duties, $\S 38 \ldots \ldots \ldots \ldots \ldots \ldots \ldots \ldots 429$

existence of partnership determined by, $\$ 7 \ldots \ldots \ldots \ldots \ldots . \ldots 415$

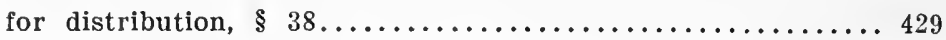

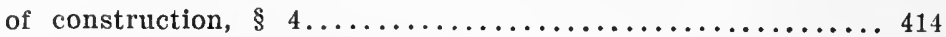

rights and duties of partners, $\$ 18 \ldots \ldots \ldots \ldots \ldots \ldots \ldots \ldots . \ldots 420$

Several liability, when, $\S 15 \ldots \ldots \ldots \ldots \ldots \ldots \ldots \ldots \ldots \ldots \ldots \ldots 19$

Specific partnership property, nature of partner's right in, $\S 25 \ldots 423$

Surviving partners, rights to an accounting against, $\S 42 \ldots \ldots \ldots 434$

Terms-

continuation of partnership beyond, $\$ 23 \ldots \ldots \ldots \ldots \ldots \ldots \ldots 422$

defined, $\S 2 \ldots \ldots \ldots \ldots \ldots \ldots \ldots \ldots \ldots \ldots \ldots \ldots \ldots \ldots . \ldots \ldots 14$

Trust, partnership bound by partner's breach of, $\S 14 \ldots \ldots \ldots \ldots 419$

Winding up partners-

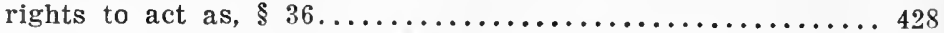

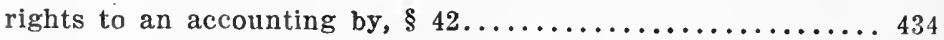

Wrongful act of partner binds partnership, $\S 13 \ldots \ldots \ldots \ldots \ldots \ldots 419$ 


\section{INDEX TO UNIFORM COLD STORAGE ACT}

Act-

construction of $\S 13 \ldots \ldots \ldots \ldots \ldots \ldots \ldots \ldots \ldots \ldots \ldots \ldots$. 4 .

how to be cited, $\S 14 \ldots \ldots \ldots \ldots \ldots \ldots \ldots \ldots \ldots \ldots \ldots \ldots \ldots$. $\ldots \ldots \ldots$

inconsistent legislation repealed by, $\S 15 \ldots \ldots \ldots \ldots \ldots \ldots \ldots 42$

Articles of food-

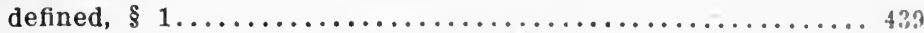

not subject to storage, exceptions, $\$ 6 \ldots \ldots \ldots \ldots \ldots \ldots . \ldots 40$

not to be stored if tainted, $\$ 6 \ldots \ldots \ldots \ldots \ldots \ldots \ldots \ldots \ldots \ldots \ldots$

Assistants may be appointed by commissioner, $\S 5 \ldots \ldots \ldots \ldots \ldots 440$

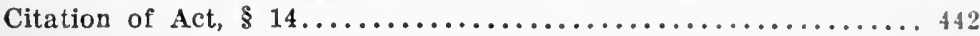

Cold storage-

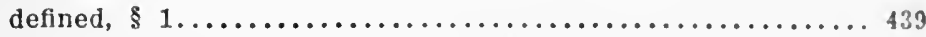

tainted food not to be received in, $\S 6 \ldots \ldots \ldots \ldots \ldots \ldots 40$

Cold storage warehouse-

defined, $\S 1 \ldots \ldots \ldots \ldots \ldots \ldots \ldots \ldots \ldots \ldots \ldots \ldots \ldots \ldots \ldots \ldots$

food in, on date act takes effect must be stamped with and

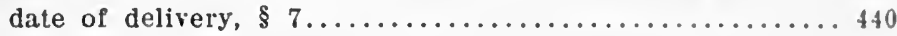

food received in or delivered from must have dates stamped

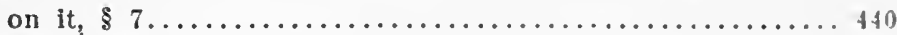

license may be revoked when unsanitary, $\$ 3 \ldots \ldots \ldots \ldots . . .439$

must have a license to act, $\$ 2 \ldots \ldots \ldots \ldots \ldots \ldots \ldots \ldots . \ldots 43$

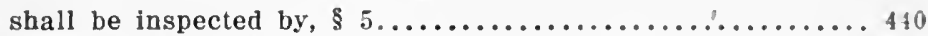

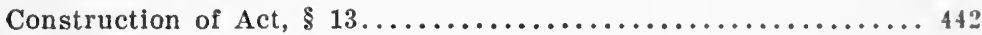

Dates-

old dates to be left on, when food transferred to another

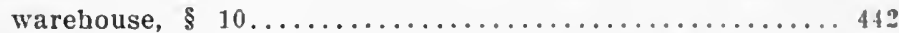

receipt and delivery dates to be marked on food, $\$ 7 \ldots \ldots \ldots 440$

Definitions-

article of food, $\S 1 \ldots \ldots \ldots \ldots \ldots \ldots \ldots \ldots \ldots \ldots \ldots \ldots \ldots \ldots$

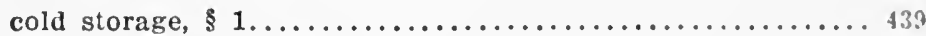

cold storage warehouse, $\S 1 \ldots \ldots \ldots \ldots \ldots \ldots \ldots \ldots \ldots \ldots+\ldots \ldots$

Deposits to have date of receipt and delivery plainly marked

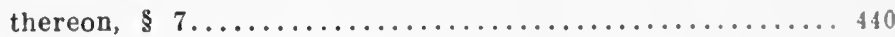

Food-

held in storage more than 30 days must be marked. $\$ 9 \ldots \ldots 441$

in storage must have date act took effect stamped thereon, \& 7 . 440

not to be received when tainted, $\$ 6 \ldots \ldots \ldots \ldots \ldots \ldots \ldots \ldots+\ldots \ldots$

removed, not to be returned to storage, $\$ 10 \ldots \ldots \ldots \ldots \ldots .42$

[655] 
Food-Continued PAGE

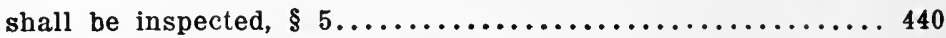

time of receipt in and delivery from warehouse must be

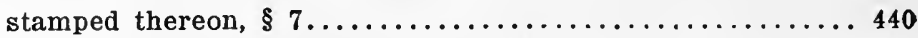

Inconsistent legislation repealed by Act, $\S 15 \ldots \ldots \ldots \ldots \ldots \ldots 442$

Inspection of food and warehouses, $\S 5 \ldots \ldots \ldots \ldots \ldots \ldots \ldots, 440$

Interpretation of Act, $\S 13 \ldots \ldots \ldots \ldots \ldots \ldots \ldots \ldots \ldots \ldots, 442$

Licensee-

may have license revoked if warehouse unsanitary, $\S 3 \ldots \ldots 439$

must keep records and file reports, when, $\$ 4 \ldots \ldots \ldots \ldots \ldots 440$

shall not keep food more than twelve months, except, § $8 \ldots 441$

Licenses-

issued on applications after inspection and payment of fee,

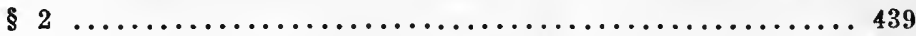

revocation of, by Commissioner, when, $\S 3 \ldots \ldots \ldots \ldots \ldots \ldots .439$

Limitation on storage cther than cold storage, $\$ 9 \ldots \ldots \ldots \ldots \ldots 441$

Marking dates of reception and removal of foods, $\S 7 \ldots \ldots \ldots \ldots . \ldots 440$

Penalty for violations, $\S 12 \ldots \ldots \ldots \ldots \ldots \ldots \ldots \ldots \ldots \ldots \ldots, 442$

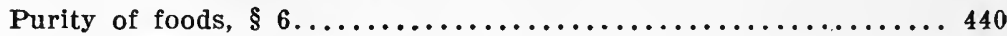

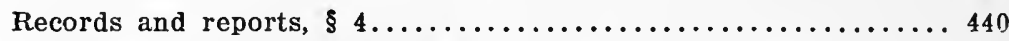

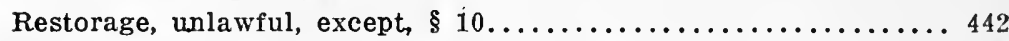

Return of food not allowed when once removed, $\S 10 \ldots \ldots \ldots \ldots 442$

Rules and regulations, $\S 11 \ldots \ldots \ldots \ldots \ldots \ldots \ldots \ldots \ldots \ldots . \ldots . \ldots 42$

Sale of articles in cold storage over 30 days, unlawful, $\S 9 \ldots \ldots .441$

State Food Commissioner-

articles not for human consumption must be marked by, §6.. 440

has no authority to extend time more than one hundred and

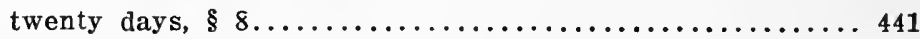

may appoint assistant to inspect, $\$ 5 \ldots \ldots \ldots \ldots \ldots \ldots \ldots . \ldots 440$

may consent to food being held more than twelve months, § 8.441

may inspect records of licensee, $\$ 4 \ldots \ldots \ldots \ldots \ldots \ldots \ldots . \ldots 440$

may issue license on application after inspection on payment

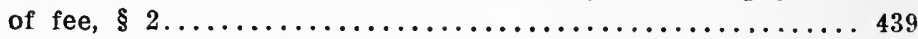

may revoke license of warehouseman for unsanitary condition,

$\$ 3$..................................... 439

rules and regulations to be made by, $\S 11 \ldots \ldots \ldots \ldots \ldots . \ldots 442$

Storage-

shall inspect and supervise warehouse and food, $\$ 5 \ldots \ldots \ldots 440$

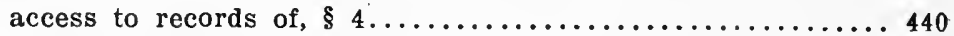

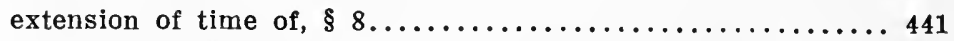

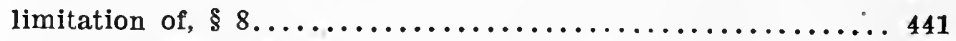

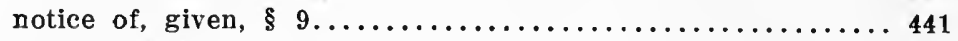

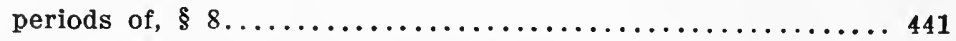

reports of, to be open to public, $\S 8 \ldots \ldots \ldots \ldots \ldots \ldots \ldots \ldots \ldots 41$

restorage unlawful, except, $\S 10 \ldots \ldots \ldots \ldots \ldots \ldots \ldots \ldots \ldots . \ldots \ldots 2$

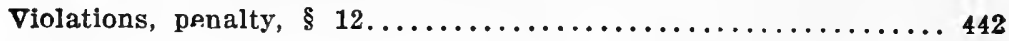




\section{INDEX TO UNIFORM WORKMEN'S COMPENSA- TION ACT}

PAGE:

Accidents, employer must report, penalty for fallure, $887 \ldots \ldots .47$ 7

Accounts, of State Insurance Manager, $\$ 71 \ldots \ldots \ldots \ldots \ldots \ldots \ldots .472$

Act-

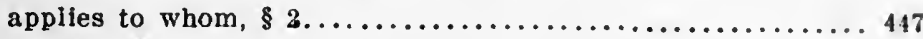

elective, $\S \S 1,2,3 \ldots \ldots \ldots \ldots \ldots \ldots \ldots \ldots \ldots \ldots \ldots \ldots \ldots \ldots 482,483$

employments covered by, $\$ 1 \ldots \ldots \ldots \ldots \ldots \ldots \ldots \ldots \ldots \ldots 47$

interstate commerce affected, when, $\$ 88 \ldots \ldots \ldots \ldots \ldots \ldots 48$

prior inconsistent statutes repealed, $\$ 95 \ldots \ldots \ldots \ldots \ldots \ldots \ldots 481$

shall not apply to injurles sustained prior to act, $\$ 93 \ldots \ldots .480$

time of taking effect, $\$ 97 \ldots \ldots \ldots \ldots \ldots \ldots \ldots \ldots \ldots \ldots \ldots \ldots$

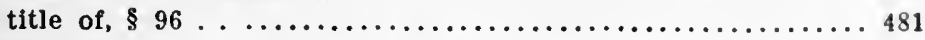

Actions-

default in payment of premium, $\$ 76 \ldots \ldots \ldots \ldots \ldots \ldots \ldots 47$

failure to secure compensation, $\$ 48 \ldots \ldots \ldots \ldots \ldots \ldots \ldots \ldots 465$

Adjustment, of premium by State Insurance Manager, \& $70 \ldots \ldots \ldots 471$

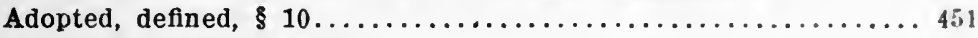

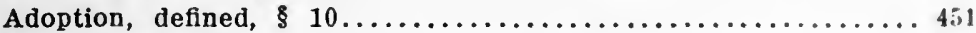

Agreements-

between employer and empioyee, $\$ 29 \ldots \ldots \ldots \ldots \ldots \ldots \ldots \ldots 459$

enforcement of, approved, when, $\$ 38 \ldots \ldots \ldots \ldots \ldots \ldots \ldots \ldots 462$

may apply to employees out of State, $\$ 4 \ldots \ldots \ldots \ldots \ldots \ldots 48$

provisions of Act may be terminated by, $\$ 1 \ldots \ldots \ldots \ldots \ldots 482$

Appeals-

from award of Board, $\$ 37 \ldots \ldots \ldots \ldots \ldots \ldots \ldots \ldots \ldots \ldots \ldots$

shall not operate as a supersedeas, unless, $\$ 40 \ldots \ldots \ldots \ldots .462$

Arbitration-

application for, $\$ 30 \ldots \ldots \ldots \ldots \ldots \ldots \ldots \ldots \ldots \ldots \ldots \ldots \ldots+459$

committee of, who compose, $\$ 30 \ldots \ldots \ldots \ldots \ldots \ldots \ldots \ldots \ldots 459$

enforcement of 1 ts award, when, $\$ 38 \ldots \ldots \ldots \ldots \ldots \ldots \ldots \ldots+\ldots \ldots$

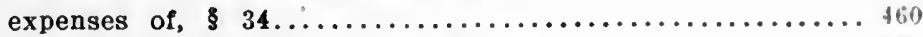

formation of, committee of, $\$ 31 \ldots \ldots \ldots \ldots \ldots \ldots \ldots \ldots+\ldots \ldots$

hearings and awards, $\$ 32 \ldots \ldots \ldots \ldots \ldots \ldots \ldots \ldots \ldots \ldots+\ldots \ldots$

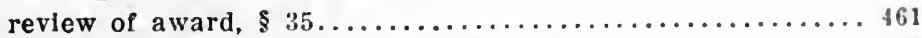

Assessments by State Insurance Manager, $\$ 7 . . . \ldots \ldots \ldots \ldots . \ldots 4$ t?

Assignment of claims not permissable, $\$ 44 \ldots \ldots \ldots \ldots \ldots \ldots \ldots 463$

[657] 
Assistants-

PAGE

cannot disclose information, penalty, $\S 85 \ldots \ldots \ldots \ldots \ldots \ldots 476$

State Insurance Manager, may employ, $\$ 61 \ldots \ldots \ldots \ldots \ldots . \ldots 468$

Attorney's fees, by whom fixed, $\S 44 \ldots \ldots \ldots \ldots \ldots \ldots \ldots \ldots . \ldots 4$ Award-

appeal from, when, $\S \S 37,40 \ldots \ldots \ldots \ldots \ldots \ldots \ldots \ldots \ldots \ldots 1,462$

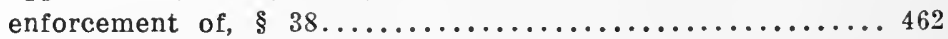

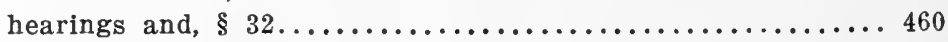

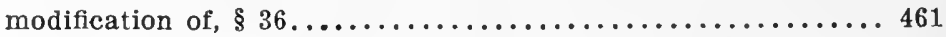

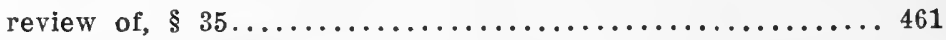

Board (Industrial Accident Board)-

agreements of employer and employee to be submitted to, $\S 29.459$ appeals from award of, when, $\S 37 \ldots \ldots \ldots \ldots \ldots \ldots \ldots \ldots \ldots$

appoints chairman of arbitration committee, $\S 30 \ldots \ldots \ldots \ldots . \ldots 49$

attorneys and physicians fees fixed by, $\S 44 \ldots \ldots \ldots \ldots \ldots \ldots 463$

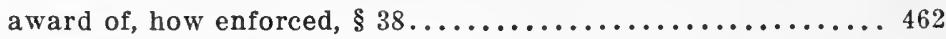

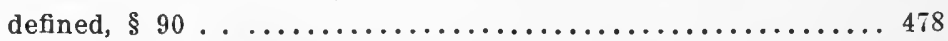

may authorize periodical payments, when, $\S 17 \ldots \ldots \ldots \ldots \ldots 45$

may commute payments, when, $\S 18 \ldots \ldots \ldots \ldots \ldots \ldots \ldots 45$

Brother-

compensation payable to, for what period, $\S 9 \ldots \ldots \ldots \ldots \ldots 450$

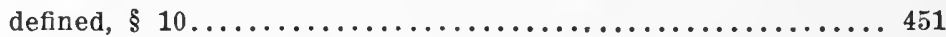

entitled to death benefit when, $\S 7 \ldots \ldots \ldots \ldots \ldots \ldots \ldots \ldots \ldots 44$

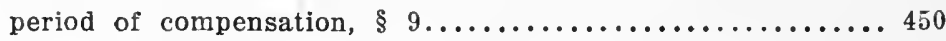

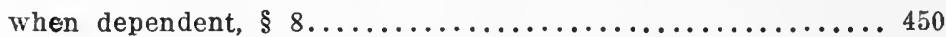

Burden of proof, injury not covered by act, $\S 3 \ldots \ldots \ldots \ldots \ldots \ldots 447$

Burial expenses, to whom payable, $\S 7 \ldots \ldots \ldots \ldots \ldots \ldots \ldots \ldots . \ldots 449$

Child-

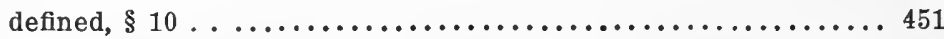

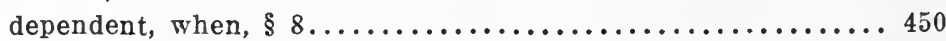

entitled to death benefit, $\S 7 \ldots \ldots \ldots \ldots \ldots \ldots \ldots \ldots \ldots \ldots 449$

period of compensution for, $\S 9 \ldots \ldots \ldots \ldots \ldots \ldots \ldots \ldots \ldots 450$

Claim for compensation-

form of, may be included in notice, $\S 22 \ldots \ldots \ldots \ldots \ldots \ldots \ldots 457$

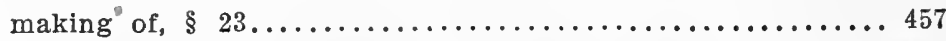

not assignable, and, exempt from creditors, $\S 44 \ldots \ldots \ldots \ldots . \ldots 463$

who may make, when, $\S 21 \ldots \ldots \ldots \ldots \ldots \ldots \ldots \ldots \ldots \ldots 46 \ldots \ldots \ldots \ldots$

Committeee of Arbitration, see Arbitration.

Compensation-

covers what periods, $\S 9 \ldots \ldots \ldots \ldots \ldots \ldots \ldots \ldots \ldots \ldots \ldots \ldots 450$

exempt from creditors' claims, $\S 44 \ldots \ldots \ldots \ldots \ldots \ldots \ldots \ldots \ldots 463$

failure to secure, effect, $\S 48 \ldots \ldots \ldots \ldots \ldots \ldots \ldots \ldots \ldots \ldots 6$

governed by contract when outside of state, $\S 4 \ldots \ldots \ldots \ldots 448$

insane persons, payable to guardians, $\S 11 \ldots \ldots \ldots \ldots \ldots \ldots . . \ldots 42$

not allowed in certain cases, $\S 3 \ldots \ldots \ldots \ldots \ldots \ldots \ldots \ldots \ldots 4$ 
Compensation-Continued.

PAGE

partial disability, $\$ 14 \ldots \ldots \ldots \ldots \ldots \ldots \ldots \ldots \ldots \ldots \ldots \ldots . \ldots 45$

payment of, by State Treasurer, when, $\$ 85 \ldots \ldots \ldots \ldots \ldots \ldots \ldots 46$

preferences against assets of employer, $\$ 43 \ldots \ldots \ldots \ldots \ldots \ldots 463$

right to, exclusive of other remedies, $\$ 4 \ldots \ldots \ldots \ldots \ldots \ldots . \ldots 48$

security for payment of, $\$ 45 \ldots \ldots \ldots \ldots \ldots \ldots \ldots \ldots \ldots \ldots 464$

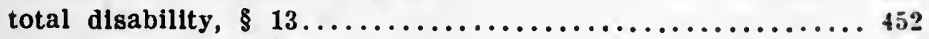

Construction, rule of, $\S 94 \ldots \ldots \ldots \ldots \ldots \ldots \ldots \ldots \ldots \ldots \ldots \ldots 4 . \ldots \ldots$

\section{Contract-}

cancellation of insurance, when, $852 \ldots \ldots \ldots \ldots \ldots \ldots \ldots \ldots 466$

compensation to be exclusive, $84 \ldots \ldots \ldots \ldots \ldots \ldots \ldots \ldots .448$

governs work outside of state, $\& 4 \ldots \ldots \ldots \ldots \ldots \ldots \ldots \ldots \ldots 44$

policy to cover entire liability, $\$ 49 \ldots \ldots \ldots \ldots \ldots \ldots \ldots \ldots .465$

presumed to be subject to Act, unless, $\$ 1 \ldots \ldots \ldots \ldots \ldots \ldots .492$

Costs, for proceeding brought without reasonable ground, $839 \ldots 462$

Counties-

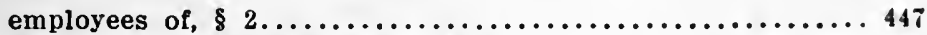

may insure employees, where, $\$ 53 \ldots \ldots \ldots \ldots \ldots \ldots \ldots \ldots 6$

Creditors, compensation exempt from, claims of, $\$ 44 \ldots \ldots \ldots \ldots 463$

Custodian of funds, State Treasurer, $\$ 66 \ldots \ldots \ldots \ldots \ldots \ldots \ldots 40$

Death benefits-

not to exceed weekly wage, $\S 11 \ldots \ldots \ldots \ldots \ldots \ldots \ldots \ldots \ldots \ldots 452$

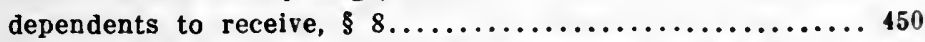

payment bona fide to dependent subsequent in right, $\$ 39 \ldots \ldots 462$

to whom payable, $\$ 7 \ldots \ldots \ldots \ldots \ldots \ldots \ldots \ldots \ldots \ldots \ldots \ldots . \ldots 49$

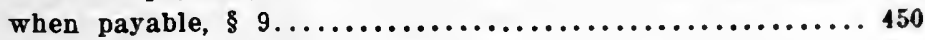

Decrees, revision of, $\$ 41 \ldots \ldots \ldots \ldots \ldots \ldots \ldots \ldots \ldots \ldots \ldots \ldots \ldots$

Defenses-

employee elects not to come under Act, $\$ 3 \ldots \ldots \ldots \ldots \ldots \ldots 483$

employer elects not to come under Act, $\$ 2 \ldots \ldots \ldots \ldots \ldots \ldots 483$

\section{Definitions-}

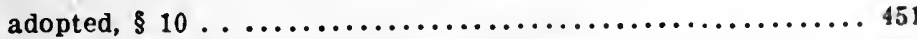

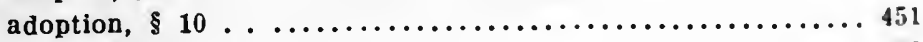

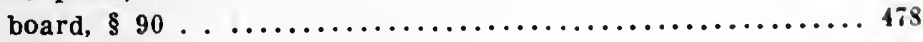

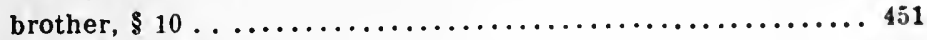

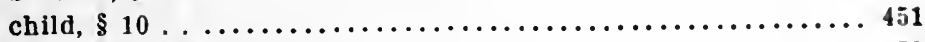

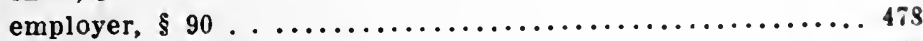

employment, $\$ 90 \ldots \ldots \ldots \ldots \ldots \ldots \ldots \ldots \ldots \ldots \ldots \ldots \ldots \ldots$

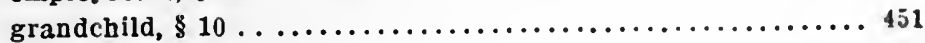

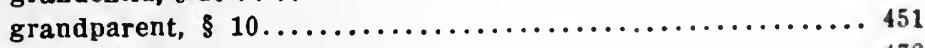

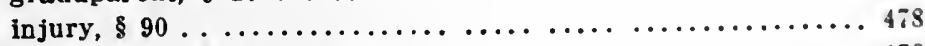

"Insurance Carrier," $\$ 90 \ldots \ldots \ldots \ldots \ldots \ldots \ldots \ldots \ldots \ldots \ldots 48$

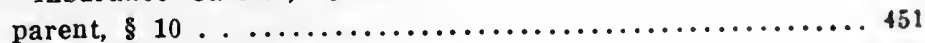

partial disability, $\$ 90 \ldots \ldots \ldots \ldots \ldots \ldots \ldots \ldots \ldots \ldots$ its

personal injury, $\$ 90 \ldots \ldots \ldots \ldots \ldots \ldots \ldots \ldots \ldots \ldots \ldots+\ldots \ldots$ 
Definitions-Continued.

PAGE

“ personal injury by accident, etc.," $\$ 90 \ldots \ldots \ldots \ldots \ldots \ldots . \ldots 78$

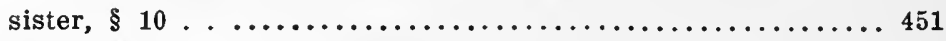

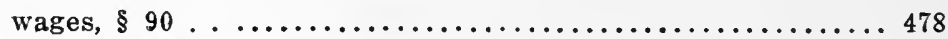

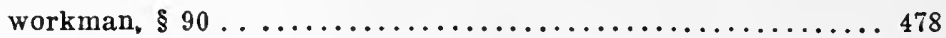

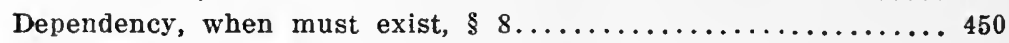

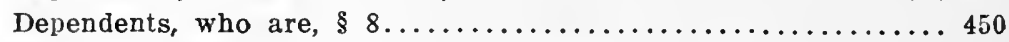

Disability, partial-

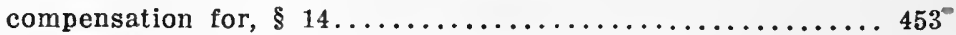

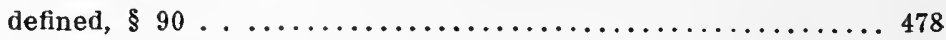

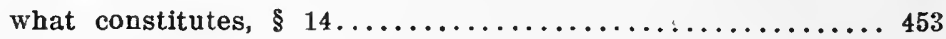

Disability, total-

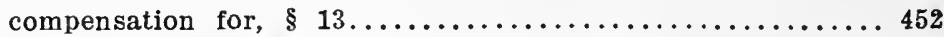

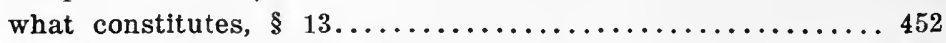

Disclosure of information, penalty, $\$ 83 \ldots \ldots \ldots \ldots \ldots \ldots \ldots \ldots 46$

Dividends, state insurance fund, $\S 72 \ldots \ldots \ldots \ldots \ldots \ldots \ldots \ldots . \ldots 42$

Election-

contract, presumption, $\S 1 \ldots \ldots \ldots \ldots \ldots \ldots \ldots \ldots \ldots \ldots \ldots 48$

employee's, not to come under Act, defenses, $\$ 3 \ldots \ldots \ldots \ldots .483$

employer's, not to come under Act, defenses, $\$ 2 \ldots \ldots \ldots \ldots 483$

Employee-

agreements with employer, to be filed with Board, $\$ 29 \ldots \ldots .459$

election to come under and employer has not, defenses, $\S 2 \ldots 483$

election to come under, implied unless, $\S 1 \ldots \ldots \ldots \ldots \ldots \ldots 482$

election to sue employer or third person, $\S 5 \ldots \ldots \ldots \ldots \ldots 448$

injuries received outside state, remedy, $\$ 42 \ldots \ldots \ldots \ldots \ldots . \ldots 463$

may enforce rights in own name under policy, $\$ 49 \ldots \ldots \ldots \ldots 465$

of municipal and state bodies, $\S 2 \ldots \ldots \ldots \ldots \ldots \ldots \ldots \ldots 44$

to whom act applies, $\S 2 \ldots \ldots \ldots \ldots \ldots \ldots \ldots \ldots \ldots \ldots \ldots 47$

wilful intent to injure himself or another, or while intoxicated,

not covered, $\S 3 \ldots \ldots \ldots \ldots \ldots \ldots \ldots \ldots \ldots \ldots \ldots \ldots \ldots \ldots 47$

\section{Employer-}

action for collection of premiums, $\S 76 \ldots \ldots \ldots \ldots \ldots \ldots . \ldots 44$

agreements with employee, effect, $\S 29 \ldots \ldots \ldots \ldots \ldots \ldots \ldots 459$

contracting away his liability, $\S 6 \ldots \ldots \ldots \ldots \ldots \ldots \ldots \ldots 48$

cannot collect dues or premiums, $\$ 54 \ldots \ldots \ldots \ldots \ldots \ldots \ldots 466$

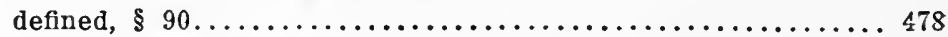

election to come under and employee has nct, defe 3 scs, $: 3 \ldots 483$

election to come under, implied unless, $\S 1 \ldots \ldots \ldots \ldots \ldots \ldots 482$

furnish state insurance manager audit of payroll, $\$ 79 \ldots \ldots 475$

insolvency of, not to release insurance carrier, $\$ 51 \ldots \ldots \ldots 466$

knowledge of, notice to insurance carrier, $\$ 50 \ldots \ldots \ldots \ldots 465$

llability for falsification of payroll, $\S 80 \ldots \ldots \ldots \ldots \ldots \ldots \ldots 45$

may withdraw from fund, when, $\S 77 \ldots \ldots \ldots \ldots \ldots \ldots \ldots 44$

must file notice where insurance not with state, $\S 46 \ldots \ldots \ldots 464$ 
Employer-Continued.

must supply physician and medicines, when, $812 \ldots \ldots \ldots \ldots 452$

notice of injury to be given, how, $822 \ldots \ldots \ldots \ldots \ldots \ldots \ldots . \ldots 45$

posting notice regarding insurance, $\$ 47 \ldots \ldots \ldots \ldots \ldots \ldots \ldots 4$

premiums to be paid by, when, $\$ 75 \ldots \ldots \ldots \ldots \ldots \ldots \ldots 73$

report of accidents by, penalty for faliure, $887 \ldots \ldots \ldots \ldots 477$

right to have injured employee examined, $820 \ldots \ldots \ldots \ldots 456$

when entitled to subrogation, $85 \ldots \ldots \ldots \ldots \ldots \ldots \ldots \ldots \ldots 448$

Employment-

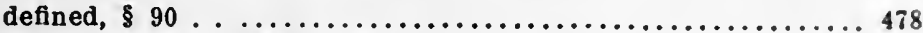

in the course of, $\$ \$ 1,90 \ldots \ldots \ldots \ldots \ldots \ldots \ldots \ldots \ldots \ldots 47,478$

outside of state, may be governed by contract, 8 . . . . 448

what employments covered by Act, $\$ 1 \ldots \ldots \ldots \ldots \ldots \ldots \ldots 447$

Examination by physictan, when, fees, $83 \ldots \ldots \ldots \ldots \ldots \ldots \ldots 460$

Exempt, compensation, is from creditors. $844 \ldots \ldots \ldots \ldots \ldots \ldots 463$

Expenses-

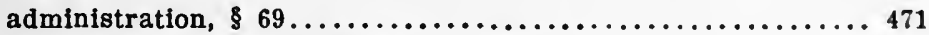

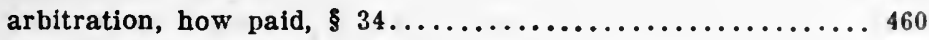

salaries and, of board, $827 \ldots \ldots \ldots \ldots \ldots \ldots \ldots \ldots \ldots \ldots$

False representations, penalties for, $892 \ldots \ldots \ldots \ldots \ldots \ldots \ldots 480$

Fees-

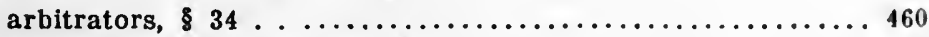

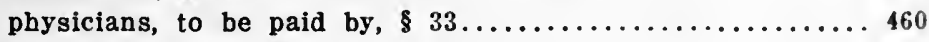

Fireman, as employee, $\$ 2 \ldots \ldots \ldots \ldots \ldots \ldots \ldots \ldots \ldots \ldots \ldots \ldots \ldots$

Forms, furnished by Board, $\$ 28 \ldots \ldots \ldots \ldots \ldots \ldots \ldots \ldots \ldots \ldots$

Grandchild-

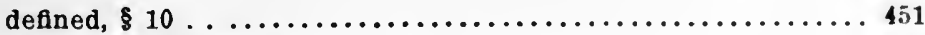

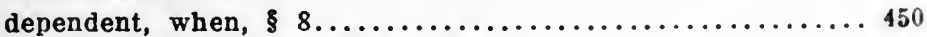

entitled to death benefits, when, $\$ 7 \ldots \ldots \ldots \ldots \ldots \ldots \ldots \ldots 44$

period of compensation, 8 . $\ldots \ldots \ldots \ldots \ldots \ldots \ldots \ldots \ldots \ldots \ldots$

Grandparent-

compensation payable, for what period, $\$ 9 \ldots \ldots \ldots \ldots \ldots \ldots 450$

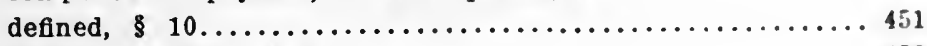

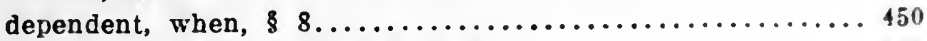

entitled to death benefits, when, $\$ 7 \ldots \ldots \ldots \ldots \ldots \ldots \ldots 4$ ?

Industrial Accident Board-

agreements between employee eand employer filed and ap-

proved by, \& $29 \ldots \ldots \ldots \ldots \ldots \ldots \ldots \ldots \ldots \ldots \ldots \ldots \ldots \ldots$

appeal from award of, $\$ 37 \ldots \ldots \ldots \ldots \ldots \ldots \ldots \ldots \ldots \ldots \ldots 1$

creation of, $\$ 26 \ldots \ldots \ldots \ldots \ldots \ldots \ldots \ldots \ldots \ldots \ldots \ldots \ldots \ldots$

costs may be taxed by, when, $839 \ldots \ldots \ldots \ldots \ldots \ldots \ldots \ldots \ldots 4$

decrees to be made to conform with rulings of, when, $\$ 41 \ldots 463$

furnishing of blank forms by, $82 . \ldots \ldots \ldots \ldots \ldots \ldots \ldots \ldots$

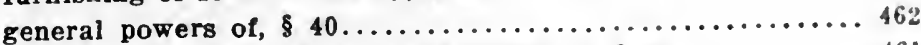

modification of awards and agreements by, $836 \ldots \ldots \ldots \ldots 461$ 
Industrial Accident Board-Continued. PAGE

physicians may be appointed by, $\$ 33 \ldots \ldots \ldots \ldots \ldots \ldots \ldots \ldots 40$

power to subpoena witness, $\S 28 \ldots \ldots \ldots \ldots \ldots \ldots \ldots \ldots \ldots 459$

reports of, to legislature, $\$ 89 \ldots \ldots \ldots \ldots \ldots \ldots \ldots \ldots \ldots$

review from awards by Committee, $\$ 35 \ldots \ldots \ldots \ldots \ldots \ldots \ldots 4$

rules of, $\$ 28 \ldots \ldots \ldots \ldots \ldots \ldots \ldots \ldots \ldots \ldots \ldots \ldots \ldots \ldots \ldots . \ldots \ldots \ldots$

salaries and expenses of, $\$ 27 \ldots \ldots \ldots \ldots \ldots \ldots \ldots \ldots \ldots \ldots \ldots$

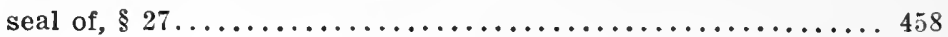

Infants-

limitation of time as regards, $\S 25 \ldots \ldots \ldots \ldots \ldots \ldots \ldots \ldots \ldots 457$

provisions of Act presumed to apply, unless, $\S 1 \ldots \ldots \ldots \ldots 482$

Information, disclosure of, $\S 83 \ldots \ldots \ldots \ldots \ldots \ldots \ldots \ldots \ldots \ldots$

Injuries-

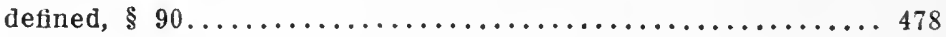

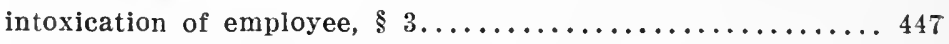

outside the state, $\S 42 \ldots \ldots \ldots \ldots \ldots \ldots \ldots \ldots \ldots \ldots \ldots . \ldots \ldots 4 . \ldots \ldots$

wilful intent to injure himself or another, not covered, $\$ 3 \ldots 447$

Insane person-

compensation payable to guardian, $\S 11 \ldots \ldots \ldots \ldots \ldots \ldots . \ldots 452$

no limitation to apply to, $\$ 25 \ldots \ldots \ldots \ldots \ldots \ldots \ldots \ldots \ldots \ldots \ldots$

Insurance-

applies to whom, $\S 2 \ldots \ldots \ldots \ldots \ldots \ldots \ldots \ldots \ldots \ldots \ldots 44$

by state, counties and municipalities, $\$ 53 \ldots \ldots \ldots \ldots \ldots 466$

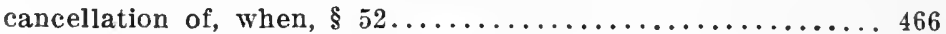

employees not to pay for, $\S 54 \ldots \ldots \ldots \ldots \ldots \ldots \ldots \ldots \ldots \ldots 6$

notice of, must be filed, when, $\$ 46 \ldots \ldots \ldots \ldots \ldots \ldots \ldots 44$

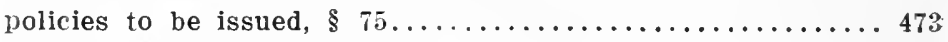

posting of notices regarding, $\$ 47 \ldots \ldots \ldots \ldots \ldots \ldots \ldots \ldots 4$

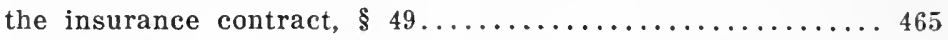

Insurance Carrier-

contract shall cover entire liability, $\S 49 \ldots \ldots \ldots \ldots \ldots \ldots \ldots 465$

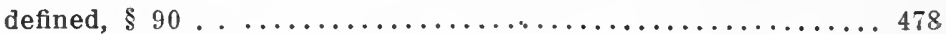

knowledge of employer, notice to, $\S 50 \ldots \ldots \ldots \ldots \ldots \ldots \ldots 4$

not released by insolvency of the employer, $\S 51 \ldots \ldots \ldots \ldots \ldots 466$

Interstate Commerce, when act applies to, $\$ 88 \ldots \ldots \ldots \ldots \ldots \ldots 48$

Intoxication, cause of injury, no compensation, $\$ 3 \ldots \ldots \ldots \ldots \ldots 447$

Legislature, reports of board shall be made to, $\$ 89 \ldots \ldots \ldots \ldots 478$

Liability-

affects interstate commerce, when, $\$ 88 \ldots \ldots \ldots \ldots \ldots \ldots . \ldots 48$

employer's, for medical attendance, $\$ 12 \ldots \ldots \ldots \ldots \ldots \ldots . \ldots 452$

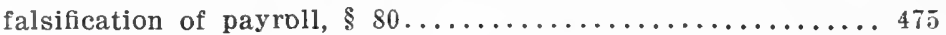

no, if injury wilful or caused by intoxication, $\S 3 \ldots \ldots \ldots \ldots 447$

on action for premiums, $\S 76 \ldots \ldots \ldots \ldots \ldots \ldots \ldots \ldots \ldots \ldots \ldots$

state insurance manager under no personal, $\S 62 \ldots \ldots \ldots \ldots 469$

third person cause of injury, rights, $\$ 5 \ldots \ldots \ldots \ldots \ldots \ldots . \ldots 44$

Limitation, not applicable to minor or insane, when, $\$ 25 \ldots \ldots \ldots 457$ 


\section{INDEX TO UNIFORM WORKMEN'S COMPENSATION ACT. 663}

\section{Medical-}

attendance, employer shail

examination

when, $820 \ldots \ldots \ldots \ldots \ldots \ldots \ldots \ldots . \ldots \ldots 6$

of time as regards, $\$ 25 \ldots \ldots \ldots \ldots \ldots \ldots \ldots 157$

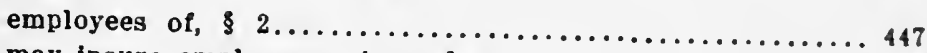

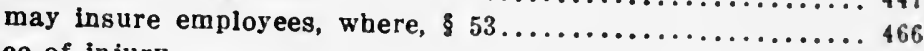

Notice of injury-

employer's, notice to insurance carrier, $\$ 50 \ldots \ldots \ldots \ldots \ldots 465$

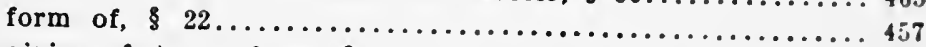

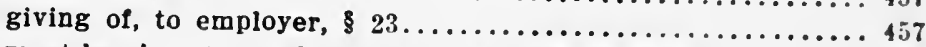

must be given to employer, when and by whom, $\$ 21 \ldots \ldots \ldots \ldots 45$

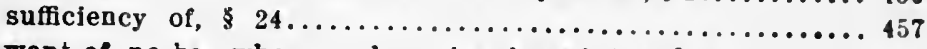

\section{Parent-}

want of, no bar when employer has knowledge, $\$ 24 \ldots \ldots \ldots \ldots 457$

defined, $\$ 10 . \ldots \ldots \ldots \ldots \ldots \ldots \ldots \ldots \ldots \ldots \ldots \ldots \ldots \ldots \ldots \ldots \ldots \ldots \ldots 451$

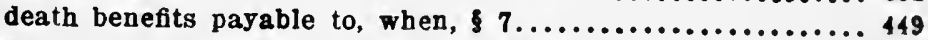

entitled to compensation, how long, $9 \ldots \ldots \ldots \ldots \ldots \ldots \ldots \ldots 450$

when compensation payable, $\$ 8 \ldots \ldots \ldots \ldots \ldots \ldots \ldots \ldots \ldots \ldots 450$

Partial disability, defined, $890 \ldots \ldots \ldots \ldots \ldots \ldots \ldots \ldots \ldots \ldots \ldots \ldots \ldots \ldots$

Payments-

action for failure to pay premiums, $\$ 76 \ldots \ldots \ldots \ldots \ldots \ldots \ldots 47$

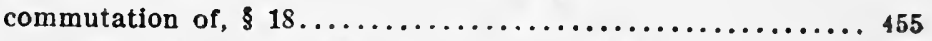

obtained by false representations, penalty, $\$ 92 \ldots \ldots \ldots \ldots \ldots 480$

periodical, $\S 17 \ldots \ldots \ldots \ldots \ldots \ldots \ldots \ldots \ldots \ldots \ldots \ldots \ldots \ldots \ldots 45$

security for, of compensation, $\$ 45 \ldots \ldots \ldots \ldots \ldots \ldots \ldots \ldots 464$

to trustee in lump sum, $\$ 19 \ldots \ldots \ldots \ldots \ldots \ldots \ldots \ldots \ldots \ldots 45$

voluntary, how credited, $\$ 16 \ldots \ldots \ldots \ldots \ldots \ldots \ldots \ldots \ldots \ldots$

Payrolls-

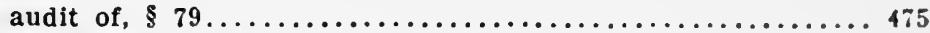

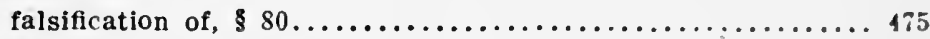

readjustment of, $74 \ldots \ldots \ldots \ldots \ldots \ldots \ldots \ldots \ldots \ldots \ldots \ldots \ldots$

Penalty -

disclosure of information, $\$ 83 \ldots \ldots \ldots \ldots \ldots \ldots \ldots \ldots \ldots 476$

employer collecting premiums or dues, $\$ 54 \ldots \ldots \ldots \ldots \ldots 466$

failure to make payment of premiums, $\$ 76 \ldots \ldots \ldots \ldots \ldots 474$

false representations, $\S 92 \ldots \ldots \ldots \ldots \ldots \ldots \ldots \ldots \ldots \ldots$. 480

security for payment of compensation not given, $\$ 48 \ldots \ldots \ldots 465$

" Personal injury by accident arising out of and in the course of such employment," defined, $\$ 90 \ldots \ldots \ldots \ldots \ldots \ldots \ldots \ldots \ldots$

Physician-

examination by, $\$ 33 \ldots \ldots \ldots \ldots \ldots \ldots \ldots \ldots \ldots \ldots \ldots \ldots \ldots+\ldots \ldots$

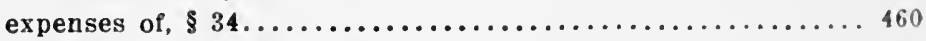

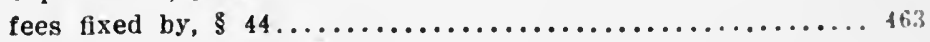

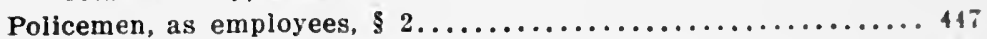

Policies to be issued, $\$ 75 \ldots \ldots \ldots \ldots \ldots \ldots \ldots \ldots \ldots \ldots \ldots . \ldots \ldots$ 


\section{INDEX TO UNIFORM WORKMEN'S COMPENSATION ACT.}

Powers-
PAGE

general, of state insurance manager, $\S \S 57,58 \ldots \ldots \ldots \ldots \ldots . \ldots 48$

state insurance manager may delegate, $\S 64 \ldots \ldots \ldots \ldots \ldots \ldots 469$

state insurance manager may sue and be sued, $\S 59 \ldots \ldots \ldots \ldots 468$

Preferences, $\$ 43 \ldots \ldots \ldots \ldots \ldots \ldots \ldots \ldots \ldots \ldots \ldots \ldots \ldots \ldots \ldots . \ldots . \ldots 4$

Premiums-

action for default in payment of, $\S 76 \ldots \ldots \ldots \ldots \ldots \ldots \ldots . \ldots 44$

adjustment of, by state insurance manager, $\S 70 \ldots \ldots \ldots \ldots 471$

payment of, when, $\S 75 \ldots \ldots \ldots \ldots \ldots \ldots \ldots \ldots \ldots \ldots \ldots \ldots \ldots \ldots$

penalty for default in payment of, $\S 76 \ldots \ldots \ldots \ldots \ldots \ldots \ldots 474$

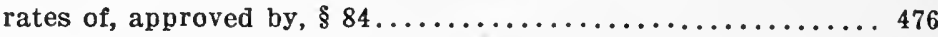

rates of, how fixed and by whom, $\S 70 \ldots \ldots \ldots \ldots \ldots \ldots \ldots 71$

subject to approval of State Insurance Commissioner, $\S 84 \ldots 476$

when not sufficient, met by assessments, $\S 73 \ldots \ldots \ldots \ldots \ldots 43$

Prior injuries, not covered by provisions of Act, $\S 93 \ldots \ldots \ldots \ldots 480$

Prior statutes, repealed, $\S 95 \ldots \ldots \ldots \ldots \ldots \ldots \ldots \ldots \ldots \ldots \ldots \ldots . \ldots 41$

Rates of premium, how fixed, $\S 84 \ldots \ldots \ldots \ldots \ldots \ldots \ldots \ldots \ldots \ldots$

Reinsurance, by state insurance manager, $\S 78 \ldots \ldots \ldots \ldots \ldots \ldots 475$

Reports-

employer to make, penalty for failure, $\S 87 \ldots \ldots \ldots \ldots \ldots \ldots 477$

state insurance manager to file, when, $\S 86 \ldots \ldots \ldots \ldots \ldots \ldots 76$

Reserves, state insurance manager to set up, $\S 71 \ldots \ldots \ldots \ldots \ldots 472$

Risks, classification of, $\S 70 \ldots \ldots \ldots \ldots \ldots \ldots \ldots \ldots \ldots \ldots \ldots 1$

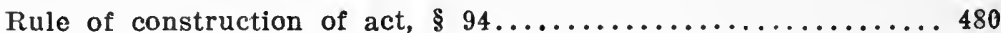

Security-

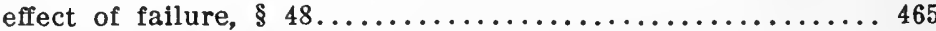

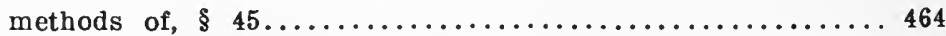

payment of compensation, $\S 45 \ldots \ldots \ldots \ldots \ldots \ldots \ldots \ldots \ldots 464$

Sister-

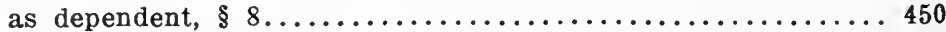

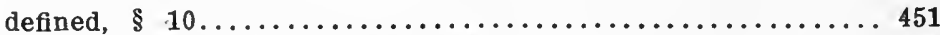

entitled to death benefits, when, $\S 7 \ldots \ldots \ldots \ldots \ldots \ldots \ldots \ldots \ldots 49$

period of compensation, $\S 9 \ldots \ldots \ldots \ldots \ldots \ldots \ldots \ldots \ldots \ldots \ldots$

State bodies-

employees of, $\S 2 \ldots \ldots \ldots \ldots \ldots \ldots \ldots \ldots \ldots \ldots \ldots \ldots \ldots 47$

may insure its employees, where, $\S 53 \ldots \ldots \ldots \ldots \ldots \ldots \ldots 466$

State Insurance Commission, premium rate to be approved by. $\$ 84.476$

State Insurance Fund-

administration, expenses of, $\S 69 \ldots \ldots \ldots \ldots \ldots \ldots \ldots \ldots \ldots 41$

creation and administration of, $\S 55 \ldots \ldots \ldots \ldots \ldots \ldots \ldots \ldots 467$

dividend out of, when, $\S 72 \ldots \ldots \ldots \ldots \ldots \ldots \ldots \ldots \ldots \ldots 42$

security for payment of compensation, $\S 45 \ldots \ldots \ldots \ldots \ldots \ldots 464$

withdrawal from, $\S 77 \ldots \ldots \ldots \ldots \ldots \ldots \ldots \ldots \ldots \ldots \ldots \ldots 4$

State Insurance Manager-

accounts to be kept by, $\$ 71 \ldots \ldots \ldots \ldots \ldots \ldots \ldots \ldots \ldots \ldots 42$

action for failure to secure compensation, $\S 48 \ldots \ldots \ldots \ldots \ldots 465$ 
State Insurance Manager-Continued. PAG:

adjustment of preminm by, $\S 70 \ldots \ldots \ldots \ldots \ldots \ldots \ldots \ldots \ldots 1$

administration expenses of, $\$ 69 \ldots \ldots \ldots \ldots \ldots \ldots \ldots \ldots \ldots \ldots$

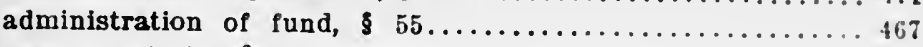

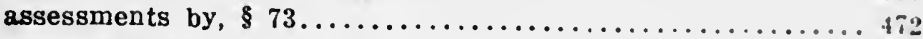

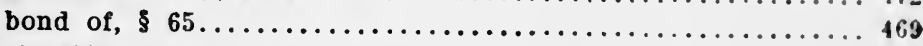

classification of risks by, $\$ 70 \ldots \ldots \ldots \ldots \ldots \ldots \ldots \ldots \ldots \ldots \ldots$

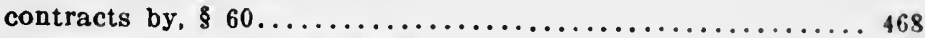

delegation of powers by, $\$ 64 \ldots \ldots \ldots \ldots \ldots \ldots \ldots \ldots \ldots \ldots 469$

disclosures by employees of, prohibited, $\S 83 \ldots \ldots \ldots \ldots \ldots 476$

dividends to be distributed by, \& $72 \ldots \ldots \ldots \ldots \ldots \ldots \ldots \ldots .472$

employment of assistants by, $\$ 61 \ldots \ldots \ldots \ldots \ldots \ldots \ldots \ldots 468$

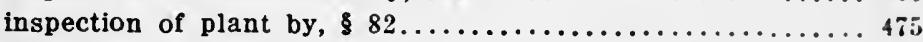

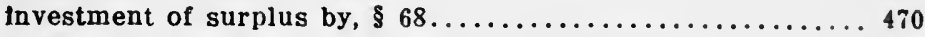

payment of compensation, how obtained, $\$ 85 \ldots \ldots \ldots \ldots \ldots 476$

personal liabilities of, $\S 62 \ldots \ldots \ldots \ldots \ldots \ldots \ldots \ldots \ldots \ldots \ldots 469$

power and duties of, $\$ \S 57,58 \ldots \ldots \ldots \ldots \ldots \ldots \ldots \ldots \ldots \ldots 4$

power to sue and be sued, $\S 59 \ldots \ldots \ldots \ldots \ldots \ldots \ldots \ldots \ldots 46$

premium rate, how fixed, $\$ \$ 4 \ldots \ldots \ldots \ldots \ldots \ldots \ldots \ldots \ldots+\ldots \ldots$

readjustment of payroli, $\$ 74 \ldots \ldots \ldots \ldots \ldots \ldots \ldots \ldots \ldots \ldots 47$

reinsurance agreements to be made by, $\$ 78 \ldots \ldots \ldots \ldots \ldots 475$

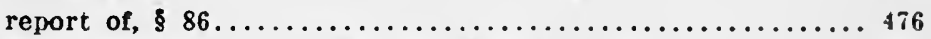

salaries, expenses and payment of same, $\$ 63 \ldots \ldots \ldots \ldots \ldots 469$

surplus and reserve to be set aside by, $\$ 67 \ldots \ldots \ldots \ldots \ldots 470$

State Treasurer, custodian of fund, $\$ 66 \ldots \ldots \ldots \ldots \ldots \ldots \ldots \ldots+\ldots$

Subpoena, Board may, $\$ 28 \ldots \ldots \ldots \ldots \ldots \ldots \ldots \ldots \ldots \ldots \ldots \ldots \ldots$

Supersedeas, appeals shall not operate as, or stay, $\$ 40 \ldots \ldots \ldots 462$

Surplus and reserve-

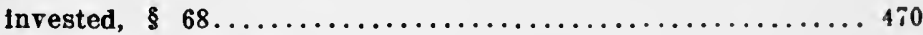

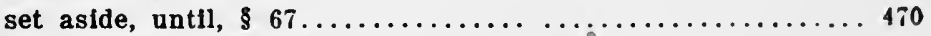

Time of act taking effect, $\$ 97 \ldots \ldots \ldots \ldots \ldots \ldots \ldots \ldots \ldots \ldots \ldots \ldots 1$

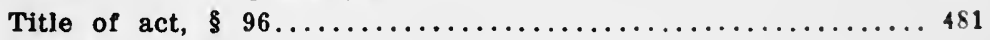

Wages-

computation of, $\$ 15 \ldots \ldots \ldots \ldots \ldots \ldots \ldots \ldots \ldots \ldots \ldots \ldots \ldots$

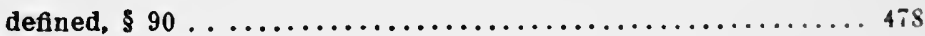

Widow-

compensation payable till death or marriage, $\$ 9 \ldots \ldots \ldots \ldots 450$

dependent under what circumstances, $\$ 8 \ldots \ldots \ldots \ldots \ldots \ldots 150$

entitled to death benefit, when, $\S 7 \ldots \ldots \ldots \ldots \ldots \ldots \ldots \ldots 449$

Widower-

compensation payable till marriage or during disability, $5 . .450$

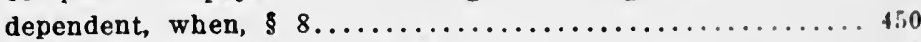

entitled to death benefits, when, $\$ 7 \ldots \ldots \ldots \ldots \ldots \ldots \ldots \ldots 149$

Witnesses may be subpoened by Board, $\$ 38 \ldots \ldots \ldots \ldots \ldots \ldots \ldots 462$

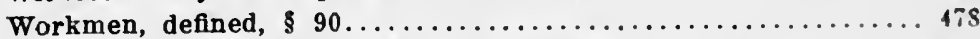

Workmen's Compensation Act, rule of construction, $894 \ldots \ldots \ldots$.... 450 


\section{INDEX TO UNIFORM FOREIGN ACKNOWLEDG- MENTS ACT}

Certificate- PAGE

officer must attach in what form, $\$ 2 \ldots \ldots \ldots \ldots \ldots \ldots \ldots . . .489$

valid if in form now prescribed, $\$ 3 \ldots \ldots \ldots \ldots \ldots \ldots \ldots . \ldots 490$

Foreign acknowledgments, what officers authorized to take, $\$ 1 \ldots 489$ Form-

certificate, $\S 2 \ldots \ldots \ldots \ldots \ldots \ldots \ldots \ldots \ldots \ldots \ldots \ldots \ldots \ldots \ldots . \ldots \ldots$

may use form now required, $\S 3 \ldots \ldots \ldots \ldots \ldots \ldots \ldots \ldots \ldots 490$ Officers--

certificate of, must contain, $\S 2 \ldots \ldots \ldots \ldots \ldots \ldots \ldots \ldots \ldots 489$

qualified to take foreign acknowledgments, $\S 1 \ldots \ldots \ldots \ldots . .490$ 


\section{INDEX TO UNIFORM PROBATE OF FOREIGN WILLS ACT}

Act-

PAGE

construction and interpretation of, $\$ 6 \ldots \ldots \ldots \ldots \ldots \ldots+96$

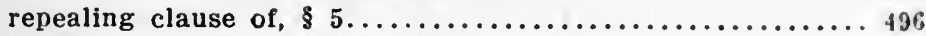

shall become effective, when, $\$ 7 \ldots \ldots \ldots \ldots \ldots \ldots \ldots \ldots . \ldots 496$

Copy-

duly authenticated where probate not required, effective, $\$ 3.495$

hearing on petition to probate, $\$ 2 \ldots \ldots \ldots \ldots \ldots \ldots \ldots \ldots \ldots+\ldots \ldots$

on due proof of foreign probate, admitted to probate, $83 \ldots 495$

Construction and interpretation of act, $\$ 6 \ldots \ldots \ldots \ldots \ldots \ldots 496$

Court-

after hearing, may admit copy to probate, when, \$ $3 \ldots \ldots \ldots 495$

may admit copy of notarial will after hearing, $\$ 4 \ldots \ldots \ldots \ldots 495$

Notice-

must be given when copy of notarial will presented for pro-

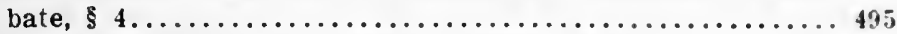

must be given when copy of will presented, $82 \ldots \ldots \ldots \ldots \ldots 495$

Probate-

copy of will duly executed and probated, entitled to, here, $\$ 3.435$ copy of will presented with petition for, time for hearing. $\$ 2$. 495 not required in other state, copy may be given probate, when.

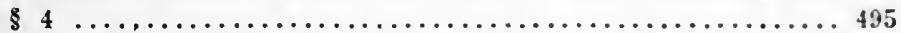

will admitted to, elsewhere, entitled to be, here, $\$ 1 \ldots \ldots \ldots 495$

Repealing clause, $\$ \mathbf{5} \ldots \ldots \ldots \ldots \ldots \ldots \ldots \ldots \ldots \ldots \ldots \ldots \ldots \ldots$

State-

copy of will executed in conformity with laws of, effect, $\$ 3 . .495$

duly probated in another, may be probated here, $\$ 1 \ldots \ldots .495$

where no probate required, copy admissible, when, $\$+\ldots \ldots 43 \overline{5}$

Time-

act shall take effect, $87 \ldots \ldots \ldots \ldots \ldots \ldots \ldots \ldots \ldots \ldots \ldots$

for hearing on presentation of copy of notarial will, $\$ 4 \ldots . .495$

for hearing where petition presents copy of will, $\$ 2 \ldots \ldots \ldots 495$ Will-

copy of, presented with petition for probate, must be fleo, $\$ 2.495$ duly probated in another state, may be probated here, $\$ 1 \ldots 495$ 


\section{INDEX TO UNIFORM LAND REGISTRATION ACT}

Act-

PAGE

application of, to land, when, $\S 89 \ldots \ldots \ldots \ldots \ldots \ldots \ldots \ldots . \ldots \ldots$ expenses incurred in administering, $\S 82 \ldots \ldots \ldots \ldots \ldots \ldots 527$

interpretation and construction, $\S 90 \ldots \ldots \ldots \ldots \ldots \ldots \ldots \ldots 50$

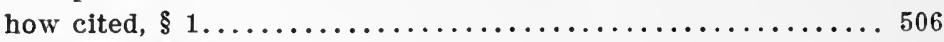

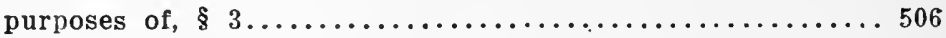

Adverse claims-

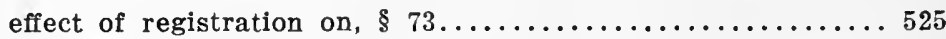

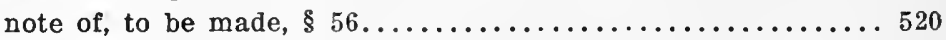

Adverse possession, none as to registered land, $\S 77 \ldots \ldots \ldots \ldots 526$

Alteration, shall be no, of certificate, except, $\S 51$ (3) ........ 518

Amendment, shall be no, of certificate, except, $\S 51$ (3) ........ 518

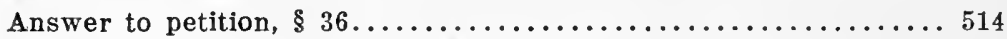

Appeal-

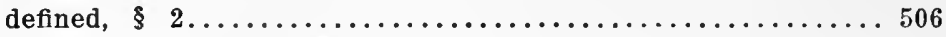

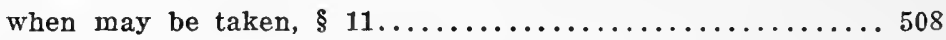

Assurance fund-

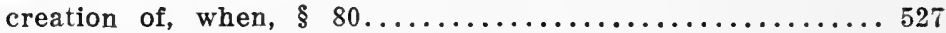

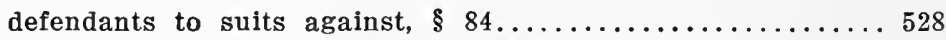

how judgment to be satisfied out of, $\S 87 \ldots \ldots \ldots \ldots \ldots \ldots 529$

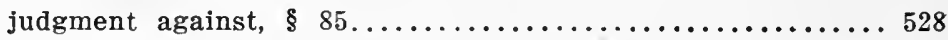

payment into State Treasury upon trust, $\S 81 \ldots \ldots \ldots \ldots \ldots . \ldots 27$

suits against, within two years, except, $\S 83 \ldots \ldots \ldots \ldots \ldots 528$

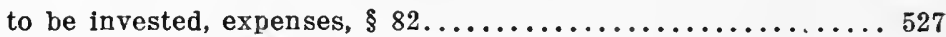

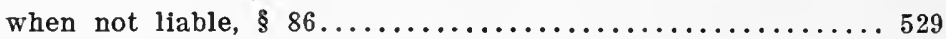

Attorney-

court shall appoint, as guardian ad litem, when, $\$ 35 \ldots \ldots \ldots 513$

examiner of titles to be, duties, $\$ 16 \ldots \ldots \ldots \ldots \ldots \ldots \ldots \ldots 10$

Attorney General, shall defend assurance fund, $\S 83 \ldots \ldots \ldots \ldots \ldots 528$

Bills of review, petition for, $\S 11 \ldots \ldots \ldots \ldots \ldots \ldots \ldots \ldots \ldots \ldots . \ldots \ldots$

Blanks, printed, to be supplied by whom, $\S 12 \ldots \ldots \ldots \ldots \ldots \ldots 508$

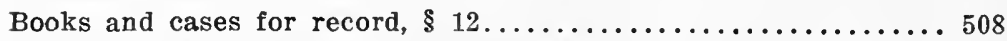

Certificate of payment of taxes, when, $\S 43 \ldots \ldots \ldots \ldots \ldots \ldots \ldots \ldots$

Certificate of service to be filed, $\S 33 \ldots \ldots \ldots \ldots \ldots \ldots \ldots \ldots \ldots \ldots . \ldots 13$

Certificate of title-

cancelled, when, $\S 54 \ldots \ldots \ldots \ldots \ldots \ldots \ldots \ldots \ldots \ldots \ldots \ldots . \ldots . \ldots . \ldots$

conclusive as to all matters contained therein, except, $\S 51$ (2) 518 decree of registration and, agreements running with land,

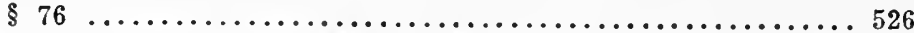

manner, time and place of filing, $\S 49 \ldots \ldots \ldots \ldots \ldots \ldots \ldots . \ldots 517$ 
Certificate of title-Continued.

new, to be issued where portion transferred, $855 \ldots \ldots \ldots \ldots 519$

no erasures or amendments to, except, 51 (3).......... 518

numbering, sealing and signing, $\$ 53 \ldots \ldots \ldots \ldots \ldots \ldots \ldots \ldots \ldots$

production of duplicate required, when, $\$ 53 \ldots \ldots \ldots \ldots \ldots \ldots 520$

registered encumbrances to be noted on, until, $\$ 56 \ldots \ldots \ldots 513$

subsequent, covering same and in like form, $\$ 48 \ldots \ldots \ldots \ldots 17$

what constitutes, $\$ 48 \ldots \ldots \ldots \ldots \ldots \ldots \ldots \ldots \ldots \ldots \ldots \ldots . \ldots 17$

when new duplicate may be issued, $\$ 71 \ldots \ldots \ldots \ldots \ldots \ldots \ldots 524$

Certiorari, writ of, see Appeal.

Cities-

act not applicable until, $\$ 89 \ldots \ldots \ldots \ldots \ldots \ldots \ldots \ldots \ldots \ldots . \ldots 30$

shall be notified, when, $\$ 30 \ldots \ldots \ldots \ldots \ldots \ldots \ldots \ldots \ldots \ldots \ldots \ldots$

Claims, conflicting, between registered owners, $\$ 79 \ldots \ldots \ldots \ldots 527$

Clerks to be registrars of title, $\S 14 \ldots \ldots \ldots \ldots \ldots \ldots \ldots \ldots \ldots \ldots 509$

Conflicting claims between registered owners, $\$ 79 \ldots \ldots \ldots \ldots . .527$

Constitution and laws of United States, liens arising under, not

affected by lack of registration, $\$ 73 \ldots \ldots \ldots \ldots \ldots \ldots \ldots .525$

Construction and interpretation of act, $\$ 90 \ldots \ldots \ldots \ldots \ldots \ldots . \ldots 30$

Corporations, signature and oath, who may make, $\$ 20,37 \ldots 511,512$

Counties and Cities to which act is applicable, $\$ 89 \ldots \ldots \ldots \ldots .530$

Courts of land registration-

action on report of examiner by, $\$ 38 \ldots \ldots \ldots \ldots \ldots \ldots \ldots \ldots 514$

appeal from decree of, when, $\$ 11 \ldots \ldots \ldots \ldots \ldots \ldots \ldots . \ldots 50 . \ldots \ldots$

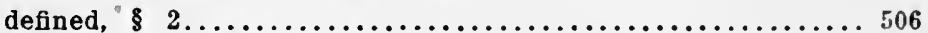

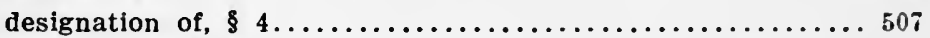

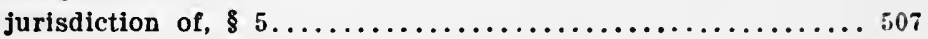

may be held by designated judges, $\$ 13 \ldots \ldots \ldots \ldots \ldots \ldots \ldots 509$

may issue new duplicate certificate, when, $\$ 71 \ldots \ldots \ldots \ldots 524$

may order erasures in or amendments of certificates, $\$$ jl (3). 518

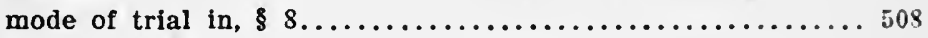

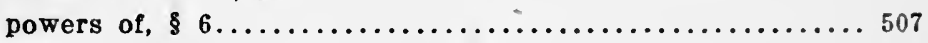

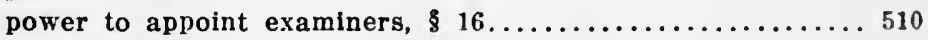

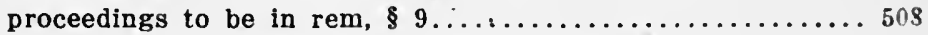

registrar of title shall act under direction of, $\$ 14 \ldots \ldots \ldots \ldots .509$

report of examiners made to, $\$ 26 \ldots \ldots \ldots \ldots \ldots \ldots \ldots \ldots \ldots 12$

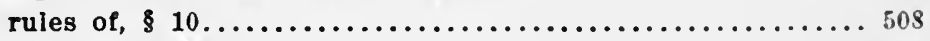

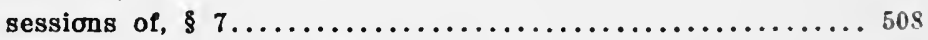

shall appoint guardian ad litem, when, $35 \ldots \ldots \ldots \ldots \ldots \ldots . \ldots 5$

Damages-

assurance fund not liable for, when, $\$ 86 \ldots \ldots \ldots \ldots \ldots \ldots . \ldots 29$

measure of, where one deprived of interest, $8 s:(3) \ldots \ldots \ldots 528$

Decedent, estates of, go to personal representatives, $861 \ldots \ldots \ldots 521$

Decree-

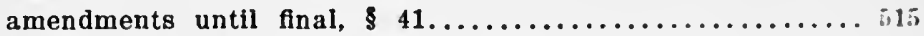

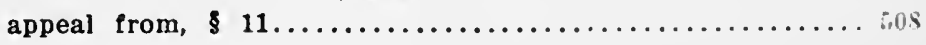


Decree-Continued.
PAGE:

defined, $\S 2 \ldots \ldots \ldots \ldots \ldots \ldots \ldots \ldots \ldots \ldots \ldots \ldots \ldots \ldots \ldots 6 . \ldots \ldots \ldots$

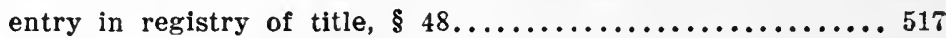

final, not entered until, $\$ 43 \ldots \ldots \ldots \ldots \ldots \ldots \ldots \ldots \ldots \ldots \ldots 515$

form and manner of registration, $\S 45 \ldots \ldots \ldots \ldots \ldots \ldots \ldots \ldots 16$

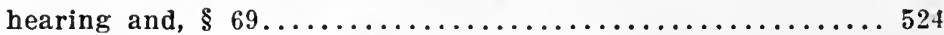

of registration is final, effect, $\S 44 \ldots \ldots \ldots \ldots \ldots \ldots \ldots \ldots \ldots 16$

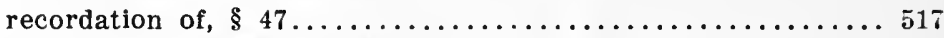

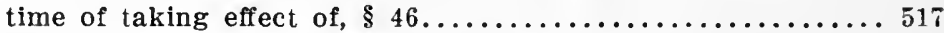

Definitions-

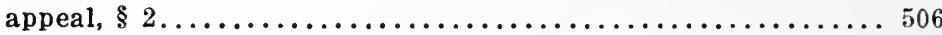

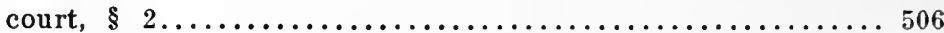

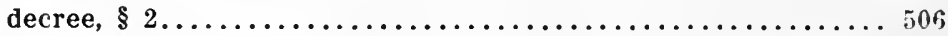

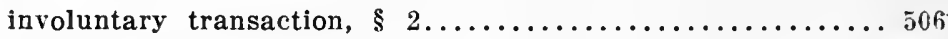

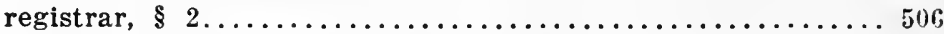

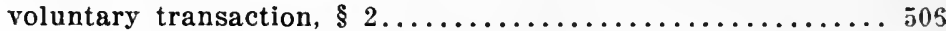

"writing, instrument or record," $\S 2 \ldots \ldots \ldots \ldots \ldots \ldots \ldots . \ldots 06$

Descent, effect of registration on, $\S 61 \ldots \ldots \ldots \ldots \ldots \ldots \ldots \ldots \ldots 21$

Destruction, see Loss.

Dismissal of petition, when, $\S 40 \ldots \ldots \ldots \ldots \ldots \ldots \ldots \ldots \ldots \ldots$

Duplicate certificate-

beneficiary's and lessee's, issued, when, $\S 55 \ldots \ldots \ldots \ldots \ldots \ldots 519$

notice to produce, when, $\S 59 \ldots \ldots \ldots \ldots \ldots \ldots \ldots \ldots \ldots 520$

proceedings upon loss or destruction of, $\S 71 \ldots \ldots \ldots \ldots \ldots 524$

shall be furnished owner, $\S 52 \ldots \ldots \ldots \ldots \ldots \ldots \ldots \ldots \ldots \ldots \ldots$

Duties of registrar of title, $\S 15 \ldots \ldots \ldots \ldots \ldots \ldots \ldots \ldots \ldots \ldots \ldots . \ldots . \ldots . \ldots$

Easements, estate and encumbrances to be in decree, $\$ 45 \ldots \ldots 516$

Encumbrances-

registration of, $\$ 55 \ldots \ldots \ldots \ldots \ldots \ldots \ldots \ldots \ldots \ldots \ldots \ldots \ldots \ldots$

registered, to be noted on certificate of title, $\$ 56 \ldots \ldots \ldots \ldots 520$

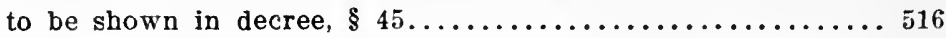

Entry book-

kept by registrars for date, time and place of filing, $\$ 49 \ldots 517$

registrar's memorandum of decree to be entered in, $\$ 47 \ldots 517$

Equitable interest and estates, registration of, $\S 60 \ldots \ldots \ldots \ldots \ldots 50$

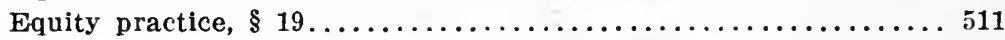

Erasures, must be no, on certificate, except, $\S 51$ (3) ........ 518

Estates-

go to personal representative, $\S 61 \ldots \ldots \ldots \ldots \ldots \ldots \ldots \ldots \ldots . \ldots 21$

transfer of whole of any registered, $\$ 54 \ldots \ldots \ldots \ldots \ldots \ldots \ldots . \ldots 19$

Evidence, certificate shall be conclusive, except, $\S 51$ (2)......5 518

Examiner of titles-

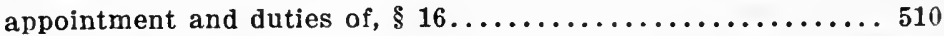

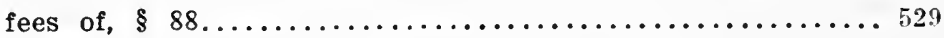

petition to be referred to, $\S 25 \ldots \ldots \ldots \ldots \ldots \ldots \ldots \ldots \ldots \ldots \ldots \ldots \ldots \ldots \ldots \ldots$ 
Examiner of titles-Continued.

1'AGE:

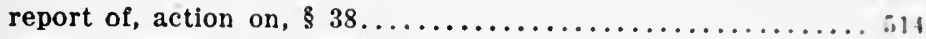

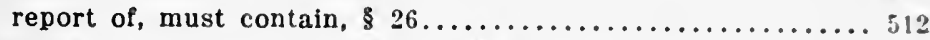

Expenses, administration, how met, $\S 82 \ldots \ldots \ldots \ldots \ldots \ldots \ldots \ldots$

Fees-

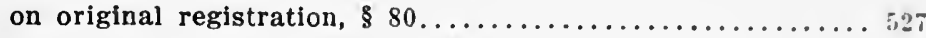

registrars' and other officers', $\$ 88 \ldots \ldots \ldots \ldots \ldots \ldots \ldots \ldots \ldots 529$

Forgery-

effect of registration procured through, $\$ 75 \ldots \ldots \ldots \ldots \ldots \ldots 26$

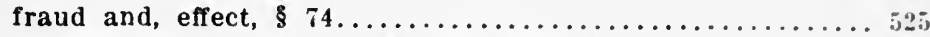

For'm of decree and manner of registration, $\$ 45 \ldots \ldots \ldots \ldots \ldots . \ldots 16$

Fraud-

effect of registration procured through, $\$ 75 \ldots \ldots \ldots \ldots \ldots \ldots 26$

procuring registration by, defendants, $84 \ldots \ldots \ldots \ldots \ldots \ldots$

registered owner participating in, $\$ 74 \ldots \ldots \ldots \ldots \ldots \ldots \ldots . \ldots \ldots$

Guardian ad litem, appointment, when, $\$ 35 \ldots \ldots \ldots \ldots \ldots \ldots \ldots$.....

Hearing-

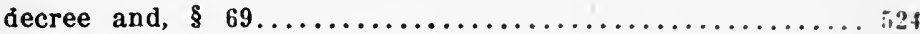

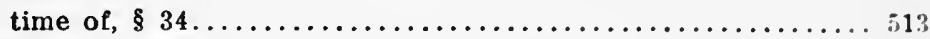

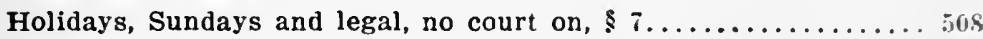

Infants-

decree of registration not affected by piea of, $\$ 44 \ldots \ldots \ldots \ldots 16$

facts about, to be included in decree, $\$ 45 \ldots \ldots \ldots \ldots \ldots \ldots . \ldots 16$

have two years from removal of disabilities to bring action.

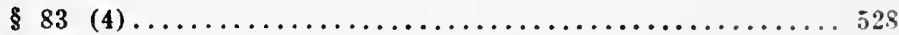

representative may file petition for, $\$ 18 \ldots \ldots \ldots \ldots \ldots \ldots . \ldots 10$

Innocent registered encumbrancer or purchaser for value, rights,

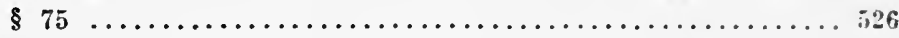

Insane, may bring action within two years after removal of dis-

abilities, $\$ 83$ (4)...........................

\section{Interest-}

court to appoint guardian ad litem to care for, when, $\$ 35 . .51 \%$

effect of registration on adverse claims, unless, $\$ 73 \ldots \ldots \ldots 525$

future, not affected by sales for taxes, $\$ 67 \ldots \ldots \ldots \ldots \ldots . \ldots 2 \%$

in lands, goes to personal representative on death of owner,

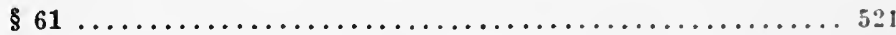

no, acquired in registered land by adverse possession, $\$$ i . $\$ 26$

Involuntary transactions-

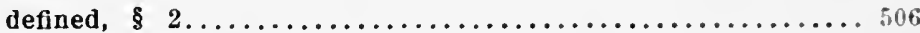

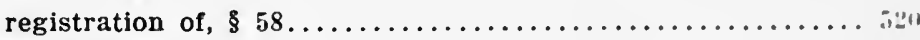

Judges, designated, may serve, others disqualified, $\$ 13 \ldots \ldots \ldots$ i09

Judgments-

against assurance fund, conditions, $\$ \$ 5 \ldots \ldots \ldots \ldots \ldots$.i2s

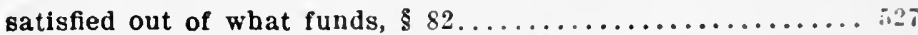

to be satisfied out of assurance fund, $\$ 87 \ldots \ldots \ldots \ldots \ldots \ldots 29$ 
PAGE
Pats

Jurisdiction, courts of land registration, $\S 5 \ldots \ldots \ldots \ldots \ldots \ldots \ldots \ldots 507$

Land-

may be dealt with pending registration, $\S 42 \ldots \ldots \ldots \ldots \ldots \ldots 515$

no rights in registered, acquired by adverse possession, § 77. 526

once registered always registered, $\S 76 \ldots \ldots \ldots \ldots \ldots \ldots \ldots . \ldots 26$

one claiming interest in, may petition court, $\S 68 \ldots \ldots \ldots \ldots .524$

passes on death of owner to personal representative, $\S 61 \ldots 521$

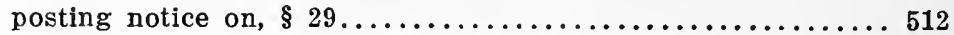

Leases-

subsequent dealing with registered, $\S 78 \ldots \ldots \ldots \ldots \ldots \ldots \ldots 26$

registration of, $\S 55 \ldots \ldots \ldots \ldots \ldots \ldots \ldots \ldots \ldots \ldots \ldots \ldots \ldots \ldots$

registration of land does not affect, when, $\$ 73 \ldots \ldots \ldots \ldots \ldots 525$

term not exceeding one year, not affected by lack of registra-

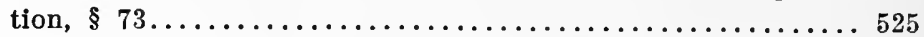

where for more than one year, new certificate, $\S 55 \ldots \ldots \ldots .519$

Liens-

estates, easements and encumbrances to be in decree, $\S 45 \ldots 516$

must appear in petition, $\$ 21 \ldots \ldots \ldots \ldots \ldots \ldots \ldots \ldots \ldots \ldots . \ldots 11$

Limitations-

must bring action within two years, except, $\S 83 \ldots \ldots \ldots \ldots 528$

transfer of land with, what necessary, $\S 60 \ldots \ldots \ldots \ldots \ldots . \ldots 520$

Lis pendens, notice of, $\$ 23 \ldots \ldots \ldots \ldots \ldots \ldots \ldots \ldots \ldots \ldots \ldots \ldots \ldots$

Loss or destruction of duplicate certificate, proceedings upon, $\S 71$. 524

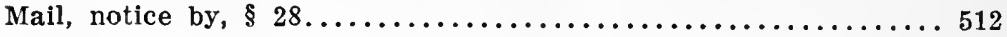

Memorial-

final sale for taxes to be registered, $\$ 66 \ldots \ldots \ldots \ldots \ldots \ldots \ldots 523$

no erasures or amendments of, except, $\S 51(3) \ldots \ldots \ldots \ldots . \ldots 18$

shall be signed and sealed, $\S 53(4) \ldots \ldots \ldots \ldots \ldots \ldots \ldots \ldots \ldots 519$

subsequent form of, $\S 45 \ldots \ldots \ldots \ldots \ldots \ldots \ldots \ldots \ldots \ldots \ldots \ldots$

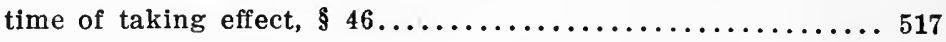

Non-resident-

bound by decree of registration, $\$ 44 \ldots \ldots \ldots \ldots \ldots \ldots \ldots \ldots 516$

must appoint a resident agent, $\S 18 \ldots \ldots \ldots \ldots \ldots \ldots \ldots \ldots . \ldots 10$

Notice-

by publication, requirements, $\S 70 \ldots \ldots \ldots \ldots \ldots \ldots \ldots \ldots \ldots 24$

by registered mail, $\S 28 \ldots \ldots \ldots \ldots \ldots \ldots \ldots \ldots \ldots \ldots \ldots \ldots \ldots 512$

certificate of service of, effect, $\S 33 \ldots \ldots \ldots \ldots \ldots \ldots \ldots \ldots \ldots \ldots 13$

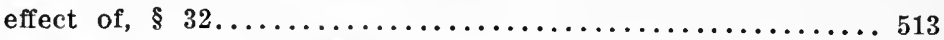

lis pendens to be kept, $\S 23 \ldots \ldots \ldots \ldots \ldots \ldots \ldots \ldots \ldots \ldots \ldots \ldots 11$

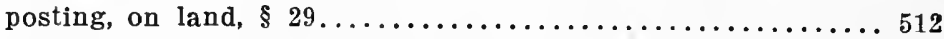

registered notice to subsequent purchasers, $\S 72 \ldots \ldots \ldots \ldots \ldots 525$

service of, evidence of, $\S 70 \ldots \ldots \ldots \ldots \ldots \ldots \ldots \ldots \ldots \ldots \ldots 24$

shall be given to city, county or state, when, $\S 30 \ldots \ldots \ldots \ldots 513$

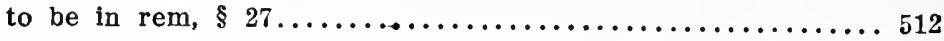


Notice of proceedings-

act to take effect in cities and counties upon, $\$ 89 \ldots \ldots \ldots . .530$

where duplicate certificate lost, $\$ 71 \ldots \ldots \ldots \ldots \ldots \ldots \ldots . \ldots 24$

Numbering-

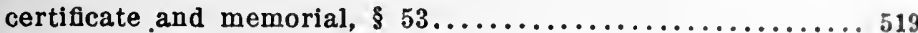

subsequent certificates, $\$ 48 \ldots \ldots \ldots \ldots \ldots \ldots \ldots \ldots \ldots . \ldots . \ldots 17$

Oath, see Signature and Oath.

Office furniture and supplies, furnished by whom, $\$ 12 \ldots \ldots \ldots 508$

Order of publication-

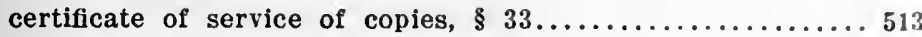

copy of, to be mailed as notice, $\$ 28 \ldots \ldots \ldots \ldots \ldots \ldots \ldots \ldots . \ldots 12$

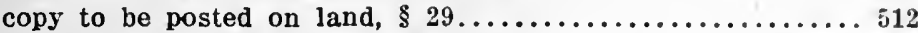

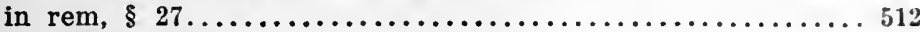

Owner, registered-

conflicting claims of one against another, older certificate

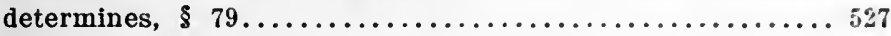

death of, land passes to personal representative, $\$ 61 \ldots \ldots . \ldots 21$

deceased, personal representative, powers of, $\$ 62 \ldots \ldots \ldots \ldots 521$

duplicate certificate issued to, when, $\$ 55 \ldots \ldots \ldots \ldots \ldots \ldots . \ldots 19$

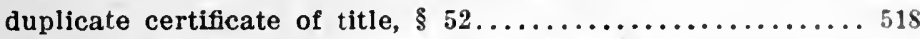

fraud and forgery participated in by, effect, $\S 74 \ldots \ldots \ldots \ldots . .525$

no rights in land of, acquired by adverse possession, $\$ 77 \ldots .526$

where he breaches trust, fund not liable, $\$ 86 \ldots \ldots \ldots \ldots . .529$

Partial transfers, encumbrances, leases, $\$ 55 \ldots \ldots \ldots \ldots \ldots \ldots . \ldots 19$

Personal representatives, powers of, $\$ 62 \ldots \ldots \ldots \ldots \ldots \ldots \ldots \ldots 21$

Personal service-

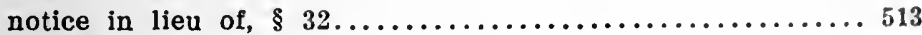

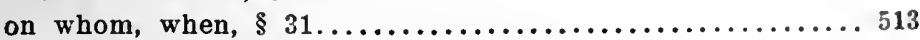

Petitions-

amendments to, any time before decree, $\S 41 \ldots \ldots \ldots \ldots \ldots . \ldots 15$

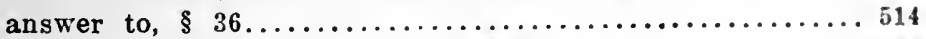

by one claiming interest in land, $\$ 68 \ldots \ldots \ldots \ldots \ldots \ldots \ldots . \ldots 24$

caveats, hearings and decrees thereon, $\$ 68 \ldots \ldots \ldots \ldots \ldots \ldots 524$

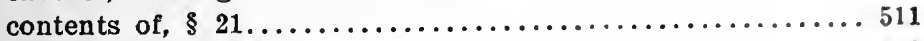

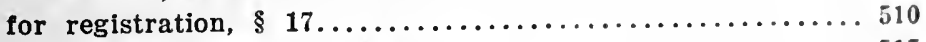

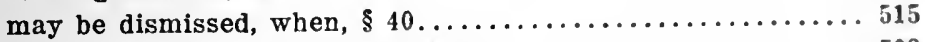

proceedings by, to be in rem, $\$ 9 \ldots \ldots \ldots \ldots \ldots \ldots \ldots \ldots \ldots . \ldots \ldots$

referred to examiner of titles, $\$ 25 \ldots \ldots \ldots \ldots \ldots \ldots \ldots \ldots . \ldots . \ldots 12$

rehearing, appeals, $\$ 11 \ldots \ldots \ldots \ldots \ldots \ldots \ldots \ldots \ldots \ldots \ldots . \ldots \ldots$

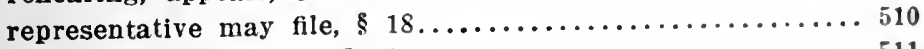

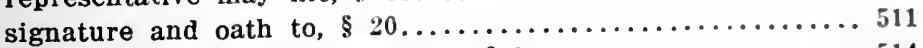

signature and oath to answer to, $\$ 37 \ldots \ldots \ldots \ldots \ldots \ldots \ldots \ldots \ldots \ldots$

to be filed and docketed, $\$ 22 \ldots \ldots \ldots \ldots \ldots \ldots \ldots \ldots \ldots \ldots \ldots$

Pleadings-

amendments to, including petition, $\$ 41 \ldots \ldots \ldots \ldots \ldots \ldots \ldots . \ldots 15$

memorandum of, entered by registrar, $\$ 24 \ldots \ldots \ldots \ldots \ldots . .511$ 
Powers-
PAGk

of courts, to enforce provisions of act, $\$ 6 \ldots \ldots \ldots \ldots \ldots \ldots 507$

of personal representative, $\$ 62 \ldots \ldots \ldots \ldots \ldots \ldots \ldots \ldots \ldots \ldots 21$

of registrar of title, duties and, $\S 15 \ldots \ldots \ldots \ldots \ldots \ldots \ldots \ldots 50 . \ldots \ldots$

Practice, rules in equity shall govern, $\$ 19 \ldots \ldots \ldots \ldots \ldots \ldots \ldots . \ldots 511$

Prescription, no right acquired by, in registered land, $\$ 77 \ldots \ldots 526$

Proceedings-

subject to rules in equitable actions, $\$ 19 \ldots \ldots \ldots \ldots \ldots \ldots \ldots 11$

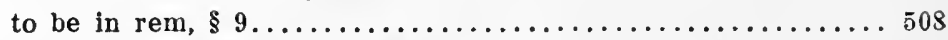

upon loss or destruction of duplicate certificate, $\S 71 \ldots \ldots .524$

Publication-

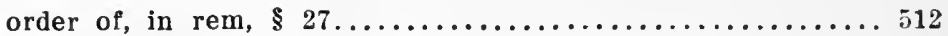

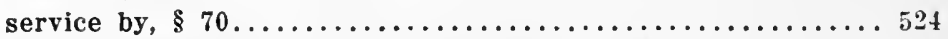

Purchasers, subsequent, registration, notice to, $\$ 72 \ldots \ldots \ldots \ldots \ldots 25$

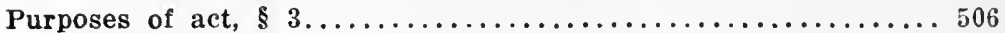

Redemption, registration of, $\$ 65 \ldots \ldots \ldots \ldots \ldots \ldots \ldots \ldots \ldots \ldots 22$

Reference of petition to examiner of titles, $\S 25 \ldots \ldots \ldots \ldots \ldots \ldots 512$

Referendum, before act effective, how, $\S 89 \ldots \ldots \ldots \ldots \ldots \ldots \ldots 30$

Register of titles-

entry of decree or memorial in, $\$ 48 \ldots \ldots \ldots \ldots \ldots \ldots \ldots \ldots 17$

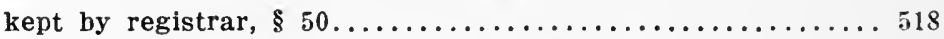

new certificate to be entered in, when, $\S 55 \ldots \ldots \ldots \ldots \ldots \ldots . \ldots 19$

Registrar of titles-

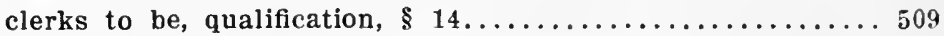

decree of court to be entered by, $\$ 48 \ldots \ldots \ldots \ldots \ldots \ldots \ldots \ldots 17$

decree takes effect when filed with, $\S 46 \ldots \ldots \ldots \ldots \ldots \ldots . \ldots 517$

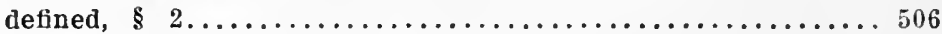

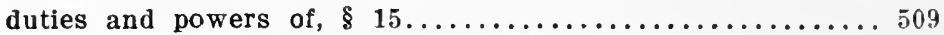

duty to keep register of title book, $\S 50 \ldots \ldots \ldots \ldots \ldots \ldots \ldots 18$

duty to register a memorial of petition, $\$ 68 \ldots \ldots \ldots \ldots \ldots \ldots .4$

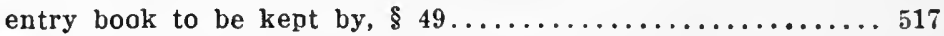

fee paid to, for original registration, $\S 80 \ldots \ldots \ldots \ldots \ldots \ldots . \ldots 27$

notice by, to produce duplicate certificate, when, $\S 59 \ldots \ldots \ldots 520$

notice of lis pendens to be kept by, $\S 23 \ldots \ldots \ldots \ldots \ldots \ldots \ldots 511$

payment of funds into State Treasury by, $\S 81 \ldots \ldots \ldots \ldots . \ldots 27$

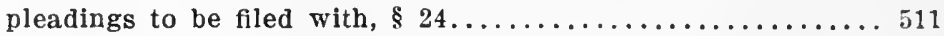

shall file and docket petitions, $\$ 22 \ldots \ldots \ldots \ldots \ldots \ldots \ldots \ldots . \ldots 11$

shall record decree of registration, how, $\$ 47 \ldots \ldots \ldots \ldots \ldots . \ldots 17$

shall register involuntary transactions, when, $\$ 58 \ldots \ldots \ldots 520$

shall sign and seal each memorial, $\S 53$ (4) ............ 519

Registration-

causes land to remain forever registered, $\$ 76 \ldots \ldots \ldots \ldots 526$

does not affect liens and taxes on land, $\S 73 \ldots \ldots \ldots \ldots \ldots . \ldots 25$

effect of, on adverse claims, $\S 73 \ldots \ldots \ldots \ldots \ldots \ldots \ldots \ldots \ldots 5$

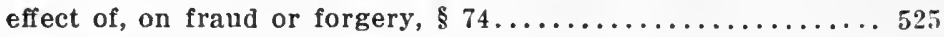

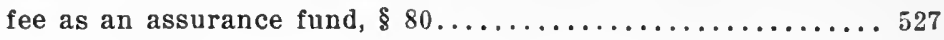


Registration-Continued.

P'A GE.

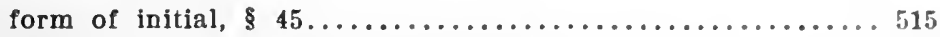

land may be dealt with pending, $\$ 42 \ldots \ldots \ldots \ldots \ldots \ldots \ldots 16$

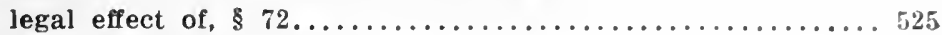

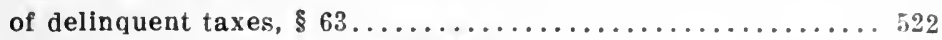

of estates of decedents, effect, $\$ 61 \ldots \ldots \ldots \ldots \ldots \ldots \ldots \ldots \ldots 21$

of final sale, if no redemption, $\S 66 \ldots \ldots \ldots \ldots \ldots \ldots \ldots \ldots \ldots$

of involuntary transactions, when, $\$ 58 \ldots \ldots \ldots \ldots \ldots \ldots \ldots \ldots$

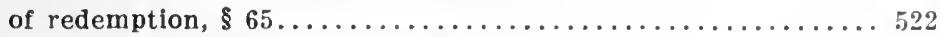

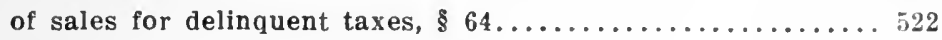

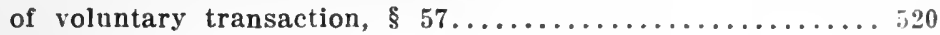

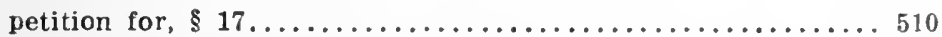

procured by fraud, defendant's, $\$ 84 \ldots \ldots \ldots \ldots \ldots \ldots \ldots 28$

subsequent dealings with land after, $\$ 74 \ldots \ldots \ldots \ldots \ldots \ldots 525$

Rehearing, when application may be filed, $\$ 11 \ldots \ldots \ldots \ldots \ldots . \ldots 50$

Report-

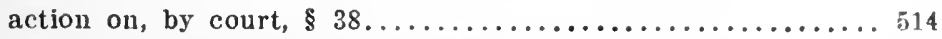

examiners shall make to court, $\$ 26 \ldots \ldots \ldots \ldots \ldots \ldots \ldots \ldots 12$

Rights-

no, in registered land acquired by adverse possession, $\S 77 . \ldots 526$

registered, to be noted on certificate of title, $\$ 56 \ldots \ldots \ldots . .520$ Rules-

colirts shall make, subject to act and statute, $\S 16 \ldots \ldots \ldots .510$

suits shall be governed by equity, except, $\S 19 \ldots \ldots \ldots \ldots \ldots 511$

Satisfaction-

of judgment out of what moneys, $\$ 82 \ldots \ldots \ldots \ldots \ldots \ldots \ldots . \ldots 527$

of judgments shall be out of assurance fund, $\$ 87 \ldots \ldots \ldots \ldots 529$

Seal, official, to be furnished by whom, $\$ 12 \ldots \ldots \ldots \ldots \ldots \ldots$

Service-

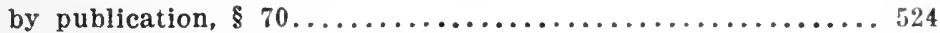

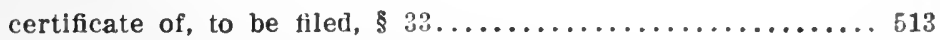

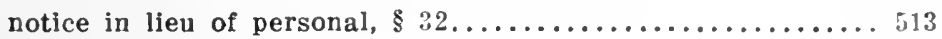

Sessions, courts shall be in, except, $\S 7 \ldots \ldots \ldots \ldots \ldots \ldots \ldots \ldots$

Sheriff-

certificate of service to be filed by, $\S 33 \ldots \ldots \ldots \ldots \ldots \ldots \ldots 5$

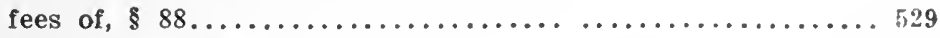

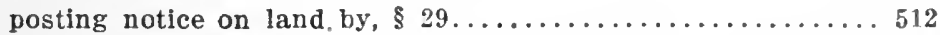

Signature and oath, of petitioner to petition, $\S \S 20,37.511,512,513,514$

State-

bound by decree of registration, $\S 44 \ldots \ldots \ldots \ldots \ldots \ldots \ldots \ldots$

notice shall be given, when, $\$ 30 \ldots \ldots \ldots \ldots \ldots \ldots \ldots \ldots \ldots$

Subsequent dealings with registered land, $\S 78 \ldots \ldots \ldots \ldots \ldots . \ldots 26$

Suits-

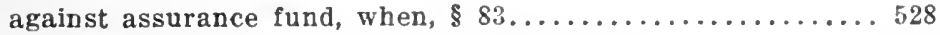

defendants in, against assurance fund, $\S 84 \ldots \ldots \ldots \ldots \ldots 28$ 
PAGE

Survey, order of, $\S 39 \ldots \ldots \ldots \ldots \ldots \ldots \ldots \ldots \ldots \ldots \ldots \ldots$

Surveyor, fees of, $\S 88 \ldots \ldots \ldots \ldots \ldots \ldots \ldots \ldots \ldots \ldots \ldots \ldots \ldots \ldots$

Taxes-

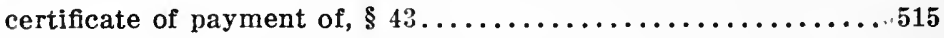

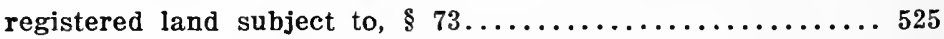

registration of delinquent, $\S 63 \ldots \ldots \ldots \ldots \ldots \ldots \ldots \ldots \ldots \ldots 522$

registration of final sale, $\$ 66 \ldots \ldots \ldots \ldots \ldots \ldots \ldots \ldots \ldots \ldots . \ldots \ldots \ldots$

sales for, future interest not affected, $\$ 67 \ldots \ldots \ldots \ldots \ldots \ldots . \ldots 23$

sales for, registration of, $\S 64 \ldots \ldots \ldots \ldots \ldots \ldots \ldots \ldots \ldots \ldots 22$

sales for, registration of redemption, $\S 65 \ldots \ldots \ldots \ldots \ldots \ldots \ldots . \ldots 22$

Time-

fling certificate to be noted by, $\$ 49 \ldots \ldots \ldots \ldots \ldots \ldots \ldots \ldots . \ldots 17$

for hearing on order, $\S 34 \ldots \ldots \ldots \ldots \ldots \ldots \ldots \ldots \ldots \ldots \ldots \ldots 13$

for taking effect of decree, $\$ 46 \ldots \ldots \ldots \ldots \ldots \ldots \ldots \ldots \ldots \ldots 17$

within which appeal may be had, $\$ 11 \ldots \ldots \ldots \ldots \ldots \ldots \ldots . \ldots 50$

Title to lands, non acquired by adverse possession in registered

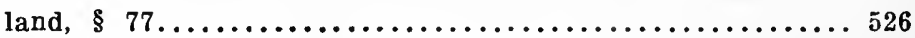

Transfers-

of portion of estate, new certificate to be entered, $\$ 55 \ldots \ldots \ldots 519$

registration of, $\S 54 \ldots \ldots \ldots \ldots \ldots \ldots \ldots \ldots \ldots \ldots \ldots \ldots \ldots \ldots . \ldots 519$

Treasurer of State-

- defendant where loss due to operation of act, $\$ 84 \ldots \ldots \ldots \ldots . \ldots 28$

right of action against other defendants, when, $\S 85$ (3) . . . 528

Trial, mode of, by jury, $\$ 8 \ldots \ldots \ldots \ldots \ldots \ldots \ldots \ldots \ldots \ldots \ldots . \ldots \ldots$

Trust-

funds received for registration to be held in, $\S 81 \ldots \ldots \ldots \ldots 527$

no liability for breach of, by registered owner, $\S 86 \ldots \ldots \ldots 529$

registration of, how, $\S 60 \ldots \ldots \ldots \ldots \ldots \ldots \ldots \ldots \ldots \ldots . \ldots 520$

Uniform land registration act, cited, how, $\S 1 \ldots \ldots \ldots \ldots \ldots \ldots \ldots 506$

United States, employees thereof, two years to sue, when, $\S 83$ (4) 528

Voluntary transactions-

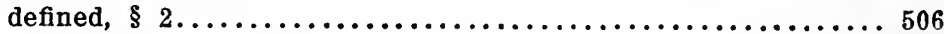

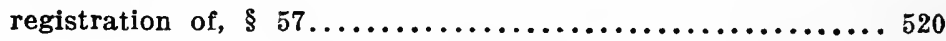

Writing, investment or record, defined, $\S 2 \ldots \ldots \ldots \ldots \ldots \ldots \ldots \ldots . \ldots 5$ 


\section{INDEX TO UNIFORM LIMITED PARTNERSHIP}

\section{ACT}

Act-

PAGE

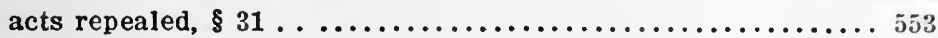

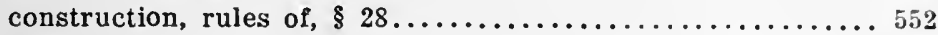

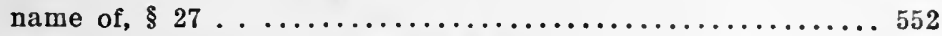

rules for cases not provided for, $\$ 29 \ldots \ldots \ldots \ldots \ldots \ldots \ldots \ldots 53$

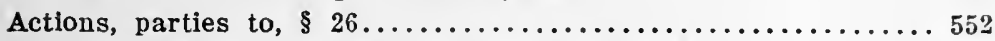

Admission of additional limited partners, how, $\$ 8 \ldots \ldots \ldots \ldots \ldots 544$

Agreement, giving one limited partner priority is valid, $\S 14 \ldots \ldots 546$

Amendment of certificate-

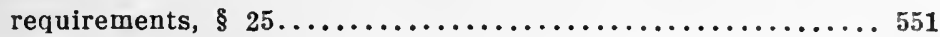

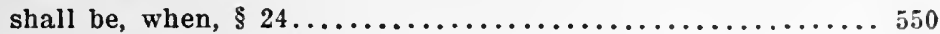

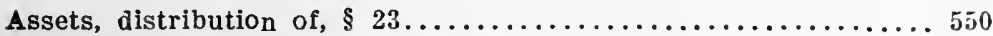

Assignee, rights, duties and liabilities, $\S 19 \ldots \ldots \ldots \ldots \ldots \ldots \ldots . \ldots 48$

Assignment of limited partner's interest, $\S 19 \ldots \ldots \ldots \ldots \ldots \ldots .548$

Business-

between limited partner and partnership, $\S 13 \ldots \ldots \ldots \ldots \ldots . .545$

which may be carried on by the limited partnership, $\S 3 \ldots \ldots 543$

Cancellation of certificate-

dissolution of partnership, $\$ 24 \ldots \ldots \ldots \ldots \ldots \ldots \ldots \ldots \ldots \ldots 50$

requirements, $\S 25 \ldots \ldots \ldots \ldots \ldots \ldots \ldots \ldots \ldots \ldots \ldots \ldots \ldots \ldots \ldots$

Certificate-

liability for false statements in, $\$ 6 \ldots \ldots \ldots \ldots \ldots \ldots \ldots \ldots . \ldots 43$

requirements for amendment and cancellation of, $\S 25 \ldots \ldots .551$

when shall be cancelled or amended, $\S 24 \ldots \ldots \ldots \ldots \ldots \ldots . \ldots 50$

Character of limited partner's contribution, $\$ 4 \ldots \ldots \ldots \ldots \ldots \ldots .543$

Compensation of limited partner, $\$ 15 \ldots \ldots \ldots \ldots \ldots \ldots \ldots \ldots . \ldots 46$

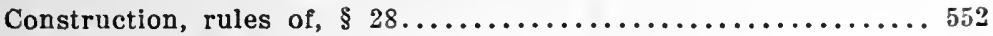

Contribution-

character of limited partner's, $\$ 4 \ldots \ldots \ldots \ldots \ldots \ldots \ldots \ldots 543$

one limited partner may be given priority, $\$ 14 \ldots \ldots \ldots \ldots \ldots 546$

withdrawal or reduction of limited partners, $\$ 16 \ldots \ldots \ldots \ldots 546$

Contributor, not a proper party, except, $\S 26 \ldots \ldots \ldots \ldots \ldots \ldots . \ldots \ldots 2$

Creditors-

entitled to priority in payment after dissolution, $\$ 23 \ldots \ldots \ldots 550$

limited partners not liable to, $\$ 7 \ldots \ldots \ldots \ldots \ldots \ldots \ldots \ldots . \ldots 44$

rights of limited partners, $\S 22 \ldots \ldots \ldots \ldots \ldots \ldots \ldots \ldots \ldots \ldots \ldots$

[677] 
Death-

of general partner, effect, $\S 20 \ldots \ldots \ldots \ldots \ldots \ldots \ldots \ldots \ldots 549$

of limited partner, $\S 21 \ldots \ldots \ldots \ldots \ldots \ldots \ldots \ldots \ldots \ldots \ldots \ldots . \ldots . \ldots$

Definitions-

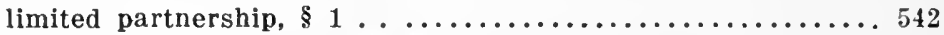

substituted limited partner, $\$ 19(2) \ldots \ldots \ldots \ldots \ldots \ldots \ldots \ldots . \ldots 548$

Distribution of assets, $\S 23 \ldots \ldots \ldots \ldots \ldots \ldots \ldots \ldots \ldots \ldots \ldots \ldots 50$

False statement in certificate, liability, $\S 6 \ldots \ldots \ldots \ldots \ldots \ldots \ldots . \ldots 43$

Formation of limited partnership, $\S 2 \ldots \ldots \ldots \ldots \ldots \ldots \ldots \ldots \ldots . \ldots 42$

General partner-

effect of retirement, death or insanity of a, $\S 20 \ldots \ldots \ldots \ldots 549$

one person both limited and, $\S 12 \ldots \ldots \ldots \ldots \ldots \ldots \ldots \ldots \ldots 45$

rights, powers and liabilities of $a, \S 9 \ldots \ldots \ldots \ldots \ldots \ldots \ldots 544$

Insanity of general partner, effect, $\S 20 \ldots \ldots \ldots \ldots \ldots \ldots \ldots \ldots . \ldots 49$

Liability-

false statements in certificate, $\$ 6 \ldots \ldots \ldots \ldots \ldots \ldots \ldots \ldots \ldots . \ldots 543$

general partner's, $\$ 9 \ldots \ldots \ldots \ldots \ldots \ldots \ldots \ldots \ldots \ldots \ldots \ldots . \ldots 544$

limited partner's, to partnership, $\$ 17 \ldots \ldots \ldots \ldots \ldots \ldots \ldots 547$

no, of limited partner to creditors, $\S 7 \ldots \ldots \ldots \ldots \ldots \ldots \ldots \ldots 54$

Limited partner or partners-

admission of additional, $\S 8 \ldots \ldots \ldots \ldots \ldots \ldots \ldots \ldots \ldots \ldots \ldots \ldots \ldots$

character of contribution of $\S 4 \ldots \ldots \ldots \ldots \ldots \ldots \ldots \ldots \ldots . \ldots \ldots$

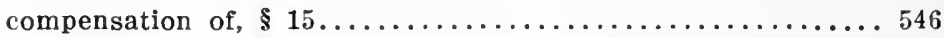

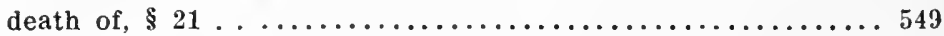

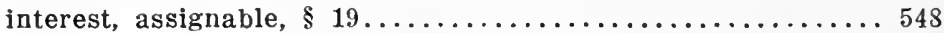

liability of limited partner to, $\S 17 \ldots \ldots \ldots \ldots \ldots \ldots \ldots \ldots 54$

liability of, to the partnership, $\S 17 \ldots \ldots \ldots \ldots \ldots \ldots \ldots \ldots 54$

loans and other business transactions with, $\S 13 \ldots \ldots \ldots \ldots \ldots 54$ 5

name not to contain surname of, exceptions, $\S 5 \ldots \ldots \ldots \ldots \ldots 543$

nature of, interest in the partnership, $\S 18 \ldots \ldots \ldots \ldots \ldots \ldots 548$

not liable to creditors, $\S 7 \ldots \ldots \ldots \ldots \ldots \ldots \ldots \ldots \ldots \ldots \ldots \ldots 44$

one person both general and, $\S 12 \ldots \ldots \ldots \ldots \ldots \ldots \ldots \ldots . \ldots . \ldots 45$

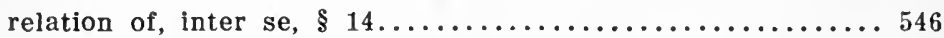

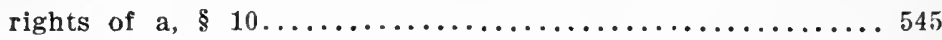

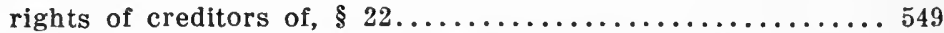

status of person erroneously believing himself $\mathrm{a}, \S 11 \ldots \ldots \ldots 545$

withdrawal or reduction of contribution of, $\S 16 \ldots \ldots \ldots \ldots 546$

Limited partnership-

business that may be carried on by, $\S 3 \ldots \ldots \ldots \ldots \ldots \ldots \ldots 543$

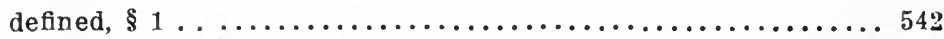

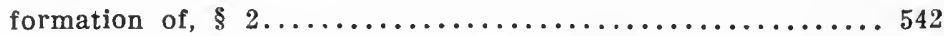

loans and other business may be transacted with limited

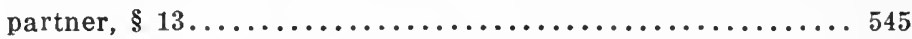

provisions for existing, $\S 30 \ldots \ldots \ldots \ldots \ldots \ldots \ldots \ldots \ldots \ldots 5$

Name not to contain surname of limited partner, unless, $\S 5 \ldots \ldots 543$ 
Name of act, $\$ 27 \ldots \ldots \ldots \ldots \ldots \ldots \ldots \ldots \ldots \ldots \ldots \ldots \ldots \ldots . \ldots \ldots \ldots$

One person both general and limited partner, $\$ 12 \ldots \ldots \ldots \ldots \ldots 545$

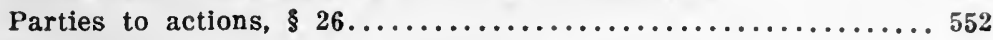

Partnership -

liability of limited partner to the, $\S 17 \ldots \ldots \ldots \ldots \ldots \ldots \ldots 57$

nature of limited partner's interest in the, $\$ 18 \ldots \ldots \ldots \ldots . \ldots 48$

one erroneousiy believing himself a limited partner is not a

general partner in, $\S 11 \ldots \ldots \ldots \ldots \ldots \ldots \ldots \ldots \ldots \ldots . \ldots . \ldots 45$

shall not contain surname of limited partner, unless, $\S 13 \ldots \ldots 545$

Person erroneously believing himself to be limited partner, status,

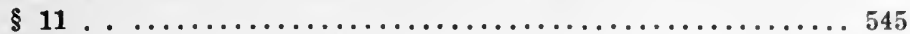

Powers of a general partner, $\$ 9 . \ldots \ldots \ldots \ldots \ldots \ldots \ldots \ldots \ldots \ldots \ldots 4$

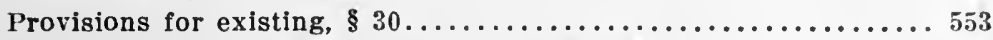

Reduction of limited partner's contribution, $\$ 16 \ldots \ldots \ldots \ldots \ldots \ldots 546$

Relation of limited partners inter se, $\S 14 \ldots \ldots \ldots \ldots \ldots \ldots \ldots . \ldots 46$

Requirements for amendment and cancellation of certificate, $\S 25$.. 551

Retirement of general partner, effect, $\S 20 \ldots \ldots \ldots \ldots \ldots \ldots \ldots . \ldots 49$

Rights-

of creditors of limited partnership, $\S 22 \ldots \ldots \ldots \ldots \ldots \ldots . \ldots 49$

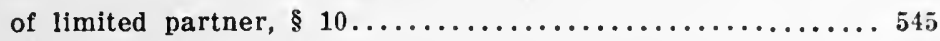

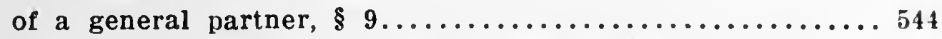

powers and liąbilities of a general partıer, \& $9 \ldots \ldots \ldots \ldots \ldots 44$ Rules-

cases not provided for by this act, $\S 29 \ldots \ldots \ldots \ldots \ldots \ldots \ldots 53$

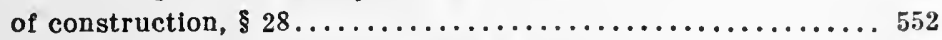

Waiver of liability of limited partner, $\S 17(3) \ldots \ldots \ldots \ldots \ldots \ldots 547$

When certificate shall be cancelled or amended, $\S 24 \ldots \ldots \ldots \ldots .550$

Withdrawal of contribution, when, $\S 16 \ldots \ldots \ldots \ldots \ldots \ldots \ldots \ldots 54$ 


\section{INDEX TO UNIFORM ACT FOR THE EXTRADITION OF PERSONS OF UNSOUND MIND}

Act-

PAGE

how to be cited, $\S 1 . \ldots \ldots \ldots \ldots \ldots \ldots \ldots \ldots \ldots \ldots \ldots \ldots . \ldots \ldots 5$

interpretation of, to effectuate uniformity, $\S 6 \ldots \ldots \ldots \ldots \ldots 56$

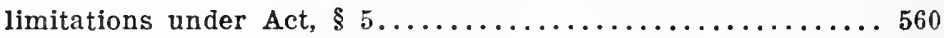

repeals laws inconsistent with, $\S 7 \ldots \ldots \ldots \ldots \ldots \ldots \ldots \ldots 61$

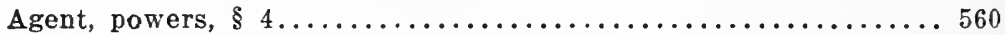

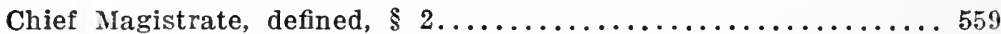

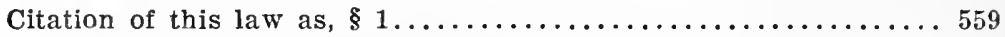

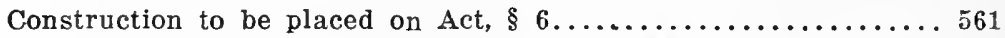

Cost to be paid by the State making demand, $\$ 4 \ldots \ldots \ldots \ldots \ldots . \ldots 60$

Definitions-

executive authority, $\S 2 \ldots \ldots \ldots \ldots \ldots \ldots \ldots \ldots \ldots \ldots \ldots \ldots \ldots \ldots$

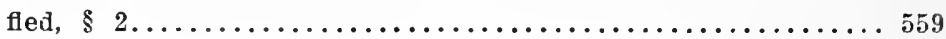

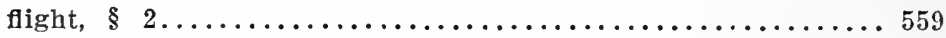

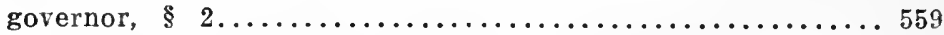

justice of Supreme Court of District of Columbia, $\S 2 \ldots \ldots \ldots 559$

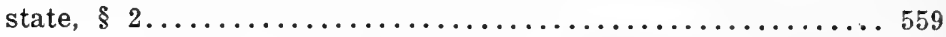

Duty to cause fugitive to be apprehended and delivered, when, $\S 4.560$

Executive authority-

defined, $\S 2 \ldots \ldots \ldots \ldots \ldots \ldots \ldots \ldots \ldots \ldots \ldots \ldots \ldots \ldots \ldots \ldots \ldots \ldots$

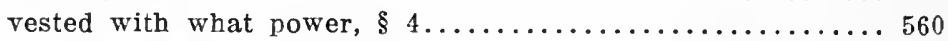

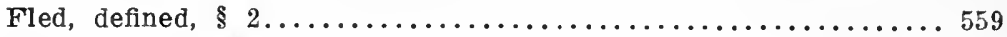

Flight, defined, $\S 2 \ldots \ldots \ldots \ldots \ldots \ldots \ldots \ldots \ldots \ldots \ldots \ldots \ldots \ldots \ldots \ldots$

Fugitives-

discharged if no agent appears, when, $\S 4 \ldots \ldots \ldots \ldots \ldots \ldots 560$

governor may demand return of, $\$ 4 \ldots \ldots \ldots \ldots \ldots \ldots \ldots . \ldots 60$

Governor-

defined, $\S 2 \ldots \ldots \ldots \ldots \ldots \ldots \ldots \ldots \ldots \ldots \ldots \ldots \ldots \ldots \ldots \ldots \ldots . \ldots \ldots$

duty to deliver up fugitive, when, $\S 4 \ldots \ldots \ldots \ldots \ldots \ldots \ldots \ldots 60$

may demand return of fugitive, $\$ 4 \ldots \ldots \ldots \ldots \ldots \ldots \ldots . \ldots . \ldots 60$

Interpretation and construction of this law, $\S 6 \ldots \ldots \ldots \ldots \ldots 561$

Justice of Supreme Court of District of Columbia is included in-

chief magistrate, $\S 2 \ldots \ldots \ldots \ldots \ldots \ldots \ldots \ldots \ldots \ldots \ldots \ldots \ldots . \ldots \ldots$

executive authority, $\S 2 \ldots \ldots \ldots \ldots \ldots \ldots \ldots \ldots \ldots \ldots \ldots \ldots \ldots 5$

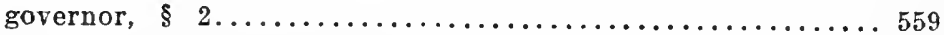

Limitation of proceedings under this Act, $\S 5 \ldots \ldots \ldots \ldots \ldots \ldots 60$

Persons subject to the Act, $\S 3 \ldots \ldots \ldots \ldots \ldots \ldots \ldots \ldots \ldots \ldots \ldots \ldots \ldots$

[680] 


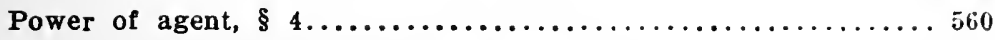

Procedure necessary before apprehension, $\S 4 \ldots \ldots \ldots \ldots \ldots \ldots \ldots 50$

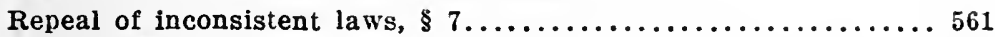

State, defined, $\S 2 \ldots \ldots \ldots \ldots \ldots \ldots \ldots \ldots \ldots \ldots \ldots \ldots \ldots \ldots \ldots . \ldots \ldots$

What fugitive shall be delivered up, $\S 3 \ldots \ldots \ldots \ldots \ldots \ldots \ldots \ldots . \ldots 59$ 


\section{INDEX TO UNIFORM FLAG ACT}

Act-

PAGE

construction and interpretation of, $\S 7 \ldots \ldots \ldots \ldots \ldots \ldots \ldots 58$

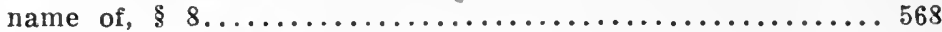

time of taking effect of, $\$ 9 \ldots \ldots \ldots \ldots \ldots \ldots \ldots \ldots \ldots \ldots \ldots \ldots$

when, does not apply, $\$ 4 \ldots \ldots \ldots \ldots \ldots \ldots \ldots \ldots \ldots \ldots \ldots$

Construction and interpretation of Act, $\S 7 \ldots \ldots \ldots \ldots \ldots \ldots \ldots 5$

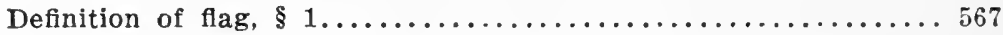

Desecration-

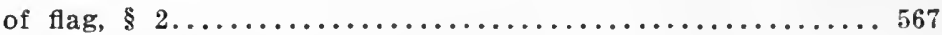

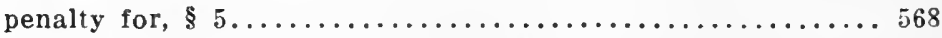

Exceptions, when Act does not apply, $\$ 4 \ldots \ldots \ldots \ldots \ldots \ldots \ldots \ldots . \ldots \ldots 8$

Flag-

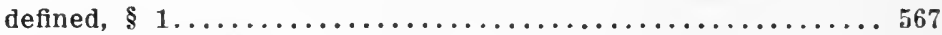

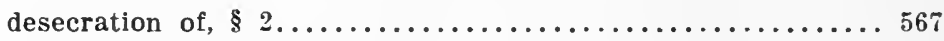

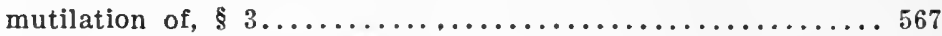

Inconsistent Acts repealed, $\$ 6 \ldots \ldots \ldots \ldots \ldots \ldots \ldots \ldots \ldots \ldots \ldots$

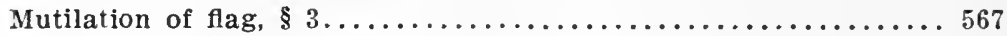

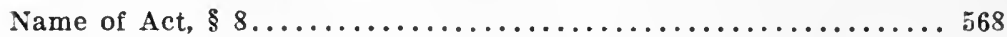

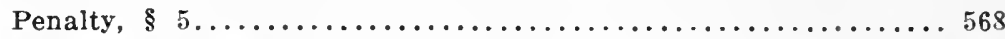

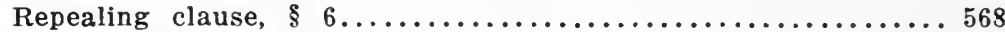

Time of taking effect of Act, $\S 9 \ldots \ldots \ldots \ldots \ldots \ldots \ldots \ldots \ldots \ldots \ldots$

United States Army and Navy regulations, not affected, $\S 4 \ldots \ldots . .568$ 


\section{INDEX TO UNIFORM CONDITIONAL SALES ACT}

Acknowledgement, not necessary to validity of contract, \& $\begin{aligned} & \text { PAG. } \\ & 575\end{aligned}$

Act-

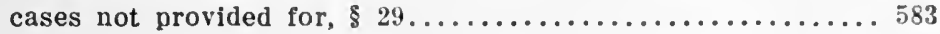

inconsistent laws repealed, $\$ 32 \ldots \ldots \ldots \ldots \ldots \ldots \ldots \ldots \ldots . \ldots 53$

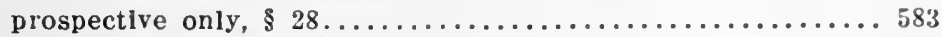

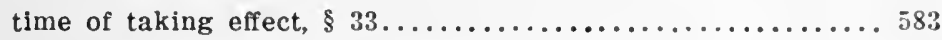

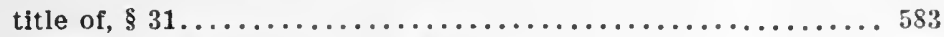

uniformity of interpretation, $\$ 30 \ldots \ldots \ldots \ldots \ldots \ldots \ldots \ldots \ldots$

Attachment or levy, before notice of provisions in conditional sale,

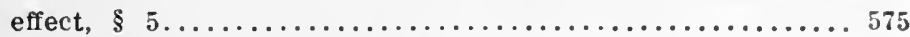

Bankruptcy, law of, as applicable, $\$ 29 \ldots \ldots \ldots \ldots \ldots \ldots \ldots \ldots . \ldots 53$

Buyer-

cannot waive statutory protection, $\$ 26 \ldots \ldots \ldots \ldots \ldots \ldots \ldots . \ldots 53$

default, gives seller right to possession, $\S 16 \ldots \ldots \ldots \ldots \ldots 579$

deficiency, liable for on resale, $\S 22 \ldots \ldots \ldots \ldots \ldots \ldots \ldots \ldots . \ldots 52$

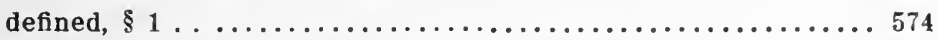

discharged from liability where no resale, $\S 23 \ldots \ldots \ldots \ldots \ldots 582$

entitled to satisfaction, when, $\S 12 \ldots \ldots \ldots \ldots \ldots \ldots \ldots \ldots \ldots 77$

interest in proceeds of resale, $\$ 21 \ldots \ldots \ldots \ldots \ldots \ldots \ldots \ldots . \ldots 58$

liable after delivery of goods for loss, $\$ 27 \ldots \ldots \ldots \ldots \ldots \ldots 53$

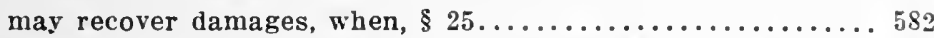

must give notice of removal of goods, when, $\S 13 \ldots \ldots \ldots \ldots 578$

must give notice to seller, when, $\S 20 \ldots \ldots \ldots \ldots \ldots \ldots \ldots \ldots 1$

must be given notice of intention to retake, $\$ 17 \ldots \ldots \ldots \ldots 580$

primary rights of, $\$ 2 \ldots \ldots \ldots \ldots \ldots \ldots \ldots \ldots \ldots \ldots \ldots \ldots \ldots$

Cancellation of contract, $\S 12 \ldots \ldots \ldots \ldots \ldots \ldots \ldots \ldots \ldots \ldots \ldots . \ldots \ldots 77$

Cases, not provided for, rules governing, $\S 29 \ldots \ldots \ldots \ldots \ldots \ldots \ldots 83$

Compulsory resale by seller, $\$ 19 \ldots \ldots \ldots \ldots \ldots \ldots \ldots \ldots \ldots \ldots \ldots 1$

Concealment of goods prior to performance of conditions, $\$ 15 \ldots . .579$

Conditional sale-

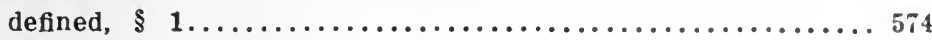

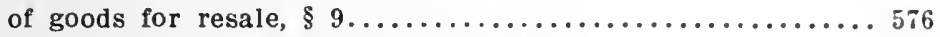

valld except as otherwise provided, $\$ 4 \ldots \ldots \ldots \ldots \ldots \ldots \ldots 575$

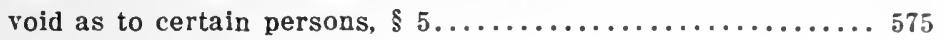

Contract-

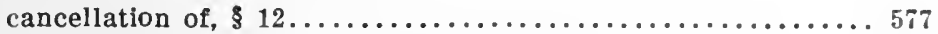

fixtures to be attached to realty, must be filed, $\S 7 \ldots \ldots \ldots .575$

periods of time filings cover, $\S 11 \ldots \ldots \ldots \ldots \ldots \ldots \ldots \ldots 77$

[683] 
Contract-Continued. PAGE

place of filing, acknowledgèment not necessary, $\S 6 \ldots \ldots \ldots 575$

time and requisites of filing, $\S 10 \ldots \ldots \ldots \ldots \ldots \ldots \ldots \ldots . \ldots 57$

Criminal liability, when, $\S 15 \ldots \ldots \ldots \ldots \ldots \ldots \ldots \ldots \ldots \ldots 79$

Deficiency, buyer liable for on resale, $\S 22 \ldots \ldots \ldots \ldots \ldots \ldots \ldots \ldots 52$

Definitions-

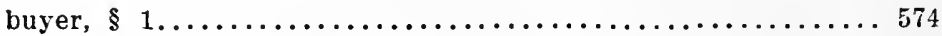

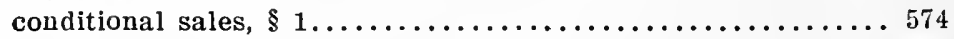

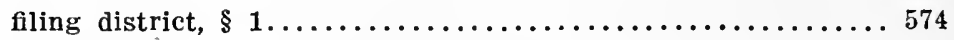

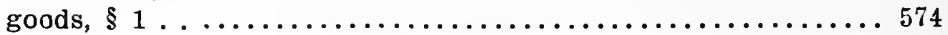

"performance of the condition," $\$ 1 \ldots \ldots \ldots \ldots \ldots \ldots \ldots \ldots 574$

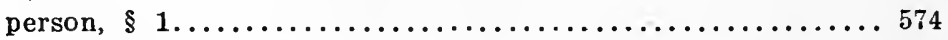

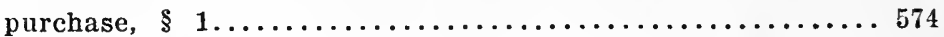

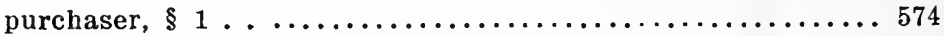

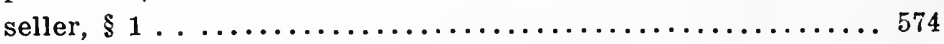

Duress or coercion, law of, $\$ 29 \ldots \ldots \ldots \ldots \ldots \ldots \ldots \ldots \ldots \ldots \ldots$

Election of remedies, $\S 24 \ldots \ldots \ldots \ldots \ldots \ldots \ldots \ldots \ldots \ldots \ldots \ldots \ldots 2$

Filing-

book, what shall be entered, $\$ 10 \ldots \ldots \ldots \ldots \ldots \ldots \ldots \ldots . \ldots \ldots 77$

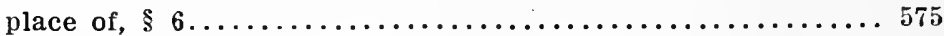

Filing district, defined, $\$ 1 \ldots \ldots \ldots \ldots \ldots \ldots \ldots \ldots \ldots \ldots \ldots \ldots \ldots$

Filing officer-

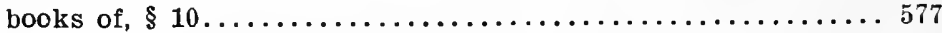

fee for filing contract, $\S 10 \ldots \ldots \ldots \ldots \ldots \ldots \ldots \ldots \ldots \ldots \ldots 77$

fee for filing satisfaction, $\S 12 \ldots \ldots \ldots \ldots \ldots \ldots \ldots \ldots \ldots \ldots 577$

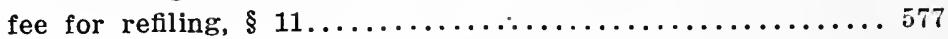

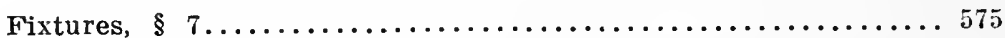

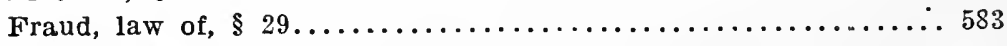

Fraudulent injury of goods prior to performance of the condition,

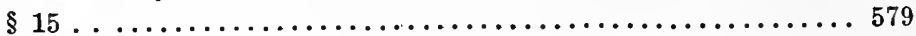

Furniture, see Fixtures.

Goods-

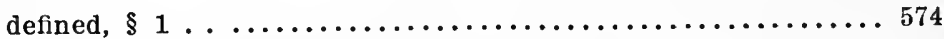

for resale, conditional sale of, $\$ 9 \ldots \ldots \ldots \ldots \ldots \ldots \ldots \ldots \ldots 76$

loss or injury, liability, $\S 27 \ldots \ldots \ldots \ldots \ldots \ldots \ldots \ldots \ldots \ldots . \ldots . \ldots . \ldots \ldots$

retaking, notice must first be given buyer, how, $\S 17 \ldots \ldots \ldots 580$

Inconsistent laws, repealed, $\S 32 \ldots \ldots \ldots \ldots \ldots \ldots \ldots \ldots \ldots \ldots \ldots$

Increase and loss of goods, $\S 27 \ldots \ldots \ldots \ldots \ldots \ldots \ldots \ldots \ldots \ldots \ldots$

Interpretation, uniformity of, $\S 30 \ldots \ldots \ldots \ldots \ldots \ldots \ldots \ldots \ldots \ldots \ldots$

Loss, when it shall rest on buyer, $\$ 27 \ldots \ldots \ldots \ldots \ldots \ldots \ldots \ldots . \ldots 53$

Misrepresentation, law of, $\S 29 \ldots \ldots \ldots \ldots \ldots \ldots \ldots \ldots \ldots \ldots \ldots 53$

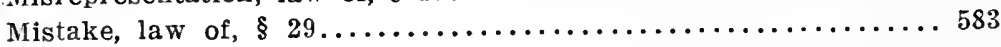

Notice-

buyer where he has not paid 50 per cent of prices, $\$ 20 \ldots \ldots 581$

intention to retake, $\S 17 \ldots \ldots \ldots \ldots \ldots \ldots \ldots \ldots \ldots \ldots . \ldots \ldots$ 
Notice-Continued.

sale without, $\S 13 \ldots \ldots \ldots \ldots \ldots \ldots \ldots \ldots \ldots \ldots \ldots \ldots \ldots . \ldots . \ldots . \ldots . \ldots$

seller must give, on compulsory resale, to whom, $\$ 19 \ldots \ldots \ldots 581$

Payments, recovery of part, $\$ 25 \ldots \ldots \ldots \ldots \ldots \ldots \ldots \ldots \ldots \ldots \ldots . \ldots \ldots 2$

Performance of the condition, defined, $\$ 1 \ldots \ldots \ldots \ldots \ldots \ldots \ldots . \ldots 74$

Perishable goods, when section applies to, $\$ 18 \ldots \ldots \ldots \ldots \ldots \ldots \ldots 58$

Person, defined, $\$ 1 . \ldots \ldots \ldots \ldots \ldots \ldots \ldots \ldots \ldots \ldots \ldots \ldots \ldots \ldots . \ldots \ldots 44$

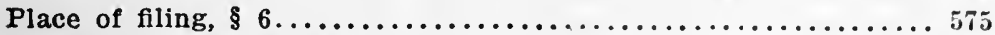

Possession, retaking of, $\$ 16 \ldots \ldots \ldots \ldots \ldots \ldots \ldots \ldots \ldots \ldots \ldots \ldots \ldots$

Principal and agent, law of, $\$ 29 \ldots \ldots \ldots \ldots \ldots \ldots \ldots \ldots \ldots \ldots$

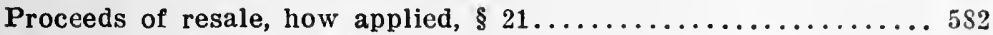

Prohibition of removal, $\S 13 \ldots \ldots \ldots \ldots \ldots \ldots \ldots \ldots \ldots \ldots \ldots \ldots$

Purchase, defined, $\S 1 \ldots \ldots \ldots \ldots \ldots \ldots \ldots \ldots \ldots \ldots \ldots \ldots \ldots \ldots$

Purchaser-

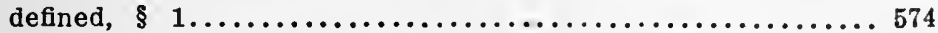

in due course, conditional sale void as to, when, $\S 5 \ldots \ldots \ldots 575$

Railroad equipment and rolling stock, $\S 8 \ldots \ldots \ldots \ldots \ldots \ldots \ldots 576$

Recovery of part payments, $\$ 25 \ldots \ldots \ldots \ldots \ldots \ldots \ldots \ldots \ldots \ldots \ldots 2$

Redemption by buyer, when, $\S 18 \ldots \ldots \ldots \ldots \ldots \ldots \ldots \ldots \ldots \ldots$

Refiling-

on removal, $\S 14 \ldots \ldots \ldots \ldots \ldots \ldots \ldots \ldots \ldots \ldots \ldots \ldots \ldots \ldots \ldots$

when and how made, $\S 11 \ldots \ldots \ldots \ldots \ldots \ldots \ldots \ldots \ldots \ldots \ldots 77$

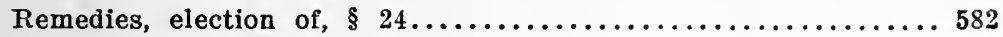

Removal-

prior to performance of condition, $\S 15 \ldots \ldots \ldots \ldots \ldots \ldots \ldots 579$

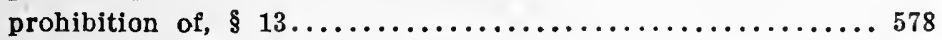

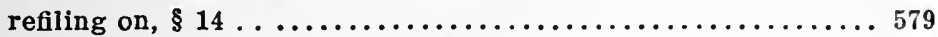

Repealed, inconsistent legislation, $\S 32 \ldots \ldots \ldots \ldots \ldots \ldots \ldots \ldots 5$ Resale-

at option of the parties, $\S 20 \ldots \ldots \ldots \ldots \ldots \ldots \ldots \ldots \ldots \ldots \ldots$

compulsory by seller, notice to whom, how, $\$ 19 \ldots \ldots \ldots \ldots 581$

conditional sale of goods for, good as to purchaser, $\S 9 \ldots \ldots 576$

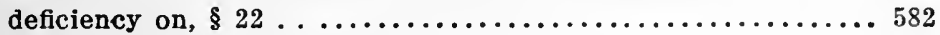

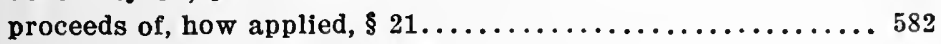

rights of parties when no, $\$ 23 \ldots \ldots \ldots \ldots \ldots \ldots \ldots \ldots \ldots \ldots . \ldots \ldots$

Retaking of possession, $\S 16 \ldots \ldots \ldots \ldots \ldots \ldots \ldots \ldots \ldots \ldots \ldots$

Rights of parties-

primary, of buyer, $\$ 2 \ldots \ldots \ldots \ldots \ldots \ldots \ldots \ldots \ldots \ldots \ldots \ldots \ldots 75$

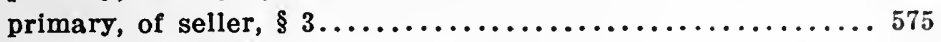

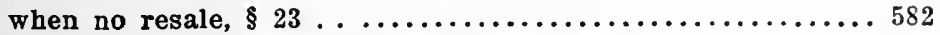

Rolling stock, conditional sale valid, when, $\S 8 \ldots \ldots \ldots \ldots \ldots . \ldots 76$

Rules for cases not provided for, $\$ 29 \ldots \ldots \ldots \ldots \ldots \ldots \ldots \ldots$

Sale-

prior to performance of condition, $\S 15 \ldots \ldots \ldots \ldots \ldots \ldots \ldots 79$

see also, Conditional Sale.

without notice, $\$ 13 \ldots \ldots \ldots \ldots \ldots \ldots \ldots \ldots \ldots \ldots \ldots$ 
Seller- PAGE:

breach of warrantles, liability of, $\$ 2 \ldots \ldots \ldots \ldots \ldots \ldots \ldots \ldots 75$

buyer may redeem where no notice given by, $\S 18 \ldots \ldots \ldots \ldots 580$

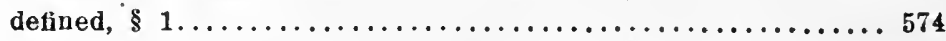

may recover deficiency from buyer, when, $\$ 22 \ldots \ldots \ldots \ldots \ldots 82$

may retain goods where no resale, $\$ 23 \ldots \ldots \ldots \ldots \ldots \ldots \ldots 582$

may retake goods for removal without notice, $\S 13 \ldots \ldots \ldots \ldots 578$

may retake possession of goods, when, $\S 16 \ldots \ldots \ldots \ldots \ldots \ldots 59$

must give buyer notice of intention to retake, $\$ 17 \ldots \ldots \ldots \ldots 50$

must refile on removal of goods to another district, $\$ 14 \ldots \ldots 579$

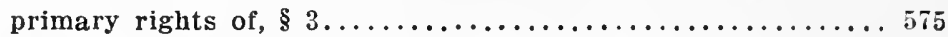

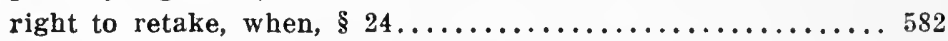

shall execute satisfaction piece, when, $\S 12 \ldots \ldots \ldots \ldots \ldots \ldots 57$

shall give notice of compulsory resale, when, $\$ 19 \ldots \ldots \ldots \ldots 581$

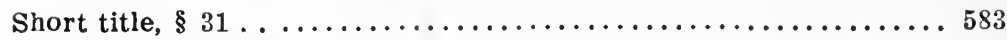

Statutory protection, waiver of, $\S 26 \ldots \ldots \ldots \ldots \ldots \ldots \ldots \ldots \ldots$

Street railway equipment, $\S 8 \ldots \ldots \ldots \ldots \ldots \ldots \ldots \ldots \ldots \ldots \ldots \ldots$

Time of taking effect of act, $\S 31 \ldots \ldots \ldots \ldots \ldots \ldots \ldots \ldots \ldots \ldots \ldots$

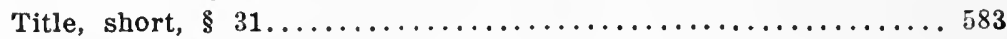

Uniformity of interpretation, $\S 30 \ldots \ldots \ldots \ldots \ldots \ldots \ldots \ldots \ldots \ldots . \ldots \ldots$

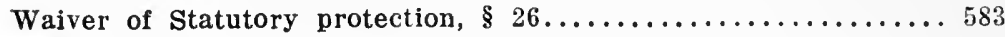

Warranties, seller's liability for $\cdot$ breach, $\$ 2 \ldots \ldots \ldots \ldots \ldots \ldots \ldots . \ldots 75$ 


\section{INDEX TO UNIFORM FRAUDULENT CONVEYANCE ACT}

Act-

PAOE

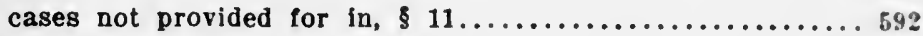

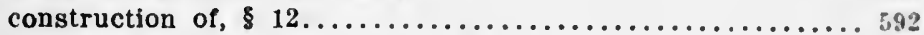

inconsistent legislation repealed, $\$ 14 \ldots \ldots \ldots \ldots \ldots \ldots \ldots \ldots$. 92

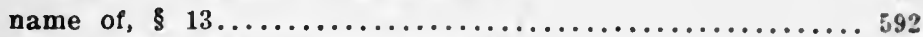

Antecedent debt, as fair consideration, $\$ 3 \ldots \ldots \ldots \ldots \ldots \ldots \ldots . \ldots 90$

Assets, defined, $81 \ldots \ldots \ldots \ldots \ldots \ldots \ldots \ldots \ldots \ldots \ldots \ldots \ldots . \ldots \ldots 9 . \ldots \ldots$

Business, conveyance by persons in, $\$ 5 \ldots \ldots \ldots \ldots \ldots \ldots \ldots \ldots . \ldots 90$

Cases not provided for in this Act, $\$ 11 \ldots \ldots \ldots \ldots \ldots \ldots \ldots \ldots$

Claims-

creditor's rights where claims not matured, $\$ 10 \ldots \ldots \ldots \ldots . \$ 91$

creditor's rights whose claims matured, $\& 9 \ldots \ldots \ldots \ldots \ldots \ldots . \ldots 1$

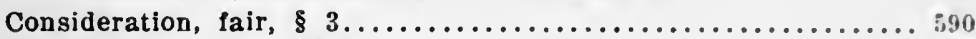

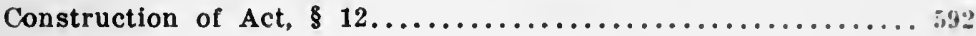

Conveyances-

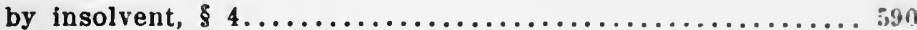

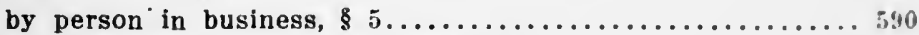

by persons about to incur debts, $\$ 6 \ldots \ldots \ldots \ldots \ldots \ldots \ldots \ldots 90$

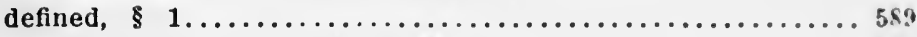

made with intent to defraud, $\$ 7 \ldots \ldots \ldots \ldots \ldots \ldots \ldots \ldots \ldots 590$

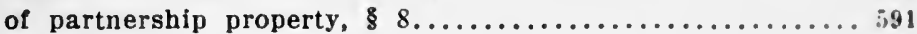

Creditors-

conveyance by person about to incur debts, $\$ 6 \ldots \ldots \ldots \ldots \ldots$

conveyance made with intent to defraud, $\$ 7 \ldots \ldots \ldots \ldots \ldots .90$

defined, $\$ 1 . \ldots \ldots \ldots \ldots \ldots \ldots \ldots \ldots \ldots \ldots \ldots \ldots \ldots . \ldots \ldots$

fraudulent conveyance as to, $\$ 5 \ldots \ldots \ldots \ldots \ldots \ldots \ldots \ldots \ldots$

rights of, whose claims have matured, $\$ 9 \ldots \ldots \ldots \ldots \ldots \ldots . . \ldots 1$

rights of, whose claims have not matured, $\$ 10 \ldots \ldots \ldots \ldots \ldots \$ .91$

Debts-

conveyance by person about to incur, fraudulent, when, $\$ 6 \ldots 5.7 n$

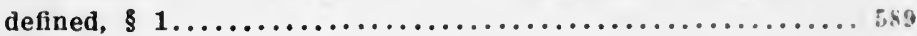

Definitions-

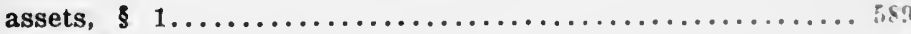

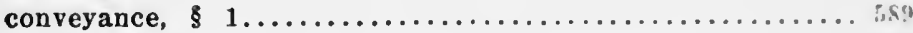

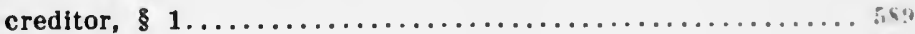

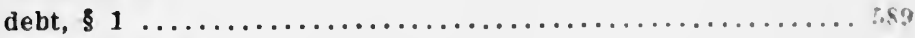

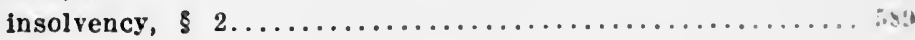

[6ST] 
Defraud, conveyance made with intent to, $\S 7 \ldots \ldots \ldots \ldots \ldots \ldots . \ldots 50$

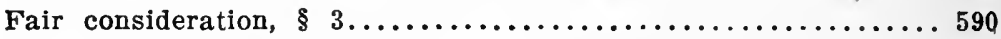

Fraudulent conveyance-

conveyance by insolvent is, when, $\S 4 \ldots \ldots \ldots \ldots \ldots \ldots \ldots \ldots 59$

what constitutes, as to creditors, $\S 5 \ldots \ldots \ldots \ldots \ldots \ldots \ldots \ldots 59$

Inconsistent legislation repealed, $\S 14 \ldots \ldots \ldots \ldots \ldots \ldots \ldots \ldots \ldots . \ldots 52$

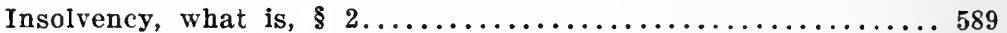

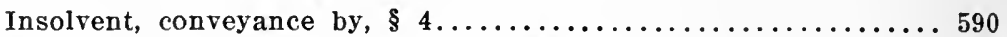

Intent to defraud, conveyances with, $\S 7 \ldots \ldots \ldots \ldots \ldots \ldots \ldots \ldots 590$

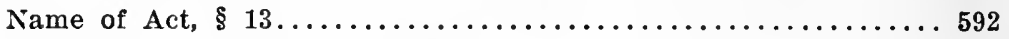

Obligation is a fair consideration, $\S 3 \ldots \ldots \ldots \ldots \ldots \ldots \ldots \ldots \ldots 50$

Partnership, insolvency of, $\S 2 \ldots \ldots \ldots \ldots \ldots \ldots \ldots \ldots \ldots \ldots \ldots$

Partnership property, conveyances of, $\S 8 \ldots \ldots \ldots \ldots \ldots \ldots \ldots \ldots . \ldots 5$

Person-

about to incur debt, conveyances by, $\S 6 \ldots \ldots \ldots \ldots \ldots \ldots . \ldots 50$

business, conveyances by, $\S 5 \ldots \ldots \ldots \ldots \ldots \ldots \ldots \ldots \ldots \ldots \ldots . \ldots \ldots$

insolvent, when, $\S 2 \ldots \ldots \ldots \ldots \ldots \ldots \ldots \ldots \ldots \ldots \ldots \ldots . \ldots \ldots$

Purchaser, may retain property, when, $\S 9$ (2) .............. 591

Repealed, inconsistent legislation, $\S 14 \ldots \ldots \ldots \ldots \ldots \ldots \ldots \ldots 2$

Rights of creditors-

whose claims have matured, $\S 9 \ldots \ldots \ldots \ldots \ldots \ldots \ldots \ldots \ldots 591$

whose claims have not matured, $\S 10 \ldots \ldots \ldots \ldots \ldots \ldots \ldots \ldots . \ldots 591$

Terms, definitions of, $\S 1 \ldots \ldots \ldots \ldots \ldots \ldots \ldots \ldots \ldots \ldots \ldots \ldots . \ldots \ldots$ 


\section{University of Callfornia}

SOUTHERN REGIONAL LIBRARY FACILITY

405 Hilgard Avenue, Los Angeles, library

Return this material to the
from which it was borrowed. 


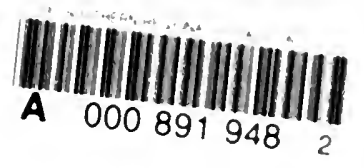


(1)

(1)

60625030

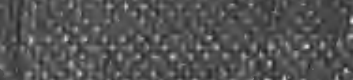

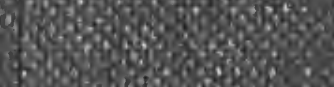

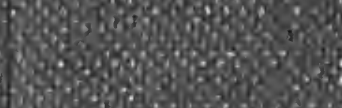

bitos

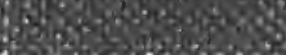

8

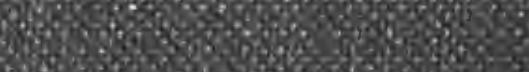

a

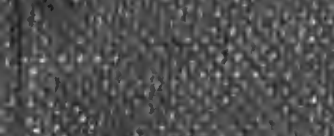

(3)

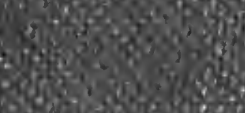

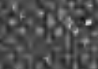

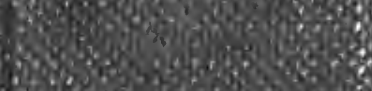

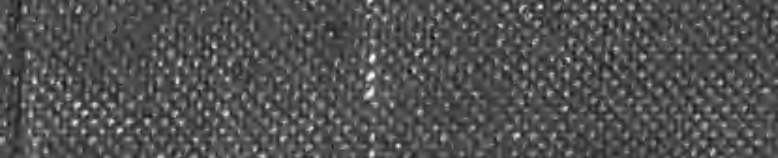

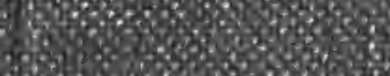

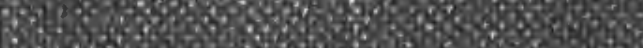

40

402

(3)

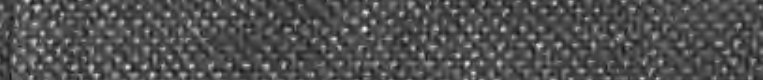

40

(1) 